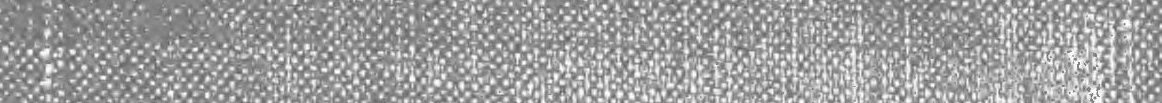

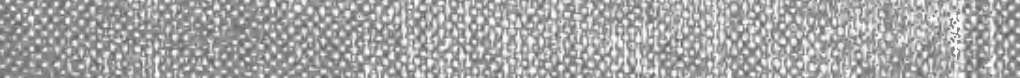
W. $\begin{array}{r}0 \\ \hline\end{array}$

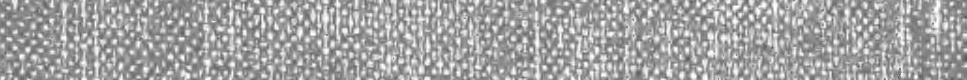

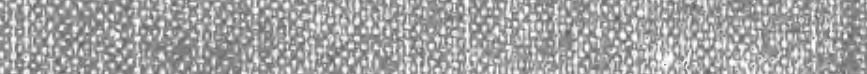

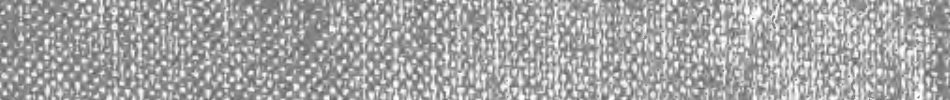

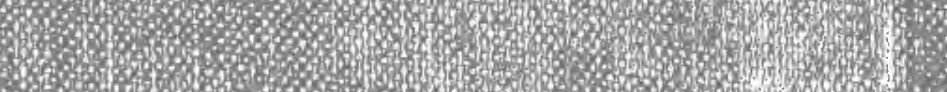
3. \begin{tabular}{|c|c|c|}
\hline & 0 & \\
\hline
\end{tabular}

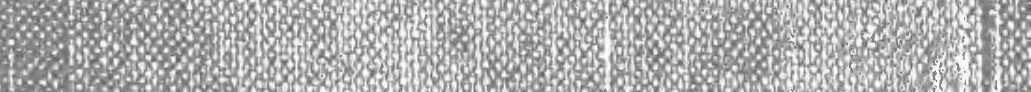

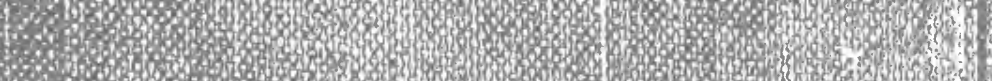

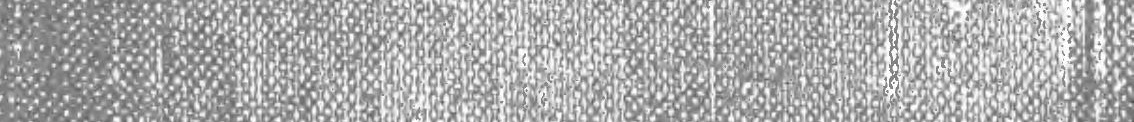
70 .

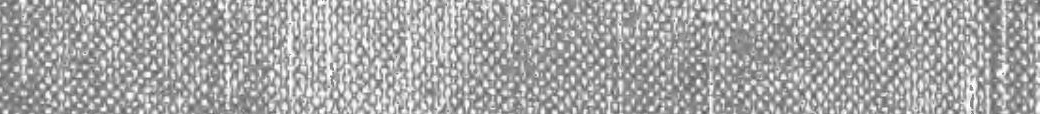

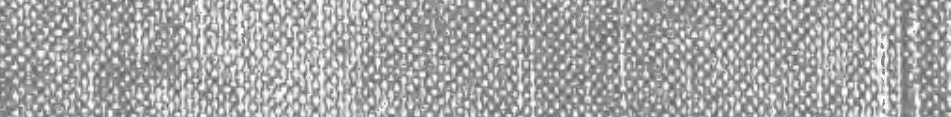

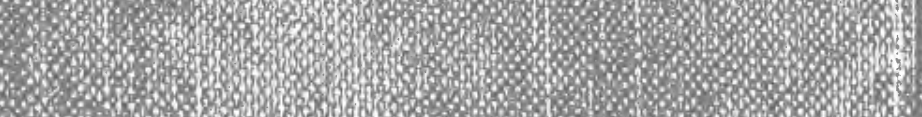

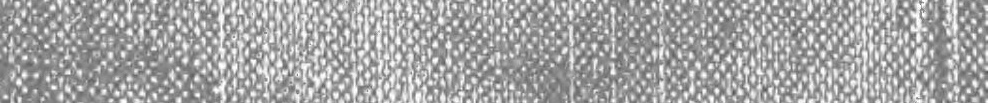

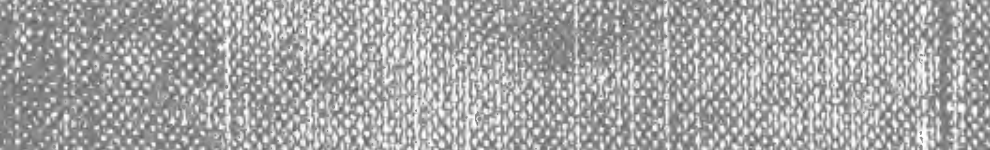

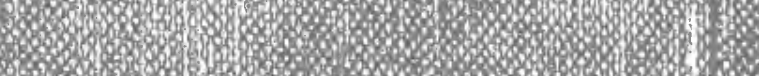

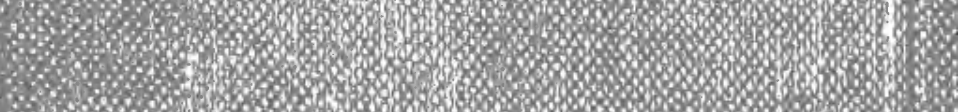
\% $000 \%$

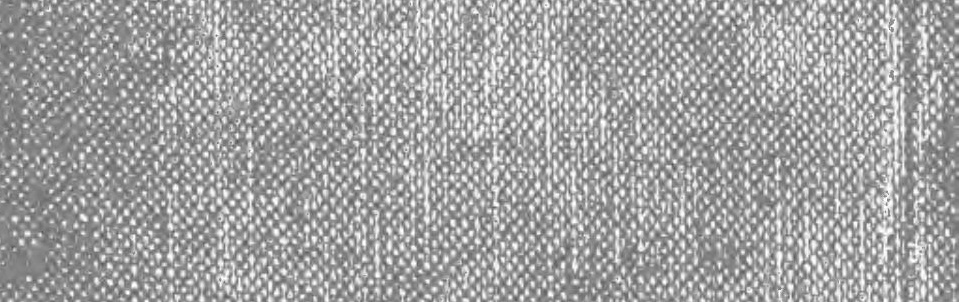
A \%

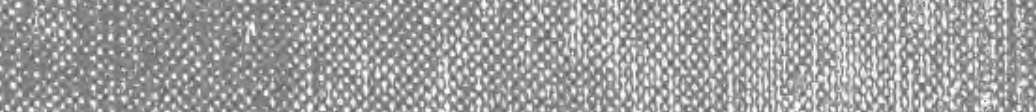

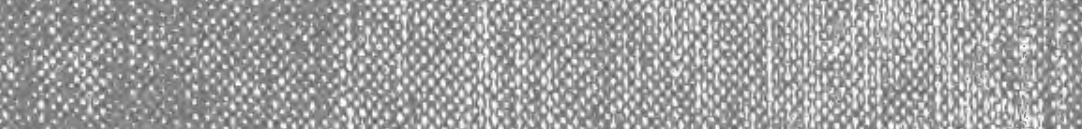

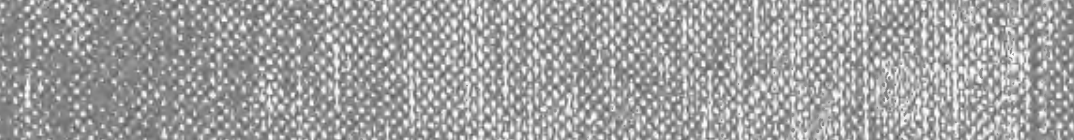

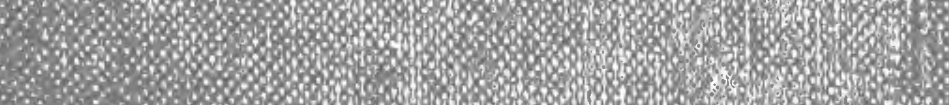

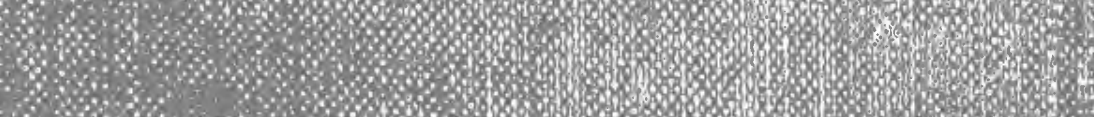
8.6. . 0
0 


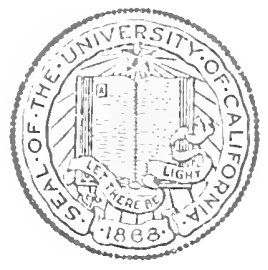

\section{UNIVERSITY OF CALIFORNIA LOS ANGELES}

SCHOOL OF LAW

LIBRARY

Gift of

Johr Adams 


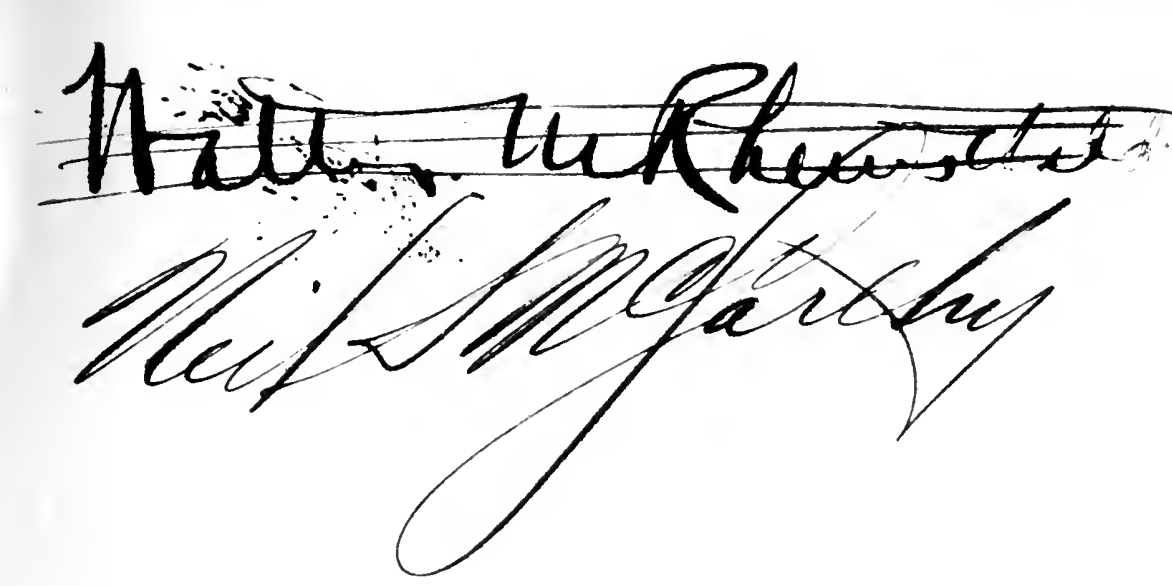





A TREATISE .

OX THE

INCORPORATION AND ORGANIZATION OF CORPORATIONS 
Digitized by the Internet Archive in 2008 with funding from

Microsoft Corporation 


\section{A TREATISE}

OX THE

\section{INCORPORATION AND ORGANIZATION}

\section{OF \\ CORPORATIONS}

CREATED UNDER TIIE "BLSINESS CORPORATION ACTS" OF THE SEVERAL STATES AND TERRITORIES OF TIIE LNITED STATES

Ixcleding tulereis a Syopels-Digest of the General Ixcontorition Acta of the several Commoxwehltus, with Decisions bearisg theneox; also, Fonys for mawing Chinters under the Law's of the several Stites and Territories; General ani

Specific Obuect Chal'ses foh insertion in Cirarters; By-Laws, Minutes, etc., etc.

IPY

TIIOMAS GOLD FROST, LI.D., Pin.I).

OF TILE NEW YORK BAR

Author of "Treatise on Gearanty Insulaxce," "The Fraxch Constitetion of 1793," Etc.

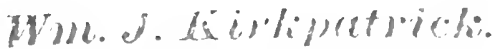

H, (1) TO N

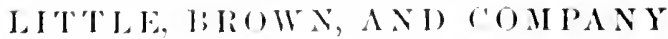

$19(1)$ 
Copyright, 1905,

By Little, Brown, and Compant.

All rights reserved.

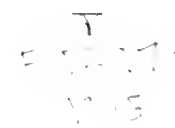

THE CXIVERITY PIRSS, CAMLRIDGE, U.S.A. gect if fot.nodsme

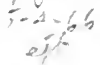


TO

J O H N B. B R O WN, EsQ.

OF TIIE ILLiNoIS Bar

THIS WORK IS DEDICATEI BY IIIS FRIEND, COLLEGE CLASSMATE AND FIRST LAW PARTNER

THE ACTHOR 



\section{P R E F A E}

THE present work might with no inconsiderable degree of fitness have been entitled "A Treatise on Comparative Ineorporation Law in the Sereral Commonwealths of the United States." Such a work if properly prepared should not fail to interest the active practitioner as well as the public at large. One of the greatest diffieulties met with in the preparation of the volume here presented, has been to successfully condense the subject matter thereof without eliminating any matters of real importance. If, in place of the eustomary copious references so freely offered in support of principles of corporation law miversally considered to be sound, the reater finds only a single citation, he may rest assured that eareful investigation has sitisfied the anthor that it represents the previling cloctrinc relative to the particular proposition in support.of which it has been eited. This method, it is believed, will meet with faror at the hands of the profession for the following reasons :

The vast majority of the decisions of the courts of this country rendered prior to 1870 , in so far as they relate to questions of corporation law, are for the most part a veritable legal " junkshop" representing either what is now "horm-hook law," or else overrulerl cases. Many of these contain enunciation of prineiples of eorporation law the sommluness of whith no one in these diys would venture to dispute. or else they represent propositions of

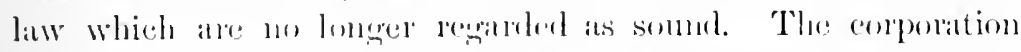
law of to-disy, ly engraftimg into its sul,ject matter aceepted principles of agency and estopluml, hats assimmed a formu which the corporation lawyer of tifty years and would lind great difficulty in recognizing. 
In the preparation of this work utility and aceuracy have been kept constantly in mind. The writer has made free use of certain exceprional fiacilities that have been open to him through his furessional comnections, inchuling aceess to a large number of forms an well as a great deal of correspondence with state oflicials in the vinions commonwealths. The forms for drawing eharters in the various states, while prepared by the author, have also been approved in every instance by competent attomeys who reside in the state muder the laws of which the draft of the charter was male.

All of this has been, it is hoped, to the advantage of the profession and the public at large.

THOMLS GOLD FROST

if Willial Street, New York City, N. Y.

December 1, 1904. 


\section{TABLE OF CONTENTS.}

Table of Cases . . . . . . . . . . . . . . . . . . Ixtroduction . . . . . . . . . . . . . . . . . 1

\section{PART I.}

\section{INCORPORATION AND ORGAXIZATION OF CORTORATIONS.}

\section{CHAPTER I.}

DRAFTING THE CHARTER.

\& 1. General Remarks on Corporate Charters .

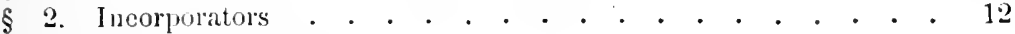

\$. 3. Corporite Name . . . . . . . . . . . . . . . . 14

$\$$ 4. Corporate Purposes . . . . . . . . . . . . . . . . 15

$\$ 5$. Number of Corporite l'urposes permitted . . . . . . . . . 19

§ 6. Coliateral Attack upon Corporate l'mploses and Powers . . . 21

\$ 7. Effect of Inserting Illegal l'urposes . . . . . . . . . . 28

§ 8. Corperate Powers, Classification of . . . . . . . . . . . 29

$\S$ 9. Common Law Powers, Definition of ; Enumeration of . . . . 30

\$10. Right to a Corporate Name . . . . . . . . . . . 31

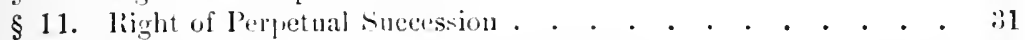

\$12. Right to arlopt and use a Corprorate Seal . . . . . . . . . 82

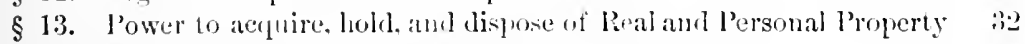

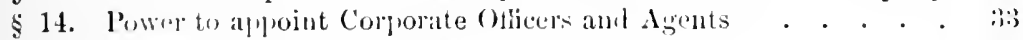

\$15. Power to establish By-Laws . . . . . . . . . . . . 3:3

§ 16. Power to sue anl be sued . . . . . . . . . . . . . : it

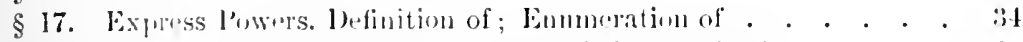

$\$$ 19. Poner of Comporations to purchase their own sitock • • • . 36

\$19. l'wwer to sulsscribe lor, furchate. and hold stock in otler Corprations . . . . . . . . . . . . . . . . 87

\$20. Pown to consolidata with uther Copporations . . . . . . is

\$21. l'ower to transant all or any l'art of the Comporate liasiness outsille of the stat" of its bombil. . . . . . . . . . 38

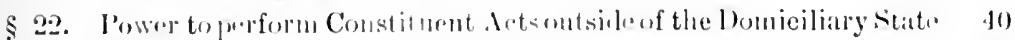

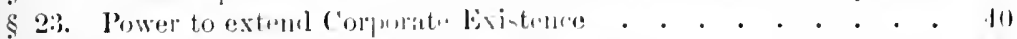

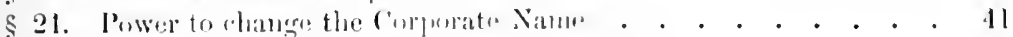

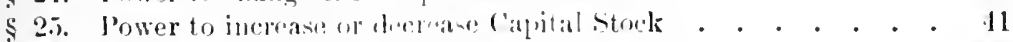

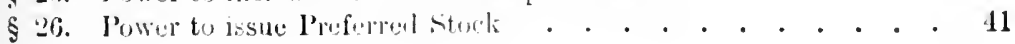


Towreto change the Corporato Purposes

Powner to change the Cenporato linposes

s. 2.s. Power to change Number of Jirectors . . . . . . . . . 46

s:?. Power to change the Corporate lomieile and Prineipal l'ace of linsines:s

s: $:$ lomer to aequire and enforee a Iien upon Stock to secure the

lalyment of lolits Dne the Corporation

s3. Power to lew Assessments against the Stocklolders with the light to forleit their Stock for Non-payment thereof

\$: :2. Power to anthorize Yoting hy Proxy at Stockholders Neetings

s. lowe to isue Stock as full paicl in Exchance for Property or

Services

\$ 35. Puwer to dispose of Corporate Assets as an Entirety . . . .

$\$ 30$. l'ower to roluntarily dissolve the Corporation withont liecourse to the courts.

\$37. Power to insert in the Charter Provisions for the Regulation of the. Internal Affairs of the Corporation . . . . . . . .

\$35. Power to anthorize Directors to adopt By-laws . . . . . .

$\$ 39$. Power to authorize Appointment of Executive Committe from

the Board of birectors . . . . . . . . . . . . . . 56

\$ 40. Puwer to enlarge or diminish Corporate Powers . . . . . . 56

$\$ 41$. Power to change Par Value of Shares . . . . . . . . . 57

4. Power of Bondholders to vote at Election of Directors . . . . 57

$\S$ 4:. l'ower to classify Directors . . . . . . . . . . . . . 57

$\S$ 4t. Power to amend Articles before Organization . . . . . . 58

\$ 4.). Power to surrender Charter lnefore Organization . . . . . . 58

$\$$ 46. Power given to Minority Stockholders to compel Purchase of their

Holdings upon Consoliclation . . . . . . . . . . 58

\$ 17. Ineirlental Powers, Definition and Enumeration of . . . . . 59

$\$$ 48. Power to make Contracts . . . . . . . . . . . . . 60

$\$$ 19. Power to borrow Money . . . . . . . . . . . . . . 60

51). Puwer to give and accept Customary Evidences of Debt . . . 60

\$1. Puwer to mortgare and pledge Real and Personal Property . . 60

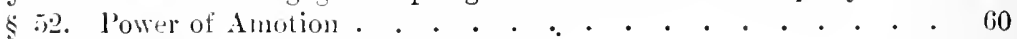

\$ 5.3. The Modern 1)octrine of Ultra Vires . . . . . . . . . 61

§5t. Corlorate Donicile . . . . . . . . . . . . . . 05

$\$$ 5. Boarl of Managenent . . . . . . . . . . . . 67

$\S 5 \%$. Capital Stock . . . . . . . . . . . . . . . 67

57. Limitations mon Amount of Capital Stock . . . . . . . 69

$\S 58$. I'al Value of C'apital Stock . . . . . . . . . . . 70

s. .9. Amount of Stock Sulseriptions . . . . . . . . . . . 70

sio. Amount of stock pair in . . . . . . . . . . . . . . 72

§ til. Amount of Stoek with which a Corporation may begin Business 73

\$ 62 . Duration of Corporate Existence . . . . . . . . . . . 73

$\S$ (j:). J hatr of Annual Neeting . . . . . . . . . . . . . 74

$\S$ if. Limitation upon Corporate lurlebtedness . . . . . . . . 74

\$ 65. Ex(1n)tion of Stockholders from Personal Liability . . . . 75

s. 6ri. Alophtion of By-Laws by lirectors . . . . . . . . . 75

$\S$ ci. Provisions for the Regulation of the Internal Affairs of the Cor-

foration . . . . . . . . . . . . . . 76 
\$68. Miscellaneous Prorisions relative to Contents of Articles of Incorporation . . . . . . . . . . . . . . . . . 76

$\S 69$. Construction of Charter . . . . . . . . . . . . . . 77

CHAPTER II.

PROCLRING THE CHARTER.

$\S$ 70. Signing the Articles . . . . . . . . . . . . . . . 79

$\S$ 71. Acknowledgment of Execution of Articles . . . . . . . 79

$\S$ 72. Publication of Articles . . . . . . . . . . . . . . 80

$\S$ 73. Affidarit as to Stock Subscriptions . . . . . . . . . . 81

$\S$ 74. Anti-Trust Allidarit . . . . . . . . . . . . . . . 81

§ 75. Special Requirenents in Particular States . . . . . . . . 81

$\S 76$. Powers of State Officials relative to accepting or rejecting Articles . . . . . . . . . . . . . . . . . . 82

§ 77. Right to Mandanus State Otlicials for refusing to file Articles . 84

§ 7. Organization Tax . . . . . . . . . . . . . . . . 81

\$ 79, Form in which charter is grantel . . . . . . . . . . 81;

$\$ 80$. Filing and recording in Local County Offices . . . . . . . 86

$\S 81$. Instinction between de jure and de facto Corporations . . . . S S

$\$ 82$. Right of Jarties other than the state to collaterally impeach Corporate Existence . . . . . . . . . . . . . 88

§ 83. Right of State to attack Corporate Existence in Direct Proceedings . . . . . . . . . . . . . . . . 90

$\S$ 81. When does Corporate Existence commence? . • • • . . 92

\section{C'HAPTER III.}

ORGANIZATION OF COLPOIRATIONS AFTER INCOHRORATION.

$\S 85$. The Incorporators' Organization Meeting . . . • . . . . 95

$\S 86$. Organization Menting, how called . . . . . . . . . . 96

§87. Organization Mlecting. where held . . . . . . . . . . 96

§ 88. Steprs Neressaly to crimulete Organization . . . . . . . . 98

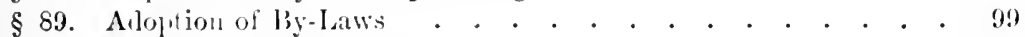

$\S$ 90. Election of lirectors . . . . . . . . . . . . . . . . . 100

§ 91. Power to hull Mertings for the Election of llirectors witlunt

thre lomiriliary state . . . . . . . . . . . . . . 101

\$ 92. Voting hy l'roxy . . . . . . . . . . . . . . . . I01

\$ 9:3. First Directrers' Nerting . . . . . . . . . . . . . 105

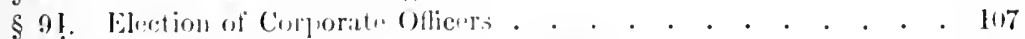

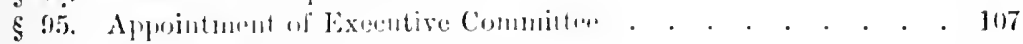

\$96. Stock Assestments . . . . . . . . . . . . . . . 108

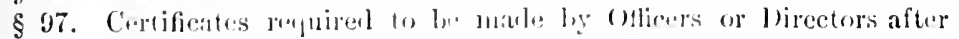

Olganizition . . . . . . . . . . . . . . . . . 10 . .

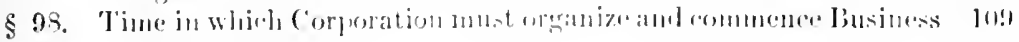

\$ 99. Steck Certificates . . . . . . . . . . . . . . 110) 


\section{CIIAPTER IV.}

ISSTANCE AND PAYMENT OF CAIITAL STOCK.

$\$ 100$. General Remarks as to the Issuance and Payment of Capital

Stock upon the Organization of a Corporation . . . . . 112

\$ 101. Mauncr of Payment of Capital Stock . . . . • . . . . 113

$\$ 102$. Payment of Capital Stock in Services . . . . . . . . . 120

\$103. Payment of Capital Stock in Property . . . . . . . . 120

$\$ 101$. Statement of True Value linle . . . . . . . . . . . 122

$\$ 105$ Statement of Good Faith Rule . . . . . . . . . . . 123

\$ 106. Statement of "Speculative Value Rule" . . . . . . . . 125

$\S 107$. Eifect of Aprraisal of Property by Ilirectors under Statutory

Anthority, when taken in Exchange for Stock . . . . . 137

$\$$ 103. Effect of Appraisal of Value of Property by State Officials when

the same is taken by Corporations in Exchange for their

Capital Stock . . . . . . . . . . . . . . . . 139

\$ 109. Meaning of Non-Assessable Stock . . . . . . . . . . 141

$\S 110$. Meaning of Full-Paid Stock . . . . . . . . . . . . 142

\section{CHAPTER V.}

\section{LEGISLATIVE CONTROL OVER DOMESTIC CORPORATIONS.}

§ 111. Statement of Principal Methods by which Legislative Control over Domestic Corporations is obtained . . . . . . 145

\$112. Amendment of Charters . . . . . . . . . . . . . 145

$\$ 113$. Reserved Right of the State to repaal Charters . . . . 153

\$114. Legislative Control over Dissolution of Corporations . . . . 154

\$115. Forfeiture of Charters . . . . . . . . . . . . . 157

$\S 116$. The Police Power of the State . . . . . . . . . . . 160

§ 117. Legislative. Investigation into Corporate Affairs . . . . . 164

$\S$ 115. Legislative Requirement of Annual Reports from Corporations 164

\$ 119. Inspection of Corporate Bools . . . . . . . . . . . 165

§ 120. Auti-Trust Legrislation . . . . . . . . . . . . . . . 167

\$ 121. Regulation of Internal Affairs . . . . . . . . . . . 168

$\S 12$. Liability of Stockholders for Debts of the Corporation . • • 169

\$ 12:3. Statutory Liability of I)irectors . . . . . . . . . . . 174

\$ 121. Extension of Corporate Existence . . . . . . . . . . 176

\$ 125. Taxation of Domestic Corporations . . . . . . . • • . 177

$\S 126$. Regulation of the Right of the Consolidation . . . . . . 178

\section{CIAPTER VI.}

IEGISLATIVE CONTROL OVER FOLEIGN CORPOLATIONS.

$\S 127$. Extent of Legislative Power of the various Commonwealths over Foreign Corporations . . . . . . . . . . 180

\$ 125. Dortrine of State Comity . . . . . . . . . . . . . 184

\$129. What constitutes doing Business on the Part of a Foreign Corporation within the State . . . . . . . . . 190 
§ 130. Penalty for transacting Business in a Foreign State without obtaining a Permit . . . . . . . . . . . . . . 195

$\S 131$. License Tax on Foreign Corporations . . . . . . . . . 195

$\S$ 132. Annual Jicense Tax on Foreign Corporations . . . . . . 199

$\S$ 133. To what Extent is the Taxing Power of the State with reference to Domestic and Foreigu Corporations engaged in Interstate Commerce limited by the "Commerce Clause" of the Federal Constitution? . . . . . . . . . . . . 202

\section{PART II.}

\section{SYNOPSIS-DIGEST OF THE INCORPORATION ACTS \\ OF THE SEVERAL STATES AND TERRITORIES}

OF THE UXITED STATES . . . . . . . 211-396

\section{APPENDIX TO PART II.}

SYXYORIS-DIGLST OF TIIE BUSINISS CORPORATION ACT.

Dominion of Canada .

Manitoba . . . . . . . . . . . . . . . . . . . . . 897

Hawail . . . . . . . . . . . . . . . . . . . . $3 ! 3$

Philippines . . . . . . . . . . . . . . . . . . . . 399

Porto Rico . . . . . . . . . . . . . . . . 400

\section{PART III.}

\section{FORJIS ANI PRECEDENTS.}

Specific Object Clauses . . . . . . . . . . . . . . . 403-112

Forms for drawing (laters in all the States and Territories . . 413-51s

General Object Clauses for Insertion in Charters . . . . . . 509-5111

Clauses regulatiug linsiness, ote. . . . . . . . . . . . 510-511

Composite Form of Minutes . . . . . . . . . . . 512-5ls

Composite Form of Bi-laws . . . . . . . . . . . . . 519-521

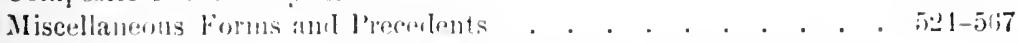

Sugrestions wative to, the lmafting of Charters and the lreplantion of Minutes for the (1reanization Meetiugs of Corpmations . . 5for-jon

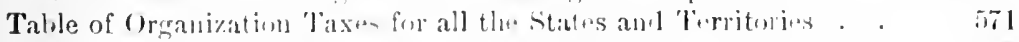

Table of Ammul leanchise Taxis for all the States and Territories 50

Miscellaneons 'Tables . . . . . . . . . . . . . . . 573-507

Gexpha INDex . . . . . . . . . . . . . . 589-611

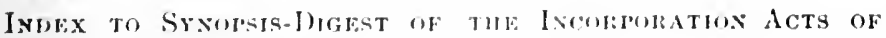

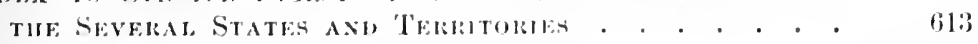
INDEX to Prackents . . . . . . . . . . . . 615-6220 



\title{
TABLE OF CASES.
}

\author{
[The references are to pages.]
}

\section{A.}

A. C. I. Co. v. Ellis, 156 Ind. 212; 59 N. E. 679 . . . . . • . . . . . . 267

A. C. Society $v$. Gartell, $2: 3 \mathrm{Ga} 448$. . . . . . . . . . . . . . . . . 257

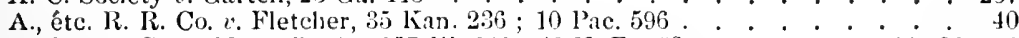

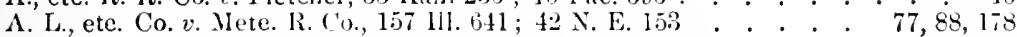

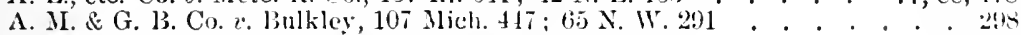

A. M. F. Insurance Co. $v$. Jesser, s7 Mass. 44 . . . . . . . . . . . . . 2!l

A. M. L. I. Co. $r$ Owen, 15 Gray (Mass), $4 ! 1$. . . . . . . . . . . . . . 1!2

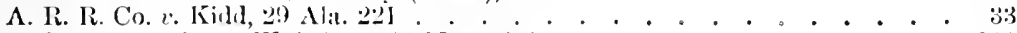

A. S. A. \& G. Co. $v$. Whittier, I17 Matss. 151 .

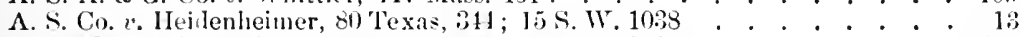

A. S. Mining Co. $r$ Company, 78 Cal. 629 : 21 Pac. 373 . . . . . . . . . . . . 232

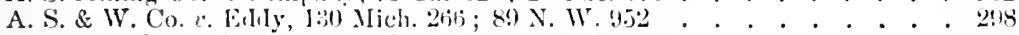

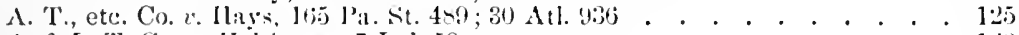

A. \& [. 'T'. Co. r. IIritionse, 7 Ind. 59 . . . . . . . . . . . . . . . 160)

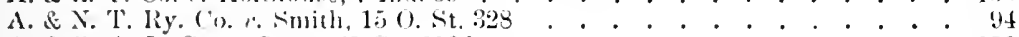

A. \& R. A. L. Co. v. State, (j3 Ga. 2183. . . . . . . . . . . . . . . 179

Alhott $\%$ Company, ;3) Barh. (N. Y.) 583 . . . . . . . . . . . . . . 113

Abbott $v$. Company, t Neb. 416 . . . . . . . . . . . . . 11,87

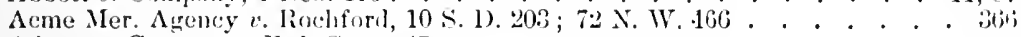

Alams $v$. Company, Ferl. Cases, 47 . . . . . . . . . . . . . . . . .

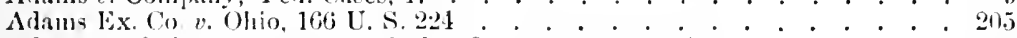

Adv. Ben. Order v. Compuny, 195 l'a. St. $002 ; 16$ Atl. 102 . . . . . . . .351

Afferton $v$ Compiny 67 Ini. 331 . . . . . . . . . . . . . . . . . . $4: ;$

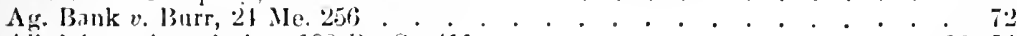

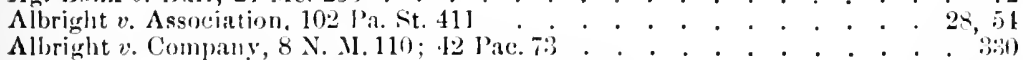

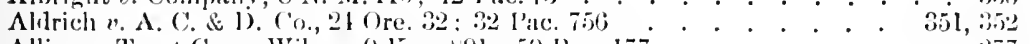

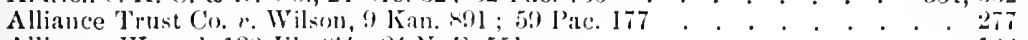

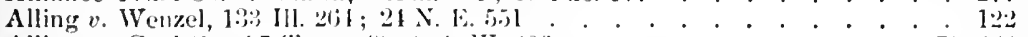

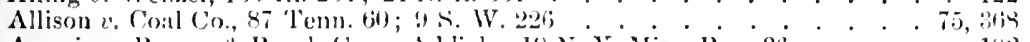

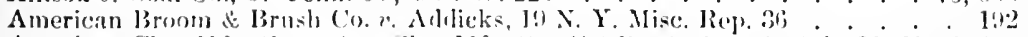

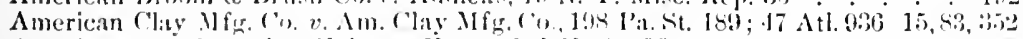

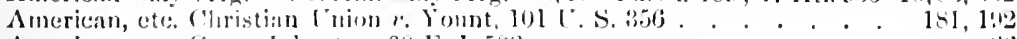

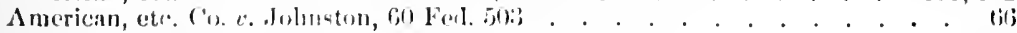

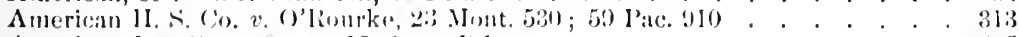

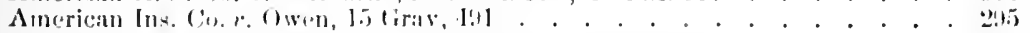

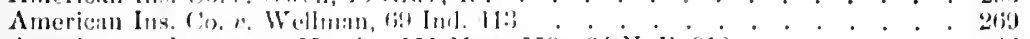

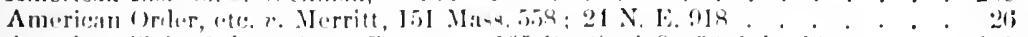

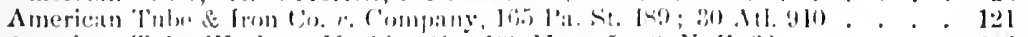

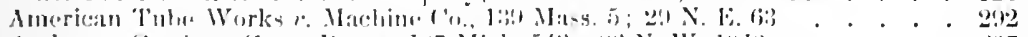

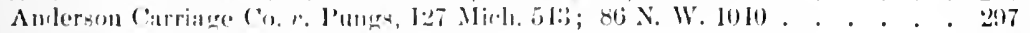

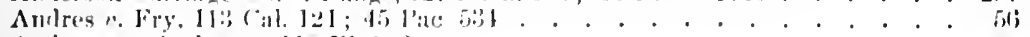

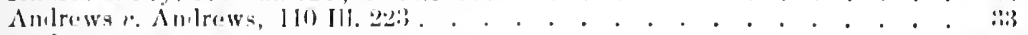

Anilrews v. ('omplany,

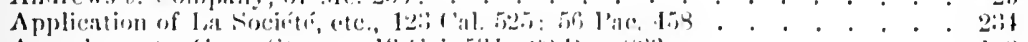

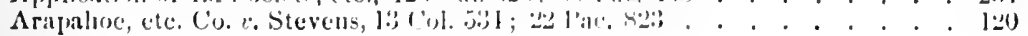


Aronts r. Company, 101 livl. 198

Arms $r$. (1)ant, Biti Vt. 7.11

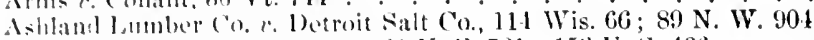

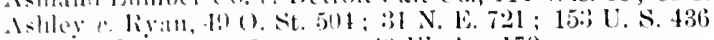

Ashley Wire (o. e. C'ompany, (60 111. Ap. 179.

Aslum $r$ Burbank, 2 l)ill. (l. S.) 103 ; Pell Cises, 582.

Astrille 1)ir. r. (1sten, 12 X. C. 578

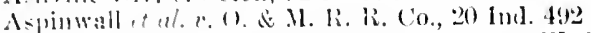

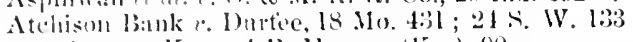

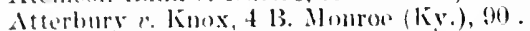

Attorney Gencral $r$. Bay state Min. (o go Mass. 148

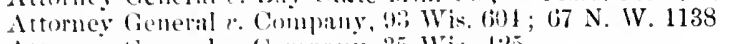

Attorney fieneral r. Company, 35 Wis. 125

Attorney tiencral $r$. Perkin, $7: ;$ Mich, :30?

Augusta Bank e. Earle, lis l'eters, ojly (so Bank of Augusta r. Earle).

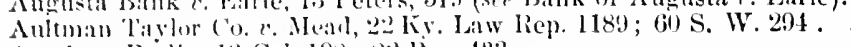

Austin 1 . Berlin, 1:3 Col. 198; 220 l'ae. 43:3

Austin $x$. Tennessee, 179 U. S. $310 ; 45$ I. E. 224

B. B. \& T. Co. v. J. B. T. Co., 101 Tenn. 54 ; 48 S. W. 228 • • • • • . 13, 08

13. l. Co. 2 A. \& C. Co., Ariz. ; 85 l'ac. !8: . . . . . . . . . . 220

B. B. R. Co. $v$ Buck, 63 Me. 81 . . . . . . . . . . . . . . . 96, 106

13. G. L. ('o. v. Clatiy, 151 N. Y. $24 ; 45$ N. F. 390 . . . . . . . . . 62

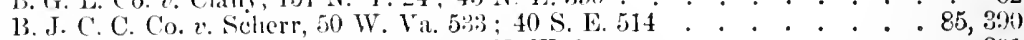

3. I'. (o.r. Rose et al., 16 is. $145 ; 70$ N. W. 302 . . . . . . . . . . 391

B. R. Y. O. Co. $v$. Ianley, $15 \mathrm{Utah}, 506 ; 50 \mathrm{P}$ 'il. 611 . . . . . . . . . . 63

B. IV. S. Co. v. Inlabitants of Braintree, 116 Mass. 482; 16 N. E 420 . . 91, 92

13. \& II. C. . \& S. M. Co. v. M. O. I’. Co., 89 Fell. 52! . . . . . . . . . 51

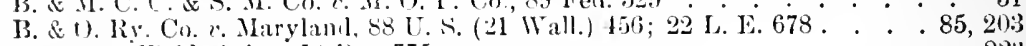

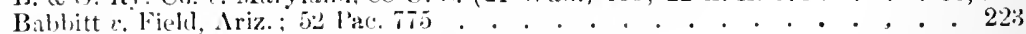

Bilbbitt $z$. E. J. I. Co., I Stew. 1)ig. 208 , sec. 19. . . . . . . . . . . . 99;

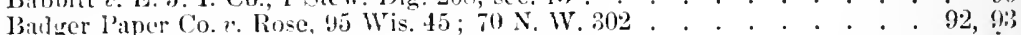

baines $x$. Babcock 9j Cal $581 ; 27$ Pac. 67t. . . . . . . . . . . . . 282

Baker $x$ Backus, :3 III. 79 . . . . . . . . . . . . . . . . . . . . 61, 88, 113

Baker Cincimati, 11 o. St. 5i34 . . . . . . . . . . . . . . . . 85

Bakers Appeal, 109 Pa. St. 461 . . . . . . . . . . . . . . . . . . 49

Balfour v. ('ompany, 27 Ore $300 ; 41$ l'ac. 164 . . . . . . . . . . . . . . 351

Ball r. Toman, 115 Cal. 35 ; 51 Pac. 546 . . . . . . . . . . . . . 175

Baltime City l'ass. ('o. $e$. llambleton, 7 Ma. 34 . . . . . . . . . . . 95

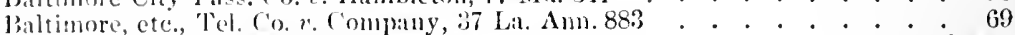

Banet $r$ Company, l: Ill. 501. . . . . . . . . . . . . . . . 46, 147

Bank $r$ Alden, 1.j U.S. 372 ; 32 L. E. 725 . . . . . . . . . . . 124, 125

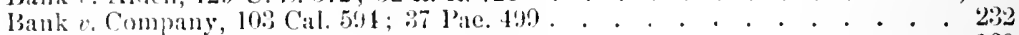

lank e. Company, 17 Ap. l)iv. (N. Y.) 521 . . . . . . . . . . . . . . . . 160

l3ank r. Compiny, $18 \mathrm{Vt} 131 \mathrm{l}$. . . . . . . . . . . . . . . 36

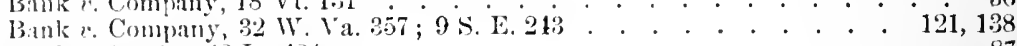

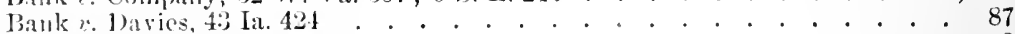

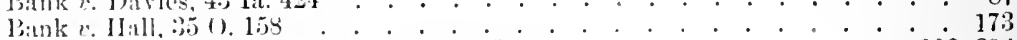

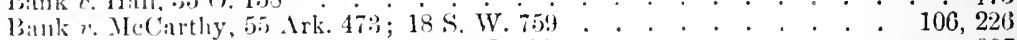

link $v$. J'jerson, 112 . Mich. $410 ; 70 \mathrm{~N} . \mathrm{W} .901$. . . . . . . . . . . . 297

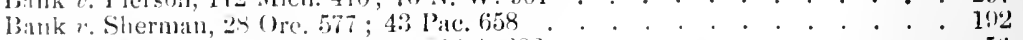

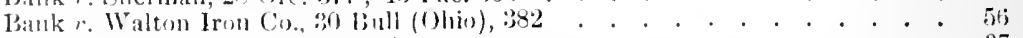

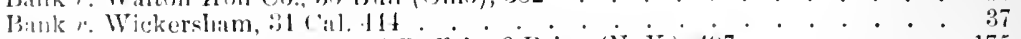

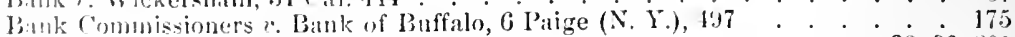

l3ink of Augusta r. Earle, 1:; l'eters, 519 . . . . . . . . . . . 38, 96,201

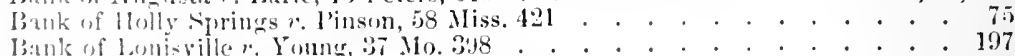

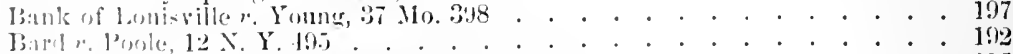

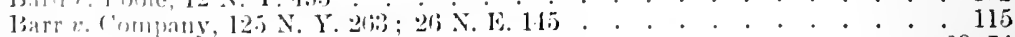

Larry 2 Company, 1 Sin. Ch. (X. Y.) 200. . . . . . . . . . . . 69,74 
Bartemeyer $\%$. Iowa, 18 WVall. 198.

Bartholomew $v$. Company, 69 Conn. $521 ; 88$ Atl. 45

Barton $v$. Associarion, $11+$ Ind. 226; 16 N. E. 486

Barton Nat. Bank $e^{\circ}$ Atkins, 72 Vt. $89 ; 47$ Atl. 176

Bartow 2 . Nlix, 15 Wash. 503 ; 4+j Pac. 1033

Jassett $x$. Company, 15 Ner. 29:3

106,813

Bates v. Day, 198 l’a. st. $51: 38$ Atl. 407

173,854

Bates $v$. Wilson, 11 Col. $140 ; 24$ l'ace. 9!!

27,67

Bayou Cook Nav, e Fisheries ('o. e. Doullut (La.), 35 Sis. 729 .

Beach $v$. Smith, $30 \mathrm{X}$. Y. 116

Beard $v$. N. \& A. [’. Co., 71 Ala 60

Beardsley $v$.Jolnson, 121 N. Y. $224 ; 24$ N. E. 380

I3ecket $t$. I Iouston, 8,2 Ind. 843

Beer Co. $x$. Missachusetts, 97 L. S. 25

Beitman 2 . Steiner, 98 Ala. 241 ; 13 So. 87

Belknap $v$. Aliams, 49 La. Ann. $1350 ; 22$ So. 332

Bellows $v$. Todd, 39 Low: 200

Benediet $v$. Company, 4! N. J. Eq. $235 ; 23 \mathrm{Atl} .485$

$74,105,107$

Bent $v$. Underdown, 156 Ind. $516 ; 60$ N. E. 307

Berger $v$. U. S. Steel Corporation, 6: N. J. Eq. $809 ; 5:$ A 1.68

Bergeron $v$. Hobbs, $96 \mathrm{Wis} 641 ; 71 \mathrm{~N}$. W. 1056

Berry $v$. Rood, $163 \mathrm{M} 0.316 ; 67 \mathrm{s.} \mathrm{W} .644$

Bertha Zinc \& Mining Co. '. Clure, 7 N. Y. Misc. Rep. 128

Berthin v. Company, 28 Ia. 210

Berwick $v$. Company, 89 Mich. 701

Bibb $\imath$. Hall, 101 Mla. $79 ; 11$ So.98 . . . . . . . . . . . . . 215

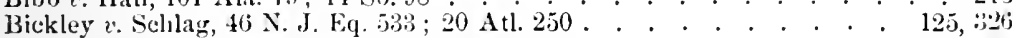

Bigelow $v$. Gregory, 73 III. 197 . . . . . . . . . . . . . . . . . . s0

Billings $e$. Robinson, 91 X. Y. 415 . . . . . . . . . . . . . . . . . $3 \%$

IBird $v$. Daggett, 97 Jass. $494 \quad$. . . . . . . . . . . . . . . . . . 290

Birls Case, 1 Simon (s. s.), 47 ; 40 Eng. Ch. 47 . . . . . . . . . . . . ㄴ.

Bishop $v$. Gilobe Co., 1:30 llass. 132 . . . . . . . . . . . . . . . 48, 29.

Black $v$. Colwell, 83 Fexl. 880 . . . . . . . . . . . . . . . . . . 189

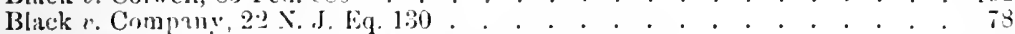

Black, etc. Co. v. Llollway, 8. Wis. 344 ; 55 N. W. 418 . . . . . . . . . . . 5ij

liackwell $v$. State, 36 Ark. 17 s

Blien $v$. Rand, 7 Minn $110 ; 79$ ․ W. 606 . . . . . . . . . . . . .

Block $v$. Womer, 100 Ill. 32 y . . . . . . . . . . . . . . . . . . 109

Blokirett $e$. L. Z. Co., 120) Fol. 893 . . . . . . . . . . . . . . . . . . 40

Board of Trustees, ete. ". ('amphell, 49 Ia. Ann. 1543; 21 So. 184. . . . . 24)

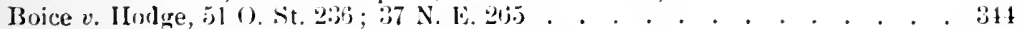

Iolen $v$. Crosby, 4:I N. Y. 15: . . . . . . . . . . . . . . . . . . 17j

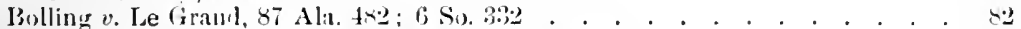

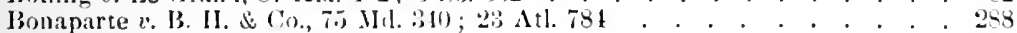

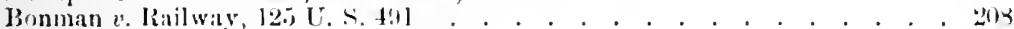

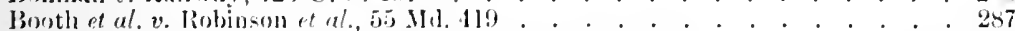

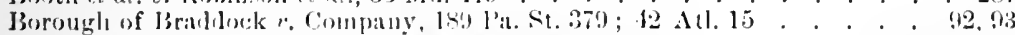

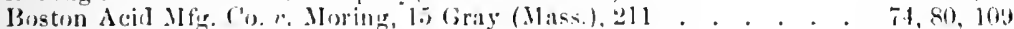

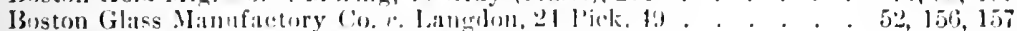

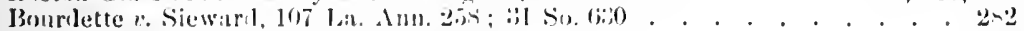

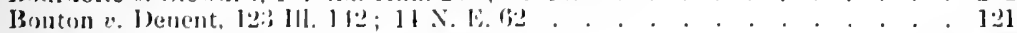

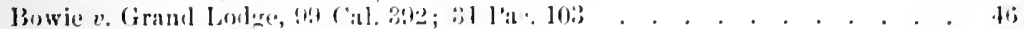

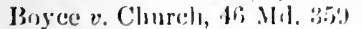

$22,20,83$

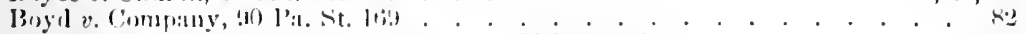

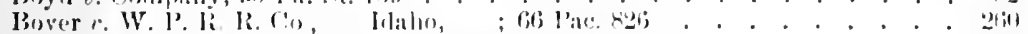

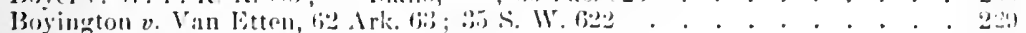

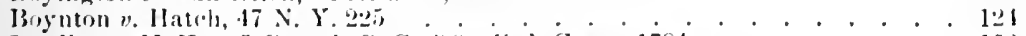

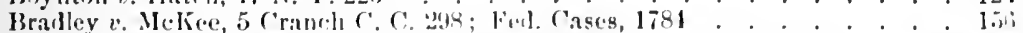

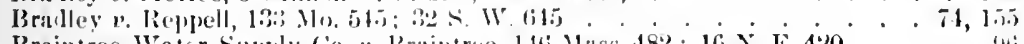

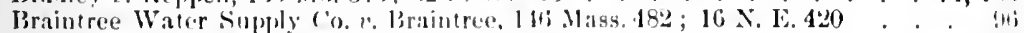

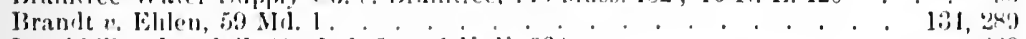

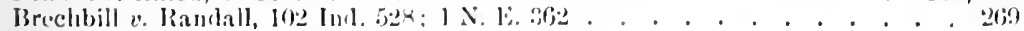

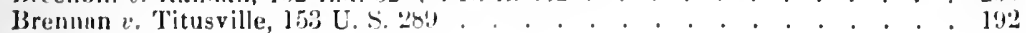


lirewster r. Ilartley, 37 Cal. 15 . . . . . . . . . . . . . . 37

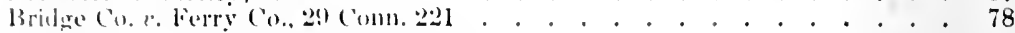

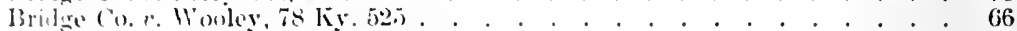

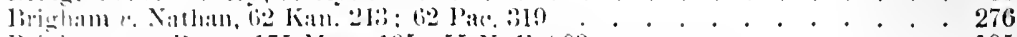

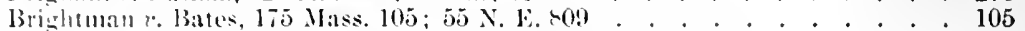

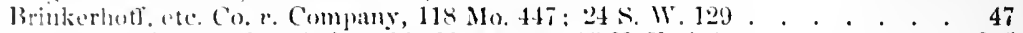

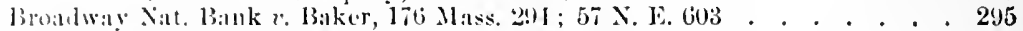

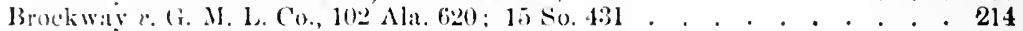

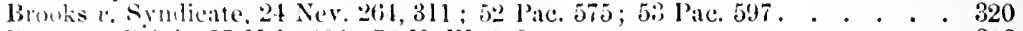

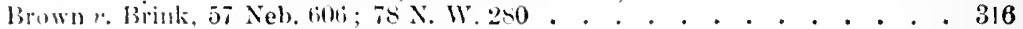

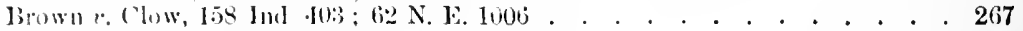

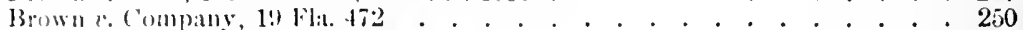

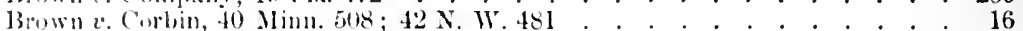

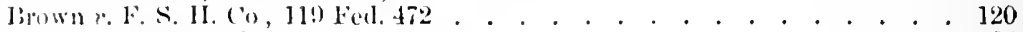

Brown $x$. lloger, $1+111.219$. . . . . . . . . . . . . . . . . . . 32

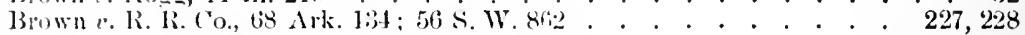

Brumlage r. Company, 12 ()re. 322; 7 l'ac. $: 14$. . . . . . . . . . . . 351

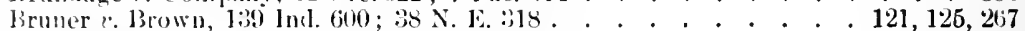

Bull थ. Company, 15 (Ore. 41:; 15 Pac. 65!) . . . . . . . . . . . . . 109)

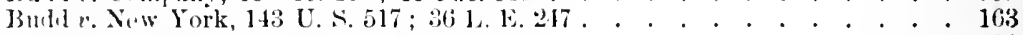

Buffilo, etc. Ry. Co. $v$. Cary, 26 N. Y.75 . . . . . . . . . . . . . . 88

Butíalo, ete. liy. ('o. r. llateh, 20 N. Y. 157 . . . . . . . . . . 69, 71, 73,81

Butfilo Zinc \& Copper Co. $v$. Crump, 70 Ark. 525; 69 S. W. 572 . . . . . 220

Burden $r$. Burden, 159 N. Y. 187 ; 54 N. E. 17 . . . . . . . . . . . . 108

Burqess v. Seligman, 107 U.S. 20 ; 2 S. Ct. 10 . . . . . . . . . . . . 60

Burham $r$. Comprany, 76 Cal. 24; 17 Pac. 940 . . . . . . . . . . . . 160

Busby r. lieilly et al., 6 S. 1). 401 ; 61 N. W. 16t . . . . . . . . . . . 363

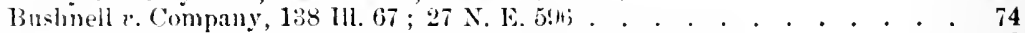

Piutchers' Lnion, etc. ". Company, 111 U. S. $7415 ; 23$ L. L. 585 . . . . . . 16:3

Buxton $v$. Ilamblen, 32 Me. 448 . . . . . . . . . . . . . . . . . 198

Byrnes $\because$ lieck, 10 Ga. 121 . . . . . . . . . . . . . . . . . . 13,98

Byronville Creamery Ass'n $v$. Ivers (Minn.), 100 N. W. 387 . . . . . . . 13

C.

C. B. \& Q. R. R. Co. v. IIarris, 12 Wall. (U. S.) 65 . . . . . . . . . . 198

C. B. \& (2. R. R. Co, v. Lewis, 5:; Ii. $101 ; 4$ N. WT. 842 . . . . . . . . . 33

C. C. liv. Co. v. Allerton, 18 Wall. 23:3 . . . . . . . . . . . . . . 41, 40

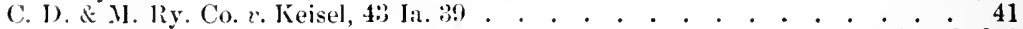

C. G. \& K. M. Co, $r$ Rnble, 8 ()re, 285 . . . . . . . . . . . 13, 98, 348, 349

C. G. L. Co. $*$ City of Covington, 22 K. L. IR. $796 ; 55$ S. W. 805 . . . . 278

C. M. 11. A. Co. r. Rosenthal, 55 Ill. 85. . . . . . . . . . . . . 197, 198

C. II. I. \& I. Ass'n r. Hunt, 127 III. 257 . . . . . . . . . . . . . . 160

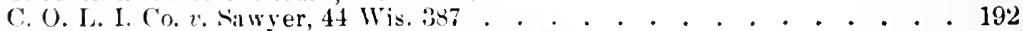

C. O. N.G. E Co.r. C. 1). Co., 600.96;53 N. 1.711 . . . . . . 30,60

C. P. E. Co. r. Company, 152 Mass. 4\%2; 26 N. E. 300 . . . . . . . . . 192

C. R. Co, v. J. R. Co., 81 N. J. Eq. 475 . . . . . . . . . . . . . . . 13, 324

C. R. li. Co. \% Company, 8.2 S. C. $319 ; 11$ S. E. 192 . . . . . . . . . . 361

C. R. S. Bank $v$. Fiske, 62 N. H. 78,180 . . . . . . . . . . . . . . . 321

C. U. А. Co.r. Scammon, 102 111. 40 . . . . . . . . . . . . . . . . . . . 192

C. V. \& P. Co. $v$. Secretary of State, 198 Mich. $621 ; 87$ N. IV. 901 . . . . 28,76

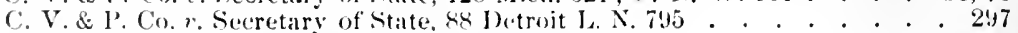

C. V. Co.v.lloffmeister, 62 O. St. 189;56 N. 1: 1039 . . . . . . . . . 844

Cahill 2 . Association, 91 Ma. 95:3 50 Atl. 1014. . . . . . . . . . . . . 289

Cahill $\%$ Company, 2 Jome. (Mich.) 128 . . . . . . . . . . . . . . 39,75

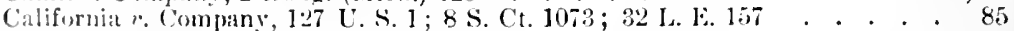

California . li. R, 127 U. S. 1 . . . . . . . . . . . . . . . . . . . 205

California Bank $r$ Kennedy, 167 I. S. $362 ; 42$ L. E. 198 . . . . . . . . 51

Callanan $r$. Windsor, 78 Ja. 193; 42 N. W. 652 . . . . . . . . . . . . 135

Calumet Paper Co. r. ('ompany, 96 Ial. 147;64 N. IV.782 . . . . . . . . 270

Camilen r. stuart $1+1$ U. S. $104 ; 12$ S. Ct. 584 . . . . . . . . . 113

Camp $\therefore$ Byrne, 41 Mo.525. . . . . . . . . . . . . . 40,96, 104,308 
Campbell $v$. Am. Zylonite Co., 122 N. Y. $455 ; 25$ N. E. 859

Canada S. Ry. Co. v. Gebhard, 109 U. S. 527 ; 3 S. Ct. 363

Canfield $v$. Gregory, 66 Conn. 9; $33 \mathrm{Atl} .5: 36$.

40,181

Carmody $v$. l'owers, $60 \mathrm{Mich} .20 ; 26 \mathrm{~N}$. Wr. 80

Carnalian $v$. Camplell, 158 Ind. 226; 63 N. L. 384 . . . . . . . . . . . 267

Carolina Iron Co. $v$. Abernatly, 44 N. C. 545

Carpenter $v$. People, 8 Col. $116 ; 5$ l'ac. 828

Carr $v$. Lal Fevre, 27 Pa. 417

Carroll $v$. Bank, 8 Mo. Ap. $25 \%$

121,135 100

Carroll $v$. Bank, 19 Wash. (6;), ;4 P's. 82

24,27

Carson Rand Co. v. Stern, 12!) Mo. $351 ; 21$ s. W. 77.2

Carter v. Company, 54 Ark. 576 ; $16 \leq .11 .579$

Casey v. Galli, 94 U. S. $67: 3 ; 24$ L. L. 168, :207

Central Ag., etc. Ass'u $r$. Company, 70 Ala. 120

Central Nat. Bank $r$. Compuny, 104 C. S. it

Central Ry Co. $v$. Collins, 40 Ga. 582

Chafee $v$. Bank, 71 Me. $51 t$

Cluaffee $v$. Company, 55 Vt. 110

Chamberlain $v$. Chamberlain, 43 N. Y. 444

Chamberlain $v$. Company, 118 Mass. $55 \%$

Chanberlain $v$. D. S. Works, 103 Mieh. $124 ; 61$ N. W. 522

Clampion Fire Kindler Co. $v$. Rischert, 74 M1. A 1 . $5: 37$

Chandler $v$. Siddle, 5 Fed. Cases No. $2594 ; 3$ 1)illon, 477

Chapman v. Company, ti2 N. J. 457; 41 Atl. 650

Chapman v. Dorily, 89 Cal. 52 ; 20 Pac. (i).

Chase v. Company, 5 Leal ('Temu.), 415

Chase $v$. Fleming, Pac. liep. 194 (not yet reported)

Chase v. Lord, $7 \%$ N. I. 1

Chase Elevator Co. 2 . Company, 152 Nass. 422 ; 28 N. E. 200

66,254

42

192

157,174

102

108

108

36

100

48

$2 \cdot 2$

109

109,291

Chattanooga, ete. Ass'n v. Denson t al., 189 L. S. 108

Chester Gliss Co, v. Hewey, IG Mass. II

Chicago Blig. Ilfg. (Co. e. 1,you, 101$) \mathrm{kl}$ is. 704; 61 l'ac. 6

76,96

34

160

Chills $v$. Cleaves, 95 Me. 495 ; 50 Atl. 714. . . . . . . . . . . . . 287

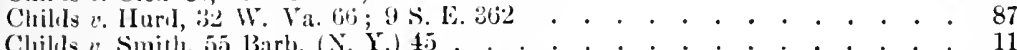

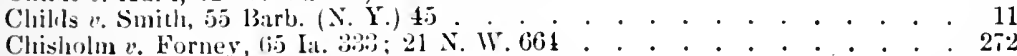

Chonten ins. Co. $v$. Floyll, it

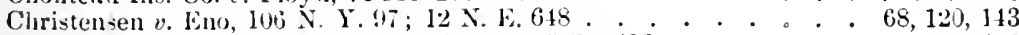

Christian v. A. F. L. \& M. Co., 8' Ala. 198; 7 So. 427 . . . . . . . . . 217

Ciar $v$. Igleliart, 36 St. 457

Cineinnati Coopertge Co. v. Bate, ic K. L. R. 626 ; 2 ; s. W. 598 
Coates r. Nottingham Water Works Co., 80 Beav. 80 . . . . . . . . . 45

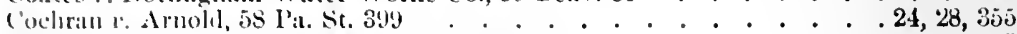

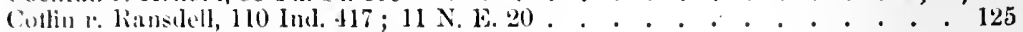

Coit e. Company, $119 \mathrm{U}$. $3.313 ; 7 \mathrm{~S}$. Ct. 231 . . . . . . . . . . . . 124

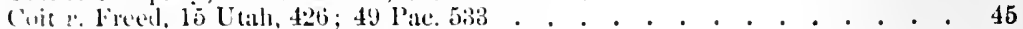

cole 6 dams, 02 Texas, $171 ; 46$ S. W. 790 . . . . . . . . . . . . . 370

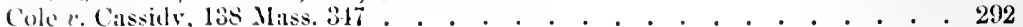

Colentan $c$.llowe, 154 111 458 ; 39 N. 1. 725 . . . . . . . 122, 125, 128, 135

Coler :. Commany, 6.1 N. .J. Eq. 117; 5:3 Atl.680 . . . . . . . . . . . 51

Collier $r$ l)aris 14 Ala. 450 ; 10 So. 86 . . . . . . ... . 217

Colorato Fuel (o. e. Lenhart, 6 Col. Ap. 511 ; 41 Pace 8.34 . . . . . . . . 237

Colorato lron Works Co. $v$. Company, 15 Col. 499 ; 25 Pac. 325 . . . . . . 191

Colwell \&. Sinrings Co., 100 U. s. 55 . . . . . . . . . . . . . . . . 182

Combes 2 . heyes, $89 \mathrm{~W}$ is. 297 ; $62 \mathrm{~N}$. W. 89 . . . . . . . . . . . 155

Combined saw \&laner Co. r Fournoy, ss Va 1029 ; 14 S. E. 976 . . 85, 178

Commereial liank $v$. Lockwood's Admrs., 211 arr. 8 . . . . . . . . . . . 247

Commorcial Bank 2 . Sherman, 28 Ore. 573 ; 4:3 Pace 658. . . . . . . . . . 351

Commercial Nitt. Bink $v$. Burch, 141 Ill. $519 ; 31$ N. 1. 420 . . . . . . . 261

Commissioners $c$. Company, 128 N. C. 558; 39 S. E. 18 . . . . . . . . . 339

Commissioners 2 . Shields, 62 Mo. 217 . . . . . . . . . . . . . . . 308

Commons $v$. Company, 12 I'a. St. 318 . . . . . . . . . . . . . . . 100

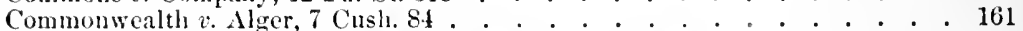

Commonwealtl $v$ v. Company, 129 Pa. St. $405 ; 18$ Atl. 414 . . . . . . . 75, 110

Commonwealth $v$. Company, $52 \mathrm{I}$ 'a. St. $500^{\circ}$. . . . . . . . . . . . . 70

Commonwealth 2 . Company, 5 Nass. 230 . . . . . . . . . . . . . . . . . 157

Commonwealth $v$. Company, 98 P’a. 90 . . . . . . . . . . . . . . . 356

Commonwealth $v$. Cullen, 1 : P'a. St. 13:) . . . . . . . . . . . . . . 46, 146

Commonwealth $v$. Dalzell, $152 \mathrm{~Pa}$. St. $217 ; 25 \mathrm{Atl} .535$. . . . . . . . . 99

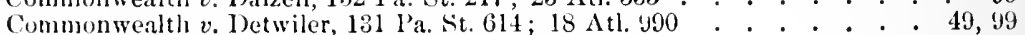

Commonwealth $v$. Ploenix Iron Co., $105 \mathrm{~Pa}$ St. $11 \mathrm{I}$. . . . . . . . . . 354

Commonwealth 2 . Railway, 142 Nlass. $146 ; 7$ N. E. 716. . . . . . . . 291

Commonwealth 2 . Read Plosphite Co., 23 Ky. L. K. 2284; 67 S. W. 45 . . . 280

Commonwealth $v$. Slifer, 58 Pa. St. 71 . . . . . . . . . . . . . . . 156

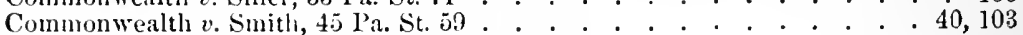

Commonwealth 2 . smith, 10 Allen (Mlass.), 448 . . . . . . . . . . . . 60

Commonwealth r. Stamlarl Oil Co, 101 l'il. St. 119 . . . . . . . . . . 191

Commonwealth $v$. Stevenson, 200 P'a. St. 509; 50 Atl. 91 . . . . . . . . 354

Commonwealth $v$. Water Co., 110 l'a. st. 391 ; 2 Atl. 63 . . . . . . . . 110

Commonwealth $v$. Woelper, 3 S. \& R. (Pa.) 29.9 .503

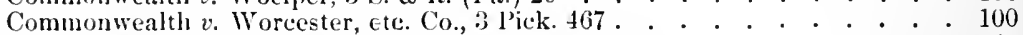

Commonwealth $v$. Yetter, 190 Pa. St. $488 ; 43$ Atl. 226 . . . . . . . . . . . 49

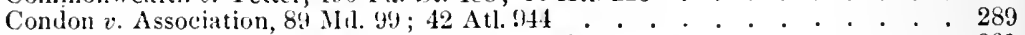

Cone, etc. Co. $x$. l'oole, 41 S. C. $70 ; 19$ S. F. 203. . . . . . . . . . . . 361

Connecticut hiver Bank $\because$. Fiske, 62 N.11. 178. . . . . . . . . . . . 175

Connolly $v$. Union S. I'. Co., 181 U. S. 540 ; 46 L. E. 679 . . . . . . . 168

Comnor v. Abbot, 35 Ark. 366 . . . . . . . . . . . . . . . . 173,225

Continental Trust Co. $x$. T., ete. Ry. Co., 82 Ferl. 642 . . . . . . . . . 88

Continental 'Trust Co. 2 . 'Toledo, etc. Iiy. Co., 72 Fed. 92 . . . . . . . . 45,47

Conway et al., ex jarte, 4 Ark. 302 . . . . . . . . . . . . . . . . 225

Cook 2 . Brick Co., 98 Ala. 409 ; 12 So. 918 . . . . . . . . . . . . . . . . 217

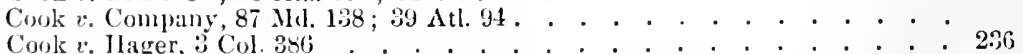

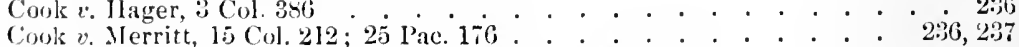

Conke $e$. Marshall, 191 l'a. St. $315 ; 43$ Atl. $314 ; 196$ l'a. St. $200 ; 40 \Lambda$ tl.

417 . . . . . . . . 68, 352,855

Conper $x$ Company, 127 . C. $219 ; 37$ s. 1.216 . . . . . . . . . 898

Conper Iffe. Co. ve Ferguson, 119 U. S. $727 ; 28$ L. L. 1187. . . . . . 191, 192

Corbett $x$. Woorlwarl. 5 Saw. 403 . . . . . . . . . . . . . . . 1103

Corev 2 Horrell, 61 Vt. $598 ; 17$ Atl. 840 . . . . . . . . . . . . . 376

Cork, ete. Ry. Co. v. Cazenove, L. R. 10 A i. \& lil. 33. . . . . . . . . . 71

Corry ". Londonturry, ete. Co., 29 Beis. $272 ; 3$ L. J. Ch. 290 . . . . . . 45

Custellor. Company, 69 N. II. 405; 4:3 Ati. f540 . . . . . . . . . . . 47

Cotton Yills : livrues, 114 N. C. 853; 19 S. E. 2:38. . . . . . . . . 389

Cotton Ulills $t$. Ciston Mills, 116 N. C. 647; 21 S. E. 431 . . . . . . . . 3338

County of Inacon $c$ Shores, 97 U. S. 272 . . . . . . . . . . . . . . 110 
Courtright $v$. Deeds, 37 Ia. 503 .

40,110

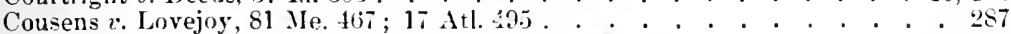

Covington, etc. Co. $e$. Sargent, I Cinn. Sup. Ct. 854 . . . . . . . . . . 45

Cowell v. Springs Co., 100 U.S. 55 . . . . . . . . . . . . . . .40,187

Coyote $v$. liuble, 8 Ore. 284 . . . . . . . . . . . . . . . . .13,98,

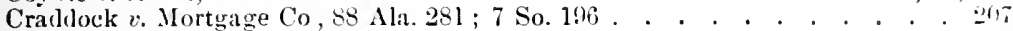

Craig Co. $v$. Smith, 163 Mass. 262 ; 39 N. E 1116 . . . . . . . . . . ill

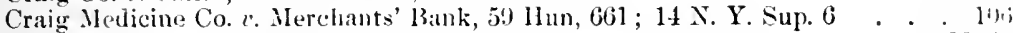

Crandall 2 Lincoln, 52 Conn. 73 . . . . . . . . . . . . . 36,41

Crease $v$. labcock, 23 l'ick. $34 t$. . . . . . . . . . . . . . . . . lit

Createau $x$. Foote Co., 40 An. Div. N. Y. 215 . . . . . . . . . . . . 1.t

Crissey v. Cooke, 67 Kan. 20 ; 72 l’ac. 511 . . . . . . . . . . . . . 43

Cromwell $v$. Ins. Co., 2 lich. Law, 5l2 . . . . . . . . . . . . . . . 350

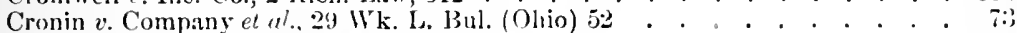

Crook $v$. Company, 87 114. 1:35; 39 Atl. 94 . . . . . . . . . . . . . 27

Cross $v$. Company, 17 Ill. 54 . . . . . . . . . . . . . . . . . . 92

Cross $v$. Company, 90 Pa. st. 392 . . . . . . . . . . . . . . . . 147

Cross $x$. Ry. Co., 35 W. Va. $174 ; 12$ S. E. 1071 . . . . . . . . . . . 376

Crumlisl Adm'r v. Ry. Co, 40 W'. Va. 627; 22 S. E. 90 . . . . . . . . . .

Crystal Ice \& Mffg. Co. c. State, 23 Tex. Civ. App. $293 ; 56$ S. W. 562 . . . 350

Cummer Lumber Co $c$ Company, 67 N. Y. Ap. Div. 151 . . . . . . . . 19

Curie $v$. Santini, 16 La. Ann 27 . . . . . . . . . . . . . . . . . 27

Curran $x$. Bradner, 27 1ll. A 1. 582 . . . . . . . . . . . . . . . . . 51

Currier $v$ ('ompany, 56 N. 14.262 . . . . . . . . . . . . . $31 \mathrm{i}$

Curry $r$. Scott, 54 Pa. $5 t .270$. . . . . . . . . . . . . . . . . 4.

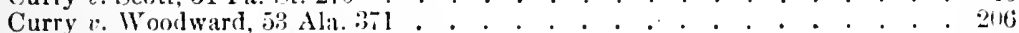

Curtis v. Tracey el al., 62111. Ap. 49 . . . . . . . . . . . . . . . . 84ti

Curtiss $v$. Murray, 26 Call 633 . . . . . . . . . . . . . . . . . 31, 219

D.

D. F. Co. v. Augustine, 5 Wash. 67 . . . . . . . . . . . . . . . . 180

D. H. Co. r. Marsh, Fell Cases, 4014. . . . . . . . . . . . . . . . 83

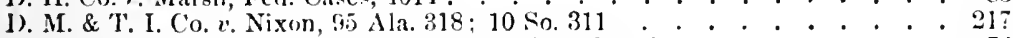

J). S., etc. Co. ". Altorney-General, 21 Can. Sup. Ct. 72 . . . . . . . . . it

D. \& (.. F. Co. ". People, $156111.448 ; 41$ N. 1. 188 . . . . . . . . 263

1). \& II. Canal Co. v. Mahenbrock, 63 N. J. L. $281 ; 43 \mathrm{Atl} 978$. . . . . . 928

J). \& S. Ry. Co. v. J) ( . Rr. Co., 2 Col. 67:3 . . . . . . . . . . . . 235

Daly $\iota$. Company 61 Inll 1 . . . . . . . . . . . . . . . . . . 180

Jana 2 lank, 5 W. \& S. (l'a.) 247 . . . . . . . . . . . . . . . . 67

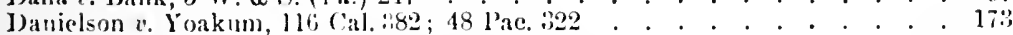

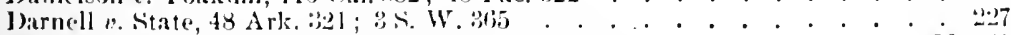

Jartmouth College ". Womlward, 14 Wheat 518 . . . . . . . . 153, liil

Javenport \% Lines, 72 conn. $11 \times ; 14 \lambda$ tl 17 . . . . . . . . . . . 241

1)it venport Nitt. laank 1 . Warris, 4:3 la. 424: 15 N. W. 865 . . . . . . . . 80

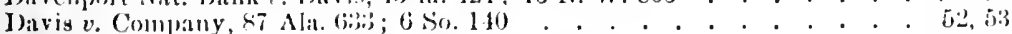

Javis $v$. Company, 2 Utah, 7 I. . . . . . . . . . . . . . . . 108

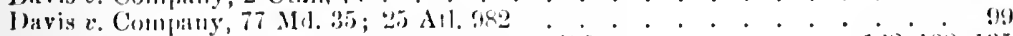

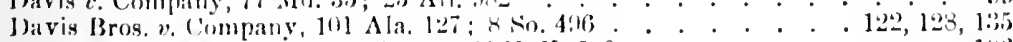

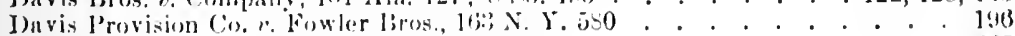

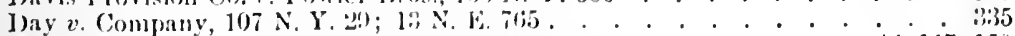

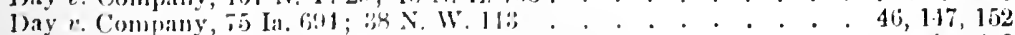

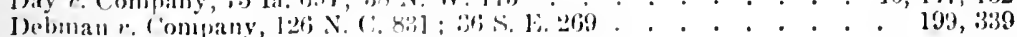

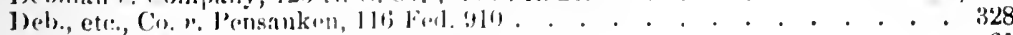

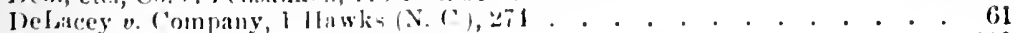

Delatielu $\because$ Illinois, 2 llill (N. Y) 172 . . . . . . . . . . . . 110

De Ia Vergne liefrigerating Machine co.r. cicr. siv. lin, 175 U. S. $40 ; 20$

S. ('t. 2) . . . . . . . . . . . 86, 37, 144

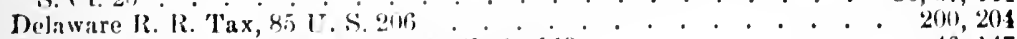

Delaware Ry. Co. v.'Tharp. I Hont. (1)el) 119 : . . . . . . . . 46, 147

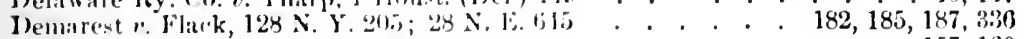

Denike $v$. Company, 80 N. Y. $59 \%$. . . . . . . . . . . . . . 157,160 
1)ensmore Oil Co. r. 1)ensmore, 64 Pa. St. 43

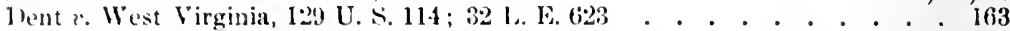

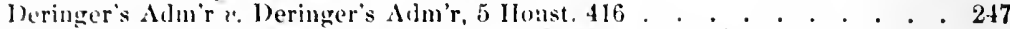

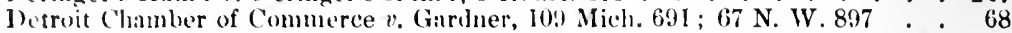

Detroit Chamber of Commerce $v$. State Secretary, 109 Mich. 691; $67 \mathrm{~N}$. W. $5: 17$

1)etroit Citizens' Street liy. Co. v. Common Conncil, 125 Mich. $673 ; 85 \mathrm{~N}$. W. 116

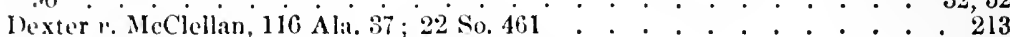

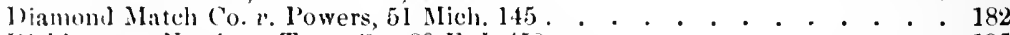

1)ickinson r. Northern Trust Co., 80 Ferl. 452 . . . . . . . . . . . . . 125

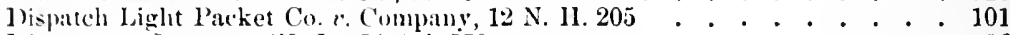

1)ittm:m $r$. Company (N. J.), $54 \Delta$ ti. 570 . . . . . . . . . . . . . . 16

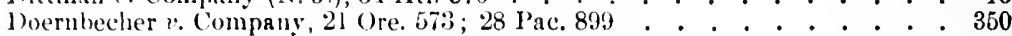

I)onald $\because$. Company, 61 N. J. Eq. $458 ; 48$ Atl. 786 . . . . . . . . . . 138

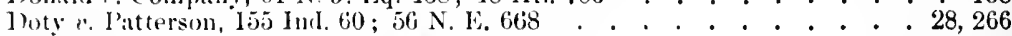

1)ourlass $\because$ Company, 118 N. Y. $484 ; 23$ N. F. 806 . . . . . . . . . . 61

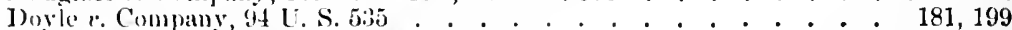

lovle $r$. Mizner, 4 Mich. $332 ; 8$ N. W. 968 . . . . . . . . . . . . 79,80

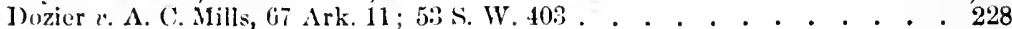

1)roege $x$. Compiny, l63 N. Y. $466 ; 57$ N. E. 747 . . . . . . . . . . . . . 191

Droitwitch Pat. Salt Co. v. C'urzon, L. R. 3 Lx. 35 . . . . . . . . . . 57

1)rummond's Case, I. R. 4 Ch. Ap. 772 . . . . . . . . . . . . . . 49,113

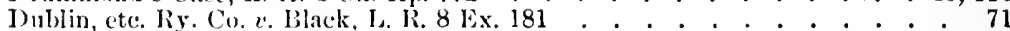

I) ncat v. Chicago, $10 \mathrm{~W}$ Wall. (U. S.) 415 . . . . . . . . . . . . . . . . 181

I) ulley $v$. Collier, 87 Ala. 4il . . . . . . . . . . . . . . . . . . . . . 198

1) negran $v$ Company, 11 Col. 119; 17 Pac. 105 . . . . . . 21, 27, 88, 91, 235

I) nke $t$. Taylor, 37 Fla. $64 ; 19$ So. $172 . . . \quad . \quad . \quad .96,103,104,182,252,254$

1) ulnth Club $v$. McIonald, 74 Mim. 254; 76 N. W. II28 . . . . . . . . 48

1) unbarton Fiax Spinning Co. . Greenwich \& Johnsonville Ry. Co., 87 N. Y.

Ap. Joiv. 21 . . . . . . . . . . . . . . . . . . . . . . 196

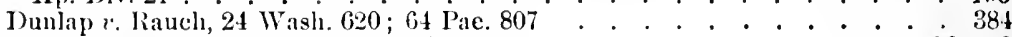

1)urfee ¿. Company, 5 Allen (Mass.), 230 . . . . . . . . . . . . . . . . 1 16, 149

Turkee $\%$ People, $155111.951 ; 40$ N. 1. 626 . . . . . . . . . . . . . . 57

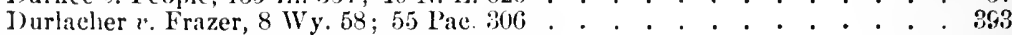

I) ykman $v$. Keeney, 160 N. Y. 677 ; 54 N. E. 1090 . . . . . . . . . . 57, 174

F.

F. G. L. Co. ". Green, 49 N. J. Eq. $329 ; 24$ Atl. 560 . . . . . . . . . 93, 325

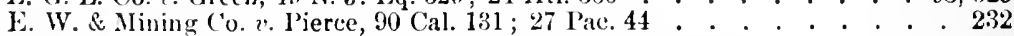

¿. \& N. Y.C. R. R. Co. $v$ Owen, 32 Barb. (N. Y.) 616 . . . . . . . . . . . 12

F. \& S. A. II. \& I. Co. ^. Ilarly, 9: Texas, $289 ; 55$ S. W. 169 . . . . . . 199

Fagle Insurance Co. $\%$ State of Olio, 153 U. S. 446 . . . . . . . . . . 165

Jakins $x$. Company, 75 Mich. $568 ; 42$ N. IV. 982 . . . . . . . . . . . 296

Eakright r. ('ompany, l3 Ind. 404 . . . . . . . . . . . . . . . 67,92

la-t X. Y.J. R. Co v. Lighthall, 36 iJow. Pr. 481 . * * . . . . 121

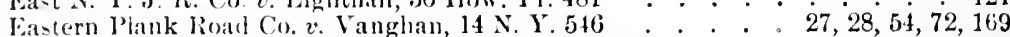

Eastern T'rust \& Banking Co. r. Willis, (6 I). C. Ap. 375 . . . . . . . . . 250

Eilison Co. $:$ Canadian Co., 8 Wash. $370 ; 36$ Pac. 260 . . . . . . . . . . 385

Elwarls 2 Conpany, 27 la Ann. 474. . . . . . . . . . . . . . . 125

Elwards r. Denver \& li. G. R. Co., 19 Col. 59; 21 lac. 1011 . . . . . . . 85

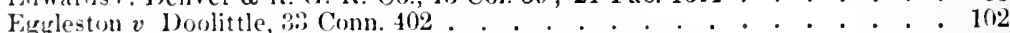

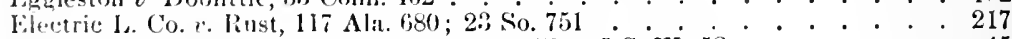

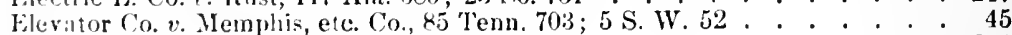

Elkins e. Conmany, :36 N.J. Eq. 2\%3. . . . . . . . . . . . . . . . 320

Filerman v. Ry. Co., 49 N. J. Viq. $217 ; 29$ Atl. 287. . . . . . . . . . . 107

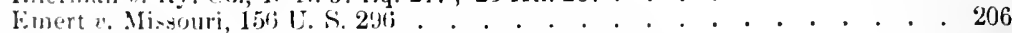

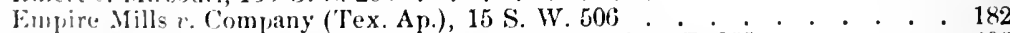

Enteruriue Brewing Co. r. Grime, lis Mass. $252 ; 59$ N. E. 855 . . . . . . . 295

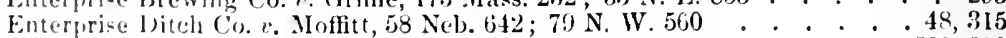

Eric li. R. $r$.'ennsylvania, Ijo U. S. 4;7 . . . . . . . . . . . . . 209, 210. 
Esgen $v$. Smith, 119 Ia. 25; 84 N. W. 954 . . . . . . . . . . . . . . 141

Erans $v$. Lee, 11 Nev. 194 . . . . . . . . . . . . . . . . . 180, 320

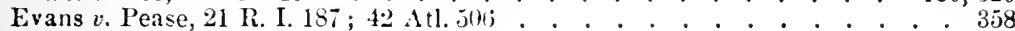

Everetts $v$. Company, 20 Conn. 443 . . . . . . . . . . . . . . . . 156

Ewing $v$. Company, 56 Cal. 649 . . . . . . . . . . . . . . . . . 232

Ex parte Fisher, 20 S. C. 190 . . . . . . . . . . . . . . . . . . 359

Ex parte Frank, 52 Cal. 606 . . . . . . . . . . . . . . . . . . 100

Ex parte IIolmes, 5 Cowen (N. Y.), 428 . . . . . . . . . . . . . . . . . 99

Fx purte Pritz, 9 Ia. 30 . . . . . . . . . . . . . . . . . . . . 10

Ex parte Spring Valley Water Works, 17 Cal. 132. . . . . . . . . . 82

Ex parte S. \& W. W.. 17 Cal. 132 . . . . . . . . . . . . . . 230

Eyre $r$. Harmon, 92 Call. 580; 28 Pac. 769 . . . . . . . . . . . . 175

F.

F. A. A. M. Co. $v$. Thies, 26 Ner. 158; 65 Pac. 373 . . . . . . . . . . 319

F. B. Co. $v$. Wood, 14 Ga. 80 . . . . . . . . 84

F. B. D. G. Co. $v$. Lester, 60 Ark. $120 ; 29 \mathrm{~S}$.W. 34 . . . . . . . . . . 192

F. C. T. Co. $v$. Floyd, 470 . St. 525 ; 26 N. E. 110 . . . . . . . . 176

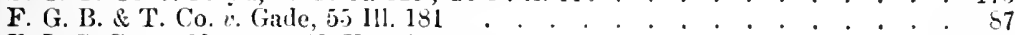

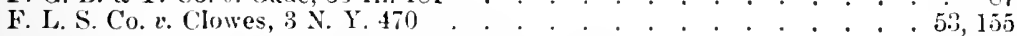

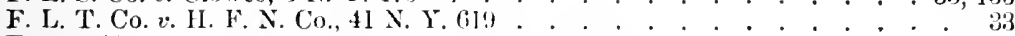

F. L. \& T. Co. v. Funck, 49 Nel. 353 ; 68 N. W. 920 . . . . . . . 316

F. M. \& Co. v. MeLeod, 8 Col. Ap. 190; 45 I'ac. 282. . . . . . . . . . 230

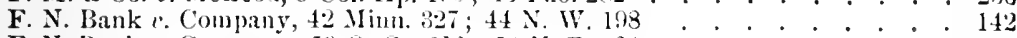

F. N. Bank $x$. Company, 59 O. St. 316 ; 52 N. E $334 \div 29$

F. \&. M. Co. v. Foster, 4 lak 329 . . . . . . . . . . . . . . . . 191

Fairchild $v$. Association, 71 Mo. 520 . . . . . . . . . . . 32, 73

Falconer $\because$. Camplell, 8 led. Cases, 4120 ; 2 HeLesn, 195 . . . . . . 30, 212

Falls $v$. U. S. S. L. \& B. Co., 97 Ala. 41 ; $1: 3$ So. 25. . . . . . . . . . 217

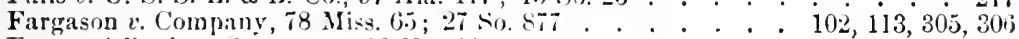

Farmers' Bank v. Company, I0S Jy.4t7; 5i s. W. 719. . . . . . . . . 60

Farmers, etc. Bank $v$. Wasson, 45 Ia. 830 . . . . . . . . . . . . . . 47

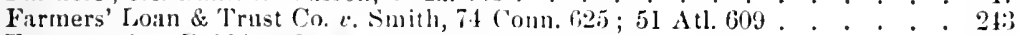

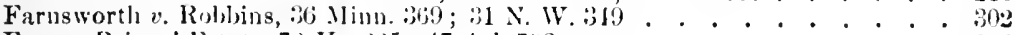

Farr v. Briggs' Estate, 72 Vt. 22:; 47 Atl. 793. . . . . . . . . . . . 876

Farrior $v$. N. L. M. S. Co., 88 Ala. $275 ; 7$ So. 200 . . . . . . . . . . . 217

Fanlis 1 Gates, 5 ill 416 . . . . . . . . . . . . . . . 102,103

Fawcette $v$. Clatrles, $1: 3$ IVend $47 ;$. . . . . . . . . . . . . . . . . 61

Featherstonhaugl $\iota$. Company, I. K. I Ex. 318. . . . . . . . . . . . 51

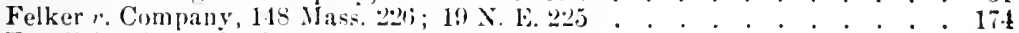

Fertilizing Co. Il Iyle l'ark, 97 U. S. 659 . . . . . . . . . . . . . . 102

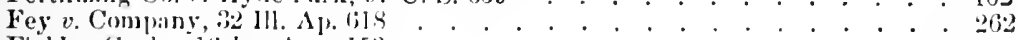

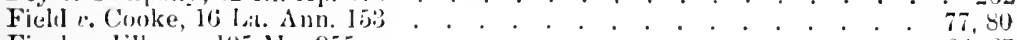

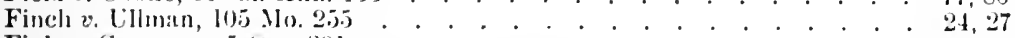

Fink e. Company, 5 (1re 301

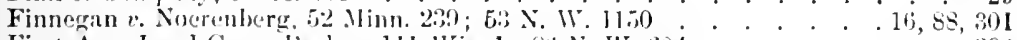

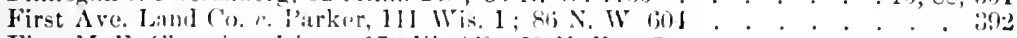

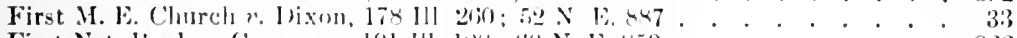

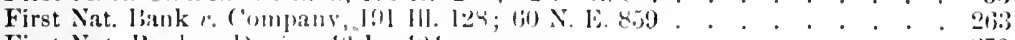

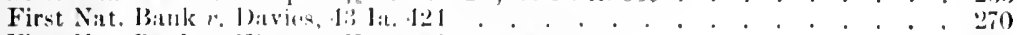

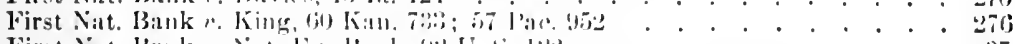

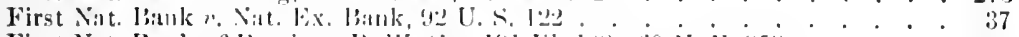

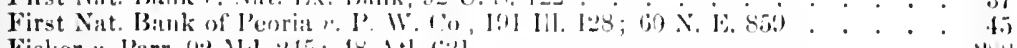

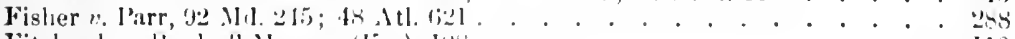

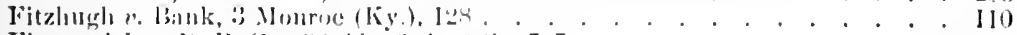

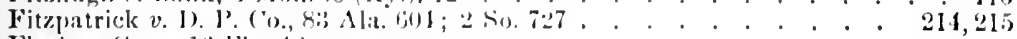

Flash ". Conn, lo lila lex . . . . . . . . . . . 109

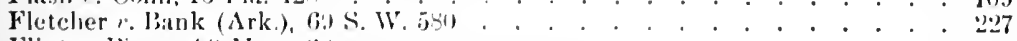

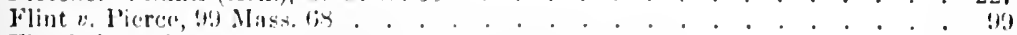

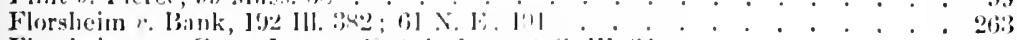

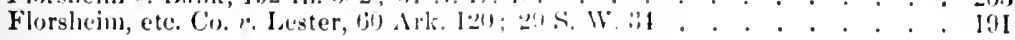


Fhoy u. N. L. \& I. Co., 49 W. Ya. $827 ; 38$ S. E. 653 . . . . . . . . . . 389

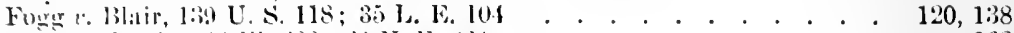

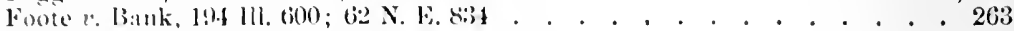

Ford 1. Association, $155111.166 ; 39$ N. L. 651 . . . . . . . . . . . 168

Forrester $\because$ (ompany, 2l Mont. 54 ; 55 P'ac. 22! ; 74 1'ac. 1088 . . . . . 51

Fortier ı. liank, $11: 2$ U. S 439 ; 5 S. Ct. 23. . . . . . . . . . . . . 28

Foster 1. lalllk, 10 llass. 245 . . . . . . . . . . . . . . . 53

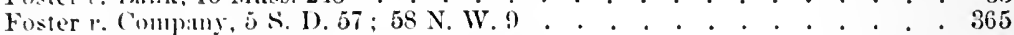

Foster r. Kinsis, li2 U. S. $201 ; 28$ L. 1. 269 . . . . . . . . . . 155, 16:3

Fonclse r. liank of kome, 110 Gat 827 ; 36 s. . 256 . . . . . . . . . . 250

Fox 2 . Comprny, $108 \mathrm{Cal} .48$; 41 l'ae. 328 . . . . . . . . . . . . 232

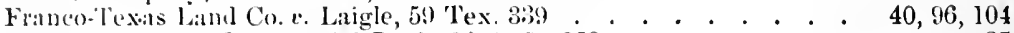

Franklin liank r. Commercial Bank, 36 O. St. 258 . . . . . . . . . . 37

Franklin Brilge Co. $r$. Wood, 14 Ga. 80 . . . . . . . . . . . . . . 109

Franklin Company $v$ Bank, 68 Me. 43 . . . . . . . . . . . . . . 285

Freeman $r$ complany, 38 He. 343 . . . . . . . . . . . . . 96, 104, 285

Freon r. Conphy 420. St. 30 . . . . . . . . . . . . . . . . 105

Fritts $v$ l'ilmer, 132 U. S. 288 . . . . . . . . . . . . 184, 192

Frost 2 Company, 57 Miun. 325 ; 59 N. W. 308 . . . . . . . . . . . 302

Frost Mfg. Co. roster, 66 Ia. $585 ; 41 \mathrm{~N}$.W. 212 . . . . . . . . . . 271

Frostberg Ilin. Co. r. Company, 81 Mld. 23 . . . . . . . . . . . . . 176

Fry's kxecutors $v$. Company, 2 Hete. (Ky.) 322 . . . . . . . . . . . . 146

Füller $v$. lowe, $5 \mathrm{i}$ N. Y. 23 . . . . . . . . . . . . . . . . . 173

G.

G. B. \& M. R. Co. $v$ Union Steamboat Co., 107 U. S. 98 ; 27 L. E. 413 • . . 15

G. I. \& E. Co. v. Toler, $80 \mathrm{Md} .278 ; 30 \mathrm{Atl} .651$. . . . . . . . . $10 \mathrm{t}, 106$

G. I. R. G. M. Co. r. G. R. Co., 128 U. S. 598; 9 S. Ct. 166 . . . . . . 14

G. L. \& II. 1. Co. $v$ Kimper, 73 Ala. 325 . . . . . . . . . . 10, 28, 41, 216

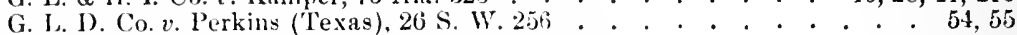

G. II. \& S. Co. r. Richards, 95 Ho $106 ; 8$ S. W. 246 . . . . . . 87, 92,93

G. R. B. Co. $v$ Rollius, 13 Col. 4 ; 21 lace 817 . . . . . . . . . . . . 235

G. R. L. Co. $x$ Company, 6 N. Dak. $276 ; 69$ N. W. 691 . . . . . . . . 342

G. \& A. Co $r$ Complny, 45 Neb. $393 ; 64$ N. W. 978,1097 . . . . . . 316

Gade e. Cumpany, 16: lill. 367 ; 46 N. E. 286 . . . . . . . . . . . . . 93

Gainey r. Gilson, 149 Ind. 58; 48 N 1. 683 . . . . . . . . . . . . . 267

Gale IIfg. ('o. v. Finkelstein, 22 Tex. ('iv. Ap. 241 . . . . . . . . . 191

Galveston, ete. Ry. Co. $v$ Cowdrey, 11 Wall. $459 ; 20$ L. E. 199 . . 40, 96, 101

Gamble v. (2. C. W. Co., 123 N. Y. 91 ; 25 N. E. 201 . . . . . . . 125, 190, 149

Gans 2. Switzer, 9 Hont. 408 ; 24 Pac. 18 . . . . . . . . . . . . 312,313

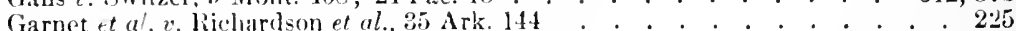

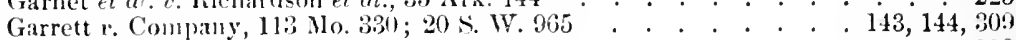

Garrett Furd ('o. e. Company, 20 li. I. 189 . . . . . . . . . . . . . 198

Garrison P. IInwe, 17 N. Y. 458 . . . . . . . . . . . . . . . . 175

Gary v. Company, 9 Utah, 461 ; 35 Pac 494 . . . . . . . . . . . . 112

Gen. Electric ('o. $r$ Inima Electric Co., 4 Uhio Nisi P'rius Rep. 167 . . . 316

Gent 2 . Company, 107 111. 652. . . . . . . . . . . . . 87,94,95

Gent $x$. .1. \& II. I. (o., 107131.652 . . . . . . . . . . . . . . . . 262

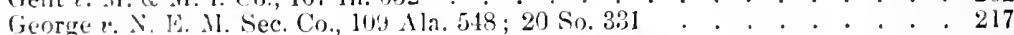

German Xatt Bank v. K. T. Co. 19 Ky. Law Rep. 361 ; 40 S. W. 158. . . . 278

Germania \at. Bank \%. Case, y.) U.S. 628 . . . . . . . . . . . 172

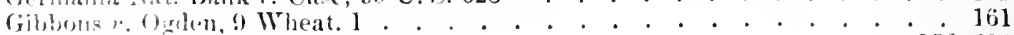

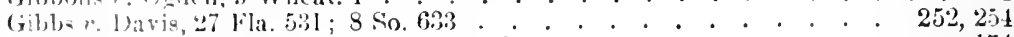

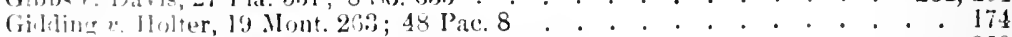

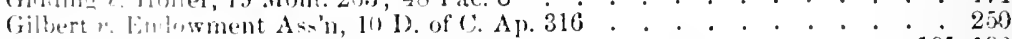

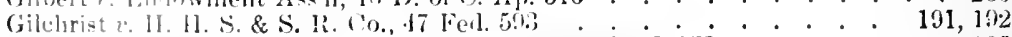

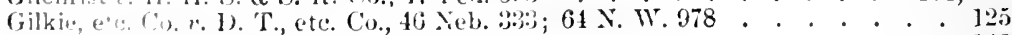

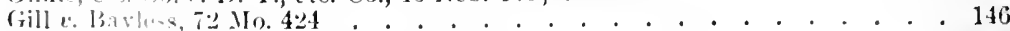

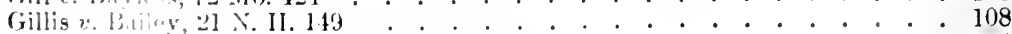

Gitlers e Clarke, 1; l'a. St. $616 ; 28$ Atl. 232 . . . . . . . . . 174 
Glass Co. v. Company, 32 Ind. 376

Glenn $v$. Hunt, 120 IL. $380 ; 25$ S. W. 181 . 171

Glenn Falls l'aper Co $v$. White, 18 Ilun (N. Y.), 214 . • . . . . . . . 175

Globe Realty Co. v. Whitney, ló La. Aun. $257 ; 30$ So. 745 . . . . . . . 242

Gloucester Ferry Co. $\iota$. l'ennsvivania, 114 U. S. 196 . . . . . . . . . . . ؛10

Goddard 2. Crefields Mills, T5 Fed. 818; 21 C. C. A. 530 . . . . . . . . 196

Godlard $v$. Merchants' Ex., 9 Mo. Ap. 290 . . . . . . . . . . . . . 100

Gollberry $v$. Carter, 100 Va. $438 ; 41$ S. E. 858 . . . . . . . . . . . . 382

Golder 2: Bressler, 105111.419 . . . . . . . . . . . . . . . . . . 147

Gomlriclt $x$ Reymolds, 31 lll. 490 . . . . . . . . . . . . . . . . . . 121

Gorder $v$. Connor, 56 Neb. $781 ; 77$ N. W. 383 . . . . . . . . . . . . 316

Gurilon v. Appeal Tax (ourt, 44 U. S. (3 How.) 13:); 11 L. \&. 529 . . . . 85, 203

Gures $v$. Day, 99 Wis. $276 ; 71$ N. W. 787 . . . . . . . . . . . 381-3.11

Graham v. Company, 118 U. S. 161 ; 6 Sup. Ct. 1009 . . . . . . . . . 98

Granby Co $v$. Ricliards, 95 Mo. $196 ; 8 \mathrm{~S}$. W. $246 \quad$. . . . . . . . . . 83,303

Grand Lodge $v$.Graham, 96 Ia. $592 ; 65$ N. W. 837 . . . . . . . . . 15, 31

Grand River College v liobertson, 67 Mo. Ap. $329 \quad$. . . . . . . . . . . . 46

Graves $v$. Brooks, 117 Mich. 424; 75 N. IV. 432 . . . . . . . . . . . . 298

Green $v$. Association, 105 Ia. 628 ; 15 N. W. 995 .

Green $v$. Breard, 35 La. Ann. 875. . . . . . . . . . . . . . . . . 16

Green $v$. Demis, 6 Conn. 304 . . . . . . . . . . . . . . . . . . . . . 32

Greenbrier Ex. $v$ lioles, 87 W. Va. 738; it S. E. 805 . . . . . . . . . . 346

Green Co. v. Blodgett, 55 IH. Ap. 556 . . . . . . . . . . . . . . . 32

Greene $v$. Company, 62 O. St. 67 ; 56 N. E. 642 . . . . . . . . . . . . 343

Greene $v$. Jlosten et al., 66 Itl. App. 345 . . . . . . . . . . . . . . . 262

Greenougl $v$. Company, 61 led. 22 . . . . . . . . . . . . . . . . 101

Greenville Compress \& Warehouse Co. 2 . Company, 70 Miss. 669; 13 So. 879

Greenwood $v$ Company, 105 U. S. 13 .

Gregory v. Bank, 3 Coll 322. . . . . . . . . . . . . . . . . . . 237

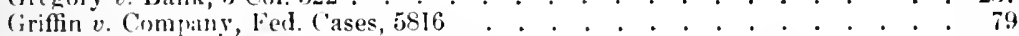

Grimlle $\because$ Sinne, 78 Me $176 ; 3 \Lambda t .180^{\circ}$. . . . . . . . . . . . . . . 265

Grocer Co. v. Crow, :3: Mo. Ap. 288 . . . . . . . . . . . . . . . . . . . . . . . 509

Grubb v. Company, 14 la. St. 300 . . . . . . . . . . . . . . . . 21

Gulliver r. Rodle, 100 Ill. 141 . . . . . . . . . . . . . . . . . . 13

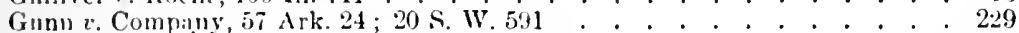

Guntlier $v$. Company, $107 \mathrm{Ky} .41 ; 52 \mathrm{~S}$. W. 931 . . . . . . . . . . 75,175

II.

H. D. P. Ass'n v. Stevens, 31 Neb. 528; 52 N. W. 568 . . . . . . . . . 68

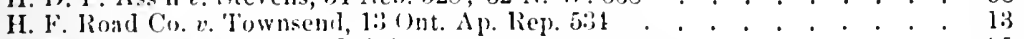

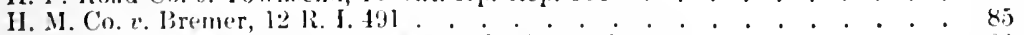

II. W. I Co. $r$ N. Y. II. I. Co., 110 N. Y. $91 ; 30$ N. E. 417. . . . . . . . 84

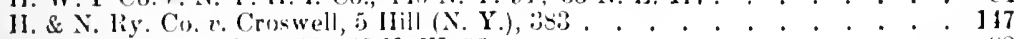

Hatas v. Pank, 11 Neb. 751 ; 60 N. W. 85 . . . . . . . . . . . . . . 88

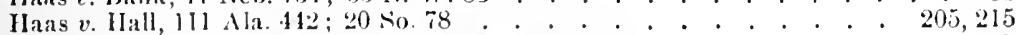

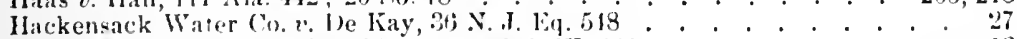

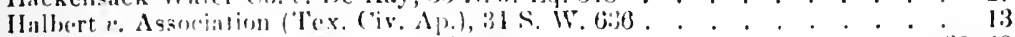

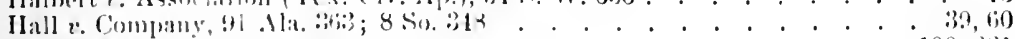

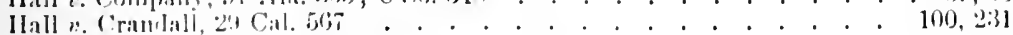

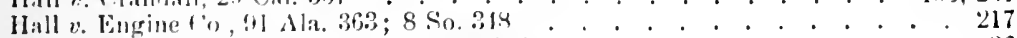

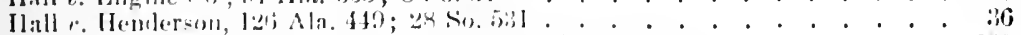

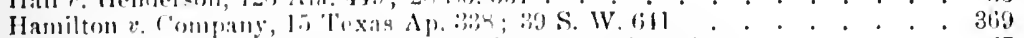

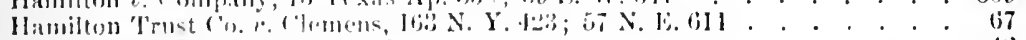

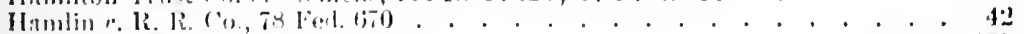

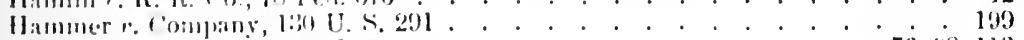

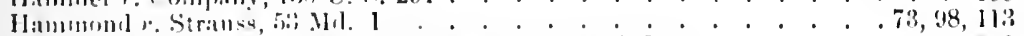

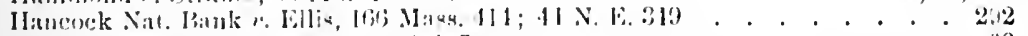

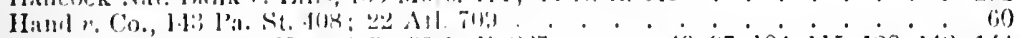

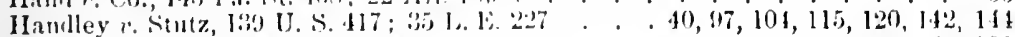

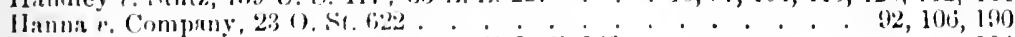

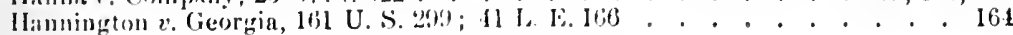


IIs] r. Mill Co., 39 Mo. Ap. 45:

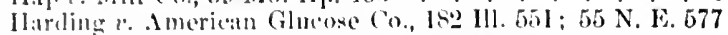

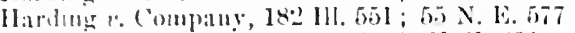

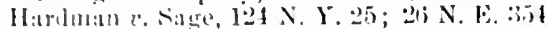

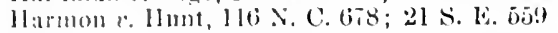

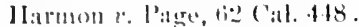

llarrell 2 . Bkount, 172 (ia. 711 ; 38 S. E. 56

llarrington e. (ombor, 51 Neb. $211 ; 70 \mathrm{~N}$. W. 911

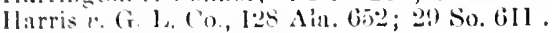

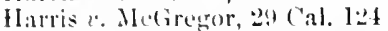

11:art 2 . Company, 40 ('omn. 5')4

Ilart $\because$. Livemore Co., 72 Mis. 809 ; 17 So. Fos

llartford Fire Fus. Co. ". Raymoml, 70 Mich. 485 ; 38 N. IV. 74

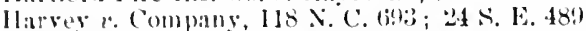

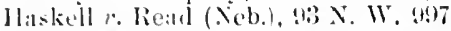

IIasting Malting (o. ('ompany, (io Minn. $28 ; 67$ N. IV. 652

Ilastings $x$. Anacortes, ete. ('o., 2!) Wash. 244: 69 Jac. 776.

Hastings 2 . Company, 2!) Wasli. 224; 69 ]'ac. 776 .

llawes 2 . Anglo-sitxon Co., 101 Mass. 285

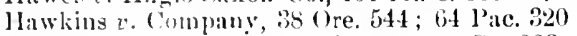

Haylen $x$. Allanta cotton Factory, 6I Ga. 233

Hairs $r$. Merkle, 70 Mo. 5ug.

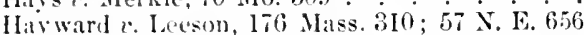

Hazelton Boiler ('o, v. Company, 1:7 111.231; 28 N. 15. 248

Ilazelton boiler Co. $r$. Company, 142 Ill. 494; 30 N. E. 839

ILtalu e. Owen, 79 la. $23 ; 44$ N. W. 210

Heath $v$. S. L. Mining Co., 39) Wis. 146

lleck $x$. Alcliwen, I2 Lea (Tenn.), 97

Hegrie $v$. Association, 107 N.C. $581 ; 12$ S. L. 27.5

Heileman Co. $v$. J'eineisl, 85 Minn. I2I; $88 \mathrm{~N}$. W. 441

Ileineg $r$. Company, sI liy. 300; 5 liy. L. Rep. 281

llellerman $x$. Naier, 116 Cal. $416 ; 48$ Jac. 877

Jeminway 2 . Heminway, 58 Conn. 449 ; 19 A 1.766

IIemderson c. Turngreen, 9 Utal, $4: 22$; 85 Pac. 495.

Hendrix $v$. Acatemy of Music, 7:3 Ga. 437

Hener $x$. Carnuchael, 82 Ia. $288 ; 47$ N. IV. 1094

Hennesey $r$. Mnlleman, 49 N. Y. Ap. Div. $175 ; 57^{\circ}$ N. Y. S. $80^{\circ}$

Henry r. Gt. Northern Ry. Co., 4 K. \& J. 1 ; 27 1. J. Cl. I

Hequembourg r. Whards, $155 \mathrm{No} .514 ; 55 \mathrm{~s}$. W. 490

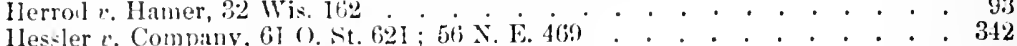

Hener $r$. Carmichael, s2 Ia. $258 ; 47$ N. W. 1084 . . . . . . . . . . 75, 270

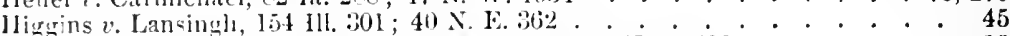

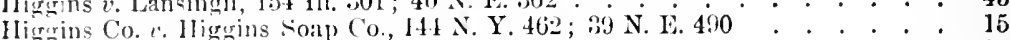

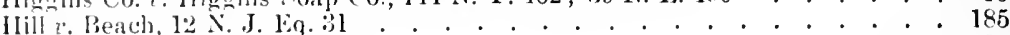

Ilill e. Nislet, log Inil. 811 . . . . . . . . . . . . . . . . . . 37,38

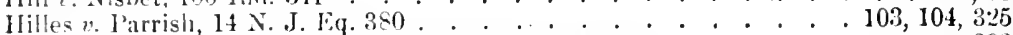

IInckley t al. $x$. Pfiester ot al., 83 Wis. $64 ; 33$ N. W. 21 . . . . . . . . 393

Hockett r. State, 105 Iml. $250 ; 5$ N. L. 178 . . . . . . . . . . . . 269

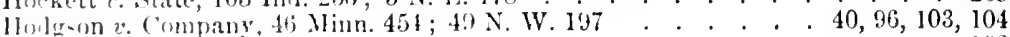

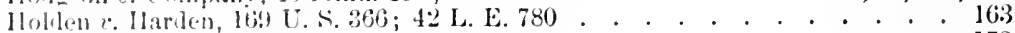

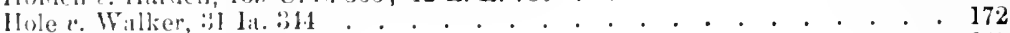

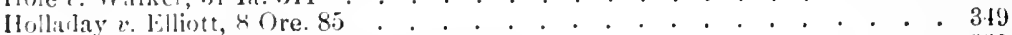

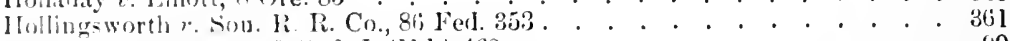

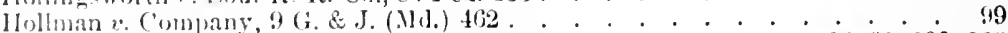

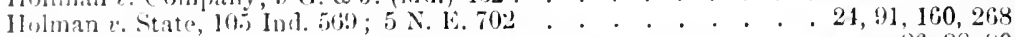

llolmes r. Gilliland, 41 Barb. (X. Y.) $56 \%$. . . . . . . . . . 26, 28, 80

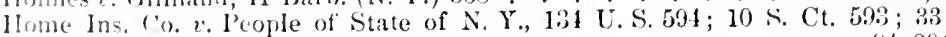
L. J., I 1,21

IIserl v. ("ompany, 42 Conn. 112

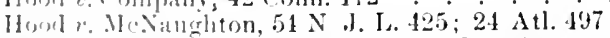

$84,204,205$

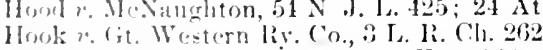

II

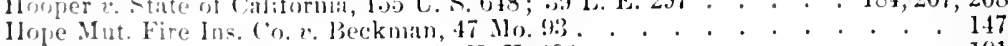

Hope Mut. Life Ins. Co. $v$. Perkins, 38 N. Y.401 
Horn Silver Min. Co. $\imath$. New York, 14:, C. S. 314 . 181, 192, 199, 200, 204, 205, 208

IIorn Silver Min. Co. $v$. Rran, 42 Ilinn. $190 ; 44$ N. W. 60. . . . . . . . 17j

Hornor $v$. Henning. 98 U. F. . . . . . . 17

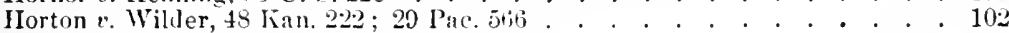

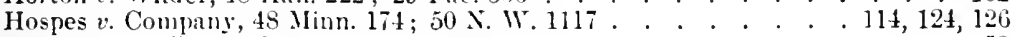

Houston $v$. Jefferson College, 63 1’a. St. 428 . . . . . . . . . . . . . . . 58

Howarl v. Association, 1.25 N. C. $49 ;$; S. E. 1!9 . . . . . . . . . . 339

Howe $v$. Scarborough (Ali.), 35 So. 113 . . . . . . . . . . . . . . . . 101

Hoyt $i$. Qnicksilver Minine Co., TS X. Y. 159 . . . . . . . . . . . . 45

Hoyt $v$. 'Thompson, etc., 19 X. Y. 207 . . . . . . . . . . . . . . . 108

Huffman $v$. Company, 19 Tex. Civ. Ap. I69 . . . . . . . . . . . 180, 199

IIughes $v$. Bank, 5 Litt. (Ky.) 45 . . . . . . . . . . . . . . . . 88

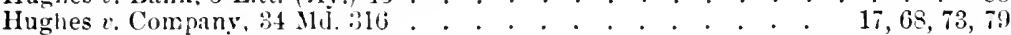

Hughes $v$. Parker, 20 X. II. 08 . . . . . . . . . . . . . . . . . . . . . . . . 74

Hugliesdale Mfg. Co. r. Vanner, 12 R. I. $491 \quad$. . . . . . . . . . . . 160, 178

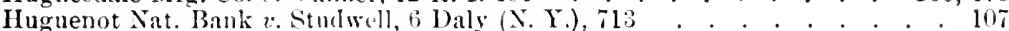

Humaston $v$. Company, 20 Wall. 20 . . . . . . . . . . . . . . . . 125

Humphreys $v$. Iloomey. 5 Col. $282 \quad . \quad . \quad . \quad 40,79,80,87,92,96,98,285,230$

Hunt $v$. Company, 11 kan. 112 . . . . . . . . . . . . . . . . . . 92

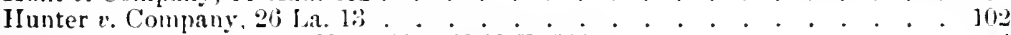

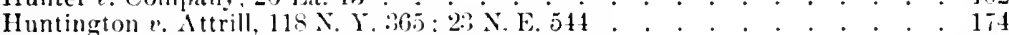

IIurlbut $v$. Marshall, 62 Wis. $590 ; 2.2$ N. W. 852 . . . . . . . . . . 67, 101

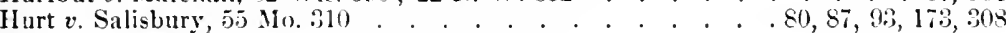

Iutton $v$. Scarborough Hotel Co., 2 Irew. \& Sim. 51t . . . . . . . . . 45

I.

I. O. of F. v. Commissioner, $98 \mathrm{~W}$ is. $91 ; 73 \mathrm{~N} . \mathrm{W}, 826$. . . . . . . . . 390

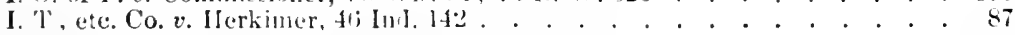

I. W. C. Co. v. I'earsun, $140111.42: 3 ; 31$ ‥ 1\%.400. . . . . . . . . . . 81

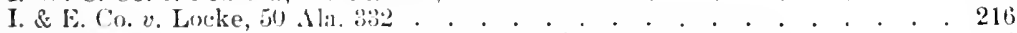

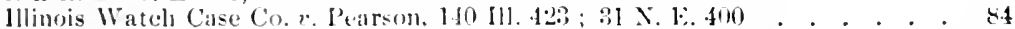

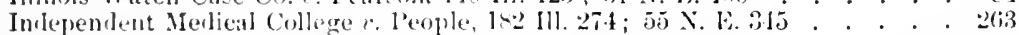

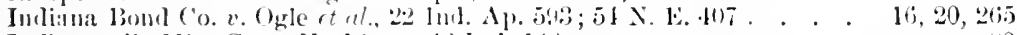

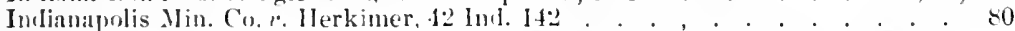

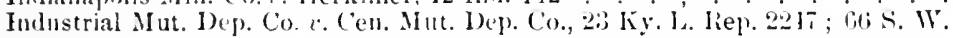
$10: 3: 2$

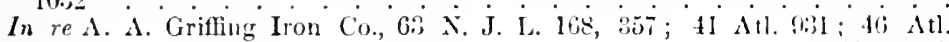

$1097.0 .0 .40 .46,76,103,107$

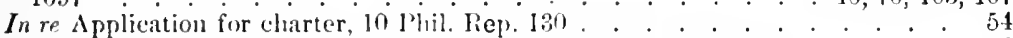

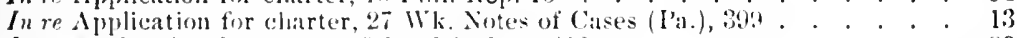

In re Application for charter, 5 l'a. l)is. Jicp. 2li; . . . . . . . . . . . 83

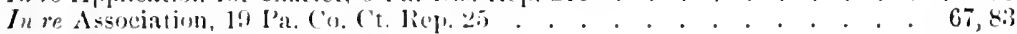

In re Barneds Biskery ('o., l. R. 2 ('lı. 674 . . . . . . . . . . . . . 24

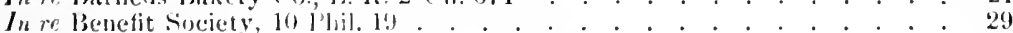

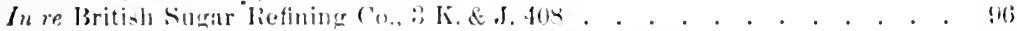

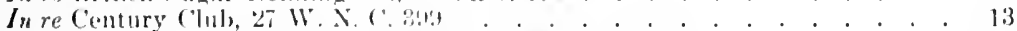

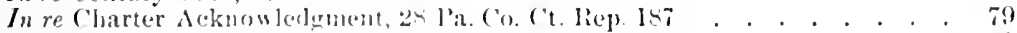

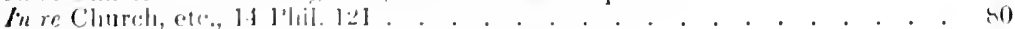

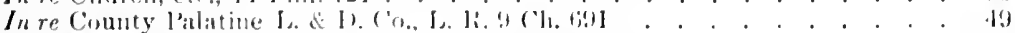

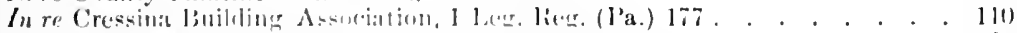

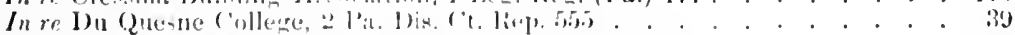

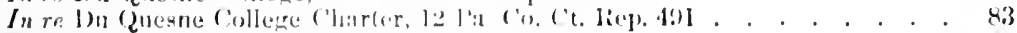

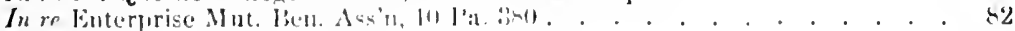

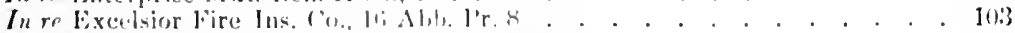

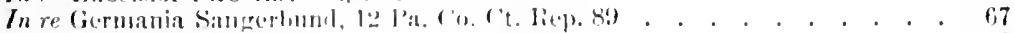

In re filho liatate 107 l'al. St.

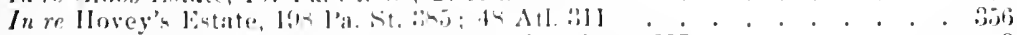

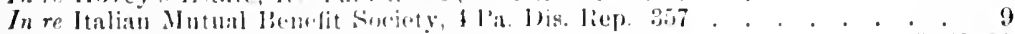

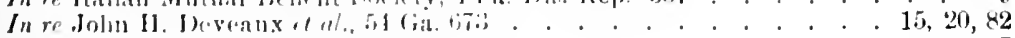

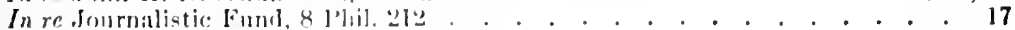

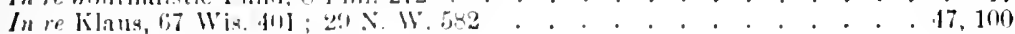

In re Larly bryan Co, 1 Sa w. s\$ . . . . . . . . . . . . . . 12 


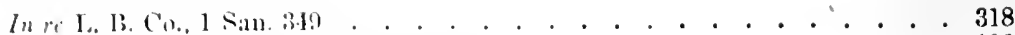

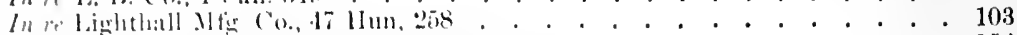

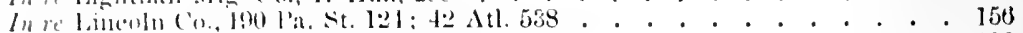

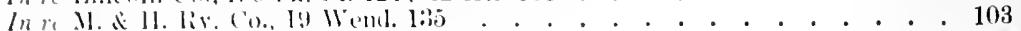

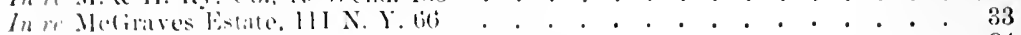

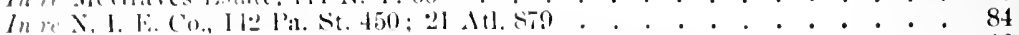

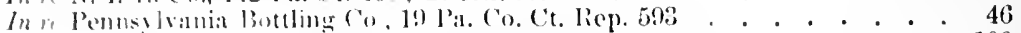

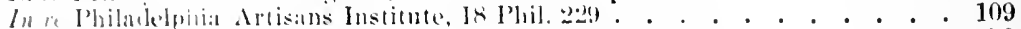

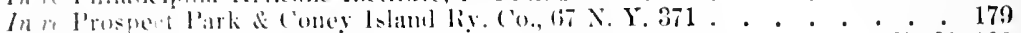

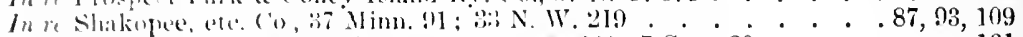

In resonth Momtan (on. Mining (o., 8.

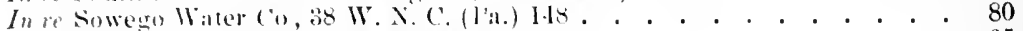

In re suring Valley llater (o., 17 ('al. 102 . . . . . . . . . . . . . 65

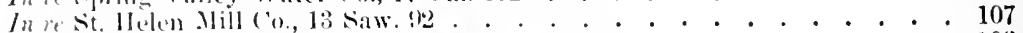

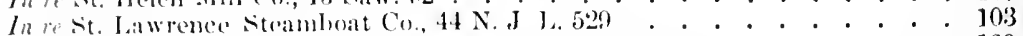

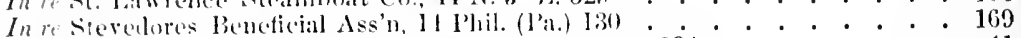

In U. S. Il. Rep. Agency, 115 X. Y. $176 ; 2]$ N. E. 1084 . . . . . . . . 41

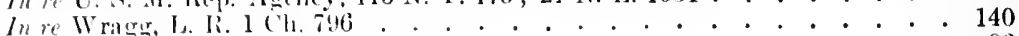

Instone $r$ Compins, 2 13ibb. (Ky.) 578 . . . . . . . . . . . . . . . . . . 96

Insurace ("o. k Kamper, 7: Ala. 325 . . . . . . . . . . . . . . . . . . . 41

Insurance Co. ․ N.11. l’. Co., 37 La. Ann. 289 . . . . . . . . . . . . . 13

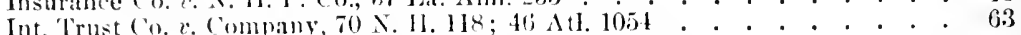

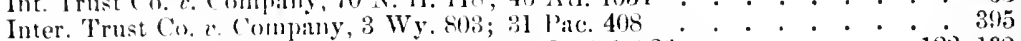

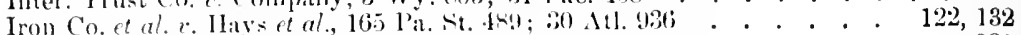

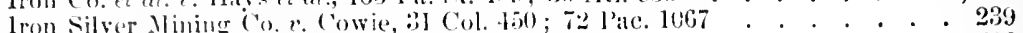

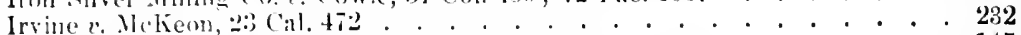

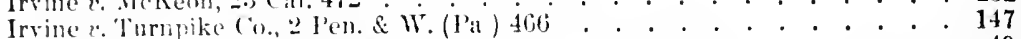

lrvine ('o. e. Bond, fl lext. st? . . . . . . . . . . . . . . . . 40

Isle Royale Land Corporation 2 . Secretary of State, 76 Micli. $162 ; 43$ N. W. 141181

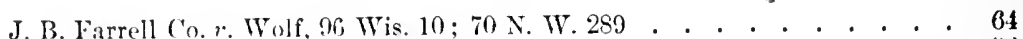

J. C. ( . Co. . Dwirlt 29 N.J. Eq. 240 . . . . . . . . . . . . . . 82

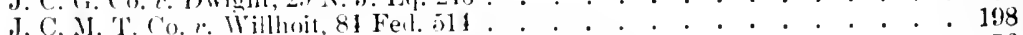

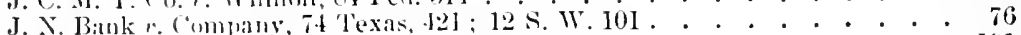

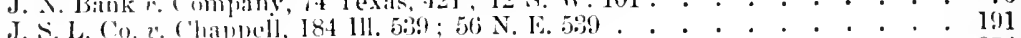

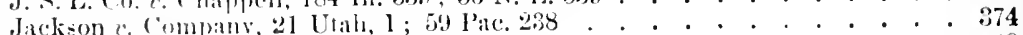

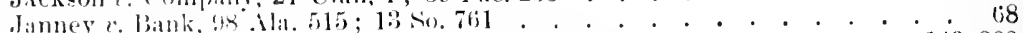

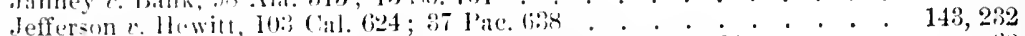

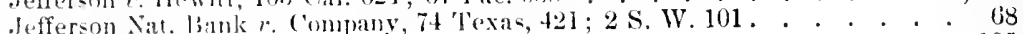

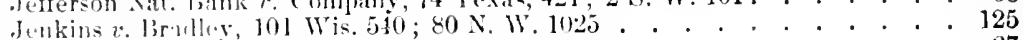

fewell $x$ (')m

Johns r. leoples .j.jich. 499 . . . . . . . . . . . . . . . . . 87,93

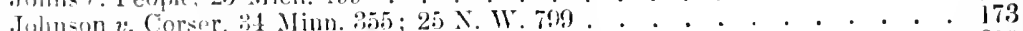

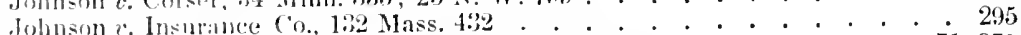

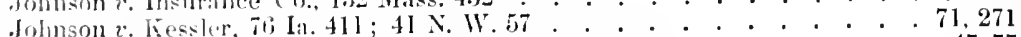

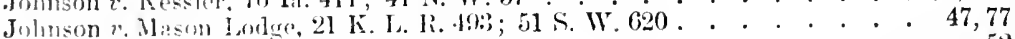

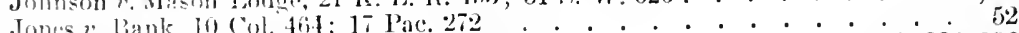

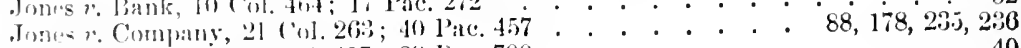

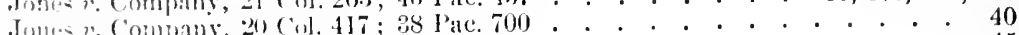

J 1 Comm

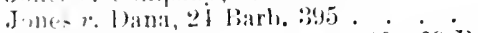

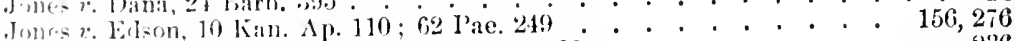

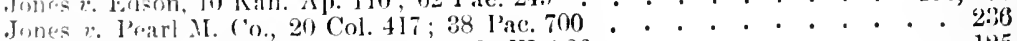

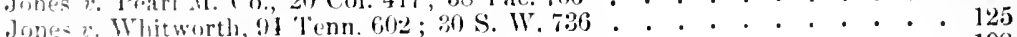

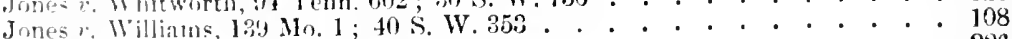

June it al. $x$. Jarman, 34 Ark. 323 . . . . . . . . . . . . . . 226 
K.

K. C. H. Co. $v$. Hunt, 57 Mo. 126 . . . . . . . . . . . . . . . . . 72

K. \& R. I. Co. $x$. Mlarsh, 17 Wis. 13 . . . . . . . . . . . . . . 179

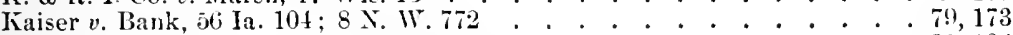

Kearney $v$. Anlrews, 10 N. J. Eq. 70 . . . . . . . . . . . . . . 33, 102

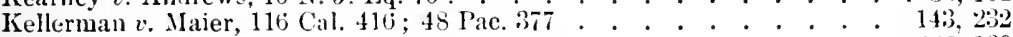

Kelley $v$. Clark, 2l Mont. 291 ; 58 l'ac. 959 . . . . . . . . . . . 125, 130

Kelley $x$. Fletcher, 94 Temn. 1; 28 s. W. 1099 . . . . . . . . . . . . 267

Kennebec Co. $v$. Company, ${ }_{2}^{2}$ llass. 204 . . . . . . . . . . . . . . 40

Kennebec lns. Co. $v$. Augusta Ins. Co., 6 Gray, 204 . . . . . . . . . . 295

Kennett $v$. Company, 68 N. H. $432 ; 39$ Atl. 585. . . . . . . . . . . 47,66

Kent $v$. Clark, 181 Ill. 287 ; 54 N. E. 967 . . . . . . . . . . . . . 175

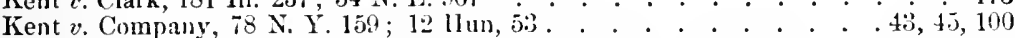

Keokuk Falls Ins. Co r. K. \& 1). M. Co., 5 Okla. 32 ; 47 lac. 484 . . . . . 348

Kephart $v$. People, 28 Col. $73 ; 62$ lac. 946 . . . . . . . . . . . . . 239

Keyser $v$. Shuts, 29 1'ac. 386 . . . . . . . . . . . . . . . . 221

Kilgore $v$. Smith, 122 Pa. St $48 ; 15$ Atl.698 . . . . . . . . . . . . . . . 191

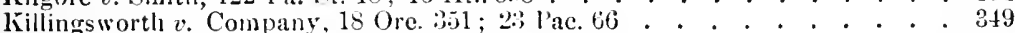

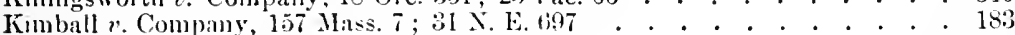

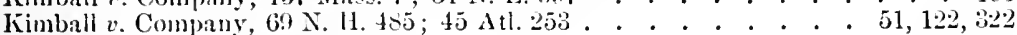

Kimball $v$. Davis, ò $^{2}$ Mo 194 . . . . . . . . . . . . . . . . . . 310

Kincaid $v$. Dwinelle, 59 N. Y. 548 . . . . . . . . . . . . . . . . 150

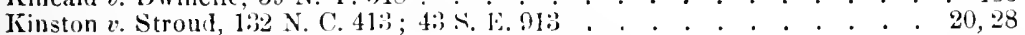

Knapp, etc. Co. 2 . Strand, + Wash. 686 ; 30 P'ace 1003 . . . . . . . . . 20

kimowles $x$. Beaty, l IlcLean, 41 . . . . . . . . . . . . . . . . 80

Lnowles $x$. Sandercock, 107 Cal. $629 ; 40$ 1'ac 1047 . . . . . . . . . 37, 290

linox v. C. L. Co., 815 Ala. $180 ; 5$ So. 578 . . . . . . . . . . . . . . 215

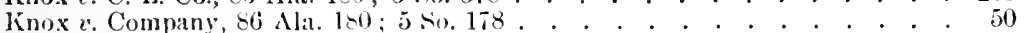

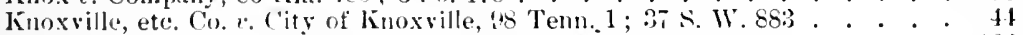

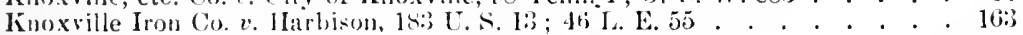

Kreisel e. Distilling Co..61 N. J. Eq. $5 ; 47$ Atl. 471 . . . . . . . . . . 105

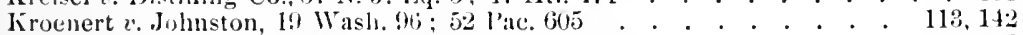

Kruse $e$. Dusenbury, 19 Wk. Di. (N. Y.) 201 . . . . . . . . . . 65, 66

Kruse $x$. Humpert, 2l Ky. Iaw Rep. 985; 59 S. W. 657 . . . 。 . . . . . 279

Kulp $v$. Fleming, 650 O. St. 321 ; 62 N. E. 334 . . . . . . . . . . . . 344

L.

I. I. Co. v. Massachusetts, 10 Wall. (U. S.) 566 . . . . . . . . . . . 31

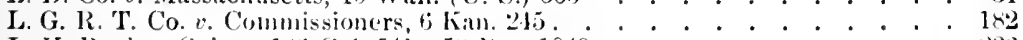

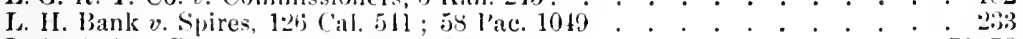

L. O. A. Ry. Co. Mison, \& N. Y, . . . . . . . . . 71,79

L. V. C. Co. $v$. Hamblen, 2.) leal. 225 . . . . . . . . . . . . . . . 1.1

L. \& N. Ry. Co. v. Kentucky, 161 U. S. (i77; 10 L. 1\% 819 . . . . . . . 88,162

Lafayette Ins. Co. r. French, is IJww. (U.S.) Hol . . . . . . . . . 180, 181

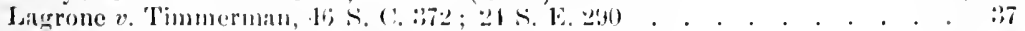

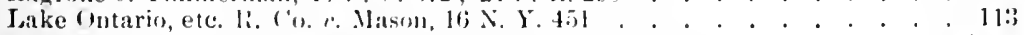

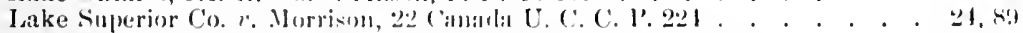

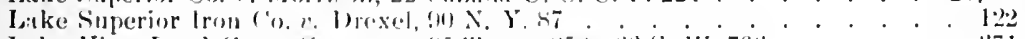

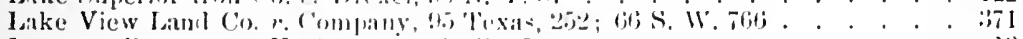

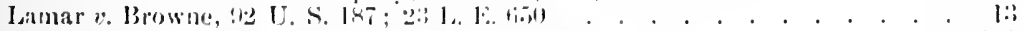

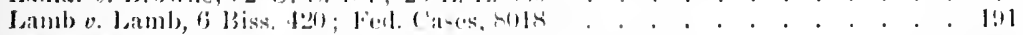

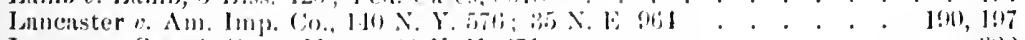

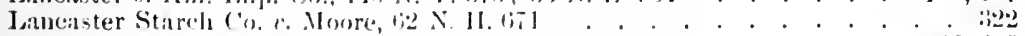

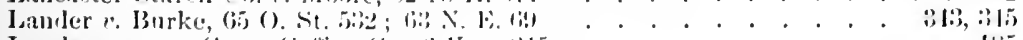

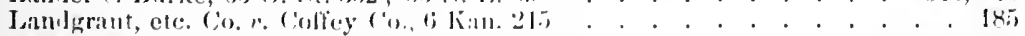

Lane $\therefore$ Bink, ! Heisk ('Tenn.) H! . . . . . . . . . . . . . . . Bs

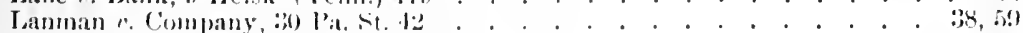

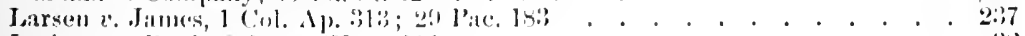

Lathrop e. Bank, o loma (Ky.), lil . . . . . . . . . . . . 32 
Iamming $\because$. Galusha, 81 IInn, 247 ; $30 \mathrm{~N}$. Y. Sup. 767; alf'd $151 \mathrm{X} . \mathrm{Y} .648 ; 45$ N. W. [1 132

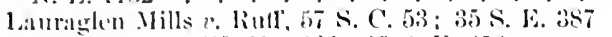

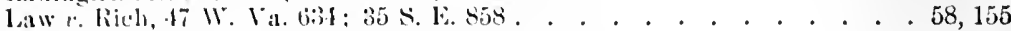

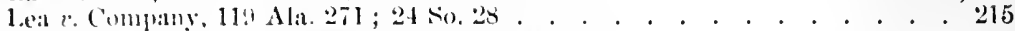

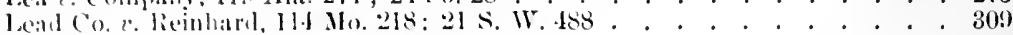

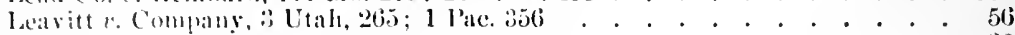

lazure r. Hilluras, 7 ser. \& li. (1'a.) 313 . . . . . . . . . . . . . 32

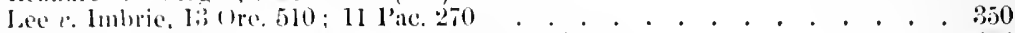

Lagenhe r. Ansuciation, 45 Lil. Ann. 66!); 12 So. 837 . . . . . . . . . 282

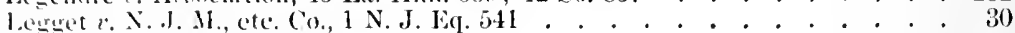

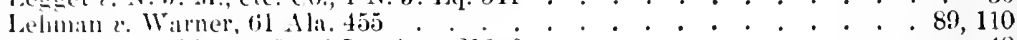

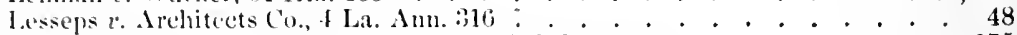

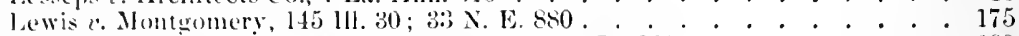

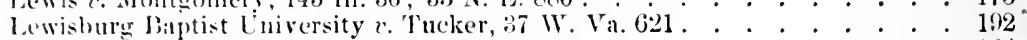

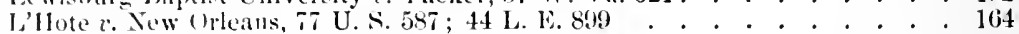

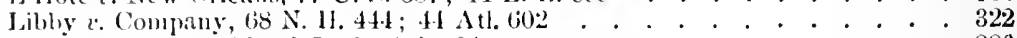

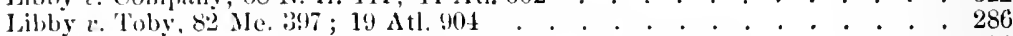

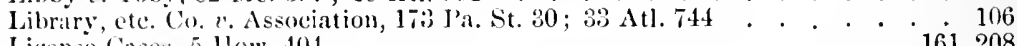

license Cases, 5 llow 404 . . . . . . . . . . . . . . . . . . 161,208

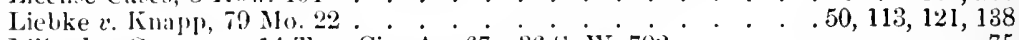

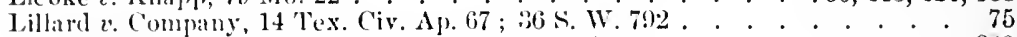

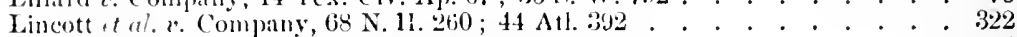

Linkanf $x$. Lombard, 137 N. Y.417; 33 N. E. 472 . . . . . . . . . . . . . . 64

Litchtield bank $r$. Church, 29 Conn. 1:37 . . . . . . . . . . . . . . . . . . . . . . 24

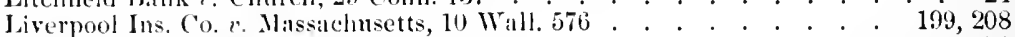

Livesey r. Company, 5 Neb. $50 \quad$. . . . . . . . . . . . . . . . . . . . . 71

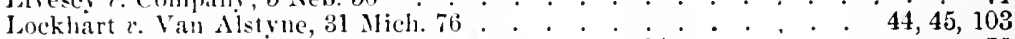

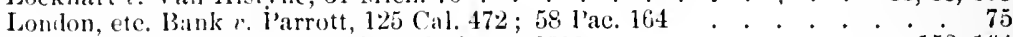

Jothrop et al. e. Stedman et al., Fed. Cases, 8519 . . . . . . . . . . . 153, 164

Jond 9 Company, 153 U. S. $564 ; 141 \mathrm{s.} \mathrm{Ct.928} \mathrm{.} \mathrm{.} \mathrm{.} \mathrm{.} \mathrm{.} \mathrm{.} \mathrm{.} \mathrm{.} \mathrm{.} \mathrm{.} \mathrm{.} \mathrm{121}$

Louisiana Savinirs bank, 85 La. Ann. 196 . . . . . . . . . . . . . . 283

douisville Banking Co. v. Eisennan, 94 Ky. $83 ; 21 \mathrm{~S}$. W. $5: 3,1049$. . . . 14

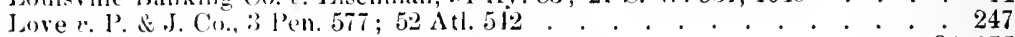

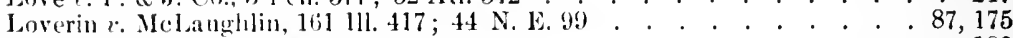

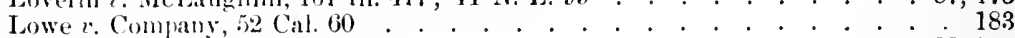

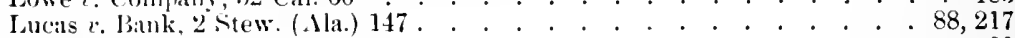

Lucas $\iota$. Pitncy, 27 N. J. L. $22 \mathrm{I}$. . . . . . . . . . . . . . . . . . . 60

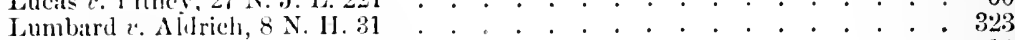

Lusk $v$. Riggs (Neb.), 97 N. W. 1033 . . . . . . . . . . . . . . . . 11

\section{M.}

M. B. C. Co. $v$. Complany, 89 Texas, $511 ; 39$ S. W. 1047

M. 13. Co. $r$ Compiny, 196 Pa. St. $25 ; 46 \mathrm{Atl} .99$

353,355

N. B. Ry. Co. 2 Sullivan, 37 Ga. 240
M. B. T. Co. e. R. G. N. Co., 81 N. Y. Sup. 302 .

H. (․ Mills 2 . springs, 56 S. C. $5: 34$; 35 S. L. 222

II. C. R. Co. I. Melvin, 21 IIinu. 389

II. F. \& No. v. 11all, 12I Mass. 272

.I. I. N. Bank $v$ llarper, 61 Minn. $975 ; 6 ;$ N. iv. 1079

M. (i. R. Co. r. Wy song, 51 Ind. 12

il. I. W. C.\& S. ('o. v. Mosher, 114 Mich. $64 ; 72$ N. IV. 117

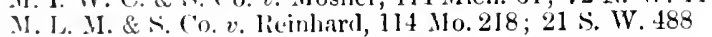

Vi. I. 'T. C'o. l. Ward, lo Ohio, l21)

11. N. T. Fo. 2 . Bambach, 32 Fed 205

M. 1. \& li. li. Co. n. Cross, 20 Ark. 44 ?

II. T. (u. 2 . S. C., etc. Co., 16 Wash. $499 ; 48$ Pac. 383

II. T. E (

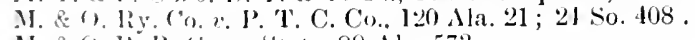

II. \& r. K. R. ( o. r. State, 29 Mla. $57: 3$

II. \& L. li. liy. Co. 1. 1)ow, 120 U. S. $287 ; 7$ S. Ct. 482 
MaeGinniss $v$. Company (Mont.), 75 Pac. 89 . . . . . . . . . . 60, 139, 107, 189,

Machine Co. v. Caldwell, 5i Ind. 270

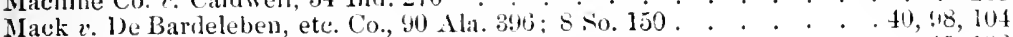

Mackintosh 2 . Ii. R. ('o., 32 Fed. $850 ; 54$ Fell. 552 . . . . . . . . . 45, $10: 3$

Madden $e$. Company, lyg Pat. St. $454 ; 49$ Atl. 2yt . . . . . . . . . . .

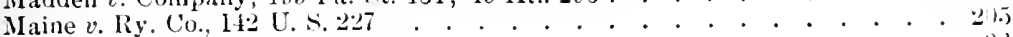

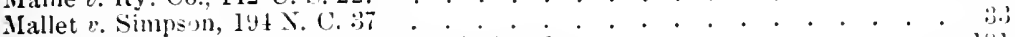

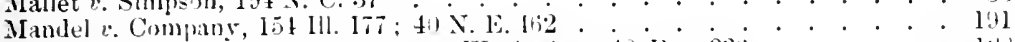

Manhattan Trust Co. r. Company, 16 Waslı. 195; 48 1'ac. 333 . . . . . . 123

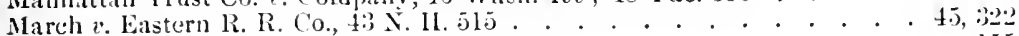

Mariners $v$. Sewall, 50 Yle. 220 . . . . . . . . . . . . . . . . . 10.5

Marion Savines Bank $v$. Dumkin, ijt Ala til . . . . . . . . . . . . . 2i

Market St. Ry. Co. $v$. Hellman, 109 Cal. $571 ; 2.2$ Pac. 225 . . . . . . . . . . . 3

Marshall $v$. Silerman, 148 N. Y. 9; 42 N. E. 119 . . . . . . . . . . . 173

Martin $v$. Association, 2 Coldw. (Tenn.) 418 . . . . . . . . . . . . . 33

Martin $v$. Deetz, 102 Cal. 55: 36 Pac. 368 . . . . . . . . . . . . 87, $98,2: 1$

Martin e. R. R., I5l U. S. 67 . . . . . . . . . . . . . . . . . . 208S

Martin $v$. Zellerbach, 36 Cal. 800 . . . . . . . . . . . . . . . . 51, 232

Marvin $v$. Anderson, 11 I IV is. 887 ; 87 N. WV. 226 . . . . . . . . . . . 835

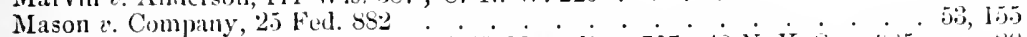

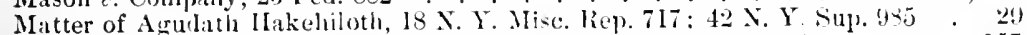

Matter of Brooklyn Elevated liy. Co., 125 N. Y. 454;26 N. E. 474. . . . Iis

Matter of Davies, I6s X. Y. S4; 61 N. E. IIS . . . . . . . . . . . . :3:14

Matter of Germicile Co., 6.5 Ilm, 600 : 20 N. Y. Sip. 49j . . . . . . . . . . . I11j

Matter of Globe, etc. Ass'u, 135 N. Y. 250 ; 22 N. E. 12.2 . . . . . . . . . . . . 1:3

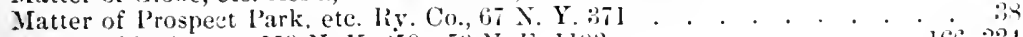

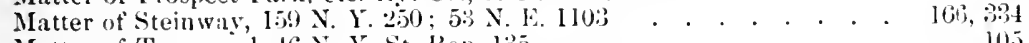

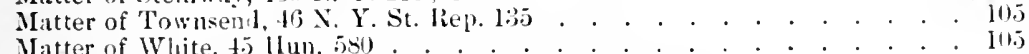

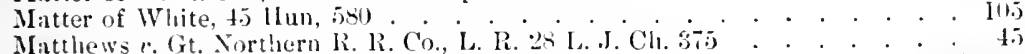

Mattlews e. Gt. Northern R. R. Co., L. R. 24 L.J. Ch. Sij . . . . . . . . 2:3, $2: 37$

Maxwell v. Akin, 89 liel. 180 . . . . . . . . . . . . . . . . . . . . . . .

Misberr $e$ Veade, 80 Me.

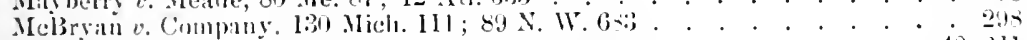

MeCill r. Company, if conn. 428 . . . . . . . . . . . . . . . . 40, 211

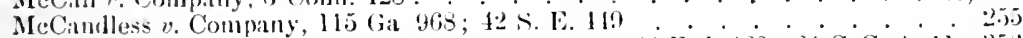

MuCimma \& Fraser Co. $v$. Citizens' Trust \& sur. Co., 76 Fed. $420 ; 21$ C. C. A. Il

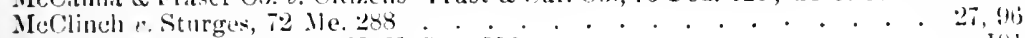

McComb v. Association, 10 N. Y. Sup. 552 . . . . . . . . . . . . . I01

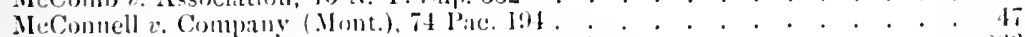

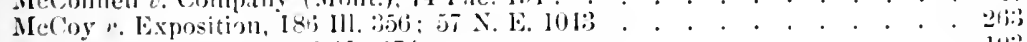

Moniniel $r$. Compans. $221.27 t$. . . . . . . . . . . . . . 10:;

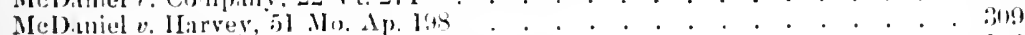

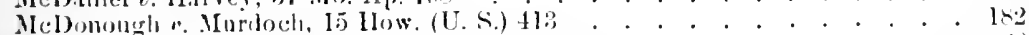

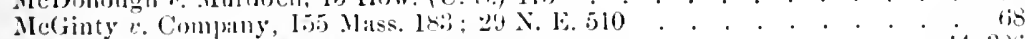

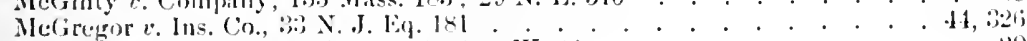

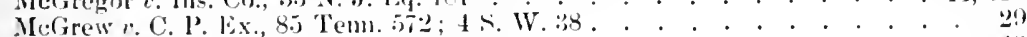

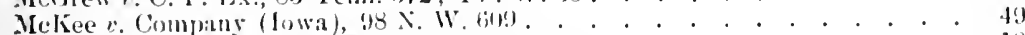

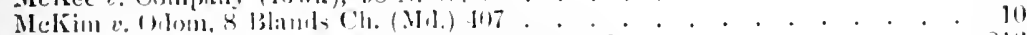

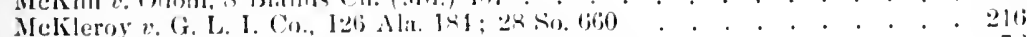

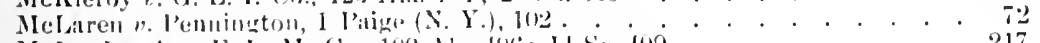

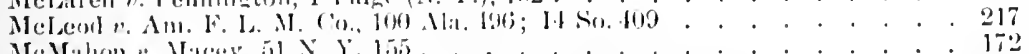

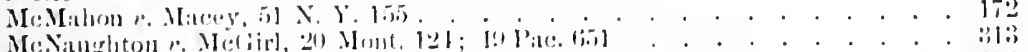

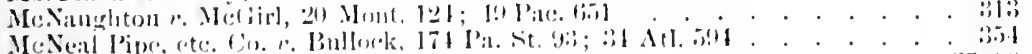

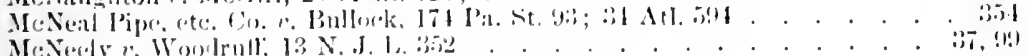

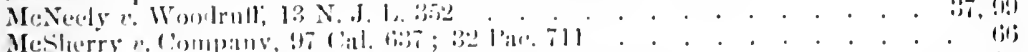

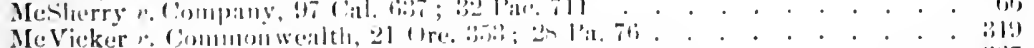

MeVicker e. Comment

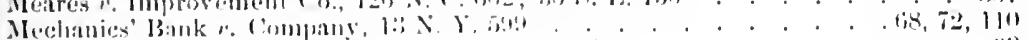

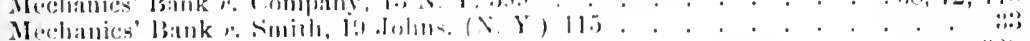

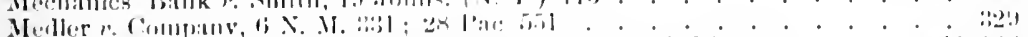

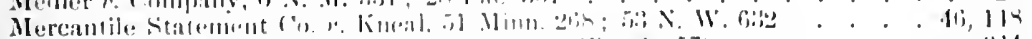

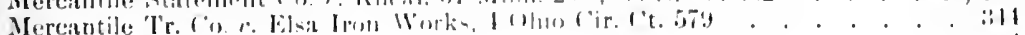

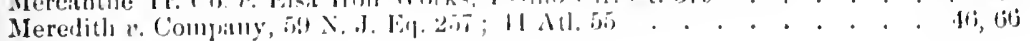


Merrick r. Van Sinroort, 31 N. Y. 203 . . . . . . . . . . . . . . 185

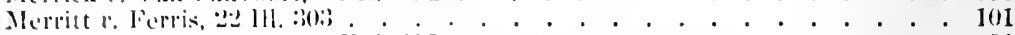

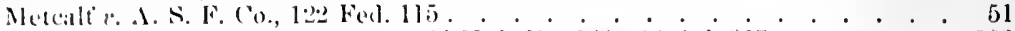

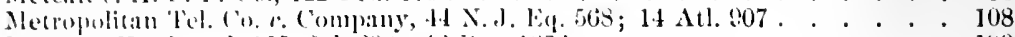

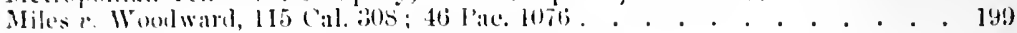

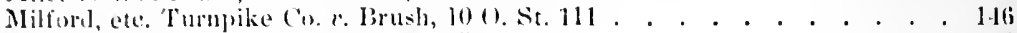

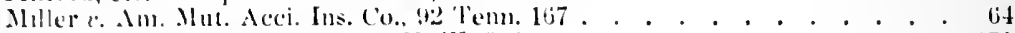

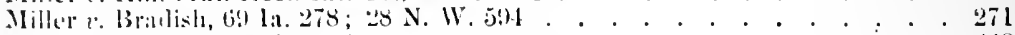

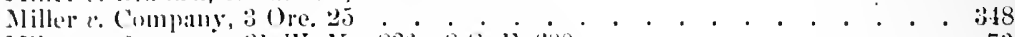

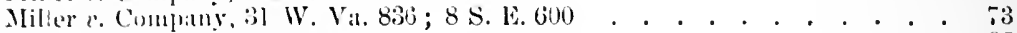

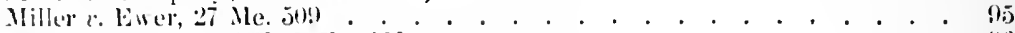

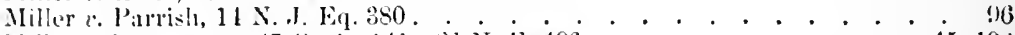

Miller \& liatterman, t7 O. Sit. $141 ; 21$ N. \&. 496 . . . . . . . . . . 45, 103

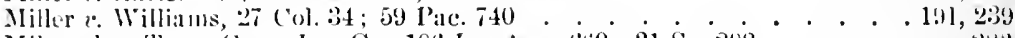

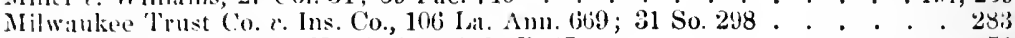

Miner $x$ lbank, I leters (U. S.), 467; T L. E. 47 . . . . . . . . . . . 71

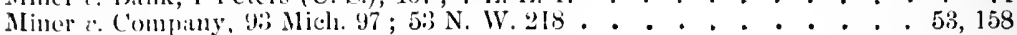

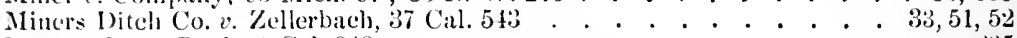

Mining Co. c. Bank, 2 Col. 248 . . . . . . . . . . . . . . . . . 235

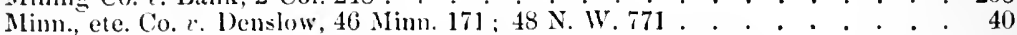

Missouri Coal Mining Co. $\iota$. Ladd, 160 Mo. 435 ; 61 S. W. 191 . . . . . . 191

Missomri lend, etc. Co. $r$. Remhard, 114 Mo. 218; 21 S. W.488 . . . . . . 106

Mitchell $v$. Vt. Copper Min. Co., 40 N. Y. Sup. Ct. 400 . . . . . . 90, 100, 104

Mobile r. Eulee, 20 ' $\mathrm{Ap}_{\mathrm{p}}$. Div. (N. Y.) 548

Mobile r. Youille, 3 Mla. 137.

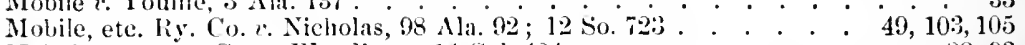

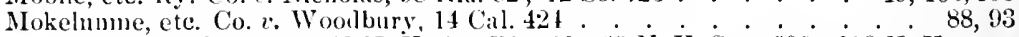

Nontgomery $v$. Company, 48 N. Y. Ap. Div. 12 ; 62 N. Y. Sup. $606 ; 168 \mathrm{~N}$. Y.

$637 ; 61$ N. E. 1131 . . . . . . . . . . . . . . . . . . 51

Montgonery r. Forbes, 148 Miss. $219 ; 19$ N. E. $342 . \quad . \quad . \quad . \quad .60,80,82,185$

Montgomery $v$. Merrill, 18 Mich. 338 . . . . . . . . . . . . . . . . . 157

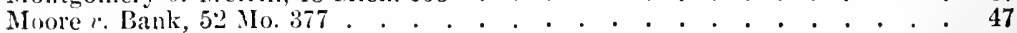

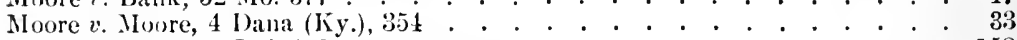

Moore $v$. Nate, 71 Ind 475 . . . . . . . . . . . . . . . . . . . 158

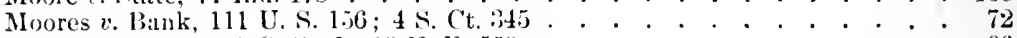

Morgan r. Lewis, 46 O. Nt. 1; 17 N. E. 558 . . . . . . . . . . . . . . 86

Morris e. Hall, 41 Mla. 510 . . . . . . . . . . . . . . . . . . . . . . . . . . 217

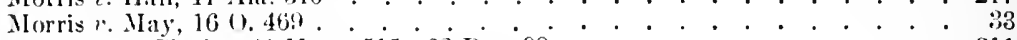

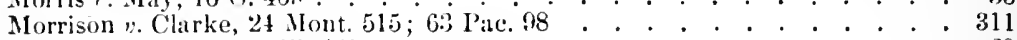

Morriss v. Cheney, 51 111. 451 . . . . . . . . . . . . . . . . . . 60

Morrow e. Edwarls, 9 Mackey, 475. . . . . . . . . . . . . . . . . . . . . 250

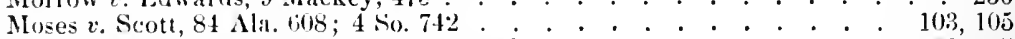

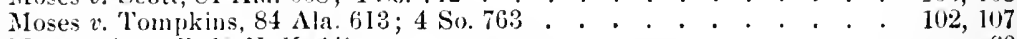

Moss v. Averell, li) N. Y. HY . . . . . . . . . . . . . . . . . . . 60

Mowrey $v$. Company, 17 Fed. Cases No. $9891 ; 4$ Bissell, $7 \dot{3}$. . . . . 59,$140 ; 179$

Mugler $v$ Línsis, 12:) U. S. 623 . . . . . . . . . . . . . . . 162, 163

Mumma r. Company, 8 let. U. S. 28I . . . . . . . . . . . . . . . . . 58

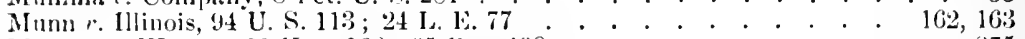

Munson $v$. Warren, 6i) lian. 162; 65 lac. 222 .

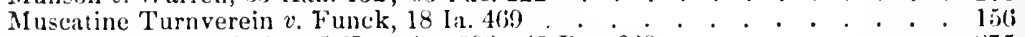

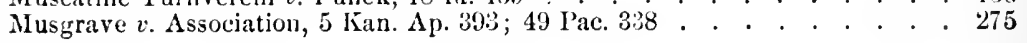

N.

N. C. Bank v. Mc̀Donnell, 92 Ala. 387 ; 9 So. 149 . . . . . . . . . . . 213

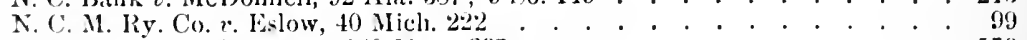

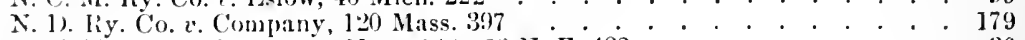

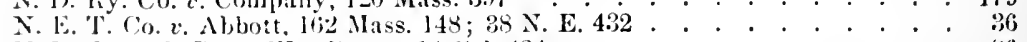

N. Il. \& \& M. Co. ". Womberry, $1+$ Cal. 491 . . . . . . . . . . . . 86

N. II. II. N. ('o. $v$ Company, 142 Mass. $349 ; 7$ N. 1. 773 . . . 125, 135, 143, 173

N. IL. \& b. liv. Co. $v$ Chapman, 38 Comn. 56 . . . . . . . . . . . . 242

N. M. G. T. Co. v. N. G.'1. Co., 2l Ia.Co. Ct. Rep. 393 . . . . . . . . 83

N. II. N.G. Co. $v$ Sinith, 27 Ind. Ap. $472 ; 61$ N. E. 10 . . . . . . . * . 269 
N. M. R. R. Co. v. Winkler, 33 Mo. 354

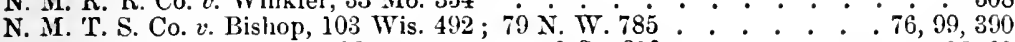

N. O. \& R. R. Co. v. Frank, 39 La. Ann. 707 ; 2 So. 310 . . . . . . . . 28,69

N. O. \& T. P. Co. v. Bank, 24 Wk. L. Bul (Ohio) 198 . . . . . . . . . 110

N. P. C. I. Co. $v$. Company, 16 Utah, 246 ; 52 Pac. 168 . . . . . . . . . 24

N. S. C., etc. Co. $v$. Field, 64 Fed. 151 . . . . . . . . . . . . . . . 184

N. S. Co. $v$. Horton (Neb.), 93 N. W. 225 . . . . . . . . . . . . . 37

N. S. R. Co. v. People, 147 Ill. 234; 35 N. E. 608 . . . . . . . . 65, 606

N. T. E. Co. $v$. Company, 76 Minn. $334 ; 79$ N. W. 315 . . . . . . . . . 300

N. W. Co v. Connell, 85 llun (X. Y.), 254. . . . . . . . . . . . .

N. Y. N. Ex. Bank $v$. Crowell, 17 Pa. 313 ; 35 Atl. 613 . . . . . . . . . 87

N. Y. N. H. etc. R. Co. $v$. Schuyler, 34 N. Y. 30 . . . . . . . . . . . 72

N. Y. \& N. E. Ry. Co. $v$. Town of Bristol, 151 U. S. 5066 . . . . . . . . 154

N. \& S. R. S. Co. v. I'eople, 147 I11. 234 ; 35 N. E. 608 . . . . . . . . . 263

Napier $v$. Poe, 12 Ga. 170 . . . . . . . . . . . . . . . . . . . 24

Nashville Bank $v$. Jetway, 3 Hun (Tenn.), 522 . . . . . . . . . . . . . 53

Nassau Bank $v$. Brown, 30 N. J. Eq. 488 . . . . . . . . . . . . . 109

Nathan $v$. Tompkins, 82 Ala. 437 ; 2 So. 747 . . . . . . . . . . . 61, 102

National Bank $v$. Company, 41 O. St. 1 . . . . . . . . . . . . . . 78

National Lead Co. $x$. Dickinson (N. J.), 57 Atl. 138 . . . . . . . . 41, 177

National Tube Works v. Gillfillan, 124 N. Y. $302 ; 26$ N. E. 538 . . . . . . 142

Nat. Cash Register Co. v. Wilson, 9 N. D. 112; 81 N. W. 285 . . . . . . . 342

Nat. Trust Co. v. Mliller, 39 N. J. Eq. 155 . . . . . . . . . . . . . . 326

Natusch $v$. Irving, 1 Smith's Cases 226 . . . . . . . . . . . . . . . 147

Neb. Nat. Bank $v$. Walsh, 68 Ark. $433 ; 59$ S. W. 952 . . . . . . . 227

Nelson $v$. Hubbard, 96 Ala. 238 ; 11 So. 428 . . . . . . . . . . . . 53, 213

Nester $v$. Company, $161 \mathrm{~Pa}$. St. 473 ; 29 Atl. 102 . . . . . . . . . . . 355

Newcomb $v$. Reed, 12 Allen (Mass.), 362 . . . . . . . . . . . . . 91,92

New Orleans $v$. Ins urance Co., 106 La. An. 31 ; 30 So. 254 . . . . . . . . . 283

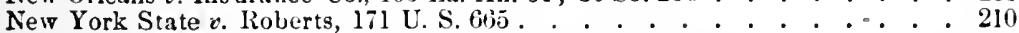

Nickels $v$. P. B. \& L. S. Ass'n, 93 Va. $380 ; 25$ S. E. 8 . . . . . . . . . 382

Nickum $v$. Burckliardt, 30 Ore $464 ; 47$ Pac. $788 ; 48$ Pac. $474.2 .95,349,350$

Nicollet Nat. Bank $v$. Company, 71 Ninn. $413 ; 74$ N. W. 160 . . . . . . 59

Nicrosi $v$. Company, 115 Ala. $429 ; 22$ So. 147 . . . . . . . . . . . . 215

Niemeyer $v$. L. R. J. Ry., 43 Ark. 111 . . . . . . . . . . . . . . . 28

Nims $v$. Scliool, 160 Mass. 177; 35 N. E. 776 . . . . . . . . . . . . . 61

Nix $v$. Miller, 26 Col. 203 ; 57 l'ac. 1084 . . . . . . . . . . . . . . 237

Norfolk, ete. R. R. v. Pennsylvania, 130 U. S. 120 . . . . . . . . . . . 210

North, etc. Stock Co. $\varepsilon$. People, 147 lll. $234 ; 35$ N. E. 608 . . . . . . . . 40

Northern Securities Co. v. United States, 193 U. S. 197 . . . . . . . . . 168

Northern Trust Co. $v$ Company, 75 Fod. 936 . . . . . . . . . . 115, 125, 142

Norton $v$. Bank, 61 N. H. 589 . . . . . . . . . . . . . . . . . . 63

Norton, etc. Co. $v$. Wysong, 51 Ind 1 . . . . . . . . . . . . . . . 58

Novelty Ifg. Co. $v$. Connell, 88 llun, 2.jt . . . . . . . . . . . . . . 191

O.

O. H. Mfg. Co. v. Carney, 51 N. H. $295 \quad$. . . . . . . . . . . . . 75

O. M. Co. v. Garst, 18 R. I. $481 ; 28$ Atl. 973 . . . . . . . . . . . . . 40

O. R. \& N. Co. $v$ O. R. Co., 130 U. s. 1; 9 Sup. Ct. 109 . . . . . . . 319

O. W. Co. v. Bliss, 132 Ala. 253 ; 31 So. 81 . . . . . . . . . . . . . 213

O. \& Mr liy Co. v. State, 490 St 6t68; $\$ 2$ N. E. 903 . . . . . . . . 81, 103

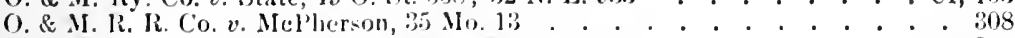

O.\& W. T. J.Co. $v$ Rathburn, 5 Saw. 20. . . . . . . . . 351

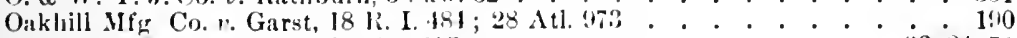

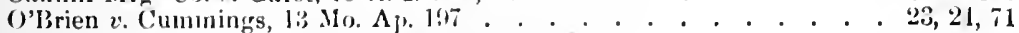

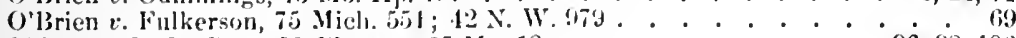

Ohio, etc. R. R. Co. v. Mlel'herson, 35.Mo. 13. . . . . . . . . . 96, 98, 106

Olds". Company (.Mass.), 70 N. li. J02: . . . . . . . . . . . . . 52, 150

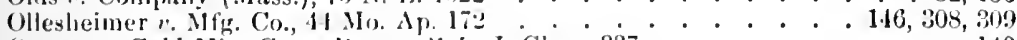

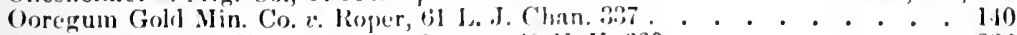

O'Reilly, Skelly \& Fogarty ('o. .. Greene, 40 N. Y. 360 . . . . . . . . . 8363

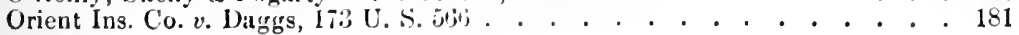


Ormsby 1. Company, 56 N. Y. 623

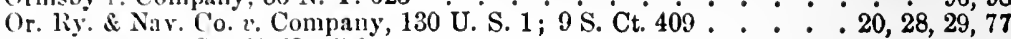
Osborne v. Ins. Co., $57 \mathrm{Vt} .278$. . . . . . . . . . . . . . . . 377 Otter v. Conpany, 50 Barb. 247 . . . . . . . . . . . . . . . . 122 Ouderkirk v. Baik, 119 N. Y. $263 ; 23$ N. E. 875 . . . . . . . . . . . 176

\section{P.}

P. B. Corporation $v$. Lamson, 16 Me. 224 . . . . . . . . . . . . . . 13

P. B. L. \& S. Ass'n v. Berlin, 201 Pa. St. 1; 50 Atl. 308 . . . . . . . . . 356

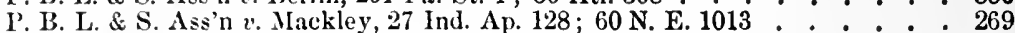

I. C. S. M. \& C. Co. v. Pennsylvania, 125 U. S. $181 \quad$ • . . . . . . . 181,199

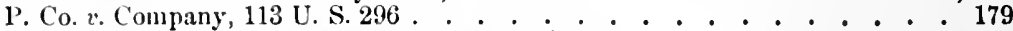

P. E. Co. v. Company, 64 Minn. $386 ; 67$ N. W. 217 . . . . . . . . . . 302

P. G. T. R. Co. v. Graham, 11 Metc. (Mass.) 1 . . . . . . . . . . . 48

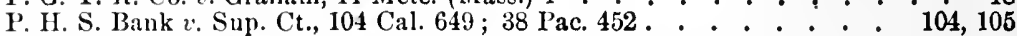

P. L., etc. Co. v. Pottland, 6 L. R. A. 295 . . . . . . . . . . . . . . 64

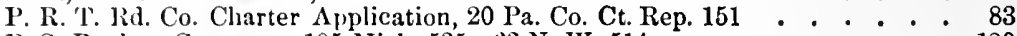

P. S. Bank $v$. Company, 105 Mich. $535 ; 63$ N. W. 514 . . . . . . . . . 120

P. T. C. Co. $v$. Company, 23 Utah 474; 65 Pac. 735 . . . . . . . . . . 373

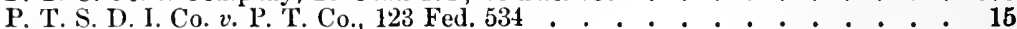

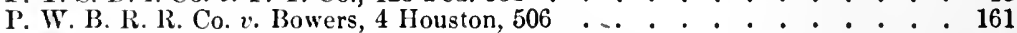

P. W. \& B. R. R. Co. v. lient Co. R. R. Co., 5 Houst. 127 . . . . . . . . 245

P., etc. P. R. Co. $v$. Griffin, 21 Barb. 454 . . . . . . . . . . . . . . 57

P. \& G. T. Co. «. Bobb, 88 Ky. $226 ; 10$ S. W. 794 . . . . . . . . . . 87

Pacific Fruit Co. v. Coon, 107 Cal. $447 ; 40$ Pac. 542 . . . . . . . . . . 142

Pacific R. Co. v. Hughes, 22 Mo. $291 \quad$. . . . . . . . . . . . . . 57

Pacific R. Co. v. Renshaw. 18 Mo. 210 . . . . . . . . . . . . . . 46, 147

Packard $v$. Company, 168 Mass. $92 ; 46$ N. E. 433 . . . . . . . . . . . 96

Page $v$. Heineberg, $40 \mathrm{Vt} 81$. . . . . . . . . . . . . . . . . . 33

Palmer $v$. Bank, 72 Minn. 266 ; 75 N. W. 380 . . . . . . . . . . . . 41

Palmer $v$. Lawrence, 3 Sandf. (N. Y.) $161 \quad$. . . . . . . . . . . . . 113

l'ark $v$. Grant Locomotive Works, 40 N. J. Eq. $114 ; 19$ Atl. $6 \dot{2} ; 45$ N. J. Eq.

$241 ; 3 \mathrm{Atl} .162$. . . . . . . . . . . . . . . . . . 61

Parkinson Sugar Co. r. Bank, 60 Kan. 474; 57 Pac. 126 . . . . . . . . 273

Parmalee $v$. P'rice, 208 Ill. $544 ; 70$ N. E. 725 . . . . . . . . . . . 115, 125

Parsons $v$. Company, 25 Wash. $492 ; 65$ Pac. 765 . . . . . . . . . . . 383

Parsons v. Eureka Powiler Works, 48 N. H. 66 . . . . . . . . . . . . 323

Parsons v. Lent, 34 N. J. Eq 67 . . . . . . . . . . . . . . . . . . . . 106

Parsons v. Joseph, 92 Ala. 403; 8 So. 788 . . . . . . . . . . . . . . 315

Paschall $v$. Whitsett, 11 Ala. 472 . . . . . . . . . . . . . . . . . . 315

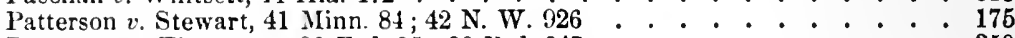

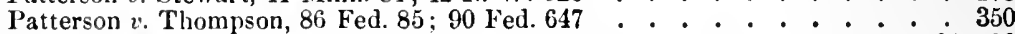

Yaul $v$. Virginia, 8 Wall. (U. S.) 161 . . . . . . . . . . . . . 181, 199

Payson v. Withers, 5 Bis. 269; Fed. Cases, 10,864 . . . . . . . . . . 191

Pearce $v$. Olney, 20 Conn. 544 . . . . . . . . . . . . . . . . . . . . 242

Pearce v. R. Co., 21 How. 441 ; 16 L. F. 184 . . . . . . . . . . . . . 38, 52

Pearsall $v$. Company, 161 U. S. $616 ; 40$ L. E. 838 . . . . . . . . . . . 163

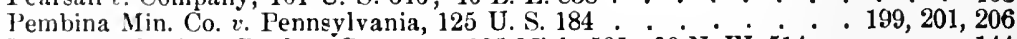

Peninsula Savings Bank $v$.Company, 105 Mich. $535 ; 63$ N. W. 514 . . . . 144

Pensacola Teleg. Co. $v$. Western U. 'Teleg. Co., 96 U. S. 1 . . . . . . . 201

People $v$. B. \& R. T. Road, 23 Wend. 222 . . . . . . . . . . . . 156,159

People $v$. Ballard, 194 N. Y. $269 ; 32$ N. E. 54 . . . . . . . . . . . 51, 156

People v. Bank, 129 Ill. 618 ; 22 N. E. 288 . . . . . . . . . . . . . . 262

People $v$. Bank, 7 Col. 226 ; 3 Pac. 214 . . . . . . . . . . . . . . . 113

People 2 . Bank, 6 Cowan (N. Y.), 211 . . . . . . . . . . . . . . . . 160

leople $v$ liank, 12 Mich. 526 . . . . . . . . . . . . . . . . . . 160

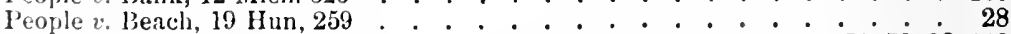

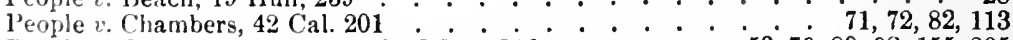

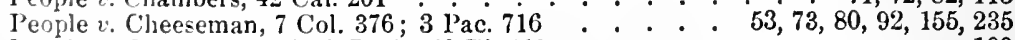

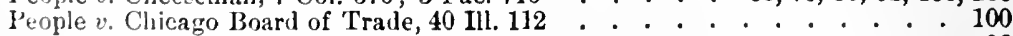

' 'eople $v$. College, 38 Cal. 166 . . . . . . . . . 33

People v. Company, 130 IIl. 268 ; 22 N. E. $798^{\circ}$. $\quad . \quad \cdot \quad 9,29,54,59,83,84,160$ 
People v. Company, 111 Mich. 405 ; 69 N. W. 653 .

$14,41,83$

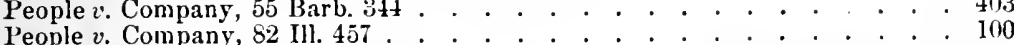

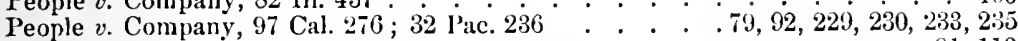

People $c$. Company, 45 Cal. 306 . . . . . . . . . . . . . . . . 81, 110

People $v$. Company, 175 Ill. 125 ; 51 N. E. 664 . . . . . . . . . . . . . 5.

People $v$. Company, 121 N. Y. 582 ; 24 N. E. 834 . . . . . . . . 38, 81, 159, 160

People $v$. Company, 153 Ill. 25 ; 38 N. E. 752 . . . . . . . . . . . . 40

People $v$. Company, 60 How. P’r. 82 . . . . . . . . . . . . . . . . 160

People $v$. Company, 70 N. Y. 569 . . . . . . . . . . . . . . . . . 60

People $v$. Company, 131 N. Y. $140 ; 29$ N. E. 947 . . . . . . . . . 160, 335

People $v$. Company, 92 X. Y. 105 . . . . . . . . . . . . . . . . . 179

People $v$. Company, 129 N Y. $474 ; 29$ N. E. 959 . . . . . . . . . . . 179

People $v$. Company, 175 N. Y. 76 . . . . . . . . . . . . . . . . . 192

People $v$. Company, 45 Cal. $306 . .50 . \quad$. . . . . . . . . . . 230, 231

People $v$. Company, 117 N. Y. 24 I $; 22$ N. E. 1057 . . . . . . . . . . . 336

People $v$. Crossley, 69 IIl. 195 .

People $v$. Dashway Ass'n, 84 Cal. $114 ; 24$ Pac. 277 . . . . . . . . . . . . . . 333

People $v$. Eadie, 63 Hun, $320 ; 133$ N.Y.573 . . . . . . . . . . . . . . . . 166

People $v$. Equitable 'Trust Co., 96 N. Y. 387 . . . . . . . . . . . . . 205

People $v$. Feitner, 77 (N. Y.) $\Lambda$ p. Div. 18) . . . . . . . . . . . . . 195

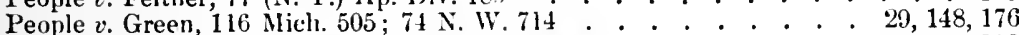

People $v$. Hawkins, 106 MIch. 479 ; 61 N. IV. 736 . . . . . . . . . . . . . . 299

People $v$. Howard, 50 Mlich. 239. . . . . . . . . . . . . . . . . . 182

People $v$. Lal Rue, 67 Cal. $526 ; 8$ Pac. $84^{\circ}$. . . . . . . . . . . . . . . . . . . 90

People $v$. Louden (Cal.), 8 Pae. 66.

People $v$. Milk Exchange, 133 N. Y. $565 ; 30$ N. E. 850 . . . . . . . . . 334

People $v$. Payne, 161 N. Y. 299 ; 55 N. E. 849 . . . . . . . . . . . . . 83,86

l'eople $v$. Perrin, 56 Cal. 345 . . . . . . . . . . . . . . . . . . . 230

People $\varepsilon$. Pfister, 57 Cal. 352 . . . . . . . . . . . . 86, 178

People $v$. Roberts, $22 \times$ Y. Ap. Div. 282 . . . . . . . . . . . . . . 192

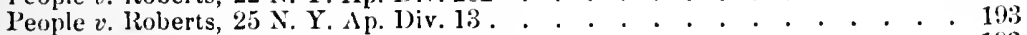

People $v$. Roberts, 27 N. Y. Ap. Div. 455 . . . . . . . . . . . . . . 193

People $v$. Roberts, 29 N. Y. Ap. 1)iv. 585 . . . . . . . . . . . . . . 193

leople $v$. Roberts, 30 N. Y. Ap. Div. 150 . . . . . . . . . . . . . . 192

l'eople $v$. Rose, 188 Ill. 268 ; 59 N. L. 432 . . . . . . . . . . . . . . 261

People $v$. Runkle, 9 Johnson (X. Y.), 147 . . . . . . . . . . . . . . . . 107

People $v$. Self redge, 52 Cal. 331 . . . . . . . . . . . . . . . . 67,91

People $v$. Society, 25 Barb. (N. Y.) 7 . . . . . . . . . . . . . . . . 100

People $v$. Society, 24 Barb. (N. Y.) 570 . . . . . . . . . . . . . . . 33

People $v$. Stanford, 77 Cal. 360 ; 18 Pac. 85 . . . . . . . . . . . . . . . 233

People $v$. Webster, 10 Wend. (N. Y.) 554 . . . . . . . . . . . . . . 101

People ex rel. $v$. Company, 111 Mich. $405 ; 69 \mathrm{~N}$. W.653. . . . . . . . . . 296

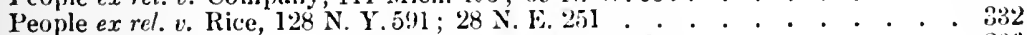

People ex rel. $v$. Wemple, 138 N. Y. $582 ; 24$ N. L. 386 . . . . . . . . . 336

People ex rel., ete. $v$. Kńnight, 174 N. Y. $475 ; 67$ N. E. 65 . . . . . . . . 177

I'eople ex rel. Blossom $v$. Nelson, 46 N. Y. 177 . . . . . . . . . . . . . . . 332

leople ex rel. H. \& II. Co. ". Camphell, 139 N. Y. $68 ; 84$ N. E. 753 . . . . . . 336

I'eople ex rel. N. Y. I'. Co. $v$. Rice, 128 N. Y. $59 ; 28$ N. F. 251 . . . . . . 84

I'eople ex rel. Pennsylvania R. R. v. Wemple, 198 N. Y. 1 . . . . . . . 206

People ex rel. S. T. Clock Co. $v$. Wemple, 133 N. Y. 323 ; 31 N. E. 238 . . . $3: 36$

Peoria, ete. Co. $v$. I'reston, 35 Ia. 115 . . . . . . . . . . . . . . 56, 146

Perkins $v$. Berders, 56 Miss. 733 . . . . . . . . . . . . . . . . . . . . . . 98

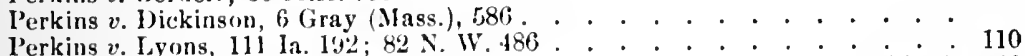

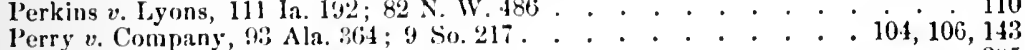

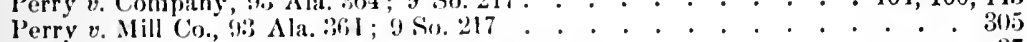

Peshitigo Co. v. Company, 50 Ill. $\Lambda_{\text {p. }} 621$. . . . . . . . . . . . . . 87

letit $\%$. Minnesota, 177 i.s. 164 ; 4 L. E. 716 . . . . . . . . . . . 164

Pettibone $v$. Company, 148 Mass 411 ; IS. F. 897 . . . . . . . . . 292

l'etty $v$. Hayden, I15 Ia. $212 ; 88$ N. W. 93:3 . . . . . . . . . . . . 24

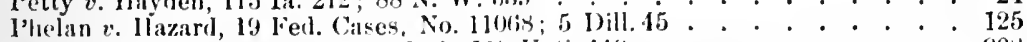

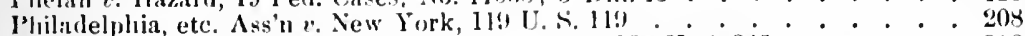

Philadelphia, ete. Steamship Co. v. Pennsylvania, 122 U.S. 345 . . . . . . 210

Phillips $v$. Albany, 28 Wis. 340 . . . . . . . . . . . . . . . . 392 
Phillips r. Wicklanm, I laige (N. Y.), 500.

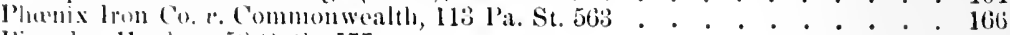

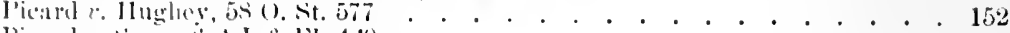

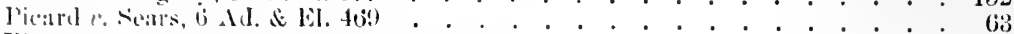

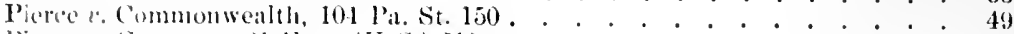

l'ince

I'ieree

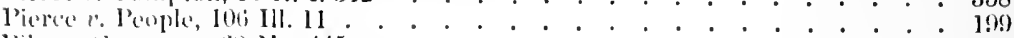

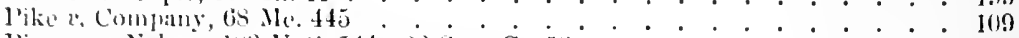

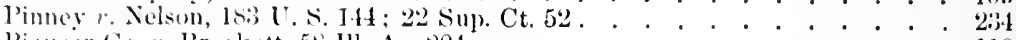

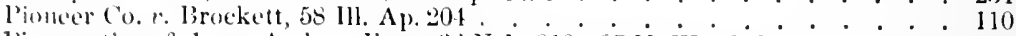

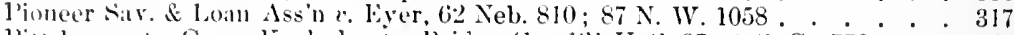

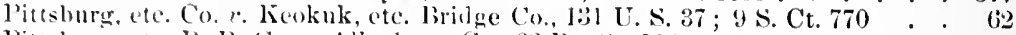

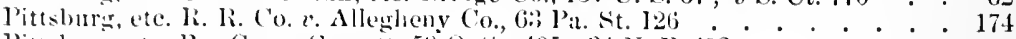

l'itshurir ete. liy. Co. e. Girrett, 50 O. St. 405 ; 34 N. E.403 . . . . . . . . 59

l'limpton r. Bigelow, 93 N. Y. 512 . . . . . . . . . . . . . . . . . . 205

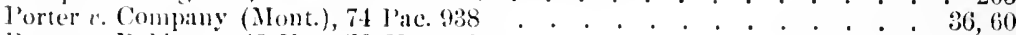

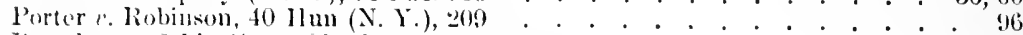

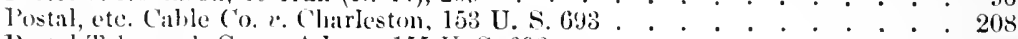

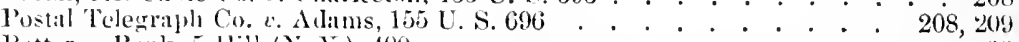

l’otter $r$ Bank, 5 llill (N. Y.), 490 . . . . . . . . . . . . . . . . . . . . 38

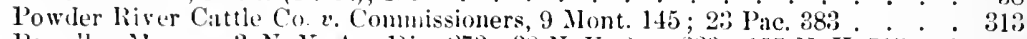

Powell $x$. Murray, :3 N. Y. Ap. 1)iv. 273 ; 38 N. Y. Sup. 23; ; 157 N. Y. $717 ; 53$

N. 1.180 . . . . . • . . . . . . . . . . . . . . 51

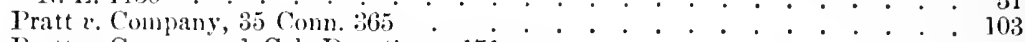

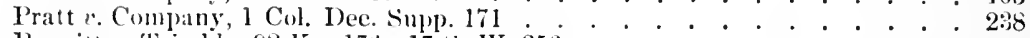

Prewitt $\iota$ 'Trimble, 92 Ky. $176 ; 17$ S. W. 356 .

I'rice's Appeal, 106 Pi. S't. 421 .

I'rinting Ilouse $x$. Trustees, 101 U. S. 7I1 .

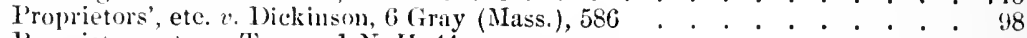

Proprietors, ete. $v$. Towne, 1 N. II. 44 . . . . . . . . . . . . . . . . . . . . 17

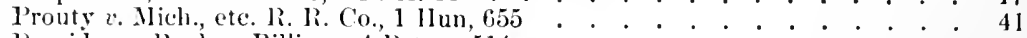

l'rovidence liank $r$. Billings, 4 l'eters, 514 . . . . . . . . . . . . . . . . . . . . . . 161

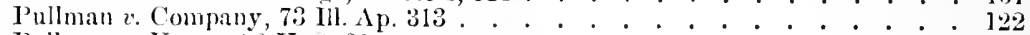

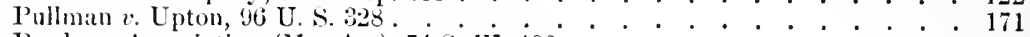

Purdy v. Association (Mo. Ap.), it S. W. 486 .

Q.

Q. C. F. \& C. Co. v. Crawford, 127 Mo. $856 ; 30$ S. WV.163 . . . . . . . . 308

Quinby $v$. Waters, 28 N. J. L. 533 .

R.

R. F. G. v. Smith, 10 Wood, 74 . . . . . . . . . . . . . . . . . 61

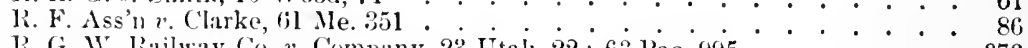

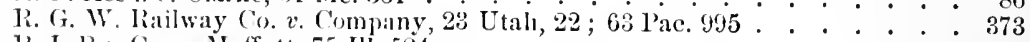

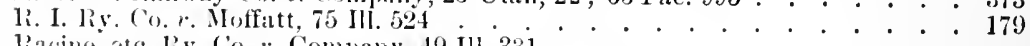

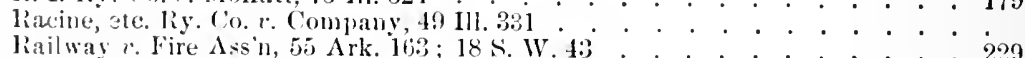

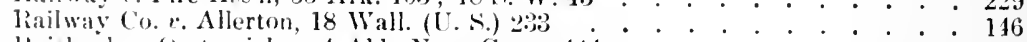

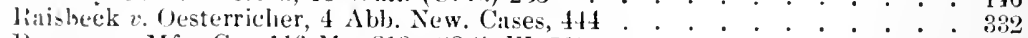

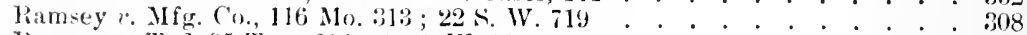

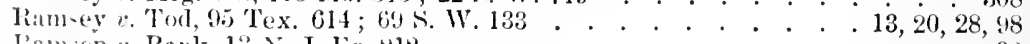

Jiamson $\approx$ Pank, 19 N. J. Eq. 212 . . . . . . . . . . . . . . . 32

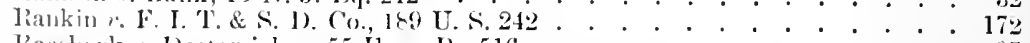

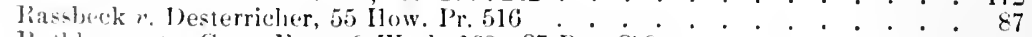

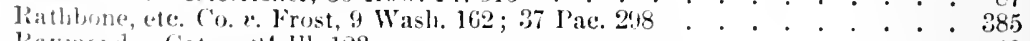

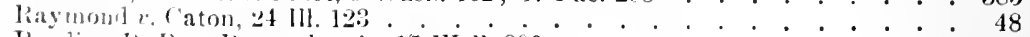

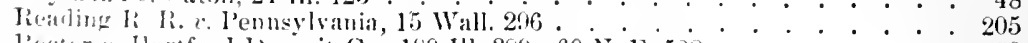

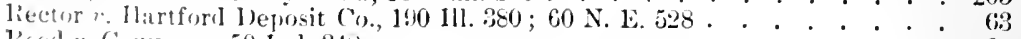

liecd $i$ Company, 50 Ind. 812 . . . . . . . . . . . . . . . . . . . 67 
Reid $v$. Colorado, 87 U. S. 137 ; 47 L. F. 108

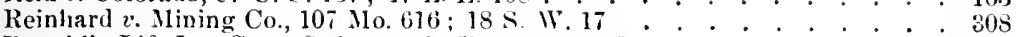

Republic Life Ins. Co. 2 . Swigert, 135 Ill. $150 ; 05$ N. E. 680 .

Revere $v$. Company, 15 Pick. (Mlass.) 351 . . . . . . . . . . . . . . . . 155

Rex v. Passmore, 3 Term Rep. 199 . . . . . . . . . . . . . . . . . . . . . . . . . 157

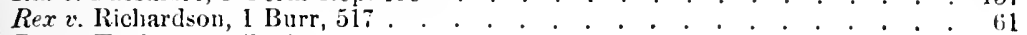

Rex $v$. Taylor, 3 Salk. 291 . . . . . . . . . . . . . . . . . . . . . . . . 61

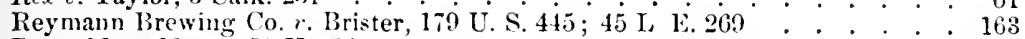

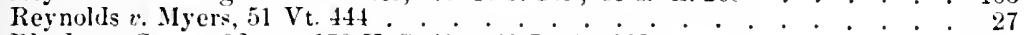

Rliotes $v$. Stite of lowa, 170 U. S. 412; 42 L. F. 1088 . . . . . . . . . . . . . 163

Ribling Stock Co. $v$. People, 147 111. 234: 35 N. E. 608 . . . . . . . . . . . . . 167

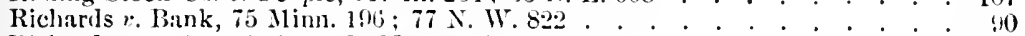

Richardson $v$. Association, 1:1 Mass 174 . . . . . . . . . . . . . 32

Richardson $v$. Conpany, 23 Utah, $366 ; 65$ l'ac. $74 . \quad . \quad . \quad . \quad . \quad . \quad . \quad . \quad . \quad . \quad .374$

Richardson $v$. Graham, 45 W. Va. 134; 30 S. E. 92 . . . . . . . . . 198, 388

Ricliardson $\varepsilon$. Sibley, 11 Allen, 65 . . . . . . . . . . . . . . . . . . . . . 62

Ricliardson $v$. U. S. 11. \& T. Co., 104 Ill. $259 ; 02$ N. E. 606. . . . . . . . . . . . 264

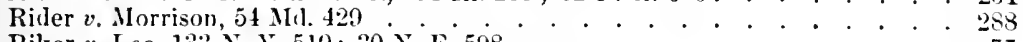

Riker $v$ Leo, 13:3 N. Y. 519; 30 N. E. 598 .

Rivanna Nav. Co. v. Dawsons, 3 Grat. (Va.) 19 . . . . . . . . . . . . . . 33

Rives $\iota$. Company, 30 Ala. 92 . . . . . . . . . . . . . . . . . . . . $44^{\circ}$

Robbins $v$. Shelby Co. Tax 1)is., 120 U. S. 489 . . . . . . . . . . . . . 192, 208

Robinson $v$. Pope, $5 \pi$ Cal. 496 . . . . . . . . . . . . . . . . . . . . . . 108

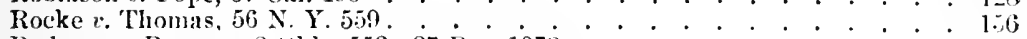

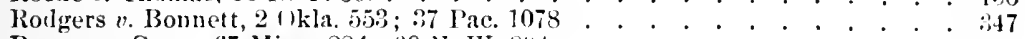

Rogers ". Gross, 67 Minn. 224;69 N. W. 894 . . . . . . . . . . . . . . . . . 144

Rondell v. Fay, 32 Cal. 351 . . . . . . . . . . . . . . . . . . . . 291

Rood $v$. Wharton, 74 Fed 118 .

Ross $\imath^{\circ}$. Company, 77 Ill. I34 . . . . . . . . . . . . . . . . . . . . . . . . . . 40

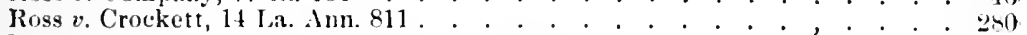

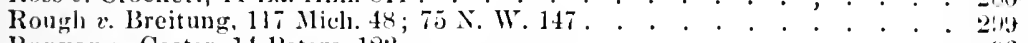

Runyan v. Coster, 14 l'eters, 122 . . . . . . . . . . . . . . . . . . . . . . 96

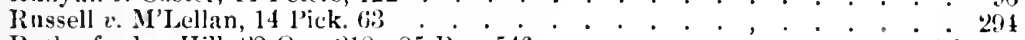

Ruthcrford $v$. Hill, 22 Ore. 218 ; 25 l'ac. 546 . . . . . . . . . . . . . . 173,348

\section{S.}

S. B. T. M. Co. $v$. Company, 4 S. D. $173 ; 56$ N. W. 98 . . . . . . . . . 363

S. E. Co. $v$. Commonwealth, 2] Ky. L. R. list; 55 K. W. 681 . . . . . . . 280

S. E. L. Co. v. Bauk, 127 N.Y. $517 ; 28$ N. F.4i7 . . . . . . . . . . . . . . . 50

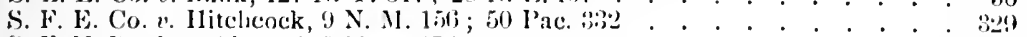

S. F. X. lank r. Almy, 117 Mass. lit;. . . . . . . . . . . . . . il, 109)

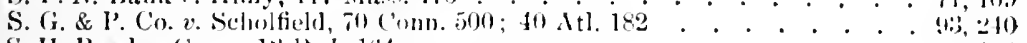

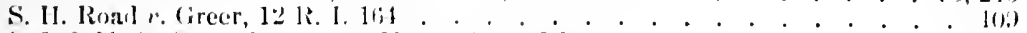

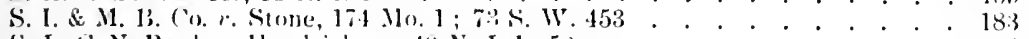

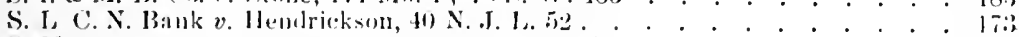

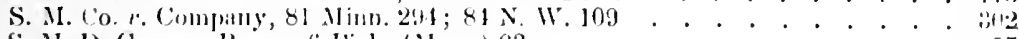

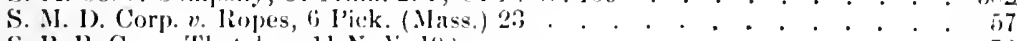

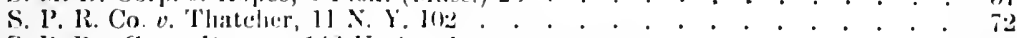

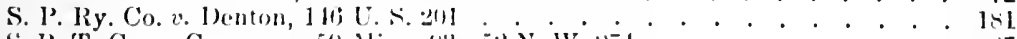

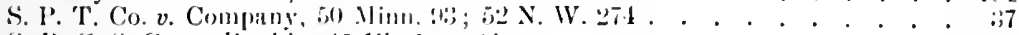

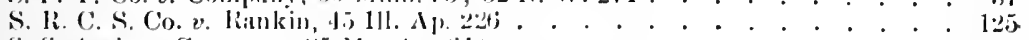

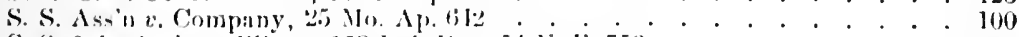

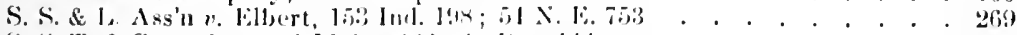

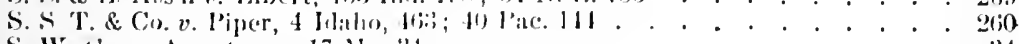

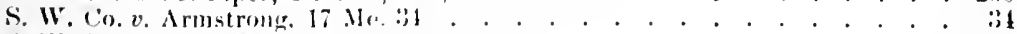

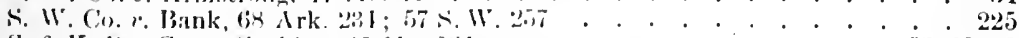

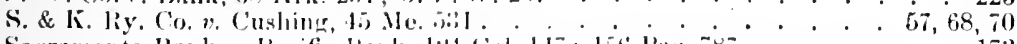

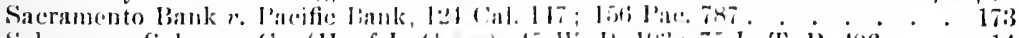

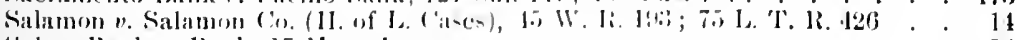

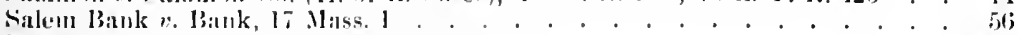

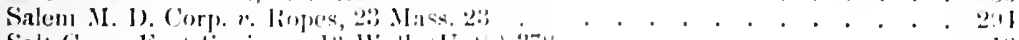

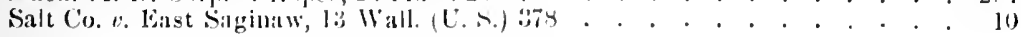


Salt Iake IIardware Co. v. Company, 13 Utah, 423; 45 Pac. 200 . . . . . 374

Singer 4. Upton, 9I U. S. 60 . . . . . . . . . . . . . . . . . 170

San Joaquin v. Beecher, 101 Cal. 70; 35 Pac. 349 . . . . . . . . . . . 48

San Pedro v. R. li. Co., 101 Cal. 3:33; 35 l’ac. 99:3 . . . . . . . . . . 233

Sinta Clara Female Aeademy v. Sullivan, 116 Ill. $375 ; 6$ N. L. 183 • . . . 192

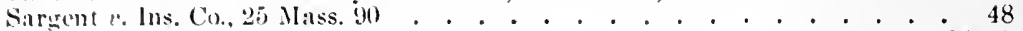

Silumlers r. Earmer, 62 N. 11.572 . . . . . . . . . . . . . 24,27

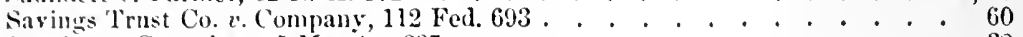

Scanlon r. Crawshaw, 5 Mo. Ap. 337 . . . . . . . . . . . . . . . 32

S'iulon v. Snow, 2 1). C. Ap. Cases, 137 . . . . . . . . . . . . . . 248

Sclienectady, etc. Ilank Road $v$.'Tliatcher, 111 N. Y. 102 . . . . . . . . 71

Sichley 2 . Dixon, 24 Ga. 273 . . . . . . . . . . . . . . . . . . . 176

Nichloss $x$ Company, 87 Ala. 411 ; 6 So. 350 . . . . . . . . . . . . . 71

Schmidt \& Bro. Co. $\%$ Mahomey, 60 Neb. $20 ; 82$ N. W. 99 . . . . . . . . 317

Schmidt $\because$ Mitchell, 101 liy. $570 ; 41$ s. W. $929 \quad$. . . . . . . . . . . . . 49

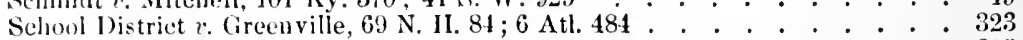

Schroers 2 . Fisk, 10 Col. 599 ; 16 Pac. 285 . . . . . . . . . . . . . . . . . . 325

Schmetzenbuml 2 . Agritations Verein, 44 Mich. $313 ; 6$ N. W. 673 . . . . . . 29

Scott v. B. \& O. R. R. Co., 93 Md. $75 ; 40$ Atl. 327. . . . . . . . . . . 45

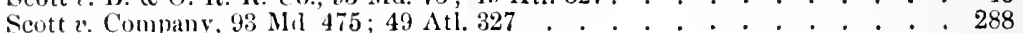

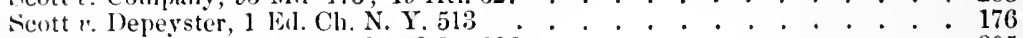

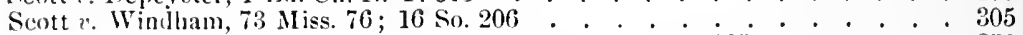

Scottish Union, etc. (oo. $v$. 1Herriott, 109 Ia. $606 ; 80$ N. WV. 665 . . . . . . 273

Scoville ". Thayer, 105 U. S. 14?. . . . . . . . . . . . 72, 115, 142, 144

Scrugers $v$. Company, 54 Ark. $566 ; 16 \mathrm{~S} . \mathrm{W} .563$. . . . . . . . . . . 229

Seabright . Payne, 6 Lea, 283 . . . . . . . . . . . . . . . . . . . 367

Seaton $l^{\circ}$ Grimm, 110 Ia. $145 ; 81$ N. W. 225. . . . . . . . . . . . . 80

Seattle Gas \& Electric Co. $v$. Citizens' Light and Power Co., 123 Fed. $588^{\circ}$. . 183

Second Nat. Bank $k$. Ilall, 85 O. St. 158 . . . . . . . . . . . . . 40

Sec. Co. $"$. Panhandle Nat. Bank, 92 Texas, $575 ; 57$ S. W. 22 . . . . . . 191

Security Co. $x$. Bank, 93 Texas, 575; 56 S. W. 22 . . . . . . . . . . . 371

Seignouret $r$. Company, 24 Fed. 332 . . . . . . . . . . . . . . . . 70

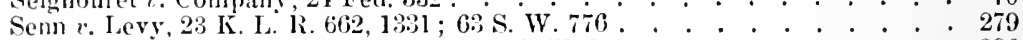

Shadford $*$ Company, 130 Mlich. $300 ; 89$ N. W. 900 . . . . . . . . . . . . . 296

Shanklin v. Gray, 111 Cal. 88; 43 1'ac. 399 . . . . . . . . . . . . . . . 175

Shamon $v$ Stevenson, 173 Pa. St. $419 ; 84$ Atl. 218 . . . . . . . . . . . . 50

Slattuck $v$. Company, 58 Cal. 550 . . . . . . . . . . . . . . . . . . 230

Shaw $\imath$. Gilbert, $11 \mathrm{I}$ Wis $165 ; 86$ N. W. 188 . . . . . . . . . . . . . . . 392

Slielmerline v. Welch, 8 l'a. Co. Rep. 330 . . . . . . . . . . . . . . 105

Shepang Voting Trust Case, 60 Conn. $553 ; 24$ Atl. 22 . . . . . . . . . . 105

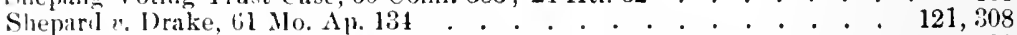

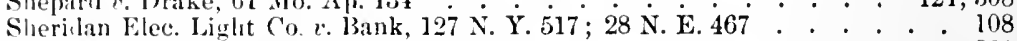

Slierwood $r$. Bank, 195 Ill. 112; 62 N. E. 835 . . . . . . . . . . . . . 263

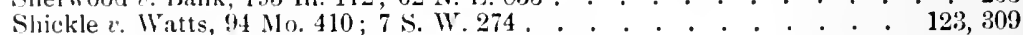

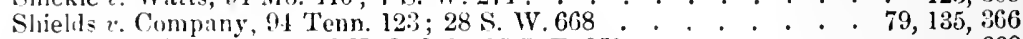

Shields v. Life Ins. Co., 119 N. C. $380 ; 25$ S. E. 951 .

Sluomn $\imath$. Armstrong ('I'enn.), 5! S. W. 790 . . . . . . . . . . . . . . . . 54

Shurtz $v$. Compang, 9 Mlich. 269 . . . . . . . . . . . . . . . . . 71

Sibley $v$. Bank, lis Mass. 515 . . . . . . . . . . . . . . . . . . . . . . 292

Silway v. Company, 104 Fel. $481 \quad$. . . . . . . . . . . . . . . 183

Sigua Iron Co. $v$. Brown, 171 N. Y. $488 ; 64$ N. E. $294 \quad . \quad . \quad . \quad . \quad . \quad . \quad . \quad . \quad .171$

Silsby $v$. Strong, 85 ()re. $86 ; 62$ lac. 6:33 . . . . . . . . . . . . . . 350

Simmings 1 . Association, 26 O. St. 483 . . . . . . . . . . . . . . . 79

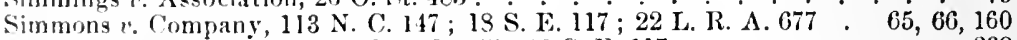

Simmons $u$ Steambont Co., 113 N. C. $117 ; 18$ S. E. 117. . . . . . . . . 838

Simon v. Association, 54 Ark. $58 ; 14$ S. W. $110 \mathrm{~L}$. . . . . . . . . . . . . . . 226

Simplex Dairy Co. v. Cole, 86 Fed. 739 . . . . . . . . . . . . . . . 192

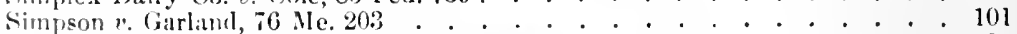

Sims r. Commonwealth, 24 ky. I. liep. $159 ; 71$ S. W. 929 . . . . . . . 87

Singer e firen, Gl Ia. 93 ; $15 \mathrm{~N}$. IV. 858 . . . . . . . . . . . . . . 272

Singer $r$. llutchinson, 183 111. 605; 50 N. E. 388 . . . . . . . . . . . . . . . 155

Singer lifg. Co. $v$. Brown, 64 Ind. 548 .

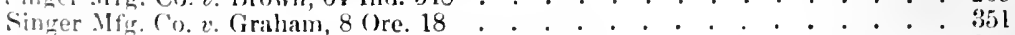

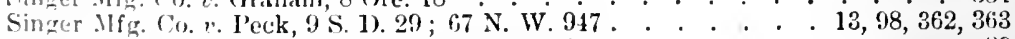

Skjck $v$. Company, 15 Ind. Ap. $310 ; 44$ N. E. 48 . . . . . . . . . . . 29 
Skinner $v$. Smith, 134 N. Y. $240 ; 31$ N. E. 911

Slaughter $v$. Common wealth, 13 Grat. 767

Slaughter House Cases, 111 U. S. 746 . . . . . . . . . . . 162, 163

Slee $v$. Bloom, 5 Jolinson's Chan. N. Y. 366 .

Sleeper $v$. Goodwin, 67 Wis. $577 ; 31$ N. W. $335 \quad$. . . . . . . . . . . . 395

Slocum $v$. Head, 105 Wis. $431 ; 81$ N. W. 673 . . . . . . . . . . . 173,391

Smead $v$. Company, 5\% O. St. 59 . . . . . . . . . . . . . . . . . . . . . 60

Smith $v$. Alabama, 124 U. S. 474 . . . . . . . . . . . . . . . . . 208

Snith $v$. Bank of New England, 69 N. H. $2 j^{4} ; 45_{\text {Atl }} 1052 ; 72$ N. H. 4 . $63,64,322$

Smith $v$. Company, 6 Cal. 1 . . . . . . . . . . . . . . . . . . . 330

Smitl $v$. Company, 27 N. H. 86 .

Smith v. Company, I How. (Miss.) 479 . . . . . . . . . . . . . . . . 109

Smith v. Company (Cal.), 57 Pac. 710 . . . . . . . . . . . . . 123,125

Smith v. Company, 30 Nla. 650 . . . . . . . . . . . . . . . . . . 14,31

Smith $v$. Company, 64 Md. 85 ; 20 Atl. 1022 . . . . . . . . . 40,96, 104, 106

Smith v. Company, 58 N. J. Eq. 381; 43 At. 567 . . . . . . . . . . 73, 176

Smith v. Company, 181 U. S. 248; 45 L. E. 847 . . . . . . . . . . . . 163

Smith $v$. Little, 67 Ind. 549 . . . . . . . . . . . . . . . . . . . . . 191

Smitl $v$. Mlorse, 2 Cal. 524 . . . . . . . . . . . . . . . . . . . . . . . . 330

Sinith v. P. R. R. Co., 30 Ala. 650 . . . . . . . . . . . . . . . . . 214

Snell v. City of Chicago, $133111.413 ; 24$ N. E. $532 \quad$. . . . . . . . . . . $\quad 11$

Sniders' Sons Co. $v$. Troy, 91 Ala. $224 ; 8$ So. 658 . . . . . . . . . . .90

Society for Sarings $v$. Coit, 6 Wall. (U. S.) 591. . . . . . . . . . 178, 205

Society Perun $v$. Cleveland, 43 O. St. 481; 3 N. E. 357 . . . . . . . . . 343

Solomon $v$. Bates, 118 N. C. 321 ; 24 S. E. 746 . . . . . . . . . . . . 338

Spangler $v$. Butterfield, 6 Col. 356 . . . . . . . . . . . . . . . . . . . . . . 235

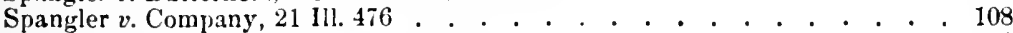

Sparks $v$. Company, 87 Ala. $294 ; 6$ So. $19 j$. . . . . . . . . . . . . . . . 86

Sparks v. Company, 3 ldaho, 806 : 29 l'ac. 134 . . . . . . . . . . . . 14

Spartenberg, ete. R. Co. $v$. Ezell, 14 S. C. $281 \quad$. . . . . . . . . . . . . . 113

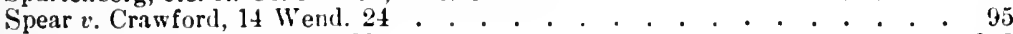

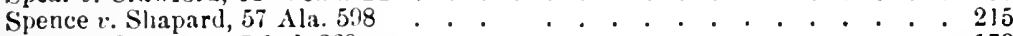

Spero v. Company, 7 Ind. 369 . . . . . . . . . . . . . . . . . . . 179

Sprague $v$. Bank, 172 Ill. $149 ; 50$ N. E. 190 . . . . . . . . . . . 172,268

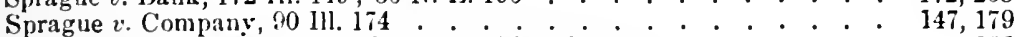

Sprague Brimmer IIfg. Co. $v$. Company, 26 Fed. 572 . . . . . . . . . . . 156

Spry Iumber Co. v. Chappell, 184 Ill. 5:39; 56 N. E.794 . . . . . . . . 264

St. Clair v. Cox, 106 U. S. 356 . . . . . . . . . . . . . . . . . . 180

St. J. \& I. R. R. Co. v. Shambaugh, 106 Mo. 557 ; 17 S. W. 581 . . . . . . 308

St. L. A. \& T. II. Ry. Co. $v$. Company, 105 Ill. $290 ; 41$ N. E. 16 . . . . . . 110

St. Louis l'er. Ins. Co. $r$ Goodfellow, 9 Mo. 149 . . . . . . . . . . . . 48

St. L., ete. Ry. Co. $v$. Fire Ass'n, 60 Ark. $325 ; 30$ S. W. 350 . . . . . . . . . 229

Stafforl \& Co. $v$. An. Mill Co., 19 R. 1.810 . . . . . . . . . . . . . 358

Standard ()il Co. v. Commonwealth, 2: Ky. L. R. $302 ; 62$ S. W. 897 . . . . 279

Standard Sewing Machine Co. r. Frince, 2 Pen. $430 ; 48$ Atl. 188 . . . . . 247

Standley v. Company, 27 Col. 391; 61 l'ac. 600 . . . . . . . . . . . . 238

Stanton Copper Mining Co. v. Tlaurmond, 7 Mo. A p. 587 . . . . . . . . . 77

State $v$. Association, 29 O. St. 3.9. . . . . . . . . . . . . . . . . . . . . . 77

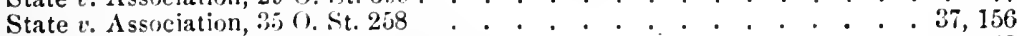

State $v$. Association, 2:3 N. J. I. 195 . . . . . . . . . . . . . . . . 48

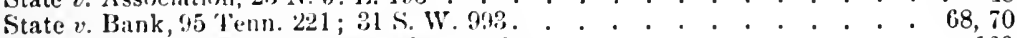

State v. Bank, 13 Sinealls \& M. (Miss.) 569 . . . . . . . . . . . . . . . . 160

State $v$. Bank, 5 Ark. 5.5 . . . . . . . . . . . . . . . . . . . . 227

State $v$. liank, 108 Alı. $8 ; 18$ So. 531 . . . . . . . . . . . . . . . 237

State v. Bank, 2 Stew, 80 . . . . . . . . . . . . . . . . . . . . . 216

State $v$. Barron, 58 N. Il. 370 . . . . . . . . . . . . . . . . . . . . . . . . .

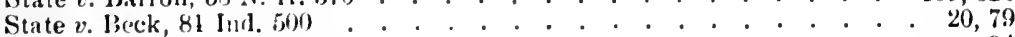

State $r^{\prime}$ Carr, 5 N. 11.367 . . . . . . . . . . . . . . . . . . . . 24

State v. Chemical liank, 10 O. Sc 6r) . . . . . . . . . . . . . . . . . 158

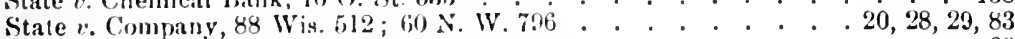

State $v$. Conplany, 16 S. (..521 . . . . . . . . . . . . . . . . . 68

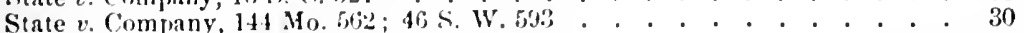

State v. Company, 40 Kan. 9); 19 l'ac. 849 . . . . . . . . . . . . . . 32,52

State v. Company, 21 'Texas, 80 . . . . . . . . . . . . . . 65, 66, 160

State $v$. Company, 45 Wis. 579 . . . . . . . . . . . . . . 65, 6t, 159 
State r. Company, 58 Minn. $830 ; 59$ N. IV. 1048

sitate 1". Compiny, +1 lul. 151

state 2 . Company, :3 llump. ('Temm.) 305

state 1 . ('ompany, 19 (). St. $137 ; 30$ N. 15. 279

State 1. Company, 102 Ala. $594 ; 15$ So. 347

state r. (ompany, s li. 1. 18:2

State 2 . Company, 1 'l'enu. Cases, 511

state $r$. (ompany, 39 Minn. $588 ; 11 \mathrm{~N}$. W. 108

state $r$ (ompany, 47 (). St. $167 ; 24$ N. 1;, 392

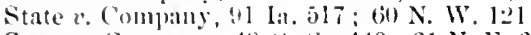

State r. Company, 4!) U. St. 440;31 N. F. 658

Sitate $r$. Company, $108 \mathrm{Alal} .29$ : $18 \mathrm{So} .80 \mathrm{l}$

State r. Company, 91 la. 517 ; (00 N. W. 121

State 2 . Company, 6l Kan. 547; 60 Yac. $3 ; 3$.

State r. Company, 52 La. Am. 18:2; 28 So. 372

state $r$. Company, 40 Minn. 213; 41 N. WV. 1020

state $x$ Compiny, 4:) Mimn. 17; 44 N. W. 10832.

$60,98,182,276,277$

State $x$. Company, 21 Wash. 451 ; 58 Pac. $58 t$

State 2 . Company, 61 Neb. $28 ; 81$ N. W. 413.

State $v$. Company, 24 Neb. $143 ; 38$ N. W. 43

State r. Company, 2y Nel. 700; 46 N. W. 155

29,817

State $x$. Company, 4 Nel. 354 . . . . . . . . . . . . . . . . . . 317

State $r$. Company, 62 (). St. $350 ; 57$ N. E. 62

345

State $x$. Company, 59 Kan. 151; 52 Pac. 422

$66,155,27 i$

State $v$. Critchett, 37 Minn. 13;32 N. W. 787 . . . . . . . . . 79, 91, 300

State $r$. Curtis, 9 Nev. 324

State $r$. Fonlkes, 91 Ind. 493

State $x$. Greer, is Mo. 188

State $*$. Lee, 210 . St. 602

State 2 Lestuenr, $110.552 ; 13$ S. W. $377^{\circ}$

State $r$. MeCullough, 3 Nev. 202

Siate $v$. Mclonniel, 220. St. 354

State $*$. McGains, 61 Mo. Ap. 225 .

State 2 . MuGrath, 75 Mío. 424

State $r$. McGrath, 92 No. $355 ; 5$ S. W. 29 .

State $x$. Nerchant, 370 . St. 251

State $x$. Ofted 1,72 Minn. $488 ; 75$ N. W. 692

State 2 . (verton, 4 Zabriskie (N. J.), $435 ; 24$ N. J. I. 435.

56

13,77

$15 \dot{31,8 \dot{3}, 84,807}$

$10 \%, 104$

State 2 l'ayne, 129 Mo. $469 ; 81 \mathrm{~S}$. W. 797

State $v$. llipps, on Kam. 609; 31 Pae. 1097

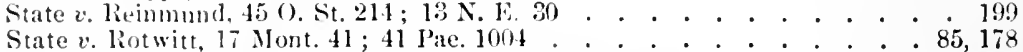

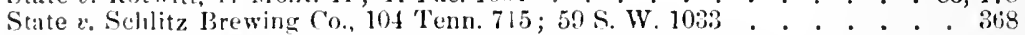

State $r$. Sherman, $2 \cdot 20$ () St. 411

179,345

State 2 . Shiphers ('ompress \& Warehouse Co., 95 Tex. $603 ; 69$ s.

State $v$. Simonton, 78 N. C.57 . . . . . . . . . . . . . . . . 159

State 2 . Stockley, 450 . St $804 ; 10$ N. E. 279 . . . . . . . . . . . . 49

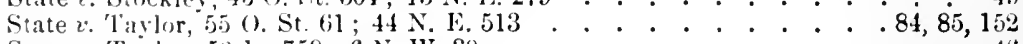

State $x$. Taylor, 5:2 la. $759 ; 6$ N. W. 39 . . . . . . . . . . . . . 40

State $x$. Tulor, 5 1)ay, 329 . . . . . . . . . . . . . . . . . . 49, 104

State 2 . Trusters, etc., 5 Ind. 77 . . . . . . . . . . . . . . 61, 156

Sitate $v$. Welb, 5 Nla. $111 ; 12$ So. 877 . . . . . . . . . . . . . . $73,91,113,216$

Sitate $r$. Well, 110 Ala. $214 ; 20$ So. 462 . . . . . . . . . . . . 125, 141

State $v$. White, 13 No. Ap. 199

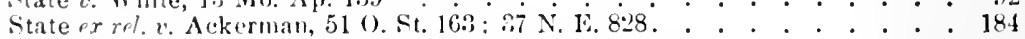

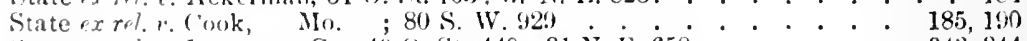

State ex r.l. Insurance Co., 490 . St. $440: 81$ N. I. 658 . . . . . . 343,341

State ex r. Attorney General $v$. Conklin, 3.8 Wis. 21 . . . . . . . . . 100

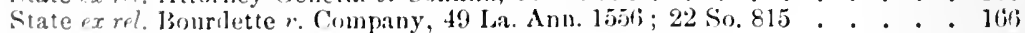

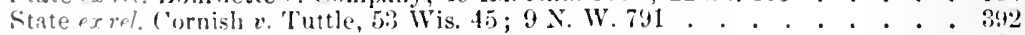

State er rel. Brake $v$. Dorle, 10 Wis. 175 . . . . . . . . . . . . . . . . . 393

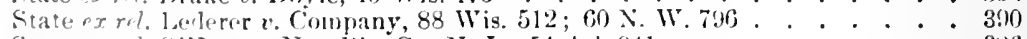

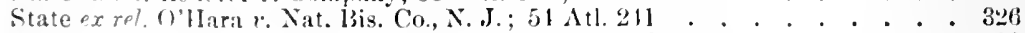

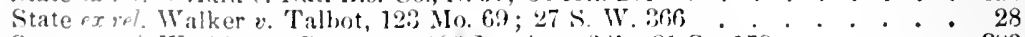

State $e x$ rel. Watkins v. Company, 106 La. Ann. 6.21 ; 31 So. 172 . . . . . . 283 
State ex rel. White $v$. Ilancock, 20 Pen. $252 ; 45 \mathrm{Atl} .851$. . . . . . . . . 244

State R. R. 'Tax Cases, 9.' U. S. 60:3 . . . . . . . . . . . . . . . . . 205

State Savings Bank $v$. Johnson, 18 Mont. 440 ; 45 Pac. 662 . . . . . . . 312

Steamship Co. $v$. Company, 28 La. Amm. 173. . . . . . . . . . . . . 37

Steger $v$. 1)avis, 8 Tex. Civ. Ap. 2:3; 27 S. W. 1068 . . . . . . . . . . 33

Stein $v$. Howard, 65 Cal $616 ; 4$ 1'ac. $622 . \quad$. . . . . . . . . . . . . 143,232

Steiner $v$. Steiner, L. L. Co. (Ala.), 26 So. 494 . . . . . . . . . . . . . . 10

Steinuetz $v$. Company, 57 ind 457 . . . . . . . . . . . . . . . . . . . . . 71,77

Stevens $v$. Company, 29 Yt. 545 . . . . . . . . . . . . . . . . . . . . . 147

Stewart $v$. Company, 83 N. J. L. 496 . . . . . . . . . . . . . . . 198

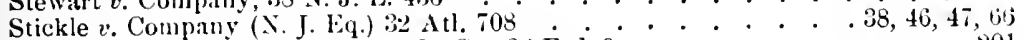

Stockton $v$. Baltinore \& N. Y. R. R. Co., 32 Fed. 9 . . . . . . . . . . 201

Stoddard $x$. Company, 44 Comm. 545 . . . . . . . . . . . . . . . . 121

Stolze $v$. Company, ivo Wis. 208; 75 N. W. 987 . . . . . . . . . . . . . 1j6

Stome $v$. Framingham, 109 Mass. 30:3 . . . . . . . . . . . . . . . 294

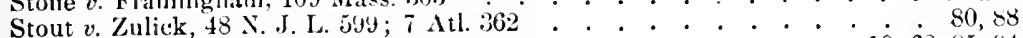

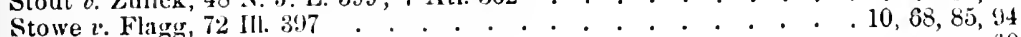

Strauss $v$. Company, 5: (). St. 59 . . . . . . . . . . . . . . . . . 60

Sturges v. Company, 7 1) Gex, M. \& G. 158 . . . . . . . . . . . . . 45

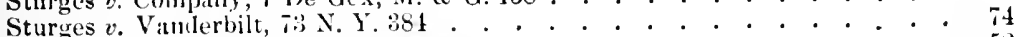

Sullivan $v$. Company. :39 Cal. 459 .

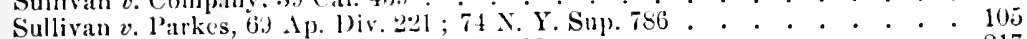

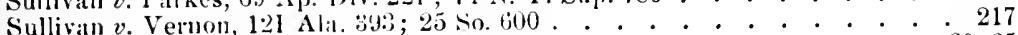

Sultons Hospital Cases, foke's liep. 25:3. . . . . . . . . . . . . . . . 30,65

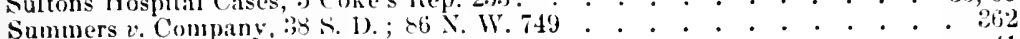

Sutherland $v$. Olcott, 9.5 X. Y. 93 . . . . . . . . . . . . . . . . . . 41

Sutro $v$. Company, 19 Nev. 121; 7 Pac. 27 . . . . . . . . . . . . . 318

Swan $v$. Buinlam, 70 N. ll. $580 ; 49$ Atl. 98. . . . . . . . . . . . . 322

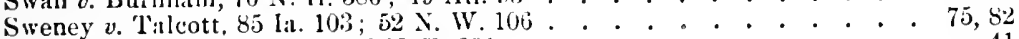

Sykes v. People, 132111.32 ; 23 N. E. 391 . . . . . . . . . . . . . . 41

T.

T. A. T. Co, $v$ Massey (Tenn.), 56 S. WV. $35 . . . . . . . . . ~ . ~ 28,54$

T. A. I. Co. v. Massey

T. M. Co. $v$ Goodlue, 18 N. C. 181 . . . . . . . . . . . . . . 98, 104

T. K. N. Co. $v$. Neal, 3 llawks (N. (.$), 526$. . . . . . . . . . . . 89,90

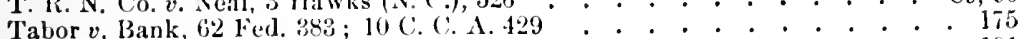

Tahor $v$. Company, 11 Col. 119 ; 18 Pac. 537 . . . . . . . . . . . . . . . . . . . . 191

Talbot $v$. Company, 74 llo. 544 . . . . . . . . . . . . . . . . . . 182

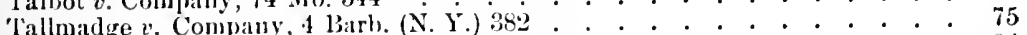

Taylor $v$. Company, 91 . We $193 ; 39$ Atl. 560 . . . . . . . . . . . . . 24

Taylor $v$. Company, 60 (). St. 83 . . . . . . . . . . . . . . . . . . . . . . . . . 37

'Taylor $v$. Company, 14 Allen (Mass.), 353. . . . . . . . . . . . . . . 157

favlor e. Cummings, 127 led. 108 . . . . . . . . . . . . . . . 125,170

Taylor v. Giriswold, it N. I. L. 22. . . . . . . . . . . . . . . . . 104

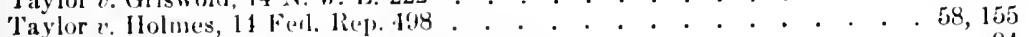

Teitig $v$. Boesman, le llont. fol :31 lac.3i

Telephone Co. v. T'elphone Co., 2: Cal. 398 . . . . . . . . . . . . . . . 2:30

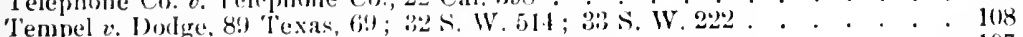

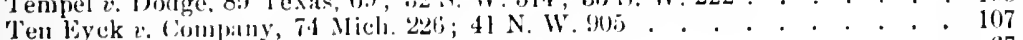

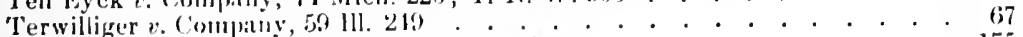

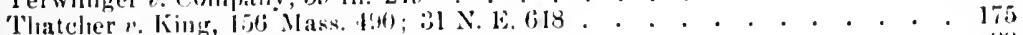

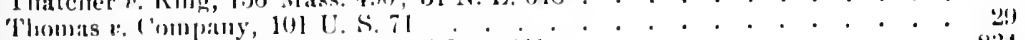

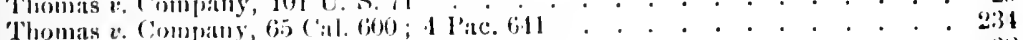

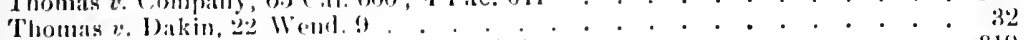

Thompen v. Bamk, lo lev. 171 ; 7 Pac 870 . . . . . . . . . . . . . . . . 819

Thompson r. Comprany, os Mi-s. 12:3. . . . . . . . . . . . . . Iot;

Thompson r. Comprang,

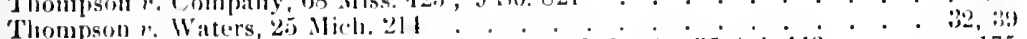

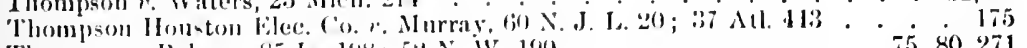

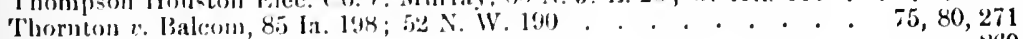

Thum v. Pyke (1taho), 6ij l'ac. liti . . . . . . . . . . . . . . . . . 260 
Tidewater Pipe Line Co.r. Berry, 53 N. J. L. 212 . . • . . . . . . . 178

Tidionte sav. lank ". Libbey, lol Wis. $193 ; 77 \mathrm{~N}$. W. 182 . . . . . . 75

Tilley e. Coykendall, $172 \mathrm{~N}$.Y. 587 ; 65 N. 1. 57. . . . . . . . . . . 40

Tillyer $r$ llero .lat Co., 17 l'hil. (l'a.) 153. . . . . . . . . . . . . 14

Titus $x$ (.. .1. 'l'. liond, 61 N. Y. 237 . . . . . . . . . . . . . . . 110

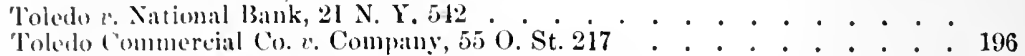

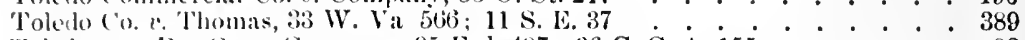

Toledo, ete lis. Co. r. Company, 95 Fed. $497 ; 36$ C. C. A. 155 : : : 38

Tuledo, ete. Co. c. Glum, etc. Co.. 55 O. St. $217 ; 45$ N. E. 197 . . . . 345

'Tolmar $\because$ Company, 2.2 N. W. 505 . . . . . . . . . . . . . . . 37

Tomlin e. Bank, 52 AIo. Ap. 430 . . . . . . . . . . . . . . . 49, 102

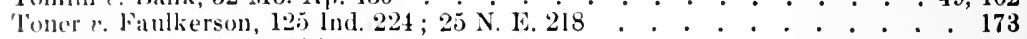

'Tomey r.s. L. K. l'., it Mo. Ap. 129 . . . . . . . . . . . . . . . 310

Topeka laper Co. $v$. Company, 7 Okla 220 ; 54 Pae 455 . . . . . . . . 346

Tourtelot $x$. Whithead, 9 N. D. $407 ; 81$ N. W. 8 . . . . . . . . . . 340

Town of Searey 2 . Yarnell, 47 Ark. $269 ; 1$ S. IV. 319 . . . . . . . . 228

Tradesmen Pub. Co. $v$. Company, 95 'Tenn. $634 ; 32$ S. W. 1097 . . . . 72, 175

Traer ${ }^{\circ}$ Company (Ia.), 99 N. W. 290 . . . . . . . . . . . . . . . 51

Treadwell $r$. Company, 7 Gray (Mass.), 393 . . . . . . . . . . . . . 51

Troy, ete. Ry. Co. v. Kerr, 17 Barb. (N. Y.) 607 . . . . . . . . . . . 147

Trust Co. $v$. Floyd, 47 O. St. $525 ; 26$ N. E. 110 . . . . . . . . . . . 344

Trust Co. $v$. State, 109 Ga. 736 ; 35 S. E. 323 . . . . . . . . . . . . 255

Trustee, etc. v. Camphell, 46 La. Amn. 1543; 21 So. 184 . . . . . . . . . 79

Trustees $v$. Manning, 72 Md. 116 ; 19 Atl. 599 . . . . . . . . . . . . 33

T'sehuni $v$. Hills, 6 Kían. Ap. 549 ; 57 Pac. 619 . . . . . . . . . . . . 57

Tuckasegee Ulining Co. $v$. Goodhue, 118 N. C. 981 ; 24 S. E. 797 . . . . . 40

Tucker $v$. Gilman, 121 N. Y. 189 ; 21 N. E. 302 . . . . . . . . . . . 333

Tuttle $v$. Nat. Bank, 101 Ill. 497 ; 44 N. E. 981 . . . . . . . . . . . 173

U.

U. M. Co. v. Bank, 2 Col. 248 .

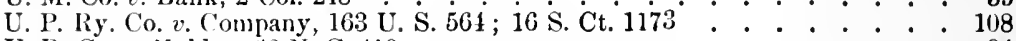

U. R. Co. $c$. IJolden, 63 N. C. 410 . . . . . . . . . . . . . . . . 94

U. S. v. Company, 1 Fed. 700 . • • . . . . . . 156

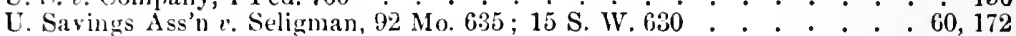

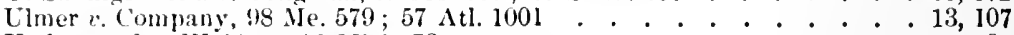

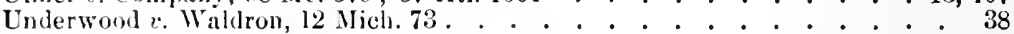

Union Bank v. Latirl, 2 Wheat. (U.S.) 990 . . . . . . . . . . . . . . 47

Union Ilorsesloe Works $v$. Lewis, 1 Abb. (U. S.) 518 ; Fed. Cases, 14383 . 85, 178

Union Nat. Bank $v$. Matthews, 98 U.s.621 . . . . . . . . 64, 77

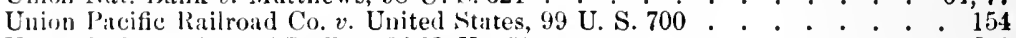

Union S. Co. 2 . City of Buffalo, 82 N. Y. 351 . . . . . . . . . . . . 332

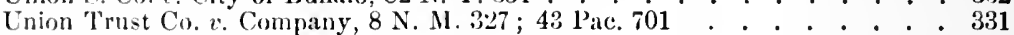

Union Watter Co. $v$. Company et al., 22 Cal. 621 . . . . . . . . . . 230

Uni,n Water Co. $v$. Kean, 52 N. J. Eq. $111 ; 27$ itl. 1015 . . . . . . . . 24

United States $"$ Association, 166 U. S. 290 ; 17 S. Ct. 540 . . . . . . 139, 167

United States $v$ Company, 29 Ferl 17 . . . . . . . . . . 191

United States Vinegar Co. $v$. Foehrenbach, 148 N. Y. $58 ; 42$ N. E. 403 . . 29

United States Vinegar Co. $v$. Schlegel, 143 N. Y. $537 ; 38$ N. E. 720 . . . 24, 27

Upton $v$. 'Triblecock, 91 U. S. 345; 21 L. E. 203 . . . . . . . . . . . 142

Utley v. Company, 4 Col. 369 .

Utley $v$. Cnion Tool Co., 11 Gray (Hass.), 139 . . . . . . . . . . . . 10

V.

V. I. R. R. Co. v. E. T. \& G. R. R. Co., 14 Ga. 327 . . . . . . . . . . 257

V. C. Railway Co. $r$ Clayes, 21 Vt. 30 . . . . . . . . . . . . . 92

V. G. 13. Co. v. Hode, 84 IId $129 ; 34 \Delta$ tl 1127.

Van Cott $\%$. Van Brunt, 82 N. Y. 535 . . . . . . . . . . . . . 124, 171

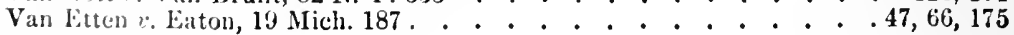


Van Pelt v. Association, 79 Ga. $439 ; 4$ S. E. 501 . . . . . . . . . . . 82

Van Pelt $v$. Gardner, 54 Neb. 701 ; 75 N. W. 874 . . . . . . . . 54,83, 174

Van Sands $v$. Bank, 26 Conn. 144. . . . . . . . . . . . . . . . . 48

Vaughn Machine Co. $v$. Lighthouse, 64 Ap. Div. (N. Y.) 138 . . . . . . 194

Vawter $v$. Franklin College, 53 Ind. 88 . . . . . . . . . . . . . 77,82

Veeder $v$. Mudgett, 95 N. Y. 295 . . . . . . . . . . . . . . . . . 109

Ventura, etc. Ry. Co. 2 . Hartman, 116 Cal. $260 ; 48$ Pac. 65 . . . . . . . 142

Vermont, etc. Ky. Co. v. Conspany, 34 Vt.2 . . . . . . . . . . . . . . 24

Vermont Loan \& Trust Co. $v$. Hoffman, 5 Idaho, $376 ; 49$ l'ac. 314 . . . . 260

Vermont Marbie Co. v. Company, 135 Cal. 579; 67 Pac. 1057 . . . . . 143, 232

Vidal $v$. Girard's Executors, 2 How. (U. S) 127. . . . . . . . . . . . 33

Visalia, etc. Co. $v$. Hyde, 110 Cal. $632 ; 43$ Pac. 10 . . . . . . . . . . . 232

Vos $v$. Association, 9 Bull (Ohio), 194 . . . . . . . . . . . . . . . . 60

W.

W. B. \& L. Ass'n v. Coleman, 89 Pa. St. 428 . . . . . . . . . . . . . 79

W. C. M. Co. $v$. Byrnes, 114 N. C. 353 . . . . . . . . . . . . . . 159

W. F. C. F. Co. $v$. Kittridge, 5 Sav. 44 . . . . . . . . . . . . . . . 159

W. G. \& S. M. Co. v. Baker, 3 Nev. 351 . . . . . . . . . . . . 320

W. H. \& H. Mining Co. $v$. King, 45 Ga. 34 . . . . . . . . . . . . 104

W. P. R. Co. v. Company, 114 N. C. $690 ; 19$ S. E. 646 . . . . . . . . . 27

W. P. R. Co. $v$. Young, 12 IId. 476 . . . . . . . . . . . . . . . . 24

W. R. Lumber Co. v. Implement Ass'n, 55 Ark. $625 ; 18$ S. W. 1055 . . . 229

W. S. Bank $v$. Bank, 107 Mo. $133 ; 17$ S. W. 644 . . . . . . . . . 108

W. U. 'T. Co. $v$. Attorney-General, 125 U. S. $530 ; 8$ S. Ct. 961 ; 31 L. E. 790 ; 85

W. \& B. T. Co. v. Maryland, 19 Md. 239 . . . . . . . . . . . . . . 157

W. \& M. Road Co. v. Board of Supervisors, 64 Cal. $69 ; 28$ Pac. 496 . . . . 22

Wagner Free Institution $v$. Pliladelphia, 132 Pa. St.612 . . . . . . . . 153

Walker $v$. Company, 34 (N. Y.) Nisc. 345 . . . . . . . . . . . . . . 71

Wallace $v$. Bank, 89 Tenn. $630 ; 13$ S. W. 48 . . . . . . . . . . . . 176

Wallace $v$. Walsh, 125 N. Y. 26 ; 25 N. E. 1076 . . . . . . . . . . . . 175

Wallace v. T. Co., 70 Minn. 521 ; $73 \mathrm{~N}$. W. $189 . \quad . \quad . \quad . \quad . \quad . \quad . \quad . \quad 302$

Walsenberg Water Co. $v$. Moore, 5 Col. Ap. $144 ; 38$ Pac. 60 . . . . . . . 107

Wal worth $v$. Brackett, 98 NIass. 98 . . . . . . . . . . . . 92, 96, 290

Ward $v$. Brigham, 127 Mass. 24 . . . . . . . . . . . . . . . . . . 173

Ward $v$. Johnson, 95 Ill. 215 . . . . . . . . . . . . . . . . . . . . 60

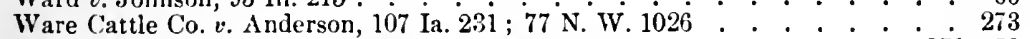

Warfield $v$. Company, 72 Ia. $666 ; 34$ N. W. 467. . . . . . . . . . 271, 272

Warner $v$. Callender, 20 O. St. 190 . . . . . . . . . . . . . . . . 79

Washburn $v$. Company, 81 Fed. 17 . . . . . . . . . . . . . . 121

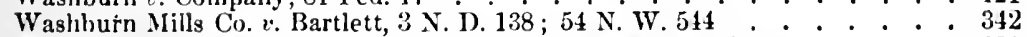

Washington Co. Mut. Ins. Co. v. I)awes, 6 Gray (Mass.), 376 . . . . . . . . . 181

Waslington, etc. Ass'n v. Stanley, 38 Ore. 319 ; 63 Pac. 489 . . . . . . . . . 349

Washington Mills Co. $v$. Roberts, 8 N. Y. Ap. Div. $20 ; 151$ N. Y. 69 . . . . 193

Waters $v$. Quinby, 27 N. J. L. 296. . . . . 109

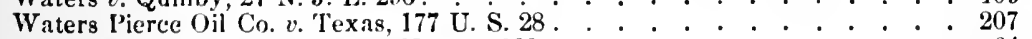

Water Works Co. $v$. Low, 46 N. Y. Sup. 63\%. . . . . . . . . . . . . . 64

Waterworks $v$. San Francisco, 22 Cal 441 . . . . . . . . . . . . . 231

Watson $v$. Company, 56 Mo. Ap. 145 . . . . . . . . . . . . . . . . 56

Wankon, etc. Ry. Co. $c$. Wwyer, 49 Ia. 121 . . . . . . . . . . . . 96

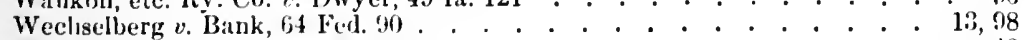

Weeks $v$. Company, 5. N. Y.Sup. Ct. 1 . . . . . . . . . . . . . . 48

Weeks $v$. Love, 5j N. Y.568 . . . . . . . . . . . . . . . . 393

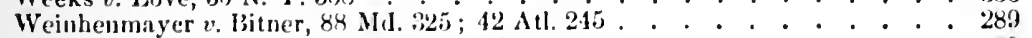

Welch $v$. Bink, 122 N. Y. $177 ; 25$ N. F. 269 . . . . . . . . . . . . . 89

Wells $v$. Black, 117 Cal 157; 48 l'ac. 109\% . . . . . . . . . . . . . 33

Wells $x$ Company, 90 Wis 412 ; 64 N. W. 6: . . . . . . . . . . . 142

Welton $v$. Missouri, 91 U. S. 275 . . . . . . . . . . . . . . . . 200

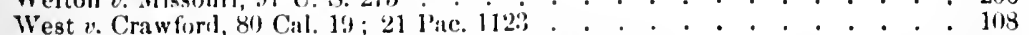

Western Co. v. Central (o., 116 Ind. 22:); 18 N. E. 14 . . . . . . . . . 268

Western Union 'lelegraph Co. v. Nayer, 280 ().St. 521 . . . . . 18t, 315

Wetherbee $v$. Baker, 35 N. J. liq. 501 . . . . . . . . . . . . . 138, 326 
Wheler 4 . Company, 113 111. 197; 38 N. E. 420.

$53,102,157$

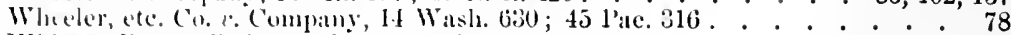

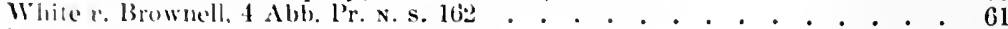

White e. Jummer. 3 Wison (U.s..), 303 • . . . . . . . . . . . . . 126

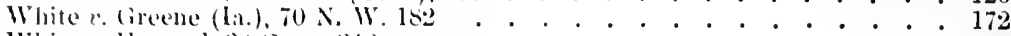

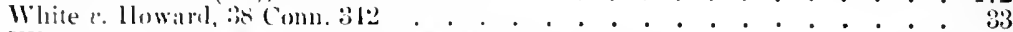

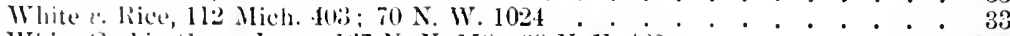

White Corbin Co. .. Jones, 167 N. Y. 158; 60 N. 1. 422 . . . . . . . . . . 334

Whitehill 2 . Jacohs, $75 \mathrm{~W}$ is. 4.4 ; $4 \mathrm{~N}$. W. 630 . . . . . . . . . 121, 124, 125

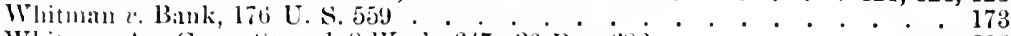

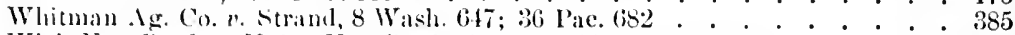

Wick Nat. Bank e. Lnim Nat. Bank, 62 O. St. $446 ; 57$ N. E. 320 . . . . . 341

Wiergins ('o. v. latst St. Lonis, 107 U. S. 874 . . . . . . . . . . . 208

Wilcox cordage Co. 2 . Mosher, 114 Mich. 64; 72 N. iv. 117 . . . . . . . . 299

Wilkinson k. Bertock, 111 Ga. 187 ; 36 s. E. 62:3 . . . . . . . . . . . 256

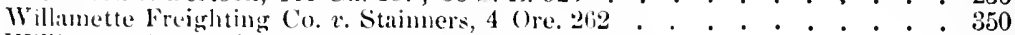

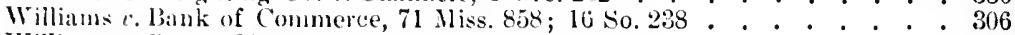

Williams ¿. Benet, it S. ('.112; 13 S. 1. 97. . . . . . . . . . . . . 360

Williams $\varepsilon$. Boice, 88 N. J. Eq. 364 . . . . . . . . . . . . . . . . 326

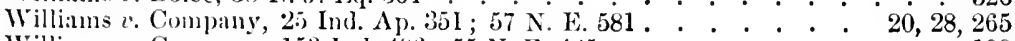

Willims $v$. Complany, 153 Ind $490 ; 55$ N. E. 425 . . . . . . . . . . . 108

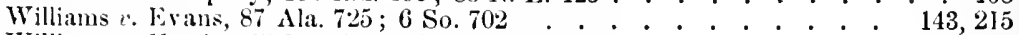

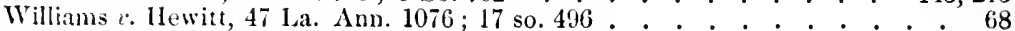

Williams $\bullet$ Lowe, 4 Neb. 382 .

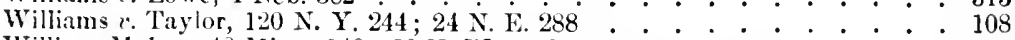

Willis $c$. Mabon, 48 Minn. $140 ; 50$ N. W. 1110 . . . . . . . . . . . . . 173

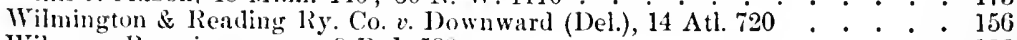

Wilson ․ Proprictors, etc., 9 R. 1. 590 . . . . . . . . . . . . . . . 156

Wing c. Slater, 19 R. I. 597 ; 85 Atl. 302 . . . . . . . . . . . . . . . . . . . 80

Winscott $\iota$. Investment Co., 63 Mo. Ap. 367 . . . . . . . . . . . . . . . 45, 309

Witters $\imath$. Sowles, 31 Fed. 1 . . . . . . . . . . . . . . . . . . . . . . . 175

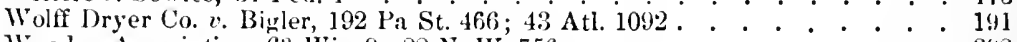

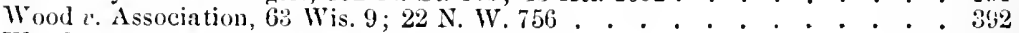

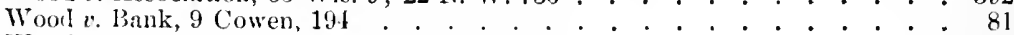

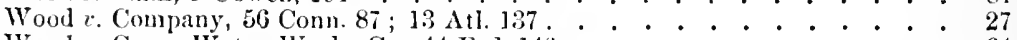

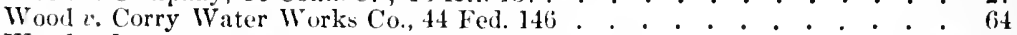

Wool v. 1)ummer, 3 Mason, 308 ; Ferl. Cases, I7944 . . . . . . . . . . 114, 122

Womberry $v$. McClurg, 78 Miss. $831 ; 29$ So. 514 . . . . . . . . . 20, 83, $306^{\circ}$

Woolman $c$. Company, 50 Ne 549 .

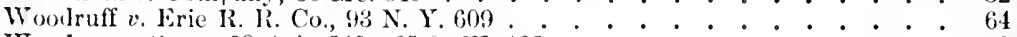

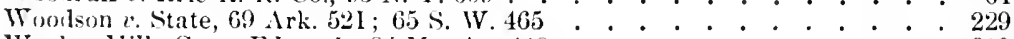

Woolen Jills Co. $v$. Elwards, 81 Mo. Ap. 448 .

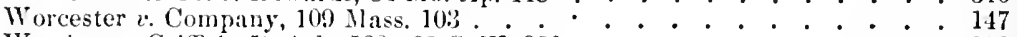

Worthen $v$ Griffith, 59 Ark. $562 ; 28$ S. IV. 286 . . . . . . . . . . . . . . . . 226

Wright 2 . Company, 67 Cal. 5:2; 8 1'ac. 70 . . . . . . . . . . . . . 102

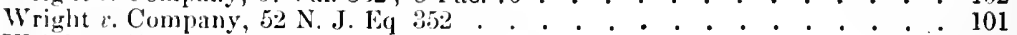

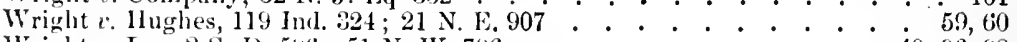

Wright $v$. Lee, 2 S. D. $5 ! 16$; 51 N. WV. $706 \quad$.

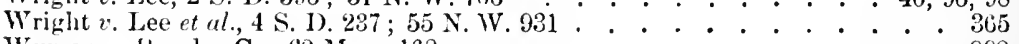

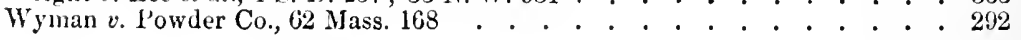

Y.

Y. R. L. N. Co. v. Company, 72 Fell. 62 .

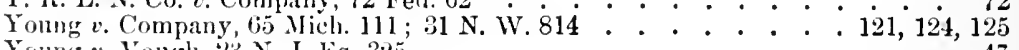

Young $v$. Vough, 2,5 N. J. Eq. 325 . . . . . . . . . . . . . . . . 47

$Z$.

Zabriskie $\imath$. Company, 18 N. J. Eq. 178 . . . . . . . . . . . 147 


\section{A TREATISE}

ON THE

\section{INCORPORATION AND ORGANIZATION OF CORPORATIONS.}

\section{INTRODUCTION.}

THE derelopment of the modern business corporation act has been most curious and interesting. Previous to the year 1837 charters could be procured only by special act of the legislature. In that year the legislature of Connceticut passed the first business corporation act that went into foree and effect in the United States. It was drawn by Theodore Hinsdale, of Winchester, Connecticut, a Yale graduate of the class of 1821. As this act forms the basic work of most of the business corporation acts of to-day, it deserves more than passing notice. It was drafted for the purpose of permitting incorporation thereunder of companies for the purpose of carrying on a manufacturing, mechanical, mining, and quarrying business. The statutory powers of corporations incorporated thereunder were enumerated as follows: To sue and be sued, to have a common seal, to elect officers, to fix their compensation and duties, to estahlish by-laws, to employ agents, mechanies, and laborers. Incorporation was limited to one purpose, to be distinetly and definitely set forth in the articles of agreement which were required to be signed by all the incorporators. A board of directors was provided for; also a president, secretary, and treasurer. Power was given to the corporation to forfeit stock of stocklolders for non-payment of stock subseriptions. The eorporation also had a lien upon the stock of its members for debts. After the articles were signed and the corporation organized and the articles of association published, 
the officers were required to make and file with the Secretary of State (and a duplicate thereof with the town elerk of the town where the corporation was to transact its business) a certificate setting forth, (1) the purpose of the corporation; (2) the amount of its eipital stoek; (3) the names of stockholders and the number of shares held by each. Amnual reports were made obligatory. Stockholders were made liable for all capital refunded to them, and made personally liable for the declaration of illegal dividends.

The passage as well as the operation of the first Connectieut act was watched closely by the legislative bodies of the neighboring States, with the result that by 1850 there were in the neighborhood of a score of general business corporation acts in force and effect in various parts of the country modelled with some few exceptions elosely after the Connecticut act above referred to. The operation of these general aets was so satisfactory that a new element appeared in the passage by various States of constitutional amendments forbidding absolutely the creation of private corporations for purposes of profit by special aet of the legrislature. This has been continued until at the present time speeial charters cannot be procurcd save in seven of the Commonwealths.

The next development is to be noted along the line of enlargement of corporate purposes and powers. Gradually the restriction of the earlier incorporation acts limiting the right and benefits thereof to those desiring to incorporate companies for manufacturing and mining purposes was removed so as to permit practically of incorporation for any lawful purpose. At the same time there came a demand on the part of prospective incorporators for greater powers than were permitted at eommon law, - such, for example, as the right to perform constituent acts outside of the domieiliary State, to loold stock and bonds in other corporations, and to amend their charters unrestrictively. In this way there came to be found in many of the corporation acts a large number of extraordinary powers which were not recognized at common law. This served to greatly popularize the corporate form of organization as compared with individual, partnership, or joint stock eompany enterprises. The result which followed was natural. The several State legislatures proceeded one after the other to cnact statutes compelling incorporators when organizing 
corporations to pay a license tax graduated according to the capitalization of the corporation. In this way certain States - notably New Jersey, New York, Delaware, IVest Virginia, and Maine hare secured a very large revenue - all to the satisfaction of the arerage tax-paycr.

It is characteristic of State legislatures that they never fail to take advantage of an opportunity to reliere a majority of voters from the burdens of taxation at the expense of a few. Doubtless it was with this laudatory purpose in mind that they nest proceeded to enact statutes requiring corporations to pay an annual liceusc tax based upon either thcir authorized capitalization, the amount of capital inrested in the State, or the amount of diridends paid annually to stockholders. The success of a fer States in sccuring large revenues from both organization and license taxes resulted in legislative action in other States taken with a riew to securing a proper share of the incorporation business, which had hitherto enured to the benefit of two or three favored Commonwealths. This may be properly described as the era of the "tramp corporation." That is, it was about this time that there appeared a well-defined tendency on the part of incorporators to go outside of the State of their residence for a charter under which they planned to do business exclusirely in some foreign State. The result has been that incorporators have gradually accustomed themselves to going for their charters to those States which are commonly known as leading incorporating States. In this group will be found at the present time New Jersey, New York, Delaware, West Virginia, South Dakota, Maine, Nerada, Arizona, Connecticut, District of Columbia, Virginia, Oklahoma, North Carolina, and Alabanua.

Syeaking in general terms, it may be said that a great majority of the business corporation acts in force in this country to-day are sadly in need of revision. Thus, for example, the incorporation acts of Iowa, Nebraska, New Inampshire, Vermont, Rhode Island, Arizona, Mississippi, and the District of Colmmbia are more or less crude in construction, and lack many of the essentials of complete and satisfactory acts. 'The incorporation laws of Georgia, Pennsylvania, and Maryland are veritable "legal antiques," and wonld bear revision without any injury whaterer to the best interests of those Commonwealthis. The inemporation acts of Iudiana, Minnesota, T'ennessee, P'unsylvania, and Lonisiana are 
so involved as to lead to almost certain confusion when an attempt is made to take advantage of their provisions.

In regard to the attitude taken by the legislatures of the several States in the framing of these General Acts, attention is called to some remarks of the Committee on Corporations addressed to the legrislature of Massachusetts in 1903, which were as follows:

"The history of corporations, as well as the logic of the case, shows that there are possible two general theories as to the State's duties in creating corporations. First, the old theory that being creatures of the State, they should be guaranteed by it to the public in all particulars of responsibility and management; and the modern, quite opposite theory that, in the absence of fraud in its creation or government, an ordinary business corporation should be allowed to do anything that an individual can do. Under the old theory the capital stock of a corporation was, in the law, considered to be a guarantee fund for the payment of creditors as well as affording a method of corporate enterprise. There resulted from this principle not only the fundamental proposition that the capital stock, being in the nature of a guarantee fund, should be paid for at its par value in actual cash, but all the other provisions to protect creditors or other persons having dealings with the corporation, such as that the debts of a corporation should not exceed its capital stock, designed primarily in the interest of creditors, and secondarily in that of the stockholders, who are looked after as carefully as if they were wards of the State when dealing in corporation matters. Under the modern theory, the State owes no duty to persons who may choose to deal with corporations to look after the solvency of such artificial bodies; nor to the stockholders to protect them from the consequences of going into such concerns, the idea being that in the case of ordinary business corporations the State's duty ends in providing clearly that creditors and stockholders shall be at all times precisely informed of all the facts attending both the organization and the management of such corporations, and particularly that there shall be full publicity given to all details of the original organization thereof."

It may be of some practical value at this point to inquire briefly what are the advantages of conducting business under corporate management rather than as an individual or a copartnership enterprise. These advantages may be enumerated as follows:

First, Immunity from individual liability for debts arising out of the conduct of the business. 
Second, The securing of the element of perpetuity for the life of the enterprise in hand, so that the death of any of the parties interested does not interfere with the conduct of the business.

Third, The good-will and prestige of the business is not then the property of an individual, but belongs to the corporation.

Fourth, The ease with which capital is obtained for the use of the business through the sale of stock, thus doing away with the danger or necessity of admitting general or special partners into the concern.

Fifth, The facility with which money can be obtained by the sale of bonds or preferred stock.

Sixth, The ease with which individual interests in a business may be sold or transferred, without the necessity of obtaining the consent of a third party to the sale.

Seventh, The remoral of the danger of being ruined through the dishonesty or extravagance of a partner.

Eighth, The small expense connected with the incorporation of an enterprise.

Ninth, The wide and far reaching extension of the powers of a corporation as compared with that of individuals and copartners.

But the advantages of corporate management being stated, the question then arises: Where should the business man of to-day go to procure a charter for the enterprise he may have in hand? With forty-five States, five Territories, and the Distriet of Columbia all offering facilities for incorporation, the task of selection therefrom is by no means an easy one. Where the eapitalization is sinall or the corporate purposes simple, it is sometimes, though not always, best to procure a charter from the State where the principal prospective incorporators reside or where they propose to carry on the company's business. On the other hand, if the capitalization is to be songht in other localities, the proposed corporate business interstate in charaeter, or the prospective capitalization large, and the corporate purposes sought for broad in character, then it may be of great alvantage to procure a charter in some ontside State. Unler such circumstances reeourse is usually had to what are recognized as the leading incorporating States already referred to.

But to go further, it may be stated that a proper investigation into the question as to where to look for a charter best suited to the immediate purposes of the proposed corporation must necessa- 
rily entail an investigation among many others into the following matters :

1. Nature of the business corporation act of the State wherein it is proposed to ineorporate.

2. Policy of such States towards corporations, domestie and foreign.

3. Publicity required as to the eondition of corporations organized under the laws of that particular State.

4. Extent of legislative control over private corporations.

5. Nature of corporate powers desired.

6. Initial expense.

7. Amount of annual franchise tax, if any.

8. Amount of eapitalization permitted, and the par value of shares allowed.

9. Time within which the capital stock must be paid up.

10. Question as to whether stoekholders' and directors' meetings must be held within the State in whieh the eharter is proeured.

11. Question as to whether the prineipal office of the corporation may be maintained outside of the State of its organization.

12. Ascertainment of the question as to whether stoek can be legally issued for property or services instead of for cash.

13. Inquiry as to what extent the appraisal of the board of directors of the property or services paid for by the issuance of stoek is conelusive upon the ereditors of the eorporation seeking, in ease of insolveney, to enforee an alleged liability for unpaid stock.

14. Power to issue preferred stock.

15. Par value of the corporate shares desired.

16. Power to ereate debts.

17. Ease or difficulty with which the charter may be amended.

18. Amount of stoekholder's' liability, if any.

19. Extent of director's' liability, if any.

20. Ease or diffieulty with which the corporation may be dissolved.

21. Nature of the laws of the various States with referenee to the terms and eonditions under whieh foreign corporations may do business therein.

Each of the foregoing questions has its proper bearing when it eomes to deeiding where to go for a eharter for some particular business enterprise whieh it is proposed to prosecute under the form of eorporate organization. 
A discussion of each of these matters will be found in Part I. of the present treatise.

Turning now to the character of the business corporation acts passed by the legislatures of the various States and Territories, it will be apparent to all that many of them are "wonderfully and fearfully made."

If one were to attempt to characterize and compare the various incorporation acts of the sereral States and Territories, it would be found a task of great difficulty, for the reason that it is almost impossible to find a logical basis for classification. Any number of arbitrary classifications might be adopted, but these would be of no value to either the practitioner or the public at large. Whatever attempt may be made here along this line must be based solely upon the most general lines of similarity of the incorporation acts of rarious States. As a preliminary to this, it has been noted that certain States and Territories are known and recognized as "leading incorporating States." The ones to which reference is made are New Jersey, New York, Delaware, West Virginia, Maine, South Dakota, Comnecticut, Massachusetts, Arizona, Nevada, District of Columbia, and Virginia. The great majority of charters taken out amnually in this country are procured in the foregoing enumerated States and Territories.

By many the New Jersey act is considered to be a model of what a business corporation act should be. This fact, coupled with the large revenue secured by the State of New Jersey through this medium, has resulted in the passage in other States of statutes modelled more or less closely after the New Jersey act. This fact prompts the first classification that will be attempted here, which will be termed the "New Jersey Class." Within the limits thereof may be properly included not only New Jer'sey, but New York, Delaware, West Virginia, Alabama, Nevada, North Carolina, and Virginia as well.

Another classification would embrace a large number of Western States and Territories, which to a greater or less extent have modelled their corporation acts along the same general lines as that of California. This class may properly be referred to as the "California Class," and included therein will be found Colorato, North Dakota, South Dakota, Oklahoma, Idaho, Montana, Oregon, Washington, Colorado, Utall, Wyoming, 'Texas, Arizona, and New Mexico. 
Another group will be known as the "Maine Group," for the reason that the plan has been therein adopted of having the corporation organized before a certificate of incorporation or organization is filed with or issued by the State officials. In this class belong Maine, Massachusetts, Connecticut, Illinois, Missouri, Arkansas, and Indian 'Territory.

Iowa and Nebraska have acts very closely resembling each other, and may be grouped as the "Iowa Class." In another groap, which we shall call the "Pennsylvania Class," are to be found Penusylrania, South Carolina, Florida, Mississippi, and Kansas. The distinguishing feature of this class is that the incorporation scheme adopted embraces a petition for incorporation by the incorporator's addressed to State olficials, to be followed by the filing of a certificate of incorporation if the petition is farombly acted upon.

Another group may be known as the "Kentucky Group," in which belong Kentucky, Ohio, New Hampshire, Rhode Island, and Vermont. The resemblance here, it must be admitted, is more fancied than real, and probably does not depend upon any actual intent to copy the first Kentucky act. In the "Michigan Class" are to be found Michigan, Wisconsin, and Minnesota, all of which possess acts resembling each other in certain features. It is impossible to place Georgia, Indiana, Louisiana, Maryland, and Tennessee in any specified class. They all possess inadequate and certainly unique business corporation acts, which are not likely to be copied by any other State in this day and generation. 
PART I.

\section{INCORPORATION AND ORGANIZATION OF CORPORATIONS.}

\section{CHAPTER I. \\ DRAFTING THE 'CHARTER.}

$\S 1$. General Remarks on Corporate Charters. - Incorporation is a form of expression of the sovereign political power of the State in the creation of a juristic person possessing such limited powers as may be granted to it by the legislative branch of our State or national gorernment. The growth of the corporate form of organization affords an example of the rapid evolution from a somewhat circumscribed beginning to proportions that can only be described in this age of industrial trusts and combinations as colossal in character. Even the courts have not infrequently called attention to the modern disposition to incorporate everything. ${ }^{1}$

Much of this is due no doubt to the passage by the various State legislatures of what are commonly known as "business corporation acts." The phrase "business corporation," in this connection, is a broad term, and includes all corporations engaged in business for profit, as distinguished from municipal and cleemosynary corporations. ${ }^{2}$ The creation of corporations organized for profit by special act is now forbidden by constitutional provision in all but seven of the States. ${ }^{3}$ The existence throughout the country of general incorporation acts has fully reversed the old policy of granting exclusive privileges of any kind to corporations. ${ }^{4}$

1 Sce In re Italian Mut. Ben. Ass'n, 4 Pa. Jis. Rep. 357.

2 Adams \%. Company, Fed. Cases No. 47.

a Connecticut, Florila, If assichusetts,
New IIampshire, Rhode Island, South Carolina, and Vermont.

4 Jerple v. Company, 130 Ill. $268 ; 2$ N. E. 798. 
The purpose of restrieting the power to create corporations by special act has been well set forth as follows: "To inaugurate the poliey of placing corporations of the same kind upon a perfect equality as to all future grants and powers by making such laws applicable to all parts of the State and thereby securing the vigilance and attention of its whole representation, and, finally, of making the judicial construetion of their powers or the restrictions imposed upon them equally applicable to all corporations of the same class," 1

It is universally recognized in this country that legislative authority is essential to the creation of a corporation. ${ }^{2}$ Incorporators camnot come together and agree to become a corporation without conforming to legislative requirements. ${ }^{3}$ It has been well said "that there is an obvious reason for making such organization by written articles of agreement a condition precedent to the exercise of corporate rights. It is the basis upon which all subsequent proceedings are to rest, and is designed to take the place of a charter or act of incorporation by which corporate rights and privileges are usually granted. If there were no such provisions, there would be an absence of any provision by which the right to exereise corporate powers could be definitely fixed and established, and there would be no means of ascertaining the rights of stockholders and of persons dealing with such association." 4

The charter of a company together with the general laws of the State of its creation, enumcrating and limiting the powers of all corporations of that class, constitutes the measure of its powers, and the enumeration thereof implies the exelusion of all other powers exeept such as are incidentally or necessarily implied. ${ }^{5}$

The instrument by which corporations are created is known by different names in various parts of the country. The term "charter" is a word which has descended to us from the common law existing in England long before the United States became a nation. It originally referred to the specific grant of certain privileges ruming from the sovereign to a subject. Subsequently it was applied in this country to a specific act of the legislature

1 Atkinson v. Company, 15 O. St. 21 ; see also, Ex frarte I'ritz, 9 Ia. 30.

2 McKin $v$. Odon, 8 Bland's Chancery (.Mri.), 407 .

3 Stowe v. Flagg, 72 Ill. 397.
4 Utley $v$. Union Tool Co., 11 Gray (Mass.), 139.

5 G. I. \& II. I. Co. v. Kamper, $73 \mathrm{Ala}$. 325; Steiner $v$. Steiner L. \& L. Co. (Ala.), 26 So. 494; Salt Co. $v$. East Saginaw, I3 Wall. (U. S.) 378. 
creating a corporation with distinct and exclusive purposes and powers. With the advent of the passage of general business corporation acts in this country, the word "charter" has becn replaced by such terms as "articles of incorporation," "articles of association," "certificate of incurporation," "certificate of organization," and "petition for incorporation." It gocs without saying that under the Business Corporation Acts referred to there must be articles of some sort properly executed. ${ }^{1}$

It has been said that the essence of a corporation consists, first, in its eapacity to have perpetual succession under a special name and in an artificial form; sceond, to take and grant property and contract obligations, sue and be sued by its corporate name as an individual; and third, to receive and enjoy corporate privileges and immunities. The first two are the privileges of the incorporators, and the third is the franchise of the corporation. ${ }^{2}$

As far back as 1612 Lord Coke enumerated the essentials of a corporate charter as follows: (1) lawful authority for incorporation; (2) persons to be incorporated; (3) corporate name; (4) domicile; (5) words sufficient in law enumerating the purposes and powers of the corporation. All of these essentials and many more, which by statute are made essentials, are to be found in the business corporation acts of to-day.

Referring now briefly to those matters which are by statute in this country made necessary parts of articles of incorporation, the following may be said: with the exception of Arkansas, Georgia, Indian Territory, Maine, Massachusetts, Mississippi, New Hampshire, Ohio, Oregon, Rhode Island, South Carolina, Tennessee, and Vermont, all have incorporation acts requiring that the duration of corporate existence shall be set forth in the articles of incorporation.

Agrain, all but New Hampshire and Tennessec require a statement as to the number and frar value of shares. More than half the States prescribe that the names of the first or temporary board of directors shall be inserted in the articles, while most of the remaining States require that the number of direetors only shall be inserted. Fully half the States anthorize the insertion in the articles of provisions for the issuance of preferred stock. A fow of the Commonwealths require that the articles

1 Abbott v. Company, 4 Nel. 416 ; Lusk v. Riggs (Nob.), 97 N. W. 1033 ; Chilils $r$. Suith, 55 Barb. (N. Y.) 45.
2 Snell n. City of Chicago, 133 Ill. 413 ; 21 N. E. 533. 
shall contain a statement as to the amount of stock subscriptions, the amount of eapital stock paid in, and the amount of capital with which the eorporation will begin business. Alaska, A rizona, Deiaware. Lonisiana, Iowa, Minnesota, Nebraska, and Utah require that the date of the annual meeting shall appear in the articles. Alabama, Connecticut, Delaware, Maryland, Massachusetts, Nevada, New Jersey, New York, North Carolina, South Carolina, Utah, Virginia, West Virginia, and Wisconsin expressly authorize the insertion in the articles of provisions for the regulation of the internal affairs of the corporation. If it is desired to protect stocklıolders from personal liability for corporate debts, there must be inserted in the articles of incorporation of companies organized under the laws of Arizona, Delaware, Iowa, Kentucky, Lonisiana, Mississippi, and Utah provision specifically exempting stockholders from such liability.

And so the enumeration might be continued almost indefinitely of special provisions required in particular States in connection with the incorporation of corporate enterprises.

Finally, attention is called to the various steps necessary to create a corporation under the modern business corporation acts, qualified in every respect to carry out the purposes for which it is formed. These steps may be enumerated as follows: (1) the drafting of the articles of incorporation; (2) the signing of the articles by the requisite number of incorporators, and acknowledgment of the same before an officer duly authorized to take such acknowledgments; (3) filing and recording the articles with the proper State and county officials after payment of the requisite organization tax and filing and recording fees; (4) organization of the eorporation ready for the transaction of business; (5) securing the necessary permit from State officials (if any is requirerl) to transact business within the domiciliary State. ${ }^{1}$

\$2. Incorporators. - An incorporator is one of the constituents of a corporation, who by petition or by means of the exccution of artieles of incorporation invokes the exercise of the supreme political power of the State in the creation of a corporation for the benefit of himself and associates and their successors in interest." The words "corporator" and "incorporator" have essentially

1 Sife Carmody v. Powers, 60 Mich. 26; 26 N. W. 80 .
2 In re Lally Bryan Co., 1 Saw. 349; E. \& N. Y. C. R. R. Co. v. Owen, 32 Barb. (N. Y.) 616. 
the same meaning. The qualifications of ineorporators rary with the State from which the charter is sought. The usual number of incorporators required by the various acts raries from one to five. In Arizona, Iowa, and Nebraska one person may incorporate. $^{2}$ Residential requirements on the part of incorporators exist in Alaska, California, Idaho, Kansas, Maryland, New York, North Dakota, Ohio, Oklahoma, Pennsylrania, South Dakota, Texas, Utah, and Wisconsin. ${ }^{3}$ Failure to state residence in articles is, however, not fatal to corporate existence. ${ }^{4}$

The general rule is that citizenship is not necessary unless specifically required by the statute of incorporators. ${ }^{5}$ It has been said that in the absence of statute providing otherwise incorporators must be stockholders. ${ }^{6}$ The rule, howerer, appears to be otherwise in Oregon, Pennsylvania, South Dakota, Texas, Tennessee, and Georgia. ${ }^{7}$ In a majority of the States, lowerer, statutes expressly preseribe that incorporators must be subseribers for at least one share of the capital stock of the proposed corporation.

If married women are under no disabilities, they may act as incorporators. ${ }^{8}$ Aliens may be incorporators if statute does not provide otherwise. ${ }^{9}$

Some of the States expressly limit the right to become incorporators to natural persons. However, where no such express limitation exists, there is no question but what the word "person," when used in the statute limiting such matters, would not permit corporations to act as incorporators. ${ }^{10}$

The rule seems to be that incorporators must be of full age. ${ }^{11}$ Incorporators must also be known persons. ${ }^{12}$ The modern rule

1 See Part III. Table 4, page 574.

2 P. B. Corporation $v$. Lamson, 16 Me. 224; Ulmer v. Company, 98 Me. 579; 57 Atl. 1001.

8 See Part III. Table 5, page 575.

- State $v$. Foulkes, 94 Ind. 493 ; see also Halbert $v$. Association ('Tex. Civ. $\Lambda$ pp.), 34 S. W. 636.

6 M. N. F. Co. v. Baumbach, 32 Fed. $205 ; \Lambda$. S. Co. v. Heidenleimer, 80 Tex. 344 ; 15 S. W. 1038.

- Gulliver $v$. Roelle, 100 Ill.141 ; B!ron. ville Creamery Ass'u 1 . Ivers (Minn.), 100 N. W. 387; Chase 2 Lord, 77 N. Y. 11; Medler $v$. Company, 6 N. Mex. 331.

7 Coyote, etc. Co. v. Ruble, 8 Ore. 284 ; Densmore Oil Co. v. Densmore, 64 l'a. St. 43; Singer Mfg. Co. $v$. Peck, 9 S. 1). 29 ;
67 N. W. 947 ; Ramsey $v$. Tod, 95 Tex. 614 ; 69 S. W. 133; Byrnes $v$. Bcck, 10 Ga. 121 ; B. B. \& T. Co. v. J. B. T. Co., 101 Tenn. $545 ; 48$ S. W. 228 ; Wechselberg v. Bank, 64 Fed. 90.

8 In $r e$ application for charter, 27 Weckly Notes of Cases (l'a.), 399 ; In re Century Club, 27 W. N. C. (Pa.) 399.

- Lamar $v$. Browne, 92 U. S. 187; 23 Law. lid. 650.

${ }^{10}$ C. R. Co. v. P. R. Co., 31 N. J. Eq. 475 ; Insurance Co. v. N. II. P. Co., 37 La. An. 233.

11 Matter of Globe, etc. Ass'n, 135 N. Y. $280 ; 32$ N. F. 122 ; H. F. Road Co. v. Townsend, 13 Ont. Ap. Rep. 534.

12 C. R. R. of N. J. v. P. R. R. Co., 31 N. J. Eq. 475. 
seems to be that incorporators are merely conduits for the pulpose of or ranization for the benefit of future stockholders. ${ }^{1}$ Under this rule there can be no valid legal question raised at this day as to the legality of the use of what are eommonly known as "dummy incorporators" in the organization of corporations. ${ }^{2}$

$\$ 3$. Corporate Name. - Erery corporation, like an individual, must have a name under which its business must be carried on. It has been said " that the name goes to the very being of the ereation, the knot of the combination, without which corporations could not do their corporate acts, without which it is unable to implead and be impleaded, to take any action until it hath gotten a name." 3 The word "company," which is usually a part of the corporate name, does not nccessarily imply a corporation." In Alabama, Colorado, Connecticut, Delaware, Kansas, Kentucky, Missouri, North Carolina, and Virginia statutes exist which provide that the corporate name must cnd with some such word as "association," "company," "corporation," "club," " society," "syndicate," or "limited." 5

In a number of the States corporations upon organization are forbidden to take the same name as that of an existing domestic corporation, or one so similar as to be calculated to deccive or canse confusion. ${ }^{6}$ Some fow of the States go still further and forbid the use of the name of any foreign corporation by newly created domestic corporations, provided the former has sccured a permit to do business in the State. The States here referred to are Connecticut, Delaware, Kentucky, Massachusetts, New York, Utah, Virginia, and West Virginia. In the absence of such statute there is ordinarily no restriction on the right to take the corporate name of a foreign corporation. ${ }^{7}$

The corporate name is the property of the corporation, and equity will protect the corporation in any jurisdiction from the

1 Densmore Oil Co. v. Densmore, 64 Pa. St. 43.

2 Salamon v. Salamon Co. (Honse of Lords Cases), 45 Weekly Rep. 193; 75 Law Times liep. 426 . But see Louisville Banking Co. v. Fisenman, $94 \mathrm{Ky} .83 ; 21$ S. IT. 531, 1049; Tillyer $v$. Hero Jar Co., 17 Thil. (Pa.) 153.

${ }^{3}$ Sinith v. Plank Road, 30 Ala. 650 ; Ilazelton Boiler Co. v. Company, 137 Ill. $231 ; 28$ N. F. 248.
77. Clarke v. Insurance Co., 7 Mo. App.
6 On nse of word "limited" see Sparks v. Company, 3 Idaho, 306 ; 29 Pac. 134.

${ }^{6}$ See State $v$. McGrath, 75 Mo. 424.

7 I. V. C. Co. v. Hamblen, 23 Fed. 225 ; G. I. R. G. M. Co. $v$ G. R. Co., 128 U. S. 598 ; 9 S. Ct. 166; People v. II. L. Sus. Co., 111 Mich. 405 ; 69 N. W. 653. 
frandulent use of another name so like it as to deceire the public and rob it of its business. ${ }^{1}$ The mere fact that the corporation against whom a restraining order is asked for has sccured a charter in that particular State while the complaining corporation lias never been incorporated there or even proeured a permit to do busmess there, will not in most jurisdictions prerent the granting of such relief. ${ }^{2}$

Where statutes cxist, such as hare been referred to, forbidding the use of similar corporate names, while the attitude of the Sccretary of State in such cases with respect to the issuance of a certificate of incorporation is ministerial, yet he has reasonable discretion in the matter and cannot be mandamused when exercising such discretion. ${ }^{3}$ In protecting the use of a corporate name the courts proceed on the theory that such name should be protected in equity on prineiples analogous to those which prerail in the use of trademarks.

$\$$ 4. Corporate Purposes. - By corporate purposes is meant the specific declaration in the articles of incorporation of the nature of the business which the corporation is authorized to carry on. Such statement is a matter which primarily concerns the stockholders, and to a less degree the State under whose authority the corporation is created.

In the granting of corporate privileges it is important to specify the purposes and objects because the courts should hare some guide in keeping them within the powers granted and conreycd. Unless they be specified with particularity in the petition or in the granting thereof, they might do as they pleased and the law be powcrless to restrain them. ${ }^{5}$ The purposes enumerated in the articles of association, read in connection with the general laws under which the charter is procured, is the measure of the powers of the corporation. ${ }^{6}$

1 Ind. Mut. Hep. Co. v. Central Mut. Dep. Co., $23 \mathrm{Ky}$ l. L. R. 2247; 6, S. W. 1032 .

2 Ind. Mut. I)ep. Co. $v$. Contral Mut. Dep. Co., 23 Kу. I. li. 22, 17 ; 6 s. W. 1032 ; R.'Т. S. j. 1. Cu. r. I'. 'T. Co., 123 Fed. 534 .

a State ex rl. v, Mefirith, 92 Mo. 35.).

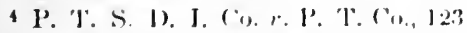
Fed. 534; Graud 1,ulge $\because$ (iraham. af Iowa, $592 ; 6.5 \times 11.837$; 11 i.foin (o. e.
Jligring Sonp Co., 14t X. Y. $462 ; 39$ ‥ L. 490; Amerienan Cliy Mfg. Co. $v$. American Clay Mf M. (o., 198 Ja. St. 189 ; 47. 111. 936: Ilazleton Boiler Company $\because$. llazleton 'T'. Builer Co., 142 IHI. 494;30 N. 1.. 333\%.

- In ve John II. Devenux ot al., 54 Ga. 673.

6 (i. I) \& .I. IR. Co, v. Union Steamboat (1., 107 L. S. 98; 27 L. J'. 413; Salt Co. v. laut Saginaw, 13 Wall. (U. S.) 378 . 
It must be remembered that articles of association under general acts are the productions of private citizens gotten up in the interest of the parties who propose to become incorporated, and who are stimulated by their zeal for personal advantage rather than for the greneral good. They are, so far as permitted in aceordance with the law, substitutes for legislative action in the place of the will of the people of the State as formerly expressed by acts of the legislature. While it was true at one time that all grants from the State to corporations were strictly construed, this principle has been subject to considerable modification of late years. This is owing to the passage of general incorporation acts which were undoubtedly framed and passed with the intent to liberalize the law in respect to such grants. ${ }^{1}$

"It is fundamental that a corporation can be ereated and exist only by statutory authority, and if a corporation organizes under a general act and inserts in its articles of incorporation regulations and provisions additional to those required by the creative statute, such additional regulations and privileges are voidable at the will of the State, nor is the corporation permitted to place any restrictions on the manner of exercising its corporate duties other than the statute provides. If the corporation claims the right to exist for a certain purpose, it must show that it was organized under a statute authorizing the creation of a corporation for that particular purpose." 2

The statutes of the various States differ of course with respect to the character of the purposes for which corporations may be formed. Some of them permit incorporation for any lawful business, without any limitations whatsoever. The phrase "other lawful business," found in so many of the statutes, is, according to the weight of authority, held not to be subject to the noscitur a sociis rule, and is used as a "catch-all" for the purpose of including any kind of business for pecuniary profit not otherwise provided for. ${ }^{3}$ In setting out the purposes, this must be done with reasonable certainty and definiteness. For example, an application for a charter was refused in Penusylrania, where it was stated that, in addition to certain enumerated objects, the

1 Finnegan $v$. Noerenberg, 52 Minn. $233 ; 5.3$ N. W. 1150.

2 Indiana Bond Co. v. Ogle et al., 22 Ind. A p. $593 ; 54$ N. E. 407.
${ }^{3}$ Brown v. Corbin, 40 Minn. 508; 42 N. W. 481 ; Green $v$. Breard, 35 La. An. 875 ; Dittman v. Company (N. J.), 54 Atl. 570 . 
corporation was organized for "such other purposes as might be agreed upon in the future." 1

In many of the States express mention is made of the various specific purposes for which corporations may be created. As a general rule the incorporators are required to set out in their articles of association the specific purpose or purposes for which the proposed corporation is to be organized. ${ }^{2}$

Turning now to the various States, we find the following statutory provisions relative to the purposes for which business corporations may be created. In Alabama for any general business or lawful enterprise. In Arizona for the transaction of any lawful business. In Arkansas for the transaction of any lawful business. In Colorado for any lawful purpose. In California for any purpose for which individuals may associate themselyes. In Connecticut for the transaction of any lawful business. In Delaware for the transaction of any lawful business or to promote or conduct any legitimate object or objects. In the District of Columbia any enterprise or business which may be lawfully conducted by an individual, except banking, real estate, and railroads. In Florida for the transaction of any lawful business. In Georgia for any purpose intended for pecuniary profit. In Idaho for any purpose for which individuals may lawfully associate themselves. In Illinois for any lawful purpose. In Indiana for the transaction of any kind of mining, mercantile, chemical, and manufacturing business; also grain elevator, union stock yards, and transit companies. In Iowa for the transaction of any lawful business. In Kansas for the transaction of any kind of manufacturing, mining, chemical, and mercantile business. In Kentucky for the transaction of any lawful business, or to promote or conduct any legitimate object or purpose. In Louisiana for the transaction of any lawful business, except stock jobbing. In Maine for the transaction of any lawful business. In Maryland for the transaction of any kind of mining, manufacturing, chemical, or mercantile business; also for shipbuilding and industrial furposes, and for the transportation of the products of any manufacturing or mining corporation. In Massachusetts for any lawful purpose except to buy or sell real estate or to sell or manufacture intoxicating liquors. In Michigan for the transaction of any lawful 
business, but only a manufacturing and a mereantile business can be carried on by the same corporation. In Minnesota for the transaction of any lawful business. In Mississippi for any lawful purpose. In Missouri for any purpose intended for profit or grain. In Montana for the transaction of any kind of manufacturing, mining, chemieal, or mercantile business, or for any lawful commereial or industrial business, or for carrying on any branch, of business designed to aid in or protect the interests of the company. In Nebraska for the transaction of any lawful business. In Nevada for any branch of trade or business, commerce, foreign or domestic. In New IIampshire for the transaction of any lawful business. In New Jersey for any lawful purpose or purposes whatever. In New Mexico for mining and manufacturing or other industrial purposes. In New York for any lawful purpose or purposes. In North Carolina for engaging in any lawful business. In North Dakota for any purpose for which individuals may lawfully associate themselves. In Ohio for any purpose for which individuals may lawfully associate themselves, except for carrying on a professional business. In Oklahoma for mining, mannfacturing or other industrial purposes. In Oregon for the purpose of engaging in any lawful enterprise, business pursuit, or occupation. In Pennsylvania for the transaction of any lawful business, but not for more than one kind of business. In Rhode lsland to carry on any ordinary business. In South Carolina for any purpose or purposes whatsoever or two or more combined. In South Dakota for the transaction of any lawful business. In Tennessee for the trade of the merehants, and for mining, boring, manufacturing, and other specified purposes. In Texas for manufacturing or mining and the purchase of goods, wares, and merehandise; also for buying and selling agrieultural products and for other specified purposes. In Utal for any purpose for which individuals may lawfully associate themselves. In Vermont for carrying on any object or business not repugnant to jublic policy or the laws of the State. In Virginia for any purpose which may be lawfully conducted by individuals or by a body folitic and corporate. In Washington for any trade or business. In West Virginia for any purpose or business useful to the public for which a firm or copartnership may be lawfully formed. In Wiseonsin for any lawful business or purpose whatever. In Wyoming for the transaction of any kind of manufacturing, 1 s 
mining, mereantile, and chemical business or any business designed to aid in the industrial or productive interests of the company.

The foregoing enumeration of purposes for which corporations may be created in the various Commonwealths named above, should be qualified by the statement that in most of them special acts are provided for certain clisses of corporations, such as banks, trust companies, insurance companies, etc., under which corporations of that character must be incorporated. Among the few States in which corporations may be created for any lawful purpose whatever including the excepted classes above referred to are Alabama, Virginia, and West Virginia.

Finally, attention is called to the fact that in some few of the Commonwealths the statutes require that the certificate set forth the particular trade to be earried on. Such a provision is in legal effect equiralent to requiring that the purpose or object of the proposed corporation be set forth.

$\S 5$. Number of Corporate Purposes Permitted. - Diffieulty frequently arises in determining whether under the provisions of some particular business corporation act parties may incorporate for the transaction of more than one line of business. In some of the States, notably, Alabami, Connecticut, Delaware, Maine, Massachusetts, Nevada, New Jersey, New York, North Carolina, Virginia, and West Virginia, the acts are so framed as to clearly authorize incorporation of eompanies for any number of purposes not corered by special acts. In all the remaining States, with the exception of District of Columbia, Indiana, Kansas, Louisiana, Michigan, Missouri, Ohio, Pennsylvania, Tennessee, Texas, and Wyoming, the matter is greatly simplified by State oflicials construing the statutes of their respective States to permit the ineorporation of companies for the transaction of any number of lines of husiness not regulated ly special statutes.

In Goorgia, Indiana, Maryland, Michigan, Pennsykania, Tennessee, and 'lexas the different lines of business are divided into elasses. Generally speaking, parties are not permitted to ineorporate for lines of business included in more than one of these elasses. In Wyoming the law reguires the certiliente of incorporation to have but one grenreril ohject. In Ohio only one purpose may be inserted. In Kansils and Missouri the number of furposes is only limited ly the provision of law that the name of

1 The rule is otherwise in Indiana and Maryland. 
the corporation shall indicate the nature of the business to be earried on by it.

Some sugrgestions along the line of determining the question as to the number of purposes which may be inserted in articles of incorporation in any partieular States may be here presented, Where the statute permits corporations to be formed for several purposes named in the alternative, separated by the disjunctive conjunction "or," it is held that a corporation cannot be organized thereunder for more than one of such purposes, and that articles of incorporation which include more than one of them are void, and that incorporation under them will be refused. ${ }^{1}$

Again, it would appear that where ineorporation for only one purpose is permitted, incorporators must make a choiee of such purpose themselves in the first instance, for the courts have quite generally refused to make it for them."

On this general subject the Supreme Court of Texas in a recent case spoke as follows: "A charter must set forth the purpose for which it is formed. This for the reason that if it had been intended that a corporation might be ereated for two or more of the purposes speeified in the statute, it would have been proper to have stated 'purpose or purposes for which it is formed.' The use of the word 'purpose' in the singular number tends to show that it was the intention of the legislature to authorize the creation of a corporation for only one purpose. It may be true that the use of the singular number may not be the conclusion of the question, and that if there were other purposes in the act which either by express declaration or elear implication indicate that it was intended to authorize incorjoration for two or more of the designated purposes, whether in the same subdivision or not, we should so hold. ${ }^{3}$

Finally, it may be said that unless the statute expressly or inpliedly permits the insertion of more than one purpose in the articles, the insertion of two or more prposes therein will elearly justify State offieials in refusing to allow the filing of the same. ${ }^{4}$

1 State $v$. Beck, 81 Ind. 500 ; In re John H. Deveaux et $t / ., 54$ Ga. 673.

2 Williams $r$. Company, 25 Ind. $\Lambda p$. 351; 5. N. E. 581; Bayoli Cook Nav. \& Fi-heries (co. v. Donllut (La.), 35 So. 729: (1r. Ry. \& Xav. Co. v. Company, 130 C. S. 1; 9 S. Ct. 109 ; State 2 . Compiny, 88 Wis $512 ; 60$ N. W. 796.

20
3 Ramsey $v$. 'Tod, 95 Texas, 614; 63 S. IV. 133.

4 Ind. Bond Co. v. Ogle, 22 Ind. $\Lambda_{\mathrm{p}}$. $593 ; 54$ N. E. 407 ; Woodberry $v$. McClurg, 78 Miss. 831; 29 Sin, 514; Kinston, ete. Co. $v$. Stroud, 132 N. C. 413 ; 43 S. E. 9. 


\section{$\$$ 6. Collateral Attack upon Corporate Purposes and Powers. -} The term "collateral attack," as used in corporation law, has reference to the attempt of parties other than the State (in direct procecdings) to question the ralidity of a corporation's existence and purposes or its right to excrcise corporate powers. The law reports are full of conflicting decisions relating to the general subject of collateral attack upon corporate existence, purposes, and powers. The scemingly hopeless confusion which exists among the courts on this subject is largely due to a failure on their part to recognize that the matter has, by a gradual process of statutory and judicial legislation, become at the present time an academic one. It is proposed at this point to discuss at length not only the question of the right to collaterally attack the legality of corporate purposes as set forth in articles of incorporation, but as well to consider in this same connection the right to collaterally attack the ralidity of corporate existence and the right to exercise corporate powers. This for the reason that all these questions are so closely related to each other as to properly permit of discussion at one and the same time.

At the outset, a word should be said as to the policy that would scem to dictate the establishment of statutory and judicial rules, forbidding the impeachment by indirect methods of a corporation's right to exist. In the first place, such attacks are rarely made except in an attempt to defeat the ends of justicc, by setting up defences to actions brought against debtors by corporations, in which the partics interposing the same have generally no direct interest whaterer. If the State legislatures had not by legislation, and the courts by an extended application of the doctrine of estoppel, forbidden such collateral inquiry into these matters, it would hare been impossible in a great number of cases for litigants to enforce their just rights in courts of law. If such a riglit were admitted in one case, it must be in all. Corporations might thus be called upon years after their creation to establish the validity of corporate existence, purposes, and powers, which public policy should hold to be valid as arainst all parties except the Stitc. ${ }^{1}$

Having already observed that the ruestion of the right to collaterally attack corporate existence, purposes, and powers has become largely an academic one, it will now be proper to sub-

1 Duggan $v$. Compauy, 11 Cul. 113; 17 Pac. 105. 
stantiate this statement. That the discussion of this question may proced along logical lines, attention is first called to the alleged right to collaterally attack the validity of corporate existence.

In twenty-six of the States and Territories collateral inquiry into the legality of corporate existence is expressly forbidden by statute, the right to impeach such existence being expressly reserved to the State alone by means of direct proceedings brought for that purpose. ${ }^{1}$ Thus, in California it is provided that where a corporation claims in good faith to be a corporation and doing business as such, its right to exereise corporate powers shall not be inquired into collaterally in any private suit to which such de facto corporation may be a party.

In Delaware the law provides "that no corporation shall be permitted to set up or rely upon the want of legal organization as a defence in any action against it, nor shall any person transacting business with such corporation, or sued for injury to its property be permitted to rely upon such want of legal organization as a defence." In Georgia the law provides that the existence of a corporation claiming a charter, under the color of law, cannot be collaterally attacked, and that all who dealt with the corporation as such are estopped from denying its corporate existence. In Iowa, Kentucky, and Nebraska statutes exist essentially the same as that in force in Delaware as cited above. In Nebraska the law provides that eridenee that the corporation is doing business under a certain name shall be prima facie proof of its due incorporation or existence pursuant to law.

In Montana collateral inquiry into corporate existence is expressly forbidden, until the fact that there was in fact no such corporation has been adjudged in a direct procecding brought for that purpose. In South Carolina, it is provided that no irregularity shall be held to vitiate the corporation until a direct proceeding to set aside or annul the charter be commenced by the proper authorities of the State, and all acts and contracts entered into shall have the same force and effect as if no irregularity existed.

In South Dakota, North Dakota, and Oklahoma the law provides that the due incorporation of any company claiming in good faith to be a corporation and doing business as such, its right to exer-

1 See Part III. Table 3, page 573 ; see M. W. R. Co. v. Supervisors, 64 Cal. 69; also Boyce $v$. Church, 46 Md. 359 ; W. \& 28 Pac. 496. 
cise corporate powers shall not be inquired into collaterally. In Tennessee the law prorides that the validity of corporate existence shall not be collaterally questioned. Persons acting as a corporation, the law says, will be presumed to be legally incorporated until the contrary is shown, and no such franchise shall be declared annulled or forfeited except in a regular proceeding brought for that purpose. In Texas no person who shall have assumed an obligation to an ostensible corporation as such shall resist the enforcement of such obligation on the ground that there was no such corporation until that fact has been adjudged in a direct proceeding for that purpose.

In Arizona persons acting as a corporation under the provisions of the incorporation act in force in that Territory are by law presumed to be legally organized until the contrary is shown, and no franchise ean be declared to be anuulled or forfeited except in regular proceedings brought for that purpose. The law also prorides that no persons acting as a corporation under such act shall be permitted to set up or rely upon the want of legal organization as a defence to any action brought arainst them as a corporation, nor shall any person who shall be sued under a contract made with such corporation sue for an injury done to its property or for a wrong done to its interest be permitted to rely upon such want of legal organization in his defence.

Finally, in Mississippi it is provided that it shall not be a defence in any action against a corporation that there was a defeet or informality in its organization.

Again in twenty-nine of the States authority is given to State officials to issue certificates of due incorporation. ${ }^{1}$ Of this number fourteen are not included in the list of States forbidding collateral attacks upon corporate existence. In such States it is safe to say that the issue of such a certificate is in itself a final arljulication against all parties except the State that a corporation has a legal existenee to the extent that it cannot be collaterally attacked hy third parties. Particularly where it is ormanized by the voluntary action of the requisite number of ineorporators with the approval and eonsent of an officer of the State possessing authority in the premises, under an enalling statute permitting corporations of that particular description to be organized thereunder. ${ }^{2}$

1 See Part III. Table 3, page 573.

2 1'Brien v. Cummings, 13 Mo. $\Lambda_{\mathrm{p}}$. 197 ; Boyce v. Church, 46 MIl. 359. 
The theory upon which the rule here stated is based seems to be that state oflicials in issuing a certificate of due incorporation act under a general statute passed by the legislature, and under the terms thereof become agents as it were thereof for that purpose. It therefore follows that the act of such State officials in certifying as to due incorporation, is in effeet the act of the legislature which has the supreme power of ereating corporations. So it may be safely said that, aceording to the best current of authority, where the statute gives the State official anthority to issue a certificate of due incorporation, such certificate is evidence thereof against all the world except the State. ${ }^{1}$

A grain it should be noted that in many of the States the statute itself gires certain probative force to the charter so issued, by providing that the eertifieate of incorporation, or a certified copy thereof, shall be evidence to a certain designated extent and for certain purposes. Thus in Connectieut, Kansas, Mimnesota, North Dakota, and Ohio statutes exist providing that a certified copy of the certifieate of incorporation shall be prima facie evidence of the legal existence of the corporation. In Colorado, Oklahoma, Oregon, Texas, West Virginia, and Wyoming statutes provide that such certificate shall be eridence of the existence of the eompany. In California, Colorado, Idaho, Illinois, Louisiana, Montana, Nevada, North Dakota, South Dakota, Oklahoma, Utah, Washington, and Wyoming such a certificate is prima facie evidence of the facts therein stated. In New York the certificate of incorporation of any corporation when duly filed is presumptive evidence of its incorporation. In Arkansas a certified copy of the articles is made prima facie evidence of the due formation and of the existence and eapacity of the corporation. In Colorado it is made evidence

1 Petty $v$. Iayden, 115 Jowa, 212;88 N. W. 339 ; Cochran $v$. Arnold, 58 Ia. St. 393 ; Litchffeld lank $v$. Church, 29 Cons. 137 ; Napier $x$. Poe, 12 Ga. 170; Carolina Iron Co. $x$. Alernathey, 94 N. C. 545 ; (ascy r. lialli, 94 L. S. 673; 24 L. E. 168, 307 ; Lake Sup. Nav. Co. $v$. Norrison, 22 L. C. C. P. 217; Birds Case, 1 Simon (x. 5.), 47; 40 ling. Ch. 47 ; In re Barneds Irakery (o, I. R. 2 Ch. 67t; O'Brien $v$. Cummings, 13 Mo. Ap. 197; N. P. C. I. Co. r. Company, 16 Ctah, 246; 52 lac. 168 ; Holman $r$. State, 105 Ind. $569 ; 5$ N. E. 702 ; State v. Carr, 5 N. HI. 367 ;
Jones $v$. Dana, 24 Barb. 395 ; Taylor $v$. Company, 91 Me. 193; 39 Atl. 560 ; Finch $v$. Lllman, 105 Mo. 255; Saunders $v$. Farmer, 62 N. H. 572; Union Water Co. $v$. Kean, 52 N. J. Eq. 111; 27 Atl. 1015; U. S. Vinegar Co. $v$. Schlegel, $143 \mathrm{~N}$. Y. 537 ; 38 N. E. 729 ; W. \& P. Ry. Co. $v$. Company, 114 N. C. $690 ; 19$ S. E. 646; Carroll v. Bank, 19 Wash. 639; 54 Pac. 32 ; Vermont, etc. Ry. Co. v. Company, 34 Vt. 2 ; Grubb v. Company, 14 Pa. St. 305 ; W. P. R. Co. $v$. Young, 12 IId. 476. 
of the existence of the corporation. In Connecticut it is eridence of the legal existence of the corporation, and it is there provided that it shall serre all the purposes of a charter for the corporation. In Delaware it is made evidence in any court of law or equity. In Georgia a certified copy of the petition for incorporation and order granting the same is made evidence of such incorporation in any court. In Kentucky the law provides that it may be used as evidence in any action for or against the corporation. In Maryland it may be used as evidence in all legal proceedings. In Michigan it is prima facie cridence of the duc formation, existence, and capacity of such corporation. In Minnesota it is prorided that it shall be eridence in all courts of such incorporation. In New Jersey it is evidence in all courts and places. In North Carolina it is prima facie evidence of the organization and incorporation of the company purporting thercby to have been established. In Pennsylvania it is evidence for all purposes. In Rhode Island a certificate must be receired in evidence before any court, tribunal, or authority. In Tennessee it is competent eridence in any proceeding. In West Virginia it shall be received as evidence of the existence of the corporation. In $W_{\text {yoming it is provided }}$ that it shall be cridence of the existence of the company.

Again, in Massachusetts and Indiana the law provides that the certificate of record shall be conclusive evidence of the existence of such corporation. In Wisconsin it must be received as conchusive evidence of the existence of the corporation or of the organization thereof in all cases where suelı facts are collaterally involved.

Again, in Alabama the certificate of the prohate judge states specifically that the incorporators are duly organized as a corporation for the purposes expressed in the declaration, having the power, capacity, and authority conferred by law. In Florila the law provides that "letters patent" shall be conchusive eridence of the existence of the corporation in all actions where the question of the existence is only eollaterally involved, and prime fiecie eridence in all other actions and procedings. In Indiana the order of the conrt declaring the existence of a corporation entered " $c x$ parte" is conclusive as to the fact of such existence. In Mississippi the law provides that the pwers specificel in the elarter shall by the approral of the Gorernor be rested in such corporation, and it shall go juto operation at the time and on the terms and conditions specified. 
Igain, certain statutes exist providing that after certain preliminary steps have been taken as preseribed by statute such ineorrorators and their suecessors and assigns shall thereupon become a body politic and corporate for certain specilied purposes. These statutes really provide that upon the observanee of certain speeilied preliminary eonditions relative to the making and execution of articles of incorporation, the incorporators, their successors and assigns, shall be a body politic and corporate under the name and for the purposes stated in the articles. The foregoing is the statutory provision as it exists to-day in substance in South Dakota, North Dakota, and Oklahoma. In Virginia the law provides that they shall be a body politic and corporate by the name set forth in the said certificate and upon the terms and powers set forth therein, so far as not in conflict with law. In Penusylvania the law provides that they shall become a corporation upon the purposes and terms named in the charter. In Maryland they are declared to thereby become a body politic and corporate according to the objects, purposes, articles, conditions, and provisions in said instrument contained. In Maine they are declared to be a corporation, with all the rights and powers and subject to all the duties, obligations, and liabilities provided by law.

In Connecticut a copy of the certificate of organization is prima facie evidence that the corporation has been duly organized and is duly authorized to exercise all its corporate powers. In Maine the certificate of the Secretary of State that the corporation has been duly organized is evidence of the corporate existence of the corporation. In South Carolina a certificate is issued by the Secretary of State that the corporation is fully authorized to commence business under its charter for the purposes indicated in the written declaration of the incorporators.

It is not claimed that the statutory provisions here referred to operate so as to preclude entirely collateral attack upon corporate existence, purposes, and powers. The most that is claimed for them where they do not make certain instruments conclusive evidence of corporate existence, purposes, and powers, is that they shift the burden of proof and render the likelihood of collateral attack more remote. ${ }^{1}$

1 As to meaning of conclusive evidence, see Anfrican Order, etc. $v$. Merritt, 151 Mass. 558; 24 N. E. 318 . As to meaning 26 of prima facie evidence, see Holmes $v$. Gilliland, 41 Barb. (N. Y.) 569 ; Knapp, ete. Co. v. Strand, 4 Wash. 686; 30 Pac. 1063 ; 
It has now been fairly demonstrated, it is hoped, that in the majority of the Commonwealths collateral inquiry into corporate existence is either prohibited by statute or else is forbidden by implication, by reason of the issuance of certificates of due incorporation, under proper legislative authority, by State officials. In the few remaining States and Territories the courts have either by a process of judicial legislation or by an extended application of the principle of estoppel, practicaliy made it impossible to suecessfully attack in collateral proceedings the due existence of a corporation. This on grounds of enlightened public policy.1

The judicial legislation above referred to covers the cases where it is impossible to apply principles of estoppel either on account of the absence of any conduct on the part of parties litigant showing their recognition of the eorporation's existence, or else is inapplicable by reason of such parties having nerer in any way dealt with the corporation or recognized its eorporate existence. ${ }^{2}$

Having now considered at some length the question as to the right to collaterally attack the validity of corporate existence, there naturally follows an inquiry as to the right to attack the validity of corporate purposes and powers when the same are inserted in the articles of incorporation. It would seem to follow, as a logical scquence, that if the rule be once established forbidding collateral attack upon corporate existence, this same rule should operate as well to prevent collateral attack upon corporate purposes and powers. This for the reason that if a corporation exists at all it must necessarily exist with such purposes and powers as are inserted in the articles of incorporation which called the corporation into being.

As has already been observed, a large number of the States hare enacted statutes forbidding collateral attack upon eorporate existence. For the reasons already stated, it would appear that these statutes would be equally efficacious for the purpose of prohibiting collateral attack upon corporate purposes and powers.

Eastern Plank Road Co. v. Vanghan, 14 N. Y. 546 ; Bates $v$. Wilson, 14 Cul. 140 ; 24 Pac. 99; Wool v. Company, sif Conn. 87 ; 13 Atl. 137; Jewell v. Company, 101 III. 57.

1 See Casey $v$. Galli, 94 U. S. $673 ;$ 1)uggan $v$. Company, $11 \mathrm{Col} .113 ; 17 \mathrm{lar}$. 105 ; MeClinch $v$. Sturgis, 72 Me. 288; Finch $v$. Ullman, 105 Mo. $255 ; 16 \mathrm{~S}$. W.
86.3; Saunders 2. Farmer, 62 N. II. 572; Hackensack Water Co. $r$. DeKay, 36 N. J. Eig. 548; U. S. Vinegar Co. i'. Schlegel, 143 N. Y. $537 ; 38$ N. E. 729 ; W. \& P. Ry. Co. v. Comjany, 114 N. C. $690 ; 19$ S. E. 646; Reynolds 2 . Myers, 51 Vt. 444 ; Carrull $v$. Bank, 19 Wash. 639; 54 Pne. 32. 2 See Marion Savings Bank $v$. Dunkin, 54 Ala. 471. 
Arain, as has already been stated, a large number of the incorpuration acts provide that the certificate of incorporation shall be issmed hy cortain designated State officials. Where such certificates are issued under express or eren implied authority of the state. the rule unquestionably is that the validity of corporate purposes anl powers not perse illegal, inserted in the articles of incorporation, cannot be attacked except by the State in a direct proceeding brought for that purpose. ${ }^{1}$

If, howerer, the charter is issued without the express or implied approval of the State officials, - their duty being merely to certify to the fact and to mark them when filed as public documents in their respectice offices, - then the insertion of purposes not authorized by the statute, yet not unlawful per se, would probably not render the charter ralid for all purposes even when filed. ${ }^{2}$

To sum up briefly the propositions herein presented, it may be said that collateral inquiry into the legality of a corporation's existence, purposes, and powers is forbidden in this country, (1) by statutes expressly forbidding such collateral attack; (2) by reason of authority vested in state officials to issue certificates of due incorporation which for the reasons already stated are not open to collateral attack; (3) by reason of statutory provisions griving to certified copies of articles of incorporation certain probative effect; (4) by an extended application of the principle of estoppel forbidding such collateral attacks; (5) by a process of judicial legislation denying on grounds of public poliey the right of parties other than the State to attack the legality of corporate existence, purposes, and powers.

$\S 7$. Effect of Inserting Illegal Purposes. - There seems to be a sound basis in law for permitting collateral attack upon purposes that are illegal per se. This for the reason that a distinction elearly exists between purposes which are merely unauthorized

1 State ex rel. Walker $v$. Talbot, 123 Mo. $69 ; 27$ S. W. $366 ;$ Doty $v$. Patterson, 155 Ind. 60 ; 56 N. E. 668 ; T. A. I. Co. $v$. Massey (Tenn.), 56 S. W. 35; Allbright r. Assuciation, $102 \mathrm{~Pa}$. St. 411 . See also People $r$. Beach, 19 Ilun, 2.59 ; N. Orleans, etc. IR. R. Co, U. Frank, 39 La. An. 707 ; 2 So. 310; Ilolmes $v$. Gilliland, 41 Barb. N. Y. 569; Eastern Plank Road Co. $v$. Vaughan, $1+$ X. Y. 5 $46 ;$ C. \& P. Co. $v$. Secretary of State, 128 Mich. $621 ; 87$ N. W. 901 ; Cochran v. Arnold, 58 Pa. St.
399 ; Casey v. Galli, 94 U. S. 673; Fortier $v$. Bank, 112 U. S. $439 ; 5$ S. Ct. 234 ; Niemeyer $v$. L. R. J. Ry., 43 Ark. 111. 2 Williams v. Company, 25 Ind. Ap. $351 ; 57$ N. E. 581 ; Kinston, etc. Co. $v$. Stroud, 132 N. C. 413 ; 43 S. E. 913; Ram. sey $v$. Tod, 95 Tex. 614; 69 S. IV. 133 ; Or. Ry. \& Nav. Co. v. Or. Ry. Co., 130 U. S. 1 ; 9 S. Ct. 409 ; State $v$. Company, 88 Wis. 512 ; 60 N. W. 796 ; G. L. H. Ins. Co. $v$. Kamper, 73 Ala. 325. 
by the terms of the general incorporation act, and those purposes which are forbidden by express statute, - ciril or penal. In the latter case it seems clear that eren the approral by a State official of such unlawful purposes as eridenced by the issuance by them of certificates of due incorporation, do not forbid collateral attack thereon in any suit whereby the corporation sceks to benefit by the insertion of such unlawful purposes in its articles. ${ }^{1}$

The rule might be still further extended so as to apply to purposes which may be lawful in a general way, yet which may be deemed unlawful on account of the limitations inserted in the articles upon the means by which such purposes are to be carried out. $^{2}$ The same principle would apply where the purposes are clearly contrary to the public policy of the State. ${ }^{3}$ But if purposes are lawful on their face, they will, as against all but the State, be presumed to be such.* Where some of the purposes are merely unauthorized, while others are ralid and proper, the insertion of the unauthorized purposes will not vitiate the incorporation. ${ }^{5}$ But where any of the purposes are illegal per se, the State officials would be clearly justified in refusing to allow the articles to be filed, though some of them are lawful. ${ }^{6}$

\$. Corporate Powers, Classification of. - By "corporate powers" is meant the right or authority of a corporation to act along certain lines prescribed for it in the instrument whereby it was created. 'The tendency of modern decisions is to assimilate the powers of private corporations to those of individuals and copartnerships. ${ }^{7}$ It is unnecessary to say that a corporation cannot assume for itself powers of action, irrespective of statute, by the mere declaration thereof in its articles of incorporation. ${ }^{8}$ Neither can they be created ly by-law. ${ }^{9}$

The Supreme Court of the United States ${ }^{10}$ has observed that

1 F. N. Bank $v$. Company, 53 Ohio St. $316 ; 52$ N. E. 834 ; In re Durluesue Collegre, 2 Pat. Dist. (t. Lep. 555 ; . Matter of A gudath IIakchiloth, $18 \mathrm{~N}$. Y. Mis. Rep. $717 ; 42$ N. Y, Sup. 985; State $x$. Company, 29 Nel, $700 ; 46$ N. W. 155.

2 Or. Ry. \& Nav. Co. v. Or. Ry. Cu., 130 L. S. 1 ; 9 S. Ct. 409.

a Sicheutzen liund $v$. A gitations Verrin, 44 Mich. 313; 6 N. W. 675; Mefirew $v$. C. 1'. Ex., 85 Tenn. $572 ; 4 \mathrm{~S} . \mathrm{W} .30 ;$ In re Benefit Society, 10 Plibl. 19; l'enple $v$. Company, 130 Ill. $268 ; 22$ N. K. 73s.
4 U. S. Vinegar Co. $x$ Fuelıreubach, 148 N. Y. $58 ; 42$ N. E. 403.

'Skick $v$, ('ompany, 15 Iml. $A_{\text {p. }} 310$; 44 N. F. 48.

"Sitate $v$. Compramy, 88 W' is. 512 ; 60

N. W. 796 .

7 Fink v. Company, 5 Ore. 301.

${ }^{8}$ l'opple v. Greeu, 116 Mich. 505; 74

N. W. 714.

9 Anitrews v. Company, 37 Me. 256.

1) Thomas v. Company, 101 U. S. 71. 
"We take the general doctrine to be that the powers of corporations orinamized muder general statutes are such and such only as are conferred hy statute. Conceding the rule applicable to all statutcs. that what is fairly implied is as much granted as what is expressenl, it remains that the eharter of the corporation is the measure of its powers, and that the enumeration of these powers implies the exchusion of all others."

The foregoing is true only as to eertain classes of powers which are hereinafter referred to as "express powers." The rule is not applicable either to what are known as "common law papers" or to the "incidental powers" of eorporations. Corporate powers may properly be divided into three general elasses, to wit: (1) Common Law Powers; (2) Express Powers; (3) Incidental Powers. Generally speaking, there is no existing rule or principle by which corporations created for a certain specifie object or to carry on a particular trade or business are to be held to be prohibited from all other dealings or transactions not coming within the exact seope of those designated. Undoubtedly the main business of a corporation is to be confined to that class of operations which properly appertains to the general purposes for which this charter was granted. But it may also enter into contracts and engage in transactions which are ineidental or auxiliary to the main business, or which may become necessary or profitable in the care and management of the property which it is authorized to hold. The same is true as to certain powers which are held to exist at common law even in the absence of any specific reference to such powers in the articles of incorporation.

$\S 9$. Common Law Powers, Definition of ; Enumeration of. Common law powers are those which the law bestows upon eorporations irrespectire of statute or charter provisions, as being necessary for the carrying out of the purposes for which it was created.' The common law gives to eorporations the powers belonging to corporations of their class, unless there is something in the nature of the corporation or in the terms of its charter, or in the aet under which it was incorporated inconsistent with the exercise of the powers, or there is some general statute restricting the same. ${ }^{2}$

1 Falemar $v$. CampteHl, 8 Fed. Cases, 593; Knowles 1 . Beatty, I McLean, 1 ; Leg$4620: 2 . M(\cdot L$ rean, 195 ; C. O. N. G. \& F. gett $v$. N. J. M., etc. Co., I N. J. Eq. 541.

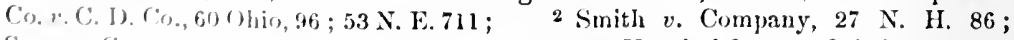
State $u$. Comprany, 144 Iı. $562 ; 46$ S. W. Sutton's Iospital Cases, 5 Cuke's Rep. 253. 
The common law powers here referred to may be enumerated as follows: (1) the right to the use of a corporate name; (2) the right to perpetual succession; (3) the right to aequire, hold, and dispose of corporate property; $(4)$ the right to appoint corporate officers and agents; (5) the right to establish by-laws for the government of the corporation, its officers and members; (6) the right to sue and be sued.

An examination of the various eorporate acts in force in the sereral States and Territories will serre to show that without exception they contain an enumeration more or less full of the common law powers above referred to. In Indiana the statute refers to them as common law powers, and proceeds to enumerate them. ${ }^{1}$

$\S 10$. Right to a Corporate Name. - The right to the use of a corporate name is a power well recognized both at common law and by statute. Corporations have a property right to the use of such name in the transaction of their business which the courts will always protect. ${ }^{2}$ They are recognized in law only by their corporate name. ${ }^{3}$

The name is said " to be the very being of their constitution; the knot of their combination; without which they could not do their corporate acts; for it is unable to implead and be impleaded, to take any action until it hath gotten a name." 4

The action of State offieials in granting the use of a name, it may be observed, is not conclusive, for courts of equity will nevertheless proteet eorporations in the use of their name. ${ }^{5}$ State officials have, however, the power to protect the use of corporate names when applications are made for eharters, even when the proposed name is not exactly similar to that of existing corporations. ${ }^{6}$

The right to have a corporate name is in itself a common law power ; but it is one which is not alienable. ${ }^{7}$

$\S 11$. Right of Perpetual Succession. - The " right of perpetual suecession" under a designated corporate name is one of the common law powers of a corporation. The words "perpetual

1 Ind. Session Laws, 1901, ch. 127, $\$ 28 . \quad$ "Siate ex rel. r. Mre(irath, 92 Mo. 355 ;

2 L. D. Co.e. Massachuselts, 10 Wall. 5. S. W. 29.

(U. S.) $566 ;$ see also ante, $\$ 3$.

3 Curtiss v. Nurry, 26, Cal. 633.

4 Smith v. Comprany, 30 Ala. 650. 5 Gramd Lodge, etc. v. Graham, 96 N. W. 96.

Ia. $592 ; 65 \mathrm{~N}$. W. 837 .
3 Site $r$. Comprany, (1) Kan. 96; 19 I'ac. 3.1: ; Detruit ('itizens' Street Ry. Co. n. Common Council, 125 Mich. 673; 85 
suceession " Wo not refer to the duration of the life of the corporation, where this is specilically limited either by statute or by the articles of incorporation, but merely operates to grant the continuation of corporate life during the period so preseribed. ${ }^{1}$ Perpetual sucession ordinarily merely conreys the right of continued unhroken succession for the period of time limited for the corporate existence. ${ }^{2}$

$\$ 12$. Right to adopt and use a Corporate Seal. - It is an inseparable incident to every corporation that it may have a common seal, and make, alter, and renew the same at pleasure. ${ }^{3}$ The doctrine of the common law requiring the use of a corporate seal in the execution of corporate contracts is practically obsolete, and the seal is now required, in the absence of express statute, only when it would be required of a natural person under similar circumstances. ${ }^{4}$ Ordinarily the exereise of this power is delegated by the stockholders to the directors by means of an appropriate by-law. ${ }^{5}$

$\$ 13$. Power to acquire, hold, and dispose of Real and Personal Property. - No doctrine of the common law is more clearly and undeniably established than that which concedes to corporations an inherent right to acquire and hold title to real and personal property, except so far only as they may be restricted by the objects of their creation or the limitations of their eliarter. ${ }^{6}$ 'The power to aequire such property, when not restricted by statute, is only limited by the rule that it must be such as is reasonably necessary or convenient to enable it to accomplish the purposes for which it was created. ${ }^{7}$

Formerly the amount of real property which a corporation might purchase and hold was very generally limited by statute in most of the Commonwealths. The existence of such statutes may be traced to the policy of the common law and to the existence in England of statutes known as statutes of mortmain, which prolibited corporations from taking and holding real estate without licenses from the king or Parliament. ${ }^{8}$ However, in most of the

$$
737
$$

1 State $v$. I'ayne, 129 Mo. $468 ; 31$ S. W.

2 Sranlon v. Crawshaw, 5 Mo. Ap. 337 ; sere, however, Fairchild v. Association, i1 $31 \% 52 \%$.

${ }^{3}$ Ransom r. Bank, 13 N. J. Eq. 212 ; Thomas $v$. J)akin, 22 Wend. 9. 32
${ }^{4}$ Green Co. $v$. Blodgett, 55 Ill. Ap. 556.

5 Woodman $v$. Company, 50 Me. 549.

${ }^{6}$ Lathrop $v$. Bank, 8 I):ana (Ky.), 114 ; Thompson $v$. Waters, 25 Nich. 214.

7 Brown v. Hogg, 14 Ill. 219 ; Richardson $v$. Association, 131 Mass. 174.

8 Leazure v. Ilillegas, 7 Ser. \& R. (Pa.) 
States such restrictions have been done away with, and corporations may now hold such property, both real and personal, as the attainment of their corporate purposes may require. In any event, the general power of a corporation to hold real estate is primarily a question betwen the corporation and the State, and cannot ordinarily be raised by third parties. ${ }^{1}$ Where such statutes exist the corporation has of course no power to exced the statutory limit as against the State. ${ }^{2}$

The general rule is that corporations, unless forbidden by statute, have implied power to take property by devise. ${ }^{3}$ The same rule applies with respect to the power of taking and holding property in trust, provided in so doing it acts within its corporate powers. ${ }^{4}$ The power of a corporation to sell and conrey is as broad as the power to purchase and hold, and is granted on the same terms. ${ }^{5}$

$\$ 14$. Power to appoint Corporate Officers and Agents. - At common law corporations have the inherent power, irrespectire of statute or charter prorision, to elect directors and exceutire officers and to appoint such agents as the business of the corporation require. ${ }^{6}$

$\S 15$. Power to establish By-laws. - Every corporation has the implied power to enact such by-laws as may be neecssary for the proper gorernment of the corporation, its officers, and stockholders. ${ }^{7}$

Sometimes the statutes preseribe the nature of the by-laws to be adopted and authorize penalties for violation thercof. ${ }^{8}$

313 ; White $v$. IIowarl, 38 Conn. 342 ; Page $v$. lleincherg, $40 \mathrm{Vt} .81$; livanna Nav. Co. 2. Jawsons, 3 Grat. (Va.) 19 ; Mrore $v$. Moore, 4 Jana (Ky.), 35.4; Mallett $v$. Simpson, 94 N. C. 37 ; Trustees $v$. Manning, 22 Mıl.116; 19 A1. 599; First M. l. Cluureh v. Jixon, 178 Jll. 260; 52 N. E. 887 .

1 C. 13. \& Q. R. li. Co. v. Lewis, 53 la. $101 ; 4 \mathrm{~N}$. IV. 842.

2 Market St. Ky. Co. v. IIellman, 109 Cal. 5il; 42 l'ac. 225; In re Mcliriw's Estate, $111 \mathrm{~N}$. Y. 66; Anlrews $r . \Lambda_{I-}$ drews, 110 Ill. 223; Graves r. Niles, I Walker (.Mich.), 3:3:.

3 White $"$. llowarl, :38 Conul. 342 ; Ravarma Nav. Co. v. Dawsons, 3 Grat. (Va) 19 .
4 Vilal v. Girards Execntors, 2 IIow. (U. S.) I27; Morris v. May, 16 (hio, 469 ; F. I. 'T. Co. $v$. II. F. N. Co., 41 N. Y. 619 ; White $v$. liice, 112 Mich, 403 ; 70 N. W. 1024; Greene v. 1)ennis, 6 Cumn. 304.

6 Miners' Ditch Co. v. Zellerlach, 37 Cill. 543; l'eople $v$. Collegre, 38 Cal. 166.

b. Kearney $v$. Androws, 10 X. J. Eq. 70;

A. R. R. ('i. N. Kill, 29 Ala. 221,

T Wolls r. Black, 117 (al. 157; 48 Pac. 10.00; l'mple ". Suriety, zt Barl, N. Y. 570; Martiu ". Assuciation, 2 Coldw. ('Yem.) 11s; Mechanics' Batuk r. Sinilh, l? Johus. (N. Y.) 115; Stecrer $r$ l)avis, 8 Trex. Civ. App. 23; 27 S. W. 1068.

${ }^{8}$ Cahill v. Company, 2 bong. (Mich.) 128; Mobile $v$. Yuille, 3 Ala. 137. 
s 16. Power to sue and be sued. - It has becn the rule of the coints from time immemorial to recognize and enforce the power of eorporations to sue and be sned under and by their corfurite mame as incilent to such cerporate existence.

$\$$ 17. Express Powers, Definition of ; Enumeration of. - Exfress powers are those which are either granted to all corporatims alike by statute, whether inserted in the charter or not, or olse are those which are permitted by statute to such corporations as maly see fit to take adrantage of them, by reserving such powers in the charter itself. Statutes of the character first referred to are construed by the courts to be ipso facto read into the charter, thereby becoming part and parcel of it. On the other land. the last-named powers can only be availed of by the corporation when, as has been stated, they are specifically reserved or set forth in the articles of incorporation. Express powers relate not only to the right to engage in a special line of business as set forth in the statement in the articles of the object or purposes for which the corporation is formed, but they relate as well to other powers which are here termed "express," inasmuch as they depend upon the cxistence of specific statutes authorizing their excreise by such corporations as desire to avail themselves thereof. 'These express powers may be divided into twenty-eight classes, emumerated as follows: (1) power to purchase its own capital stock; (2) powcr to subseribe for, purchase, and hold stock in other corporations; (3) power to consolidate with other corporations; (4) power to transact all or any part of its business outside of the State of its origin; (5) power to extend its corporate existence; (6) power to ehange its corporate name; (7) power to increase or decrease its capital stock; (8) power to issue preferred stock; (9) power to change the corporate purjuses ; (10) power to ehange the number of directors; (11) power to change its domiciliary office or place for the transaction of its business; (12) power to aequire and enforce a licn upon stock of the eorporation to secure the payment of debts due the corporation from stocklolders; (19) power to lery assessments against the streklublers with the right to forfeit the stock for non-payment thereof: (1t) power to authorize roting at stockholders' meetings 1,y juxy: (15) power to allow cumulative voting at the election of lincetors; (16) power to issue stock as full paid and non$1 \mathrm{~S} . \mathrm{W}$. Co. $v$. Armstrong, 1; Me. 34. 
assessable in exchange for property or serrices; (17) porrer to sell the corporate assets; (18) power to roluntarily dissolve the corporation without recourse to the eourts; $(19)$ power to insert in the charter provisions for the regulation of the internal affairs of the corporation ; (20) power to authorize directors to adopt bylaws; (21) power to authorize appointment of executive committce from board of dircetors; (22) power to enlarge or diminish corporate powers; (23) power to change par value of shares; (21) power of bondholders to rote at elections of directors; (25) power to classify directors; (26) power to amend articles before organization; (27) power to surrender charter before organization; (28) power giren to minority stockholders to compel purchase of their loldings upon consolidation.

Of the foregoing enumerated powers, the following when expressly authorized by statute are applicable to all corporations alike, whether reserved or enumerated in the articles of incorporation, to wit: The power to consolidate with other corporations; to perform constituent acts outside of the State of its origin; to extend its eorporate existence; to change its corporate name; to increase or decrease its capital stock; to change the corporate purposes, the rimber of its directors, its domiciliary office or place for the transaction of its business; to acquire and enforce a lien upon stock of the corporation to secure the payment of debts due the corporation from stockholders; to lery assessments against the stocklolders with the right to forfeit stock for non-parment thereof; to authorize voting at stockholder's' meetings by proxy; to permit cumulative roting at election of directors (unless such right is merely made permissible by statute); to issue stock as full paid and non-assessable in exchange for property or services; to sell the eorporate assets in their entirety; to roluntarily dissolve the corporation without recourse to the conrts; to authorize the directors to adopt by-laws (muless such authority is by statute refuired to be reserved in the articles of incorporation); to appoint an executive committee; to enlarese or diminish the corporate powers; to change the par value of shatres: to amend articles before orranization; to surrender charter before organization; power given to minority stockholders to compel purchase of their holdings upon consolidation.

Of the remaining express powers it is probilhy in accorl with the general current of authority in this country to say that to be 
arailable to the corporation they must be reserved or specified in the articles of incorporation. The powers to which reference is here made may be enumerated as follows: To subseribe for, furchase, and hold stock in other corporations; to transact all or any part of its business ontside of the State of its origin; to issue preferred stock; the power to insert in the charter provisions for the regulation of the internal affairs of the corporation; power of bondholders to vote at election of directors; power to classify directors ; and possibly power to purchase its own capital stock.

$\$ 18$. Power of Corporations to purchase their own Stock. 'There is considerable conflict of opinion in this country relative to the question whether a corporation may purchase its own stock without express statutory authority so to do. One line of decisions holds to the view that such power exists only when expressly conferred by statute no matter what the purpose may be. ${ }^{1}$ Other courts of equally high standing take the riew - and this we believe to be the true one - that every corporation has implicd power to purchase its own stock provided it does so in good faith and without prejudice to the rights of ereditors. ${ }^{2}$ It has been said that, "generally speaking, a corporation, when acting within the scope of the purposes of its organization, has the same power to contract with reference to such powers as an individual. We believe the rule to be well settled in the United States by the overwhelming weight of authority and reason that a private corporation may purchase its own stock if the transaction is fair and in good faith; if it is free from fraud, actual or constructive; if the corporation is not insolvent and in process of dissolution, and if the rights of creditors are in no way affected thereby." 3

Where there is no formal corporate action taken, authorizing the purchase of the company's own stock, a purchase made thereof, cren though all the stockholders separately consented thereto, would be invalid as against creditors. ${ }^{4}$

1 Crandall v. Lincoln, 52 Conn. 73; Currierv. Company, 56 N. H. 262; Morgan v. Lewis, 46 (). St. 1 ; 17 N. I. 558.

${ }^{2}$ City Bank Columbus v. Bruce, 17 N Y. $507 ;$ N. F. T. Co. ". Abbott, 162 Maso $149 ; 39$ N. E. 432 ; Clapp v. PeterEen, 104 III. 26; Ilall \& Farley $v$. HenderEo11, 126 Ala. 449; Bank $v$ Company, 18 36
Vt. 131 ; Chapman v. Company, 62 N. J. 497 ; 41 Atl. 690; Belknap v. Adams, 49 La. Ann. 1350; 22 Sou. 382 ; Ins. Co. v. Swigert, 135 Ill. $162 ; 25$ N. W. 382 ; Porter v. Company (Mont.), 74 Pac. 938.

${ }^{3}$ Porter $v$. Company (Mont.), 74 Pac. 938.

4 De La Vergne Refrigerator Machine 
Some of the States expressly authorize corporations to purehase shares of their own capital stock, while others expressly forbid it. ${ }^{1}$ The rule of course does not apply to those cases where statutes exist expressly authorizing the forfeiture of stock for non-payment of assessments. ${ }^{2}$ The purchase by a corporation of its own stock does not extinguish it. ${ }^{3}$ Many of the States have statutes expressly forbidding corporations to rote their own stock when held or owned by them. Eren in the absence of such statute, it is probable that the courts would enjoin corporations from voting their own stock. ${ }^{4}$ By statute in a number of States corporations are forbidden to purchase their own stock. ${ }^{j}$

$\S 19$. Power to subscribe for, purchase, and hold Stock in other Corporations. - The prevailing lule in this country is that unless the power is expressly given by statute or by reservation of such right in the charter, corporations have no implicd power to subscribe for, purchase, or hold stock in other corporations. ${ }^{6}$

An attempt has been made in some States to establish the rule that where the statute does not expressly prohibit such act, the corporation may purchase stock in other corporations withont any express authority so to do, provided the circumstances are such as to render the transaction a necessary and proper means for aceomplishing the objects of its creation. ${ }^{i}$

If, however, there is no statntory prohibition in the matter and the State officials permit the insertion in the articles of the power to purchase and hold stock in other corporations, the exereise of such power is unquestionably valid. ${ }^{8}$ In the same connection it may be observed that a corporation cannot organize subsidiary companies inless such power is given in express terms in the charter or by necessary implication from the powers thereby conferred. ${ }^{9}$

Co. v. German Savings Institution, 175 U. S. $38 ; 4+$ L. E. . 6.5 .

1 Sice l'art III. T'able 15, pagere 585; also [o]

2 laylor a. Comprang, of (thine, 83; State $r$. Association, 35) (1. St. 2.58.

" liank v. Wirkerslam, 3. Cal. 4H; Clapp ". Pelersen, 10+ III. 26.

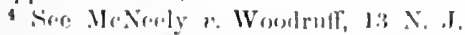
Law, 352 ; lirewstar $\cdots$. Iartley, 37 ('al. 15.

s Sce Tolman 2 . Company (1)ak.), 22" N. W. 505.

6 Franklin Bank n. Commorrcial Bank, 36 (). St. 2.88; Central Rig. Co. v. Collins,
40 Cia. 582 ; First Natt. Bank r. Nat. Fxchatlge Rank, 92 U. S. 122; Kmowles $x$.

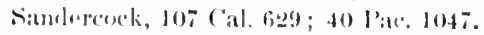

; Ilill $r$. Nishet, Ion ImI. 311 ; Peslatigo

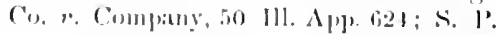

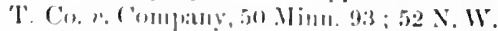

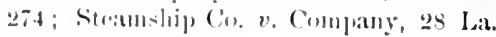
A11. 173

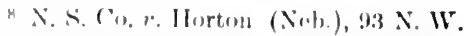
22.5; Do: La lerene Rofrigerating Marhinr (a) re (ierman Satrings Institution,

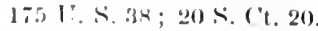

9 Laurone v. 'Timucrman, 46 S. C. 332 ; $2+5.1 \therefore 290$. 
In Mliska. Mistrict of Columbia, and Georgia corporations are forhidine ly statute to hold stock in other corporations.

: (). Power to colsolidate witl other Corporations. - Corporations cimnot consolidate as against dissenting stockholilers, lumerey elesirable or beneficial the consolidation may be, unless levishative authority is granted to that end. In the exereise of the police puwer of the state it may lawfully prohibit the consolidation of conporations.2

Comsolidation of corporations to a greater or less extent is permitted by statute at the present time in the States of Alabama, Cilifomia, Connectient, Delaware, Illinois, Kentucky, Maine, Montana, Nerada, New Jersey, New York, North Carolina, Virginia, and West Virginia. An attempt has been made to lay down the rule that in orler to effect a lawful consolidation as between two corporations, the power to so consolidate must be conferred by each of the States under whose laws they were created. ${ }^{3} \quad \mathbf{A}$ better rule, however, and the only practicable one seems to be this: That either statutory power to dispose of all the assets of the corporation, or in the absence thereof, the consent of all the stocklrolders inust be obtained to the sale of the assets of one corporation to another. Consolidation in this way then takes the form of a selling ont and of accepting money or shares in the new corporation in return for the assets of the old. ${ }^{4}$

$\$ 21$. Power to transact all or any Part of the Corporate Business outsicie of the State of its Domicile. - If there are no statutory restrictions, a corporation has implied power to carry on its business at any place within the State in which its charter is procured. 5 The statutory requirement requiring the corporation to fix in the articles its principal place of business does not prohibit under ordinary circumstances the transaction of other business within the State. ${ }^{6}$

Long ago in Bank of Augusta $v$. Earle ' Chief Justice Tancy,

1 I'earece $v$. Ry. Co., 91 Ilow. 341 ; Ilill Racine, etc. Ry. Co. $v$. Cumpany, 49111. $\because$ Nistet, 100 linl. 341 ; l'eople $t$. Com- 331.

Jany, 12 I.Y.582; 24 N. E. 834; L. \& N. 5 Ashley Wire Co. v. Company, 60 liy. $\because$ r. Kentucky, 161 U.S.677. Ill. Apl. iz9; City Bank $v$. Beech, I

${ }^{2}$ L. S. liy. Co.l. Kentucky, 161 U.S. Blatchiorl, 425; Stickle ". Company (N. 6.;.

II.

Mattrer of l'perpect Park, ete liy. Co.,

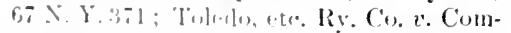

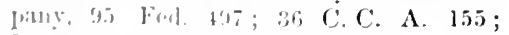
Janinath $v$. Complaty, 30 Pal. St. 42 ; $\therefore i$
J. Iif.), 32 Atl. 708 ; Underwood v. Waldron, 12 Mich. 73; Berthin $x$. Company, 28 Ia. An. 210 ; Lane $v$. l3ank, 9 II eisk.

(Teun.) 419.

6 I'otter v. Bank, 5 Hill (N. Y.), 490.

713 Peters, 519. 
commenting upon the right of a corporation to transact business beyond the limits of the domieiliary State, spoke as follows:

"It is very true that a corporation can have no legal existence out of the boundaries of the sovereignty by which it is ereated. It exists only in eontemplation of law, and by force of the law; and where that law ceases to operate, and is no longer obligatory, the corporation can have no existenee. It must dwell in the place of its creation and cannot migrate to another sovereignty. But although it must live and have its being in that state only, yet it does not by any means follow that its existence there will not be recognized in other places; and its residence in one state ereates no insuperable objection to its power of contracting in another. It is indeed a mere artificial being, invisible and intangible; yet it is a person for certain purposes in eontemplation of law. . . . Natural persons through the intervention of agents are continually making contracts in countries in which they do not reside; and where they are not personally present when the eontraet is made; and nobody has ever doubted the valiclity of these agreements. And what greater objection ean there be to the eapacity of an artificial person, by its agents, to make a contract within the scope of its limited powers, in a sovereignty in which it does not reside; providerl such contraets are permitted to be made by them by the laws of the place." 1

The strictly legal existence of a corporation is confined to the State which ereated it, and it can exercise its powers in another State only by permission, express or implied, of the legislative power thereof; but the mere right to purehase and sell property will be recognized and protected in any State subject only to the limitations that the exercise of such right shall not be contrary to the laws or settled policy of the latter State or prejulicial to its interests or those of its citizens. Unless the Constitution or statutes declare a contrary rule, the eourts of another state are hound to recognize the right of a foreign corporation to collect debts due to it, by receiving a conveyance of lant."

In order, howerer, to avoid complieations that might possibly arise through lostile action on the part of stockloblers or of foreign States, statutes have been enacted in a number of the Common-

1 See IIall $v$. Company, 91 Ala. $3633 ; 8$

2 Thompson $v$. Waters, 25 Mich. 214. So. 348 . 
wealths cxpressly antherizing the transaction of business in foreign states and jurisdictions. ${ }^{1}$

Lnder the frogressive incorporation acts in force in many of the states at the present time it is unquestionably permissible to organize corporations in one State for the exclusive purpose of transacting their entire hnsiness in other States and Territories. ${ }^{2}$

$\leq 2.2$. Power to perform Constituent Acts outside of the Domiciliary State. - By constituent acts is meant such corporate transactions as are separate and apart from its ordinary business dealings with third parties; such, for example, as the organization of the cornoration in the first instance, the adoption of by-laws, the issuance of stock certificates, the election of directors and oflicer's, and the holding of stockholders' meetings. ${ }^{3}$ As a general rule such constituent acts camnot be performed without the domiciliary state. ${ }^{2}$

The legislature may, of course, anthorize the performance of constituent acts beyond the limits of the State. This has been done in a number of the Commonwealths. ${ }^{5}$ It is probably safe to say that aside from organization meetings the presence of stockholders of the corporation at a meeting lield without the State will estop them from attacking the validity of the proceedings had at such meeting. ${ }^{6}$

\$ 23. Power to extend Corporate Existence. - In twenty-seven

1 See Part III. Table 12, page 582. See Ashley Wire Co. v. Company, 60 1ll. App. $17 y$; Kennebec Co. v. Company, 72 Mirss. 204; Aspinwall $v$. Company, 20 Ind. 492; Blodgett $x$. L. Z. Company, 120 Fed. 893.

2 Sec. Nat. Bank $v$. Ilall, 35 O. St. 158 ; M. L. \& S. Co. $\bullet$. lieinharl, 114 Mo. 2I8; 21 S. W. 488 ; O. M. Co. r. Garst, 18 R. I. 484; 28 Atl. 973; People $v$. Company, 153 11l. 25 ; 38 N. I. 752 ; Tilley $v$. Coykentall, 172 N. Y. 87 ; 65 N. L. 574; Minn., fte. Co. $v$. Denslow, 46 Minn. 171; 4e X. W. $7 / 1$; Wright $v$. Lee, $2 \mathrm{~S}$. D. $546 ; 51$ X. W. $706 ;$ A., ete. R. R. Co. $v$. Firecher, 35 Kan. 236 ; 10 Pae. 596 : North, etc. Steck $C_{1}$ ). $v$. People, 147 Ill. 234; 35 X. F, 6,68: Canada S. liy. Co, v. Geb. hartl, log [ S. 527; 3 S. Ct. 363; Cowell

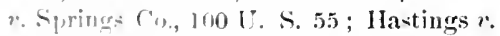
Anacrerts, f.te. (o), 29 Wash. 224; 69 Iac. 7ifs: Irsine Co, v. Bond, 74 Ferl. 849.

a See MaCall $r$. Company, 6 Conn. 40
428; Galveston, etc. Ry. Co. v. Cowdrey, 11 Wall. 459; 20 Law. Ed. 199.

${ }^{4}$ Commonwealth $v$. Smith, $45 \mathrm{~Pa}$. St. 59 ; Snith $v$. Compauy, 64 Md. 85 ; 20 Atl. 1032 ; Tuckasegee Mlining Co. $v$. Goodhue, 118 N. C. 981 ; 24 S. E. 797 ; Camp v. Byrne, 41 Mo. 525 ; F. T. L. Co. $v$. Laigle, 59 Tex. 339; Craig Co. v. Smith, 163 Mass. 262 ; 39 N. E. 1116 ; Bellows $v$. Todd, 39 Iowa, 209; Hodgson v. Company, 46 Mimn. $454 ; 49 \mathrm{~N}$. W. 197 ; Ilarding $v$. Company, 182 11l. $551 ; 55$ N. L. 577 ; Jones $v$. Company, 20 Col. 417 ; 38 Pac. 700 ; Mack v. Company, 90 Ala. $396 ; 8$ So. 150 ; Aspinwall $v$. Company, 20 Ind. 492 ; Courtriglit $v$. Deerls, 37 Iowa, 503.

5 See Part 1II. Table 11, page 581.

6 Haniley $v$. Stutz, 139 U. S. 4I7; Galveston, etc. Ry. Co. v. Cowdrey, 11 Wall. 459; see also Humphreys v. Mooney, 5 Col. 282. 
of the Commonwealths perpetual existence is permitted in the incorporation of companies therein. The power to extend such existence is not of any material importance in these Commonwealths. Twenty-fire of the incorporation acts specifically proride for the extension of corporate existence. Without such statutory authority corporate existence cannot be extended. ${ }^{1}$

In some of the States extension of corporate existence must be accompanied by the payment of an organization tax, as is the case of new corporations. Thus, in New Jersey, where such a provision exists, it has been held that such tax must be paid even though the extension of the corporate existence was obtained in the guise of an amendment to the charter. ${ }^{2}$

$\S 24$. Power to change the Corporate Name. - Without statutory authority so to do corporations cannot change their name. ${ }^{3}$ If the proposed change of name conflicts with the name of an existing domestic corporation, State officials are justified in refusing to allow the certificate showing the adoption of the new name to be filed. ${ }^{4}$

Some of the States, as, for example, New York and California, only permit change of name by application to the courts.

$\S 25$. Power to increase or decrease Capital Stock. - A corporation has no implied power to either increase or decrease the capital stock. ${ }^{5}$ Such power must be conferred in express terms by the incorporation act under which the corporation is organized. ${ }^{6}$

Power to increase or decrease capital stock rests in the stoekholders and not in the directors. Frequently incorporation acts provide that the stock shall not be diminished to less than the amount of the corporate debts. Such is the case in California and other States. Certificates of stock issucd on a fictitious increase of stock are void. ${ }^{8}$

$\$ 26$. Power to issue Preferred Stock. - Stockholders enjoying

1 See Part III. Talble 8, page 578; also post, sec. 120 .

2 National Iead Co.l. Jickinson (N. J.), 57 Atl. 138.

a Sykes $r$ Perple, 132 Ill. $32 ; 23 \mathrm{~N}$. E. 391 ; C. 1). \& $11 . \mathrm{liy.}$ Cr. $v$. Keisel, $4.3 \mathrm{l}$.t. 39; Glass Co. r. Comprany, 32 In] 376.

4 In re U.S. M. Rep. Agency, 115 N. Y. $176 ; 21$ N. 1\%. 10.34; l'oople r. Company, 111 Wich. $405 ; 65$ X. $11,6.53$

6 Ins. Co.v. liamper, 73 Ala. 325 ; J'ull. man 2 . Upton, 96 U. S. 328.
"Sutherland v. Olcott, 95 N. Y. 93; Cramlall r. Lincoln, 52 Comm, 73; G. J. \& II. Iusurance Co. I. Kamper, 73 N1a. 325; l'almer e. Bank, 72 Minn. 26fi; 75 N. W. 360; Hotroit Chamber of Commerce $n$. Sitale Secretary, 109 . Miel. 691 ; 69 N. W. $89 \%$.

i C. C. liy. Co. v. Allerton, 18 Wall. 233.

8 Britman v. Steiner, 98 Ala. 241; 13 Soll. 87. 
freferential or additional rights not enjoyed by the holders of common shares are called "preferred stockholders." The issuance of preferred stock is a mode by which a corporation obtains funds for its enterprise, without borrowing money or contracting a clebt.' The question as to whether or not preferred stock may he issued by corporations without express authority by law is a somewhat dificult one to settle. In twenty-five of the States ${ }^{2}$ the question is seltled by the existence of statutes expressly authorizing the issumuce of preferred stock, and even in those States where no such statutes exist it is, with some few exceptions, the custom of the State officials to permit the insertion in the articles of incorpuration of provisions authorizing the issuance of preferred stock. 'The action of such offieials is certainly conclusive as against all the world except the State. ${ }^{3}$

The true rule governing the matter now before us is, in the opinion of the writer, best set forth in the case of Campluell $v$. American Zylonite Company." In this case the articles of incorporation divided the capital stock of the corporation into shares, equal in amomt and value. Some time after incorporation one of the stoekholders executed a blank assignment of certain stock owned by him to a third party as security for a loan. Subsequently all the stockholders, except the owner of this pledged certificate, at a meeting duly called for that purpose, voted to surrender to the corporation, withont consideration, forty per cent of their stock, and authorized the corporation to reissue this forty per cent in the form of preferred shares. The legality of this act was contested by the holder of the pledged certificate, and in passing upun the legal question involied, the court spoke as follows:

" The right of every shareholder to his proportion of the profits of the corporation was vested, and in the absence of some power to ehange the relative value of the shares conferred by statute or by the articles of incorporation, no change could be malle without the consent of all the shareholders. . . . The assignee of shares having possession of the certificates, although holding under unregistered trausfers, are nut bound by contracts between the registered sharehollors, the eorporation and all the other shareholders which are not within the express or implied powers of eoryorations or of their sharehollers. Is between the assignor and the assignee, the unregistered

1 Chaffere 2 . Comprany, $55 \mathrm{Vt} .110$.

2 See Pont III. Table 8, parge 578. 4
3 See IIamlin ". R. R. Co., 78 Fed. 670.

4122 N. Y. $455 ; 25$ N. L. 853. 
assignment was not void. It follows that the change in the relative value of the shares which this corporation and its registered shareholders sought to effect was not within the express or implied powers conferred upon the corporation or shareholders, and that their action is not binding upon the holder of the assigned certificate who did not consent to the issuance of the preferred shares."

In Kent $v$. Quicksilver Company ${ }^{1}$ the court addressing itself to the question now before us, spoke as follows:

"There arises the query whether there was power in the corporation to distinguish between the stockholders in it to form them into two classes, and to grive to one class rights in the corporate property and business and earnings from which the other was shut out. We are not prepared to say that at the first the corporation might not have lawfully divided the interest in its capital stock into shares arranged in classes, preferring one class to another in the right which they should have in the profits of the business. The charter gare power to make such by-laws as it might deem proper consistent with Constitution and law. We know of nothing in the Constitution or the law that inhibits a corporation from beginning its corporate action by classifying the shares of its eapital stock, with peculiar privileges to one share over another, and thus offering its stoek to the public for subscriptions thereto. No rights are got until a subseription is made. Each subscriber would know for what class of stoek he put down his name, and what right he got when he thus beeme a stockholder. There need be no deception or mistake, there would be no treading upon rights previously acquired; no contract, express or implied, would be broken or impaired. Shares of stock are in the nature of choses in ation, and give the holder a fixed right in the division of prolits or earnings of the company so long as it exists, and of its effeets when it is dissolved. That right is as inviolable as is any right in property, and can no more be taken away or lessened against the will of the owner than ean any other right, unless power is reserved in the lirst instance, when it enters into the constiution of the right; or is properly derived afterwarl from a superior law giver. It is manifest that any action of a corporation which takes hold of the shares of its capital stock already sold and in the hamels of lawful owners, and divides them into two elasses, - one of whieh is thereby given prior right to a reesipt of a fixed sum l'rom the earnings before the other may have any reeeipt therelrom, and is given an equal share afterward with the other in what earnings may remain, - destroys the equality of the shares, takes away a right

$$
1 \text { is X. Y. I6r. }
$$


which originally existed in it, and materially varies the effect of the certificate of stock. It is said that when a corporation can lawfully buy propurty or get money on loan, any known assurance may be exincted and given which does not fall within the prolibition, express or implier, of some statute. But the prohibition to such action as this is fonmid not, indeed, in a statute commonly so called, but in the constitutional provision which forbils the impairment of vested rights, save for public purposes and on due compensation. The right which a stockholder gets on the purchase of his share, and the issue to him of the eertificate therefor, is such a vested right. It is contended that the power so to do is an incidental and implied power neecssary to the use of the other powers of the corporation, and is a legitimate means of raising money before securing the agreed consileration therefor. We have already conceded that it is legitimate to borrow money and to secure the repayment of it with a compensation for the use of it. But that is when it is done in such way as to put the burden upon every share of stock alike, and to enable erery share of stock to be relieved therefrom alike; in such way as to preserve the equality of right and privilege and value of the shares, and maintain intact the contract thereto with the stockholders.

"We are, therefore, of the opinion that there was no power in the corporate body, nor in a majority of the stockholders, to provide by by-law for the ereation of a preferred stock, so as to bind a minority of the stockholders not assenting thercto."

In what has been stated a most important principle lias been referred to, which, it is believed, is controlling upon the question at hand. This principle to whieh reference is here made is that the cliarter proceeds from the State, and that nothing ean be legally done by the corporation acting through its stockholders not authorized either by statute or by the charter itself. 'Thus it is clear that in these States where the statutory right to issue preferred stock is not granted and the charter itself only provides for eommon stock, no preferred stock can be legally issued by the stuckinolder's as against the State, exeept by amending the charter itself. This, too, even where the stockholders consent. ${ }^{1}$

This question is likely to be presented in a troublesome form where common stock has been pledged to creditors before the preferred stock was issued. ${ }^{2}$

Frm a careful examination of the authorities it may be said

2 Kunsille, etr. Co. 2 . City of Knox. ville, $9 \times$ Thun. $1 ; 37$ S. W. 883.

2 Sce generally Lockhart $v$. Van Alstyne, 3I Mich. 76 ; McGregror $v$. Insurance 41 
that in order to constitute an issue of preferred stock ralid as against all the world, there must be a statute anthorizing it, or provision therefor inserted in the elaarter. To make the issue ralid as against all but the State, the consent of all of the holders of common stock to the issuance of preferred stoek is, doubtless, all that is necessary. ${ }^{1}$ It is hardly necessary to add, in addition to the foregoing, that the total amount of common stock added to the preferred stock so issued must not in any case exceed the total authorized capital stock of the corporation.

The rights of holders of preferred stock depend upon the terms of the statute or of the charter or by-law authorizing it. ${ }^{2}$ Ordinarily the power to authorize the issuance of preferred stock vests in the stockholders and not in the directors. ${ }^{3}$

Where a portion of the stock of the corporation is issued as preferred, no ereditor of the corporation can object, provided the money paid for the stock reaches the treasury of the corporation, and the diridends on the stock are not to be paid exeept out of net profits. ${ }^{4}$ Unless the statute provides otherwise, preferred stockholders may be deprived of the right which they would otherwise have, to rote their stock in the same manner as common stockholders. ${ }^{5}$ This is commonly done either by eharter provision or by a by-law adopted before any preferred stock is issued.

Preferred stock cannot be lawfully issued with the provision that it shall bear interest absolutely. ${ }^{6}$ In order to make preferred stock a lien upon the corporate assets statutory authority is necessary. ${ }^{7}$

Co., 33 N. J. Fq. 181 ; Higgins v. Lansingh, 154 111. 301 ; 40 N. E. 362 ; Corington, etc. Co. v. Sargent, 1 Cinn. Sup. Ct. 354 ; Elevator Co. v. Nemphis, etc. Co., 85 Tenu. $703 ; 5$ S. W. 52; March $v$. Eastern R. R. Co., 43 N. II. 515 ; Bates v. Androscoggin, etc. R. R. ('o, 49 Me. 491; Prouty $i$. Mich., etc. R. R. Co., l Hun, 655; Kent v. (quicksilver Min. Co., 12 Hun, 53; Jones r. 'Terre Ilaute, etc. Co., 57 N. Y. 196; Ifoyt 2 Q Quickilser Muning Co., 78 N. Y. 159; s. c. 9 Week. Digest, 187, aff'g 17 IIun. 169; Curry $v$. Scott, 54 Pa. Sit. 270; Sturges $v$. F. Un. Ry. Co., 7 De Gex, II. \& G. 158; Mattlews v. Gt. Northern R. R. Co., 28 L. J. Ch. 375 ; Green's 13rice Lltra Vires, 145; Intton v. Scarborough Hotel Co., 2 I)rew \& Sim. 514; Hook $v$. Gt. Western Rv. Co., 3 L. R. Ch. 262 ; Jenry v. Git. Northern
Ry. Co., 4 K. \& J. 1; 27 L. J. Ch. 1; Corry $v$. Londonderry, etc. Co., 29 Beav. 272 ; 3 I. J. Ch. 290; Coates $v$. Nottingham Water Works Co., 30 Beav. 86.

1 Higgins 2 . Lansingh, 154 1ll. 301 ; 40 ऽ. . . 362.

2 Scott v. B. \& O. R. R. Co., 93 Md. $75 ; 49$ Atl. 327.

8 See Coit $v$. Freed, 15 Utal, $426 ; 49$ Pac, 5.33.

* First Nat. Bank of Peoria v. Peoria Watch Co., 191 Ill. 128; 60 N. E'. 859.

b Iockhart $v$. Van Alstyne, 31 Mich. 76 ; Mackintosh v. Company, 32 Fel. 350; Miller $v$. Ratterman, 470 . St. 141 .

"Winscott $v$. Investment Co., 63 Mo. A 1. 367 .

7 Continental Trust Co. $v$. Toledo, etc. Ry. Co., 72 Ferl. 92. 
527 . Power to change the Corporate Purposes. - In the early days the right of amendment, when the same related to altering the origrinal purposes of corporations, was jealously guarded and limited both by statute and by judicial construction. In later years there has been crinced greater liberality in this regard, as cridenced by granting to corporations unlimited power of amendment. 'The only real difficulty in this connection arises when an attempt is made to so completely change the original purposes for which a corporation was formed as in effect to create a new corporation. Under the Pemsylrania Incorporation $\Lambda$ ct governing amendments, it was held that this conld not be done.2

The present attitude of the courts on this subject is well shown by a recent New Jersey decision, - that of Meredith $v$. New Jersey Zinc \& Iron Company. ${ }^{3}$ In this case the right of amendment, eren when producing fundamental changes in the corporate purposes, was sustained. ${ }^{4}$

It appears clear that under the liberal power of amendment existing to-day in the majority of the States, any changes may be made, no matter how fundamental, by the consent of all the stockholders. And where the matter is simply one between the corporation and the State, the right to make such an amendment cammot, in the States referred to, be questioned when adopted by the requisite number of stockholders.

$\$ 28$. Power to change Number of Directors. - Only in those States where the number of directors is required to be fixed in the articles, is it necessary to have statutory authority to change the same. In other States the matter of amendment may be legulated by the by-laws. However, in the larger number of the Commonwealths, the power to amend the articles with reference to changing the number of directors is required to be based upon express statutory anthority so to do. ${ }^{5}$

1 See Part III., Table 8 , page 578.

2 In re lennsylvania Bottling Co., 19 Pennsylunia County Court Reports, 533. See a]so State $v$. 'Taylor, 53 Iowa, $759 ; 6$ र. W. 39 .

8 Merelith $v$. Company, 59 N. J. Eq. 257 ; 4 Atl. 55. See also sec. 112 , post.

4 tee al-o Grand liver College $v$. Robertson, f; Mo. Ap p. 329 ; Mercantile State. ment ('), r. Kneal, 51 . Iinn. 263; 53 N. W. 6.32 ; Iswie 2 . Crand I.odge, $99 \mathrm{Ca} .392$; 34 Pac. 103; J)ay 2 . Company, 75 Ia.
694 ; 38 N. W. 113; Stickle v. Liberty Cycle Mfg. Co. (N. J. Eq.), 32 Atl. 708; Banet $v$. Company, 13 111. 504; Ross $v$. Company, 77 Ill. 134; Pac. Ry. Co. v. Ren. shaw, 18 Mo. 210 ; Aslitov $v$. Burbank, 2 Dill. (U. S.) 435; Del. Ry. Co. $v$. Thorp, 1 Hurst (1)l.), 149; M. B. Ry. Co.r.Sullivan, 37 Ga. 240; Com. v. Cullen, 13 Pa. St. 133.

5 See Part J11. Table 16, page 586; also see Natter of Grifling Iron Co., $63 \mathrm{~N}$. J. Law, 168; 41 Atl. 9311; 63 N. J. Law, $357 ; 46 \Lambda$ tl. 1097. 


\section{\$ 29. The Power to change the Corporate Domicile and Principal} Place of Business. - As will hereafter be seen, it is essential to corporate existence that the corporation should have a home. ${ }^{1}$ It is the naming of the domiciliary office in the articles which fixes the residence of the corporation for jurisdictional purposes, and fixes the usual place for holding stockholders' and directors' meetings. If it is desired to change the domicile, or if the location of the corporation's principal place of business is to be transferred from one place to another, an amendment to the articles must be had under legislative sanction.2 It should, however, be noted in this connection, that the corporation's domicile and its principal place of business are not necessarily one and the same thing. ${ }^{3}$

Again, if, as is the case in some States, the name of the agent upon whom process upon the corporation may be served, is required to be set forth in the articles, in order to lawfully substitute a new agent, an amendment to the articles is necessary, made pursuant to statutory anthority given in the premises. ${ }^{4}$

$\S 30$. Power to acquire and enforce a Lien upon Stock to secure the Payment of Debts Due the Corporation. - In a large number of the States statutes exist expressly granting to corporations the right to enforce a lien upon the stock of its members for the purpose of securing the payment of debts due from such members to the corporation. ${ }^{5}$

The courts are not by any means in entire agreement as to whether statutory authority to enforce such a lien is essential to its validity. Some courts, of excellent repute, maintain the affirmative, and others take the opposite riew. ${ }^{6}$ It seems fairly certain that at common law such a right did not exist.

The true view appears to be that while at common law a corporation had no lien on the shares of its eapital stock for the debts due it from the stocklolders, nevertheless such a lien may be acquired either when given by statute or when such right is

1 See post, sec. 54.

2 See Stickle $v$. Liberty Cycle Mfg. Co. (I. J. Eq.), 32 Atl. T08; Kemmott $r$ Company, 68 N. H. $432 ; 39$ All 585 ; llarris 1 . Mckiregor, 29 ('al. 124.

8 Vas litten $r$. Faton, 19 Micl. J87; McConnell v. Company (Mont.), it l'ace. 194.

4 See Johnson v. Mason I, mlge, $21 \mathrm{Ky}$. Law liep. 493; 51 S. W. figo.
6 Sce Part III. Table 9, pare 579.

6. Costellis $v$. Company, 69 X. II. 405, 43 Atl. fito; Young ". Vough, 23 N. J. F. 325 ; Moure r. Bank, 52 .10. 377; In re Klaus, 67 Wis. 401 ; 29 N.IV 582 ; Farmcrse, rete. I3ank, r. Wassim, 48 Ia. 336; Cint. T. K. Co. «. Toledo, etc. liy. (o., 72 [ind. 92.

i Brinkerlıff, ctc. Co. v. Compauy, 118 Ilo. $+17 ; 24$ S. W. 129. 
meserved by inserting provisions therefor in the Articles of Incorporation, of by the passage of a valid by-law, or by inserting a morision thelefor in the stock certifieates.

$\$$ 31. Power to levy Assessments against the Stockholders with the Right to forfeit their Stock for Non-payment thereof. - With some few exceptions the right to forfeit stock for non-payment of valid assessments levied against it is preserved by statute in most of the Stales and Territories." Eren in the absence of such statute the right to forfeit stock for non-payment of valid assessments when given to the eorporation by its by-laws will probably be enforced by the courts. In any erent the common law remedy would exist, giring the eorporation the right to recorer judgment against the delinquent stockholders for the amount of such assessments. ${ }^{3}$

In all eases the right to forfeit stock is considered to be merely a cumulative remedy. ${ }^{4}$ The right to levy assessments upon stockholders does not exist after payment by such stockholders for their stock in full, unless the power to do so is conferred either by statute, by the articles of incorporation, or by the manimous consent of all the stockholders. ${ }^{5}$ But even in the absence of express power to declare a forfeiture of stock for non-payment, a corporation may sue for amount of subscription to the capital stoek, and on failure to collect the amount subseribed may secure payment by sale of stock subseribed. ${ }^{6}$

On the general subject of assessments the following may be said: provisions for the forfeiture of eapital stock for the non-payment of assessments nust be just and reasonable in order to be valid. ${ }^{7}$ The terms of the statute in any cvent must be strictly complied with. ${ }^{8}$ The power to lery assessments rests in the directors by virtue of their office and not in the stockholders. ${ }^{9}$ Even where

1 Lnion Bank $v$. Laird, 2 Wheaton (U. S.), 390 ; St. Louis Per. Ins. Co. $v$. Goodfellow, 9 Mo. 149; Van Sands $v$. Bank, 26 Conn. 14t; Sargent $v$. Insurance Co., 25 Mass. 90. See also Atchison Bank $v$. Durfee, 118 Mo. $431 ; 24$ S. W. $133 ;$ V.G. B. Co. $v$. Bloede, 84 Mid. 129 ; 34 Atl. 1127 ; Bislop v. Glohe Co., 135 Mlass. 132.

2 See Part III. Table 17, page 587.

3 San Joaruin v. Beecher, 101 Cal. 70; 35 Pac, 349.

4 .I. F. \& N. Co.v. Ilall, 121 Mass. 272 ; Raymonil $\because$ Caton, 24 Ill. 123; I.esseps $v$. Architects' (o), 1 La. Ann. 316.

s linterprise litch Co. v. Moffitt, 58 15
Neb. 642 ; 79 N. W. 560 ; Duluth Club v. MeDonald, $7+$ Minn. 254; 76 N. W. 1128; State 2 . Association, 23 N. J. Law, 195; Sullivan Co. Club v. Butler, 26 N. Y. Miscellaneous Reports, 306 ; Mayberry $v$. Meade, 80 Me. 27 ; 12 Atl. 635; Price's A ppeal, 106 Pa. St. 421 ; Weeks $v$. Company, 55 N. Y. Sup. Ct. 1.

6 Chase v. Company, 5 Isea (Tenn.), 415.

7 Crissey v. Cooke, 67 Kan. 20 ; 72 I'ac. 541 .

${ }^{8}$ P. G. T. R. Co. v. Graham, 11 Hetcalf, 1.

${ }^{9}$ Chouteau Ins. Co. v. Floyd, 74 Mo. 286. 
the statute expressly gires power to the stockholders to lery assessments they may doubtless delegate this power to directors. ${ }^{1}$ Director's, howerer, cannot lawfully delegate such power to ministerial officers. ${ }^{2}$

\$2. Power to authorize Voting by Proxy at Stockholders' Meetings. - At common law the right of stockholders to rote by proxy was not recognized. The right in order to be arailable must be granted either by statute, charter, or appropriate by-law. ${ }^{3}$ Voting by proxy is not however per se unlawful.* Therefore the right may be secured to stockholders by appropriate by-law duly passed even without a statute authorizing it. ${ }^{5}$

$\S 33$. Power to permit Cumulative Voting at Election of Directors. - The right of cumulative roting exists where a stockholder has a number of rotes equal to the number of shares held by him multiplied by the number of directors to be chosen, and is allowed to cast or distribute them as he sees fit. The purpose thereof is to seeure minority representation on the board of dircetors. To authorize cumulative voting the right must be preserved either by constitutional, statutory, or charter prorision or by the passage of a by-law looking to that end. ${ }^{6}$

If the right is conferred absolutely by constitutional or statutory provision, it cannot be taken away by means of a by-law or resolution denying such right to stockholders.;

In twenty-one of the Commonwealths the right to eumulate votes is secured to stockholders either by constitutional enactment or by statutory provision. ${ }^{8}$

$\$ 34$. Power to issue Stock as full paid in Exchange for Property or Services. - In the quaint wording of an English case, "stock must be paid for, in the absence of constitutional or statutory provision providing otherwise, "in meal or in malt;" that is, in money or in money"s worth. ${ }^{9}$ Forty of the States have enacted laws authorizing the payment of stock not only in cush but in

1 Rives $t$. Compans, 30 Ala. 92.

2 In re County Paliatiuse I. \& 1). Co., L. R. 9 Ch. 691 ,

'Ilarvey zo. Company, 118 N. C. 6993:

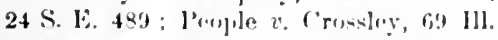
195 ; Mckee e. Company (I:1.), 98 N. W.609.

4 M. \& O. Ratilroal Co. e. Nichulats, gr Ala. $92 ; 12$ Sin. 723.

5 State v. Turlor, 5 I aty (Comn.), 329 ; Commonwealeh, r. Detwiler, 131 I'at. St. $614 ; 18$ Atl. 990.

o Pierce v. Communwalth, 104 Pa. St. 150 ; Sichunilt r. Withell. 101 Ky. 570;

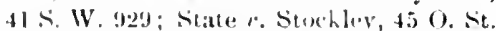

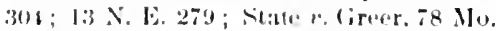

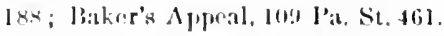

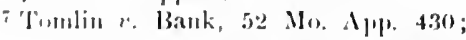
Commonwealth 2 . Yetter, 190 l'a. St. 488 ; 13 At1. 226.

h. . I'art III. 'Table 9, page 579.

y I) rummoml's Case, L. R. + Ch. 772. 
serviecs or property. Some of the States - for example, Alahamal and Virginia - have somewhat elaborate provisions on the sulijeet.

Thus, in Alabama, stoek may be issued in exchange for all sneh real and personal property as may be necessary or convenient for the elficient construction, operation, and maintenance of its works or plants, lines, shops, factories, or other buildings, or for the eonduet and managrement of its business or as its purposes may require. ${ }^{2}$

in Virwinia the new Incorporation Act authorizes subseriptions to the capital stock to be paid for in money, land, or other property, real or personal, leases, options, mines, minerals, mineral rights, patent rights, rights of water or easements, contracts, labor, or serrices. ${ }^{3}$

Even in those few Commonwealths where no statutes exist authorizing the payment of stock in property or services, the courts will presume that corporations have inherent power to purchase property and labor and pay for the same in stock instead of money, provided the transaction whereby the stoek is to be issned in exchange for such property or services is made in good faith and no fraud is perpetrated upon stoekholders or creditors. ${ }^{4}$

The statute to prohibit absolutely the payment of subscriptions to the capital stock in property or services must be clearly restrietive in character. ${ }^{5}$ The only effect apparently of the absence in partieular Commonwealths of any provision, constitutional or statutory, authorizing the payment of stock in property or serriees, is to induce the courts to adopt what is known as the "true value pule" rather than the "good faith rulc." 7 But in the Commonwealths referred to, the eharacter of the property, labor, or serrices aceepted in exchange for stock must be strictly such as the corporation under its charter has the power to acquire, and when property is so taken it must be fairly represented to the corporation and for a just, lawful, and needed equivalent for the money subscribed. ${ }^{8}$

1 See Part III. Table 10, page 580.

2 Sees Alatrama Session Laws, 1903, p. 395. .er. 7, -ubliv. c.

"sres ression Laws of Virginia, 1903, chap. 270 .

4 Lietser $\%$ Kinapp, 79 Mo. 22 ; Beach $v$.
Sinith, 30 N. Y. 116 ; Shannon $v$ Stevenson, 173 Pat. St. $419 ; 34$ Atl. 218.

5 Sie Kuox $v$. Company, 86 Ala. 180; 5 So $5: x$.

6 See post, sec. 104.

7 See prost, sec. 105 .

${ }^{8}$ Liebke $v$. Knapp, 79 Mo. 22 ; Powell 


\section{\$35. Power to dispose of Corporate Assets as an Entirety. -} In ten of the Commonwealths express power is conferred upon corporations to disjose of their entire corporate assets by obtaining the consent of a certain percentage of the stockholders to such disposition. ${ }^{1}$ Much controversy has arisen as to whether or not express statutory power is necessary in order to anthorize transfer by a corporation of the entire corporate assets. At common law neither the directors nor a majority of the stockholders had power to sell or otherwise transfer all of the property of an acting and prosperous corporation able to achieve the objects of its creation as against the dissent of a single stockholder. ${ }^{2}$

The view is taken by the New Jersey court in Coler $v$. Company $^{3}$ that the sale of the corporate assets as an entirety is equiralent to a dissolution, and therefore can only be done through the courts under statutory anthority. Many courts, howerer, take the riew that it can be done where it is not in frand of the rights of ereditors or in violation of charter or statutory restrictions, and this, too, by a majority of the stockholders against the dissent of a minority where the exigencies of the business seem to require it." Thus, it has been asserted that "it is a well settled rule that a strictly private corporation has the same right to dispose of its property that an individual has, and that when insolrent or in a failing condition it may sell all thereof without the consent of all of the stockholders. It is the general rule, howerer, that neither the directors nor a majority of the stnckholders of a corporation have power at common law to sell or otherwise transfer all its property while the corporation is a going, prosperous concem against the dissent of any shareholder." 5

It may be adder in this comnection that the right to exist as a

v. Murray, 3 N. Y. App. Jiv. 273; 38 N. Y. Sup. 233; II. 157 X. I $717 ; 53$ N. I..1130; Kimball a Company, 69 N. II. $485 ; 45$ Atl. 253; Nontgumery r. ('um-

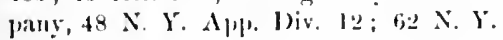
Suj. 606; II. 168 N. Y. 657 ; t1 N. J. 1131.

1 See Part III. Table 9, puge 579.

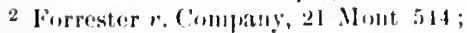

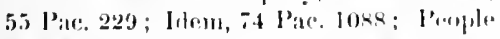
r. Ballaril, 134 N. Y. 269; 32 N. li 5t; California Bank $v$. Kemmely, l67 1 . S. 362 ; 42 L. J. 198; ]3. \& .1. (: C.\&. . II.
Co. . M. O. I'. Co., 89 Ieul. 529; Metcalf r. A. S. F. Co., 122 Fed. 115; Traer $v$. Company (lit.), 99 N. IV. 290.

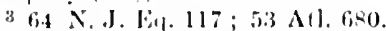

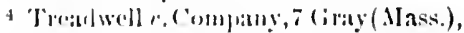
393; Martin 2. Zellerbach, 3R Cal. 3to0; Minars' Jiteh (a, r. Zallerbach, 37 Cal. 513; Foullerslombanderla Company, I. R. 1 bil. $31 \times$; Barlunlonew 2 . Company, 69

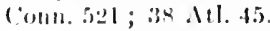

6 'Triter $\therefore$ Complany (Ia.), 99 N. W. 290. 
corporation is not alienable. ${ }^{1}$ The sale of all the corporate propcrty does not operate to dissolve the corporation. ${ }^{2}$

$\$ 86$. Fower to voluntarily dissolve the Corporation without Recourse to the Courts. - The dissolution of a corporation is a peculiar function that rests primarily in the legislature, and is conferred upon courts or upon the corporation itself, only by explicit legislatice authority. ${ }^{3}$ Stockholders, in the absenee of statutory prorision, cannot extinguish the corporate charter or dissolve the corporation, nor can a cont of equity accomplish a similar result at their instance. ${ }^{4}$ In all the States some provision is made for dissolution of corporations. For example, in Alabama, Comecticut, New Jersey, North Carolina, Virginia, and West Virginia the incorporators have the right to surrender the charter before organization. In twenty-seren of the Commonwealths corporations may be dissolved under statutory authority without recourse to the courts. ${ }^{5}$

The doctrine that dissolution can only be effected by the joint aet of the State and corporation is set forth in a Massachusetts case as follows: "Charters, are in many respects compacts betreen gorermment and corporators. And as the former cannot deprive the latter of their franchises in violation of the compact, so the latter cannot put an end to the compact without the consent of the former. It is equally obligatory on both parties. The surrender of the charter can only be made by the formal act of the corporation; and will be of no avail until accepted by the government. There must be the same agreement of the parties to dissolve, that there was to form the compact. It is the aceeptance which gives efficacy to the surrender. Dissolution of a corporation, it is said, extinguishes all its debts. The power to dissolve itself by its own act would be a dangerous power, and one which camnot be supposed to exist." 7

In this connection it may be observed that the stockholders

1 Jetroit Citizens' Street Ry. Co. $v$. Common Council, 125 .lich. 673;85 N. .W. 96 ; I'earce $v$. IR. IR., 21 Ilow. 44l; 16 L. E. 184; State $\imath$. Company, 40 Kan. $96 ; 19$ I'ace 349 .

2 Nimers' I)itch Co. $v$. Zellerbach, 37 Cal. 543 ; Sullivan $v$. Company, 39 Cal. 459.
3 Olds $v$. Company (Mass.), 70 N. E. 1022.

4 Benedict $v$. Company, 49 N. J. Eq. 235 ; 2.3 Atl. 485.

5 Sce Part III. Talle 8, page 578.

- Buston Glass Manufactory Co. $v$. Langrlon, 24 Pick. 49.

7 See also Davis $v$. Company, $87 \mathrm{\Lambda la}$. $633 ; 6$ Sou. 140. 
alone have power to surrender the charter. ${ }^{1}$ It will be remembered, of course, that the expiration of the time limited by the charter as a corporation's term of existence is held in most jurisdictions to result in the dissolution of such a corporation. ${ }^{2}$ But neither insolvency nor sale of all of the corporate property, nor eessation of business operates to dissolve the eorporation. ${ }^{3}$

But in the absence of any provision in the charter limiting corporate existence, the corporation is entitled to perpetual life. ${ }^{*}$ If the articles provide for a longer period of corporate existence than the law allows, the excess is void..$^{5}$ In many of the States statutes exist providing that the corporation shall contime in existence for periods ranging from three to fire years after the expiration of the time limited for its existenee for the purpose of winding up its affairs. ${ }^{6}$

A majority of the States delegate to the courts the power to dissolve the corporation on application of stockholders or ereditors. ${ }^{i}$ The fact that eertain States make the directors trustees for ereditors on dissolution does not necessarily take away the jurisdietion of courts of equity to appoint a reeeirer. ${ }^{8}$ IIany States have statutes providing that upon the expiration of the time limited by their eharter as the duration of their corporate existence, they shall nevertheless be continued for a certain period of time in order to permit of the winding up of the corporate affairs. Without such statutory provisions suits camnot be maintained against the corporation after such period has expired. ${ }^{9}$

$\$ 37$. Power to insert in the Charter Provisions for the Regulation of the Internal Affairs of the Corporation. - The incorporation acts of eighteen of the States contain provisions relative to the eontents of certificates of incorporation, authorizing the insertion therein of provisions for the regulation of the business of the corporation, or for the purpose of defining or limiting the powers of the corporation, its offeers, dircetors, and stoekholders. ${ }^{10}$

1. Wones $v$. Bank, $10 \mathrm{Col}$. 4fit; 17 Jac. 272 ; larton $v, \Lambda$ ssociation, 114 Ind. 22e6; 16 . . F. $486 \%$

2 Wison $x$. Compialy, 25 Ferl. 892.

" Javis $v$. Company, 87 Ala (3333; 6 So. 140.

4 F. I. S. Co. r. Clowes, 3 N. Y. 170.

5 people $v$. Checeseman, 7 Col. 3 s; ; 3 I'ac. 716 .

${ }^{6}$ See Part III. Tallie 17, patge 587 ; see alow Foster 2 . liank, 16 Mass, 245 ; Nash. ville Bauk o. J'etway, 3 Ilıu. ('T'(mu.) 522 .

i See . Niner $x$. Complauy, 93 Nich. 97;

53 N. W. 218 ; Whelur v. Compnny, 143

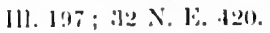

8 ('ily l'oltery ('o, o. Yates, 37 N. J. Eip. 51:.

"Nelson r. Ilubbard, 96 Ala. 238; 11 Soll. 128.

1) See I'art III. 'Table 10, page 580. 
Unkess the law expressly permits the insertion of such provisions in the certificate of incorporation, State officials are justified in refusing to acept and file certificates containing such provisions. This crenerally on the ground that in the absence of statutory provision so authorizing, they are properly the subject of by-laws and not proper for insertion in the eertificate of incorporation. ${ }^{1}$

Learing out of consideration the fact of acceptance by State officials, and approval by them of certificates of incorporation containing such provisions as are here referred to, when there is no statute authorizing the same, the following may be said: The general test as to whether provisions not called for by the statutes are valid when inserted in certificates of incorporation must be determined from their character. If they are not powers, but are merely in the nature of by-laws, they are invalid as not being called for by the statute. If they are powers, but not authorized by statute, to permit such insertion in the eertificate of incorporation would be equiralent to saying that the legislature had clothed the incorporators with a number of their legislative functions. ${ }^{2}$ On this general subject the opinion of the Supreme Court of Alabama in a lcading case in that State is instructive: "It is apparent," observes the court, "that the creation of corporations under general law rather than by special act was not intended to work any essential change in their nature and eharacter. Whether deriving existence from a special law, or from incorporation under the gencral law, the corporation is an artificial being of legislatire creation, having no other powers or properties than such as the law confers, or which may be incidental to their very existence. The mode of incorporation the statutes have earefully prescribed. The persons proposing to be incorporated must file and cause to be recorded in a designated public office a declaration in writing, stating the name of the corporation, the objects for which it is formed, the amount of the capital stock, the number of shares into which it is divided, the names of the stuekholders, and the number of shares each may loold. The office and the effect of the declaration the statutes do not leave in doubt-

1 In re Application for charter, 10 Phil. Rep. 130; Van I'elt $v$. Garduer, 54 Neb. $701 ; 75 \mathrm{~N}$.W. 874 ; Bent $v$. Underdown, 60 ‥ F. $307 ; 156$ Inl.516; IIeck $v$. McEwen, 12 J.a, 97 ; T. $\Lambda$. I. Co. $v$. Hassey, 56 S. W. $35 ;$ L. P. R. Co. $v$. Vaughan, 14 51
N. Y. 546 ; G. L. D. Co. $v$. Perkins ('Texas), 26 S. W. 256 ; Albright $v$. Association, 102 Pa. St. 411 ; Shoun v. Armstrong (Tenn.), 59 S. IV. 790.

2 l'eople ex rel. $v$. C. G. T. Co., 130 Ill. $268 ; 22$ N. E. 798. 
when recorded, the persons signing it and their successors become a body corporate by the name stated therein and with the powers conferred by law. It is an acceptance by the corporation, under the name designated, for the objects expressed, of the corporate powers and eapacity the law confers, and a statement of the principal constituents of the corporation, - the amount of the capital stock, the names of the stockholders, and the quantity of interest each has in the capital stock. There is no authority of law for introducing more into it, and if more be introduced, it is mere surplusage, not adding to or detracting from the force of the declaration. A controlling purpose, as we suppose, in authorizing or in compelling the creation of corporations under general laws, is to secure uniformity and equality of corporate powers, functions, and privileges; that all corporations of the same class, formed for like purposes, should possess the same capacities and properties, and exereise and enjoy the same franchises and privileges. Unless it was intended to work a radical change in the nature and character of these artificial beings, the mere creatures of the law, and to subvert the whole theory which has prevailed in reference to them, it camnot have been contemplated that they should for themselves create powers and privileges by declaration or reservation, whether the declaration or reservation is expressed in the articles of incorporation or in the by-laws ordered by the corporators for their gorernment. Such declarations or reservations would soon become more liberal and diverse than was the liberality and diversity of the grants of corporate powers by special legislative enactment, the evil it was intended to remove. Of every corporation formed under the general law, the law itself becomes the eharter, defines and emmmerates the powers which are to be exercised, the nature and extent of eorporate franchises and privileges. The declaration of incorporation, the by-laws adopted for corporate government, do not form the charter, or define or emmerate the corporate powers. These are the acts of the eorporators. The charter is the grant from the sovereign power of the State, and by that source only can be varied or enlarged." I

$\$ 38$. Power to authorize Directors to adopt By-Laws. - In a number of the States statutes cxist authorizing the directors to adopt by-laws under certain conditions. The conditions here re- 
ferred to are usually either that the right referred to should be cxpressly inserted in the certificate of incorporation, or, in lieu thereof, that the stockholders expressly delegate this power to the directors.' Unless the statute or charter provides otherwise, the by-laws must be adopted by the stockholders. ${ }^{2}$ However, where the right to adopt by-laws is expressly limited to the directur's, it is exelusive.

\section{Power to authorize Appointment of Executive Committee} from the Board of Directors. - In Connecticut, Delaware, Massachusetts, Nerada, New Jersey, Virginia, and West Virginia statutes exist expressly authorizing directors to appoint an executive committee from their own number to whom may be delegated, to such extent as shall be provided in the by-laws, any of the powers of the board of directors. 'There has as yet been no fair test in the courts as to the ralidity of such statutes where an attempt has been made by the directors to practically delegate all their powers to an executive committec. A reasonable view of the matter would seem to be that where the statute clearly eonreys such power it is ralid when exereised by an executive committee duly appointed from the full board of directors pursuant to the statute in such case made and provided. ${ }^{3}$

The power of the board of directors is not a delegated authority, and when the transaction of the business of the company will be facilitated by the appointment of an excentive committee such appointment may miquestionably be made. ${ }^{4}$

$\$$ 40. Power to enlarge or diminish Corporate Powers. - The right here referred to becomes one of importance only in those States wherein it is permitted to insert specific corporate powers in the articles of incorporation. The powers here referred to are such, for example, as the right of the corporation to acquire its own stock; to hold stock and bonds in other corporations; to delegate to directors power to adopt by-laws, etc. It will be found that wherever such a right exists the power to amend will be found sufficiently broad to permit of the enlargement or diminishing of

S.e l'art III. Table 12, page 582.

2 Seere Nurton, etc. Co. $v$. Wysong, 51

Ind. 4: Salrm Bauk $v$. Bank, 17 Mass.

1; Wat-1, 2 Comprany, 56 Mo. App. 145;

State 1: rurti- 9 Ner. 325.

s. E. I. C\%. l. Isank, 127 N. Y. 517 ; Pac. 356.
28 N. E. 467 ; Black, etc. Co. $v$. Holway, 85 Wis. $344 ; 55$ N. W. 418 ; Andres v. Fry, 113 Cal. 124; 45 Pac. 534; Bank v. Walton Iron Co., 30 Bull. (Ohio) 382.

4 Leavitt $v$. Company, 3 Utah, 265 ; 1 isf 
corporate powers by complying with the terms of the statute relative to such amendments. ${ }^{1}$

$\S 41$. Power to change Par Value of Shares. - Where the charter fises the number and par value thereof, a corporation cannot increase or diminish the par value of its shares without legislative sanction. ${ }^{2}$ If however the certificate of incorporation says nothing as to the number and par value of shares, they may donbtless be changed by the stockholders of the eorporation without legislative sanction. ${ }^{3}$

The legal effect of a change in the number of shares withont any corresponding increase or decrease in the par value thereof, is to increase or decrease the capital stock, and this ean only be done by permission of the legislature. ${ }^{4}$

In thirty-six of the States the par ralue of the capital stock may be any amount, while in the remainder such par ralue is limited from amounts ranging from one dollar to one hundred dollars per sliare. $^{5}$ In some few of the States it will be noted that the prorisions of the statutes limiting amendments fail to authorize changes in the par value of the shares of eapital stock. ${ }^{6}$

$\S 42$. Power of Bondholders to vote at Election of Directors. Very few of the States have enacted statutes giving to bondholders the right to participate in the election of directors. Virginia and Delaware are the exeeptions to the general rule. Most of the States provide that the board of directors shall be eleeted by the stockholders, and thus by implication forbid the giving of the right to bondholders to vote at such election. ${ }^{7}$ Howerer, if ncither by constitutional or statutory provision bondholders are barred from participating in the election of directors, such right may be bestowed upon them either by provision therefor in the eharter or by proper by-law duly adopted. ${ }^{8}$

$\$ 43$. Power to classify Directors. - Ordinarily the tenure of directors is fixed by statute, and where so fixed these provisions are of course controlling. If the statute requires direetors to be elected

1 Peoria, ete. Co. 2. Preston, 35 Ia. 115 ; P', ete. I'. R. Co. v. Griffin, 2I Barb. 454 ; l'ac. R. ('o. r. Ilughes, 22 VIs. 291.

2 Droitwich Patcut Sialt Co. r. ('urzon, L. R. 3 lix. 3.; 'Tschumi $r$. Ilills, f Kan. App. 549; 51 Pac. 61:?; S. 2I. I). (or. $v$. Ropes, 6 P'ick. (.Irass) 23.
${ }^{8}$ S. \& K. Ry. Co. e. Cushing. 45 . Me. 534.

4 I)roitwich l'atent salt Co. v. Curzon,

L. R. 3 lix. 35.

5 Sine l'art III. Table 4, page 565.

- Sire I'art III. Talile 14, page 575.

7 lurkee n. People, 155 III. 354; 40

N. E. 1206 .

$\varepsilon$ State $r$. McDaniel, 22 O. St. 354. 
anmully, this by implication prohibits the classification of directors lor terms in excess of the statutory limit. ${ }^{1}$ ln a large numbel of the states statutes exist expressly authorizing elassification of lilectors.2

If the statute does not require annual election of directors, there would appear to be nothing illegal in a corporation's classifying its directors in any manner it sees fit so to do, provided (in the abscuce of statutory regulations) directors hold their office at the pleasure of the corporation.

$\$ 44$. Power to amend Articles before Organization. - As has alrealy been seen, the power to amend, if it exists at all, must be derived from the legislature. Very few of the Commonwealths have granted to incorporators the right to amend articles of incorporation before organization. Statutes, however, to that effect exist in Alabama, Comnecticut, New York, New Jersey, Nortl Carolina, and Virginia.

$\$ 45$. Power to surrender Charter before Organization. - It is often an advantage to a corporation which does not care to avail itself of the right to actively engage in business, to surrender its charter to the State before organization, without going through the expensive and usually complicated proceedings incident to dissolntion. Snch right is expressly given in Connecticut, New Jersey, North Carolina, Virginia, and West Virginia. ${ }^{3}$

$\$ 4$ i. Power given to Minority Stockholders to compel Purchase of their Holdings upon Consolidation. - In the States of Alabama, Connecticut, Massachusetts, Delaware, and New York statutory protection is afforded to minority stockholders in case the corporation has consolidated with another. 'The Connecticut statute may be lriefly summarized as an example of such statutes. ${ }^{4}$

The act provides that any stockholder in any corporation consolidating, who at the time of such consolidation objects thereto in writing, may, within ten days after the agreement of consolidation has been filed for record in the office of the Secretary of State, demand in writing from the consoliclated corporation payment of his stock; and such corporation sluall within three months thereafter pay him the value of his stock at the date of

1 State a. IIC('ullongh, 3 Nev. 202.

2 See l'art III. Table 14, page 584.

${ }^{3}$ Munma $v$. Company, 8 I'et. U. S. 281; 'Taylor $v$. IIolues, 14 Fed. Rep. 498; Houston v. Jefforson College, 63 l'a. St.

5.)
428; Law $v$. Rich, 47 W. Va. 634 ; 35 S. E. 858.

4 Sec. 79 , chap. 194, of the Session Laws of 1903. 
such consolidation. In case of disagreement as to the ralue thereof, such ralue shall be ascertained by three disinterested persons, to be chosen, one by the stockholder, one by the directors of the consolidated corporation, and the third by the two thus selected; and in case their award is not paid within thirty days from this date it shall become a debt of said consolidated corporation and may be collected as such. Upon receiving payment of the amount awarded, such stockholder shall transfer his stock to the consolidated corporation, which shall dispose of it on the best terms attainable. ${ }^{1}$

$\S 47$. Incidental Powers, Definition and Enumeration of. - An incidental power is one that is directly necessary or proper to the execution of an express power, and not one that has a slight or remote relation to it. ${ }^{2}$ The term expresses those powers which flow necessarily out of the exercise of the express powers conferred by statute or by charter. ${ }^{3}$

The exercise of a power that might be beneficial to the principal bnsiness of the corporation is not necessarily incident to it. ${ }^{4}$ The principal incidental powers may be enumerated as follows: (1) power to make contracts; (2) power to borrow money ; (3) power to gire and accept customary evidences of debt; $(4)$ power to mortgage or pledge real and personal property; (5) power of amotion.

The implied powers which a corporation has in order to carry into effect those expressly granted, and to accomplish the purposes of its creation, are not limited to such as are indispensable for these purposes, but comprise all that are necessary in the sense of appropriate, convenient, and suitable, including the right of reasonable choice of means to be employed. Acts of a corporation which if standing alone or engaged in as a business would be beyond its implied powers, are not necessarily ult ra vires when they are incidental to or form part of an entire transaction which in its general scope, is within the eorporate purpose. The validity of such a transaction is to be determined from its general

1 See Janman v. Company, 30 l'a. St. 798; J'eople v. Company, 175 Ill. 125; 51 42, Mowrey $v$. Company, it Fed. Cals. No. $9891 ;+$ Bissell, 78 ; Pittsburg, etc. Ry. Co. v. Garrett, 50 (). St. $405 ; 34$ N. F. 493.

2 I Iood r. Company, 42 Conn. 112; People $v$ Company, 130 III. $269 ; 22$. . L. . Ninu. $413 ;$ it N. W. 160. 
charicter considered as a whole rather than by segregation into individual parts and each regarded as distinct from the other. ${ }^{1}$

$\$$ 48. Power to make Contracts. $-\Lambda$ corporation is a creature of lan, and may do any act or thing under contract the same as natural frersons might do, subject to the rights conferred on it by the law of its ereation or by its charter. ${ }^{2}$ Where chartered in one State for any purpose, it may lawfully make a contract in furtherance of that purpose in any other State where not prohibited by the laws thereof. ${ }^{3}$

$\S 49$. Power to borrow Money. - The power to borlow money in carrying ont the purposes of the corporation's organization is one of the incidental corporate powers. ${ }^{4}$ In this connection it may be said that the power to borrow money has been held to imply the power to issue bonds. ${ }^{5}$ Howerer that may be, in addition to an enumeration in the statute of the power to borrow money, a majority of the business corporation acts expressly confer the right upon corporations to issue bonds. ${ }^{6}$

$\$ 50$. Power to give and accept Customary Evidences of Debt. This incidental power includes the right of corporations to make notes or bills of exchange, to accept drafts and notes, and to draw eheeks. ${ }^{i}$

\$51. Power to mortgage and pledge Real and Personal Property - Every corporation has the incidental power to mortgage and pledge its real and personal property in order to procure and secure necessary luans to be made to the corporation. ${ }^{8}$ It is sometimes said that a corporation has power to pledge both its issued and unissued shares. ${ }^{9}$

$\$ 52$. Power of Amotion. - The power of amotion has reference to the remoral of officers and directors. The term "dis-

1 C. O. న. G. F. Co. $v$. Company, 60 Ohin, $96 ; 53$ న. L. 711 ; Porter $v$. Company (Mont.), it Pac. 938.

2 Hand v. Company, 143 Pa. St. 408 ; 22 Atl. 709 ; People 2 . Company, $70 \mathrm{~N}$. Y. 569 ; MacGinniss $v$. Company (Mont.), 75 Pac. 89.

${ }^{3}$ IIall v. Company, 91 Ala. $363 ; 8$ Sou. 348 .

4 See Ward v. Johnson, 95 Ill. 215 ; Wright $\%$ Hugles, 119 Ind. $324 ; 21$ N. E. 907 .

${ }^{5}$ Commonwealth $v$. Smith, 10 Allen (Mass.), 448; Smith $v$. Law, 21 N. Y. 296.
6 See Part III. Table 14, p. 584.

7 Moss v. Averell, 10 N. Y. 449 ; Lucas $v$. Pitney, 27 N. J. Law, 221 ; Smead $v$. Company, 11 Ind. 104; Strauss $v$. Company, 52 O. St. 59 ; Morris $v$. Cheney, 51 Ill. 451 .

8 State $v$. Company, 61 Kan. $547 ; 60$ Pac. 337 ; Farmers' Bank v. Company, 108 Ky. 447; 56 S. W. 719 ; Savings Trust Co. $v$. Company, 112 Fed. 693.

3 See U. Savings Ass'n v. Seligman, 92 Mo. 635 ; 15 S. W. 630 ; Burgess $v$. Selignan, 107 U. S. 20 ; 2 S. Ct. 10. 
franchisement" has reference solely to the deprivation of the right to rote as against stockholders. ${ }^{1}$ The right is delegated by statute to the stockholders in fifteen of the Commonwealths. ${ }^{2}$ In the absenee of such statute there is no power in the stockholders to remove directors before the expiration of their allotted terms, except for cause, provided such terms are fixed by statute. ${ }^{3}$

It seems to have been the rule of the common law that every corporation had an implied power to remove directors for cause when their terms of office were not prescribed by statute. ${ }^{4}$ In New York it has been held that the power to remove directors may be covered by by-law. ${ }^{5}$

The main grounds which justify amotion where no statute exists limiting the same, are the conviction of crime on the part of directors, misconduct in offiee, and violation of statutory provisious. ${ }^{6}$ If the charter or statute prorides steps which must be taken to remore director's, such statute must be strictly followed.7 In the exereise of this power the stockholders meet, charges must be preferred, and the director removed by a majority vote. ${ }^{8}$ Equity will not interfere in such matters in the absenee of usurpation or gross negligence. ${ }^{9}$

$\$ 53$. The Modern Doctrine of Ultra Vires. -- To define in a general way the ancient doctrine of ultra vires is to say that a contract of a corporation which is unauthorized by or in riolation of its charter, or entirely outside of the seope of the express purposes of its creation or beyond the powers granted to it by the charter or by statute, is roid in the sense of being no contract at all, because of a total want of power to enter into it; that such contract will not be enforeed by any species of action in a court of justice; that being void al, initio, it cannot be made good by ratifieation or by any suecession of renewals, and that no performance on either side can give validity to the mlawful contract, or form a foundation of any right of action upon it. ${ }^{10}$

1 White r. Browncll, 4 A h. l'r. s.s. $16 \div 2$

2 See Part III. 'Tahle 9, jage 579.

${ }^{3}$ Nathan v. Tompkins, 8: Alat. 4is7; 2 So. $7+7$.

+ Fiweette ". Charles, 13 Wenl. 4 i3.

6 Douglass 2 . Company, 118 N. Y. 4 4.4; 23 N. F. 806

"Rex $v$. Richardson, 1 Purr. ili.

$i$ State $v$. Trusters, etc., 5 Inul. $i$.
${ }^{8}$ Rix r. Tavlor, 3 Salk, 231; R. l. G.

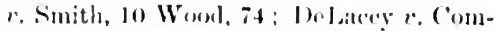
pany, I llawks (.犬. (.). 2al; l'urily $r$

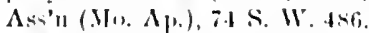

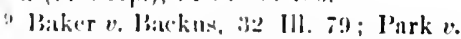
Grant locomolive Works, to N. J. liq. 114; 19 A11. 62: I1. 45 N. J. 1\%. 241, 30,$2 ; 3$.11. J62.

"S. Sere Thompen on Corporations, vol. r. $596, x$; for history of doctrine of ultra 
'lhe meessities of modern business and the arrival by the conrts at a bettel conception of the true relations governing the matter, have hromght abont radical changes in the doctrine as here staterl. What wo propose to do in this comnection is to set forth what may be termed "the modern doetrine of ultra vires." Preliminary to this a statement should be made showing how the loctrine of ultru vires originated, and how it came to be applied from time to time.

In the early diys corporations were created mainly for public pmroses, and it was in connection with quasi-public corporations that the loctrine of ultra vires first originated. In view of this fact, as has been well stated, there was no reason why the doctrine shonlel ever have been applied to private corporations not formed for public purposes. ${ }^{\prime}$

The gromnds of the old doctrine are stated by Judge Gray as follows: " "That the charter of a corporation which contains its grant of powers is a public statute, which all persons are bound to take notice of and be governed by; that the restraints thereby established on the alienation of the framehises of the property of the corporation are founded on considerations of public policy, which neither the corporation nor any other persons can be allowed to evade or disregard." In a later case, when sitting on the United States Supreme Court bench, the same judge observed: ${ }^{3}$ "The reason a corporation is not liable on a contract ultre vires are the interests of the public that the corporation shall not transcend the powers granted; the interests of the stockholders that the capital stock shall not be subjected to the risk of enterprises not contemplated by the cliarter, and therefore not authorized by the stockholders in subseribing for the stock; the obligation of every one entering into a contract with a corporation to take notice of the legal limits of its powers."

Turning now to this statement, attention should be called to those reasons which have aided a great majority of the courts in evolving a new doctrine of ultra vires better suited to the conditions of the present time. In the first place, except in the case of what is known as "quasi-public-private corporations," the

vires spe P. G. I. Co. $v$. Claffy, 151 N. Y. 24; 45 ऽ. E. 390 .

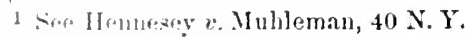
A 1. J)iv. 175; 57 X. Y. S. 8.54.

$1 ; 2$
2 Richardson 2 . Sibley, I1 Allen, 65.

3 l'ittshurgh, etc. Co. $v$. Keokuk, ete. Bridge Cu., 131 U. S. 37 ; 9 S. Ct. 770. 
public has no direct interest whatever in the nature of the powers vested in them. Corporations are no longer created by special act, except in a few cases, and it would be a poor rule which would require a stranger to take notice of the contents of charters not public and diffieult to obtain. In modern times the placing in articles of incorporation of a large number of purposes, in some cases giving the corporation almost unlimited scope along business lines, has practically removed the objections spoken of above, to the effect that eapital shall not be suljected to the risk of enterprises not contemplated by the charter.

Turning now to the changes already referred to, as having taken place in the doctrine of ultra vires, they may be stated in the form of the following propositions: (1) "The claim that a contract is roid, because under the charter beyond the power of a corporation is seldom recognized as a defence to an agreement otherwise objectionalle, and never where it would defeat the ends of justice or become a shield against wrong; " 1 (2) the doctrine of ultra vires is not usually applied where the party setting it up has received a benefit from the unlawful act relied upon as a defence ${ }^{2}$ (3) where the most that can be said of a corporate act is that it is an abuse of power, the State alone can act $;^{3}(t)$ the doctrine that persons dealing with corporations are bound to take notice of their power is now practically done away with by the application of the doctrine of estoppel in the case of completed contracts.

Again, it should be earefully noted that by the fullest application of the doctrine of estoppel where attempts have been made to set aside contracts on the ground that they were ultra vires of the corporate powers, the courts have practically revolutimized the doctrine as it once existed in this conntry. The doetrine of estoppel here referred to is of the character referred to by Lord Denman in Piekard $v$. Sears, ${ }^{4}$ where he says that where one by his words or conduct wilfully canses another to believe in the existence of a certain state of things, and induces him to act on that belief so as to alter his own previous position, the fonmer is precluded from averring against the latter at different state of things as cxisting at the same time. By an extemled applieation of the

1 Int. Trust ro. r. Company, io N. II. 118 ; 4f, Arl. 105.4; B. Li. V. (1. Co. I. Hauley, $15 l^{\circ}$ tall, $506 ; 50$ l'a. St, fill.

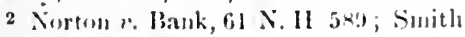
r. Bank, i2 N. II. 4.
3 Rectur r. Hartord Deposit Co, 190 Ill. :I-6); 6il N. F. 528.

46 . A. \& El. 469. 
doetrine latid down by Lord Denman, the courts hold that where there hats been no express violation of the law the corporation is estopped by its own contract or conduct from setting up, as a defence to an action to enforee such contract, that it was not in the power of the corporation to make it. So too the courts hold that where a private corporation enters into a contract in excess of its grinted powers and has received the benefits of the contract which the other partics acted upon, the corporation is estopped to repudiate the contract on the ground that it was ultra vires. Repeatedly the courts have held that where a contract with a corporation the making of which is beyond its chartered powers - has been fully executed by both parties to the contract, neither of them can assert its invalidity as a canse of action as against the other.

Again, it may be stated that where a corporation has acted in exeess of its granted powers or in the face of express or implied statutory prohibition it is clear that there ean be no objection raised on that ground between it and a private party, for this can only be raised by the State in a direct proceeding to forfeit the franchises of the corporation. ${ }^{1}$ Again, it may be stated that the doctrine of estoppel, as well as the doctrines of ratification and contirmation by acquiescence, apply under modern rules to ultra vires contracts. ${ }^{2}$

An Ohio court has divided unauthorized acts of a corporation into two classes: (1) where it has no power to do what it promises or to receive what is promised; (2) where it has no power to do what it promises but may receive what is promised. In each class, it was said, if action is brought, one of three states of fact will appear: (a) where it has performed its promise, but the other party has not; $(b)$ where the other party has performed, but it has not; $(c)$ where neither party has done all that was promised. In case $1 a$ the corporation camnot recover; the contract has no existence. In case $2 a$ the corporation may recover for performance if it has eliminated the ultra vires element and there is no want of mutrality. In cases $1 b$ and $2 b$ what remains to be done is ultra vires, and neither party can recover. In cases $1 \mathrm{c}$ and

1 Crion Nat. Bank v. Matthews, 98 L. S. 6.21 ; Pullman e. Cpton, 96 U.S. 328.

2 Ser: Water Works Co. v. Low, 46 N. Y. Sup. f,3:3 ; Wres]ruff $\varepsilon$. Lirie R. R. Co., 93 N. Y. for ; Willer 2 . Am. Mut. Acci. Ins. Co., 92 Tim. 165; Wood $v$. Corry Water 6.t
Works Co., 44 Fed. 146 ; Linkauf $x$. Lombard, 197 N. Y. 417 ; 33 N. L. 472 ; Nims v. Sclonol, 160 Mass. 177 ; 35 N. L. 776 ; J. B. Farrell Company $v$. Wolf, 96 Wis. 10 ; $70 \mathrm{~N}$. W. 289 ; Smith $v$. Bank of New Englaud, 72 N. Il. 4. 
$2 c$ neither party can recover because the contract is ultra vires. Recovery cannot be helped by promises of the officers. Pure assertion of law cannot give rise to estoppel. Nor is recorery aided by the fact that a consideration was conveyed to an individual as trustee for the corporation. ${ }^{1}$

$\S 54$. Corporate Domicile. - Corporations, like individuals, must have a place of abode. ${ }^{2}$ As far back as Lord Coke's time a place of abode was held to be of the essence of a corporation. ${ }^{3}$ Unless provided otherwise by statute, the rule at the present time is that corporations to have any legal existence must have a home within the boundaries of the State which creates it.

In the words of Justice McAdam in Krnse $v$. Dusenbury, ${ }^{4} " \mathrm{~A}$ corporation cannot become a tramp. It must have a domicile not in theory, but in fact - within the sovereignty which created it. ... A corporation in the nature of things must hare some office or place of business in the State where it was incorporated, so that creditors may know where to find it, that they may present and if necessary prosecute their just demands. The statute contemplates that such place of business shall exist not only in name, but in fact; for, if the corporation has no place of business in the state where it was incorporated, it does not affect the charter, but it canmot have branch offices elsewhere. Like a live tree, it cannot consist of branches only, but must take root in its native soil before it can extend its branches into other States."

Most of the States have statutes expressly requiring the maintenance of a domiciliary office within the State of the corporation's origin, and failure to comply with this requirement renders the charter of suclı corporation liable to forfeiture upon proper action taken by the State. ${ }^{5}$

Thus in Minnesota a charter was forfeited for the failure on the part of the corporation to maintain a domiciliary office therein. In this case," the court observed, " that independently of statute, it is incumbent upon a private corporation to keep its principal place of business, its books and records, and its principal oflices in

1 Vos v. Association, 9 Bull. (()hio) 19.4. Tex. 80; State $v$. Compnany, 45 Wis. 579)

2 In re Spring Valley Water Co., 17 Simmonse Company, 113 N. C. 147; 18 Cal. 132.

8 See Sutton's IIospital Cases, 5 Coke's Rep. 25.3.

419 Wk. I)i. (N. Y.) 201.

5 See N. \& S. R. Co. v. People, 147 Ill. 59 N. W. 1048.

234 ; 35 N. E. 609; State v. Company, 24 
the State where it is incorporated, to an extent necessary to the fullest jurisdiction and visitorial power of the State and its courts and the eflicient exereise thereof in all proper cases, and that a forfeiture may be adjudged for a violation of this common law obligation." 1

'The anthorities have on more than one occasion brought actions to forfeit charters of corporations for failure to maintain domiciliary offices therein. ${ }^{2}$

In the words of one court, a corporation "must have some fixed office or place of business in the State where it is incorporated, so that ereditors may know where to find it." 3 Again, the object of naming the domicile is to fix the place for the holding of stockholders' and directors' meetings, and to fix a location for the books of the corporation where the stockholders and ereditors may demand an inspection thereof, if this right is given to them by statute. ${ }^{4}$ Another purpose is to fix the venue of actions brought against a corporation where the law requires that suits shall be brought in the county where the defendant resides. In those States which have statutes expressly authorizing a corporation to transact all of its business outside of the domiciliary State, this provision for a domiciliary office is of the utmost importance.

A corporation cannot have two domiciles at the same time. ${ }^{5}$ The domicile, residence, and citizenship of a corporation are in the State from which the charter was procured. ${ }^{6}$ The place of residence is in the county where the principal office is located. ${ }^{7}$

The principal office of a corporation and the place for the transaction of its business are not one and the same thing. A corporation may have its office in one locality and transact its business in another. ${ }^{8}$

1 See also State ex rel.v. Company, 45 Wis. 579 ; Stickle $v$. Liberty Cyele Co. (N. J.), 32 Atl. 708.

2 S.e N. \& S. R. Co. v. People, $147 \mathrm{Ill}$. $234 ; 35$ N. E. 608; State $v$. Company, 24 Texas, 80 ; State $v$. Company, 45 Wis. 579 ; Cimmons $v$. Company, 113 N. C. $147 ; 18$ S. F. $117 ; 22$ L. R. A. 677 ; State $\because$ Crimplany, 58 Minn. $330 ; 59$ N. W. 1048; State $v$. Company, 59 Kan. 151; 52 Pac. 422; Montgomery $v$. Forbes, 148 Mass. $249 ; 19$ N. E. 342.
${ }^{3}$ Kruse $v$. Dusenbury, 19 Wk. Dig. (N. Y.) 201.

4 State v. Ry. Co., 45 Wis. 580.

5 Bridge Co. $v$. Woolley, 78 Ky. 525.

6 American, etc. Co. v. Johnston, 60 Fed. 503; Chafee v. Bank, 71 Me. 514.

7 McSherry $v$. Company, 97 Cal. 637; 32 Pac. 711.

8 Van Etten $v$. Eaton, 19 Mich. 187 ; Kennett $v$. Company, 68 N. II. $432 ; 39$ Atl. 585; Meredith v. Company, 59 N. J. Eq. 257 ; 44 Atl. 55 ; Harris v. McGregor, 29 Cal. 124. 
$\S 55$. Board of Management. - A corporation without a responsible management is like a boat without oars, a ship without sails. It must have certain recognized and duly appointed agents to represent the stockholders in the management of the company. These agents are generally known as a board of directors, or less commonly as a board of trustees. Twenty of the States require the names of the first board of directors to be inserted in the certificate of incorporation, while of the remainder nine require merely the number of directors to be stated therein. Twenty-two of the States prescribe residential requirements for directors, while others require that all directors shall be stockholders. The number of directors required by the various business corporation acts rary from an unlimited maximum to a minimum of one. ${ }^{1}$

Where the statute requires the number of directors to be set forth in the articles, the incorporators cannot name a number less than the minimum required by law. ${ }^{2}$ The power to have and elect directors is inherent in every corporation, irrespectire of statute. In fact, it is an essential feature of corporate existence. ${ }^{3}$

In the absence of express provision in the charter or by-laws the management of the business of the corporation is vested in the Board of Directors and not in the stockholders. ${ }^{4}$ Failure to name directors in the articles when the same is required by statute will justify State officials in refusing to file articles. ${ }^{5}$ Merely providing for executive officers in the articles is insufficient. ${ }^{6}$ The original directors named in the certificate of incorporation under direction of the incorporation act are directors de jure, clothed with all the powers of the corporation, and may exercise the same powers as though elected by the stockholders. ${ }^{7}$

$\$ 56$. Capital stock. - Capital stock is the fund of money or other property fixed as the basis for conducting the business of the corporation, and contributed by the corporators to the capi-

1 See l'art III. Table 14, page 584.

2 In re Germania Sangerbmol, 12 l'enn. Co. Ct. Rep. 89.

8 Terwilliger v. Company, 59 Ill. 249; Reed $v$. Company, 50 Ind. 342 ; IlurJbut $v$. Marshall, 62 Wis. $590 ; 22$ N. W. 852.

4 Dana v. Bank, 5 W. \& S. (Pa.) 247.
" Fakwright ". Compauy, 13 Ind. 404; In re Association, 19 l'enn. Co. Ct. Rep. 25 ; Irenple r. Sielf redge, 52 Cal. 331.

"Bates v. Wilson, 14 Col. $140 ; 24$ Pac. 99.

7 IIamilton 'Trust Co. v. Clemens, 163 N. Y. $423 ; 57$ N. E. 614. 
tal, and is usually represented by shares issued to subseribers to the stoek on the initiation of the enterprise. ${ }^{1}$ Capital stock from another aspect is the security for creditors of the corporations, and entitles the owners thereof to participate in the management of corporate business and share in its profits and in its surplus after payment of corporate debts. ${ }^{2}$ Shares of stock, on the other hand, are simply the muniments and evidence of the holder's title to a given sliare in the property and franchises of the corporation in which he is a member. ${ }^{3}$ Frequently the words "capital" and "capital stock" are used interchangeably to express the property and assets of the corporation.

It is not altogether clear whether express authority to issue shares of capital stock is necessary, yet it has been repeatedly held that in order to increase or reduce the capital stock of a corporation, legislative authority is necessary. The prevailing riew seems to be in favor of the necessity of legislative authority. ${ }^{4}$

In the absence of statutory or charter requirements neither subscription for capital stock nor payment thereof is necessary to corporate existence. 5 If the charter of a corporation docs not fix the amount of its capital stock, it must be fixed by the stockholders, or, with their consent, by the directors. ${ }^{6}$ Stock can be issued only by direction of the corporation.;

In many of the Commonwealths the minimum amount of capital stock which a corporation may have is fixed by statute. Very few of the States limit the maximum amount of capitalization. ${ }^{8}$ To determine the amount of capital stock that a corporation has, preferred stock must always be included thercin. ${ }^{9}$ It is not always an easy question to determine who are and who

1 Christensen v. Eno, 106 N. Y. $97 ; 12$ N. E. 648 . 761 .

'Mechanics' Bank 2 . Company, 13 N. Y. 599.

${ }_{4}$ Cuoke v. Marshall, 191 Pa. St. 315; 43 Atl. 314; 196 Pa. St. $200 ; 46 \Lambda$ tl. 447 ; Detroit Chamber of Commerce $v$ GarIner, 109 Mich. 691; 67 N. W. 897.

5 McGinty $v$. Company, 155 Mass. 183 ; 29 N. F. 510; Jefferson Nat. Bank $v$.
Company, 74 Texas, 421 ; 2 S. W. 101 ; Stowe $v$. Flagg, 72 Ill. 397.

${ }^{6}$ So. K. Ry. Co. $v$. Cushing, 45 Me. 52.4; State $v$. Bank, 95 Tenn. 221 ; 31 S. W. 993.

7 II. D. P. $\Lambda$ ss'n $v$. Stevens, 34 Neb. $528 ; 52$ N. W. 568 ; Hendrix $v$. Academy of Music, $73 \mathrm{Cia} 437$; State $v$. Company, 41 Ind. 151; Williams $v$. Hewitt, 47 La. $\Lambda$ nn. $1076 ; 17$ So. 496.

8 See Part III. Table 5, page 575. See also II ughes $v$. Company, 34 Mil. 316.

${ }^{9}$ State $v$. Company, 16 S. C. 524. 
are not stockholders. The question must usually be determined by the particular facts of each case. ${ }^{1}$

Sometimes the incorporation act requires the articles to state the time when and the manner in which stock shall be paid for. It is sufficient in this connection to say, for example, that the stock shall be paid for in cash, and that no certificate of stock shall issue until such payment is made. ${ }^{2}$ The statement may be broadened if desired by setting forth in the artieles that the stock shall be paid for in property, at such times and of such a character and with such notice to the subseribers as the directors shall deem for the best interests of the corporation. ${ }^{3}$

Where the statute requires the amount of the capital stock to be stated, it has been held sufficient to simply state the number of shares and the par value of the same. ${ }^{4}$

$\$ 57$. Limitations upon Amount of Capital Stock. - As has already been observed, the great majority of the incorporation acts provide that the amount of capital stock which the corporation is to have shall be fixed in the articles of incorporation. This is the usual and often the only limitation on the amount of eapital stock which any particular corporation is authorized to have. However, in fourteen of the Commonwealths the minimum capital stock of all corporations is fixed by statute, while in three of them the maximum capitalization is also preseribed. 5

In this connection the words of the court in Barry $v$. Merchants Exehange Co. ${ }^{6}$ are peculiarly instruetive. In that case Clancellor Sanford observed: "That the capital stock of a corporation is the aggregate amount of the funds of the corporators which are combined together under a charter, for the attainment of some common object of public convenience or private utility. This amount is fixed in the act of incorporation. It is thus limiterl, in reference to the convenience of the intencled corporators, and for the information and seemity of the public at lare. 'To the eorporators it preserihes the amomt and the subdivisions of their respective contributions to the com-

1 See O'Brien v. Fulkerson, 75 Mich. $554 ; 42$ ‥ W. 973 .

2 N. (). Ry. Co. $v$. Framk, 39 La. Am. $707 ; 2 \mathrm{~S} 0.310$.

a Ser: Baltimore, etc. Tolephone Co. v. Company, 37 La. Am. 883.
4 Buffalo, etc. Ry. Co. v. IIatch, 20

N. Y. $15 \%$.

5 Sie l'art III. 'Table 5, page 575.

"1 Sim. Chan. (N. Y.) 280. 
mon fund; the roice which each shall have in the control and manigement; and the apportionment of the profits of the enterprise. To the community it announces the extent of the means contributed and forming the basis of the dealings of the corporate body, and enables every man to judge of its ability to meet its engagements and perform what it undertakes. And when the statute requires the stoek to be paid in before the corporation can transact business, security to those contracting with it is thereby superadded to the information of its resources. These objects for the public benefit are sueh as the legislature had in view in limiting the amount of eapital stock, and requiring a speeified sum or proportion to be paid in. One other consideration dictates the amount thus fixed. This is the probable and reasonable extent of the means requisite to the accomplishment of the end proposed, qualified in many cases by the unwillingness of the legislature to create these artificial beings with an undue amount of capital."

\$58. Par Value of Capital stock. - In thirty-six of the States the par value of the shares of the capital stock may be any amount. In the remainder the par value is limited by statute. ${ }^{1}$ Where the corporation act does not require that the number and par value of shares be set forth, the presumption is that the legislature intended that this should be fixed by the stockholders of the corporation at the organization meeting. ${ }^{2}$ The matter may be entrusted by the stockholders to the directors if desired. ${ }^{3}$

The question sometimes arises as to whether changing the par value of shares without increasing or decreasing the capital stock constitutes such a "variation" therein as to come within the statutory prohibition forbidding such variation without legislative authority. The prevailing rule seems to be that such rariation may be made only by conforming to the statute (if any exists) authorizing amendments to the charter in this regard. ${ }^{4}$

\$59. Amount of Stock Subscriptions. - Unless made so by statute, no subscription, in whole or in jart, of the eapital stock of a corporation is necessary, either to the validity of a corpora-

1 See I'art III. Table 6, page 576.

$2 \mathrm{~S}$ \& K. R. Co. $v$. Cushing, 45 Me.

524; State 2 . Bank, 95 Tenn. 221; 31 S. W. 993.
${ }^{3}$ Commonwealth $v$. Company, $52 \mathrm{~Pa}$. St. 506.

4 C. C. Ry. Co. v. Allerton, 18 Wall. 233 ; Seignouret $v$. Company, 24 Fed. 332. 
tion's existence or to its right to transact business. ${ }^{1}$ The rule, howerer, that exists in this country to-day is doubtless opposed to the common law rule on the subject. ${ }^{2}$ The States of Washington, Illinois, and Missouri require subscriptions to the full amount of the authorized capital stock. ${ }^{3}$

Fourteen of the Commonwealths require the amount of stock subscribed for by each incorporator to be set forth in the articles, while others require the amount of stock with which the corporation will commence business to be stated. A few prescribe that the amount of stock actually subseribed shall be set forth. ${ }^{4}$ Sometimes provisions are found requiring the residences of subscribers to the capital stock to appear in the articles. ${ }^{5}$

Any person capable of contracting may subscribe for stock or become a stockholder. This includes alicns, married women, and corporations. ${ }^{6}$ Subscriptions for stock must be made through commissioners where the law so prorides. ${ }^{7}$ But even where such subseriptions are made through parties other than commissioncrs contrary to the statute, such subscriptions may be afterwards ratified by the proper party. ${ }^{8}$

Occasionally attempts are made to limit by charter provisions the amount of stock which may be owned by any one stockholder. Such provisions are generally held roid, as not called for by the governing statute. ${ }^{9}$ An important question that arises in connection with the general subject of stock subscriptions, amount of stock paid in, and amount of capital with which the corporation may begin husiness, has reference to the effects which follow a failure on the part of the corporation to comply with such statutory requirements. In gencral, it may be said that the penalties which follow a failure to comply with such provisions are generally along the following lines:

First, they afford a basis for an action to be brought by the State

1 Livesey $c$, Compray, 5 Neb. 50; Jolunson $v$. Kícsser, 76 la. $411 ; 41 \mathrm{~N}$. IW. 57; S. F. N. Bank N. Mlmy, 117 MasH. 476; Minur 2 . Bituk, I P'eters (L.S.), 46 ; 7 [. E. 47 ; Schenectinly, etc. I'lank Riviul Co. v. T'hatcher, 11 I N. Y. 102

2 Schloss $v$. Company, 87 Alt. 411 ; ; So. 360 .

"Denny IJotel Co. $v$. Schram, 6 Wish. $134 ; 32$ l'ac. 100:2.

4 Sce Buffalo, etce. Ry. (co. r. llatch, 20 N. Y. 15i; l'eople $v$. Chamlers, 42
Cal. 201 ; I. O. A. Ry. Co. v. Mason, 16 N. Y. 451.

5 Sie Steinmetz 12 Company, 57 Ind. 457.

"I Dublin, etce Ry. Co. r. Black, L. R. \& Exch. 1si; Cork, "te. Ry, Co. r. Cazenove, L. K. I0 NA. \& lil. 935.

7 Slunrty v. Comprany, 9 Mich. 269.

* Wather v. Company, 34 Mise. (N. Y.) 24.5.

9o'Brien $v$. Cummings, 13 Mo. Ap. 197. 
looking to the forfeiture of the charter. Secondly, they sometimes result in rendering the incorporator's liable as co-partners, the courts lolding that by failing to comply with the statute they have forfeited their right to immunity from individual liability for what would otherwise be distinetively corporate debts. 'Thirdly, in some jurisdictions a penalty is prescribed by statute making directors and officers liable for all debts contraeted before the statutory requirements above referred to liave been complied with.

It goes without saying that corporations cannot legally issue stock in excess of their authorized capitalization. ${ }^{1}$ However, this does not mean that bona fide purchasers of such shares are withont remedy, for ordinarily in such cases both the corporation and its officers are liable. ${ }^{2}$

$\S 60$. Amount of stock paid in. - It has already been observed that neither the subscription to nor the payment of the whole amount of capital stock authorized by the charter is a condition precedent to the legal existence of the corporation muless it is made so by a governing statute. Ordinarily, it merely goes to the right to transact business, without subjecting the directors or the corporate officers and agents to personal liability. ${ }^{3}$ However, in some few of the States the corporation acts provide that before the corporation may commence business a certain percentage of the capital stock shall be paid in. ${ }^{4}$ Where the articles fail to so set forth the amount of stock paid in as required by statutes, this does not affect ipso fucto the legality of the corporation's existenee, but it is a matter which can only be taken advantage of by the State in quo warranto proceedings. $^{5}$

Statutory payments must be made in the manner and time provided by statute, and they must be paid in in good faith. ${ }^{6}$

1 Mechanics' Bank v. Company, 13 Mnsic, 73 Ga. 437 ; K. C. H. Co.v. Hunt, 57 N. Y. 599; Scovill $v$. Thayer, 105 U. S. Mo. 126; Tradesmen Publishing Co. v. 143.

Company, 95 Tenn. 634; 32 S. W. 1097;

2 N. Y. N. H. R. Co. $v$. Schuyler, 34 Ag. Bank $v$. Burr, 24 Me. 256; Y. R.

N. Y. 30 ; Huores $v$. Bank, 111 U.S. 156 ; $4 \mathrm{~S} . \mathrm{Ct} .345$.

${ }^{3}$ I). S., ete. Co. $v$. Attorney-General, 21 Can. Sup. Ct. $22 ;$ S. P. R. Co. $v$. Thateluer, 11 N. Y. 102.

4 Sec Part III. Table 6, page $\mathbf{5 7 6 .}$

L. N. Co. $v$. Company, 72 Fed. 62.

${ }^{6}$ MeLaren $v$. Pennington, I Paige (N. Y.), 102 ; P'eople $v$. Chambers, 42 CaI. 201 ; State $v$. Company, 3 Hump. ('Tenn.) 305 ; People $x$. City Bank, 7 Col. $226 ; 3$ l'ae. 214 ; J'eople $v$. Bank, 129 Ill. 618 ; 22

5. I. J. R. Co. $v$. Vaughan, 14 N. Y. N. E. 288 ; Hammond $v$. Strauss, 53 Md. 1. 5tfo. See also Ilendrix $v$. Academy of 
Failure to state, in the affidarit relative to the amount of stock paid in, that such payments had been made in good faith to the directors is not fatal, as the bona fules of the transaction will be implied. 1

$\S 61$. Amount of Stock with which a Corporation may begin Business. - Some few of the States require that the amount of eapital with which a corporation will begin business shall be set forth in the articles. In some cases, as in New Jersey and New York, the minimum amount is prescribed by statute. The failure, however, to actually pay in the prescribed amount of capital stated in the articles will not operate to destroy the corporate existence. ${ }^{2}$

\$62. Duration of Corporate Existence. - At one time there was a tendeney on the part of the States to limit the duration of corporate existence of corporations to a definite period in the supposed interest of the public. ${ }^{3}$ At the present time in twenty-six of the Commonwealths perpetual charters may be procured under the business corporation acts in foree therein. In the remaining States the periods rary from one hundred years to twenty. ${ }^{4}$ Eren in these States provision is made for extension of corporate existence by complying with the statute in such ease made and provided. 5

The phrase "perpetual sucession" has been held not to be equivalent to perpetual existence. ${ }^{6}$ The naming of a period of corporate existence in the cliarter in excess of that permitted by law will not render the charter void, but the corporate existence will not be continued beyond the statutory period.i

It is scarcely necessary to say that the continuance of active corporate existence during the entire period limited by the charter is not binding upon the eorporation. ${ }^{8} A$ diflicult question often arises when the corporation attempts to continue its active business as a corporation and to perform its corporate

1 Buffalo, etc. Ry. Co. v. Ilatch, 20 N. Y. 157 .

2 Staunton copper Mining (o. $r$. Thurmond, 7 . Io. $\Lambda_{\text {p. }}$. 587; Hammond $v$. Stratus, 5.3 JId 1; State $\varepsilon$. Wobh, 97 Mlat. $111 ; 12.50 .37 \%$.

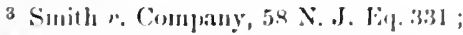

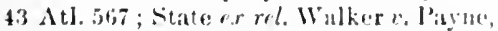
$129 \mathrm{No.} 468 ; 31$ \$. W. 79.

4 See l'art 111. Table 13, pagro .54:3.
6 See post, sec. 120.

"Fisirchild $r$. Association, il Mo. 526; State re rel. Walker 2 . I'syse, 1293 Mo. $468 ; 31$ s. W. 897.

7 l'ouple r. Cluesentur, 7 Col. $376 ; 3$

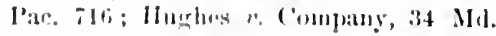
31t. Sue iblse liuffalo, ete. Ry. Co. $v$. H:ath, 201 X. Y. 15\%.

" ('runin r. Company et al., 29 Wk. L. liul. (Ohin) 52. 
functions after the expiration of its charter. Ordinarily this is a matter which concerns the State alone. ${ }^{1}$ Under such circumstances, in order to protect third parties, the courts recognize such corporations as corporations de facto on the ground that there is elearly authority for their attempting to act as corporations. ${ }^{2}$ Many courts of high authority have held that a corporation is dissolved and ceases to exist when its charter expires. ${ }^{3}$ In many States there are statutes permitting corporations to exist as such for certain purposes after the expiration of their charter. ${ }^{4}$ 'The purpose of such statutes is to grant to the corporation time to close up its corporate affairs. It has been held that the object of such statutes is not to limit but to enlarge corporate privileges so that the corporation may continue active business throughout the whole charter period. ${ }^{5}$

$\$$ 63. Date of Annual Meeting. - In Alaska, Arizona, Delaware, Iowa, Minnesota, Nebraska, and Utah the corporation acts require that the date of the annual meeting of the corporation be inserted in the articles. Such provisions are to be regarded as directory rather than mandatory, and their legal effect is essentially the same as if such provision was merely made in a valid by-law of the corporation. In Arkansas, Louisiana, and Tennessee the date of the organization meeting must appear in the certificate of incorporation. ${ }^{6}$ Eren when the statute requires that the directors shall be chosen at the annual meeting, this has no reference to the election of the first board at the organization meeting. ${ }^{7}$

$\$ 64$. Limitation upon Corporate Indebtedness. - In the absence of constitutional or statutory provision, there are no limitations imposed upon corporations with respect to the amount of indebtedness which they may incur. ${ }^{8}$ The whole extent of corporate credit is measured and controlled by its capital. The laws of trade have placed more efficient barriers than the State

1 Bushnell $v$. Company, 138 Ill. $67 ; 27$ N. E. 5996 .

2 Miller $x$. Company, 31 W. Va. 836 ; 8 S. J.. 6,00.

SBratley v. Reppell, 133 Mo. 545; 32 S. W. 645 ; Sturges v. Vanderbilt, 73 N. Y. 384 .

4 See l'art III. Table 17, page 587. $7 t$
5 Berwick $v$. Company, 39 Mich. 701.

6 IJughes $v$. Parker, 20 N. II. 58; Beardsley $v$. Jolinson, 121 N. Y. $224 ; 24$ N. E. 380 .

7 B. $\Lambda$. M. Co. v. Moring, 15 Gray (Mass.), 211.

8 Barry $v$. Company, 1 San. Chan. (N. Y.) 280,310 
legislatures to the power of corporate borrowing. In Alaska, Arizona, Florida, Iowa, Minnesota, and Nebraska, the incorporation acts require that the maximum amount of indebtedness which the corporation may incur shall be set forth in the articles of incorporation.

In twenty-two of the Commonwealths statutes, either expressly or by implication, preseribe the amount of indebteduess which corporations may incur. ${ }^{1}$

When the phrase "implied limitation upon corporate indebtedness" is used, reference is had to that not uncommon form of limitation where directors or stockholders are made liable for corporate debts in case the corporate indebtedness exceeds a certain definite amount. ${ }^{2}$

$\S 65$. Exemption of Stockholders from Personal Liability. While there is no common-law liability imposed upon stockholders for corporate debts, nerertheless parties may lawfully contract to any extent they see fit as to their own personal liability for such indebtedness. ${ }^{3}$

In order that stockholders may avoid personal liability for corporate debts it is necessary in Arizona, Delaware, Iowa, Kentueky, Louisiana, Mississippi, Nebraska, and Utah, to insert provisions in the certificates of incorporation expressly exempting stockholders from such liability.

$\S 66$. Adoption of By-Laws by Directors. - In a large number of the States and Territories the incorporation acts expressly provide for delegation of power to directors to make, alter, or repeal by-laws. ${ }^{4}$ In many of the States in order that the corporation may have this power it is necessary to insert provision therefor in the charter. ${ }^{5}$ Unless the power to make, alter, or repeal by-laws is thus delegated to the board of directors, it ean only be exercised by the stockholders. ${ }^{6}$

1 See Part III, Talle 12, page 582. See also Commonwealth $x$. Company, 129 Pa. St. 405; 18 Atl. 414; O. H. NIfg. Co. $v$. Canney, 54 N. II. 295; Thorutron r. Bascom, 85 Ia. 198; 52 N. W. 190 ; Ilner ". Carmichnel, 82 It. $288 ; 47$ N. W. 1034.

2 Sec Tallmarlge $r$. Company, 4 Barb.

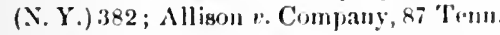
$60 ; 9 \mathrm{~S}$. W. 226 ; Sweney $v$. Talcott, 85 Ia. $103 ; 52$ N. W. 106; funther v. Company, $107 \mathrm{Ky} .44 ; 52 \mathrm{~S} . \mathrm{W} .931$.
${ }^{3}$ Iondon, ete. Bank $\%$ I'arrott, 125 Cal. 472; 58 1'ace 164; Lillarel v. Compamy, 14 Tex. Civ. $\Lambda_{\text {p. }} 67 ; 36 \mathrm{~S} . \mathrm{W} .792$; Ticlionte Sav. Bauk v. Libhey, 101 Wis. $193 ; 77$ N. W. 182.

+ Sce I'art III., Table 12, page 582.

s Caltill r. Compriny, 2 I)oug. (Mich.) 128; Ilcintzrlutar $r$. Association, $38 \mathrm{Ninn}$. $138 ; 36$ N. W. 100 ; lank of 1 lolly Springs r. l'inson, 58 Mlike. 421.

6 Norton (iravel Road $v$. Wysong, 51 
$S$ (iT. Provisions for the Regulation of the Internal Affairs of the Corporation. - In a number of the States statutory anthority is to he found for inserting in the articles of incorporation any provisions that may be desired relative to the regulation of the business, and for the conduct of the affairs of the corporation, creatine, defining, and limiting the powers of the corporation, the ollicers, and the stockholders. ${ }^{1}$ Under such anthority the elanses which are usually inserted are the following: giving the directurs power to sell all the business of the corporation as an entirety; the power to sell entire corporate property at the request of a majority of the stockholders; giving the right to directors to make and alter by-laws; giving the power to directors to borrow money upon bond and mortgage withont anthority therefor being first given by the stockholders; power to appoint additional rice-presidents and assistant secretaries and treasures's; to declare dividends; to reserve and fix working capital; to appoint an executive committee from the board of directors; giving stockholders power to remove directors; giving power to create a lien upon stock for indebtedness due company from stockholders; provision for the examination of books by the stockholders, and in connection therewith power to insert private publicity clanse; to provide for cumulative voting and limiting the power to vote; reservation of power to change provisions in the articles of incorporation; power to create preferred stock.

$\$$ 68. Miscellaneous Provisions Relative to Contents of Articles of Incorporation. - It would be impossible to enumerate all the peculiar provisions under the several business corporation acts which exist in the various States. Among those not already referred to are the following: Statement of the amount of strek sulsscribed for by the incorporators; a list of all partics who hare subscribed for stock as preliminary to incorporation. ${ }^{2}$

In setting forth the subscribers to the capital stock it is sufficient to use above the first name the words "names,"

Ind. 4; N. M. T. S. Co. v. Bishop, 103 Wis. 492; 79 N. W. 785 ; In re A. A. Grithing Iron Co., 63 N. J. Law, 168,357; $41 \mathrm{Atl} 9.31 ; 46 \mathrm{Atl} .1097$.

1 Sce I'art 11I. Table 10, page 580.
2 Chester Glass Co. $v$. Dewey, 16 Mass. 94 ; C. V. \& P. Co. v. Secretary of State, 128 Mich. $62 ; 87$ N. W. 901 ; J. N. Bank v. Company, $74 \mathrm{Tex} .421 ; 12 \mathrm{~S}$. W. 110. 
"residences," "shares," and then immediately follow the same with the names of the subseribers to the capital stock. Among other provisions are those requiring the naming of an agent upon whom service of process upon the corporation may be served; ${ }^{2}$ another, a statement of the manner of conducting the business of the corporation. ${ }^{3}$ A number of the States require the names and residenees of the incorporators to be set forth in the articles. ${ }^{4}$ Sometimes it is necessary to secure the approval of the Attorney-General to the form and contents of the articles. ${ }^{5}$

$\$ 69$. Construction of Charter. - Under the liberal prorisions of the modern incorporation acts, the articles drawn thereunder necessarily assume, by the sole action of the incorporators, numerous powers, many of which have been heretofore of a public character, affecting the interests of the public very largely and very seriously. The Supreme Court of the United States has taken the view that, for the reasons just given, these articles do not commend themselves to the judicial mind as a class of instruments requiring or justifying any very liberal eonstruction. That court has said in this comnection, that where the question is whether they conform to the authority given by statute in regard to corporate organization, it is always to be determined upon a just construetion of the power granted to them with a due regard for all other laws of the State upon that subject. ${ }^{6}$

In eonstruing charters the following rules seem to govern the courts: First, the intention of the legislature must be given due weight. ' Second, due consideration must be given to the policy of the State with reference to such matters as evidenced by the character of legislation. Third, all ambiguities in the terms of the articles of ineorporation must be construed agrainst the corporation in favor of the public. ${ }^{8}$ Fourth, words should be giren their ordinary meaning. ${ }^{9}$ Fifth, the construction given 88.

1 Vawter v. Franklin College, 53 Ind.

${ }^{2}$ Johngon v. Masous' Jodge, 21 Ky.

L. R. $493 ; 51 \mathrm{~S} . \mathrm{V}, 620$.

${ }^{3}$ State v. Association, 29 O. St. 399.

4 Steinmetz $v$. Compans, 57 Ind. 457 ; State $v$. Foulkes, 94 Ind. 493.

5 See Field $v$. Cooks, 16 La. Ann. 598. 153.

- Or. Ry. Co. v. Or. Ry. Co., 130 U. S. 1; 9 S. Ct. 409.

7 Union Nat. Bank v. Matthews, 98 U. S. 6,21.

8 A. L. \& T. Co. v. Company, $157 \mathrm{Ill}$. $641 ; 42$ N. F. 153.

"Riker $v$. Leo, 133 N. Y. $519 ; 30$ N. E. 
\$ 69 inconforation and oRganization of corporations. [PART í. the charter must always be reasonable. ${ }^{1}$ Sixth, where the language of the certificate as to corporate purposes and powers permits of two constructions, that the more favorable to the State is to be adopted. ${ }^{2}$

1 I3lack v. Company, 22 N. J. Eq. 130 ; Wheeler, ete. Co. $v$. Company, 14 Wash. 221. $630 ; 45$ Pac. 316 ; Nat. Bank v. Com. pany, 41 O. St. 1. 


\section{CHAPTER II.}

\section{PROCURING THE CHARTER.}

$\S 70$. Signing the Articles. - With but few exceptions the business corporation acts of the rarious Commonwealths provide that the artieles shall be signed by the incorporators. ${ }^{1}$ It is not requisite to the validity of such articles that they be signed within the State from which the eharter is procured. ${ }^{2}$ The articles may be drawn on separate sheets, the last one of which only need be signed by the incorporators. ${ }^{3}$ If the incorporator is unable to write he may sign the articles by his mark. ${ }^{4}$ The full name need not be signed. ${ }^{\tilde{D}}$

If seals are required by statute they must be used. ${ }^{6}$ The use of a power of attorney to sign articles would probably not be sanctioned where the statute calls for additional matters which are necessarily personal in their nature. ${ }^{i}$

$\S$ 71. Acknowledgment of Execution of Articles. - With some few exceptions, the incorporation acts of all the States require that the articles of incorporation shall be acknowledged by the incorporators, before some officer authorized by law to take acknowledgments of deeds. There must in all cases be a proper number of acknowledgments. ${ }^{8}$ Where the statutes designate some particular officer to take the acknowledgment, the charter is voidable if taken before any other official. ${ }^{9} A$ failure, on the part of the officer taking the acknowledgment, to certify that the

1 State $v$. Critchett, 37 Minn. $13 ; 32$ No. 5816 ; Wamer $v$. Callender, 20 O. St. N. W. 787 ; leople v. Comprany, 97 Cal. 190.

276; 32 l'ae. 236; Hughes v. Company, 34 Ar. 316 ; W. B. \& L. Ass'n $v$. Coleman, 89 P'a. St. 428.

2 IIumphreys $v$. Mooney, 5 Col. 2 \&2.

${ }^{a}$ Sec I. O. A.\& N. Ky, Co. v. Mason, 16 . . Y. 451 .

4 Trustee, ctc. $v$. Campbell, 46 La. Ann. $1543 ; 21$ So. 184.

6 State $v$. Beck, 81 Ind. 500.

- Griffen v. Company, Fed. Cancs, in re Charter Acknowledgment, 28 Ya. Co. Ct. Rep. 187.

8 l'enple 2 . Company, 97 Cal. $276 ; 32$ Pac. 236; Inughes v. Company, 34 Md. 316: Wovle $v$. Mizner, 42 Mielı. 332; 3 N. W. 9tis; Kaiser $v$. Bank, 56 Ia. 104;8 N. W. $77_{2}$; State $v$. Critehett, 37 Miun. $13 ; 32 \mathrm{~N}$. W. 787 .

- Shiclils v. Company, 94 Tenn. 123, 28 S. IV. 668 ; State r. Lee, 21 O. St. 662 ; Simmings $v$. Association, 26 O. St. 483. 
incorporators were personally known to him will not invalidate the incorporation proceedings. ${ }^{1}$

Even where the statutes require the organization meetings to be held within the domiciliary state, it is not necessary that the articles be signed and acknowledged therein. ${ }^{2}$

The omission of immaterial parts of the acknowledgment does not operate to render the ineorporators liable as partners. ${ }^{3}$ In order to entitle articles to be filed with the proper State official, they must be signed and acknowledged in all respects as required by law. ${ }^{4}$

$\S 72$. Publication of Articles. - In ten of the Commonwealths the law requires that either the petition for a charter or the charter itself or the substance thereof shall be published for a prescribed length of time. ${ }^{5}$ The original theory upon which such requirements are based appears to have been that the ereation of a corporation should be attended with all possible publicity, in order that all the world might aequaint itself with the fact that it is dealing with a corporation and not with a natural person. ${ }^{6}$ At the present time the legislatures seem to proceed on the basis of furnishing the newspapers with additional paid matter on the theory that they need it in their business. However that may be, it still remains true that the statutes governing publication of articles must be substantially complied with, otherwise the charter may be declared void at the instance of the State. ${ }^{7}$

Sometimes due publication of articles carries with it immunity from personal liability. ${ }^{8}$

It has been held that the publication of more than the law requires will not invalidate the legality of the publication. ${ }^{9}$

1 People $v$. Cheeseman, $\boldsymbol{7}$ Col. 376; Bigelow $v$. Gregory, 73 Ill. 197; Field $v$. 3 Pac. 716 . See also Boston Acid Mfg. Cooks, 16 La. Ann. 153; Hunt v. SalisCo. $v$. Moring, 15 Gray (Mass.), 211.

2 Humphreys $v$. Hooney, 5 Col. 282.

${ }^{3}$ Stout v. Zulick, 48 X. J. L. 599 ; i Atl. 362 .

4 Doyle v. Mizner, 42 Mich. $332 ; 3$ N. W. 968 ; Montgomery $v$. Forbes, 148 Nass. $249 ; 19$ N. E. 342 .

5 See Part III. Table 7, page 577.

- See In re Church, etc., 14 Phil. 121 ; Seaton $v$ Grimm, 110 Ia. $145 ; 81$ N. W. 225.

- Clerg v. Company, 61 Ia. $121 ; 15$ N. W. 865 ; Thornton $v$. Balcom, 85 Ia. 198 ; bury, 55 Mo. 310 ; Indianapolis Min. Co. $v$. Herkimer, 46 Ind. 142; IIolmes $v$. Gilliland, 41 Barb. 568; Davenport Nat. Bank v. Davis, 43 Ja. 424 ; 15 N. W. 865.

8 Davenport Nat. Bank $v$. Davis, 43 Ia. $424 ; 15$ N. W. 865 . See, however, Clark v. Richardson, 17 Ky. Law Rep. 514; 31 S. W. 878 ; Wing $v$. Slater, 19 R. I. 597; 35 Atl. 302 ; Heinig $v$. Company, $81 \mathrm{Ky}$. 300; 5 Ky. Law Rep. 281.

9 In re Sowego Water Co., 38 W. N. C. (Pa.) 148. 
\$73. Affidavit as to stock subscriptions. - The laws of Florida, Georgia, Illinois, Kansas, Michigan, Missouri, Ohio, Oregon, Pemnsylrania, South Carolina, Texas, Utah, Vermont, and West Virginia require in addition to the ordinars acknowledgment of the execution of the articles, that the same be accompanied by an affidarit showing that the amount of stock required by law as a preliminary to doing business as a corporation has been duly subscribed.1 The same matter appears in the certificate of organization required in Arkansas, Connecticut, Indian Territory, Maine, and Virginia.

On the other hand, the incorporation acts of Alabama, California, Delaware, Idaho, Kentucky, Nevada, New Jersey, New York, North Carolina, Ohio, Virginia, and Washington merely require that the amount of stock subscriptions be set forth in the articles.

As to the content of the affidavits as to stock subscriptions, it is sufficient if they serre to show clearly that the statute relative to the same has been substantially complied with. ${ }^{2}$

Unless the statute designates some officer before whom such affidavit be sworn to, it may be made before any officer authorized to administer oaths and to certify to the same. ${ }^{3}$

$\S$ 74. Anti-Trust Affidavit. - Some few of the States - such, for example, as South Dakota, Missouri, and Illinois - require either of the incorporators before organization or of certain designated officers of the corporation after organization that they certify and make oath to the effect that the corporation is organized for the transaction of a lawful business and not for the purpose of enabling the corporation to violate the provision of the anti-trust act in force in that particular Commonwealth. Just what practical purpose the refuirements here referred to serve, it would be difficult to say. In its practical operation it is usually a mere formality, and has, so far as observation goes, seldom serred any useful purpose. 4

\$ 75. Special Requirements in Particular States. - Owing to the varied refuirements existing in the several States and 'I'erritories relative to the steps necessary to procure charters umler

1 People $v$. Company, 45 Cal. 306.

2 People r. Compinay, 45 Cal. 3ur; \& P. Ry. Co. v. Hateh, 20 N. Y. 157.

3 Wood $v$. Bank, 9 Cowen, 194.

- See Ohio St. Ly. Co. v. State, 49

$$
6
$$

o. St. 66,8; 32 N. F. 933 ; I'eople r. Cum3rany, 121 N. Y. $582 ; 24$ N. 1:. 834: State r. Standard Oil Co., 49 O. St. 137; 30 ‥ F. 279 . 
the laws thereof, it will be impossible to do more than merely refer to a few of these requirements not already discussed. Under the statutes of some of the States it is necessary before a charter can issue that the capital stock either be subseribed for in whole or in part. ${ }^{1}$ In others it is necessary that all or part of the authorized capital stock be actually paid in. ${ }^{2}$ However, in many of the States it is not necessary that the capital stock be subseribed for as a condition precedent to corporate existence. ${ }^{3}$ Some of the States require that the ecrtificate shall show the amount of the capital stock, the amount actually paid in, and that it shall give the names and residences of the shareholders, and the amount of stock which each has subscribed. Where such prorisions exist substantial compliance therewith is essential to the creation of a de jure corporation. ${ }^{4}$

Sometimes incorporation acts require that the certificate shall state the maximum amount of indebtedness which the corpora. tion is authorized to incur. ${ }^{5}$ In Indiana the articles must contain an impression or description of the seal. ${ }^{6}$ In Georgia charters are issued by the courts upon petition therefor. Here as well as in other cases the statute governing the matter must be substantially complied with.?

In some States the law requires that the certificate shall set forth the name and location of the principal place of business of the corporation. Such provision must be substantially complied with. ${ }^{3}$

In Penusylvania, where the incorporation act required the application for a charter to show the place of busincss of the proposed corporation, and the application merely stated location of its office, it was held insufficient. This for the reason that a corporation may have its office in one place and its place of business in another. ${ }^{9}$

$\S 76$. Powers of State Officials Relative to Accepting or Rejecting Articles. - Where the statute either expressly or by implica-

1 J. C. G. Company v. Dwight, 29 N. J. Eq. 246; Boyd v. Company, 90 l'a. St. 169.

2 People v. Chambers, 42 Cal. 201.

3 See ante, sec. 2.

4 Hendrix v. Academy, 73 Ga. 437 ; Bolling v. Le Grand, 87 Ala.482; 6 Sou.332. 5 Sweney $v$. Talcott, 85 Ia. 103; 52 N. W. 106.
- See Vawter $v$. Franklin College, 53 Ind. 88.

7 Van Pelt $v$. Association, 79 Ga. 439 ; 4 S. E. 501 ; In re Deveanx, 54 Ga. 637.

8 Montgomery $v$. Forbes, 148 Mass. 243 ; 19 N. E. 342 ; Ex parte Spring Valley Works, 17 Cal. 132.

${ }^{9}$ In re Enterprise Mataal Benefit Ass'n, 10 Pa. 380. 
tion bestows upon Statc officials the duty of examining articles of incorporation and passing upon their legal sufficiency and authorizes State officials to certify that the incorporators have become a corporation, then the issue of such certifieate becomes an adjudication that the corporation has been duly formed until the State has racated the charter by proper proceedings taken in the courts. ${ }^{1}$ Usually this duty is bestowed upon the State department which is a branch of the executive, and cannot therefore pass upon questions which are purely judicial. ${ }^{2}$ It is confined to an examination as to whether the purposes of the proposed corporation are legal on their face and whether conditions precedent have been complied with so that a charter should properly issuc. ${ }^{3}$

The main points to which State officials should address themselves in passing upon corporation papers presented to them are as follows: (1) Have the requisite number of incorporators signed the articles of incorporation? (2) Have the articles been properly acknowledged by the incorporators? (3) Is the corporate name mentioned in the articles one that can be lawfully used by the proposed corporation? (4) Have the statutory requirements relative to the contents of the articles of incorporation been substantially complied with ? ${ }^{4}$

Generally speaking, permission to filc charters may be refused upon the following grounds: If the name of the proposed corporation is identical or closely resembles that of an existing corporation, the State officials may exercise their discretion and refuse to pass the charter. ${ }^{5}$

It has been held, however, by a court of excellent authority that a statute prohibiting the corporation from assuming a name in use by any other organization or so elosely analogous to it as to mislead the public is designed to protect domestic corporations. ${ }^{6}$

1 Boyee v. M. E. Church, 46, MA. 359; I). II. R, I., Co. v, Marsh, Jial. Cas. 4014.

2 Cirauby (oo, 1) Richaris, 95) MI1. $106 ; 8$ S. W. 246; Vau Pelt v. Garduer, 51 Neb. $701 ; 75$ N. W. 874.

8 J'. R. 'T. lal. Co. Claterter Appli. cation, 20 Pat. Connty Ct. liepr. 151; X. M. I;. 'Г. Co.r. N. ('r. T'. Co., 21 I'b. County C. licp. 393; Peoplev. Company, 130 [l] $268 ; 22$ N. F. 798.

4 State $\because$ National Inv. Co., 88 Wis.

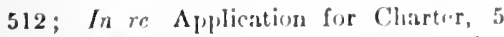
1'a. Dis. Iep. 243; In re Application for
Charter St. I. Ass'n, 19 I'a. County Ct. Rop. 25; In ro buQnesne Collegre Chartrr, 12 1'a. County Ct. Kep. 49]; Woulberry v. MeClurg, 78 Miss. 831; 29 Sin. 511.

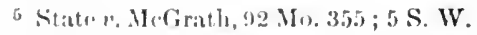

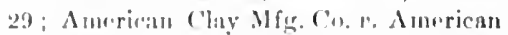

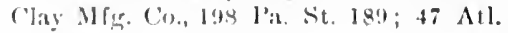

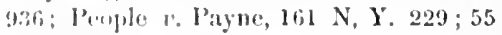
N. I\%. 4.8\%.

e Inoplo v. II. L. A. Co., 111 Mich. $405 ; 69$ N. W. 6.53. 
Gencrally speaking, the action of the Secretary of State in issuing a license or certificate of incorporation is ministerial. ${ }^{1}$ Neither State olficials nor the courts can with respect to incorporation add new conditions to those prescribed by statute. ${ }^{2}$ Generally, the test of the extent of powers of ministerial offices is the right to compel performance by mandamus. ${ }^{3}$

It is an almost universal rule that after the certificate is once issued, the officer who issues it has no power to revoke the certifieate. For this purpose application must ordinarily be made to the courts. ${ }^{4}$

\$7. Right to Mandamus State Officials for refusing to file Articles. - Ordinarily mandamus is the proper remedy where Statc officials refusc to file a certificate of incorporation, prorided the duty of receiving and filing the same is lodged with them. ${ }^{5}$

$\$ 78$. Organization Tax. - By the term "organization tax," as here used, is to be understood the amount of money exacted by the State from individuals in return for a grant from the former to the latter of the right or privilege of being a corporation; that is, of doing business in a corporate capacity and under the privilege or franchise which when incorporated the company may exercise. The right or privilege to be a corporation or to do business as such body is one generally decmed of value to the corporation, which is the right or privilege by which several individuals may unite themselves under a common name and act as a single person with a succession of members without dissolution or suspension of business and with a limited individual liability. The grant of such a right or privilege rests entirely in the discretion of the State, and may unquestionably be accompanied with such conditions as the legislature thereof may judge most befitting to its interests and policy.

Thus the latter may require of the incorporators, as a condition to the original grant of the franchisc as well as of its continued exercise, that the corporation pay a specific sum to the Statc. ${ }^{6}$

1 P'(c) le v. C. G. T. Co., 130 Ill. 269; 22 ‥ E. 798.

2 Ilastings v. A. P. Co., 29 Wash. 224; 69 Pac. 7 i6.

a F. R. Co. $v$. Wood, 14 Ga. 80.

4 See, huwever, I. W. C. Co. v. Pear- 5 S. W. 29 ; Illinois Watch Case Co. v. son, I 14) [1]. 423 ; 3I N. E. 400 ; In re N. I. Pearson, 140 IiI. 423 ; 31 N. E. 400.

E. Cu., 142 Pa. St. $450 ; 21$ Atl. 870. $\lesssim 1$
5 J'eople ex rel. N. Y. P. Co. v. Rice, 128 N. Y. 59, 28 N. E. 251 ; H. W. I. Co. $v$. N. Y. II. I. Co., 140 N. Y. $94 ; 35$ N. F. 417 ; State $v$. Taylor, 55 O. St. 61, 4t N. E. 513 ; State $v$. McGrath, 92 Mo. 355; - IIome Insurance Co. $v$. People of the 
There are two hroad grounds for sustaining the power of the State to impose organization taxes. The first of these is their inherent power to regulate corporations. Corporate capacity itself is a franchise. No persons can make themselres a body corporate and politic without legislatire authority. ${ }^{1}$ The other ground referred to is the inherent power of the State to enact such legislation as may be necessary in order to raise revenue for State purposes. ${ }^{2}$

The term "organization tax" should be carefully distingnished from the phrase "franchise tax;" the latter referring to the tax imposed by the State upon corporations for the privilege of doing business in a corporate capacity after incorporation. All of the States and Territories with the exception of Arizona, Arkansas, District of Columbia, Georgia, Indian Territory, Louisiana, and Oklahoma, impose graduated organization taxes upon corporations organized under their laws. There can be no question as to the validity of such graduated taxation. ${ }^{3}$ The same is true eren when in such matter's the legislature distinguishes, as is the case in West Virginia and New Hampshire, between resident and nonresident domestic corporations. ${ }^{4}$

At the present time it is a rule of almost unirersal application that the payment of an organization tax is a condition precedent to corporate existence. 5 Organization taxes cannot be eraded on the gromnd that the corporation calls itself an "eleemosynary" corporation when in fact it is otherwise. ${ }^{6}$

The State is not bound to permit corporations to consolidate or to extend their corporate existence, and for this reason it may lawfully impose the payment of an organization tax as a condition precedent to consolidation or to the extension of its corporate existence. ${ }^{i}$

State of Now York, 134 U. S. $594 ; 10$ S. Ct. $593 ;$; 33 I. I\%. 1025 ; Fiordon $v$ Appeal Tax Court, 44 W.S. (3 Ilow.) 133; 11 Law lid. j29; B. \& (). Ky. Co. v. Maryland, 88 U. S. (2) Wall) $4.26 ; 22$ I. E. 678; l'erple $v$ Rose, 210 Ill. 582; 71 N. I\%. 580.

1 Califormia $v$. Company, 127 U. S. 1 ; 8 S. Ct. $1073 ; 32$ L. 1\&. $15 \%$.

2 Baker $r$ Cincinnati, 11 O. St. 534; W. U. 'P. Co. A. Atorney-fiencral, 125 U. S. $530 ; 8$ S. Ct. 961 ; 3i I. E. 790.

3 See Ashley v. liyan, 49 O). St. 504; 31 N. E. $721 ; 153$ U. S. $436 ; 14$ S. Ct. 865 ; 38 L. H. 773.
4 B. J. C. C. Co. v. Scherr, 50 W. Va. $533 ; 40$ S. E. 514.

5 Union IIorseshoe Works v. Icwis, 1 Abh. (1). S.) 5ls; Fed. Cases, No. 14383; Combined saw \& Planer Co. $v$. Flonrow, 8k Va 1029; It S. L. 976; biwarls r. Denver \& li. G. R. Co., $13 \mathrm{Col}$. $59 ; 21$ l'ac. 1611; State $r$. Lotwitt, 17 Nont. 11; 1] l'ar. 1001; Ashley 1. Rỵan, 4 9 1. St. $504 ; 31$ N. 1). 721 ; II. M. Co. v. lirmer, le li, 1. 4)].

"Sitate D. I.esueur, 99 Mo. 552; 13 S. W. 237 .

7 Ashley r. Ryan, 49 O. St. 504; 31 N. E. $721 ; 153$ U. S. 436 ; 14 S. Ct. 
ร 79. Form in which Charter is granted. - In only twenty-nine of the States do the corporation acts expressly provide for the issuance of a certificate of incorporation or charter by State oficials. In some few of the remainder the power to issue such instruments is assumed by the officers having the matter in charge withont any express authorization therefor in the statute. In the remaining States proof of incorporation is usually had by procuring certified copies of the articles of incorporation. The matter becomes one of practical importance in connection with the right of third parties to collaterally attack not only the corporate existence but the corporate purposes and powers as well. This matter has already been discussed at length in a previous section. ${ }^{1}$

Ordinarily the commencement of corporate existence dates from the time when the certificate of incorporation is issued. Where the statute expressly provides for the issuance of a charter by State officials the latter have no discretion in the matter, and must issue the same upon demand of the parties who have legally entitled themselves to the same. ${ }^{2}$ The certificate must be issued immediately, and must be in the form, if any, prescribed hy the statute. $^{3}$ The Secretary of State should always affix his seal to the certificate of incorporation. ${ }^{4}$

$\S 80$. Filing and Recording in Local County Offices. - Generally speaking, it is part of the plan adopted by the various legislatures in the enactment of general incorporation acts, to provide in addition to requiring that articles of incorporation be filed with some designated State official, that they always be filed in one or more local county offices. ${ }^{5}$ Usually the latter requirement is confined to the provision that they be filed in the county where the corporation's domiciliary office is located. However, in some few of the States such articles must be filed in every county wherein the corporation transacts its business or holds real property. In some of the States, such as California and Maryland, more importance appears to be attached to the filing of the articles in the local county office than with State officials. ${ }^{6}$

865 ; 38 L. E. 773 ; People v. Pfister, 57 Cal. 532.

1 See ante, \$6.

2 State v. Taylor, 55 O. St. $61 ; 44$ N. E. 513; Sparks v. Company, 87 Ala. 294; 6 So. 195 .

${ }^{2}$ Stowe v. Flagg, 72 IIl. 397 ; R. F. 86
Ass'n v. Clarke, 61 Me. 351 ; Sparks $v$ Company, 87 Ala. 294; 6 So. 195; People v. Pavn, 161 N. Y. $229 ; 55$ N. F. 849.

4 Benner v. State, 7 Lea (Tenn.), 682.

6 See Part III. 'Table 4, page 574.

${ }^{6}$ See N. H. C. \& M. Co. v. Woodberry, 14 Cal. 434. 
The purpose of filing articles in county offices has been said to be in order that persons dealing with the corporation may hare an easy and public inspection of the basis of its corporate organization. $^{1}$ With some few exceptions corporate existence is not made to depend upon the filing of the articles in the local county offices. In any erent, where such filing is not had, the corporation is treated as a corporation de facto, if not de jure. ${ }^{2}$ The foregoing is certainly true in the absence of any proceedings by the State in the nature of quo warranto. ${ }^{3}$

In some States the filing of articles in designated offices is specifically made a condition precedent to the legal existence of the corporation, while in others it is merely made a condition precedent to the right of the corporation to engage in business as such. ${ }^{4}$ It has been held, however, in Missouri that in order to the creation of corporate existence articles must be filed in both State and county offices. ${ }^{5}$

At the present time it is safe to say that as to third partics the validity of corporate existence will be presumed cren when articles have not been filed in local county offices as required. But in some jurisdictions attempts have been made to hold the incorporators liable as partners under such conditions. ${ }^{6}$

$\S 81$. Distinction between de jure and de facto Corporations. - A corporation de jure is one whose right to excreise corporate functions would prove invulnerable if assailed by the State in quo warranto proceedings. ${ }^{7}$ A de facto corporation, on the other hand, is one the legality of whose existence may be inquired into by the State in quo warranto procedings. The general rule is that to prove the existence of a corporation de facto it is necessary to

1 Loverin $v$. McLaughluin, 161 Ill. 417 ; 44 N. E. 39.

2 Curtis v. 'Tracey, 62 Ill. $\Lambda_{\text {p. }} 49 ; 13$. \& T. Co. v. Gade, 55 III. 181; Jolus $v$. People, 25 Mich. 499 ; Whitney $e$. Wyman, 101 U.S. 392.

${ }^{3}$ Bank $v$, l)avies, 43 Iowa, 424 ; Martiu v. Deetz, 102 Cal. 55 ; 3f ['ace. 3fis; I. 'T', etc. Co. r. Ilerkimer, 46 Ind. 14:; Humphreys ". Mooney, 5 Col. 282 ; Lims $"$ Cominonwealth, 24 Ky. L. Rep. 159; 1 S. W. 929 ; Childs $n$ IIurl, 32 W. Va. $66 ; 9$ S. E. 362 ; Abbott $v$. Co., 4 Neh. 416.

4 Bergeron $v$. Hobbs, 96 Wis. 641; 1
N. W. $1056 ;$ In re Shakopee Mfg. Co., 37 Jim. $91 ; 33$ N. IV. 219 ; G. M. S S. Co. 2. Richarils, 95 Mo. 106 ; 8 S. W. 246.

5 Ilurt $v$. Salishury, 5.5 . I\%. 310.

"Siee P. \& G. T. Co, r. Rol, , $89 \mathrm{kr}$. 226 ; $10 \mathrm{~S}$. W. 794; Rassheck $n$. Destrir.

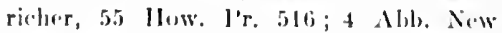
Calses, 444; F. (B. 13. \& T. (O) v. Gialle, 5.$)$ I11. 181: N. Y. N. Exchange bank $r$. Crowell, 173 J'iz.313; 3.5 Atl. 613; Cleger r. Company, 61 Ia. 121; $15 \mathrm{~N}$. W. 865; Girnt r. Company, 107 IIl. 652; Childs $v$. Iluril, 32 W. Va 66; 9 S. E. 362.

-Clapp v. Comprany, 40 Neb. $470 ; 28$ N. IV. 956 . 
show (1) an act authorizing the creation of a corporation of that ehanacter; (2) an application duly made thereunder by the reguisite number of incorporators praying for incorporation. (3) It is sometimes necessary, although not always, to show user thereunder. ${ }^{1}$

S. S. Right of Parties other than the State to collaterally impeach Corporate Existence. - The right here referred to has already been considered somewhat at length in comnection with a discussion of the right of third parties to eollaterally attack corporate purposes and powers. ${ }^{2}$ There are some additional matters, howerer, not already discussed to which attention will now be calleił.

As has already been suggested, the courts have taken varied and conflicting views relative to the right of parties other than the State to collaterally attack the existence of a corporation with whom they chance to be involved in litigation. The diverging views here referred to may be classified as follows: (1) the view that the State alone can test the question whether or not a corporation which has procured a charter from the proper State officials is in law as well as in fact a corporation $;^{3}(2)$ the view that this question may be inquired into by third parties, but that it is sufficient in such cases for the corporation to show substantial compliance with the conditions prescribed by the general incorporation act in order to prove that it is a corporation de jure as well as de facto $:^{*}$ (3) the view that the matter may be inquired into by third parties, and that under such circumstances it is necessary that the corporation shall show striet compliance with each and every condition precedent prescribed by the general incorporation act in order to establish the fact that it is a corporation de jure as well as de farto. ${ }^{5}$

For purpose of convenience these three diverging views may be

1 Stout $r$. Zulick, 48 N. J. Law, $599 ; 7$ AtI. 36으 ; Ilats $"$. Bank, 41 Neb. 754; 60 N. W. 85 ; Dugrean $v$. Company, 11 Col. 113 ; 1; l'ac 105; Central $\Lambda$ g., etc. $\Lambda$ ss'n $v$. Company, 70 Ala. 120; Baker v. Backus, 32 IIl. 79 ; Inghes v. Bank, 5 Litt. (Kiy.) 4.); Buffale, etc. Ry. Co. v. Cary, 26 X. Y. T; Finnegan $v$. Noerenberg, 52 Ninn. 239; 53 N. W. 1150; Continental Trust ( $a$ r. T., etc. Ry. Co., 82 Fedl. 642; City of Guthrie $v$. Territory, l Okla. 188; 31 l'ac. 190 ; A. L., ete. Co. v. M., etc. R.
Co., 157 11l. 641 ; 42 N. E. 153 ; In re Gibbs Estate, 157 Pa. St. $59 ; 27$ Atl. 383.

2 See ante, $\$ 6$.

3 see ante, $\$ 6$.

4 Jones $v$. Company, 21 CoI. $263 ; 40$ Pac. 457 ; Stout $v$. Zuliek, 48 N. J. L. 599 ; 7 Atl. 362 ; Finnegan $v$. Noerenberg, 52 Minn. $239 ; 53$ N. W. 1150.

5 Mokelunne, etc. Co. $v$. Woodbury, 14 Cal. 424; Lueas $v$. Bank, 2 Stew. (Ala.) 147. 
distinguished as follows: referring to the first as to the true, the second as the substantial compliance, and the third as the strict compliance rule. Space will permit of discussion here of only the first of the rules just referred to.

The legislatures alone, as has been shown, can create a corporation. Under the modern practice these bodies have passed general incorporation acts entrusting the execution of the law to the exccutive department of the gorernment. Under the rule now generally established, either by statute or judicial construction, in most of the States a corporation becomes a corporation de facto from the moment the charter or certificate of incorporation is issued by the proper State authorities. ${ }^{1}$ The basis of holding such certificates as conclusive of corporate existence as against all the world except the State is that where by reason of such certificate a corporation is held out to the world as ready to undertake business, most disastrous consequences would follow to commercial undertakings if any private person was allowed to go back and enter into an examination of the circumstanees attending the original incorporation. ${ }^{2}$

The power which creates the corporation it is needless to say should alone hare the power to take it away. It should not be permitted to parties other than the State for this reason to eollaterally impeach corporate existence, for to permit such impeachment would be in legal effect to permit third parties, for the purpose at least of that particular action, to destroy the effeet of the previous action of the State in the premises. On grounds of public policy as to all parties but the State, it should under such circumstances be conclusively presumed that the statutory requirements relative to incorporation have been duly complied with. $^{3} \quad A$ corporation must of necessity be presumed to be rightfully in possession of the franchise and rightfully exercising the power which the legislative grant confers. Individnal right is not invaded if the presmmption is true in fact and there is no usurpation. It is the state-the sovereign-whose rights are invaded and whose anthority is usmrped. The individual could not create the corporation, could not grant, define, or limit its powers; any grant of these by the sovereign cannot

1 See ante, $\$ 6$.

2 Lake Superior Co. v. Morris $m, 22$ Canada C. P. 22.4.
3 Tar Liver Nav. Co. e. Neal, 3 Inawk (X. C.). 520; Weleh v. Bank, 122 N. Y. $177 ; 2.5$ N. E. 269. 
lessen his right. 'There can consequently be no cause of complaint by the citizen, and no right to inquire whether the corporate existence is rightful, de jure, or merely colorable. ${ }^{1}$

Corporations may exist either de jure or de facto. If of the latter class, they are under the same protection of the law and gorerned by the same legal principles as those of the former so long as the State acquiesces in their existence and exercise of corporate functions. A pricate citizen whose rights are not invaded and who has no cause of complaint has no right to inquire collaterally into the legality of its existence. This can only be done in a direct proceeding on the part of the State from whom is derived the right to exist as a corporation and whose authority is usurped.2

A corporation de facto may legally do and perform every act and thing which the same entity could do and perform were it a de jure corporation. As to all the world except the paramount authority under which it acts and from which it receives its charter, it occupies the same position as though in all respects valid, and even as against the State, except in direct proceedings to arrest its usurpation of powers, its acts are to be treated as efficacious. ${ }^{3}$

Finally, it may be observed that the principle here contended for has been held by at least one court to be applicable to a case where a corporation had incorporated under an unconstitutional law, yet nevertheless the validity of the corporation's existence could not be collaterally attacked, as it had been chartered by the implied consent of the State.

$\S 83$. Right of State to attack Corporate Existence in Direct Proceedings. - This section has reference only to actions brought by the State for the purpose of testing the legality of corporate existence where it is alleged that there has been a failure on the part of the incorporators to perform all the conditions prescribed by statute as a precedent to corporate existence. The action here referred to is that of quo warranto, which, even in the absence of statutory provision, may be maintained at common law in behalf of the State against incorporators who assume to exercise corpo-

1 Tehman $v$. Warner, 61 Alit. 455.

'Snider's Sons' Co. v. 'Troy, 91 Ala. $224 ; 8$ So. 658 ; Tar River Nav. Co. $v$. Neal, 3 llawks (N. C.), 520.
${ }^{3}$ People $v$. LaRue, 67 Cal. 526; 8 Pac. 84.

${ }^{4}$ Richards $v$. Bank, 75 Minn. $196 ; 77$ N. W. 822. 
rate powers without being legally incorporated, for the purpose of ousting them from the exercise of such powers. ${ }^{1}$

In all such proceedings as against the State not merely a de facto corporate existence must be shown, but a de jure existence as well. The general prevailing view at the present time seems to be that, as against the State in such proceedings, it is necessary to show a specific statute authorizing the creation of corporations of the character of the one against which the quo warranto proceedings are brought, and also substantial compliance in the preliminary organization of the corporation with all conditions precedent prescribed by statutc. ${ }^{2}$

In quo warranto procecdings the burden of proof is upon the corporation to show that it has been legally incorporated. ${ }^{3}$ In the proceedings of the character referred to it has been well said that "public policy demands that the power to oust de facto corporations from the exercise of corporate powers because of failure to comply substantially with conditions precedent be sparingly exercised." 4

Were the rule otherwise, disastrous consequences would follow in the commercial world, and in all such cases the courts should take extraordinary care to see that the rights of third parties are fully protected. In proceedings brought by the State, the most important matter to be looked at is whether there has been a failure on the part of the incorporators to comply with the provisions of the statute, which are merely directory as opposed to those that are mandatory. A "directory" provision is one which the legislature did not intend as essential to corporate existence, and the failure to comply with which is a mere irregularity and is not fatal to corporate existence. A "mandatory" provision, on the other hand, is one which must be substantially complied with in order to create a corporation de jure. ${ }^{5}$ Whether the particular prorision of the statute is directory or mandatory is to be determined by "the intention and true meaning of the legislature deduced from the act and sometimes aided by other acts in pari

1 Greene v. People, 150 III. 513; 37 N. E. 842.

2 State $v$. Webb, $97 \mathrm{Ala} .111 ; 12$ So. 377 ; People v. Selfriclge, 52 Cal. 331; State $v$. Critehett, 37 Minn. $13 ; 32 \mathrm{~N}$. W. 787 ; Holman $v$. State, 105 Ind. $569 ; 5$ N. E. 702.
B People v. Lowden (Cal.), 8 I'sc. 66.

- Inggan $v$. Company, II Colo. 113; 17 I'ae. 105.

- Newcomb $v$. Reed, 12 Allen, 362 ; B3. IV. S. Co. v. Inliahitants of Braintree, 146 Mass. 482 ; 16 N. E. 420. 
materia and extraneous circumstances." l Even as against the State it is only necessary that a mandatory provision shall be sulstantially complied with. ${ }^{2}$

S 4 . When does Corporate Existence commence? - Where the statute provides, as it does in some of the Commonwealths, that the articles of incorporation shall be filed with State officials or in some local comnty office or both, the general rule is that the corporate existence dates from the time of filing of the articles with such officials and not from the time it begins to do business. ${ }^{3}$ The foregroing seems to be the rule in force in the majority of States. Some of the States, however, provide by statute as to when corporate existence shall commence, as, for example, Alabama, California, Colorado, Connecticut, Delaware, Idaho, Iowa, Kansas, Kentucky, Maine, Massachusetts, Michigan, Mis sissippi, Missouri, Montana, Nebraska, Nerada, New Hampshire, New Jersey, New York, North Dakota, Ohio, Pennsylvania, Rhode Island, South Carolina, South Dakota, Tennessee, Texas, Utah, Virginia, Washington, West Virginia, Wisconsin, and Wyoming. In a number of the States corporate existence depends not merely upon filing articles with the Secretary of State, but also upon filing the same in the local recording office of the county where the principal place of business of the corporation is to be located, as, for example, in Arizona, California, Colorado, Delawarc, Idaho, Maryland, Montana, New Jersey, Utah, and Wisconsin. In some few of the States the statute by reason of its peculiar prorision seems to contemplate the corporate existence shall commence before the filing of articles of incorporation with any official, either State or county; this for the reason that the certificate required to be filed with such officials must be signed by corporate officers. States to which reference is here made are Arkansas, Illinois, Indian Territory, Maine, Massachusetts, Michigan, and Missouri.

1 Cross v. Company, 17 Ill. 54 ; Eakright $v$. Company, 13 Ind. 404; Newcomb v. Reed, 12 Allen, 362.

2 People $r$. Company, 97 Cal. 276; 32 Pac. 236; State $v$. White, 13 Mo. Appeals 139; Perple $v$. Cheeseman, 7 Colo. 376 ; 3 J'ac. 716 : Newcomb v. Reed, 12 Allen, 362 ; Eakright v. Cumpany, 14 Ind. 404; Walworth $\because$. Bracket, 19 Mass. 98 ; B. W. S. Co. $v$. Inhabitints of Braintree, 146 Mass. $482: 16$ N. E. 420.
${ }^{3}$ Ilanna $v$. Company, 23 O. St. 622 ; G. M. \& S. Co. $v$. Richards, 95 Mo. $106 ; 8$ S. W. 246 ; Humphreys $v$. Mooney, 5 Colo. 293 ; V. C. Railway Co. v. Clayes, 21 Vt. 30 ; Borough of Braddock $v$. Company, 189 Pa. 379; 42 Atl. 15; Badger Paper Co. v. Rose, 95 Wis. 45 ; 70 N. W. 302 ; Hunt v. Company, 11 Kan. 412.

4 See Part II., Synopsis-Digest of the Corporation Laws of the several States and Territories. 
There seems to exist in some jurisdictions the theory that in the matter of determining when the corporate existence commences reference must be had, first, to the primary franchise of being a corporation resting in the incorporators and next to the secondary franchise to do certain specific acts which rests in the corporation. ${ }^{1}$ Again, in some States, while filing articles of incorporation constitutes a condition precedent to the creation of corporate existence, it is also a condition precedent to the right of doing business. ${ }^{2}$

Ordinarily corporate existence does not commence until all conditions precedent are performed. ${ }^{3}$ There is a rery obvious distinction between such acts as are declared to be necessary stejs in the process of incorporation and such as are required of the individuals seeking to become incorporated, but which are not made prerequisites to the assumption of corporate powers. Witl respeet to the former any material omission will be fatal to its existence as a corporation de jure, as against the State. In respect to the latter, failure to comply therewith is not ordinarily accompanied by forfeiture of its charter powers, but rather goes to the question of the personal liability of the individuals who attempt to do business as a corporation without having complied with all the conditions subsequent. ${ }^{4}$

Corporate existence in this immediate connection ordinarily means full authority to transact business as such in contradistinction to the qualified existence of such corporations which dates from the time of filing the articles of association with the Secretary of State. ${ }^{5}$ So too, in those States where organization precedes the filing of a certificate of incorporation, it has been held that a corporation has a qualified existence from the date of the incorporators' first meeting. ${ }^{6}$

In Illinois eorporate existence does not commence until the reception of a license from the Secretary of State to take stock

1 State v. Water Co., 61 Kan. 547; 60) Pac. 337.

2 Garle $v$. Company, 165 Ill. $34 ; 7 ; 6$ N. İ. 286; Martin v. I)ect\%, 102 (al. 5.5; 36 Pac. 368; In re S. MI. (Co., 37 Nlim. 91; 33 N. W. 219 ; Johus r. People, 25 . Viclt. 499; G. M. \& S. Co. r. Richarils, 95 1 I\%. $106 ; 8 \mathrm{~S}, \mathrm{~W}, 246$.

${ }^{8}$ Afferton $v$. Company, 6r Ind. 33.I; Borongh of Bratluck v. Compatiy, 189 l'a. St. 379; 42 Atl. 15; laulger layer Co. 1 . Rose, 95 Wis. 145; 70 N. W. 302.

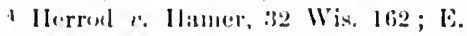
G. L. (A) ". (irent, t6 N. I. J\%. 118; 18 At1. 844; M. II. M. Co. v. Woodlunry, 14 ('i1). 124.

5 Ilurt P. Salislury, 55 Mo. 310.

6. S. A. \& I'. Co. v. Scholfteld, io Conn. $500 ; 40$ Atl. 182. 


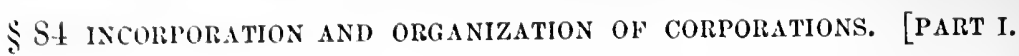
subseriptions. ${ }^{2}$ It would of course follow, from the necessities of the case, that before a corporation ean contract as such, it must have a full and complete organization.2 While ordinarily such organization is not neecssary to the commencement of corporate existence, it is sometimes made so by statute. ${ }^{3}$

1 Stowe $e$. Flarge et al., 72 Ill. 397 ; Curran 2 Braduer, 27 Ill. $\alpha_{\mathrm{l}}$. 582.

2 Gent $"$. Company, 107 Hll. 652.

3 A. \& N. T. Ry. Co. v. Smith, 15
O. St. $328 ;$ U. R. Co. $v$. IIolden, 63 N. C. 410 ; Teitig $v$. Boesman, 12 Mont. 404; 31 Pac. 371. 


\section{CHAPTER III.}

\section{ORGANIZATION OF CORPORATIONS AFTER INCORPORATION.}

$\S 85$. The Incorporators' Organization Meeting. - That a corporation shall have a full and complete organization and existence as an entity before it can enter into any kind of contract or transact any business, would seem to be self-evident. A corporation until organization has no franchises or faculties. Its existence before is but a qualified existence. Its powers are limited for the time being to the right to organize itself into an active corporate organization, and, as we have seen, those engaged in bringing it into being have no power to bind it by contract unless so authorized by the charter. Until organization as authorized by the charter, it does not possess the right to exercise its corporate functions, nor has it a valid existence for all purposes. ${ }^{1}$

In this connection it was observed in a leading case, that "it is often stated in the books that a corporation is created by its charter. This is not precisely correct. The charter only confers the life and provides the instruments by which it may become an acting entity. Such a corporation has been well defined to be an artificial being, existing only in contemplation of law. The instruments provided to bring the artificial being into active operation are the persons named in the charter, and those who by viltue of its provisions may become associated with them. These persons - the incorporators - as natural persons have no such power. The charter confers upon them a new faculty for this purpose, a faculty which they can have only by virtue of the law which confers it." 2

The better, if not the prevailing, rule appears to be, that not only are the incorporators named in the articles of incorporation entitled to participate therein, but also all subscribers to the preliminary stock subscription to the capital stock of the proposed corporation may do so. ${ }^{3}$

1 Gent v. Company, 107 III. 652.

2 Miller $v$. liwer, 27 Me. 509. a Baltimore City Pass. Ry. Co. v. Ham. bleton. 77 Mll. 341; Spear v. Crawford, 95 
$\$$ S6. Organization Meeting, how called.-The more recent incorporation acts, such as are in force in Connecticut, Maine, Massachusetts, New Jersey, North Carolina, and West Virginia, point out specifically how the organization meeting of a corporation is to be called. Where no such statutes exist the better and saler practice is for all the.incorporators, as well as the subscribers to the preliminary subscription agreement to the capital stock of the proposed corporation, to sign a waiver and agreement fixing the time and place for the organization meeting of the corporation.

It has been held that all are not required to be present at the organization meeting who sign the articles of incorporation unless the statute requires it. A majority, it is said, is sufficient. ${ }^{2}$ The safer practice, howerer, is to comply with the rule stated above. ${ }^{3}$

Virginia is one of the few States possessing a statute giving the incorporators the right to assign their interests as such in a prospective corporation. Failure to call a meeting as provided by statute is to be regarded as a breach of a condition subsequent and is not fatal to the creation of a valid corporation. ${ }^{4}$

$\$ 87$. Organization Meeting, where held. - It was laid down at an early date by the Supreme Court of Maine in Miller $v$. Ewer, ${ }^{5}$ that all acts and proceedings of persons pretending to act in the capacity of incorporators when assumed without the bounds of the sovereignty granting the charter are absolutely void. 'The principle established in Miller $v$. Ewer has been quite generally adopted in other parts of the country. ${ }^{6}$

The reasoning of these cases is to the following effect: the charter bestows upon the incorporators certain privileges which

14 Wend. 24; Nickum r. Burkluarlt, 30 ()re. 464; 47 Pac. 788; Waukon, ete. liy. Co. v. I)wyer, 49 Ia. 121 ; Instune $v$. Company, 2 Bihb. (Ky.) 578; Chester Glass Co. $v$. Dewey, 16 Mass. 94; Iaskell $v$. Read (Neh.), 93 N. W. 997.

1 B. B. R. Co. v. Buek, 68 Me. 81 .

2 lackard $v$. Co., 168 Mass. $92 ; 46$ N. E. 433.

8 See Bablitt v. F. J. I. Co., 1 Stew. Dig. 208, §13, not otherwise oflicially reported (1876); Walworth v. Bracket, 98 Mass. 98.

4 Mc Clineh v. Sturges, 72 Me. 288; Braintree Water Supply Co. $v$. Braintree, 146 Ilass. 482 ; 16 N. E. 420 ; Ih re British sugar liefining Co., 3 Kay \& J. 408; I'urter $\because$. Rohinson, 40 IIun (N. Y.), 209.
527 Me. 509.

6 Freenau v. Company, 38 Me. 343 ; Sinith 2 . Company, 64 Md. 85; 20 Atl. 1032; Camp v. Byrne, 41 Mo. 525; Ilumphreys $v$. Mlooney, 5 Col. 282; Duke $v$. Taylor, 37 Fla. 64; 19 So. 172; Miller v. Parrish, 14 N. J. Eq. 380 ; Crmsby $v$. Comprany, 56 N. Y. 623 ; Mitehell $v$. Cornpany, 40 N. Y. Sup. Ct. 406 ; F. 'T. I. Co. $v$. Laigle, 59 Texas, 339; Hodgson $v$. Company, 46 Minn. 454; 49 N. IV. 197 ; Ohio, ete. Ry. Co. v. Mcl'hersom, 35 Mo. 13; Arms v. Conant, 36 Vt. 744; Galveston, etc. Ky. Co. v. Cowlrey, 11 Wall. 459; liunyan v. Coster, 14 l'eters, 122; A ugusta liank v. Earle, 13 I'eters, 519; Wright $v$. Lee, 2 S. I. $596 ; 57$ N. W. 706. 
they can possess only by virtue of the law which confers it; that law is inoperative beyond the bounds of the legislatice power by which it was enacted; that, as the foregoing faculty cannot accompany the incorporators beyond the bounds of the sovereignty which creates it, they cannot possess or exereise it there, and can hare no more power there to make the artificial being act than other persons not named or associated as incorporators. Therefore any attempt to exercise such a faculty there is merely a usurpation of authority by persons destitute of it and acting without any legal capacity to act in that manner. If the foregoing reasoning be sound, it follows that all fundamental corporate acts and proceedings when assumed without the bounds of the sorereignty granting the charter are absolutely void. The principle here stated has been materially qualified in a large number of jurisdictions by an extended application of the doctrine of estoppel. $\Lambda \mathrm{s}$ an example of this, attention is called to the case of Handley $v$. Stutz.

This was a case where a Kentucky corporation at a meeting of the stockholders of the corporation, held outside of the State, increased the capital stock of the company from one hundred twenty thousand dollars to two hundred thousand dollars. It was contended that this increase was illegal, for the reason that the meeting of the stockholders authorizing it was held outside of the State of Kentucky. The court, in its opinion upon this point, spoke as follows:

"Nor were the proeeedings of such meeting any less binding upon those participating in it by reason of the fact that it was held outside of the boundaries of the State under the laws of which the company was incorporated. By act of the Kentucky Legislature, it is provided, that all elections for directors and other oflicers by private corporations shall be held within the territorial limits of the State of Kentucky, and that any such election held outside of Kentucky shall be void. Beyond the election of officers, however, there is no statutory restriction of corporate action to the limits of the State, and in the absence of such inhibition the proceedings of such meeting would, with regard to directors' inectings, be linding upon all those participating in it, as well as upon those acting upon the faith of its validity or receiving the stock anthorized to be issued at said meeting. It is true that there are cases holding that stockholders' 
meetines cannot be legally lield ontside of the home State of the corporation. but the question has generally arisen where a majority present had attempted by their action to bind a dissenting minority, or haul talien action prejulieial to the rights of third persons. Inderel. so far as we know, the authorities are miform to the effect that the action taken at such mecting was binding upon those who participated in or partook of the benefits of them. In this case the mceting was attended by all the stockholders but two, who were present by proxy. The rote increasing the stock was unanimous, and it does not lie in the mouth of those who participated in this act, or received the stock voted at this mecting, to question its validity." 1

Unquestionably the legislature has the legal right, in the absence of constitutional provision, to provide that all meetings of corporations, whether organization or otherwise, may be held outside the State. 2

\$ 88. Steps Necessary to complete Organization. - The principal matters which demand attention at the organization mecting of a corporation may be enumerated as follows: (1) the adoption of by-laws; (2) election of directors; (3) providing for the issue and pasment of the capital stoek of the corporation. The subject of the adoption of by-laws and the payment of the capital stock of the corporation will be left for subsequent consideration.

With respect to the matter of the election of a board of directors the following may be said. Many of the incorporation acts require that the names of the first board of directors shall be set forth in the articles of incorporation, and this ordinarily obviates the necessity of electing a new board at the organization meeting of the corporation. ${ }^{3}$ Unless the statute so requires it, it is not necessary, in order to give the incorporators the right to particifrate in the organization meeting, that they be stockholders. ${ }^{4}$ But ordinarily it is contemplated by the incorporation acts that the incorporators shall be stockholders or subscribers for capital stock.

1 Sine to the same effect Heath $v$. S. L. Min. Co., 39 Wis. 146 ; O. \& M. Ry. Co. v. Mel'herin, 35 Mo. 13; Ormsby $v$. Vermont Min. Co., 56 N. Y. 632 ; Humphrey r. Irrnes, 5 Col. 282 ; Wright $v$. Lee, 2 S. 1). $596 ; 57$ X. W. 706 ; 'T. H. Co. $v$. Gresdlupe, 18 N. C. 981.

2 Ginham 2 Co., 118 U. S. 161 ; 6 Sup. Ct. lonst.

Intuilton Trust Co. v. Clemens, I 63 N. Y. 423; 57 N. E. 614.
4 IJammond v. Straus, 53 Md. 1 ; Perkins $v$. Perders, 56 Miss. 733; Proprietors, etc. $r$. Dickinson, 6 Gray (Mass.), 586 ; Coyote $r$. Ruble, 8 Oregron, 284; Densmore (jil Co. v. Iensmore, 64 Pa. St. 43 ; Singer Mfg. Co. v. Peck, 9 S. D. $29 ; 67$ N. IV. 947; liamsey v. 'Tod, 95 Texas, 614; 69 S. IV. 133; Byrnes v. Beek, 10 Ga. 121 ; B. B. \& T. Co. v. J. B. 'T. Co. l0l Tenn. 545 ; 48 S. W. 228 ; Wechselberg $v$. Bank, 64 Fed. 90. 
The right to rote stock is an incident to stock ownership, and was recognized at common law as a property right. ${ }^{1}$

In some few of the States, statutes exist limiting the right of stockholders to own more than a certain percentage of the total stock of the corporation. ${ }^{2}$

Sometimes the incorporators are appointed commissioners to take stoek subseriptions. It has been held that the failure of such commissioners to take the oath of office as required by statute, will not render the subscriptions roid. ${ }^{3}$ Where authority to open books of subseription is given by statute to the incorporators, this authority may be exelusive, so that subscriptions cannot lawfully be received by others. Such subseriptions, howerer, may of course be ratified by proper parties. ${ }^{4}$

Ordinarily the election of officers is by statute devolred upon the board of directors. Howerer, in some few of the States certain officers are required to be elected by the stockholders.

$\S$ 89. Adoption of By-Laws. $-\Lambda$ by-law is in effect a continuing rule of action for the grovermment of the corporation, its members and offiecrs. ${ }^{5}$ The purpose of a by-law is to regulate and define the duties of the stockholders between themselves and the conduct of the officers and the management of the corporate aflairs. ${ }^{6}$

All corporations have the implied power to make by-laws for the government of the corporation and the management of its affairs. ${ }^{7}$ Unless otherwise provided by statute, the by-laws must be adopted by the incorporators at their organization meeting or else by the stockholders at a meeting duly called for that purpose. ${ }^{8}$

Some few of the States, among them being South Dakota, North Dakota, and Oklahoma, permit incorporators to alopt by-laws, whether they are subseriber's for the eapital stock of the proposed corporation or not. Statutory provisions exist in several of the

1 Commonwealth 2 . Dalzell, 152 I'a. St. $217 ; 25 \Lambda$ tl. 535 .

" Mack r. Company, 90 Ala. 396; 8 So. 150: (ommonwealth r. Detwiller, 131 I'at. St. 614; 18 Atl. 990. On riglit of corpuration to vote its own shares sec IICNesly $\because$. Woodruff, 13 X. J. I. 352; Ex prerte Itolmes, 5 (owen (X. Y.), 120; on right of corporations to vote slaters in another corporation see llavis $v$. Company, 77 Id. 35; 25 Atl. 982.
3 IJIlman v. Company, a Gill \& J. (Mal.) 4fie.

1 N. C. II Ry, Co. $v$. Elow, 40 Mich. 222.

"… M. 'T. S. Co. r. Jishop, 103 Wis. $492 ; 79 \times 1 \% .85$.

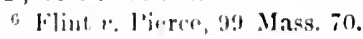

- Fingechardt r. Association, 148 N. Y. $281 ; 42$ ․ \&. 710.

8 .I. G. R. Co. v. Wysong, 51 lnd. 12. 
states, expressly permitting provision to be made, if desired, for the adoption of by-laws by the directors. In the absence of any such statutory authority, by-laws adopted by the directors are not binding unless subsequently ratified by the stockholders. ${ }^{1}$ On the other hand, if the directors are rested by statute with exclusive power to pass by-laws, those passed by the stockholders are not ralid. ${ }^{2}$

The adoption of by-laws is a constituent act, and for this reason they must be adopted within the State by whose laws the corporation was ereated, if action of stockholders is necessary to their adoption." In the absence of statutory power or charter provision, by-laws can be altered or repealed by the stockholders alone. ${ }^{4}$

In the absence of statutory prohibition, the power to amend or alter by-laws may be delegated by the stoekholders to the directors. In general by-laws must be adopted in conformity to the charter and be reasonable and proper. ${ }^{5}$

The by-laws of a private corporation will be interpreted by the courts as interpreted by the corporation. ${ }^{6}$

The reasonableness of a by-law is a question of law and not of fact. ${ }^{i}$

In drawing by-laws the following rules should govern: they should be made certain $;^{8}$ they must be directed to all within the sphere of their operation; ${ }^{9}$ they must operate equally upon all to whom applied; ${ }^{10}$ they must be lawful as against members possessing rights, and must be reasonable. ${ }^{11}$

Sometimes the statute requires by-laws to be adopted within thirty days after ineorporation and eopied into a book of by-laws. ${ }^{12}$ Such statutes are clearly directory and not mandatory.

§.90. Election of Directors. - The power to choose a board of

1 Carroll $\imath$. Bank, 8 Mo. Ap. 253.

2 In re lilaus, 67 Wis. $40 ; 29$ N. W. 582; I'eojle $r$. Company, 82 Ill. 457 ; S. S. Ass'n v. Company, 25 Mo. Ap. 642.

3 In re lílaus, 67 Wis. $40 ; 29 \mathrm{~N}$. W. 582 ; Mitehell $v$. Company, 40 N. Y. Sup Court, 413.

4 M. G. R. Company v. Wysong, 51 Ind. 12.

5 See Kent $\because$ Company, 78 N. Y. 182 ; Pergman $v$. Association, 29 Minn. 275; 13 N. W. 120 ; Commons $v$. Compauy, 12 Pa. St. 318; I'eople v. Chicago Board of Trale, 45 III. 118.

100
${ }^{6}$ State ex rel.Attorney-General $v$. Conklin, 33 Wis. 21. 435.

8 Goddard v. Merchants' Exchange, 9 Mo. A p. 290.

${ }^{9}$ Ex parte Frank, 52 Cal. 606.

10 People $v$. Suciety, 25 I3arb. (N. Y.) 7.

11 Com. ". Worcester, 3 Pick. 461 ; King v. Union, 170 Ill. 135; 48 N. E. 677. ()n failure to post by-laws, see Langon $v$. Company, 49 Ia. 317.

12 Sce Hall $v$. Crandall, 29 Cal. 567; Clapman $v$. Doray, 89 Cal. 52 ; 26 Pac. 605. 
directors is inherent in all prirate corporations irrespective of statute. ${ }^{1}$

The election of directors in connection with the organization of a corporation ordinarily follows the adoption of by-laws. After the organization the election of directors is usually had at the anmual mecting of the corporation. In giving the notice of such annual meeting it is customary to specify in the notice that a board of directors is to be chosen. ${ }^{2}$

In choosing the directors it is incumbent upon the incorporators or stockholders, as the case may be, to observe the provisions of the statutes relative to the number of directors to be chosen and their qualifications as to stock-holdings, residence, and citizenship if any such are prescribed by statute. In the absence of such statutes as exist in many of the States authorizing the dividing of directors into classes, so that only a certain portion of the board are elected annually, the full board must be elected each year. In the absence of statute making the ownership of stock a qualification for holding the oflice of director such ownership is not necessary.3 Even where the statute requires that directors shall be stockholders, it is not necessary that they shall become such before their election if they become stockholders before entering upon the duties of their office. ${ }^{4}$ In the election of directors by the incorporators it is sufficient in order to qualify him that a director be a subscriber for stock, though no certificate has in fact been issued. ${ }^{5}$ Where ownership of stock is necessary to qualify one as a director, the prevailing rule secms to be that the moment a director ceases to be a stockholder, he ceases to be a director de jure (but not de facto) without proceedings laving first been taken to remove him. ${ }^{6}$

Where a director is required to take an oath of office before entering upon the discharge of his duties, his failure to take such an oath will not present him from becoming a director de frecto. Any person who can he a business arent for another ean, if possessed of statutory rinalifications, become a director. ${ }^{8}$ Ordinarily

1 Hurlbut $v$. Marshall, 6.2 Wis. 590; 22 N. W. 852.

2 Merritt $v$. Forris, 22 Ill. 303.

3 Wright $e$. Colnpaluy, 117 Mlass. 226.

4 Greenugh v. Complamy, fil Fenl. 22.

5 .McComb 2 . Aasociation, Io N. Y. Sup. 552 ; Beckett $\imath$. IIouston, 32 Ind. 393.
" Dispatwh Light I'acket i. Company, 12 N. II. 20.i; Wright $v$. Company, 52 x. I. Bi. 352 ; Howe $v$. Scarborough (A1:6), 3is S1, 113.

i Cimpsom r. Garlaml, to Me. 203.

" l'erple e. Wiebster, 10 Wenl. (N. Y.) 5.4. 
it is not mecessary that resignations of directors be accepted in oreler to becone effective.

lersons owning a majority of stock have a right to elect directurs." It is a fundamental principle in corporation law that a majonity of stockholders shall control the policy and regulate the businesis affairs of the corporation, and to this cach stockholder inplicaly agrees when he acquires stock in the corporation. Howerer, in order to insure minority representation on the board, emmulative roting for directors is permitted in a large number of the States. Where sneh right to emmulate votes is mandatory such right camnot be taken away by by-law.

'The fiact that a corporation begins business with an insuffcient number of dircetors does not invalidate debts contracted by them, nor deprive it of its corporate rights and privileges unless some action is taken by the State to that end. ${ }^{6}$ Failure to elect a board of directors ammally does not work dissolution. The old board will hold orer by implication of law.' 'This is a rule not only established by statute in a large number of the States, but is a well established rule of corporation law in the absence of such statutes. ${ }^{8}$ In the election of directors a majority vote of all present is sufficient, provided a majority of the stock is represented at the mecting. 9 Tacancies in the board of directors cannot be filled by the remaining directors, but must be filled by the stockloblers, unless such power is expressly granted by statute. ${ }^{10}$ Even where the right to fill racancies is giren to the remaining directors it is probably true that there must be present at the meeting a majority of the whole number of directors preseribed by the eharter, and that such vacaney be filled by a majority rote thereof."

Culess regulated by statute or by-laws, the board of directors may fix any place within the domicilialy State at which amual

1 Pres., pte of Maulhattan Co. v. Kaldenterer, 165.5 X. Y. 1; 58 N. E. 790 ;

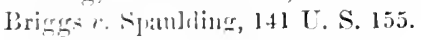

2 Fanduse $v$. Yates, 50 Ill. 416.

3 Wheler $v$. Complany, 143 Jll. 197; 32 ‥ 1.420.

4 See ['ut III. Table 9, parge 579.

- Tonlin 2 . liank, 52 .Mo. Ap. 430; Wricit $\because$ Company, 67 CaI. $532 ; 8$ l'ac. io.

G. Farcaseru $r$. Company, is Miss. 65; 27 is $87 \%$
7 IIunter v. Company, 26 La. Ann. 13.

8 Chamberlain $x$. D). S. Works, 103 Mich. 124; 61 N. W. 5:22; Moses $v$. Tompkins, 84 Ala. $613 ; 4$ So. 763.

9 Eigleston $v$. Dorlittle, 33 Conn. 402.

1) Moses $v$. Tomplins, 84 Ala. 613; 4 So. 763 ; líearney $v$. Anlrews, 10 N. J. E⿰氵. 70.

in Moses $r$ Tompkins, 84 Ala. 613; 4 So. 763 ; Nathan $v$. Tompkius, 82 Ala. $437 ; 2$ So. 747. 
meetings for the election of directors may be held. ${ }^{1}$ There there are mandatory provisions in the charter, statute, or by-laws as to place of holding amnual meetings these must be followed. ${ }^{2}$ Where the certificate of incorporation is required to fix the number of directors, such number cannot be changed except by amendment thereof. ${ }^{3}$

In connection with the general subject of clection of director's the question not infrequently arises as to the validity of the so-called "roting trusts" now becoming so common in this conntly. The prevailing and it is believed the true rule on this subject is set forth in Clowes $v$. Miller, ${ }^{t}$ where it was held that in the absence of any improper motive such trusts are ralid. ${ }^{5}$ It is, in the absence of such improper motires, merely a conrenient method of roting by proxy.

In the absence of statute, charter prorision, or valid by-law to the contrary, holders of preferred stock have the same rights in the election of directors as belong to the holders of common stock. ${ }^{6}$ It has been held that stockholders may in voting for director's eliange their vote while the election is in progress. ${ }^{7}$ Mandamus is the proper remedy to compel canvassing of rotes at election of directors to determine whether or not such election was valid. ${ }^{5}$

In some of the States there are certain statutory officers known as "Inspectors of Election," who must be chosen prelininary to the election of the board of directors. These inspectors should be chosen in the mode provided in the by-laws.9 Inspectors have no power, express or implied, to pass upon the eligibility of directors. ${ }^{10}$ The failure to have the inspectors sworn before acting as such will not invalidate an election." In the absence of statutury provision

1 Corbett v. Woodward, 5 Siaw. f(1)3; Commonwealth $r$. Suith, 45 l'a. St. 59 ; Pratt 2 . Company, 35 Conn. 365 ; luke v. Taylor, 37 Fla. 6f: 19 Sist. 172; llilles v. Larish, 14 X. J. H. 380 ; Arms v. (C) nart, 36 Vt. it1; Ilwlewn r. Comprany, 46 .linn. $454 ; 49 \times 1 \%, 197$.

2 Ifclaniel $v$. Complany, 2.2 Vt. 27.4.

${ }^{3}$ Sce Matter of (iriftin Iron (os, 63 N. J. L. 168; 41 Atl. 9.3.

460 N.J. Ei 179; 47 itl. 315.

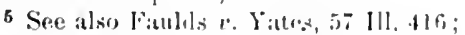
Moges 2 Scott, 84 Nla. Gor ; 4 Sir. 7t2; O. \&..I. Ry. Co. v. State, 49 (). St. fir : 32 N. k. 933; Mrblile, ctc. liy. Cis. Nicholas, 98 Ala. 92 ; 12 So. 723.
- Mackintosh r. R. R. Co., 32 Fol. 350; 51 Fil. 582; Lockhart $r$ Vin Alstyne, 3) Mich. 76 ; Miller 1. liatterman, 77 0. St. $1+1 ; 21$ N. $1 \% 496$.

7 State $e$. Motinius, 6.4 Mo. Ap. 225.

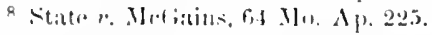

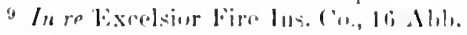

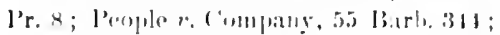

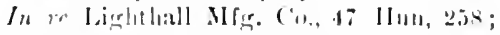
Stater. Murchant, 37 (). St. 2.5l ; Commonwealth r. Woulpor, 3 s. \& li. (1'a.) 20.

1) In re st. Iawremo Sicamboat Co., 4. X. I. L. 529.

11 In ip M. \& II. IRy. Co., 19 Wreud. (N. Y.) 135 . 
or regulation hy by-laws providing otherwise, the power to appoint insprecturs of election lies with the stockholders alone. ${ }^{1}$

\section{$\$ 91$. Power to hold Meetings for the Election of Directors with-} out the Domiciliary State. - The general rule unquestionably is that in the absence of statute or unanimous consent of all the stockholders no election of directors by the stockholders ean be legal, so as to make them directors de jure, when had at a meeting called without the limits of the State under whose laws the corporation is created."

Twelve of the Commonwealths have statutes expressly authorizing the holding of stockholders' meetings without the domiciliary State. ${ }^{3}$ In any event, it seems to be now well settled that where all the stockliolders meet without the State and transact business thereat, even though such business be the annual clection of directors, the stockholders present at such meeting are estopped to question the validity of the proceedings had thereat. 4 An excellent method of validating any action taken by stockholders at meetings held without the domiciliary State is to have subsequent action taken by the stockholders at a meeting called within the State ratifying what has been previously done by them without the State. 'This, it has been held, eures all previous defects. ${ }^{\bar{j}}$

$\$ 92$. Voting by Proxy. - At common law, voting of stockholders at annual meetings or special meetings was required to be done in person. ${ }^{6}$ In the absence of statute, charter provision, or ralid by-law giving stockholders this right, the same rule would apply at the present day. ${ }^{7}$

1 State $v$. Merchant, 37 O. St. 251.

2 Harding $r$. Ainerican Glncose Co., 182 Ill. $5.31 ; 55$ N. E. 577 . See Iloitgson v. Company, 46 Minn. $454 ; 49$ N. W. 197 ; Freeman $v$. Company, 38 Me. 343 ; Smith v. Silver Valley Min. Co., 64 Md. 85; 20 Atl. 1032; Aspinwall et al. v. Ohio \& M. R. R. Co.. 20 Ind. 492 ; IV. II. \& II. Mining Co. $v$. King, 45 Ga. 34 ; Ililes $v$. Parrish, 24 N. J. Eq. 380; Arms v. Con. nant, 36 Vt. 750 ; leellows 2 . 'Toill, 39 Imwa, 209; Franco-Texas band Co. $v$. Lairle, 59 Tex. 339 ; Mack $v$. De Bardell, 11 , etc. Co., 90 Ala. 396; 8 So. 150; J) ukf $v$.' 'aylor, 37 Fla. 64 ; 19 So. 172; Canp $r$. Bvrne, 41 Mo. 525; Mitchell $v$. Vt. Copper Min. Co., 40 N. Y. Sup. Ct. 406; Galiveton, etc. liy. Co. v. Cowdrey,
11 Wall. 459; 20 Law Fd. 199. The principle of estoppel may be applied here. Ilandley $v$. Stutz, 139 U. S. 417 ; 1 I Sup. Ct. 5:30.

3 See Part III. Table 11, page 581.

4 T. M. Co. v. Goodline, 18 N. Car. 981 ; Ilandley $v$. Stutz, 139 U. S. 417 ; 11 Sup. Ct. 530.

5 G. I. \& E. Co. $v$. Toler, 80 Md. 278; $30 \mathrm{Atl} .65 \%$.

6 J'erry v. Company, 93 Ala. $364 ; 9$ So. Rep. 217.

7 I'hillips $v$. Wickham, 1 Paige (N. Y.), 590; 'Taylor v. Griswold, 14 N. J. L. 222 ; P. Il. S. Bank ?. Superior Court, 104 Cal. 649 ; 38 Pac. 452 ; State $v$. Tudor, 5 May, 329 ; l'eople v. Crossley, 69 Ill. 195; Perry v. Company, 93 Ala. 364 ; 9 So. 217. 
Owing to the unquestioned right of a corporation to adopt a valid by-law permitting roting by proxy, even in the absence of a statute authorizing it, the question has ceased to be one of any great practical importance in the country to-day. Besides this, statutes exist in all of the States and Territories, except Arizona and Georgia, expressly anthorizing the voting of stock by proxy. It should be observed, however, that where the right to rote by proxy is given by statute without restriction it camnot be qualified by by-law. ${ }^{1}$

Proxies may be issued in blank and lawfully filled in by the holder. ${ }^{2}$ It has been held that stockholders camnot give an irrerocable proxy to secure the payment of a debt. ${ }^{3}$ It is against the settled rules governing the control of corporations that an irrevocable power of attomey which directs the rote on stock, should be rested in a person who has no interest in the stock or is not a representative of a person interested therein. ${ }^{*}$

The foregoing suggests the question as to whether or not voting trusts, so common at the present time, are valid. $A$ "voting trust" may be defined to be an agreement of stockholders to give any designated trustee the right to vote at his diseretion through stockholders for a given period of time. It may be said that such roting trust is valid where neither the purposes nor the means used contrarene any constitutional or statutory provision or well-recognized principles of public policy, and are within the scope of the powers of the contracting parties. 5

\$93. First Directors' Meeting. - The principal business to be transacted at the first meeting of the board of directors of a eorporation is (1) the election of the officers provided for in the by-laws; (2) the carryiug into effect the resolutions passed at the organization meeting of the stockholders, if any, looking to the payment of the stock in property, or, in lien thereof, the

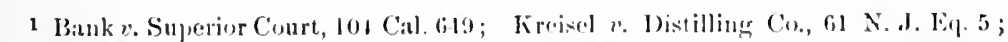
38 I'a. 45.2.

47 Atl. 171; liriphtmatl 2 . Bate.s, 17.5 Matss.

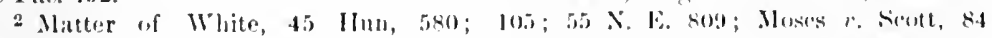

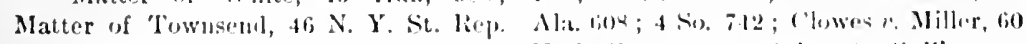
135.

3 Mattrar of Cirmuicile Co., 6.5 limu, $606 ; 20$ N. Y. Sinp. 4!5.

N. I. lip. 179; 17 A \. 345; Sillivin 12

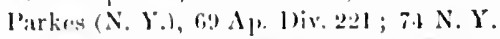

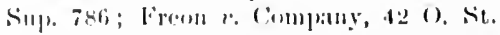

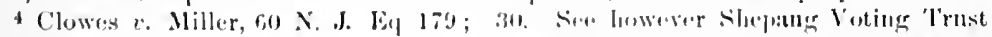
47 Atl. 345 .

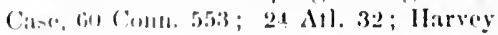

5 N. \& O. R. $x$. Niclols, 98 Ala. 92; 12 r. Compruy, 118 N. C. 693; 21 S. F.

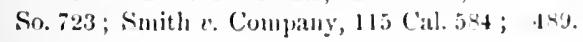


passage of a resolution by the board of directors ordering an assessment, either in whole or in part, upon the par value of the capital stock. 'The general rule appears to be that muless the worerning statute or a by-law of the corporation expressly provides that directors' meetings shonld be held within the domiciliary state, that such meetings may be held without the limits of such state if desired.

Some courts, howerer, apparently distinguish in this regard between meetings of the board of directors for the election of ofliecrs and those meetings merely called for the transaction of routine business. Such courts hold that meetings of the first class must be held within the domiciliary State, while the others may be held withont sucl State if desired. ${ }^{2}$ In nearly half of the States statutes exist authorizing the holding of directors' meetings without the State. ${ }^{3}$ It is mquestionably true that where incorporators can perform constituent aets outside of the domiciliary State directors can elect officers in like manner."

When calling the directors together for their first meeting, the mode of notice provided for in the by-laws must be given. In the absence thereof personal notice must be given, or a waiver of notice must be had from each of the directors. ${ }^{5}$ It is luadly necessary to state in this comection that no director can lawfully delegate power to act for him to another person. ${ }^{6}$

At common law a majority of the directors present and roting at a meeting was necessary to constitute a quorum of the full board.' In some few of the States, notably Oregon, statutory provisions exist permitting less than a majority of the board of directors to constitute a quormm. Provisions in statutes and bylaws requiring the election of directors to be held on a specified date are ordinarily construed to be merely directory. ${ }^{8}$ The general rule is that a majority of the directors constitute a quorum

1 Thompson $v$. Company, 58 Miss. 423 ; Leal Co. 2 . Reinhari, 114 IIo. 218; 21 S. W. 488 ; Bassett $v$. Mining Co., 15 Nev. 293; l'arsons v. Lent, 34 N. J. Eq. 67; IIanna \%. Company, 230. St. 622.

2 Smith v. Mining Co., 64 Mld. 85 ; 20 Atl. 10):2; G. I. \& E. Co. $v$. Toler, 80 II $278 ; 30$ Att. 6.51.

3 , ife l'art Ill. Tahle 12 , pare 582

4 (his, rete. R. R. Co. r. Mcllierson, 35 I10. 13.
5 Bank v. MeCarthy, 55 Ark. $473 ; 18$ S. W. 759 ; B. B. R. Co. r. Buek, 68 Me. 81; Library $v$. Association, $173 \mathrm{~Pa}$. St. $30 ; 33 \Lambda$ tl. 744.

s I'erry $v$. Company, 93 Ala. 364; 9 So. 217; Craig Medicine Co. $\varepsilon$. Mercliants' Bank, 59 Ilun, 661; $14 \mathrm{~N}$. Y. Sup. 16.

' Blackwell $v$. State, 36 Ark. 178.

${ }^{8}$ Bearisley $v$. Johnson, 121 N. Y. 224; 24 N. E. 380. 
for the transaction of business, and a majority of the quorum have power to bind the corporation by their votes. ${ }^{1}$

$\$ 94$. Election of Corporate Officers. - In nearly all of the States statutes exist designating certain officers that business corporations must have, and providing that such offieers shall be elected by the board of directors duly convened for that purpose. Where, however, as is sometimes the case, this power is derolved upon the stockhollers by statute, then directors have no power to elect such officers. ${ }^{2}$ In the absence of such statutes as are here referred to, giving the directors power to clect officers, it must be admitted that the current of authority is to the effect that the power then lies in the stockholders alone. ${ }^{3}$

The law implies that directors shall hold their office until their successors have been elected and qualified. ${ }^{4}$ Where vacancies occur in the board of directors they must be filled, in the absence of statute, charter provision, or by-law giving the power to the directors, by the stockholders only, and eren where the power to fill racancies is lawfully bestowed upon the remaining directors, racancies can then be filled only by action of a majority of the anthorized number of director's. ${ }^{5}$

Questions of policy, or management, or expediency of contract or action, or consideration of gross misappropriation or unlaw ful appropriation of corporate funds to the detrinent of corporate interests, are left generally to the decision of the directors if their powers are withont limitation and free from restraint. To hold otherwise would be to substitute the judgment and discretion of others in place of those determined on by the scheme of incorporation. ${ }^{6}$

$\$ 95$. Appointment of Executive Committee. - The incorporation acts of Connecticut, Delaware, Massachusetts, Nevada, New Jersey, North Carolina, Virginia, and West Virginia all authorize the appointment by the board of direetors from their own number of an executive conmittee to whom may be entrusted most of the ordinary duties that devolve upon the full board of lirectors.

1 'Ten Eyek e. Company, it Micll, 2zo; 41 N. W. 90.5; see also IInyt $v$. Thumpson, 19 N. Y. 207.

2 See In ro St. Ilelen Mill Co., 1n, Saw. 92; Walsenbers Water ('o. v. Nowre, 5 Col. $A_{1}$ 1. $141 ; 38$ I'as. 60.

3 Beardsley rofohnson, 121 N. Y.221; 24 N F. $380 ; \ln$ re. A. A. G. Iron Co., 63 X. J. Law, 168,$357 ; 41$ Atl. $931 ;$.16 Atl. 1057.

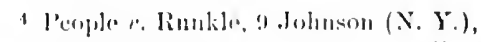

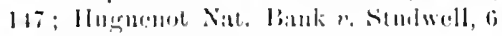
J)ily (X. Y.), :133.

b Muces e. 'I'mulkins, 81 Alt. 613; 4 Sim. 76i3.

"Ell.rman $x$ lig. Co., 19 N. J. E. 21; ; $2: 3$ An. 22, ; I luner v. Complany, 98 IIC. $579 ; 57$ A11. 1001. 
It was at one time held that the performance of any duties loy the board of directors involving the exereise of discretion and judgment could not be so delegated.' 'The modern rule, even in the absence of statute, is that directors have the power to delegate to a part of their own number authority to perform any part of the ordinary business of the eorporation, even though it involves the exereise of the broadest judgment and diseretion. ${ }^{2}$

In any event, whenerer a question is raised as to the validity of acts done by an executive eommittee, the ratification of their action by the full board will undoubtedly correct all defects in the act complained of which would have been valid in the first instance if performed by the board itself. ${ }^{3}$

\$96. Stock Assessments. - Where the capital stock of a corporation is not all issued in the first instance in exchange for property, it is customary for the board of directors to pass a resolution at their first meeting, making an assessment upon the stock of stockholders either for its entire par value or some fractional part thereof. Generally speaking, in order to sustain a right of action on stock subscriptions, it is neeessary to show that a valid call or assessment has been made. ${ }^{4}$ An assessment is a rating or fixing of the proportion by the board of directors or by the stockholders, which every sulsscriber is to pay of his subscription, of which notice is given, which notice is referred to as a "call." 5

While it is doubtless true that a "call" may be made either by the directors or the stockholders, nerertheless it is usually made by the directors. This of course necessitates the organization of the corporation as a preliminary to the making of a valid assessment. ${ }^{6}$ The purpose of the "call" is to fix the time for payment where that is not provided for either by statute, charter provisions, or by-law.7 The better rule seems to be that the

1 Gillis $\imath$. Bailey, 21 N. II. 149.

2 lloyt $r$.'Thompson, ete., 19 N. Y. 207 ; Burikn $v$. lsurden, 159 N. Y. $187 ; 54$ ‥ L. 17 ; Jones $v$. Wrilliams, 139 Mo. 1 ; 40 S. W. 383; Javis $v$. Company, 2 Utah, 74; Tempel v. Woulge, 89 'T'exas, $69 ; 32$ S. W. $514 ; 33 \mathrm{~S} . \mathrm{W} .222$; Metropolitan Triephone Co. v. Company, 44 N. J. Eq. 568 ; 14 Atl. 907 ; Sheridan Jlectric Light Co. 2 . Pauk, 127 N. Y. 517 ; 23 N. E. 467.

${ }^{3}$ U. P'. liy. Co. v. Company, 163 U. S. $564 ; 1$ f S. S. C t. 1173.

10)
${ }^{4}$ Chandler $v$. Siddle, 5 Fed. Cases No. 2594; 3 I Billon, 477.

5 Spangler $v$. Company, 21 Ill. 276.

6 Williams $v$. 'Taylor, 120 N. Y. 244; 24 N. E. 288 ; Williams v. Company, 153 Ind. $496 ; 55$ N. E. 425.

7 West $v$. Crawford, 80 Cal. $19 ; 21$ Pac. 1123; W. S. Bank v. Bank, 107 Mo. 133 ; 17 S. W. 644 ; Champion Fire Kindler Co. $v$. Rischert, 74 Mo. $\Lambda_{1}$. 537. 
directors have implied power by rirtue of their office to make assessments. ${ }^{1}$

In any event, sharcholders may delegate such power to the directors when the same is giren to them by statute or by-law. ${ }^{2}$ It is questionable, howerer, whether the directors have power in their turn to delegate the power of making assessments to some ministerial officer. ${ }^{3}$ In the making of assessments the utmost eare should be obserred to see that all the statutory requirements relative to the same are complied with.

$\S 97$. Certificates required to be made by Officers or Directors after Organization. - In Maine, Massachusetts, Arkansas, and Indiana the statutes require that the board of directors together with certain of the corporate officers shall file a certificate. of organization with certain officers. Ordinarily the failure to file such certificate would not affect the legal character of the corporation unless there was a statutory provision to that effect. ${ }^{*}$ In Illinois, Missouri, Temnessce, and Utals a certificate of due organization is issued to the eorporation by State officials. ${ }^{5}$

In New York, New Jersey, District of Columbia, Nerada, Indiana, Massachusetts, North Carolina, and Coloralo the law requires that after the payment, either in whole or in part, of the capital stock a certificate shall be made and filed in the proper State office setting forth the facts relative to such payment. ${ }^{6}$ In some of the States, notably New Jersey, failure to file such certificate renders the officers neglecting or refusing to make such certificate for thirty days after written request so to do, jointly and severally liable for all debts contracted before the filing of such certificate. ${ }^{7}$

Unless there is a penalty provided, such provisions are merely directory. ${ }^{8}$

1 Budd $v$. Company, 15 Ore. $413 ; 15$ Pac. 659; Smith $x$. Company, I Ilow. (dliss.) 479.

2 Rives $v$. Company, 30 Ala. 92.

${ }^{3}$ Pike $v$. Company, 68 .IJ. 445; S. II. Road $v$. Green, 12 R. I. 164.

4 In re Siliakopec, ctc. Co., 37 Vinn. $91 ; 33$ N. W. 219; Jranklin Brilge Co. v. Wood, 14 Ga. 80; In re Plitialuplohia $\Lambda$ rtisaus Institute, 8 l'hila. $229 ; \Lambda$. S. $\Lambda$. \& G. Co. v. Whittier, 117 Mass. 451.

6 See Boston Acirl MIfg. Co. v. Mo riug, 15 Gray (Mass.), 251.
- Also in Delaware upon request of a ereditor or stockholder.

7 Nassan Bank e. Brown, 30 N. J. In. 478 ; Waters $v$. Quinly, 27 N. J. L. 296. See S. F. N. Bank v. Aluy, 117 Mass. 476 ; Clase's l'at. El. Co.t. ('ompany, 15e Mass. $428 ; 28$ N. V. 300 : Chinse e. Jurl, i7 N. Y. 1; Block i. Womer, 100 Ill. 328; llardman v. Sage, 124 N. Y. 25; 26 N. E. 354 ; Flash 2 Contl, 16 Jili. 428; Austin v. Berlin, 13 Col. 200; 22 l'ac. 433.

8 Veeler $v$. Uudgett, 95 N. X. 295 
5 98. Time in which Corporation must organize and commence Business. - Orer half of the States have provisions upon their statute books requiring corporations to organize and commence business within from one to fire years after the issuance of their charter. Usually the penalty for failure to so organize and commence business is the right given to the State to bring proceedings for the forfeiture of the corporation's charter on the ground of non-mser thereof during the statutory period. It is undoubtedly true, howerer, that as against all but the State failure to organize and commence business within the time limited by statute will not prevent it from becoming a corporation de facto. ${ }^{2}$

\$ 99. Stock Certificates. - Stock certificates are the muniments and eridence of the holder's title to a giren share in the property and franchises of the corporation in which he is a member. ${ }^{3}$ Subscribers to the capital stock upon complying with the terms of their subscription are entitled to certificates of stock showing the number of shares orned by them. 'These certificates must be signed by the officers designated for that purpose by statute or, in the absence of statutory provision, by such officers as are designated in the by-laws for that purpose. ${ }^{4}$ A seal is not necessary to the validity of a corporation of stock in a corporation (although it is customary to affix onc), and this, too, even in the presence of statutory requirements. ${ }^{5}$ Neither is it necessary to the validity of a stock certifieate that it should be issued in the State of the corporation's domicile. ${ }^{6}$ Generally speaking, however, the stock certificate book, seal, and stock transfer books must be kept within the State unless the statute provides otherwise. ${ }^{7}$

Statutory provisions exist in nearly all the States providing the minimum and maximum par value of shares of capital stock. ${ }^{8}$ In some few states the statute expressly provides that all the stock certificates issued by a corporation shall be of a uniform par value. Eren in the absence of such a mandatory provision, it is at least

1 See Part 1II. Table 11, page 581; see also People $v$. Ry. Co., 45 Cal. 306 ; Commonwealth $v$. Water Co., 110 l'a. St. $391 ; 2$ At1. 63.

${ }^{2}$ Lehman $v$. Warner, 61 Ala. 455; S. L. A. \& T. II. liy. Co. v. Company, 158 Ill. 3911 ; 41 N. E. 916 ; County of Macon ข. Shorea, 97 C. S. 272. 595.

Ischanics Bankv. Company, 13 N. Y.
4 N. O. \& T. P. Co. v. Bank (Olnio), 24 Wk. Law Bul. 198; Titus v. G. W. T. Road, 61 N. Y. 237.

5 Fitzhugh $v$. Bank, 3 Monroe (Ky.), 128;

Halsted v. Dorlge, 1 IIow. I'r. (N. Y.) 170.

${ }^{\circ}$ Courtright $v$. Deels, 37 Ia. 503.

7 Perkins $x$. Lyons, 111 Ia. $192 ; 82$

N. W. 486 .

${ }^{8}$ See Part III. Table 6, page 576. 
questionable whether the courts would sustain the issuance of stock certificates of more than one designated par value. ${ }^{1}$ In the absence of statute prohilbiting the same, corporations may insert in stock certificates such stipulations as they choose relative to the rights of the holders of such certificates, and these constitute ralid contracts between the stockholders and the corporation. ${ }^{2}$

1 See In re Cressona Building Ass'n, 1 pany, 129 (Pa.) St. $405 ; 18$ Atl. 414 ; DelaLegal Register (Pa.), 177. As to meaning field $v$. Illinois, 2 Hill (N. Y.), 172.

of par value, see Commonwealtb $v$. Com- 2 Pioueer Co. $v$. Brockett, 58 Ill. Ap. 204. 
CIAPTER IV.

\section{ISSUANCE AND PAYMENT OF CAPITAL STOCK.}

\section{$\$ 100$. General Remarks as to the Issuance and Payment of Cap-} ital Stock upon the Organization of a Corporation. - In connection with the issuance and payment of capital stock following the organization of a corporation, several important matters should be considered, such, for example, as the time within which the capital must be paid in; the question as to how the capital must be paid in with reference to whether in cash, in property, or in services; and, finally, consideration of the safest and most convenient method to be adopted by the corporation so that it can sell a portion of its capital stock at less than par, if necessary, for the procuring of working capital for the corporation; and this, too, without subjecting the purchasers of such stock to any liability to creditors for alleged unpaid stock subscriptions thereon.

It appears that in certain of the States, notably South Dakota and 'Tennessee, it is not necessary that any of the capital stock be either subseribed or paid in, in orcter that the corporation may transact business. In the sereral States provisions of the several incorporation acts in force therein differ greatly in regard to the matter of the time within which capital stock must be paid in. New York requires that half of the authorized capital be paid in within one year; Missouri, fifty per cent thereof immediately ; Maryland, one-fourth of the capital must be paid in each year; in Indiana, manufacturing corporations must pay in all their capital within eighteen months. Twenty of the States require a certain percentage of the capital to be paid in, in order to commence business; while in twenty-five a certain percentage of the authorized capital must be subscribed. ${ }^{2} \Lambda \mathrm{s}$ a general rule the effect of the provisions of law here referred to when they are not complied with has been held not to affect the existence of a corporation as a corporation de jure, but merely afford ground for a

1 See ante, \$ 2.

2 See Part III. Table 6, page 576. 
judgment of ouster in a proper action brought by the State for that purpose. ${ }^{1}$

Sometimes the statutes go further and require certificates as to the payment of the capital stock to be filed in designated offices. ${ }^{2}$

$\$ 101$. Manner of Payment of Capital stock. - Probally no subject of corporation law is more involved in apparently hopeless confusion than that growing out of the question of the payment of capital stock of corporations where the rights not only of stockholders, but creditors as well, are incolred. Frequent attempts have been made from time to time by both State legislatures and the courts looking to the enactment or declaration of rules which will remove the question from its present rague and unsatisfactory form into the realm of certainty and security. It may not be without its practical value to trace here the sporadic development of the various doctrines that have been advanced from time to time relative to both how the capital stock of a corporation may be paid in, and when so paid in whether the valuation placed upon the property accepted by the corporation in exchange for stock, shall be conclusice alike upon stockholders and ereditors. The common law rule with reference to the manner of payment of the capital stock of a corporation appears to have been from time immemorial that it must have been paid for either in money or money's worth. ${ }^{3}$ In this country such a rule scems to have obtained at an early date. Even when required, by constitutional provision or statute, that stock shonld be paid for in cash, nevertheless the courts early adopted the view that the same might be paid for in money or money's worth. Otherwise it would simply put the corporation to the necessity of issuing stock in the first instance for money, and then ordering it to be immediately paid out for necessary labor, property, or services.s

The next step in order of development was the enaetment of either constitutional or statutory provisions expressly anthorizing

1 Baker ". Backins, 32111 79; rargason 2 . Company, i× Miss. 6.5; 27 sio.

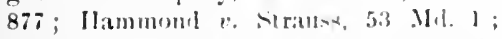

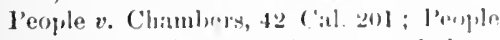
v. Bank, T Col. 226; 3 l'ac. 214; l'almur v. Jawrence, : Siandf. N. K. lat; Latie Ontario, ete. R. Co. $r$. Iason, lif N. Y. 4.51 ; Spartenburg, etc. R. Co. V. Racill, 14 S. C. 281 ; State ex rel. $e$. Well, 97 Ala. $111 ; 12$ So. 377 . 
the parment of stock of corporations in money, property, or services. Later came a wave of constitutional cnactments mainly confined to the Western States, to the effect "that no corporation should issue stock exeept for money, labor done, or property actually received, and deciaring that all fictitions increase of stock should be roid." In early times, when the number of corporations formel were few in number, and their charters limited to a few purposes, the courts were seldom called unon to determine whether or not eapital stock had been actually paid in in accordance with law,-- this for the reason that in most eases the mode of payment of such stock had been in cash. However, carly in the nineteenth century the question became a vital one through the not infrequent attempts on the part of certain corporations to pay for their stock in property taken at a valuation which in the opinion of many was largely fictitious if not fraudulent. When such corporations became insolvent, ereditors, and sometimes before that time stockholders, brought the question in its practieal form before the courts as to whether such valuation were binding not only upon the corporation, but upon its creditors as well. It was such a case which led Justice Joseph Story in 1824 to give utterance to the famous "trust fund doctrine" to the effect that the capital stock of a corporation is to be regarded at all times as a fund held in trust by the corporation for the benefit of its creditors. ${ }^{1}$

In its practical application the trust fund doctrine was found to be an instrument of injustice rather than of justice. Besides this it had never received the sanction of the common law, as it existed in England before the Revolution, and had not in its last analysis any right to demand recognition on the broad basis laid down for it by its founder. By degrees the majority of the courts refused to recognize the trust fund doctrine, at least in its original form, and declared upon the only safe ground, which was that stockholders should only be held liable to creditors on stock issued in exchange for property, upon the ground of fraud." At the same time the courts dirided upon the question whether in the appraisal of property taken in exchange for eapital stock corporations should be required to appraise such property at its true value without recard to the intention of the parties upon whom the duty of

1 See Wurd $x$. Iummer, 3 Mason, 308 ; Fed. Cabes No. 1794t.
2 See opinion of Justice Wm. Mitchell in Ilospes $v$. Company, 48 Minn. 174; $50 \mathrm{~N}$. W. 1117. 
making such appraisal was imposed, or whether they should treat all such appraisals as conclusire upon both the corporation and creditors when made in good faith and where no actual fraud appeared in the transaction. At this time, too, the courts almost universally decided to distinguish in this regard between the rights of the corporation and its stockholders on the one hand and the rights of creditors on the other. Such a distinction as is here referred to was evideneed by the adoption of the rule now recognized everywhere that a valuation placed upon stock by the corporation may be ralid and binding upon the corporation and its stockholders and yet not conclusire as against ereditors. ${ }^{1}$

The doctrine here referred to is well stated by Judge Showalter in a Federal case as follows : ${ }^{2}$

"Whatsoever may have been in fact the value of the property turned over to the company for its stock, the latter agreed to take it for the stock. The persons interested were the stockholders, and there was no dissent on the part of any person concerned in what was thus done. Neither any person thus holding stock nor any person who afterwarls became a stockholder by assigument from one who then held stock can now make complaint on behalf of the corporation against the lawfulness of that transaction. This I take to be the settled law ou that subject."

The next erolutionary step is to be found in the recognition by both the legislatures and courts of a number of the Commonwealths of the unsatisfactory results attending the application of not only the narrow and falsely conceived "true ralue rule" above referred to, but that of the "groorl faith rule" as well. It was clearly seen that something further was needed in order to remove the subject for all time from its sitnation of uncertainty and doubt. Both the legrislatures and the courts of these Commonwealths undertook to remedy the matter, with what suceess it will hereafter apyear. Certain of the States, such as New Jersey, New York, Delaware, West Virginia, Comnecticut, and others, enacted statutes providing in substance that in those casses where corlorations attempled to issue their eapital stock as fully paid in exchange for property,

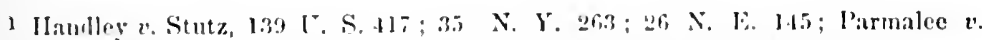

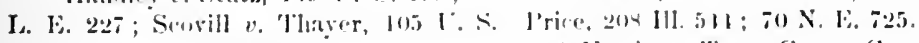
$143 ; 26$ I. E. 968; Larr v. Company, 12:

a Nirlleru Trust Co. 2 . Company, 75 Ficd. 9.36. 
the raluations placed upon such property by the board of direetors thereof should, in the absence of actual fraud or gross overvaluation, be eonchusive in the premises. Again, other States souglit to remedy the evil in a surer, if less generally satisfactory form. 'Thus, for example, Michigan, Virginia, Florida, and other. States have acts upon their statute books requiring a deseription of the property winch they desire to accept in exchange for their capital stock to be submitted to State officials in order that the valuation placed upon such property by the corporation may be approved by such State officials before the stock can be issued; the act further generally providing that after such appraisal has been approved by the State officials, it should be conclusive in the premises.

Turuing now to the efforts of the court on their part to remedy the evil abore referred to, the following may be said. Without in terms adopting what is hereinafter referred to as the "speculative value rule" the courts in recent years have often recognized, in connection with attempts on the part of corporations to issue stock as full paid in exchange for property, the distinetion that clearly obtains between property which has either a well-known or easily ascertained market value and that other species of property of the character commonly known as "speculative," which without any present large intrinsic value, possesses nevertheless in almost every instance a large value for future speculative purposes, not determinable, however, by the ordinary market value standards. Such a rule, when generally recognized, will have the effect in law of practically dividing corporations into two great classes with respect to the question of issuing stock thereof in exchange for property, to wit, non-speculative and speculative corporations.

On the sulject now before us certain portions of the able report of the Massachusetts legislative committee on corporations rendered in 1903, is so peculiarly instructive and appropriate that we venture to quote the following extract therefrom:

"The history of corporations, as well as the logie of the case, shows that there are possible two general theories as to the State's duty in creating corporations: first, the old theory that, being creatures of the State, they should be guaranteed by it to the public in all particnlars of responsibility and management; and the modern quite onusite theory that, in the absence of fraud in its organization 116 
or govermment, an ordinary business corporation should be allowed to do anything that an individual may do. Under the old theory, the capital stock of a corporation was, in the law, consiclered to be a guarantee fund for the payment of creditors, as well as affording a method of conveniently measuring the interests of the individual owners of a corporate enterprise. There resulted from this principle not only the fundamental proposition that the capital stock, being in the nature of a guarantee fund, should be paid up at its full par in actual cash, but all the other provisions to protect creditors or other persons having dealings with the corporation: such as, that the debts of a corporation should not exceed its capital stock, designed primarily in the interest of creditors and secondarily in that of the stockholders, who were looked after as carefully as if they were the wards of the State when dealing in corporation matters. Under the modern theory the State owes no duty to persons who may choose to deal with corporations, to look after the solvency of such artificial bodies; nor to stockholders, to protect them from the consequences of going into such concerns, the idea being that in the case of ordinary business corporations the State's duty ends in providing clearly that creditors and stockholders shall at all times be precisely informed of all the facts attending both the organization and the management of such corporations, and particularly that there should be full publicity given to all details of the original organization thereof.

"The committee has had little hesitation in determining which of these theories it should adopt. The limit of capitalization both in amount and in valuation to the net tangible assets of the corporation has unquestionably had much to do with the arrest of corporate growth in this Commonwcalth. Good-will, trade-marks, patents may unquestionably be valuable assets, which, under our present method, may not be capitalized. Admirable as this theory may have been, of payment of capital stock in full in cash, the condition is so easily avoicled in practice that the result is that our existing law promises a protection which, in reality, it does not afford, and is merely an cmbarrassinent to those who feel obliged to cemply not only with the letter but with the spirit of the law. It is no longer true that persons dealing with corporations rely upon the State laws to gnarantee their solvency or their proper managenent. The attempts of the Commonwealth to do so by laws still remaining on its statute books result, as we apprehend, only in a false snise of security; and we believe that the act proposed, while giving "up the attcmpt to to the impossible thing, will really, ly its greater attention to the details of organization required to be marle public ly all corporations, result in an arvantage to stockholders and creditors more sulstantial than the 
present partial attempt to enforce a principle impossible of complete realization and which is, under existing laws, easily evaded.

"It is impossible to reconcile or combine the two systems. Either the old theory must be maintained, under which the State attempts thougl vainly to guarantee both to stoekholders and creditors that there is one humdred dollars of actual value behind each one hundred dollars of par value of capital stock, or some other system must be atopted which, while not being chargeable with the vagueness and laxity of the newer legislation of other States, will permit a share of capital stoek, although nominally one hundred dollars in value, to represent, as the word implies, only a certain share or proportion, which may be more or less than par, of whatever net assets the corporation may prove to have. Under a system of this sort the State machinery will only provide that the stockholders and, perhaps, the creditors, may at all times have access to the corporation records or returns in such manner as elearly to show, both at organization and thereafter, all of the property or assets of which such share of capital stock actually represents its proportion of ownership.

"The question of monopoly the committee does not conceive to have been left to its consideration. The limitations now existing on the capitalization of business corporations are, no doubt, attributable to the sentiment which has always existed against monopoly, but it is clearly the poliey of the Commonwealth, as shown in its recent legislation, to do away with the attempt to prevent large corporations, simply because they are large. Moreover, it is apprehended that the question of monopoly, or rather of the abuse of the power of large corporations, does not result necessarily from the size of corporations engaged in business throughout the United States. In the opinion of the committee, some confusion has been created, in the discussion of the form of so-called trust legislation, by a failure to appreciate that its real olject is not to protect the investor, who can or should learn to take care of himself, or the creditor who has already learned to do so. The real purpose of such legislation is the protection of the consumer. In other words, therc is no reason for an arbitrary limitation of capitalization unless it can be used as a means of creating a monopoly which will influence the price of commodities. In the opinion of the committee, the question of capitalization is not a contributing factor in the fight for a monopoly. The Unitcd States Steel Company wonld have no greater and no less a monopoly of the steel business if it were organized with one-half of its present capitalization. The Standard Oil Company has a very conservative capitalization, and yet it is the most complete monopoly of any industrial corporation in this country. 
"At all events, it is no better for the State to leave its citizens at the mercy of the large corporations created by other less careful sovereignties, than to permit the organization of corporations adequate to the demands of modern business unler its own laws, subject to its own more careful regulation and control. Under our State and Federal system it is practically impossible for any one State, by its own laws, to control foreign corporations, but so far as possible at present the committee has sought to subject them to the same safeguards of reasonable publicity and acenrate returns, both as to organization and annual condition, as the State requires of its own corporations. The simple requirement of an anmul excise tax, based on the capitalization of such foreign corporations, will serve to bring them under the control of this State, and the way will be open for their further regulation if desirable. This ammal tax has been levied upon the same principle as the corresponding tax paid by home corporations. The State should inpose no greater burden on foreign corporations than on its own, but should, so far as possible, subject them to its own laws.

"The committee rould repeat its opinion that, so far as purely business corporations are concerned, and excluding insurance, financial, and public service corporations, the State camnot assume to act, directly or indirectly, as guirantor or sponsor for any organization under corporate form. It can and should require, for itself and for the use of all persons interested in the corporation, the fullest and most detailed information, consistent with practical business methols, as to the details of its organization, the powers and restrictions imposed upon its stockholders, and as to the property against which stock is to be or has been issued.

"Capital stock may be paid for in cash or by property. If it is paid for in cash, it may be pail for in full or by instalments, and a machincry has been created for protreting the corporation against the failure of the subscribers to stork to pay the balance of their subscriptions. If stock is pail for by property, the incorporitors and not the State are to pass upen its value. liefore any stock, however, can be issued for property, a clescription of the property sufficient for purposes of identification, to the satisfaction of the Commissioner of Corporations, must be filen in the ollice of the Secretary of the Commonwealth. This document heeomes a publie record, and may be consulted by any one interested in the corporation. If the oflicers of a corporation make a return which is false and which is known to be false, they arc liable to any one injured for actual damages. If a full and honest description is male of property against which stoek is issucd, a stockholder cammot complian beeanse of his failure to inform 
himself by personal examination or investigation of the value of the preprerty in which he is, or eontemplates becoming, an investor.

. The second principle "yon which the committee has acted in its specific recommenciations is this: that the State should permit the utmost freelom of self-regulation if it provides quick and effective mathinery for the punishment of fraud, and gives to each stockholder the right to obtain the fullest information in regard to his own rights and privileges before and after he becomes the owner of stock."

$\$ 102$. Payment of Capital Stock in Services. - The statutes of Alabama, Arkansas, California, Colorado, Delaware, Florida, Ilaho, Kentucky, Maine, Missomi, Montana, North Dakota, Sonth Carolina, South Dakota, Texas, Utah, Virginia, Washington, West Virginia, and Wisconsin expressly anthorize the payment of stock in serrices. It sometimes becomes a question of importance to know just what is meant hy "services" as used in this connection. Frequently attempts are made to issue stock to persons gratuitously for the use of their mame in the promotion of the corporation under the theory that permission to use their name is a proper service rendered to the company, against which stock may be issued. The current of authority seems to be against this proposition.2

Still again, the constitutional provision which exists in many of the States declaring all fictitions increase of stock roid militates against such lines of procedure. ${ }^{3}$

Oftentimes an attempt is made to issue stock to promoters of colporations muder what is known as "promotion stock." The promoters are usually the incorporators, and as such are not entitler to gifts of stock. However, if in the promotion of the compang serviees and time have been employed, the same may be recompensed to the extent of the just value of such services.

S 10:\%. Payment of Capital Stock in Property. - In most of the Commonwealths statutes exist expressly anthorizing the payment of eapitial stock of a corporation in property. ${ }^{5}$ Even in the absence

1 Sice Arapahor, etc. Co. v. Stevens, 13 C.1. 534 ; 22 Pac. 823 ; Clevenger $v$. Moore ( (.. J.), 58 Atl. 88.

2 P. S. Bank v. Company, 105 Mich. 535 ; 93. X. W. 514 ; Christensen $v$. Eno, $105 \%$ X. Y. $97 ; 12$ ×. E. 648 ; Handley $v$. Stutz, 139 C. S. 417 ; 35 Law Ld. 227; $1 \div 0$
Fogg v. Blair, 139 U.S. 118; 35 Law Ed. 104.

3 See Hellerman $v$. Maier, 116 Cal. $416 ; 48$ Pac. 377.

+ Brown $v$. F. S. II. Co., 119 Fed. 472.

5 See Part III. Table 10, page 580. 
of such statute stock may doubtless be issued in the same manner, provided the purchase of such property is within the express or implied powers conferred by the charter and the property is of such a character as to be suitable for the specific purpose for which the corporation was formed. ${ }^{1}$ Some few of the States describe in considerable detail just what kinds or classes of property may be accepted by the corporation in exchange for its capital stock. The incorporation acts of Alahama, North Carolina, Virginia, West Virginia, and New Jersey are particularly full in this regard. In the absence of such provisions corporations under the restrictions stated above may accept in payment of their capital stuck all kinds of real and personal property having some monetary value, such as mining lands, gas lands, patent rights, sceret formulæ, trade-marks, and the good will of an established business. ${ }^{2}$

The payment of capital stock may be made in notes, bonds, or mortgages in the absence of any statutory or charter prohibition. ${ }^{3}$ But as to creditors, if the notes, bonds, or mortgages should turm out to he worthless, the parties accepting such stock might be compelled to pay the par value of such stock in money. ${ }^{4}$ So it has been held that stock of a corporation may be paid for in advertising, ${ }^{5}$ in a license to take minerals from lands, ${ }^{6}$ and in stock in other corporations. ${ }^{7}$

In other words, capital stock of a corporation may be issned against any property which the corporation is authorized to purchase, or which is necessary for its legitimate business. ${ }^{8}$

One of the most frequent questions with which an attorney has to deal in comnection with the organization of a corporation has reference to devising some safe method whereby stock may be legally issued in the first instance as full paid and non-assessable, to be thereafter sold below par if necessary for the purpose of procuring a working capital for the company. The main thing

I Jichke $v$. Kinapl, 79 Mo. 22.

2 Lourl $\because$. Company, 1.53 I'. S. 564; 141 S. Ct. 928; Carr r. La Fevre, 27 l'a. 417 ; American 'lube \& Iron Co. 1. Com-

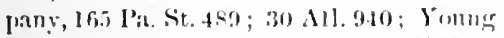
r. Company, 65 Mich. 111: 31 X. W. A11; Washburu $\%$ Company, 81 Fesl. 17; Wlitehill v. Jacols, ij Wis. 4it; 4 N. W. 630; Bank r. Comprany, 32 W. Va. 37 ; 59 S. 1‥24:3; Kelly e. Clark, 21 Nont. $319 ; 53$ l'ac. 959.
3 Gomblich $v$. Reyuolis, 31 111. 490; Stodiard r. Company, 4 Comm. 545.

4 limtur $v$, Jenent, 1:23 III. 142; 14

N. 1\%. 6i2.

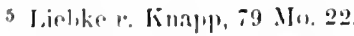

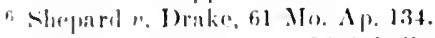

F Ert N. Y. J. R. (O) r. Lighllhall, 36 II)w. I'r. 4R].

8 Brmoer $\ell$. liruwn, 139 Ind, $600 ; 38$ N. IS. 318. 
to be kept in mind in comnection with the foregoing is to see that the stnek is so issucd that future purehasers thereof shall not be liable thereon either to the corporation or to creditor's. 'This can be acemplished most satisfactorily in the following mamer.

Ilave the corporation acept the proposition to issue its capital stock, cither in whole or in part, against real or personal property to be thereafter duly conveyed or transferred to the corporation. Next the property so conveyed or transferred should be appraised at a raluation which will stand the test according to the claracter of the property so conveyed or transferred of either the good faith or the speculative value rules already referred to. The next step is for the praty to whom such stock is issued to transfer such stock, either in whole or in part, back to the corporation under a trust agreement providing that the same shall be sold at such times and at such prices as to the board of directors of the corporation will seem adrisable for the purpose of procuring the necessary working capital. Under such circumstances the stock so transferred, while originally issued at par, may be sold at the best price obtainable, and the purchascrs will not incur liability beyond the agreed price cren to subsequent creditors. ${ }^{1}$ The same is true of stock that has been forfeited for non-payment of assessments. ${ }^{2}$

$\$ 104$. Statement of True Value Rule. - In connection with the appraisal of property taken by a corporation in exchange for its capital stock, the courts liave established rarious rules with a view to laying down some satisfactory principle upon which such appraisal may be based in those cases where creditors seck to cuforce as agrainst the holders of such stock an alleged liability for unpaid stock subscriptions. The various rules here referred to may be emmerated as follows: "the true valne rule," "the good faith rule," and "the speculative value rule." It is to the first of these that our attention will now be directed.

What is known as "the true value rule" is a natural outgrowth of the adoption by many of the courts of the trust fund doctrine enunciated by Judge Story in Wood $v$. Dummer. ${ }^{3}$ 'This may be

1 Iron Co.ft al. v. Hayes ct al., 165 Pa. 7 S. Ct. 482; Coleman v. IIowe, 154111. St. $489 ; 30$ Atl. 936 ; Lake Sup. Iron Co. 458; 39 N. E. 725 ; limball $v$. Company, r. 1)rexel, 90 N. Y. 87 ; Davis Bros. v. 69 N. 11. $485 ; 45 \Lambda$ tl. 253.

Company, 101 Ala. 127 ; 8 So. 496 ; Alling 2 Pullman v. Company, 33 Ill. Ap. 313 ; v. Worzel, 133 Ill. $264 ; 24$ N. L. 55I; Otter v. Company, 50 liarb. 247.

MI. \& L. R. Ry. Co. v. Dow, 120 U. S. 287 ;

3 Mason, 308; Fed. Cases, No. 17944.

122 
stated as follows: That the courts will not treat anything in the shape of property accepted by the corporation in exchange for its capital stock as payment thereof except to the extent of the true value of the property received, wholly withont regard to the presence of fraud or the absence of good faith in the transaction. ${ }^{1}$

Not only has the true value rule been adopted by many eourts, irrespectire of statute, but it las found legislative recoguition as well. Thus the incorporation act of Alaska requires that such property shall be assessed at its true money value; that of Connecticut and Delaware, at its actual value; in Kentucky, at its market price; in North Dakota and Sonth Carolina, at its true money value; in Tennessee and Utah, at its fair casls value, and Florida, at a just raluation. In Connecticut, Massachusetts, and North Dakota the necessity of making such appraisal according to the strict letter of the statute is rery foreibly suggested by making the directors liable to all parties injured thereby in ease they fail to make such appraisal as directed by the act. Statutory provisions which exist in so many of the States declaring all fietitions increase of stock roid have been held by the courts not to make the ralidity of an orer-issue of stock dependent upon the inquiry whether the money or property receired therefor was of equal value in the market with the stock so issued, or to restrict private corporations acting without the approval of their stockholders in the sale of their stock for money, property, or labor done upon such terms as they might deem proper, provided always tlıat the transaction is a real one, based upon present consideration, laring reference to legitimate corporate purposes, and is not merely a device to erade the law and accomplish that which is forbidden. ${ }^{2}$

$\$ 105$. Statement of Good Faith Rule. - As has already been observed in a previons section, ${ }^{3}$ the trust fund theory of Justice Story no longer obtains in a majority of the States. With the absence of any general recognition by the courts of this doctrine, there necessarily followed the abrogation of the true value rnle, which was based largely upon the trust fund doetrine. In its place has appeared in many jurisdietions what is known as the "good faith rule." The true value rule in its practical application was harsh and unconscionable, was wholly in the interest of

1 Shickle v. Watts, 94 Mo. $410 ; 7$ Pac. $582 ;$ M. \& L. R. Ry. Co. v. Dow, S. W. 274 .

2 Sinith 2 . Company, 115 Cal. 584; $47 \quad{ }^{3}$ Ante, $\$ 101$. 
creditors. and male little accomt of the interests of equally imnocent stockholders. The good faith rule, on the other hand, while often diflicult of practical application, is much more liberal and farr to all concenced than the rule which it is now so rapidly supylunting. It may be stated as follows:

'That where the governing statute anthorizes the shares to be paid for in property instead of cash, or where the law of the State concedes this power, then the fact that they are so paid for at a fail valuation of the property, affords no ground of complaint to the creditors, provided such payment is made and accepted in good faith. In fact, in order to render the transaction void either gross over-valuation or actual fraud must be shown. ${ }^{1}$

In order to obtain a clear understanding of the distinction that exists between the true value rule and the good faith rule, it is necessary to understand the reasons which actuated so many of the courts in repudiating in the first instance the trust fund doctrine in order to elear the way for the adoption by such courts of the grood faith rule. Nowhere will be found a better statement of this matter than that presented by Justice William Mitchell of the Minnesota Supreme Conrt in the case of Hospes $v$. Northwestern Manufacturing Company. ${ }^{2}$

"It is difficult," said Justice Mitchell, "if not impossible, to explain or reconcile decisions and cases bearing upon the trust fund doctrine, or, in the light of them, to predicate the liability of the stockholder upon that doctrine. But by putting it upon the ground of fraud, and applying the old and familiar rules of law on that subject to the peculiar nature of a corporation and the relation which its stockholders bear to it and to the public, we have at once rational and logical ground on which to stand. The capital of a corporation is the basis of its credit. It is a substitute for the individual liability of those who own its stock. People deal with it and give it credit on the faith of it. They have a right to assume that it has paid in capital to the amount which it represcnts itself as laving; and if they give it credit on the faith of that representation, and if the representation is false, it is a fraud upon them; and in case the corporation becomes insol-

1 Bank v. Alden, 129 U. S. $372 ; 32$ Whitehill $v$. Jacobs, 75 Wis. 474; 44 L. E. 725; Roorl $v$. Wharton, 74 Fed. 118; N. W. 6.30; Young ". Company, 65 Mich. Coit $\because$ Company, 119 U. S. 343 ; 7 S. Ct. 111 ; 31 N. W. 814.

231 ; Joyutom $v$. Hatch, 47 N. Y. 225;

248 Minn. 174;50 N. W. 1117.

Van Cott $v$. Van Brunt, 82 N. Y. 535;

121 
rent the law, upon the plainest principles of common justice, says to the delinquent stockholder, 'Make that representation good by paying for your stock.' It certainly cannot require the in rention of any new doctrine in order to enforee so familiar a rule of equity. It is the misrepresentation of fact in stating the amount of eapital to be greater than it really is that is the true basis of the liability of the stockholders in such cases; and it follows that it is only those creditors who have relied, or who can fairly be presumed to have relied, upon the professed amount of capital, in whose faror the law will recognize and enforce an equity against the holders of 'bonus stock.' This furnishes a rational and uniform rulc, to which familiar principles are easily applied, and which frees the subject from many of the difficulties and apparent inconsistencies into which the 'trust-fund' doctrine has involved it; and we think that even when the 'trust fund' doctrine has been inroked the decision in almost every well-considered case is readily referalle to such a rule."

Another statement of the good faith rule is to be found in Kelley $v$. Company, to the following effect: If the nature of the property and the extent of the valuation are such that the latter might have been due to errors of judgment, then to render the transaction invalid as against creditors actual frand must be shown, and the question is one of fact. On the other hand, if the orer-valuation is so gross that it could not have been due to mere errors of judgment, the transaction will be held fraudulent as a matter of law.

$\S 106$. Statement of "Speculative Value Rule." - It must be admitted that neither the "true ralue rule" nor the "good

121 Mont. 319 ; 51 Pac. 959.

2 Coleman $v$. IIswe, 154 III. $458 ; 39$ N. E. $725 ;$ N. II. II. N. Co. v. Company, 142 Nass. $349 ; 7$ N. Li. 733 ; Ilastiness Malting (o v. Comprany, 65 Mimn. 28; 67 N. IV. 6.52; Northern 'l'rust Co. v. ('om. pany, 75 Fed. 936; allirmed in llorkinsom $v$. Northeru'I'rust Co., solierl. 4.52; Washburn v. Company, 81 lied. 17; Gomlrich

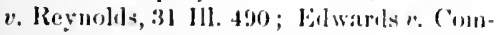
pany, 27 La. Amu. 474; Whitrhill e. Jatobls, 75 Wis. $474 ; 44$ N. W. 6.30) 11 mmaston e. Company, 20 Wull. 20 ; State r. Wriht, 110 Nla. 211; 20 So, 462; Skinurer $v$. Smitl, 134 N. Y $210 ; 31$ N. F. 911; l'armalce v. l'rice, 208 111.541; 70 ㅈ. li. 725; Phelan $r$. Ilazatrd, 19 Jiel. C'atus No. 11068 ; 5 1)ill. 45; Sunth v. Ferrice, cte.
Ry. Co. (Cal.), 51 Iac. 710 ; Jenkins $v$. Bralley, 104 Wis. 540 ; 80 N. W. 1025; Gamble r. Q. C. IV. Co., 123 N. Y. 91 ; 25 N. E. 201 ; Ioung 2 . Erie Iron Co., 6.5 Micl. $111 ; 31$ N. W. 81t; Bank 1. Mllen, 129 U. \&. $372 ; 32$ l. E. 72.5 ; ('ollin n. Ranstlell, 110 Jul, $41 ; ; 11$ N. E.

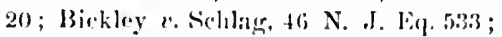
20) Atl. 250 ; S. R. (. S. Co. r. Rankin, 45 III. $\Lambda_{p}$. 226; Brmuer 2 . Brown, 139 Ind. 600; 38 N. L. 3I8; Gilkie, ete, Co.

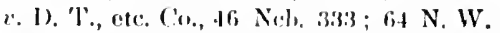

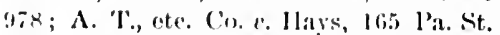
$489 ; 30$ Atl. 936; Junes r. Whitworth, 94

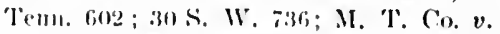
s. (\%, ete. (i), 16; Wasl, 499; 48 l'ac. 3333 ; 'Jaylor $v$. Coummings, 127 Ferl. 108. 
faith rule" affords a satisfactory basis for determining all questions that maly arise relative to the issuance of the capital stock of a corporation as full-paid and non-assessable in exchange for property transferred to it. In practice, neither the inequitable "true ralue rule" nor the fairer" grood faith rule" will be fonnd to rest on any satisfactory or substantial basis. Of late rears, without in terms ealling it by that particular name, courts of high repute hare in substance adopted what will be termed here the "speculative value rule." 'This may be defined as that rule whereby a corporation is permitted, in issuing its capital stock as full paid and non-asscssible in exchange for either real or personal property, to appraise the latter at its potential speculative value, looking towards its future development rather than at its present intrinsic value. The statement of the rule would be ineomplete withont adding that in all cases where such appraisal is questioned, the burden of proof of attacking the same is upon the ereditor.

The rule in its practical application throws upon the creditor the burden of showing that, viewed from a purely speculative standpoint, the appraisal made by the corporation of such property constituted not merely an over-rahuation, but a fraudulent overvaluation as well. Before attempting to discuss at length the "speculative ralue rule," as stated above, it might not be without its adrintage to trace bricfly those crolutionary steps along legal lines which appear to have paved the way for a fuller recognition on the prart of the courts of the rule here contended for. In the first place, we have the enunciation by Justice Story, in 1824, of the now all but moribund "trust fund doctrine" already referred to. ${ }^{1}$ Then ensued a period of year's when the conrts, one after another, proceeded to adopt the doctrine just mentioned, although it was mknown to the common law. Gradiually, however, it came to be recognized that the trust fund theory was wrong in principle as well as incruitable, leading in its practical operations to harsh and unconseionable results. This gradually led to the adoption by many courts of a better and more enlightened doctrine which predicated the liability of stockholders to creditors, not upon the trust fund doetrine, but upon the sounder ground of fraud. ${ }^{2}$

$$
30 \mathrm{~s}
$$

1 Sire Wrood $r$. Dummer, 3 Mason, U. S.

2 Sire statement of this doctrine by $1: 1 ;$
Justice Mitchell in IIospes v. Company, $48 \mathrm{Minn} .174 ; 50 \mathrm{~N}$. W. 1117. 
This was followed by the enunciation on the part of certain courts of several important rules governing the question of the burden of proof in eases where attempts were made by creditors to enforce an alleged stockholder's liability, on the ground that the property against which such stock had been issued had been grossly over-valned. A fair presentation of the rules here referred to may be found in the opinion of the Supreme Court of Minnesota, in Hastings Malting Co. v. Iron Range Brewing Co., ${ }^{1}$ reading as follows:

"In principle it ean make no difference whether the stock issued as paid up is bonus stock, pure and simple, or whether it was sold for cash for less than its par value, or for property at a gross overvaluation. In the first two eases the question of frand would be one of law, for on the issuing by the corporation of its stock as paid and its acceptanee by the stockholders when in fact nothing was ever paid for it, or where a sum of money less than its par value was paid and accepted for it, there is no opportunity for a mistake of judgment; the law in such cases presumes an intention to defraud. Ordinarily, however, the question is one of fact.

" $\mathrm{U}_{\mathrm{l}}$,on prineiple and authority a corporation may in good faith issue paid up shares of its stock for the purehase of property at a fair valuation, and in such ease the corporation and its ereclitors are bound by it.

"In the practical application of the rule it must be kept in mind that fraul, actual or constructive, is the basis of the stockholder's' liability to the ereditor. On the one hand, the value of the property is to be deternined, not from subsequent events, but as of the time of the transaction, and from the nature, situation, and condition of the property as they honestly appeared to the parties at the time. Nlthongh there was in faet an over-valuation of the property, it will not render the stoekholders liable for the leficiency if it was the result of an honest mistake or error of jurlgunent. On the other hand, where the nature and condition of the property are such that its ralue is well known and unlerstood, or is cantable of being reatily estimated and ascertained, and the property is transfermen to the corporation at a gross over-valuation for paill-up shares, the transfer is prime furie frandulent as to subsequent creditor's, and as aribust them the burden is upon the shareholders to rebut the presmmptimn."

It is a principle of law misersally recognized that, except in eases of trust rclationships. the lurkn of prof in all casces relative

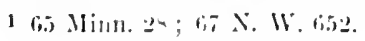


to prool of fraud is east mpon the party who alleges that such flatud exists.'

liy no streteh of the imagination ean the relationship that exists between ereditors of a corporation and the corporation itself be termed a ".trust relationship." 'The relation is neither confidential nor fiduciary, as the same is construed by the courts. ${ }^{2}$ 'There is no more reason for treating this relationship as one of trust than there is in the ease of ordinary erediturs and debtors. It was doubtless, howerel, as a sort of concession to the fanciful trust fund doetrine of Justice Story, that there early appeared a tendency, upon the part of eertain courts, to engraft thereon the absurd principle that, where the board of directors of a corporation hare duly appraised in the first instance property taken by the latter in exchange for its capital stock, the rule should obtain that where such property has a well known or easily ascertained value, and is taken at a valuation which to the comt seems greatly in excess of its real value, then in such cases it will be presumed that such valuation is not made in good faith, but is male for a fraudulent purpose. 'To overcome this presumption the burden is upon the stockholders to introduce satisfactory evidence explanatory of this presumptively frandulent overraluation. Some courts even went further, and asserted that where the over-valuation was so great that the fraudulent intention appeared on its face and it is not explained, it should be held frandulent as a matter of law, without submitting the question to a july.

These drastic rules had full sway for a number of years, until certain of the courts saw fit to modify their rigor to no inconsiderable extent. Then the rule was enunciated that where stoek has been paid for either in property or services, although it appears that there was an over-valuation in appraising the same, yet if it appears to the court not to be so gross and unconscionable as to compel it to say, as a matter of law, that it must have been intentional, it will be presmmed that the valuation was honestly made, and the burden of attacking the same will be upon the creditors who seck to hold the stockholders npon an alleged stockholder's' liability fol' unpaid stock subseriptions. ${ }^{3}$

1 See Phelan $v$. Inzarl, 5 I)il. 45; . N. I. 725 ; I)avis Bros. $v$. Company, 101 Bickley 2. Schlag, 46 N. J. Ei. 533. Ala. $127 ; 8$ S. W. 496 ; Manhattan Trust 2 Sief Robinson v. P'ope, 57 Cal. 496 . Co. $v$. Company, 16 Wash. 499 ; 48 I'ac.

a Coleman v. Howe, 154 Ill. $458 ; 39333$. 125 
So much, then, for the historical development of the various doctrines relative to the subject matter now before us. Turning again to consider the "speculative ralue rule," the same must be looked at from two separate and distinct standpoints, to wit: (1) as diriding all properties which a corporation proposes to take over in exchange for its capital stock into two broad and well-defined classes, known respectively as "speculative" and "non-speculative" properties; (2) as establishing a rule for appraising the ralue of speculative properties based not upon the intrinsic valuc of the same, but rather upon their arailability for purposes of speculation, looking towards an enhancement of their present value by the future expenditure of funds in the derelopment thereof.

Let us now turn our attention to the classification of propertics abore referred to designated as "speculative" and "non-speculative." "Speculative" properties may be defined as those whose nature is such that they have not only a present intrinsic value, but a considerable potential valuc as well, speculative in its nature, and dependent upon future development in order to arrive at a definite estimation as to the amount thereof. Non-speculative properties, on the other hand, are those whose intrinsic worth alone gives them a market value or a value which ean be easily ascertained by reference to well-recognized standards of value. In the first class of properties might be enumerated mining rights, patent rights, oil and gas lands, sccret processes and trade secrets, patent medicines, etc. In the second class might be named real estate to be employed for business, dwelling, farming, and grazing purposes, stock in trade and personal property which is the common sulject of bargain and sale between man and man at current prices, determined by the law of supply and demand. In the opinion of the Supreme Court of Ninnesota, in Hastings Malting Company v. Iron Range Brewing Company, cited abore, it will be noted that the rule that is to be applied in those cases where the nature and condition of the property are such that its ralue is well known or understoorl, or is capable of being readily estimated and ascertined, is elearly stated. 'The oprinion, however, fails to state with equal clearness the rule that is to be applied where the value of the property is not of the character just deseribed, but is of that type herein referred to as "speculative," having no present or well-known readily ascertained 
ralue. but depending entirely upon future development in order to determine what such value may he. By implication only is the truc rule in such cases suggested by the Mimnesota court. However. in Kelly $v$. Clark, ${ }^{1}$ the Montana supreme Court in effect declares the rule in such cases to be that where the property is speculative in character, and as such the alleged over-valuation thereol may have been possibly due to error's in judgment, then the burden of proof is upon the creditors seeking to attack the valuation by showing actual frand in the transaction.

Let us turn now to the question as to how the valuation of speculative properties is to be asecrtained. Generally speaking, the rule to be adopted is this: "What, under all the circumstances, considering the proposed use to which it is to be put, and the general purpose for which the corporation was created, is the fair value of the property against which its capital stock is to be issned?" 2 In this age of speculative enterprises it is a matter of common knowledge that the value of properties taken over by corporations about to embark in speculative enterprises is dependent almost wholly upon their availability for the purpose in hand and upon the promise which external appearances give them as to their haring a large and considerable potential value. Thus, for example, sixty square feet of land may have a very small intrinsic value when considered as farming, grazing, or residence property, and yet possess an immense potential value when treated as mining property. It is the expectation of success which induces investors to put their money into such enterprises, and which justifies a valuation far in excess of the property's intrinsic value. Such valuations, it must be admitted, are necessarily arbitrary in character. This fact the legislatures in many States have recognized, and the courts shonld not hesitate to do the same. ${ }^{3}$

The value of property which is transferred to the corporation is also not to be estimated by what it cost the promoter. It is the speenlative and experimental results which afford a basis for the large valuation. By value in such eases is meant the speculative raluc for the uses and purposes of the company in its proposed speculative cnterprise, and not the actual market value or the

121 .Iunt. $291 ; 53$ Pac. 959.

2 Sor. Gianble $v$. Company, 123 N. Y. $\$ 410$.

$91 ; 2.5$. ‥ 1. 201. 
actual intrinsic value thereof at the time the propertics are taken over by the company.

The riew of the matter here presented was first suggested, it is beliered, by the United States Circuit Court many year's ago in the case of the South Mountain Consolidated Mining Co. ${ }^{1}$ At the trial below in this case the court spoke as follows:

"The mode in which mining companies are formed is familiar to all. The owners of the property, or persons expecting to become such, by complying with a few simple formalities form themselves into a corporation, to which the property is conveyed. The amount of capital stock which is required to be stated in the certificate of incorporation is usually fixed at a purely arbitrary sum, and divided into as many shares as convenience or caprice may dictate. It neither bears nor is intended nor supposed by the public to bear the slightest relation to the real value of the property - a value nearly always conjectural and very often imaginary."

In this same case on appeal the court observed as follows : ${ }^{2}$

"The mode of forming mining corporations is well known to any body. A prospector finds, as he supposes, a valuable mine. It requires eapital to work it which he does not possess. IIe goes to the money and business centres, where he finds capitalists accustomed to organize corporations for the development of new mines, and makes such arrangements as he can. He presents such evidence of the value of his mine as he has obtained. Little is known of the real value. It may be worth nothing and it may be worth millions. larties are found willing to take hold of the enterprise. They agree to incorporate and fix the capital stock at some purely nominal amount, and diride it into a certain number of shares, corresponding to the amount of capital adopterl. The owner of the mine, for an agreed number of shares and in consideration of the promises of the other parties to assist in the development of the mine, eonveys the mine and receives for it the amonnt of stoek agreed upon. The other jarties, for their serviees in orranizing and managing the eompany and its business, receive a latre protion of the stock, this being usually a considerable amount of stock reserved by the company, which is put upon the market and sold for such priec as can be whtaned, to mise? a fund to secure machinery and develop the mine. The priec of this stock is of eourse determined by the presperet of the mine, its location, and its probahn richness, and the confinlmor of the public reposed in

1 T Sawyer, 30; 8 Sawger, 366.

28 s.twger, L.S. 366. 
the experience, ability, and character of those having the management. Mining eorporations are sui generis. They are organized and earried on npon prineiples wholly different from banking, railroad, insurance, and orlinary commereial corporations having a subseribed capital stock."1

But nowhere is the speculative element in the valuation of property hetter considered than by the Supreme Court of Pennsylvania, in the case of Iron Co. et al. $v$. Hays et al. ${ }^{2}$ 'The facts in this case briefly stated are as follows:

A corporation was organized by two co-partners to take over certain lands owned or leased by them and believed to contain gas and oil. They capitalized the company for $\$ 500,000$, and issued the whole of its capital stock to themselves against the properties above referred to. These latter had an intrinsic value representing but a rery small pereentage of the eapitalization of the company. The incorporator's retained $\$ 175,000$ of the capital stock of the corporation for their own benefit, and transferred the balance to the corporation in trust to be sold by the board of directors thereof for the purpose of procuring working capital for the corporation. Later on, the lands proved to be practically worthless, and the company became insolvent, and creditors thereof sued the stockholders, alleging that the stock held by them had not been fully paid for. In passing upon the various legal questions involved, the court spoke as follows:

"Attention should be called first to the method of organization, to the facts showing the situation of the parties, the necessity for obtaining corporate powers, and the provision made for a working capital with which to enter upon the proposed corporate enterprise.

"The corporators had been partuers. As such they hal been engaged in procuring leases and drilling wells in search for oil. In their search they had not been successful, but two of the wells drilled by them proved to be valuable gas wells. This, taken in connection with other developments in the same general region, was well calculated to induce the belief that they were the possessors of a large and valuable gas territory that should be promptly developed and utilized or its value would steadily decline by reason of drainage from the operation of others. They could not utilize their gas without transporting it to a market. They could not transport it to advantage except as a natural gas company possessing the powers conferred by

1 In re South Mountain Con. Min. Co., 2165 Pa. St. $489 ; 30$ Atl. 936. 8 Saw 36,6 .

132 
law. This determined them to organize a corporation for the production and transportation of natural gas and to transfer their gas wells and leases to the corporation. When this had been decided on, the first question to present itself was, how shall the partnership convey its property to the corporation so as to secure to its members the same relative interest in the stock of the corporation they now have in the partnership property? The next question was, how shall we secure the necessary working capital to enable the corporation to go forward with the work of producing, transporting, and selling uatural gas? In a general way these questions were auswered by the adoption of the seheme alrealy referred to. The value of the properties held by the firm was set down at $\$ 175,000$, the working capital needed at $\$ 325,000$. To meet both purposes the capital stock of the corporation was fixed at $\$ 500,000$. It was all to be issued as paid up stock in exchange for the property conveyed to the corporation, subject to the agreement that all except $\$ 175,000$ thereof was to be contributed to the treasury to be sold as a means of raising the money needed for a working capital....

"In what respect, then, have the defendant stockholders failed in the performance of their undertaking to the corporation? The scheme was to turu over all the gas wells, leases, etc. to the corporation for $\$ 175,000$, and provide it with the means of prosecuting the gas business by putting into its trensury paid up stock, or ahat should be sold as paid up stock, to the amount of $\$ 325,000$ more. . . .

"The court below found 'that the facts in evidence, connected with the fact that within a few months it was demonstrated that the property was of very small value, threw on the stockholders the burden of showing clearly that the sale from themselves to themselves was in good faith on a reasonable belief in the value of the property.' But whent has the fact thut, "ffer some months spent in derelupment of the ir territory, the corporation foumd itself dis"pryminted in its prorluctiveness and a hervy loses in constrquence, to do with the good fuith of their pur-

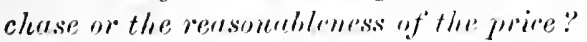

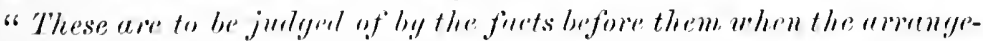

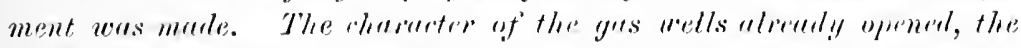

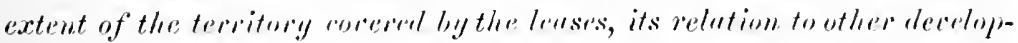

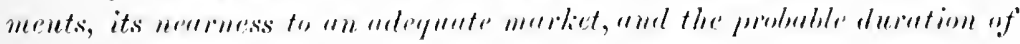

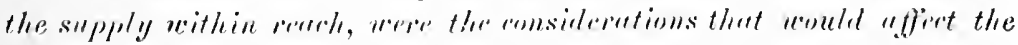

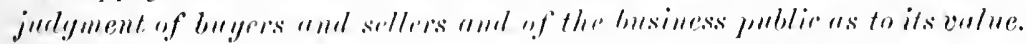

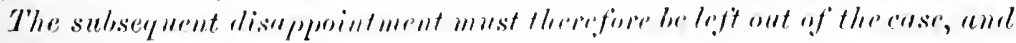

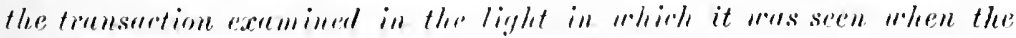

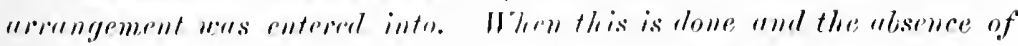
any surggrstion or finding of frund is remembered, it is not ensy to see 
What there is in the eqse to shift the burden of proof or to require the

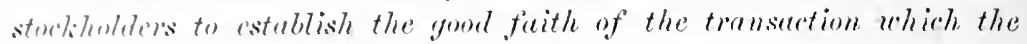
pleintifis hare not attreked. The action proceeds on the theory that the subseriptions to the capital stock are wholly unpaid. The proofs show that they were paid exactly in accordance with the agreenent, and that this payment had been recognized by the corporation from the first. The deeree, as finally made, seems to rest on the eonelusion that although paid they were paid in property which was taken at too high a price. It is true that no such thing was alleged in the bill or shown in the proofs, but if the value of the property is to be determined in the light of subsequent events, a light which the parties dicl not have when this sale was arranged, the conclusion of the court below would be reasonable. The trouble with it, howerer, is, that it rests on the intrinsic value of the property as ascertained by actual developments made after the sale, while the real question relates to the apparent value as indicated by the circumstances existing at the time of the sale. . .

"We should agree with the court below that the property was sold at more than its actual value, if that value was to be determined by subsequent results rather than by prospects as they appeared at the time of sale. But if the parties were mistaken in relation to its value, we do not see loow, in the absence of any averment of fraud in the transaction, the sale can be disregarded and the subscriptions to the capital stock treated as unpaid. The proofs show that they were paid exactly in accordance with the agreement under which they were made, and until that agreement is attacked as fraudulent, the creditors stand in no better position than the corporation itself. The reeree is reversed so far as it requires payment of the stock subscriptions or any part thereof." 1

So much, then, for the question as to the proper basis for appraising property of a speculative character when the same is transferred to the corporation in exelange for its capital stock. Let us add a few more words to what was said in the foregoing opinion relative to the question as to where the burden of proof lies in such cases, when the valuation placed upon the property is impeaclicd by crediturs who seek to enforce an alleged stockholder's liability for unpaid stock subseriptions. Let us note in this eonuection, first, the statement of the law made by the Court of Appeals of Maryland in Brandt $v$. Ehlen, ${ }^{2}$ whore the court chserved "we take the law to be well settled, that a company

1 \&

291 ; 5.3 Pite. 959; Montana Ry. Co.

$259 \mathrm{Md} . \mathrm{l}$.

v. Warren, 6. Mont. $275 ; 12$ Pac. 641.

$1: 1$ 
may receive, in payment of the shares of its capital stock, any property which it may lawfully purchase. So long as the transaction stands unimpeached for frand, the courts will treat as a parment that which the parties shall agree to be a payment, and this too in cases where the rights of creditors are involved." The Supreme Court of Massachusetts in a recent case ${ }^{1}$ observed that it appears to be well settled that in the absence of frand an agreement can ordinarily be made by which stockholders can be allowed to pay for their shares in patents, mines, or other property to which it is not easy to assign a determinate value. At least, one court of high authority has adopted the rule that where one becomes a creditor of a corporation knowing the manner in which its stock has been paid, he is deemed to waive his right to assert that there has been an orer-valuation of the property against which the corporation issued its stock. ${ }^{2}$ It is to go but a step forward to say that in the ease of corporations engaged in speculative enterprises it is a matter of common knowledge that shares are to be paid for in property appraised at its potential rather than its present intrinsic value, and that therefore the rule stated above should obtain, even in the absence of actual knowledge on the part of creditors as to the mamer in which the capital stock of the corporation had been issued. Again, where stock has been paid for by the conreyance of property to a corporation of the character known as "speculative" and upon which a valuation has been placed, - not its present intrinsic value, but rather its prospeetive value after development thereof, - then in such eases the conrts should presume that the valuation was honestly made and place the burden upon the creditor of attacking the transfer. ${ }^{3}$

The ordinary practice, as has been observed, is for corporations engaged in non-speculative enterprises to issue stock for property which has a well-reeggnized market ralne or one which can be easily ascertaincd. In regard to such eorporations, where the nature and eondition of its property is such that its vilue is wetl known or moderstood or is eapable of beingreadily estimaled and aseertained, and the same is transfored to the corporation at a gross overraluation for paid up shares, it wonld mupestionably be proper

$1 \mathrm{~N}$. II. II. N. ('o, 1. Company, 142 \& So. $496 ;$ (B) Mass. 349, 7 N. E. 7 氵3.

4ie: 3!) N. 15. 225; Carr v. Le Forre, 27

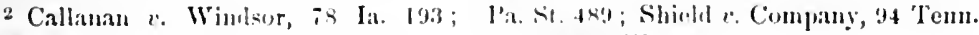
42 N. W. 6.52.

$123 ; 2 \times 5$. W. 66, 9.

3 Davis v. Company, 101 Ala. 127; 
for courts to treat such transactions as presumptively fraudulent, and to plice the burden of proof upon the stockholders in such cases to rebut such presumption by clear and satisfactory proof. On the other hand, where the corporation is engaged in speculatire enterprises of the eharacter above referred to, and stock is issued against property accepted by the corporation at a valuation not based upon the present intrinsic value of the same, but avowedly (as is the universal custom) at its potential speculative value (to be determined after development thereof by the corporation which has accuired the property), then the practical attitude for the courts to take in such eases would be to adopt what is termed here the "speculative value rule," and to attach to the valuation placed by the corporation upon such property the presumption that it was lonestly made, and place the burden of proof in such cases upon the ereditor attacking the transaction. In practical operation it will be found that the shifting of the burden of proof would be equivalent in nearly all cases to making the valuation placed upon the property in any case, whether speculative or nonspeculative in character, conclusive respectively upon the stockholders and the creditors. The reason of this is that in the case of non-spreculative properties it is easy to demonstrate that the same has been grossly overvalued; as, for example, by showing the market value of the same. Again, in the case of speculative enterprises the same is true for the reason that the valuation placed upon the properties from a speculative standpoint, if honest and fair, would be such as to render it practically impossible as a matter of proof to show that such valuation was frandulent or grossly overvalued, - this for the reason that in every such case it will be found that there exists an immense margin for honest difference of opinion, and although it may appear that there were scrious errors of judgment, nevertheless it will be foumd in practice that such valuations should not and will not be set aside exeept for actual fraud.

It is the recognition of the necessity of shifting the burden of proof according to whether the property against which stock is issued is speculative in character or not, which, in connection with the basis of appraisal already referred to, affords a practical basis for the operation of the speculative value rule. Finally, the following may be said:

Upon principle and in the interest of justice both to the stockholders and creditors alike, in determining the question whether 
stock has been in fact fully paid, the line should be drawn with the utmost clearness and distinctness between ordinary corporations such as trading, mercantile, banking, insurance, etc., whose capital stock is formally subseribed for and ordinarily paid in in cash or in real and personal property haring a well-recognized or casily established market ralue on the one hand, and those corporations on the other hand incorporated for the express and arowed purpose of engaging in speculative enterprises - such, for cxample, as corporations organized to take over mining properties, oil and gas lands, patent and patent rights, secret processes, concessions, franchises, etc. In this era of speculative enterprises the courts can no longer remain blind to the fact that the stock of such corporations is not intended by the incorporators or understood by the creditors or the public generally to represent anything but certain property having a speculative value, which may or may not ultimately prove to be worth the par value of the stock against which the latter has been issued. The credit obtained by such corporations concerning which the courts lave in the past displayed such intense solicitude in the interest of creditors to the exclusion of the interests of equally meritorious stockholders, is seldom, if erer, extended to the corporation without full knowledire on the part of creditor's as to the nature of the assets of the corporation, or as to the manner in which the stock has been issued in exchange for property of a speculative value.

\section{$\$ 107$. Effect of Appraisal of Property by Directors under Stat-} utory Authority, when taken in Exchange for Stock. - The incorporation acts of Comnecticnt, Delaware, Maine, Montana, New Jersey, New York, North Carolina, South Carolina, Virginia, and West Virginia all contain provisions relating to the effect of appraisal of property by directors when taken by the corporation in exchange for its capital stock. The provisions of the New Jersey act may be given as an example of such legislation. The statute referred to reads as follows: 1

"Any corporation formed unfer this act may furchase mines, manufactories, or other property necessary for its lusiness or the stock of another company or companies owning a mine, mamnfatory, or producing mills or other property lrecessary for its business, and issue stock to the amount of the value thereof, in paynent therefor,

1 Public Laws of New Jerseg, 1896, chap. 85, $\$ 49$. 
:mb the stock so issued shall be full-paid stoek and not liable to any further call, wer shall the holder thereof be liable for any further payments nuder any of the provisions of this act, and in the absence of actuil friud in the transaction the judgment of the directors as to the value of the property purehased shall be conclusive."

In commenting upon the foregoing section in the case of Donald r. Ameriean Smelting \& Refining Co., the cont spoke as follows:

"The distinction between the contemplated issue of corporate stock for property and its issue for money lies not in the rule for valuation, but in the fact that different estimates may be formed of the value of property. When such differences are brought before judicial tribunals, the judgment of those who are hy law entrusted with the power of issumy stock to the amount of the value of the property, and upon whon therefore is placed the first duty of valning the property, may be accorled considerable weight. But it cannot be deemed conclusive when duly subjected to judicial scrutiny, nor is it necessary that conscions orer-valuation or any form of fraudulent conduct on the part of its primary valuers should be shown to justify judicial interposition. Their honest judgment, if reached without due examination of the elements of value, or if based in part upon an estimate of matters which really are not property, or if plainly weighed by selfinterest, may leal to a violation of the statutory rule as surely as would corrupt motives. The original issue of corporate stock is a special function in the exercise of which the legislature has fixed the standard to be observel, and it is the cluty of the courts, so far as their jurisdiction extends, to see that this standard is not violated either intentionally or unintentionally. When corporate stock has once been issued for property purchased, then the legislature has directed the application of a different rule. In the words of the statute, 'the stock so issned shall be full-paid stock, and not liable to any further call, neither shall the holder thereof be liable for any further payment uncer the provisions of this act; and in the absence of actual fraud in the transaction the juldgment of the directors as to the value of the property purchased shall be enclusive. Under these provisions, after the property has been purchased and the stock issued therefor, nothing short of actual fraul in the transaction can impair the right of the holder to holl his stock as full-paid stock, free from further call." " 2

1 fil X. J. Fif. 45s; 48 Atl. 786 .

2 Lee also Wetherbee $v$. Baker, 35 N. J. Er. $5(s)$; liank $v$. Lumber Co., 32 W. Va. 357 ; 9 S. L. 243; Richardson v. Graham, 135
45 W. Va. $134 ; 30$ S. E. 92 ; Clark $v$. liever, 139 U. S. 96 ; $11 \mathrm{~S} . \mathrm{Ct} .468$; Fogg v. Blair, 139 U. S. 118 ; 11 S. Ct. 496 ; Liebke $v$. Knapp, 79 Mo. 22. 


\section{$\S 108$. Effect of Appraisal of Value of Property by State Officials} when the same is taken by Corporations in Exchange for their Capital stock. - Owing to the conflicting decisions of the courts of the various States relative to what does and what does not constitute as against ereditor's full payment of the capital stock of a corporation, attempts have been made by the legislatures of a number of the States to remedy this situation by means of statutory enactments. Such legislative enactments may be said to be indicative of the public poliey of the State in that regard. The "public policy of the State," as the term is used in this connection, frequently varies from time to time. In the absence of express statutes of the character here referred to, it has been said that it is not to be measured by the private combinations or notions of the persons who happen to be exercising judicial functions, but by reference to the enacturents of the law-making power, and in the absence of them to the decisions of the courts. When, however, the legislature has spoken on a particular subject and within the limits of its special puwers, its utterance then becomes the public policy of the State. In view of the fact that the near future is likely to see many attempts by other legislatures to solve the question here referred to by the enactment of statutes gorerning the same, the matter now under consideration should reccive careful attention.

It is a fair supposition to say that the passage of such acts in this country originated doubtless in a desire to transfer to this country certain sections of what is known as the "English Company's Aet of 1867." Under the act just referred to, corporations which desired to aecept property in exchange for their eapital stock were required to register in a designated gorernment office a description of the property arainst which any particular corporation proposed to issue its full-paid shares. The construction by the English courts put upon this section of the English Company's Aet does not seem to give to the legislative provision referred to the full effect which is clatmerl for such statutes in this country. In substance the loolding of the English conte in this regard is as follows:

That where the property is so registered murler the act it is not unlawful for the vendor to sell such property to the corporation in

1 See Marfinnisy v. Compray (Mont.), 75 l'ac. 89 ; Uniterl States v. Association, 166 L. S $290 ; 17 \mathrm{~S} . \mathrm{Ct} .540$. 
exchange for stock having a par value in exeess of what the vendor paid for the preperty. 'That ordinarily the court will not in the interests of stockholders or ereditors go behind the contract and inquire whether the consideration represents the full value against which the shares are issued muless the contract itself is impeached or the consideration on the face thereof appears to be insufficient or elusory.

'l'urning now to the statutory enactments in this country of the same character, they may be explained as follows: In Florida the incorporation act there in force provides that incorporators may provide in the charter that the eapital stock, either in whole or in part, shall be payable in property, labor, or services, at a valuation fixed in the charter. The latter must also contain a general description of the property to be taken in exchange for stock. In Utah the statute is very similar to the one in force in Florida. In Massachusetts the artieles of organization must set forth the amount of capital stock to be issued, the amount thereof to be paid for in eash, and the amount thereof to be paid for in property. If such property consists of real estate, its location and the amount of stock to be issued therefor must be stated. If any part of such property is personal, it must be described in detail. The whole matter is then submitted to and passed upon by the commissioners of corporations. But the statute makes no provision relative to what the legal effect thereof shall be as to ereditor's where the issuance of stock in exchange for property is approved by the commissioners of corporations.

Unquestionably the most effective statute in existence is to be found in the Michigan act, ${ }^{2}$ which in preseribing the requisites of articles of incorporation reads in part as follows: "The amount of capital paid in at the time of executing the articles, which shall not be less than ten per eent of the authorized capital, ete. Such eapital stock may be paid in either cash or in other property, real or personal; but where payment is made otherwise than in eash there shall be included in the articles an itemized description of the property in which such paynent is made, with the valuation for which such item is taken, which valuation shall be conclusive in the absence of actual fraud."

I In re Wragg, L. R. 1 Chan. 796; Ooregum (iold Min. Co. v. Ropes, 61 L. J.

Chan. $3: 37$

2 Session Laws of 1903, § 232. 
The intent of the legislature would clearly appear to be to establish conclusively that the property received and accepted by the corporation mnder the authority of the State in exchange for its stock constituted a fair equivalent of the amount of stock so giren. It rould seem to forbid all claim of fraud thereafter to be made, and to establish the raluation as conclusire upon both stockholders and creditors. ${ }^{1}$

$\S 109$. Meaning of Non-Assessable Stock. - In entering upon the subject of non-assessable stock as contrasted with full-paid stock the discussion of the former will be confined to questions arising between the corporation and its stockholders, while the latter will be diseussed from the standpoint of the stockholder in his relation to ereditors. It is unquestionably within the power of a corporation to agree with stockholders that stock shall be issued to them at less than par, and that when so issued shall not be sulject to any further assessments on the part of the corporation. $^{2}$

In West Virginia, Nerada, Wyoming, and otler States this principle has found recognition in the incorporation acts in force in those Commonwealths. The West Virginia act will serve as a fair example. The law there provides in substance as follows: that upon the vote of three-fourths of the stockholders corporate stock may be sold or disposed of at less than par. The act then goes on to provide that nothing therein contained shall be construed as to prevent any mining or manufacturing company from issuing stock and negotiating the sale of the same in payment of real and personal estate for the use of the corporation at such price and upon such terms and conditions as may be agreed upon by the owners and directors or stockholders of the corporation, and any subseriber to the capital stock of any such corporation may pay for the same by the transfer and conveyance to such corporation of real or personal property upon such terms as may be mutually agreed upon. All stock so issued shall be full paid and not liable to any further call or assessment.

Such a statute as is here referred to mquestionahly has the effect of making the stock non-assessable as between the corporation and the subscribers to its capital stock, but it clearly has not the effect of preventing subsequent creditors in case of insolvency

1 Sce State $v$. Webl) ol al., 110 Ala. $214 ; 20$ So. 462 .
${ }^{2}$ Exgen $v$. Smith, 113 I.. $25 ; 84$ N. W. 954. 
compelling the payment of any umpaid balance on such stock. On this suhjert dudue Slrowalter, in Northern 'Trust Co. v. Columbia straw P'aper Co., spoke as follows:

"Whateres may have been in fact the value of the property turned orer to the company for its stock, the latter agreed to take it for the stock. The persons interested were the stockholders, and there was no dissent on the part of any person in what was done. Neither any person then holding stock, nor any person who afterwards became a stockholder by assigmment from one who then held the stock, can now make complaint on behalf of the corporation against the lawfulness of that trausaction. This I take to be the settled law on that subject."

In the ahsence of statutory authority conferred upon the corporation or in the absence of unanimous consent of all the stocklivlders, it is clear that the directors of a corporation have no power to assess shares which have been fully paid up. ${ }^{3}$

$\$$ 110. Meaning of Full-Paid Stock. - The term "full-paid stock" as here used may be defined to be stock whose par value has been paid either in cash or in property, the ownership of which does not subject the holder thereof to any further liability either to the corporation or to the creditors. The mere declaration that stock is full paid, either by resolution or by stamping upon the stock this statement, does not make it so, at least as to creditors."

It has already been said that stock may be issued for less than its par value to subseribers as full paid and non-assessable and be binding as between the corporation and the stcckholders. ${ }^{5}$ Where statutes exist declaring that stock issued in a particular manner shall be full paid and non-assessable, they are merely to be construed to the effect that stock may be issued in this manner, and that the holders thereof shall not be lield liable to further calls or assessments on the part of the corporation, but such immunity

1 The Wroming statute would appear Pacific Fruit Co. v. Coon, 107 Cal. 447; (1) be inaterially different from the West 40 Pac. 542.

Virginia and Vevada acts.

275 Fed. 936 .

3 Wells $\%$. Company, 90 Wis. $442 ; 64$ X. W. 69 ; Ventnra, etc. Ry. Co. v. Hartma11, 116 Cal. 260; 48 I'ac. 65; Handley 2. Stutz. 39 L.S. 417 ; 11 S. Ct. 530 ; Gary ¿. Company, 9 Ltah, 464; 35 Pac. 494;

4 Upton $v$. Triblecoek, 91 U.S. 345; 23 L. E. 203; F. N. Bank $v$. Company, 42 Minn, 327 ; 4 N. WV. 198; National Tube Works $v$. Gilfillan, 124 N. Y. $302 ; 26$ N. F. 538 ; Kroenert v. Johnston, 19 Wash. $96 ; 25$ Pac. 605.

5 See Scoville v. Thayer, 105 U. S. 143. 112 
will not be extended in such suit so as to prerent subsequent creditors enforcing their claims for the payment of the unpaid residue. Many of the States hare statutory provisions to the effect that no corporation shall issue stock except for money paid, labor done, or property actually received, declaring all fictitions increase of stock to be roid. Under such provisions an original issue of stock as fully paid at less than par will be held to be roid. ${ }^{2}$

Many eases will be found bearing upon the question as to the ralidity of so-called "bonus" or "promotion stock." In regard to the validity of such stock the courts differ. One line of decisions is represented by the courts of New York and Massachusetts. In Christensen $v$. Eno ${ }^{3}$ the New York Court of Appeals spoke as follows :

"It may be admitted that the liability of subscribers on unpaid stock subscriptions constitutes an asset of the corporation which cannot be given up by the corporation without consideration on the part of creditors. The missued shares of a corporation are not assets. When issued, they represent the proportionate interest of the shareholders in the corporate property, - an interest, however, subordinate to the elaims of creditors. There are unquestionably public evils growing out of the creation and multiplication of shares of stock in corporations not based upon corporate property. The remedy is with the legislature. But the liability of a shareholder to pay for the stock does not arise out of his relation, but depends upon his contract, express or implied, or upon some statute, and in the absence of either of these grounds of liability, we do not perceive how a person to whom shares have been issued as a gratuity has by accepting them committed any wrong upon the creditors or made himself liable to pay the nominal face of the shares as upon his subscription or contract." 4

On the other hand, courts of almost equal anthority have refused to treat such stock in the interest of creditors as full paid and nonassessable, and have enforced in their faror an alleged stockholders'

1 Vt. Marble Co. v. Company, 135 Cal. $579 ; 67$ Pac. 1057.

2 Willians $v$, Lvans, 87 Ala. $725 ; 6$ So. 702; P'orry v. Mlill Co., 93 Nla. 364; 9 So. 217 ; Iieitman $x$. Steiner, 99 Ala. $241 ; 13$ So. 87; Stein 2. Llowarl, 65 Cal. $616 ; 4$ Pac. 662; Jefferson $v$. Hewitt, 103 (al. 6,24; 37 lac. 6338; liellerman $v$. Matr. 116 Cal $46 ;$ \$ I'ac. 375; Garrett $\because$ (omplatyy, 113 $.110 .330 ; 20$ S. W. 9055.

3 lof X. Y. 97; 12 X. E. 648.

4 sime rule in N. H. II. N. Co. v. Company, 142 Muss. $349 ; 7$ N. L. 773. 
$\$ 110$ 1 NOORPOLATION AND ORGANIZATION OF CORPORATIONS. [PART I.

liability therem. It has been held, however, that even though a stockholder has paid nothing for his stock, he is entitled to vote the sinme.2

I See l'eninsula Savings Bank $r$ Com- N. W. 894; Seoville $v$. Thayer, 105 U. S. fally, 10.5 Mich. 535 ; 63 N. IV. 514; 143; Garrett $v$. Company, 113 Mo. 330 ; Haiblley 2 Stutz, 189 U. S. $417 ; 11$ S. 20 S. W. 965.

Ct. 530; De la Vergue liefrigeraling Nachine Co. 2 . Cierman Savings Institution, 1 .5 U. S. $40 ; 20$ S. Ct. 20 ; 44 L. E. 65 ; liogers $v$. Gross, 67 Minu. 224; 69

2 Cartwright v. Dickinson, 88 'Tenn. $476 ; 12$ S. W. 1030 ; W. E. L. Co. $v$. Landy, 66 Vt. 248; 29 Atl. 248; see also Busey $v$. Hooper, 35 Md. 15. 
CHAP. V.] LEGISLATIVE CONTROL OVER DOMESTIC CORPORATIONS. $§ 112$

\section{CHAPTER V.}

\section{LEGISLATIVE CONTROL OVER DOMESTIC CORPORATIONS.}

\section{$\$ 111$. Statement of Principal Methods by which Legislative} Control over Domestic Corporations is obtained. - Under our modern system legislative control over domestic corporations ordinarily takes the following forms, to wit: (1) control orer amendment of corporate charters; (2) reserration on the part of the State of the right to repeal all charters; $(3)$ control orer dissolution of corporations; (4) by the exercise through State officials of the right to forfeit charters by means of quo warranto proceedings; (5) by means of the exercise of the police power; (6) through legislative inrestigation into corporate affairs; (7) by requiring ammual reports of corporations; (8) by compelling corporations to permit inspection of their books and records for the benefit of stockholders and creditors; (9) by means of anti-trust legislation; (10) by the enactment of statutes regulating the internal affairs of the corporation ; (11) by the imposition of liability upon stockholders for corporate debts over and beyond their liability for unpaid stock subseriptions; (12) enactment of statutes imposing liability upon director's for misfeasance or non-feasance in office; (13) by means of legislative control over the extension of colporate existence; (14) hy the exercise of the right of taxation upon corporations; (15) by regulating the right of consoliration of corporitions.

$\$ 112$. Amendment of Charters. $-\Lambda$ grance at the general business acts in force in the screral States and Territories will serve to show that in all of them more or less attention has heen paid by the lecrislatures to the question of the right to amend with more or less frectom - articles of incorporation. In a majority of these the power of amemoment will be fomd to be practically unlimited. In nine the limitations imposed are not wide in seope, while in eleven the pwer refered to may lie characterized 
as being very narrow in its practical operation.' The practical ynestions to be comsidered in this immediate comnection have reference. first. to ascertaining in what body the legislatures have seen fit to platee the power of amendment, and, secondly, an inquiry whether the power when granted, apparently in the broadest terms, is in lewal effect withont any limitations whatsoever.

Is a general rule, the director's have no power to amend charters muless such right is expressly conferred upon them by statute. Power to amend resides exclusively in the stockholders. ${ }^{2}$ 'Turning now to the sceond inquiry referred to above, the following may be said. With respect to the right on the part of majority stockholders to exercise the power of amendment, there are two practical riews of the question which deserve consideration. 'The furst has reference to the effect, if any, the exercise of such right may have upon the right of the corporation to enforce stock subscriptions which were made in reliance upon the corporate purposes set forth in the original charter. The other relates to the binding effect of such amendments, when had, upon dissenting minority stockholders who have previously paid up their stock subscriptions.

In the first case it appears to be the generally accepted view that when a party makes a subscription to the capital stock of a corporation he does it in reliance upon the implied understanding that no changes shall be made in the charter without his consent which produce material and fundamental changes therein. ${ }^{3}$ The rule howerer can clearly not apply where the changes made were trifling or immaterial or were in furtherance of the original objects of the corporation. There is a well-defincd tendency at the present time on the part of many courts to take the view that in order that a subscriber to the capital stock may escape liability on his subscription on the ground that there has been a material amendment to the charter since his subscription was made, that

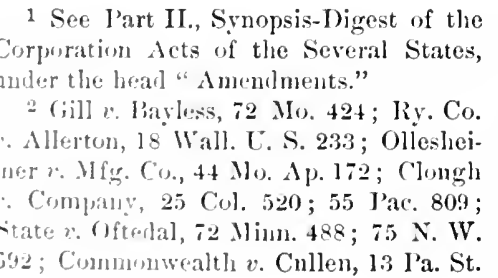

$1+1 ;$
133; Albott v. Company, 33 Barb. (N. Y.) 583.

3 Mowrey $v$. Company, 4 Bissell (U. S.), 78 ; l'rinting IIouse $v$. 'Trustees, $10+$ U. S. 711 .

4 Fry's Executors $v$. Company, 2 Metealf (Ky.), 322 ; I'eoria $v$. P'jeston, 35 Ia. 115 Milford, etc. 'Turnpike Co. v. Brush, 10 O. St. 111; Durfee $v$. Company, 5 Allen (Mass.), 2.30. 
such amendment must necessarily hare brought about ehanges of the most radical and fundamental character. ${ }^{1}$

Turning now to the second question here referred to, the following may be said. Important questions frequently arise as to the right of majority stockholders to amend the charter of the corporation against the dissent of minority stockholder's so as practically to ereate an entirely new corporation with purposes and powers wholly different from those conferred in the original charter.

Before the passage of the modern liberal amendment acts, specifically authorizing majority stockholders to change ad libitum corporate purposes and powers, the rule undoubtedly was that majority stockholders had no power to depart, under the gruise of an amendment to the charter, from the objects for the accomplishment of which the corporation was created. At that time majority stockholders would be enjoined on the application of minority stockholders from making fundamental and radical changes in the origrinal corporate purposes, which had the effect of practically creating a new corporation, with power to engage in lines of business wholly foreign to that set forth in the original charter. $^{2}$ But whatever the rule may have been in times past, changed conditions have brought about material modifications therein.

Owing to the recent statutory enactments in the great majority of the Commonwealths relative to amendment of charters, it may be said that this question has ceased to be one of great practical importance at the present time, however it may have been in the past. In view of these statutory provisions it may be said that as a general rule the extent of the power of amendment when exereised by a majority of the stockholders according to the statute in suels case mate and provided, depends entirely upon the terms of such statute and the construction given by the conrts thereto. ${ }^{3}$ If broad

1 Banet 2 . Company, 13 III. 504; l'acifie Ry. Co. r. Ronslaw, ls No. 2]0; Spragno 1. Company, 19 III. 171; Irvine r. 'l'urmpike Co., 2 I'en. \& W. (I'a) dof; Cross v. Company, 90 l'a Sit. 392; 'Troy, etc. Ry, (o, r. Kerr, 17 Barb. (N. Y.) 607 ; Worcester $x$. Company, 109 . Miss. 103; 1).1. Ry. Co. v. J'harp, I Jisunt. (1)el.) 149 .

2 Zalriskie $\because$. Company, 18 X. J. Eү. 178; Stevens 2 . Company, 29 Vt. 545;
Natusch $v$. Irving. I Smith's Casce, 226; Inim Jocks aml ("anals r. Towme, I N. II. 44; Ashton r. Burlank, 2 bill. 435; Fed. rases No. 5,82; II. \& N. II. Ry. Co. $v$. Croswull, 5 llill (N. Y.), I83.

8 J):u r. ('omplany, 75 Ia. 694; 38 N. W. il3; Goller 1 . Bresisler, 105 Ill. 419 ; Spriefr. Company, 46 M1. 67 ; llope Mutnal fire los. Co. r. Barkman, 47 Mo 93 ; 1)retroit Chambre of Commercer. Secretary of State, 109 Mich. 691; 67 
in seopre, they unquestionably permit majority stockholders to Lring ahout radical and eren fundamental changes in corporate funpuses and powers if they so desire.

The question here presented is one of so much practical importince that it deserves more attention than has been yet given it. 'The New York Court of Appeals in Buffalo \& New York City Risilload Co. $v$. Dudley laid the fomdation for the establishment in that State of the present just rule that there obtains with reference to the right of majority stockholders to materially change the corporate purposes argainst the dissent of minority stockholders. In that case the conrt permitted a change of name and an extension of the line of the railway by means of an amendment to the original charter. In passing upon this point the court spolie as follows:

"The stock subscription having been valid so as to give a right of action in case of non-payment to the corporation, did the alteration of the charter and the extension of the road subsequently absolve the defendant from his liability upon such subscription? The right to alter was reserved in the charter, and the subscription must be taken to have been made subject to having such additional powers conferred as the legislature might deem essential and expedient. The change is not fundamental. The new powers conferred are identical in kind with those originally given. They are enlarged merely, the gencral objects and purposes of the corporation remaining still the same. It may be admitted that under this reserved power to alter and repeal the legislature would have no right to change the fundamental character of the corporation and convert it into a different legal being, for instunce, a banking corporation, without absolving those who did not choose to be bound. But this they have not attempted to do. The alditional powers are of the same character and have been regularly acquired from a legitimate source of power, and if they had been fairly exercised the defendant, although the change may have operated to his pecuniary disadvantage, is still bound by his undertaking. The whole matter is manifestly a question of power; and if the power was legitimately acquired and has been exercised without fraud, the rights of the parties are in no respect changed as between themselves whether the alteration is beneficial or injurious to the defendant's interest.

N. W. 897 ; Mercantile Statement Co. People $v$. Green, 116 Mich. 505; 74 N. W. 2. Kn:al, 51 Minn. 263; 53 N. W. 632; 714.

114 N. Y. 342. 
Whether he has made or lost by the change in no respect affects the question of authority in the plaintiff."

Many years later this same court, in discussing the respective rights of majority and minority stockholders or corporations, spoke as follows :

"The court would not be justified in interfering even in doubtful cases, where the action of the majority might be susceptible of different constructions. To warrant the interposition of the court in favor of the minority shareholiers in a corporation or joint-stock association, as against the contemplated action of the majority, where such action is within the corporate powers, a case must be made out which plainly shows that such action is so far opposed to the true interests of the corporation itself as to lead to the clear inference that no one thus acting could have been influenced by any honest desire to secnre such interests, but that he must have acted with an intent to subserve some outside purpose, regardless of the consequences to the Company and in a manner inconsistent with its interests. Otherwise the court might be called upon to balance probabilities of profitable results to arise from the carrying out of the one or the other of different plans proposed by or on behalf of the different shareholders in a corporation, and to decree the adoption of that line of policy which seemed to it to promise the best results, or at least to enjoin the carrying out of the opposite policy. This is no business for any court to follow.", 1

It is difficult to find a better presentation of the more modern and better view taken of the question now under discussion than that to be found in the opinion of the Massachusetts Supreme Court in Durfee $v$. Old Colony \& Fall River Railway Company.2 While the ease had special reference to the riglit of a State legislature to exereise its reserved right to amend corjorate charters so as to produce radical changes in the purposes named in the original charter, nevertheless the reasoning is equally applicable to those cases where majority stockloblers attempt coually radical amendments under general acts permitting such stockholders to amend eharters on their own initiative.

"We suppose," said Chicf Justice Bigrow in the case referred to, "it may be stated as an indisputable proposition, that every

1 Gamble r. Company, 123 N. Y. 91 ; 25 Allen, 230.

25 N. E. 201. 
person who becomes a member of a corporation agregate by purchasing and holding shares agrees by necessary implication that he will be hound by all acts and proceedings, within the scope of the powers and anthority conferred by the charter, which shall be adopted or sanetioned by a vote of the majority of the corporation, duly taken and ascertained according to law. This is an unaroilable result of the fundamental principle that the majority of the stockholders can regulate and control the lawful exereise of the powers conferred on a corporation by its charter. A holder of shares in an incorporated body, so far as his individual rights and interests may be involved in the doings of the corporation, acting within the legitimate sphere of its corporate power, has no other legal control over them than that which he ean exereise by his single vote in the meetings of the company. To this extent he has parted with his personal right or privilege to regulate the disposition of that portion of his property which he has invested in the capital stock of the corporation, and surrendered it to the will of a majority of his fellow corporators. The jus disponendi is rested in them so long as they keep within the line of the general purpose and object for which the corporation was established, although their action may be against the will of a minority however large. It cannot, therefore, be justly said that the contract, express or implied, between the corporation and the stockholders is infringed or impaired by any act or proeecding of the former which is authorized by a majority, and which comes within the terms of the original statute creating and establishing their franchise, and confering on them capacity to exercise control over the rights and property of their members. On the contrary, the fair and reasonable implieation resulting from the legal relation of the stockholders and the corporation is, that the majority may do any act either coming within the scope of the corporate authority, or which is consistent with the terms and conditions of the original charter, without and even against the consent of an indiridual member." Again, in this same opinion the court obserred that, "in creating a corporation, no contract is made by the legislature with the individual members or stockholders, any further than they are represented by the artificial body which the act of incolporation calls into being. They have no other ricrhts exeept those which exist or grow ont of the constitution of the body corporate of which they are members. To 1.50 
this can we only look, in order to ascertain whether there has been any breach of contract or violation of chartered rights. It constitutes, of itself, the contract by which the rights of all parties are to be governed. When, therefore, it is expressly provided between the legislature on the onc hand and the corporation on the other, as part of the original contract of incorporation, that the former may change or modify or abrogate it or any portion of it, it cannot be said that any contract is broken or infringed when the power thus reserved is excreised with the consent of the artificial body of whose original creation and existence such reservation formed an essential part. The stockholder cannot say that he became a member of the corporation on the faith of an agreement made by the legislature with the corporation, that the original act of incorporation should undergo no change except with his assent. Such a position may be asscrted with more plausibility, if there was an absence of a clause in the original act of incorporation providing for an alteration in its terms. In such a case it might perhaps be maintained that there was a strong implication that the eharter should remain inviolate, and that the holders of shares invested their property in the corporation relying upon a contract entered into between it and the legislature that the provisions of the act creating it should remain unchanged. But it is difficult to sec how such a construction can be put on a contract which contains an express stipulation that it shall be subject to amendment and alteration. If it be asked by whom such amendment or alteration is to be made, the answer is obvions: by the parties to the contract, the legislature on the one hand and the corporation on the other; the former expressing its intention by means of a legrislative act, and the latter assenting thercto by a vote of the majority of the stockholders, according to the provisions of its charter. It is nothing more than the ordinary case of a stipulation that one of the parties to a contraet may vary its terms with the assent of the other contracting party. In such case, all persons claiming derivative rights or interests under the original contract, with notice of its terms. would he bound by the amendment or alteration to which the parties should agree. It is a mistake, therefore, to say that the contract of a stockholder with a corporation established under onr statutes binds the latter to undertake no new enterprise and engage in no business or operation other than that contemplated by the original 
chanter. 'This interpretation puts aside the express provision antherizing an ancendment or alteration of the act of incorporation, and grives it no eflect as against a stockholder withont his assent, althugh he bought his stock or subseribed for his shares subject to the leginl effect of such a stipulation. The real contract into which the stockholder enters with the corporation is, that he ayrees to become a member of an artificial body which is created and has its existence by virtue of a contract with the legislature, which may be amended or changed with the consent of the company. ascertained and declared in the mode pointed out by law. Having, by virtue of the relation which subsists between himself and the corporation as a holder of shares, assented to the terms of the original act of incorporation, he cannot be heard to say that he will not be bound by a rote of the majority of the stockholders accepting an amendment or alteration of the charter made in pursuance of an express authority reserved to the legislature, and which by such acceptance has become binding on the corporation."

In some few of the States, as for example Ohio, ${ }^{1}$ the law provides that no amendment shall change substantially the original purposes of the organization. In many of the States great similarity is to be observed in the formalities necessary to be taken in order to legally amend the charter. Usually the matter is brought to the attention of the stockholders by a resolution passed by the board of directors directing the calling of a meeting of the stockholders for the purpose of passing upon certain proposed amendments. A meeting of the stockholders is then called in the manner prescribed by statute, if any, or according to the method set forth in the by-laws. If the requisite number of stockholders vote in faror of such amendment, a certificate to that effect is usually made by the officers of the corporation and filed in the same offices as is required in the case of the original articles of incorporation. Therempon the amendment ordinarily becomes effective. If the statute does not prescribe the method of amending the charter, the only safe plan to pursue is to adopt substantially the same procedure therefor as is prescribed by statute in the case of original articles.2

1 She Pievised Statutes of Ohio, sec. 32.58 ; also State v. 'Taylor, 55 O. St. 61 ;

2 Day $v$. Company, 75 Ia. $694 ; 28$ I'icard $v$. Inghey, 580 . St. $57 \%$.

1.52 
$\$$ 113. Reserved Right of the State to repeal Charters. - Without exception, under the system of incorporation now in rogue, each of the sereral States and Territories reserves the right in the granting of corporate charters under general acts to alter, amend, or repeal the same at any future time. The presence of such enactments is due to the decision of the United States Supreme Court in Dartmonth College $v$. Woodward, wherein that tribunal announced the principle that the charter of a private corporation was entitled to protection from alteration, amendment, or repeal on the part of State legislatures muder the clause of the Federal Constitution forbidding impaiment of the obligation of contracts. When this case was decided, it became obrious at once that " many" acts of incorporation which had been passed as laws of a pulblic character, partaking in no general sense of a bargain between the States and the corporations which they created, but which ret conferred private rights, were no longer sulject to alteration, amendment, or repeal except by the consent of the corporate borly, and that the general control which the legislatures creating sueh bodies luad previously supposed they had the right to exereise, no longer existed." It was no doubt with a view to sugresting a method by which the State legislatures conld retain in a large measure this important power withont riolating the provisions of the Federal Constitution, that Justice Story, in his concurring opinion in the Dartnouth College Case, suggested that, "when the legislature was enacting a charter for a corporation, a jurision in the statute reserving to the legislature the right to amend or repeal it must be held to be a part of the contract itself, and the subsequent exereise of the right wonld be in accorlance with the contract and could not therefore impair its obligation." 2

With respect to the right to repeal, the power of the legislature in this regard, when exereised, is all but absolute, and the eonrts ordinarily will not inquiles into the legislative motive for rxereising it. Under such circumstances it will he presmmerl that the power is properly exeleiserl.3 The mly exception aplents to be

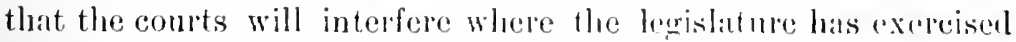
its power of repeal so wautomly ame maselessily as palpubly to violate the prineiples of matural justin..'

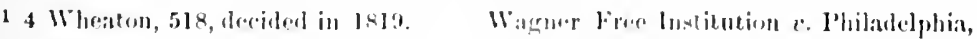

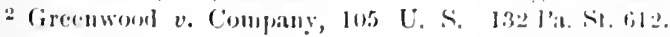
13.

a Grecuwool e. Company, 105 U. S. 13; Canew, No s519.

+ Lathrup + al. v. Stedman et al., Fed. 
Another question, however, is presented when the legislature attempts to alter or amend the charter. In order to justify the cxercise of this power by the legislature the same must be so exercised as not to defeat or substantially impair the object of the grant or any lights rested under it which the legislature may deem neeessary to secure either that object or some public right.1 From the foregoing it is to be seen that the reserred power to repeal and alter is not unlimited. On this subject the U. S. Supreme Comrt, in Union Pacific Railroad Co. $v$. United States, spoke as follows:

"That the power to alter or amend a charter even when reserved has a linit no one can doubt. All agree that it camnot be used to take away the property already acquired under the operation of the charter or to deprive the corporation of the fruits actually reduced to possession of contracts lawfully made. It may safely be affirmed that the reserve power may be exereised to almost any extent to carry into effect the original purposes of the grant or to seeure the due administration of its affairs so as to protect the rights of stockholders and ereditors, and for the proper distribution of its assets. Also to protect the rights of the public and of the ineorporators or to promote the due administration of the affairs of the corporation. The alterations must, however, be reasonable. They must be made in good faith, and be consistent with the olject and scope of the act of incorporation. Sheer oppression and wrong cannot be inflicted under the guise of alteration or amendment."

\section{$\$$ 114. Legislative Control over Dissolution of Corporations. -} Legrislative control over dissolution of domestic corporations (omitting any reference to forfeiture of charters by State action,) is exereised in the following four ways: (1) by prescribing the maximum duration of corporate charters; (2) by permitting corporations to surrender their charters before organization; (3) by authorizing voluntary dissolution, with or without recourse to the conrts; (4) by enaeting statutes anthorizing involuntary dissolution on application of stockholders or creditors. Each of these matters will now be taken up briefly for disenssion.

(1) Legislative limitations upon corporate duration. In the absence of any provision in the governing statute or in the eharter limiting corporate duration, the corporation is entitled to perpetual

1 N. Y. \& N. E. Railway Co.v. Town of Bristrol, 151 L. S. 556.

299 U.S. 700.

$$
154
$$


CHAP. V.] LEgislative CONTROL OVER DOMESTIC CORPORATIONS. $\$ 11 \pm$

existence. ${ }^{1}$ The legislature may however, if it sees fit, limit the duration of corporate existence to any specific number of rcars. This right has been excreised in a majority of the States. $^{2}$ Upon expiration of the period of time limited in the cliarter as the duration of corporate life, dissolution results by operation of law. ${ }^{3}$ If the articles provide for a longer period of duration than the law allows, then the excess is of no force or effect. 4

In many of the States statutes exist continuing the existence of corporations after the expiration of the period limited in their charters for certain periods of years in order to permit them to close up their corporate affairs. Such statutes may be lawfully enacted subsequent to the creation of the corporation, for the reason that they provide for the enforcement of rights which equity recognizes eren in the absence of statute. ${ }^{5}$

(2) Surrender of charter before organization. Statutes exist in the States of Connecticut, Delaware, Maine, Massachusetts, Nerada, New Jersey, New York, North Carolina, Virginia, West Virginia, and Wisconsin expressly permitting corporations to surrender their charters either prior to organization or to the commencement of corporate business. It is unquestionably true that in order to render such a surrender valid it must have been made under authority of the statutory provision enacted, which is of course equivalent to acceptance by the State. ${ }^{6}$

(3) Voluntary dissolution with or without recourse to the courts. "Charters," it has been said, "are in many respects compacts betwcen the government and the corporators. And as the former cannot deprive the latter of their franchises in violation of the compact, so the latter cannot put an end to the compact without the consent of the former. It is equally obligatory on both parties. The surrender of a charter can only be made by some formal act of the corporation, and will be of no avail mitil accepted by the government. There must be the same agreement of the parties to dissolve that there was to form the compact. It

1 F. L. \& S. Co. v. Clowes, 3 N. Y. 470.

2 See Part III, 'Table 13, parre 58.3.

a Mason v. Company, 25 I.iet. 882; Bradley $v$. Reppell, 133 Mo.545; $32 \mathrm{~S}$. W. $6+5$.

․ IIutchinson, 183 Ill. $605 ; 56$ N. E. 388.

6 Taylorn. IIolmes, 14 Fed. 98; Revere v. Company, 15 l'ick. (Mass.) 35l; Combes, r. lieyes, 89 Wiм. 297; 62 N. W. 89;

4 People $v$. Cheegeman, 7 Col. $376 ; 3$ Pae. 716.

Jaw $r$. Kich, 47 W. Va. f.3.1; 35 S. E. 858; Mariners $\because$ Sewall, 50 Me. 220 ; Barton $v$.

6 Foster v. Bank, 16 Mass. 245 ; Singer

Association, 114 Ind. $226 ; 16$ N. E. 486. 
is the aceeptance which gives effieieney to the surrender. Dissolution of a corporation extinguishes all its debts. The power of dissolving itself by its own act would be a dangerous power, and one which camnot be supposed to exist." 1

'The foregoing statement of the law is unquestionably based upon both reason and authority. Accordingly, a corporation may dispose of all its assets, cease entirely to do bnsiness, and neglect to elect offieer's or hold meetings of any kind, yet it cannot be legrally dissolved by any action of its stockholders or a surrender of its eharter unless such surrender is authorized by some statute. ${ }^{2}$

Where statutes exist authorizing dissolution of corporations prior to the termination of the period limited in their charters, such statutes are of course equivalent to an aceeptance by the legislatule of the surrender of the charter. All that is neessary is that the statute shall be substantially complied with in order that the dissolution may be effective. ${ }^{3}$

It may be remarked, in passing, that no cessation or abandonment of its corporate business, failure to hold corporate meetings or to elcet oflicers, alienation or loss of all its property, has the effect in law of lissolving the corporation. ${ }^{4}$

(4) Involuntary dissolution on application of stockholders and creditors. Most of the States have enacted statutes giring eourts possessing equitable powers the right to wind up corporations for cause shown upon application of some stockholder or on petition of ereditors. But such proceedings, eren when the eorporation is insolvent, do not neeessarily dissolve the corporation, unless the statute that is invoked expressly so provides. ${ }^{5}$

It has been expressly held that corporations are not dissolved by

1 Boston Glass Manufactory $x$. Lang. don, 24 J'ick. 49 ; see also Olds v. Company (Mass.), 70 N. L. 1022.

2 Everetts $\%$ Company, 20 Conn. 448 ; Rorke $v$. Thomas, 56 X. Y. 559 ; People $v$. Ballard, 134 N. Y. 269 ; 32 N. E. 54 ; Commonwealth $v$. Silfer, 53 Pa. St. 71; Wilson $v$. I'ropyrietors, ctc., 9 R. I. 590 ; State $\because$. Ascoriation, 35 (). St. 258.

${ }^{3}$ Commonwealth $v$ Slifer, 53 Pa. St. 71; In re I.inonln Co., 190 Pa. St. 124; 42 Atl. 532; Wilson $v$. Proprietors, etc, 9 R. I. 590 .

${ }^{4}$ Perpler. B. \& R. T. Road, 23 Weud. 150
222 ; Boston Glass Manufactory v. Lang. don, 24 Pick. (Mass.) 49 ; Kincaill $v$. Dwinelle, 59 N. Y. 548; Jones v. Edson, 10 Kan. Ap. 110 ; 62 I'ac. 249 ; State $v$. Trustees, 5 Ind. 44; Wilmington \& Reading Ry. Co. $v$. Downward (1)el.), 14 Atl. 720; Muscatine Turnverein $v$. Funck, 18 Ia. 469 ; U. S. $v$. Company, 1 Fed. 700 ; Brad. ley $v$. MeKee, 5 Cranch C. C. 298; Fed. Cases, No. 1784.

5 Sprague Brimmer Mfg. Co. $v$. Company, 26 Fed. 572 ; Stolze $v$. Company, 100 Wis. $208 ; 75 \mathrm{~N}$. W. 987 ; Olds $v$. Company (.Iass.), 70 N. E. 1022. 
statutory proceedings in bankruptcy or insolrency, or by appointment of receivers in equity or by assignment for the benefit of creditors. ${ }^{1}$

$\$ 115$. Forfeiture of Charters. - At common law forfeiture of charters was accomplished by means of scire fucias, or by an information by the proper State officials in the nature of a writ of quo warranto." "An information for the purpose of dissolving a corporation or of seizing its franchises," it has been said, "cannot be brought except by the authority of the Commonwealth, exercised by the legislature or by the attorney or solicitor-general acting under its direction or ex officio in its behalf. For the Commonwealth may waive any provision of any condition, express or implied, on which the corporation was created; and courts cannot give judgment for the scizure by the Commonwealth of the franchises of any corporation unless the Commonwealth be a party in interest to the suit and assents to the judgment." 3

A corporation camnot within the meaning of the law forfeit its riglits and seal up the corporation. A corporation without rights, without legal capacity to do anything, not ercu to acquire rights, is an impossibility. It has never been seriously contended that mere non-performance of conditions subsequent on the part of a corporation has the effect ex proprio vigore to put an end to corporate life. By such non-performance the corporation is not ipso facto dissolved or deprived of its corporate existence or corporate rights, but it is simply exposed to procecdings in behalf of the State to estahlish and enforce a forfeiture. The State which gave the corporate life may take it away. The State which imposed the conditions may waive their performance, and the corporate life may run on until the State by proper procecdings (ordinarily quo warranto, or in the nature of quo warranto) interposes and enforces a forfeiture."

Courts of equity have no inherent jurisdiction, in the absence of statute conferring the same, to decree a dissolution of a corporation or declare a forfeiture of its charter on any grounds. ${ }^{5}$

1 Chamberlain 2 Company, I18 Mass. 5.32; 'laylor r. Compuny, It dllen (.llass.), 95.3; Monlennery $v$. Merrill, l\& Micl. 338; Buston Gilass Mantfactory $\because$. Lambdon, 24 l'ick. (Mass.) 40 ; ('entral Nat. liank v. Company, $101 \mathrm{~L} . \mathrm{S} .51$.

2 liex 2 . Passmore, 3 T'rerm licpurts, 199; Slee v. Bloom, 5 Jolunsun's Claan. ‥ Y. 366; W. \& B. T. Ca. v. Marylamel, $1 ! 131.239$.

3 ('ommonwealth $\%$ Complayy, 5 Mass. 230 .

1 Mater of Bronklyu Lilevated Ry. Co., 12.5 X. Y. 431; $20 ; .1 \% 474$.

b Wlueder t. Comprauy. 143 Ill. 197; 32 ‥ I. 420; Denike $\because$ Company, 80 


\section{\$11) INCORPOLATION AND ORGANIZATION OF CORPORATIONS. [PART I.}

The puincipal gromels under the statute upon which charters will be forfeited may be entmerated as follows: (1) non-user of corprorite frinchises; (2) mis-user or abuse of corporate powers; (3) for non-prerformance of eonditions preedent to valid existence as a corpration; (t) for non-performanee of conditions snbsequent to valid continnance of existence as a corporation; (5) for violation of express statutes; (6) for non-payment of taxes; (7) for insolveney. These will now be taken up briefly for separate consileration.

(1) Furteiture for non-user of corporate franchises. It is a wellestablished doetrine of the law that eourts should proceed with extreme caution in proceedings which have for their object the forfeiture of corporate franchises; nor should such a penalty be risited excejt for plain abuse of power by which the corporation fails to fullil the designs and purposes of its organization. ${ }^{1}$ Again it has been well said: "It is not every failure to perform a duty imposed that will work a forfeiture. It must be something more than acidental negligence, something more than an excess of power, something more than a mere mistake in the mode of executing the acknowledged powers; and thongh a single act of simple non-feasance may be a ground of forfeiture, a specific act of non-feasance not committed wilfully and not producing or tending to produce mischievous consequences to any one, and not being contrary to formal regulations of the charter, will not be." 2

All these judicial utterances are little more than a declaration of the fact that the policy of the State, of its officers and courts should be to encourage in all legitimate ways the organization and operation of all corporations organized to promote any legitimate enterprise. "The rights, privileges, and franchises of such corporations," it has been well said, "should not be declared forfeited, and they should not be ousted and excluded therefrom, exeept for solid, weighty, and cogent reasons, for the violation of a prositive or prohibitory statute and not of a statute whose provisions are permissive and apparently directory, and never upon mere technical grounds." 3

The term "forfeiture of charter for non-user of corporate franchises," as liere used, has a very broad signifieation. It

X.Y. Is4. Ser however Miner v. Company, 9.3. Mich. 97; Arents v. Company, 101 Fed. 138.
1 State $v$. Chemical Bank, 10 O. St. 535.

2 State $v$. Company, 8 R. I. 182.

3 Noore $v$. State, 71 Ind. 478.

155 
may hare reference to action taken by the State with a view to forfciture of corporate charters on any one of the following grounds: failure to organize the eorporation within the time prescribed by statute; ${ }^{1}$ failure to earry on the business enumerated in its articles $;^{2}$ failure to eleet offieers $;^{3}$ failure to maintain domiciliary office within the State; ${ }^{4}$ failure to commence business within the time designated by statute. ${ }^{5}$

(2) Forfeiture for misuse or abuse of corporate powers. "To work a forfeiture on the ground of misuser or abuse of corporate powers, there should not only be a wrong, but one arising from wilful abuse or improper neglect. The eorporate default must be something more than aceidental negligence or mere mistaken excess of power, or mistake in the mode of exercising an acknowledged power. There must be an abuse of trust, of such a nature as would render a trustee liable to forfeit his station on the complaint of his cestui que trust if the question stood on the relation between them. Corporations are political trustees. Hare they fulfilled the purposes of their trust or acted in good faith with a view to fulfilment? is the question to be asked when they are called upon to forfeit their charter, either for acts of commission or omission." 6

"It appears to be settled," observed the New York Court of Appeals, "that the State as prosecutor must show on the part of the eorporation aceused some aet against the law of its being which has produced or tends to produce injury to the publie. The transgression must not be merely formal or accidental, but material and serions, and such as to harm or menace the jublic welfare. For the State does not eoneern itself with the cuarrels of private litigants. It furnishes for them sufficient courts and remedies, but interferes only where some public interest requires its action. Corporations may and often do exceed their authority where only private rights are affected. But when the transgression has a wider scope and threatens the welfare of the people, they may summon the offender to answer for the abuse of its framelises or the riolation of its corporate duty." ;

1 State $v$. Simonton, 78 N. C. 57.

2 W. C. M. Co. v. Burns, 114 N C. 353 ; 19 S. E. 238.

3 State r. Barron, 58 N. II 370.

4 State v. Company, 58 . VimI, 330; 59

N. W. 1048 ; State 2 . Company, 59 Kan. 151; 52 l'ac. 422; State v. Company, 45 Wis. 579 .
G W. F. C. F. Co, r, Kittrilge, 5. Saw. 4t; People r. liank, I29 III. 618; 22 N. F. 288.

"I'opple 2 . B. \& R. T. lival, 23 Wend. 222.

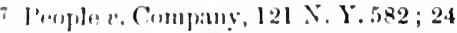
N. R. 831; ke ald M. O. \& R. R. Co, v. ('rusk, 20) Ark. 443. 
\$11 MCORPORATHON AND ORGANIZATION OF CORPORATIONS. [PART I.

(3) Forfiture for non-pertormance of conclitions precedent. Even a corporation defectively organized may lave what is termed a "defecto existence," so that it camnot ordinarily be imprached by parties other than the State. Nevertheless the right to bring proceedings to forfeit the charter of such corpolition rests with the State which may bring proceedings to forfeit the same and oust it from the exereise of corporate powers.

(4) Forfeiture for non-performance of conditions subsequent. It has been well settled that charters of corporations may be forfeited by proper action brought by the State for failure to comply with conditions subsequent which are elearly mandatory and not merely directory in their nature."

(5) Forfeiture for violution of express statute. This is one of the elearest grounds for the cxereise by the State of its right to forfeit charters. The most common ground for the exercise thele of is in comnection with anti-trust legislation. ${ }^{3}$

(6) Forfeiture for non-payment of taxes. Screral of the States authorize forfeiture of charters for non-payment of organization and anmual franchise taxes. This right has been cxercised with great frequency, and constitutes unquestionably a valid exercise of the power of suel legislature orer corporations. ${ }^{4}$

(7) Forfeiture for insolecncy. In the absence of statutory provision to that effeet, insolvency alone will not anthorize the State to forfeit corporate charters. ${ }^{5}$ However, it is unquestionably valid for a State to preseribe that if a corporation be insolvent for a certain length of time it shall constitute a forfeiture of its charter. 6

$\$$ 116. The Police Power of the State. - The police power of the State comprehends all those general laws of internal regulation which are necessary ro secure the peace, good order, health, and

1 Holman $x$. State, 105 Ind. 569 ; People v. City lsank, 7 Col. 226 ; 3 Pac. 214.

2 State $v$. Company, 1 Tenn. Cases, 511; l'eople v. Company, 131 N. Y. 140; IIammund v. Strauss, 53 Md. 1.

3 Simmons $x$. Company, 113 N. C. 147; State $v$. Comjany, 24 Texas, 80 ; IInyler 2. Company, 40 N. J. Fin. 392 ; l'eople $v$. Comprany, follow. I'r. 82; l'eople $v$. ComIany, 130 Ill. 268; State $v$. Standard Oil Cu. 49 0. St. 137 ; People v. Company, 121 N. Y. 582 ; see also P'ople v. Cham- bers, 42 Cal. 201 ; People v. Bank, 129 Ill. $618 ; 22$ N. E. $288 ; 24$ N. L. 834.

4 IIughesilale Mfg. Co. $v$. Vanner, 12 R. I. 491; Bank v. Company, 17 Ap. Div. (N. Y.) 524 .

5 l'euple v. Bank, 6 Cowen (N. Y.), 211 ; A. \& I. T. Co. v. Holthonse, 7 Ind. 59 ; State v. Bauk, 13 Smeads \& M. (Miss.) 569 ; Chicagro Life lus. Co. 2 . Needles, 113 U. S. 574.

6 People v. Bank, 12 Mich. 526 ; C. M. I. \& I. Ass'n v. Ilunt, 127 Ill. 257 ; Denike v. Company, 80 N. Y. 599. 
comfort of society, but the proper limit in its bearing upon charter rights and privileges of private corporations, for public uses would seem to be this: That the legislature may at all times regulate the exercise of the corporate franchises by general laws passed in good faith for the legitimate ends contemplated by State police power; that is, for peace, good order, health, comfort, and welfare of society; but it cannot under the color of such laws destroy or impair the franchises itself, or any of the rights or powers which are essential to the exercise of it. ${ }^{1}$

After the decision of the United States Supreme Court in Dartmouth College $v$. Woodward, ${ }^{2}$ that court proceeded to enunciate the doctrine that in the exercise of what is termed "police power," the screral States might pass laws as a valid excreise of such powers when otherwise they would be forbidden to do so under Section 10, Article 1, of the Constitution of the United States, which forbids the impairing of the obligations of contracts by means of laws enacted by them.

The police power arises primarily from the nature of the social contract, just as when each person upon hecoming a member of a society nust of necessity relinquish some of the rights and privileges which, as an individual and considered alone, he might retain. The Supreme Court of Massachusetts in Commonwealth $v$. Alger ${ }^{3}$ says: "All property" is subject to such reasonable restrictions and regulations established by law as the legislature under the governing and controlling power rested in them by the Constitution may think necessary and expedient."

In Gibbons $v$. Ogden ${ }^{4}$ the United States Supreme Court held that the police power is lodged with the several States. In Providence Bank $v$. Billings ${ }^{5}$ the eou't took another step forward, anl held that the abandonment on the part of the state of its power of regulation in this regard onght never to be presumed in any case where the purpose of the State to abandon it does not clearly appear.

In the License Cases " the cont held that, in the exereise of its police power, a State may pass quarantine and simitary laws damaging and even destroying property in some cases. In Bartemeyer $v$. Iowa the court held that a state law prohibiting the mannlac-

1 l'. W. B. R. li. Co. v, Bowers, \& Houston, I)el. 506 .

$2+$ Wheat. 518 .

37 Cush. 84.
4 ?) What. $].$

5 fecters, 514.

65 Howarl, 404.

7 18 Wial. 133. 
tule and sale of intoxicating linuors was a valid cxercise of the puliec power. In lieer Company 2 . Massachusetts ${ }^{1}$ the court held that as a measure of police regulation, looking to the prescrvation of public morals, a state law prohibiting the mannfacture and sale of intoxieating liquors is not repugnant to any clause of the Constitution of the United States.

In Mugler '. Kinsas ${ }^{2}$ it was helel that a State may absolutely mohibit the mannfacture and sale of intoxicating liquors as a beremge, and may declare places where such liquors are manufactured or sold to be musances, and may authorize the destruetion of such linuors found therein, and of all property used in keeping and manufacturing such muisances. Such a statute is valid as to such. liquors larfully manufactured before the enactment of the statute, and although it greatly deteriorates the value of the property lawfully used in such manufacture before the enactment of the statute.

In Mumn $"$. Illinois ${ }^{3}$ it was held that when the owner of property devotes it to a use in which the public has an interest, he in effect rrauts to the public an interest in such use, and must to the extent of that interest submit to be controlled by the public for the common good as long as he maintains the use.

In Fertilizing Company $v$. Hyde Park ${ }^{4}$ the right of State authorities to compel the remoral of a bone fertilizing business from a location near the village to a point farther removed, was lueld to be ralisl as an exercise of the police power.

In the Slaunher IIouse Cases ${ }^{5}$ the court held that the power of State lenislatures to make a contract of such a character that muler the provisions of the Constitution it camnot be modified or abrogatorl dow not extend to subjects affecting publie health and jublic morals, so as to limit the further exercise of legislative jower wer those subjects, to the prejudice of the general welfare.

To smmanize bricfly the general doctrine of the federal Sulneme: Coment on this sulject, the same may be done by presenting the following abstract propositions :

(1) Laws for the welfare and safety of a community being ossulial to the existence of every state, it camot be supposed to have !n within the intention of the original thirteen States to linit hi- wwer by assenting to the Federal Constitution.

\footnotetext{
14.4 .25$.

$212: \because<0,23$.

$3: 411^{\circ}-113$.

\& $40.1 \%$. lii:
}

5111 U. S. 746.

6 Iouisville \& N. R. Co. v. Kentucky, 161 U.S. $677 ; 40$ L. E. 849. 
(2) Generally speaking, the extent to which a State can regulate the business or affairs of a corporation depends upon the nature of the business - whether it affects the public closely or remotely. If it is of such a character or magnitude that the public are directly interested in its proper management, then it falls within the proper sphere of legislative control.'

(3) Being an inherent right as well as a duty, the legislature may pass enactments looking towards the safety of life and property, and general laws of this nature are a legitimate exercise of the "police power." Thus it may compel railroads to fence tracks, maintaiu eattle guards, put up signboards at crossings, construct viaduets, require all trains to stop at intersections of railroads, etc. ${ }^{2}$

(4) Laws intended to prevent or remore nnisances are clearly within the "police power" of the State. ${ }^{3}$

(5) A State may pass laws for the protection of its inhabitants. against the evils of intemperance, eren though existing contracts. be affected thereby. ${ }^{4}$

(6) Laws regulating the employment of persons of a certain age in manufactories are a ralid exereise of the general power of the State to enact laws to secure the health and education of the community. ${ }^{5}$

(7) A State may by statute protect the interest of employees when the commun law affords no protection; as for example, a law proriding that all railroad companies shall be liable for wages due to day laborers cmployed by contractors engaged to construct the company's railroad and works was held to be ralid. ${ }^{6}$

(8) A State may by general laws regulate the use and disposition of property within its jurisdiction, although existing incorporated compranies be thereby affectel.

(9) A State may pass laws for the protection of the morals

1 Munn r. Illimeie, of r. S. I13; 2428 L. J. $629 ;$ Mugler $r$ Kansas, 123 L. S.

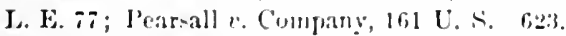

$640 ; 40$ L. 1: 1834 .

3 Linoxville Jron Co. P. Jlarbison, 1s3

2 Reill r. Collorallo, 197 L. S. 137; 47 I. F. 108 ; Smith r. Company, 181 1'. S. $26 ; 45$ L. L. 817 .

: Slansiner llonse Casea, if Wall. 36 ; 21 L. L. 394.

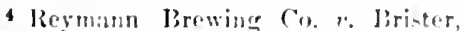
179 U.S. $445 ; 45$ L. E. 269 ; libulus 1 . State of Jiwa, 170 L. S. $+12 ; 12 \mathrm{~L}$. L. 1088 ; Foster e. Kansas, 112 C. S. 201; ;

U. S $13 ; 46 \mathrm{I}, \mathrm{H}, 55$.

6 Kuoxville Irm Co. r. IIarbisom, 183 1. S. 1.3; 16 I. J.. 5.5; Butchers' Uniom,

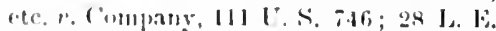

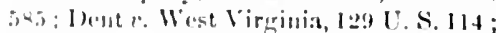

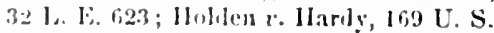
36,$3 ; 4$ J. F. 780.

7 lim r. New York, 143 U.S. 517 ; .36 I. I:. 247 . 
of its eitizens, even though rested corporate rights be thereby athected.

117. Legislative Investigation into Corporate Affairs. - The statutes of California, Michigan, Minnesota, North Dakota, Oklahoma, South Dakota, and Wisconsin contain express provisions for the appointment of legislative eommittees to examine into the affars of corporations organized under their laws. The prorisions of the South Dakota aet may be quoted as exemplifying the niture of such statutory provision. It reads as follows:

"The legislative assembly, or either branch thereof, may examine into the affairs and condition of any corporation in this State at all times; and for that purpose any committee appointed by the said assembly, or either branch thereof, may administer all necessary oaths to the directors, officers, and stoekholders of such corporation, and may examine them on oath in relation to the affairs and conditions thereof; and may examine the safes, books, papers, and docnments belonging to such corporation, or pertaining to its affairs and condition, and compel the production of all keys, books, papers, and doeuments by summary process, to be issued on application to any cireuit eourt or any judge thereof, under such rules and regulations as the eourt may prescribe." 2

Such an inquiry as is anthorized by the statutes just referred to has been held not to constitute a judicial act, and is therefore considered a ralid exercise of legislative powers. ${ }^{3}$ On this particular subject the Supreme Court of Massachusetts spoke as follows:

"The inquiry into the affairs or defaults of a corporation with a riew to continue or discontinue it, is not a judicial act. No issue is framed. No deeree or jurgment is passed. No forfeiture is adjudged. No fine or imprisomment is imposed. But an inquiry is had in such form as is deemed most wise and expedient, with a view to aseertaining facts upon which to exert legislative power or to learn whether a contingeney has happened upon which legislative action is required."4

\section{\$ 118. Legislative Requirement of Annual Reports from Corpora-} tions. - Statutes exist in thirty-three of the Commonwealths

Austin v. Tennessee, 179 U. S. 343 ; 4.5 I. I. 22.24 ; l'etit $x$. Mlinnesota, 177 U.S. If 4 ; 4 I. R. . 1 fo; Ilammington r. Georgia, 16.11 . S. $299 ; 41$ L. E. I66; L'Ilote v. New ()rleans, it L. S. 587 ; 4 L L. E. 899. 161
2 Sec. 478, Rev. Civ. Code; sec. 2970, Comp. L.

${ }^{3}$ Lothrop r. Stedman, 42 Conn. 583;

Fed. Cas. No. 8519.

${ }^{4}$ Crease v. Babeock, 23 I'ick. 344. 
requiring annual reports from domestic corporations. ${ }^{1}$ The validity of such statutes was considered by the Supreme Court in the case of Eagle Insurance Company $v$. State of Olio. ${ }^{2}$ The court in its opinion therein spoke as follows:

"The right of the plaintiff in error to exist as a corporation and its authority in that capacity to conduct the particular business for which it was created were granted suljeet to the condition that the privileges and franchises conferred upon it should not be abused or so employerl as to defeat the ends for whieh it was established, and that when so abused or misemployed they might be withdrawn or reclained by the State in such way and by such modes of procedure as were consistent with law. Although no such condition is expressed in the plaintiff's charter, it is implied in every grant of corporate existence. Equally implied in our judgment is the condition that the corporation shall be subject to such reasonable regulations in respect to the general conduct of its powers as the legislature may from time to time prescribe which do not materially interfere with or obstruct the substantial enjoyment of the privileges the State has granted only to secure the ends for which the corporation was created. If this condition be not implied, then the creation of corporations with rights and privileges which do not belong to individual citizens may become dangerous to the public welfare through the ignorance or misconduct or fraud of those to whose management their affairs are entrusted. It would be extraordinary for the legislative department of a government, charged with the duty of enacting such laws as may promote the health or morals or prosperity of the people might not when unrestrained by constitutional limitations upon its authority, provide by reasonable regulations against the nisuse of special corporate privileges which it has granted, and which conld not except by its sanction, express or implied, liave been exercised at all."

The conclusion of the court in the case just referred to was that the charter of the corporation did not exempt it from olligrations to comply with the subsequently established police regulations of the State, requiring certain corporations to make anmual statements of their condition.

$\$ 119$. Inspection of Corporate Books. - In all the Commonwealths but fire statutes have heen enacted recpuiring the keeping of certain corporate books and giving to stockloblers, and sometimes to crelitors as well, the right to inspect the same. $\mathrm{At}$

1 See I'art III. Table 7 , page 57.

$21.33 \mathrm{Y}$. S. 4.46. 
common law stockholders had the right to inspect books and fapers of the corporation at reasonable times and for a proper jurpose." Creditors had no such common law rights.

() this sulject the New York Court of Appeals in the Matter of steinwa spolic as follows:

"The elementary works unite in holding that the incorporator has the risht in question and that mandamus is the proper remedy. We think that according to the decided weight of anthority a stockholeler has the riglit at common law to inspect the books of his corporation at a proper time and place and for a proper purpose, and that if this right is refused by the officers in eharge, writ of mandamus may issue in the sonnd discretion of the court with suitable safeguards to protect the interests of all concerued. It should not be issued to aid a blackmailer, nor withheld simply because the interest of the stockholder is small, but the court should proceed cautionsly and discreetly, according to the facts of the particular case. To the extent, however, thit an absolute right is conferred by statute, nothing is left to the discretion of the court but the writ to issue as a matter of course, although even then doubtless due precautions may be taken as to time and place so as to prevent interruption of business, or other scrious inconvenience. We do not think, however, that the statute now in force in this State is exclusive, or that it has abrirged the common law right of stockholders with reference to the examination of the corporate books. By enabling the stockholder to get some information in a new way, it did not impliedly repeal the common law rule, which enabled him to get other information in another way, for the courts do not hold the common law to be repealed by implication unless the intention is obvious. By simply providing an additional remedy the existing remerly was not taken away. 'The statute merely strengthens the common law rule with reference to one part thereof, and left the remainder intact."

The right of inspection of corporate books is not the inspection of the ille, the impertinent, or the curions, but an inspection with a laudable object to accomplish, or a real and actual interest upon which is predicated the request for information disclosed by the books.3

1 Perple $v$. Fallie, 63 IIun, $320 ; 133$ N. Y. 573; Burham v. Company, 76 Cal. 24;17 I’ac. 910; Phoenix Irun Co.v. Com. monwealth, 113 Pa. St. 563 ; Hemingway v. IIenningway, 58 Conn. 443.

$11 j 6 j$
2159 N. Y. 250.

a State ex rel. Bourdette v. Company, 49 La. Ant. 1556 ; 22 So. 815. 
The purpose of requiring a copy of stock books and books of account at the corporation's domiciliary office is to protect the rights of stockholders and to aid the State in exercising its visitorial powers, or to enable creditors or stockholders to ascertain the number of shares standing in the names of each so as to lery execution and attachment thereon. The mere fact that a domestie corporation has kept its books in another State when required by law to keep its books at its domiciliary office, is not a ground for dissolving the corporation when parties entitled to inspection of such books have nerer been refused the right to inspect the same at the domiciliary office. ${ }^{1}$

$\$ 120$. Anti-Trust Legislation. - The term "trust" includes any form of combination or combinations between eorporations or between corporations and individuals for the purpose of regulating production and repressing competition by means of the power thus centralized.2

Under the common law agreements, pools, trusts, or combinatious between persons or corporations looking towarls any absolute restraint of trade or to regulate prices or to promote monopolies, were against public policy, and as such were unlawful and roid. But when the question of public policy is at issue, certain matters should be noted.

It has been well said "that the public poliey of the State varies from time to time. It is not to be measured by the prirate combination or combinations of the persons who happen to be exercising judicial functions, but by reference to the enactment of the law-making power, and in the absence of them to the decisions of the courts. When, however, the legislature has spoken upon a particular subject and within the limits of its constitutional powers, its ntterance is the public policy of the State." 3

Congress dealt with illegal trade combinations in relation to interstate commerec as eally as $\mathbf{1 8 8 7}$, when it passed the InterState Commeree Act, and later on, July 2,1890, it passed what is known as the "Sherman Anti-Trust $A$ et." Since that time thirtythree of the States have passerl more or less stringent anti-trust acts. ${ }^{4}$ All this legislation has been framed with the same purpose.

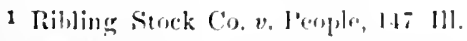
$234 ; 3.5$ న. . . 608 .

2 Mac(iniss v. Company (Almul.), i.j 1'ac. 89. a Mac(iimiss r. Company (Mont.), is

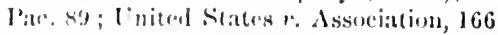

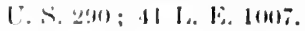

1. Sice l'art [11. 'Talle 3, page 573. 
In some of these acts an arbitrary distinetion is male between dealers and producers. Such provisions have under certain cir. cunstances heen deelared to be "class legislation," and as such are invalid nuder the Fourteenth Amendment to the Federal Constitution.

Lndur this prineiple the anti-trust acts of Illinois and Texas lave recently been declared to be unconstitutional. ${ }^{1}$

In the note below will he found the dates of the passage of the earlier anti-trust acts in the sereral states. ${ }^{2}$

$\$ 1: 1$. Regulation of Internal Affairs. - In many of the States the rewulation of the internal affairs of corporations has been larecly delewated by statute to the corporations themselves. Such is the case in Alabama, Comecticut, Delaware, lowa, Maryland, Massachusetts. New Jersey, Nebraska, New York, North Carolina, Sonth Cirolina, Temessee, Utah, Virginia, West Virginia, and Wisconsin.

In other of the Commonwealths, withont express provision of law prermitting the same, State officials allow clauses for the regulation of the internal affairs of the corporation to be incorporated in articles of incorporation filed with them. As an

${ }^{1}$ Connully $v$. Union S. P. Co., 184 L. S. $5 \$ 0$; 46 L. I. 679 ; State $v$. Shippers \& Compress Warehouse Co., 95 Texals, 603; 69 - W. 58 ; Furll $v$. Assuciation, 155111 . 166 ; 33 N. E. 651 ; Harding 2 . Company, 182 Ill. $551 ; 55$ N. E. 577 . See also Northern Securities Co. $v$. United States, 193 L. S. 197 .

2 The Ferleral Anti-Trust Act commonly known as "the Sherman $\Lambda$ ct" was apfiruved July 2, 1-90. The following is a list of the states wherein anti-trust legislation of a more or less comprehensive character was passed, togrether with the diate the sinne went into effect:

Alalsua, Insurance $A$ (t. Feb 18,1897; Arkansis, Anti-Trust Act, Mar. 16, 1897; ('alifurnia, (attle Trust $\Lambda(t, F(b), 27,1893$; Delaware, Life Insurauce Act, F(b). 15, le9l; Florila, Trate in Cattle, June 11, Ingi; (imergia, Anti-Monowly Aet, 1)ee 23, 1×96: Illimis, P'rohilitory P'ools, Trusts, anl (')mbinations, Original Act, Inly 11 , 1691, amrulwd Juns 10, 1897; Indiana, Mar. 5. J4gi, Cieneral Anti-Prust; Iowa, Fromeral Auti-lrust, May 6, 1890 ; Kansas, sar. 8,140 , Ifefines a trust in five sec$11 ;$; tiins; Kentucky, General, May 20, 1890 ; Lonisiana, General went into effect July 7 , 1892 ; Maine, General, Mar. 7, 1889 ; Mich. igan, became a law July 1, 1889; Minnesutil, $A_{\text {pril }} 20,1891$; Mississippi, l'art of the Code of the General St. Laws of Mississippi adupted in 1892, and amended March 11, 1896; Missonri, Original $\Lambda$ ct, $A_{\text {pril 2, 1891, revised under } A \text { ct of }}$ April 11, 1895, and revised again March 24, 1897 ; Nontana, Annotated Code of 1895, secs. 321-325; Nelraskil, $\Lambda$ ct of $\Lambda$ pril 8, 1897; New Mexico, Feb. 4, 1891; New York, Miy 7, 1897; North Carolina, March 11, 1889; North Dakota, March 9, 1897; Oklahoma, Dec. 25, 1890; South Carolina, Fel. 25, 1897 ; Soutl I Dakota, March, 1, 1897 ; 'Temessee, $\Lambda$ pril 6, 1889 amended March 30, I891; Texas, Origi-

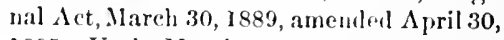
1895; Utah, March 9, 1896; Washington, Con., Art. XlI sec. 22, anil also Act of March 21, 1895, Session Laws, 1895, chap. cxlviii.; Wisconsin, $\Lambda_{\text {pril } 27,1897 .}$ (See "Biography of Commercinl Trusts," by Wm. H. Winters, librarian of the N. Y. Law Institute in 1890 .) 
example of the statutes above referred to, attention is called to the provisions of the New Jersey Act, which reads as follows:

"The certificate of incorporation may also contain any provision which the incorporators may choose to insert for the regulation of the business and for the conduct of the affairs of the corporation, and any provision creating, defining, limiting; and regulating the powers of the corporation, the directors, and the stockholders or any class or classes of stockholuers." 1

Without such statutory authority State officials are unquestionably justified in refusing to allow articles of incorporation to be filed containing such clauses as are here referred to. ${ }^{2}$

The Court of Appeals of New York in an early ease, commenting upon the legal effect of the insertion of provisions in the articles not authorized by the incorporation act, spoke as follows:

"The want of anthority for this provision would not affect the validity of the corporation. The articles must contain the statements affirmatively requircd by the act, because those statements constitute the conditions precedent to the right of the company to become incorporated. If unauthorized provisions are added, all the acts done pursuant to such provisions will be roid, but until the company is proceeded against for abuse of its franchises its rights as a corporation will not be affected by such unauthorized provisions." s

The more modern view in regard to such matters is that where State officials are either expressly or impliedly empowered to pass upon the validity of articles of ineorporation submitted to them with a riew to filing in their office, the approval of such State official once olstained renders such elauses as are here referred to valid as against all but the state, even when their insertion in the articles is not expressly anthorizcd."

$\$ 122$. Liability of Stockholders for Debts of the Corporation. The general subjeet of stocklublers' liability may be best discussed undre three lıcals: (a) Tsiability for umpaid stock subseriptions; (b) Double liability as established by statute in certain

1 New Jersey Session Laws of 1890. chap. 185, sere. suldivision 7.

2 In re stevelores' Jinllefirial Ass'u, 14 Phila. I'a. 130; sec ante, sec. 5.
3 Vastorn llank liond Co. v. Vaughan, $11 \mathrm{Y} Y .51$.

4 Sine ante, sec. o. 
States: (c) Epecial liability as established by statute in certain States.

(1) Liability for umpaid stock subscription. 'The statutes which exist in nearly every Commonwealth in the Union making stocklolkers liable for mpaid stock subseriptions are merely declaratory of the common law. 'The liability of stockholders of corporations for mpaid stock subseriptions with reference to creditors is oftentimes confused with their liability to the corporation itself. The latter liability is directory and the right to enforce it may be waived by the corporation. In the absence of such waiver the subscribing stockholders are bound by the contract of subscription to pay the full value of their shares in such instalments and in snch manner as may be prescribed by the laws of the State or bylaws of the corporation. In such cases the liability may be enforced by the ordinary remedies. The corporation usually has a lien upon the stock, and may sell the same in satisfaction of the debt, and may collect the deficiency, if any, by action against the delinquent stockholders.

On the other hand, as the corporation is a legal entity distinct from the stockholders who constitute it, no debts or obligations incurred by it can, in the absence of a direct statutory provision, impose any lawful liability upon the stockholders. But in equity, under what is termed the "trust fund doctrine," the debts of the stockholders to the corporation are regarded as equitable assets of the corporation and may be reached by the creditors if the legal assets prove insufficient. This trust fund doctrine derives its main support at the present time from the Supreme Court of the United States, but it lias secured recognition in many jurisdictions.

As stated in Sanger $v$. Upton, " The capital stock of an incorporated company is a fund set apart for payment of its debts. It is publicly pledged to those who deal with the corporation for their security. Unuaid stock is as much a part of this pledge, and as much a part of the assets of the company as the eash which has been fraid in.

"The stockholders thus become individually liable for the debts of the corporation, to the extent of the unpaid balance on their strock. 'They are also in some States subject to other statutory liabilities hereinafter set forth. The statutory remedy is usually by equitable action, but in some States by an action at law.

1 Taylor $v$. Cummings, 127 Fed. $108 . \quad 291$ U. S. 60. 170 
Under nearly all such statutory provisions, the liability of stockholders is intended merely as a secondary security for creditors in case the assets of the corporation are insufficient to meet its debts, but in special cases stockholders may be marle parties defendant in an original action, and if they are obliged to pay any debt of the corporation they may bring an action against the colporation for the amount so paid, and are usually entitled also to exact contribution from the other stockholders."

The only other questions which are of practical importance in connection with the present subject may be restricted to two classes: one relates to the liability for unpaid stock subscriptions to creditors as between the transferor and the transferee, and the other relates to the liability to creditor's of pledgecs and trustees of stock.

With reference to the first question it may be said that the question depends upon the law of the State in which the stockholder may reside and in which action may be brought. In most States transferors of stock are not subject to stockholders' liability, and are thereafter released from liability for assessments made by the corporation. ${ }^{2}$

In the absence of statutory provision to the contrary, a lona fide transfer of stock perfected on the bouks of the corporation, discharges the transferor from any further liability either to the corporation or to creditors for calls made after the transfer and for calls made prior thereto, and the transferee takes his place and becomes liable for calls made after the transfer but not for calls made before. ${ }^{3}$ The distinction which elearly obtains between one who holds his stock by transfer and one who is an original subscriber to the stock of the corporation, must be carefully noted. The former may in good faith discharge himself from liability for unpaid instalments by due transfer of his shares, while the latter camnot obtain immunity in this way. The subscriptions for stock and the acceptance of a certificate for the shares constitute a contract betwecn the subseriber and the corporation hy which he engages to pay the remaining instalunents on demand from the corporation. From this agreement the subseriber cannot recede withont the consent of the corporation." In some of the sitates

1 Gienn v. IIunt, 120 Mo. 330; 25 also Signa Iron Co.v. 13rown, 171 N. Y. S. W. 181 .

2 if L. T. Co. v. Wari, 13 ohio, 120.

a Pullman v. Epton, 96 U. S.328; see $448 ; 61$ N. 1: 1918.

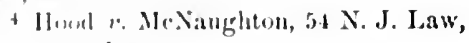
$425 ; 24$ A 1.45 . 
this matter is regrulated by statute. In Mine, Massachusetts, North Carolina, West Virginia, the original subseriber alone is liable. In lllinois, Iowa, Nebraska, New Ilamplire, Rhode Islaml, and Virginia the original subseriber remains liable as well as the transferee. I In Georgia, Ohio, 'lennessee, and Oregon the original subseriber is liable upon default in payment by the transferee. In Mississippi and IVisconsin the original subseriber remains liable for the debts contracted before his ownership or those contrated thereafter. In California, Indiana, Kentucky, Maryland, Michigan, Mimmesota, New York, and Temnessee the origrinal subseriber remains liable for the debts of the corporation contracted during his ownership and not for debts contracted after such transfer. In Alabama, Arizona, Arkansas, Colorado, Connecticut, I) laware, District of Columbia, Florida, Idalı, Kansas, Louisiana, Massachusetts, Minnesota, Missouri, Montana, New Jersey, North Dakota, Oklahoma, Pennsylvania, South Carolina, South Dakuta, Texas, Utal, Vemont, Washington, and Vyoming upon the transfer of stock the transferee becomes liable for all debts contracted both before and after transfer, and the transferor is discharged in all these States as to debts contracted after such transfer, and in some of these States from liability for debts contracted before such transfer as well. ${ }^{2}$

'Turning now to the question of liability of pledgees and trustees of stock, it ma! be said that unless protected by statute, as is the case in New York, Missouri, California, and Michigan, the prerailing rule scems to be that pledgees and trustees of stock are liable thereon to the extent of the unpaid portion of the stock held by them. ${ }^{3}$

On the other hand the Sinpreme Court of the United States has enunciated a different doetrine to the effect that a pledgee of stock taken as collateral security or as a loan is not subject to personal liability for the debts of the corproration imposed on other shareholder's mnless lie lias either become the owner of the shares in fact or has held himself out to he the owner, and thereby estopped himself from denying his personal liability as such. ${ }^{4}$

\footnotetext{
1 White $v$. Greene (Iowa), $70 \mathrm{~N}$. W. 182 ; Spraque 2 . Bank, 172 Ill. 149; 50 N. E. I $19(1)$.

2 Vin Cott $v$. Yan Brunt, 82 N. Y. 535.

3 Hele; 1 . Walker, 31 Ia 344; Cuion Savinge A $x^{\prime} 11$ r. Seligman, 92 Mo. 635;

172
}

65 S. W. 630; Germania National Bank v. Case, 99 U. S. 628 ; McMahon $v$. Macy, 51 N. Y. 155.

4 Rankin $r$. F. I. T. \& D. Co., 189 U. S. 242 . 
(b) Double liability as established by statute in certain States. What is known as the "double liability" of stockholders for debts of the corporation which existed formerly in a large number of States, has now been so far remored by statute that it exists at the present time in the ease of ordinary business eorporations in only two States, to wit, California and Minnesota. In the lastmentioned State it does not exist in the ease of corporations organized exclusively for the purpose of carrying on a mantifacturing, mining, or mechanical business. ${ }^{2}$

(c) Special liability as established by statute in certain States. Stockholders at common law were not liable for debts of the corporation beyond their liability for unpaid stock subseriptions. ${ }^{3}$ Personal responsibility of stockholders is inconsistent with the conception of corporate liability at common law, and for this reason, if it exists at all, must rest mpon some positive statute.

The particular liability under consideration here arises by reason of the existence of statutory provisions that may be stated as follows: Liability of incorporators as partners through failure to legally organize the corporation. In Florida, Iowa, Minnesota, Nebraska, and Wisconsin stockholders are individnally lable by statute for failure to comply with certain prescribed regulations in regard to organization and publicity.j In a few of the States the courts construe the liability of incorporators where they have failed to legally organize the corporation, not as partners at all. 'This on the ground that no such relationship or liability is contemplated by the incorporators, and that the creditors' only remedy is against the officers and agents who actually made the contract. ${ }^{6}$

In Indiana, Massachusetts, Miehigan, New York, North I akota,

1 The liability may posilily still exist in Indiana and Kansas; see pagess 257, 265.

2 Sacramento lank $x$, l'acific Bank, $124 \mathrm{Cal} .147 ; 56 \mathrm{~J}$ 'ac. 787 ; Jiniclson 2 .

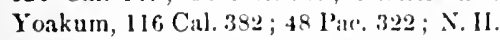
II. N. Co. v. Company, 142 Mass. $349 ; 7$ N. E. 773 ; Bates $r$. Way, 198 l'al St. 513 ; $48 \mathrm{Atl} .407$; Whitman $v$. Jank, $176 \mathrm{l}, \mathrm{S}$. 559; Willis v. Malon, 48 Minn. 140; 50 N. W. 1110 ; Marslaall e. Sherman, 1 th N. Y. $9 ; 42$ N. 1. 419 ; 'Tuttlo 2 National Bank, 161 Ill. 497 ; 44 N. li. 984.

8 Toner v. Faulkerson, 125 lnd 221; 25 N. E. 218; Ilool $v$. IICNanghtem, 54 N. J. I. $425 ; 2+A$ tl. 497.

4. S. L. C. N. Lank v. Hendrickson, 40
N. J. Law, 52; Ciar v. Igleliart, 3 O. St. $45 \%$.

5 Kaiser $r$. Baste, 56 Iowa 104; $8 \mathrm{~N}, \mathrm{~W}$. 7i2; luller $e$. Rowe, 57 N. Y. 23; Cumor r. Abbrt, 35 Ark. 366 ; Johuson r. Corser, $3+$ Winll. $355 ; 25 \mathrm{~N}$. W. 799 ; Ilırt $v$.

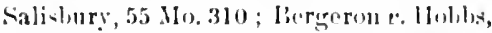
gf 11 is, 641 ; $71 \mathrm{~N}$. W. 105ti; Cleger v. Comprang, fi lowa, 121 ; 15 X. W. 16.5 : slomu $v$. Iead, 105 Wis. $431 ; 81 \mathrm{~N}$. W. 673.

6) Warl r. Brigham, 127 Mass 24; lintluerforl $r$. Ilill, 22 ()re. 218; 25 Pac. 546; ('anfield r. Grewry, 66 Conn. $9 ; 33$ Atl. 536; Bank 1. 11all, 35 O. St. 158. 
Oklahoma, l'ennsylvania, South Dakota, Temnessec, and Wisconsin they are liable for the wages of employees of the corporation. In Now Jork, in what is known as full liability corporations, stocklubleters are liable for debts of the corporation in full. In Arkinsas, Delaware, Iowa, Maine, Michigan, Mimmesota, New Hamplise, New Jersey, North Carolina, Vermont, and West Virginia stocklolders are individually liable to the extent of any part of the corporate assets refunded to them respectively. In Jaho, Nimnesota, North Carolina, and Sonth Carolina stockholders are individnally liable for any fraud or misconduct on their lart. In Arizona, Delaware, Iowa, and Nebraska stucklolders are personally liable for the debts of the corporation, muless they linit this liability by provision therefor in the charter. ${ }^{1}$

$\$ 123$. Statutory Liability of Directors. - With the exception of Alabama, Arizona, Lonisiana, and Utah, all of the Commonwealths have statutes, either civil or penal, imposing liability upon directors for certain designated acts of misfeasance or nonfeasance. These statutes are direrse both in scope and character. It will only be possible in this connection to enumerate without discussion the sereral liabilities thus imposed upon directors.

(1) For illegal declaration of dividends. ${ }^{2}$

(2) For illegal withdrawal of eapital stock. ${ }^{3}$

(3) For making false reprorts, or keeping false books of account, or making false representations. ${ }^{4}$

1 Van Pelt $v$. Gariner, $5+$ Neb. 701 ; 75 N. W. 974.

2 Such lialility exists in Alaska, Arkansas, California, Coloralo, Connecticut, Jelaware, District of Columbia, Floriła, (ieorria, Ilaho, Illinois, Indiana, Iowa, Kansa4, Kentucky, Maine, Maryland, Massachusetts. Michigan, Minnesota, Mississippi, Missouri, Montana, Neloraska, Nevala, New Hampshire, New Mexico, New Jersey, New York, North Carolina, Nortl Dikota, Ohio, Oklahoma, Oregenl, Lennstrania, Rhode Island, Sonth Dakota, 'T'unesee, Texas, Vermont, Virginia, Wa-hington. West Virginia, Wis-

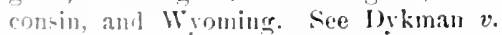
leeney, 160 N. Y. 675; 54 N. E. 1090; Chamberlain $v$. Company, 118 Mass. 552; $17 t$
Pittsburg, etc. R. R. Co. $v$. Allegheny Co., 63 Pa. St. 126.

3 Such liability exists in Alaska, California, Comnecticut, Georgia, Idaho, Iowa, Mississippi, Montana, Nevada, New Jersey, New Mexico, North Carolina, Oklahoma, Oregon, Suntl Dakota, Washington, and West Virginia.

* Such liability exists in Delaware, District of Columbia, Iucliana, Kentucky, Montana, Nevada, New Hampshire, New York, Rhode Island, South Carolina, Tennessee, and Virginia. Sce IImutington $v$. Attrill, 118 N. Y. $365 ; 23$ N. E. 544 ; Giddluer $v$. Ilolter, 19 Mont. 263; 48 l'ac. 8 ; Felker $v$. Company, 148 Nass. $226 ; 19$ N. E. 22.5; Githers $i$. Clarke, 158 I'a. St. 616; 28 Atl. 232; Thompson llouston 
(4) For failure to file annual reports. ${ }^{1}$

(5) For riolation of express statutes.2

(6) For authorizing the contraction of debts in excess of the amount limited by law. ${ }^{3}$

(7) For contracting debts before statutory requirements, such as subscriptions for stock, either in whole or in part, publication of articles, etc., have been complied with. ${ }^{4}$

(8) For failure to file certificates as to reduction of capital stock. ${ }^{5}$

(9) For false oaths to articles of incorporation. ${ }^{6}$

(10) For making loans to directors. ${ }^{i}$

(11) For making loans to stockholders. ${ }^{8}$

(12) For loss of funds through negligence.9

(13) For failure to display name or itemized accounts at domiciliary office. ${ }^{10}$

(14) For failure to allow inspection of books. ${ }^{11}$

Electric Co. $v$. Murray, 60 N. J. I. 20 ; 37 Atl. 443.

1 Such liability exists in Coloralo, Michigan, Nontana, New Jampshire, New York, anı] ()klahoma. See (iarrison $v$. Howe, 17 N. Y. 458; Van Etten $r$. Eaton, 19 Mich. 187; Shanklin e. Gray, 111 Cal. 88 ; 43 Pac. 399 ; Cinciunati Cociperage Co. v. O'Keeffe, 120 N. Y. $603 ; 2+$ N. L. 993 ; Wallace $r$ Walsh, 125 N. Y. $26 ; 25$ N. E. 1076; Glenn Falls Pajer Co. 2 . White, 18 Hun (X. Y.), 214; Bulen $x$. Crushy, 49 N. Y. 183; Talbor 2. Bank, 62 Fed. $383 ; 10$ C. C. A. 429

2 Sucl, liability exists in Arkansas, Iraho, Imliana, Kientucky, Michigan, North 1)ikinta, ilul Sonth I)ilkota. Sice Jatterson $v$. Stewart, 41 Minn, s1; 42 N. IV. 92f; Lowerin $r$. Melanglilia, lob Ill. $417 ; 41$ N. 15. 99; ('H)w v. Piruwn, 1.0) Jur]. 185; 48 ‥ I․ 10\%4; 49 X. [\%. 10.5; Guntlere e. (ompany, al liy. I. licp. 65s; 52 ×. W. o:31.

3 Snch linbility rexists in Califormia, Illinsis, Jlalu, Misissipli, Montaua, Now Ilamphire, Now Moxien, North Daketa,

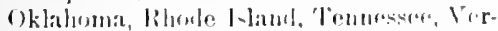

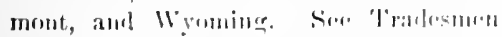

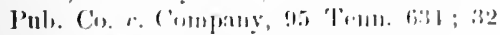

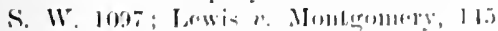
Ill. 30 ; 32 ‥ L. 880; Ilormor v. Ilcunine, 93 U. \$. 228.
4 Such liability exists in Illinois, (Hhio, Vermont, and liseomsin. See lient $x$. Clark, 181 111. 237; 51 N. L.967; Cluw e. Brown, 150 Jull 185; 48 N. IE. 10:34; 49 N. L. 10.5 ; Hequembonrg e. Elwarels, 155 No. 514 ; 55 S. W. 490 ; lowrin $v$. Mclauglilin, 161 Ill. 417 ; 44 N. 1.. 99.

5 Such liahility exists in Indiana, New Jersey, and North Carolina.

" Such liahility exists in Massachusetts.

7 Such liahility exists in Massachusetts anr New York. Sre Thacher $v$. Kingr, 156 .Hass. 490 ; 31 N. E. 618; Comnectiont River liank 2 . Fiske, 62 N. Il. 178; Witters $\because$. Sumles, 31 Fed. 1.

8 Such liahility exists in Jistrict of Colmubia, Misisipli, Missomi, Now lamplipre. New York, (lklaluma, lilume

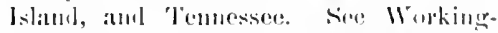
mrn's Bankinger (o. r. Rantrulleren, J03 111. 460); Bank ('ommissinneres 1, l3ank of

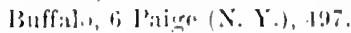

9 Surlr liablility exists in Mimuesota.

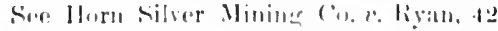

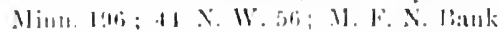

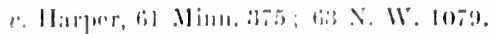

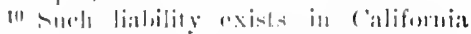

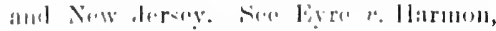

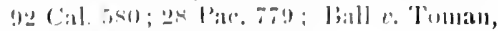

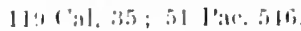

11 such lialnility "xist in New Jersey. 
(1i) Fol culberlenent of oflicers. ${ }^{1}$

(1i) For failure to make ecrtificate of payment of capital stikli:"

(17) For making false appraisal as to value of property taken in exchange for corporate stock. ${ }^{3}$

(18) For not producing list of stockholders at the annual election of directors. ${ }^{4}$

(19) For permitting an illegal issue of stock or bonds. ${ }^{5}$

(20) For making prohibited transfers of property. ${ }^{6}$

(21) For issuing stock as full paid when less than its par valuc is paid thereon. ${ }^{7}$

$\$ 124$. Extension of Corporate Existence. - In order to extend corporate existence special legislative action is necessary. ${ }^{8} \mathrm{In}$ nearly all of the States statutes exist providing that for a period of three years after the term of existence limited by its charter has expired, the corporation shall continue to exist for the purpuse of winding up its affairs. Express power to extend corporate existence is granted in twenty-fire of the Commonwealths. ${ }^{9}$

Where corporations are permitted under their clarter to make their term of existence perpetual, this right to extend corporate existence is of rery little practical importance. As, however, perpetual existence is permitted in only twenty-seven of the States, it is a question of much practical importance in the remaincler. It has been held by at least one court of excellent repute that where the power of amendment of the charter is unlimited, even though it does not refer specifieally to the right to extend corporate existence, it may nevertheless be used for that purpose. ${ }^{10}$

When so extended, it must pay an organization tax if the law

1 Such liability exists in Colorado, New Mexico, and l'ennsylvania. See Scott $v$. Deperster, I Elw. Ch. (N. Y.) 513; Wallace $r$. lank, 89 Tenn. $630 ; 13 \mathrm{~S}$. W. 48 ; ()ulerkirk $\iota$. Pank, 119 N. Y. $263 ; 23$ N. E. 875 .

2 Such liability exists in Colorado, Jelaware, Maryland, New Hampsinire, North Carolina, and Rhode Island.

3 Sirch liability exists in Connecticnt.

Se IIerpembourg $v$. Edwards, 155 Mo. $51+; 56$ S. W. 490 ; F. C. T. Co. v. Floyd, 47 0. St. $52.5 ; 26$ N. E. 110.

4 Such liability exists in Delaware and New Jersey. 176
5 Such liability exists in North Dakota and New York. See Clow $v$. Brown, 150 Int. 185; 48 N. E. 1034.

6 Such liability exists in New York.

7 Such liability exists in North Dakota. See Schley $v$. Dixon, 24 Ga. 273.

8 People $x$ l'fister, 57 Cal. 532; Attorney-General v. I'crkin, 73 Mich. 303; Smith v. Company, 58 N. J. Eq. 331; 43 Atl. 567 ; People $r$. Greene, 116 Mich. $505 ; 74 \mathrm{~N}$. W. 714 ; Frostberg Mining Co. v. Company, 81 Mil. 28; 31 Atl. 698.

${ }^{9}$ See Pirt III. 'Tahle 8, page 576.

10 People $v$. Greene, 116 Mich. 505; 74 N. W. 714. 
so provides, eren though existence is extended under guise of an amendinent. 1

$\$ 125$. Taxation of Domestic Corporations. - Legislative control over domestic corporations is exercised by means of the unquestioned right of sucl legislatures to impose a tax upon their organization and annually thereafter in the form of a franchise tax. The latter may be defined to be a tax levied by the State upon the capital of a corporation in return for the privilege of exercising its corporate power's within the limits of the State lerying such tax. On the general subject of franchise tax the New York Court of Appeals in a recent case ${ }^{2}$ spoke as follows:

"The system of taxation in this State is so eomplicated as to invite mistakes on the part of those who are called upon to enforce the law. In some instances the tax is laid upon property and in others upon rights and privileges conneeted with the property. There is direct taxation of real estate and of some personal property, indirect taxation of other personal property, taxation of the capital stock of corporations and of their franchises, taxation upon the right of succession to the property left by decedents, and the like. . . .

"There is, first, an organization tax, yayable to the State, which is imposed but once, and is exaeted for the privilege of becoming a corpolation. Next, there is a tax upon the real estate owned by the corporation in this State, which is assessed the same as if it were owned by an individual. The personal property of the corporation is not directly taxer, but its capital stock and surplus after deducting the assessed value of its real estate and making some other deduetions, is assessed at its actual value. Finally, there is a framehise tax on corporations which is payable anmally to the State, ' computed upon the basis of the amount of its eapital stock employed within this State.' This is not a tax upon property, although it is measured by the value of property, but upon the right of a corporation to exist and exercise the powers granted by its eharter. These forms of taxation do not all rest mon the same principle. The organization tax is in the nature of a license fee for the right to become a corporation. The tax mon real estate is a direct tax mpon real property, while the franchise tax is not laid njun proprerty at all, but is imposed upon the oupuration for the privilues of earying on business in this state aml exereising the eorporate franchises granted by the Statc. The distinction betwern a tax upon the prop-

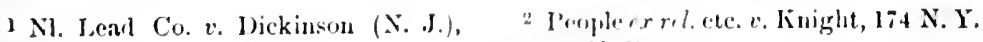
57 Atl. 138. 4.5: 6. X. L. E. 6. 
ert? of a corporation and a franchise tax, although well established ami of and importance, is easily overlooked, as we find from our omn experience."

With leference to organization taxes there can be no question raised as to the constitutionality of such taxation. ${ }^{1}$

'The constitutionality of franchise taxes being imposed upon the franchise as a species of property is clearly within the constitutional powers of State legislatures. ${ }^{2}$ In all of the States and 'Territories, with the exception of Alaska, Arkansas, District of ('olmmbia, Georgia, Indian 'lerritory, and Oklahoma, graduated orenination taxes are imposed upon domestic corporations.

With respect to annmal franchise taxes these are imposed only in the States of Mlabama, Colorado, Delaware, Maine, Massachusetts, New Jersey, New York, North Carolina, Ohio, Oregon, Pennsylvania, South Carolina, Texas, Vermont, Washington, and West Virginia. In Alabama, Colorado, Maine, North Carolina, Oregon, Fonth Carolina, Texas, Vermont, Virginia, Washington, and West Tirginia the tax is levied mon the total amomnt of anthorized capital stock, irrespective of the amount that may have heen issued and ontstanding.

In Melaware, Massachusetts, New Jersey, and Ohio the tax is graded according to the amount of capital stock issued and ontstanding. In New York the tax is determined largely by the dividends on the par value of the anount of capital stock authorized. It is also graded on the amount of eapital stock employed within the State.

$\$ 12 \%$. Regulation of the Right of Consolidation. - To accomplish a ralid consolidation of two colporations that are organized under the laws of the same or of different States, legislative authority is necessary. It is not over-stating the matter to say that legislative authority is as necessary for the accomplishment of a valid consuliclation of existing eorporations as it is to the creation of a conporation in the first instance. ${ }^{3}$ Any attempt, therefore, on the

1 Unitel Horses lue Works $v$. Jewis, I Ahb (C.S.) 518 ; Fed. Cas. No. 14365 ; Combinerl Saw \& I'laner Co. $x$. Flournoy, 83 Va. 1029 ; I4 S. 1. 976 ; State $v$. Rotwitt, 17 .Iont. 41 ; 41 Pac. 1004; HnghesIile .Ifg. Co. $v$. Vanner, 12 R. I. 491 ; June 2 . Company, 21 Cul. 263; 40 Pac. $4 \%$.

2 Society for Sarings $v$. Coit, 6 Wall. (U.S.) 594 ; Tillewater l'ipe Line Co. $v$. Berry, 5:3 N. J. I. 2I2; 21 Atl. 490; Atturney-General v. Bay State Mining Co., 99 ilass. 148.

3 Pearce v. Company, 22 IIow. (U. S.) 441 ; A. I. \& 'T'. Co. r. Company, 1.57 Ill. 641 ; 42 N. E. 15.3 ; Cole $v$. Company, 133 N. Y. $164 ; 30$ N. E. 847 . 
part of corporations to consolidate in the absence of any statute permitting consolidation will not be recognized by the courts. ${ }^{1}$ Where power is granted to corporations to consolidate it is usually done by means of a general statute. Such statutes exist in a comparatively small number of the Commonwealths, the legislatures of the remaining States eridently looking upon consolidation as a form of a trust and therefore to be restricted. ${ }^{2}$ Some of the statutes limit the right of consolidation to corporations of the same eharacter or engaged in the same line of business. ${ }^{3}$ Where the right to consolidate existed at the time the corporation was created it can ordinarily be affected by rote of a majority of the stockholders against the dissent of the minority. ${ }^{4}$ However, in the absenee of such authority conferred prior to the incorporation of a company, it has been held that consolidation cannot be affected against the dissent of the minority stockholders. ${ }^{5}$

When it comes to the matter of consolidation, creditors have no right to intervene for the purpose of preventing such a consolidation providing the same is undertaken under legislative authority. The remedy of ereditors in such eases is to proceed in equity with a riew to suljecting the property of the consolidated corporation to the payment of their claims. ${ }^{6}$ Sometimes, though not always, when a new corporation is formed by the consolidation of a domestic corporation with a foreign corporation, it is required to pay an organization tax, at least upon so much of the capital stock as is represented by the capitalization of that of the eonsolidated domestic corporation.'

1 Greenville Warehonse Irress Co. v. Company, 70 Miss. 669 ; 13 So. 879.

2 Sec Part III. Talle 9, paige 579.

${ }^{3}$ See In re l'rospect l'ark \& Coney Island Railway Co., fi N. Y. 37 I.

4 Spero r. Compruy, 7 Ind. 369 ; Spragrue v. Company, 90) Ill 174.

- Clearwater v. Heredith, 1 Wall. (U.S.) 25 ; K. \& R. I. Ry. Co. $v$. Marsh, 17
Wis. 13 ; Mowrey $v$. Company, 4 Bissell, 78 ; Fed. Cas. No. 9891.

6 People $x$. Company, 92 N. Y. 105. See R. I. Ry. Co. $v$. Mloffatt, is Ill. 524;

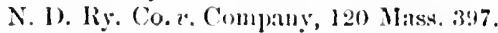
7 Stitte $r$. Sherman, 220 . St. $411 ; P$. Co. $v$. Company, 113 U. S. $296 ; \Lambda$. \& R. A. I. Co. $r$ State, 63: (ia. 2183 ; comtra, l'eople v. Company, 129 N. Y. 474; 29 N. E. 951 . 


\section{CHAPTER VI}

\section{LEGISLATIVE CONTROL OVER FOREIGN CORPORATIONS.}

\section{$\$ 127$. Extent of Legislative Power of the various Commonwealths} over Foreign Corporations. - A foreign corporation may be defined as one ereated under the laws of a State, Territory, govermment, or comntry other than that wherein it seeks to do business. ${ }^{1}$ With some few exceptions nearly all of the Commonwealths have cnacted statutes prescribing the terms and conditions upon which foreign corporations may carry on business within their borders. ${ }^{2}$ Most of these statutes closely rescmble each other in character, and generally look to the attaimment of the same end. 'Thus, for' example, in order to give courts of the forcign State jurisdiction over the foreign corporation and to secure proper protection for such of its citizens as may transact business with the latter, the statutes prescribe that foreign corporations shall designate an agent residing within the State upon whom service of process upon the corporation may be served, and also designate a place of business where it may be found. Such provisions are unquestionably ralid. ${ }^{3}$

Again, most of the acts require that a certified or sworn copy of the eharter of the foreign corporation shall be filed in certain designated offices, usmally with the Secretary of State and in the local recording office of the connty where its principal place of business is to be located. The olject of such enactment is to furnish casily accessible cridence of the existence of the corporation, and to protect parties dealing with it from frand and imposition. ${ }^{4}$

Still other States require the filing of reports enumerating the officers, giving information relatire to the business to be transacted within the foreign State and as to the financial condition

1 loaly v. Comprany, fot Ind 1 .

2 see Part III. Table 13 , page 583.

z S.t. Clair $\varkappa$. Cox, 106 U. S. 356 ; Lafarette Ius. Co. 2 . French, 18 llow. (L. B.) 404 .
4 Evans r. Lce, II Nev. 194; D F. Co. v. Augustine, 5 Wash. 67; 31 Pac. 327; Huffman $v$. Company, 13 Tex. Civ. Ap. $169 ; 36$ S. W. 306. 
of the corporation. ${ }^{1}$ The right to transact business in a foreign State is a matter of State comity, pure and simple. The recognition of a foreign corporation and enforcement of its contracts in States other than that of its creation rests only on comity, and any conditions gorerning the right to transact business ontside of the domiciliary State of the corporation may be imposed upon them or they may be entirely exchded. ${ }^{2}$ But the conditions imposed must not be repugnant to the Constitution of the United States or to the public policy of the foreign State as evidenced by its statutory enactments and judicial decisions, nor can they be repugnant to rules of public law. ${ }^{3}$

In this connection it may be observed that foreign corporations cannot elaim the protection of the prolibition of the United States Constitution against denying to eitizens of any State the privileges and immunities of eitizens of the sereral States. ${ }^{4}$ Nor can they claim the benefit of the clause against denying to any person equal protection of the law. ${ }^{5}$

A State may preclude all foreign corporations not engaged in interstate commerce or in the enploy of the general government from transacting business within its limits, and the courts camnot incuire into its reasons for so doing. ${ }^{6}$ A State may discriminate between foreign and domestic corporations. ${ }^{i}$ In short, the power of States orer foreign corporations with respect to imposing conditions for doing business are as broad as those exereised over domestic corporations. ${ }^{8}$ Wherever a corporation transacts its business it carries its charter with it, and that becomes the law of its existence in the foreign state, for the charter is the same abroad as it is at liome. Whaterer disabilities are plaecd non the corporation at home are orlinarily cqually binding unon it abroad, and whatever proper legislative control it is subject to must in general he recognizerl and submitted to by those who deal with it elsewhere." The foregoing mo should be qualified

1 Washington County Mut. Ins. Co, r. Dawes, of Gray, Mase, 3 ifi.

2 l'anl r. Virginia, 8 Wall (I. S.) 161.

3 Lafaycte Ins. Cor, Mrench, 18 lhow.

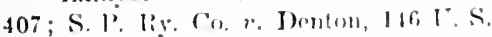
201; Am., retro Chriatian Lnim r. Yomnt, 101 U, S. $35 \%$.

4 Panl $n$, Virginia, 8 Wall, (I S S) $16,8$.

b I. C. S. M. \& C. Co.v. l'entsylvania, 125 U. S.. 181.
"Doyle r. Company, 94 I. S. 511 Ilorn Silver Minime Cu. IN. Now York, 143 I. s.. 316.

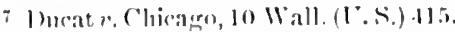

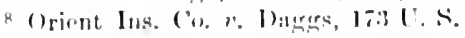
$, 3,6$.

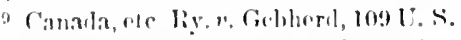

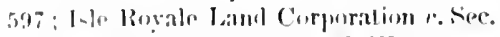
of Sitale, 76 Mlich. 162; 43 N. W. 14. 
wh the statement that a foreign corporation can do no act in a foreinn state which camnot be done through the intervention of. a nuere agent and which is not in contemplation of law the linect act of the corporation itself. ${ }^{1}$

Comity between States anthorizes a corporation to excrcise its charter powers within any State, but it does not permit the exercise of a power where the policy of that State distinctly marked he lerislatire enactments or constitutional provisions forbids it.2 It has been well said that " no rule of comity will allow one state to charter corporations to operate in another State unless there is willinguess on the part of the foreign State that it should be so. To hold otherwise would be to say that the right of one State by comity is superior to the sovereign will of the other. 'This involves the surrender of sovereignty to a rule of comity and to a matter of international etiquette, which no sovereign State should for a moment think of." 3

A great deal of litigation has arisen through the question whether or not forcign corporations may exercise the same powers in a forcign State that their charter anthorizes them to exereise in the domestic State. It has been held that foreign corporations camnot excreise outside of the domicile State powers which their own charters do not permit them to exercise within the State of their origin, nor can they excreise powers in a foreign State not permitted to corporations organized under the laws thereof." They cannot, howerer, do any acts which are contrary to the public policy of the foreign State. ${ }^{5}$ Nor can they transact business for which domestic corporations cannot be formed on accomt of statutory prohibition thereof. ${ }^{6}$

In some jurisdictions what are termed "retaliatory statutes" have been enacted. The purpose of these statutes is to put eorporations coming from other States upon the same plane as domestic corporations of that State are placed when they seck in turn to transact business in the States referred to. ${ }^{7}$ Sometimes the laws of the foreign State expressly provide that foreign

1 Juke $v$. Taylor, 37 Fla. 641; Dema- Mich. 145; Clarke v. R. R. Co., 50 Fell. rest r. Flack, 129 N. Y. 205; 28 N. E. 645; 338; State v. Water Co., 61 Kan. 563; Culwell \% Company, 100 U. S. 55.

2 Melonough $\ddot{v}$. Murdoch, 15 IIow. (C. S.) 413 .

3 Eimpire Mills $v$. Company (Tex. $\Lambda$ p.), 15 S. W. 506.

4 I) iamond Match Co. v. Powers, 51 People $v$. Howard, 50 Mich. 239.

G L. G. R. T. Co. v. Commissioners, 6 Kan. 245.

G Empire Mills v. Company ('Tex. Ap.), 15 S. W. 200.

7 Talbot $v$. Company, 74 Mo. 544.

142 
corporations shall have no rights or privileges other than those possessed by domestic corporations of the same character. A fair interpretation of such statutes would scem to be that such foreign corporations shall have equal powers with domestic corporations of a character similar to their orn. ${ }^{1}$

In a recent case an interesting question arose as to the legal effect of inserting powers in a charter to be exercised only outside of the State, such powers being forbidden by the laws of the State in which the corporation was organized. ${ }^{2}$ In this case the Federal Court of the State of Washington spoke as follows:

"It has become a habit of business men in this country to organize corporations in one State to operate in another, and presumably there is some advantage to be gained thereby, otherwise the practice would not be continued. But no sound reason has been adranced, and none occurs to my mind, for giving additional encouragement to the practice by judicially expanding the powers of such corporations so as to include additional rights and powers to be exercised abroad but not at home. Corporations organized under legislative statutes are not endowed with the rights of natural persons to do as they please except when restrained by prohibitive laws. On the contrary, the rule is that they have only such powers and rights as the statutes confer, and the enumeration of their powers implies the exclusion of all others except such subordinate and incidental rights and powers as are essential to their existence and the exercise of the rights and powers conferred in express terms, and the corporation can make no contracts and do no acts other than permitted by the State which created it except such as are authorized by its charter."

The general rule is that forcign courts will not interfere in the internal management of foreign corporations; that is, except in the presence of extraordinary circumstances. ${ }^{3}$ In this connection a distinction obtains where the act complained of affects the party solely in his capacity as stockholder, for there he must seek redress of his grierance in the eonts of the domiciliary State of the corporation. Int where the act affects his indiridual

1 See sec. 15, Art. XII. California ('onstitution; sec. 11, Art. XV. Montina Comstitutions; I. \& .11. 13. Co. r. Stone, 17.

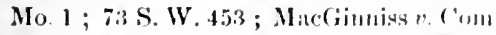
pany (Mont.), 75 Iace 80 ; Lowe e. Company, 52 (al. 60.
2 Sinattle Gas \& Finctric Co. r. Citiznns' light \& lower Co., le? liol. 588; $125 \mathrm{Fed}$ 1001 .

3. Silw:1y 2. Compraty, 104 Fed. 4\$1; Kimlall $r$ Comprany, 157 Mass. 7 ; 31 ㅊ. 15. 697. 
rights he may seck redress in any tribunal where jurisdiction maly properly be aequired. ${ }^{1}$ Foreign courts have not the power to forleit charters of foreign corporations."

(une uaranto is the proper proceeding to try the right of a foreign corporation to carry on corporate business in a foreign State. ${ }^{3}$

The ecrtificate of the Secretary of State authorizing a forcign compuration to transact business within the State is a franchise cmanating from the State, and camnot be gone behind or revoked by any authority but the State. ${ }^{4}$

"128. Doctrine of State Comity. - What is known as the "ductrine of State comity" is nothing more nor less than a recognition of the principle that the right of foreign corporations to engage in business in a State other than that of their creation depends solely on the will of such other State. ${ }^{5}$

While there are exceptions to this rule they only exist where the corporation created by onc State rests its right to enter another and engage in business therein upon the nature of its business. As, for instance, where it is necessarily an instrumentality of interstate commerce, and its business constitutes such commeree, it is therefore wholly within the paramount authority of Congress. In this casc the exceptional business is protected agrainst interference lyy such anthority.

If the power to regulate applies to all the instances to which such commerce gives rise, and to all contracts which might be made in the course of its transactions, that power would embrace the entire sphere of mereantile activity in any way connected with the tralle between the States, and would exclude State control orer many contracts purely domestic in their nature. The power to exclude where it exists, embraces the power as well to regulate and to enforce all legislation in regard to things done within the state which may be directly or incidentally requisite in order to render the enforcement of the State powers efficacious to the fullest extent, subject always of course to the paramount anthority of the United States. ${ }^{5}$ Let us now turn our attention

\footnotetext{
1 x r r , ete. Co. r. Field, $6+$ Fed. 151 ; .I. 13. I. Co. $e$. IR. G. N. Co., 81 N. Y. Sup. $3(12$

2 Frits r. Jalmer, 132 U. S. 289.

3 Situr $r$ Ins. Co., 39 Minn. 538; 41 N. W. W1

4 State ex rel. $v . \Lambda$ ckerman, 510 . St. $163 ; 37$ N. 1. 828 .

5 II\%) U.S. 148 .

f. W. U. Tel. Co. v. Mayer, 28 O. St. 521. 
to the attitude maintained by the State courts towards foreign corporations.

One of the familiar features of the present day is the organization of corporations mnder the laws of one State whose statutes are particularly farorable with the intention of carrying on no business in the State of its organization and with the arowed purpose of carrying on business in other States. Long ago these corporations were nominated as "tramp corporations," and there was at the outset some effort made on the part of the courts to limit the powers and quiestion the legal status of such corporations. There was an attempt made to induce the courts to refuse to judicially recognize such corporations, and to hold their stockholders liable upon their contracts as partners and npon their torts as joint tortfeasors. ${ }^{1}$

But the liberal policy of the American States in extending hospitality to foreign eorporations and the powerful influence of interstate comity has completely orereome the tendeney here referred to, so that at the present day the doctrine is established in practically every State in the Union, that each of these States will reeognize as valid a corporation formed under the laws of another state for the express purpose of doing business ontside of the State of its origin. ${ }^{2}$

The broader view taken by the courts on this question is weil set forth by the decision of the New York Court of $A$ plyeals in Merrick $v$. Van Sanroort. ${ }^{3}$ In this case attempt was made to establish the doctrine that where a Connecticnt corporation conducts all its business in the State of $\mathrm{New}$ York, it must thereby be deemed to have migrated to New York and to have forfeited its charter, thus permitting creditors of the corporation to hold the members, officers, and agents of the corporation personally liable for the debts and torts of the corporation. In refusiug to recognize this doctrine the court spoke as follows:

"Iitherto eorporate enterprise has not boen trammelled ly mofriently lergislation. So jealousy or competition or rivalry of adverse interest lats been permitted te convort stiate lines into harriers

1 Sce Ilill r. Beach, 12 N. .I. Eq. 31:

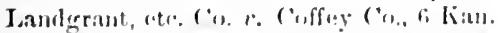

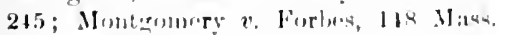
249; 19 N. N.342; Atterlerry v. Kimx, 929. 4 B. Nonroe (ky), 90.
2 Sers Marriek r. V:un Siumoort, 34 N. Y. 2uk: Hematrest r. Flack, $128 \mathrm{~N}$. Y.

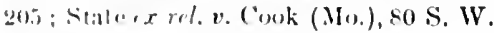

33 N. Y. 208. 
of ohstruction to the free course of general commerce. Its avenues hive been open to all.

"In this comntry our indivilual interests are so interwoven that the mion of the States is lue, in its continuance, if not in its origin, as much to commereial as to political necessity. 'The citizens of each claim a birthright in the alvantages and resources of all. 'They denand from their local antlorities such facilities as the law-making power can afford in the employment of labor and capital. They claim such corporate franchises and immunities as may enable them to compete on equal terms with the citizens of other States. For these, with the structure of our institutions, they naturally look to their own gorermment. They acknowledge a donble allegiance in their local and federal relations, which, by general consent, carries with it a correlative community of rights. They may live in an inland State, but they are none the less eitizens of a maritime nation, and they may lawfully organize companies at home for traffic on ocean highways.

"A corporate charter is in the nature of a commission from the State to its citizens, and their successors in interest, whether at home or abroad. Each government, in the exercise of its own discretion, determines the conditions of its grant. It is free to impose or omit territorial restrictions, but it can confer general powers to be exercised within its bounds or withont them, wherever the comity of nations is respected. For the purpose of commerce such a commission is regarded like a grovermment flag, as a symbol of allegiance and authority ; and it is entitled to recognition abroad until it forfeits a recognition at home. . .

". . We think the policy of this State is in harmony with that of the comntry, and that it would be neither provident nor just to inaugurate a rule which would unsettle the security of corporate property and rights and exclude others from the enjoyment here of privileges which have always been accorded abroad. Our national commerce is but the aggregate of that of the States, and every needless restriction by the operation of local laws is unjust and calamitous to all. We suppose the rules of comity on which we have litherto acted to be generally accepted and approved. We see no reason why a Southern State may not grant to a corporation of its planters the right to erect mills for the manufacture of their cotton in New England; nor why the legislature of Massachusetts may not authorize a company of Lowell millers to raise cotton in South America or the Sea Islands. The State of Illinois touches neither the Atlantic nol the Pacific; but if it should organize a company of its eitizens on the ocean with its office in the City of New York $15 t$ 
and its business conducted by managers elected annually in Chicago, the rights of the eorporation would be reeognized wherever the obligations of national law are respected."

Through the operation of interstate comity corporations organized under the laws of one State may exercise their corporate powers outside of the geographical limits of the State from which they have obtained their charter. The doctrine of the eourts on this subject is well set forth by the United States Supreme Court in Cowell $v$. Colorado Springs Co. ${ }^{1}$ as follows:

"By the general comity which, in the absence of positive direction to the contrary, obtains through the States and Territories of the United States, corporations created in one State or 'Ttritory are permitted to carry on any lawful business in another State and Territory, and to aequire, hold, and transfer property there equally as individuals. If the policy of the State or Territory does not permit the business of the foreign corporations in its limits or allow the corporation to aequire or hold real property, it must be expressed in some affirmative way; it cannot be inferred from the fact that its legislature has made no provision for the formation of similar corporations or allows eorporations to be formed only by general law."

$\Lambda$ most instructive case in this immediate conncetion is that of Demarest $v$. Flack, ${ }^{2}$ wherein the New York Court of Appeals observed that:

"The courts of every State and country recognize foreign corporations through what is termed national or State comity. Iint whether such reeognition shall be griven must be decided by the conrts of the country where the corporation seeks to do business. In our State, as in others, it is a question of domestic poliey, and what that policy is must be determined by an examination of our own legrislation. If we find any direct enactment upon the subject, it is our duty to obey it, and in its alsence we must determine the question with reference to our general legislation and to the eireunstances which surround us as a great and growing commereial community, having neerl of and employing large amomnts of combined eapital, amel for whose prosperity and growth it is of the ntmost importance that such rapital should have the greatest facilities extrmled it for nsoful cmployment, with reasonable and proper frersonal exemptions from liability. We can find no reason for a domestic policy that should exelude from recog-

1100 U. S. 55.

2128 N. Y. 205; 28 N. F. 645. 
nition by our courts foreign corporations generally. It may safely be suid there ('an be no sueh domestic policy at the present day in a civilized state. . .

"In examination of onr laws shows that it is, and for many years has inen, the poliey of this State to enlarge the facilities for the formation of eorporations. General laws are ou our statute book for the formation of eorporations of almost every conceivable kind, and mnler some one of them a corporation of the kind mentioned in the case could ravlily be formed. The freedom from personal liability would be as great and couhl be as easily attained under our own as under the laws of West Virginia. The security of the creditor would not be substantially greater in the ease of the domestic than in that of the foreign eorporation. In the latter the ereditor has the remedy by attachment, and he can obtain about as easy aecess to its property as if it were domestie insteat of foreign.

"There is really nothing to evade by incorporating muder a foreign law. No harmful results flow to a crentitor or to the community here by such incorporation. Where the corporation formed under another jurisdietion comes here to do business of a kind which we permit to be lone by eorporations, and where our laws provide for incorporating individuals for the purpose of doing that business, it is dittienlt to see how the terms 'evasion' and 'fraud' can be properly applied to acts of our citizens whereby they obtain incorporation in another State. When they come in our State to do business they must conform to our laws relating to foreign corporations and comply with the terms laid down by us as conditions of allowing them to transact business here. In the case of many kinds of corporations such conditions have alrealy been imposed by our laws, and if there be any kind where none is imposed it is conchusive erizence that up to this time the legislature has not thought it conducive to the true interests of the State and its eitizens to impose them. I lo not intimate that it is neeessary for a State to expressly by statute exclurle foreign corporations from acting within its jurisdiction. The policy of the State may exelure them, and that poliey may be clarly establisher by a reference to the general legrislation of a State. I find none such in the laws of this State.

"It las been urged that the easy way which our laws provide for forming corporations is itself a reason why we should not recognize as a colporation those of our own eitizens who have gone to another State for the purpose of incorporating themselves under the laws thereof, to do business in our own State as such eorporation.

"Th" think there is very little force in the aroument. The public policy which we see in onr own State, as evidenced by her laws upon $1>5$ 
the subject of the formation of corporations, is one which looks to their ready and easy formation as a means of transacting business with an accumulation of capital and an exemption from personal liability to the largest extent consistent with reasonable supervision by the State. The facilities for incorporation offered by this State are not the result of any desire to promote the formation of corporations here as against their formation in other States. They are offered because of a policy on onr part which urges upon the State the propriety of furnishing them as one means of controlling the business done by them and keeping it within our borders. If in any particular case it is thought by those interested in the matter that the business can be done in our own State and by our own citizens with greater facility under the form of a foreign corporation than under that of a domestic one, there is no public policy which forbids its transaction under such form. The supervision of a foreign corporation by this State may easily be exercised by imposing terms as a condition of permitting it to do business here. The absence of any such terms in our legislation forms no reason for refusing to recognize the corporation. The power rests with the legislature to say whether any, and if so what, terms shall be imposed upon such corporations as a condition of granting them permission to do business here. Those terms can only be imposed by the legislature, and in their absence our courts ought not, merely on that account, to refuse to recognize a foreign corporation. In the absence of legislation, our courts must either refuse absolutely, or else they must recognize the right of such corporations to eome to this state and do business here. The courts cannot themselves impose terms or conditions. . . .

"The truth is, foreign corporations are not properly to be regarded with suspicion, nor should unnecessary restraints be imposed upon their doing business in our midst. They carry no black flag, and the policy of all civilizer nations is to grant them recognition in their courts. It scems to me that every reason which urges upon us the recognition of foreign corporations organized with power to do business in our State and eomposerl of citizens of the forejon sitate, is equally potent when the foreign corporation is eomposed of om own citizens. It las always heen supposed that a state should at least deal as liberally with its own eitizens as with those of forrign States. If therefore, wo promit foreign citizens to come within on limits in the form of a foreign corporation orgatumen with power to do business here and recongized by ns, why should we not frumit our own citizens to avail themselves of the like privilege? Il wo impose terms and conditions upon foreign corporations, as snch, doing business liere, those same terms and conditions still and 
equally apply to a foreign corporation when composed of our own citizens. Why should they not be placel at least upon an equality with the foreign citizen?" 1

\section{0 . What constitutes doing Business on the Part of a Foreign} Corporation within the state. - There is perhaps 110 subject of corporation law wherein will be found greater diversity in the opinions of the courts of the several Commonwealths than that ruating to the rights of foreign corporations. 'The growth of corporate organization as well as the rast cxtension of the business of eorporations ontside of the State of their origin has made the question of determining what in legal effect constitutes doing business on the part of a forcign corporation in States other than that of its domicile one of great practical importance. As has already been observed, parties may incorporate in one State at the present time for the purpose of transacting their business in another Commonwealth.2

In some of the States, notably Sonth Carolina, the legislatures have attempted to give a statutory definition as to what constitutes doing business on the part of a foreign corporation within the Commonwealth. In most of the States, however, the question is left for juclicial determination. A fair example of such statutes is to be found in the New York statute ${ }^{3}$ which provides that "no foreign corporation, other than a moneyed corporation, sluall do business in the State without laving first procured" a proper ecrtificate from the Seeretary of State that it has complied with the statutes in such case made and provided. From the foregoing it will appear that the whole question centres upon the meaning of the worl "business" as used in the statutes, of which the foregoing is a fair example. It will be impossible within the limits of this work to discuss at any length the conflieting decisions of the comets on the point here referred to. All that it is proposed to do is to present certain rules which a careful reading of the anthorities have shown to represent the prevailing and better consilered opinions of the rarious courts on the questions presented. These rules may be cnumerated as follows:

\footnotetext{
I See 11 so Lancaster $v$. Amsteriam 484; 28 Atl. 973; Ilanna $v$. Company, Improvement Co., 140 N. Y.576; 35 N. E. 23 O. St. 622.

3 New York Session Laws of 1890 , 2 State prel. $v$. Cook (Mo.), $80 \mathrm{~S}$. W. chap. 563, scc. 150 ; amended by Laws of 923 ; Jakhill Ifg. Co. $c$. Garst, 18 IR. I. 1901, chaps. 96, 538.
}

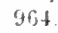


(1) In order to constitute the transaction of business by a foreign corporation within the foreign State, it is not indispensable that it should do the greater part of its business therein. If it does any part of its ordinary business therein and the same camnot properly be styled purely interstate commerce, the same constitutes the transaction of business therein within the meaning of the statute. 1

(2) Generally speaking, the making of a single contract within the foreign State does not eonstitute the transaction of business therein. ${ }^{2}$ There must be more or less continuity in the matter.

(3) The institution and prosecution of actions not arising out of previous transactions had within the foreign State does not constitute the transaction of busincss within the meaning of the statute. ${ }^{3}$

(4) Sales of merchandise by foreign trading corporations made by means of non-resident travelling salesmen, or by correspondence had between the forcign corporation at the domiciliary office and customers in the foreign State, or upon unsolicited orders from customers in the foreign State, do not constitute transaction of business within the meaning of the statute regulating the transaction of business by foreign corporations. ${ }^{4}$

Aside from the question of the nature of the act, there are constitutional grounds upon which it would be held that corporations were not, under the circumstances here referred to, sulject to the statutes in such foreign State compelling foreign corporations to obtain a permit to do business therein. The constitu-

1 Lamb v. Lamb, 6 Biss. 420; Fed. Cas. No. 8018.

2 Cooper llf $t$. Co. v. Ferguson, 113 U. S. 727; Gilehrist $x$. Ulelena II.S. \& S. R. Co., 47 Fed. 5933 ; Colorato Iron Works Co. v. Company, 15 Col. 499 ; 25 Pac. 325; Commonwealth $v$. Stamlarel (oil Co.,

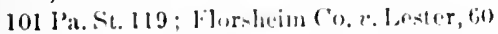
$\Lambda$ rk. 120 ; 29 S. W. 34; Nlillerr. Williams (Col.), 59 l'ac. 740 ; Tabur 2 (ompany, 11 Col. 419 ; 18 lac. 537 ; Creterall r. Finte Co., 40 Ap. Hiv. (N. Y.) 215 ; Sece. Co. 1 . l'auliamlle lat liank, 93 Texas, 575 ; 57 S. W. 22; Missouri Conl Minine (o. r. Indld, 160 Mo. $435 ; 61$ S. W. $191 ;$ layson 2 . Withers, 5 l'Biss eng); Finl r'as. No. 10861; Iloge Mut. life Ins. ('i. $"$ Perkins, 38 N. Y. 401 ; llart r. Livermores
Co., 72 Miss. $809 ; 17$ So. 769 ; Kilgore ". Smith, 122 l'it. St. 48; 15 Atl. 698; United States $r$. Company, 29 Fell. 17.

3 Mamlel $v$ Company, 154 Jll. 175; 40 N. E. 462 ; Sunth r. Little, 6i lud. 549. 4 'T. L. Co. r. Hollert, 5 X. Y. $\Lambda$ p.

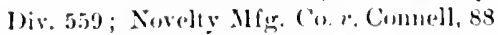
IIn1, 25।; .1. 1. W. C.ss. (o. v. Mosluer, 114 Mirh. 64; i2 X. W. U7; I. \& J.

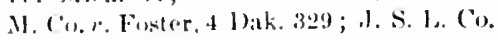

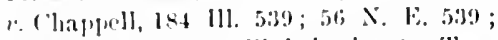

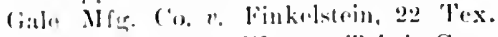
(iv. Ap. 211 ; 5. \$. 11. 619; Poledo Commercial Co. r. (omprang, 55 1). St. 217; Wolf inrer ('o. M. ligkler, 192 l'a.st. 466; 43 Atl iwne; 11romge r. Company, 163 ‥ $1.465 ; 57$ N. 2.747. 
tional gromels here referred to have reference to those trading or yuasi-public corporations engaged wholly in interstate trade and commere and therefore not subject to regulation by State cnacturents.' 'The same rule applies where the corporation is in the employ of the general government. ${ }^{2}$

(5) Foreign corporations may take mortgages by way of inrestment or as security, or maly take real estate as security or otherwise without coming within the prohibition of the statute, provided such acts are not within the express purposes for which such corporations were ereated, as for example where they are engaged in the mortgage loan or real estate business. ${ }^{3}$

(6) Foreign corporations ma take property by derise in foreign jurisdictions, if their charter authorizes it, either expressly or by implication, without coming within the purview of the statute. ${ }^{4}$

(7) The mere fact that a corporation pays rent for offices for its agent employed to solicit order's in the foreign State does not in itself prove that the corporation is transacting business within the foreign State. ${ }^{5}$ The question in all such eases is whether it is actually transacting business within the foreign State, and not whether some incident preliminary to the transaction of such business is to be performed there. ${ }^{6}$ The maintenance of an office within the State may be considered as a circumstance done in connection with others to show that a foreign corporation is transacting business in the State, but it is by no means conclusive of the question. ${ }^{i}$

(8) Where a foreign corporation consigns goods to persons in a foreign State to sell, and sales are made there by the factor in his own name and the proceeds collected by him, this does not

1 Rolbins $v$. Shelby Connty Tax I)istrict, 120 U. S. 489 ; Brennan $v$. 'Titusville, 153 U. S. 289.

2 IIorn Silver Mining Co. $v$. New York, 143 U. S. 305.

${ }^{3}$ C. U. A. Co. v. Scammon, 102 Ill. 46 ; Bard x. Puole, 12 N. Y. 495; A. II. I. I. Co. v. Owen, 15 Gray (Mass.), 491 ; Black $v$. Colwell, 83 Fed. 880 ; C. O. L. I. Co. $v$. Sawyer, $4 t$ Wis. 387; Fritts $v$. l'almer, 132 I. S. 288; Bank $x$. Sherman, 28 Ore. $5 i 7$; 43 Pac. 658; Simplex Dairy Co. $v$. Cole, 86 Fed. 739 ; Gilehrist $v$. Company, $4 ;$ FerI. 593; C. P. E. Co. v. Company, 152 Nass. 432 ; 28 N. L. 300 ; Cooper Mfg. Co. $v$. Ferguson, 113 U. S. $727 ; 28$

192
L. E. $1137 ;$ F. B. D. G. Co. $v$. Lester, 60 Ark. $120 ; 29$ S. W. 34 .

4 Am., etc. Christian Union $v$. Yount, 101 U. S. 352; Santa Clara Female Academy $v$. Sullivan, 116 Ill. 375 ; 6 N. E. 183; Lewishurg lhaptist University $v$. 'Tncker, 31 W. Va. 621 ; 8 S. E. 410 ; Chamberlain v. Chamberlain, 43 N. Y. 444 .

5 P'eople ex rel. Brewing Co. $v$. livberts, 22 N. Y. Ap. Div. 284.

6 Tallapoosa Lumber Co. v. Holbert, 5 N. Y. $\Lambda_{\text {P. }}$. Div. 516.

7 Perple r. Company, 175 N. Y. 76 ; American Broom \& Brush Co. $v$. Addicks, I9 N. Y. Hise. Rep. 36. 
constitute doing business within the foreign State within the meaning of the statute. ${ }^{1}$

(9) The renting of an office in a foreign jurisdiction in charge of a selling agent who distributes therefrom samples to customers and to travelling agents whose salaries are paid therefrom, together with the keeping of a bank account in such jurisdiction, does not necessarily constitute doing business within the foreign State within the meaning of the statute. ${ }^{2}$

Finally, in addition to the foregoing rules, it may not be without value in this comnection to call particular attention to a few cases which seem to throw considerable light upon the general subject of what constitutes the transaction of business within a foreign State within the meaning of the Statutes already referred to. Attention is first called to the case of People ex rel. Kellogg Paper Co. $v$. Roberts. $^{3}$ Here an Illinois corporation furnished printed matter to local publishers in the State of New York. It kept solicitors in the State of New York to secure advertising patronage for a newspaper published by it in Chicago. For this purpose it had an office in the State of New York with a manager and five clerks. It also kept a New York bank deposit from which rent and salaries were paid amounting to an annual expense of $\$ 13,000$. It had office furniture in the State of New York valued at $\$ 700$. It was held that the corporation had no capital employed in the State of New York which rendered its capital stock liable to assessment for taxation. The court in its opinion stated :

"Office conveniences are permitted here to a foreign corporation doing business in another State to solieit orders to be executed in the other States without liability to our franchise tax. In People $e x \mathrm{rel}$. Smith Co. $v$. Roberts, ${ }^{4}$ the court held that office leases, bank aceounts, and the kceping of samples within the State by foreign corporations were nominally incidental to the business of soliciting orders and making sales which the relator eould carry on in the foreign State without being liable to taxation. It also observed that the maehinery with which an interstate business is carried on is to some extent erected within the State and loes not make such business taxable there."

1 Bertha Zine \& Mining Fo. $v$. Clure, 7 N. Y. Misc. Rep. 128.

2 Washington .Mills Co. p. Roberts, 8

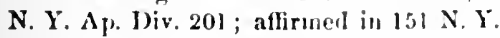
619 ; P'eople ex rel. $u$. Roberls, 25 N. X.
Ap. Dir. 13; People ex rel. $v$. Roberts, 24 S. Y. Ap. Iniv. 585.

${ }^{3} 30 \mathrm{~N}, \mathrm{Y} . \Lambda_{\mathrm{p}}$. 1)iv. 150.

427 N. Y. $\Lambda$ p. INiv. 455. 
In V:mghan Machine Co. v. Lighthonse, ${ }^{1}$ the testimony showed that a foreign corporation had sold merchandise in New York both hy agents and by correspondence, and in this case it had no oflice within the State. Upon the question whether this constituted the transaction of business within the State, the court spoke as follows:

"The statute does not intend to relate to business conducted in the manner just referred to. It contemplates a location, a domicile, liaving an oflice and the investment of some part of its capital within the State. Orders can then be transmitted and dealings had with it at this office and the conduct of its business is thus transferred, in a measure at least, to the headquarters established within the territorial limits of this State. It thus settles within the State, and enjoys the benefits incident to a domestic corporation, and the legislature imposes requirements and obligations upon it by reason of the privilege conferred of doing business like a body corporate organized in this State. It was never intended to hamper trade and restrict interstate commerce by bringing within its ban every. corporation which happens to cross the State boundary with its wares to supply customers who have ordered them from the home office.

". . . It must be kept in mind that it was not designed to fetter or exclude business from the State. Its aim was to require a foreign corporation, which was on a level in its privileges with one organized here, to bear the burdens and be equally accessible to process with State corporations. To give it the construction contended for by the defendant would interfere with that comity between the States in their trade relations which has been potential in the development of our commercial and industrial business."

In Cummer Lumber Company $v$. Insurance Company, ${ }^{2}$ the court spoke as follows:

"This statute - relative to foreign corporations obtaining a permit to do business in this State - was simply declaratory of the policy of the State that foreign stock corporations shonld not carry on any business in this State which similar corporations organized under its laws could not lawfully conduct. Its purpose was not to avoid contracts, but to provile an effective supervision and control of the business propreserl to be carried on here by foreign corporations, and it is absuril to contend that it had no reference to the facts established by the evilence in the case at bar."

$16+$ X. Y. Ap. Niv. 138.

267 N. Y. Ap. Div. 151. 
Again, the court said:

"The scope of the law here under consideration is that of merely undertaking to regulate the business of foreign corporations so that they shall not do business under more advantageous terms than those allowed to corporations of this State. It has no relation whatever to the incidental contracts of a foreign corporation made with a domestic corporation, such as the insurance of the property of a lumber company organized under the laws of Florida and doing business in that State."

Finally, attention is called to People ex rel. Dires Pelican Company $v$. Feitner. ${ }^{1}$ In this case a corporation organized under the laws of the State of Colorado had its principal place of business in the State of New York and had an office in the City of New York. The New York office was maintained for the sole purpose of enabling the directors of the corporation to meet in it and declare dividends on its stock. No goods of the eorporation were sent to or sold in New York. It had no bills receival,le in New York, and the only assets which it had in that State were office furniture and money on hand and in bank which had been sent from its principal office to its New York office for the purpose of paying dividends. It was held that the corporation was not doing business in the State of New York within the meaning of the statute.

\section{$\S 130$. Penalty for transacting Business in a Foreign State} without obtaining a Permit. - The statutes of the various States differ materially with respect to the penalty that attaches to the transaction of business by a foreign corporation without having first complied with the statute relative to obtaining a permit to transact the same. The form of penalty prescribed usually takes one of five forms, to wit:

(1) Suspending the right to maintain snits in the courts of the foreign State until the stante has heen complied with. (2) Statutes absolutely prohibiting the rifrlt to bring suit on contracts entered into in the foreign state before the oldaning of a permit to do business therein. (3) Stitntes proviling that all contracts made by a foreim enporation before obtaining a permit to do business in a foreign State shall he ahsolutely void. (4) Statutes providing penalties in certain designated amount for failure to

$$
1 \text {; X. Y. A , Bir. } 1 \text {. }
$$


obtain a permit in a foreign State before transacting business therein. (5) Statutes merely giving the right to the State to bring procecdings to oust or exclude foreign corporations from doing business within the foreign State without having first obtained a prermit so to do. Each of the foregoing will now be taken up briefly for separate consideration.

(1) Suspending the right to maintain suits in the courts of the foreign State until the statute has been complied with. Such statutes do not affect the validity of contracts previously made in the foreign State by a foreign corporation, but merely prevent it from enforcing the samc thercin until it has obtained a permit to do business in such State. ${ }^{1}$

(2) Statutes absolutely prohibiting the right to bring suit on eontracts entered into in the foreign State before the obtaining of a permit to do lusiness therein. Such statutes exist in New York and read as follows:

"No foreign corporation now doing business in this State shall do business herein after December 31st, 1892, without having procured such certiticate from the Secretary of State; but any contract previously made by the corporation may be permitted and enforced within the State subsequent to such date. No foreign stock corporatiou doing business in this State shall maintain any action in this State upon any contract made by it in this State unless prior to the making of such contract it shall have procured a certificate."

In interpreting this provision of the statutes the Supreme Court, in Dunbarton Flax Spinning Co. v. Greenwich and Johnsonville Railway Company, ${ }^{2}$ spoke as follows:

"Unless prohibited by law, a foreign corporation, duly organized, can come into this State and exercise the legitimate powers conferred upon it and carry on any business not prohibited by our laws or against public policy. The State has the power, however, to compel compliance with its laws or to punish the corporation if it does not do so. And the legislature can deny to such corporation failing to comply with its laws by procuring a certificate and paying the license fee, all recourse to its courts to enforce its rights or to redress its wrongs. These statutes are, however, mere revenue regulations,

1 Goddard v. Crefields Mills, 75 Fed. v. Fowler Bros., 163 N. Y. $580 ; 57$ N. E. 818 ; 21 C. C. A. 530 ; Davis Provision Co. 1108. 
compliance with which is made necessary in order to acquire the right to do business here and to enforce causes of action in our courts.

"In Lancaster $v$. A. I. Co. ${ }^{1}$ it is said to be the policy of the State to encourage foreign corporations to enter its boundaries for the transaction of lawful business, and it is manifestly for the interest of the State that foreign capital should be actively employed within its borders."

(3) Statutes providing that all contracts made by a foreign corporation before oltaining a permit to do business in a foreiyn State shall be absolutely void. To have the effect stated above the statute must in express terms declare that contracts made by corporations which have not complied with the statute relative to obtaining a permit to do business within a foreign State, shall be absolutely roid. Where such is the case, it is entirely clear that no action can be maintained by the corporation thereon in such foreign State. ${ }^{2}$ Such statutes, however, have no extra-territorial effect.

In an Illinois case ${ }^{3}$ the court spoke as follows:

"To permit the company, when they admit that they have disregarded all these requirements, to recover, would be for the courts to disregard the clearly expressed will of the general assembly, and to say what it has said shall be unlawful is and shall be lawful and binding. To enforce the payment of this note would be, virtually, to repeal a plain enactment of the legislature. When the legislature prohibits an act, or declares that it shall be unlawful to perform it, every rule of interpretation must say that the legislature intended to interpose its power to prevent the act, and, as one of the means of its prevention, that the court shall hold it roir. 'This is as manifest as if the statute had declared that it should be void. To hold otherwise would be to give the person, or corporation, or inclividual the sane rights in enforeing prohibited contracts as the good citizen who respects and conforms to the liw. To permit such contracts to be cuforced, if not offering a preminm to violite law, certainly withdraws a lare portion of the frim that deters men from defying the law. To rlo so places the person who violates the law on an equal footing with those who strictly observe its reppirements. That this contract is absolutely voik, as to appellee, we entertain no donbt." 4

1140 N. Y. 576,$591 ; 35$ X. F. 964.

2 Bank of Louisville $v$. Yonng, $37.3 \%$. 398.
8 C. .I. II. A. Co. Y. Rosenthal, 55 Ill. 85.

4 Sie also McCinna \& Fraser Co. $v$. Cimpany, it Fell. 597. 
(4) Stututes providing penalties in certain designated amounts for fixilure to obtuin a permit in a foreign State before transacting lnsiness therein. In this connection two opposing lines of authority are to be met with, one holding that where a penalty is improsed, this is exclusive, but does not render the contract made by the foreign eorporation, out of which the imposition of the penalty arose, invalid. ' 'The other, and what appears to us the better, riew is that although a specific penalty is provided, this in itself operates to render the contract, ont of which the imposition of the penalty arose, illegal and unenforceable in the courts of such foreign State. ${ }^{2}$

(i) Stututes merely giving the right to the State to bring proceclinys to oust or exclude foreign corporations from doing business within the foreign State without having first oltained a permit so to do. Unless some other remedy is prescribed by statute, the proper remedy, in ease foreign corporations engage unlawfully in business in a foreign State, is for the State to bring quo warranto procecdings to oust or exclude such forcign corporation fiom doing business within the foreign juristiction. ${ }^{3}$ In such procedings the courts have the right to review, if they see fit, the action of the Secretary of State in issuing a permit to such foreign corporation to do business within the State. ${ }^{4}$

$\$$ 131. License Tax on Foreign Corporations. - There is a clear distinction to be observed of course between the creation of a corporation under State anthority and the licensing of a corporation already existing, to do business within the jurisdiction of such State. ${ }^{5}$ Sometimes the statute provides that after foreign corporations have complied with certain formalities relative to obtaining a permit to do business within a foreign State, they shall thereby ipso facto become domestic corporations. Under such a statute it has been held that they thereby become for all purloses, except for such matters as pertain to federal affairs, domestic corporations and not mere lieensed corporations. ${ }^{6}$ It

\footnotetext{
1 Clarke $\cdots$. Mildleton, 19 Mo, 54; Gar- 517; $60 \mathrm{X}$. W. 121 ; State v. Company, 39 rett Forll Co. $v$. Company, 20 R. I. 189 ; Minn. 5:38; 41 N. W. 108.

I. C. .I. 'T. Co. r. Willhojt, $84 \mathrm{Ferl} .5 \mathrm{I} 4$.

2 Durlleg collicr, 87 Ala. 431 ; 16 So. 304 ; C. .I. H. A. Co. e. liosenthal, $55 \mathrm{Jll}$. 45 ; Late $\ell$. Brigers, 116 Ind. 55 ; 18 X. E. 35. ; Puxton 2 IIamblen, 32 He. 448; Stewart 2 Company, 38 N. J. Law, 436.

State 0 Company, 47 O. St. $167 ; 24$

‥ J. 392 ; State $v$. Company, 91 Iowa,

4 State $v$ Company, 49 O. St. $440 ; 31$

N. E. 6.58; State $v$. Company, 91 Iowa, $517 ; 60$ N. W. 121.

5 C. B. \& Q. Ry. Co. v. Ilarris, 12 Wall. U. S. 65 .

6 Debnam $v$. Company, 126 N. C. 831 ; 36 S. E. 269. 
has been repeatedly held by the United States Supreme Court that State legislatures may impose license taxes to any amount upon foreign corporations as a condition to the granting of the right of such foreign corporatious to transact business in a foreign State. ${ }^{1}$

In addition to the payment of a tax, there are a number of other requirements in force in the rarious States differing one from the other, such, for example, as requiring the filing of a copy of the articles of incorporation, appointing an agent within the State to accept and receive service of process, etc. Such requirements if reasonablc are valid. ${ }^{2}$

The State may, if it choose, tax without restriction as to amount or entirely prohibit a forcign corporation from doing business within the State, provided, howerer, it is not engaged in interstate commerce or is in the employ of the general government. ${ }^{3}$ Some States, such for example as Ohio, New Jersey, and Nerada, adopt what are known as retaliatory statutes. The purpose of such statutes is to place foreign corporations which do business in foreign States under the same regulations as are imposed by the domiciliary State upon forcign corporations seeking to do business within such State. ${ }^{4}$

The power of a State to exclude foreign corporations from transacting business within its borders cannot be questioned, neither can its motives in so doing. ${ }^{5}$

Thirty-three of the States lave imposed the payment of license taxes upon forcign corporations desiring to do business within the foreign State. ${ }^{6}$

$\S$ 132. Annual License Tax on Foreign Corporations. - The right of a State to impose an annual license tax on foreign corporations transacting business within its borders is unequirocally established by the decision of the Supreme Court of the United States

1 Paul v. Virginia, 8 Wall. 168; P. C. S. M. \& N. Co. v. Pennsylsuia, 125 U. s. 181; Liverposl Ins. Co. C. Masichusetts, 10 Wall. 576; l'embina Min. Co. v. l'entsylvania, 125 U. S. 184.

2 Hnff inam $v$. Comprany, 13 T'ex. Civ. Ap. $169 ; 36$ S. W. 306; L.\&S. A. M.\&I. Co. v. Ilardy, 93 'Texas, 249; 55 s. IW. 169; Ctley v. Company, 4 Col. 369 ; (irwen v. Association, 105 lowa, $628 ; 15 \mathrm{~N} . W$. 935; Ilamme- $v$ Company, 130 L. S. 291 .
3 Jlorn Silver Mining Co. v. N. Y., 143 U. S. 305 ; I'ierce $"$ I'eojele, 106 III. 11 ;

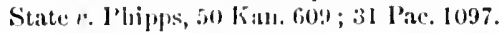

+ State $r$ Reinmuml, 45 (). St. 214 ; 13 N. li. 30; Miles r. Wundwarl, 115 Call. $308 ; 46$ J'ac. I076; Situte e. Company, 39 Mim. 538; 41 ก. IV. $10 \mathrm{x}$.

4 Doyle $\therefore$ Comprany, 94 U. S. 535; Ilartfori Fire Jus. Co. v. liaymond, 70 Mi..1. $48.3 ; 38 \mathrm{~N} . \mathrm{W} .474$.

6 Sce l'art III. 'Table 13, page 583. 
in IIorn Silver Mining Co. v. State of New York.' Upon the subjeet just referred to, that court spoke as follows:

"The right and privilege, or the franchise, as it may be termed, of being a corporation, is of great value to its members, and is consilered as property, separate and distinet from the property which the eorperation itself may aequire. Aecording to the law of most Stittes this franchise or privilege of being a corporation is deemed personal property and is subject to separate taxation. The right of the states to thus tix it has been reeognized by this court and the State courts in instances withont number. It was said, in Delaware Railroad Tax, ${ }^{2}$ that 'the State may impose taxes upon the corporation as an entity existing under its laws, as well as upon the capital stock of the corporation or its separate corporate property. And the manner in which its value shall be assessed, and the rate of taxation, however arbitrary or capricious, are mere matters of legislative discretion,' except, we may add, as that diseretion is controlled by the Organie Law of the State. And, as we there said also, "it is not for us to suggest in any ease that a more equitable mode of assessment or rate of taxation might be adopted than the one preseribed by the Legislature of the State; onr only concern is with the validity of the tax; all else lies beyond the domain of our juristietion.'

"The granting of the rights and privileges which constitute the franchises of a corporation being a matter resting entirely within the control of the legislature, to be exercised in its good pleasure, it may be aceompanied with any such conditions as the legislature may deem most suitable to the public interests and policy. It may impose as a condition of the grant, as well as, also, of its continued exercise, the payment of a speeifie sum to the State each year, or a portion of the profits or gross receipts of the corporation, and may preseribe such mode in which the sum shall be ascertained as may be deemed convenient and just. There is no constitutional inhibition against the legislature adopting any mode to arrive at the sum which it will exact as a condition of the creation of the eorporation or of its continued existence. There ean be, therefore, no possible objection to the validity of the tax preseribed by the statute of New York, as far as it relates to its own corporations. Nor can there be any greater objection to a similar tax upon a foreign corporation doing business hy its permission within the State. As to a foreign corporationand all corporations in States other than the State of its creation are

1 I 43 C.S. 305.

285 U. S. (I 8 Wall.) 206. 
deemed to be foreign corporations - it can claim a right to do business in another State to any extent, only subject to the conditions imposed by the laws.

"This doctrine has been so frequently declared by this court that it must be deemed no longer a matter of discussion, if any question can ever be considered at rest.

"Only two exceptions or qualifications have been attached to it in all the numerous adjudications in which the subject has been considered, since the judgment of this court was announced more than half a century ago in Bank of Agusta $v$. Earle. ${ }^{1}$ One of these qualifications is that the State camnot exclude from its limits a corporation engaged in interstate or foreign commerce, established by the decision in Pensacola Teleg. Co. $v$. Western U. Teleg. Co. ${ }^{2}$ The other limitation upon the power of the State is, where the corporation is in the employ of the general government, an obvious exception, first stated we think by the late Mr. Justice Bradley in Stockton $v$. Baltimore \& N. Y. R. Co. ${ }^{3}$ As that learned justice said, 'If Congress should employ a corporation of ship-builders to construct a man of war, they should have the right to purchase the necessary timber and iron in any State in the Union.' . And this court, in citing this passage, alded, 'without the permission and against the prohibition of the State.' 4

"Having the absolute power of excluding the foreign corporation, the State may, of course, impose such conditions upon permitting the corporation to do business within its limits as it may judge expeclient; and it may make the grant or privilege dependent upon the payment of a specific license tax, or a sum proportioned to the amomnt of its capital. No individual member of the colporation or the corporation itself can call in question the validity of any exaction which the State may require for the grant of its privileges. It loes not lie in any foreign corporation to complain that it is subjeeted to the same law with the domestic corporation. The counsel for the appellant objects that the statute of New York is to be treated as a tax law, and not as a lieense to the corporation for permission to do business in the State. Coneeding such to be the ease, we do not pereeive how it in any respect affects the validity of the tax. However it may be regarded, it is the eondition npon which a loreign corporation ean do business in the State, and in roing such business it puts itself under the law of the State, however that may bo charicterized."

113 Peters (U. S.), 519.

2 af I. S. 1.

3 3. Ferl. Rep. 9.
4 Temlinia ('on. S. Min. \& Mill. Co.v. Penusylvania, 125 U.S. 181. 
From the foregoing opinion it is elear that it is nuquestionably within the power of the rarions State legislatmes to impose an ammal license tax upon foregign corporations transacting business within their limit. Huwerer, but few of the States have chosen thus far to excreise this power. Alabama, Colorado, Massachusetts. Sow York, Ohio, Oregon, Texas, Termont, Virginia, Washington, and West Virginia are the only States which impose an annual license tax upon foreign corporations. In each of these States the tax is a graduated one, the amount thereof depending either upon the anthorized capitalization of the corporation, or the amount of the eapital stock represented by capital invested in the foreign State where such anmual license tax is imposed.

$\$$ 133. To what Extent is the Taxing Power of the State with Reference to Domestic and Foreign Corporations Engaged in Interstate Commerce Limited by the "Commerce Clause" of the Federal Constitution? - The question as to the extent of the legislative power of the various State legislatures with reference to taxing domestic and foreign corporations must always be arrived at by giving due consideration to the limitations imposed upon this power by the plorisions of what is known as the "Interstate Commerce Clause of the Federal Constitution." 1

Again, this question, in order to permit of intelligent consideration, must be viewed from four standpoints, to wit: (1) What effeet, if any, has the Interstate Commerce Clause of the Federal Constitution upon the right of the sereral States to impose organization taxes upon corporations engaged in interstate commerce? (2) What effect, if any, has the Interstate Commerce Clause of the Federal Constitution upon the right of the several States to impose franchise taxes upon corporations engaged in interstate commerce? (3) What effect, if any, has the Interstate Commeree Clause of the Federal Constitution upon the right of the sereral States to impose license taxes upon corporations engaged in interstate commerce? (4) What effeet, if any, has the Interstate Commerce Clause of the Federal Constitution upon the right of the several States to impose property taxes upon corporatirons engaged in interstate commerce? Each of these will now be taken ur for separate consideration.

(1) What effect, if any, has the Interstate Commerce Clause of the Federal Constitution upon the right of the several States

1 See Constitution of the United States, Art. I. sec. 8, clause 3. 202 
to impose organization taxes upon corporations engaged in interstate commerce? The State is said to possess inherent power to tax its corporations. So the State has undoubted power to exact a bonus for the granting of a franchise, payable in advance or in futuro. ${ }^{1}$ A round sum or an annual charge, with or without reierence to capital stock, may be asked by the legislature for such a franchise. ${ }^{2}$ In discussing the question of the right of a State to impose a fee, a license or a tax upon corporations, the Supreme Court of the United States in Ashley $v$. Ryan, ${ }^{3}$ spoke as follows:

"At the time the articles were presented for filing, the statute law of the State charged the parties with notice that the benefits which it was sought to procure could not be obtained without payment of the tax for consoliclation which the Secretary of State exacted. As it was within the diseretion of the State to withhold or grant the privilege of exereising corporate existence, it was as a neeessary resultant also within its power to impose whatever conditions it might deem fit as prerequisite to corporate life. The aet of filing, constituting, as it did, a elaim of a right to the franchise granted by the State law, carried with it a voluntary assumption of any bur. den with which the privilege was accompanied, and without which the right of corporate existence could not have been procured. Having thus aceepted the act of grace of the State and taken the advautages which sprang from it, the corporation cannot be permitted to hold on to the privilege or right granted and at the same time repudiate the condition by the performance of which it eonld alone obtain the privilege which it sought. That the right to be a State corporation depends solely upon the grace of the State and is not a right inherent in the parties, is settled.

"... It follows from these principles that a State in granting a corporate privilege to its own eitizens, or, what is equivalent thereto, in permitting a foreign corporation to become one of the eonstituent elements of a consolidater corporation organized under its laws, may impose such eonditions as it deems proper, and that the aceptance of the franchise in eithor case implies a submission to the contitions without which the franehise could not have been oltained."

The right of the State to impose such taxes mpon the organization of a corporation is in no wise affected by the Interstate Commerce Clause of the Federal Constitution; this, too, even when

1 B. \& O. R. R. Co. v. Marylam \& \& 2 Cimrlon v. Alpeal liax Court, 3 How. U. S. 456 .

(T. S..) 134 .

3 1.53 U. S. 436 
the corporation is formed for the express purpose of engaging in interstate commeree. In the words of the United States Supreme Conrt. " the right and privilege of being a corporation is of great ralue to its members, as it is considered as property separate and distinct from the property which the corporation may acquire. Accorling to the law of most States this franchise, or privilege of being a corporation, is deemed personal property and is subject to separate taxation. The right of the State to thus tax it has been recognized by this court and the State courts in instances without number." 1

(2) What effect, if any, has the Interstate Commerce Clause of the Federal Constitution upon the right of the several States to impose franchise taxes upon corporations engaged in interstate commeree? Again, attention is here called to the decisions of the United States Supreme Court relative to the exereise of the power in question. "The granting of the rights and privileges," observes that tribmnal, "which constitute the franchises of a corporation, being a matter resting entirely within the control of the legislature, to be exercised in its good pleasure, it may be accompanied with any such conditions as the legislature may deem most suitable to the public interests and policy. It may impose as a condition of the grant as well as also of its continued exercise, the payment of a specific sum to the State each year, or a portion of the profits or gross receipts of the corporation, and may prescribe such mode in which the sum shall be ascertained as may be deemed conrenient and just. There is no constitutional inhibition against the legislature adopting any mode to arrive at the sum which it will exact as a condition of the creation of the corporation or of its continued existence. There can be, therefore, no possible objection to the validity of the tax preseribed by the statutes of any State so far as it relates to its own corporations, nor can there be any greater objection to a similar tax upon a foreign corporation doing business by its permission within the State. As to a foreign corporation, it can claim a right to do business in another State to any extent only subject to the conditions imposed by its statutes. Only two exceptions or gualifications have been attached to the foregoing, to wit: One is that the State camnot exclude from its limits a corporation en-

1 Horn Silver Mining Co. v. New York, York, 134 U. S. 594 ; Delaware R. R. 143 C. ‥ 305; Home Ins. Co. v. New Tax, 85 C. S. 206. 204 
gaged in interstate or foreign commerce. The other limitation is that where the corporation is in the employ of the government. Having the absolute power to exclude the foreign corporation, the State may of course impose such conditions upon permitting the corporation to do business within its limits as it may judge expedient; and it may make the grant or privilege dependent upon the payment of a specific license tax or a sum proportioned to the amount of its capital. No individual member of the corporation or the corporation itself can call in question the validity of any exaction which the State may require for the grant of its privileges. It does not lie in any foreign corporation to complain that it is subjected to the same law with the domestic corporation." 1

In a certain sense the imposition of an organization tax is as much the lerying of a franchise tax as the imposition by a State of annual taxes upon corporations in return for the right to exercise their corporate powers within the jurisdiction of the State. The one las been defined to be a "franchise to be," and the other as a "franchise to do." 2

(3) What effect, if any, has the Interstate Commerce Clanse of the Federal Constitution upon the right of the sereral States to impose liccuse taxes upon corporations engaged in interstate commerce? Strictly speaking, the imposition of a franchise tax has reference only to domestic corporations, while license taxes, when apylied to eorporations, have reference not only to domestic corporations, but to foreign corporations as well. Foreign corporations, as such, can be taxed by foreign States only upon corporate property situated within such forcign State, or upon the business done there. They cannot be taxed in a foreign State on account of their corporate franchises, as that was not given by the laws of the foreign State but was dependent upon the laws of the State of its creation and had an existence separate therefrom. A corporation may, through its agents, extend its operations into other States, and thus, metaphorically speaking, go there; but it never really travels, and its franchises exist only at the place of its domicile and residence. ${ }^{3}$

1 Horn Silver Mining Co. $v$. New York, Tax Cases, 92 U. S. 603; California $v$. 143 U. S. 305. Company, 127 U.S. 1 ; Society for Savings

2 Alams Express Co. v. Olio, lf,f, 1 . Coite, f, Wall. 606; Maine $v$. Ry. Co., U. S. 224 ; IIome Insurance Co, v. Now 142 L. S 227

York, 134 C. S. 600: Rearling R. R. ". ${ }_{3}$ People r. Equitalle Trust Co,, 96 N. Y. Pennsylvania, 15 Wall. 296 ; State R. R. 397 ; l'limpton v. Bigelow, 93 N. Y. 592. 
On the other hand, there is clear distinction between a license tax and a property tax. The former involves a eharge for permission or anthority to transact certain business, while the latter, when applied to corporations, is a contribution imposed upon and measured by the property of the corporation. ${ }^{1}$

The right to impose a license tax upon corporations is subject to the following limitation: If the tax is essentially a regulation of interstate commerce and its imposition does not constitute a proper excreise of the police power of the State, then it comes within the inhilition of the Interstate Commerce Clause of the Federal Constitution. ${ }^{2}$

Again, in Pembina Consolidated Silver Mining \& Milling Co. $v$. Pennsylvania, ${ }^{3}$ the United States Supreme Court spoke as follows:

"The exaction of a license fee to enable the corporation to have an oflice for the transaction of its business within a foreign State is clearly within the competeney of the legislature of that State. The reeognition of the foreign corporation's existence in a foreign State, even to the extent of allowing it to have an office within its limits for the use of its officers, agents, and employees, was a matter dependent upon the will of the State. It could make the grant of the privilege conditional upon payment of a license tax and fix the same according to the amount of the authorized capital of the corporation. The absolute power of exclusion ineludes the right of a conditional and restricted exercise of its corporate powers within the State. The equal protection of the laws which these bodies may claim is only such as is accorded to similar associations within the jurisdietion of the State. - The plaintiff in error is not a corporation within the jurisdiction of Pennsylvania. The office it hires is within such jurisdiction, and on condition that it pays the required license tax it can claim the same protection in the use of the office that any other corporation having a similar office may claim. It would then have the equal protection of the law so far as it had anything within the jurislietion of the State, and the constitutional amendment requires nothing more. The State is not prohibited from discriminating in the privileges it may grant to foreign corporations as a condition of their doing business or hiring offices within its limits, provided always sueh discrimination does not interfere with any transaction

1 Cooley on Taxation, 2nd ed.pp. 383, 576 ; Welton $v$. Missouri, 91 C. S. 275 Emert v. Missouri, 156 U. S. 296.

2 People ex rel. Pennsylvania R. R. $v$. 206 
by such corporations of interstate or foreign commerce. It is not every corporation lawful in the State of its creation that other States may be willing to admit within their jurisdiction or consent that it have offices in them; such, for example, as a corporation for lotteries. And even where the business of a foreign corporation is not unlawful in other States the latter may wish to limit the number of such corporations or to subject their business to such control as would be in accordance with the policy governing domestic corporations of a similar charicter. The States may therefore require for the admission within their limits of the corporations of other States, or of any number of them, such conditions as they may choose, without acting in conflict with the concluding provision of the first section of the Fourteenth Amendment.

"The only limitation upon this power of the State to exclude a foreign corporation from doing business within its limits, or hiring offices for that purpose, or to exact conditions for allowing the corporation to do business or hire offices there, arises where the corporation is in the employ of the Federal Government, or where its business is strictly commerce, interstate or foreign. 'The control of such commerce, being in the Federal Government, is not to be restricted by State authority."

\section{In Waters Pierce Oil Co. $v$. Texas ${ }^{1}$ it was said that:}

"Having no absolute right of recognition in other States, but depending for such recognition and enforcement of its contracts upon their assent, it follows, as a matter of course, that such assent may be granterl upon such terms and conditions as those States may think proper to impose. They may exclude the foreign corporation entirely; they may restrict its business to particular localitics, or they may exact such security for the performance of its contracts with their citizens as in their julgment will best promote the public interest. The whole matter rests in their discretion."

In Hooper $v$. California, ${ }^{2}$ conditions imposed upon a foreign corporation were considered, and a statute was sustainerl, making it a mistemeanor for a person in California to procure insurance for a resident in that State from an insurance company not incorporated moler its laws, and which lual not filed a lomd repuired by the law of the Sitate. All precening cases were cited, and it was assumed as settled "that the right of a forcign corjoration to engage in busincss within a State ofluer than that of its creation,

1177 C.S. 28.

2155 U. S. 648 ; 39 I. I.d. 297. 
depends solely upon the will of such other State." And the excontion to the rule was stated to be "only cases where a corporation ereated by one State rests its right to enter another and to cngage in business therein upon the federal nature of its business."

A State may tax the franchise of a domestic corporation or impose a license tax upon a foreign corporation, but can only subject a corporation engaged in interstate commerce of in the employ of the general gorermment to such property taxation as only incidentally affects its occupation, as all business, whether of individuals or corporations, is affected by common governmental burdens. 1

The power to license is a police power, although it may be exereised for the purpose of raising revenue. ${ }^{2}$ But the State in the exereise of the police power cannot impede interstate commerce by discriminating taxes. ${ }^{3}$

The question next arises as to what constitutes a proper exercise of the police power on the part of a State. A State may lawfully in the excreise of this power provide for security of lives, limbs, health, and comfort of persons and protection of property, or in regulation of highways, canals, railways, and other commercial facilities, passage of laws to regulate sale of articles deemed injurious to health or morals of community; imposition of taxes on persous residing within the State and upon occupations pursued therein, not directly connected with foreign or interstate commerec or with some other business excreised under anthority of the United States and imposition of taxes upon all property within the State mingled with and forming part of the great mass of property therein.

(4) What effect, if any, has the interstate commerce clause of the Federal Constitution upon the right of the several States to impose property taxes upon corporations engaged in interstate commerce?

1 Postal Telegraph Co. v. Adams, 155 U. S. 696 .

2 Wiggins Co. v. East St. Louis, 107 U. S. 374 .

8 Austin $v$. Tennessee, 179 L. S. 344; License Cases, 5 How. (U. S.) 592.

${ }^{4}$ Robling $v$. Shelby Co. Tax District, 120 U. S. 493. See also Liverpool Ins. Co. v. Massachusetts, 10 Wall. (U.S.)
576 ; Philadelphia, etc. $\Delta$ ss'n $v$. New York, 119 U. S. 119 ; Horn Silver Mining Co. $v$. New York, 143 U. S. 305; Postal, etc. Cable Co. v. Charleston, 153 U. S. 693 ; Martin $v$. R. R., 151 U. S. 677; Hooper $v$. California, 155 U. S. 652 ; Bonman $v$. Railway, 125 U.S. 491; Smith v. Alabama, 124 U. S. 474. 
A State may tax corporations for their privileges within the State in licu of all other taxes, provided the amount is made dependent on the ralue of its property within the State and payment is not a condition precedent to the right to carry on its business. The tax then becomes a mere property tax and not an interference with interstate commerce. ${ }^{1}$

The existence of federal supervision orer interstate commerce is not inconsistent with the power of the State to control its internal commerce and to tax franchises, property, or business of domestic corporations engaged in such commerce, nor with power to tax foreign corporations on property within the State. ${ }^{2}$ In this connection it has been well said that

"commerce between the States consists of intercourse and traffic between their citizens and includes the transportation of persons and property, and the narigation of public waters for that purpose as well as the purchase, sale, and exchange of commodities. It makes no difference whether such commeree is earried on by individuals or by corporations. It is true that the property of corporations engaged in foreign or interstate commerce, as well as the property of corporations engaged in other business, is subject to State taxation, provided always it is within the jurisdietion of the State. Where there is jurisdiction on the part of the State neither as to persons nor property, the imposition of a tax is uneonstitutional and void. If the legislature of a State enacted that the eitizens of another State or country should be taxed in the same mamner as the persons within its own limits, and subject to its authority or in any other manner whatsoever, such a law would be as much a nullity as if in conflict with the most explicit eonstitutional inhibition. Jurisdiction is as necessary to valid legislative as to valid judieial action. It has been repeatedly decided, and is settled law, that a tax upon the eapital stoek of a eorporation is a tax upon its property and assets; that it is undoubtelly competent for the legislature to lay a franchise or license tax upon foreign eorinrations for the privilege of doing business within the State, but that such a tax is in mo sense al liecnse tax. It is a fundamental principle that in order to tax the enporation it must have a domicile within the State; that when it is sought to tax eapital stoek of a corporation, the liaw imposing such at tax must be eonstrued to mean so much of the eapital stork as is measured by the property actually brought within the state by the corporition in the transition of its business. Tu the states must be conceded power

${ }_{1}$ Postal Tel. Co. $v$. Alams, 155 U.S. 2 Firie R. R. P. Pennsylvania, 158 696. U. S. 43 . 
$\$ 133$ inconforation and ORGanization of corporations. [PART i.

to exchule foreign corporations altogether from its borders or to impose a license tax so heary as to amount to the same thing. They must be denied the power to tax either persons or property not within their jurisdiction." 1

1 Ghucester Ferry Co. v. Pennsylvania, 136 U. S. 120 ; $\Lambda$ shley $v$. Ryan, 153 114 C. S. 196. See also I'hiladelphia, ete. U. S. 446 ; Erie R. R. v. Pennsylvania Steamship Co. v. Pennsylvania, 122 U.S. 158 U.S.437; New York State $v$. Roberts, 345; Norfolk, cte. R. K. v. Pennsylvania, 171 U.S. 665. 


\section{PART II.}

\section{SYNOPSIS-DIGEST OF THE INCORPORATION ACTS OF THE SEVERAL STATES AND TER- RITORIES OF THE UNITED STATES.}

\section{ALABAMA.}

(The references are to the Session Laws of 1903, chap. 395, where not otherwise stated.)

1. Statute under which Business Corporations may incorporate. Business corporations are organized under the Act of Octoher 2, 1903, found in the Alabama Session Laws of 1903, chap. 395. Lnder it corporations may be organized " for any lawful business or businesses of any kind or nature whatsoever."

2. Incorporators. - Three or more. There are no residential requirements (Session Laws of 1903 , cliap. 395, sec. 1).

3. Contents of the Certificate of Incorporation. - The certificate must contain :

a. Name. - Similarity of names is forbidden. If the name of a person or partnership be assumed, it must be followed by the adilition of some word designating the nature of at least one of the businesses to be carrjed on, followed by the word "Company " or " Corporation."

b. Purposes. - The objects for which the corporation is to be formed. Corporations may be formed under the General Act for any purpose whatever, and for as many purposes as desired. The only limitation is that banking and trust company jowers cannot be exercised by corporations formerl for any other purpose.

c. Inomicilinry Office - location of principal oflice in the State.

d. C'npital stock. - The amount of total anthorized capital stock not to be less than $\$ 2,000$. There is un maximm limit. The number of shares into which it is dividerl, also anount of capital stock with which it will commence business, not to be less than twonty-five per cent of the anthorizen calital, in no case less than s1,001. If there he more thith one clats of siock, the certificate must entatin a deseription of the different elasses of stock, with the terms on which each clase is created.

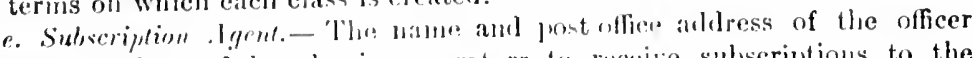
or agent designated by the incorporators to receive subseriptions to the capitial stock.

f. Incorporators, Dirertors, and officers. - Names and atdresses of the incorporators, together with the mumber of shares subseribed for hy each, this representing the amount of eapital stock with which the corporation will 
begin business. In addition, the incorporators' names, and names and addresses of the directors and oflicers for the first year must be given. (See ant', sec. 2, and post, sec. 12.)

9. Corporate Existence. - Duration of corporate existence, which may be perpetual if desired.

h. Corporate Rules and Regulations. - Provisions desired for the regulation of the husiness and for the conduct of the affairs of the corporation, creating and defining the powers of the corporation, the directors and stockholders or any class or classes of stockholders (Id. sec. 2).

Noте. - Additional statements are required for railway transportation, canal, telegraph, telephone, and public utility corporatious (Id. sec. 2, sub. h, i).

4. Statutory Powers. - The statute gives to corporations organizing under the general act the following powers, which being such as existed at common law without any statutory enumeration thereof may be termed "common law powers." They are as follows: (1) The power of succession ; (2) to sue and be sued; (3) to make, use, and alter the corporate seal ; (4) to adopt by-laws; (5) to purchase and hold real property for the purposes of the orgauization; (6) to receive and grant by the corporate name: (7) to appoint officers and agents ; (8) to borrow money; $(9)$ to issue negotiable paper; (10) to mortgage the corporate property (Id. sec. 72).

Falconer $v$. Campbell, 2 McLean, 195.

In addition to the foregoing statutory enumeration of the common law powers of corporations, the following additional powers are conferred: 'To hold stockholders' and directors' meetings without the State, provided certaiu preliminary formalities are observed; to carry on corporate business in other States and foreign countries; to subscribe for, purchase, and hold stock and bonds of other corporations (Id. sec. 7); under certain conditions to operate railroads (Id. sec. 14); to issue houds and mortgages or create indebtedness without limit with the consent of a majority of the stockholders first obtained (Id. sec. 7) ; to accept real and personal property in payment of capital stock; to create liens upon the stock of members for debts due the corporation (Id. sec. 7 , sub. c). Corporations other than railway, telegraph and telephone, banking, insurance, and trust companies may consolidate with other corporations (Id. sec. 7, sub. $\mathrm{j}$ and $\mathrm{k}$, secs. 39-42; see also Laws of 1903, chap. 117). Certain corporations doing a business of a quasi-public nature but organized under the General Act, may exercise the power of eminent domain (Id. secs. 8 and 9 ).

Railway, mining, manufacturing, and quarrying corporations may construct, acquire, and operate steanboats, barges, ships for transportation of freight and passengers (Id. sec. 10). They may also subscribe for or aid any other corporation in the construction of a railroal, etc. (sec. 12).

Mining, manufacturing, and quarrying corporations may construct and operate to and from their plants, railways, tramways, canals, tumnels, and roads, and as common carriers, transport freight and passengers thereon (Id. sec. 14).

Only corporations formed for the transaction of a banking or trust company business can engage in banking within the State (Id. sec. 22).

Corporations also have power to issue preferred stock ; to anthorize voting by proxy at stockholders' meeting; to forfeit stock for non-payment of assessinents (Id. secs. 2,37 ; see also Session Laws of 1903, chap. (is; also Id. chap. 111 ). 
5. Corporate Indebtedness. - There is no statutory limit upon he amount of indebtedness that nas be contracted by a business corporation. To create a bonded indebtedness or increase the same or to mortgage the real property of the corporation, the vote of the larger amount of stock present and roting at a meeting duly called for that purpose must be had (Id. sec. 7, sub. c; sec. 46).

Under the Constitution (Art. XIV. sec. 6) corporations cannot issue bonds except for money, labor done, or money or property actually received, and all fictitious increase of indebtedness shall be void.

Nelson $v$. Hubbard, 96 Ala. 238, 11 Sou. 428; Dexter $v$. MfClellan, 116 Ala. 37, 22 Sou. 461.

6. Procuring the Charter. - The certificate must be signed by all the subscribers to the capital stock named therein. The statute does not expressly require that the certificate be acknowledged by the subscribers. The certificate must then be filed and recorded in the office of the probate judge of the county where the corporation will hare its principal place of business. After it has been recorded the probate judge endorses thereon a certificate of registration. Within ten days after the filing of the certificate in the office of the probate judge, the corporation must eause to be filed in the office of the Secretary of State a statement signed by said probate judge, giving the name of the corporation, the names of its incorporators, the date of the incorporation, the amount of the capital stock, and the name of the county in which located. The certificate must have attached to it a statement unfler oath by the person authorized by the incorporators to receive subscriptions to the capital stock, which shall show the amount of capital stock which has been paid in and the amount of stock secured by contracts for stipulated labor or services or transfer of property, which amount shall le at least twenty per cent of the stock subscribed for, and in no case less than 81,000 . At the time the certificate is filed with the judge of probate the incorporators must pay the organization tax to the judge of probate (Id. secs. $3,4,5$, and 6 ). $A$ copy of the subscription list must be also attached to the certificate.

Corporate existence commences as soon as the articles are filed and recorded in the office of the probate judge of the county where the domiciliary office is located and the organization tax and filing fees paid.

O. W. Co. v. Bliss, 132 Ala. 253 ; 31 Sou. 81 ; M. \& (). Rv. Co. v. P. T. C. Co., 120 Ala. 21 ; 24 Sou. 408 ; N. C. Bank 1 . Mcl)onnell, 92 Ala. 387; 9 Sou. 149 ; IItrris $v$. G. L. Co., 128 Ala. $652 ; 29$ Son. 611.

7. Organization $\mathbf{T a x}-0 \mathrm{O}$ capitalization not exceeding $\$ 50,000,825$; not excecding $\$ 100,010,850$; any amonnt in excess of $\$ 100.000,850$, on tho first one hundied thonsand, and 5.5 on "ach additional on humetred thon. sand dollars or fractional part theleof ( irl. sec. 5).

8. Filing and Recording Fees. - For examining the certificate the probate julge is entitled to a fie of \&.2.50, and for recuriing the certificate in his office, lis cents per folio 'Tho siecretary of Sititr is entitled to a fee of 5 f cents for filing in his office thr atatement of the firobate juilse required by law giving the name of the curporation. names of incorporators, date of incorporation, amount of capital stock, and the nane of the county in which incorporated. 
9. Commencing Business. - Twenty-five per cent of the authorized capital stock of a corporation must be subseribed in good faith, payable in money before the commencement of corporate existence, but subscribers may have the privilege of lischarging the same in service, labor, or property at the reasonable value for such services, labor, or property. Twenty per cent of all subseriptions for stock must be actually paid in, and said amount must never be less in the aggregate thim $\$ 1,000$ (Id. secs. 2 and 4 ; see also Laws of 1903, chap. 110). Pusiness must be commenced within five years from the date that the charter issues (Id. sec. 37).

10. Organization Meetings $-\Lambda$ preliminary organization is effected by the incorporators meeting within the State (by proxy, if desired) and authorizing some person to receive subseriptions to the capital stock of the proposed corporation. After the clarter is secured from the State by the compliance with the necessary formalities prescribed by statute (as stated above), the incorporators, who, under the statute, must likewise be subscribers to the capital stock, should sign a written consent to the lolding of an organization meeting, fixing the time and place for holding the same. The incorporators should then organize by adopting by-laws and by the transaction of other routine organization business. There is no statutory time prescribed within which this organization meeting must be held, the law simply providing that non-user of corporate franchise for a period of five consecntive years is a forfeiture of such franchises. Immediately after the adjourmment of the organization meeting of the incorporators and stockholders, a meeting of the board of directors should be called for the purpose of electing a president, secretary, and treasurer, and such other officers as the by-laws may prescribe.

11. Meetings, Stockholders' and Directors'. - In the absence of the written consent of all resident stockholders, stoekholders' meetings must be held within the State, but such meetings may he held without the State upon the written consent of such resident stockholders. All corporations holding their stockholders' meetings without the State must give the name and residence within the State of the agent in charge of their principal office within the State, to be sigued by the president or sccretary of the corporation under the corporate seal. The certificate should theu be filed in the office of the Secretary of state and in the office of the probate judge of the county in which it has its principal office. A coly of all proceedings had at stockholders. and directors' meetings held without the State must be deposited with such agent. Written consent of the stockholders residing within the State, for stockholders' meetings to be held without the State when filed in the office of the Secretary of State, shall remain in force until revoked. Directors' meetings may be held within or without the State as the by-laws may provide (Id. sec. 7 ).

Brockway v. G. M. L. Co., 102 Ala. 620 ; 15 Sou. 431.

12. Directors' Qualifications. - There must be at least three directors, who shall be stocklolders and hold office for one year or until their successors are elected. There are no residential requirements (Id. sec. 36).

Smith v. P. R. Co., 30 Ala. 650 ; Fitzpatrick v. D. 1’. Co., 83 Ala. 604; 2 Sou. 727.

13. Stockholders' Liabilities. - Stockholders are liable for the debts of the corporation only for the unpaid stock owned by them. The corporation may, by the adoption of a proper by-law, place a lien upon the shares 214 
of its stockholders for any debt or liability they may incur to the company (ld. sec. 27).

Lea $v$. Company, 119 Ala. 271 ; 24 Soa. 28 ; Nicrosi v. Company, 115 Ala. 429; 22 Sou. 147.

14. Stock Certificates. - Every stockholder is entitled to have a stock certificate signed by the president and secretary or treasurer. The par value may be any amount (Id. sec. 28).

15. Preferred Stock. - Preferred stock is expressly authorized under the new act (sec. 43). If provided for in the original certificate of incorporation, the terms on which it is issued must be therein stated. If subsequent to incorporation it is desired to issue preferred stock, this may be done by the vote of the holders of two-thirds in value of the capital stock outstanding at a meeting called for that purpose. The proceedings of this meeting must be certified to the Secretary of State and filed and recorded in his office. After this has been done, preferred stock, not to exceed two-thirds of the capital stock paid in in cash or property, may be issued. Each stockholder shall be first entitled to the pririlege of taking such preferred stock in proportion to the amount of common stock held by him, or a less amount should he desire, before the preferred stock is offered for sale to the public (Id. sec. 43).

16. Payment of Capital Stock. - Under the Coustitution corporations can only issue stock for money, labor done, or money or property actually receired. All fictitious increase of stock is roid (Cons., Art. XIV. sec. 6).

All subscriptions to capital stock must be paid in cash, except that, if so prorided in the contract of subscription, such subscriptions may be discharged by the rendition of stipulated necessary services, or the performance of stipulated necessary labor, or the transfer of property at the reasonable ralue thereof. In such cases the subscription list shall state the names of such subscribers, with the nature of the services or labor to be performed and a brief description of the property and when it is to be transferred to the company (Id. sec. 26).

Bibb v. Hall, 101 Ala. $79 ; 14$ Sou. 98 ; Haas v. Hall, 111 Ala. 442; 20 Son. 78; Paschall $v$. Whitsett, 11 Ala. 472 ; Spence $v$. Shaparl, 57 Ala. 598 ; Knox r. C. L. Co., 6 Ala. 180 ; 5 Sou 578 ; Fitæpatrick $v$. P. Co., 83 Ala. 604; 2 Sou. 727 ; Williams $v$. Evans, 87 Ala. $725 ; 6$ Sou 702 ; l'arsons $v$. Joseph, 92 Ala. 403; 8 Sou. 783; Beitman v. Steiner, 98 Ala. 241 ; 13 Sou. 87 ; l'erry $v$. Mill Co., 93 Ala. $364 ; 9$ Son. 217.

17. Books. - It is contemplated by the statute that the books, records, and papers of the corporation shall be kept at the principal oflice within the State unless the by-laws otherwise provide. 'The statute gives to all stoekholders the right of access to, and inspection and examination of, suel books and records and papers at reasonahli. and proper times (Inl. sec. 35). It is specially provided that a stock register shall he kept with an agent in the state, showing list of stockholders, trausfers, and hypotheeations (II. sec. :;2).

18. Office and Agent. - Every corpuration must have an oflice within the State, and an agent in charge thercof ujom whom process may he serverl (Id. sec. 2).

19. Reports. - No anuual reports are required.

20. Anti-Trust Statute. - The State has an anti-trust statute, modelled closely after the New York let.

Beitman v. Steiner, 98 Ala. $241 ; 13$ Sou. 87. 
21. Statutory Ground for Forfeiture of Charter. - Non-11ser for a period of tive consecutive years is ground for forfeiture of the charter upon proper action taken by the State (Id. sec. 37). Also non-payment of license tax.

Stale r. Bank, 2 Stew. 30 ; Curry $v$. Woodward, 53 Ala. 371 ; M. \& O. R. R. Co. r. State, 2 ! Ala. 573 ; 1. \& E. Co. $v$. Locke, 50 Ala. 332 ; State $v$. R. R. Co., 108 Ala. 29 ; 18 Sou. sol.

20. Amendments. - If through accident or inddvertence the corporation has failed to comply with any of the requirenents of the act, the president or other executive head of the corporation may supply such omission or delect by filing, in the office of the judge of probate of the county in which the corporation was organized, a statement in writing under oath, setting forth the omission or error, and supplying or eorrecting the same (Id. sec. 45). The articles may be also amended for any purpose desired by complying with the statute (Id. sec. 7, sub. $\mathrm{m}$, and n ; secs. 44, 46, 47, see also Laws of 1903, chap. 106).

G. L. C. H. Ins. Co. $r$. Kamper, 73 Ala. 325.

23. Renewal of Corporate Existence. - May be renewed for an additional period of twenty years by compliance with the statute in such case mate and provided (Laws of 1903, chap. 105; see also Id. ehap. 395, sec. 7. sub. n, sec. 47 ).

24. Annual Privilege Tax. - When paid up capital is under $\$ 10,000$, $\$ 10$; when it exceeds $\$ 10,000$ and does not exceed $\$ 25,000, \$ 15$; when it exceetls $\$-15,000$ and does 110 exceed $\$ 50,000, \$ 25$; when it exceeds $\$ 50,000$ and is not over $\$ 100,000, \$ 50$; when it exceeds $\$ 100,000$ and does not exceed $\$ 200,000, \$ 75$; when it exceeds $\$ 200,000$ and does not exceed $\$ 300,000, \$ 125$; when it exceeds $\$ 300,000$ and does not exceed $\$ 400,000, \$ 170$; when it exceeds $\$ 400,000$ and does not exceed $\$ 500,000, \$ 200$; when it exceeds $\$ 500,000$ and does not exceed $\$ 1,000,000, \$ 300$; when it exceeds $\$ 1,000,000, \$ 500$ (Code, $\$ 4122$, as amended by Laws of 1901, Act No. 1151). 'Tax becomes due October 1st.

25. Dissolution. - Dissolution may be effected by an agreement of all stockholders signed and acknowledged, filed and recorded with the probate judge of the county of organization, and published in a newspaper of county of principal place of business four weeks; or (if such agreement eannot be had) holders of two-thirds in value of stock may petition Court of Chancery or other court of competent jurisdiction for dissolution.

State $v$. Webb, 97 Ala. 111 ; 12 Sou. 377; Mckleroy v. G. L. I. Co., 126 Ala. 184; 28 Soll. 660 .

20. Foreign Corporations. - Under the Alabama Constitution of 1901, Art. XII. sec. 292, no foreign corporation can do any business in the State without having at least a known place of business, and an anthorized agent or agents therein, and without filing with the Secretary of State a certified copy of its articles of incorporation. The Legislature is directed to provide for the fayment of franchise tax by such corporation to be based on the actual amount of carital employed witlin the State. Lnder the laws of 1903, No. 369, every foreign corporation, except railway, telegraph, long-distance teleThone, express, sleeping-ear, life and fire insurance companies, building and loan assoriations authorizerl to do business uurler general law, must pay to the probate judre of the county in which it has a resident agent a license tax of 216 
one-tenth of one per cent for the use of the State and one-half of that sum for the use of the county, to be computed upon the basis of the actual amount of capital employed by it within the State. This tax is payable on the first day of January of each year. Corporations not authorized to do business within the State before obtaining permit to do so must pay to the State Treasurer for the use of the State a tax of one-tenth of one per cent upon the amount of capital to be actually employed within the State before they are permitted to file necessary papers ujon which to base their application for the permit. A statement is required to be filed by the executive head of such foreign corporation with the officer whose duty it is to receive the payment of the tax, giving certain necessary iuformation relative to the corporate organization with reference to the character and description of the property and value thereof within the State. The penalty for non-compliance with the statute is inability to sue in the courts, and subjects the corporation to liability of fine. The act expressly provides that it shall not apply to corporations organized under the laws of the United States nor to colporations engaged in transacting the business of interstate comnerce.

Hall $v$. Engine Co., 91 Ala. 363; 8 Sou. 348; Morris $v$. Hall, 41 Ala. 510 ; Lucas $v$. Bank, 2 Stew. 147; Craldlock $v$. Mortgage Co., 88 Ala. 281; 7 Sou. 196 ; Cook $v$. Brick Co., 98 Ala. 409; 12 Son. 918; State v. Bank, 108 \la. 3; 18 Sou. 533; George $v$. N. E. M. Sec. Co., 109 Ala. 548; 20 Sou. 331 ; Electric L. Co. $v$. Rust, $11 ;$ Ala. 680 ; 23 Son. 751 ; Farrior r. N. E. M. S. Co., 88 Ala. 275 ; 7 Sou. 200 ; Collier $r$. Davis, 94 Ala. 456 ; 10 Sou. 86 ; Christian $v$. A. F. I. \& .I. Co., 89 Ala. 198 ; 7 Sou. 427 ; City of Greenville $v$. G. W. Co., $1 \div 5$ Aln. $625 ; 27$ Son. 764 ; Sullivan $x$. Vernon, 121 Ala. 393 ; 25 Sou. 600 ; Bearl $v$. U. \& A. I'. Co., 71 Ala. 60 ; Falls $v$. U. S. S. L. \& B. Co., 97 Ala. 417 ; 13 Sou. 25 ; MeLeorl $v$. Am. F. L. II. Co., 100 Ala. $496 ; 14$ Sou. 409 ; Chattanooga, ete. Ass'n $v$. Denson et al., 189 U. S. 408; D. M. \& T. I. Co. $v$. Nixon, 95 Ala. 318 ; 10 Sou. 311.

\section{ALASKA.}

(The references are to the Act of Congress [Public Act, 135] approved March 2, 1903, unless otherwise stated.)

1. Statute under which Business Corporations may incorporate. The Business Corporation Act of Alaska is found in Acts of Congress No. 135, approved Mareh 2, 1903. Under this act corporations may ormanize for the purpose of transacting the following lines of business in Alaska only, to wit: railway, street ralway, wagon road, canal, flume, telegraph, telephone, mining, fishery, smelting, el•ctric power, lighting, doek, wharfage, elevator, warebouse, hotel, tradr, transportation, agricultural, lumbering, and namufacturing companies.

2. Incorporators. - Three or more alult persons, all of whom must he bona firle residents of the district of Aliskn (sere. 1).

$\because$. Contents of the Articles of Incorporation. - Articles nust continin :

a. Corporate Name. - Similarily of names not forliblen (sec. 2).

b. I'urposes. - Nalure and ehitacter of the business. Nay be incorporated for one or more of the purpuses alecis onmerated (Id.).

c. Iomiciliury Ofjice. - J'rincigal Jlam for transacting lusiness.

d. Duration. - 'l'ime of commencement nud period of continuance not to exceel fifty years (Id.). 
e. Cupritul Stock - Amount of capital stoek and manner in which the same is to be paid in, and the number and par value of the shares (ld. sec. 10).

$f$. Indebtcdness. - Ilighest amount of indebtedness or liability that may be incurred (lel.).

g. Nimes of Incorporators. - Names and residences of the incorporators (II.).

h. Directors. - Nimber and names of first board of directors, and also statement as to what oflicers shall have charge of the managenent of the corporate affairs and when they shall be elected and their terms of office (Id.).

4. Statutory Powers. - The statute merely enumerates the common law powers of corporations. The power to remove oflicers and directors is expressly granted, as well as the right of stockholders to vote ly proxy. Stock may be forfeited for non-payment of assessments (secs. 4-6, 10).

5. Procuring the Charter. - Incorporators must subscribe and acknowledge written articles of incorporation in triplicate. One of these must be filed and recorded in the office of the secretary of the District of Alaska and another in the office of the clerk of the district court of the recording division where the principal place of business of the corporation is to be located ; the third to be retained in the possession of the corporation. Corporate existence commences as soon as the foregoing steps have been taken (secs. 2-4).

6. Corporate Indebtedness. - The corporate indebtedness cannot exceed the capital stock (sec. 17).

7. Organization Tax. - There is no organization tax in the district of Alaska.

8. Filing and Recording Fees. - The filing and recording fces in the office of the secretary of the District of Alaska have not yet been fixed by the Attorney-General of the United States. For recording articles in the office of the clerk of the district court of the recording division where the principal place of business of the corporation is to be located a fee of 15 cents per folio must be paid for such service. (See Public Act No. 150, Title I. sec. 30, approved Jan. 6, 1900).

9. Commencing Business. - liusiness may be commenced as soon as the articles are filed in the proper offices and the organization effected (sec. 4).

10. Organization Meeting. - The organization mecting must be held in the District of Alaska. Corporations must organize within one month after filing articles of incorporation by the adoution of by-laws (secs. 9-16).

11. Meetings of Stockholders and Directors. - Stockholders' meetings must be held within the District of Alaska. The requirement that a majority of the directors must be residents of the district requires that all meetings of the board of directors as such shall be there held (sec. 6).

12. Directors' Qualifications and Liabilities. a. Qualifications. - There must be not less than three directors, who shall be stockholders and a majority shall be residents of the District of Alaska. They are each required to subscribe to an oath of office (sec. 6).

b. Ciabilities. - Directors are liable for illegal payment of dividends or for the unlawful withdrawal of any part of the capital stock of the corporation (sec. 13).

13. Stockholders' Liabilities. - Stockholders are liable only for the amount that remains unpaid upon the par value of their stock (sec. 14).

14. Stock Certificates. - Each stockholder is entitled to a stock certificate signed by such officers as the by-laws may preseribe. The par value of stock nay be any amount. 
15. Preferred Stock. - There is no provision for preferred stock.

16. Payment of Capital Stock. - Stock may be issued in consideration of money, labor, or property, estinrated at its true money value (sec. 14).

17. Books. - Books of account, stock books, and record books must be kept at its principal office in Alaska. These are open to the inspection of stockholders (sec. 16).

18. Office and Agent. - The ofince and the principal managing officer or superintendent must respectively be maintained and reside in the District of Alaska (secs. 2, 16).

19. Reports. - The president, secretary, and treasnrer must annually make out and publish weekly for three weeks a statement showing, first, number of shares of stock outstanding; second, amount paid in on each share; third, actual paid up capital of the corporation; fourth, actual cash value of the property and its location; fifth, statement of debts and liability and a description of the same; sixtl, salaries paid officers, manager, and superintendent; seventh, increase or decrease, if any, in the stock, the capital and the liability of the corporation during the preceding year. On or before September 1 of each year there must be filed, in the office of the clerk of the district court of the recording division where the principal office of the corporation is located, a list containing the names of the principal officers, including the president, cashier, secretary, and managing agent (secs. 20, 23).

20. Anti-Trust Statute. - There is no anti-trust statute specially applicable to the district of Alaska. (See Anti-Trust Act, U. S. Statutes of 1890, chap. 6.17.)

21. Statutory Grounds for Forfeiture of Charter. - The act does not provide for forfeiture of charters.

22. Amendments. - Articles may be amended for the purpose of increasing or diminishing the capital stock, or for the purpose of amending any of the general provisions of the articles (secs. 17-19).

23. Extension of Corporate Existence. - There is no provision for the extension of corporate existence.

24. Dissolution. - The corporation may be dissolved by the voluntary action of the stockholders taken as provided for in the act (sec. 22).

25. Annual License Fee. - There is no annual license fee in the District of Alaska.

26. Foreign Corporations. - Under Act of Jnue 6, 1900, cháp. 23 of Title III. U. S. Statutes at Large, 19u0, pp. 321-528, a foreign corporation, whether created under the laws of the Lnited States or those of any State or Territory of the United States, is required, before doing business within the distriet of Alaska, to file wilh the secretary of the district and the clerk of the distriet court for the division within which the business is to be carried on, an authenticatel copy of its charter or articles of incorporation, and a statement verifier by oath of the presilent and secreting of the corporation and atlested hy a majority of the diretors, showing : namo and location of prineipal place of husiness withont, and also (if it have one) within the district; amount of capitisl stock: amomnt thereof piad in in money, and amount paid in any other way, and mamer therof ; annmin of assets and of what they consist, aud actuil cash value therenf; liabilities, and if any of its indebterness is semrol, how and upon what property. It must also file with the foregroing lapers a certificate moler seal of the president, vice-president, or other arting heid of the corporation, and the secretary, 


\section{INCORPORATION AND ORGANIZATION OF CORPORATIONS.}

if there be one, certifying that such corporation has consented to be sued in the courts of the district upon all eauses of action arising against it in the district, and that process mily be served upon a designated agent residing in the district: and must file therewith written consent of such agent. Such corporation must also anmally, within thirty days from July 1 , report in substantially the sime form required in the foregoing statement and containing similar information.

\section{ARIZONA.}

(The references cited below are to the Revised Statutes, 1901, unless otherwise stated.)

\section{Statute under which Business Corporations may incorporate. -} The General Corporation Act in foree in Arizona went into effect September 1, 1901. It is fouml in the Revised Statutes of 1901, secs. 764-783 and secs. 909-927, and amendments thereto. It is entitled "Title XIII." Chap. 2 thereof refers to business corporations. In 1903 an act was passed amending secs. $766-750$ of the act ahove referred to. Under it parties may incorporate for any lawful purpose.

2. Incorporators (R. S., sec. 761). - Any number of persons may be incorporators. There are no residential requirements.

3. Contents of Articles of Incorporation. - The articles of incorporar tion must contain the following:

a. Name and Domiciliary Office (Id. sec. 766). - The articles of incorporation must state the principal place of business of the corporation within the Territory. Sinilarity of names is not forbidden.

b. General Nature of the Business proposed to be transacted. - The Territorial aulitor allows as many purposes as may be desired to be inserted in the articles. Any kind of business may be authorized except insurance, sarings and loan and eleemosynary corporations.

B. B. Co. $v$. A. \& C. Co., Ariz, 35 Pac. 983.

c. Capital Stock. - The amount of the capital stock authorized, and the time when, and conditions upon which, it is to be paid in. Capital stock under this section is without limit as to amount. The par value of the shares may be any arnount.

d. Corporate Existence. - The time of the commencement and termination of the corporate existence of the corporation. 'This period is limited by statute to twenty-five years (Id. sec. 771). Corporate existence may be renewed for another period of twenty-five years upon a vote of threefourths of the stockbolders given at a meeting duly called for that purpose (ld. sec. $7 i 1$ ).

e. Officers and Directors. - The names of the officers or persons by whom the affairs of the corporation are to be conducted, and the times at which they are to be elected. Reference is made in the articles to a board of directors of a designated number, who shall be elected annually by the stocklolders. As far as the statute is concerned, one would scarcely know that corporations organized under the General Act were supposed to have a board of directors.

f. Corporate Liability - The highest amount of indebtedness or liability to which a corporation is at any time to subject itself. This liability must not in any case exceed two-thirds of the capital stock (Id. sec. 767).

g. Annual Meeting. - This is inserted by inference from sec. 5 of the 220 
Amendment of 1903 , which requires a statement of the time at which the officers in charge of the affairs of the corporation are to be elected.

h. Slochholders' Liability. - Unless the private property of the stockholders is expressly exempt in the articles of incorporation from liability for corporate debts, stockholders are liable for the debts of the corporation in the proportion which their stock bears to the entire capital stock.

i. Corporate Rules and Regulations. - While the statute does not anthorize the insertion in the articles of any corporate rules and regulations, the Territorial auditor permits such rules and regulations to be inserted in the articles filed in his office.

4. Statutory Powers. - The statute (Id. sec. 765) enumerates the com. mon law powers of corporations. A sinking fund may be established for the payment of debts (Id. sec. 77\%). No mining or mannfacturnng corporation can have the power to operate or construct any railway, tranway, turnpike, or public highway, except such as lead from their principal work to adjacent streams, railways, or highways (Id. sec. $7 \$ 1$ ).

Debts cannot be contracted for in excess of two-thirds of the authorized capital stock.

Keyser $v$. Shuts, 29 Pac. 386.

5. Procuring the Charter (Id. secs. 706-769). - The articles must be signed and acknowledged before some officer anthorized to take acknowledgments. Every corporation must record its articles of incorporation in the office of the county recorder of the county where the principal place of business of said corporation within the Territory is located, and a certified copy thereof must be filed in the office of the Territorial auditor. The articles must be published at least six times in some newspaper published in the county in which the principal place of business is located or works established, and an affidavit of publication must be filed in the office of the Territorial auditor, stating that such publication has been made according to law. The statute expressly provides that the corporation may commence business as soon as its articles of incorporation are filed for record in the office of the county recorder and a certified copy with the Territorial anditor, and its incorporation shall then be complete if the publication is made and an affidavit thereof filed in the oflice of the Territorial anditor within three months after date of the filing with the county recorder. 'The act provides (Id. secs. 770,780 ) that there shall be no collateral incuiry into the legality of the corporate existence.

6. Corporate Indebtedness. - Must not exceed two-thirds of capital stock (sec. $76 j$ ).

7. Organization Tax. - There is no organization tax inposed.

8. Filing and Recording Fees. - For filing articles of incorporation with the 'Ferritorial auditor, $\$ 10$; for filing aflirlavit of publication of articles with same officer, \$3; for filing alpwintment of statutory agent with 'Territorial auditor, 8.3 ; same oflicers' fees for issuin; certified copy of the articles, where they do not exceed one thousand worls, 8.3) cost, of publishing artinles of incorporation of the averagr leugth of one thousand words, 87.50 ; for recording articles in local connty recorder's oflice where length does not exceed one thonsand words, about sili.lo, which includes certified copy for filing in auditor's oflice.

9. Commencing Business (Id. sre. 769). - The corporation may commence business as soon as the articles of incorporation are filed for record in 
the office of the county recorder, and a certified eopy with the Territorial anditor. No speciticl amount of eapital stock need be subscribed for or paid in before eommencing business. IBusiness must commenee within five years from the tine the chinter is issued (Id. see. 771 ).

10. Organization Meetings. - These must be held within the Territory after the articles are filed and recorded as required by law. The organization meeting shoull be held at the principal place of business within the 'lerritory as lesignated in the articles.

\section{Chase 2 . Fleming, Iac. Rep. 1904. (Not yet reported.)}

11. Meetings. Stockholders' and Directors'. - There is no statute authorizing stockholders' meetings to be held without the Territory. With respeet to stoekliolders' meetings, by inserting such a power in the articles of incorporation, it is perhaps safe to hold stockholders' meetings without the State. Direetors meetings maty be lield within or without the State, as the by-laws may provide. In the absence of any statute giving that right, authority to rote by proxy at stockholders' meetings should be provided for in the articles of incorporation.

12. Directors' Qualifications and Liabilities. a. Qualifications. - There may be any number of directors. They need not be stockholders, and there are no residential requirements.

b. Liabilities. - There are no statutory hiabilities imposed upon directors.

13. Stockholders' Liabilities. - Unless the articles of incorporation specifically exempt them from liability, stockholders are liable for the debts of the corporation in the proportion which their shares of stock bear to the whole capital stock. Stockholders are individually liable to the amount of the unpaid instalments on the stock owned by them or transferred to them for the purpose of defrauding creditors, and an execution against the corporation to that extent may be levied upon the private property of such stockholder. (Id. see. 776 ).

14. Stock Certificates. - The statute does not require specifically the issuance of stock certificates, nor does it preseribe who shall sign the same. This must be regulated by the by-laws. The par value of the stock certificates may be any amount.

15. Preferred Stock. - The statute does not expressly authorize the issuance of preferred stock. The Territorial auditor permits the filing of articles in his office providing for preferred stock.

16. Payment of Capital Stock. - The statute is silent as to how the capital stock shall be paid. In the absence of express provisions in the artieles authorizing the payment of stoek in property or services, stock must be paid for in money or money's worth.

17. Books. - The statute does not require that any books shall be kept within the Territory. It does require that a transfer book shall be kept showing the names of the persons by whom and to whom stock transfers are made, the number of shares, and the date of the transfer. It shall also show the original stockholders, their respective adoresses, the amount which has been paid in and all transfers thereof. Such books and records or correct copies thereof, so far as they relate to the items mentioned above, shall be at all tines subject to the inspection of any stocliholder (Id. sec. 778).

13. Office and Agent (Id. sec. 783). - All corporations are required to name in their articles the location of their principal place of business withiu the Territrry. They are also required to appoint a bona fide resident of the 
Territory who has a residence of three years' standing, as its agent upon whom process may be served within the Territory (Laws of 1903, Act 82).

19. Reports. - No anmual reports are required.

20. Anti-Trust Statute.- There is no anti-trust statute in force in the Territory except such as have been passed by Congress and are in force everywhere.

21. Statutory Grounds for Forfeiture of Charter. - The statute provides that persons acting as a corporation under the General Act shall be presumed to be legally organized until the contrary is shown, and no such franchise shall be declared to be actually null and forfeited except in a regular proceeding brought for that pnrpose (Id. sec. 779). The statute further provides that any corporation organized or attempted to be organized under the General Act shall cease to exist by non-user of its franchises for five years at any one time (Id. sec. 774). (harter may be forfeited for failure to appoint and maintain resident agent (Laws of 1903 , Act 82 ).

22. Amendments (Id. sec. 770).-C Capital stock may be increased or decreased and articles may be amended in any particular by the affirmative vote of a majority of the stocliholders. Such amendments shall be signed and acknowledged by the president and attested by the secretary of the corporation, and must be recorded and published in the same manner as the original articles.

23. Annual Franchise Tax. - There is no annual franchise tax.

24. Extension of Corporate Existence. - May extend corporate existence for an additional period of twenty-five years (Id. sec. $7 / 1$ ).

25. Dissolution. - Corporations may be dissolved by a majority vote of its nembers unless a different rule is adopted in the articles of incorporation (Id. secs. 772,775 ).

26. Foreign Corporations. - Before transacting business in the Territory foreign corporations must file a certified coly of their articles of incorporation or charter, and the appointment of an agent upon whom service may be served, with the anditor of the Territory and with the county recorder of each county in which it does business or has an office. It must also publish at least six times in some newspaper published in each of sairl counties a copy of its articles of incorporation, and upon the expiration of such publication file an affidavit thereof in the office of the Territorial anditor. The appointment of the agent must be by the board of directors. Fees for filing and recording are the same as for domestic corporations (Id. secs. 909-925).

Babbitt $v$. Field, 52 Pac. 775.

\section{ARKANSAS.}

(The references cited are to Sandels \& Hill's 1)igest, 1894, chap. 47, unless otherwise stated.)

1. Statute under which Business Corporations may incorporate. The Gemeral licorporation Act of Arkansas is to be fomm in simulels \& Ilill's Digest, chap. 47, secs. 1:32-1358, 1425-1131, and acts amendat ory thereof. Special acts exist for the incorporation of nawigation, turmpike, plank roal, railway, raft, and booning corporations, as well as those incorporited for eleemosyuary purposes.

2. Incorporators (Sandels \& Hill's Direst, 1891, sec. 1326). - Three or more. There are uo residential rerpuimututs.

3. Contents of the Articles of Association (Id. secs. 1327-1328). - Tho articles of association must contain :

a. Name. - Any lame jermitted. 
b. Incorparators. - Names and residences of the incorporators.

c. Domiciliury Ofince. - 'The location of the principal place of business and the otlice of the eompany for the trinsation of business within the State.

1. Purposes - Persons desiring to incorporate under the General Act may do so for the purpose of "engagring in, or carrying on, any kind of manuficturing. mechanical, or other lawful business," not provided for by the special incorporation aets referred to above.

'The cieneral Act was originally framed with the intention of limiting the business to be pursued by the corporation to one purpose (Id. sec. 1331), but in the anendment which took effect leb. 12, 1903, the word "purposes" is used, which undoubtedly permits corporations to be now formed for more than one line of business. There has been no amendment, however, to sec. 13:28, muless the amendment above referred to by implication also amends see. 1323, which reals as follows: "The purpose for which every such corporation shall be established shall be designated in their articles of association, and it shall not be lawful for such corporation to direct its operations or appropriate its funds for any other purpose." 'The Secretary of State permits the insertion of as many purposes as are desired, provided they are not covered by special acts.

e. Capital Stock. - The amount of capital stock must be stated. There is no limit as to what this amount may be. The anount of capital stock subscribed for by the several incorporators must be set forth, and this shonld be followed by a provision that the residue of the capital stock may be issued and disposed of as the hoard of directors may from time to time order and direct.

$f$. Number and Par Value of Shares. - The par value of the shares must be $\$ 25$ (Id. sec. 1327 ).

g. Directors. - The number of the directors must be set forth, together with the provision that they shall all be stockholders of the corporation, and to this should be added a provision that the board of directors shall elect one of its members president and another as vice-president, and shall also elect a secretary and treasurer. 'The number of directors may be any number not less than three. There are no residential requirements, but they must be stockholders, and must be chosen annually by the stockholders at such time and place as shall be provided by the by-laws of the corporation (Id. sec. 1330). The presirlent is a statutory officer' and must be a director. The secretary and treasurer are also statutory officers, but need not necessarily be directors. The last two named must reside and have their place of business within the State.

h. First Election for Directors. - This clause should provide that the first election for directors shall be held inmediately after the organization of the corporation, and that the directors shall serve for one year and until their succes. sors are elected.

i. Powers of the Boarl of Directors. - This clause may provide that the board of directors are empowered to establish all by-laws and regulations necessary to the management of the business and affairs of the corporation and to alter and repeal the same at pleasure.

j. Organization Meeting. - This clause should fix a time and place for the holding of the organization meeting, and should contain a waiver by the incorporators of the notice of such meeting.

k. Corporate Existence. - Corporate existence under the statute is perpetual. The period of existence is not required to be stated.

4. Statutory Powers. - The statutory powers found in the General In221 
corporation Act are the usual common law powers of corporations (Id. sees. $13: 36,1340)$. There is a statutory lien given the corporation upon the stock of its members for debts due it. Voting by proxy is permitted.

S. W. Co. v. Bank, 68 Ark. 234; 57 S.W. 257; Conway et al. ex parte, 4 Ark. 302.

5. Procuring the Charter. - The articles of association, drawn in accordance with the form above set forth (sec. 111), must be signed by all the incorporators. The statute does not require that the execution of the same should be acknowledged. The incorporators must meet and hold their organization meeting at the time set forth in the articles of association. At that meeting they will proceed to the election of a bourd of directors and the adoption of by-laws for the corporation. The directors must then meet and elect a president, secretary, and treasurer, and such other officers as the by-laws of the corporation shall prescribe. The corporate existence appears to begin as soon as this last step has been complied with, but the statute provides further (Id. sec. 1344) that before the corporation shall commence business the president and directors thereof shall file a proper copy of their articles of association at full length, and record a certificate setting forth the purposes for which such corporation is formed, the amount of its capital stock, the amount actually paid in, and the names of its stockholders and the number of shares by each respectively owned, with the county clerk of the county in which the corporation is to have its principal place of business, and shall file such articles and certificates bearing the endorsement of the county clerk in the office of the Secretary of State. After recording the same, the Secretary of State is authorized to issue a certificate of incorporation, which certificate or certified copy thereof is prima facie evidence of due incorporation (sec. 1344 as amended by Laws of 190:3, Act XVIII.).

6. Corporate Indebtedness. - There is no limit prescribed by statute to the creation of corporate indebtedness. To create a bonded indebtedness the consent of the larger amount in value of stock must be obtained at a meeting duly called for that purpose. Bonds cannot be issued except for money or property actually received or libor done, and all fictitious increase of indebtedness is roid (Cons., Art. XII. sec. S).

7. Organization Tax (Id. sec. 3299). - The organization tax on any capitalization is $\$ 25$.

8. Filing and Recording Fees (Id. sec. 292). - For filing articles of association and certificate of incorporation in the office of the secretary of State, \$25. For issuance of certificite of incorporation, $\$ 5$. Certified copy of articles, 15 cents per folin. The average fees, in the smaller comties to the county clerk, for filing articles of association and certificate of incorporation, \$2.20. In some of the more thickly populated connties th" county recording fee often reachrs sis for articles of average length (Laws of 1903, Act XVIII.).

9. Commencing Business (ll. sec. 1:3i1). - Corporations may commence business as soon as the presilent and board of directors have filed a true copy of the articles of association and the certificate referred to in sec. 5 above.

Garnett et al.v. Jicharlson ot al,, 35 Ark. 144; Comner 1: Abbott, 35 Ark. 365; I3lackwell $v$. State, $36 \mathrm{Ark}$. 178 .

10. Organization Meeting (W. sre. !32!). - The organization meeting must be held within thr. State. lian incorporator is presmucl to he a slockholker to at least the extent of one share. It is usual to fix the time and place 
for the holling of the organization meeting in the articles of association. In the athence of any such provision, two of the incorporators may call the first menting at such time and place as they may appoint by giving notice thereof in any one or more newspapers published in the county in which such corporation is to be established or any aljoining connty at least fifteen days hefore the time appointed for snch meeting (1d. sec. 13:9). The duty of the incorporators is to arlopt hy-laws and elect a board of directors. Immediately after the incorporators' and stockholders' mecting adjomrns, a meeting of the boardeof directors should be held for the purpose of electing a president, sectetary, and treasurer, and such other ofticers as may be required by the by-laws.

11. Meeting of Stockholders and Directors (Id. sec. 1329). - In the abience of any statute providing otherwise, all stockholders' meetings must be hell within the state. Directors' meetings, after the first meeting, may be held within or withont the State as the by-laws may provide.

Bank v. NeCarthy, 55 Ark. 473; 18 S. W. 759; Blackwell v. State, 36 Ark. 178.

12. Directors' Qualifications and Liabilities. a. Qualifications. - There must be at least three directors who shall be stockholders. There are no residential requirements (Id. sec. 1330.)

Jones et al. $v$. Jarman, 34 Ark. 323 ; Worthen $v$. Griffith, 59 Ark. $562 ; 28$ S. W. 286.

b. Liabilities. - Directors are jointly and severally liable for the declaration and payment of a dividend when the corporation is insolvent or the payment of which would rencer it insolvent, knowing such corporation to be insolvent or that the payment of such dividend would render it so, for all debts lue from such corporation at the time of the payment of such dividend. They are also jointly and severally liable for all debts of the corporation contracted during the period when they shall neglect or refuse to comply with any of the provisions of the incorporation act imposed upon them. If, by reason of the riolation of any of the provisions of the act by the directors, a corporation shall become insolrent, then all directors ordering or assenting to such violation shall he jointly and severally liable for all corporate debts contracted after such violation (Id. sees. 1347-1351).

Simon 2. Association, 54 Ark. 58; 14 S. W. 1101 ; Bank $v$. McCarthy, 55 Ark. 473; 18 S. W. 759.

13. Stockholders' Liabilities. - Stockholders are liable for the debts of the corporation only to the extent of the unpaid stock subscribed for or held by them. The corporation may, by the adoption of a proper by-law, place a lien upron the shares of its stockholders for any lebt or liability they may incur to the cotupany. The statute (Ll. sees. 1:352, 195:3) provides a method for the enforcement of this lien. If the capital stock should be withdrawn or refumled to the stockholders before the payment of all the debts of the corporation for which such stock wonld have been lialle, the stockholders are liall, to any creditor of the corporation for the amount of the sum refunder to them respectively (Id. 134S).

Jonestal. $v$.Jarman, 34 Ark. 323; Worthen $v$. Griffith, 59 Ark. 562; 28 S. W. 286.

14. Stock Certificates. - Every stockholıler is entitled to have a stock certificate i-suerl to him. Stock certificates may be signed by such officers as 2015 
the by-laws may proride. The par value of the shares must be $\$ 25$, except in the case of railroad corporations, when they may be $\$ 100$.

15. Preferred Stock. - There are no special provisions relating to the issuance of preferred stock.

16. Payment of Capital Stock. - Cuder the constitution capital stock can be issued only for money and property actually received or labor doue (Cons., 1874, Art. XII. sec. 8; Laws of 1!00:3, chap. 25.3). $5 \varepsilon 0$.

Carter $v$. Cumpany, 54 Ark. 576, 16 S. W. 579; Fleteher $v$. Bank, Ark.; 69 S. W.

17. Books. - The books must be kept within the State at the principal office of the corporation thercin or at the office of the treasurer within the State (Id. sec. 1:311). The statute gives to all stockholders the right to inspect and examine the same (ld. sec. 13:1).

15. Office. - The corporation must maintain an office within the State, and its secretary and treasurer must reside therein (Id. secs. 13:32, 1:341).

19. Reports. - At least once a year, by order of the directors, a true statemient of the accounts of the corporation shall be made to the stockbolders (Id. sec. 1341). In aldition to this the president and secretary shall annually make a certificate showing the condition of the affairs of the company on the first diny of Jimury or of July next preceding the time of the making of the said certificate in the following particulars, to wit: the capital stock paid in, the value of its real estate, its personal estate, the amount of its debts, the name and number of shires held by each stockholder. This certificate must be deposited on or before the 15th day of February or August with the county clerk of the comnty within which said corporation transacts its business, who shall reeord the sime at length in a book to be kupt by him for that purpose (Id. 13:3i). 'The charge for recording is ten cents per folio.

Neb. Nat. Bank 2 . Walsh, 68 Ark. $433 ; 59$ S. W. 952.

20. Anti-Trust Statute. - Under the Act of March 16, 1597, and March 6,1899 , all trusts or combinations intended to restrain competition in the importation or manufacture of articles of domestic growth, and all such trusts or combinations which tend to alvance, derluce, or control the prices or the cost to the consumer, are declareil to be ayainst public policy and void.

21. Statutory Ground for Forfeiture of Charter. - The only ground for forfeiture of charter prescribed by the statute in Arkinsas is for any violation of the anti-trust statute.

I)arncll $r$. State, 48 A rk. $321 ; 3 \mathrm{~S}$. W. 365 ; State $\tau$. Batnk, 5 Ark. 595 ; Blackwell v. State, 36 Ark.178; Brown $v$. li.y. Co., 68 Ark. 134; $56 \mathrm{~S}$ S. 11.862.

2.2. Amendments. - The jower of amendmont in Arkansas is broar, lut is also somewhat complieaterl. Tor reduce the capital stock either by releasing unpaid subscriptions for stowe or by returning to the sharehohlers a portion of the amount prite in ly tinem, such molution must be made ly a resolution duly ardoptes hy a majority of the stockholders, and a copy of sinch resolution must be filed as amenlunest to the charter in the oflices of the Secretary of State, and the connty clork of the comnty in which the corporat-

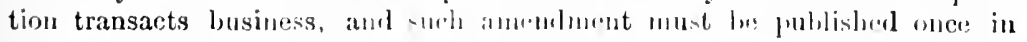
some newspaper pulli leed within the connty. 'To anthorize the corporation to engage in anditional lines of husinese, the stockholders must anthorize such change by a majority vote at a mertime duly called for that purpose. Then the president and directors shiall eamsos sucl of the amended articles as 
specify the purposes for which the corporation is formed, subscribed by the stockhollers, to be published in a newspaper printed in the county in which such corporation is located, or any adjoining county, and shall also make a certificate of the purpose for which such corporation is formed as changed by the amended articles, which certificate shall be signed and deposited and recorded in the same manner as the original certificate. To increase the capital stock such increase must be voted for by a majority of the stockholders at a meeting specially called for that purpose. After the increase is approved the president and directors shall within thirty days thereafter make a certificate thereof which must be signed, deposited, and recorded the same as the original certificate. By the Act of April 11, 1901, a corporation may change its name and number of directors by a resolution of the stockholders duly adopted by a majority thereof at a meeting called for that purpose. A copy of such resolution duly certified by the president and secretary must be filed with the clerk of the county court of the county in which the principal place of business is located, and also with the Secretary of State. To change its principal place of business within the State to a county within the State the president and secretary must procure from the county clerk of the county where it is removed a certified copy of the records, of its articles of association, etc., to which certified copy shall be attached the certificate of such president and secretary that such corporation is thus removed, which certified copy of the certificate must be filed and recorded in the office of the county clerk of the county in which such corporation shall be removed. A similar certified copy of the certificate must be filed in the office of the secretary in such State. A duplicate copy of such certificate must be published in a newspaper in the county in which such corporation shall be located. If the removal is from one county to another, there must be two publications, one in a newspaper in each county (Id. 1327, 1343).

Brown v. W. \& S. E. Ry. Co., 68 Ark. $134 ; 56$ S. W. 862.

23. Annual Franchise Tax. - There is no annual franchise tax.

24. Extension of Corporate Existence. - There is no provision for extension of corporate existence.

25. Dissolution. - Corporations may be dissolved by application to the courts having equitable jurisdiction. Any corporation may surrender its charter by resolution of a majority in value of the stockholders, at a meeting duly called for that purpose, and filing a certified copy of such resolution in the office of the Secretary of State, and in the office of the county clerk of the county where the principal place of business of such corporation is located (Id. secs. 1429-1434).

Town of Searcy $v$. Yarnell, 47 Ark. 269 ; I S. W. 319; Dozier v. A. C. Mills, 67 Ark. $11 ; 53$ S. W. 403.

26. Foreign Corporations. - To transact business within the State, foreign corporations must, through their president, file in the office of the Secretary of State and with the county clerk of the county in which the corporation has an office for the transaction of business, a copy of the articles of incorporation, and shall also file in these offices within six months after the establishment of said office, or of the beginning of said business in the State, a statement showing the proportionate amount of its capital stock which it has in use in the operation of its business, both in the State and in the county in which it is doing business. The penalty for not complying with this pro-

228 
vision is that it is cut off from all recourse to the courts and is subject to fine. Such corporation must also, under the hand of the president and seal of the corporation, file in the office of the Secretary of State a designation of an agent (who must be a citizen of the State) upon whom service of summons and other process may be made. Such certificate shall also state the principal place of business of such corporation within the State. The corporation must also pay into the treasury of the State, the same fees required of domestic corporations. The cost of filing articles and certificates and for certified copy thereof is $\$ 28.50$ (Id. sec. 1322).

Gunn $v$. Company, 57 Ark. 24; 20 S. W. 591 ; Scruggs v. Company, 54 Ark. 566; 16 S. IV. 563 ; St. L., etc. Ry. Co. $v$. Fire Ass'n, 60 Ark. 325 ; 30 S. IV. 350 ; Buffalo Zine \& Copper Co. v. Crump, 70 Ark. $525 ; 69$ S. W. 572 ; W. R. Lumber Co.r. Implement Ass'n, 55 Ark. 625 ; 18 S. W. 1055; Boyington $v$. Van Etten, 62 Ark. 63; 35 S. W. 622 ; Railway $v$. Fire Ass'n, 55 Ark. 163 ; 18 S. W. 43 ; Woodson $v$. State, 69 Ark. $521 ; 65$ S. W. 465.

\section{CALIFORNIA.}

(The references cited below are to the Civil Code, unless otherwise stated.)

1. Statute under which Business Corporations may incorporate. The Civil Code of California, Part IV. secs. 28:3-403 as amended in certain respects by subsequent Session Laws constitutes the General Incorporation Act of the State of California for insiness corporations. There are special acts applicable only to insurance, railway, street railway, wagon roal, bridge, ferry, wharf, chute, pier, tclegraph, telephone, water, canal, homestead, savings and loan, mining, gas, and eleemosynary corporations, but any kind of a business corporation may be incorporated under the General Act.

2. Incorporators. - There may he any number of incorporators not less than five, a majority of whom must reside in the State (C. C., secs. 255, 292).

People $v$. Company, 97 Cal. 276 ; 32 Pac. 236.

3. Contents of the Articles of Incorporation (C. C., sec. 290, as amended by Laws of 1901, chaps. 147 and 201). - The artieles must contain :

a. Name. - The use of a name identical with that or similar to that of an existing domestic corporation is forbidden (C. C., sec. 296).

Curtiss v. Murray et al., 26 Cal. 633.

b. Purposes. - The statıte as well as the constitution (Cons., Art. XII. sec. 9) apparently contemplates incorporation for only oue purpose or for one line of business.

c. Domicilingy offece. - 'The location of an offee within the State where its principal business is to be transacted.

1. Corporate lixistence. - The term for which it is to exist not to exceed fifty years.

e. Derectors. - Number of directors not less than five, together with the nanes and resilences of those who are appointed for the first year. The directors must be stockhohders, and a majority residents of the State.

f. Capital Stock. - The amomut of eapital stork, which may be any amount. The number of shawes must alsw be stated, the par value of which must not be less than 81 nor more than 8100 .

g. Origunal Stock Subscriptions. - The amount actually subscribed and by 


\section{INCORPORATION AND ORGANIZATION OF CORPORATIONS.}

whom. There need be no particular amount subseribed beyond the one share required for each of the incorporators.

11:uris et al. v. McGregor, 29 Cal. 125 : Ex parte, S. v. W. W., 17 Cal. 132; People r. Comprany, 45 Cal. 306 ; l'eople $e$. Perrin, 56 Cal. 345; P'eople $v$. Company, 97 Cal. $276 ; 32$ Yac. 236.

4. Statutory Powers (C. C., sees. 283, 354, 355). - In addlition to the statutory enumeration of the common law powers of corporations (C. C., sec. 3.5) there are some express limitations npon the ordinary corporate powers. (ne is the provision that no corporation shall acquire or hold any more real property thin may be reasonably necessary for the transaction of its business or the construction of its works. The bonled indebtedness of a corporation may be created or increased by a rote of the stockkolders representing at leist two-thirds of the subscribed capital stock at a meeting called by the board of directors, and after publishing notice of such meeting once a week for at least sixty days, which notice slall stite the anount of bonded indebtedness which it is proposed to create, or the amount to which it is proposed to increase the said indehtedness. The necessity of publication may be obviated by written consents from the holders of two-thirds of the outstanding capital stock (C. C., sec. 359). Domestic mining corporations possessing mining claims adjoining each other may consolidate in such manner and upon such temus as may be agreed upon, provided the written consent of all the stockholders representing two-thirds of the capital stock of each corporation is first obtined, and provided the statutory requirements relative to calling meetings, fublishing notice thereof, etc. are complied with (C. C., sec. 361). Only so much real property as is neeessary for the transaction of corporate business can be held (C. C., sec. 360; also Session Laws, 1875-76, chap. 653).

The following additional powers are conferred: To authorize voting by proxy, to permit cumulative roting in the election of directors, and to forfeit stock for non-payment of assessments (Cons., Art. XII. sec. 12; C C., secs. $307,312,331-319 ;$ Laws of 1903, chap. 215). Also to sell and dispose of all the corporate assets with the consent of two-thirds of the stockholders (Laws of 1903, chap. 271). Also to remove directors (sec. 310). To aecept devises (Laws of 1903 , chap. 228).

See Smith $v$. Morse, 2 Cal. 524 ; Smith $v$. Company, 6 Cal. 1 ; Knowles $v$. Sandercock, 107 Cal. 629 ; 40 Pac. 1047 ; 'Tel. Co. $v$. Tel. Co., 22 Cal. 398 ; Uniou Watur Co. v. Murphy Co. et al., 22 Cal. 621.

5. Procuring the Charter. - The articles must be signed and acknowledged by each of the five or more incorporators, a majority of whom must be residents of the State (C. C., sec. 29:). Next, the articles must be filed in the office of the county clerk of the county in which the principal business of the company is to be transacted, and a copy thereof, certified by the county clerk, must he filed with the Secretary of State (C. C., sec. 296). liefore the articles can be filed with the latter the organization tax (see below) unst be paid. When such tax is paid and the articles duly filed with the Secretary of State, the latter issues to the corporation, over the Great Seal of the State, a certificate that a copy of the articles containing the required statement of facts has been filed in his office, and the statute then provides that the persons signing the articles and their associates and suceessors shall thereupon be a body politic and corporate by the name stated in the certificate (C. C., sec. 296; Laws of 1901, chap. 201). The due incorporation of any company claimingr in good faith to be a corporation, doing business 2:0 
as such, and its right to exercise corporate powers shall not be inquired into collaterally in any private suit to which such de facto corporation may be a party, but such inquiry may be had at the suit of the State, except in those cases where the corporation has been doing business for ten consecutive years as a corporation (C. C., sec. 35s; Laws of 1901, cliap. 206).

Martin $v$. Deetz, 102 Cal. 55; 36 Pac. 368; Rondell $v$. Fay, 32 Cal. 354; Waterworks $v$. San Francisco, 2․ Cal. 441 .

6. Organization Tax. - If the capital stock does not exceed $825,000,815$ if not over $\$ i 5,000, \$ 25$; if not over $\$ 200,000, \$ 50$; if not over $\$ 500.000, \$ 55$ if not over $\$ 1,000,000, \$ 100$; if over $\$ 1,000,000, \$ 150$ (Laws of 1901 , chap. 70 , amending C. C., sec. 416).

7. Filing and Recording Fees. - The Secretary of State is entitled to no additional fee for filing articles of incorporation other than the payment to him of the organization tax, but for recording such articles he is entitled to charge 20 cents per folio. For issuing certificate of ineorporation, \$3. For copy of articles of incorporation on file $i_{11}$ his office, 20 cents per folio, and for affixing to certificate seal of State thereto, s. For comparing copy of articles with the original on fils in his office, 5 cents per folio. The county clerk is entitled to a fee of $\$ 1$ for filing articles of incorporation, and for copy of same 10 cents per folio, and for certificate for same, 50 celuts (Pol. Code, 416; Gen. Laws, Title 81 , Stat. 1 $\leadsto 95$, p. 268).

8. Corporate Indebtedness. - Cannot exceed amount of capital stock (C. C., sec. 359, as annended by Law's of 1911:3, chap. 253).

9. Commencing Business. - Corporations may commence business as soon as the certificate of incorporation is issued by the Secretary of State. They must commence business within one year upon penalty of baving their charter forfeited by proper action commenced by the State (C. C., sec. 358; see also Laws of 1901 , chap. 117). If the corporation lits property in other counties than that where its oritrinal articles are filcol, it must within sixty days after such property is purchased, located, or held, file with the elerk of such counties certified copies of its articles of incorporation (C'. C., sec. 299).

l'eople v. Company, 45 Cal. 306.

10. Organization Meetings. - A preliminary organization is effecterl by the stockholders' meeting within one month after incorporation within the State (by proxy, if desirerl) and proceerling to alopt by-laws. liy-linws may, however, be adopted by the written assent of two-thirds of the stockholders without a meeting (C. C., sice. :301). The by-laws must be rertifind by a anajority of the directors and the secretary, and copied in the book of by-laws (C. C., sec. 361 ).

Iall $\ell$. Cramlall, 29 Call. 568.

11. Meetings of Stockholders and Directors. - Mretings of hoth stoek-

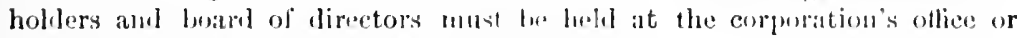
principal place of hinsiness ( $($ '. ('.. sere. :il!1).

12. Directors' Qualifications and Liabilities. a. Qunlifientims. - 'l'lere must be at least five directors who shall lwe stockholders and a majurity of

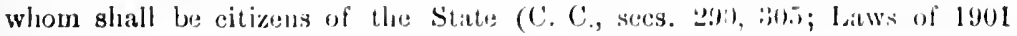
chap. 145).

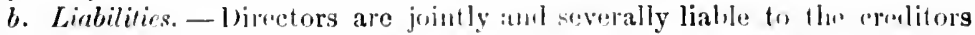

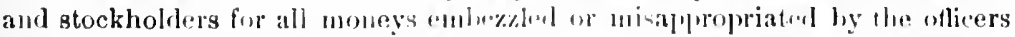
during their term of otlice (Cons., Art. Xll. sece. 3). They are also jointly 
and severally liable to the corporation and to the creditors to the full. amount of the capital stock withdrawn as dividends when there are no surplus protits (C. C., sec. 309). They are also jointly and severally liable where they create debts beyond the subseribed eapital stock (C. C., sece. 3(19). They are also liable for the withdrawal of capital stock or the increase or leerease thereof, except when made in accordance with the statute in such ease mate aml provided (C. C., sec. 309).

Fox \% Company, 108 Cal. $478 ; 41$ Pac. $328 ; \Lambda$. S. Mining Co. $v$. Company, 78 Cal. 629: 21 l'ac. 373; Martin 2 . Zellerbikd, 38 Cal. 300 ; E. W. \& Mining Co. v. P'ierce, 90 Cal. 131 ; 27 Pate. 44 ; Shattmek $v$. Com $a n y, 58$ Cal. 550 ; Irvine $v$. McKcon, 23 Cal. 472.

13. Stockholders' Liabilities. - $a$. Wach stockholder is individually liable for such proportions of the corporate debts contracted or incurred while he wis a stockholder as the amount of stock or shares owned by him bears to the whole of the subscribed capital stock (Cons., Art. XII. sec. 3; C. C, sec. 322). Stockholders are also liable for the amount of their unpaid-stock subscriptions.

Harmon $v$. Page, 62 Cal. 448; Baines $v$. Babeock, 95 Cal. 581 ; 27 Pac. 674; Vermont Marble Co. $e$. Company, 135 Cal. 579; 67 Pac. 105i; Bank v. Company, 103 Cal. 594 ; 37 I'ac. 499.

b. Stock Assessments. - Assessments are levied in the first instance by the board of directors after one-fourth of the capital stock has been subscribed. The amount of the assessment is limited except in the case hereafter referred to, so that no one assessment shall exceed ten per cent of the amount of the authorized capital stock. The exception is where the whole capital stock has not been paid up and the corporation is unable to meet its liabilities or to satisfy the claims of creditors. The assessment must be levied according to statute, and must be made payable not less than thirty nor more than sixty days from the time of making the order leaving the assessment. The day to be fixed for the sale of delinquent stock shall not be less than fifteen nor more than sixty days from the day the stock is declared deliuquent. In addition to the penalty provided for forfeiture of stock for failure to pay assessments, a corporation may recover the amount of such instalment directly against the stockholder by proper action brought for that purpose (C. C., secs. 331-319).

Visalia, etc. Co, $v$. Ilyde, 110 Cal. 632 ; 43 Pac. 10.

11. Stock Certificates. - Every stockholder is entitled to have a stock certificate issued to him signed by the president and secretary (C. C., sec. 32:3). The corporation may provide in its by-laws for issuing certificates prior to full payment, but any certificate issued prior to full payment must show on its face what amount has been paid thereon. The par value of stock certificates may be any amount (C. C., sec. 290, or amended Laws of 1901, chap. 147).

15. Preferred Stock. - There are no special provisions relating to the issuance of preferred stock.

19. Payment of Capital Stock. - Under the constitution no corporation can issue stock except for money pail, or labor done, or property actually received (Cons., Art. XII. sec. 11; C. C., sec. 359, as amended by Laws of 19103 , chap. 253).

Ewing v. Company, 56 Cal. 649; Stein v. IIoward, 65 Cal. 616; 4 Pac. 662; Martin $v$. Zellerbach, 38 Cal. 309 ; Jeffersun v. Ilewitt, 103 Cal. 624; 37 Pac. 638; Kellerman v. VIaier, 116 Cal. $416 ; 48$ Pac. 377.

$2: 32$ 
17. Books. - The book of by-laws and stock books must be kept at the principal office of the company within the State, and are subject to inspection thereof by auy stockholder. The stock and transfer books are open to inspection of creditors as well as stockholders (C. C., secs. 304, 37\%378, and Cons., Art. XII. sec. 11).

18. Office. - The corporation must maintain an office within the State (Cons., Art. XII. sec. 14).

19. Reports. - No reports are required to be made or published.

20. Anti-Trust Statute. - Corporations cannot combine or agree to any act to prevent any person from buying live-stock in the state, or having it for sale or selling it on commission (Session Laws of 1593, chap. 30).

21. Statutory Grounds for Forfeiture of Charter. - If a corporation does not organize and commence the transaction of its business or the construction of its works within one year from the date of its incorporation, or if after organization and commencement of business it loses or disposes of all of its property and for a period of two years fails to elect officers and transact in a regular way its business, its corporate powers shall cease, and the corporation may be dissolver by proper action brought by the State for that purpose (C. C., sec. 358; C. C. Pro., secs. 802-\$10; Laws of 1901, chap. 206).

People $v$. Stanford, 7 Cal. 360; 18 Pac. 85; People $v$. Dashaway Ass'n, 84 Cal. 114 ; 24 Pac. 277; San Pedro $x$. R. R. Co., 101 Cal. 333; 35 Pace. 993; I'onple $v$. Water Co., 97 Cal. 276; 32 Pac. 236; L. II. Bauk v. Spires, 120 Cal. 541 ; 58 Pac. 1049.

22. Amendments. - The power of amendinent in California is broad and is also somewhat complicated. The name of the corporation can be changed only by application to the Superior Court. The corporation must file in the office of the Secretary of State a certified coly of the decree of the court ehanging the nane (Code of Civ. Pro., stcs. 1276-1277). In other respects articles may be amended, except for the purpose of extending its corporate existence beyond the time fixed in the original articles, or diminishing its capital stock, by a majority vote of its board of directors and by the rote or written assent of the stockhohders representing at least twothirds of the subscribed capital stock of such corporation. A copy of the amended articles duly certified to be correct by the president and secretury or the board of directors shall be filed in each oflice where the original articles of incorporation are or copy thereof is required to be filed. If the assent of two-thirils of the stockholders to such amendment has not been obtained, a notics of the intention to make the amendment shall first be advertised for thirty diys in sone uewspaper, published in the county in which the principal place of business of the corporation is locaten, before the filing of the proposed amendment. To increase or diminish its capital strek where such meeting is called by the board of directors, notice thereof must be given by publication as provided in the statute. 'Pluis motice must le published at leat once a week for sixty litys (C. C.. sec. 342 ). The capital stock cannot be diminishnd to an amomt less thu thr imlehtedness of the corporation. The publication may he done away with hy the aloption of a resolution by the unanimons vote of the board of directors incrusing the capital stock at a regralar called meeting for the purpose when surb resolution is approved by the writtion assest of the stockloblers holding two-thirds of the subseribel or issued capital stock. The place of business may be changerl if desired by amemen mt (C. ('., sec. sisl a). If articles are filed in the wrong county in the first instanee, the cude provides a means of remedying 
this. (See C. C., see's. 359, 3633 see also Laws of 1903, chaps. 216, 219, 253, 2Si.)

Applianion of La socinté, ete., 123 Cal. 525; 56 I'ac. 458.

2:3. Annual Franchise Tax. - There is no annual franchise tax.

21. Extension of Corporate Existence. - Only corporations formed for a priol of less than fifty years have the power, prior to the expiration of the term of its eorporate existence, to extend such term to a period not exceeding fifty year's from its formation (C. C., see. 401).

25. Dissolution. - The dissolution of a corporation is effected by decree of the superior court of the comnty where the principal place of business is situated upon voluntary application signed by a majority of the board of directors (Cole Civ. I'ro., sees. 1227-1231).

26. Foreign Corporations (Laws of 1901, chap. 93). - Foreign corporations doing business or maintaining an oflice in this State must file with the Secretary of state a certifiel eopy of its charter, or articles, or statute, or legislative or governmental at creating them, and also file a certified eopy with the county clerk where the principal place of business is located, and also where the corporation owns property. 'The same fee shall be paid for filing and issuing a certitied copy as is paid by domestic corporations. A resident agent must also be appointed within forty days after commeneement of business within the state (C. C., secs. 405-107). By statute the same liability imposed upon stockhollers in domestic corporations is imposed upon foreign conprations doing business within the State (C. C., sec. 322). The constitutionality of this provision has been affirmed by both the State and the Lniterl States Suprene Courts. (See also Laws of 1903, chap. 215.)

Thomas $v$. Company, 65 Cal. 600; 4 Pac. 641 ; Pinney v. Nelson, 183 U. S. 144; 22 sup. Ct. 52.

\section{COLORADO.}

(The references cited below are to Mills Revised Statutes, 1891, unless otherwise stated.)

1. Character of the Law under which Business Corporations may incorporate. - The Business Corporation Act of Colorado is found in the lievised Statutes of Colorado, secs. 472 et seq. There have also been recent amendments passed thereto. Sprecial acts are provided for the incorporation of railways, banks, and trust companies. The law itself is fairly satisfactory, but lacks completeness in some rexpects.

2. Incorporators. - Three or more. There are no residential requireinents (li. S., sec. 473).

3. Contents of the Certificate of Incorporation. - The certificate must set forth :

a. Nrme. - The name must commence with the word "the" and end with the word "corporation," "complany," "association," or "society," and must indicate the business to be carried on. Similarity of names is forbidilen (li. S., secs. $47 \cdot 2,475$ ).

b. Purposes. - The statute clearly contemplates that corporations may be organized for any number of purposes not covered by the special acts.

c. Capital Stock. - The amount of the capital stock. This nay be any aurount.

d. Duration. - Must not exceed twenty years.

e. Number and Par Value of Shares. - The par value of shares must not be less than 81 nor more than $\$ 100$.

2.it 
f. Directors. - The number of directors must not be less than three nor more than thirteen. In the case of mining companies and banks the number must not exceed nine (sec. 55.5).

g. Names of First Board of Directors. - This board under the statute has control of the affairs of the company for the first year of its existence.

h. Nomiciliary Office. - The name of the town and conuty in which the principal office of the company shall be kept.

i. Place for the Transaction of Business. - Name of the county or counties in which the principal place of business shall be carried on. When the corporation is to carry on part of its business without the State, the certificate must state that fact, and also state the name of the town and county in Colorado in which the principal office shall be kept, and also state the names of the counties in which the principal business of the corporation is to be carried on within the State.

j. By-Laws. - To directors may be delegated the right to make by-laws if so desired.

$k$. Directors' Meetings. - If it is desired to hold directors' neetings without the State, this right shonld be reserved in the certificate(R. S., sec. 473).

Schroers $x$. Fisk, 10 Col 599 ; 16 Pac. 25.5; Juggan $v$. Company, 11 Col. 113 ; 17 Pac. 105; Humphreys $v$. Mooney, 5 Col. 293; People $v$. Cheesenia, 7 Col. 376; 3 Pac. 716 ; 1). \& S. Ry. Co. $v$. D. C. Ry. Co., 2 Col. 673; G. R. B. Co. $v$. Rollius, 13 Col. 4; 21 Pac. 897; Jones e. Compauy, 21 Col. 263 ; 40 P'ac. 457.

4. Statutory Powers. - 'The main statutory powers are what are known as the conmon law powers belonging to all business corporations (R. S., sec. 476). Corporations have, however, the following extranrlinary powers in Colorado: To consolidate with another corporation when, by a vote of at least three-fourths of the stock of each company severally had, the proposition shall be approved. The method of consolidation is pointed out in detail in the statute (R. S., sec. (j25). The statute contains one express limitation upon the powers of corporations, which may be enumerated as follows: They are forbidden to use any of the corporate funds for the purehase of their own stock except such as may be forfuted for the non-payment of assessments thereon (R. S., sec. 195). Manufacturing and mining companies cannot encumber their plant or mines or machinery without the vote of a majority of the stocklolders (R. S., sec. 4bl). The power to consolidate is expressly given (R. S., sec. $6 ; 2)$. Cumulative voting for diretors is permitted; also voting by proxy (Luws of 1895, Pl' 150-152, see. 1; Laws of 1891 , p. 93, sec. 4 ; see also Laws of 130:3, p. 158).

Jones v. Ilardware Cu., 21 Col. 263; 40 Pac. 457 ; Spangler r Buttritichl, 6 Col.

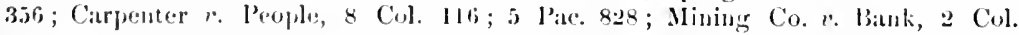

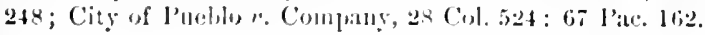

5. Procuring the Charter. - Th: certificate must he signol and acknowledged ly uach of the incorprators. In practice it is woll forsecute a sutlicient number of original certitioates so ats fo prermit the liling of one original in every comty where the huniness of the enrporation is to be earred on as well as in the oflices of the secretary of State. As som as fhe corlitiote has been filed in the ollice of the reorder of deeds in wach of th. comuties in which the princigal place of buniturs shall be carrien on as well as in the

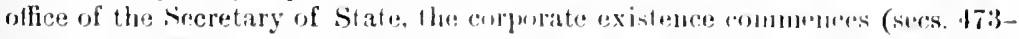
475). The ficeretary of state i-sues a croliticate of authority to transact business as a corpration within the state. The l'resiclent and a majority 
of the directors, after the last installment of stoek is paid in, must make a certificate stating the amount of the capital so fixed and paid in, which certificate shall be signed and sworn to by the President and a majority of the dimetors and must be recorded in the same office where the certificate of incorporation is recorded (R. S., secs. 487, 491).

Anstin $e$ Berlin, 13 Col. 198; 22 l'ac. 433; Cook $v$. Merritt, 15 Col. 212 ; 25 Pae. 176 ; Matthews $v$. Yatterson, 16 Col. $215 ; 26$ Pate. 812; F. M. \& Co. $v$. MacLeod, 8 Col. $\Lambda_{\mathrm{p}}$. $1900 ; 45$ l'ac. 282.

6. Corporate Indebtedness. - There is no statutory limitation upon the amount of indebtedness which a corporation may incur.

7. Organization Fee. - There must be paid to the Secretary of State s: 0 for filing the certificate of incorporation of companies with a capitalization of not more thin $\$ 50,000$, and for every thousand dollars in excess of $\$ 50,(104)$, an organization tax of 20 cents per thousand is exacted (Laws of 1901, chap. 52, sec. 1).

Jones $r$. Company, 21 Col. $263 ; 40$ Pae. 457.

8. Filing and Recording Fees. - There are no fees due the Secretary of State for filing articles of incorporation other than payment of the organization tax. For certified copy of articles of incorporation, 15 cents per folio of one hundred words, and $\$ 1$ for seal. For issuing certificate of authority showing that all fees prescribed by law have been paid, $\$ 5$; for filing and recording impression of the corporate seal, $\$ 2.50$; for filing certificate of payment of stock, $\$ 2.50$ and upwirds, according to capitalization. With respect to fees of county recorder, wherein articles of incorporation are required to be filed, the counties are graded for fee purposes. The filing fee there ranges from 10 cents to 25 cents. If the articles are recorded, the fee ranges from 50 cents to $\$ 2$ (Lalws of 1901, pp. 116-121, secs. 1-10).

9. Commencing Business. - Corporations may begin business as soon as their certificates have been filed, State fees paid, and certificate of payment issued (Laws of 1901, chap. 52, sec. 1).

10. Organization Meeting. - The incorporators should sign a written agreement fixing the time and place within the State for the organization of the corporation. The incorporators may be represented by proxy if desired. If the certificate of incorporation does not bestow upon directors the right to make lyy-laws, the incorporators should adopt by-laws themselves. Immediately after the arljournment of the incorporators' organization meeting, the board of directors named in the articles of incorporation should meet and elect the oflicers of the corporation. The statutory officers are a president, who must be ehosen from anong the directors, and such subordinate officers as the company may by its by-laws designate.

Humphreys v. Mooney, 5 Col. 283.

11. Meetings of Stockholders and Directors. - Neetings of the stockholiers inust be held at the office of the company within the State. Inirectors' neetings may be held without the State only by making provision therefor in the certificate of incorporation (R. S., secs. 481, 19:3).

IHumphreys v. Mooncy, 5 Col. 283; Jones v. Pearl M. Co., 20 Col. 417; 38 Pac. r00; Cuok $c$. Hager, 3 Col. 386 ; Utlay v. Company, 4 Col. 371.

12. Directors' Qualifications and Liabilities. a. Qualifications. There must be not less than three nor more than thirteen directors, all of $2: 36$ 
whoin must be stockholders. In case of mining companies and banks not more than nine are permitted. There are no residential requirements (R. S., sec. 481; see also R. S., sec. 585; Laws of 1895, pp. 150-152, sec. 1).

b. Liabilities. - Directors are jointly and sererally liable for the declaration and payment of dividends which render it insolrent or which decrease the amount of its capital stock. The extent of the liability is for all debts of the corporation then existing and for all that shall thereafter be contracted while the capital remains so diminished (R. S., secs. 491, 492, 494). They are also liable for failure to file annual reports (Laws of 1901, chap. 52, sec. 11), or to make certificates as to final payment of stock.

Nix $v$. Miller, 26 Col. 203; 57 Pac. 1084; Austin $v$. Berlin, 13 Col. 195; 22 Pac. 433; Matthews $v$. Patterson, 16 Col. 215 ; 26 Pac. 812 ; Larsen $v$. James, 1 Col. App. 313; 29 Pac. 183; Gregory v. Bank, 3 Cul. 322 ; Col. Fuel Co. v. Lenhart, 6 Col. App. 511; 41 Pac. 834; Cook $v$. Merritt, 15 Col. 212 ; 25 Pac. 176.

13. Stockholders' Liabilities. - Stockholders are liable for corporate debts to the extent of their unpail subseriptions to the corporate stock (R. S. sec. 486).

14. Stock Certificates - Every stockholder is entitled to hare a stock certificate issued to him signed by such officers as the by-laws shall prescribe. The par value of stock certificates must not be less than $\$ 1$ nor more than $\$ 100$ (R. S., sec. 450 ).

15. Preferred Stock. - The issuance of preferred stock is not expressly authorized by statute.

16. Payment of Capital Stock. - The corporation may purchase mines, manufactories, and other property necessary for the corporate business, and issne stock to the amount of the value thereof in payment therefor. Stock so issued shall be declarel full-pail stock and not liable to any further assessments. Neither shall the stockholders be liable to any further payments therefor. The constitutional provision (Cons., Art. XV. sec. 9) is that no corporation shall issue stock or bonds except for labor done, service performed, or money or property actually received (R. S., sec. 61 s).

17. Books. - The directors are required to keep at the principal office or place of business within the State correct books of accomit. These books shall be open to the inspection of stockholders at any time. In addition to the foregoing a stock register must be kept containing the names and residences of the stockholders, the number of shares held by them, the time when they became or ceasel to be stockholders, and the amonnt of stock actually paid in and what proportion has been paid in cash. 'This book is open to the inspection of stockholders and creditors during business hours (R. S., secs. 488, 508; Laws of 1903, chap. 77 ).

18. Office. - The colponation must maintain an oflice within the State (R. S., sec. 473 ).

19. Reports - Anumally wilhiu sixty days from January 1st, reports must be filed with the Secretily of State, covering the names and residences of officers and directors, the anount of capital stock fixed, and the proportion paid in; a statement of the mamer of the payment of capital stock, a statement that the company is or is not enguged actively in business within tho State, am other information necessary to show the finaneial condition of the company. Also the amount of inlebtedness of the company at the diale of the filing of the report. (Mining, diteh, and power companies must include other statements.) In case of failure to file such report the oflicers and direc- 
tors become liable for corporate indehtedness contracted during the preceding year, or while such default continues (Laws of 1901, chap. 52, sec. 11). A report of firticulars of financial condition must also be made to the State Board of Assescors, and tiled before Junc lst, under penalty of $\$ 100$ per day for defillt (liaws of 1902, pp. 71-73, sec. (i:3).

2i). Anti-Trust Statute. - There is no anti-trust statute.

21. Statutory Grounds for Forfeiture of Charter. - Failure to pay license tax subjects the corporation to forfeiting of charter at the instance of the State (Laws of 1001, chap. 94, sec. $70 \mathrm{C}$ ).

2.-. Amendments. - By two-thirds rote of ontstanding stock at a stockholders ineeting duly convened for that purpose, the articles may be amonded in any particular, exeept that the objects or purposes for which the corporation is organized mily not be altered and the rights of creditors must not be prejuliced in diminishing the capital stock (R. S., secs. 477-479 as amended by Laws of 1891, p. 92. 93, secs. 1-6).

23. Anmual Franchise Tax - Where the capitalization is less than 8.25.000, there is no annual franchise tax exacted. In case the capitalization is 825.000 or more, the amual franclise tax is two cents per thousand for each thousand dollars (Laws of 1902, p. 73, secs. 64, 66). After January 1, 1905 , this tax is payable to the Secretary of State (Laws of 1903, p. 155).

24. Extension of Corporate Existence. - In case a majority of the stockholders of the corporation cast their vote at a meeting duly called for that purpose in favor of rencwing the corporate existence of the corporation, the presiclent and secretary thereof shall under the seal of the corporation certify that fact, and shall make as many certificates as may be necessary so as to file one in the ollice of the rccorder of deeds in each county wherein the corporation may do business, and one in the office of the Secretary of State, and thereupon the corporate life of such corporation shall be renewed for any term not exceeding twenty years. There must be paid to the Secretary of state the same fee as is now required by law for filing certificates for a new corporation (Laws of 1599, chap. 89 ; Laws of 1903, chap. 76, sec. 2).

Pratt $v$. Company, 1 Col. Dec. Supp. 171.

25. Dissolution. - If all debts are paid, a company may be dissolved by the rote of two-thirds of the ontstanding stock at a mecting of the stockholders called for that purpose. A certificate of such dissolution must be filed and likcwise published (Stat., secs. 497, 619, 620; Laws of 1891, p. 95, secs. 1,2 ; Laws of 1903 , chap. 76 , sec. 1$)$.

Standley v. Company, 27 Col. 331 ; 61 l'ac. 600.

26. Foreign Corporations. - A foreign corporation desiring to do any business, institute or defend actions or hold property within the State is required to file with the Secretary of State a copy of its charter, or of its certificate of incorporation, duly certified and authenticated by the proper authority from the State from which the charter issues. It must also file a certificate, signed and acknowledged by the president and secretary, with the Secretary of State and in the ollice of the recorder of deeds of the county or counties in which it proposes to carry on its business within the State, designating the principal place wherein the business of said corporation is to be carried on in the state, and appointing an agent at this principal place of business upon whom process nay be served. The license tax for foreign corporations is one-half more than for filing original certificates of domestic corpo235 
rations. The annual license tax for foreign corporations is 4 eents on each thousand dollars of its capital stock, but if the par value of its shares is less than 81 per share the tax is $2 \frac{1}{2}$ cents per thousand shares (Stat., secs. 499, 500 , 501; Laws of 1893 , p. 88, amending sec. 499 ; Laws of 1902, p. 73, secs. 65 , 66; Laws of 1903, chap. 76, secs. 3-5). Must also file annual reports.

Miller $v$. Williams, 27 Col. 34; 59 Pac. 740; Kephart $r$. People, 28 Col. 73 ; 62 Pac. 946; Iron Silver Nin. Co. $x$. Cowie, 31 Col. $450 ;$ i2 Pac. 1067.

\section{CONNECTICUT.}

(The references cited below are to the Session Laws of 1903, chap. 194, unless otherwise stated.)

1. Character of the Law under which Business Corporations may incorporate. - The corporation laws of Connecticut including the Corporation Act of 1901 (General Statutes 1901, chap. 157) liave been entirely revised. The provisions of the General Statutes of 1902 have been repealed, and the revised law - Laws of $190: 3$, chap. 194 - has been substituted therefor. Special acts are provided for the incorporation of banking, trust, building and loan, insurance, surety, railway, street railway, telephone, telegrapl, gras, electric light, and water companies. Corporations may, however, he incorporated for the purpose of transacting any of the said lines of business just enumerated in any other State or foreign country if not prohibited by the laws of such State or foreign country (sec. $(i 2)$ ).

2. Incorporators. - Three or more. There are no residential requirements (sec. 602).

3. Contents of the Certificate of Incorporation. - The certificate must set forth :

a. Name, which must be such as to listinguish it fiom any other corporation chartered by or organizerl under the laws of the State, and from any corporation engaged in the same business or promoting or carrying ont the same purposes within the State. The name nust begin with "the" and end with the word "corporation," "company," or "incorporated" (sees. $2,63)$.

b. Domiciliury Offece. - The name of the town in the State in which the corporation is to be located (sec. (j3).

c. Nature of the Business to be transicted or the Purposes to be promoted or carried out. - The statute clearly contemplates that corporations may be organizer for any number of purposes not covered by the special at.ts (rece (i:3).

d. Copital stock. - The amonut of the total anthorized eapital stock, which shall not be less than $82,(00)$; also the number of shares into which the same is divided, which shall not he less than s...). If there he more thatn me elass of stock, a description of the grencral clisses with the terms upon which they are respectively created (sec. $1 ; 3)$.

e. Commencing liusiness. - Amount of eipitil stock with which the corpo-

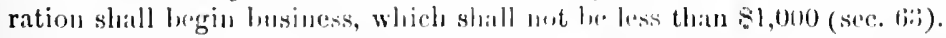

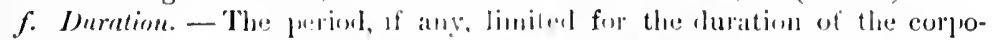

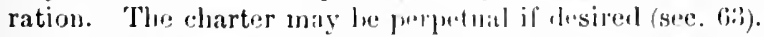

g. Regulation of Juternal Afinirs. - There may also be inerted any law ful provisions which the ineorporitors maty elonese to insert for the regulation of the business of the corperation, or fur defining on limiting the powers of the corporation, its officers, directors, or any clisss of sturkloblers (sec. iil). 
4. Statutory Powers. - In adlition to the statutory enumeration of the powers of corporitions (Laws of 19113, chap. 194, sec. 3) corporations have the following extrardinary powers: To carry on their business in any State or 'Territory of the Cnited States or in any foreign country. To share protits with employees. To acquire its own stock. To voluntarily dissolve itself. To mortgage real and personal estate, including its franchises, and issue promissory notes, honds, or other evidences of indebtedness. To issue one or more classes of stock. 'To consolidate with another corporation engaged in the same or similar line of business. To enforce a lien upon corporate stock for all dehts inclurling assessments. To appoint an executive committee from the board of directors. To vote by proxy and to purcliace and hold the stock of other corporations (secs. $3,4,9,11,21,25,27,59,75$ ).

5. Procuring the Charter. - The certificate must be signed by each of the incorporators, but it need not be acknowledged. It must then be approved by the Secretary of State. The law provides that the corporate existence shall begin upon the approval of such certificate by the Secretary of State. It also provides that after such approval and until the directors are elected, the incorporators shall have charge of the affairs of the corporation, and may take such steps as are necessary to obtain subscriptions to its stock (secs. $60,60)$.

S. G. \& P. Co. v. Scholfield, 70 Conn. 500; 40 Atl. 182.

6. Corporate Indebtedness. - There is no limitation upon amount of corporate indebtedness.

7. Organization Tax. - Fifty cents on every thousand dollars of its capital stock up to $\$ 5,000,000$. Beyond that amount 10 cents upon every thousand dollars of excess. The minimum fee however is $\$ 25$ (sec. 61).

S. Filing and Recording Fee. - The Secretary of State is entitled to receive in aldition to the organization tax $\$ 1$ for recording certificate of incorporation and $\$ 1$ for recording certificate of organization. For ccrtified copy of certificate of incorporation, 50 cents per legal page of two hundred and eighty worls. For recording in local county oflice, $\$ 1$.

9. Commencing Business. - Corporations cannot commence business until the amount of capital specified in the certificate of incorporation as the amount with which it will begin business has been paid in, nor until its directors ancl officers have been duly elected and its by-laws duly alopted, and until a majority of the directors have filed with the Secretary of State a certificate of organization setting forth (1) The amount of each class of stock subscribed for. (2) The amount paid thereon in cash. (3) The amount paid thereon in property other than cash. (1) The amount paid on each share of stock which has not been paid for in full. (5) The name and residence of each of the original subscribers with the number and class of shares subscribed for by each. (6) 'The directors and officers of the corporation have been duly elected and by-laws adopted. (7) The name and residence and postoflice address of each of the officers and directors. A certified copy of said certificate, duly certified by the Secretary of State, must be filed in the office of the clerk of the town where the sail corporation is to be located before the corporation can commence business (sec. 69).

10. Organization Meeting. - A majority of the incorporators may call the organization meeting at such time and place as may be designated by a notice published twice at least seven days before the time designated in a zewspaper in the State having circulation in the town in which the corpora. 240 
tion is located, and such notice may be waived by a writing signed by all the subscribers to the stock, and a majority of the incorporators specify the time and place for such meeting. When the meeting is held, the subscribers for the stock, who may be present in person or be represented by proxy, must choose a temporary clerk, and proceed to the election by ballot of three or more directors, who are subscribers to the capital stock, and shall adopt bylaws for the regulation of the affairs of the corporation. Inmediately upon the adjonrnment of the organization meeting of the incorporitors, the directors should meet and organize by choosing from among their number a president and shall appoint a treasurer and secretary, and such other officers as the by-laws shall prescribe. The same person may fill the offices of president and treasurer or of secretary and treasurer (secs. $67-71$ inclusive).

11. Meetings of Stockholders and Directors - Meetings of stockholders must be held at the office of the company within the state. Directors' meetings may be held without the State by making provision therefor in the by-laws or by the consent of all the directors (secs. 3,22 ).

McCall $v$. Company, 6 Conn. 428.

12. Directors' Qualifications and Liabilities. a. Qualifications.-There must be at least three directors, who must be stockhollers. There are no residential requirements. They may be divided into classes if desired (sec. 10). The board of directors may appoint an executive committee if they see fit (sec. 10). May adopt by-laws subject to those adopted by the stocklioliers.

b. Liabilities. - Every director voting for a dividend or other distribution of assets, except from the net profits or actual surplus of the corporation, is liable to a fule of not more than $\$ 500$. If such payment or distribution leaves the company insolvent, the directors so voting shall be jointly and severally liable to the amomut so paid or distributed to any creditors existing at the date of such roting which shall have obtained judgment against such corporation and on which execution shall have heen returned unsatisfiel. Where the directors concur in a fraudulent overvaluation of property taken in exchange for stock of the corporation, they are jointly and severally liable to the corporation for the amount of the difference between the actual value of any property so accepted in payment at the time of such indebteduess, and the amount for which it is receiverl in payment (sec. 5).

Davenport $v$. Lines, 72 Comn. $118 ; 44 \Lambda t 1.17$.

13. Stockholders' Liabilities. - Stocklinhlers, whether original subscriliers or not, are lialle for any halance dne on the stock luell by them. After the par value of their strick has leen paid they are not liablie for any further assessments. They are liable for causing insolvency by illegally reducing stuck (secs. 6, 16).

14. Stock Certificates. - Every strolkholder is entisferl to haw a stock certificate issued to hin muder the seal of the corporition sinned by the presi-

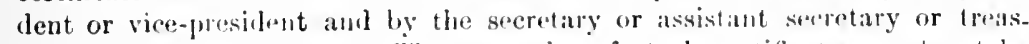
urer or assistant treasurer. The par malue of stock ecrtificates must not be less thin 8.25 (rees. 15, 17, 6:3).

1i. Preferred Stock. - Special authority to issue jueforred stock is given by statute if provision is malle therefor in the certificate of incorpmation. The terms upon which such preferred stock is isured must be stated in the

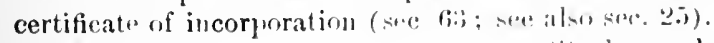

19. Payment of Capital Stock. - Stock may be jritil for either in cash 
or in property. If mot paid for in eash, a majority of the clirectors shall make ancl sinn upon the eorporate records a statement showing the property received in payment for stock and that it has an aetual value equal to the amount for which it was so recered. The judgment of the directors as to the value of the proprerty upon this subjeet is made final. But the directors concurring in the justerment of such valuation, in the case of frand in the overvaluation of such property, are jointly and severally liable to the corporation for the difference between the actual value of such property so aecepted in payment and the anount for which it is received in pilyment (sec. 12).

17. Books. - The stock book or duplicate thereof, containing the names and addreses of the stockholders and the mmmber of shares held by them, shall at all times luring the usmal hours of business be open to the examination of every stockholder at its principal ofliee and place of 'usiness in the State. If a creditor milies an atlidavit that he is a cleditor of the corporation, the person in charge of the stock books is obliged to furnish him information as to the number of shares held by such stockholder in any corporation (secs. 18, 39).

Heminway $x$. Ileminway, 58 Conn. 443 ; 19 Atl. 766.

18. Office. - The corporation must maintain an office within the State (sec. 63).

19. Reports. - The president and trensurer must annually, on or before the 15th dity of February or August, make, sign, swear to, and file in the oflice of the Secretary of state a certificate setting forth as of the first day of January or duly immediately preceding : the name, residence, and post-office address of all of the officers and directors; amount of ontstanding capital stock which has not been paid for in full, with the amount due thereon: location of the principal office within the State, with the street number if there be any, and the name of the person in charge thereof upon whom process against the corporation may be served. I certified copy of said certificate must be re. corded in the oflice of the town clerk of the town in which said corporation is located (sec. 37).

20. Anti-Trust Statute. - There is no anti-trust affidavit in force in Connecticut.

21. Statutory Grounds for Forfeiture of Charter. - The grounds for proceedings in the nature of quo warranto against corporations are to be found in the Statutes of Conn. 1\$87, secs. 1296-1:302 inclusive.

Pearce $v$. Olney, 20 Conn. 544 ; Hart $v$. Company, 40 Coun. 524.

22. Amendments. - Articles may be amended before commencing business in any respect desired. 'The corporation may change its name, nature of limsiness, principal office, increase or reluce its eapital stock, or make any changes required by the approval of two-thirds of the stock issued and outstauding of each class. A certificate setting forth the amendment and its adoption must be filed in the same nanner as the certificate of incorporation (recs. 73, 7i).

N. H. \& 1). Ry. Co. $v$. Chapman, 38 Conn. 56.

23. Annual Franchise Tax. - There is no anmual franchise tax.

21. Extension of Corporate Existence. - There is no provision for extension of corporate existence.

25. Dissolution. - The franchise may be surrendered at any time before any part of subscriptions are paid and business begun. Thereafter voluntary disolution may be accomplisher by preliminary vote of the directors followed by the affirmative vote of three-fourths in interest of each cliss of stock issued 213 
and outstanding. Minority stockholders owning one-tentl of the capital stock may petition the court for dissolution (secs. $26-36$ inclusive, 72 ).

26. Foreign Corporations. - Before a foreign corporation can transact business in the State it must file in the ottice of the Secretary of State a certified copy of its charter or certificate of incorporation, togrether with a statement signed and sworn to by the president, treasurer, and a majority of its directors, showing the amount of its authorized capital stock, the amount paid thereon, if any, and if any part of snch paynent has been made otherwise than in cash, said statement shall state the particulars thereof; and must also appoint in writing the Secretary of State to be its attorney upon whom process may be served. Foreign corporations are required to file annual reports similar to those required of domestic corporations. 'The fee for filing certified copy of the charter is $\$ 10$, and a further fee of $\$ 5$ is charged for filing the statement required by law (secs. 80 to 88 inclusive).

Farmers' Loan \& Trust Co. $v$. Smith, 74 Conn. $625 ; 51$ Atl. 609.

\section{DELAWARE.}

(The references cited below are to the Laws of 1903, chap. 394, unless otherwise stated.)

1. Character of the Law under which Business Corporations may be incorporated. - The Business Corporition Aet of l)elaware is to be found in the lievision Act of 1899 , and anemlments thereto found in the Session Laws of 1901 and 1903. Under it parties may incorporate for any lawful lusiness exerpt banking. Special provisions are to be found for incorporating railway companies for the purpose of operating railways within the State.

$\therefore$ Incorporators. - 'lhere must be at least three incorporators. There are $n$ residential requirements (sec. 1 ).

3. Contents of the Certificate of Incorporation (sec. 5). - The certificate of incorporation numst set forth:

a. Name. - The name of the corporation must contain one of the words "association," "company," " corporation," "club," "incorporated," "society," "union," or "syudicate." No name can be employed which does not serve to distinguish it from that of any other corpuration engaged in the same business or promoting or carrying on the same objects or purposes within the State.

b. Domicilingy Offire. - The name of the city, connty, or place witluin the connty in which the principal office or place of business is to be located within the ritate.

c. Purposes. - The nature of the husinrss olyects, or purposes proposed to be transacted, promoted, w earied on. 'The statute clealy contemplales that corporations may be organized for more than me pupose not exerent by the special acts. Janking is the only purpos forbilden fo corperations oranized under the Genwal s.t.

1. Conpilul Stork. - The amonut of capital whirle shall not he liss than \$2,0m, the number of shares inte which the sane is dividenl, and the par value of each share, which may lor any anomint, the amomut of capilal stock with which it will commence husiness, which cannot he less than 81,000 . If the corporation is to hise mone than one class of stock, a deseription of each class must be given, with the terms on which the respective classes of stock are created. 
e. Incorporators. - The name and place of residence of each of the original subseribers to the capital stoek, who are in practice the incorporators of the company.

f. Duration. - The corporation miy have perpetual existence. If not, the time when the existence is to commence and the time when its existence is to cease must be stated.

g. Exemption of Stockholders from Liability for Corporate Debts. - The cerlificate must state whether the private property of the eorporation shall be subject to the payment of corporate debts, and if so to what extent.

$h$. Requlation of the Internal Afjairs of the Corporation. - The certificate mily continu any provision desired for the regulation of the business and the conduct of the affairs of the corporation, the directors and stockholders, or any classes of stockliohlers permitted by hw (sec. 5).

4. Statutory Powers. - In addition to the eommon law powers which are entmerated in the statute, Delaware corporations have the following additional powers: 'To guaranty, purchase, hold, assign, transfer, mortgage, pledge, or otherwise dispose of stoek and bonels of other corporations, and to exercise in the ease of stock the right to vote thereon. Corporations also have power to acquire and hold their own shares, but not to vote thereon. To conduct business in any State, Territory, or colony of the United States or in any foreign country. To issue stock for property or services, and to forfeit stock for non-payment of assessments; to have one or more offices out of the State, and to hold, purchase, mortgage, convey real and personal property out of the State, provided such powers are included within the objects set forth in the certificate of incorporation. 'To elassify director's. 'The corporation also has express power to create preferred stock, if desired, provided this power is set forth in the articles of incorporation. The eonsolidation of corporations carrving on any kind of business is expressly permitted. Also to authorize roting by proxy, to forfeit stock for non-payment of assessments (secs. 2, 9, $13,14,17,19,22,29,59,135)$.

State $e x$ rel. White $v$. Hancock, 2 Pen. 252; 45 Atl. 851.

5. Procuring the Charter. - The certificate of incorporation must be signed and acknowledged by each of the incorporators. The original certificate of incorporation is then recorded in the office of the Secretary of State and a certified copy thereof recorded in the office of the recorder of deeds in the county in which the prineipal office as stated in the certificate of incorporation is located. When these acts have been eompleted, and the organization tax paid to the Secretary of State, the corporate existence begins (secs. 5, 6, 7, 11). Collateral inquiry into legality of corporate existence is forbidden (sec. 68).

6. Corporate Indebtedness. - There is no limit upon the amount of indebtelness which a eorporation may iucur.

7. Organization Tax. - The organization tax is 15 cents for each thousand dollars of the total authorized capital stock. Said tax, however, never to be less than $\$ 20$ (sec. 129 ).

8. Filing and Recording Fees. - To the Secretary of State for filing and indexing certificate of incorporation, $\$ 2$; for certified copy of the certificate of incorproration to be filed in the oflice of the recorder of reeds, about $\$ 1.50$. Fee to the recorder of deeds for recording certified copy of the certificate of incorporation averages about $\$ 4.50$.

9. Commencing Business. - At least $\$ 1,000$ of the capital stock must be subscribed for before the corporation can begin business. If the corporate $2+1$ 
business is not begun in good faith within two sears from the date of the incorporation, the franchise is subject to forfeiture (secs. 5,67 ).

P. W. \& B. R. R. Co. v. Kent Co. R. R. Co., 5 Houst. 127.

10. Organization Meeting. - This may be held either within or without the State (sec. 30). The incorporators ordinarily sign a written agreement fixing the time and place within the State for the organization of the corporation. The incorporators may be represented by proxy if desired. Until the directors are elected the signers of the certificate of incorporation have by statute control of the affairs and of the organization of the corporation, and may take such steps as are proper to obtain the necessary subscriptions to stock. As soon as the meeting is organized by the election of a chairman and secretary, by-laws should be adopted. If the certificate of incorporation so provides, the directors to le elected at the organization meeting of the corporation may adopt by-laws. The incorporators should then proceed to the election of not less than three directors. The directors must own at least three shares of stock and one must be a resident of the State. The by-laws may provide for the election of officers either by the stockholders or the directors. If by the stockholders, the election of the statutory officers should be had before the adjomrmment of the organization meeting. Immediately after the adjournment of the incorporators' meeting the directors named in the articles of incorporation should meet and elect the officers of the corporation. The statutory officers are a president, secretary, and treasurer. The president must be chosen from among the directors. The secretary and treasurer may or may not be the sanic person, and if the corporation have a rice-president, he may, if deemed advisable by the directors, hold the office of vice-presilent and secretary or vice-president and treasurer, but not the office of viee-presiltent, secretary, and treasurer. The directors may, if auth orized by the by-laws or liy a resolution passed by a majority of the whole board, designate two or more of their number to constitute an executive committee, who shall have and exereise all the powers of the board of directors in the manarrement of the business affairs of the company (secs. 7, 8, 9, 11).

11. Meetings of Stockholders and Directors. - The stockholders and directors may holl their meetings outside of the State if the by-laws so provide. It will be fonnd more convenient to hold the organization meeting within the State (secs. 30, :32).

12. Directors' Qualifications and Liabilities. a. Qualifications. - 'There must be a board of directors of not less than three directors, one of whom must be a resident of the State. 'The lirectors must hold at least three shares of stock. They may be divided into classes if desired. Power nay he given the directors to adopt by-laws for the corporation, by inserting such a provision in the certificate of incorporation (secs. 9, 12).

b. Liabilities. - Directors who knuwingly canse to he published, or give out or consent thereto in writing, a statement or report of the corporate business or condition that is fals: in any material respect, are jointly and severally liable for any loss or lamage resulting therefrom. Ihrectors aro also liable for declaring dividends unt earned, for refusing to make certificates of full payment of the capital stork, and for not prolucing list of stuckholders at election (secs. 28, $8,5,37$ ).

13. Stockholders' Liabilities. — Stockbolders are only liable for their unpaid stock subseriptions (s"cs. :20, 29).

14. Stock Certificate. - Livery stockholder is entitled to hare a stock 
eertificate issucd to him signed by the president and treasurer. The par value of stock certificates may be any anrount (sec. 15).

15. Preferred Stock. - Corporations have the power to create two or more kinuls of stock with such preferences and voting powers and with such restrictions or qualifications thereof as shall be stated or expressed in the certificate of incorporation. The preferred stock, however, must not exceed twothirds of the actual eapital pail in in cash or property. The preferred stock may, if desired, be male subject to redemption at not less than par at a fixed time and place to be fixed in the certificate of incorporation. Preferred stockholders shall be entitled to receive a fixed yearly dividend to be expressed in the certiticate, not exceeding eight per cent payablo quarterly, half yearly or yearly. Such dividends may be mado eumulative. Preferred stock cannot be created unless provided for in the original certificate or amended certificate of incorporation. Corporations are authorized to issue bonds and to confer upon the holders thereof the power to vote in respect to the corporate affirs and manarement of the company, to the same extent and in the same manner as stockholders, if so provided in the certificate of incorporation (sec. 13).

16. Payment of Capital Stock. - The Delaware Constitution provides (Cons., Art. IX. sec. 3), that no corporation shall issue stock except for money pail, labor done, or personal property or real estate or leases thereof actmally received by the corporation, and no labor or property shall be received in payment of stock at a greater price than the actual value at the time the said labor was done or property delivered or title acquired. The statute attempts to change the constitutional provision by providing that in the absence of frand in the transaction the judgment of the directors as to the value of such labor or property, real estate or leases, shall be conclusive (sec. 14).

17. Books. - The original or duplicate stock ledger containing the names and addresses of the stockhollers and the number of shares held by them respectively must be kept at the principal office within the State. These are open to the inspection of stockholders. The general books of account need not be k'jut within the State (sec. 29 ).

18. Office. - The corporation must maintain a principal office or place of business in the State, and have an agent, a resident of the State, in charge thereof. A sign containing the name of the corporation must be displayed at a conspicnous place in said office (sees. :32, 33, 137).

19. Reports. - Business corporations must file with the Secretary of State on or before January 1st a report stating the date of election, principal office within the State, names of officers, amount of authorized capital stock and amount actually paid in, amonnt invested in manufacturing and mining within the State. 'This report may be made by the president, treasurer, or other corporate officer ('Tax Law, secs. 2, ;).

20. Anti-Trust Statute. - There is none in force within the State.

21. Statutory Grounds for Forfeiture of Charter. - The statutory grounils for forfeiture of charter are failure, for two years after the corporation is created, to commence in good faith the business to be promoted or the objects or purposes for which it was organized. Also failnre for two successive years to pay the State tax assessed against it which it is required to lay under the law, renders the charter void (sec. 67 ; Tax Law, secs. 10, 11).

22. Amendments. - The certificate of incorporation may be amended before parment of any part of the capital by merely filing with the Secretary 246 
of State an amended certificate of the filing and recording in the same manner as the original certificate. Such amended certificate may modify, change, or alter the original certificate if desired. Thereafter amendment may be had by a resolution duly adopted by the board of directors in the first instance, setting forth the amendment proposed, declaring its advisability, and calling a meeting of the stockholders. The amcudment is adopted by a majority rote of all the stockholders given at such meeting. The charter may be amended in the following respects: Changing the corporate powers and purposes, increasing or decreasing the authorized capital stock, chingring the number and par value of the shares, and changing the corporate name (secs. $22,25,26$ ).

23. Annual Franchise Tax. - The aunnal franchise tax on the amount of authorized capital stock actually paid in up to and including $\$ 3,000,000$, is one-twentieth of one per cent. When the latter exceeds $\$ 3,000,000$ and does not exceed $\$ 5,000,000$, one-fortieth of one per cent and a further sum of $\$ 30$ per anuum is exacted for every million dollars or part thereof in excess of $\$ 5,000,000$. Manufacturing or mining corporations having at least fifty per cent of their capital stock issued and outstanding invested in manufacturing and mining within the State are exempt from the tax (Tax Law, sec. 1). The tax is due and payable on Mareh 1st.

24. Extension of Corporate Existence. - Corporate existence may be extended by complying with the terms of the statute in such case made and provided (secs. 131-131).

25. Dissolution - Before payment of any part of the capital stock or beginuing business the incorporators may surrender their franchises by filing in the office of the Secretary of State a certificate verified by it majority of the incorporators to the effect that no part of the capital has been pair and that such husiness has not been begun. A majority rote of the directors cast in favor of the dissolution of the corporation, conpled with the written consent of two-thirds in interest of the stockholders, affords the necessary basis for a dissolution of the corporation by consent. In addition to this, notice of the stockholders' meeting called for the purpose of roting upon the question of dissolution must be published for four successive weeks. The consent of the directors and officers must be certified by the president, seeretary, and treasurer and filed with the Secretary of State, who issues his certificate that such consent has been filed, which certificate must be publishor for fonr eonsecutive weeks. If all the stockholders consent in writing, no mceting or notice is required (secs. 38-5s).

Corn. Bank $v$. Lockwoul's Adm'r, 2 II:urr. 8.

2f. Foreign Corporations. - Before loing business within the State foreign corporations are requiren to file with the Serpetary of state a certified copy of their certificite of ineorporation, the name of the authorized agent within the Sitate, a sworn statement of assets and liabilities, and must pay to the sireretary of Stale a lirense fre of $\$ .00$. The emporation must also file with the elerte of the superior conrts in rach of the eounties of Delaware a certificats giving the nane and resilence of the andut anthorized to accept service of pocess npon the corporation (Laws of 19003, chap. 395, secs. 1-10).

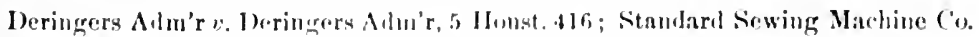

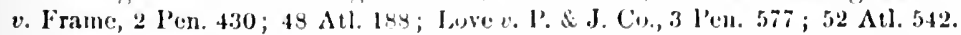




\section{DISTRICT OF COLUMBIA.}

(The references are to the District of Columbia Code (1902), unless otherwise stated.)

1. Statutes under which Business Corporations may incorporate. The Business Corporation Aet in force in the District of Columbia is to be found in the United States Statutes at Large, Vol. 31, pp. 12-8t ei seq., as amented by the $A$ cts of Jinuary 31,1902 (U. S. Stat. at L., Vol. 32, p. 2), and Aet of June 30, 1902 (U. S. Stat. at L., Vol. 31, p. 529 et seq.). Under this act companies may be formed for the purpose of carrying on any business or enterprise which may be lawfully conducted by an individual, excepting banks, corporations formed to buy, sell, or deal in real property, railways, and such other enterprises or business as is provided for by special acts.

2. Incorporators. - There must be at least three incorporators. There are no residential requirements (sec. 60.5).

3. Contents of the Certificate of Incorporation (sec. 606). The cortificate must set forth:

a. Name. - The act does not forhid the use of a name already in use.

b. I'urposes. - Object for which it is formed. The recorder of deeds only permits the insertion of one line of business in the certificate of incorporation. (See sec. 612.)

c. Duration. - May be perpetual if desired.

d. Capital Stock: - Amount thereof and the number of shares. Both may be any amount desired.

e. Trustees. - Number of trustees with the names of those who shall manage the corporation for the first year.

f. Domiciliary Office. - Location of the office in the district in which the operations of the company are to be carried on.

4. Statutory Powers. - In addition to a statutory enumeration of common law powers the act authorized roting by proxy; also forfeiture of stock for non-payment of assessments. The statute expressly forbids the purchase of stock in other corporations (secs. 607, 609,613).

Scaulon $v$. Snow, 2 D. C. Ap. Cases, 137.

5. Procuring the Charter. - The charter must be subscribed and acknowledged by each of the incorporators, and then filed in the office of the recorder of deeds for the district (secs. 60.5, 607).

6. Corporate Indebtedness. - By implication the debts should not at any time exceerl the amount of capital stock (sec. 634).

7. Organization Tax. - There is no organization tax, the only expense being a nominal fee for recording the certificate of incorporation.

8 . Filing and Recording Fees. - To the recorder of deeds, 50 cents for the first two hundred words in articles of incorporation. 15 cents for each hundren words in addition thereto, extra charge of 25 cents for each separate acknowledinent over one. For each certificate and seal, 25 cents.

9 . Commencing Business. - Business may be commenced as soon as the articles are executed and filed as required by law. Before business can be transacter ten per cent of the capital stock must be paid in either in money or property at its actual value (sec. 61:3). Within thirty days after the prayment of the last instalment of the capital stock the president and a majority of the trustees must make, verify, and record in the office of the 
recorder of deeds a certificate stating the amount of capital fixed by the certificate and paid in (sec. 616).

10. Organization Meeting. - The organization meeting must be held within the district (this in the absence of any statute expressly authorizing such meeting to be held without the district).

11. Meetings of Stockholders and Trustees. - Stockbolders' meetings must be held within the district. Owing to the provision that a majority of the trustees must be residents of the district, it is in practice almost a necessity to hold trustees' meetings in the district, where a majority of the body is required to be present. In practice, however, throngh the expedient of the appointment of an executive committee, composed of a majority of the board of tristees to whom is delegated all the powers of the full board in the transaction of the business outside of the District of Columbia, meetings of the trustees who are members of an executive committee can be held outside of the distriet. Notice of the holding of annual meetings for the election of trustees nust be published in the district not less than thirty days previous thereto (secs. 605, 609).

12. Trustees' Qualifications and Liabilities. a. Qualifications. - There must be not less than three, nor more than fifteen trustees, who shall be stockholders, and a majority citizens of the district (sec. 60S).

b. Liabilities. - 'Trustees are jointly and severally liable for making false cerlificates or reports, knowing the same to be false, which liability extends to all debts of the company contracted while acting as such trustees (secs. $61 \mathrm{~S}, 619,631)$. They are also liable for loans of money upon the security of the company's own stock. They are also liable for illegal declaration of dividends (secs. 6201-62:3).

13. Stockholders' Liabilities. - All stockholders are severally liable to the creditors of the corporation for the unpial amount due on the shares of stock held hy them respectively, for all debts and contraets made by the corporation until the whole amount of the capital stock of said company shall have been paid in, and a certificate thereof shall have been made and recorled. This certificate, signed and sworn to by a majority of the trustees and the president, must within thirty days after the payment of the last instalment of the capital stock be recorded in the office of the register of deeds of the district (secs. 615, 616).

14. Stock Certificates. - Each stockholler is entitled to a certificate showing the number of shares owned by him, signed by such oflicers as the by-laws måy prescribe.

15. Preferred Stock. - There is no express provision authorizing the issuance of preferred stock.

16. Payment of Capital Stock. - Stock may be paid for in moncy or property at its actual cash value (sec. 613).

17. Books. - A stock rerister must be kept within the district. This should be open to the inspection of stockholders and creditors (secs. 627 , $625,6: 31,6: 32)$.

18. Office. - Every corporation must maintain an office at all times within the district (sec. $600(5)$.

19. Reports. - Wvery corperation shall annually within twenty days from the lst of January make a report, which must be published in a newspaper published in the district, stating the amome of capital and the proportion aetually paid and the anount of existing debts, which report shall 
Le simed ly the president and a majority of the trustees and verified by the oath of the presilent or secretary of the company and filel in the office of the recorder of deeds of the district. The only penalty for failure to make this report is that any creditor of the corporation may, hy petition for mandinns against the corporation, compel such publication to be made, ami in such case the court shall require the corporation to pay all expenses of the proceding including counsel fees. If any false report is made, all officers who have signed the same knowing it to be false are individually liable for all debts of the company contracted while they are stockholders or ollieers thereof (stes. 617,618 ).

211. Anti-Trust Statute. - There is no anti-trust statute specially applicalle to the District of Columbia.

21. Statutory Grounds for Forfeiture of Charter. - The act does not provide for forfeiture of charters.

See Gilluert $r$ Endowment $\Delta s s^{\prime} n, 10$ D. C. $A_{j}$ ). 316.

2.2. Amendments. - Articles may be amended for the purpose of increasing or decreasing its eapital stock and for the purpose of extending its business (secs. 633-639!).

23. Extension of Corporate Existence. - There is no provision for the extension of corporate existence except by reincorporating under the general statute.

24. Dissolution. - Corporations may be dissolved on application to the court having jurisdiction, for cause shown (secs. 768-797).

Norrow $r$. Edwards, 9 Mackey, 475.

25. Annual Franchise Tax. - There is no annual franchise tax.

26. Foreign Corporations. - Foreign corporations may obtain a permit to do business in the district if they desire to do so. They are, further, required to publish in at least two daily newspapers published in the district semi-annually during the months of March and September of each year, a full statement under oath, showing their capital stock and the amount paid in, the assets and liabilities, debts, deposits, dividends, dues as well as other current expenses during six months ending .January and July 1st preceding under penalty of revocation of license or permit to do business in the district.

Eastern Trust \& Banking Co. v. Willis, 6 D. C. Ap. 375.

\section{FLORIDA.}

(The references cited below are to the Revised Statutes, 1892, unless otherwise stated.)

1. Statute under which Business Corporations may incorporate. The Business Corporation Act of Florida is found in the Revised Statutes, 18\%2, secs. 2122-2158 inclusive and acts amendatory thereof. Special provisions are marle for banking, building, and loan, insurance, surety, railway, canal, and telegraph companies.

2. Incorporators (Laws of 1901, chap. 4895). - Three or more persons. There are no residential requirements (Laws of 1901 , chap. 4895).

Brown $v$. Company, 19 Fla. 472.

3. Contents of the Charter. - The charter must set forth:

a. Nume. - Similarity of names is forbidden.

b. Dimiciliary Office. - The place or places of business must be set forth. 2.50 
c. Purposes. -- The general nature of the business or businesses to be transacted. The statute clearly contemplates that corporations may be created for more than one purpose, provided none of the purposes set forth are covered by special acts.

d. Capital Stock. - The amount of the capital stock authorized, the number and par value of the shares into which it is divided, and the terms anc conditions upon which it is to be paid in must be set forth. The par ralue of the shares must not be less than ten dollars. The capitalization may be any amount. If it is desired to pay in the capital stock in anything but money, this fact must be staterl in the charter. This statement should include a provision either that the whole capital stock or some portion thereof shall be payable in property, labor, or serrices at a just valuation to be fixed by the incorporators or by the directors at a meeting called for that purpose (Laws of 1901, chap. 4896 ).

e. Corporate Existence. - The charter may be perpetual if desired.

f. Corporate Officers. -- The charter must designate the officers by whom the business is to be conducted, the times at which they are elected. and the names of the officers who are to conduct the business until those elected at the first election shall have qualified. The directors must all be stockholders. The statutory officers are a president and treasurer or cashier and such other officers as the by-laws may desinnate.

g. Corporate Indebtedness. - The highest amount of indebtedness to which the corporation can at any time subject itself must be set forth.

$h$. Incorporators. - The names and residences of the incorporators must be stated. The subscribing incorporators must also state the amount of stock subscribed for by each. Such amount shall be not less than ten per cent of the authorized capital stock (sec. 2123) as amended by Laws of 1901, chap. $4895)$.

4. Statutory Powers. - Florida statutes enumerate fully the common law powers of corporations. The only additional powers conferred by statute are the right to vote by proxy and to forfeit stock for non-payment of assessments. The power to adopt by-laws may be delegated in the charter to the directors if desired (secs. 2121, 21:29, 2137, 2146).

5. Procuring the Charter. - The charter must be subscriber and acknowledged by each of the incorporators. Then the proposed charter together with notice of the intention to apply to the governor for letters patent thereon, must be pullished for fonr weeks, once each week, in some newspaper published in the county where the principal place of business is to be located. This notice nust be signed with the names of at least thee of the incorporators and the proposed chater must be filed in the Secretaly of state's office during the four weeks of pullication. Then the proposel chater, accompanicd by proof of publication of nolice, must be submitted to the governor, who, if he finds it to be in proper form, and for objects antlorized by law, and that the formalities just roferred to have been olsedvel, will issue letters patent to the corporation. The Secretary of State will then ammex to the letters patent a certified copy of the charter, retaining the original on file and recoriing it. The organization tax must be paifl to the Scerctary of State, who issues a certified copy of the charter. Corporate existence commences from the time the certifuel copy of the charter is issued hy the sieretary of State. The statute specifically provides that letters patent, or a ertificd copy thereof, shall be conclusive evillence as to the existence of the corporation in all 
actions am procedings where the question of its existence is only collaterally involved, and prima facie evidence in all other actions and proceedings (secs. $21: 21-2126,215: 1)$.

6. Corporate Indebtedness. - There is no statutory limitation npon the amount of corporate indebteduess.

7. Organization Tax. - Two dollars upon each thousand dollars of the capital stock, provided no fee shall be less thin $\$ 5$ or more than $\$ 250$ (sec. 212.7 as amended by Laws of 1901, chap. 489.5).

8. Filing and Recording Fees. - To the Secretary of State, in addition to the payment of organization tax, there must be paid a filing fee of $\$ 1$. 'The average charge for certified copy of letters patent and charter is $\$ 3.50$. For pullication, nsually about $\$ 10$. For recording certificate of ineorporation together with athilasit of the treasurer as to amount of capital stock paid in, in the office of the clerk of the circuit court in the county where the corporation does business, the fees usually amount to about $\$ 3.50$.

9. Commencing Business. - Before commencing business letters patent together with a certified copy of the charter nust le recorded in the office of the elerk of the circuit conrt of the county where the principal place of business is located. There must also be filed with the Secretary of State and with said clerk of the circuit court duplicate affidavits by the treasurer of the corporation that ten per cent of the capital stock has been subscribed and paid. The organization tax must likewise be paid (sec. 2127).

10. Organization Meeting. - Must be held within the State (sec. 2141).

11. Meetings of Stockholders and Directors. - Stockholders must hold their meetings within the State. The directors may hold their meetings withont the state if the by-laws so provide (secs. 2137, 2141).

Duke $v$. 'Taylor, 37 Fla. 64 ; 19 So. 172.

12. Directors' Qualifications and Liabilities. a. Qualifications. - The number of directors is not limited by law. They must all be stockholders. There are no residential requirentents (secs. 2121, 2138).

b. Linbilities. - Directors participating in the direction of illegal dividends are jointly and severally liable for the debts of the corporation then existing to the extent of the dividend declared, unless they at the time object to the declaration of the dividend in writing (sec. 2163).

13. Stockholders' Liabilities. - Stockholders are liable to the extent of their unpaid stock subscriptions (sec. 2152 ; see also sec. 2127).

Gibbs 2 . Davis, 27 Fla. 531,8 So. 633.

14. Stock Certificates. - Every stockholder is entitled to have a stock certificate issued to him signed by such officers as the by-laws may designate for that purpose. The par value of stock certificates may be any amount not less than $\$ 10$ (Laws of 1901, chap. 4896).

15. Preferred Stock. - There is no statutory provision expressly authorizing the issuance of preferred stock.

16. Payment of Capital Stock. - Unless otherwise provided in the charter, stock subscriptions must be paid in cash. Incorporator's may however provide in the charter that the capital stock, either in whole or in part, shall be payable in property, labor, or services at a valuation to be fixed in the charter. The charter must also set forth the general description of the property to be taken in exchange for stock (sec. 2128 as amended by Laws of 1901, chap. 4896).

252 
17. Books. - The secretary or other officer who by the by-laws is made the custodian of its books, is required to keep the same in his possession at all times during business hours, and have the same ready to be inspected by any officer, director, or committee appointed by the stockholders representing onetenth of all the subscribed stock. The treasurer or cashier is required to keep a stock book containing a list of the stocklolders with the number of shares owned by each, which is subject to inspection by any stockholder upon written application (secs. 21:33, 2147).

18. Office. - Every corporation must have a place of business within the State, and the custodian of its books and papers must reside within the State (sec. 2133; see also sec. 2123 as amended by Laws of 1901, chap. 4\$95).

19. Reports. - The corporaion shall annually make a report to the State comptroller containing the name and residence of each stockholder, with the number of shares and the par and cash market value of such shares, the whole amount of capital stock, the amount actually paid in, the real estite subject to assessment of taxes, and the personal estate. A statement of the amount of capital stock subscribed and the amount actually paid in and of the indebtedness of the corporation shall be filed once every six months in the office of the State comptroller (secs. 2136, 2134).

20. Anti-Trust statute. - Trusts to control meats, cattle, or edible animals are prohibited (Laws of 1897 , chap. 4531).

21. Statutory Grounds for Forfeiture of Charter. - Diversion by a corporation of its funds or property to objects other than those named in the charter or to payment of divilends, leaving insufficient funds to meet outstanding liabilities, work a forfeiture of the charter (sec. 2162).

2.2. Amendments. - To change the name of a corporation a resolution to that effect must be passed by a majority rote of the stocliholders at a meeting called for that purpose, and a certificate setting forth such resolution under the corporate seal (attested ly the secretary) must be filed in the office of the Secretary of State. Therenpon letters patent shall issue, reciting the change in name, which must be recorded in the Secretary of State's office and in the office of the elerk of the circuit eourt where the original charter is recorded.

With respect to increasing or reducing the capital stock, the statute reads that any corporation desiriug to alter or amend its charter shall do so in a certain prescribed manner as set forth in the statute. 'To increase the capital stock, notice of the meeting of stockholders called for that purpose must be published once a week for four consecutive weeks prior thereto in one newspaper published in the county. In addition to this the usual notice for stockholders' meetings provinled for in the by-laws must be served upon or inailerl to the stockholders. If at such meeting two-thirds of all the stockholders rote to increase the capital stock, the presirlent within thity days thereafter must make a return to the Secretary of State uniler oath of the anount of such increase and the trrms on which said eapitul sterek is issued, and from the time the said return is filed fluc incruase of stuck slatl lw. anthorized, and when issued shall become a part of the rapilal. At the sime time the capitalization tax must he paid upw the ammunt of incroased ealpital stock. To reduce the capital stock of alter or change the par value of the shares thareof requirng the unanimens rote of all the stockholilers cast at a meeting called in the same inanner as is above referred to in the case of the increase of the eapital strek. In oreler to legalize the reduction of the capintal stock, the president must make within thirty days thereafter under onth his 
return to the Secrelary of State of the amount of such decrease, and upon his athiarit must be endorsed a certificate of the state comptroller that in his judgurent the ability of the corporation to meet its outstanding liabilities and debts will not be impared thereby.

To ancent the eharter in other respects a meeting must be called in the manner set furth alove with reference to increasing or reducing the capitalization. At this meeting the proposed amendment must receive a vote of three-fourths of the ontstanding eapital stock. If the proposed anendment is anlopted, the corproration must then give four weeks' notice, once each week, of intention to aplly to the governor therefor, in sone newspaper published in the county wherein the principal place of business is loeated, setting forth the desired alteration or amendment. The corporation nust then prepare a certificate which shall be filed in the Secretary of State's oflice during the time of publication, and afterwards, together with the proof of publication of notice. 'These are all submitted to the governor, who, if the same are fonnd in proper form and lengally adopted, if the proposed amendment will be beneficial and lawful and of interest to the community and in accord with the purposes of the charter, will approve the same, and thereupon letters patent shall issue reeiting the amemlment, and the same shall then be recorded in the office of the secretary of State and in the oflice of the clerk of the circuit court where the original charter was recorded (secs. 2148, 2149, 2150, 2151).

23. Annual License Tax. - There is no annual license tax.

24. Extension of Corporate Existence. - The statute makes no specific provision for extension of corporate existence. (See, however, sec. 2150.)

25. Dissolution. - A majority in interest of the stockholders may petition the circuit court for the dissolution of the corporation, and the court after publication for a reasonable period may hear the matter and may decreo a dissolution (R. S., sec. 2157).

Gibbs $x$. 1)avis, 27 Fla. 531 ; 8 So. 633.

26. Foreign Corporations. - There are no statutory provisions prescribing the conditions upon which foreign corporations may do business in this State.

Duke $v$. Taylor, 37 Fla. 64; 19 So. 172.

\section{GEORGIA.}

(The ref rences cited below are to the Code of Georgia, 1895, unless otherwise stated.)

1. Statute under which Business Corporations may incorporate. The Inu-iness Corporation Act of Georgia is to be found in the provisions of secs. 18:31-1591, 2350, of the Civil Code of 1895. Under it a private corporation may lie formed for any purpose except banking, insurance, railway, canal navigation, express and telegraph companies, by apllication to the superior court of the eounty in which the corporation desires to transact business.

2. Incorporators. - There must be at least two incorporators. There are no residential requirements (sec. 2350 ; see also sec. 1854 ).

3. Contents of Petition for Charter. - The petition addressed to the Superior Court must state:

r. Purposes. - The objects of the corporation and the particular business propresed to be carried on. It is doubtful whether under this section a corporation may be incorporated to carry on more than one line of business.

251 
b. Name. - Similarity of names is not permitted.

c. Capital Stock. - The amount of capital stock to be enployed and actually paid in. Capital stock may be any amount.

d. Domiciliary Office - The prinejpal place of business must be set forth.

e. Duration. - Corporate existence is limited to twenty years (sec. 2350).

4. Statutory Powers. - In addition to a statutory enmmeration of common law powers, the following additional powers are conferred: To receive donations by gift or will; to create a lien upon the stock for debts due from stockholders (secs. 1552, 28.5). The rights of majority and minority stockholders are eummerated in the statute (sees. 1559, 18f0). Corporations are forbidden to buy stock in other corporations. Corporators have an interest in the franchises of the corporation of which they cannot be deprived except by due process of the law. Nandamus will lie against the corporation to enforce such right if there is no other legal remerly (C'ons., Art. IV. sec. 2, p. 4).

Trust Co. $v$. State, 109 Ga. $736 ; 35$ S. E. 323.

5. Procuring the Charter - The petition must be published once a week for four consecutive weeks in the nearest newspaper to the point where the corporate business is to be carried on. When the court grants a petition by order to that effect, the petition and the order must be recorded by the clerk of the superior court in the record of "Superior Court eharters." The proceedings must also be reeorded in the minutes of the court as part of the proceedings thereof. 'The order itself is to the effect that the petitioners and their sncessors are incorporated for a term of not exceeding twenty years, with the privilege of renewal at the expiration of that time $i$ the mamer provided by statuts. Before business can be commeneed ten per cent of the authorized eapital stock must be paid jn. Corporate husiness must be conlmeneed within two years after the issuance of the charter (sec. 2:350).

Existence of a corporation eannot be collaterally attacked. All who have dealt with the corporation as such are estopped from denying its corporate existence.

6. Corporate Indebtedness. - 'There is no statutory limitation npon the amount of corporate indebtedness. If the corporation lesires to issue bonds, it must furnish to the Secretary of State a eertified statement in relation thereto (Laws of 1900, chap. 139).

7. Organization Tax. - There is no organization tax imposed as such in Georgit. Unler the statute the clerk of the court has power to eollect the usual fees allowed for similar services in other calses. These fees vary from $\$ 10$ to $\$ 20$.

8. Filing and Recording Fees. - The average eost for filing petition for charter in the otliee of the consty elerls and for docketing and spreading the order granting petition on the minutes. 510.50 . The cost of ecrtified cong of the charter is se.5); cost of mulishing articles of ineorpration depends npon whether the publication is male in a connty or city new-paper, and ranges from s.i to sivo.

9. Commencing Business. - Corporations before commuring husiness

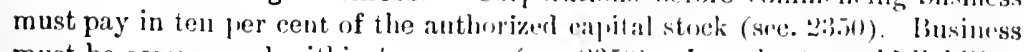

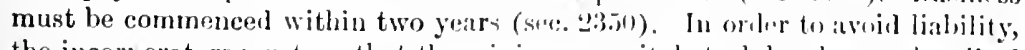
the incorporaters must see that the minimum eiphal stock has bern subseribed for before commenring business.

McCandless v. Company, 115 Ga. 96, ; 42 S. I. 419. 
10. Organization Meeting. - In the absence of any statute expressly anthrizing the holding of meetings elsew here, organization meetings must be held within the state.

11. Meetings of Stockholders and Directors. - Stockholder's' meetings must be held within the state. 1)irectors' meetings may be held without the state if the by-liws so provide.

12. Directors' Qualifications and Liabilities. a. Qualificalions. -- The stitute makes no special provision with relation to directors other than to provide that they shall represent the corporation and its stockholders. 'Their number, qualifications, term of oflice, and powers are left largely for determination to the by-laws adopted by the incorporators (secs. 1858, 1 s(i1).

b. Liabililies. - Directors are liable for the declaration of any dividend or the distribution of money anong the stockholders as profits when such divilend or money is not the legitimate proceets of such investments. (See Code, sec. 691 ; Laws of 1902, chap. 131, p. 58).

13. Stockholders' Liabilities. - Stockholders are liable for the debts of the company only to the extent of their unpaid stock subscriptions. Stockholders who are incorporators and who organize the company and transact business under that name before the minimum anount of capital stock has been subscribed for, are liable to creditors to make good the minimum stock witl interest (secs. 1859, 1890, 2350). Whenever a stockholder purchases stock upon which there is a liability for unpaid subscriptions it shall be exempt from further liability unless the corporation fails within six months from the date of the transfer (sec. 1888).

Fouche $v$. Bank of Rome, 110 Ga. 827 ; 36 S. E. 256 ; Wilkinson. $v$. Bertock, 111 Ga. 187 ; 36 S. E. 623 ; Harrell $v$. Blount, 112 Ga. 711 ; 38 S. E. 56.

14. Stock Certificates. - Every stockholder is entitled to have a stock certificate issued to him signed by such officer's as the by-laws may designate for that purpose. The par value of stock certifieates may be any amount.

15. Preferred Stock. - There is no statutory provision expressly authorizing the issuance of preferred stock.

16. Payment of Capital Stock. - The statute does not authorize in express terms the issuance of capital stock for anything except cash.

See Ilayden $v$. Atlanta Cotton Factory, 61 Ga. 233.

17. Books. - The corporation is required to keep a stock register which is open to the inspection of cretitors (Penal Corle, secs. 591, 1891).

18. Office. - Every corporation must maintain an office within the State.

19. Reports. - No annuil reports are required.

20. Anti-Trust Statute. - By statute all combinations made with a view to lessen free competition in the importation or sale of articles or in the manufacture or sale of articles of domestic growth are illegal and void (Laws of $1891 \%$, chap. 122).

21. Amendments. - The statute does not give the right of amendment save in one or two particulars to ordinary business corporations. If the charter so provides, provision may be inade for increasing or decreasing the stock (Fecs. $1840,23.50$, sub. 6 ).

22. Annual License Tax. - There is no annual license tax.

2:?. Extension of Corporate Existence. - Corporate existence may be extended by complyin's with the statutes in that regard (sec. $2: 350$, sub. 7). 256 
24. Dissolution. - Corporations may be roluntarily dissolved by a surrender of its franchises to the State. This is ordinarily done by applieation to the court. 'The court has statutory power to appoint a reeeiver, and to administer the assets (secs. 1852, 1854, 1856). The death of all the members of the eorporation or so many of them as to leave it impossible under the charter to proride suecession is a dissolution thereof. (See also secs. 1883-1857.)

25. Foreign Corporations. - Foreign corporations of States which give like recognition to corporations incorporated in Georgia are recognized upon principles of comity. There are a few minor statutory requirements relatire to doing business within the State. (See secs. 1816-1850.)

V. B. R. R. Co. v. E. T. \& G. R. R. Co., 14 Ga. 327 ; A. C. Society $v$. Gartell, 23 Ga. $4+8$.

\section{IDAHO.}

(The references cited below are to the Revised Statutes of Idaho, 1887, unless otherwise stated.)

1. Statute under which Business Corporations may be incorporated. - The Business Corporation Act of Idaho is found in the lievised Statutes of that State, sees. $\mathbf{2 5 7 5}$ to 2653 , as amended by the Act of March 11 . 1901. Special acts are provided for bridge, ferry, flume, boom, gas, fidelity, domestic insurance, railway, telegraph, telephone, water and eanal companies.

2. Incorporators. - The incorporators may be any number of persons not less than five, one of whom must be a resident freeholder of the State (sec. 2576 as amended by Laws of 1899 , p. 104).

3. Contents of the Articles of Incorporation. - The articles must set forth :

a. Name. - Similarity of names is not forbidden.

b. Purposes. - The statute uses the singular noun "purpose." In practice, however, the Seeretary of State allows articles to be filed providing for any number of purposes not covered by special acts.

c. Domiciliary Office. - The place where the principal business is to be transacted must be set fortl. fifty.

d. Corpurate Existence. - May be any number of years not exceeding

e. Boarl of Directors. - The number of the directors and the names and resilences of those who are appointed for the first year. The number must be not less than five, nor more than eleven. The directors must all be stockholders and a majority resirlents of the state.

f. Capitnl Stock. - The anomit of the capital tock and the number of shares into which it is dividrod. The capital stock as well as the par value of the shares may be any amount.

g. Stock Subscriptions. - If there is eapital stock, the amount actually subscribed and by whom should he set furth (sec. 2579 ).

4. Statutory Powers. - In adlition to a statutory enumeration of common law powers the following alditional powers are granted: 'To removo directors; to authorize woting by proxy; to forfeit stoek for non-payment of assessments; to extend corjorite existence (sees. 2633, 2567, 2519, 261.42626 inclusive, 26.35$)$.

5. Procuring the Charter - Th" articles must he subscribed aud acknowledged by each of the incorpmrators. The articles most then fwe filed in the office of the county recorder of the conuty in which the principal place of business of the comprany is to be trankated, and a copy thereof, eertified hy 
such recorther, mist be filed with the Secretary of State. Thereupon the Secretury of stite issues to the corporation a certificate that a cony of the nrticles containing the required statement of facts has been filed in his office. 'Thereupon the corporate existence commences. If it is proposed to prichase or hucate property in any other eounty of the State, there must be filed with the combly recoriler of that county within sixty days after such purchase or location is make, a certified copy of the articles of incorporation. The due incorfrorition of any company or its right to exercise corporate powers eanuot be inyuired into collaterally in any private suit to which such de facto corporation way be a party (secs. 2581, 2581, 2587, 2636).

6. Corporate Indebtedness. - Must not exceed amount of authorized eapital stock (sec. 2637).

7. Organization Tax. - When the capital stock does not exceed $\$ 25,000$, the organization tax is $\$ 5$; when it does not exceed $\$ 100,000, \$ 10$; when it does not exceed $\$ 500,000, \$ 20$; for all capitalization in excess of $\$ 500,000, \$ 25$ (Laws of 1901, 1. 141).

8. Filing and Recording Fees. - To Secretary of State for eopy of articles of incorporation, 20 cents per folio; for affixing his certificate and seal of State thereto, $\$ 1$; for recording articles of incorporation, 20 cents per folio; for issuing each certificate of incorporation, \$3; for recording articles in recorder's office in loeal county, 50 cents; for certified copy of articles of ineorporation by recorder of eounty where prineipal place of business is located, 20 cents per thonsand words.

9. Commencing Business. - Corporations may commence business as soon as the articles of incorporation are filed. Within one month after filing the articles of incorporation a corle of by-laws must be adopted. If the corporation does not organize and commence business or the construction of its works within one year from the date of its ineorporation, its corporate powers cease (secs. 2554, 2587, 2585, 2636).

10. Organization Meeting. - The incorporators within one month from the late the charter is issued shonlu sign a written agreenent fixing the time and place within the State for the organization of the corporation. In the absence of such written agreement the meeting is called by advertisement of it in alvance of the date of the meeting in some newspaper published in the county in which the principal place of business of the corporation is located. The written assent of the holders of two-thirds of the stock subscribed or two-thirds of the members shall be sufficient to adopt a corle of by-laws without a meeting for that purpose. The statute sets forth certain matters which may be covered by the by-laws inchuding penalties for violation of by-laws not exceeding in any case 100 for any one offence. The by-laws must be certified by a majority of the directors and the secretary of the corporation and copied in the book of by-laws to be kept at the prineipal office of the corporation within the State. Immediately after the adjournment of the incorporators' meeting the directors named in the articles of incorporation should meet, and after the election of a chairman and secretary should proceed to the election of the otficers named in the by-laws. These officers under the statute must consist of a jesident, who is himself a director, and a secretary and treasurer. 'The law provides that at the first meeting at which the by-laws are adopted, or at such subsequent meeting as may be then designated, directors must be electer to hold their office for one year and until their successors are electert and qualify. Organization meeting must be held within the State in the 
absence of any statute authorizing such meetings to be held without the State (sec. 2593).

11. Meetings of Stockholders and Directors. - All meetings of directors and stockholders must be held at the principal place of business of the corporation presumably within the State (sec. 2606.)

12. Directors' Qualifications and Liabilities. a. Qualifications. - There must be not less than fire lirectors and not more than eleven, all of whom inust be stockholders and a majority citizens and residents of the State (sec. 2592 as amended by Laws of 1599, p. 4114 ).

b. Liabilities. - Directors are jointly and severally liable for authorizing the payment of dividends other than from the surplus profits arising from the business. They are also liable for dividing or withdrawing or paying to the stockholders any part of the capital stock unless they enter their dissent on the minutes of the directors at the time, or when not present as soon as they are informed of the action referred to. 'They are also subject to further liability for certain acts specified in the Revised Statutes (secs. 2596, 2603, i114-7127 inclusive).

13. Stockholders' Liabilities. - Stockholders are liable for the amount unpaid upon the par or face value of the shares owned by them. To arail themselves of this provision of the statute they must cause to be written or printed under the corporate name on its stock certificates, letters, bill heads, and all official documents the word "limited" (Laws of 1899, p. 115, anending R. S., sec. 2 (609); see also Cons., Art. XI. sec. 17).

14. Preferred Stock. - There is no statutory provision expressly anthorizing the issnance of preferred stock.

15. Payment of Capital Stock. - Cnder the Idaho Constitution no corporation can issuc stock except for labor done, services performed, or noney or property actually received. The statute however provides that money actuislly paid upon the indebtedness of the corporation as provided by such statute may be credited npon stock subscriptions to the full amount so pail (Cons., Art. XI. sec. 9; Laws of 1899 , p. 115, anending sec. 2609).

16. Books. - The stock and transfer books must be kept within the State at the principal office of the corporation. Also a book of by-laws must be kept at the company's office within the State. All books are open to inspection of stockholders and creditors (secs. 2591, 2639, 2610).

17. Stock Certificates. - Each stockholder is entitled to a certificate showing the number of shares orned by him, signed by the president and secretary (sec. 2610).

18. Office. - Every corporation must maintain an office within the State (secs. 2.91, 2610).

19. Reports. - No reports are required to be filed

20. Ant1-Trust Statute. - Combinations for fixing prices on any article of commerce, of produce, of sale, or of consumption by the people are illegal. Sce Cons, Art. XI. sec. 18.)

21. Statutory Ground for Forfeiture of Charter. - Fiture to orginize and transact the corporate busi less or the coustruction of corporate works within one year from the date of incorporation is a grouml for forfeiture (sec. 2636i).

2.2. Extension of Corporate Existence. - Every corporation furmed for a period less than fifty years may, at any time pirio to the expiration of the term of its corporate existence, extend such term to a period not cxceed- 
Ing fifty sears from its formation. Such extcnsion may be made by a twothirds vote of the stockholelers cast at a meeting called by the directors for thiat purpose. The certificate of the proceedings must be signed by the chairmiln and seeretary of the meeting and be filed in the office of the county recorder where the original articles of incorporation are filed, and a certified copy thereof must be filed in the office of the Secretary of State (secs. 2619, 2650).

⒊ Annual License Tax. - There is no annual license tax.

21. Amendments. - Articles may be amended for the purpose of increasing or decreasing the capital stock, by a majority rote of the directors calling a meeting of the stockholders for that purpose. At this meeting twothirks of the capital stock must vote in favor of increasing or decreasing the capital stock. The written assent of the holders of three-fourths of the subscribed capital stock is as effectual to authorize the increasing or decreasing of the capital stock as if the meeting were called and held (R. S., sec. 2637). The act also authorizes an increase in the number of directors (sec. 2579), and a change in the loeation of the principal place of business (sec. 2608).

25. Dissolution. - Corporations may be dissolved upon application to the courts (secs. 2648, 5181-5191).

S. S. T. \& Co. v. Piper, 4 Illaho, $463 ; 40$ I'ac. 144.

20. Foreign Corporations. - Every foreign corporation before doing business within the State must file with the county recorder of the county in which its principal business is to be transacted a copy of its articles of incorporation, certified by the Secretary of State of the State in which said corporation was organized, and file in the oflice of the Secretary of State a copy of the articles certified by the recorder, and pay the same fees as provided for incorporating domestic corporations. Must also file in the office of the clerk of the district conrt of the county where such principil place of business is to be located and also in the office of the Secretary of State a designation of some person residing in said county, on whom process may be served (Cons., Art. XI. sec. 10 ; R. S., sec. 2653, as amended by Laws of 1903, pp. 49-50).

Vermont Loan \& Trust Co. v. IIoffman, 5 Ilaho, $376 ; 49$ Pac. 314 ; Boyer $v . \mathrm{W}$. P. R. R. Co., Idaho; 66 Pac. 826; Thum $v$. I'yke, Idaho; 66 Pac. 167.

\section{ILLINOIS.}

(The references cited below are to the Revised Statutes, 1899, chap. 32, unless otherwise stated.)

1. Statute under which Business Corporations may be incorporated. - The Business Corporation Act of Inlinois is found in the Revised Statutes of that State, secs. 955-1063 inclusive. Special acts are provided for banking, insurance, real estate, brokerage, and railway corporations (sec. 1).

2. Incorporators. - Any number of persons not less than three nor more than seven may form a corporation. There are no residential requireinents (sec. 2).

3. Statement of Incorporators (sec. 2). - The incorporators must make a statement setting forth:

a. The Name of the Proposed Corporation. - Similarity of names is for bidden (secs. 2, 281/2).

b. Purpose. - The statute uses the singular noun "object." The Secretary of State permits the insertion of any number of purposes not covered by srecial arts. 
c. Capital Stock. - Capital stock may be any amount.

d. Number of Shares. - The par value of the shares must be not less than $\$ 10$ nor more than $\$ 100$ (sec. 7 ). State.

e. Domiciliary Office. - The location of the principal office within the

f. Duration. - The corporate existence cannot exceed ninety-nine years.

4. Statutory Powers. - The statute enumerates the common law powers of corporations. There is a limitation even on these to the extent that all real estate acquired by the corporation in satisfaction of any liability shall be offered at public auction at least once in every year unless the same is necessary and suitable for the business of the corporation. The power to adopt by-laws is granted to the board of directors (sec. 6). The statute expressly authorizes mining and manufacturing corporations to hold stock of one or more railroads connecting different plants of the corporation with each other and with other railroads or wharves. Whenever consolidation takes place the consolidated company is liable for all dehts of the two consolidated corporations. Power is also given to authorize voting of stockholders by proxy, to permit cumulative voting for directors, to classify directors, and to forfeit stock for non:payment of assessments (secs. 3, 5, 7 ; Cons., Art. XI. sec. 3).

Com. N. B. v. Burch, 141 Ill. 519 ; 31 N. E. 420.

5. Procuring the Charter. - The statement mnst be signed and acknowledged by each of the incorporators, and unst then be filed in the office of the Secretary of State. The latter will then issue to the incorporators a license as commissioners to open books to the subscription for capital stock at such tines and places as they may determine. As soon as the capitil stock is fully subscribed the commissioners must convene a neeting of the subscribers for the purpose of electing directors and the transaction of such other business as may be proper. Unless the tine and place of the meeting are fixed by consent, written notice thereof must be given to each subscriber at least ten days in advance. The commissioners then make a full report of their proceedings, including a copy of the notice of the meeting or agreement fixing the time and place of such meeting together with a copy of the subscription list, the names of the directors elected and their terms of office, which report, after having been sworn to by a majority of the commissioners, is filed in the oflice of the Secretary of State. There must also be filed with the Secretary of State a statement sotting forth the post-office address of the corporation's business office, giving street and number. The Secretary of State therenpon issues a certificate of complete organization of the corporation. 'This last must be filed in the office of the recorder of leeds of the eomnty where the prineipal office of the corporation is located. Lipon the recording of the latter the corporation is deened fully organized and mity proceed to business (secs. 2, 3; Laws of 1901, p. 121).

I'erple v. Rose, 188 Ill. $268 ; 59$ N. E. 432.

6. Corporate Indebtedness - Corporate indebtedness should not exceed the anthorized wilpital stock (see Ifi).

7. Organization Tax. - The orguturation tax on ally capitalization up to

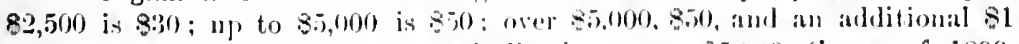
for each thonsand dollats of eapitalization over 85,000 (laws of 1899 , p. 117).

8. Filing and Recording Fees. - For receiving and filing articles of 


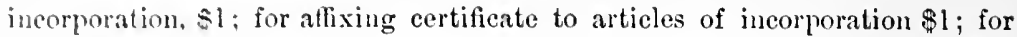
copying articles 1.5 cents per folio. The recording fees in loeal county oflice average ahout s.2.e).

9. Commencing Business. - Corporations may commence business as soon as the Secretary of State issues a certificate of complete organization and the same is recorded in the office of the recorder of deeds of the county where the prineipal place of business of said eoryoration is loented. 'Jlue corpuration must organize and proceed to business within two years after the Secretary of State issues his certificate of complete organization (sec. 4).

People r. N. S. Bank, 129 Ill. 618; 22 N. E. 288; Gent. v. M. \& M. I. Co., 107 111. 6.2.

10. Organization Meeting. - In the absence of any statute providing otherwise, this meeting' must be held within the State. 'The commissioners approinted by the Seeretary of State to receive stock subseriplions have power under the statute to convene a neeting of the subscribers to the eapital stock of the corporation for the purpose of electing directors, etc. Notice of this meeting may be waived in writing (the statute requires ten days' notice), the time and place fixed for said meeting to be designated therein. At this meeting the subseribers to the eapital stoek may vote in person or by proxy. $\mathrm{Cu}$ mulative voting is permitted if desired. Stockhohlers may divide the board of directors into three classes, to hold office for one, two, and three years respectirely. After the Secretary of State has issued a certificate of complete organization, the board of directors should neet and after effecting a temporary organization should first adopt a code of by-laws. They then should proceed to the election of a president, seeretary, and treasurer, and such other officers as shall be designated by the hy-laws so adopted (sec. 3 ).

11. Meetings of Stockholders and Directors. - Stockholder's meetings must be held within the State. lireetors' meetings to be valid must be held within the State, unless any action taken by the board without the limits of the State is either authorized or the action thereat taken ratified by a vote of two-thirds of the directors cast at a regular meeting of said board (sec. 20).

Harding $v$. Company, 182 Ill. $551 ; 55$ N. E. 537.

12.). Directors' Qualifications and Liabilities. a. Qualifications. - There must be not less than five nor more than eleven directors. There are no residential requirements. Directors maly be divided into classes if desired. Cumulative voting for directors is mandatory (secs. 3, 6).

Fey v. Company, 32 Ill. Ap. 618.

b. Linbilities. - If the indebtedness of any corporation shall exceed the amonnt of its capital stock, the lirectors assenting thereto are individually liall]: for such excess to the creditors of the corporation. They are also jointly and severally liable for all debts of the corporition then existing or thereafter contracted when they declare and pay any dividends when the corporation is insolvent or any dividend the grayment of which would render the corporation insolvent or which diminishes the amomit of its eapital stock; also for assuning to exercise corporate powers before all the capital stock is subseribed in good faith (sees. $16,17,18,19,21$ ).

Greene v. Mosten et al., f6 Ill. Ap. 345; Kent $v$. Clark, 181 Ill. 237 ; 54 N. E. 967.

19. Stockholders' Liabilities. - Stockholders are frersonally liable for the amount unpaid nyon their stock (sec. 8). The law also provides that all 262 
persons assuming to exercise corporate powers or to use a corporate name without complying with the law in regard to procuring charters before all stock named in the articles of incorporation is subscribed in good faith, shall be liable for all debts and liabilities contracted by them in the name of such corporation (sec. 1s).

Spragne $v$. Nat. Bank, 1:2 Ill. 149 ; 50 N. E. 19; First Nat. Bank v. Company, 191 Ill. 128; 60 N. E. 859; Sherwood $x$. Bank, 195 Ill. 112 ; 62 N. E. 835 ; Foote 2 . Bank, 194 Ill. 600 ; 62 X. E. 834 ; MeCor $v$. Exposition, 186 Ill. 356 ; 57 N. E. 1043 ; Flursheim $v$. Bank, 192 Ill. 382; 61 N. E. 491.

14. Preferred Stock. - There is no statutory provision expressly authorizing the issuance of preferred stock.

First Nat. Bank $x$. Company, 191 Ill. 128 ; 60 N. E. 859.

15. Payment of Capital Stock. - The statute is silent as to how the capital stock shall be paid. Under the common law rule, in the absence of any statutory prohibition, stock may be paid for in cash or in property taken in good faith at a fair valuation (Parmalee $r$. Price, 208 Ill. $544 ; 70$ N. E. 725).

16. Books. - The directors must keep at the principal office within the State books of account of the corporate business (sec. 13). They are open to inspection of stockholders.

17. Stock Certificates. - Each shareholder is entitled to a certificate showing the number of shares owned by him signed by such officers as the by-laws shall prescribe.

18. Office. - Every corporation must maintain an office within the State (secs. 2, 13).

19. Reports. - Before receiving a certificate of complete organization, corporations shall file with the Secretary of State a statement showing the postoflice address of its business office, giving street and number, and it shatl annually between Februtry 1 st and March 1 st file with the Secretary of state a statement showing the location of the mincipal office within the State, with town, street, and number, nomes of its oflicer's and their residences, - town, stret, and number, - date of expiration of their terms of office; whether or not the corporation is pursuing an active business under its charter, and the kind of business; report must be under the corporate seal, signed and sworn to by some officer of the corporation, and a fee of 81 must be pail to the Secretary of State (Laws of 1903, Pp. 121. 12.2). Within twenty days from December 1st of each year, a statement must he filed with the Secretary of State, and recorden with the recorder of the connty wherein the principal place of business of the corjuration is located, showing the real estite holdings of the corproration.

20. Anti-Trust Statute. - Illinois has an claborate statute forbirlding pools, trusts, and comblinations of every eliss and deseription. 'l'his stalute has in part at letst been declared unconstitutional (Crin. (inde, secs. 2ti9 a, $2(j 9 \mathrm{~b}, 615)$.

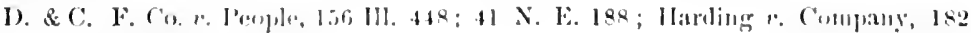

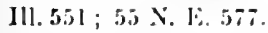

21. Statutory Ground for Forfeiture of Charter. - The charler may be

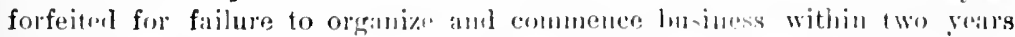
from the rate of incorporation. It is alus suliject lo forfoiture for entering into illegal trusts, pools, and combinitions (sees 4, $249 \mathrm{~m}$ ).

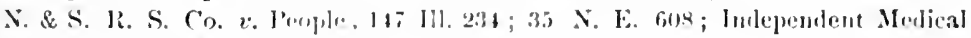
College r. People, 182 Ill. 27.4 ; 5.5 X. 1.. 34. 
22. Extension of Corporate Existence - There is no statutory provision for extending corporate existence after the expiration of the term limited in the chinter. (See sec. 10.)

2.). Annual License Tax. - There is no annual license tax.

24. Amendments. - The stockholders may at any meeting called by the directors, by rote representing two-thirds of the corporate stock, change the corpurate name or place of business, enlarge or change the object for which the corporation was formed, increase or lecrease capitalization, change number of shares or number of directors, managers, or trustees, increase or deerease par value of shares, decrease capitilization not to prejudice of creditors. or consolidate with another corporation carrying on the sane general business in the same vicinity (Laws of 1903, pp. 116, 117). A certificate of the vote by which such change, etc. was made, verified by the president, must be filed with the Secretary of State.

25. Dissolution. - Any court of competent jurisdiction may decree dissolution of a corporation upon petition therefor. Voluntary dissolution may be effected by vote of two-thirds of capital stock (secs. 49 a, $49 \mathrm{~b}, 149$ ).

26. Foreign Corporations. - A foreign corporation, in order to do business in this State or sue in its courts, must designate some person as its agent upon whom service of legal process may be had, and must maintain an office in the State fortransaction of business, and where proper books shall be kept; and it must file with the Secretary of State a certified copy of its charter or certificate of incorporation, and forward therewith a statement verified by one of its officers, showing the proportion of its capital stock represented in this State by the corporate property located and business transacted therein, also showing name and address of the agent in this State; and shall pay to the Secretiry of State, upon the proportion of its capital stock so represented, fees equal to those required of domestic corporations. It must report to the Secretary of State by verified statement any change in name or address of its agent, and any increase or decrease of proportion of its capitalization represented in this State by its property and business therein (Laws of 1899, p. 118). A foreign corporation may by letter of attorney constitute any fierson its agent to perform any act or business which the corporation may do or carry on (sec. 66 , chap. 32).

Spry Lumber Co. v. Chappell, 184 Ill. 539 ; 56 N. E. 794 ; Richardson v. U. S. M. \& T. Co., $19+$ Ill. $259 ; 62$ N. E. 606.

\section{INDIANA.}

(The references are to the Revised Statutes, 1897, unless otherwise stated.)

1. Statute under which Business Corporations may be incorporated.The Business Corporation Act of Indiana is found in Thornton's Statutes, 1897 (secs. 3490-3519, 5202-5256). Important amendinents to the original act are found in the Session Laws of 1901 and 1903. Special acts are provided for manufacturing, mining, mechanical, and chemical companies (secs. 5051, 5087).

2. Incorporators. - Any number of persons not less than three may be incorporators. There are no residential requirements (Laws of 1901, chap. 127: Laws of 190:3, chap. 73).

3. Contents of the Articles of Association. - The articles of association inust set forth:

261 
a. Name. - The corporate name of the proposed corporation. Similarity of names is forbidden as to donestic corporations.

b. Capital Stock. - The articles must set forth the amount of capital stock, and the number of shares into which the sane shall be divided, with the par value of the same. The capital stock may be any amount (except gas and oil companies, where capital stock is limited to $\$ 2,000,000)$, and the par value of the shares may be auy amount not exceeding $\$ 100$. (See Laws of 1903, chap. 12S.)

c. Purposes. - The object of the corporation with the proposed plan of doing business must be fully set out. The purposes may include any or all of the purposes included in any one of the twenty-six classes, which may be described in general terms as follows : horticultural, literary, drainage, educational, elcemosynary, cemetery, fraternal, military, fire, shade trees, safe deposit, and loan companies, hotels, real estate and rental companies, mining, health resorts, oil and gas wells, live-stock, trading corporations, commission merchants. title insurance abstract and loan, women's exchange, bond and money brokerage, medical and scientific research, storage, transfer, and scientific purposes (Iaws of 1901, secs. 1-2S). The amendment of 190:3 permits incorporation for more than one of several designated classes of purposes (Laws of 190:3, chap. 73).

d. Incorporators. - Names and places of residence of the incorporators must be set forth.

e. Domiciliary Office. - The principal place of business must be set forth, which by implication would seem to refer to the principal place of business within the State.

f. Duration. - The term of existence must not excced fifty years for mining and manufacturing companies. In all others except banks, health resorts, and telephone companies, the duration may be nnlimited.

g. Corporate Seal. - A demonstration of the corporate seal must be attached.

h. Board of Directors. - The manner of election or appointment of directors and officers who are to manage the business must be set forth.

$i$. Number and Nanes of Directors. - The number of directors together with the names of those who shall manage the affairs for the first year must alpeal. If desired, the date of the annual meeting may be set forth in the articles (Laws of 1901 , chap. 127 , sec. 1 ; Laws of $190: 3$, chaps. $37,73,128$ ).

4. Statutory Powers. - The statute fully enumerates the implied common law powers of corporations. The consolilution of two corporations is expressly permitted. Corporations are expressly forbilden to become stockholders in other corporations except thint railroads may own stock in trlegraph, telephone, union railway, and brilge companies muler certain circumstances, and that manufacturing corjorations may own stock in compani-s organized for the purpose of furnishing water jower (I aws of 1901, chap. I 27 , sec. 28; Laws of 190:3, chap. 220). Nay issue preferred stock, vote liy proxy, and

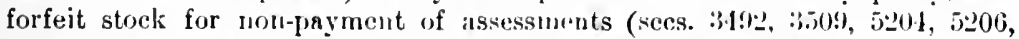
5212 ; Laws of 190I, chaps. 127, 1!7 ; Laws of 190:3, chatp. 2201).

Williame v. Company, 25 Ind. $\Lambda_{\text {p. }} 351$; 57 N. E. 581; Indiana Bond Co. $v$. Ogle, 22 Ind. $\Lambda$ p. $593 ; 54$ N. L. 407.

5. Procuring the Charter. - The articles of association must he signed and acknowledged by each incorporator. 'Tliey must then be presented to the Secretary of State for filing. At this time there must he presented a full 
written or printed statement of the proposed plan of doing business. If upon examination the articles are found to be according to law, the proposed plan of doing business legal, and the organization tax and filing fees paid, the secretary of State will issue to the corporation a certificate of incorporation.

'This is primu fucie' evidence of incorporation. 'Thereafter the corporation must tile a duplieate of its artieles in the recorder's oflice of the conuty in which the principal place of business is located, and upon paying the filing and recording tees, the law provides that such record or a certified copy thereof shall be conclusive evidence of the matters and things therein stated. It appears, however. from the section which follows the preceding (see. 28), that the corporate existence does not commence until the recording in the recorder's oflice. 'I'he corporation nust, at the time of filing its articles with the Secretary of State, file a copy thereof in the office of the State Auditor, and must also file from time to time copies of its constitution or by-laws thereaiter adopted (Laws of 1901, chap. 127, secs. 27-29; Laws of 1903, chat). 73).

Doty v. Paterson, 155 Ind. $60 ; 56$ N. E. 668

6. Corporate Indebtedness. - There is no statutory limitation upon the amount of corporate indebtedness.

7. Organization Tax. - Where the capital stock is $\$ 10,000$ or less, $\$ 10$; for all capital stock over $\$ 10,000$ the tax is one-teuth of one per cent (R. S. 1894 , sec. $7(331)$.

8. Filing and Recording Fees. - The Secretary of State is entitled to a fee of $\$ 1$ for recording articles of incorporation not exceeding two hundred words, also 50 cents for certifieate. 'The county recorder is authorized to collect 11$)$ cents per hundred words for recording articles of incorporation.

9. Commencing Business. - Corporations may commence business as soon as the Secretary of State issues a certificate of incorporation and a duplicate of the articles filed in the Secretary of state's office are recorded in the recorder's office of the county where the principal place of business of the corporation is located. Manufacturing companies must pay up their capital stock within eighteen months after incorporation. As soon as the last payment is made the president and a majority of the directors must make a sworn statement setting forth this fact, and the same is then recorder in the office of the clerk of the county where the principal place of business is located (secs. 5:211, 5:1:3).

10. Organization Meeting. - Organization meeting must be held within the State (sec. 319t). The incorporators should sign a written agreement fixing the time and place for holding the organization meeting. After a temporary secretiry and chairman have been chosen, the corporation should proceerl to the adoption of by-laws. Stockholders may vote by proxy. Inmerliately after the adjournment of the incorporator's' meeting the board of directors named in the articles of incorporation should meet and organize by the election of the officers prescribed in the by-laws. The statntory officers are a president, secretary, and treasurer. The secretary and treasurer are requirer to give bonds with such sureties as shall be required by the by-laws, aud must be sworn to the faithful discharge of the duties which may be assignel to either of them. The same person may be elected to the office of secretary and treasurer. The law provides that when the steps necessary to organization have been completed a statement thereof must be filed in the 26 if 
office of the clerk of the circnit court of the proper county; that said court at its next term thereafter shall on proof of such organization cause to be entered an order declaring the existence of such corporation. The law provides that such order shall be conclusive as to the fact of such existence of the date which said court may fix in the order.

11. Meetings of Stockholders and Directors. - Stockholders' meetings must be held within the State. It seems to be contemplated by the statute that directors' meetings should be held at the principal office within the State (secs. 3514, 3515, 5252).

12. Directors' Qualifications and Liabilities. a. Qualifications. There must be not less than three nor more than thirteen directors; cannot exceed eleven in case of manufacturing, mining, mechanical, and chemical companies. In the last-named class of companies directors must be stockholders and residents of the United States. In other corporations there are no such requirements (secs. 3516, 5205, 5206; Laws of 1903, chap. 37).

b. Liabilities. - If any corporation reducing its capital stock shall fail to file a certified copy of the vote of the stockholders thereon within thirty days thereafter in the office of the elerk of the circuit court in which the corporation's original certificate was filed, and also a dup]icate of the same in the office of the Secretary of State, the directors shall be jointly and severally liable for debts contracted after the said thirty days or before the record of such vote. Directors are also jointly and severally liable for all damages resulting in case any certificate, report, or public notice given as required by law shall be false in any material respect, or if they shall fail to give such notice or make such report, and any person shall be misled or deceived thereby. The directors are also jointly and severally liable for all debts contracted and for the declaration and paynent of a dividend knowing the company to be insolvent, or knowing that such dividend would render it so, or if they violate any of the provisions of the act which shall thereby render the corporation. insolvent (secs. 5214, 5217, 5219, 5220, 5230).

Brown v. Clow, 158 Ind. $403 ; 62$ N. E. $1006 ;$ A. C. I. Co. v. Ellis, 156 Ind. 212 59 N. E. 679.

13. Stockholders' Liabilities. - Stockholders and members of manufacturing and mining compranies are only liable for the anount of stock subscribed by them respectively, with the exception that stockholders are individually liable for all debts due or owing laborers, aplrentices, and employees for services rendered the corporation. Stockholders in other corporations are liable to the anount of stock held by them at the time the debts were eontracted. This liability may, however, be increaside by vote of a majority of the stockholders anthorizing the directors to increase their liability to any anount not exceedling three times the amomt of stock held by each stockholder (secs. 3519, 52.21, 5255). They are also liable for illexal withdrawal of capital (see. 3197 ; see generally, Cons., Art. XI. sec. 2213).

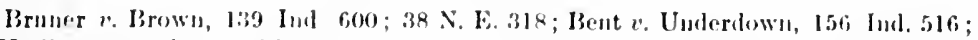

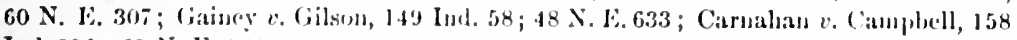
Ind. 226 ; 63 N. E. 384 .

14. Stock Certificates. - Every storkholiler is entitled to have a stock certificate issued to him under the seal of the corporation signed hy the treasurer. Stock in manufacturing companies cannot be transferred intil it is paid ul' (sec. 3193 ). 
15. Preferred Stock. - The statute expressly authorizes business corporations to issue preferred stock by providing therefor in the articles of incorporation. 'They may also do so after incorporation by a three-fourths vote of the stexholders given at a regular or speeial necting. By a vote of a majority of the common stock they may athorize and empower the board of directors to dispose of and issue such preferred stock npon such terms and conditions as the boircl of directors may deem best, and in such ease the validity and issuance anl the disposition made of such preferred stock by the directors shall be bimling and conclusive upon the company. Within thirty days after the time such preferred stock has been authorige! there shall be filed with the Secretary of State a certificate in writing signed by the president and attested by the seeretary duly acknowledged certifying that the issuance of preferred stock has been authorized, the anount of the same, the number of shares into which it is divided, and the amonnt of each share (secs. 5225-5231; Laws of 1901, chap. 197, as amended by Laws of 1903, chap. 122).

16. Payment of Capital Stock. - The statute does not provide as to how the capital stock shall be paid in. In the absence of statutory prohibition it may be paid for in money or moncy's worth. (See secs. 3509, 3510.)

17. Books. - Corporations are required to keep at their office or place of business within the State a stock book open to inspection during business hours to all stockholders and crelitors, who may take extracts therefrom if they desire (secs. 3.500, 3501 ).

18. Office. - Every corporation must have an office within the State (sec. 3500 ; Laws of 1901, chap. 127; Laws of 1903, chaps. 73, 128).

19. Reports. - The company shall amnally within twenty days from the first day of Jannary make a report, which it shall cause to be published in some newspaper printed in the county where its office is located, if any (otherwise in the county nearest thereto), which shall state the amount of capital, amount of assessments made and actually paid in, and amount of existing debts, which report shall be signed by the president and a majority of the directors and shall be verified by the oatlss of the president and such directors aud secretary (R. S., 1901, secs. 5215, 5217).

20. Anti-trust Statute. - There is a statutory prohibition directed against trusts and combinations tending to lessen free competition in the importation, sale, or manufacture of various artieles (Laws of 1899 , chap. $143)$.

21. Statutory Grounds for Forfeiture of Charter. - Allowing a judgment to stand against the corporation for a period of one year without satisfying the same is a gromb for forfeiture (sec. 3506).

Westeru Co. $v$. Central Co., 116 Ind. 229 ; 18 N. E. 14; Holman v. Estate, 105 Ind. $569 ; 5$ N. 1. 702 .

22. Extension of Corporate Existence.- Corporations may extend their corporate existence by a vote of the stockholders at any annual meeting for a term not to exceed fifty years from its first organization (sec. 5209).

23. Annual License Tax. - There is no annual license tax.

21. Amendments. - To change the name of the corporation application to the courts is necessary (sec. 1020). The power of amendment in some other respects is given to the board of directors. Express power is given to stockholders of manufacturing and mining corporations to amend for all furpores except change of name (secs. 3514, 3516, 3517, 5209, 5214, 5222; l.aws of $19(13)$, chap. $3 \pi$ ).

269 
25. Dissolution. - May roluntarily dissolre without recourse to the courts by compliance with the statute (Laws of 1903, chap. 152).

State $v$. Trustees, 5 Ind. 77.

26. Foreign Corporations. - Foreign corporations desiring to do business in Indiana must file with the county clerk of the county wherein the corporation proposes to transact its business the written appointment of its agent, with a consent that service upon him shall be deemed sufficient to bind the corporation. Foreign corporations are required to pay a license fee upon the amount of capital incested in the State at the same rate required of local corporatious but never less than $\$ 25$. They are also required to file a copy of their certificate of incorporation and a sworn statement of the proportion of capital stock represented by property located and business transacted in Indiana (Laws of 1901, chap. 265; Laws of 190:3, chap. 127).

Hockett $v$. State, 105 Ind. $250 ; 5$ N. E. 178; Machine Co. $v$. Caldwell, 54 Ind. 270; Am. Insurance Co. $v$. Wellman, 69 Ind. 413 ; Singer Manufacturing Co. $v$. Brown, 64 Ind. 548; Brechbill $v$. Ranlall, 102 Ind. 528; 1 N. E. 362; P. B. I. \& S. Ass'n $v$. Narkley, 27 Ind. Ap. 128; 60 N. E. 1013; N. M. N. G. Co. v. Sinith, 27 Ind. Ap. 472 ; 61 N. E. 10 ; S. S. \& L. Ass'n $v$. Elbert, 153 Ind. 198; 54 N. E. 753.

\section{INDIAN TERRITORY.}

\section{(See "Arkansas.")}

The Corporation Laws of Indian Territory. - Are, by Act of Congress of February 18, 1901 (U. S. Stat. 1900-1901, chap. 379, p. 791) adopted from the laws of Arkansas as published in 1881 in Mansfield's Digest, which laws, to wit, sec. 504 and succeeding sections down to and including sec. 509 , sec. 960 , and succeeding sections down to and including sec. 1035 , are by said act extended over and put in force in the Indian Territory, so far as applicable and not in conflict with previons congressional legislation. Said act of Congress also provides that in reading said Arkansas laws, read for the word "county" the words " judicial district;" for "county courts," the words "United States courts ;" for "State," the words "Indian Territory;" for "Secretary of State," the words "clerk of the judicial district;" for "General Assembly," the words "Congress of the United States;" for "vest in the State," the words, "vest in the United States." The fees to be paid to the clerk of the judicial district or clerk of the United States Court of $A$ ppeals are by said act made the same as those paid under the Arkansas law to similar officers.

\section{IOW A.}

(The references are to Statutes of 1897 unless otherwise stated.)

1. Statute under which Business Corporations may bo incorporated. - The Business Corporation Act of Iowa is found in the statutes of that State, Title IX. secs. 16017-1652 inclusive, as anenderl hy the Session Laws of 1901 and 190:3. Special acts are provided for banks, building associations, fidelity companies, insurance, railroad, telegraph, telephone, water and water-power companies.

2. Incorporators. - Any number of persons may be incorporators. The law expressly provides that a single: person may incorporate muder the (ieneral Corporation Act. There are no residential requirements (secs. 1607, 1608). 
3. Articles of Incorporation. - The act requires that before commeneing busine'ss the incorporators must adopt articles of ineorporation, but it does not print ont speritically the contents of the same. The act does, however, prescribe the eontents of the notice of incorporation which is required to be published. The notice here referred to must contain:

a. Name. - Sinilarity of names is not forbidilen.

b. Domiciliary Office. - The principal place of business must be stated.

c. Purposes. - 'The general nature of the business to be transacted must be set forth. There is no express authority for the issuance of a charter authorizing the transaction of more than one general line of business.

d. Copital stock. - The amount of capital stock authorized and the times and conditions on which it is to be paid. The capital stock may be any amount. The par value of the shares may be any amount.

e. Duration. - The time of the commencement and the duration of the corporation. This is limited to twenty years (sec. 1618).

$f$. Number of IBirectors. - Designation as to what officers are to conduct the corporate affairs and the times when and manner in which they are to be zlected. A board of directors of any number of persons mat be named.

g. Corporate Indehtedness. - The highest amount of indebtedness to which the enrporation shall be at any time subject. 'This must not in any ease exceed two-thirds of the authorized capital stock. This section does not alply to railway or bond and debenture companies.

Heuer $r$. Carmichacl, 82 Iowa, $288 ; 47$ N. W. 1034.

h. Exemption of Stockholders from Individual Liability for Corporate Debts (secs. 1610, 161:3).

4. Statutory Powers. - The Iowa statutes merely enumerate the implied common law powers of corporations (sec. 1609). For the purpose of repairs, rebuilding, enlarging or to meet contingencies, or for the purpose of creating a sinking fund, the corporation may set apart a sum which it may loan and take proper security therefor (sec. 1630). Stock certificates cannot be issued without having endorsed on the face thereof the amount paid thereon and whether sush payment has been in money or property (sec. 1627; Laws of 1901, chap. 55.)

Calumet Paper Co. r. Company, 96 Iowa, $147 ; 64$ N. W. 782.

5. Procuring the Charter. - The incorporators must sign and acknowledge the articles of ineorporation. They must be recorded in the office of the recorder of deeds of the county where the principal place of business is loeated. The articles bearing the endorsement of the recorder as to the time when same were recorded and the book and page of such record must be forwarded to the Secretary of State and by him recorded. The organization tax must be paid at the time of such recording. Within three months from the date of the certificate of incorporation a notice must be published once each week for four successive weeks in some newspaper as convenient as practicable to the principal place of business, which must contain substantially all that is set forth in the articles of incorporation themselves. Proof of such publication by affidarit of the publisher of the newspaper in which it is made must be filed with the Secretary of State. Both the corporation and persons sued by the corporation are forbidden to set up want of legal organization on the part of the corporation as a defence (sees. 1610,1613,1636; Laws of 1902, chap. 67).

First Nat. Bank $v$. Davies, 43 Iowa, 424 ; Heald $v$. Owen, 79 Iowa, $23 ; 44 \mathrm{~N}$. W. 210. 
6. Corporate Indebtedness. - Corporate indebtedness except when bonded and secured by mortgage cannot exceed two-thirds of the capital stock (sec. 1611).

Warfield $v$. Company, 72 Iowa, 666;34 N. W. 467.

7. Organization Tax. - Up to $\$ 10,000, \$ 25 ;$ and an additional fee of $\$ 1$ per thonsand for all stock authorized beyond that amount (R. S., sec. 1610; Laws of 1902 , chap. 66).

8. Filing and Recording Deeds. - For filing and recording articles in office of Secretary of State, 10 cents per folio; for furnishing certified copy of articles, 10 cents per folio, for preparing same, $\$ 1$ for certifying the same; recording fees in local county offices, 10 cents per folio. The legal rate for adrertising articles of incorporation averaging one thousand words in length is about $\$ 30$. It varies, leing liased upon so many lines of brevier type of a specified length. The newspapers will usually publish for fifty or even twonty per cent of the legal rate.

9. Commencing Business - Corporations may commence business as soon as the articles of incorporation are filed and recorderl in the office of the recorder of deeds of the county where the principal place of business is located, and in the office of the Secretary of State; provided further that the publication required by law is thereafter male and proof thereof duly filed in the office of the Secretary of State. Business must be commenced within two years from the time the articles are filed in order to avoid forfeiture of its franchises (secs. 16I4, 1628).

Thornton $v$. Balcom, 85 Iowa, 198; 52 N. W. 190; Johnson v. Kessler, 76 Iowa, $411 ; 41$ N. W. 5 .

10. Organization Meetings. - Ordinarily organization meetings arc held within the State (sec. 161:). 'The statute reads as follows: "If the corporation transacts business in this State, the articles shall fix its principal place of business, which must be in this State, and in charge of an agent of the corporation, at which place it shall keep its stock and transfer books and hold its meetings" (Id.).

11. Meetings of Stockholders and Directors. - Stockholders' meetings must ordinarily be held within the State. IDirectors' neetings may be held without the State if the by-laws so provide. (See sec. 1612, cited at length above.)

12. Directors' Qualifications and Liabilities. a. Qualifications. - Any number of persons nay act as directors. 'There are no residential or other requirements.

b. Liabilities. - Directors are penally liable for unlawful diversion of corporate funds, for declaring illecral dividents, and for keeping false hooks or account. The payment ly the directors of any dividemd when the corporation is known by then to le insolvent, or any divilfond the payment of which would render it insolvent or which diminisles th." anount of its capital steck, renders the directors knowingly eons.nting thereto jointly and severally liablo for all debts of the corporation than existing. If the indebtedness of any corporation shall exceed the amount of indeliteduegs permitted hy law, the direetors knowingly consentiur thereto shall be personally liable to the creditors of such for such excrss (secs. 16221, 162:2, 162:3).

Frost Mfg Co. v. Foster, $76 \mathrm{I} w \mathrm{wn}, 535 ; 41 \mathrm{~N}$. W. 212 ; Miller 2 . Bradish, 69 lowa $2 ; 8 ; 28$ N. W. 594. 
13. Stockholders' Liabilities. - Failure to comply substantially with the requirements in relation to organization and publicity renders the individual property of stoclsholders liable for corporate debts (sec. 1616). 'They are also liable to ereditors of the corporation for all unpaid instaluents on stock owned by them or transferred by them for the purpose of defrauding creditors (sec. 16:31). 'The receipt of illegal dividends by stockholders makes them liable to the amount of such dividend so received for all liabilities of the corporation then existing (sec. 1621). Intentional frand and failure to comply substantially with the articles of incorporation or in deceiving the public or individuals in relation to their means or their liabilities shall be a misdemeanor and shall sulject those guilty thereof to fine or imprisonment or both at the discretion of the conrt. Any person who has sustained injury from such fraud may also recover damages therefor against those guilty of participating in such fraud (sec. 1620).

W:arfield $\cdots$ Company, 72 Iowa, 666; 34 N. W. 467 ; Chisholm v. Forny, 65 Iowa $333 ; 21$ N. W. 664.

14. Stock Certificates. - Every stockholder is entitled to have a stock certificate issued to him signed by such oflicers as may be designated in the by-laws. (As to contents thereof, see section 1627.)

15. Preferred Stock. - The statute does not expressly authorize the issuance of preferred stock by domestic corporations.

16. Payment of Capital Stock. - Stock may be issued for money or property (sec. 16:27). A statement of the amount of capital stock as subscribed, the amount of capital stock actually paid in, and the amount of corporate indebtedness inust be posted in the principal place of business and be subject to public inspection (sec. 1625).

Singer $v$. Given, 61 Iowa, 93 ; 15 N. W. 858.

17. Books. - Transfer books showing the name of the person by whom and to whom stock is transferred, the number of shares and the date of the transfer, must be kept within the State at the principal office of the corporation (secs. 1612, 1626). They are open to public inspection.

18. Office and Agent. - Every corporation must maintain an office within the State with an agent in charge thereof in which must be posted a copy of the by-laws, a statement of the amount of capital stock subscribed, the amount of capital stock actually paid in, and the amount of indebtedness, all for public inspection (secs. 1612, 1624, 1626).

19. Reports. - No reports are required to be published. The corporation must annually in January file with the Secretary of State a list of its officers and directors and any change in the location of its place of business made by a vote of the stockholders (sec. 1612).

20. Anti-Trust Statute. - Iowa has an elaborate anti-trust statute prohibiting certain pools, trusts, and conspiracies (Code, sec. 5060).

21. Statutory Grounds for Forfeiture of Charter. - Intentional fraud in failing to comply substantially with the articles of incorporation, or deceiving the jublic in relation to the corporation's means and liabilities, or a diversion of funds which results in the insolvency of the corporation, works a forfeiture of the corporate privileges to be enforced as directed by law. Failure to use the charter for two successive years is a ground for forfeiture of the charter. Charter may also be forfeited for violation of the anti-trust act (secs. 1622, 1628; see also secs. 4313-4335, 5065).

$$
272
$$


22. Extension of Corporate Existence. - Corporate existence may be extended for an additional period of twenty years if desired (sec. 1618; Laws of 1900, chap. 56 ; Laws of 1902 , chap. 66 ; Laws of 1904 , chap. 2).

23. Annual License Tax. - There is no annual license tax.

24. Amendments. - Articles may be amended in any respect by complying with the statute in such case made and provided (sec. 1615).

25. Dissolution. - May be dissolved prior to the period fixed in the articles of iucorporation by unanimous consent of stockholders, or in accordance with the provisions of its articles, and notice thereof must be given in the same manner and for the same time as is required for its organization. Courts of equity have power to dissulve or cluse up the business (R. S., secs. 1617, 1640).

26. Foreign Corporations. - Every foreign corporation shall file with the Secretary of State a certified copy of its articles of incorporation, accom. panied by a resolution of the board of directors or stockholders authorizing the filing thereof, and also alpointing an agent upon whom service of process may be had within the State, and shall pay the same fee required for the organization of corporations with a similar capital within the State (R. S., sec. 1637 ; Laws of 1904, chap. 54).

Ware Cattle Co. $v$. Anderson, 107 Iowa, 231 ; 7 N. W. 1026; Scottish Union, etc. Co. $r$. Herriott, 109 Iowa, 606; 80 N. W. 665 ; State $v$. Company, 91 Iowa, 517 ; 60 N. W. 121

\section{KANSAS.}

(The references cited below are to the Revised Statutes of Kansas, 1897, chap. 66, unless otherwise stated.)

1. Statute under which Business Corporations may Incorporate. - The Business Corporation Act of liansas is found in the Revised Statutes of that State, 1837, chap. 66 , and the Session Laws of 1399, 1901, and 1903. Special acts are provided for binking and insurance companies (sec. 4).

2. Incorporators. - There must at least be five incorporators, three of whom must be citizens of the state (sec. 4 ).

3. Content of Application for Charter. - An application must be filed by the incorporators with the charter board, settiug forth :

a. Nume. - There can be only one corporation of the same name. This must indicate the nature of the business intended to be carried on. It must begin with the word " the " and end with the word "corporation" "company," " association," or "society" (sec. $\$$ )

b. Domicilinry Offee. - The place where its principal oflice or place of business is to le located within the state.

c. Duralion. - Not to exeed twenty yours.

d. Purposes. - Full nature and charicter of the business in which it proposes to enginge. 'The "statutes of this state," observes the seeretilly of State, "provide that the nane of the enromation shall indieate the chamacter of the business in which it proproses to engagen, and it is the pratetice of the charter board to limit the operation of the corporation to a single line of business, except as its engrugements in uhere husiness may be incidental to or necessary to the successful op ration of such husiness. I gromping of this character is authorized by s.e. 1.20) of the (ieneral Statutes of 1901."

l'arkiuson Sugar Co. $v$ l lank, 60 Kitn. $474 ; 57$ l'ak. 126.

e. Incorporators. - Nanes and abliesses of the incorjorators. 
i. Copital sinck. - This may be any amount. The par value of shares may be any antount (sec.:3 b).

4. Statutory Powers. - In aldition to a statutory enumeration of comnon law powers the act confers the following additional powers: 'T'o anthorize voting by proxy, to permit eumulative voting, to forfeit stock for non-payment of assesiment, to issue preferred stock (secs. 3, 13, 21, 27, 104); to issue bonds (sec. 1 is).

5. Procuring the Charter. - The petition for a charter must be presented to the charter boarl, eomposed of the Attorney-General, the Secretary of sitate, and the State Bank ('onmissioner. The application must be accomfraned by the payment of $\$ 2.5$, known as the "application fee" The board is required to make an investigation of each alplication, and if satisfied therewith it shall he granted, and the secretary of the board issues lis certificate setting forth the fact that the persons named in the application have been authorized by the charter hoard to form a private corporation. This authorization is in fact merely a legal authority to organize the corporation. Thereupon the charter must be prepared, containing : (1) Name of the corporation. (2) Purposes thereof. (3) Location of principal place of business within the state. (4) Duration of corporate existence. (5) Number of directors, names and resilence of those appointed for the first year. (b) Amount of capital stock. and the mumber of shares into which it is to be divided. ( 7 ) Names and residences of the stockholders and the number of shares lield by each. This charter must be subscribed and acknowledged by at least five incorporators. Before the charter issues it must be filed with the Secretary of State and the organization tax provided by law must be paid to the State Treasurer. Upon the payment of the State fees the Secretary of State issues a certified copy of the charter to the incorporators. This copy is by statute made evidence of the creation of the corporation (secs. 5, 10, 11, 12).

6. Corporate Indebtedness. - Must not exceed amount of authorized capital stock (sec. 18).

7. Organization Tax. - The application must be accompanied by a fee of 825. Before the charter is filed applicant must pay to the State Treasurer a charter fee of one-tenth of one per eent of its authorized capital on the first $\$ 100,000$ of its capital, or any part thereof; 1 pon the next $\$ 400,000$ or part thereof, one-twentieth of one per cent; and for each million dollars or major part thereof above the sum of $\$, 500,000, \$ 200$ (secs. $3 \mathrm{e}, 3 \mathrm{f}$, as amended by Laws of 1901, chap. 125).

8. Filing and Recording Fees. - Fce to the charter board is $\$ 25$; to the Secretary of State for filing and recording charter, \$2.50 not exceeding ten folios, and an additional fee of 25 cents for each folio in excess of ten. The payment of this fee entitles the corporation to a eertified copy of the charter (sec. $3 \mathrm{f}$ ).

9. Commencing Business. - Corporitious may commence business as soon as their petition has been favorably acted upon by the eharter board, the application fee fraicl, and chartel properly filed with the Secretary of State, the organization tax and filing fees paid, and an affidavit filed with the Secretary of state, made by the presinlent or secretary, setting forth that not less than twenty per cent of the authorized capital has been paid in cash. Corporations must commence business within one year after filing the charter (sec. 4; Laws of 1901, chap. 125, sec. 4).

11). Organization Meeting. - Must be held within the State, in the absence of any statute providing otherwise.

$$
27+
$$


11. Meetings of Stockholders and Directors. - All meetings of stockholders must be held within the State. I)irectors' meetings may be held without the State if the by-laws so provide (sec. 27 ; Laws of 1901, chap. 126).

12. Directors' Qualifications and Liabilities. a. Qualifications. There must be at least three and not more than twenty-four directors. Three of these must be residents of the State. All direetors must be stockholders. Cumulative voting for directors is permitted. The power to adopt by-laws may be delegated to the directors. An oath of office is required (secs. 13, 26, 72,42 ; Laws of 1901 , ehap. 126).

b. Liabilities. - Directors are jointly and sererally liable for knowingly declaring or paying any dividends when the corporation is insolvent, or any dividend the payment of which would render it insolvent. They may avoid this liability by filing their objections in writing with the seeretary of the corporation (sec 32).

13. Stockholders' Liabilities. - The Legislature of 1903 passed an act repealing statntes imposing a double liability on stockholders. The constitutionality of this act is questioned in some quarters, but the Supreme Conrt has not yet passed upon it. In any event stockholders are liable for unpaid stock subscriptions (Laws of 1903, chap. 152, see. 51).

Musgrave $v$. Association, 5 Kan. Ap. 393 ; 49 Pac. 338; Munson v. Warren, 63 Kan. 162 ; 65 Pac. 222.

14. Stock Certificates. - Every stockholder is entitled to have a stock certificite issued to lim signed by such officers as may be designated in the by-laws.

15. Preferred Stock. - Pleferred stock may be issued by insertion of a provision therefor in the eliarter, or by the unanimous consent of all the common stockholders of the eorporation after incorporation (sec. 101).

16. Payment of Capital Stock. - The capital stock is payable in such amomits and in such manner as maty be required by the by-laws under direction of the board of directors (sees. 19, 20). It is payable in money or money's worth.

17. Books. - A record unust be kept of all stoek subscribed and transferred and all business transactions. Snch reeords must be open at all times to the inspection of stockholders (secs. 31, 12, 52).

18. Office. - Every corporation must mantain an office within the State. The law provides that the oflice of the treasurer must be within the State (sees. 42, 41).

19. Reports. Every corpuratin, excephing hanking, insurance, and railroal eorporations, shall file ammually. on or before Amgust 1st, a statement of comlition of snch eorporation on the :3oth of June preceding. Such statement shall sot forth anthorized eapital stock, paid up capital stock, par value and market vatue of shares of sturk, statchucut of assets and liabilitios, list of

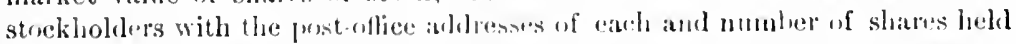
and paid for by atch, namms am post-offee aldresses of ollicers, trustees, or directors amd manarer alected for ensuing year, and a certificate of the time and manner in which olection was held. Fee for filing report is sl (laws of 19.1, (hity. linis, sice. :3).

20. Anti-Trust Statute. - Liunas has an elalorate anti-trust statute providiug for the prohibition of certitin lind of pools, trusts, or conspiracies (chaly) 1.15, secs. 1-21.).

21. Statutory Grounds for Forfeiture of Charter. - The eharter boird 


\section{INCORPORATION AND ORGANIZATION OF CORPORATIONS.}

is authorized by law to declare a charter roid for failure to furnish such information in the way of anual reports or otherwise as may be required by the Seeretary of State. The charter may be forfeited for illegal use or alıuse of corporate powers or for entering illegal trusts and combinations or for failure to commence business within one year from filing of charter, or for failure to maintain its doniciliary office and resident directors (secs. 43, 45, 98; chap. 145 , sec. 16 ; Laws of 1901 , chap. 125 , sec. 124).

State $v$. Company, 59 Kan. 151 ; 52 I'ac. 422 ; First Nat. Bank v. King, 60 Kan. 733; 5 i 1'ac. 952.

2.2. Extension of Corporate Existence. - Corporate existence may be extended for successive periods of twenty years, by filing with the Secretary of State at any time certificate of its intention to so extend its time of existence, signed and duly acknowledged by the president and secretary after the same has been authorized by its board of directors and approved either by two-thirds of its stockholders in writing or by a two-thirds vote of its stockholders present at any meeting duly called for that purpose (sec. 38).

23. Annual License Tax. - There is no annual license tax.

24. Amendments. - Nay change nature of its busivess, change its name, increase the shires of its capital stock, change place of its principal office in this State, and make such other alterations or amendments as desired, when authorized by a two-thirds vote of stockholders at a meeting held in conformity to by-laws, and as so amended each charter shall be subscribed by directors, and acknowledgred by not less than three thereof who shall be citizens of the State. When name is changed, notice of such change shall be immediately thereafter published by president, or other chief officer, for six weeks, in some newspaper printed and published in the connty where the principal oftice is located; if there is no such newspaper, in some paper of general circulation. For decrease of capital stock a meeting of stockholders must be ealled for that purpose, and upon two-thirds vote of outstanding stock a certificate of such decrease under the corporate seal signed by the president and secretary of the corporation should be filed in the office of the Secretary of State (secs. 9, 11, 16; Laws of 1901, chap. 125, see. 7 ; Laws of 1903, chap. 151).

25. Dissolution. - May be dissolved on application to the courts (secs. $45-50)$.

Brigham $v$. Nathan, 62 Kan. 243; 62 Pac. 319 ; Jones $v$. Edson, 10 Kan. Ap. 110; 62 Pac. 249.

26. Foreign Corporations. - Foreign corporations must apply to the charter board for lermission to engage in business in the State, setting forth : certified copy of its charter; place where its principal office is located; nature and claracter of the business in which it proposes to engage; names and addresses of the trustees, oflicers, or dircetors and stockholders of the corporation; a statement of the assets and liabilities. This statement must be subseribed and sworn to by the president, secretary, and managing officer, and be accompanied by the charter fee of $\$ 25$, and also its written assent that actions may be commenced agaiust the corporation by service of process upon the Steretary of State. This stipulation must be executed by the president and secretary of the company, authenticated by its seal and accompanied by a certified copy of the resolution of the board of directors authorizing saine. Such corporations shall also pay the state fees on their eapital stock as requited of domestic corporations. I)uring the month of February of each yeat formitn corporations must file with the Secretary of State a statement of 276 
the condition of such corporation at close of business on the day of last annnal statement made by such corporation for its own use, and within one hundred and twenty-fire days preceding filing of such statement or - if no such previous statement las been made - the statement so filed shall show condition of the company at close of business on the 31 st day of December preceding. This statement must show: name; location of principal place of business within the State and withont the State; names and addresses of officers and directors; amount of authorized capital stock and par value of shares; amount of eapital stock subscribed and amount and general nature of its sources and liabilities. This report must be signed and sworn to by the president or general manager and by the secretary (Laws of 1901, chap. 195, secs. 2, 3, 4; see generally Laws of 1903 , chap. 153 ; Laws of 1903 , chap. 150).

State 2 . Topeka Water Co., 61 Kan. 54i; 60 Pac. 337; Alliance Trust Co. $v$. Witson, 9 Kan. Ap. 891 ; 59 Pac. 177.

\section{KENTUCKY.}

(The references cited below are to the Rerised Statutes of 1894, unless otherwise stated.)

1. Statute under which Business Corporations may incorporate. The Business Corporation Act of Kentucky is found in the Revised Statutes, 1894, sees. 538-576, and acts amendatory thereof. Under it parties may incorporate for transaction of any lawful business. There are special provisions applicable to collection agencies, banks, bankers, bridge companies, building and loan associations, insurance, railroad, and real estate corporations (sec. 535).

2. Incorporators. - Any number of persons not less than three may be incorporators. There are wo residential requirements (sec. 5:38).

3. Contents of the Certificate of Incorporation. - 'The articles must specify:

a. Name. - Similarity of names as to existing domestic corporations is forbidden. The worl "incorporated" must always follow the name adopted (sec. 576$)$.

b. Domiciliary Office. - Location within the State of the principal office or place of business of the corporation.

c. Purposes. - The nature of the business, the objects or purposes proposed to be carried on, promoted, or transacted. This permits of incorporation for more than one purpose.

1. Capital Stock. - The amount of capital stock and the number of shares into which the same is divided. 'The capital stock may be any amount. The par value of shares may be any anount.

e. Sulscrilsers to Coupital Stock. - The names and places of residence of the stockholders and the mumber of shares sufseribed by each.

f. Juration. - The time when the corprote existence commences and the duration of the same. This may le molimiterl.

g. Directors and Offeers. - $i$ designation of the oflicers or persons who are to conduct the affairs of the corporation and the time and place at which they are to be elected. Throre must he at least three directors.

h. Corporate Indmoledness. - The highest anownt of indebtedu'ss or liability which the corporation may at any time incur. This may he unlimitul.

i. Sitockholders' Linbility. - Stitement as to whether the private property 
of the stockhollers shall be subject to the payment of corporate debts, and if so, to what extent (see. $53 \%$ ).

1. Statutory Powers. - In adlition to the enumeration of the common law powers of corporations, the statute gives the corporation power to remove oflieers, to define their duties, and to require from any of them a bond for the filithful performance of their luties, and gives boards of directors power to alopt by-laws. The statute forbils the purchase by the corporation of its (win cajital stock exeept to prevent loss upon debts previously contracted, and the stock so purchaset shall in no case be held for more than one year. It also pernits corporations to consolidate and to issue preferred stock. Also a lien on stock for debts due the eorporation from stockholelers may be enforced by the corporation. Corporations cannot hold any real estate except as may be necessary for carrying on its legitimate business for a longer period than five years. P'ower to rote by proxy, to forfeit stock for non-payment of assessment, to permit cumulative voting, and to classify directors is given (secs. 542, $54:, 551,555,564,567$; Laws of 1902 , chap. 58).

German Nat. Bank v. K. T. Co., 19 Ky. Law Rep. $36 \mathrm{I} ; 40$ S. W. 458 ; C. G. L. Co. $v$. City of Covington, $22 \mathrm{Ky}$. Law Rep. $796 ; 58 \mathrm{~S}$. W. 805.

5. Corporate Indebtedness. - There is no limit to the amount of indebtedness which a corporation may incur. No bonds can be issued except for equivalent in money paid, labor done, or property actually received and appliel to the purposes for which the corporation was created (sec. 568).

6. Procuring the Charter. - The articles of incorporation must be signed and acknowledged by each of the incorporators. They must then be recorded in the county clerk's office of the county in which the principal place of business is to be located, and a copy thereof filed and recorded in the office of the Secretary of State (secs. 540, 542, 570). Collateral inquiry into the legality of corporate existence is forbidden (sec. 566).

7. Organization Tax. - An organization tax amounting to one-tenth of one per cent on the amount of its authorized capital stock is exacted (Laws of 1902, chap. 128, Art. XI. sub. I, sec. 1).

8. Filing and Recording Fees. - Recording fees in the office of the Secretary of State, 20 cents per folio. Recording fees in local county office for articles averaging one thousand words in length, $\$ 3$, which includes cost of certified copy for filing in the office of the Secretary of State.

9. Commencing Business. - Corporations in order to transact any business with persons other than the stockholders must procure subscriptions in good faith for at least fifty per cent of the authorized capital stock. When this has been done, the corporation may commence the transaction of its business. Such business must be commenced within two years after organization (secs. 543, 5(5)). Before commencing business the corporation must file in the office of the Secretary of State a statement signed by its president or secretary, giving the location of its office or offices within the State and the name or names of its agent upon whom process may be served (sec. 571).

10. Organization Meeting. - Organization meeting must be held within the State in the absence of any statute providing otherwise.

11. Meetings of Stockholders and Directors. - All meetings of stockholders must be held within the State. Directors' meetings may be held withont the State if the by-laws so provirle (sec. 551).

12. Directors' Qualifications and Liabilities. a. Qualifications. There must be at least three directors, each of whom must own in lis own 278 
right not less than three shares of stock. There are no residential requirements. Directors may be classified if desired. They must also adopt by-laws (secs. 542, 551).

b. Liabilities. - Directors are jointly and severally liable for the declara. tion and payment of dividends when the corporation is insolvent or the declaration or payment of which renders it insolvent or which diminishes the amount of its capital stock. They are also jointly and severally liable for knowingly causing to be published or given out any false statement or report of the condition of the corporate business, or for failing or refusing to comply with or for violation of any provision of the Business Corporation Act applicable to them (secs. 548-550 inclusive).

Prewitt $v$. Trimble, $92 \mathrm{Ky.} 176 ; 17$ S. W. 356; Kruse $v$. Humpert, 21 Ky. Law Rep. 985 ; 53 S. IV. 657.

13. Stockholders' Liabilities. - Stockholders in ordinary business corporations are liable only for their unpaid stock subscriptions (Laws of 1902 , chap. 10).

Cincinuati Cooperage Co. $v$. Bate, $16 \mathrm{Ky}$. Law Rep. $626 ; 26 \mathrm{~S}$. W. 538 ; Senn $v$. Levy, $23 \mathrm{Ky}$. Law Rep. 662, 1331; 63 S. W. 776.

14. Stock Certificates. - Erery shareholder is entitled to hare a stock certificate issued to him signed by such officers as may be desiguated in the by-laws.

15. Preferred Stock. - Corporations may provide in the articles of incorporation for classes of stock such as preferred, common, or deferred shares. Preferred stock cannot be issued except for cash or its equivalent, nor for less than the par value of the shares. The rights of preferred stockholders are specifically set forth in the statute (sec. 564; Laws of 1904, chap. 105).

16. Payment of Capital Stock. - Stock ean be issued only for money paid, labor done, or property actually received and applied to the purposes for which the corporation was created. No labor nor property shall be receired in payment of stock at a greater value than the market price at the time the labor was done or the property delivered. All fictitious iucreases of stock shall be roid (sec. 568 ).

17. Books. - A book containing the name and post-office address, the number of shares held by each stockholder, and the time when such person became a stockholder must be kept. Also a stock transfer book must be kept at the principal office of the corporation within the State (sec. 516). This is open to the inspection of stockholders and ereditors.

18. Office and Agent. - Fvery corporation must maintain an office within the State and have an authorizd agent therein upon whom process may be served. The designation of such agent must be filer in the office of the Secretary of State hy certificate signed by the president or seeretary giving location of the office of the company in the State, and the name of the agent upon whom proeess may be served (see. 571).

Standard Oil Co. \%. Commonwealth, 23 Ky. Law Rep. 302; 62 So. W. 897.

19. Reports. - No anmual reports are required.

20. Anti-Trust Statute. - There is an anti-trust statute in foree directed against illegal combinatims, jools, and trusts (Cons., sec. 198; K. S., secs. 3915-3921 inclusive).

21. Annual License Tax. - There is no annual license tax. 
22. Extension of Corporate Existence. - There is no statutory provision therefor.

2:: Statutory Grounds for Forfeiture of Charter. - Every charter is liable to be forfeited by suit bronght for that purpose, by the State for failung to comply with any requirement or provision of its charter or for any abnse or misuse of its corporate powers, and shall have thereby become detrimental to the intermal welfare of the State. 'The charter is liable to forfejture for failure to commence business within two years after its organization, for entering into illegal trusts, combinations, and pools, or for giving money to fix the result of any election (secs. 565, 569).

S. E. Co. 2 . Commonwealth, 21 Ky. Law Rep. 1556 ; 55 S. W. 684.

24. Amendments. - By consent in writing of owners of two-thirds of capital stock, the articles of incorporation may be annended for any purpose. Said alteration or amendment to be signed and acknowledged by the directors or a majority of them, and filed and recorded as articles of incorporation are required to be filed (secs. 559, 574).

25. Dissolution. - Any corporation may, by consent in writing of the owners of a majority of its stock, close its business and wind up its affairs (sec. 561).

26. Foreign Corporations. - The only requirements necessary to be complied with in order to transact business within the State on the part of foreign corporations is the desiguation of an agent upon whom process may be served, and a declaration of the name of such agent and the domicile of the corporation, by filing same with the Secretary of State (Act 1890, p. 185 ; see also Cons., sec. 202).

Commonwealth v. Read Phosphate Co., 23 Ky. Law Rep. 2284; 67 S. W. 45; Aultman Taylor Co. $v$. Mead, 22 Ky. Law Rep. 1189 ; 60 S. W. 294.

\section{LOUISIANA.}

(The references cited below are to Wolff's Rerised Statutes of 1904 unless otherwise stated.)

1. Statutes under which Business Corporations may incorporate. The Business Corporation Act of Louisiana is found in the Revised Statutes of that State, 1904, secs. 683-741; see also Civ. Code of J.ouisiana, 1870, secs. 427-447. (See Laws of 1902, Acts 53, 154; Laws of 1904, Act 78.) Special acts are provided for banking, building and loan, canal, insurance, railway, safe deposit, and trust, street railway, surety, telegraph and telephone companies. Incorporation for stock-jobbing business is expressly forbidden (sec. 6s:3; Laws of 1858, Act 36).

2. Incorporators. - The number of incorporators varies with the nature of the corporation. For many purposes six incorporators are required. There are no resirlential requirements (sec. 68:3; Laws of 1882, Act 111; Laws of $19(22$, Act 154). Three or more persons may form themselves into a corporation for the purpose of carrying on any mechanical, mining, or manufacturing husiness (except distilling or manufacture of intoxicating liquors), or for the purpose of carrying on any lawful business or purpose not otherwise provided for. There are no residential requirements (Laws of 1904, Act 78).

Ross $v$. Crockett, 14 La. Ann. 811 ; Board of Trustees, etc. v. Campbell, 48 La. Ann. $1543 ; 21$ So. 184.

3. Contents of the Charter (sec. 685). - The charter must contain : 250 
a. Name. - A corporation organized under "Limited Liability Act" must have the word "limited" in its name. Similarity of names is not forbidden.

b. Domiciliary Office. - The location of the principal office or place of business within the State.

c. Purposes. - Corporations may be organized for more than one purpose if none of these are within those classes for which special acts are provided and if the eorporation has a subscribed eapital of $\$ 3,000$ or orer (Laws of 1904 , Aet 78).

d. Service of Process. - An officer must be designated upon whom process may be served.

e. Capital Stock. - Amount of capital stock, number of shares, par value of same, time when and manner in which payment thereof sliall be made. The capital stock of any corporation carrying on a mechanical, mining, or manufacturing business (except the distilling and manufacture of intoxicating liquors) must be not less than $\$ 5,000$ nor more than $\$ 1,000,000$. Limited liability companies must have a eapital stock of not less than $\$ 5,000$ actually subscribed. The par value of the shares may be any amount.

$f$. Election of Directors. - The mode in which the election of directors shall be conducted.

g. Dissolution. - The mode of liquidation at the termination of the charter (sec. 685).

The duration of charters is ninety-nine years (sec. 681).

4. Statutory Powers. - The stitute enumerates the implied common law powers of corporations, and also confers the following additional powers : Business and manufacturing corporations whose oljects are of the sime general nature may consolidate. The right to receive legacies and donations is also given (sec. 684; Laws of 1874, Act approved Dec. 12 ; see also Cons., 1898, sec. 26.5).

5. Corporate Indebtedness. - Railway, plank road, turnpike, eanal, warehouse, drainage, sewage, land reclaimer, leree building, waterworks, electric lighting and power, bridges, mills and refineries, saw-mills, rice-mills, cotton-oil mills, erecting companies, ship-building and dock corporations may borrow money and issue bonds and mortgage their properties and franchises under such terms as the directors may direct or deem expedient (Laws of 1902, Act 30; see also Laws of 1902 , Act 121).

6. Procuring the Charter. - The articles must be signed and acknowledged before a notary. Charters for commercial and manufacturing purposes must be recorded in the office of the recorder of mortgages of the parish of their domicile, together with a list of subscriptions to their stock. Such charters must also be published in some daily newspaper within the parish of the domicile five times within thirty days. It is not neeessary to publish the list of subscribers. A duly certificd eopy of the charter taken either from the record of the notary before whom the act was passed or froin the record thereof in the office of the recorder in whose office said charter shall have been recorded, must be filed in the office of the Secretary of State. To this copy wust be affixed the certificate of the recorter, attesting recordation of the act in his office, etc ; also a copy of one issue of the ne:wsplaper wherein the said charter shall have heen lmblished, together with the affilavit of publication (secs 677, 686; Laws of 18919, Act 5!1).

7. Organization Tax - There is mo or ranization fax, properly speaking. The preliminary fee to the Secretiry of State is 825. Notiry's fees range from \$25 npward for lrawing the rharter, being regulated by the length of the charter and the amount of capital stock. 
8. Filing and Recording Fees. - For filing and recording in office of Secretary of state, s.5. Notary's fees for ordinary charter should not exceed Sob for dian ing same; recording the charter in eounty recorder's office, 25 eents per folio: for publishing articles in newspaper the price varies with the locality, being much higher in New Orleans than elsewhere; average charge is $\$ 15$; cost of certified copy of the articles averages about $\$ 5$; district attorney's fees, 85 (Laws of 1902, Act 163).

9. Commencing Business. - Corporations may lregin business immediately after the first publication of the charter. No specific amount of the capital stock need be subscribed for or paid in in order to entitle the corporation to hegin business.

Globe Realty Co. $v$. Whitney, 106 La. Ann. 257; 30 So. 745.

10. Organization Meeting. - In the absence of any statute providing otherwise, the organization meeting must be held within the State (see. 711).

11. Meetings of Stockholders and Directors. - All ineetings, whether of stockholders, directors, or oflicers, must be held at the domicile of the corporation within the State. 'Ihe law provides that any such meeting held elsewhere and any business transacted thereat sliall be unlawful and of no effect (sec. $7+1)$.

12. Directors' Qualifications and Liabilities. a. Qualifications. - The statute does not provide the specific number of directors, neither are there any resilential requirements (sec. 684).

b. Liabilities. - There are no statutory liabilities imposed upon directors.

13. Stockholders' Liabilities. - Stockholders are liable for unpaid balance due the company on shares owned by them. The statute specifically provides that no mere informality in organization shall have the effect of exposing a stockholder to any liability for unpaid balance due on their stock. The statute further provides that the word "limited" shall be the last word of the name of every corporation. The act further provides that the omission of the word "limited" in the use of the name of the corporation shall render it and every person participating in such omission or knowingly acquiescing therein liable for any indebtedness, damage, or liability arising therefrom (sec. 690 ; Laws of 1888 , Act 36 ).

14. Stock Certificates. - Every stockholder is entitled to have a certificate issued to him signed by such officers as may be designated in the by-laws.

15. Preferred Stock. - There is no statutory anthorization for the issuance of preferred stock.

16. Payment of Capital Stock. - Stock may be issued under the constitution for labor done or money or property actually received. All fictitious issues of stock are declared void (Cons., Art. 266).

17. Books. - The corporation is required to keep a stock transfer book at its domicile within the State. This book must be kept open for public inspection (Cons., Art. 273).

Legendre $v$. Association, 45 La. Ann. $669 ; 12$ So. 837 ; Bourdette $v$. Sieward, 107 La. Ann. 258 ; 31 So. 630.

18. Office. - Every corporation is required to keep a public office or place of business within the State for the transaction of its business (Cons., Art. 264, 273 ; li. s., sec. 740$)$.

19. Reports. - The presilent, cashier, secretary, or agent of every stock corporation must, on or before the first day of $\mathrm{M}$ illch in each year, make and deliver to the State collectors or assessors of the parish in which such com-

$$
2>2
$$


pany is liable to be taxed a written statement under oath specifying: first, the real estate, if any, owned by such company when the same is located in this State; second, the capital stock actually paid in and not invested in real estate; third, the place of its principal business or where its principal operations are carried on in which it is liable to be taxed (sec. 736; see also Laws of 1898 , Act 170 ).

20. Anti-Trust Statute. - There is a constitutional prolibition forbidding corporations to combine or conspire together for the purpose of forcing up or down the price of any agricultural product or article of necessity for speculative purposes (Cons., Art. 190). Linder the Act of July 7, 1892, this Constitutional provision is put in force in the form of an express anti-trust statute (Laws of 1892, Act 90).

21. Annual License Tax. - There is no aunual license tax, properly speaking, in existence in Lonisiana.

22. Extension of Corporate Existence. - There is no statutory provision therefor.

23. Statutory Grounds for Forfeiture of Charter. - The charter may be forfeited for fictitious issues of stock, for violation of the anti-trust act and for insolvency (Laws of 1902, Act 224 ; see also Cons., Art. 266, and R. S., sec. $731)$.

La. Savings Bank, 35 La. Ann. 196.

24. Amendments. - Ordinarily amendments may be adopted by rote of three-fourths of the stock represented at any meeting called for that purpose. The capital stock may be increased or decreased, howerer, by a two-thirds vote. Amendments must be recorded and filed in the local office and in the office of the Secretary of State, but do not need to be published (Act 26, 1852; Act July 14, 1898; sec. 687). The charter may be annended in any other respect desired.

25. Dissolution. - Corporations may be dissolved by vote of three-fourths of the stockholders represented at any meeting called for that purpose (Civ. Code, Art. 447; R. S., sec. 688; Laws of 1902, Act 2.24).

Curie $v$. Santini, 16 La. Ann. 27.

26. Foreign Corporations. - Foreign corporations must deposit in the office of the Secretary of State a statenent showing the place of its domicile, together with the name of the agent or officer within the State upon whom service of process may be made (Cons., Art. 261; Act of July 10, 1 590 ; Act of June 28, 1900, sec. 375). They are also required to file the same annual reports as domestic corporations (sec. 736 ; Lawws of 1898 , Aet 170).

State ex rel. Watkins v. Company, 106 La. Ann. $621 ; 31$ So. 172 ; State $v$. Southern Pacific Co., 52 La. $\Delta u n .1822$; 28 S̆o. 372; Milwaukee Trust Co. $v$. Insurance (o., 106 La. Ann. 669; 31 So. 298; New Orleans v. Insurance Co., 106 La. Ann. 31 ; 30 So. 254.

\section{MAINE.}

(The references citec below are to the Revised Statutes of 1904 , chap. 47 , unless otherwise stated.)

1. Statutes under which Business Corporations may incorporate. Business corporations are organized undur the provisions of chap. I7 of the Revised Statutes of 1904 . Special acts are provided for lianlis, gas and electric companies, navigation, railway, insurance, and trust companies, telc- 
graph and telephone, water and aqueduct corporations. Corporations may, howerer, be formed for the construction and operation of railways without the State; also telegraph and telephone companies, gas and electrical companies with the same limitations (sec. 6).

2 Incorporators. - Any number of persons not less than three may in. corporate. 'There are no specific resilential requirements (sec. 6).

3. Procuring the Charter. - The incorporators should first prepare and sign written articles of association, setting forth the purposes of the corporation, the place where the first meeting of incorporators shall be held, and the date thereof, together with the names and residences of the incorporators. They should then sign a waiver of notice of the first meeting of incorporators, fixing the time and place of holding said meeting, describing the purposes thereof as follows: (1) to organize into a corporation; (2) to adopt a corporate name; (3) to define the purposes of the corporation; (4) to fix the amount of eapital stock and divide the same into shares; (5) to elect a president, not less than three directors, a clerk, a treasurer, and all other necessary officers; (6) to adopt a code of by-laws; (7) to act upon any other business which may properly come before the meeting. 'The meeting should then be held, whereat a chairman and a clerk are chosen. The clerk should be forthwith sworn. After the business described above is concluded, a certificate of organization shonld be prepared and signed by the president and a majority of the board of directors (for contents of certificate of organization see sec. 4 , post). This certificate must be sworn to by the persons signing the same. The certificate of organization must next be submitted to the AttorneyGeneral for examination and approval. After this is obtained, the certificate of organization, together with the certificate of the Attorney-General approving the same, must be recorded in the oftice of the register of deeds of the county where the principal place of business of the corporation is located. Next, a certified copy of the certificate of organization must be filed in the office of the Secretary of State. As soon as the certificate above referred to is filed in the office of the Secretary of State, the corporate existence commences (secs. 3, 4, 6, 7, 8, 9, 10).

4. Contents of the Certificate of Organization. - The certificate must set forth :

a. Name. - The name of the corporation. Similarity of names is not forbidden.

b. Purposes. - As many purposes as may be desired may be inserted provided they are not covered by special acts.

c. Corpital Stock. - The capital stock cannot be less than $\$ 1,000$.

d. Capital Stock paid in. - No particular amount required by statute.

e. Par Value of Shares. - This may be any amount.

$f$. Stockholders. - Names and residences of the subscribers to capital stock.

g. Domiciliary Office. - The name of the county where the corporation is located.

Chafee v. Bank, 71 Me. 514

1. Directors. - Number and names of directors. There must be at least three, and all must be stockholders. There are no residential requirements.

i. Clerk. - Name and residence of the clerk. The clerk must be a resident of the State (secs. 3, 7 ).

5. Statutory Powers. - In addition to the enumeration of the common law powers of corporations, the statute grants to corporations a number of ad284 
ditional powers which may be enumerated as follows: To hold stock and bonds in other corporations, to conduct business in other States and countries, to issue preferred stock, to consolidate with other corporations, to rote by proxy, to forfeit stock for non-payment of assessments, to hold directors' meetings outside of the State, to issue stock for services and property (secs. $16,17,37,38,46,51)$.

Franklin Co. $v$. Bank, 68 IIe. 43.

6. Corporate Indebtedness. - There is no statutory limitation as to the amount of indebtedness.

7. Organization Tax. - The organization tax is $\$ 10$ for companies having a capital stock of $\$ 10,000$ or less. Beyond that and up to $\$ 500,000$ the organization tax is $\$ 50$, and for each hundred thousand dollars in excess of $\$ 500,000, \$ 10$ additional (sec. 8 ).

8. Filing and Recording Fees. - Fee to Attorney-General for examining and approving certificate of organization, $\$ \bar{s}$; fee to register of deeds for recording certificate of organization and certified copy, usually from $\$ 4$ to $\$ 5 ;$ fee to Secretary of State for filing certified copy of certificate of organization, $\$ 5$; fee to Secretary of State for certified copy of organization certificate, $\$ 3$ (sec. 8).

9. Commencing Business. - Aside from the right to perfect the organization of the corporation, no business can be transacted until after the certificate of organization is approved by the Attorney-General. rccorded in the oflice of the register of deeds, and a certified copy thereof filed in the office of the secretary of State (sec. 10).

10. Organization Meeting. - Must be held within the State in the absence of any statute authorizing it to be held elsewhere (sec. 11). 'Tlue first directors' neeting should also be held there (Laws of 1903, chap. 182).

Freeman $v$. Company, 38 Me. $3+3$.

11. Meetings of Stockholders and Directors. - All meetings of stockholders must be held within the State. Directors' meetings may be held with. out the State if the by-laws so provide (sees. 11, 19).

12. Directors' Qualifications and Liabilities. a. Qualifications. - There must be at least three directors, each of whom must be a stockholder. 'There are no residential requirements. 'They may be classified if desired, and may act through committees (sec. 19).

b. Liabilities. - Directors are liable for the illegal declaration of dividends (sec. 32 ).

1:3. Stockholders' Liabilities. - Stockholders in ordinary business corforations are liable only for thrir unpaid stock subscriptions (sces. 41,95 ). 'They are also liable to creditors to the extent of illegal dividends received by them (sec. 32).

Grindle $v$. Stone, 78 . Me. 176; 3 Atl. 183.

14. Stock Certificates. - Wach shareholder is entitlen to lave a stock certificate issucd to him signed by the president or vice-president and by the cashice, clerk, or treasurer (sec. : : 4 ).

15. Preferred Stock. - Two or more kinls of stock may be created with such distinctions, preferences, and roting luwers as shall be fixed and determined by the by-laws or by wote of thro storkfolders at a uneding called for that purpose. Any or all of the eapital stock may be prefermol, and any dividend paid thereon that maty be desired (see. 49 ). 
16. Payment of Capital Stock. - 1 corporation may purchase mines, mamulaturies, or other property necessary for its business, and the stock of other companies owning mining, mamufactming, apparatus, mills, or other proprenty necessary for its business, and issue stock to the amomit of the value thereof in pryment therefor. May likewise issue stock for services rendered to such corporation, and the steck so issued shall be full-paid stock and not liable to any further call or payment thereon, and in the absence of actual framl in the transaction the judgment of the directors as to the value of the froperty purehased or services rendered shall be eonchusive (sees. 50, 51).

Libly r. Tohey, 82 Me. 397 ; 19 Atl. 904.

17. Books. - The clerk is requirel to keep at the office of the eorporation within the State all corporate records and a stock register which shall be open at all reasonable hours to the inspection of persons interested, who may make extracts therefrom (sees. 19, 21).

15. Office and Clerk. - All domestic corporations must have a clerk and must kcep at some fixed place within the State a elerk's office where shall be kejt the corporate records and the stock register (sees. 3, 20).

19. Reports. - Corporations must file in the oflice of the Seeretary of State ammally on or before the first day of Jume a statement signed and sworn to by the president or treasurer containing the names of the directors, the presilent, treasurer, and clerk, with the residence of each, the location of its principal oflice within the State, and the amount of authorized eapital stock sec. 26$)$.

20. Anti-Trust Statute. - Combinations for regulating prices are prohibited (secs. 53, 5i).

21. Annual Franchise Tax. - Where the authorized capital stock does not exceed $\$ 50,000$, the ammal franchise tax is $\$ 5$. Where the capital stock does not exceed $\$ 2(10,000$, the tax is $\$ 10$; where it does not exceed $\$ 500,000$ the tax is $\$ 25$; where it does not exceed $\$ 1,000,000$, the tax is $\$ 50$; for each additional million dollars, or part thereof, $\$ 25$ additional. This tax beeomes due and payable on the first day of September, and is assessed on or before the first day of July of each year (chap). S, secs. 18, 2.2).

22. Statutory Grounds for Forfeiture of Charter. - Failure to organize within two years from the date when the eertificate of organization lias been filed with the Secretary of State renders the eharter liable to forfeiture. Also whenever the ammal franchise tax shall have remained in arrears for the period of one year after the same shall have become payable (chap. 1, secs. 28, 29 ; chap. 8, secs. 21, 22).

23. Amendments. - Corporations may change their names and location, increase or reluce the amount of authorized eapital stock, change the number of shares or the number of directors by a majority vote of the stock issued and ontstanding. 'The amendment to take effect when a certificate of the change has been filed in the office of the Secretary of State, which must be done within ten days after the vote is taken. The purposes of the corporation camnot be changed except by act of the legislature (sees. 36, 39, 40, 44, 45, $47,52)$.

24. Extension of Corporate Existence. - There is no provision for the extension of corporate existence.

2:. Dissolution. - Corporations may be dissolved upon application to the courts (secs. 77, 83).

215. Foreign Corporations. - There are no statutory requirements as to 256 


\section{SYNOPSIS-DIGEST OF INCORPORATION ACTS.}

the transactions of business by foreign corporations within the State. No license fee is exacted.

Cousens $v$. Lovejoy, 81 Me. 46i ; 17 Atl. 495; Childs $v$. Cleaves, 95 Me. 498 ; 50 Atl. 714.

\section{MARYLAND.}

(The references cited beiow are to Art. XXIII. of the Public General Laws, 1888, unless otherwise stated.)

1. Statutes under which Business Corporations may incorporate. - The Business Corporation Act of Maryland is found in the Public General Laws of Maryland, 1888, secs. 1-303 inclusive. Under this act corporations may be formed for any purpose designated in twenty-five classes.

2. Incorporators. - Five or more persons, who must be citizens of the United States and a majority of them citizens of Maryland (secs. 14, 42).

3. Contents of the Certificate of Incorporation. - The certificate wust set forth :

a. Incorporators' Names. - Names in full and places of residence of the incorporators (sec. 42, sub. 1.)

b. Name. - Corporate name, which shall always include the name of the county or eity in which it may be formed. Similarity of names not forbidden (sec. 42 , sub. 2 ).

c. Purposes. - The objects or purposes for which the corporation is formed. The statute expressly provides that companies may be incorporated for two or more of the purposes designated in the various classes (secs. 35, 42, sub. 3 ).

d. Duration. - 'Time of existence not to exceed forty years (sec. 42, sub. 3).

e. Provision for the Regulation of Internal Affairs. - Articles, conditions, and provisions under which the corporation is formed (sec. 42, sub. 3).

$f$. Domicile. - Places where the operations of the corporation shall be carried on and location of the domiciliary office within the State (sec. 42, sub. 4).

g. Capital Stock. - Amount of capital stock, if any. This is unlimited as to ainount (sec. 42 , sub. 5).

h. Shares. - Number and par value of shares. Par value of shares may be any amount (sec. 42 , sub. 6).

i. Directors. - Number of directors and names of the board for the first year (sec. 4:, sub. 7).

4. Statutory Powers. - In addition to the statutory enumeration of common law powers, corporations have the following additional powers: To vote by proxy at stockhollers' meeting, to forfeit the stock for non-payment of assessments, to consolirlate with other corporations, to renove directors, and to hold property within or without the state (sees. 7, 11, 39, 39 a, 50-5fi).

Booth el al. v. Robinson ef al., 55 MIl, 419.

5. Procuring the Charter. - Charter must be executed and acknowledged and then submitted to one of the judges of the jurlicial circuit within which the principal office of the emporation is to be Incated (in Baltiunore, to one of the judgres of the supreme l'neh of lialtimore ('ity). If he alproves it, he certifies that fact 11 on the certificate. 'The certificate is then recorded in the oflice of the clerk of the cirenit conrt of the eonuty in which the principal office is to be located (in Paltiunce in the ollice of the clerk of siuperior Court of Baltimore City). Upon so recorling corporate existence commences. 
The certificate of the judge is male conclusire evidence that the certificate does conform to law.

Bonaparte e. B. 11., etc. Co., 75 Md. 340; 23 Atl. 784.

6. Corporate Indebtedness. - Corporate indebtedness must not exceed total amount of authorized capital stock (sec. 75).

7. Organization Tax. - The organization tax is one-eighth of one per cent upon the capital stock authorized (G. L., Art. IXXXXI. sec. $88 \mathrm{f}$ ).

8. Filing and Recording Fees. - Filing fees in local comnty office, jo cents per folio; clerk of courts fees, $\$ 5$; cost of certified copy of the certificate of incorporation for filing with State tax commissioner, $\$ 3.00$.

9. Commencing Business. - Corporations camot commence business until a certified copy of the articles is filed with the tax commissioner. No special amount of stock need be subscribed, but one-fourth of the capital stock must be paid in each year.

10. Organization Meeting. - The organization meeting must be held within the State, in the absence of any statute providing otherwise.

11. Meetings of Stockholders and Directors. - Stockholder's' meetings must be held within the State. Directors' meetings may be held without the State if the by-laws so provide (secs. 6,7).

12. Directors' Qualifications and Liabilities. a. Qualifications. - Must not be less than four nor more than twelve. All must be citizens of the United States and a majority of them citizens of Marylaul. They may be removed by the stockholders (sec. 57). Cumulative voting may be provided for if desired (sec. 58).

b. Liabilities. - Jirectors are liable for illegal payment of dividends and for loans to stockholders. The president and a majority of the directors must within thirty days after the payment of the last instalment of the capital stock make a certificate stating the amonnt of capital stock paid in and of all property received in payment of stock subscriptions and the extent to which such payments have been male in property. The certificate must be then signed and sworn to by the president, and must be filed with the clerk of the court in which the certificate of incorporation is recorded (secs. 65, 67, 68, 69).

Fisher $v$. Parr, 92 Nd. 245; 48 Atl. 621.

13. Stockholders' Liabilities. - Stockholders are liable to the extent of their unpaid stock subscriptions. They are also liable to creditors to an amount equal to the amount of their stockholdings for all debts contracted in the name of the corporation until the amount of capital stock fixed in the certificate of incorporation has been paid in, and a certificate thereof made and filed by the secretary and board of directors as provided by law (secs. 64, $66,271)$.

Rider $v$. Morrison, 54 Md. 429.

14. Stock Certificates. - Each stockholder is entitled to a certificate signed by such oflicers as the by-laws may prescribe.

15. Preferred Stock. - Preferred stock may be issued either by providing for such issuance in the certificate of incorporation, or by vote of the common stockholders thereafter had (sec. 291).

Scott $v$. Company, 93 Id. $475 ; 49 \Lambda$ tl. 327.

16. Payment of Capital Stock. -- Stock subscriptions may be paid for in land or other property at a valuation agreed upon between the corporation 258 
and the subscribers where the property is such as is suitable for corporate purposes (sec. 61 ; see also sec. 65).

17. Books. - A book must be kept containing a list of stockholders, showing place of residence and number of shares held by them, time when they became owners of such shares, and such book must be kept open for inspection during business hours by the stockholders (sec. 72 ; see also sec. 5 ).

Weihenmaver $v$. Bitner, 88 IId. 325; $42 \mathrm{Atl}$. 245; Brant $v$. Ehlen, 59 IId. 1 : Cahill $v$. Association, 94 IId. $353 ; 50$ Atl. 1044 .

18. Office. - Must maintain an office in the State (sec. 12).

19. Reports. -- Stockholders owning five per cent of the capital stock are entitled, upon written request, to have a report in detail of assets and liabilities of the corporation. In January or July the president and treasurer file statement of affairs in records of the corporation (secs. 5, 71, 73).

20. Anti-Trust Statute. - There is no anti-trust statute in Maryland.

21. Statutory Grounds for Forfeiture of Charter. - Charters may be forfeited for failure to pay taxes for a period of two years, or for nou-user or misuser of corporate powers (secs. 85 e, 255, 263; Laws of 1900, chap. 272).

22. Amendments. - Charters may be amended for any purpose lesired. A peculiar provision is in force in Maryland which has the effect of permitting a change in the par value of the shares. Where the par value of the stock is reducerl by losses, the stockholders may establish the true value of the stock at a meeting called for that purpose, and may provide for calling in and cancelling the whole or any part of such stock and issue stock in lieu thereof at such par value as they may decide so as to represent the amount of the true value so estahlished (secs. $47,71-78,79,80$ ).

2). Extension of Corporate Existence. - (See Laws of 1900, clap. 272).

21. Dissolution. - liy the State (Attorney-General) forfeited for misuse, etc., or by vote of stockholders for any reason, by bill in equity in name of the corporation. There can be no dissolution until all State taxes are paid (C., Art. X.III. secs. 25.5, 264, 26.5; Act 1892, chap. 399 ; Laws of 1902 , chap. 198).

25. Annual Franchise Tax. - None after organization, but one-eighth of one per cent each year, unless the company is organizerl within two years from date of certificate of incorporation (Laws of 1900, chap. 272).

26. Foreign Corporations. - File with Secretary of State their charter, with fee of \$2.5 and a statement setting forth amount of capital stock anthorized and issued, assets and liabilities, chanacter of husiness, principal oflice in State, and appoint agent to receive process (Laws of 1898, chap. 270, secs. $109 \mathrm{a}, \mathrm{b}, \mathrm{c}, \mathrm{d}, \mathrm{e})$.

Crook v. Company, 87 Mrl. 138; 39 Atl. 94 ; Condon v. Association, 89 MId. $99 ; 42$ Atl. 944.

\section{MASSACHUSETTS.}

(The refereness cited helow are on the Jaw of $190 \%$, chap. 437 , commonly known as the "Business Corporation lalw.")

1. Statutes under which Business Corporations may incorporate. Unler the act that went into effect Iugust 1, 190:, parties may incorporate for any lawful [urpose not coverel hy special act, except to buy and sell real estate or to clistil and manuficture jutoxicating linjors. Sipecial acts are provided for banking, trust, surety, silfe deposit, insurance, railway. striet 
railway. telegraph, telephone, was, electric light, heat, power, canal, aqueduct, cemelery amb erematory companies.

$\because$ Incorporators. - There must he at least three incorporators. There are 110 resilential repluirements (sec. 7 ).

Mialworth 2 . Braketet, 98 Mass. 98.

$\therefore$ Articles of Incorporation and Organization. - The incorporators shonhl tirst prepare and sign an agrement of association, stating (a) that the suberibers thereto associate thenselves together with the intention of forming a corporation. The arreement shonlu also set forth $(b)$ the corporate name to be assumel, (c) the location of the principal oflice of the corporation in the commonwealth and olsewhere, as well as if the corporation is organized to do business wholly outside of the Commonwealth. In addition to the foregoing the agreement shonlu also set forth (d) the purposes for which the corporation is formel, the nature of the business to be transacted,1 $(e)$ total amomt of authorizul capital stock of the corporation not to be less than $\$ 1,000$, par value of the shares not to be less than $\$ 5$, and the number of shares into which the capital stock is to be diviled, and the restrictions if any imposed upon its transfer. If there are more than two classes of stock, a description of the classes and a statement of the terms npon which they are to be created and the methor of voting thereon. ( $f$ ) If desired, provisions may be inserted for the comluct and the regulation of the business of the corporation, for its voluntary dissolution, or for limiting or defining or regulating the powers of the curporation or of its directors of stockholders. (g) The subscribers by whom the first meeting of the corporation is to be called must be stated, or, in lien thereof, the notice of said meeting is waved in writing by each of the incorporators. (h) There must also appear the names and residences of the incorpulators, and the amount of stock subscribed for by each. The meeting shoull then be hell, whereat a chairman and temporary clerk should be chosen. The clerk slonkl be forthwith sworn. After by-laws have been adopted the incorporators must proced to the election of directors, a treasurer, clerk, and such other ofheers as the by laws may prescribe. A majority of the directors must forthwith mike, sign, and make oath to the articles of organization (for contents of articles of organization see sec. 4 , post). The articles of organization and the records of the first meeting of incorporators must be sulunitter to the commissioner of corporations for examination, and he may require such amenlments thereof and such allitional information as he may think necessary. If he funls the articles conform to the provisions of the statute, he shall so certify and endorse his approval thereon. Thereupon the articles shall upon payment of the organization tax be filed for record in the oftice of the Secretary of State of the Commonwealth, who will issue a certificate of incorporation. The corporate existence commences upon the filing of the articles of organization in the oflice of the Secretary of the Commonwalth. The certificate of incorporation or a certified copy thereof is conclu-ive evilence of the existence of the corjoration (secs. 8, 9, 10, 11, 12).

IBiril $v$. Mitgrgett, 97 Mass, 494.

1. Contents of the Articles of Organization. - The articles of organization must set forth : (1) A true copy of the agreement of association, and the names of the subscribers thereto. (b) The date of the first meeting and

The Socretary of State permits the insertion of any number of purposes in the articles of a werciation mot covered by special act.

290 
all adjournments thereof, if any. (c) Amount of capital stock to be issued, the amount thereof to be paid for in cash, by instahments, and the instalment to be paid before the corporation cormmences business, and the amount thereof to be paid for in property. If such property consists in part of real estate, its location and the amount of stock to be issued therefor shall be stated. If any part of such property is personal, it shall be described in such detail as the commissioner of corporations maty require and the amount of stock to be issued therefor shall be stated. If any part of the capital stock is issued for services or expenses, the nature thereof and the amount of stock which is issued therefor shall be stated. (l) The name, residence, and post-office address of each of the ollicer's of the corporation (sec. 11).

5. Corporate Name. - The name nsed shall indicate that it is a corporation as distiuguished from a natural person or partnership. It is forbidilen to use the name of another domestic corporation or of a foreign corporation, or of any partnership or association carrying on business in the Conmonwealth at the time of such organization or within three years prior thereto, or a name so similar thereto as to be liable to be mistaken for it, except with the consent in writing of said corporation, association, or partnership. Courts are giren express jurisdiction in equity to enjoin the illegal use of the corporate name (sec. 5).

6. Statutory Powers. - In addition to the enumeration of common law powers of corporations, the statute grants to corporations a number of extraordinary powers which may be enumerated as follows: To have perpetual succession ; to insert in the agreement of association rules for the regulation of the internal affairs of the corporation; to alpoint an executive committee from its board of directors, to whom may be delegated the management of the current and ordinary affairs of the corporation. 'The act expressly forbils a corporation to vote upon any share of its own stock. It anthorizes corporations to vote by proxy, to forfeit shares for nou-payment of assessments, to issue preferred stock, and to classify directors (secs. $4,16,19,23,21$ ).

Conmonwealth $v$. Railway, $1+2$ Mass. $146 ; 7$ N. I. 716.

7. Corporate Indebtedness. - There is no limit to the amount of corporate indebterness in Massachnsetts.

8. Organization Tax. - The organization tax is 25 cents on each thonsand dollars of authorized capital stock, except that in no case shall it be less than $\$ 10$ (sec. 88 ).

9. Filing and Recording Fees. - There are no filing fees in the oflice of the Secretary of State other than the organization tax. For certified copy of the articles of incorioration, 85 (secs. $5 !), 90)$.

11. Commencing Business. - Aside from the right to prerfect the organization of the compration, no business ean be transacted mutil the articles of organization have luen approved by the commissioner of corporatious, the organization tax pain, and the certificate recorden in the ollice of the sieretaly of the Commonwealth (sie. 1:2).

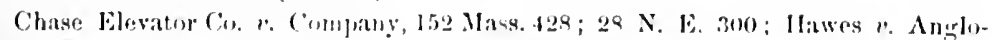

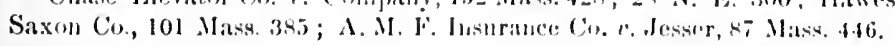

11. Organization Meeting. - I'he: varions strps necessary to procure the organization of the corporation have alrealy heren sut forth in sece. 3, anle. The organization menting must take place within the ('ommonwealth. The statntory officers in Massachusetis are a fresident, clerk, and treasurer (sces. $9,10,20)$. 
12. Mcetings of Stockholders and Directors. - All meetings of stockhollers must be hehl within the state. 1)irectors' meetings may he held without the state if the by-laws so provide (secs. 20,25 ; Laws of 1901 , chap. 207).

13. Directors' Qualifications, Powers, and Liabilities. a. Qualificafions. - There must be at least three directors, each of whom must be a stockboleter unless the by-laws otherwise provide. There are no residential requirements. The president of the corporation must be elected annually by nul from the hand of directors. The other ollicers are elected by the stockhohlers. Directors may be divided into classes not exceeding five, if desired (sec. 18). Under the statute the board may elect from its members an executive committee, to whom may be delegated the management of the current and orlinary business of the corporation (secs. 17, 18, 19).

b. Linbilities. - l)irectors who make oath falsely to articles of organization are jointly and severally liable to any stockholder for actual damages caused by false statements therein and which they knew to be false. Also, for debts aind contracts of the corporation where they deckare or assent to a dividend when the corporation is or thereby is rendered bankrupt or insolvent, to the extent of such dividend. Also, for debts contracted between the time of making or assenting to a loan to the directors and the time of its repayment, to the extent of such loan unless they roted against such dividend or the paying of such loan (secs. 34,35). No director can be held liable for its debts or contracts unless the corporation has been duly adjudicated bankrupt or unless a jutgment has heen recovered against it and it has neglected for thirty days after demand made upon it to pay the amount due (secs. 14, 36).

Cole $v$. Cassidy, 138 Mass. 437.

11. Stockholders' Liabilities. - Stockholders are liable for the debts of the corporation in any crent to the extent of their unpaid stock subscriptions. The statute also provides that stockholders who vote to reduce the capital stock of the corporation coutrary to law shall be liable for the payment of the debts and contracts of the corporation existing at the time of such reduction to the extent of the amonnt withdrawn. Stockholders are also liable for all moners due to operatives for services rendered within six months before demanl imarle upon the corporation and its neglect or refusal to make such prayment (secs. 3:3, 36, 39).

Ilancock National Bank $v$. Ellis, 166 Mass. 414 ; 44 N. E. 349 ; Pettibone $v$. Company, 145 Mass. $411 ; 19$ N. E. 337.

15. Stock Certificates. - Every stockholder is entitled to have a stock certificate issued to him, signed by the president and treasurer (sec. 26).

Wyman r. Jowder Co., 62 Mass. 168; Sibley $v$. Bank, 133 Mass. 515.

1i. Preferred Stock. - One or more kinds of stock may be created under such terms and conditions as may be provided for in the agreement of association or in an amendment there to adopted as provided by statute (secs. 27,40).

An. Tuhe Works $v$. Machine Co., 139 Mass. 5 ; 29 N. E. 63.

17. Payment of Capital Stock. - Capital stock may be issued for cash, property, services, or expenses. If it is paid for in instalments, this fact must lie set forth upon the certificate. If any stock be issued subsequent to the issue of stock anthorized by the articles of association, then a certificate is prefarrd within thirty days after the date when said stock has been anthorized, and is signed and sworn to by the president, treasurer, and a majority of the directors, setting forth: (a) Total amount of capital stock authorized. (b) The ancunt of stock already issued for cash, payable in instalments, and the 292 
amount paid thereon; also the amount of full-paid stock already issued for either property, services, or expenses. (c) A description of said property an! the nature of said services or expenses. 'This certificate must be submitted to the Commissioner of Corporations. If he finds it conforms to the law, he shall so certify and endorse his approval thereon. The certificate must then be filed in the office of the Seeretary of the Commonwealth, who upon payment of the proper fee shall cause it and the endorsement thereon to be recorderl. The law provides that no stock shall he at any time issued unless the cash or property, services or expeuses for which it was authorized to be issued has been actually receired or ineurred by or convered or rendered to the corporation, and the president, treasurer, and directors shall be jointly and sererally liable to any stockholder of the corporation for actual damages caused to him by such issue (sec. 11).

18. Books. - The clerk is required to keep a record of all proceedings of the stockholders and board of directors. The corporation is required to keep a stock transfer book within the State. These books are open to the inspection of stockholders at all times (see. 30).

19. Office and Clerk. - All corporations must have an office within the State, and must appoint a clerk who is a resident of the Commonwealth (secs. $8,18)$.

20. Reports. - Every corporation shall annnally within thirty diys after the date fixed by the by-laws for the ammal meeting, or within thirty days after the final adjoumment of such meeting, prepare a report of the condition of the company, signerl and sworn to by its presilent, treasurer, and at least a majority of its direetors, stating the name of the eorporation; location of its principal oflice in the Commonwealth or elsewhere in ease the corporation is organized to do business wholly outsicle of the Commonwealth; date of its last preeeding annual meeting; total anomnt of its anthorized cilpital stock; amount due and outstanding and amount then paid thereon; the eliss, or classes, if any, into which it is divided ; the par value and number of its shares; names and addresses of all the directors and officers, and the date on which the term of ollice of each expires; statement of the assets and liabilities of the corporation as of the date of the end of its last fiscal year. . This report must be submitted to the commissioner of corporations for his approval and who shall endorse his approval thereon in conformity with the law. If the corporation has a capital stock of $\$ 100,000$ or more, it shall be aceompanied by a written statement of the affairs of sueh corporation. The statement of the auditar of the corporation's hooks must be filed with the annual report.

In adlition to the foregoing, every compration shall anmally, between the first am tenth of May, malie a return to the tax commisione muler oath of its treasurer, stating the name of the eorporation and setting forth the following as of the first day of May of the year in which the return is marle: the total anmont of the eapital stock of the emporition, amomt issued and ontstanding, and the anomut then paid thereon; closses into which it is diviled ; par value of shatres: mumber of its hames, ambl their marliet value, as to each class of shares, if there are two or wore classen; statement of the real antate,

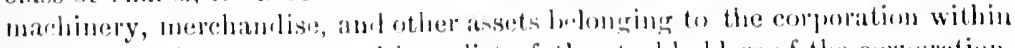

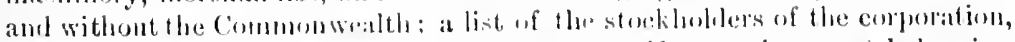
their resileness, the ammut aml class of stock (if more than me) belonging

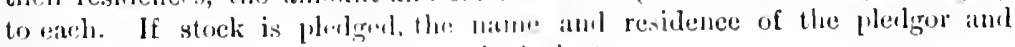
pledgree must be given (sces. t5-50 inelusive). 
21. Anti-Trust Statute. - There is no anti-trust statute.

2:. Ammual Franchise Tax. - The annul franchise tax is based upon the ralue of the eorporate franchises. 'This tax upon the ralue of the corporate franchises, after making eertain deduetions enumerated in the act, shall neessitate a tax levied at a rate to be determined by a proportionate part of the whole amount of money to be raised by taxation upon property in the Commonwealth during the same year, as returned by the assessors of the sereral eities and towns of the State, containing an amount, less said deductions, of not exeeeling twenty per cent in excess of the value as found by the tax eommissioner of the real estate, machinery, merchandise, and securities, which, if owned by a natural person resident of the Common wealth, would be liable to taxation: and the total amount of taxes to be paid by such corforation in any year upon its property to be taxed in the Commonwealth, and upou the value of its eorporate franchises, shall amount to not less than onetenth of on per eent of the market value of its eapital stock at the time such assessment is made by the tax commissioner (secs. 71, 76-87 inchusive). The tax becones clue and payable on November 1st (See also Laws of 1901, chaps. $2 \cdot 25,41 \%$.)

23. Statutory Grounds for Forfeiture of Charter. - Charters may be forfeited for usurpation of franchises or privileges not conferred by law (I. S.. chap. Ist, sec. 1721). Also for failure to pay annual taxes and make annual statements for two successive years (secs. 49, 78).

liussell 2 . M'Lellim, 1+ Pick. 63.

21. Amendments. - Articles of association for the purposes hereinafter designated may be amended at a meeting called for that purpose by a vote of two-thirds of all its stock, or two-thirds of each class of stock outstanding and entitled to vote, or by a larger vote if the agreement of association so requires, to wit: changing the corporate name, nature of its business, classes of stock aud roting powers thereof, sell, lease, or exchange its property or assets, including its good-will and its corporate franchises. After a vote of a majority of its stockholders at a meeting duly called for that purpose the corporation may authorize the change of the location of its principal offee or place of business in the Commonwealth, or change the par value of the shares of its capital stock, and increase or reduce the same, or authorize proceedings for dissolution (secs. 40, 42, 43, 44).

Salem M. D. Corp. $v$. Ropes, 23 Mass. 23.

25. Extension of Corporate Existence. - There is no express provision for the extension of corporate existence. (See however sec. 40.)

20. Dissolution. - By a majority vote of all classes of stock entitled to rote, a petition for dissolution, to be aldressed to the conrts having jurisdiction in the premises, may be authorized (secs. 51-55 inclusive).

Stone $v$. Framingham, 109 Mass. 303.

27. Foreign Corporations. - Every foreign corporation which has a usual place of business within the Commonwealth or which is engaged therein f"rmanently or temporarily, and with or without the usual place of business therein, in the constructim, eretion, alteration, or repair of buildings, brilges, railrouls, or structures of any kiurl, shall, before doing business in this Commonwalth. in witine appoint the commissioner of corporations to be its attrorey upon whom all lawful process may be sorved. A copy of the power of attorney and a coly of the rot: authorizing its execution, duly certified, munt h... film I in the office of the state commissioner, and a eopy of its char291 
ter, a certified copy of its articles of association, and also a true copy of its by-laws, and a certificate in such form as the commissioner of corporations may require, setting forth the name of the corporation, location of its principal office, names and addresses of its president, treasurer, clerk, or secretary, or the members of its board of directors, date of its annual meeting and for the election of officers, anount of its capital stock authorized and due, number and par value of its shares and the amount paid in, and if any part of such payment has been made otherwise than in money, the details of such payment. This certificate nust be signed and sworn to by the president and treasurer and by a majority of its directors. No foreign corporation can transact any business which is not permitted to domestic corporations by the laws of the Comnonwealth.

Before transacting business within the State foreign corporations must pay $\$ 25$ for filing copies of the charter, by-laws, and certificite reyuired by the act. They are also required to make an annul certificate of the condition of the corporation (secs. 50-70 inclusive, also sec. 91). Each year foreign corporations are required to pay an excise tax of one hundredth of one per cent of the par value of its authorized capital stock, as staten in its annual statement of condition, this amount never to exceed $\$ 2,000$ (sec. 75).

Broadway Nat. Bank v. Baker, 176 Mass. 294; 57 N. L. 603; Kennebec Ins. Co. $v$. Augusta Ins, Co., 6 Gray, 204; American Ins. Co. $v$. Owen, 15 Gray, 491 ; Linterprise Brewing Co. $v$. Grime, 173 Mass. 252 ; 53 N. E. 855 ; 11 iyward 2 . Leeson, 176 Mass. 310 ; 57 N. E. 656 ; Bishop $v$. Globe Co., 135 Mass. 132 ; Johnston $v$. Insurance Co., 132 Mass. 432.

\section{MICHIGAN.}

(The references below are to the Session Laws of 1903, chap. 232, unless otherwise stated.)

1. Statutes under which Business Corporations may incorporate. The Business Corporation Act of Michigan is found in the Session Laws of 1903, chap. 2:32. Special acts are provided for banking, insurance, and railway companies. Under the act referred to above, corporittions may be organized for any lawful purpose. Special provision is however made for mining corporations. (See Laws of 190:3, chaps. 130, 23:3, 214.)

2. Incorporators. - 'Three or more persons may incorporate. There are no residential requirements (Laws of 190): chap. 23:- sec. 1).

3. Contents of the Articles of Association. - The articles of association should contain :

a. Name, - Similarity of names among domest ic corporations is forbidden (Laws of 190:3, chilp. 2:3:, sec. '2).

b. Purpeses. - A complany may incorporate and carry on manufacturing or mercantile business or any unisu of the fwo, or for buying, selling. or boreding live stoek, or for enraging in martime commerce or navigntion; or for purchasing, holding, or dealing in real estate: or for comducting warehonses and storage business, or for ereeting and wwing buildings, or for the production and supplying of gats aml electricity ; or for printing, publishing, and hook-making, or for carying on any other liwful business "xcept such as is excluded by sec. :3f of the act, hut a compriny camot combine any two lines of husiness except manufacturing and mercantile. Which is expressly provided

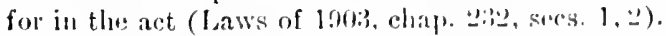

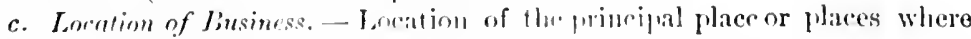
the corporate operations are to lie conductul (lil). 
1. Copitul Stock, - The total authorized capital stock, which shall not be less than \$1.100 nor more than $\$ 25,000,000$ (ld.; see also Laws of 1903, chap. $2333)$.

c. Number and Par Jialue of shares. - The par value of the shares must be either $\$ 10$ or $\$ 100(\mathrm{l}, \mathrm{l}$.$) .$

$f$ The 1 monnt of Stock Subscriplions. - This must be not less than fifty per cent of the atuhorized capital stock (Id.).

17. I'refered stock. - If preferred stock is desired, this must be provided for in the aricles. and an exact statement of the terms upon which the common and preferred stock are created, and the amount of each subseribed and the amoune of each paid in (ld.).

h. ('ispitul slock paid in. - The amount of capital stock paid in at the time of executing the articles, which shall not be less than ten per cent of the authorized carital, and not less than si,000, except where the capitalization is $2.0,0110$ or nuder, when it shall be twenty-five per cent thereof. Under this section the mamer of payment of the eapital stoek is required to be set forth in detuil - this to include an itemized description of the property in which the stock pinment is made, with the value at which each item is taken, which valuation slaill be conclusive in the absence of actual frand (Id.).

i. Homicilitry Gffice. - The location of the office in the State of Michigan for the trinsaction of business (Id.).

j. Durution. - The corporate existence, which shall not exceed thirty sears (11.).

$k$. Stuclitioliers. - The names of stockholders, residences, and number of shares of stuck subscribed for by each must be set forth (Id.).

l'eople tx rel 2 . Company, 111 Mich. $405 ; 69$ N. W. 653.

4. Statutory Powers. - In addition to the statutory enumeration of the common law powers of corporations, the act gives the following extraordinary powers: The corporation may conduct its business in whole or in part, if it desires, without the State and within the United States. Also the power to issue capital stuck in exchange for real and personal property, with the power to make such capital stock full-paid stoek and not liable for any further call, and to relieve the holders thereof from any stockholders' liability in the absence of actual fraud in the trinsaction. To vote by proxy, to forfeit stock for non-prayment of assessments, to enforce a lien for non-payment of debts, to cumblate votes in the election of directors, to issue preferred stock (Laws of $1941:$, chaps. $223,23: 2$, secs. $10,11,13,11,20$; see also Laws of 1901 , chaps. $170,13: 3)$.

Eakins 2 . Company, 75 Mich. 568 ; 42 N. IV. 982 ; Slradfurd v. Company, 130 Mich. $300 ; 89$ X. W. 960.

5. Procuring the Charter. - The articles of asso siation must be signed and acknowledged by each of the incorporators. It seems to be contemplated by the statute that the corporation shall be organized before the articles are filul in any state or local office (see Organization Meeting, post, see. 10). The statute luovides that before any eorporation organized to operate in the State shall commence business the presilent shall cause the articles of association to be recorded in the office of the Secretary of State and in the office of the cunty clerk of the county in which its operations are to be carried on. If it is oreanized to operate outsile of the State, the requirement is the same, except that the articles must then be filed in the office of the Secretary of State and in the office of the county clerk of the county in the State where the domicili206 
ary office is located. The corporate existence, however, commences as soon as articles are subscribed and acknowledged (Id. secs. 2, 9).

6. Corporate Indebtedness.-There is no limit prescribed by statute upon the creation of corporate indebtedness.

7. Organization Tax. - One-half of one mill on each dollar of authorized capital stock, that is, 50 cents on each thousand dollars, with a minimum fee of $\$ 5$ (Laws of 1891 , chap. 2 ; laws of 1893 , chap. 79 ; C. L. of 1897 , sec. 8574 ).

8. Filing and Recording Fees. - Filing articles of association in the Secretary of State's office, 50 cents, and for recording sane, 20 cents per folio. Cost of certified copy of the articles, $\$ 1$ if copy is prepared and submitted for certification. For filing in local county uffice, 50 cents, and for recording the same 20 cents per folio (Id. sec. 19).

9. Commencing Business. - Corporations may commence business as soon as the articles of association are filed and recorded in the office of the Secretary of State, and - in the case of corporations formed to carry on its business within the State - in the office of the clerk of the comnty in which its corporate business is to be carried on, or - in the case of nonresident corporations - in the office of the county clerk of the county where the domiciliary office is located (Id. sec. 9). In the case of manufacturing, commercial companies, etc., before commencing business, at least ten per cent of the capital must be paid in and fifty per cent subscribed (Laws of 1903, chap. 232, sec. 2).

C. V. \& P. Co. v. Secretary of State, 8 Detroit Leg. Nows, 795.

10. Organization Meeting. - Any two of the stockhollers named in the articles of association may call a meeting of the stockholders for the purpose of organization, by publishing notice thereof in the manner required by statute. 'This notice may be waived in writing by all the stockholders specifying the time for the organization meeting. The organization meeting should be held within the State in order to avoid any possible question as to the legality thereof (Id. sec. 3).

11. Meetings of Stockholders and Directors. - The statute specifically provides that corporations may establish an office or offices for the transaction of business without the State and within the United States, and to hold any meetings of the stockholders and directors thereat. The place must be chosen by a vote of a majority of the stockholders at a meeting duly called for that purpose, and after being fixed cannot be changed within one year, and must be certified by the directors of the corporation to the Secretary of State within two months from the time such office is located (Id. see. 20).

12. Directors' Qualifications and Liabilities. a. Qualifications. - There must be at least three directors who shall be stockholders. There are no residential requirements (Id. sec. 4). Cumulative roting is provided for (Laws of 1903, chap. 201).

Anderson Carriage Co. v. I'ungs, 127 Mirh. 543; 86 N. W. 1040.

b. Lialilities. - The directors are liable to creditors for failure to make annual reports as provided by law, for declaration of dividends when the company is insolvent, or when the payment of the same would render $i^{*}$ insolvent, and are jointly and severally liable to the extent of three times the amount paid on the stock ontstanding in their name for violation of any provision of the IBusiness Corporation Act (I1. secs. 12, 22, 23).

Bank $v$. I'ierson, 112 Mich. 410 ; 70 N. W. 901 ; M. I. W. C. \& S. Co. $x$. Mosher, 114 Mich. $64 ; 72$ N. W. 117. 
1:. Stockholders Liabilities. - If the capital stock of a corporation is withlrawn bere the payment of the corporate debts for which such stock would hus heen liable. the slockholelers are jointly and severally hiable to any "reditor to the amount that hats been withdrawn. Stockholders are individually liable for all liblur performed for the corporation. They are also liable to the :monnt of their unpaid stock subseriptions (Id. secs. 14, $21,: 99)$.

A II. A (i. 13. Co. 2 Bulkley, 107 Mich. 447; 65 N. IV. 291; Graves v. Brooks, 11: Yho. 404: 75 N. W. 932; A. S. \& W. Co. v. Elly, 130 Mich. 266; 89 N. W. 93: : Mcliran $t$. Company, 130 Mich. $111 ; 89$ N. W. 683.

11. Stock Certificates. - Every stockholder is entitled to have a stock certificate issued to him signed by such oflicers as the by-laws matrescribe. The lar value of shitres may be either $\$ 10$ or $\$ 100$ (Id. sec. 2).

1.). Preferred Stock. - The corporation may provide in its articles of assoriation. or by amentment thereto, for the issuance of preferred stock, not to exceed two-thirds of the capitill stock paid in, which shall be subject to redemption at parl at a certain time to be fixed by the by-laws of the corporation and to be expressed in the certificate therefor. 'The holders of preferred stock shall be entitled to a dividend payable quarterly, half yearly, or yearly, same to be cumulative, and not to exceed eight per cent per annum. Preferred stockholders are not liable for the debts of the corporation excepting debts for libbor. Preferred stockholders shall have voting power except when otherwise providel in the articles of association or amendments thereto. The right to vote is also given under certain other conditions (Id. sec. 35).

16. Payment of Capital Stock. - The statutes of Michigan are peculiar with respect to the mamner of the payment of capital stock. Such stock may he paid for either in cash or in real or personal property. If paid in property, an itemized description thereof must be inserted in the articles of association, together with the valuation of each item taken, and this valuation is conclusive in the absence of actual fraud (Laws of 1903, chap. 232, secs. $2,14)$.

17. Books. - Books containing accounts of the company must be kept at the office of the treasurer of the corporation within the State for the inspection of stocliholiters (Id. sec. 15). Corporations having their principal place of business within the State are required to keep their stock transfer book at such oflice.

18. Office and Agent. - Every corporation must maintain an office within the State and an agent to receive process. Such office cannot be changed within one year (Laws of 1903 , chap. 232, sec. 2).

19. Reports. - Anuual reports must be made in January or February stating condition of stock; amount of capital invested iu real or personal estate and actuil value; amounts of debts and credits; names and addresses of the stocliholiers, and number of shares owned by each. Duplicates of this report must be filed with the secretary of State, who later on files one with the county clerk of the county where the principal business is carried on (11. sec. 12).

20. Anti-Trust Statute. - Unrler the Act of March 3, 1899, all trusts or combinations intended to prevent free competition in business are prohibited (Stat., sees. 95,351 j-93.51 p : Laws of 1899 , chap. 255).

21. Statutory Grounds for Forfeiture of Charter. - The charter may be forfeited for entering illegal trusts or combines, for attempting to act as a 
corporation when not legally incorporated, or for misuser or non-user (Stat., secs. $8618,8657,9354 \mathrm{~m})$.

22. Amendments. - The articles of association may, at any meeting duly called for that purpose by a resolution adopted by a rote of two-thirds in interest of its capital stock, amend $j$ ts articles of association in any manner desired not inconsistent with the provisions of the Business Corporation Act. To render such amendment effective a copy of the resolution sigued by the president and secretary must be recorded in the same mamer as is provided for original articles of association. Special provisions are made as to the manner in which the capital stock may be increased or decreased. Also special provisions exist for changing the place of business of the corporation from one place to another (Id. secs. 2, 17, 18).

23. Extension of Corporate Existence. - At any meeting called for that purpose to be held within one year inmediately preceding the date of the termination of the corporate existence as fixed by the articles of association, the corporation may by a rote of two-thirds of its capital stock direct the continuance of the corpolate existence for a further term not exceeling thirty years. After the adoption of this resolution, the president and secretary shall make, sign, and acknowledge articles of association as in the case of the new corporation, to which shall be apprenled a copy of such resolution verified by the oath of the secretary, which shall be filed and recorded as in the case of a new corporation (Id. sec. 3:3).

24. Dissolution. - Corporations may be dissolved only upon application to the courts (Stat., secs. $4161 \mathrm{~b}, 4161 \mathrm{~d} 7-4161$ inclusive, S174, 8211 a).

25. Foreign Corporations. - Foreign corporations must file certified copy of their articles with the Secretary of State and evidence of appointment of agent to receive process. Must pay franchise fee of one-half of one mill on each dollar to be determined by the Secretary of State upon the proportion of capital stock represented by its business in Michigan, but which fee shall never be less than $\$ 25$ (Laws of 1901 , chap. 206, as amended by Laws of 190:, chap. 34). At the time articles are filed the corporation must make and file a statement with the Secretary duly sworn to by at least two officers of the corporation setting forth the location of its oflices in Michigan; names and addresses of the oflicers and agents in charge of its business in Michigan, value of property ownel aud used by the company; aggregate amount of business transacter by the company therein and the capital stock of such corporation invester in Sichigan. Foreign corporations must also file an anmual report with the auditor-general duly sworn to by its president or other oflicer (C. L. of 1 s.99, sec. 71015). The anti-trust act applies to forejgn eorporations as well as lomestic. (See I aws of 1899 , chap. 25.5, sec. 12.)

Jeople r. Ilawkins, 106 Mich 479; 64 N. W. 736; Rough $n$. Breitung, 117 Mich. 48; 75 N. W. 147; Wilcux Corlitge Co. v. Wosler, 114 Mich. 64; 72 N. W. 117.

\section{MINNESOTA.}

(The references cited below are to the (inneral Statutes of 1894 unless ofherwise stated.)

1. Statute under which Business Corporations may iucorporate. The Business Corporation Act of Minnesola is fomm m llue fincral statutes

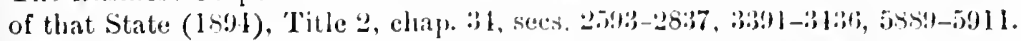
Special attention is called to the fact that 'litle :2, chap. 31 , really embraces -29!9 
thres sparate incorpolation acts, - one being a general act and the others beimg applicable to mining and mannfacturing companies. Special acts are probided for banking, bulling and loan, electric, insurance, plank roads, \{umpilit, milway, safe deposit and trust, bridge, telegraph, telephone, water and wems nary corporations. (See secs. 2794, 2805.)

2 Incorporators. - Any number of persons not less than three. There are no residential requirements (secs. 2791, 2805, 25:27).

Sitate 4 Critchelt, 37 Minn. 13; 32 N. W. 787.

3. Coutents of the Articles of Incorporation. - The articles must set forth :

(1. Comprate Name. - Similarity of names anong domestic corporations is fortiditen.

b. Nonure of the Business. - The Secretary of state permits the insertion of any number of purposes in the articles not covered by special act.

c. I'rincipul I'lace of Business. - The location of the principal place for the transaction of the corporate business must be set forth.

1. Intration. - Time of the commencement and period of existence, which camot exceen thirty years (secs. 2802, 2826).

e. Coprinl stock. - The amount of capital stock and how paid in. The anthorizel cantal cannot be less than $\$ 10,000$ (secs. 2797,2530 ; Laws of 1901 , chap. 317).

f. Corporute Indebtedness. - The highest amount of indebtedness or liability which the corporation shall at any time ineur.

g. Incorporators. - The names and residences of the incorporators must be set forth.

h. Directurs. - The names and residences of the first board of directors and in what oflicers the government of the corporation and the management of its affairs shall be vested, and when the same shall be elected.

i. The Par V'alue of the Shares. - The number and par value of the shares of the capital stock. This must not be less than $\$ 1$ nor more than $\$ 100$ (secs. 2591,2796 ; Laws of 1897 , chap. 249 ; Laws of 1901 , chap. 99 ; sec. 2797 , as amended by Litws of 1901, chap. 347). Special provision is made with reference to articles of incorporation of mining and manufacturing corporations (secs. $2527,2-2 s)$.

State $v$. Company, 40 Minn. 213; 41 N. W. 1020.

4. Statutory Powers - In addition to the statutory ennmeration of the conmon law powers of corporations, the act gives the following extraordinary powers: The right to enforce a lien upon the stock of its members for all dehts due from then to the corporation; the power to hold real and personal prolerty as shall be necessary for the business of the corporation, or such as nuay be taken in pament of or security for dehts. Express power is conferred upron the directors to meet without the State, and the corporation is em["wern] to establish oflices without the State for the transaction of its busiuss. If it majority of the stockholders shall so elect, the corporation may tak", acyure, and hold stock in other corporations. Also to rote by proxy (secs. 2791, 2795, 2798, 2799, 2816, 2817, 2833, 2831, 2835, 3412). Also to is sum preferred stock and to forfeit stock for non-payment of assessment (secs. $311,: 315) . \quad$ Also to classify directors (sec. 3107).

Iblien 2 . Jand, 7 Minn. 110 ; 79 N. W. 606; N. T. E. Co. v. Company, 76 Miun. $334 ; 73$ N. W. 315.

$$
: 300
$$


5. Procuring the Charter. - The articles should be signed and acknowledged by each of the incorporators. The articles must then be published in a legal newspaper published at the capitol of the State or at the county where the corporation is organized. Two publications are sufficient. Upon filing an affidavit of proof of such publication in the office of the Secretary of State the persons named in such articles thereupon become a corporation. The articles of incorporation must be recorded in the office of the register of deeds of the county where the principal place of business is to be located as well as in the office of the Secretary of State. In the case of mining and manufacturing corporations the articles are required to be executed in duplicate, one of which is deposited for record in the office of the register of deeds in the comnty where the corporation shall establish its principal office, and the other with the Secretary of Stite, and upon being so deposited the corporation is deemed to exist for the purposes specified in its articles. There must be filed with the articles with the Secretary of State a duplicate receipt of the State Treasurer showing the payment of the organization tax required by law. This provision does not apply to any manufacturing corporation whose articles provide that its functions shall be limited to manufacturing and to business essential thereto, or to mining any stone quarry, or the quarrying, manufacturing, or marketing of any kind of stone, or for raising or improving live stock, or for cultivating or improving farms, gardens or horticultural lands, growing sugar beets or for canning fruits or vegetables, or to local telephone companies connecting towns or villages of less than two thousand inhabitants (secs. $2593,2595,2796,2813,2829$; Laws of 1901 , chap. 99 ; Laws of 1903 , chap. 300). The Secretary of State issues a certificate of incorporation in the form provided by statute (sec. 3314 ).

Finnegan $v$. Noerenberg, 52 Minn. 239; 53 N. W. 1150.

6. Corporate Indebtedness. - There is no limit upon the creation of corporate indebteduess, save as to certain classes of corporations : to wit, those empowered to take private property for public uses (sec. 2722).

7. Organization Tax. - Fifty dollars for the first fifty thousand dollars of the capital stock and an additional five dollars for every adlitional ten thousand dollars of its caprtal stock. Manufacturing corporations, when their articles confine their business exclusively to manufacturing, are not required to pay incorporation fees (Laws of 1901, chap. 206).

8. Filing and Recording Fees. - Filing fees in the office of the Secretary of State, 15 cents per folio. Cost of certified coly of articles of incorporation, 50 cents per folio. For issuing eretificate of incorporation, s1. Filing affidavits and proofs of publication, free. Filing and recording fees in local county offices average abont $\$ 3$. Cost of publishing articles, about $\$ 15.4$ discount of usually $\tilde{j}^{\prime \prime}$ per cent on this anount cau be obtained by the attorneys. Cost of filing certificate priminary to the commencement of business in the office of the Secretary of State and with the register of deeds, ahont $\$ 1$.

9. Commencing Business. - Cuporations may commence business as soon as the articles of jucorpuration are filel and recorded in the office of tho Secretary of State aud in the oflies of the register of deeds of the county whero the principal place of business is locaterl, and as som as the articles are published as required by liw, and an aflilinit in proof thereof filed in the office of the Secretary of State (sers. 25:41, 2796).

10. Organization Meeting. - Organization mreting must be held within the State in the absence of any statute expressly authorizing the holding of 
such menting mintile of the State. (See, however, secs. 2808, 2833, 3407, 3 (114.)

11. Meetings of Stockholders and Directors. - Stockholders as well as direntus maly met and transat business without the State if the by-laws so provide: ullerwise the meetings must be held within the State (secs. 2808,

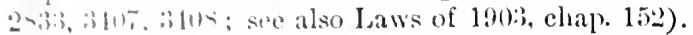

1:. Directors Qualifications and Liabilities. a. Qualifications. - There must be at heist three directors and not more than fifteen. There are no residential repuldenents. The board may by a resolution divide the directors into thee classe's, wne-third to be elected ammually (secs. 2809, 2831, 3107).

b. Lintilitis. - Directors are liable for the declaration and payment of mlawful divilends. They are also liable if they suffer the corporate funds or propertr to be wasted or lost through gross negligence or inattention to duty. Directors aml officers may be removed by the district court of the coninty in which is located the principal business of the corporation, or be suspended upon proof of abuse of trust or gross misconduct (secs. 2793, 2800,

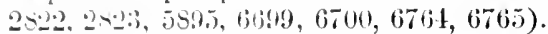

13. Stockholders' Liabilities. - Stockholders in all classes of corporations are liable in any event to the amount of stock subscribed by them and umpail. Stucklublers of all ordinary business corporations that may be organized under the General Act, except those organized to carry on exclusively a mannfacturing or mining busmess, are liable to the amount of stock held or owned by them. This is a constitutional liability not requiring any statute to put it in rff cet, the Supreme Court having held it to be self-executing. Stookhollers in corporations organized to carry on an exclusively manufacturing or mechanical business are only liable to the extent of their unpaid stock subseriptions (Cons., Art. X. secs. 3, 2600). Stockholders are also liable tu the extent of capital illegally withdrawn from the corporation and received by them (sec. 2522). They are also liable for a failure on the part of the corporation to comply sulstantially with the provisions with reference to organization and publicity (sec. 2600).

Wallace $v$ Company, 70 Minn. 321 ; 73 N. W. 189; Frost v. Company, 57 Minn. 325 : 59 X. W. 308; L. F. Co. v. Company, 64 Minn. 386 ; 67 N. IV. 217 ; Farnsworth v. Robins, 36 Minn. $369 ; 31$ N. W. 349 ; S. M. Co. $v$. Company, 81 Minn. 294; 84 N. 11.109.

11. Stock Certificates. - Every stockholder is entitled to have a stock certificate issued to him signed ly such officers as the by-laws may prescribe (sec. :316j). The par value of the shares may be any anount not less than $\$ 1$ nor more than $\$ 100$ (Laws of 1901 , chap. 347 ; see also sec. 2830 , where par value of shares of mining and manufacturing companies is fixed at not less than $\$ 10$ and not more than $\$ 100$ each ; see also sec. 2806).

1.). Preferred Stock. - Corporations may by their original articles or by arnendment thereto provicle for special, preferred, and common stock, and any corporation uay without changing its articles of incorporation issue its capital strock as prart special and part preferred and part common, or part common and part either special or preferred, by direction of its loard of directors whon nuthorized by a majority of the stockholders at a meeting called for that purpose (ser. 3415).

16. Payment of Capital Stock. - Stock is payable in money or money's worth. Siock cannot be issued for a less amount to be actually paid in on each share than the par value of the shares so issued. The foregoing pro802 
vision does not apply to railroad, navigation, mamufacturing corporations and corporations organized for dealing in real estate. This latter class are authorized to create, issue, and dispose of such amount of special, preferred, or full-paid stock as the directors may deem advisable (sec. \$\$15).

17. Books. - Books of acconnt shall be kept, and shall at all reasonable times be open to insprection, in the comuty where such corporation is located or at the office of the treasurer within the state (secs. $2599,2800,2818,3429$ e).

15. Office and Agent. - Every corporation must maintain an oflice within the State, and must at all times have an agent within the State upon whom process may be served (sees. $2801.28: 3: 3,9407$ ).

19. Reports. - No reports are requirel to be published. The directors are howerer required to make a statement of the accounts of the corporation at least once a year to the stockholders.

20. Anti-Trust Statute. - Under the Act of April 10, 1901, all pools, trusts, and conspiracies for certain mulawful purposes are declared illegal (Laws of 1901, chap. 194; see also Laws of 1899, chap. 359).

21. Statutory Grounds for Forfeiture of Charter. - The cliarter may be forfeited for violation of law, for misuser and non-user of corporate powers. It may also be forfeited if the charter was procured upon some frandulent suggestion or the concealment of material facts by the persons incorporating or some of them or with their knowledge and consent (sec. $56 \%^{\circ}$ ). The charter may be forfeited also if it remains insolvent for one year or for one year refuses to discliarge its debts, or for one year suspends its lawful business (sec. 5899). Also for violation of Anti-Trust Aets.

M. C. R. Co. v. Melvin, 21 Minn. 339.

22. Amendments. - The cliarter may be amended by a resolution of the board of directors ratitied by a majority of the stockholders in the following respects: Changing the name or the nature of the business, the principal place of transacting the same, changing the amomit of capital stock and low to be paid in, the amont of corporate liability, and the number and amount of the shares of the capital stock. Also the number of directors and their term of office and the manner of their election. The anduded articles are required to be filed, pmblished, and recorded in the sane manner as the original artieles are required to be filed, published, and recorded (secs. 2595, 2735, 2503, 2801; Laws of 1901 , chilp. 215).

2:3. Extension of Corporate Existence. - Colporations mas renew the term of their corporate existence for a term not excerding the original perion of its existence hy anlopting a resolution expressing such renewal hy a twothirds rote of its strocholulers at a meeting duly called for that furpose and by filing and prblishing the samm in the same manner as is providul for original articles of inemprortion (Laws of 1901 , chatp. 2017; Laws of 1903 , chin. 33:3).

21. Annual License Tax. - Thre is no ammal license tax.

25). Dissolution. - Corporations maly be lissolved upou application to the courts (sees, :31:30, :31:3,: L,aws of 1901:3, chap. :3:31).

26. Foreign Corporations. Every formign colporation hefore doing business within the Sitate must file in the oflice of the Sirevetary of State a copy of its charter or atticles of incorpuration duly rertified and andlontieated.

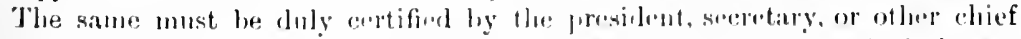
executive oflicer of such corporation, and the corporate seal attached thereto 
(Laws of $149 ?$. ('hrans. 69,70$)$. Foreign corporations are taxed the same as domestic enrporations.

Siate l. Cimpinye. 43 Minn. 17; 44 N. W. 1032; IIeileman Co. v. Peimeisl, 85 Mint. 121; ss 1 . W. +41 .

\section{MISSISSIPPI.}

(The referenees cited below are to chap. 25 of the Annotated Code of 1892, unless otherwise stated.)

1. Statutes under which Business Corporations may incorporate. - The linsiness Corporation Act of Mississippi is found in the Annotated Cole of 1892 , chap. 25, sees. $832-860$ inclusive. Special acts are provided for railway and insurance corporations.

2. Incorporators. - There must be at least two incorporators. There are no residential requirements (sec. $\$: 33$ ).

3. Contents of the Charter. - The charter must contain :

a. 'lurposes. - Any number of purposes not including those for which corporations can be organized only under special acts may be inserted.

b. Incorporutors. - The names of the incorporators must be inserted.

c. Nune - Similarity of names is not forbidden.

l. Corporute Powers. - The powers to be exercised nust be set forth.

e. Inuration. - This cannot exceed fifty years.

f. Capital stock. - There is 10 maximum or minimum amonnt of capital stock fixed by law for corporations. There is an implied limit by reason of the provision that no corporation, except mamfacturing companies and banks, may hold real and personal estate exceeding $\$ 250,000$ in amomt. Manufucturing companies and banks may purchase and hold property to the amount of $81,000,1100$.

g. Any provisions that may be desired for the regulation of the internal affairs of the corporation (sec. 833).

1. Statutory Powers. - The act enmmerates the common law powers of corporations. In addition thereto it limits, except in the case of manufacturing companies and bauks, the amount of real and personal property necessary and proper for its purposes to $\$ 250,000$ in amount. Corporations are forbidien to own or purchase the capital stock of other corporations or to acquire the franchise, plant, or equipments of other corporations. Corporations are expressly giren power to execute bonds in suits in which the corporation is interested (sec 836). Voting by proxy is permitted; also forfeiture of stock for non-payment of assessments (secs. 836, 837, 8:38, 613). May cumnlate votes in election of directors (sec. 8:37).

Greenville Compress \& Warehonse Co. v. Company, 70 Miss. 669; 13 So. 879.

5. Procuring the Charter. - The charter must be signed and acknowlerlged by each of the incorporators. It must then be published for three consecutive weeks in a newsaper published at the domicile of the corporatirn. After publication it inust be submitted for approval to the governor, who is requirer to take alvice of the Attorney-General as to the constitutionality and legality of the provisions of the charter. If the cluarter is aplured, the goveruor so endorses such approval thereon, and the Secretary of Stat: shall affix the State seal thereto. Upon the payment of the organization tax and upon recording the charter in the office of the Secretary of State the corporate existence commences. The law provides that it shall not be 301 
a defence to any suit against the corporation that there was a defect or informality in the organization thereof (secs. 833,835 ). The charter must be recorded also in the office of the clerk of the chancery court of the county in which the corporation does business. Collateral inquiry into the legality of corporate existence is forbidden by statute (secs. S33, S35, 811).

6. Corporate Indebtedness. - Minufacturing and trading companies are not permitted to contract debts to exceed the amount of their capital stock paid in. No loan of money can be made by the corporation to a stockholder (secs. 851, 853).

Fargasou $v$. Company, 78 Miss. $65 ; 27$ So. 877.

7. Organization Tax. - Capital stock not exceeding $\$ 10,000$, $\$ 20$; between $\$ 10,000$, and $\$ 30,000, \$ 40$; between $\$ 30,000$, and $\$ 50,000$. $\$ 60$; exceeding $\$ 50,000$, one tenth of one per cent, but no fee to exceed $\$ 250$ (Laws of 1900, chap. 45).

S. Filing and Recording Fees. - There is no filing or recording fee other than the organization tax to be paid to the Secretary of state. For certified copy of a domestic charter, $\$ 10$ (Laws of 1900, chap. 45). P'ublication fee about $\$ 10$.

9. Commencing Business. - Corporatious may commence business as soon as the charter is duly executed, published, and aplroved by the governor, the organization tax paid; and the charter recorded in the office of the Secretary of State and with the clerk of the chancery court of the county in which the corporation does business (secs. 8:30-8:5j inclusive).

10. Organization Meeting. - The organization meeting must he held within the State. Cnless the incorporators sign an agreement fixing the time and place for the organization meeting of the corporation, a notice signed by one or more persons named in the charter must be published in some business newspaper for at least ten days before the time appointel for such meeing. At this meeting the by-laws must be arlopted and the board of directors chosen. Immediately after the adjournment of the organization meeting the board of directors elected thereil should mect and elect such officers as may be provided for in the ly-laws (sec. 836).

11. Meetings of Stockholders and Directors. - Stockholders' meetings must be held within the state. Directors' meetings may be held without the State if the by-laws s, provide (see. $8: 37$ ).

Thom sou v. Company, 68 IIiss. 423; 9 So. 8.21.

12. Directors' Qualifications and Liabilities. a. Qualifications. - The corporation may have any number of diretors desired. There are no residential requirements. No person can sorve on the hoarl of directors who is enganed or interested in a eompeting business withont the consent of a majority in interest of the stoekhollers thereof (sece s::78).

b. Lielilities. - Directors are juintly aud scrolially liable for the payment of dividents when the compuny is insolvent or when such payment would render it insolvent. Wrectors are also liable for illdabl withdratial of eapital stock. Oflicers and directors are jointly and severally liable for permitting the toan of moncy to stuckholders. 'bey are also liabl. in case debts are contracterl in excess of the anonit or capitial stock fritul in (secs. 851 , 852, 85:3).

13. Stockholders' Liabilities. - Stocklwhers are lialse in any event

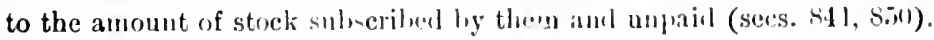

Scott $v$. Windham, 73 II iss. 76 ; 16 S.s. 206. 
11. Stock Certificates. - Every stocklıolder is entitled to have a stock certitieste issued to him signed by such ollicers as the by-laws may prescribe. The par value of shanes may be any amonnt.

1.1. Preferred Stock. - Tlie act loes not provide in terms for the is-

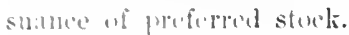

li, Payment of Capital Stock. - The statute seems to contemplate that stone numit the pail for either in money or money's worth. 'The act provilles that a note, ubligation, or security of any kind given or transferred ly any sulseriber for stock shall not be considered, taken, or held as payment of any part of the capial stock of the company (sees. 814, 850).

Farmatson e. Compuny, is viss. 65; 27 So. 877.

17. Books. - There are no statutory regulations concerning books.

1.. Office and Agent. - Tlue statute by implication would seem to require the maintenance of a domiciliary office within the State.

19. Reports. - No reports to State offieials are required.

20. Anti-Trust Statute. - All pools, trusts, or combinations for certain designated purposes are declared illegal (chap. 88, Laws of 1900).

Wuollerery $r$. McClurg, 78 Nliss. 831 ; 29 So. 514.

21. Statutory Grounds for Forfeiture of Charter. - The charter may le forfeited for entering unlawful trusts or combines or for misuse or abuse of its jowers (Act of March 12, 1900, secs. 3520-3.529; see also sec. S3S).

2.2. Amendments. - Provisions for the amendment of clarters are the sane as guvern with respect to the issuance of the charter in the first instance (sec. $3: 34$ ).

23. Extension of Corporate Existence. - The act refers to renewals of charters, but contains no express provision with reference thereto (sec. 834).

21. Dissolution. - Corporations may be dissolved upon application to the courts (secs. $\$ 47,848$ ).

25. Foreign Corporations. - Every foreign corporation before doing business within the State must file in the office of the Secretary of State a copy of it: charter or articles of incorporation duly certified and authenticated. The same must be luly certified by the president, secretary, or other chief executive ofticer of such corporation, and the corporate seal attached thereto. Fee of Secretary of State for filing charter, $\$ 15$ (Laws of 1900 , chap. 45 ; sec. 849).

Willians $v$. Bauk of Commerce, 71 Miss. 858; 16 So. 238.

\section{MISSOURI.}

(The references cited below are to the Revised Statutes of 1899 unless otherwise stated.)

1. Statutes under which Business Corporations may incorporate. The lininess Coryoration Act of Missouri is found in the Revised Statutes of 13.14 sec. 91:3-1.11 inclusive. Special acts are provided for banking, bond, inestment. booning and rafting, sivings and loan, building, railway, street lialway. telergrafl, telephone, and trust companies.

2 Incorporators. - Any number not less than three. There are no residential rejuirements (see. 1312, as amended by the Session Laws of 1901, lage (3). 
3. Contents of the Articles of Incorporation. - The articles must set forth:

a. Name.-Similarity of names is forbidden. When the name of a person or firm is assumed, it must designate the nature of the business to be carried on and eud with "company" or " corporation" (secs. 959, 1312).

b. Domiciliary office. - The name of the city or town in the comnty in which the corporation is to be located (sec. 1312).

c. Cupital Stock. - The anount of capital stock, the number of shares into which it is to be divided, and the par value thereof, together with a statement that the same has been lone fule subscribed and one-half thereof actually paicl up in lawful money of the lnited states, and in the custody of the persous namerl as the first board of directors. Capital stock cannot be less than $\$ 2,000$ nor more than $\$ 10,000,000$. The par ralue of the shares may be any amount (secs. 1312, 1320; Laws of 190:3, p. 124).

d. Stockliders. - The names and places of resillence of the stockholders and the number of shares subscribed by each (sec. 1:31:2).

e. Board of Diretors. - Number of directors and names of the board for the first year. There must be not less than three nor more than thirteen. Three of these must be citizens and residents of the state, ant all must be stockholders (secs. 97:3, 1022, 1312, 1:320; Laws of 190:3, p. 1:21).

f. Duration. - The number of year's the corporition is to continue, which must not exceed fifty (50) years (sec. 1:312; Laws of 190:3, p. 12.1).

g. I'urposes. - The statute specifies eleven classes of corporations which may be organized muler the General Act (sec. 1:) 1 !).

h. Prefered stuch: - If preferred stuek is desired, the articles must set out the amount therof, the number of shares theren, the names of the subscribers therefor, the number of shares sulseribed by each person, and the preferences, priorities, qualifications, and character thereof as provided in stc. 13:32 of the lievised statutes of Nissouri, 189!, as anended Laws of 1901, p. 91 .

State $v$. MIcGrath, 92 Mo. $355 ; 5 \mathrm{~S} . \mathrm{W} .29$.

4. Statutory Powers. - The Missouri statutes enmmerate the common law powers of corporations, and also confer the folkwing aulditional powers; Permitting the use of proxics: anthorizing cumulative voting for directors; allowing directors to forfeit stock for non-paynent of assessment; rermitting the classilication of directors; allowing the issuance of preferred stock, and the issuance of stock for services or property (secs. 95:), 961, 962, 971, 1:202). Conpratims engagen in a sintilar line of business maly consolinlate (sec. 1:3:3). linels may he issurd and afterwards converted into stock if desired (stec. 13:3: ; see also laws of 1!11:3, pl. 111. 1:21).

5. Procuring the Charter. - Th" articks must he signed and acknowledged by the ineorporaters. They must then be reserded in the otlice of

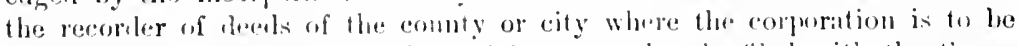

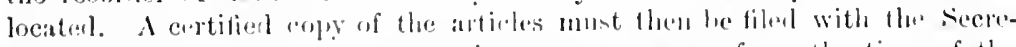
tary of state, and the corpurate cxistrume commenese from the time of the

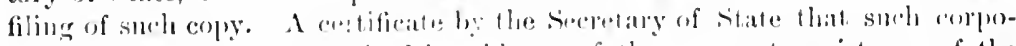

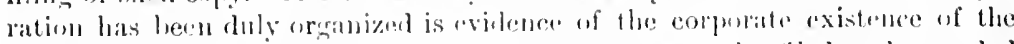

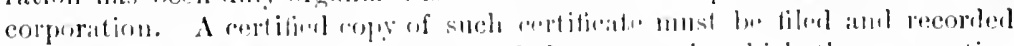

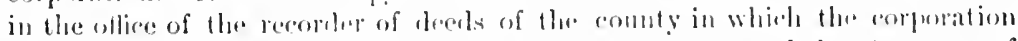

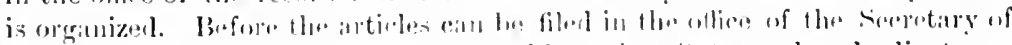
State the organgation tax must he paid to the State, and a dupheate re- 
ceipt of the stat, 'Treasurer showing the payment of such tax must be filed with ihe secretiry of stite (secs. 955, 956, 1313; Laws of 1903, pp. 123, 125).

Hut 2 . Siliabury, 5) 15 o. 310 ; Com'rs $v$. Shields, 62 Mo. 247; Granby Co. v.

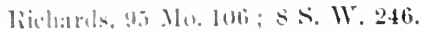

(:. Organization Tax. - Fifty dollars for the first fifty thousand dollars or less of cilpital stock, and s. for each additional ten thousand dollars.

․ Filing and Recording Fees. - 'To the Secretary of State for issuing ant recording eertificate of corporate existence, $\$ 1.50$. For certifying copies of recork, 81 . liecording fees in local connty ollices averages $\$ 1.75$.

s. Corporate Indebtedness. - There is no statutory limitation upon the anount of debts a corporation may contract, except that the bonded indebteduess must not exceed the amonnt of authorized capital (sec. 962).

9. Commencing Business. - As soon as the certificate of organization is issuen by the Secretury of state and a certified eopy thereof filed in the otlice of the recorder of deeds the company may at once commence business. A: a preliminary to procuring the charter one-half of the capital stock must first be patil in and the balance subscribed for (sec. 1312).

Shepard r. Drake, 61 Mo. Ap. 134; Reinhard v. Mining Co., 107 Mo. 616; 18 S. 1 . 17 ; St. J. \& I. R. R. Co. $v$. Shambaugh, 106 Ho. 557 ; 17 S. W. $58 \mathrm{I}$; Q. C. F. \& C. Cu. 2 . Crawford, 127 Mo. $356 ; 30 \mathrm{~S}$. W. 163.

10. Organization Meetings. - Mnst be held within the State.

Cimp r. Byrne $t$ al., 41 Mo. 525 ; N. M. R. R. Co. v. Winkler, 33 Mo. 354.

11. Meetings of Stockholders and Directors. - Stockholders' meetings must be held within the State. All meetings of directors, other than boards of mining and railway corporations, must be held at the general office of the corporation within the State (R. S., sec. 973).

O. \& M. R. R. Co. $v$. MePherson, 35 Mo. 13; M. L. M. \& S. Co. v. Reinhard, 114 Mo. $218 ; 21$ s. W. 488.

12. Directors' Qualifications, Duties, and Liabilities. - There must be not less than three nor more than thirteen directors. Three of them nust be citizens and residents of the State, and each must be a shareholder. IDirectors may be classified if desired. Cumulative roting for directors permitted (secs. $51,973,1022,1312,1320)$. Inspectors of election are provided for (secs. 917,940).

Ilap r. Mill Co., 39 Mo. Ap. 453.

a. Limbilities. - Directors are liahle for knowingly declaring and paying dividends when the corporation is insolvent or which will render it insolvent. This liability is a joint and several one, and extends to debts of the corporatins then existing or thereafter contracted. Directors voting against the declaration of such dividenrls are not liable (secs. 953, 1321). They are also liable for makiner lons to stockholiters (sec. 132:3).

1:). Stockholders' Liabilities. - Stockholders are liable for corporate dehts to the extent of their unpaid stock subscriptions (Cons., Art. XII. sec. $9 ;$ isec. 9.5.).

Ram-fy $\iota .11 \mathrm{fg}$. Co., 116 Mo. 313; 22 S. W. 719 ; Ollesheimer $v$. Mfg. Co., 44 Mo. A. 1.2

$809^{\circ}$ 
14. Stock Certificates. - Each stockholder is entitled to have a certificate issued to him, signed by such officers as the by-laws may provide. Par value of shares may be any amount.

15. Preferred Stock. - Preferred stoek may be issued if provision is made therefor in the articles of incorporation or if all stoekholders consent (sec. 13:52 ; Cons., Art. XI. sec. 10; Laws of 1901, pp. 91, 92).

Winscott $v$. In restment Co., 63 Mo. Ap. 367.

16. Payment of Capital Stock. - Stock can only be issned for money paid, labo: done, or property aetually received. All fietitious inerease of stoek is roid (Cons., Art. XII. sees. 8, 962, 1323).

Schickle $r$. Watts, $9+$ Mo. 410 ; 7 S. W. 274 ; Grocer Co. v. Crow, $362 \mathrm{I}$ o. Ap. 288; Garrett $v$. Mining Co., 113 Mo. 330 ; $20 \mathrm{~S}$. W. 965 ; MeDaniel $v$. Harvey, 51 IIo. Ap. 198 ; Berry v. Rood, 168 110. $316 ; 67$ S. W. 644.

17. Books. - A transfer book and stoek register shall be kept at the general office of the corporation, which shall be open to inspection of stockholders during usual business hours for thirty days previous to an election of direetors (sec. 966). The books and reeords of the proeedings of such eorporation shall be kept open for the inspection of all persons interested (see. 192:2-1826).

18. Office. - Every domestic corporation is required to keep an oflice within the State (sec. 1022).

Cleaton $v$. Emery, 49 Mo. Ap. 345; M. I. MI. \& S. Co. $v$. Reinhard, 114 Mo. $218 ; 21$ S. W. 488 .

19. Reports. - Corporations shall annually, on or before July 1, report to Seeretary of state the location of the principal office, name of president and saeretary, amomnt of capital stock, both subscribed and paid up, par value of stoek and actual value of stoek at the time, eash value of all the personal property and real estate within this State on June 1st preedling, and anount of taxes paid by the corporation in this State for year list preeding the report (sec. 101:3).

20. Anti-Trust Statute. - All comlinations to limit prices of certain designated articles are by statute deelared to be illegal (Laws of 1901, chap. 1+3). An anti-trust affidavit is required to be made out and swom to by the president, secretary, or treasurer of each corporation on or before July 1 st of each year (see. $897 ;)$.

21. Statutory Ground for Forfeiture of Charter. - The ehister may be forfeiturl for cutering illerral trusts or combinations; also for failure to maintin an oflice within the state for six months consecutively ; also for abuse, non-11se, or tnisuse of eorporate rights and priviliges (sees. 8971,1022 ).

22. Extension of Corporate Existence. - ('mporite existenes may be extender for a further perior of fifty years by complying with the law in respect the reto (sec. 972). Corpuntions may also beineorporate under the old name if they so desire (see. 1001).

2:). Ammual Franchige Tax. - There is no :umual franchise tax.

24. Amendments. - Articles may he amended for the following pur. poses: 'To increase or diminish the capital stock, to chame the corporate name, extend the conprate purpeses, to increase or diminish the number of directors to not less than three nor more than thirteen (sees. 958, 962, $961,971,1327-1329$; latws of 1!603, 1. 111).

Ollesheimer $v$. Mfg. Co., $44 \mathrm{M} v . \Lambda_{p}$. 122 . 
ㄷ. Dissolution. - A corporation may be dissolved only on applieation to the courts for ciuse shown hy majority vote of the stockholders or without catns shum hy a two-thinls vote thereof (see. 977).

21i. Foreign Corporations. - Foreign corporations in order to transact lusiness within the state must file in the ofliee of the Secretary of State a (o) of their charter, duly authentieated by the proper authority, together witi a sworn statement uncler the corporate seal setting forth the business of the corporation which it is engaged in carrying on or which it proposes to carry on in the State; and the principal oflicer or agent in Missouri must milie and forward to the Siecretary of State with the affidavits required, a statument sworn to, of the proportion of eapital stock which is represented ly its wererty locafed and husiness transacted in Missomi, and setting forth the lecation of its prineipal oflice within the State where legal service may be obtained upon it. 'The corporation is required to pay into the State treasury upun the proportion of its capital stoek represented by its property and business in Missouri ineorporating taxes and fees equal to those required of similar domestic corjorations with an addition of ten dollars as the license fee. The Secretary of State is not permitted to issue a license to any foreign corporation hearing the same name as that of a domestie corporation (Laws of 1903, P?. $121-123)$.

In artition to the foregoing, every foreign corporation must maintain a llace of business within the State where service of process may be made and where books shall be kept showing all of the corporate assets and liabilities as well as the names and residences of the shareholders and the officers and managers of the corporation (Laws of 190:3, pp. 119-121).

Cirson-Rand Co. $v$. Stern, 129 1Io. 381 ; 31 S. W. 772; Tooney v. S. L. K. P., it . $1 \% . \Lambda_{1}$. 129; Woollen Mills Co. $x$. Edwards, 84 Mo. Ap. 448; Kimball $v$. Davis, 5.2 110.194 ; Hays $x$. Merkle, 70 Mo. 509.

\section{MONTANA.}

(The references cited below are to Civil Code of 1895 unless otherwise stated.)

1. Statutes under which Business Corporations may incorporate. The linsiness Corporation Act of Montana is found in secs. 390-563 of the Civil Corle of Montana. Special aets are provided for banking, trust, mutual insurance, building and loan, railway, telegraph, and telephone companies (secs. 39:4, 411). Corporations may be formed under the General Act for any kind of business.

2 . Incorporators. - There must be at least three incorporators. There are 110 residential requirements except that it is customary to have at least one resirlent ineorporator (sec. 405 ).

3. Contents of the Articles of Incorporation (sec. 403). - The articles inust contain :

a. Nime. - Similarity of names is not expressly forbidden (sec. 403).

b. I'urposes. - The purposes for which it is formed must be set forth. The laws set forth speeifically the purposes for which corporations may be formed (sec. 393). The Secretary of State permits the insertion in the articles of inerrporation of any number of purposes not covered by special acts.

Domiciliery office. - The place where the principal business is to be transacterl inust appear (see. 403).

310 
l. Duration. - Term for which the corporation is to exist - not to exceed twenty years (sec. 403 ; see also sec. 411).

e. Boarl of Lirectors. - The number, which shall not be less than three nor more than thirteen, and the names and residences of those who are to serve for the first three months (sec. 403).

$f$. Capital Stock. - Amount of capital stock and the number of shares into which it is divided. The capital stock and par value of shares may be any amount (sec. 40:3).

g. Stock Subscriptions. - Amount actually subscribed, and by whom (sec. 403).

h. Stoch Assessments. - If stock is assessable, it must be so stated (sec. 40:3):

4. Statutory Powers. - The Montana statutes enumerate the common law powers of corporations and also confer the following additional powers. To remove directors; permitting stockholders to vote by proxy : permitting mining companies to consolidate; authorizing forfeiture of stock for nonpayment of assessments; permitting the imposition of fines, not to exceer $\$ 100$, for violation of by-laws; allowing cumnlative voting for directors (secs. 432, 436, 439, 452, 476, 520, 526 ; Laws of 1599 , chap. 527).

5. Procuring the Charter. - The articles must be signed and acknowledged $b y$ each of the incorporators. They must then be filed in the oflice of the county clerk of the county in which the principal place of business is to be located, and a cony thereof certified by the county clerk with the Secretary of State. Thereupon the latter official issues a certificate that a copy of the articles containing the required statement of facts has been filed in his oftice. Thereupon the corporate existence commences (secs. 405, 406). Collateral inquiry as to the legality of corporate existence is forbidden (sec. 895 ).

6. Organization Tax. - No fee less than $\$ 10$; the fee of the Secretary of State is 25 cents on each thousiml dollars of capital stock up to $\$ 100,000$; additional from $\$ 100$, (1100 to $\$ 250,000$, 20 cents per $\$ 1,000$; arditional from $\$ 2.50,000$ to $\$ 500,000,15$ cents 1 er $\$ 1,000$; additional from $\$ 500,000$ to $\$ 1,000,000,10$ cents per $\$ 1,000 ;$ additional over $\$ 1,000,000,5$ cents per $\$ 1,000$ (Laws of 1899 , chap. 151, as amended by Laws of 1903, chap. 127).

7. Filing and Recording Fees. - For issuing certificate of incorporation, 83. The recording and filing fees are incinded in the organization tax, Recording fees in locil comty office, 1.j cents per hundred worls; 5 l) cents for acknowledgment, and 10 cents for indexing. Usually $\$ 3$ covers this entire service (Laws of 190:), chap. 127).

8. Corporate Indebtedness. - Must never exceed the amount of capital stock (secs. 138, 5):-3. sub. ?).

9. Commencing Business. - As som as the certificate of incorporation has been recorded in the ofliee of the connty clurk and a copy therenf duly

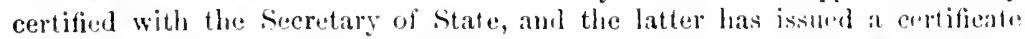
that a copy of the inticles, fropmly drawn, has bern filed in his oflice, the corporation may commence busines (s.c. Joli). liy-laws must be adopted within one nonth after filing articles (soc. $1: 3(0)$. No corporation can purehase.

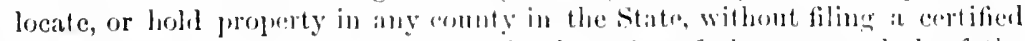

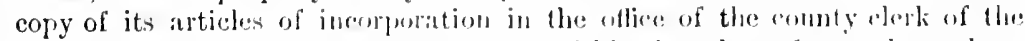
combly in which such property is situatnd, within sixty ditys after such purchase or location is male (sec. lug). The compration must orgatize and commeneo business within une year inter ditt" of incorporition (stc. 52:3).

Murrison v. Clarke, 24 Mont. $515 ;$ 6.3 l'ac. 98. 
11. Organization Meetings. - These must be held within the State, in the alianlen of ally" statute providing otherwise.

11. Meetings of Stockholders and Directors. - Stockholders' meetings must lu hele at the otlice or principal place of business of the corporatim within the slate. Jirectors meeting may be leld within or without the state if the ly-laws so provide. If held without the State, either the original or a coprof all procordings had at such meeting, certificd by the president and seretiry meler the corporate seal shall be sent to and kept at the prineipal ofliec of the corporation in Montana, and shall be part of the records thereat (sece, 41 th)

12. Directors' Qualifications and Liabilities. a. Qualifications. - There must be not less than three nor more than thirteen directors, who must likewise be stockholders to the amonnt prescribed in the by-laws. The only excention is that the lirectors anthorized by the articles of incorporation to act as such for the first three months need not be stockholders (sec. 4:34).

b. Lichilities. - Directors are jointly and severally liable to the corporation and the creditors in the event of its dissolution, to the full amount of capital stock divided, withdrawn, paid ont or reduced, and for debts contracted in riolation of law. Dissenting directors may protect themselves by causing their dissent to be entered at large in the minutes of the directors' meetings (see. 438). 'Ther are also liable for wilfully making false certificates or reports and for failure to make anuual reports (sec. 445; Laws of 1903, chap. 32).

Gaus $v$. Swit\%er, 9 Mlont. 408 ; 24 Pac. 18; State Sav. Bank v. Johnson, 18 Mont. $440 ; 45$ Pac. 662.

13. Stockholders' Liabilities. - Stockholders are liable, to the extent of their unpaid stock subseriptions, for all acts and contracts made by such corporation until the whole amount of eapital stoek subseribed by them shall have been pairl in (sec. 470 ).

11. Stock Certificates. - Each stockholder is entitled to a certificate of stock signed by the president and secretary (Civ. Code, sec. 471). Par value of shares may be any anount.

1.). Preferred Stock. - There is no express power given by statute to issue preferverl stock.

16. Payment of Capital Stock. - Corporations call issue stock or bonds only for libor done, services perforned, money or property actually received. All fictitions increase of stock is void (Cons., Art. XV. sec. 10 ; sec. 525). The Corle proviles that the directors may purchase mines, manufactories, and other froprerty necessary for its business. and issne stock in the amount of the value thereof in payment thereof, and the stock so issued shall be declared and deened to be full-paid stock and not liable to any further call. Neither shall the lowlws thereof he liable for unpaid st ock subseriptions as provided in sec. 4.0 of the Corte. 'The law provides that any arbitrary value may be fixed on for min's, irrespective of actual value. Wherever stock has been issued therefor, such stock shall be deemed full-paid stock regardless of the aetual value of the mine at the time of such purchase (sec. 410).

17. Books. - Books of by-laws. stoek register, transfer book, and record book fof corporation must be kept at principal oflice within the State. Stockloblers have the right of inspection at any time during business hours (ser. 511 ).

1.. Office. - Every domestie corporation is required to keep an office within the state. The statute provides that the principal place of business $: 1: 2$ 
within the State must be named in the articles of incorporation (secs. 403,445 .

19. Reports. - Oflicers and directors are held individually liable for debts of the corporation if the president and a majority of directors fail between December :31st and January oth following to make, file, and publish a rerified statement of amonnt of stoek, amonnt paid in, and amount of existing debts (sec. 451; Laws of 19(0:3, chap. :32).

20. Anti-Trust Statute. - Certain kinds of trusts and combinations are declared illegal by statutes. (See Cous., Art. XV. see. 20; Penal Code, chap. 8 , secs. 321, , ;2.)

21. Statutory Grounds for Forfeiture of Charter. - The cliarter may be forfeited upon direct proceedings taken by the state for misuser or nonuser thereof. Also for failure to organize and commence business within one year from date of incorporation (C'ode Cir. Pro., sec. 1411; Civil Corle, sec. 5:3).

22. Extension of Corporate Existence. - The corporate existence may be extended by compliance with the statute in such case made and provided (secs. 412, 562).

23. Annual Franchise Tax. - There is no annual franehise tax.

24. Amendments. - Ameudments may be made increasing or decreasing capital stock, changing par value, location of principal office, or the character of business (sees. 413, 450, 52.5).

25. Dissolution. - Dissolution may be had only by application to the conts (Code Cir. l'ro., title VI. part III.; title X. prart II. chap. 5, secs. 2190--196; see also (iv. Cole, sec. 561).

Gans: $\iota$. Switzer, 9 Mont. 408 ; 24 Pac. 18.

26. Foreign Corporations. - Foreign corporations desiring to do business in Montina must tile in the oflice of the secretary of state and in the oflice of the comnty recorder of the comnty wherein they propose to carry on their businsss, a duly authenticated coly of their charter or certificate of incorporation, and a veriferl statement made by the president aml secretary. and attested by a majority of the boarl of directors, showing nane of corporation and location of its principal place of business within the State: anomt of capital stock, amonnt of capital stock paid in in moner, pairl in in any other way; amount of assets of the corporation, of what they consist and actual ralue theref : statement of the liabilities of the corporation. secured and unsecured. The colpuration must also appoint an agent. who shall be a citizen of the State, upon whmu service of process may be male (Act of March !)

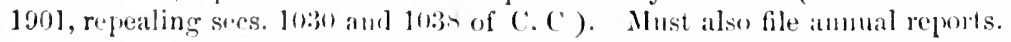

Powler River Cattle (or. r. ('ommissiners, 9 Mont. 1.t5; 23 l'ac. 38:3; Amel. H. S. Co. e. o'honrke, 23 Mont. 530; 59 Pac. 910; MeNiunghton Co. r. Me(iirl, 20 Iont. 124; 49 I'ace. 651.

\section{NEBRASKA.}

(The referencers are to the rompilind latws of 1903 unless otherwice stated.)

1. Statutes under which Business Corporations may incorporate. -

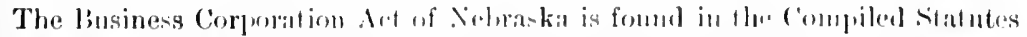

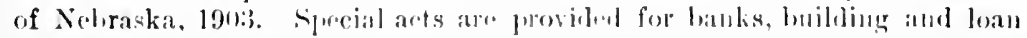
railway, safe deposit and trust, stree railway, firlelity, and guaranly compa- 
nies. l'mler lin General let parties may incorporate for any lawful business, incluling the anstruction of cantsls, ritways, bridges, and other works of internis! imprimemem.

$\therefore$ Incorporators. - Any number of persons may incorporate. There are no resilential requirements (C. I., sec. 2081).

$\therefore$. Contents of the Articles of Incorporation. - It is customary to provide in the articles of incorporation for the following matters:

4. Nime.- The name of the corporation. Similarity of names is not furbiahlen (C. L., sec. 20ss).

1. Immicilimy (Ifice. - The principal place within the State for the transaction of husincsio (il.).

c. I'urposis. - The general nature of the business to be transacted. 'This would seem to permit of the incorporation of a company for more than one 1nupose. The secretary of State construes the act to permit of the insertion of any number of purposes (Il.).

d. Copitul stock. - The amount of capital stock authorized and time and conclitions upon which it is to be paid in. The capital stock may be any amount. The par value of shares may be any amount. It is customary to insert provicion that in case new stock is issued it shall be distributed proruta anong the existing stockloolders (Lu.).

e. Duration. - 'Time of the commencement and termination of the corporation. The corporate existence may be perpetual if desired (Id.).

f. Corporate Indebtedness. - Ilighest amount of indebteduess or liability to which the corporation is at any tine to subject itself. The corporate indebtedhess cannot exceed two-thirds of the capital stock (C. I., secs. 208., 2085).

9. Directors. - A statement must be male to the effect that the affairs and business of the corporation shall be conducted by a board of directors of a certain designated number and by the officers by them to be elected as hereinafter provided (C. L., sec. 2085).

h. Organization and Ammul Meeting. - A statement to the effect that the first meeting of the corporation shall be held upon the day of the organization of thrs corporation, and thereafter the annual meeting shall be held at the office of the corporation on a certain designated clay. 'This should be followed by a statement that at such meeting and at the immual meetings thereafter the board of directors shall be electel by the stockholders from their own number to hold office until the annual meeting next after their election and until their snceessors are elected and qualify (ld.).

$i$. Iffers. - A provision to the following effect should be inserted. The directors shatl in each instance as soon as convenient after their election flect from their own number a president, vice-presilent, secretary, and treasurer, who shall hold office until the annual meeting next after their election and until their successors are elected and qualify. Any two of said offices may lie hold by one and the same person, excepting the oftices of lresilent and vice-president (Irl.).

j. By. Lanes. - The board of directors shall have full power and authority to inalie all rules and by-laws for the proper govermment and control of the busine-s affairs of the corporation, and (if desired) they may alter and amend the same at plearure (Id.).

$k$ Filling of Vacancies. - Vacancies occurring in the board of directors shall be fillinl by the stockholders. Oftices vacated from whatever cause shall be filled by the hoard of directors (Id.).

$$
311
$$


l. Amendments. - Provisions may be inserted proriding as follows: These articles of incorporation may be amended at any time. Every amendment shall be first approved by a two-thirds vote of the entire board of directors, and upou being so approved, it shall be entered at Iarge upon the records of the board. A draft of the proposed amendment, or amendments as the case may be, shall then be submitted to each stockholder, with the notice of the meeting called for the purpose of voting upon the same, which notice shall be given at least ten days prior to the date fixed for the meeting. If such amendment or amendments, or either of them, shall then be approved by the holler or holders of two-thirds of the capital stock of the corporation, each and every amendment so approved shall be considered adopted and be macle a part of the articles of incorporation, and the board of directors shall thereafter subscribe, acknowledge, record, and publish the same, as by law required ( $\mathrm{Ill}$.).

4. Statutory Powers. - The statute merely enumerates the common law powers of corporations (C. I., sec. 2US2; see C. L., sec. 19S9). By constitntional provision the legislature is required to provide by law for cumulative voting by person or by proxy in the election of directors (Cons., Art. XIII. sec. 5).

Williams $v$. Lowe, 4 Neb. 382 ; Enterprise Ditch Co. $v$. Mothitt, 58 Neb. $642 ; 79$ N. W. 560 ; Fremont Carriage Co. $v$. Thomsen, 91 N. W. 376.

5. Procuring the Charter. - The articles of incorporation must be signed by each of the ineorporators. After the articles have been signed and acknowledged they must be filed in the office of the Secretary of State. Before such copy can be filed the organization tax must be paid together with the filing fees. Thereupon the corporation becomes a body corporate. The law specifically provides that no body of men acting as a corporation under the provisions of the Business Corporation Aet shall be permitten to set up the want of legal organization as a defence to any action brought against them as a corporation; nor shall any person suing on a contract male with such corporation, or for an injury to the property of said corporation, be permitted to set up the want of legal organization in defence of said action. The articles of incorporation must also be filed with the county clerk in the county where the corporation's headquarter's are to be located (C. I., sec. 2083 ; see also C. I., see. 1958).

6. Corporate Indebtedness. - The amount of corporate inlebtedness must not exceed two-thirds of the capital stock (see. 311).

7. Organization Tax. - On filing the artieles the Secetary of State must be paid a fee of slo if the capital stock rloes not exeeed slio, 000 . Where it exceeds that amount an adhitional 10 enuts for each adilitional s1,0c0 of authorized eapital stock in exerss of $\$ 100,000$.

8. Filing Fees. - Filing fres in the otlice of the siccretary of Statce, 10 cents per folio. Cortifierl enly of articles of incorporation, in cents per folio. Publication of notice of the intention to incorporate costs fom sion to \$15 (Laws of 1s:77, ehaj. 18: see also ('. L., chitp. 4:3, Art. 2, sec. :3).

9. Commencing Business. - Hefore a colporation can transact any lusiness except its own organization, it must, in arldition to arkpting articles of ineorporation and filing and recorling them in the oflice of the secretary of State, also file sain artieles with the comnty elork of the commty where their hearlinarters are to be located (sec. 20833$)$. Within four months after filing the articles a notice must be published in a newspaper near the principal place of 
Muiness for fom werlis, setting forth the eorporation's name, principal place uf hoviness, weneral nuture of the business, amount of capital stock authoriced, the time and conditions of prayment, timo of commencenent and termi11:tinn, highest amount of indebtedness or liability to which the corporation is alt anl time to subject itself, and by what oflicers its affairs are to be conductin. It is nut meesary, however, for the corporation before commeneing Insiness to wat the completion of the publication of the notice above referred

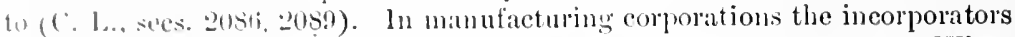
ale ipso fincto enmmissioners to open the hooks for stock subseriptions. When terl fer cent of the cappital stock is subserihed, such corporations may commence business (C. I.., sec. 1!173). The corporation must organize within one year after its incorporation (sec. 2086$)$.

10. Organization Meeting. - Organization meetings must be held within the siate. In the case of manufacturing corporations the law provides that the incerporators slall he commissioners to open books for the subseription to the capital stuck of saicl company before the corporation is organized by the adopution of articles of ineorporation as set forth above. Immediately after these atrticles hive been adonted the incorporators should meet as stockholders and chonse a board of directors of the mumber designated in the articles. 'The boarl of directors shall elect at this meeting the officers and adopt bylaws. The corporation must organize within one year after incorporation (C. L... ses. 1571, 1973).

11. Meetings of Stockholders and Directors. - In the absence of any statute authorizing the holding of stockholder's' meetings outside the State, such meetings should be held within the State. Directors' meetings may be held without the state if the by-laws so provide (C. L., sec. 1972).

12. Directors' Qualifications and Liabilities. a. Qualifications. - The law does not prescribe the number of directors. There are no residential requirements. The directors of manufacturing corporations must be stockholclers, and they must eleet a president from their own number. (See C. L., sce. 15\%:-)

b. Limbilities. - Directors are liable for the illegal payment of dividends (Corle of (iv. Pro. sec. 5260 ; C. 1., secs. 2009, 2099).

13. Stcckholders' Liabilities. - Stockholders are liable to the extent of their unpail stock subseriptions. If the corporation fails to publish the annual nolice of existing debts hereafter referred to, then in case the assets of the rorporition are therenfter exhansted, leaving debts unpaid, the stockholilers are liable to the amount of stock owned by them for all debts contricter] before nuch notice was given (C. I. sec. 209:3). If any corporation fails to connly substantially with the provisions of law relative to giving urtice and other requisites of organization, then in such case, after the assets of the crimation are first exhausted, the property of stockholders shall be liable for corporate lebts to the amount of capital stock owned by them (C. L., sec. 2u! 4 i). (See also Const., Art. XI. b. sec. 4.)

F. \& .1. Co. r. Company, 46 Nels. 333 ; 64 N. W. 978, 1097 ; F. L. \& T. Co. $v$. Funck, 49 . 16. 3.53; 68 X. W. 520; Gorler $v$. Connor, 56 Neb. 781 ; 77 N. W. 383 ; Brown $v$. lirink, 5i Net, f,06; ; 8 N. W. 280.

11. Stock Certificates. - Every stockholder is entitled to have a stock certificate issued to him signed by such officers as the by-laws may prescribe.

1.). Payment of Capital Stock. - Neither the Constitution nor the statnte jrescribes how the capital stock shall be paid in. In the absence of $: 16$ 
such prorision it is implicd that it must be paid in in money or money's worth.

G. \& A. Co. $v$. Company, 46 Neb. $333 ; 64$ N. W. $978,1097$.

16. Books. - Stock books and books of account must be kept at the principal place of business of the corporation within the state, and be open to the inspection of stockholders. The foregoiug provision would seem to apply only to manufacturing companies (C. L., sec. 1972).

17. Office. - Every corporation is required to keep an office within the State (C. L., sec. 2uss).

15. Reports. - Every corporation must give notice annually by publication in a newspaper published in the county where its principal place of business is locited of the amomnt of existing debts. This statement must be signed by the president and a majority of the directors (C. L., sec. 2093).

19. Anti-Trust Statute. - Ender the Act of 1897 , chap. 79 , all trusts and conspiracies against trade and business as defined in the statute are declared to be illegal and roid.

State $v$. Neb. Dis. Co., 29 Neb. $700 ; 46$ N. W. 155.

20. Preferred Stock. - There is no express provision in the statute authorizing the issuance of preferred stoek.

21. Statutory Grounds for Forfeiture of Charter. - The charter may be forfeited through any violation of the provisions of the General Corporation Act, such as the payment of dividends when the corporation has insulficient funds to meet its liabilities, etc. Repeated acts of misuser or non-user have been held to constitute grounds for forfeiture of franchise (C. I.., sce. 2100 ; Code of Cir. I'ro., secs. 5295-5260 inclusive). The charter may be forfeited if the corporation does not organize within one year after its incorporation (sec. 2081j).

State $v$. A.\& N. R. R. Co., 24 Neb. $143 ; 38$ N.W. 43 ; State $v$. Nebraska Dis. Co, 29 Neb. $700 ; 46$ N. W. 155; State 2 . Company, 4 Neb. 354.

22. Annual Franchise Tax. - There is no ammal franchise tax

23. Amendments. - The power of amendment extends to the following matters: calpital stock may be increased or decreased and nature of business may be changed. Also to change in par value of shares (C. I., sec. 1990).

21. Dissolution - ('orporitions may be dissolvesl by consent of twothirds of the stockholder's (C. L., sec. 1996; see also C. L., sees. 20!1, 2101).

Harrington $v$. Conuor, 51 Neb. 214; $70 \mathrm{~N}$. W. 911.

25. Extension of Corporate Existence. - Provision is madl for the extension of corporite existence for companing incorpurater for the purperse of erecting any publie improvenent ( ${ }^{2}$. L., sices. 1991, 19!2).

26. Foreign Corporations. - Sild corpurations must file with the secre. tary of State a eripy of their chater or anticles and a erryified enper of the

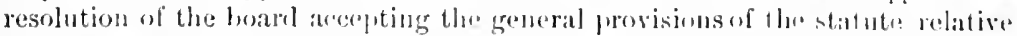

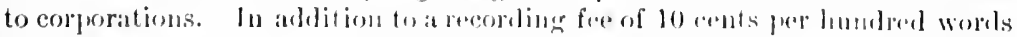

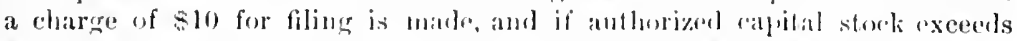
$\$ 100,000$, a further charge of 10 cents for eideh exeess $\$ 1,000$ is malde.

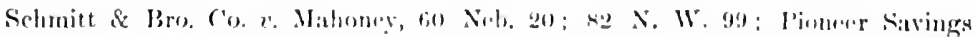

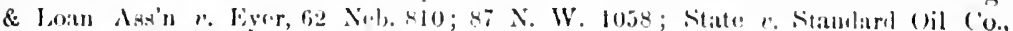
61 Nels. 28; 84 N. W. 413. 


\section{NEVADA.}

(Lieferences thelew are to the laws of Nevala, 190)3, Chap. 88, unless otherwise stated.)

1. Statutes under which Business Corporations may incorporate. - "lie lim-iness corporation Aet of Nevada is to be fomd in the Laws of

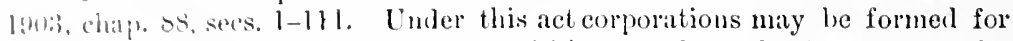
the transiction of any lawful business within or without the State, except insurallece surety, or railway compranies. These last may be incorporated under the ant if formed to transact business exelusively out of the State.

$\therefore$ Incorporators. - 'Threc or more. No residential requirements (sec. 1).

See In re L. B. Co., 1 San. 349.

8. Contents of the Certificate of Incorporation. - The certificate must set forth:

a. Vome. - Similarity of names is forlidden (sec. 4, sub. 1). It must end with "incorporated," or contain one of the following words, "association," "company," "corporation," "club," "socicty," or "syudicate" (Id.).

b. Purposes - Oljects for which the company is formed. Any number of purposes nuay be inserted (sec. 4, sub. 3).

c. Capitul stock. - Not less than $\$ 2,000$, number of shares and par value thereof, which may be any amount. Amonnt of subseribed capital stock with which it will begin business not less than $\$ 1,000$. Amount actually subscribed and anount actunlly paid up, if any. If preferred stock is to be issued, a deseription thereof and terms of its creation must be set forth (sec. 4, sub. 4).

d. Intution. - May be perpetual if desired (sec. 4, sub. 6).

e. Original Subscribers. - Nanes and post-office addresses and lesidences of each of the original subscribers to the capital stock and amount subscribed by each (sec. 1, sub. 5).

f. Directors. - Whether the members of the first govening board shall be styled "directors" or "trustees," and the number thereof, which shall not be less than three (see. 4, sub. 7 ).

g. Iomiciliury Office. - Location of principal office in the State, giving street and number if practicalle (sec. 4, sub. 2).

h. Assesments. - Whether stock shall be subject to assessments or not (sec. 4. sub. 8).

i. Regulntion of Internal Affairs. - Any provision for the regulation of the internal affairs of the corporation that may be desired may be inserted (sec. 4, sub. ()).

4. Statutory Powers. - The act enumcrates the common law powers and also confers the following additional powers : to vote by proxy, to forfeit struck for mon-payment of assessments, to issue preferred stock, to transact busines: ontsile of the State, to hold stockholder's' and directors' meetings outside of the State, to permit cumulative voting, to al point an executive committee from the hoard of directors, to consolidate with other corporations, to issue slock for labor or property, to issue bonds, to remove directors, to delewate the prower to directors to arlopt by-laws, to surrender cliarter, to hold strock in other corporations (secs.7, 8, 9, 10, 11, 17, 20, 23, 30, 4., 54, 78, 110).

Sulro 2 . Company, 19 Nev. 121 ; 7 I'ac. 271 ; Bassett $v$. Company, 15 Nev. 293.

5. Procuring the Charter. - The corporators must subscribe and acknowldge the articles, after which they must be filed and recorded in the :3) 
office of the clerk of the county where the principal place of business is to be located. Next, a copy of these articles certified under the seal of the clerk of said county must be filed and recorded with the Secretary of State. - This official, after payment to him of the organization tax and filing fees, issues a certificate that a coly of the articles containing the required statement of facts has been filed in his office. Thereupon the corporate existence contmences (secs. :3. 5. 6).

6. Corporate Indebtedness. - There is no statutory limitation upon corporate indel,tedness.

7. Organization Tax. - Before incorporation there must be pail to the Secretary of State 15 cents for each thousand dollars of capital stock authorized, but in no case less than 815 .

8. Filing and Recording Fees. - There is no extra charge for filing and recording in the Secretary of States ottice other than the payment of the organization tax. Cost of certified copy of charter, 4 cents per folio and $\$ 5$ for certificate and seal of state. The filing and recording fees in local county otfices vary according to the population of the connty. 'The filing fee ranges from 15 cents to 25 cents, and the recording fee from 20 cents to 30 cents per folio, and copying fee from 20 cents to 30 cents per folio ; the cost of affixing certiticate to copy ranges from 50 cents to 81 . Cost of filing certificate of election of directors, etc., with secretary of state, \$1. Cost of filing certificate of payment of iustalment of capital stock in secretary of State's office, $\$ 5$.

9. Commencing Business. - Business may be communced as soon as the certified copy of articles is filed in the ollice of the secretary of state. The time limited hy statute within which husiness may be comnunced is two years (sec. 5). Certiticate of payment of stock either in whole or in part. duly sworn to by fresilent, secretary, or treasurer, must be filed in the oflice of the Secretary of state within ten days thereafter (secs. 31, 35). Corporate exist. ence camot be collaterally attacked (sec. 5).

10. Organization Meeting. - May be held within or without the State. Provisiuns for calling the same is made in the act (secs. 1:2, 13,:38).

11. Meetings of Stockholders and Directors. - Stockholder' meetings may be held within or withont the state. Foting ly froxy permitted. Cumblative voting allowel. Directors' nertings may be held wherever lylaws provide (secs. 1:3, 11, 17, 20, 2:3).

12. Directors' Qualifications and Liabilities. a. Qualifiontions - There must be at lea-t thre directors. They need not be stockholders. They must take the oatl of oflice. No resilential mpluirments (s.e. 1, sub. 7. 1!1). They are empowerer to alpoint an executive committee of two or more of their number (sere. $2: 3)$.

b. Coinlilitios. - Jointly and severally liable where they give ont framblulent

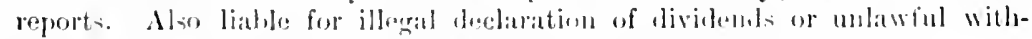

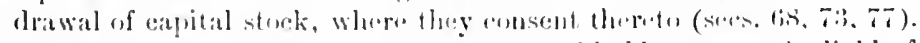

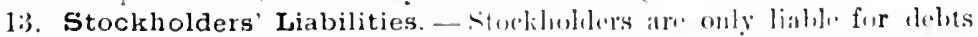

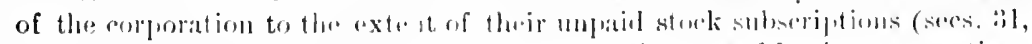

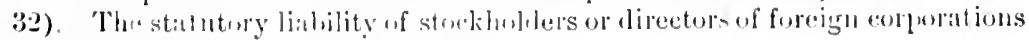

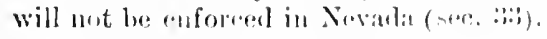

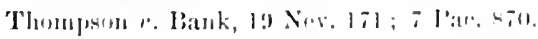

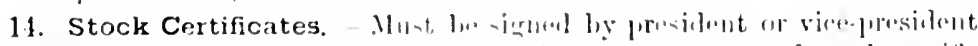
and secretary or triaturer. The stalnte points ont coutents of stock antificates (sec. is(i) 
1.) Preferred Stock. - 'The statute expressly authorizes the issuance of

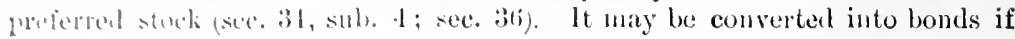
derired (seresiti).

lii. Payment of Capital Stock. - May be paid for in money, labor, or

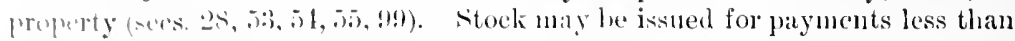
the par value the be be tomplying with the provisions of the act (see. 53).

1. A. A. M. ('o. l. Thies, 26 Nev. 158; 65 P'ac. 373.

17. Boolss. - Original or duplicate stoek ledger must be kept at prineipal oflice "ithin the statte for inspertion of stocklokters (sec. 14).

1․ Office and Agent. - Corporation must have an oflice and agent in charee within the state (sce. 16i).

I!! Reports. - The presilent, secretary, or treasurer, upon the payment of each instalnent of capital stock, must make a certifieate stating the amount so patil, and whether pain in cash or by the purchase of property, and the lature and amonnt and character of and value of services or property accepted in parment of stoek, stating also the amomnt of capital stock, if any, previonsly paid and recorded. This certificate signed and sworn to must in ten disy atter said parment be filed in the oflice of the Secretary of State. No nther repurt is recjuired (see. 35 ).

20. Anti-Trust Statute. - There is no anti-trust statute in force in this State.

21. Statutory Grounds for Forfeiture of Charter. - Charters may be forfeited for failing within two years to organize and commence in good faith the business or promote the objects or purposes for which the corporation was organized.

22. Annual License Tax. - There is no amnal license tax.

23. Amendments. - Charters may be amended both before and after organization for any purpose desired (secs. 37, 39, 40,42).

24. Extension of Corporate Existence. - Charters may be renewed if desirel (secs. 107, 105).

25. Dissolution. - The charter may lie surrendered by the incorporators before organization if desired (see. 8 s). By resolution of a board of directors a meeting of the strokholders maly be called to vote upon the question of dissolution. 'Two thirds in interest of the stockliolders or ereditors entitled to vote are required to bring ahout a voluntary dissolution; it may be effected ly writen consent of nine-tenths in interest of secured ereditors entitled to vote "ith stockholders without a meeting (sec. S9).

2(). Foreign Corporations. - Foreign colporations desiling to do business in the state are governed hy what is known as the lietaliatory Taxation Law. Ihis proviles that such corporation shall pay the same taxes in Nevala that foreign eorporations are recpured to pay in the domicile of the aforesaid foreign corprotion. 'They must also file certified copy of certiticate of incorporation with recorder of each connty in which they are engaged in husiness, with a list of ofleers, duly certifierl by the proper officers; nust appoint a resident arent in this state to receive legal process by certificate filed with secretary of state, failing in which process may be served upon Secretary of State, and un-t fulh sh an ammal report in January and file same with county assessors where business i carried on (nec. 106; C. L., secs. 897,901 ; Laws of 1911. chap. 108). Fee for permit and filing fees, $\$ 10$.

W. C. \& S. M. Co.r. Baker, 3 Nev. 351 ; Evans $v$. Lee, 11 Nev. 194; Brooks 1 . Syndicate, 24 Xer. 264, $311 ; 52$ Pite. $575 ; 53$ P'ac. 597.

$(; 20)$ 


\section{NEW HAMPSHIRE.}

(References below are to Public Statutes of New Hampahire, 1891, unless otherwise stated.)

1. Statutes under which Business Corporations may incorporate. The Business Corporation .let of New IAmpshire is to he found in the Publie Statutes of New ilamphire, 1891. cha! 14. Enter this a corporations may be formed for the purpose of carrying on any haw business, excentiner banking and life insurance, and the making of contracts for the paymint if money at a fixed date or upon the lappining of sume contingency and the construction and maintenance of railroads.

2. Incorporators. - There must be fire or more incorproters of lawful age. There are no residential requirem (chap. 117, sec. 1).

3. Contents of Articles of Association. The articles must set forth :

a. Name. - Similarity of names is forbidden (chan. 1+S, secs. 2, 3).

b. Purposes. - Ol,ject for which the corporation is formed. State oflicials construe this to anthorize incorporation for any number of purposes not provided for by special act (chup. 14s, sec. 2).

c. Domiciliary Offee. - Location of principal place of business (IH.).

d. Capilal Stack - Amount therent. Capitalization cannot be less than $\$ 1,900$ nor more than $\$ 1,000,000$. Par value not less than $\$ 25$ nor more than $\$ 500$ (chap. 148 , sec. (6).

e. Incorporalurs. - Names and post-oflice alliesses of the incorporators (chap. 14 , sec. 2 ).

The duration of corporate existenee may be unlimited if desired.

4. Statutory Powers. - In adition to the statutory enmeration of common law powers, the act anthorizes stockholders to vote hy proxy, and provides for the forfeiture of stock for non-payment of assessments (chap) 14t, secs. 1-9 inclusive : chap. 119, sees $22,29,25,26$; Il secs. 16-1s inclusive)

5. Procuring the Charter. - Articles must be recorded in the office of the clerk of the town in which the husiness of tho corporation is to be carried on, and also in the otfice of the Secretary of state. Thw charter fee mu-t he paid to the Seeretary of State at the time articles are filed (chap. 117, sec. 1).

6. Corporate Indebtedness. - Delits caunot be contracted exceeding one-half of the value of the corjoratr property (chit). 150, sec. 4).

C. R. S. Bank $\because$ Fiske, 62 X. II. $\approx s, 180$.

7. Organization Tax. - Corporations formad to carrs on hu-ines with-

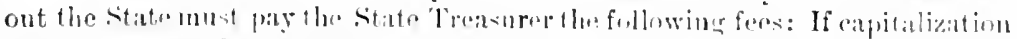

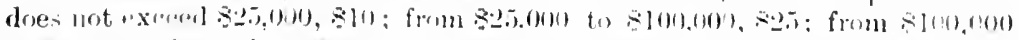

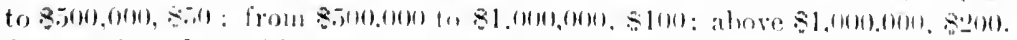

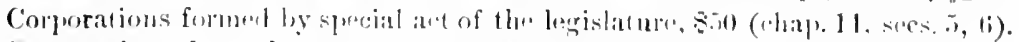

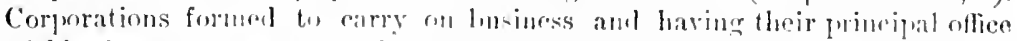

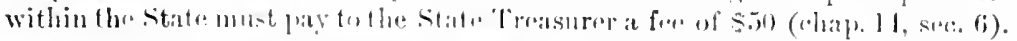

8. Filing and Recording Fees. The Sientiry of State is entition to

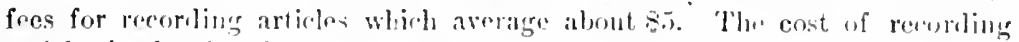
artioles in the city clerk's oflier, s1.50.

9. Commencing Business. - ('orporations may commone business as

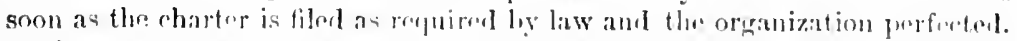
Business must he commenend within thre years from the date of incongma-

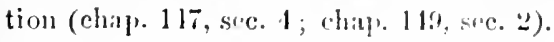


10. Organization Meeting. - The organization meeting must be held within the state. This in the absence of any statute expressly anthorizing such mentins to be held withont the state (see chap. 148, secs. 4, 5).

11. Meetings of Stockholders and Directors. - Stockholders' meetings must be hehl within the slate. Birectors' meetings may be held without the state it the by-laws so provide. There is no statnte anthorizing the holding of stuckholders' meetings without the State, and at stockholders' meeting each stockholder may give one vite for each share he owns therein not exceeding one-eighth part of the whole number of shares (chap. 149, sec. 9).

I.?. Directors' Qualifications and Liabilities. a. Qualifications. $\rightarrow$ There mmst be at least three directors, one of whom must be a resident of the State, providen the corporation has any stockholders within the State (chap. 149, sece. 1).

b. Linhitities. - Inirectors are liable for the declaration of jllegal dividends or for premitting contraction of corporate indebtedness beyond the amonut limited by law. The directors ant treasurer must, within thirty days after the whole amomnt of capital stock has been laid in, make, subscribe, and file in the othee of the clerk of the town where the corporation has its principal place of bu-iness a certificate to that effect, under penalty of being liable for all debt: of the corporation contracted after the expiration of said thirty days and hefore said certificate shall he so male and recorded; also liable for loans and false certificates to stockholders (chap. 150, secs. 2, 3, 4, 5, 6, 14, 19). 1)irectors are also individually liable for all debts of the corporation until the annual report is male as required by law (chap. 150, sec. 16).

13. Stockholders' Liabilities. - Stockholders are liable to the extent of their unpair stock subscriptions. Stockholders receiving unlawful refund from the capital stock, or for knowingly receiving illegal dividends, are indivilually liable for debts of the corporation then existing or afterwards contracter until the same is refunded or paid to the creditors of the corporation. They are also liable as partuers if the charter is void (chap. 150, secs. 7, 8, 9; chap. 11, sec. 9). Stockholders are lialie for all debts and contracts of the corporation until the whole amount of capital shall have been paid in, and a certificate thereof signed by the treasurer and a majority of the directors has been filerl and recorded with the clerk of the city or town where such corporation lats its principal place of business. No note or obligation given by a stockholder shall be considered as payment of any part of the capital stock (chap. 150, sees. 8,9).

Swan r. Burnham, 70 N. II. 580 ; 49 Atl. 93; March $v$. Eastern R. R., 43 N. II. 516 ; Smith 2 . Bank of New Eugland, 69 N. H. 254; 45 Atl. 1082; Lancaster Starch Co. 2. Monre, 62 N. II. 671.

11. Stock Certificates. - Each stockholiler is entitled to have a certificate issued to him signer by the treasurer or cashier and such other officer as the hy-laws may prescribe. No certificate must be issued until the par value rif hares nnentioned in it have been fully paid to the corporation. 'The par vilne of the shares must not be less than $\$ .5$ (chil). 149 , secs. 5, 10).

1.). Preferred Stock. - P'referred stock is authorized (chap. 149, sec. 8).

16. Payment of Capital Stock. - Stock must be paid for in money or money's worth. The statute forbids the payment of capital stock by promissriry inite. The statute also provides that no shares shall be sold at less than Jis (chal, I19, sec. 9; chap. 150, sec. 9). No certificate can be issued until $\because 201$ 
the par value of the shares mentioned in it has been fully paid (chap. 119, sec. 10 ; see also chap. 150 , sees. 10,11 ).

Libby $x$. Company, 68 X. H. $444 ; 44$ Atl. 602 ; Lincott et al. $r$ Company, 68 X. H. 260 ; 44 Atl. 392 ; Kimball r. Company, 69 N. H. $485 ; 45$ A 1.253.

17. Books. - Records of the proceedings of stockholders and directors and all papers must be recorled in the oflice of the clerk of the corporation in the Stite. Books of account, nanes, anl resilences, mumler of shares owned by each stockholder, shall also be kept with the clerk (chap. 149, sec. 12 ; chap. 140 , secs. 10,11 ). All records. accunts, and papers are open to inspection of stockhollers (chap. 148, sec. 1:).

18. Office and Agent. - Every conporation must maintain an office within the state, and a clerk therein to receive process, who shall keep the records of the company (I'ub. Stat., chap. 145, secs. 10, 11, 1.2).

19. Reports. - Corporations, excepting insurance, railroad, bank, anıl loan and bnilding associations, shall ammally in Nay make a report to the Secretary of State, and to the clerk of the town in which the princigal business is carried on, stating amount of assessments paid in; amomnt of debts due to ind from corporation and value of all property and assets of the corporation on the first day of May. Non-compliance makes the treasurer and directors individually liable for all debts and contracts (P'ub. Stat., chap. 150, sec. 16).

20. Anti-Trust Statute. - There is no anti-trust statute.

21. Statutory Grounds for Forfeiture of Charter. - The charter may be declared void for failure to pay the fees requires by law or for falsely pretending that the corporation is to cary on its business and have its principal oflice within the state for the purpose of avoiding the payment of the charter fee required by law (sec. 44 , chap. 11, sees. 8, 9, 10 ; Laws of 1896 , p. :319).

State $v$. Barron, 58 X. II. 370 ; Parsons $v$. Lureka Powler Works, 48 N. II. 66.

22. Amendments. - Charter may be amented for the purpose of changing its name, increasing or decreasing the capital stock, or for amculing its articles of association in any other respect desired (Laws of 1895 , chap. 2 ; chap. 119 , sec. 7 ).

2:3. Extension of Corporate Existence. - There is no prorision for extension of corporate existruce.

21. Dissolution. - Stuckhohers owning one-fourth of the stock may petition in the superior eourt for lissolution (sec. 31, l'. S., chalp. 117, secs. 10-12; see also chip. 115. sec. 1s).

School Distriet 2 . Rireenfiell, 61 N. II. $84 ; 6 \mathrm{At1}, 184$.

25. Annual License Fee. - There is no ammal license fer.

26. Foreign Corporations. No spreial refuirements exacted to carry on business. Neerl not reelure th" nam of its agent. May maintain a suit in the state. Foreign corporations doing hunesu in the stat most file with the State librarian on or hefore lammary lst of each year all printed reports of their condition issued by them during the twelve months preceding (lawis of 1595 , chap. 3).

Lumbard $v$. Aldrich, 8 ㄷ. II. 31 . 


\section{NEW JERSEY.}

(The references citeil bolow are to haws of 1896 , chap. 185, unless otherwise stated.)

1. Statutes under which Business Corporations may incorporate. The linsiness ('orporation let is to he fomd in chap. 185, Laws of 1896, and amembents therete made in the years 1597, 189s, 1899, 1900, 1901, 1902, and 1!n::). Special acts are provided for the incorporation of savings banks, buihling and han associations, surety, railway, telegraph, telephone, canal, turnpilse, hamlinu, safe deposit, and trust companies. 'The statute, however, proviles that eorporations may incorporate uneler the General $\Lambda$ ct for the purjore of eontrueting, maintining, and operating railroads, telegraph and telephome companies outside of the state.

2. Incorporators. - Three or more persons. There are no residential requirenents (sec. 6).

C. K. R. ґ. I'. R. R. Co., 31 N. J. Eq. 475.

3. Contents of the Certificate of Incorporation (sec. 8). The certificate must set fortls:

a. Nime. - No name can be used alrearly in use by any existing corporation of the state, or so nearly similar thereto as to lead to uncertainty or confusion. It must be in the English Janguage (sec. 8; Laws of 1897, chap. 274; Laws of 1903, chap. 119). The name insuranee, safe deposit, trust eompany, or bank cannot form part of the name (Laws of 1897, p. 274).

b. Demicile.- The location of the principal oflice in the State; street and number must be given if located in a city (sec. \$). Also the name of the agent in charge thereof and upon whom process may be served (Laws of 1898, p. 410$)$.

c. P'urposes. - Any number of objects may be inserted provided they are not covered by the special acts above referred to (sec. 8).

d. Capital stock, - Amount of total authorized capital stock (not less than so, (nim), the number of shares into which the same is divided, and the par value of each share (par value may be any amomt). The amount of capital with which the corporation will begin business, which cannot be less than $s 1,000$. If there be more than one class of stock, a description of the different classes with the terms on which the different classes are created nust be set forth (secs. 8, 1s).

e. Iurntion. - May be mlimited if desired (sec. 8).

f. Procisions for the Regulation of the Internal Affairs of the Corporation.If desired provisions may be inserted for the regulation of the business and for the conduct of the affiirs of the corporation as well as for creating and defining anl limiting or regulating the powers of the corporation, the directors and the stockholders or any cliss of stockholders (sccs. 8, 11, 12, 17, 34, 47).

g. Inecryoretors. - Naues and post-office addresses of the incorporators and the number of shares subscribed for by each. The aggregate amount of strock subscriptions must he equal to the amount of stock with which the corloration will conmence business, which renders stock subseriptions necessary to the annunt of $\$ 1$,

1. Statutory Powers. - In addition to the statutory enumeration of common law powers, the statute confers the following additional powers: To conduct business in other States and foreign countries; to have one or more offices out of the State; to hold, purchase, mortgage, and convey real and per. 
sonal property out of the State. Corporations for the construction of railroads, water, gas, or electric works, canals, tunnels, bridges, viaduets, hotels, wharres, piers, etc., may subseribe for, pay for, hold, use, and dispose of stock or bonds in any corporation for the purpose of constructing, maintaining, and operating works of a similar character, and the directors of such corporations may accept in payment of stock subscriptions real or personal property necessary for the purposes of such corporation or work, labor, and services performed or materials furnished to or for such corporation, to the amount of the valne thereof, and issme full-paid stock in payment thereof. All classes of corporations which may be incorporated under the General Act are given express power to purchase, hold, sell, assign, transfer, mortgage, pledge, or otherwise dispose of the shares of the capital stock or ang bonds, securities, or evidences of indebtedness created hy any corporition of New Jersey or any other State, and while the owner of such stock to exercise all the righis, powers, and privileges of ownership, including the right to rote thereon. Other enumerated powers are the right to vote by proxy, to issue preferred stock, to lease its property and framehises to another corporation, to extend the corporate existence, to consolidate with other corjorations, to dissolve itself, to enforce a lien upon the stock of its members for debts due the corporation, to sell stock subseribed for for non-parment of stock subseriptions, and to provide for cumulative voting in the election of directors. Power to adopt by-laws may be delegated to the directors by inserting a clause to that effect in the by-laws. Direetors maly also be given power to fix amomet of profits to be reserved as working capital. I corporation may aequire and hold its own shares (secs. 1, 7, 11, 17, 15. 29, 34, 36, :38, 18, 49, 51, 101, 105; law's of 1900 , p. 418 ; Laws of 1902 , p. 217 ).

Hilles $v$. Parrish, 14 N. J. Eq. 380 ; M. T. \& T. Co. $r$. D. T. \& T. Co., 44 N. J. Eq. $568 ; 14$ Atl. 907; Berger $v$. U. S. Stecl Corporation, 63 N. J. Eq. 809; 53 Atl. 68.

j. Procuring the Charter. - The certificate of incorporation must be proved or acknowledged as required for deeds of real estate. If acknowledged withont the state, the oflicer taking the acknowledgment must procure a county clerls's certificate of his appointment. The certifieate, together with two copies thereof, should be taken to the oflice of the clerk of the cominty wherein the principal oflice of the corporation within the state is to be establisher. 'Tlye clerk will then keep one of the copies for the purpose of recorling the sime, and will amlorse upon the original and the other copy certificates that they have been filed in his oflice. 'Then the original is filed in the ofliee of the seeretary of state, and a duplicate copy with the comty clerdi's certificate emlorsed throreon ean he used by the secretary of state for the purpose of formishiug the incorporators with a eertifuer eopy of the ecrtificate of incorporation (secs. $8, !)$.

E. G. L. Co. ". Green, 49 X. J. E. $329 ; 24$ A1. 560.

6. Corporate Indebtedness. - There is no statutory limitation upon the amount of inelebterluess which a corpontion mily incur.

7. Organization Tax. - l'wenty conts for each thousand dollaws of eapital stock authorized, hut never liss than s:5.

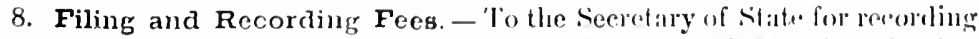
articles, 10 cents per folin witl a minimum chatge of 21 . For issuing certified eopy of the articlus where same are furnished for that purpose, st. Fee to the comnty clurk for recorling certificate of incorporation, 2.5 cents per folio (Laws of 1501 , chap. 115). 
9. Commencing Business. - $B$, fore any corporation can begin business

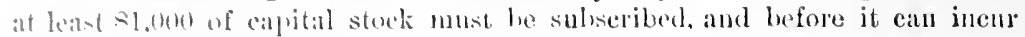
dehts the sail sl.0(1) shall. within the diseretion of the board of directors, be paid in either mon' or property. The law requires the president and seere-

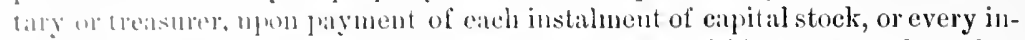
"reitse therent to file in the seeretary of State's ollice within ten days thereafter

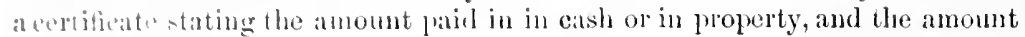
previonsly pitil. 'There is no penalty attached for failure to comply with this furision, but oflierers neglecting or refusing to do so, for a period of thirty dily after written reguest served on them by any stockholder, shall be jointly anil severally liable for all debts contracted before said filing (secs. 25, 26).

10. Organization Meeting. - Must be held within the State. The law fyorifes that where one or more of the incorporators shall die before the corpolation is organized, the survivors may in writing designate other persons who nay take thra place of the deceased incorporators in the organization (sec. 115).

11. Meetings of Stockholders and Directors. - Stockholder's' meetings must be hell within the state at the registered oflice. Directors' meeting may be held withont the State if the by-laws so provide (sec. 44).

12. Directors' Qualifications and Liabilities. a. Qualifications. - The mininum number of directors in New Jersey is three, one of whom must be a resident of the State. All director's must be stockholders, the number of shares to be fixel by the charter or by the hy-laws. They may be classified if desirul. Cumulative roting may be provided for in the certificate of incorporation if desired (secs. $12,36,39$ ).

b. Linblilities. - The directors are jointly and severally liable for payiug cividends ont of capital or for reducing the same. They are also liable for not making and publishing notice of decrease of capital, or for failing to display mame of the company at the principal oflice, and for failure to allow incpection of books or to furnish a list of stockholders at elections, also for failure to file cerificate of payment of capital stock within thirty days of written notice so to do (secs. 25, 206, 33, 45; Laws of 1898, p. 410; Laws of 1901 , chap. 143).

Willians r. Boice, 38 న. J. Fiq. 364.

13. Stockholders' Liabilities. - Stockholders are personally liable to creditors to the amount of mpaid stock lield by them where the capital stock is insuflicient to meet the corporate debts and obligations.

Nat. 'Tru-t Co. l. Miller, 33 N. J. Eip. 155; Wetherbee v, Baker, 35 N. J. Eq. 501 ; Biekley $v$. Selulag, 46 X. J. Eq. 533; 20 Atl. 250; Ilood $v$. MeNaughton, 54 N. J. Law, $425 ; 24 \Lambda t 1.497$.

11. Stock Certificates. - Stock certifieates must be signed by the presirent and treasurer.

15. Preferred Stock. - The right to create preferred stock must be re-ervel either in the original charter or in a certificate of amendment throeto. At no time must the total anomt of preferred stock issued and culstanding exceed two-thirds of the capital stock paid in in eash or property. 'The prefored stock may, if desired, be made suliject to redemption, at any time inftrer three years from the issue thereof at not less than par. No lividrold excerding eight per cent per annmu can be paid thereon. Dividends may he mart: cummlative or non-cumulative as desired (sce. 18; see also Laws of $191 \% 2,1 \% 217$, sec. 2).

Elkins $x$. Confrany, 36 N. J. Eq. 233; McGregor v. Company, 33 N. J. Eq. 181. $\because \because 26 ;$ 
16. Payment of Capital Stock. - Nothing but money shall be considered as payment of any part of the capital stock of any corporation except in the following cases: Any corporation formed under the provisions of the General Act may purchase mines and manufactories or other property necessary for its business, or the stock of any conpany or compranies owning mines or manufactories, or purchase nuaterials or other property necessary for its business, and issue stock to the amount of the value thereof in payment therefor, and stock so issued shall be fully raid and non-asisessable and not liable to any further call. In the alsence of actual fraul in the transaction the judgment of the directors as to the ralue of the property shall be conclusive (secs. 48, 49). Within ten dilys after the payment of the capital stock a certificate of such payment signed and rerified by the president and secretary or treasurer must be filed with the Secretary of State (secs. 25, 2(i).

17. Books. - The books of the corporation, except the stock and transfer books, may be kept ontside the State if the by-laws or the certificate of incorporation so provide (secs. 33,44 ). The tro books mentioned are open to the inspection of stockholders.

State $e x$ rel. O'IIara $x$. Nat. Biscuit Co., 54 Atl. 241.

18. Office and Agent. - Every corporation must maintain its principal office within the State, and have an agent in charge thereof, wherein shall be kept the stock and transfer books of the corporation (sec. 1.t; Laws of 1897 , p. 175; Laws of 1895 , p. 410 ).

19. Reports. - Within thirty days aiter the first election of officers and thereafter within thirty days after the ammal election a report must be filed in the oftice of the Secretary of State, signed either by the president and one other officer, or by two directors, setting forth the name, rusistred office within the State, and agent in charge thereof, business anthorized, capital stock and anonnt actnally issued and ontstunding, names and addresses of officers and terms thereof, the date of the next annual election. It must also state whether the name of the company has been at all times displayed at the entrance of its registered otlice, and whether it has kept at its registered oflice a transfer book and stock book contaning the names and adresses of the stockhohlers and the mmuler of shares beld by then. In aldition to the foregoing the corporation nust on or hefore the 1st day of May make a report as of Jannary lst preceding, signed by the presiclent or treasurer, showing the anom of stock actually issurel

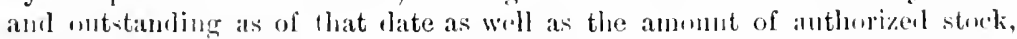
and whether payment has been mate threfor in cash or property (sec. 13;

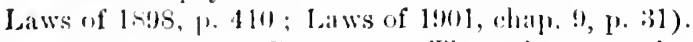

20. Anti-Trust Statute. - Thrre is no anti-trust statute in fores in New Jersiy.

21. Statutory Grounds for Forfeiture of Charter. Cluarturs litiv he forfoited in Now. Tersey upun the following crounds: For failure to coimply

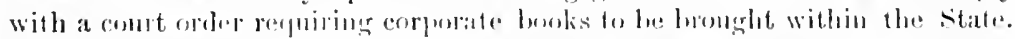

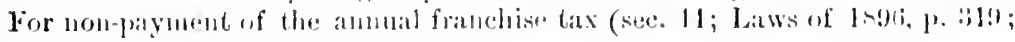
Laws of 1(401, chay). "2l?).

2.). Amendments. - Chatrors may he amendocl in the following wepets:

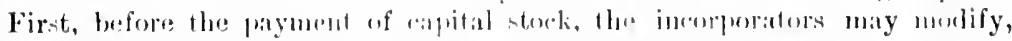

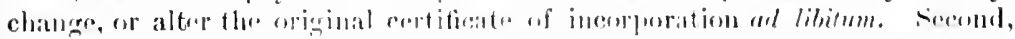
after the payment of eapital stock amculments mily b. male, changing the 
matule of the business maned, increasing of decreasing the capital stoek, chanding lhe frar value of shares, the beation of the prineipal oflice within the state, extending the corpurate existence, eleating preferred stoek, and making such other amentment, change, or alteration as may be desired. 'Thirel, whenever there are any errors or omissions in the certifieate of ineorforation the board of directors may take steps to correet the same in the mamne provided loy statute (sec. 27 ; Laws of 1897 , p. 175; Laws of 1898, I. $1(1 ;)$.

:i:. Extension of Corporate Existence. - May be extended by compliance with the statute for any period desired.

24. Dissolution. - Voluntary dissolution of the corporation requires a majority rote of direetors and written assent of two-thirds in interest of the stuck. If the written assent of all the stockholders is obtained, a meeting for the purpose of voting upon the question of dissolution is unnecessary (sec. :31).

25. Annual Franchise Tax. - An aimual franchise tax of one-tenth of one prel. cent on the par value only of that proportion of the authorized stoek which is issued and ontstanding on the lst day of Jannary is exaeted where the total authorized eapital stoek cloes not exeed $53,000,000$. Over that sum and 11 ' $10,55,000,000$ the tax is one-twentieth of one per cent. When above $\$ 5.000,000,850$ for every $\$ 1,000,000$ or part there of in excess of $\$ 5,000,000$. Mining or manufacturing companies having at least fifty per eent of their issued or ontstanding stock invested in mines or nanufacturing within the State are cxempt from sueh franchise tax. In those cases where less than fifty per cent is so invested the assessed value of the real or personal estate so used in the State is dedueted (Liaws of 1901, p. 31).

26. Foreign Corporations. - Must file coly of charter with the Seeretary of state attested by its president and secretary under its corporate seal, and a statement attested in like manner of the amount of its capital stock anthorized, ant the amount actually issued, the character of the business which it is to transact in the State and designating its principal office in the State, and an acent who shall be a romestic corporation or a natural person of full age, aetnally resident in the state, together with his place of abode, upon whom process may be served. They must also file the same reports required of them in their domieiliary State, if any, before they are allowed to transaet business therein. They must pay the same license tax as is required by the law of such domiciliary state of New Jersey corporations. Annual reports are also required. This report when filed is made the basis for levying an anmual tax of five per cent per anum upon the amomt of gross receipts from business doue in New Jersey. This tax may be redueed by showing that by the laws of the domieiliary State of such corporations, a lower tax is levied there upon New Jersey eorporations doing business therein. Foreign corporations having firty per cent of their issued and outstanding capital stock inventel in mining or manufacturing carried on within the State of New Jersey are exempit from the tax; or if less than fifty per cent is so invested, the eorporation is entitied to have dedueted such proportion of its gross receipts as ice reecived from goors or property so manufactured or mined within the State of New dersey (Laws of 1901, cliap. 221).

I). \& II. Canal Co. $v$. Mahenbruck, 63 N. J. L. 281 ; 43 Atl. 978; Del., etc. Co. $v$. Persiaken, 116 l'ed. 9[0. 


\section{NEW MEXICO.}

(Unless otherwise stated, the references below are to the Compiled Laws of New Mexico, 1897.)

1. Statutes under which Business Corporations may incorporate. The Business Corporation Aet of New Mexico is to be found in the Compiled Laws of 1597, secs. 411-45t). Under it corporations may be formed for mining, manufacturing, industrial. or other lawful pursuits, except railway, wagon roads, irrigation ditches, or for colonization and improvement of lands (sec. 411).

2. Incorporators. - Any number not less than three. There are no res. idential requirements (sec. 415 ).

3. Contents of the Certificate of Incorporation. The certificate must set forth :

a. Name. - There cannot be more than one corporation of the same name except in the case of mining, mechanical, or manufacturing corporations (secs. $415,438)$.

b. Purposes. - Objects and purposes for which the corporation is formed. Any number of purposes not corered by special act are permitted (sec. 115).

c. C'apital Stock- - Amount of capital stock, number of shares, and par value thereof. Capitalization may be any amomt. Par value may be any amount (sec. 415 ).

d. Durution.-- Term of existence, which camot exceed fifty years (sec. 415$)$.

e. Directors. - Number of board of directors not less than three, and names of board for first three months, together with their addresses (secs. 415, 420).

f. Domiriliery Office. - Name of the city or comty where the principal business is to be transacted (sec. 415 ).

g. Incorporntors. - Full uames of incorporators (sec. 415).

4. Statutory Powers. - In aldition to a statutory cnumeration of common law powers, the following additional powers are granted: To authorize voting by proxy, to authorize railroad corporations to consolidate, to forfeit stock for non-payment of assessments ; to remove directors (sces. $417,420,4 \cdot 5)$.

Medler $x$. Conpany, 6 N. M. 331 ; 28 Pac. 551 ; S. F. L. Co. $v$. Ilitchcock, 9 N. MI. $156 ; 50$ l'ac. 33:.

5. Procuring the Charter. - The charter must be subseribed and acknowledged by each of the incorporators, and then filed with the Secretary of the Territory, to whom the organization tax is paid $A$ certified cony of the articles must he filed with the recoreler of dects of the enonty where the principal business onlice is locaterl (sees. 115, 117: Laws of 1903, chilp. 111). liy

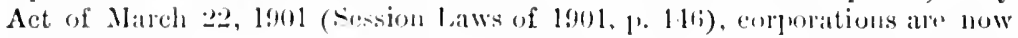
required, within thity digs after filing their artieles of ineorguration with

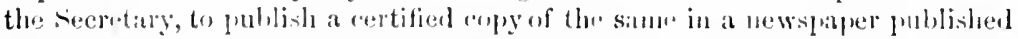
in the comnty where its primcipal place of husiunss is lowated. Proof of such puldication mont b. filed with th. Secretary of state within twonty diys after the last pullication.

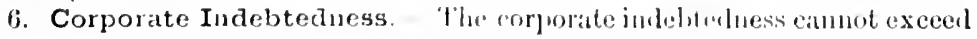

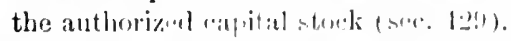

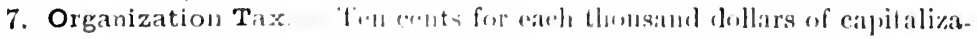

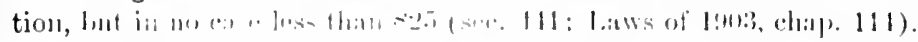

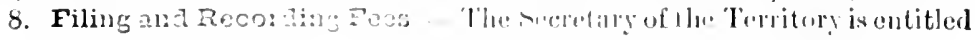


to mo fees for filing or resolding articles, other than the payment of the organigation tax: for cortilied copy of the articles, 10 cents per folio, plus $\$ 1$ for cerunicate. Jiending fees in local connty oflice, 15 cents a folio for first ten folion, and 10 cents a folio for all over. Filing fees, 50 eents. The law reguires ouly filing and not recording in local county oflice: cost of publishing anticles of incolporation averages about $\$ 10$; cost of filing certificate of publiciltion in the otlice of the secretary of the Turritory, 1 ; for filing appointment of arent in local county ofliee, 50 eents; s. sor filing same with the Secretary of the Turitory ; retified copy of the appointment of agent eosts 81.50 . This lint is required in catse the majority of the stock is held and owned outside of the Territory (Laws of 190:, chap. 111).

(). Commencing Business. - Corporations may commenee business as soon as the articles are filed as required by law. They need not wait for the jublication of the artieles before commencing business. The charter is subject 10 furfitme if business is not commenced within two years after the certiticate of incorporation is tiled (sec. $4: 36$ ).

11. Organization Meeting. - The organization meeting must be held within the Territory. This in the absence of any statute anthorizing such meetings to be held without the Territory. (See however sec. 456.)

11. Meetings of Stockholders and Directors. - Stocklıolder's' meetings are ordinarily requiral to be held within the Territory. Where a majority of the stock is held outside the Territory, the by-laws may provide for the holding of stockholders' meetings ontsile. I) irector's' meetings may be held within or withont the Territory as the by-laws provide (sec. 450 ).

1.2. Directors' Qualifications and Liabilities. a. Qualifications. - There must be at least three directors, who must be stockholders and a majority of them citizens of the United States and one-third residents of the Territory (see. 1:2)

6. Linlilities. - Directors are liable to creditors and stockholders for momess misappropriated, for the illegal declaration of dividends, or the mnlawful witldrawal of capital stock. They are also liable to the extent of the incruse of corporate indebtedness beyond the authorized eapital stock (secs. $125,12(3)$.

1:;. Stockholders' Liabilities. - Stockholders are liable only for their unpulit stock sulseriptions (sec. 430).

Albriglit $v$. Company, 8 N. M1. 110 ; 42 Pac. 73.

11. Stock Certificates. - Each stockholder is entitled to a eertificate showing the number of shares owned by him and signed by such ofticers as the by-laws may prescribe.

15. Preferred Stock. - There is no express provision for the issuance of preferred stuck.

16. Payment of Capital Stock. - Stock must be paid for in money or noney's worth.

17. Books. - A record of stockholders' names and residenees and of shares helit ly them, of stock paid in, how much in cash, must be kept at the principal phice of business in the county where the eorporation's business operations are located; which shall be subject to inspection by stockholders and creditrors during lousiness hours (sec. 4.j).

18. Office and Agent. - The corporation shall establish a principal place of burines and designate an agent residing thereat, in the Territory, on whom 1nocens and lotices may be served (chap. 6.5, Laws of 190:3).

$3: 30$ 
19. Reports. - No reports are required.

20. Anti-Trust Statute.- There is no Territorial anti-trust statute.

21. Statutory Grounds for Forfeiture of Charter. - Charters may be forfeited for failure to commence business within two years after filing articles of incorporation (sec. 436).

2.2. Amendments. - The charter may be ameniled by the directors to correct mistakes in original certificate (sec. 415 ). Charters may be amended for any purpose desirel by complying with the statutory provisious relative to the same (secs. 431,432 ).

23. Extension of Corporate Existence. - Corporate existence may be extended for an additional period of fifty years if desired (see. 119).

24. Dissolution. - Dissolution may be had by judgment of probate court upon petition authorized by two-thirds vote of stocliholders (sec. 4:35).

25. Annual License Fee. - There is no anuual liceuse fee.

26. Foreign Corporations. - Foreign corlorations must, before doing business in the Territory, file with the Secretary of the Territory and with the recorder of deeds of the county of its principal place of business in the Territory a certified copy of the charter, or if incorporated under general law a cony of its articles and of the law under which incorporated, and file with sitid ollicers a certificate signed and acknowledged by the president and secretary designating the principal place in the Territory where the business shall be carried on, and an agent residing therein upon whom process may be served, and shall pay to the Territorial Secretary the same fees as required of domestic corporations on incorporation. A certified copy of the articles and certificates of place of business and agent must be filed in the office of the recorder of deeds in the county in which the principal place of business is to be. A copy of the articles must be published in the county where resides the resilent agent, and ecrtificate of publication filed with the Territorial Secretary (secs. 445, 446; Laws of 1901, chap. 77 ; Laws of 190:3, chaps. 65, 114).

Union Trust Co. $v$. Company, 8 N. $11.327 ; 43$ I'ac. 701.

\section{NEW YORK.}

(The reference below, B. C. I., refers to Business Corporation Law, chap. 567, Laws of 1890 as amented by Laws of 1892 , chap. 69l. The reference $G$. C. L. refers to (ieneral corporation Law, Laws of $18 \% 0$, chap. 563, as amended by Laws of 18:3, chap. 687. The reference S. C. I. refers to Strck Corporation Law, chap. 5154, Laws of 1850 , as amented by latw's of 1892 , cliap. 658.)

1. Statutes under which Business Corporations may incorporate. -

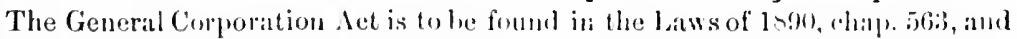

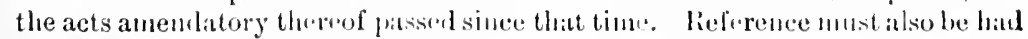

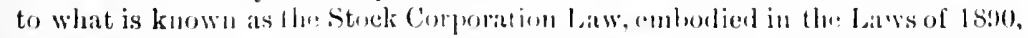
chap. sfil, and subsegnent anculuents thereto. Finally, reference must also be

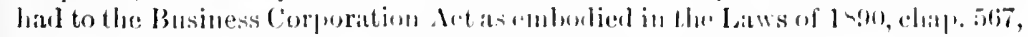

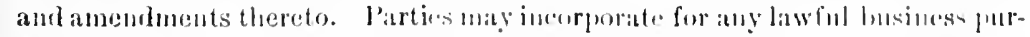
pose or purposes. Special ants are providerl for milway, banking, navigation,

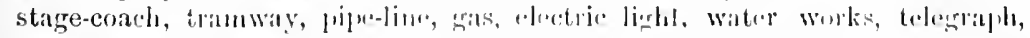
telephone, turmpike, plank ruall and hridge complutios, hanks, insurance, savings and loan associations, mortrarg", loan, salfe depesit and investment companies.

2. Incorporators. - Three or more alult persons. Two-thirls must be :i:) 1 
citizens of the lnited siates, and at least one a resident of the State of New

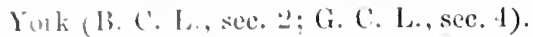

3. Contents of the Certificate of Incorporation (Laws of 1903, chap. i25). Thu certificale must set forth :

4. Vitme? - The name must not confliet with that of any existing domesticerpuration or of any foreign corporation authorized to do business in the

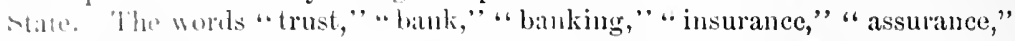
· intemuity," "guaranty," "guarantee," "sarings,", " investment," "loan," (1)." thenctit" cannot be used (G. C. L., sec. 6 ; l3. C. I., sec. 2; Laws of 1904, chatp. 110$)$.

b. I'urposes. - Iny number of objects may be inserted provided they are mot covered by the special acts above referred to (B. C. I., sec. 2).

c. Cipital Slock. - Amount of total authorized capital stock not less than s.ju0. If any proportion be preferred stock, the preferences thereof must be set forth (13. C. L., sec. 2); S. C. L., see. 47).

1. Sheres. - Number of shares with the par value, which must not be less that s.5 nor nore than $\$ 100$ (13. C. L., sec. 1.2 ; Laws of 1903, chap. 525).

e. Amount of C'apilal with which the Corporation will begin Business. - This must not be less than $\$ 500$ (B. C. L., sec. 2 ).

$f$ Domicile. - State the village or town in which the principal business olice is to be located (13. C. I., sec. 2, as amended by Laws of 190:3, chap. 525). If in New York City, state the borough (Laws of 1903, chap. 525).

g. Duration. - Nay be perpetual if desired (B. C. L., sec. 2).

h. Nirectors. - Number and names of directors. There must be not less than three directors, and the names and post-oflice addresses of the directors fur the tirst year must be set forth (B. C. L., sec. 2; G. C. I., sec. 29).

i. Sluck Subscriptions by Incorporators. - Names and post-office addresses of the inconpurators and a statement of the number of shares of stock subscribed for hy each (B. C. L., see. 2).

j. I'rocisims for the legulation of the Internal Affairs of the Corporation. 'lhe certificate may contain any other provision for the regulation of the husiness and the conduct of the allatils of the corporation and any limitation npon the powers or upon the powers of the directors and stockholders which lues not exempt them from any obligation or from the performance of any duty inposed by law (B. C. L., sce. 2; Laws of 190:3, chap. 525).

4. Statutory Powers. - In inllition to the statutory enumeration of common law powers, the statute confers the following additional powers: 'To furchase, hold, and dispose of the stock ancl bonds and other evidences of indebtedness of any other corporation. Also to issue in exchange therefor it: nwn stock and bonds if authorized so to do by a provision in the certificate of incorporation; or, without surh a provision in the certificate, if the corporation whose stock is so purehased is engaged in a business similar to that of the hohling corporation, or engaged in the mannlacture, use, or sale of property, or in the construction or operation of works necessary or useful in the business of such holding corporation or in which or in enneetion with which the manufactured article, produce, or property of the holding corporation may be used, wris a corporation with which the latter is anthorizer to consolidate. 'To vote ly liroxy. to issne prefrred stock, to enforce a lien mpon the stock of its mimhers for debts due the corporation, to sell stock subscribed for for non-paym.3.t of stork subseriptions, to acquire or dispose of property in other States or foresinn conntries, to consolilate with other corporations organized to carry cn any lind of business of the same or a similar nature which a corporation $\because \because 3.1$ 
organized under the General Act might carry on. To provide for cumulative roting. To delegate the right to directors to adopt by-laws. To issue preferred stock and to issue stock in exchange for property. To sell all the corporate assets and to guarantee bonds of other domestic corporations engaged in the same line of business. Limited voting trusts are permitted (G. C. L., sec. 11 ; S. C. L., sec. 40 ; G. C. L., sec. 20 ; S. C. I., secs. 2, S; B. C. I., sec. 2 ; S. C. L., sec. 77 ; C. C. L., sec. 14 ; S. C. I., sec. t2 ; B. C. L., sec. S; S. C. L., secs. 23 , $33,40,58$; (. C. J., secs. 21, 29; Laws of 1941 , chilp. 236 ).

5. Procuring the Charter. - The certificate of incorporation must lie acknowlerged by each of the incorporitors before some otticer anthorized to administer oaths. It must then be filed and recorded in the office of the secretary of State. A certified copy of the certificate or a duplicate original, together with the receipt of State Treasurer for payment of the organization tax, must be filed and recorded in the office of the connty elerk of the comnty where the principal place of business of the corporation is to be located (B. C. L., sec. 2; G. C. L., secs. 4, 5).

People ex rel. Blossom $x$. Nelson, 46 X. Y. $47 \pi$; Raisbeck $r$. Oesterricher, 4 Abb. New Cases, 434 ; Peuple er rel. $x$. Rice, 1.28 N. Y. 591 ; 28 N. F. 2.51 : Lamming $x$ Galusha. 81 Iun, $247 ; 30$ N. Y. S. 767 ; aff 4151 X. Y. 648; 45 N. I. 1132 ; Lnions. Cu. $v$. City of Buffalo, s? N. Y. 351.

6. Corporate Indebtedness. - There is no limitation upon the amount of indebterness which a corporation may incur. (See S. C. L., sec. 2-.)

7. Organization Tax. - One-twenticth of one per cent (or 50 cents per thousanl) upon the authorizerl capital stock as set forth in the certificate of incorporation (Tax Law, sec. 180).

5. Filing and Recording Fees. - To siceretary of state for filing certificate of incorporation, s10; for recording. 1.5 cents per folio; to the county clerk for filing certificate, 6 cents, and for recording, 10 cents per folio; for certified copy of articles, 15 cents per folin and \$l adlitional for certificate muler the Great Seal of the State; for recording certificate of payment of capital stock, 15 cents per folio.

9. Commencing Busines.3. - It least 8500 of stock mut be sulucriberl lefore the corporation may begin business. bufore any conporation ran ineur debts the amount of capital specified in the certificate of incorporation as the anount of capital with which the corporation will begin business must have been pail in, cither in money or in property. On:-half of the stock must bo paid in, ather in money or punery, within one year. Within thirty days after such payment a cortifieat. duly signed aud rerified by a majority of the directors and the president on vion-presilent and the secretary or treature must be filed with the fereretary of state and with the clerk of the county in which the principal oflice in locatuel. If onse-half the capital is not patil in within one year, the charter is suligert to forfeiture (li (C. L., sere. 5). Tho

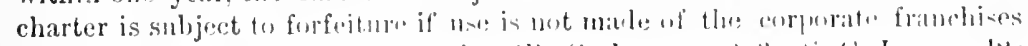

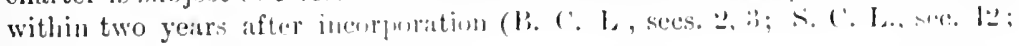
13. C. L., sec. i).

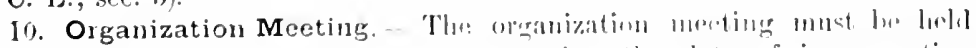
within the State, and within two gears after the date of inmermation ((i. C. L., sec. 31$)$.

11. Meetings of Stockholders and Directors. - Whilw there ire no stat-

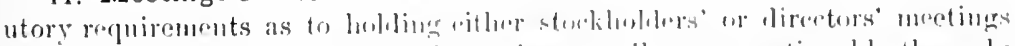

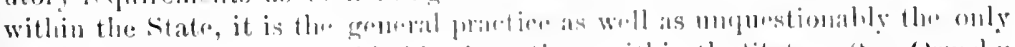

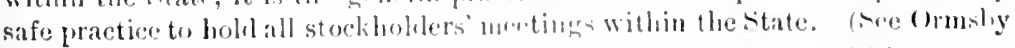
$\because \because ;$ 


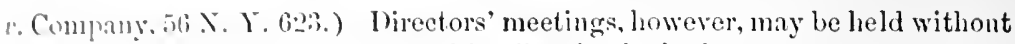
the state in making provision to this effect in the by-laws.

12. Directors' Qualifications and Liabilities. a. Quulificaltons. - Minimum directors muler the statute are three. At least one-fourth of them must be thend ammally. They must all be stockholders mless otherwise provitul in the certificate of incorporation or in the by-laws. At least one of them must be a resilent of New York (B. C. L., sec. 2; G. C. L., see. 29; $\therefore$ ( C. L. see, 2(1). They may be elassified if desired. Inspectors of elections are provided for (A. C. L... sec. 2S). Cumnlative voting is permitted if authorized by the certificate of incorporation (f. C. L., sec. 20).

b. Cidbilitics, - In ease of the withdrawal of any of the capital by means of loans to oflicers or stoeklolelers of the corporation, or prohibited transfers of property, or false rejorts issued, directors are jointly and severally liable for the loss sustained thereby. They are also liable for illegal declaration of divilends (S. C. L., secs. 22, 29, 25, 31, 4s).

13. Stockholders' Liabilities. - Stockltolders are personally liable to creclitors to an amomnt equal to the amount of unpaid stock held by them for debts of the corporation contracted while such stock was held by them; and are jointly and severally liable for all debts dne or owing to laborers or serrants or employees other than contractors, provided written notice of intention to enforce such liability is given within thirty days after termination of the services rendered (S. C. L., secs. 5 t, 5.); as to liability of stockholders in full liability corporations, see B. C. L., see. 6 ).

Billings $\iota$. Lohinson, 94 N. Y. 415 ; Weeks $v$. Love, 50 N. Y. 568 ; Tucker $v$. Gilman, 121 N. Y. $189 ; 2+$ N. E. 302 .

11. Stock Certificates. - Stock certificates must be signed by the president or vicepresident, and by the secretary or treasurer (S. C. I., sec. 40). Stock certificates are not transferable without the consent of the corporation, until all indebtedness to the corporation has been paid (S. C. T., sec. 26). The par value of shares may be any amount not less than \$5 nor more than $\$ 100$ (13. C. L., sec. 2, sub. 4).

15. Preferred Stock. - Preferred stock may he issued if the certificate of incrmporation so provides or by consent of the holders of two-thirds of the capital stock wiven at a sneeting duly caller for that purpose. The corporation man, upm the written repuest of the holders of preferred stock by a twothinls vote of its directors, exchange the same for common stock (S. C. I., see. 45 ).

16. Payment of Capital Stock. - Corporations cannot issue stock except for money, labor done, or property actualy received for the use or lawfin purposes of the corporation. The statute provirles further that in the absence of fratul in the transaction the judgment of the directors as to the value of lrolerty so purchased shall be conchusive (S. C. L., sec. 42).

White Corlin \& Co. v. Jones, 167 N. Y. 158; 60 N. E. 422.

17. Books. - Every corporation must keep at its office within the State correct books of acconnt of all its business transactions, and also a stock book, containing an alphabetical list of the stockholders of the corporation, showing thrir phees of resilence and the number of shares held by them respectively, the time when they respectively became owners thereof, and the amoint paid thereon (. C. C. L., sec. 29). The stock book is open to the inspection of stockholders and judgnent ereditors.

Matter of Stcinway, 159 N. Y. $250 ; 53$ N. E. 1103.

$3: 4$ 
18. Office. - Every corporation must maintain a domiciliary office within the State (B. C. L., sec. 2 ; Tax Laws, see. 11).

19. Reports. - All domestic business corporations must aunually during the month of January, or, if doing business without the United States, before the first of May, make a report as of the first day of January, which will state: First, the amount of its capital stock and proportion actually issued. Second, the amount of its debts, or an amount which they do not exceed. Third, the amount of its assets or an amount which its assets at least equal. Such report to be made by the president or vice-president, secretary or treasurer, and filed in the office of the Secretary of State. If such report is not made and filed, any officer of the corporation who shall thereafter neglect or refuse to make and file such report within ten days after witten request so to do shall have been made by a stockholler or a ereditor of the corporation, shall forfeit to the people the sum of 850 for every day he shall so neglect or refuse. In addition to the foregoing the corporation is requirerl between November 1st and 15th to make an amual report to the State Comptroller showing the condition of the business on Oetober :31st of that year, stating the amount of the capital stock paid in, the amount of its dividends declared during the year endiug October:31st, the amount of its entire capital, and the percentage thereof emplored within the state during the preceding year. 'lhis report must be signed and swom to by the president, vice-president, seeretary, or treasurer (S. C. L.. sec. 30 ; Tax Laws, see. 1s!). After each amual election of directors a certifiente of the result of such election made by the inspeetors must be filed, with the oath of the inspectors, in the offee of the clerk of the county in which the election is held (S. C. L., sec. 25 ; see Lnion Nat. loutk

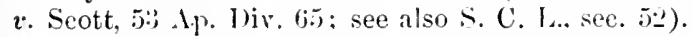

20. Anti-Trust Statute. - The Anti-Trust Aet of New York is to be found in Laws of 1-9!, chap. 690.

Mattr.r of Davies, 169 X. Y. 89 ; 61 X. E. 118 ; leople 2 . Milk Exclange, 133 N. Y. $56.5 ;: 20$ N. 1.. 8.50.

21. Statutory Grounds for Forfeiture of Charter. - Charters may be forfeited for failure to organize and commence the transaction of corporate business or the discharge of corporate duties within two years from the date of incorporation ( $\mathrm{r}$. C. L.. see. 31). Also if onc-half the capital stock is not paid in within one year (B. C. L., see. 5). Aiso for failure to pay the anmual State tax within one vear from the time a statment of the tax is sent to it

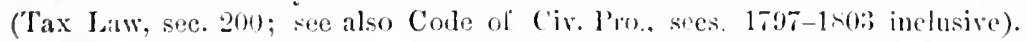

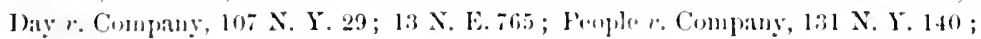
29 N. B. 947.

22. Ammual Franchise Tax. - The ammal franchise tax is based on the

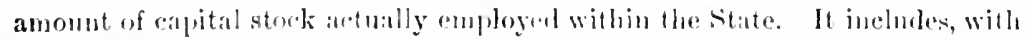

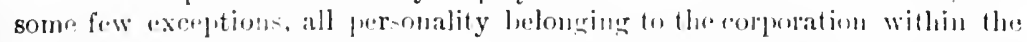

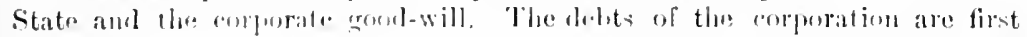
derluster in arriving at the valuation. If dividenels are duelaned amonuting to six prer rent or more on the anoment of the far value of the entime issued

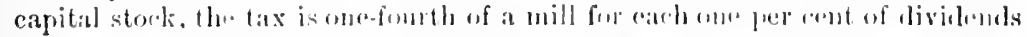

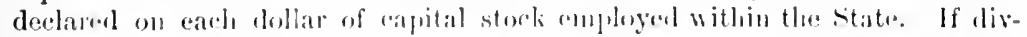

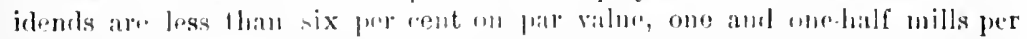
dollar upon surh proportion of eapital stomk at par as the amomnt of capital employer within the state bears to the cutire capital of the corporation. If no dividend is reclared, the tax is tixml at the rate of nne and one half mills 
upun each dullat of the appraisel capital employed within the Siate. lianks, insmance amb surety companies, railroad, gis, light, or power, steam heat,

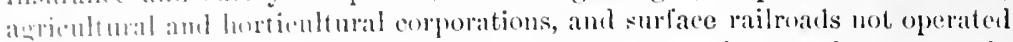
hy stean itrevermpt. Lamuly, mamufacturing corporations, to the extent only of the apitat stome employed within the State in manufacturing and in the sale of the moluct of such manufacturing, and mining corporations wholly congund in mining ores within the state, are exempt from this tax provided at least forty por cent of their capital stoek is actually invested in property in this state (Tax laws, secs. 152, 183, 189, 190). A corporation is taxed on its personal property only in the connty designated in the articles as the place where its principal place of business is (Tax Laws, sec. 12).

2:3. Amendments. - Corporations may change their names only by six weeks pullication of the notice of intention so to do and application thereafter to the Supreme (ont for an order authorizing such change. The purposes and powers of the corporation may be enlarged or altered by a vote of three-tifths of the capital stock. The number of shares may be increased or liminished ly vote of two-thirds of the capital stock. 'The capital stock may be increased or deereased by majority rote of the stockholders at a meeting duly called for that purpose or by unanimons consent of all the stockhollers expressed in witing. Director may be increased or (liminished hy a majority vote of the stockholders. All amendments to articles are required to be filed in the same oflices as in the case of original articles (Laws of 1903, cliap. 3.21: S. (. L., secs. $21,32,41,45$; G. C. L., sec. 6 ; Laws of 1904 , chaps. 110, 12:3).

21. Extension of Corporate Existence. - Corporate existence may be extendel, if desired, by compliance with the statute (G. C. L., sec. 32).

25. Dissolution. - Voluntary dissolution may be brought about in two ways: First, ly a two-thirds rote in interest of the stockholders favoring dissolution precerled by a resolution to that effect passed by the board of directors; second, by applieation to the Supreme Comrt (S. C. L., sec. 57 ; Revised Stat., Part I1I. chay. 8, title 4, secs. 66-89 inclusive; Code of Civil Procedure, sess. 17-1-1796, 2119-2.431). The charter may be surrendered by the incorporaters before the payment of any part of the capital stock and before commencing business (Laws of $190 \mathrm{i}$, chap. 296 ).

26. Foreign Corporations. - Must tile with the Secretary of State copy of articles of incorporation with statement of business carried on within the State. Cammot legin business mntil Secretary of State issues certificate of authority. Camot sue in State without having first secured certificate of anthority. Annual reports required as of domestic corporations. Stock book with dita of stockholders must be kept at office of transfer agent in State, and sliall be ogen to inspection under jenalty of $\$ 250$. Within thirteen months of the time the corporition commences to carry on business within the State it must pry the State Treasurer a license fee of one-eighth of one per cent on the anount of capital stock employed by it in the State during the first year of carying ou business therein. This license tax is payable annually thereafter. Permits will not be issued if foreign corporation has same name as that of domestic (G. C. I., secs. 15, 16; S.. C. L., sec. 53 ; Code of Civ. Pro., secs. 492, 1779; Tax laws, sec. 181 ; Laws of 1901 , chap. 490).

Jemarest $\%$ Flick, 128 N. Y. 205 ; 28 N. L. 645 ; People ex rel. II. \& H. Co. v. Campl,ell, 139 X. Y. 68; 34 N. E. 753 ; People ex rel. S. T. Clock Co. v. Wemple, 133 N. Y. 323 ; 31 N. F. 238 ; People $x$. A. 13. T. Co, 117 N. Y. 241 ; 22 N. E. 1057 ; People ex rel.v. Wcmplr, 138 N. Y. 582; 34 N. E. 386; O'Reilly, Skelly \& Fograrty Co.v. Greene, 40 N. Y. 36,0 . 


\section{NORTH CAROLINA.}

(The references cited below are to chap. 2, Laws of 1901, unless otherwise stated.)

1. Statutes under which Business Corporations may incorporate. The Business Corporation Act of North Carolina is to be found in the Session Laws of 1901, chap. 2. Lnder this act corporations maty be formed for any purpose excepting railroad, insurance, and banking corporations (sec. 8).

2. Incorporators. - Any number of persons not less than three. There are no residential requirements (secs. 8,36 ).

3. Contents of the Certificate of Incorporation. The certificate must set forth :

a. Nome. - No name can be used already in use by another domestic corporation. 'The name must end with the word "Company" (sec. S, sub. 1; Laws of $190: 3$, chap. 4.53$)$.

b. Domicile. - Location of principal office within the State (sec. 8, sub. 2).

c. Purposes. - The object or objects for which the corporation is formed. Any number of purposes may be inserted in the certificate (sec. 2, sub. 3).

d. Capital Stock. - Authorized capital stock (unlimited). Number of shares into which divided, and par value (any amount) thereof, amount of capital stock with which corporation will begin business (no anount limited in the act). If there is more than one class of stock, a descrjption of all classes must be inserted together with terms upon which created (sec. 8, sub. 4).

$e$. Stock Subscriptions. - Names and post-ottice aldiesses of subseribers for stock and the number of shares subseribed by each. The act provides that the agregate of such subscriptions shall be the amount of eapital stock with which the corporation will begiu business (sec. 8, sub. 5).

f. Duration. - Nay be perpetual (sec. 8, sub. 6).

\%. Protisims for the liegulation of the Intermal Iffairs of the Corporation. Provisions inty be inserted for the regulation of the liusiness and for the purpuse of creating, defining, limiting, or regulating the powers of the corporation, directors, and stockholders (sec. 8, sub. 7).

4. Statutory Powers. - In addition to a statutory enumeration of counmon law powers corporations have the following adilitional powers: To authorize voting by proxy: to forforit stock for non-payment of assessments; to provide suitable penalties for violation of hy-laws, not exceeding $\$ 00$ for any one offence; to elelegato the power to directors to alopit by-laws: to issue preferred stock to the exient of one-hall of actual e:upital paid in in eash or property and to make the same subject to redemprion: to authorize thr holdjug of hirectors' meetings and kepping of eorporate books, "xcept struck and

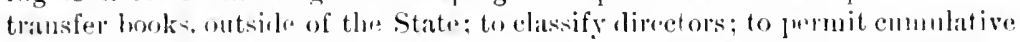
votine in election of diretors, and to condnct husiness in nther states and

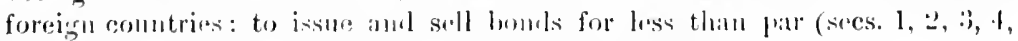

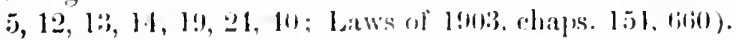

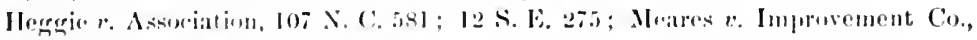
126 ‥ C. 662 ; $36.5 .1 \% 130$.

5. Procuring the Charter. Incorpmators must subseribe amb ank nowlodge

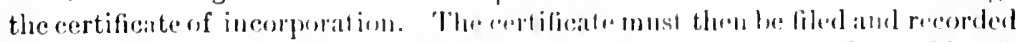
in the ollice of the secretary of tatu. the organization lax lwing then paid. A

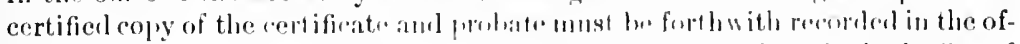
fice of the clerk of the sule rior count of the connty where the principal onlice of

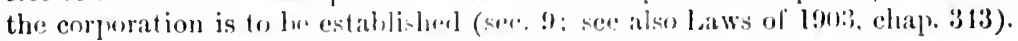

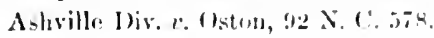


(i. Conporate Indebtedness. - There is no statutory limitation upon the

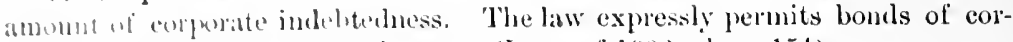
porations to be suld for less than par (baws of 190:3, chap. 151).

7. Organization Tax. - 'Twenty cents for each $\$ 1,1000$ on the amount of eapital stock authorized, but in 110 case less than $\$ 25$ (see. 96 ; see also Laws of

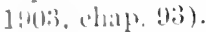

$\therefore$ Filing and Recording Fees. - For recording articles in the oflice of the suretary of state, $\$ 1$ for the first three copy sheets and 10 cents for each ahlitinnal humbed words. For certified articles of incorporation, \$1 for the tirst three coly sheets and 10 cents for each additional hundred words. 'Tu the elerk of the superior Court for preparing eertificate of incorporation sl for the first three copy sheets and 10 cents for each additional sheet. For filing list of oflieers and directors, \$l.

1. Commencing Business. - Corporations may commence business as soon as the eertificate of incorporation is filed as required by law (sec. 10). Within thirty days after the election of the first board of directors there must be filer in the oflice of the Secretary of State, a statement anthenticated by the signatures of the president and secretary containing the names of all the directors and oflicers with the late of the election or appointinent, term of office, residence and post-otfice aduress of each, the character of its business and location, giviug the street and number, if any, of its principal office in the State. and the name of the agent in charge of said office upon whom process may be served (sec. IS). Business must be commenced within two years from the time certificate is filed (sec. 106).

11). Organization Meeting. - The organization meeting must be held within the state. The statute provides for ealling the same, and also gives the inemporators the direction of the affairs and organization of the corporation until directors are elected (secs. 11, 18).

11. Meetings of Stockholders and Directors. - Stockholders' meetings must lie hel] within the state. Direetors' meetings may be held without the State if the by-laws so provide (sec. 49 ).

12. Directors' Qualifications and Liabilities. a. Qualifications. - There must be a hoard of not less than three directors. At least one of them must he a resident of the State. They must all be bona fide stockholders. 'They may be divided into classes, provided no elass is elected for a shorter loriul than one year or for a longer perion than five years (secs. 14, 44).

1) Limbilities. - Direetors are liable for the illegal deelaration of dividends, for nerglecting or refusing to make certificate as required by law upon the fayment in full of each instahment of the capital stock, and filing the same within ten days after such payment in the oflice of the Secretary of State. 'They are also liable for not publishing notice of lecrease of capital, and for illegal voting for reduction of eapital (secs. $26,27,33,53,56,65,107$ ).

Sulumon $v$. Bates, 118 N. C. 321 ; 24 S. E. 746.

18. Stockholders' Liabilities. - Stockholders are liable for their unpaid stocli subseriptions. They are also liable for fraud committed by them, to creblitres: and others injured thereby (see. 22).

Inrmon e. Hunt, 116 X. C. 678; 21 S. L. 559 ; Cooper $v$. Company, 127 N. C. 219; 37 S. L. 216 ; Cutton Nills v. Cotton .1113 , 116 N. C. 647 ; 21 S. E. 431.

11. Stock Certificates. - Every stockholder is entitled to a certificate signeil by the president and treasurer or secretary, specifying the number of shatres hald hy him in the corporation (sec. 20).

$$
: ;:)
$$


15. Preferred Stock. - Preferred stock may be issued not to exceed onehalf of the actual capital. It may be created with such preferences and roting powers, restrietions or qualifications thereof as shill be stated and expressed in the certificate tlereof. Dividends may be made eumulative if desirel, and in case of insolvency holders thereof have a preference over the hollers of common stoek (sec. 19).

16. Payment of Capital Stock. - itock may be issned in exchange for money, labor done, personal property, real estate, or leases thereof. In tise absence of fraud in the trinsaetion, the judgunent of the directors as to the value of such labor, proprerty, real estat.; or leases thereof shall be eonclusive (sec. 19). Corporations may purchatse mines and manufactories and issue stock in payment therefor to the anount of the value thereof, and the stoek so issued shall be full-paid stock and not liahle to any further call. In the absence of fraud the judgment of the directors as to the value of the property so taken shall he eonelusive. Cpon the payment in full of each instalnent of capital stock a certificate setting forth the particulars thereof verified by the president and secretary or treasurer must within ten days after such parment be filed in the office of the Secretary of state (sces. 19, 20,53 , $51,55)$.

17. Books. - Must keep at its prineipal ofliee in the State the transfer books and the stoek books of the eorloration (sec. :58). These are open to the inspection of all stockholuers.

15. Office and Agent, - Every corporation is required to have an oflice within the State where its name nust be displayed in enspienous letters. Mnst have an agent in charge of its princigal oflice within the state residing therein (secs. 19, 50); see also Laws of 190:3, chap. s019).

Simmons r. Stemboat Co., 113 x. C. 147; 18 s. N. 117.

19. Reports. - Annual reports must be filed with the secretary of State in each yoar (see. 18). 'The contents of the rejort is similar to that required under the New Jersey let. (Sce ante, sece. 9.)

20. Anti-Trust Statute. - There is a somewhat drastie anti-trust statute in force in North Caroliua (Lilws of lsit), ehitp. (606).

21. Statutory Grounds for Forfeiture of Charter. Charter may be forfeiter for failure to hring the boeks of the corperation into the state after an order to that effect mad by the superior eourt npon proper callse shown. Charter may also be dissolved by the state for abuse, misuser, or non-uxer of its eorprote powers and privileges and for violation of the anti-trust statute. Also for assuminer or exereising any franchise or transacting any business unt

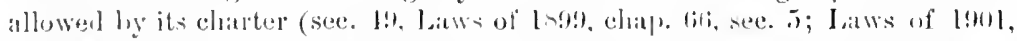
ehate. 2., sece 107). ('hatrer maty also he forfeitul if the corporators for wo

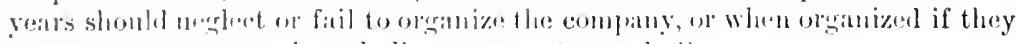

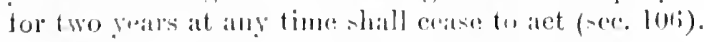

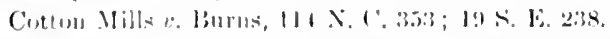

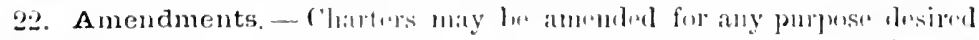

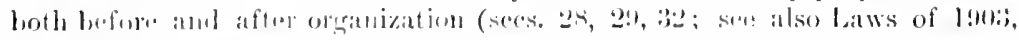
clial. 5l(1).

23. Extension of Corporate Existence. Corporition may axtend its

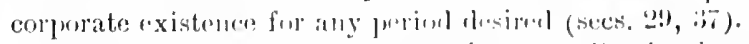

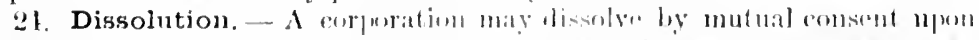

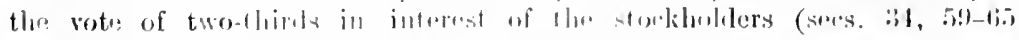
inclusive). The chater may les suremenes hy the incorporators before the: 
payment of any part of the eapital and before beginning business by complying with the siatutw in such calse mate and provided (see. 3.j).

… Anmual License Fee. - Whre the corporation hats a eapital stock

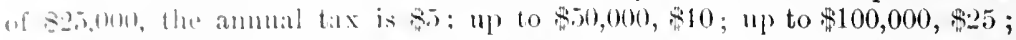

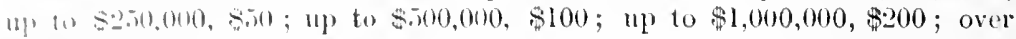

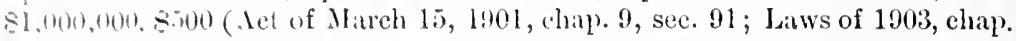
$217,50.51)$.

26. Foreign Corporations. - Foreign corporations must file with the Serretary of state a copy of thril chinter attested by the president and scretay meler the corporate seal, and aceompanied by a statement attested in like mannor setting forth the amomut of capital stock authorized, amount issurd, beation of principal oflice in the State, and name of agent in ehatrge thereof. character of the buxiness to be transacterl, and name and post-office aldruses of otheers and directors. Such corporations must also pay a tax of 10 exnts fer thousand dollins on anthorized capital stock, provided however that the sime shall never be less than $\$ 10$ nor nore than $\$ 100$ (Laws of 1903 , chap. 766 ).

Dehuam r. Company, 126 N. C. 831 ; 36 S. E. 269 ; IIoward v. Association, 125 N. C. 49 ; 34 S. E. 199 ; Commissioners 2. Company, 128 N. C. 558 ; 39 S. E. 18; Shichds r. Lile Ins. Cu., 119 X. C. $380 ; 25$ S. E. 951.

\section{NORTH DAKOTA.}

(The references cited below are to the Revised Code of 1899 unless otherwise stated.)

1. Statutes under which Business Corporations may incorporate. The Business Corporation Act of North Daknta is to be found in the Revised Corle of 1899, secs. 2450-33265 b, as amenled by the Session Laws of 1901. Limler this act corpurations may be formed for any purpose for which indivimals may lawfully associate themselves, except that special acts are provided for railway, waron roul, insurance, bridge, agricultural, fair, and eleemosynary corporations (sec. 2855). There are some special provisions applicahlo to mining and manufacturing companies (secs. 3154, 3161).

2. Incorporators. - Not less than three, one-third of whom must be resilents of the state (sec. 2458 ).

3. Contents of the Articles of Incorporation. The articles must set forth :

a. Nime. - There is no statute expressly forbidding the use of a name already in use by another domestic corporation, but the power is assuned by the Secretry of state to refuse articles attempting to make use of such name

b. Purposes. - P'urjose for which it is formed. The Secretary of State permits the insertion of any number of purposes in the articles not covered by sprecial acts (secs. 2561, 3155).

c. Mnniciliary Office. - Place where its principal business is to be transacted.

1. Inution. - 'Term for which it is to exist, not exceeding twenty years.

e. Jirectors. - Number of directors and names and residences of those who are to serve until their sncessors are elected and qualify.

f. C'upitul Stock. - Amount of capital stock, number of shares into which it is lividerl. Iroth may be any anount desired (see. 2861).

1. Statutory Powers. - In arldition to a statutory enumeration of comIm, law powers, the following adlitional powers are grantrd: To anthorize whitr ly lloxy; to forfeit stock for non-payment of assessments; to own $: ; 11)$ 
its own stock; to provide penalties for violation of by-laws not to exceed $\$ 100$; to permit cumulative roting; and to remove directors (sees. $28 \pi 5,28=0$, 2852, 2884, 28s8, 2894, 2895, 2917-2935).

Tourtelot $v$. Whithead, 9 N. 1). $407 ; 84$ N. W. 8 .

5. Procuring the Charter. - The charter must be subseribed and acknowledged by the incorporators. The articles must then be filed with the Secretary of state (secs. 28:54, 2567 ). There must be filed with the Secretary of State a duplicate receipt of the State Treasurer showing payment of organization tax. When all these formalities have bern eomplied with, the Secretary of State issues a certificate of incorporation. Collateral inquiry into the legality of corporate existence is forlidilen (secs. 2852, 2-6i).

6. Corporate Indebtedness. - Corporate indebteduess munt not exceel the amount of suliscribed capital stock. Express authority is given to issue bonds (sees. 2s!1, 29\%.j).

7. Organization Tax. - For capitalization up to $\$ 50,000$, fee of 850 to be paid to the State Theasurer and $\$ 5$ for every additional $\$ 10,010$ or fractional part thereof. This schedule of fees does not apply to corporations for the manufacture of dairy products, agrieultural fair corporations, building and loan associations, connty mutual insurance companies or to corporations whose eapitalization does not exceed \$.5,000 formed for the purpose of the purchase of male auimals for the improvement of stoek.

8. Filing and Recording Fees. - Filing fees in the office of the Secretary of State, S.5; for issuing certificate of incorporation, \$3: for certified copy of articles of incorporition where copy is prepared for that purpose. S1 (Laws of 1901, chap. 9:3).

9. Commencing Business. - Business may be conmencel as soon as the articles are secuted and filed as requirel by law (sec. 2868). by-laws must be alopted within one month after filing articles (sec. 2583). The corporation must organize and commence business within one year after filing articles (s^c. 29!1:3).

10. Organization Meeting. - In the ahsence of a provision in the articles providing otherwise the organization meeting must be helu within the State (sec. 2898). By making provision in the anticles therefor all meetings may be held withont the State, at some place within the Lnited States (see. $810(1)$ ).

11. Meetings of Stockholders and Directors - In the alosence of it frovision in the articles proviling of inewise meetings of stocklolders and directors for the reertion of chllicers of the corporation mos be liek at its principal place of business wilhin the state. Other meeting of the hoird of directors nay be hele at such place within or withont the statr as the by-

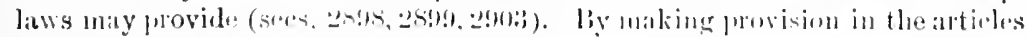
therefor, all mertines may he held willont the Stabe at som. plane within the: Lnited Stales (sece. :ilfiol).

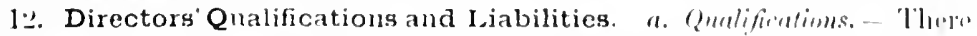

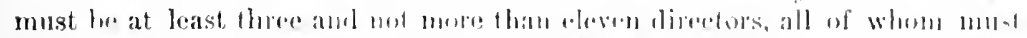

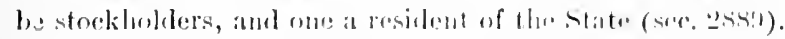

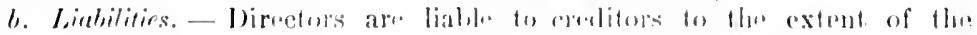

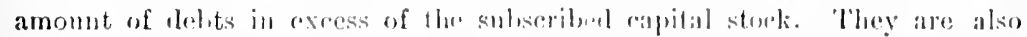

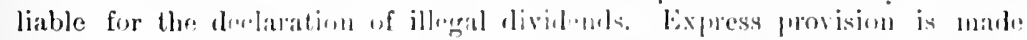

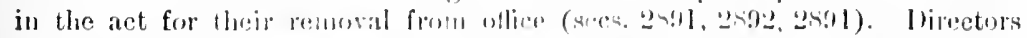

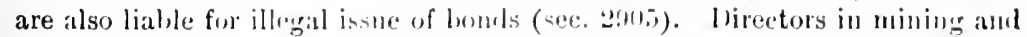


manufuturing amplanes are liable for violations of law which result in

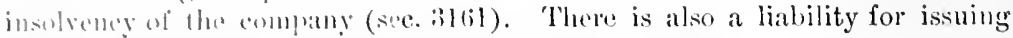
stexk at less tham palr vilue paid thereon (see. 25iti).

1:i. Stockholders' Liabilities. - Stockhullers are liable to the extent of their unpitil stork subseriptions. Stockhohers of manufacturing and mining eorporations are jointly and severally liable for all debts to mechanles, workmen, and laborers eimployed by such eorporation (secs. 2902, 3157).

11. Stock Certificates. - Wach stockholder is entitled to a certificate showing the number of shares owned by him, signed by the president and seceretiny (secs. 2866,2901$)$.

1.5. Preferred Stock. - The act does not expressly authorize the issuance of prefirreol stock.

1i. Payment of Capital Stock. - stock may he issued for money, labor done, (1) properly estimated at its true money value actually received by it. All ollicers wh ensent to the issuance of stock for lahor or property in excess of its antual eash value, ol who, having kuowledge thereof, lo not formally disisut therefrom, are jointly and severally liable to electitors of such corporation for the lifference betwern the actual value of such labor or property at the time the stuck was issuen and the par value of the stock issued therefor. Corperations are expresily forbiklen to accept notes in payment of stock subscriptions (secs. 2877, 2875). Corporations are expressly forbidden to issue stock "ith the moretanding that the full jar value shall not be paid (sec. $257 i j)$. The act provides that the directors named in the certificate of incorporation shall preeed to open books of subscription to the capital stock then nusubscribed, and to secure subscriptions to the capital stock still unsubscribel, and to secure subseription to the full amomnt of the fixed capital (sec. $2-71$ ).

17. Books. - The corporation records must be kept at the prineipal oflice within the tate. Also stock register, book of by-laws, and books of account

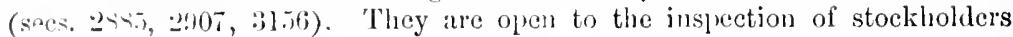
and ereditors.

15. Office and Agent. - All corporations must maintain an office within the State. and an agent to rereire process (secs. $286(31,2855,2907,3160,3265$ a).

19. Reports. - No repurts are necessily.

20). Anti-Trust Statute. - There is a more or less effective anti-trust statute in fore in North l)ikotal (sees. 7L(1)-7.1S1).

21. Statutory Grounds for Forfeiture of Charter. - Charter may he forfoitor for entering illegal trusts and combinations. It may also be forfeited forminn-er or non-11:er by proper action taken by the State. Also for failing for one yrar to transact its usual business within the state, or failing for one vear to $k$ esen and maintain a public office at its principal place of business within the state for the transartion of its usual and regular business and at the same time. hy instrument duly filed in the Secretary of State's oflice, ap[ointed the last-named officer its resident agent, upon whom process maly be serverl (secs, :;26ij a, 7480-7.184). Also for failure to organize and commence busines within one year (sec. 2913 ).

2.-Amendments. - Articles may be amended for the purpose of increasincr rerlecreasing the capital stock or for any other purpose desired (secs. 2905, $29(1), 2910,2 ! 111)$.

2:) Extension of Corporate Existence. - Corporations may be extender for an additional period of twenty years if desired (sec. 3250). 
24. Dissolution. - Dissolution may be had throngh the district cont by the State or hy a private person in the name of the state (secs. 2!12.291:3, 2914; Laws of 190:3, cliap. 59 ).

25. Anmual License Fee. - There is no ammunl license fee.

26. Foreign Corporations. - Forrign corporations munt file articles of incorporation and excente a power of attorney to sucretary of state to receive

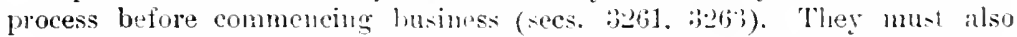
maintain an office wilhin the state (Cons. Art. VIl. sec. 136).

G. R. I. Co. r. Company, 6 X. D. $276 ; 69$ X. W. b91; Nit. Cash liegister Co. . Wilson, 9 X. 1). 112; 81 N. W. 285 ; Wasliturn Nlilis Co. $v$. Bartlett, 3 N. 1). 13854 N. IV. 544 .

\section{OHIO.}

(The references cited below are to Bates's Annotated S'atutes, 1901, unless otherwise stated.)

1. Statutes under which Business Corporations may incorporate. The Business Corporation Act of Ohio is to be fomm in the Revisel statutes

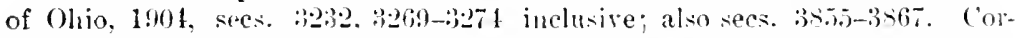
porations may be organized for any propose for which indivisuals may latwfully assnciate themselves, excepting for carrying on professional husiness (sec. $32: 35)$.

2. Incorporators. - Not less than five, a majority of whom must be citizens of Ohio (sec. 32.36).

Ilessler r. Comp:tuy, fol ()hio St, 6.21; 56 N. E. 469.

3. Contents of Articles of Incorporation. The articles must set forth:

a. Name. - The name must hegin will the worl "The" and end with the word "company." Similarity of names as brtween domestie corpora-

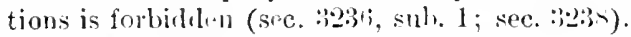

b. Domirile. - Ilace where it is to be located, and where its principal business is to le located (sec. :3:36, sul, 2).

c. Purposes. - The purpose for which it is formed. This provision is construed by the Secretary of state to forbid the incorgoration of eompunics for more than one purposs: (sec. :i2:3(; sub, :3).

1. Coppital Stork. - Amount of its eaprital stock, Number of shares. Capitalization and par value may lo any amomit (sec. :32:3i, suls. 1). If a corporation desires to do away with cumblative voting purabul

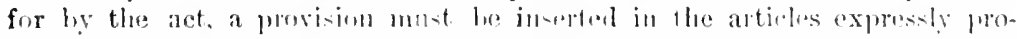

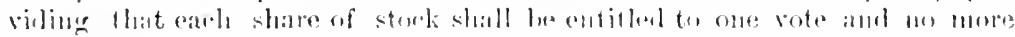

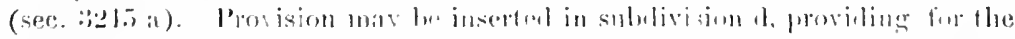

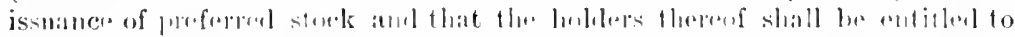

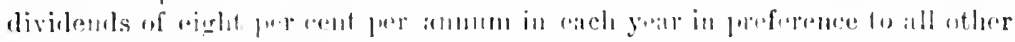

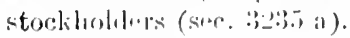

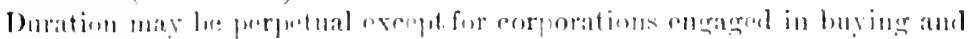

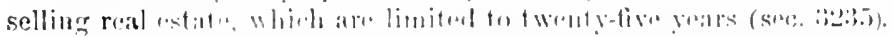

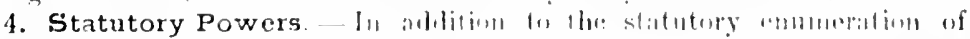

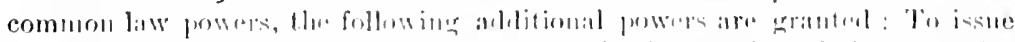

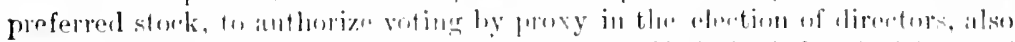

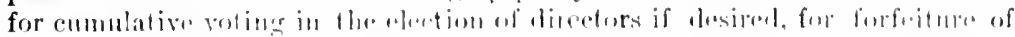

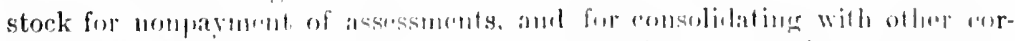

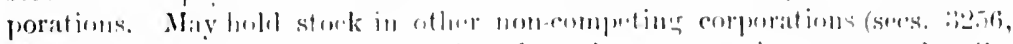

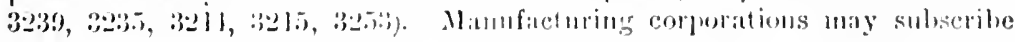


for stock in railroall and transportation companies (sec. 3863). Mining and manfaturing corperallions may lold and convey real estate and transact business ontsille of the state (see. $\left.3866^{\circ}\right)$.

(irene $\bullet$. Company, 62 Ohio st. 67 ; 56 N. E. 642; Lauder $v$. Burke, 65 Ohio St.

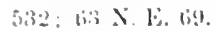

万. Procuring the Charter. - Articles must be subscribed and acknowlellyed by "ach of the incorporators, and the oflicial character of the ofticer trking the acknowledgment must be certified to by the clerk of the common yleas of the comty wherein taken. The articles must then be filed in the oflice of the secretary of state (sec. 8236,3235 ).

state cr rel. c. lns. Co., 49 Ohio St. 440; 31 N. E. 658; Society Perun v. Cleveland, 430 )hir. $41.481 ; 3$ N. E. 357.

6. Corporate Indebtedness. - Corporate indebtedness must not exceed the anom of its anthorized capital stock. Provision may be made in the catse of mortgage indeltedness where the same does not exceed one-half of the eapital stuck actually pail in, that the hollers of the debt secured by such mortigge shall have the right to convert the sume into either common or preferred stock (secs. 32,56, 32257).

7. Organization Tax. - Corporations having authorized capital stock of $\$ 10.00$ or under, $\$ 10$; corporations with more than $\$ 10,000$, one-tenth of one per cent on such eapital stoek (sees. 148, 148 a).

$\therefore$. Filing and Recording Fees. - The payment of the organization tax inchules all filing and recording fees in the Secretary of State's office: for entificate of incorporation, $\$ 5$. The cost of filing certificate of subscription is $\$ 2$. For making certificate under the Great Seal of the State, $\$ 1$. For recurling niscellaneous papers, 20 cents per folio. For making copies, 10 cents fer folio. For affixing seal of office to copies, 50 cents.

4. Commencing Business. - As soon as ten per cent of the capital stock is suluseribed a majority of the direetors must certify in writing to the Secretary of state snel fact, and thereupon call a meeting of the stockholders for the purpose of choosing not less than five nor more than fifteen directors. As soon as the directors are clected and have organized, the corporation may commence business. Buiness must be commenced within five years after date of ineorporation (secs. 324:3, :3:44,6780; Laws of 1901 , p. 170).

Statte er rel. r. lus. Co., 49 Ohio St. 440 ; 31 N. E. 658.

10. Organization Meeting. - The organization meeting must be held within the state at snch time and place as the Jy-laws may prescribe (sec.

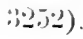

11. Meetings of Stockholders and Directors. -- Stockholders' meetings must he liell within the State. Directors' meetings may be held without the State if the by-laws so provite (secs. $32: 38$ a, :525:).

1.. Directors' Qualifications and Liabilities. a. Qualifications. - There nust be not less than five nor more than fifteen directors. All must be stockholders and a majority residents of (Hhio. The statute expressly authorizes the directors to arlopt a corle of by-laws for their own management. The directors must earh subscrilie to an oath of office (secs. 3214, 3247, 3218, 3250).

1. Directors are liable for the illegal declaration of dividends (secs, 3269, 1-1). They are also personally liable for contracting debts before ten per cunt of the cayital stock has been subscribed.

Trust Co, v. Floyd, 47 Ohio St. $525 ; 26$ N. E. 110. $\because 11$ 
13. Stockholders' Liabilities. - Since the Constitutional Amendment adopted in 1903, stockholders in Ohio corporations are only liable to the extent of their mpaid stock subscriptions. (See former statute, sec. 325s; see also Laws of 1904, p. 3!t6.)

Wick Nat. Bank $v$. Luion Nat. Bank, 62 Ohio St. $446 ; 57$ N. E. 320 ; KuIp $v$. Fleming, 65 Ohio St. 321 ; 62 N. E. 334 ; Boice $v$. Hodge, 51 (hio St. 236 ; 37 ‥ E. 265.

14. Stock Certificates. - Each stockholder is entitled to have a stock certificate issued to him, signed by the president and secretary (sec. 3254).

15. Preferred Stock. - Preferrel stock is expressly anthorized by providing therefor in the articles of incorporation or by subserpent action of the stockholders. Holders of preferred stock are entitled to dividends not to exceed eight per cent per annum out of the surplus profits in preference to all other stockholders. It no time can the preferred stock exceen two-thirds of the actual stock pail in in cash or property (secs. 3:35 a, ::26:3).

16. Payment of Capital Stock. - Stuck may be issned only for money or property. (See sec. 3235 a.)

17. Books. - Must keep a stock book open to inspection of stockholders in which is recorled subseriptions and transfers of stock. Mimntes of the stockholders' and directors' meetings must be kept (sec. 3251). Manufacturing companies must keep their books of account at their principal oflice. This is open to inspection of assessors.

C. V. Co. r. Iloffmeister, 62 Ohio St. $189 ; 56$ N. E. 1033.

18. Office and Agent. - Every corporation must unaintain an office and agent to receive service of process, and keep accounts of financial conditions and also trausfer books (secs. $32: 31 ;,: 3855,5 t ; .51$ ).

Mercantile Tr. Co. v. Elsa Iron Works, 4 Ohio Cir. Ct. $5 i 9$.

19. Reports, - Juring $M$ ity a report must be filod with the Secretary of State, containing among other things names anl addresses of the otlicers and directors; anonnt of capital stock subseribed, is sned, ontstanding, and paid in; kind of business engaged in. Ammual reports must also be made to stockholders (sec.. 3268, :326!) ; Laws of 1902, p. 1:21).

20. Anti-Trust Statute. - Ohio has in somewhat drastic anti-trust statute on its statute-looks (secs. 1127, 1-12).

21. Statutory Grounds for Forfeiture of Charter. - Chatters may be forfeited by the state for misuser or non-user for five years, or for violation of the anti-trust act, or for failure to pay ammal license tax (secs. 1427-14:32, 6760,$671 ; 1,6750$; Laws of 1901, Pl. 381-:3;:3).

State $v$. Company, 6.2 ()hio St. 350; 57 N. E. 62.

22. Amendments. - Articles may lw ancuded so as to incresise or decreas. the eapital stock, change the rorporate nume, the domiciliary oflice, to enlarge or diminish the olijerts or pmoleses for which it is fomed or to adh therets or change the par valur of shares, but the articles eamot bes anended so as to change the original purposes of its organization (snes. 32:38,

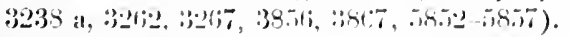

2:). Extension of Corporate Existencs. - Thure is nu provision for extension of corpurate existunce.

24. Dissolution. $-\Lambda$ majonity of the managing loand or stockliolders

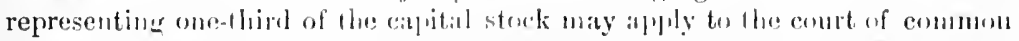

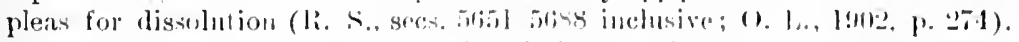
Charters may be surenderent if desired lefore any inntahuent of capital stoek 
has born prid in ar debts inemred, by complying with the statute in such case malle and prosiled (se. itizt; laws of 1901, p. 383).

2-. Amual License Fee. - ()nc-tenth of one per cent mpon subseribed or is-menl and outstandiug stock (rees. $2780-21$ ).

21i. Foreign Corporations. - liofore commeneing to transact business within the state "very forrign corporation must, under oatlo of its president, sereting, teasurer, superintenlent or managing oflicer within the State, make and lile with the sechtary of state a statement containing the following lints: (1) Number of shares of anthorized eapital stock amb par value thereof;

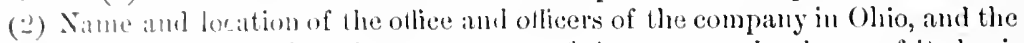
mame and anlerss of the oflieers an agents of the company in charge of its busines: in ()ho; (3) The value of the property owned and used by the company in (1hin, where situate, and the value of the property owned and used ontside of (Ohio: (4) Th" proportion of the capital stock of the company which is represinted by proputy owned and used and hy business transacted in Ohin. Thereupon the secretiry of State shall determine the proportion of the capital stoek represented hy property and business in Ohio and shall impose and collect a tax of me-fenth of one per cent upon the proportion of the authorized capital stuck of the corporation represented hy property owned and used and husiness transactol in ohio. Foreign corporations transacting business without a permit are sulject to fine and are cut off from all recourse to the courts. 'The law however provides that foreign corporations obtaining a permit shall not be subject to attachment as a foreign corporition (Laws of 1904, p. 38:3).

W. L. Telegrayh Co. v. Mayer, 28 (hio St. 521 ; Clarke v. C. R. R. \& B. Co. et al., 50 Fent. Rep. 338 ; 'Tuledo, etc. Co. v. Glum, ete. Co., 55 Ohio St. 217 ; 45 N. E. 197 ; Gen. Elentric Co. $x$. lima Electrie Co., 4 Ohi, Nisi Prius Rap. 167 ; State $v$. Sherman, 22 U!hio St. 411 ; Lander r. Burke, 65 Ohio St. 532 ; 63 N. L. 69.

\section{OKLAHOMA.}

(The references cited below are to the Oktahoma Statutes (1893), chap. 17, unless otherwise stated.)

1. Statutes under which Business Corporations may incorporate. The Business Corloration Act is to be foumd in chap. 17, arts. 1 to 12 of the Statutes of 1093. Pauties may incorporate under the General Act for the following purposes: Mining, manuficturing, and other industrial pursuits, the construction of railrouls, wagon roads, street railways, eleetric light, powe anl gas plants, water works, irligating ditches, eleemosynary purposes, for conducting the business of insurance, banks of discount and deposit (but not of issuc), bnilding and investment companies, loan, trust, and guarantee corprations, merchandising. wholesale or retail or both; for the purpose of lociting. laying ont and improving town sites, and buying and selling real atate threfor, ineluling the sale and conveyance of the same in lots, subdivision, or otherwise. For the purpose of constructing telegraph and telethone linesulul systems, and the organization and maintenance of commercial club and husiurs exchanges, and for the purpose of constructing sewers and other muicipal improvements (sec. 12 as amended by Laws of 1903, chap. 9).

2. Incorporators. - Not less than three, one-third of whom must be residents of the 'Territory (sec. 12 as amended by Laws of 1903, chap. 9).

3. Contents of the Articles of Incorporation. 'The articles must set forth:

r. Nime. - The Secretary of the Territory will not permit two domestic corporations of the same name. 
b. Purposes. - Purposes for which it is formed. State cfficials allow articles to pass allowing incorporation for different lines of industrial business so long as they do not conflict witl any special statute in regard to the organization of corporations.

c. Domicile. - The place where the principal business is to be transacted.

d. Duraion. - The term of existence of corporations formed for manufacturing and other industrial pursuits is limited to twenty years.

e. Directors. - Number of clirectors and names and residences of those who are to serve until formal election of the first board of directors. The qualifications of the directors nust also be set forth.

f. Capital Stock- - The amount and number of shares into which it is divided. Both the capital and the par value of shares may be any amount (sec. 14).

4. Statutory Powers. - In addition to the enumeration of common law powers the statute confers the following alditional powers: To purchase its own shares, to vote by proxy; to have a business office without the Territory at any place within the United States, and to hold any meeting of the stoekholices or directors of the corporation at said oflice; to forfeit stock for non-payment of assessments; to rensove directors; to provide penalties to the amount of $\$ 100$ for violation of by-laws (secs. $27,30,: 32,84,43,-14,56-75,161$ ).

Topeka Paper Co. v. Company, 7 Okla. $220 ; 5+$ Pac. 45.5.

5. Procuring the Charter. - The articles must be suberibed by each of the incorporators aml acknowledged before some offeer authorized to take acknowledguents of conveyances of real property. The articles must then be filed with the Secretary of the Territory (secs. 17, 18). Collateral inquiry iuto the legality of corporate existence is forbidden (sec. 1).

6. Corporate Indebtedness. - Th: corporate indebtedness is limited to the amount of snbscribed capital stock (sec. 11).

Rorlgers $v$. Bonnett, 2 Okla. $5.53 ; 37$ Pitc. 1078.

7. Organization Tax. - There is no organization tax imposed upon corporations.

8. Filing and Recording Fees. - 85 to the Secretary of the l'erritory for filing articles; \$; for issuing certificate of incorporation: for affixing cortiticate to copy of articles, $\$ 1$; for making eopy of articles, 10 cents per folio.

9. Commencing Business. - The compuny must be organized and business must he commencel within one yair from the date of the issuluce of the certificate of incorporation. The comprany mut lwe organized - to the extent of the adoption of by-laws at least - within thirty days after the filing of articles of incorpurition (secs. 83, 52).

10. Organization Meeting. - Whe oremization meetine maty be held

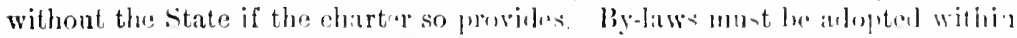

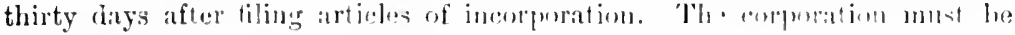

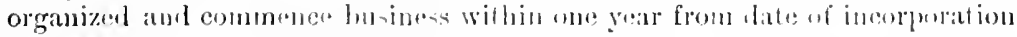

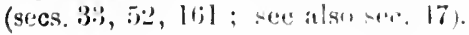

11. Mectings of Stockholders and Directors - If the (hater so pris-

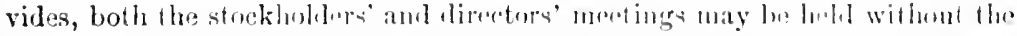

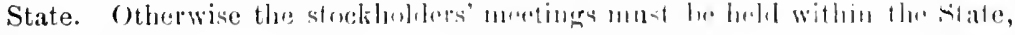

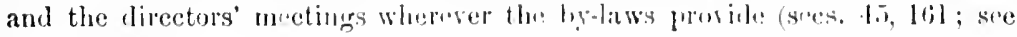
also sec. 17 ).

12. Dircctors' Qualifications and Liabilities. a. Qurlificalions. - Thiere 
must he at least three directors and not more than eleven, all of whom must be stockluklers. One-thinl of the ofheers must be residents of the Territory. At the first meeting at which by-laws are adopted or at such subsegmint meotings as may then be designited, directors may be elected to hold their oflice for on year or until their successors are elected and qualify (sies. ?, :37, 39).

b. Limbitilies. - lirectors are liable for illegally increasing or reducing the stock of the eorporation, for declaring illegal divilends; also for making false reports, for creating debts beyomi the amount of subseribed capital stock, and for making loans to stockholders (secs. H1, 42, 156).

13. Stockholders' Liabilities. - Stockholders are liable for debts of the compray to the extent of their umpaid stock subscriptions. Also for dehts lne mechunics, workmen, and laborers employed by the corporation (secs. 46, 15s).

Chicago Bhig \& Mfg. Co. 2 . Lỵon, 100 kla. 704; 64 Pac. 6.

14. Stock Certificates. - Stock certificates must be signed by the president ani secretary (sces. 48, 2ss).

15. Preferred Stock. - The act makes no special provision for the issuance of preferrel stock.

16. Payment of Capital Stock. - Corporations can issue stock for money, labor lone, or money or property actually received. The act expressly provides that all stock certificates issued in excess of the capital stock shall be roid.

17. Books. - Stock transfer book and a journal of the meetings of director's and stockholders must be kept open for inspection of stockholders, but the place where such book is to be kept is not specified by statute (secs. $85,50,15 \%$ ).

18. Office. - The act requires every corporation to have its main office for the transaction of its business within the Territory (secs. 45, 161).

19. Reports. - Corporations for mining, manutacturing and other industrial prrsuits must ammually within twenty diys from the first day of Jamury make a report which mut be published in some newspaper published at the place where the principal business of the corporation is carried on, stating the capitin stock, and the amomt thoreof actnally paid in, the amount and rating of its imbebtemess, and the amount due the corporation, the number and amount of dividenis and when pail, and the net amount of [nofits. This report must be signed by the president and a majority of the directors and verified by the president or secretaly and filed in the office of the reginter of deels of the comty where the corporate business is carried on (sec. 159 ).

20. Anti-Trust Statute - Certain classes of trusts and combinations are pruhibited. (Ste Stat., sec. 6110.)

21. Statutory Ground for Forfeiture of Charter. - The charter may be forfeited for failure to organize and commence the transaction of business within one year from filing articles, also ly neglect, abuse, or surrender of its corporate rights (sec. 5, ; Stat., secs. 5:357, 5:358, 5359).

22. Annual Franchise Tax. - There is no annual franchise tax in Oklahoma.

23. Amendments. - The articles may be amender in any particular desired (secs. 15, 49).

21. Extension of Corporate Existence. - Corporate existence may be extended, if desired, by compliance with the statute (sec. 262).

3.18 
25. Dissolution. - Two-thinds, vote of the stockholders anthorizes petition for dissolution in the district court. Failure to commence business within one year from date of incorporation dissolves such company (Stat., secs. 5357-5:559, chap. 16, Art. V. secs. 51, 52).

26. Foreign Corporations. - Foreign corporations must file in the office of the Secretary of the Territory an authenticated copy of their charter anit appoint an agent to receive process. This agent must resicle in the county where the principal business of the corporation is to be carried on. An anthenticated copy of the agent's appointment must be filed in the othice of the Secretary of the Territory and also in the office of the register of dects of the county where the agent resicles. Foreign corporations paly merely filing fees. There is no amnual license fee imposed on then (chap. 17, Art. XXI. sec. 1167$)$.

Keokuk Falls Imp. Co. v. K. \& D. MI. Co., 5 Okla. $32 ; 47$ l'ac. 484.

\section{OREGON.}

(The references cited below are to Bellinger \& Cotton's Annotated Code and Statutes (1902), unless otherwise stated.)

1. Statutes under which Business Corporations may incorporate. The Business Corporation Act of Oregon is to be found in secs. 50.5-20 (073) of chap. 1, Title 41, Bellinger \& Cotton's Ammotaten Code of the Statutes of Oregon, as amended by the laws of 190:3. Cuder this act corporations may be formed for any liwful business enterprise.

2. Incorporators. - Three or nore persons. There are no resilential requirements (sec. 5052).

Rutherford $v$. Ilill, 22 Ore. 218 ; 29 l'ac. 546 ; Miller e. Comprany, 3 Ore. 25 ; Coyote, etc. Co. $v$. Rulle, 8 Ore. 28.5 .

3. Contents of the Certificate of Incorporation. The ecrificate must set forth :

a. Name. - Similarity of names with existing corporations is expressly forbidden (Laws of 19083, p. 41).

b. Duration. - May be unlimited if desired.

c. Purposes. - Enterprise, husiness, pursuit, or necupation in which the corporation proposes to cngage. State oflicials permit the insertion of any number of purposes in the articles.

Maxwell $\because \Delta$ kin, 89 led. 180.

d. Domicilimy Offire. - Place where the corporation proposes to have its princigal place of husiness or places of husiness.

e. Capital stork. - Anomut thereof, which is mulimiterl.

f. Number and Por Volue of Shaters. - These mity be any amount.

g. If the corporation is formen for the purpese of niwigation. constructing railroads, roats, catnals, or bricleres, the termint of such navigation road or of

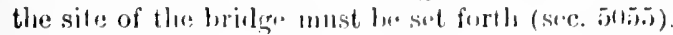

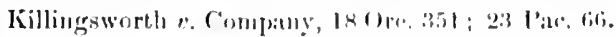

4. Statutory Powers - In indition the the statutory enumeration of common law powers the conpolation has the followion allitional powers:

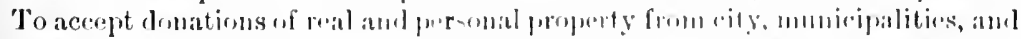
persous; to forfeit the stock of its mumbers for mon-pinyment of assessments: 
to promit railroul eompanies to consolidate; to authorize voting by proxy

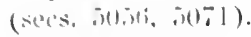

(1. I. A N. Co. r. O. I. Co., 130 U. S. I ; 9 Sup. Ct. 409 ; IIolladily r. Elliott, s ( tre.s.

j. Procuring the Charter. - The articles must be subscribed and andinowledged ly each of the incorporators and should be execnted in iniplicale. (bne of these must be filed in the ofliee of the Secretary of stane another with the clerk of the cominty where the corporate business is $t$ b entried on or where the principal plice of business is to be located, and a third shund be retained in the possession of the company (sec. 5053.) liefore a certilicate of ineorproration will be issued, not only must the organization tax he paicl, but the proportionate anount of the anmal franchise tax for the first rear (Laws of 190:3, p. 41). The Secretary of State thereupon issues a certilicate of ineorporation (Liws of 190:3, pp. 40, 41).

Wish., ete. As'n $r$. Stanley, 38 Ore. 319; 63 P'ac. 489.

6. Corporate Indebtedness. - 'There is no limit upon the amount of corporate inlebterness.

7. Organization Tax. $-\mathrm{U}_{\mathrm{l}}$ to $\$ 5,000, \$ 10 ; \$ 10,000, \$ 15 ; \$ 25,000, \$ 20 ;$ $\$ 50,000,+25: \$ 100,000,835 ; \$ 250,000, \$ 15 ; \$ 500,000, \$ 60 ; \$ 1,000,000, \$ 75 ;$ $82.000,010,590$; in excess of $\$ 2,000,000, \$ 100$ (Laws of $1903, \mathrm{pp} .39-49$ ).

8. Filing and Recording Fees. - There is no eharge for filing and recorting articles in the oflice of the seeretary of State. For recording with comty clerk, about \$1.2.) (see Laws of 190:3, p. 41 ).

9. Commencing Business. - As soon as the articles are filed as required by law and one-lialf of the capital stock has been subscribed, the corporation mily commence the transiction of business. Directors must be elected and business commeneed within one year from time of filing articles (secs. 5057, 5067).

C. G. \& S. II. Co. c. linble, 8 Ore. 285 ; Ilolladay $v$. Llliott, 8 Ore. 85 ; Willamette Freighting Co. a. Stanuers, 4 Ore. 262; McVicker $v$. Cone, 21 Ore. 353; 28 Pac. 76; Niekum $i$. liurekhare, 30 Ore. $464 ; 47$ Iace. 788 ; 48 Pac. 474.

10. Organization Meeting. - The organization meeting must be held within the State in the absence of any statute proviling otherwise. Provision is male for the ealling of the organization meeting. At the incorporators' neeting the incorporators act as inspectors of election and eertify that they will elect directors and appoint time and place for their first meeting (see. 50.5.5). Directors cannot be eleeted until one-half of its eapital stock has been sulserilsed (see. 50.5).

Niekum r. Burckhar 1 t, 30 Ore. $464 ; 47$ Pac. $789 ; 48$ Pac. 474.

11. Meetings of Stockholders and Directors. - Stockholders' meetjugs must be hald within the State. 'The provision that a majority of the directors shall be residents of the state, prictically renders it necessary to hold the directors' nertings within the state unless the expedient is resorted to of delegating the powers of directors to an executive committee composed of a minority of the directrors (sec, 5062 ).

J)eruber hro Conpray, 21 Ore $573 ; 28$ l'ac. 899.

12. Directors' Qualifications and Liabilities. a. Qualifications. - There mnst he not liss than three directors, all of whom must be stockholders and a majority resilents of the state. Each must subseribe to an oath of office (sec. $5(1.5)$. Less than a majority may constitute a quorum if desired (sec. 5062).

Silsty u. Strong, 38 Ore. 36 ; 62 Pac. 633.

$$
\text { :30) }
$$


b. Liabilities - Directors are liable for the illegal declaration of dividends and for the unlawful withdrawal of capital (sec. ju66).

Patterson $\imath$. Thompson, 86 Fed. $85 ; 90$ Fed. 647.

13. Stockholders' Liabilities. - Stockholders are liable to the extent of their unpaid stock subscriptions (Cons., Art. XI. sees. 3, 5065).

Lee $v$. Imbrie, 13 Ore. 510 ; 11 l'ac. 270; Bruadige $v$. Company, 1.2 Ore. 322; 7 Pac. 314; Ilawkius e. Company, 38 Ore. 54t; 64 l'ac. 320; Mhrich $c$. 1. C. \& 1). Co., 24 Ore. 32 ; 32 Yake. 756 ; Batlour $t$. Company, 27 Ore. $300 ; 41$ l'ace. 164.

14. Stock Certificates. - Each stockholder is entitled to a errtificate showing the number of shares held by him, signed by such otlicers ats the bylaws may preseribe.

15. Preferred Stock. - There is no express provision authorizing the issuance of preferred stock.

16. Payment of Capital Stock. - Stock may be paid for in money or money's worth.

17. Books. - The stock book and all other books of the corporation, necessary in carrying on its business, must be kept within the State at the principal oflice (see. 506:3). They are open to inspection at all reasonable hours.

18. Office and Agent. - Every corporation must maintain an ollice within the State at all times (sec. 5(0,5).

19. Reports. - All corporations shall, during the month of June of each year, furnish the Secretary of state with a statement sworn to by one of the oflicers, setting forth the name of the corporation, location of its principal othice, names of its presilfut, secretary, and treasurer, am their post-ollice addresses, date of annmal election of ufticers and directors, anomit of anthorized capital stock, number and par value of shares, anomint of cipital stoek subseribed, anount issued and paid แp (.tet of Feb. 16, 190:;, see. 5).

20. Anti-Trust Statute. - There is no anti-trust statute in force in Oregon.

21. Statutory Grounds for Forfeiture of Charter.-- Charters mily be forfeited if the corporation for any period of six months after the commincement of business neglects or ceases to carry on the same. It may alio be forfoited for abuse or misuser of its corporate powers, or for frilure to clect directors and commence husiness within one year after filing articles of incorporation (sec. Bofit). The right to transact husiness is in aloegance while the

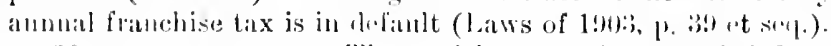

20. Amendments. - The articles may be amenterl for the purpose of

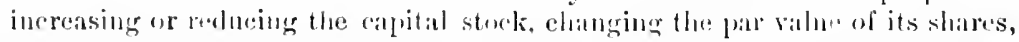

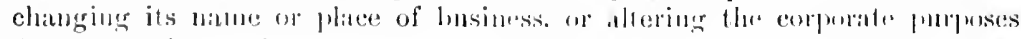

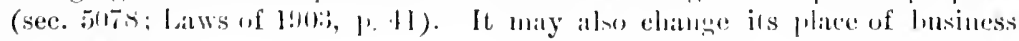
(sec. $5(17:-)$ ).

2: Extension of Corporate Existence. - There is no prerision for

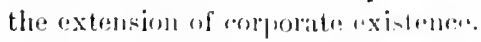

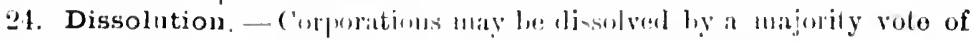

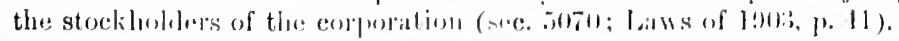

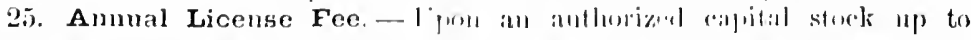

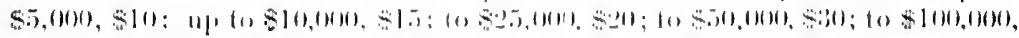

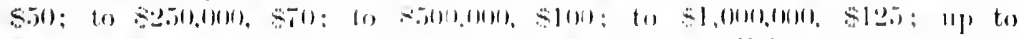

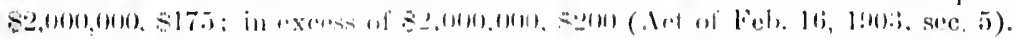

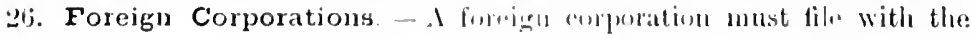


Socretary of state a declaration of its purposes to engage in business within thu shatc, and state nam. umler which it proposes to transact business, name of State under whose laws it is organized, location of its lome oflice, date of its incorpuration, anuont of eapital stock, nature of its business, location of its principal oflice within the state, name of its attorney in fact, names and indlesses of its principal oflicess and lirectors, and nime and residence of principal anest within the State: also eertified copy of its charter, certified to ly the legal kerper of the original together with a certifieate of the Secretary if - ratte of the state issuing the charter, as to whether said articles of incorfuration are gemuine: and must pay to the secretary of State 5.50 for filing and reording the same, together with amunal license fee for the sneeeding fration of the vear. The ammual license tax is the same as for domestic corporations. Mist also file ammual reports same as domestic corporations, anl must appoint an attomey within the State upon whom process may be served (. Let of Feb. 16, 190:3, sees. 6,7).

(). \& W. T. I. Co. c. Rathburn, 5 Saw. 32 ; Commercial Bank v. Sherman, 28 Ore. 5.3; 43 P'ace 65s; singer Mfg. Co. $v$. Graham, 8 Ore. 18 ; Aldrich $v$. Anchor Coal, ete. Co., 24 Orc. $32 ; 32$ Pac. 756.

\section{PENNSYLVANIA.}

(The references below are to the I'ublie Laws of Pennsylvania, 1894, unless otherwise stated.)

1. Statutes under which Business Corporations may incorporate. The Business Corporation let of Lemsylvania is to be found in Act 29 of the Session Laws of 187t, Public Laws, chap. 7:3. This law was amended by Act of $A$ pril 17, 1570; also by Aet of July 9, 1901. Special acts are provided for bauking, canal, coal, navigation, railway, pipe line, street railway, motive pown, natural gas, domestic insurance, anl co-operative companies. Under the Aets of $187 t$ and 1876 corporations were divided into twenty-five classes, and charters conlu be procured for the transaction of any business mentioned iu one of thuse elasses. By the Act of July 9, 1901, corporations may be formed for the transaction of any lawful business not otherwise provided for.

2. Incorporators. - Three or more persons, one of whom must be a citizen of l'ensylyuia (Laws of 1901 , chap. 207; Laws of 1903, ehap. 204).

$\because$ Contents of the Certificate of Incorporation. The certificate must set finth :

a. Name - Similarity of names is forbidden. A charter will be refused where the proposed name is alrearly in use by a domestic corporation (P. L., 73, sec. 3: see Laws of 190:3, Aet 185).

American Clay Mffr. Co. v. Company, 198 Pa. 189; 47 Atl. 936.

b. Purpress - Purposes for which corporation is formed. Only one pur. prose may be-iuserter (Il.). Certificates for incorporation of manufacturing or merantile companies deseribe in a general way the goods to be manufactureel or solel.

c. Momicile. - Place where business is to be transacted (Id.). Only one oflice can be numed, and that must be where the corporate functions are to be exerciserl.

1. Iuration. - T'erm of existence. May be perpetual if desired (P. L., 73, sece. 4).

e. Subscribers' Trmes and Subscriptions. - Names and residences of subcribers and number of shares subseribed for by each (P. L., 73, sec. 3).

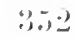


f. Directors. - Number of directors. Not less than three. Names and residences of those for the first year (P. L., 73, sec. 3; Laws of 1901, chap. 51).

g. Capital Stock. - Amount thereof. Number and par ralue of shares. Capital stock may be any anount. Par ralue of shares must not exceel $\$ 100$ (I'. L., 73, secs. :3, 11; Laws of 1899 , chap. 120 ; see also Laws of 1901 , chap. 302).

h. Preliminary Payment of Stock Subscriptions. - A statement that ten per cent of the eapital has been paid in to the treasurer together with his name and residence (P. L., 7:3, sec. 3).

Cook $v$. Marshall, 191 Pa. $315 ; 43$ Atl. 314.

4. Statutory Powers. - In addition to the common law powers corporations have the following adlitional powers: To consolilate with other eorporations; to purchase and hold stock and bonds in other corporations; to issue preferred stoek; to vote by proxy ; to enforce a lien for corporate delits; to forfeit stock for non-parment of assessments; to issue stock for property purchased. The corporation has power to cumulate votes in election of directors, to classify directors, and to dispose of all corporate assets (P. L., 30, sec. 5) ( Cons. Art. XVI., sec. 4 ; P. L., 47, sec. 1; P. L., 73, sec. 1; Laws of 1901 , Act 210 ; Laws of 1901 , Act 298 ; P. L., 37, see. 1; P. L., 73, sees 16, 1:3; P. L., 79, sec. 1 ; P. L., 47, sec. 1; P'. L., 141. sec. 1; 7 Sm. L., 820, secs. 1-2; P. I.. 7:;, secs. 11.39 ; P. L., 30, sec. 4 ; Cons., Art. XVI. sers. 6,7 ; P. I., 30, sec. 6 ; Laws of 1903 , Aets 17,115$)$.

5. Procuring the Charter. - The certificate must be subseribed and acknowledged by at least two of the incorporators, who must also swear that the statements contained in the certifieate are true. Notice of intention to apply for elarter must be inserted in two newspapers once a week for three weeks, stating the character and object of the proposed corporation. Certificate together with proof of publi ation must then be forwarled to the governor. who, if he approves of it, enfors's his approval thereon and directs letters patent to issue. The certificate is then recorded in the oflice of the secretary of state, registered with the Aulitor-General, and the original artieles with the endorsement mentioned, must then be recorded in the oflice of the recorder of leeds of the connty where the chief operations of the company are to be carried on (Laws of 1901 , Act 207 ; P. L., 73, sec. 3; P. L., 18, sec. 1; P. I., :30, sec. 6 ; P. L., 420. sec. 19; Law's of 19193, chap. 2(1).

I. I3. Co. r. Company, 196 l'a. St. $25 ; 46$ Atl. 99.

6. Corporate Indebtedness - Loans to an amount not exceeling onehalf thr caljital stoek may be made on real istate and machinery, or on real estate alone. Corporations belonging to elasces 1, 5, (i, 7, 9, 11, 2.1, nay

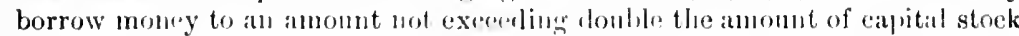
paid in. Under Laws of 1901 , let 1 , all limitations as to the horrowing power of eorporations other than thrse in the classes above commeraterl are

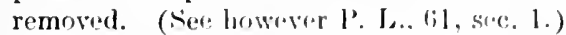

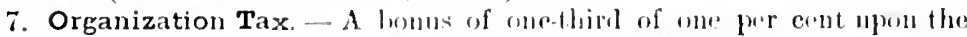
authorized capital strek must be painl (Laws of 1,49!, Act 1:0) Laws of $19(1) 1$, Act 1).

8. Filing and Recording Fees. - Filing fres in the oflice of the Sieretary

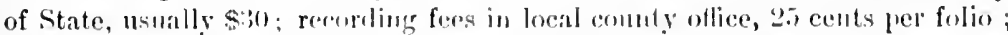
fee upon or ranizition for tilin's statumput, s.5; cost of publishiug notice of application for letters patent, usually about 89. 
?. Commencing Business. - linfore the corporation can commence business ten fere exut of the anthorizel eapital stock must have been paid in in carle to the treasurer of the intended corporation. The corporation cannot conmmen business withut first tiling with the Auditor of the Commonwealth the n:me of the corporation, the date of incorporation, the authority under which incurpurated, place of husiness, post-oflice adlress, and names of the presilent. secrotary, and treasurer, the amount of eapital anthorized by the chanter, and amonint of capital paid in to the treasurer of the company (P. L., 30. sec. (i; I. I.. 112, sec. 1; P. I., 420, sec. 19). I3usiness must be comnenced within two years after incorporation (P. L., 626, secs. 2, 3; P. I., 1.2.2. see. is: I'. I., 2.11, sec. 2).

10. Organization Meeting. - The organization meeting must be held witlin the C'ommonwealth, unless a majority of the incorporators or stockholilers are citizens of another State. (See I'. L., 61, sec. 1.) When a majority of the directors, corporators, or stockholders thereof are citizens of inother State. the corporation may be organized without the State if desired (1'. 1., 12.2s, sec. 1).

11. Meetings of Stockholders and Directors. - The annual meetings for the election of oflicers must be held in the State of Pennsylvania. Special stockholders meetings and meetings of the hoard of directors may be held without the State if a majority of the stockholders and a majority of the directors are respectively citizens of another State (P. L., 355, sec. 1; P. L., 12.-S. sec. 1). Iron and steel corporations may loold all meetings without the itate if desired (P. L., chap. 73, sec. 38).

12. Directors' Qualifications and Liabilities. a. Qualifications. There must be at least three directors, one of whom must be a resident of the state. If the by-laws so provide, the number of directors may be changed from time to time by the directors without a vote of the stockholders and withont amending the certificate of incorporation. Directors may be classified if desired. If the certificate so provides, directors may adopt bylaws (P. L, 61, sec. 1). Cumulative roting is permitted (P. L., 47, sec. 1; P. L., S0, sec. 1 ; P. L., 411, sec. 1; P. L., 2S1, sec. I, as amended by Laws of 1901 , let $.11 ;$ P. L., 73, sec. 35).

Commonwealth $v$. Stevenson, 200 1'a. St. $509 ; 50$ Atl. 91.

b. Liabilities. - Directors are liable for the declaration of illegal dividends. They are also liable to creditors and stockholders for moneys embezzled by officers (I. 1.., 73. sec. 39 ; P. L., 196, sec. 1; P. L., 72, sec. 3; P. L., 196, sec. 3).

Strunk v. Owen, 199 Pa. St. $73 ; 48$ Atl. 888.

13. Stockholders' Liabilities. - Stockholders are liable to the extent of their nuparl stock subscriptions. They are also liable for labor debts to the amount of stock lield by them (Cons., Art. XVI. sec. 7 ; P. L., 30, sec. 3 ; P. L., 7:) sees 15,$21 ;$ P. I., 73, sec. 39 ; P. L. 437, sec. 5). They are also lialle for the illegal withdrawal of capital (P. L., 73, secs. 35, 39).

Als. Ben. Order $x$. Company, 195 1'a. St. $602 ; 46$ Atl. 102 ; Bates $v$. Day, $198 \mathrm{~Pa}$. St. $313 ; 48$ Atl 407 ; IICNeal P'ipe, etc. Co. $v$. Bullock, 174 Pa. St. $93 ; 34$ Atl. 594.

11. Stock Certificates. - Each stockholder is entitled to a certificate signed liy the president or vice-president, and countersigned by the treasurer and sealed with the seal of the corporation (P. L., 73, sec. 7; Laws of 1895 , Act 3$)$.

15. Preferred Stock. - Preferred stock may be issued if authorized in 3.5 
the certificate of incorporation, or with the consent of a majority in interest of the stockholders after incorporation. It may be dirided into classes if desired. The amount of preferred stock cannot at any time exceed onehalf of the authorized capital stoek. The amount of dividends thereon is limited to twelve per cent. The holkers of preferred stock are not liable for debts of the corporation (P. I., 37, sec. 1; P. L., 73, secs. 16, 39; P. L., 79, sec. 1).

16. Payment of Capital Stock. - Stock may be issued in exchange for money, labor done, or property actually received. Stock may be issued for real and personal estate, mineral rights, patent rights, and other property necessary for the purposes of organization. 'The stock so issued shall be declared and taken to be full-paid stock and not liable to any further calls or assessments. One quarter of the capital stock must be paid up within two years (P. L., 122, sec. 5). No note of a stockholder can be accepted in payment of stock (P. L., 30, sec. 4 ; see also Cons., Art. XVI. sec. 7 ; P. L., Act 278 , sec. 1).

17. Books. - Directors of manufacturing, mechanical, miuing, quarrying, and other business, provided in sec. 18 of the enumeration of the classes of business corporations, are required to keep a stock book or stock register, which must be open for inspection during business hours to all persons (P. L., 563 , sec. 21).

Commonwealth $x$. Phornix Iron Co., 105 l'a. 111.

18. Office and Agent. - Isirle from iron and steel manufacturing companies, the principal office of all business corporations must be located in the State, and the place where the husiness is to be transicted must be designated in the certificate. In the case of iron and steel companies, the hatter may have an office without the State, if the by-laws so authorize, where meetings of stockholders and directors may be held (l'. L., 73, sec. 3; I'. L., :351, sec. 2; P. I., 35.5, sec. 1; P. L., 73, sec. :38).

19. Reports. - Every colporation shall make an ammal report, in the nonth of November, of the comdition of the corporation. Special provisions require anumal reports from railroal, cancl, navigation, and telegrapl compalies (P. L., 420, sec. 19; I'. L., 2.29, sec. 4; Laws of 1901, chap. 121).

20. Anti-Trust Statute. - There is no anti-trust statute.

See Nester $v$. Company, 161 l'at. St. $473 ; 29 \mathrm{\Lambda t}$. 102.

21. Statutory Grounds for Forfeiture of Charter. - Charter may be forfeited for failure to oratuize within two years after the issuance of letters patent, and after une-fourth of its capital stock hats been paid "ip. It may also be forfeited for misusin or nom-user, or by the commission of any act wherely forfoiture theresf shall by law be created. Neglect to pity the bonms tax

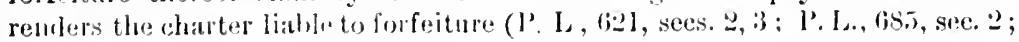

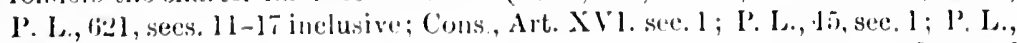
12., sec 5; I'. L., 241, see. 2; P'. L., 122, sec. 5; I'. L., 25\%, see. 3; Laws of 1901 , Iet 176$)$.

Cowlian v. Armoli, 58 l'it. St. 399.

22. Amendments. - rharte may he ameuled for the purpose of improving, amending, or altr.ring the conditions npon which it, was formul and estab-

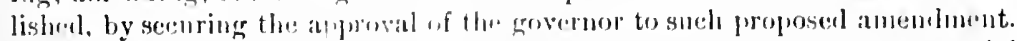

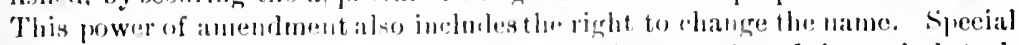
provision is mate for increasiog or decreasing the par value of the cupital stock 
and changing the number of directors (P. L., 189, sec. 2; P. L., 355, sec. 1; 1'. L.. 1.2. ste. 1 ; laws of 1899 , Act 120, see. 2; Laws of 1901, Acts 1, 51, 302: Laws of 1 !)(1:3, chitp. 185).

Cerhe 2 . Marshall, 191 l'a. St. $315 ; 43 \&$ tl. 314.

2.). Extension of Corporate Existence. - Provision is made for the extension of corporate existence of business corporations (P. L., 73, secs. 4, f11: Laws of 1895 . Act 1).

-1. Dissolution. - Court of common pleas may accept surrender of powers and cuter a decree dissolving corporation with consent of a majority of the stockhohlers, and after advertisement in two newspapers (P. L., 293, sec. 11; I'. L.. sec. 95: Law's of 1903, chap. 74).

II. B. Co. 2 . Company, 196 l'a. St. $25 ; 46$ Atl. 99.

25. Annual License Fee. - Five mills upon each dollar of the actual value of its whole capital stock of all kinds, including common, special, and preferred. must be paid to the Treasurer of the Commonwealth amually within thirty days from date of settlement of the account by the Auditor Genrral and state Treasmrer. Manufacturing companies with property exelusively in the State are generally exempt from this anual license fee (Gen. Law Taxation, secs, 2, :3; P. L., 35:, sec. 1; Laws of 1899 , Act 120).

21. Foreign Corporations. - Statement must be filed with the Secretary of the Commonwealth, showing name and object of the corporation, location of its oflice and resident agent therein; must also pay State Treasurer a bonus of one-third of one per cent upon the capital actually employed or to be employed wholly within the State. Must file annual report with the AuditorGeneral. Foreign corporations may become domestic if they so desire, by complying with the statute in such case made and provided (P. L., 89, secs. 1. 2). The same amunal tax is required as of domestic corporations (P. L., 353 , sec. 1 ; Con., Art. XVI. sec. 5; Laws of 1901, Act 121 ; P. I., 108, sec. 3 ; P. L., 127, sec. 1 ; P. I., 249, sec. 1; P. L., 3S, secs. 1, 2; P. L., 39, secs. 1. 2 ; I. L., 89, secs. 1, 2, 3; P. L., 176, secs. 1, 2; P. L., 252, sec. 1; P. L., :1; , sec. 2; P. L., 216 , sec. 3 ; P. L., 35t, sec. 6; P. L., 359, sec. 2 ; P. L., 460 , sec. 1 ; Laws of 1903 , chaps. 2, 67).

Ic Canna \& Fraser Co. $v$. Citizens Trust, etc. Sur. Co., 76 Fed. $420 ; 24$ C. C. $\Lambda .11$; Commonwealth $v$. Company, 98 Peun. 90 ; In re Hovey's Estate, 198 Pa. St. $385 ; 48$ Atl. 311 ; P. B. L. \& S. Ass'n $v$. Berlin, 201 Pa. St. 1; 50 Atl. 308; Madden $v$. Company; 199 Pa. St. $454 ; 49$ Atl. 296.

\section{RHODE ISLAND.}

(The references citel below are to General Laws, 1896, unless otherwise stated.)

1. Statutes under which Business Corporations may incorporate. The lisusiness Corporation Act of lihode Island is to be found in the General Laws, chayss. $176,177,180$. Lnder this act corporations may be formed for the transaction of any ordinary business, except railroad, canal, turnpike, insurance. bankiug and trust companies, and corporations created for dealing in bonds, notes, and other evidences of indebtedness.

2. Incorporators. - Three or more persons. No residential requirements (char, 176, sec. 2 ).

$$
3.56
$$


3. Contents of the Certificate of Incorporation. - The eertificate must set fortlı :

a. Name. - Agreement to eonstitute an ordinary business corporation under a designated name. The latter nust be one that must not be mistaken for that of a copartnership, and one not in use by an existing domestic corporation.

6. P'urposes. - Business for which it is eonstituted. State offieials construe this to anthorize the insertion of any number of purposes in the articles not covered by speeial aets.

c. Domiciliary Office. - Town or eity in which it is to be loeated.

d. Capital Stock. - Amount of eapital stock, whether common or preferred, and how much of it, and the par value of shares. Capital stock may be any amount. 'The par value of shares may be any amount. If preferred stock is desired, the articles must set forth the advantigres thereof over eommon stock (ehap. 176, see. 2).

$e$. If desired, provision may be male that the corporation shall have a lien on all shares for indebtedness of the shareholders due to the eorporation. The right may also be griven to the corporation in case of sale of stock by any stockholder to purehase siud stoek at the lowest price at which he is willing to sell before the same shall be sold by him to any other larty (see. 9).

Corprorate existence may be mlimited if desired.

4. Statutory Powers. - In aldition to a statutory enuneration of common law powiss, the following alditional powers are conferred: The right to authorize voting by proxy; the right to issue preferred stock: the creation of a lien nyon shares for assessments or indebtedness due the eorporation; the right to forfeit such stoek for non-payment of assessments (chip. 17t, sees. 1, $3,9)$. Corporations cannot acquire real and personal estate to an anomnt to exceed $\$ 100,000$, without express permission from the legislature (chap. 176$, sec. 13$)$.

5. Procuring the Charter. - The agreement must he signed by eneh of the ineorporators, with their residenees set forth and jointly acknowledged. The arreonent must then be filed in the ollice of the Secretary of sitate, together with the eertificate of the general treasurer that the organization tax hats been paid (chitp. 176, sees. :3 and 1 ). Thereupon he issues a certificate of ineorporation in the form preseriber ly statute (chap. 176, sec. 1). As soon as a trasurer is eleeted, his nane and address must be filed with the Seeretary of state (Laws of 19192 , chay. 975 ).

ij. Corporate Indebtedness. - ('orporate indebtedness in manuficturing corporations camot be ereated beyond the amomt of the actual calpital paid iul (chap. liso. sece li)).

7. Organization Tax. - On capinal stock liss than slm,(m), the tix

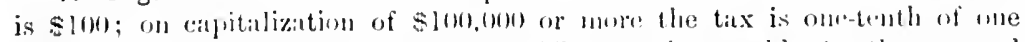
per cent on antherized capital slow. 'The tax is payallo to the seneral treasurele.

8. Filing and Recording Fees. - There are no rucorling fees in the sice-

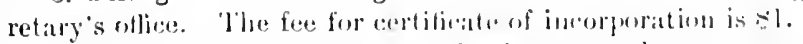

9. Commencing Business. - liusiness mity be commonem as soun as tho articles are filed ats procribed ly law. Within thirty days after orgaration

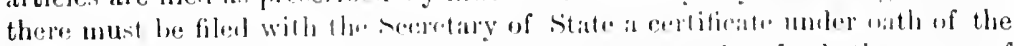

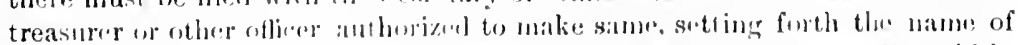
the corporation, date of organizalion, ammut of eapital soek actually piad in 
upou orymization, the town in which such corporation is located, and the nillue and pust-ollice adiless of its treasurer (chip. 177, sec. 24). Corpuration must tw unduiget within two years after incorporation.

10. Organization Meeting. - 'The organization meeting must be held winhin the state, in the absence of any statute providiug otherwise. (See chap. 17. sec. 1.)

11. Meetings of Stoclsholders and Directors. - Stocklioliler's' meetings must be held within the siate. 1)ireetors' neetings may be held witlout the slate if the hy-laws so provide (chip. 177, sec. 33 ).

l:. Directors' Qualifications and Liabilities. - a. Qualifications. 'The number of directors is not limited. Nor are there any residential repuirements.

b. Liabilities. - Inirectors of manufacturing corporations are liable to the creditors fur filihre to file the certificate executen by themselves, together with the president, treasurer, and clerk of the company, within ten days after the payment of the last instalment of the caprital stock fixed and linited by the charter, or hy rote of the company, stating the amount of the capital so fixed and paid in. The certificate must then be recorded within the said ten divs in the office of the town clerk of the town wherein the manufactory shill be established. They are also liable for illegal declaration of dividents. They are also liable to the extent of the excess of dehts created by them in excess of the annount of stock actually paid in. Directors are also liable for naking false certificates knowing them to be false. They are also liable for making loans to stuckholders to the extent of such loan and interest thereon (chil]. 1)(1. secs. 2, 3, 6, 15, 16, 20, 21).

13. Stockholders' Liabilities. - Stockhollers are liable to the extent of their unpaid stock subseriptions (laws of 1901, chap. 839).

Wing $v$. Slater, 19 R. I. $597 ; 35$ At1. 302.

14. Stock Certificates. - Each stocklolder is entitled to a stock certificate showing the number of shares held by lim, signed by such officers as the by-laws may preseribe.

1.). Preferred Stock. - The issue of preferred stock is expressly authorized by law, and provision therefor must be made in the artieles of incurporation.

16. Payment of Capital Stock. - Stock in all companies, save manufacturing, must be pairl for in money or money's worth. In the case of nannfactming compluies stock may be issmed for property appraised by the assesiors accorling to law at a fair valuation. The amount of the capital stock represented by such property shall not exceed the sum at which the sime may be appraised by the certificate of such iustrument, sigued and sworn to ly the assessors making the sime, and must be recorded before the liability of the stockhollers of such corporation for the debts contracted shall cease.

1\%. Books. - looks are required to be kejt within the State (chap. 177, sec, 19).

15. Office and Agent. - All corporatious must have a place of business within the State, and shall have a clerk, treasırer, or other agent, who shall renile theriu (chap. 177, sec. 21). The oflicer whose duty it is to record stock transfers lunst be a resident of the state.

19. Reports. - 'There ale no ammual reports required.

21. Anti-Trust Statutes. - Jhere is no anti-trust statute in force in Iihist: lsiand.

$$
\text { :3.: }
$$


21. Statutory Grounds for Forfeiture of Charter. - The charter may be forfeited for failure to organize within two years after filing articles of agreement (chap. 17i, sec. 23).

22. Amendments. - Articles may be amended for any purpose desired (chap 176, sec. 11 ).

23. Extension of Corporate Existence. - There is no statutory provision for the extension of corporate existence.

21. Diszolution. - Corporate powers cease if organization is not completed within two years, and court of common pleas may dissolve any company for non-user. May also dissolve voluntarily by resolution of stockhohlers representing a majority of capital stock (chip. 17T, see. 2:3; Laws of 191\%, Act 556).

25. Aunual License Fee. - There is no aunual license fee.

26. Foreign Corporations. - Foreign corporations must file with the Secretary of state declaration designating principill place of business in State and name of agent to receive service of process, and must also file in same office copy of the charter and by-laws with amembments. Must also file annual statement showing residence of corporation; anount of capital stock actually paid, names of officers and board of directors, with their residences (Stat., secs. 14615, 1467,1469). An agent must be appointed who shall be a resident of the State, upon whom process may be served (Laws of $1900^{\circ}$, chap. $980)$.

Pierce $v$. Compton, 13 R. I. 312 ; Stafford \& Co. v. American Mill Co., 13 R. I.310; Evaus $v$. Pease, 21 R. I. $187 ; 42 \lambda$ th. 506.

\section{SOUTH CAROLINA.}

(The references cited below are to the Cole of laws, 1902, unless otherwise stated.)

1. Statutes under which Bnsiness Corporations may incorporate. - The linsiness Corporation Act of South Carolina is found in the coule of Laws of 190:2, chals. 47,48 . P'arties may incorporate under this act for any purpose whatsuever.

2. Incorporators. - Two or nore persons. There are no resilential requirements (chap. \$s, sec. 18s0).

3. Contents of the Petition for Incorporation (chilp. 18, see. 1880).

a. Incorporahers. - Names and residences of the incorporiators.

1). Name. - Name of the proposed corporation. Simblarity of names not forbidilen.

c. Inmiciliury Office. - I'rineignal place of business.

d. Purposs. - May lo formed for any mumber of purposes not evered by special acts.

e. Coppital storki. - Amount of capital stork, and how and when payable.

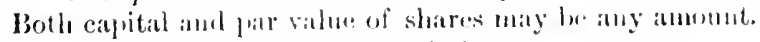

f. Number and l'ar lialue of sterres.

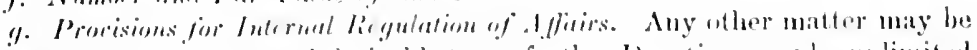
inserted which it is deened desirable to set forth. Doration mat he mulinited if desirel (nec. 18:11).

4. Statutory Powers. - In allition lo the stat atory anmulation of common law prowers, the following alditional powers are granted by statute: 'los cumblate rotes in the election of limetors; lo have a lien mon the shares of stockholders; to iosue preferted strek; to enforee paymont of assersments 
Jue upon espitil stick; to forfeit the stock for non-payment thereof; to rote hy prey in the wection of directors; to enforce a lien upon the stock of sixklichiters fur dehes due the eorporation (chap. 47, secs. 1843, 1846, 1818,

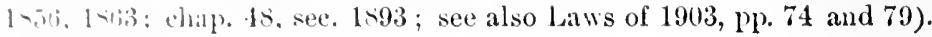

\section{Fir wate Fisher, 20 s. C. 190.}

5. Procuring the Charter. - The petition must be signed and acknowlcilgenl hy wath of the ineorporators, anul must then be signed by the Secretary of stitte. He then issues to the incorporators a commission constituting them a hancl of eorporators, and authorizing them to open books of subscription to the capital stnck of the proposed colporation, after such public notice, not excerding ten days, as may be required in such commission. When not less than fifty per cent of the capital stock shall have been subseribed by bona fide lurchasers, the board of corporators shall call the subscribers together. At this meeting the company shall organize by the election of a board of directors. not to exceed nine in number. They shall also adopt by-laws. The board of directors shall then clect from their number a president, a secretary, anl a treasurer. I pon the payment to the treasurer of the corporation of at kast twenty per cent of the aggregate amount of the capital subscribed, payable in money, anu also upon delivery to such ofticer of at least twenty per cent of the property subseribed to the aggregate amount of the capital stock, the board ot corporators, or a majority of them shall, over their signature, certify to the secretary of state that all the requirements of law have been complied with. This certificate is known as the "return of the corporators." Upon the filing of the return amil the receipt of the charter fee, and upon payment of all filing fies, the secretary of State issues to the board of corporators a certificate known as a charter. Thereupon a copy of the charter must be recorded in the oftice of the reyster of conveyances or clerk of each county wherein the corporation shall have a business oflice. In cases where by the terms of the declaration the capital stock of the corporation is to be paid in instalments, the treasurer may issue stock when fifty per cent of the first instalment of the capital stock has been paid in, and the provisions of the act have in other respects been complied with. Collateral inquiry into validity of corporate existence is forbiden (chap. 45, secs. 1880, 1855).

ij. Corporate Indebtedness. - There is no statutory limitation upon the amount of corporate indebtedness.

7. Organization Tax. - On capital stock not exceeding $\$ 100,000$, one mill on each dollal" from $\$ 100,000$, and not exceeding $\$ 1,000,000$, one-half mill on each dollar in addition to the $\$ 100$ on the first $\$ 100,000$; exceedins $\$ 1,(1000,(10)$, one-t]uarter mill on eich dollar in addition to $\$ 550$ on the first $81.000,000$ (ehay. 1o, secs. 1888, 1859 ; Laws of 1901, chap. 245).

8. Filing and Recording Fees. - Fee to the Secretary of State for recorrling petition for incorporation, \$.3. For recording return of Board of Corporators. \$3. For recording articles in local county office, \$2.

9. Commencing Business. - (See also ante, "Procuring Charter.") The copporation must organize and commence business within two years from the late of its incorporation or the date of the commission appointing the board of cripoliator. (chap. 47, sec. 1850$)$ ).

16. Organization Meeting. - The organization meeting must be held within the sate, in the absence of any statute providing otherwise (see chap. $4 \bar{i}$, sec. $\operatorname{lin} 16 j)$.

11. Meetings of Stockholders and Directors. - At least one meeting of :ivil 
the stockholders shall be held annually within the State. IDirectors' meetings may be held at such place a: the by-laws may provide (chap. 47, sec. 1846).

12. Directors' Qualifications and Liabilities. a. Qualifications. There may be any number of directors not exceeding nine. There are no residential requirements (chap. 4s, sec. 185:3).

b. Liabilities.-Directors are liable for making false representations as to resources and for misrepresentations in certificites (chap. 48, see. 1843).

13. Stockholders' Liabilities. - Stockholders are liable to creditors only to the extent of their unpaid stock subseriptions (Cons., 1s95, Alt. IX. sec. 18$)$.

M. C. Mills $v$. Springs, 56 S. C. $534 ; 35$ S. E. 222 ; Lauraglen Mills $v$. liuff, 57 S. C. $53 ; 35$ S. E. 387 ; Willians $v$. Benet, 34 S. C. $112 ; 13$ S. E. 97.

14. Stock Certificates. - Each stockholder is entitler to a certificate under the seal of the corporation, signed by the treasurer (chap. 17, sec. 1517).

15. Preferred Stock. - There is express provision for the issuance of preferred stock (chap. 17 , sec. 15.56).

16. Payment of Capital Stock. - Stock can be issued only for labor done, or money or property actually receivel (chap. 47, sec. 15.5.); ehap. 4s, sec. 1582). Luless the charter provides that stock may be liaid in instalments, it cannot be issued until fully paid (chaj. 4s, sec. 1891). No sub. scriptions in labor or property can be received unless the same and ralue thereof is approved by the Board of Corporators (chap. 18, see. 1582).

17. Books. - liooks are required to be kept open to inspection of stockholders, aml it may be construed from the statute that they must be kept in the State (chit]. 18, sec. 1s!7).

15. Office and Agent. - There are no express requirements as to having a principal oflice or plaee for the transaction of business within the state, but by construction it is necessary to maintain a domiciliary ottice.' (Sce Cromwell $v$. Lus. Co.. 2 Rich. Law, 512.)

19. Reports. - Must report to the Comptroller-(ieneral annually during the month of February (Laws of 1904 , chap. 269 ).

20. Anti-Trust Statute. - There is an :unti-trust statute in foree in South Carolina. (See C. C., 1!02, secs. 2515, 2si7.)

21. Statutory Grounds for Forfeiture of Charter. - Charter may be forfeited for non-user for five years, or for non-pilyment of lises, or for noupayment of ammual franchise tix, or for violation of anti-trust statute (chap.

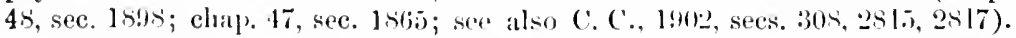
It may also be forfeited for failure to organize and commence business within two years from incopporation (chat) 17, sec. 1\%50).

20. Amendments. - The chitrter may le amented only for the purpose of increasing or tecreasing the capital stuck, or for the purpuse of rhinging

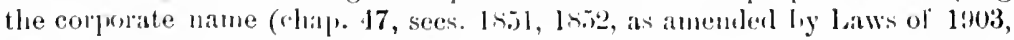

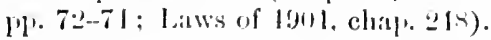

23. Extension of Corporate Existence. - Provision is male for extert-

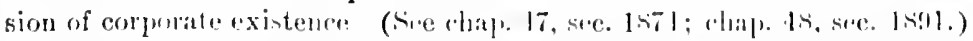

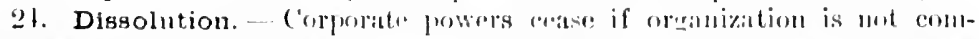

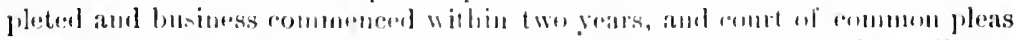

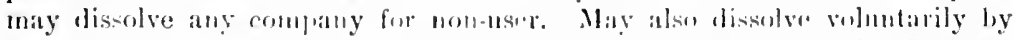

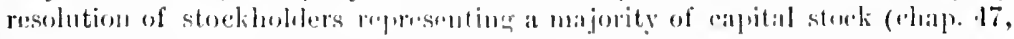

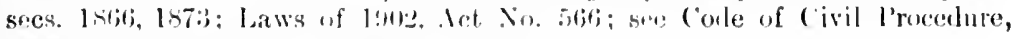

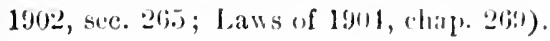


2.) Ammual License Fee. - Vuder the franehise tax of 1903, whieh did not gu inlo eftect until April 1, 1!nt, all business corporations exeept those of a inasi-puhlie nature, must pay to the State Treasurer on or before April 1st of each year an anmul liwense fee of one-half mill upon every dollar paid in uncm the cilpital stock, and not less than tive tollats in any ease (haws of lint1. chap. 2(in).

21: Foreign Corporations. - Foreigu corporations must file with the secetary of state a declaration designating principal place of business in the siate and the name of agent to recejve service of process, and must also file in same nflice a eopy of the charter am by-laws with amendments. Must also tile anmul statement showing residence of corporation, anount of eapital stock actmally pail, names of offiecrs and hoard of direetors with their residence, etc. They are required to pray a fee of one-half mill on each clollar of property ownel by them within the Stite (C. C., 1902, sees. 1779, 1795, 2360; (liaws of 1901, chaps. 247, 269).

Central R. R., ete. Co. $\imath$. Company, 32 S. C. 319 ; 11 S. E. 192 ; Cone, ete. Co. $v$. l'oule, 4 l S. C. 70 ; 19 S. E. 203 ; llollingsworth v. Sou. R. R. Co., 86 Fed. 353.

\section{SOUTH DAKOTA.}

(The references cited below are to the Revised Civil Code of 1903 and to the Compiled Laws of 1887 , unless otherwise stated.)

1. Statutes under which Business Corporations may incorporate. The Business Corporation Act of South Dakota is to be found in Revised Civil Code of 190:3, secs. 396-179 (Compiled Laws of 1887, sees. 2889-2971). Those relating to mining, manufucturing, and other industrial corporations are secs. 780-797, Revised Civil Colle, 1903 (Compiled Laws, 1887, secs. :310s to 3125$)$. The provisions relating to amendment of charters are found in chap. 106, Session Laws of 1903. As to the extension of eorporate existence, see chalp. 105, Session Laws of 1903. Under this act corforations may be formed for any lawful purpose. Special acts are, however, provided for incorporation of railway, street railway, wagon road, irrigation, insurance, loan, trust, mortgage, and for banks of discount.

2. Incorporators. - Three or more, one-thire of whom must be residents of the State (R. C. C., sec. 407 ; C L., sec. 2900 ).

Singer Mfg. Co. v. Peck, 9 S. 1). $29 ; 67$ N. W. 947.

8. Contents of the Certificate of Incorporation. - The certifieate must set forth :

a. Nome. - The Secretary of State will not permit the use of another name already in ust fy a domestic corporation.

b. I'npuses. - The purpose for which it is formed. The Secretary of State allows the insertion of any number of purposes not covered by special acts.

c. Inmicile. -- I'lace where the frineipal business of the corporation is to be transacted.

1. Huration. - Not to exceed twenty years.

ค. INirctors. - Number and names and residences of those who are to serve until the election of their successors, and qualifieations must also be set forth.

f. Crapitul Stock. - Amount and number of shares into which same is diviled. 'There is no linit as to the amount of capital stock. The par value of shares may be any anount (R. C. C., sec. 408; C. L., sec. 2902). 


\section{SYNOPSIS-DIGEST OF INCORPORATION ACTS.}

4. Statutory Powers - In addition to the statutory enumeration of common law powers the act provides for roting by proxy at elections of directors, for eumulative voting, for forfeiture of shares, for non-payment of subscriptions, for liaring a business office without the state but within the Lnited States, and for holding therein any meeting of the stockholders or directors; for removal of directors; for extension of corporate existence; for purchase of the corporation's own stock: for issuing stock in exchange for property or services (R. C. C., see. 427 ; C. L., sec. 2199 : R. C. C., see. 429 ); C. L. 2921 ; Con. Art. XVII. sec. 5; R. C. C., secs. 45:3-16! inclusive; R. C. C., sec. 786 ; C. L., sec. 3114 ; R. C. C., sec. 43s; C. L., sec. 29:31 R. C. C., sec. 439 ; C. L., sec. 2931 ; Laws of $1913: 3$, chap. 105 ; R. C. C., sec. 1.2); C. L., 2917; R. C. C., sec. 42.2 ; C. L., sec. 2914 ; R. C. C., sec. 464 ; C. L., sec. 2956 ; Con., Art. XVII. sec. 8$)$.

Summers $t$. Company, 86 N. W. 749.

5. Procuring the Charter. - The charter must be signed and aclinowledged by the incorporators before the same can be filed and certificate of incorporation issued. Two of the incorporators must take oath that the corporation is not formed for the purpose of enabling it to avoid the purposes of the South Inakota Anti-trust Act, and upon the filing of the articles the Secretary of State issues a certificate of incorporation (li. C. C., secs. 4lo, 411 ; C. L., sec.. 2901, 2941.; lievised Penal ('ode, see. 781).

6. Corporate Indebtedness. - Debts cannot be contracted beyond the amount of stoek subscribed (R. (C. C., see. 436 ; C. L., see. 29:-i).

7. Organization Tax. - Where authorized capital stock is 825,000 or less, the organization tax is $\$ 10$; where it does not exceed $\$ 100,000, \$ 15$; where it does not exceed $8,000,000,820$; where it does not exceed $\$ 1,000,000,825$; over \$1.000.000. \$10 (Laws of 1903, chap. 141, see. 1).

8. Filing and Recording Fees. - Where copy of charter is prepared, the charge for certified copy of the articles of incorporation is sil (hitws of $1: 103$, chap. 141, sec. 1). For any "xeess of one thousand words in articles, a fee of 10 cents jer folio is chitrged.

9. Commencing Business. - Unless the corporation organizes and commences the transaction of business or the construction of its works within one year from the date of its incorporation. its corporate powers cease. Every corporation must within one month after filing articles of incorporation adopt a code of by-laws for its government, lut no penalty or forfeitme is leelared in case of non-eompliance with this provision, and it is regardecl as directory only (li. C. C., see. 111; ('. L., sec. 2905). No colliteril incuiry into cor-

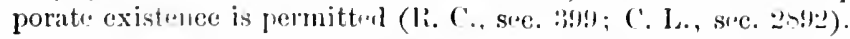

10. Organization Meeting. - The orgatization meetiur may lue leeld at the prineipal oflies of the conporation withent the state if furvision is male therefor in the articles, otlecewise it must be freld within the state (R. ('. ('.,

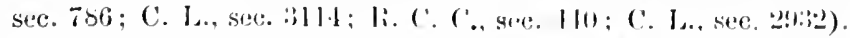

11. Meetings of Stockholders and Directors. - Inempurators', stock-

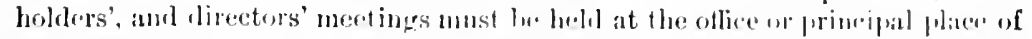
business of the company. All mentinge of storliholiers and directors of mining,

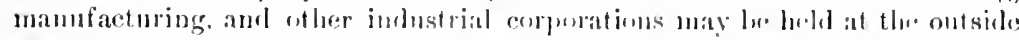

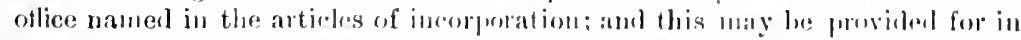

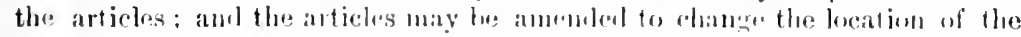

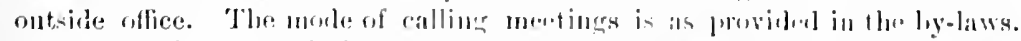
The domieiliary oflice is kept at the phice in the state named in the articles 
as the prineipal plate of business. The original books and records may lue kepe at the ontsible business oflice if there be one (R. C. C., sec. 786; ('. 1.., ste. :3111; see also li. C. C'., sec. 410; C. 1., sec. 29:32).

1.2. Directors' Qualifications and Liabilities. a. Qualifications. - The statute's of suuth l)akota provide that one-third of the oflicers of all business corpurations shall be residents of the State. The bar of the State generally renath this porision an being applieable only to the executive heads of the colpuration, sueh as president, riee-president, secretary, and treasurer. The scoretiny of state, however, in the absence of any judicial decision on the subject if a controlling nature, and in order to protect himself, requires that onc-third of the first board of directors shall be residents of the State. They are eleeten ammually ly a majority vote of stockholders. 'The board must he compused of at least three and not more than eleven members. birectors nunt be stockhollers to an amount to be fixed by the by-laws (R. ('. C., sec. 1:31: C. 1... sec. 2926).

b. Lubilities. - 1)ireetors are liable for the illegal declaration of dividends, or for the mulawful withdrawal of capital, or for any violation of law applying to corporations whereby the latter beeame insolvent. Directors assenting to such violation are jointly and severally liable for all debts contracted after such violation (li. C. C., sec. 436; C. L., see. 2925 ; R. C. C., sec. 757 ; C. L., sece : :115).

13. Stockbolders' Liabilities. - Stockholders are liable to the amount of their mpail stock subscriptions (R. C. C., see. 43l; C. L., sec. 2933). They are also liable for labor claims (R. C. C., see. 783 ; C. L., sec. 3111).

S. B. T. M. Co r. (ompany, 4 S. D. $173 ; 56$ N. W. 98 ; Busby $\%$ Reilly et al., 6 S. 1). $401 ; 61$ ․ W. 164 ; singer $\mathrm{Hlfg}$. Co. $v$. Peck, 9 S. D. $29 ; 6 z$ N. W. 947.

14. Stock Certificates. - Each stockholder is entitled to a certificate signed by the president and secretary (R. C. C., sec. 423; C. L., sec. 2915).

15. Preferred Stock. - There is no express provision of law authorizing the issuance of prefered stock. 'The Seeretary of State, however, permits the insertion of provisions in the articles authorizing the issuance of preferred stock.

16. Payment of Capital Stock. - Stock may be issued in exchange for money, lahor done, or money or property actually received (Cons., Art. XVII. see. s). The act provides that the directors named in the articles of incorfroration must proceed to open books of subserijetion to the eapital stock unsubseriber and to seeure subscriptions to the full anount of the fixed cajital (li. C. C., sec. 121; C. L., see. 2913).

17. Books. - Every corporation must keep a journal of meetings of directors an! stockholders. They must also keep a stock and transfer book, which with the journal is open to inspection of stockholders, direetors, and ereditors of thr eorporation, containing a record of all stock, the names of stockholines, alphalietically arranged, instalments paid or unpaid, transfers, etc. Ako a look of by-laws, to be open to inspection during office hours. Th. law lues not provile, however, that any of these books shall be kept within the Stat and provisions in the articles of incorporation for keeping thesn at the ontside office are regularly allowed by the Secretary of state (R. C. C.. sec. 123); C. L., sec. 2915 ; R. C. C., sec. 428 ; C. L., sec. 2920 ; li. ('. C. sec. 115: C. L., sec. 2937 ; R. C. C., sec. 782 ; C. K., sec. 3110 ).

13. Office. - The law provides that every corporation having a business office ont of the State must have its main oflice for the transaction of business $\because ; i 1$ 
within the State, to be set forth in the articles (R. C. C., sec. 786 ; C. L., sec. $3114)$.

19. Reports. - The statute prorides that business corporations doing business within the State shall amnually within twenty dilys from the first day of January make a report which must be published in some newspaper at or nearest to the place where the business of the corporation is carried on, which report must state the capital stock and the amount thereof actually paid in, the amount and nature of indebtedness, and the amomit due the corporation, the number and amount of dividends, and when paid, and the net amount of .profits. Such report must be signed by the president and a majority of directors, and be rerified by oath of the president or secretary, and filed in the oflice of register of deeds of county where the business of the corporation is carried on. The only penalty providerl for failure to comply with the statute is that a person who wilfully neglects or refuses to mike, sign, or publish such report shall be guilty of misdemeanor (R. C. C., sec. 781; C. L., sec. 3112).

20. Anti-Trust Statute. - There is a somewhat drastic anti-trust statute in force in South Daliota (Revised l'enal Code, 1903, sces. 770 to 781 inelusive).

21. Statutory Grounds for Forfeiture of Charter. - Lnless the corporation is organized and commeneed business within two years after incorporation the corporate powers cease. Charters may also be forfeited by the State on any of the following grounds : For violating any of the laws creating, altering, or renewing corporations: by violating any express provisions of the law whereby the corporation shall have forleited its charter by abuse of its power; by failure to exereise its powers; whenever it shall have done or omitted to do any act which anounts to a surrender of its colporate lights; for exercising franchises or privileges not conferred upon it by law (R. C. C., sec. 447 ; C. L.., sec. 2939 ; R. C. C., sec. 571 ; C. I., sec. 53.16 ).

22. Amendments. - Articles may be annended so as to morlify or enlarge corporate husiness or purposes, change number of directors, chingre name or location of its business within the State or without the State, increase or decrease the capital stock, or in any other respeet ly rote of two-thirds of all outstanding stoek at any regular or special meeting called for that purpose after thirty days' notice (sixty days for increase of stock) given to each stockholder stating nature of proposed amendment. After notice of proposed anendment is served upon stockholiers, time may be waived hy all of them, and amendment can be adopted immediately. Capital stock camot be dininished to an amount less than indebterlness of corporation or estinated cost of works which it maty be the purpose of the corporatim to construct. After amendment is atopted, the presilent and seerotary of the corporation shall prepare in duplicate a certificate setting forth anemlment, stating number of rotes cast therefor, and total number of shares of stock subseribed and outstanding, and that lenal notice was given. One of then certifieates must be filed with the feeretary of State, and the other with secretary of the corporation. The signature of presilent and secetaly to such ecrtificate must be acknowledged liefore some oflicer anthorized to take ackmoledgments, who knows the parties signing the same to bo the fresiflent and seretary of the corporation, and when snch certificate is filed with the seeretary of state he shall issue a certificate of amenrment, setting forth in what particular the original artieles of incorpuration have been amended (Laws of 1903, chap. 106, sees. 1-7 inclusive). 
2:3. Extension of Corporate Existence. - Corporate existence may be extemled fin : iturther preriod of twenty years if desired (Laws of 1903, chap. $10, i)$.

21. Dissolution. - Voluntary dissolution is effected by application to the circuit. court of the county where the corporation's principal place of business is situated, upon verified petition of a majority of the board of directors, the proceedings being simple and brief. Involuntary dissolution is ctivected unler enie of civil procedure by action in the name of the State, on 1. are of the eirenit court or julge (R. C. C., sec. 446 ; C. L., sec. 2938).

25. Annual License Fee. - There is no annual license fee.

26. Foreign Corporations. - Before any foreign corporation can transact business within the State, or acquire, hold, and dispose of property within the state, or sue in the courts therein, it must file in the office of the Secretary of State a duly authenticated copy of its charter or articles of incorporation, and shall also appoint an agent within the State upon whom process may be had. $A$ inly authenticated copy of the appointment of such agent or officer must be filed aud recorded in the office of the Secretary of State, and register of deeds of the county where said agent resides (R. C. C., sec. 853; C. L, sec. 3190).

Wright $v$. Lee et $a l .,+$ S. I). $237 ; 55$ N. W. 931 ; Acme Mer. Agency $\%$. Rochford, 10 S. 1). 203 ; 72 N. W. 466 ; Foster $v$. Company, 5 S. D. 57 ; 58 N. W. 9.

\section{TENNESSEE.}

(The references cited below are to the Code of 1884 unless otherwise stated.)

1. Statutes under which Business Corporations may incorporate. The linsiness Corporation Act of Tennessee is based upon the Act of March 19, 1875 (Session Laws of 1575 , chap. 142). The law is peculiar in that it specifically prescribes for what purposes companies may be incorporated, and sets forth the form of charter for each. 'The above "Charter Act" has been amended from time to time until now it is possible to incorporate in Tennessee under said act for ordinary business purposes (Laws of 1903, chap. 174).

2. Incorporators. - Not less than five, except for brewery corporations where only three incorporators are required. There are no residential requirements (sec. 1692 ; Laws of 1903, chap. 474).

3. Contents of the Certificate of Incorporation. - The forms for drawing charters are set out at length in the statutes, and vary according to the purposes sought to be obtained by incorporation. Speaking generally, all the forms set forth: first, name of the corporation, which the Secretary of State requires shall be different from that of any existing corporation. Second, the purposes must be set forth, and the incorporators are limited strictly to purposes included in one class. Third, the capital stock is unlimited except in the case of brewery companies, which must be capitalized for not less than 5,000 and not more than $\$ 500,000$. Fourth, an enumeration of the general powers of the corporation, which are in substance merely an enumeration of common law powers. The statutory form also contains a large number of provisions for the regulation of the internal affairs of the corporation. It also provides that the first board of directors shall consist of the incorporators named in the charter of incorporation (secs. 1692, 1852, Act of April 30, 1897; Laws of 1899, chaps. 17, 224, 300, 304; Laws of 1003, chap. 474). Duration may be unlimited if desired.

360 
4. Statutory Powers. - The statute enumerates the common law powers of corporations, and in addition thereto grants the following powers: For the purpose of repairs, rebuilding, or to meet contingencies, or for the purpose of a sinking fund, corporations may establish a fund of which they may loan and in relation to which they may take proper sectrities. Mining companies are authorized to subscribe for stock in railway corporation whose line of road is contiguons to their works. Minufacturing eorporations are given power to locate on their own lands, elevators, hoisting, warehonses, transfer truclis, etc. Mining corporations are given power to purchase, nse, or dispose of patent rights. All corporations are given power to rote by proxy. To consolidate with other corporations engaged in the same general husiness. Also to sell in its entirety all the assets of the corporation to any corloration engaged in the same general line of husiness (see references eited at end of sec. 3 ; also secs. 1704, 1709, 1710, 1711 a, 155:, 1560, 1861, 1561:- 1564, 1866 , 1867, 1868, 1872, Act of March 2S, 1887 ; Laws of 1903, chap. 4\$6).

5. Procuring the Charter. - Ineorporators must subscribe and acknowledge the execution of the eharter, which is in fact a petition for incorporation. This instrument when so acknowledged must be registered in the county where the principal office of the company is situated, and also in the office of the Secretary of state. 'The latter officer issues a certificate of registration which in turn must be registered in the register's office of the county where the principal business office of the company is situated. Thereupon the formation of the corporation is completed (secs. 169.2.1691). Collateral inquiry into the legality of corporate existence is forbidden (secs. 169:3, 1712; Laws of 190:3, chap. 474).

Shields $v$. Clifton Co., 94 Tenn. 123 ; $28 \mathrm{~S}$. W. 668.

6. Corporate Indebtedness. - Corporations are limited in the creation of debts to the amount of the authorized eapital stock (sec. 1858; Laws of 1903 , chap. 471).

7 . Organization Tax. - For business corporations a tax of one-tenth of one per cent on the authorized capital stock is exacted. There is also a registration tax of 810 (Act of June 17,1895 ; Laws of 1597 , chap. :3.'; Laws of 1899 , chap. $43: 2)$.

8. Filing and Recording Fees. - Ten dollars to Secretary of State for filing articles of incorporation; to regrister of deeds. s.3: for certified eojy of articles of incorporation, fee arejages 85 ; to fees for certificate of ineor roration, \$3.

9. Commencing Business. - Business may be commentill as som as the charter is registered as required by law and the organization completed. If the eorporation estahlishes agrences in any other comnty, the eharter must be recorded there (see. 1691).

10. Organization Meeting. - The oroanization merting must he held within the state, in the alsenre of any statute providing othrowise. The incorporator's atet ats the first board of lirecturs.

11. Meetings of Stockholders and Directors. - Ammul strekholders'

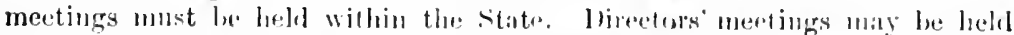
without the slate if the ly-latws so provill. (sere. 17ori, 1stis).

12. Directors' Qualifications and Liabilities. "1. (qualificutims — There must be, "xont in the ans of brewery enmpanins, where there may be thee, at least five directors. There are nin resilential requirements (sees. 1702, 1706 ; Laws of 1903 , chal 171$)$.

b. Liabilities - Direetors are liable for illewal ileclaration of dividends, or 
for anthorizint the creation of any indeluterluess in excess of the capital stock fail in. lirectors are liahle for hans to stockholders in mining corporations, fuitrying. horing, or mamufacturing companies. They are also liable for infontional fratud in faling to comply substantially with the articles of incorpuration, or in deceiving the public or individnals in relation to their lia!nitities (stes. 1716, 1717,1556, 1857, 15.88, 1859, Laws of 1897, chap. 49: labws of 1941), ehap. 174).

Allison r. Cual Co., 8 ; Tenn. 60 ; 9 S. W. 226.

13. Stockholders' Liabilities. - Stockholders are liable for the amount of their unpaid stock subseriptions. They are also jointly and severally liable for moneys due or owing to the laborers, servants, clerks, or operators of the company in case the corporation becomes insolvent (secs. 1708, 1858; laws of 19+13. (hap. 4it).

11. Stock Certificates. - The par value of stock certificates may be $\$ 100$ or less (s.c. 2(0.)2). Wach shareholder is entitled to a certificate showing the number of shares held by him signed by such oflicers as the by-laws may prescribe.

15. Preferred Stock. - The statute does not expressly authorize the issuance of preferred stock.

1ii. Payment of Capital Stock. - In the case of mining, quarrying, horing, and manufacturing companies nothing but cash or land at a fair cash valuation can be accepted in payment of capital stock. Manufacturing companies are, however, authorized to receive an assignment of a patent in payment of stock subscribed to the amount of the value of such patent. The act specifically provides that the amount of any unpaid stock due from the subscriber to the corporation shall be a fund for the paynent of any debts due from the corporation; the transier of stock by any subscriber does not relieve him from payment unless his transferee has paid up all or any of the balance due on said original subscription (secs. 1708, 1856, 1872; Laws of 1903 , chap. 474).

Searight $v$. Iayne, 6 Lea, 283; Kelley $v$. Fleteher, 94 Tenn. 1; 28 S. W. 1099.

17. Books. - The act requires the keejing of books showing the list of stochholders, with their respective interests, the amount paid on shares subscriled, and all stock transfers by and to whom made (sec. 1707; Laws of 1903, chap. 474).

18. Office and Agent. - There are no express statutory provisions reruiring the maintenance of an oflice and agent within the State. By implication, horrever, the company must maintain a domiciliary office within the state. (See sec. 1993.)

19. Reports. - By acts adopted previous to 1903 semi-annual statements are required of hanks and trust companies and annual statements of building and loan companies, mining, quarrying, boring, and manufacturing companirs. Anmual statements are required of all corporations securing their charters under the Act of 1903 (Law's of 1903, chap. 474). The report must be published in a newspaper printed in the county where the principal office or husiuess is located, showing the amount of capital stock, existing liabilities, and list of names of stocklolders.

20. Anti-Trust Statute. - There is an anti-trust statute in force in Tennessee. (See Act of Narch 10, 1890; Act of March 30, 1891; Act of April 30, 1897.)

21. Statutory Grounds for Forfeiture of Charter. - Charters may be forfeited where the corporation has by neglect, non-user, abuse, or surrender, :36) 
forfeited its corporate rights. Any act of the board of lirectors as a board constituting an express violation of the statute is declared to be a forfeiture of the charter (sees. 1718, 416.2; see also sec. 2484; Code of 1896, see. 66:25).

22. Amendments. - Charters mily be amended for the purpose of changing the name, increasing or decreasing the capital stock, or for the purpose of obtaining any powers granted uucler the General Act (secs. 1695, 186.5, 1866 ; Aet of April 7, 1893).

23. Extension of Corporate Existence. - Perpetual existence is open to incorporators if they desire it. There is no provision for the extension of corporate existence.

24. Dissolution. - The corporation may be dissolved on application to the courts. Directors are by statute made trustees for that purpose unless other persons are appointed by the court (secs. 1719-1723; Act of March 28 , 1887 ).

25. Annual License Tax. - See secs. 6269, 6.521 z; also Laws of 1901, chap. 174.

26. Foreign Corporations. - Foreign corporations must file with tle Sec retary of State a copy of charter and have alstrict thereof recorded in the register's office of each county in which they propose to do business or own land. Tax on the eapital stock is as follows: $\$ 100.060$ and less. $850 ;$ u]' to $\$ 250,000, \$ 100 ;$ to $\$ 500,000, \$ 1.00 ;$ to $\$ 1,000,000, \$ 200 ;$ over $\$ 1,000,000$, 8250 lf a foreign corporation locates its prineipal oflice and does all its business in and from Temessee and has all of its main property holdings in Tennessee, it must pay a privilege tax of one-tenth of one per eent on anthosized capital stock. For filing charter of foreinn corporation, Secretary of State is entitled to a fee of $\$ 20$; for each abstract thereof, 820 (secs. 2.516, 2553 ; Laws of 1895 , chilp. 21 ; sec. 119 , Laws of 1899 , chay. 2 ; Laws of 1559 , chaps. 11-31 ; Laws of 190:3, chap. 29:9).

State $v$. Sehlitz Brewing Co., 104 Tenn. $715 ; 59$ S. W. 1033.

\section{TEXAS.}

(The references cited below are to the lievised Statutes, 1895, unless otherwise stated.)

1. Statutes under which Business Corporations may incorporate. - The Business Corporation Act of 'lexas is to he foumd in the linvised Statutes of 1595 , secs. (j.10-ti70 inclusive, sees. (5-1)-456t, sees. 711-7.19 e., and the amenduents of $18.17,1899,1901,1901$, and 19413. Sipeeial acts nre provided for railroat and insurance conperations. linter the fieneral det corporations are divilled into some sixty-lour different elasses, cuvering almost all lines of husiness (sec. (j12).

2. Incorporators. - Three or more persons. Two must be citizens of Texas (sees ijll, ij11).

Hamiltou $"$ Company, 15 Tex. App. 334; $39 \mathrm{~S}$. W. 611.

3. Contents of the Articles of Incorporation. - The articles surst set forth:

a. Neme. - The Serretary of Slate will not jurmil the use of a name alrealy in use by a lome-tir corporation.

b. Purpose. - Corporitions ar. liniterl in their purposes to those namod in some one of the sixty-fint rlisses reforrecl to, except in cases especially provided for otherwise. (sees sec. fis) it.) 
c. Donicilim!l Ofice. - l'lace or places where the business is to be transnetil.

1. Inurution. - Term for which it is to exist not to exceed fifty years. Where we propind is limited the duration is twenty years.

c. Hirecturs. - Number and names and residences of the board for the first year.

f. ("upinal stock. - Anount thereof and number of shares into which it is diviled (see, (it:3). both eapital stock and par value thereof may be any :mreunt (nec. 1;:33).

4. Statutory Powers. - In aldition to a statntory enumeration of common law powers of eorporations, the following additional powers are granted: Tho rote hy proxy, to forfeit stock for non-prament of assessments, to issue preferred itock, and to inthorize directors to adopt by-laws (secs. 651, 653, 6tis, 6699 ).

i. Procuring the Charter. - The charter must be subscribed by all the incorporator's and acknowledged by them. 'The charter is then filed in the oflice of the seeretary of State, at which time the organization tax must be paid. Corporate existence commences from the time the charter is filed in his oflice. The articles must be accompanied hy an affidavit of one of its "xecutive officers, to the effect that fifty per cont of its authorized capital stock has been subscribed for, and ten per cent paid in, or that at least 8100,000 of eipital stock has been paid in in cash (sees. 6t4-646).

(i. Corporate Indebtedness.-Corporate indebtedness cannot be created in excess of the amount of the anthorized capital stock (sec. 653).

7. Organization Tax. - For the charter, $\$ 25$ must be paid to the Secretary of itate, and $\$ 5$ for each ten thousand dollars or fraction thereof of cajitil abure 810,000$)$ (sec. 2439).

8. Filing and Recording Fees. - There are no fees due the Secretary of State other than the organization tax. This includes a certified copy of the charter.

9. Commencing Business. - The smallest amount of paid up capital stock with which the corporation may begin business is ten per cent of its authorized calpital, of which fifty per cent thereof must have heen subscribed. In lien of the foregoing, the eorporation may furnish satisfactory evidence to the Secretary of state that at least $\$ 100,000$ of its authorized capital stock has been plail in in eash. Business must be conmenced within three years after filing the charter, and in lefanlt thereof the corporation may be dissolved upen proper action brought by the State for that purpose (Laws of 1901, chap. 15).

10. Organization Meeting. - The organization meeting must be held within the state. The statute makes no provision for the organization of the corporation.

11. Meetings of Stockholders and Directors. - Meetings of stockloolders nuty be held within the State at such time and place as the by-laws of the colloration may require. Directors' meetings may be held without the State if the by-laws so provide.

12. Directors' Qualifications and Liabilities. a. Qualifications. - There numst be at least three and not more than thirteen directors. There are no residential rerpuirements (see. 651, sub. 8).

b. Linblities. - Jirectors are liable for knowingly declaring illegal dividend:. The extrnt of their liability is, however, limited to the amount of such divilends (rec. 6ro).

$$
: ; 0
$$


13. Stockholders' Liabilities. - Stockholders are liable to the extent of their unpaid stock subseriptions (sec. 6sii).

M. B. C. Conpany r. Company, 89 Texas, 511 ; 39 S. W. 1047 ; Cule $v$ Adans, 92 Texas, $171 ; 46$ S. W. 790 .

14. Stock Certificates. - Stockholders are entitled to certificates showing the number of shares owned by them, signed by such olficers as the by-laws mity prescribe.

15. Preferred Stock. - The right to issue preferred stock is only given in express terms to corporations organized for the purpose of storing, transporting, buying and selling oil, gas, salt, brine and other mineral solutions.

16. Payment of Capital Stock. - Stoek may be issued in exchange for money, labor done or property actually received (sec. $65: 3$ ).

17. Books. - I stock register, transfer book, and record of business transactions must be kept (statute does not provile where to be kept), and the books and records must be open to inspection of stuckholders at all reasonable times. Execution creditor's mat demand names of, and anount of stock held by stockholders (secs. $66: 2,67 \cdot 2$ ).

15. Office and Agent. - In oflice must be kept in the State, and an agent therein upon whom process may be served (secs. 673, 12:2.2, 12:23).

19. Reports. - The directors shail, when reduired by one-third of the stockloolders, make report showing anount of company's business, etc. No anutal report required (sec. 663 ).

20. Anti-Trust Statute. - There was formerly a drastic anti-trust statute in force in 'Texas, but it has been declared unconstitutional to the extent that it will not support actions by the state to recover penalties for a violation of the law, nor afford a defense to an action on a right originating in it violation. (See State $v$. Shipers' and Compress Wirehouse Company, 95 'Texas, 60:3; 69 S. W. 53 ; see new act, Laws of 1903, chap. 94.)

Crystal Ice \& Mfre. Co. $v$. State, 23 Texas Civ. $\Lambda_{p}$ p. $293 ; 56 \mathrm{~S}$. W. 562.

21. Statutory Grounds for Forfeiture of Charter. - Charters may be forfeited for violation of the anti-trust act, or for acts of misuser or non-user, or for failing to organize and commence business within three years from date of incorporation. (See Laws of 190:3, chap. 92.)

22. Amendments. - Charters mity be amonded in any respect desired, except to so change the original pur pose as to prevent the execution thereof, or to decrease the ealital stock (recs. 1517, (i.19), 6.51, 65:2).

2:. Extension of Corporate Existence. - There is no provision for the extension of corlonate existence.

21. Dissolution - The corporition may he dissolved hy expiration of the chartes, or by judgnent of dissolntion by a comrt of competont juristiction. Also throngh faihue to commenos business within three years from date of charter (-ees. (;is), (;-1) ).

2.). Annual License Tax - lin dellars; if the appitalization is over

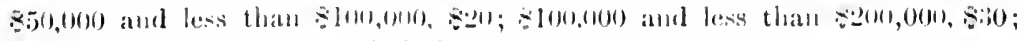

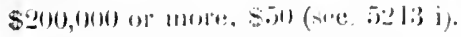

26. Foreign Corporations. - Foreign corpuntions must filw with the

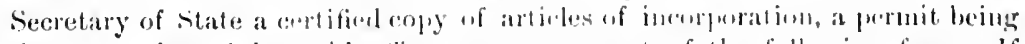

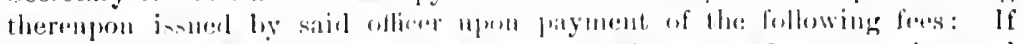

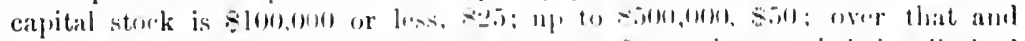

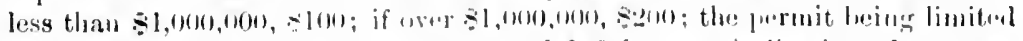

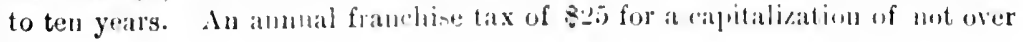


S.5.1001, of slo0 for over that and not over $\$ 100,000$, and in addition thereto 81 on each ten thousatul dollars of stock above $\$ 100,000$, and not (1)er $81,001.000$. and a further adhitional tax of sl on each hundred thousand

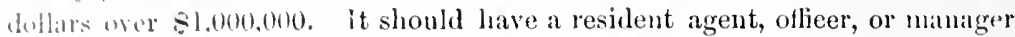
in its 'Texals ollice, upon whon process against the eorporation may be served (iut. Thi. li. s.. amended chap. 119, Laws of 1597; Arts. 746, 7.5, 1222122.), 21:9, li. S., Laws of 1903, (chap. 92).

Lake View Latud Co. 2 . Company, 95 'Texas, 252 ; 66 S. W. 766 ; Security Co. $v$. bauk, 93 rex. $575 ; 57$ S. W. 22.

\section{UTAH.}

(The references below are to the Revised Statutes of Utali, 1898, unless otherwise stated.)

1. Statutes under which Business Corporations may incorporate. The Business Corporation Act of Utah is to be found in the Revised Statutes of 1895 of that Stite, secs. 314-373, as amended by the Laws of 1899 and 1901. Lnder this act eorporatious may be formed for any purpose for whieh indivicluals may lawfully associate themselves. Special provisions are made for insuranee, irrigation, trust, aud railway eompanies.

2. Incorporators. - Five or more persons, one of whom must be a resident if the state (sce. $31 \%$ ).

3. Contents of the Articles of Agreement. The contents must set forth:

a. Nome. - No corporation ean use the name of a corporation already organized, or of any corporation duly authorized to transact business within the state (sec. 315, sub. 1; Laws of 1899, ehap. 52; Laws of 1901, ehap. 81).

b. Domicile. - l'recinct or city where it is organized (Laws of 1901, ehap. S1, sub. :2).

c. Incorporators. - Names and places of residenee (Id.).

(1. Iuration. - 'Time thereof, which shall not be less than three nor more than one hundred years (ld.).

e. l'urposes. - P'ursuit or business agreed npon, speeifying it in general terms. State officials permit the insertion of any number of objects in the artieles (Id.).

f. I'laces of General Business. - (Id.).

g. Strek Subseriptions. - Amount of stoek subseriptions. Amount of stock which each incorporator has subseribed for (Id.).

h. Copritul Strock - Iimit of eapital stock agreed upon and the par value of shares. both may be any amomnt desired (Id.).

i. Offuers and birectors. - Number and kind of officers, their qualifieations, terms of uffice, and time and manner of their election, removal, and resignation, with the names of the oflicers to serve until first general eleetion; the number of directors to be not less than three nor more thin twenty-five (ld.).

j. Cuorum of Directors. - Ilow many of the entire board shall be reeessury to f guorum shatl not be less than one-fourth of the entire board (Id.).

$k$. Simclinglders' Lialsility. - Whether or not private property of stockholders shall be liable for its obligations (Id.).

1. I'rorisions for the liegulation of Internal Affairs. - Sueh general elauses as incorpritors deem necessary for condueting the business of the corporation for its future welfare (ld.).

$$
\because 7:
$$


The act provides that the articles of incorporation shall also contain provisions relative to the parment of stock subscriptions in property, if it is desired to pay them in this manner. (See sec. 5, Procuring Charter.) The act also provides that the articles of incorpioration may provide what proportion of the ontstanding capital stock shall be represented at a stockholders' meeting. and what proportion of the stock so represented shall be necessary to determine any question of election (Laws of 1901, chap. 81, amended; Revised Statutes of 1598 , sec. 316).

4. Statutory Powers. - In addition to statutory enumeration of common law powers corporations have the following additional powers: To authorize rotin' by proxy, to forfeit stoek for non-payment of assessments, to consolidate with other corporations engaged in the same line of business in the same vicinity, to enforce a lien npon the stock of its nembers for debts rlue the corporation, to remove directors and to authorize directors to adopt by-laws (R. S., sec. 322 ; R. S., secs. 335 , 356, 373; A. L., secs. 340, 341 ; R. S., sec. 333 ; R. I., sec. 327 ).

5. Procuring the Charter. - The agreement must be subscriber by alI the incorporators, and sworn to and acknowledged by at least three. In addition to the foregoing there must be added the oath of at least three of the ineorporators to the fact that they have commenced, or it is their bone fide intention to commence and earry on bnsiness mentioned in the agreeinent, and that they verily believe that each party to the agreement bas paid or is fully able to pay the amount of stoek subseriptions made by lim. This agreement cannot be made until at least ten per cent of the stock subserilied by each stockholder and not less than ten per cent of the authorized capital stock has been pail in. Where subscriptions to the capital stock eonsist in whole or in part of jroperty necessary to the pursuit agreed npon there must appear in the articles of incorporation a description of the property so taken, with a statement of the fatir eash value thereof, which statement. except in the case of mining and irrigation corporations, shall be accompanied by the affulavit of three persons, to the effect that they are aequainted with such property and that it is reasonably worth the amonnt in cash for which it was accepterl by the corporation. As soon as the foregoing provisions are complied with, and the officers named in the agreement have taken and subseribed the oaths of office, the agreement with the oaths of office and the affidavits attached thereto, must be filerl and recorded in the office of the county clerk of the county in which the principal business is carried on within ten days from the date of execution thereof. The county elork issnes a certificate to the rffeet that the agrement and oathe of office have been filise in his oflice. which certificate together with a coly of the articles of agreement and oaths must be filed in the office of th. Secretary of State, who therenpon issues a certificate that the alove mentined instruments have bern filerl in his oflice (li. I..,

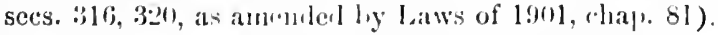

J. T. C. Co. v. Compriny, 23) Itah, 474; fis l'at. 735.

f. Corporate Indebtedness. - Thre is no statutory limit to the amount of eorperite: iurlebtuluess.

7. Organization Tax. - Twenty-five crnts on each thonsand dollars of the

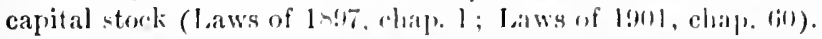

8. Filing and Recording Fees. - Tw the secrutary of state for issuing

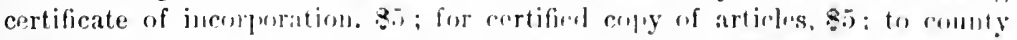
clerk for filing and indexing articles of incorporation, s.2.5); for romreling 
same, 20 cents per folio; filing oath of officers, 50 cents each (Laws of l!m (1) chip. (io).

1). Commencing Business. - Business may be commenced as soon as the articles are filed as reguired by law and ten per cent of the capital stock subsilued and ten per cent of the authorized capital stock has been paid in, and the utlicers have duly taken their oaths of office. Business must be commened within the period of two yeirs after the time of filing articles to avoil forfeiture of charter (Laws of 1891, chap. 81, amending R. S., secs. 316, $: i 21)$

10. Organization Meeting. - The organization meeting must be held within the Statc. 'This in the absence of any statute expressly authorizing the holding of organization meetings without the State.

11. Meetings of Stockholders and Directors. - Meetings of stockholders and directors may be held at the time and place designated by the bylaws. (ln the absence of any statute expressly authorizing the holding of stockhollers meetinus without the State it is safe to say that without the consent of all stockholders such meetings must be lield within the State (R. J., sees. :3:31, 3:36).

12. Directors' Qualifications and Liabilities. a. Qualifications. There must he at least three and not more than twenty-five directors, one-third of whom must be residents of the State. One-fourth of the entire number may con-titute a quorum if the artieles so provide. Directors must be stockholders. Sprecial provision is made for their removal by the stockholders (1i. S.. secs. 324, 327 ; Laws of 1901, chap. 81).

b. Liabilities. - There is no civil statutory liability of directors. Criminal penalties are, however, provided for misconduct of directors (R. S., secs. 4411, $442.2)$.

13. Stockholders' Liabilities. - Unless the articles of agreement otherwise provide, stockholders are only liable to the creditors to the extent of their unpaid stock subseriptions (R. S., sec. 331 ; see also Cons., Art. XII. sec. 18 ; see also li. S, secs. 335,354$)$.

Richardson $r$ Company, 23 Utah, 366; 65 Pac. 74; Salt Lake Hardware Co. $v$. Company; 13 Utah, 423; 45 Pac. 200; Hendersou $v$. Turngren, 9 Utah, 432; 35 Pac. 495.

11. Stock Certificates. - Each shareholder is entitled to a certificate showing the number of shares owned by hin, signed by such officers as the by-laws may prescribe.

15. Preferred Stock. - The issue of preferred stock is expressly authorized by statute (Laws of 1908 , chap. 59).

16. Payment of Capital Stock. - Capital stock may be paid for in property, by providing therefor in the articles of agreement and describing such propery therein (Laws of 1901, chap. 81, amending R. S., sec. 316. See also Cons., Art. XII. sec. 5).

17. Books. - Correct books of the proceedings and business of the corporation must be kept open for inspection by stockholders. The place where such books are to be kejt is not regulated by statute (R. S., secs. 328, 329, $4115)$.

1.. Office and Agent. - The Constitution provides that no corporation shall do l,usiness within the State without having one or more places of business within the State upon whom process may be served (Art. XII. sec. 9; see also li. S., sec. 4415).

$37+$ 
19. Reports. - The statutes do not require reports to be made except for insurance, banking, loan, trust, and guaranty companies.

20. Anti-Trust Statute. - There is a moderate anti-trust statute in force in $\operatorname{Ctah}$ (R. S., secs. 1752, 1762).

21. Statutory Grounds for Forfeiture of Charter. - Charter may be forfeited for non-user for a period of two years consecutively, or for entering illegal pools or trusts (R. S., secs. 321, 1758).

Jackson $v$. Company, 21 Utah, 1 ; 59 Pac. 238.

22. Amendments. - Articles of incorporation may be anended in any respect desired, by conforming to the provisions of law in such case made and provided (R. S., sec. 33s).

23. Extension of Corporate Existence. - There is no provision for the extension of corporate existence.

21. Dissolution. - Voluntary dissolution may be had by application to the district court upon two-thirds vote of the stockholders at a special meeting of the stockholkers (R. S., secs. 3114,3661 et seq).

25. Annual License Fee. - There is no annual license fee.

26. Foreign Corporations. - Foreign corporátions must file with Secretary of State and county clerk of the county where the office is to be located, a copy of the articles of agrcement, by-laws, and the appointment of some person residing in county where principal place of business is situated to receice service of process, and shall pay the same fees to the Secretary of state as domestic corporations. No annual license tax or annual report is necessary (R. S., secs. 351, 352). Under Const., Art. XII. sec. 6, no corporations organized outsile of the State are permitted to transact business within the State on conditions more favorable than those prescribed by law to similar corporations organized under the laws of $\mathrm{Utah}$.

R. G. W. Ry. Co. v. Company, 23 Utal, 22; 63 Pac. 995.

\section{VERMONT.}

(References below are to the Statutes of Vermont, 1894, and acts amendatory thereof.)

1. Statutes under which Business Corporations may incorporate. The Business Corporation Act of Vermont is found in the stantes of Vermont (1\$91), secs. $3473-3: 312$ inchusive. Cuder it corporations may be formed for any lawful jurpose excepting telephone, telegraph, banking, insurance, railway, construction and operation companies, savings bauks, trust eompanies, and corporations intended to derive irofil from the loan of money or real estate.

2. Incorporators. - Five or more persons. There are no residential requirements (sec. $37(11)$ ).

3. Contents of the Articles of Incorporation. 'The articles of incorporation must ermtain:

a. Nome. - Similarity of names with that of existing corporations forbidden (s.c. 97(15).

b. Pupposes. - Oliject or ohjocts for which established. Any number of purposes may be inserted in the articles (sec. 370.5).

c. Domicile. - l'lace in which corporate business is to be carried on (sec. 3705$)$. 
1. Copingl Stock. - Amount thereof. Capital stock is limited to a minimmm of $=$. 110 and a maximmm of $\$ 1,000,000$. The par value of shares must not excerd 8100 (secs. 3705,3728$)$. Duration of corporate existence is unlimiterl.

1. Statutory Powers. - ln allition to a statutory enumeration of common law powers, the following additional powers are granted: 'The right to vele hy moxy at stockholkers' meetings, to forfeit stock for failure to pay assesments, and to have a lien npon the stock of its members for debts due to the corporation (sees. 3691, :375, 37:27).

5. Procuring the Charter. - Articles must be subseribed by all the incorporators and then submitted to the Secretary of State for his approval. The litter may, if he sees fit, refer the same to a Judge of the Supreme Court who is grien power to determine whether the proposed corporation may or nay not be organized under the Gemeral Act. If the articles are approved they are recorded in the office of the Secretary of State, and a certified copy thereuf numst be recorded in the oflice of the clerk of the town in which the principal place of business of the corporation is located. The organization tax must be pail to the Secretary of State before corporate existence begins (sees. $3705,3706,3707)$.

6. Corporate Indebted ness. - One-fourth of the capital stock must be laid in before the corporation can contract debts. No debts can be contracted in any cvent exceeding in amount two-thirds of the capital stock actually paid in (see. 3724 ).

7. Organization Tax. - Capital stock up to $\$ 5,000, \$ 10$; not exceeding $\$ 10.000, \$ 25 ;$ not exceeding $\$ 50,000, \$ 50 ;$ not exceeding $\$ 200,000, \$ 100$; not exceeding $\$ 500,000$, $\$ 200$; not exceeding $\$ 1,000,000$, $\$ 300$; exceeding $\$ 1.000 .000$, 8500 (Laws of 1898 , chap. 19, sec. '2; see also Laws of 1900 , chap. 15).

8. Filing and Recording Fees. - Filing fees in the office of the Secretary of State, $\$ 2$. Recording fees in local town or city oflice, $\$ 1$; for filing certificate of the payment of capital stock, $\$ 1$.

9. Commencing Business. - Before commencing business also, the president or elerk must unake a certificate under oath stating the amount of capital actually paid in. This must be at least one-fourth of the capital stock, if debts ille to be contracted. This certificate is filed in the office of the Secretary of State, and a certified copy thereof with the clerk of the town in which the principal place of business is to be located (secs. 3722, 3724).

10. Organization Meeting. - The organization meeting must be held within the State. The law provides how the same shall be called (sees. $37(14-3710)$.

11. Meetings of Stockholders and Directors. - There is no statute authorizing the holding of stockholders' meetings without the State, and by implication at least they must be held there. Directors' meetings may be leeld within or withont the State as the by-laws may provide.

12. Directors' Qualifications and Liabilities. a. Qualifications. There must be at least three directors who must be stockholders, and two of them must be resilents of the State (secs. 3677,3717 ).

b. Lirlilities. - Directors are liable if the corporation contracts debts before a copy of its articles of association and a certificate as to the amount of capital stock pair in are filed in the office of the clerk of the town in which the principal oflice of the corporation is to be located. They are also liable for illegal payment of dividends, or for permitting the creation $: 36$ 
of indebtedness in excess of two-thirds of the capital stock paid in (secs. $37-2-3724)$.

Farr $x$. Briggs Estate, 72 Vt. $225 ; 77$ At. 793.

13. Stockholders' Liabilities. - Stockholders are liable to the extent of their unpaid stock subscriptions. If the capital stock is withdrawn or refunded to the stockbolders, before the full payment of its debts, each stockholder is personally liable to the amount thereof refunded to him (secs. 3725,3726 ).

Barton Nat. Bank $v$. Atkins, 22 Vt. $33 ; 47$ Atl. 176 ; Corey $v$. Morrill, 61 Vt. $598 ; 17$ Atl. 840 .

14. Stock Certificates. - Stockholders are entitled to a certificate signed by sneh oflicers as the by-laws preseribe.

15. Preferred Stock. - There is no provision expressly authorizing the issuauce of preferrel stock.

16. Payment of Capital Stock. - Stock can be issued only in exchange for money or money's worth.

17. Books.-- Stock book must be kept within the State, containing the names of the holders of stock, their places of residence and number of shares held by each, amount actually paid in on each share and time when they acquired the same (secs. 3653, 3714, 37333). All records, amounts, and papers of the corporation are open to the inspection of stockholders.

18. Office and Agent. - Must have an oftice within the State in charge of a clerk in the town where its principal place of business is located (secs. 3712,3713$)$.

19. Reports. - There is no statutory provision as to reports. There is a statute, lowerer, requiring all moneyed corporations annually, on or before April 15th, to transmit to the clerk of each town in which stockiliolders of the corporation resile, a list of the stockholders with the amomnt of shares held by them and the amount paid thereon. They must also transmit to the clerk of the town where the corporation has its prineipal business a list of all stockliolders with the number of shares owned by them and the amount paid thereon (secs. 380, 381, 382).

20. Anti-Trust Statute. - There is no anti-trust statute in force in Vermont.

21. Statutory Grounds for Forfeiture of Charter. - Charter may be forfeited for failure to pay license taxes (sees. 575, 578; Laws of 1902, ehap. 20 , sec. $5(i)$.

22. Amendments. - Articles may he ausended for the purpose of increasing of lecreasing the capital stock, for the pmponc of changing its name. or for change of domicile (secs. 3729, 3730, 3733, 3731; see also Latws of 1898, chitp. (54).

23. Extension of Corporate Existence. - C'umpanics may be incorporated for an mulimited tem. There is no provision for extension of corporate "xistence.

21. Dissolution. - () vote of the stordibulders owning one-fourth of the capital steck a corpuration may luntion court of chlincery for dissolution

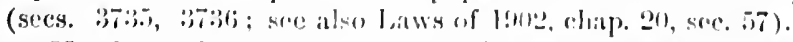

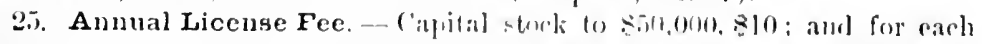

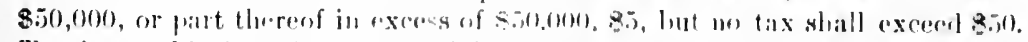

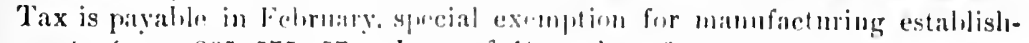

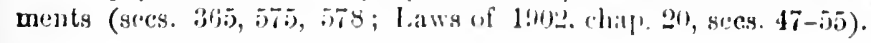


26. Foreign Corporations. - Foreign corporations must file with the Secretary of state a copy of charter and statement setting forth the business of the corporation, location of oflice within the state, and an agent upon whom process una be made; and pay an annual license tax of $\$ 10$, if capitalization is 50,000 or less, and if over $\$ 50,000$ or part thereof in exeess of $\$ 50,000, \$ 5$, hut in no ease to execel 850 (R. S., sees. 575,4165). The Seeretary of State will isue certificate showing compliance with the law and authorizing the corporation to do business within the State (Laws of 1902, chap. 20, secs. 47, $59-61)$.

Osborne i. Ins. Co., 57 Vt. 278

\section{VIRGINIA.}

(The references cited are to the Business Corporation Act of 1903, found in Acts of Extra Session (1902-1904), clap. 270 . This is in turn subdivided into five subsidiary chapters, to whieh reference is made below.)

1. Statutes under which Business Corporations may incorporate. The Business Corporation Aet of Virginia is to be found in the Laws of 1102-1901, 11. 437-481. Under it charters may be proeured for any lawful business.

2. Incorporators. - Three or more. There are no residential requirements (chap. 1, see. 1).

3. Contents of the Articles of Incorporation. The contents must set forth :

a. Name. - Name must contain the word "corporation" or "incorporated," and must be such as to distinguish it from any other corporation engaged in a similar line of business (chap. 1, sec. 2).

b. Domicile. - Name of the county, eity, or town where the principal office within the State is to be located (Id.).

c. Purposes. - Purposes for which it is formed. There may be any number not covered by special act (Id.).

d. Capital Stock. - Maximum and uninimum amonnt of capital stock and number of shares. If preferred stock is desired, there must be inserted a description of the several classes of stock with the terms on which they are createrl (Id.).

e. Duration. - May be perpetual if desired (Id.).

f. Officers and Directors. - Names and residenees of officers and directors for the first year (ld.).

g. Leal Estate. - Limitation upon amount of holdings thereof (Id.).

h. Rerpulation of Internal Affairs. - Any provisions may be inserted for the conduct of the affairs of the corporation; also any provisions defining, limiting, or regulating the powers of the corporation to the directors or stockholders (It.).

4. Statutory Powers. - In addition to a statntory enumeration of common law jowers, the following additional powers are granted; To take real and personal estate by gift, devise, or bequest; to subseribe, guaranty, or become surety in respect to stock and bonds of other corporations; to conduct linsiness in other States and Territories and foreign conntries; to hold meetings of directors within or without the State; to have offices, to holk, purehase, mortgage, or convey real and personal property both within and without the State; to authorize voting by proxy in the election of direc378 
tors; to classify directors; to permit the insertion in the articles of a provision delegating the power to adopt by-laws to the directors; to remove directors; to forfeit stock for non-payment of assessments; to issue preferred stock; to permit cumulative voting by inserting prorision therefor in the articles; power to insert in the articles provision conferring upon the bondholders right to vote in respect to corporate affairs, management, and consolidation with other corporations (chap. 5, secs. 2., 3, 4. 5, 6, 7. 8, 10, 1.2, 1:3, 16, 19, $40,41,42)$. The statute authorizes the directors to appoint an executive committee of two or more directors from their own number (chap. 1, sec. 13).

5. Procuring the Charter. - The certificate of incorporation must be subscriber by each of the incorporators, and is then presented to the judge of the circuit conrt of the county or to a judge of the corporation, circuit or chancery court of the city wherein the corporation is to be located, for his certificate to the effect that it is executed according to law. When so endorsed and when organization tax is paisl, the certificate must be presented to the State corporation commission, which is authorized to pass npon the question whether the applicants have by complying with the requirements of the law entitled themselves to the charter. If satisfied in this regard, the fact is certifierl by them to the Secretary of the Commonwealth, and the charter is recorded by him in the charter records. This done, the Secretiry of the Commonwealth certifies the certificate to the clerk of the circuit court of the county or to the corporation court of the city wherein the principal office of the corporation is to be located, or to the clerk of the chancery conrt of the city of Richmond in case the principal oflice is to be located there. These officials are required to record the certificate in their oflices and to endorse the fact of such recorlation upon the certificate. Whereupon the said certificate with all endorsements thereon is returned by such lastnamed official to the clerk of the State corporation commission, and lodged with him. Corporate existence conmences as soon as the certificate has been lodged for record in the oflice of the Secretary of the Commonwealth (chap. 1, sec. 3).

6. Corporate Indebtedness. - There is no statutory limitation upon the amount of corporate indebtedness. (The statute expressly gives the right to a corporation to create a bonded indebtedness. If provision is so made in the articles of incorporation or by anendment thereto, votning powers in the corporation may be granted to bondholders (chap. 5, secs. 1 and $2 ! 1$ ).

7. Organization Tax - On capitalization of 50.0000 , or less, sin; over 850,000 , and less than $\$ 1.000,000,20$ cents for each thousand dollars or fraction thereof; $s 1,(100.0000$ or more, s(60). (The foregoing schedule does not apply to trinsportation or tran

8. Filing and Recording Fees. - The organization tax is payilh to the Secretary of the Commonwealth. The following alditional fees are chargen?; 81, for application of the seal of the ehater commission to the certiticate, and 50 cents per page plus 52 , for recorling the charter in the oflice of the Secretary of the Commonwenlth. The registration fee as wall as the franchise tax is payable anmmally on or before Marcl lst of each year. The annual franchise tax is parialye to the order of the Treasurer of Virginia, and forwarled to the aurlitor of pullie accounts at lichumul. There is no charge for the approval of the lorial judge, or for olutaining his certiticate to the effect that the cortificats of incorpmration is exentent according to law. The State charter comnission charges \&1 for certificate under seal that the 
applicants in a charter have complied with the requirements of law and are entithel to a chinter. The Secretary of the Commonwealth makes no additional charge other than the charges referred to above for giving his certiticate to the clerk of the circuit court, as to the filing in his office of the certiticate of incorporation. The charges for filing and recording in the heal ullice ( $\rho g$. clerk of the State court), are the same as for the Secretary of the Commonwealth griven above. The State charter commission makes no charge for tinally lodgring the certificate of incorporation in their otlice. The secretary of the Commonwealth charges $\$ 1.50$ for issuing certificate of incorporation. The cost of certified copy of the certificate of incorporation is 50 cents per page, 50 cents for certificate, plus $\$ 1$ for applieation of seal when required under seal. There are no charges made for filing and reending report as to othicers, directors, etc. Under sec. 39, chap. 5 . of the act concerning corporations, a report is required to be filed with the charter commission. Under sec. 14, chap. 1, of the same act a report is required to be fikd with the clerk of the court. There is no charge as to the report unter see. 39, chap. 5 , of the Corporation Act, but a charge of 25 cents to the clerk of the court for the report under sec. 14, chap. 1, is marle. There is an arditional charge of 50 cents per page where the certificate of incorporation exceeds two pages in length.

9. Commencing Business. - Business may be commenced as soon as the certificate has been recorded and approved as required by law, and as soon as the minimum capital stock as fixed by the certificate of incorporation las been subscribed. The corporation must commence business within two years from the time the charter is issued (chap. 1, sec. 3; chap. 5, sec. 1). Within thirty days after the first election of oflicers and directors a report anthenticated by the signature of the president or one of the rice-presidents and the secretary of the corporation must be filed in the office of the State corporation commission, stating character of its business, corporate nillue, location, name of agent upon whom process may be served, amount of its authorized capital stock, amount actually issued and outstanding, names and aldresses and terms of office of officers and directors and date of annual meeting (chap. 5 , sec. 39 ; chap. 1 , sec. 14).

10. Organization Meeting. - The organization meeting should properly be held within the State. The corporation must organize and commence business within two years after granting of the charter (chap, 1, sec. 4; chap. 5, sec. 51).

11. Meetings of Stockholders and Directors. - The annual meeting of the stockholder's must be held within the State. It would seem that slrecial meetings should likewise be held within the State. Directors' meetings may be beld within or without the State as the by-laws provide (chap. 5, sec. 7 ).

12. Directors' Qualifications and Liabilities. a. Qualifications. There must be at least three directors, including the president, who must be a rlirector. The act provides for the appointment by the directors of an executive committee to manage the business of the corporation (chap. 1, sec. 13; chap. 5, sec. 10).

b. Linbilities. - Directors are jointly and severally liable for any damage resulting from their wilfully and frandulently causing to be published or given out a report of the condition or business of the corporation known to them to be fals in any material respect. 'T'o enforce this liability action must be brought within two years after the right of action accrues (chap). 5, secs. 26, 350 
35). They are also liable for illegal declaration of dividends if they do not dissent therefrom (chap. 5, see. 60 ).

13. Stockholders' Liabilities. - Stockholders are only liable for their unpaid stoek subscriptions (ehap. 5, sec. 9). No stoek can be assigued on the books of the corporation without the consent of the eorporation until all dues and debts are paid thereon (ehap. 5 , sec. $5 \overline{7}$ ). If the stock is assigned before all stock subscriptions are paid thereon, the assignee is liable for any instalments which have accued or which may thereafter acerue under the subscription agreement (Id.).

14. Stock Certificates. - Eich stocklolder is entitled to a certificate signed by the president or one of the vice-presidents and the treasurer, or by any two officers of the eorporation thereto authorized by the board of directors (chap. 5, sec. 14).

15. Preferred Stock. - Preferred stock is expressly authorized by the aet. Provision may he made for the issuance of the same, either in the original certificate or by subsequent amendment thereto. l'referred stoek may be issued if desired subject to redemption if desired three years af ter the issue thereof at a price not less than par. Dividends thereon may be male cumulative or non-eumulative as desired (chal. 1, see. 2; ehap. 5, see. 1:3).

16. Payment of Capital Stock. - Stock may be issued for money, land, or other property. real or personal, leases, options, mines, minerals, mineral rights, patent rights, rights of way, easements, contracts, libbors, or serviees. The act provides that there shall be no individual liability on any subscriber beyoud the obligation to comply with his contract of subscription. Corporations are expressly authorized to ilispose of its stock for the purposes of its incorporation, at such prices and for snch consideration and on such terms and conditions as it sees fit, proviled, however, that the entire flan for the issuance of stock together with the valnations placed npon the property to be taken in exchange for stoek shall be submitted to the state corporation commission before the issue is made. The act further provides that the judgment of the directors as to the value of the property taken in exchange for stock shall, in the absenee of frimd in the transaction, be conelusive. For violating this provision a fine of $\$ 1,000$ may be imposed, and julgment entered therelor by the said corporation eommission, which is given judicial powers for this purpose (chilp. j, sec. !).

17. Books. - Transfer books must be kept (chap. 5, sec. 18)

1\%. Office and Agent. - Corporations must have a prineipal oflice within the State. In case the oflicers and direetors are non-residents of the connty, eity, or town where the principal oflice is located, they unst ammally, liy written power of attorney, alfurint some practining atturney of law residing therein as its attrung or acent mon whom servien of process may he male who shall be authorized to chter an appearance in its behalf. johis powrer of attorney must be recoriled in the clerk's otlice of the cirenit eourt of the county or the eroporation or chancery eourt of the eity wherein the prineipal office of the enporation is lecated. It must also be filed in the oflice of the secrotary of the (ommonweallh ('hap. 1, see. 2'; chay). 5, secs. $\overline{7},: 9 !)$.

19. Reports. - Companies incorpromaterl moler the gencral laws must,

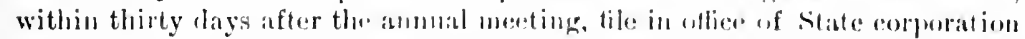
commission a repert stating name of the corporation. heation, character of businesy, authorized eapital stork, anomul jssmed and ontstanding, names and addresses of ofleers and firetors, fate of $n \cdot x t$ ammal meetime. bery cor- 
poration mmst file with the State corporation commission by February 1st of catch reitl repurt of the amomnt of its maximum capital stock. Every corporation shall also at the time of paying its ammal registration fee make to the State corpuration eommission sueh report of its status, business, or condition ats the state corpuration eommission shall require. Non-compliance with there furisions subjects the corporation to a time of not less than $\$ 25$ and not more thall $\$ 100$ for e'teh thirty days' default (ehap. 1, sec. 39).

:(0. Anti-Trust Statute. - There is no anti-trust statute in force in Virginia.

21. Statutory Grounds for Forfeiture of Charter. - Whenever the principin purpose for which the corporation was formed has failed or the maningment thereof is abandoned by its oflicers, or when operations under the charter have been suspended or abandoned for a period of three years, or the eorporation has hecome insolvent, the charter of such corporation is liable to forfeiture or may be dissolved (chap. 1, sec. 15).

2.2. Amendments. - At any time before the amonnt of stoek fixed by the incorporators shall have been subseribed, my alteration or amendment of the original certnticate may be had by complying with the provisions of the act. 'The same right is given at any time after subscriptions have been completed but before the corporation is duly organized. After organization the corporation may anend its eharter for any purpose desired by complying with the provisions of the act (chap. 1, secs. $5,6,7,9,111$ ).

2:3. Extension of Corporate Existence. - There is no provision for the extension of corporate existence after the expiration of the charter.

21. Dissolution. - The incorporators before the payment of any part of the eapital stock and before begimning business may surrender all their corporate rights and framehises by following the steps preseribed in the statutes. After organization on resolntion of a majority of the board of directors with the consent of two-thirds in interest of the stockholders the charter may be voluntarily dissolved (chap). 1, sees. 11, 12, 15).

25. Ainual Franchise Tax. - Before Iarch 1st of each year every corporation shall pay into the treasury of the State a tax assessed by the State corpration commission as follows: With cipital stock of $\$ 25,000$ and under, $\$ 10$; over $\$ 25,001$ and not exceeding $\$, 0,000, \$ 20$; over $\$ 50,000$ and not txceeding $\$ 110,0 m) . \$ 10$; over $\$ 100,000$ and not exceeding $\$ 300,000, \$ 60$; over $\$ 300,(10,0)$ and not exceeding $\$ 500,000, \$ 100$; over $\$ 500,000$ and not exceeding $\$ 1,000,(000, \$-200$; in excess of $\$ 1,000,000, \$ 10$ for each additional $\$ 100,000$ or fraction threof. Non-payment within the time required subjects the corporation to at penalty of five per cent per annum (Acts of 1903, p. 182).

269. Annual Registration Fee. - All domestic corporations other than charitable and foreign corporations doing husiness within the State shall pay anmmally into the treasury of the state before March 1 of each year the following reristration fee: With eapitalization of $\$ 15,000$ or under, $\$ 5$; over $\$ 15,(0)$ and not exceeding $\$ 50,000, \$ 10$; over $\$ 50,000$ and not exceeding $\$ 100,000 . \$ 15$; over $\$ 100,000$ and not exceeding $\$ 300,000, \$ 20$; over $\$ 300,000$ s... This fee is payable in addition to the ammal franchise tax or other taxes imposed upon the corporation. Failure to pay such fee for two years and ninety days operates as revocation of the charter of the corporation (Act of $190:$, pp. 180, 182).

27. Foreign Corporations. - Must file with Corporation Commission a]prointinent of agent upon whom process may be served, together with two anthenticater copies of their charter and a certificate of State Auditor showing 302 
payment of license fees. Thereupon a license is issued. They are taxed the same as domestic corporations upon their property within the State. Code, secs. 1104, 1105, as amended by Laws of 1903 , chap. 242.

Slaughter $v$. Comuonwealth, 13 Grat. 767 ; Nickels $v$. I. B. L. \& S. Ass'n, 93 Va. 380 ; 25 S. E. 8 ; Goldsberry $v$. Carter, 100 Va. 438 ; 4 l S. E. 858.

\section{WASHINGTON.}

(The references below are to Ballinger's Code and Statutes of Washington (1897), unless otherwise stated.)

1. Statutes under which Business Corporations may incorporate. The Business Corporation Act of Waslington is to be found in liallinger's Code, secs. 4250-1302 and acts anenrlatory thereof. Parties maly incorporate thereunder for minufacturing, mining, milling, wharfing, and diggring, mecluanical, banking, mercantile, improvement, and luilding purposes, or for the building, equjpping, and managing water flumes for the transportation of wood and lumber, or for the purpose of building, equipling, and renting railroads, or constructing canals or irrigation canals, or engaging in any other species of trade or business. (Ste Laws of 1903, chil). 8t.)

2. Incorporators. - Two or more persons. There are no residential requirements (sec. 4251).

Hastings $v$. Company, 29 Wash. 224 ; 69 Pac. 766.

3. Contents of the Articles of Incorporation. - The articles of incorporation must contain :

a. Nime. - No name can be used similar to that of an existing romestic corporation or of any foreign corporation that las obtained a permit to do business within the State (sec. 4251 ; Laws of 190:), eha!. 81).

b. Purposes. - The objects for which the corporation is formed must be stated. The statute is constried by the Secretary of State to permit the insertion of any number of purposes in the articles (sec. 1251).

c. C'rpital Stock. - The amount of capital stock, which may be any anount (sec. 4251 ).

d. Inuration.-- Time of existence, not to exceed fifty years (sce. 1251).

e. Number of Sheres. - It is not necessary to state the par value of shares, and this may be any amount (-ee. 4.2.51).

f. Trusters. - Nunber of trustees and names of those who shall manare the concerus of the company for at least two and not more than six months (sec. 4.201$)$.

9. Immirile. - The uame of thre eitg, town, or Ineality in the comnty in which the principal place of business of the eompany is to be heated (sec. $4 \cdot 251$ ).

4. Statutory Powers. - In anlition to the stalutory emumeration of common law juwers, the statute oufors the following alditional pwwers: The

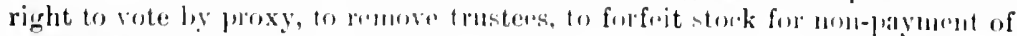
assessment, and givines stocklolders in minime componjes the right to inspeet

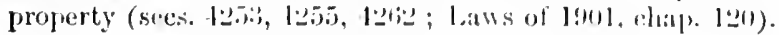

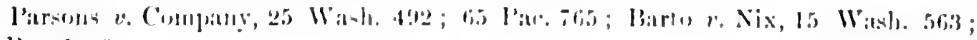
46 l'ice. 10:33.

5. Procuring the Charter. - Thu incmoristurs must subsribe alul acknowlelge before an oflicel aul horizent to talic acknowledgunents the artieles

$$
\text { ;i:, }
$$


of incorpuration in friplicale. One of these must be filed in the oflice of the serentary of state and another with the comnty anditer of the comnty in which the principal phace of business of the company is intended to be located.

A thinl copy should be retained by the incorporators (sec. 42.51).

1i. Corporate Indebtedness. - There is no limitition upon the anount of enrpriate indebledness which a corporation may incur.

․ Organization Tax. - lhere is no organizition tax in Washington.

$\therefore$ Filing and Recording Fees. - To the Secretary of State, \$10 for filing fees : \$5 for issuing eertificate of incorporation; 15 cents per folio for recording articles with the county anditor; 10 cents per folio for filing. For certitiel coly of articles, \$.5. If copies to be certified exceed twenty folios, a charre of 15 cents per folio for such excess (secs. 4285, 4287, 4288).

1. Commencing Business. - Before commencing business and within thirty dins after it shall have filed its certificate of incorporation with the connty anditor of the connty in which it has its principal place of business, the corporation must file with the latter a statement sworn to by its presiclent and attested by its secretary and sealed with its corporate seal, containing a list of all its officers and names and addresses and terms of office for which they have been chosen (secs. 4259, 4260). Before business is commenced all the eapital stock must be subseribed.

City of Spokane $v$. Trustees, 22 Wash. 172; 60 Pac. 141.

10. Organization Meeting. - The organization meeting must be held within thirty days after the certificate of incorporation is filed with the county auditor as requirel by law. The meeting must be held within the State, and statutory provision is made for calling the same (secs. 4255, 4258, $4: 60)$.

11. Meetings of Stockholders and Trustees. - There are no provisions as to where meetings shall be held, except that meetings for the election of trustees must be held at the principal place of business within the State. Places for other meetings are fixed by the by-laws (secs. 4255, 4258, 4276).

12. Trustees' Qualifications and Liabilities. a. Qualifications. There must be at least two trustees who must be stockholders and one of whom shall be a resident of the State of Washington, and a majority of them citizens of the United States, and must take and subscribe to an oath of office (sec. 425.5$)$.

b. Liublitities. - All trustees not formally dissenting to the declaration of illegal divilends or to the unlawful withdrawal of any part of the capital stock are jointly and severally liable to the corporation and to the creditors to the full anount so divided or reduced or paid out (sec. 4265 ; see also laws of 1903 , chap. 93).

13. Stockholders' Liabilities. - Stockholders are only liable to the extent of their unpaid stock subscriptions (sec. 4262; Cons., Art. XII. sec. 4).

11. Stock Certificates. - Stock certificates must be signed by such officers as the by-laws prescribe.

15. Preferred Stock. - The act does not expressly authorize the issuance of preferred stock.

11i. Payment of Capital Stock. - Stock must be paid for in money or money's worth. Special provision is, however, made in the case of mining corlorations. Where the amount of capital stock of such corporations consists of the acgregate valuation of the whole number of feet, shares, or interest in any mining elaim within the State, no material subscription to the capital

$$
3>1
$$


stock is necessary, but each owner thereof shall be deemed to have snbscribed such an amount to the capital stock of the corporation as in its hy-laws shall represent the value of so much of his interest in sain mining chim or lewal title to which he may by deed or other instrmment rest in the corporation for mining purposes (sec. 1280 : ('ons., Art XII. ste. (i).

Dunlap $v$. Rauch, 24 Wash. 6020;64 l'ac. soz.

17. Books. - Stock transfer books must be kept at all times at the principal office of the corporation in the state (sec. 4269). These are opren to the inspection of stockholders.

State v. Company, 21 Waklı. 451 ; 58 Pac 584.

18. Office and Agent. - Every corporation must maintain an oflice within the State and an agent to receive service of process (sec. [1.i1).

19. Reports. - Before the second Tuesday in January incorporators must file with the auditor of the county where business is located a statement showing names and addresses and titles of company's oflicers and terms of office, and also, within thirty days of date of incorporating, must file a sinilar report. No penalty for failure, and the provision is generally disregarded (secs. 1250, 4260).

20. Anti-Trust Statute. - There is no anti-trust statute in force in this State. The constitution, however, prohibits combinations to tix the pree or limit the production of commodities (Cons., Art. Xll. ser. 2.2).

21. Statutory Grounds for Forfeiture of Charter. - The provisions of law as to the bringing of information in the nature of yeo warme aganst corporations will he fond in Ballinger's ('odes and statutes (sees. 5l st, 5190).

22. Annual Franchise Tax. - On or before June lat of each year erery corporation must pay an annual license fee of 810 (sce. 4.49 ).

23. Amendments. - The power of amendment only extends ly express enactment to the increasing and decreasing of capital stock and to change in the location of the principal place of business (sees. 1251, 4.271, 1.76; Laws of 1899 , chap. 106).

24. Extension of Corporate Existence. - No pervision is made for the extension of corporate existence.

25. Dissolution. - Corporations may he dissolved on rote of two-thirts of all stoekholders upon application to the conts, or by thee-fourths rote of all its membrers it mily surmoler its corporate powers (sec. 1275).

26. Foreign Corporations. - Must file with the sircretiry of State certified coly of charter and appointment of resident agent to receive servide of proees:. Shall pay a license fee of Slo rach year (latws of 1s!9), whip. 5s, secs. $4259-4291)$.

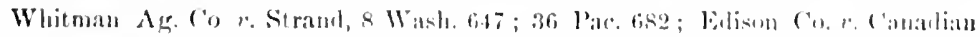

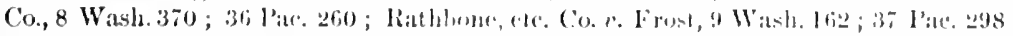

\section{WEST VIRGINIA.}

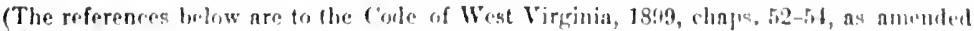
by laws of $1 !(1) 1$, chap. 3is.)

1. Statutes under which Business Corporations may incorporate. - The lansiness (orporation . Int is to be foumb in the Corle of Wost Virsinia

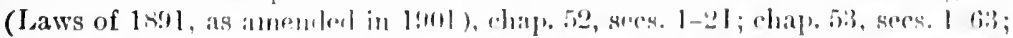

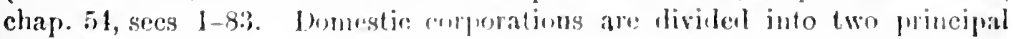


classes: linsidnt corporations, whose principal business and chief works are to le locited within the state; and non-resident corporations, whose principal business and chict works are to be located without the State. No corporation call be incomporated for the sole purpose of purchising real estate in order to soll the silme for profit (Code 5: : 3, as amended by Laws of 1901, chap. 35, alul Laws of 16003 , chap. 3).

‥ Incorporators. - Five or more persons. There are no residential requirements (Code $i t: 6$ ).

(rmulish Admr. $\iota$. Ry. Co., 40 W. Va. 627 ; 22 S. E. 90.

3. Contents of the Agreement of Incorporation (Non-Resident Corporations). The agreement of incorporation must contain :

a. Sume. - Similarity of corporate names forbilden (Code 54:6, sub. 1; see also ('ode $53: 11$; Laws of 1903, chap. :3, sec. 3).

b. Domicile. - Lncation of its principal place of business and its chief works (Code 51:6, sub. 2). The principal oflice need not be within the state. (See Code $53: 46$.)

c. Purposes. - Objects for which the corporation is formed. Any numher of purposes may be inserted (Code 51:6, sub. 3).

d. Cipitul Stock - Amount of total authorized capital stock, number of shares and par value thereof, and the amomnt of the same paid in. If prefrrred stock is desired, the terms on which the same is issued must be set forth (Code $51: 6$, sub. 4 ; see also Code $53: 17$, as amended by Laws of 1901, chap. $: 5.5)$. Capitalization and par value of shares may be any anount (Code $53: 15)$.

e. Stock Sulscriptions by Incorporators. - Names and post-office addresses of the incorporators and the number of shares subscribed for by each (Code $51: 15, s u b .5)$. There must be at least five bona fide stockholders, who are required to pay in ten per cent of their subscriptions forthwith (Code 53:17, 2.).

f. Duration.- Period of corporate existence not to exceed fifty years (Code 51:6, sub. 6; see also Code 54:11, as amended by Laws of 1901, chap. 35).

g. Propisions for Regulution of Corporate Affuirs. - Any provisions desired may lie inserted for the regulation of the business and for the conduct of the affairs of the corporation, or defining, limiting, or regulating the powers of the corporation, the stockholders, and directors (Code 51:6, sub. 7 ).

$h$. If the corporation desires to hold more than ten thonsand acres of land in Wret Virginia. the agreement must set forth the maximum number of acres it desires to hold (Corle 54:6).

4. Statutory Powers. - In addition to a statutory enumeration of the conmon law powers of corporations (Code, chap. 52, sec. 1), the following alditional powers are granted: To subseribe with the consent of the stocklolrler for the stock of other corporations; to rote by proxy; to transact Imsiness in other States and comutries; to hold its organization, stockholders', and directors' mectings ontside of the State; to purchase its own stock; to triuf for all its assets; to issue its stock for property or services; may have an office, own property, and carry out the corporate purposes without the State; cumulative roting in the election of directors is mandatory; to appoint itn executive committee from the board of directors; to forfeit stock for nonjayment of assessments; to remove directors, and to issue preferred stock and bonds (Code $5.2: 1 ; 52: 3 ; 53: 3 ; 54: 6 ; 51: 23 ; 53: 18 ; 54: 83$, as 356 
amended by Laws of 1901, chap. $35 ; 53: 24 ; 53: 42 ; 53: 44 ; 53: \tilde{5} 3 ; 53: 16$; $54:$ S.2 c, sub. 11.

Cross r. Ry. Co., 35 W. Va. 174; 12 S. E. 1071.

5. Procuring the Charter. - The agreement of incorporation must be signed and acknowledged by each of the five incorporators. Each incorporator must be a subscriber for at least one share of stock. Two of the incorporators must give their affidarit that the amount stated therein to have been paid on the capital stock has been in good faith paid in for the purposes of the business of the intended corporation and with no intention or understanting that the same shall be withlrawn. The original agreement of incorposation must be filed in the office of the Secretary of state. Within three nonths therefrom a certified copy thereof must be rocorded in the office of the clerk of the county conrt where the principal office is, or wherein the resident agent resides (Code $51: 6-9 ; 54: 20$, as amended by Laws of 1901, chap. 35).

Greenbrier Ex. $\imath$. Rodes, 37 W. Va. 738 ; 17 S. E. 305.

6. Corporate Indebtedness. - There is no statutory limitation upon the amount of indehtednss which the corporation may incur.

7. Organization Tax.-- The organization tax is in fact the first ycar's annul tax. The statute distinguishes between resident and non-resident corporations in the matter of organization taxes. Resident corporations are those whose prineipal place of business and chief works are to be located in West Virginia. Non-residenf corporations are those whose prineipal place of business and chief works are lucated outside of West Virginia. For both classes of corporations the license year begins May 1st. On every certificate issued after August lst the State only collects one-tenth of the anmul license tax for each inonth or fraction thereof for the remainder of the license year, but in no case to be less than s.j for resident, $\$ 10$ for non-resident corporations. However, if the chartor issurs on or after Mareh 1st. then in addition to the proportionate tax for the remaining two months, there must be raid also a tax for the full license year beginning May 1st thereafter. For resilent corporations the annual license tax is as follows: Where the authorized capital is $\$ 10,000$ or less, $\$ 10$; up to $\$ 25,1100$. $\$ 1.5 ;$ up to $\$ .50 .000,8.8) ;$ up to $\$ 100,000$, \$25; for each additional $\$ 1,000$ up to sl,000,000, 5 cents per thousand. Where the capital stock is more than $81,00(0,00 m$, the tax is 870 , and $\$ 10$ additional for every s1.000,001 or fractional part thereof over the first million (Code 32: 86, as amented ly Laws of 1901, chap. 35; Laws of 19413, chatp. 3).

For non-resident corprotime the annul licenss tax is as follows: lor any

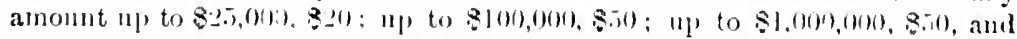

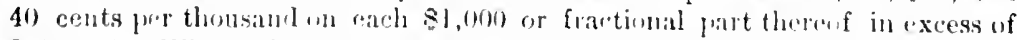

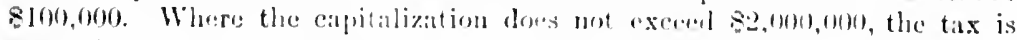

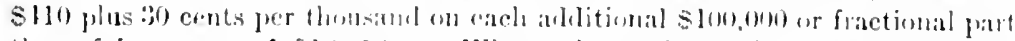

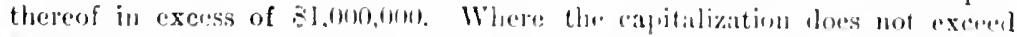

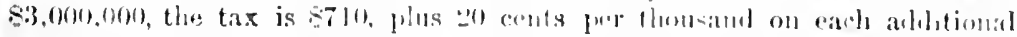

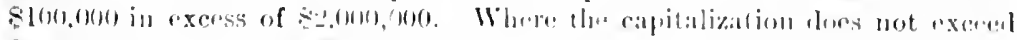

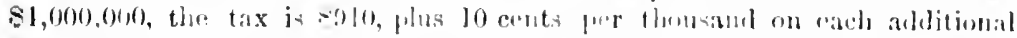

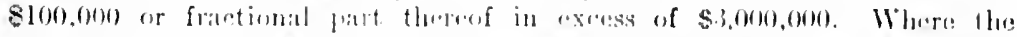

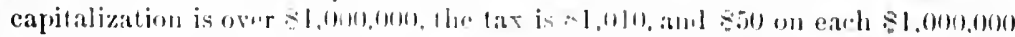

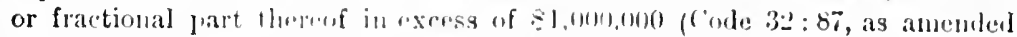

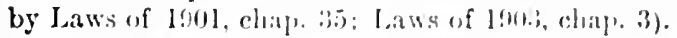

8. Filing and Recording Fces. - T, the Secretary of State fur eharter, 
Si; cortified copy of arreement of incorporation, $\$ 5$; to filing and recording fumer of attormey to act as resident agent in Secretary of States office, \$5; for tiling and recording simm in county clerk's oflice, about \$1.25, agreement of incorporation. S-2 if it lues not exceed four humbed words; if over that, 3 cents for each adilitimal thirty words.

9. Commencing Business. - 'lhe corporation must hold its organization meeting within six months after the issuance of the certificate of incorporation. Within thirty days aftre organization an agent within the State must be apprinted upon whom process may be served. Business must be commenced within one year from time charter is issued (Code 53:6 and 54:15, as amentid by laws of 190 , chap. 35).

10. Organization Meeting. - May be held within or without the State (Code $51: 1.5,2: 3)$.

11. Meetings of Stoclsholders and Directors. - If the by-laws so provide, any stockholder's' or directors' meetings may be held withont the State. Otherwise they must be held within the State (Code 54:23; see also Code 53 : il. as aminded by Laws of 1901 , chap. 35).

12. Directors' Qualifications and Liabilities. a. Qualifications. There must be at least five directors, mless the by-laws otherwise prescribe. Lnles; otherwise provided by the by-laws, directors must be stockholders and residents of the State (Code $53: 49$ ).

b. Liallitities. - Assenting directors are jointly and severally liable to creditors for the illegal declaration of dividends, to the extent of the capital illegally withdrawn in this manner (Code 53:40).

13. Stockholders' Liabilities. - Stockholders are liable to creditors to the amount of their unpaid stock subscriptions. They are also liable to creditors to the extent of any illegal dividends received by them (Cons., Art. II. sec. 2: Code $5: 3: 2 \cdot 2,40$ ).

11. Stock Certificates. - Must be signed by the presilent or vice-president and such other officers, if any, as the board of directors may direct. The certificates must show the amount paid on each share (Code 53:35, as annended hy Laws of 1901 , chap. 35).

15. Preferred Stock. - The act specifically provides that preferred stock may be issued either by providing for it in the certificate of incorporation, or by resnlution adopted at a general meeting of the corporation (Code 53:61; Code 51: 6, as amended by Laws of 1901, chap. 35).

16. Payment of Capital Stock. - The statute provides that at least ten per cent of the par value of each share shall be paid at the time of such subscription, and the residue as required by the boarl of directors or the commissioners having control of the subscription. Stock in corporations other than mining and manufacturing shall not be sold or disposed of at less than par, except by a vote of three-fourths of all the stock of the corporation outstanding after the arlvertisement of such intention. But unining or mannfacturing corporations may issue stocks or bonds, and negotiate the sale of the same, in payment for real and personal property, at such price and upon such terms and conditions as may be agreed upon by the owners and the directors or stockhriliders. All stock so issued shall be fully paid, and not liable for any further call or assessment, and in absence of actual fiaucl in the transaction the raluation placed by the directors upon the property so purchased shall be conclusire (Code $53: 25,52: 24$, as amended by Laws of 1901, chap. 35).

Richardson $v$. Graham, 45 W. Va. $134 ; 30$ S. E. 92.

$$
388
$$


17. Books. - No books are required to be liept in the State (see Code $53: 47,54)$.

18. Office and Agent. - Every non-resident corporation must, within thirty days after its organization, execute a power of attoruey appointing a resident agent upon whom serrice of process may be made. 'This power of attorney must be filed in the office of the Secretaly of State, and in oflice of the county clerk where the attorney resides (Code, chatp. 54, sec. 21).

19. Reports. - 'The board of directors must make an annual report to the stockholders of the coudition of the corporation. 'They must also within ninety days after the first election, and after every annual meeting thereafter, make a report giving the names and post-office addresses of the president and secretary, and post-office address of the principal office of the corporation. I penalty is provided for not making this report (Code, chap. 53 , sec. 46, as amended by Laws of 1901, chap. 35).

20. Anti-Trust Statute. - There is no anti-trust statute in force in West Virginia.

21. Annual License Tax. - Is the same amount as the organization tax already set forth. It becomes due and payable on May lst of each year. The penalty for not paying the tax before September 1st is $\$ 5$. After September 1st an additional one per cent for each month such failure continues, together with costs of publication, etc., is exicterl (chap. 19, sec. 1 ).

22. Statutory Grounds for Forfeiture of Charter. - The charter may be forfeited on the following grounds:

(1) For failing to have five stockholders for a period of six months (Code, chap. 53, sec. 1i).

(2) For failure to pay license tax (Code, chap. 32, sec. 90, as amended by Laws of 1901, chap. 35 ; Laws of 1903 , chap. 4).

(3) For suspension of husiness for two years (Code, chap. 53, sec. 7).

(1) For failure to organize and commence husiness within one year after incorporation (Code, chap. 53, sec. 6 , as amendel by laws of 1901 , chap. 35).

(5) For misuse o1 abuse of charter (Code, chap. 109, secs. 6-12).

(6) Where the certificate has leen obtained for a fraululent purpose, or for a purpose not anthorized by law (Code, chap. 109. secs. 6-12).

(7) For failure to appoint resident agent as required by law (Code, chap. 54 , sec. 21 ).

23. Amendments. - Charter may be amended for any purpose desired by complying with the provinions of law relative thereto (Code, clap. 54, sec. 10,

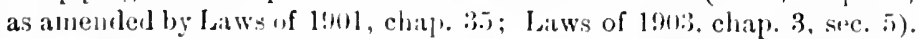

21. Extension of Corporate Existence. - Mity he rxtended upon conlpliance with the statute for an ahlitional period of fifty years (Corle 51 , sec. 11 , as amented ly laws of 1941. chap. :3i).

2.- Dissolution. - A mijority of the stockholders may at any time at a meeting resulve to discontinue the corporate business, aml may divide the

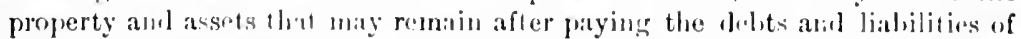

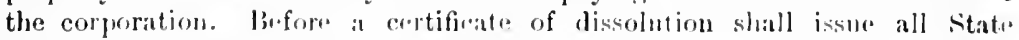
jicense taxes must lo. patil. Not lese than ourethird in intrest of the storkholders of a corporation desiring to wind up its affiars may getition the conrt of chancery in the conuty in which the principal otfice or place of husiness

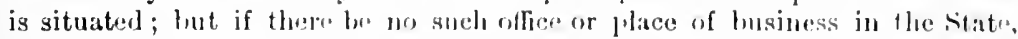
they may petition the circuit court of the county in which the of her stockholders, or any one or more of them reside, stating the grommls of their application. The charter may also be voluntarily surrendered hefore organ- 
ization (Cole, chap. 53. sec. 56; chap. 53, secs. 57-59; chap. 53, sec. 6, as amended by laws of 1901 , ehaly. 35 ; Laws of 190.j, chap. 3, sec. 4).

26. Foi eign Corporations. - Foreign corporations must file in the Secretary of state's utlice and in the oflice of the connty clerk of the county where the prineipal ollice is lueated, a copy of the charter, and a certificate of authority 10 ho business from the secretary of state. It must also file with the secretiry of state a witten acceptance of the condition that it will exercise its powers subject to sime conditions imposed upon tomestic corporations. It must also appoint a resident agent upon whom process may be served, which nust he filed with the Secretary of state and with county clerk on or before March 1st. In executive oficer of such foreign corporitions must file a sworn reprort with the state Auditor showing the name of such corporation, where and when ineorporated, names of oflieers, capitalization, the amount of property owned and used within the State, and the proportion it bears to the total capital stoek. If the corporation has property to the amount of $\$ 5,000 \mathrm{em}$ ployed within the state, it is entitled to pay the same license fee as is imposed on resident domestic corporations. No such corporation, however, shall pay an annual license tax of less than $\$ 100$ (chap. 32 , see. 88 ; chap. 51 , sec. 30 , as aneuded by Laws of 1903 , chap. 3).

Toledo, etc. Co. $v$. Thomas, 33 IV. Va. 566 ; 11 S. E. 37 ; B. J. Co. $v$. Scherr, 510 W. Va. 533; 40 S. E. 514 ; Flogd v. N. L. \& I. Co., 49 W. Va. 327 ; 38 S. E. 653.

\section{WISCONSIN.}

(The references are to the Wisconsin Statutes of 1898 , unless otherwise stated. They are published in two volumes, and are edited and annotated by Sanborn \& Berryman.)

1. Statutes under which Business Corporations may incorporate. - 'The Business Corporation Act is found in the Revised Statutes of Wisconsin (1ऽ98), secs. 1718-1791 in. Special acts are provided for banking, insurance, railway construction and operation compunies, and plank and turnpike roads.

2. Tncorporators. - Three or more. All must be residents of the State (R. S., sec. 1761).

3. Contents of the Certificate of Incorporation. The certificate of incorporation must contain:

a. Purposes. - Any number of the classes specificd (R. S., sec. 1771).

State ex rel. Lederer $x$. Company, 88 Wis. $512 ; 60$ N. W. 796.

b. Name. - Sinilarity of names not forbidden. Cannot use the names of individuals in the manner in which they are ordinarily used in copartnerships (R. S., sec. 1772, sub. 2).

1. O. of F. $v$. Commissioner, 98 Wis. $94 ; 73$ N. W. 326.

c. Domicile. - Location within the State (R. S., sec. 1772).

d. Capital Stock. - Amuunt, number of shares, and par value of same (R. S, sec. 1772).

e. Inirectors and Offeers. - Designation of general officers and number of directrors. There must be at least three directors, and they may be divided into classes if desired (R. S., secs. 1776, 1772, sub. 4).

f. Inties of Officers. - Principal duties of the several officers respectively (R. A. sec. 1772, sub. 5).

g. Memiership. - Method and eonditions upon which members shall be accel,ted, discharged, or expelled (R. S., sec. 1772, sub. 6). 
h. Regulation of Corporate Affuirs. - Provisions for the interests of the corporation, the acknowledgment of the purposes thereof (sec. 1772, sub. 7 ).

Ford $v$. IHill, 92 Wis. $188 ; 66$ N. W. 115.

i. Corporate Existence. - Duration may be inserted if desired; otherwise unlimited.

j. Organization Meeting. - Time and place for first meeting for election of officers (R. S., sec. 1773).

4. Statutory Powers. - In addition to a very full statutory enumeration of the "common laws" and "incidental powers" the act provides for the following additional powers: A limited power to hold stock in other corporations ; to vote by proxy ; to issue preferred stock; to acquire the rights, privileges, or franchises conferred upon any person by the law of the State where the same would be in direct aid of the corporation's business: may establish a siuking fund for the payment of corporate debts, classify directors, and hold stock in cother corporations; may sell all of its property (li. S., secs. $1748,1754,1757,1759$ a, 1760 , 1775 ; Laws of 1899 , chaps. 100, 19s; Laws of 190:3, chap. 12).

N. M. T.S. Co. No. $2 v$. Bishop, 103 Wis. $492 ; 79$ N. W. 785 ; Marvin $v$. Auderson, 111 Wis. $387 ; 87$ N. W. 2.26 .

5. Procuring the Charter. - The articles of association luly signed and acknowledged, or a true copy thereof, verified as such by the allidarits of two of the signers thereof, must be first filed in the ollice of the secretary of State. A like verified copy and certifieate of the secretary of State showing the date when the articles were filed and accepted, must within thirty days thereafter be recorded by the register of deeds of the county where the corporation is located. No corporation shall have a legal existence until such articles have been so left for record. The organization tax must he paid to the Secretary of State at the time the articles are presented to him for filing (R. S., sec. 1773, as amended by chap. 2:35, Session latws of 1901). Iinsiness cannot be commenced mutil one-half of the capital stock is subseribed and twenty per cent paid in (R. S., sec. 1773).

Attorney General 2. Company, 35 Wis. 425 ; B. I'. Co. v. Rose et al., 95 Wis. 145 ; 70 N. W. 302; Slucum $v$. Heatl, 105 Wis. 431 ; 81 N. W. 673.

6. Corporate Indebtedness. - Bonds can only be issued for money, labor, or property estimated at its true money value, equal to seventy-five per cent of the par value thereof (R. S., sec. 17.53). There is no statutory linitation upon the amount of eorporate indehtedness.

7. Organization Tax. - For tiling articles of heet sugar or dairy conpanies, \$10; for filing articles of complanies former for the purpose of mining, smelting, and owning mines and mincrals in the state of Wisconsin. s:-5. if

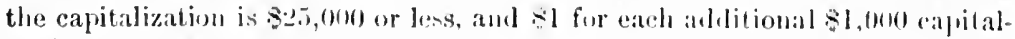

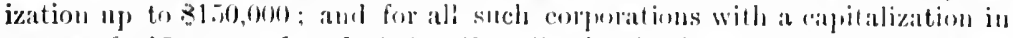

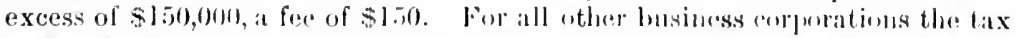
is 825 if the capital stowk is $8.5,000$ or less ; if in exeess of 825.1710 , there is

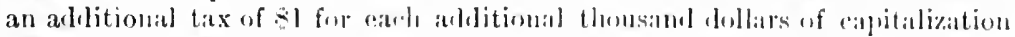

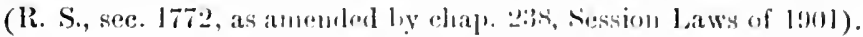

8. Filing and Recording Fees. - There are un fers for filing articles in the ollice of the Secretary of state other than the payment of the oremization tax. For certified copy of anticles of incorporation the charge is 85.

9. Commencing Business. - Corporitions cannot trausact business ex- 
cept with its numbers, mitil one-half of the authorized capital stock is subseribud. and twenty per cent thereof actually pail in (R.S., see. 1773). Business mus be tonsmened within one year after articles are filed (R. S., sec. 1763).

10. Organization Meeting. - Mnst be held within the State. It cannot be hehl mutil one-half of the capital stoek has been subseribed (R. S., sec. 17:3). Fintil organization the incorporators bave by statute direction of the ativits of the conporation (ld.).

lleah r. Company, 39 Wis. 146.

11. Meetings of Stockliolders and Directors. - Stockholders' meetings must he lyeld within the State (R. S., sec. 1762). Directors' meetings maty be held withont the state if the by-laws so provide (R. S., 1776).

'1:. Directors' Qualifications and Liabilities. a. Qualifications. - There must be at least three directors, all of whom must be stockholders (R. S., sec. 17.2. sub. 4, sec. 1776). There are no residential requirements.

b. Linbilities. - Directors are liable for illegal declaration of dividends and for transacting business before one-half of the capital stock is subscribed for, and twenty per cent actually paid in (R. S., secs. 1765, 1773).

Gores 2 . 1)ay, 99 Wis. $276 ; 7+$ N. W. 787.

13. Stockholders' Liabilities. - Stockholders authorizing the transaction of business before half of its authorized capital is subscribed and twenty per cent paid in, are liable for debts of the corporation incurred prior thereto (R. S., secs. $1755,1756,1773$ ). 'They are also personally liable to the amount of the stock held by them for wages due clerks, servants, and laborers, for services performed for a period not exceeding six months in length (R. S., sec. $1769)$. They are also liable for the debts of the corporation to the extent of their unpaid stock subscriptions (Ii. S., sec. 1756). They are also liable to existing creditors to the extent of any diminution of capital stock (R. S., sec. 1755 ; see also Laws of 1901 , chap. 129).

Sleeper $v$. Goodwin, 67 Wis. 577; 31 N. W. 335 ; Clokus v. Company, 92 Wis. 325; 66 N. W. 398.

11. Stock Certificates. - Certificates are ordinarily signed by the president and secretary (R. S., sec. 1751).

15. Preferred Stock. - Provisions may be made for preferred stock either in the charter or by manimous vote of the stockholders at any time thereafter (li. S., sec. 1759 a ; Laws of 1903 , chap. I09).

10. Payment of Capital Stock. - Stock can be issned only for money, labor, or property estimaud at its true money value, equal to the par value thereof. All fictitious increase of the capital stock is roid. An exception is made in the case of stocks listerl on the stock exchanges of New York, Chicago, Boston, and Philadelphia (R. S., sec. 175:); Laws of 1899, chap. 193).

Fir-t Ave. Lam Co. v. Parker, 111 Wis. $1 ; 86$ N. W. 604 ; Shaw $v$. Gilbert, 111 Wis. $165 ; 86$ X. W. 188.

17. Books. - Stock books and books of account must be kept by the corpromion at its principal office in the State (R. S., secs. 1750, 1757). The former are open to the inspection of stockholders and creditors.

1.). Office and Agent. - Every business corporation must have its principal offrce in the State, and its managing officer or superintendent shall also reside ther in (li. S., sec. 1750 ).

19. Reports. - Must within ten days after election of its officers file in :3) 
office of register of deeds of county in which the corporation is located, and where its articles of ince riporation are recorded, a list containing name of its president, vice-presilent, if any, secretary, cashier, or maniging agent, upon whom service of process may be made (R. S., sec. 1775 b).

20. Anti-Trust Statute. - There is a rather stringent anti-trust statute

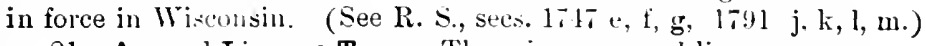

21. Anmua: Iicense Tax. - There is no anumal license tax.

22. Statutory Grounds for Forfeiture of Charter. - The charter may be forfeited for failing to keep' an office and a managing oflicer or superintendent within the State (R. S., sec. 1750); for entering into illenal trusts (sec. $1791 \mathrm{j}, \mathrm{k}, \mathrm{l}$ ) ; also where charter is procured upon some fraudulent suggestion or enactment (R. S., secs. 3240, 3241). If a corporation remains insolvelit or neglects to pay its debts or suspends its ordinary business for one rear, it is deemed to have surrendered its charter, and shall be aljudged to be dissolved (R. S., sec. 176:3).

Phillips $v$. Albany, 28 Wis. 340 ; State $e x$ rel. Cornish $v$. Tuttle, 53 Wis. 45; 9 N. W. 791 ; Attorney General v. Company, 93 Wis. $604 ; 67$ N. W. 1138.

23. Amendments. - Charter may be amended in the following respects: Modification or enlargement of its purposes; changing its name or location; increase or diminish its capital stock ; change its officer's or number of directors, or to provide anything which might have been provided for in its original articles (R. S., secs. 1774, 1790; Laws of 1901, chap. 23s).

Wood $x$. Ass'n, 63 Wis. $9 ; 22 \mathrm{~N}$. W. 756.

24. Dissolution. - Corporation may be dissolved by two-thirds rote of capital stock, at a meeting called for the purpose (R. S., sec. 17s9). The charter may also be surrendered before orgatuizatiou (R. S., sec. 1773).

Hinckley et al. $v$. Pfister at al., 83 Wis. 64; 33 N. W. 21.

25. Extension of Corporate Existence. - There is no provision for ex. tension of corporate existence.

26. Foreign Corporations. - Foreigu corporations must file a copy of articles of incorporation in office of Secretary of State, accompanied by asworn statement of an officer of the corporation stating the proportion of capital stoek represented in the State of Wisconsin hy its property located and husiness transacted therein, and shall pay a fee of $\$ 2.5$ to the State if the eapital stock so represented is 825,000 or less, and an additional 81 for each additional thousand dollars of capital stock (R. S., sec. 1760 a and b, as amemled; Laws of 1901, chaps. 351,399 , and 1:31, sec. 1).

State er rel. Drake v. Duyle, 40 Wis. 175 ; Ashland Lumber Co. 2 . Detroit Salt Co., 114 Wis. $66 ; 89$ న. W. 904.

\section{WYOMING.}

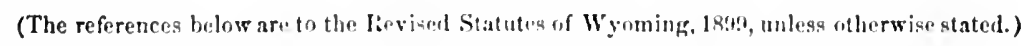

1. Statutes under which Business Corporations may incorporate. -

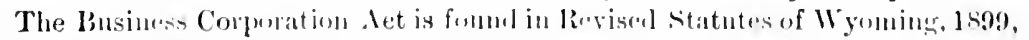

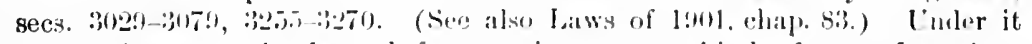
corporations may he formed for calryiur on any kind of manufaetmring, mining, chenical, m.rchandining. "r mechanteal business, constructing wagon 
roakls, lailmals, thengiph lines, digging ditches, building flumes, mining tuntels, denling in real estate or carrying on any husiness designed to aid in the industrial or productive interests of the comntry.

?. Incorporators. - Three or nore. No residential requirements (R. S., see. $302(1)$.

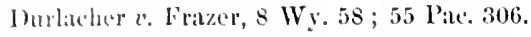

;). Contents of the Certificate of Incorporation. The certificate must set forth:

11. Name. - (Similarity of uames not expressly forbidden by statute, but seretary of State will not allow the use of any name already adopted by an existing domestic corporation.)

1. P'urposes. - Ohject for which the company is formed. Under the Constitution (Art. X. sec. (j) no corporation can have power to transact more than one general line or department of business, which shall be distinetly specified in its charter of incorporation.

c. (ippilul Slock. - Anount thereof (unlimited by law). If preferred stock is to be issued, this must be set forth (R. S., sec. 3042).

d. Durmion. - Term of existence not to exceed fifty years.

c. Numbr of Shares. - Number and par value of shares (par value may be any amount).

$f$. Trustes. - Number and names of the board for the first year.

g. Domiciliury Office. - Name of the town and county in which the operations of the company shall be carried on. Nore than one locality may be named if desired. If it is to transact business outside of the State, this must also be set fortlı (R. S., secs. 3029, 3033, 30:34).

h. If trustees are to adopt by-laws, provision therefor must be made in the certificatts.

4. Statutory Powers. - In addition to a statutory enumeration of the common law powers, the law provides for the following additional powers: 'To hold stock in such other corporations as are subsidiary to and contribute to the objects and purposes of the corporation; to issue prefered stock; to purchase mines, mannfactories, and other appropriate property in exchange for capital stock; to vote by proxy; mining conpanies may construct and operate railways, tramways, and wagon roads for their own particular purposes; to transact business ontide of the State (R. S., secs. 3032, 3034, 3035, 3040, $: 3041,: 3014,3059,: 3078,: 3079)$.

5. Procuring the Charter. - The incorporators must sign and acknowledge duplicate certificates of incorporation before some officer competent to tak acknowledintents. (ne of these must be filed with the county clerk of rach comnty wherin the business of the corporation is to be carried on. The other must be filed in the office of the Secretary of State, to whom the organization tax must first be paid. After the secretary of State has filed and recorled the same in his oflice, corporate existence commences. Within ninety lays after filin' certificate of incorporation with Secretary of State an additional certificate inust be filed with same official signed by the president or secretary lesignating the location of the domiciliary office and the name of the agent in charge thereof and upon whom process may be scrved (R. S., sec. 3029, 319:30, :3132; Laws of 1903, chap. 53).

(j. Corporate Indebtedness. - The indebtedness shall at no time exceed amount of the capital stock (R. S., sec. 3049, 3053).

7. Organization Tax. - Capital stock not exceeding $\$ 5,000$, $\$ 5$; over 394 
$\$ 5,000$ and not exceeding $\$ 100,000, \$ 10$; over $\$ 100,000$, $\$ 10$, and 5 cents additional for each $\$ 1,000$ in excess of $\$ 100,000$ (sec. 3030 ).

S. Filing and Recording Fees. - The payment of the organization tax includes filing and recording fees of the Secretary of State. The fee for recording in local county office approximates $\$: .50$. For filing certificate of agency, \$2.50. (See sec. 30.31.) To secretary of state for issuing certified copy of articles where copy is furnished, s1. (See Laws of 1899 , chap. 69.)

9. Commencing Business. - May commence business as soon as certifieate of incorporation is filed and recorded in the office of the secretary of State (R. S., sec. 303:). $3036)$.

10. Organization Meeting. - Should be held within the State (secs. 3035,

11. Meetings of Stockholders and Directors. - The act does not authorize meetings of stockholders to be held without the State. Directors' neetings may be held wherever the by-laws prescribe (R. S., secs. $80: 35,3036$ ).

12. Trustees' Qualifications and Liabilities. a. Quzalifications. - There must be at least three and not more thin nine trustees. All must be stockholders. There are no residential requirements (R. S., sec. 30:35).

b. Liabiities. - Trustees are personally liable for payment of corporate debts, where they participate in an illegal declaration of a dividenl, or in the creation of corporate indebtedness in excess of the capital stock (R. S., secs. 3045,3019 ).

13. Stockholders' Liabilities. - Stockholders are only liable to creditors for their unpaid stock subscriptions (li. S , sec. 3045 ).

14. Stock Certificates. - Must be signcd by such officers as the by-laws prescribe.

15. Preferred Stock. - May be provided for in the certificate of incorporation, or may be issued thereafter by the unanimous consent of all the stockholders (R. S., secs. 3041, 3012).

16. Payment of Capital Stock. - Capital stock may be issued in exchange for mines, manufactories, and other necessary property to the amount of the value thereof. 'The act specifieally provides thit stuck so issued sluall be taken to be full stock, and the holders thereof shall not be liable thereon either to the corporation or to creditors (R. S., sec. 3016). Mithin thirty days after the payment of the list instahnent of capital stoek the president and a majority of the trustees must make record in the oflice of the register of deeds of the county where the principal lusiness is carried on, a certificate stating the amonnt of the capital so fixed and pail in (R. S., soe. : $: 017$ ).

17. Books. - Tlere is no provision as to what books must he kipt other than the strek bork (R. S., s.c. 30.5.). Filtern per cent of the stocklolilers may demand a statement of the comprany's affatirs from the treasurer (R. . ., sec. 3057 ).

18. Office. - The corporation unst maintain an oflice within the state (R. S., secs. 302!, 30:3:3, 3(1:31).

19. Reports. - Thro ape no anmual reports to lo mates. Statement of

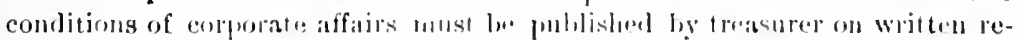
quest of fifteen per cont of stockliolilers (li. S... sece. 301.5 ).

20. Anti Trust Statute. - Throre is 110 anti trust stitute in foree in

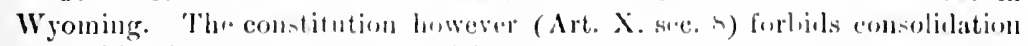
or combination to prevent rompertitim, ate.

21. Statutory Grounds for Forfeiture of Charter. - The charter may be forfeited for nom-user am misusel of its corpurate franchises and privileges 
(I. S., sec. 1:31). Also for failing to file certificate of agent and place of business (laws of 1903, chap. 53).

2:-2. Amendments. - The chirter may be anended by complying with - the provisions of the act in that respect as follows: Change of name, change in numbler of trustees, increase or decrease of capital stock; to extend or change the corporite busine's (R. S., secs. 3029, 3053-3056).

23. Annual License Tax. - There is no annual license tax.

24. Extension of Corporate Existence. - No provisions for this in the act.

25. Dissolution. - By a termination of its period of existence; and voluntarily by a two-thirds rote of the stockholders, whereupon the trustees become trustees for the creditors and stockholders (R. S., secs. 3255-3264 inclusive).

Inter. 'Trust Co. v. Company, 3 Wy. $803 ; 31$ Pac. 408.

26. Foreign Corporations. - Must file with the Secretary of State and register of deeds copy of charter, or, if incorporated under general law, copy of certificate of incorporation and of such incorporation law, and appointment of agent mpon whom service of process may be made. They must pay same tax for filing certificate as is required of domestic corporations. No annual license fee and no reports to make (R. S., secs. 3265-3270 inclusive). They must also accept the provisions of the Wyoming Constitution (R. S., sec. 3058; see also Laws of 1901 , chap. 83 ).

\section{SUPPLEMENT TO PART II.}

\section{DOMINION OF CANADA.}

1. Capital Stock. - May be any amount. Par value of shares may be any amount.

2. Duration. - Charters are all of perpetual duration.

3. Application for Charter Patent. - Must set forth: Corporate name; purposes; location of business in Canada ; anomnt of capital stock ; number of shares and par value of each ; name, address, and business of each incorporator: names of provisional directors from among the incolporators; anount of subscriptions and amomt paid thereon by each incorporator, how pail, and how held for the company.

4. Commencing Business. - A notice giving short particulars of the company must first be published in the Canadia Gazette. The application for letters fatent may be presented one month after expiration of such notice, and must he signed by at least five persons and filed with the Secretary of State, who must issue letters patent to the company before it can commence business. Application is accompanied by an agreement in duplicate under seal, l, wween the incorporators, giving name of company, capital stock, shares and value of each, and covenanting to subscribe and take the respective ammmat of stock set oplosite their names. No definite amount need be subseriber or paid in lefore obtaining charter. Before commencing business ten fer crent of the authorized capital stock must be subseribed and paid in. Notice of granting charter is published twice in the Gazette.

5. Payment of Subscription. - May be made in money or property. 3945 
6. Cost of Incorporating. - Organization fees are: For capitalization less than $\$ 20,000, \$ 50$; over that and less than $\$ 50,000, \$ 150$; to less than $\$ 100,000, \$ 200$; to less than $\$ 150,000, \$ 225$; to less than $\$ 200,000, \$ 250$; to less than $\$ 300,000,83110$; to less than $\$ 100,000$. $8325 ;$ to less than $\$ 500.000$, $\$ 350$; to less than $\$ 600,000,8375$; to less than $\$ 700,000,8100$; to less than $\$ 800,000, \$ 425 ;$ to less than $\$ 901,000, \$ 150$ : to less than $\$ 1,000,000$. \$175; when $\$ 1,000,000, \$ 500$; for every additional million dollars or part thereof, $\$ 100$. For increase of capitalization, fee is as above, but on increase only. Publication of notice, sit to $\$ 10$.

7. Annual License Fee. - There are no annual license fees exacted by the Dominion fovermment.

8. Amendments. - Imendments to charters can be obtained by supplementary letters patent on petition to the Secretary of State when authorized by a resolution of two-thirds of the subscribed stock.

9. Incorporators. - Must be at least five, with no restrictions as to sex, nationality, or residence.

10. Directors. - Must be not less than three and not more than fifteen. They must be stockholders. No restrictions as to residence.

11. Meetings. - Stockholders' meetings must be held within the Dominion, but lirectors' meetings need not be.

12. Books. - The books of the company must be kept at the head office.

13. Reports. - Cpon the written request of Secretary of State, a refum must be made to him of amount of cayital of the company: number of shares taken from the commencement of the company: amount of calls made: amount of calls received: amount of calls umpaid: amomt of slares forfeitel; names, addresses, and occupations of persons who have ceased to be nembers within the preceling twelve months, and number of shares held by each.

14. Office and Agent. - Must have desigmated office in the Dominion of Canada. It may have a branch ollice located outside of the Dominion.

15. Liabilities. - Stockholder's are liahle only for the umpaid balance of their shares.

16. Dissolution. - The company may dissolve by a resolution of the sharelooders passecl at a special mecting.

17. Foreign Corporations. - Are governed by the Dominion and the respective Provincial laws.

\section{MANITOBA.}

Under the laws of the Province of Manitoha, the requirements in connection with incorporation aud manarement are, sucrinctly stated. sulstantially as follows:

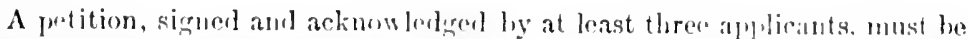

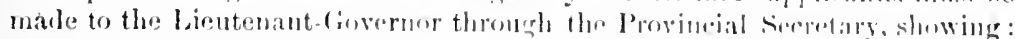

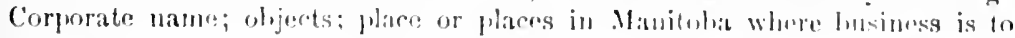
be carried on, specially mentioning one of such places as the ching place of

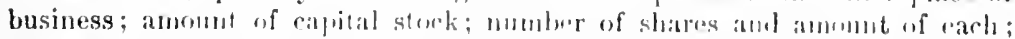
names with adluess and ralling of each applieant, will speribl mention of names of not less than three nor more than nine of them who will be first

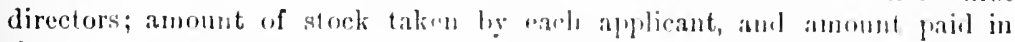
thereon, and whether pail in east meprerty, or how otherwise. No adver- 
tisement of intention to incorporate is necessary. The fees for incorporating, lidil to the goverument, range from \$15 where capitalization does not exceed $\$ 5,0(4)$, to $\$ 200$ for one million capitalization; all over that, \$250. No paymont on stock is necessary at time of incorporating. Stock may be paid for in money or property. The directory is composed of at least three and not over nine members. Sharcholders may be residents in or citizens or subjects of iny country or State. Before commencing business ten per cent of the capital stock must be subseribed aud ten per cent of subscriptions paid up. No residential requirements as to incorporators, directors, or stockholders.

Foreign Corporations. - Must take out a license to do business in the l'rovince. hy tiling a petition, with certified copy of the act of incorporation; a copy of the last fiuancial statement of the company's proper officer; an athilarit verifying that the company is entitied to do business; and an attorney resident in the province must be appointed to represent the company in all suits aml actions. A fee of $\$ 150$ must be pail to the government, regardless of amount of capitalization. There are also fees to be paid under the Corporation Taxation Act, accolding to the character and the amount of its capital stock.

\section{HAWAII.}

1. Capital Stock. - May be any amount. Par value of shares may be any amount (C. I., secs. 2031, 2032).

2. Duration. - Any perior not exceeding fifty years (C. L., sec. 2035).

3. Articles of Incorporation. - For joint-stock companies, must show : Name, to be followed by word "Limited"; place of principal office; purposes; amount of capital stock, and if privilege of subsequent extension of capital stock is askel for, the limit of such extension; number and designation of officers proposed. Articles must be signed and acknowledged by incorporators, and recorded in office of Secretary of 'Territory. An affidavit sworn to by president, secretary, and treasurer, showing number of shares, amount of capital stock, names of subscribers for shares and amount paid in, must be filed with Territorial Secretary; and when object of the corporation is to take over anl conduct any existing business or enterprise, etc., the affidavit must describe property representing capital stock of company, a valuation of each item thereof, and copy of conveyance to be made by owner to the proposed corpolation (C. L., secs. 2031-20:34).

4. Amendments. - ('harters may be amendel, hut not beyond powers contained in original charter (C. L., sec. 204:3). They should be approved by all stoeklonders mless the by-laws otherwise provide (7 Haw. Rep. 779).

5. Incorporators. - Any number not less than five (C. L., sec. 2031).

6. Meetings. - May be held at place or places designated in the by-laws (2) Haw. liep. 22).

7. Directors. - As provided in the by-laws. The statute does not seem to specify as to the number.

8. Books and Records. -- Original articles shall during business hours be open to inspection of public in office of Territorial Secretary (C. L., sec. 2(1:3:3). Territorial secretary may call for and examine corporate books and papers (.lct of June 29, 1898, sec. 4).

9. Office and Agent. - The company must maintain an office within the Territory (C. L., sec. 20:2).

$$
398
$$


10. Liabilities. - Stockholders are liable only to extent of amount unpaid on stock (C. L., sec. 2018).

11. Reports. - The corporation shall annually, on July 1st, present to Territorial Seeretary an exhibit of its affinis (C. L., sec. 2024.)

12. Dissolution. - Three-fourths of stockholders, at a meeting called for the purpose, may petition for dissolution of corporation by Territorial Secretary (C. L., sec. $: 022$ ).

13. Foreign Corporations. - In order to do business or hold realty in Hawaii, corporation shall file with Territorial Secretary certified copy of charter or act of incorporation, and certificate stiting names of its oflicers, and name of person upon whom legal notices and process may be served; also certified copy of by-laws; and shall pay a fee of $\$ 50$ to Territorial Secretary (Act of June 12, is9s, secs. 1, 2).

\section{PHILIPPINES.}

The Philippine Civil Commission has now under advisement and preparation a local corporation law which will probably be enacted early in 190.;. For a foreign corporation to do business in the Plilippines it is necessary to comply with the provisions of the Corle of Commerce (Arts. XV., Xil., XXI.). The requirements stated therin, so far as they relate to obtaining a permit by foreinn corporitions to do business in the Philippine Islands, are as follows :

(1) The corporation must he a commercial association within the meaning of the Code of Commerce of the Philippine Islands, and as sucl be subject to its provisions.

(2) That by reason of its domicile in the Lnited States it stiuds in the same relation to the laws of these islands as did Spain before their cescion. (See also Ait. XV. of the Corle of ('ommerce.) Art XXI. of the C'ode of Commerce provides what forrign eorporations must do who desire to estahlish themselves or ereate business in the Ihilippine Islands. Art. XVil. of Code of Commerce provides how they shitl he registererl.

It is necessary to have a Spanish comsular certifieate for their establishment and anthorization.

The Register, known as the Commercial Register, at Manila, consists of two independent books of record in which are recorled private merchints and associations.

Art. XXI. of Corle of Commere provinles that " $O$ ) the sheet of the reeori of each merchant there shall be entered:

"1. Nanne, firm nam. or title.

“2. The kinl of commere or transadion engined in.

":3. The date on whinh business is fo herin or was leerun.

"4. Th" somicile, with a statenent of the branches which may have been establisluenl.

“5. The altinles countituting a rommoreial assoriation, whatsorver may

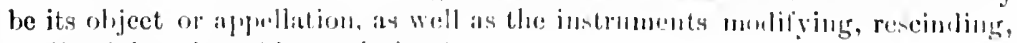
or dissolving the siatl itsueciation"

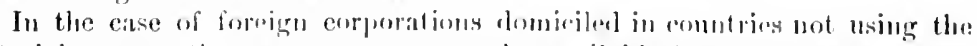

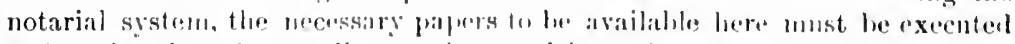

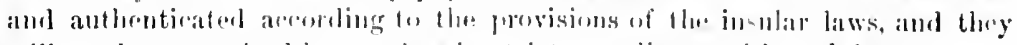
will not be recognized here muless in strict compliance with sheh laws. 
For the registration of a company organized in the United States to do business here there would be required:

(1) The sevoral acts of the leristature which constitute the charter, each of which must have attached the ordinary certificate of the Secretary of State maker his ollicial seal.

(II) The evilence of the organization of the company under its eharter, the hest attimable, such as would he necessary to pove the facts in the State courts. The best evidence wonkl probaluly be the documents showing the "prening of hooks for subscription, the names of subscribers and the proeedings thereat, the issue of shares, the filing of certificate of amount paid up, and atl the formal papers and proceedings required in organizing under the charter and under the provisions of the corporation and laws applicable under the terms of the charter.

liefore the cession of these islands this certificate, for nse in Spanish colonies. to register a corporation domiciled in Spain, was given by a Spanish minister. By analogy, this now being a United States colony, the certificate woull be given by the similar Member of Cabinet of the United States, but owing to the difference of political organization, that officer is not vested with power in such cases.

So far as we have been able to ascertain no provision has been made for the sulstitntion of any authority in the Uniter States to supply this certificate, and that is the reason why the documents and facts showing the establishment and authorization should be set ont in such manner as to enable some proper officer in the domiciliary State to make the certificate which in such case the secretary of War could authenticate as entitled to full faith and credit.

(III) The by-laws of the company and all ehanges therein.

(IV) All additional issues of stock, and all the matters embraced within Art. XXI. preseribing what is necessary to be recorded. (See also Code of Civil l'rocerlure, sees. 299, 301, :39:3, 31:3.)

In arldition to this a power of attomey conferring upon a resident agent such power as is desirel, is necessary. It must be in Spanish and earefully drawn and authenticated, and it must expressly confer power to register the company in the Commercial liegister at Manila. The power must contain or have annoxed thereto by the notary the resolution of the board of direetors authorizing the execution of the power by the officers appearing before the notary for that purpose.

All documents must be translated from English into Spanish before they can be registered, and the cost is $\$ 1$, Cnited states currency, per page for translation. The registry fees are nominal.

\section{PORTO RICO.}

1. Capital Stock. - May be any amount not less than $\$ 2,000$

2. Duration. - Any number of years.

3. Certificate of Incorporation. - Must state: Name; location of principal office in Porto Rico; purposes; amount of capital stock; nu nber of shares, and par value of each; amount of paid in capital (not less than $\$ 1,000$ ), with which it will commence business; names aurl addruses of incorporators; number of shares subscribed by and amount paid in by each. Articles must 
be signed and acknowledged by the incorporators, and filed in office of Secretaly of Porto Rico.

4. Commencing Business. - At least $\$ 1,000$ of capital stock must be paid in before commencing business.

5. Cost of Incorporating. - Simply the legal fees to Secretary of the 'Territory for filing and recording articles and issuing certificate of incorporation.

6. Annual License Fee. - There is none.

7. Amendments. - Articles may be amended in all respects, upon resolution of board of directors, and rote of two-thirds of the stock.

8. Incorporators. - Must be three or more persons of lawful age. No residential requirements.

9. Directors. - Must be at least tluee, one of whom must reside in Porto Rico.

10. Meetiugs. - Must be held at the principal oflice in Porto Rico.

11. Reports. - No reports are required to be made.

12. Books. - Stock and transfer books, open to inspection of sharcholders and others interested, must be kept at the principal oflice; and ten days before election of directors or officers a list of stockholders entitled to vote nust be made and be open to inspection of stockholders.

13. Office and Agent. - A principal oflice must be maintained in I'orto Rico, with an agent in charge. stock.

14. Liabilities. - Stockholders are liable only for amount unpaid on

15. Dissolution. - Voluntary dissolntion may be had by resolution of the directors, and by written consent of two-thirds in interest of stockholders.

16. Foreign Corporations. - 'There seems to be no law pertaining to Porto Rico regulating foreign corporations. 



\section{PART III.}

\section{FORMS AND PRECEDENTS.}

\section{SPECIFIC OBJECT CLAUSES.}

\section{INI) E X.}

Form

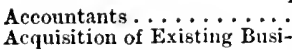

ness $\ldots \ldots \ldots \ldots \ldots \ldots \ldots$

Advertising $\ldots \ldots \ldots \ldots \ldots$

Air Brakes ...........

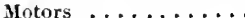

Power . . . . . . . . . .

Aluninum Goods ........

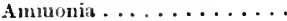

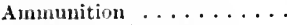

Amisement Company ....

Ang ora Go.ts ........

Animal Fanciers.......

Apartinent 11 ouses ......

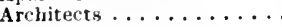

Asphalt ...........

Aullitors. See Form 1.

Antromobile $3 \ldots \ldots \ldots \ldots$

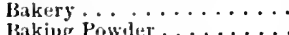

Ballot Boxes ...........

Banking and Trust Cour

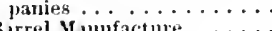

Birrel Misufactire .....

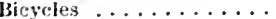

Bi rouit Comprany .......

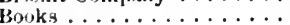

Borts and Slues . . . . . . .

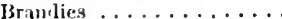

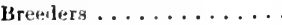

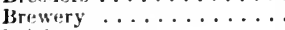

Brick

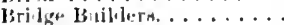

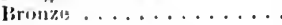

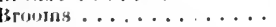

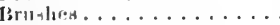

Builling Contravturs.....

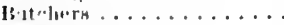

biltons

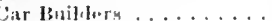

Cагlun Furian. .......

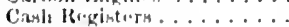

Cattl:

Comptum

Cormal

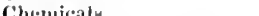

Cigurs.

Clething Mandarturers

Coal

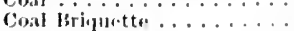

Conal Transportation ('un.

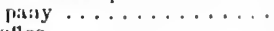

Coll string. . . . . . . .

Colonization Comprany ...

Form | Form Commercial Colmpany.... 53 Hotel Company ....... 107

Juspecti in of Elevators.

vators ... 109

3 Constrution Company . . . 50; Insmrance . . . . . . . . 111

4 Contracturs and Builders... $5 i$ Investment .......... 11 I

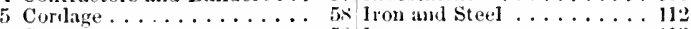

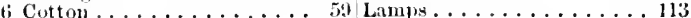

7 Cotton Brokers ......... to to Lumb and Developinent Com-

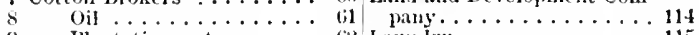

9 Plantations, ete. . . . . fiz Lamudry . . . . . . . . . 115

11) Cut]ery ........... (i3 Letd Company . . . . . . 11tj

11 Dairy Products ... . . . . . lit Leather . . . . . . . . . 117

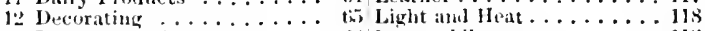

13 Department Stores ...... diti Locomobiles . . . . . . . . . . 11!

14 Distillers............ ti L Lumber and Nursery . . . . . 1:21

15 Dock Compatiy . . . . . . . th Marhuery . . . . . . . 121

16 Dredging . . . . . . . . 6. Magazines . . . . . . . 122

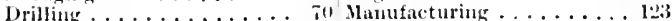

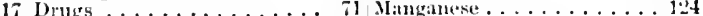

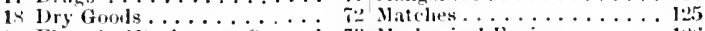

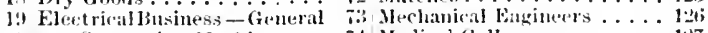

20 Generating Machinery . it Medienl Collige ........ . .27

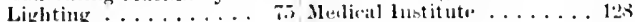

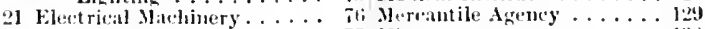

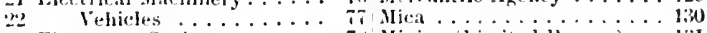

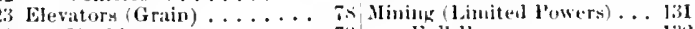

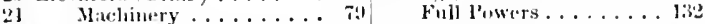

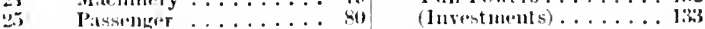

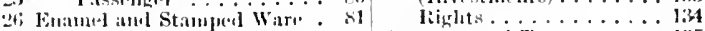

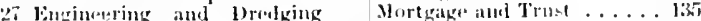

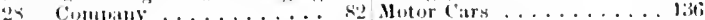

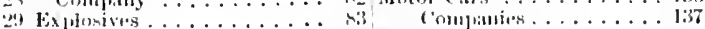

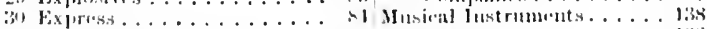

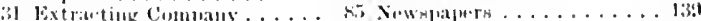

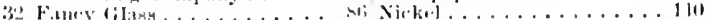

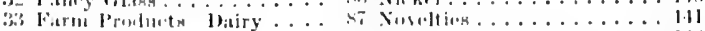

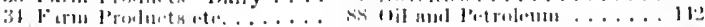

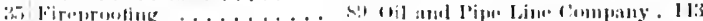

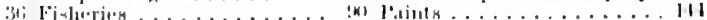

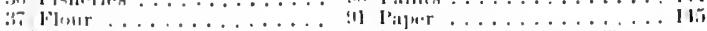

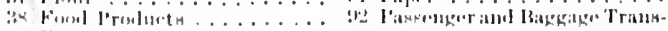

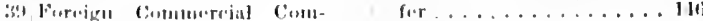

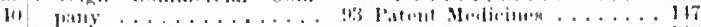

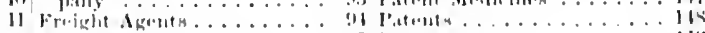

12 Frut rompany .......

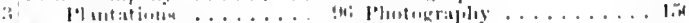

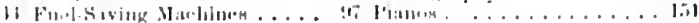

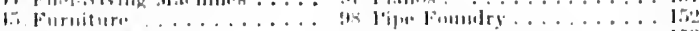

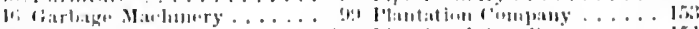

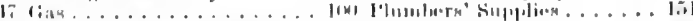

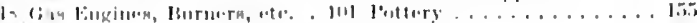

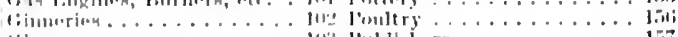

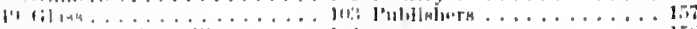

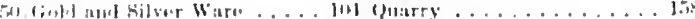

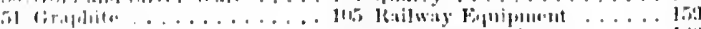

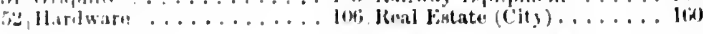




\begin{tabular}{|c|c|c|}
\hline $\begin{array}{l}\text { Furm } \\
\text {. litil }\end{array}$ & Stationers ........... & Train Control \\
\hline 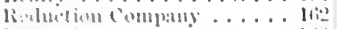 & steimbuats ......... 1s'2 & Trumeportation Company. \\
\hline lientineriess ........... 1ti3 & Siterel litth and riroprouting & Tropical 'T'athing Company \\
\hline kistintulatuls..... & l'mulpilliy $\ldots \ldots \ldots . . . .183$ & Trust Cinupuny ........ \\
\hline 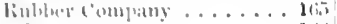 & Stend Nounfacture ...... Ist & Turbius Fingines. \\
\hline cislt ............... ltiti & Stcrenplicen Maclatues ... Isin & Typesetting Machines \\
\hline$\ldots \ldots \ldots 11 i_{i}$ & Stevedores $\ldots \ldots . . . .$. Isti & Typewiters...... \\
\hline 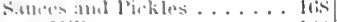 & Stock brokers . . . . . . 1si & Valve Company .. \\
\hline Mills ............ |(tit) & Storago biateries ....... Isis & Farnisl Removers. \\
\hline si:aling . . . . . . . . . 170 & 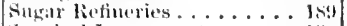 & Warehousey's .... \\
\hline r:alors ...........171 & Sturgical Instruments .... 1!H & Watches nad viamonds . . . . c00 \\
\hline 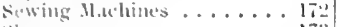 & Tatilors............. & Water, Liglit, l'ower, and \\
\hline Sherepl........... 173 & $\ldots 1 ! 2$ & Traction Company ..... 210 \\
\hline ship dinileding . . . . . 17.t & Tat Manufaturing . . . . . . 193i & Water Heaters........ \\
\hline silk $\ldots \ldots \ldots \ldots \ldots$. 175 & Thlegraph and Telephone & Watur Works ... \\
\hline Slate and Tile $\ldots . . . . . .17 i$ & 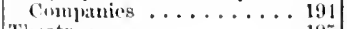 & Weigling Machines.. \\
\hline Slompliter-llouses ....... 177 & Theatres $\ldots \ldots \ldots \ldots$. 19. & Wharf ame Warehouse \\
\hline Slut Inohimes ......... 17 & 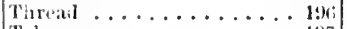 & Woollen and Worsted. \\
\hline 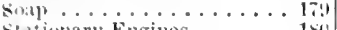 & Tobaceo . . . . . . . . . 197 & Yarn Mill ........... \\
\hline Shationary Engines ...... & Cors 1940 & \\
\hline
\end{tabular}

\section{FORM I. - ACCOUNTANTS.}

To open, take charge of, examine, iuspect, and andit books of account; to ecrtify to the results of such exannination, inspection, and audit, and to guaranty the correctness of the same. 'To furnshl facilities to individuals, firms, and corporations for opening sets of books of account and for auditing and balancing the same. (See 1. 550 .)

\section{FORM 2. - ACQUISITION OF EXISTING BUSINESS.}

To purchase, arquire, and take over the business and property, both real and personal, name ind assets of every nature and description of the business now being curricd on by in the city of State of

\section{FORM 3.- ADVER'TISING.}

To carry on a general advertising business in all its various branches; to solicit and contrict for and give publicity to all hinds of advertising; to preparc, mannficture, construct, and arrange for advert ising devices, aldvertisements, and novelties. To erect, eonstrnet, puschisse, lease, or otherwise aequire fences, bill-boards, signboarels, buildings, and other structures suitable for advertising purposes. To do a general bill-posting, sign-tacking. eircularizing, and distributing business of every kind appertaning to any and all kinds of advertising.

\section{FORM 4.-AGRICULTURAL IMPLEMENTS.}

To carry on the business of manufacturers and dealers in agricultural implements; to iramufacture, bny, sell, export, import, and generally deal in harvesters, binders, reapers, mowers, harrows, hay racks, headers and shredders, cutters, binding machines, threshers, drillers, seeders, and agrienltural tools and implements of all kinds, and such other goods, wares, and merchandise as are nsually manufactured or sold, exported or imported, and dealt in by manufacturers and dealers in a similar line of business.

\section{FORM 5. - AIR BRAKES.}

To carry on the business of manufucturers and dealers in air or pneumatic brakes and braking devices and appliances of every description; to manufacture, buy, sell, export, import, and generally deal in air or puemuatic braking deviecs and appliances, en tracks, railway appliances and supplies, machinery and appliances if every deseriphion. Also, fo manuficture, buy, scll, export, import, and erverally deaf in compressed air machinery and parts, and to acquire by purchase or ollorwo inventions, patents, licenses, and patent rights, and such brakes, braking Arvices, railway machinery and appliances and compressed air machinery and apfratus as may he manufactured, longht, sold, imported, exported, and dealt in by manufucturers and dealers in a similar linc of business. 


\section{FORIS AND PRECEDENTS.}

\section{FORM 6. - AIR MOTORS.}

To manufacture, construct, purchase, or otherwise acquire, deal iu, sell, hire, lease, use, repair, operate, and maintain machinery, engines, compressors, or motors, tools, derices operated by eompressed air or other expansible thids, apparatus and appliances of any and every eliarieter.

\section{FORM 7.-AIR POWER.}

To manufacture, buy, scll, import, export, and generally deal in air compressors, machinery and apparatus usetul or convenient for use in connection with the aforrsaid business or any part thereof ; to purchase or otherwise aequire, sell, lease, ex'port, or import maehinery, engines, truehs, and ears suitable for use in comnection with the aforesaid line of business or any part thercof.

\section{FORM 8. - ALUMINUM GOODS.}

To maufacture, buy, sell, export, import, and geue rally deal in aluminum goods, and such other grools, wares, and merehindise as are usually manufaetured. bonght, sold, exprorted, or imported and deal in by manufacturess and dealers in a simitar line of business. 'To earry on the business of mining, milling, eonecutrating, eonverting, smelting, treating, preparing for market, manufacturing, buying, selling, and otherwise producing and dealing in aluminum and other products.

\section{FORM 9. - AMMONIA.}

To prepare, distil, manulicture, buy, sell, and generally deal in ammonia and such olher products as are usmally distilled. manufactured, bought, sold, and dealt in by manulacturers and dealers in a similar line of business.

\section{FORM 10. - AMMUNITION.}

To manufacture, buy, sell, export, import, and geuerally deal in gumpowder, shont, bullets, eartridges, shells, explosives, and such onher goods, wares, and merchandise as are usually manulientured, bought, sold, exported, imported, and dealt in by dealers in a similar line of business.

\section{FORM 11. - AMUSEMENT COMPANY.}

To build, buy, lease, or otherwise arcquire, own, operate, and maintain morry-go-

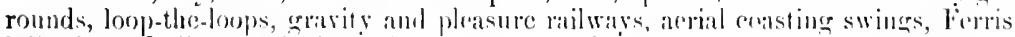
Wheels, and all other devices of a like nature cialenilated to offer amusement to the

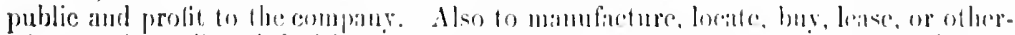

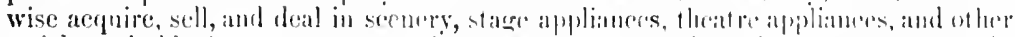

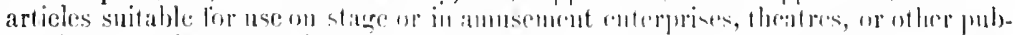

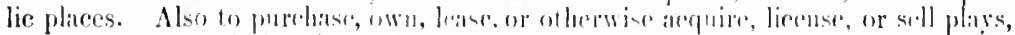

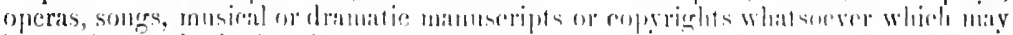

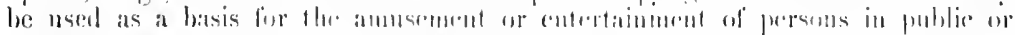

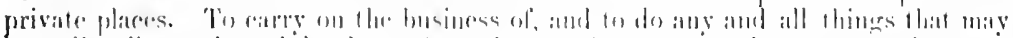

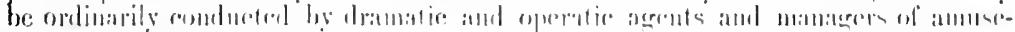

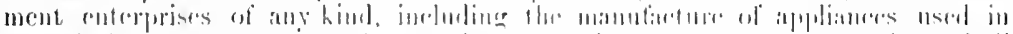

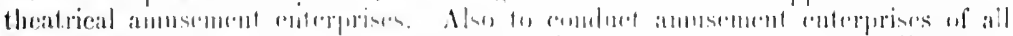

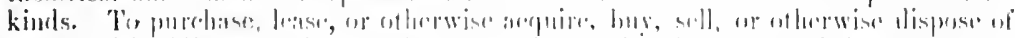

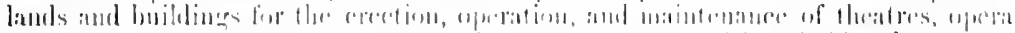

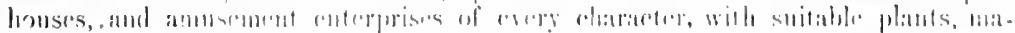

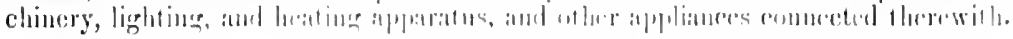

\section{FORM 1:-ANGORA GOATS}

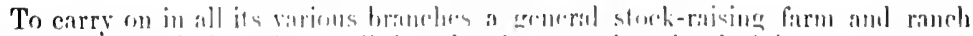

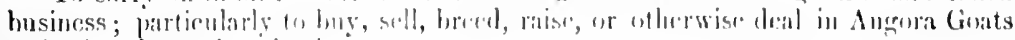
and other domestie animals. 


\section{FORM 13. - ANIMAL FANCIERS.}

T' bur, soll, impur, export, and generally deal in all kinds of animals, domestic

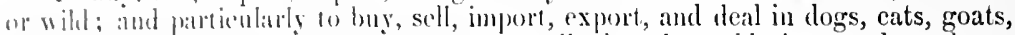
birke, and such uther animals as anc usually bought, sold, imported, and cxjurted by dealers in a similar line of business.

\section{FORM 14. - APARTMENT HOUSES.}

Tw ereet, build, equip, operate, maintain, buy, and sell apartment houses; to supply electricity for lighling, licating, power, signalling, and other purposes. 'To construet, own, and operate electrie telephone exchinges.

\section{FORM 15. - ARCHITECTS.}

To conduet, manare, and earry on the businesses of architects and engincers in all or iny of their respective brimehes, and also the development of real estate sitnate in the State of or elsewhere; to make eontracts for the preparation of plans or other drawings and specitieations of huildings or parts of buildings of any kind and deseription; to superintend the construetion thereof and to do any and all arets in the line of the businesses of arehiteets and enginecrs which it may deem neressiry, protitable, or desinible for the promotion of its business. 'To acquine by pureliase or oflerwise own, hold, buy, sell, convey, lease, mortgage, or encumber real estate ineluding quary lands or other property, personal or mixed. 'T'o surver, subdivide, plat, improve, and derelop lands for purposes of sale or otherwise, and to do and perform all things necdful and lawful for the development and improvement of the same for residenee, tracle, or business. 'To aequire to the same extent as matural persons and without limit as to anomnt, by purehase, lease, exchance, hime, or otherwise, linds, improved or mimproved, tencments, hereditaments, chattels, real or personal, or any interest therein; to ercet and construct louses, buildings, and works of every deseription on any lands of the company or npon any other lands; to rebuik, enlarge, alter, or improve existing houses, builkings, or works thereon; to subdivide, improve, and develop lauds for purposes of sale or otherwise; to eonvert and appropriate any snch land into and for roads, streets, and other eonveniences, and to do and perform all things needful and lawful for the development and improvement of the sime, and generally to deal with and improre the property of the eompany and of other parties; to own, hold, and maintain any property acquired by the eompany; 10 scll, convey, lease, release, let, exehange, mortenge, or otherwise cncumber or rlispose of lauds, louses, buildings, herefitiments, itppurtenances, chattels, and other property of the eompany; to equip, furnish, conduet, operate, manage, lease, and maintain hotels, apartment houses, boarding houses, dwelling houses, saniturimus, warehouses, or any kind of building for dwelling. amusement, recreation, charitable, or religious purposes; to undertake or direct the management and sale of the property of the company, real and personal ; to sell, assign, release, hold, or satisfy mortgages which may become the property of the company ; to lom on bond or mortgage or otherwise, or to advance money to, and to enter into contracts and arrangements of all kinds with contractors, laborers, skilled or wherwse, builders, property owners, and others.

\section{FORM 16. - ASPHALT.}

To mine, manufacture, protuce, prepare, buy, sell, cxport, import, and generally deal in arphalt, roment, and such other produets as are usually dealt in by dealers rngarged in a sinilan line of husiness; to manufaeture, produee, prepare, export, inprot, and deal in any proluet in the manufacture or composition of which asphalt or cement is used; to prospect for and locate lands suitable for elearing and mining all kinds of minerals, strne, and other products; also to enter into contracts for the paving, repairing, and improving of streets, alleys, and arcas in and about public or jrivate buiktings or grounds.

\section{AUDITORS. See ACCOUNTANTS, FORM 1.}




\section{FORIS AND PRECEDENTS.}

\section{FORM 17, - AUTOMOBILES.}

To manufacture, buy, sell, import, export, and generally deal in all hinds of vehicles, engines, machines, or apjlianees for the generation of steam, electrie, gasolene, or other power for the purpose of propelling cars, carriages, wagons, trueks, and rehicles of every hind and deseription; and also to manufacture, buy, sell, import, export, and generally deal in machinery of all kinds and such mechanieal devices and engineering appliances as are greneralls mamulietured, bouglit, sold, exported, imported, and dealt in by manutaeturers, and dealers in a similin line of busincss.

\section{FORM 18. - BAKERY.}

of

To earry on the business of bakers in all its rarious branclies in the eity and ricinity; to mannfacture, make, purchase, sell, export, and import bread, crackers, biscuits, cake, sweetmeats, and confectioners of all kinds; also to manufacture, bus, sell, import, export, and gencrally deal in baking powders, reasts, cream of tartar, and all other articles which may be neeessary or con reniently used in connection with the aforementioned business or businesses.

\section{FORM 19. - BAKING POWDER.}

To carry on the business of manufacturers and dealers in baking powder and its ingredients. 'To manufacture, bur, sell, export, import, and generilly deal in baking powder and all the ingredients, whether chemical or otherwise whieh are or may be eomponent parts of baking powder, and to manufature, bus, sell, export, import, and generally deal in sueh other goods, wares and merehandise as are made or carried by manutacturers and dealers in al similar line of business.

\section{FORM 20.- BALLOT BOXES.}

To manufacture, buy, sell, lease, export, import, and gencrilly deal in articles commonly known as roting or ballot boxes, and particularly to purehase of otherwise acquire letters patent of the United States or of foreign countries governing the manulacture of such roting or ballot boxes, together with all extensions and rencwals of the same.

\section{FORM 21.-BANKING AND TRUST COMPANIES.}

To earry on a banking and trust emupany husiness and in eonneetion therewith

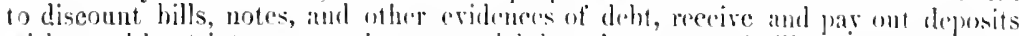
with or without interest, reeeive on spreial deposit money or bullion or foreign eoin, stocks, bonds, or otleer scentities; to huy and sell forcion and domestic exchange,

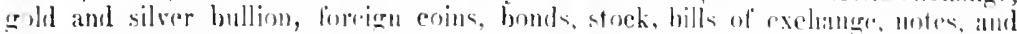

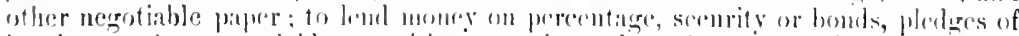

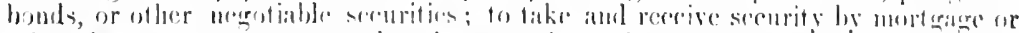

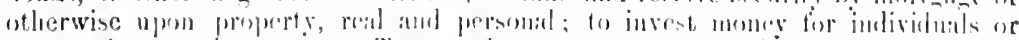

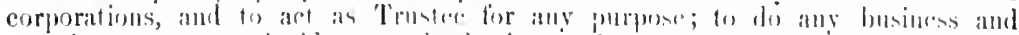
exercise any powers incident to the busimess of trust companies doing a banking business.

\section{FORM 22. - BARREI، MANUFACTURE.}

To manufarture, buy, scll, report, impurt, and genelally deal in barcels and

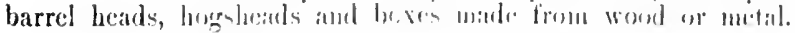

\section{FORM 23. - BICYCLES.}

To carry on the tmeines of mannfarturers and dealere in hieveles nnd hierele

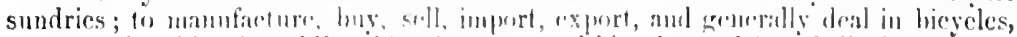

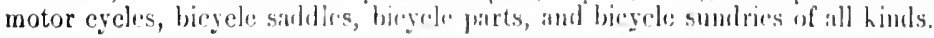




\section{FORM 24. - BISCUIT COMPANY.}

To juepare, minufineture, buy, sell, import, export, and greuerally deal in biscuits, cothes, clatekers, protzels, passtry and bread of all kinds, and in other food products. 'lo mannlacure, buy, sell, import, export, and generally deal in maehinery for the miking and biking of biseuits, eakes, erackers, pretzels, pastry, and bread.

\section{FORM 25. - BOOKS.}

'To earry on the business of booksellers, stationers, bookbinders, and engravers, litherraly)hers, publishers, and mamulactmers of inks and all articles and things of the same eharacter as the loregoing or comected therewith.

\section{FORM 26. - BOOTS AND SHOES.}

To earry on the business of manulaeturers and dealers in boots, shocs, and footwear of every kind and deseription. To mannfacture, buy, sell, import, export, and generally deat in boots, shoes, rubbers, soles, basts, and all kinds of leather, rubber, or elotli goods. To make, manutacture, buy, sell, import, export and deal in machinery of all kinds for the mannfacture of hoots and shoes, rublers, soles, lasts, and all kimls of leather, rubber, and eloth goods. To mannfacture, buy, sell, export, import and generally deal in all kinds of blacking, polishes, varnishes, lasts, but ton hooks, fisteners, and such other articles of merehandise as are usually manufactured by manufaeturers and dealers in a similar line of business.

\section{FORM 27. - BRANDIES.}

To carry on the husiness of mannfacturers, distillers, and dealers in brandies, wines, and liquors of evcry class and deseription. To manufacture, buy, sell, export, import, store, warehouse, and generally deal in brandies, wines, whiskey, malt liquors, gin. spirits, and beverages of all kinds, and their products and by-products of cvery nature whatsoever. 'T'o earry on the general business of distiling and rectifying brandies, wines, whisker, and liquor, and the blending of gins and whiskeys of all classes and deseription, and generally deal in grain, sugar, molasses, and all liquors, used in eomeetion with the operation of a distillery. To manufacture, buy, sell, import, and export maelinery for the manulacture, distillation, and rectification of liquors of every elass and deseription. To build, operate, and maintain warehouses, bonded or otherwise, and to do a general wareliouse business. To issue, register, and ecrtify warehouse receipts. To mamutacture, buy, sell, and deal in ice.

\section{FORM 28. - BREEDERS.}

To earry on the business of breeding, raising, training, buying, selling, importing, and exporting horses. To conduct any and all manner of business permitted at fair and race courses, and in general to do any and all things in accordance with law that mat diretly or indirectly be eometed with the raising of horses. 'To keep carrfial lists of the most eclchinated horses of all noted breeds, and their pedienree and distinguishing elaracteristies, aud to publish from time to time every kind of information on snch subjeets of interest to horsemen. To buy, sell, raise, and liundle live stock of all kinds and deseription.

\section{FORM 29. - BREWERY.}

To prepare, brew, manufacture, export, import, buy, sell, makc, and deal in beer, jorter, atc and all other elasses and kinds of malt liquors. To maunfaeture, buy, sell, import, and export malt. 'To buy and sell grains of all kinds; to manufacture, buy, scill, and refine liquors of all kinds; to manufacture, buy, sell, and deal in ice. To build, operate, and maintain warehouses, and to do a general warehouse business. Th minulicture, bur, sell, import, and export machinery for the manufacture, distillation, brewing, and treating of malt liquors. 


\section{FORM 30. - BRICK.}

To manufincture for purposes of sale pressed brick, building brick, terra cotta, tile, roofing, ritriticd, and other building matcrials which can be made from clay.

\section{FORM 31.-BRIDGE BUILDERS.}

To manufacture, sell, export, and gencrilly deal in bridges and structural work. To manufacture, buy, sell, export, and import steel, iron, tim, aluminum, and other metals. Also to manufacture, buy, sell, export, and import cngines, boilers, machiners, plates, apparatus, tools, appliances, and materials uschul or conrenicut for carrying on any of the sercral lines of business heretofore set torth.

\section{FORMI 32. - BRONZE.}

To manufacture, buy, sell, cxport, imprt, and generally deal in brouzes of all kinds, classes, and descriptions. Also to mimulicture, piepare, buy, sell, export, import, and generally deal in silicon, alumimum, and all kinds of metals or metallic compounds suitable and convenient to be used or commonly used by dealers in bronzes.

\section{FORM 33. - BROOMS.}

To earry on the business of manufacturer's and deaters in brooms of all classes and descriptions; to mannticture, bus, sell, import, export, and generilly deal in brooms, broom corn, broon hangers, binding awine, binding wire, and all ot leer articles snitable for use in such manulicture; also to deal in such other goods, wares, and merchindise as are nsually mimufictured or dealt in by manufacturers and dealers in a similar line of business.

\section{FORM 34.- BRUSHES.}

To manufacture, buy, scll, export, import, aud grenerally deal in hair brushes, scrubbing brushes, mail brushes. alectric brushies, brooms and dusters of all clisses and descriptions. Also to manufieture, buy, sell, expolt, import, and grencrally deal in such ofher grosels, wares, and merehandise as are commonly manufietured and dealt in by those cngaged in a similar line of business.

\section{FORM 35. - BUILDING CONTRACTORS.}

To engage generally in the business of enutracting for, recting, decomatiug.

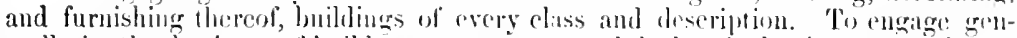
erally in the business of builders, eontractors, and dealers in lumber, stone, brick, cement, marble, plunbers' supplies, and all other kinds of huilding matcrial.

\section{FORM 36. - BUTCHERS.}

To carry on the business of whellesale and retail dealers in meat and meat

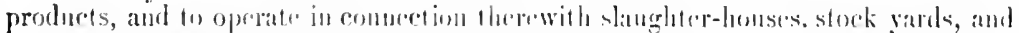

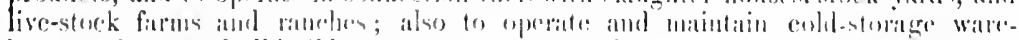

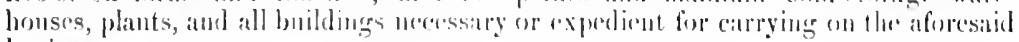
busiuess.

\section{FORM $3 \pi .-$ BUTTONS.}

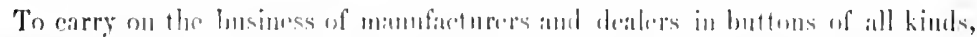

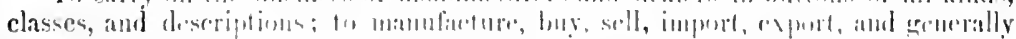

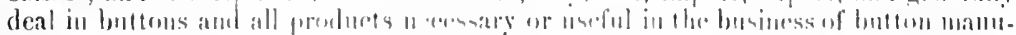

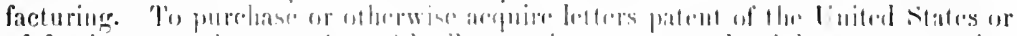

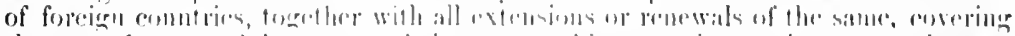

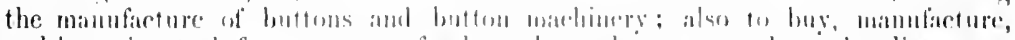

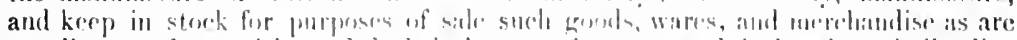
usually manufactured by and dealt in by mandiuturers and dealcres in at similat line of business. 


\section{FORM 38, - CAR BUILDERS.}

'Tu earry on the husiness of manuticturiner, buving, leasing, or otherwise aequir-

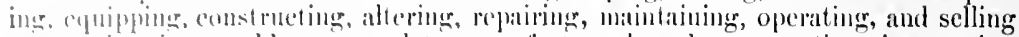

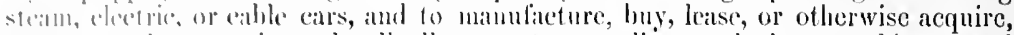

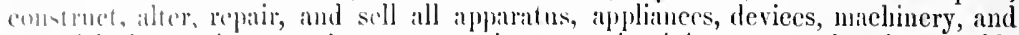

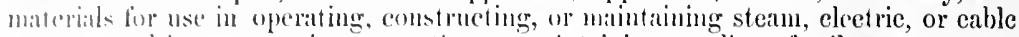
carls, or und in constructing, operating or maintining any line of railway, steam, or clectrie lines or otherwise, or the stations, terminals, or equipment thereof.

\section{FORMI 39. - CARBON ENGINES.}

To manufaeture. huy, sell, import, export, and deal in carbon engrines and all kinds of machiners, tools, and implements ineidental to the development of new and useful mechinieal deviees, and to obtain letters patent thereupon; to acquire lenters patrint, domestie or foreign, for the right to construct machines upon which patents lave already been issued and applied for.

\section{FORM 40. - CASH REGISTERS.}

To manufacture, buy, sell, export, import, and grenerally deal in cash registers, cleck, slip, and antomatic printing registers, autographic registers, weighling, adding, calculating and registering miehines of all kinds, clisses, and descriptions.

\section{FORM 41. - CATTLE.}

To breed, raise, buy, sell, export, import, and deal in cattle, sheep, horses, and lire stoek of all elasses and descriptions. T'o build, construet, buy, lease, or otherwise aequire, own, and maintain slimghter-houses. To earry on the business of hutehers ind puckers; also to manufieture, buy, sell, and generally deal in all articles malle from the careasses of animals. T'o purehase, lease, or otherwise acquire farms and lands suitable for stock rising and agricultural business.

\section{FORM 42,-CEMENTS.}

To mamfacture, prepare, buy, sell, import, export, and deal in cement, Portland or otherwise, lime, limestonc, and all kinds of phasters and artificial stone. To build, buy, kease, or otherwise aefuire manufaetories, plants, buildings, and warehouses suitable for the mannfaeture, selling, and storing of eement and other prodnects of it similar nature. To mimufieture and deal in such other goods, wares, and merehandise as are usually mannfactured and dealt in by those cngaged in a similar line of business.

\section{FORM 43. - CEREALS.}

To lur, sell, import, export, and generally deal in all kinds of cereals and the masufictired products thereof. 'lo grind material for eereals and the various jeroluct s thereof'. 'To erect, eonstruct, own, purehase, lease, or otherwise aequire elcsators, mills, grantries, and buildings for the storing, handling, mamnfacturing, and selline of grains and eereals, am the various produets thereot. To carry on a gencoul milling and manufucturing business in the preparation of grains, ecreals, atnd of heer products for market, and to minutacture, buy, sell, import, export, and deal in milling, clevator, and all other machinery for the handling of grains and ecreals and their various produets and by-products.

\section{FORM 44. - CHEMICALS.}

To manufacture, buy, sell, cxport, import, and generally deal in all kinds of chemenls, and to earry on th: business of ehemists, druggists, ind manufacturers of, and dealers in pharmacentical, medicinal, chemieal, and oflere preparations, articles, compounds, pigrments, drugs and druggrists' sundries, ehemical, surgical, 
and scientific apparatus and machinery. To analyze and refine when necessary all kiuds of chemicals, medicines, and preparations. 'To apply for, obtain, register, purchase, or otherwise acquire, use, operate, sell, assign, or otherwise dispose of any and all trade marks, seeret processes, trade mames, distinetive marks, and all inventions, improvements, and proeesses used iu commection whth or secoured under letters patent or otherwise, domestic or foreign, and of ler governuental grants or concessions, and to use and employ the sanc in connection with the purposes hereinbefore set forth.

\section{FORM 45. - CIGARS.}

To carry on the business of manfacturers and dealers in eigars and tubaceo. To manufacture, buy, sell, exchange, import, export, and generally deal in leaf tobacco, elewing tobaceo, cigars, eigarettes, and cheroots; to plant, grow, and treat leaf tobacco, and to mamufieture, sclt, lease, or otherwise acquire makehery, tools, implements, and appliances incidental and necessary in the enltivation, care, and treatment of leaf tobacco, or in the manulacture of cheroots, chewing and sunting tobaceo, cigitrs and cigarettes. To build, operate, maintain, lease, or oflerwise acquire factories, warchouses, and buildizgs suitable for the caring, storing, preparation, and manufacture of tobacco and its several products.

\section{FORM 46. - CLOTHING MANUFACTURERS.}

To manufacture, buy, sell, inport, export, and generally deal in clothing and wearing apparel of esery mature and description. To engige in manufucturing. buying, selling, importing, and exporting underwear and gentlemen's fumishing goods.

\section{FORM 47.- COAL.}

To buy and sell antluacite, bitmninous, semi-bituminous coal, lignite coal, and

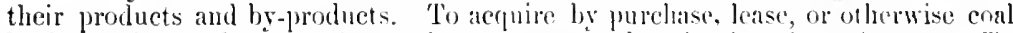
lands, shales, and properties, and to operate and maintain mines theren. T'o engage in the business, both wholesale and retail, of dealers in coal, coke, wood, and fucl oil.

\section{FORM 48. - COAL BRIQUETTE.}

To manfacture, buy, scll, deal in, and deal witl coal briquettes; to mine, buy, sell, dea! in and deal with eoal and other minerals, and to manufacture and sell coke and its by-products; to aequire by purchase, lease, or of herwise coal mines, coal lants, coal properties, mineral and mining rights: fo matublacture, purehase,

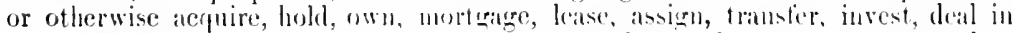
and deal with and trade in gends, wares, merchandise, and property of crery elass and descriptioli.

\section{FORM 49. - COAL TRANSPORTATION COMPANY.}

To mine, buy, srll, import, export, and gencrally deal in autluacite, bituminous,

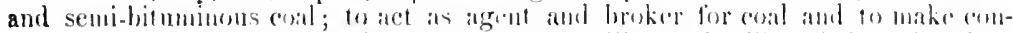

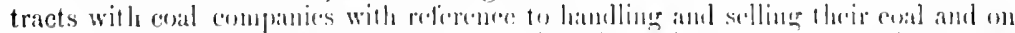

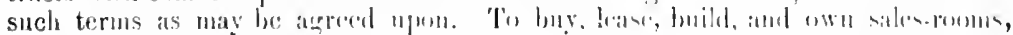

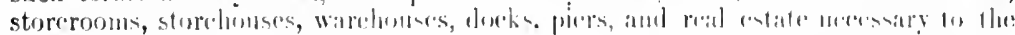

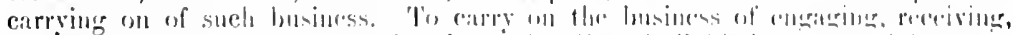

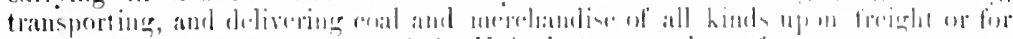

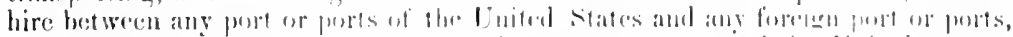

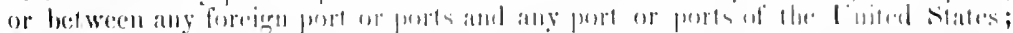

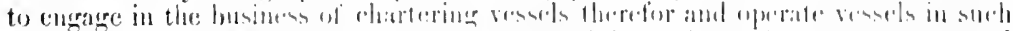

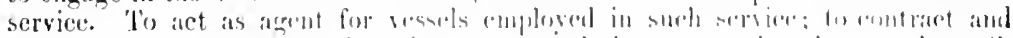

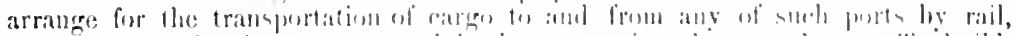

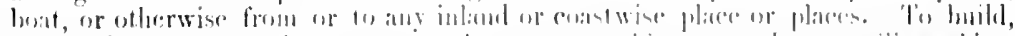

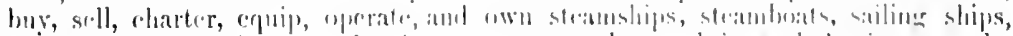
coal harges, eanal buals, and ofleer property to be used in such bunimese, trable, commerce, aud navighttion. 


\section{FORM 50. - COFFEE.}

To raise, cultivate, produec, export, import, treat, eure, ripen, polish, burn, ronst. brown, huy, scll, and remerally deal in cotlees of every grade, charaeter, and description. 'lin acquire hy purehise, lease, or otherwise lands and properties suitahle for planting and rasing eotlee plants. T'o huy, sell, and generally deal in such other groods, wares, and merchundise as are usually dealt in by those engaged in at similar line of business.

\section{FORM 51.- COLD STORAGE.}

To preserse in cold storage and generally deal in all kinds of food products of a perishahle nature or otherwise. To manufacture, buy, sell, and deal in ice. To buy, sell, store, import, and export fruit, lish, butter, milk, and all kinds of food produets, whether atnimal or regetable. 'lo operate and maintain stores, buildings, wirrehomses, defots, and whares for the carrying on of any of the aforesaid lines of baisiness.

\section{FORM 52.-COLONIZATION COMPANY.}

To buy, sell, lease, or otherwise aequire lands and other property for the pur: men' uf disposing of the same to settlers; to plant, grow, and eultivate tobaceo, fruits, sugrar, cotfec, and all kinds of vegetables; to mine for gold, silver, eopper, lead anl all kinds of minerals; to manufietmre mable, stone, brick, and building materials of a similar nature; to ent, minnlacture, buy, sell, and deal in wood and lumber; to build, maintain, and operate hotels, stores, packing-houses, warelouses, elevators, saw-mills, flomr-mills, dwellings, stations, and wharves; to raise, bur, sell, and deal in mules, sheep, and horses; to engage in the business of farmers and planters.

\section{FORM 53. - COMMERCIAL COMPANY. (See FORM 92.)}

\section{FORM 54. - COMMISSION MERCHANTS.}

To engrge in the business of sclling groods, wares, and merclandise as commission merehauts, and as general selling agents; partieularly to aet as agents or brokers for the solling upon eommission or otherwise of the following elasses of property, to wit: (here insert deseription of property to be sold.)

\section{FORM 55. - CONFECTIONERY.}

To purcliase, manufueture, buy, sell, import, export, and deal in eandy, eonfectionery, sugar, glueose, iees, chocolite, and chewing gum; to manufacture, purehase, or otherwise acquire, sell, import, export, and generally deal in such goods, wares, and merehandise as are ondinarily carried by manufaeturers or dealers in a similar line of business.

\section{FORM 56. - CONSTRUCTION COMPANY.}

To manufactme, luy, sell, or otherwise aequire, import, export, and gencrally deal in shect,iron, enper, tin, gilvanized iron, eomiees, skylights, smokestaeks, walcr, cras, and electrie works, whaves, roads, reservoirs, einals, factories, warehonses, and mills; to manufacture, buy, sell, import, export, and generally deal in iron, sterl, manganese, copper, and other materials or alloy thereof, coke, gas, coal, lunber, and building materials or any article eonsisting or partly eonsisting of iron, stecel, coprer, and other materials, and any products thereof.

\section{FORM 57.-- CONTRACTORS AND BUILDERS.}

To construet, creet, crupe, repair, and improve houses, buildings, public or private roads, alleg's, tramways, lailways, reservoirs, irrigation ditehes, wharves, sewers, fumels, conduits, and subways. 


\section{FORIS AND PRECEDENTS.}

\section{FORM 58. - CORDAGE.}

To manufacture, buy, sell, import, export, and generally deal in cordage, binding twinc, rope, hemp, harsers, chams, and ot her eommoditics of a similar nature.

To bur, sell, export, import, ind generally deal in rope, hemp, and all raw materials suitable for use in the manufacture of cordage and binder twine.

\section{FORM 59.-COTTON.}

To bur, sell, import, cxport, plant, raise, sather, gin, and elcau cotton; to balc cotton by hand or mechancal process; to build, operate, and maintain watrehouse's, and to do a general wirelonse bonsiness. To manufacture, bus, sell, export, import, and generally deal in machinery for the grimning, eleaning, baling, and compressing of cotton and other fibrous mitterials. To cuener in the business of producing, buying, selling, importing, and exporting cotton seed. Also to mamufacture, purchase, lease, or otherwise actuire, operite, and sell machinery for compressing cottou or other fibrous matcrials, and for the purpose of ginining and cleaning the same.

\section{FORM 60. - COTTON BROKERS.}

To carry on the business of busing, selling, and otherwise dealing in cotton, either as principals or on commission.

\section{FORM 61. - COTTON OIL}

To buy, gin, bale, and prepare seal cotton. To carry on the business of buying, selling, importing, cxporting, manulachuring, relining, preparing, producing, and generally dealing in cotton wil and other oils; to carry on the business of buring, sclling, importing, ginning, baling, warehoming, and shipping seed cotton and any and all other kinds of cotton ; to manufacture, proluce, prepare, buy, sell, iumpert, export, and generally deal in cotton secd and any and all products and by-products thereof.

\section{FORM 62.-COTTON PLANTATIONS, ETC.}

To manufacture from the cotton plint or other substances pulp, paper, clicmicals, and other material, and all or any artieles ennsisting or partly consisting of pulp, paper, chemicals, or other materials, and all or any products thereol." "To acquire, own, lease, occups, use, improve, multivate, or develop any cotton plantations, wood lands, lands contaning eoal, iron, or other ores, or ofler lands for anty

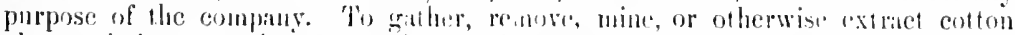
plants, timber, or other verotation, coill, ures, or other mincrals from any lands

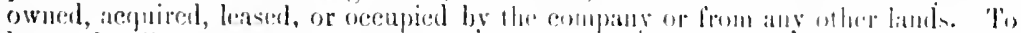
buy and sell or sotherwise to deal or to tratlic in raw eotton, cottent plant, pulp,

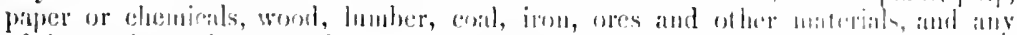

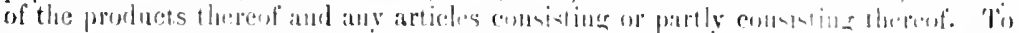

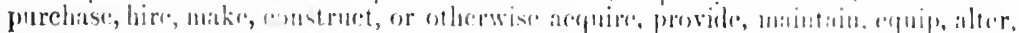

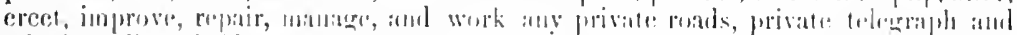

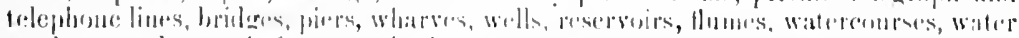

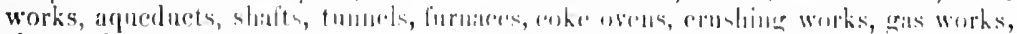

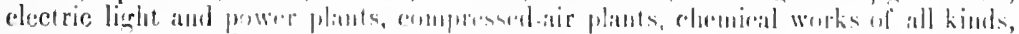

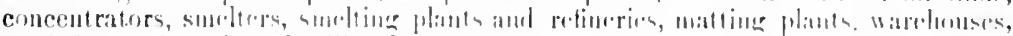

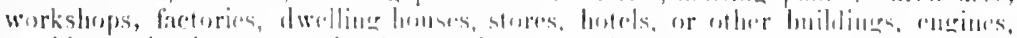

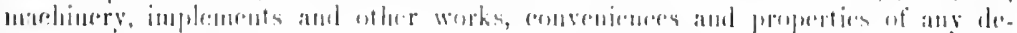

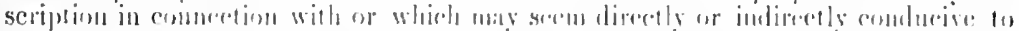

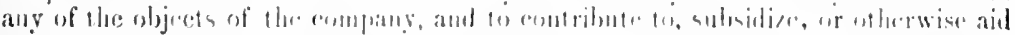

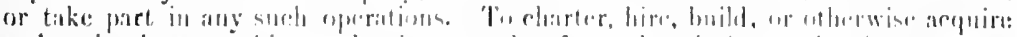

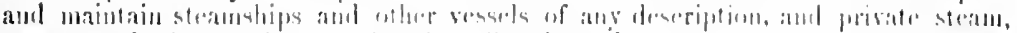

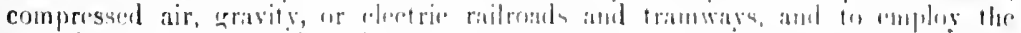

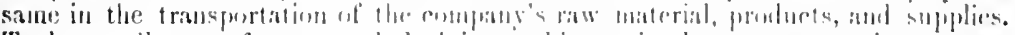

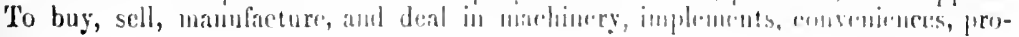


risions, and things capable of being used in eomection with mannfacturing operations or any of the business of the eompany or required by workmen and ofliers cmployed by the company. 'T'o buy, sell, hold, mantge, lease, turn to account, and otherwise aequire land and frechold estates and interests therein; and to lay off realty into luts and blocks, street alleys and parks, and to dedicate such portion thereot to the publie ats the company may think proper.

\section{FORM 63. - CUTLERY.}

To manuficture, bny, sell, lease, export, import, and generally deal in cutlery, razors, tools, and machinery of all kind, classes, and deseriptious.

\section{FORM 64.-DAIRY PRODUCTS.}

To mannfacture, bux, sell, import, cxport, and generally deal in butier, buttermilk, oleomargatrine, and butterine; to buy, sell, and generilly deal in milk and all kinds of dairy produets ; to construct, maintain, and operate refrigerating cars, fast freight liucs, and warchouses.

\section{FORM 65.-DECORATING.}

To carry on the business of painting, paper hanging, and the decoration of houses and buildings of evers class and deseription; to earry on the business of manufacturing, buving, selling, inporting, exporting, and generally dealing in stained and cuamelled glass and all kinds of goods, wares, and merchandise suitable for use or ornamentation in the decoriting husiness. 'To mannfaeture, prepare, buy, sell, import, and export paint and painters' supplies and kindred articles.

\section{FORM 66. - DEPARTMENT STORES.}

To carry on the business of a general department storc; to establish and condnet therein the business of dry-goods merehants, milliners, cloth and fubric manufacturers, furriers, gents' furnishing goods, lossiers, hatters, elothicrs, boot and shoe merehants, ehemists, druggrists, dealers in leather gools, wholesale furniture, silver, china, and glass ware, books, stationery, notions, photographs, pictures, and jewels. 'To buy, sell, import, export, and generally deal in plated goods, perfumery, toilet irtieles, biercles, motor carriages of all kinds, wines, liquors, tobacco, aud photographic suppilies.

\section{FORM 67.-DISTILLERS.}

'To engage in business as distillers and reetificrs of brandies, whiskics, and liquors of all kinds, classes, and descriptions. To earry on the business of manufacturers, distillers, and dealers in wines, hrandies, spirits, and liquors of all kinds; to carry on the general business of distilling and rectifying wines, brandies, spirits, and 'lignors of all kinds, and generally to deal in grains, sugar, molasses, and all prodncts used in eomeetion with the operation of a distillery. To maunacture, bmy scll, import, export, and deal in maehinery for the distillation and rectification of liquors of every class and descriptions. To build, operate, and maintain warelomse's, bonded or otherwise, and to do a general warehouse business. To issue, register, cruaranty, and certily warehouse receipts. To maunfacture, buy, scll, and d(all in iee.

\section{FORM 68. - DOCK COMPANY.}

To crinstruet, erect, and maintain docks, elevators, piers, basins, loading and unloading nachines, enal-yards and all kinds of terminal and transfer facilities for railway or watre transportation. Also, to engage in freighting, lighterage, wharfage, and wirchonsing business. Also, to load and unload ears and vessels of all kinds and descriptions. Also, to purchase doeking and berthing facilities for steam and sailing ressels of all kinds and descriptions.

\section{4}




\section{FORMS AND PRECEDENTS.}

FORM 69. - DREDGING.

To carry on the business of dredging in all its various branches; to buy, sell, manufacture, purchase, lcase, or otherwise acquire, own, maintain, and operate docks, scows, lighters, derricks, vessels - stean or otherwise - engines, cars, wagons, tools, and personal property of every class and description convenient or necessary in carrying on the business of dredging.

\section{FORM 70. - DRILLING.}

To prospect, bore, drill for, and produce oil and natural gas; to purchase, lease, or otherwise acquire lands believed to contain vil and gas, and to erect and maintain thereon pumping and drilling stations, reservoirs, tanks, pipe lines and other facilities and conveniences that may be necessary or required in and abuut said business.

\section{FORM 71, - DRUGS.}

To manufacturc, buy, sell, import, export, and generally deal in all kinds of drugs, druggists' sundries, pharnaceutical, medicinal, chemical, and all other preparations; to manufacture, buy, sell, import, export, and generally deal in compounds, pigments, electrical, medicinal, surgical, and scientific apparatus and proprictary articles of all kinds. To maintain a laboratory for the analysis of all hinds of chemical, animal, and vegetable products.

\section{FORM 72. - DRY GOODS.}

To buy, scll, import, export, manufacture, and deal in dry goods of crery class, nature, and description; to conduct a ceneral retail and wholesale dry-goods business, cither as principals or on commission or both. To buy, sell, import, export, and deal in laces, linens, white goods, silks, ribbons, neck wear, gloves, cotton, and dry goods of all classes and descriptions.

\section{FORM 73. - ELECTRICAL BUSINESS - GENERAL.}

To carry on the business of electricians, electrical enginecrs and dealers in electricity, and electric motive power, lighting, and heating. To mandicture, buy, sell, import, export, and generally deal in electrical machinery of all elasses and descriptions; also to produce, accumnlate, distribute for hire clectricity and electromotive force, and to supply the same for use as power for lighting. lieating, and motive purposes; to carry on the business of lighting cities, towns, villages, streets, buildings - public or private - by means of clectricity, and to supply light and heating power to carriers of passengers and goods, cither by land ur water. 'To construct, build, purchise, lease, or of herwise aequire, maintain, equip, opreate, and build street railways, strect ears, and of her pissenger or freight velices operated by electricity or otherwise. 'T'o matublature, use, purchase, lease, or otherwise acquire and inaintain telephones, trlographs, phomocrapha, and atl kinds of electrical

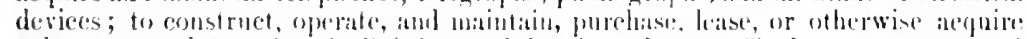

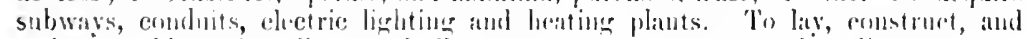
maintan cables, wires, lines, and all necessary appurtenances and alpiliances.

\section{FORM 74. EIECTRIC GENERATING MACHINERY.}

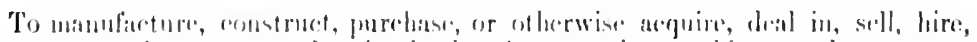

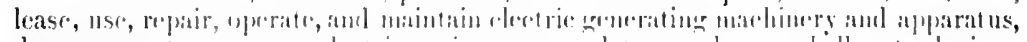

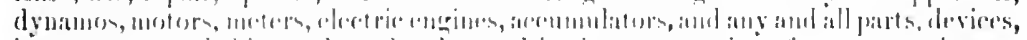

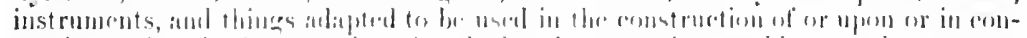

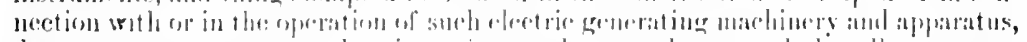

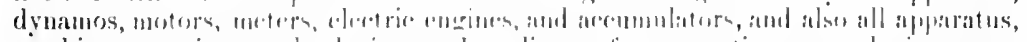

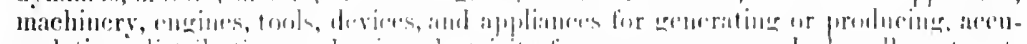

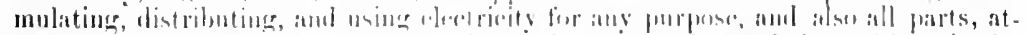

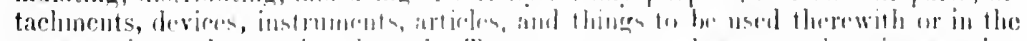

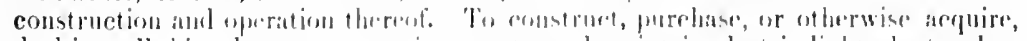

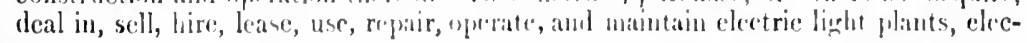


trie prower plints, clectric plants and power plants of any and every claracter and for any and aver purpose, and mitchinery, engines, tools, devices, and appliances of

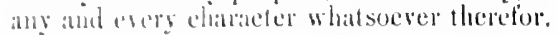

\section{FORM 75. - ELECTRIC LIGHTING.}

To mannficture, grenerate, store, transmit, and distribute electric current for light, heat, and jower; to mam hacture, huy, sell, import, export, lease, or otherwise

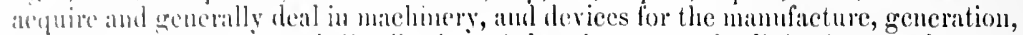
sturage, transmission, and distribution of chetric current for light, heat, and power purpusis; to erect, buy, sell, lease, or otherwise acquire, operate, and maintain electrie lighting, heating, and power plants ; to mamufacture, huy, sell, lease, or otherwise acquire, import, export, and gremerally deal in electric apparatus of all kinds; to ereet, buy, stll, lease, or oflerwise acquire, maintain, and operate undergrombl subwars, conduits, poles, string wires, above, "now, or under the streets, alleys, and territories of eonnties, townships, cities, towns, and villages, whether maintained or owned by public or private corporations or individuals.

\section{FORM $76 .-$ ELECTRICAL MACHINERY.}

To mamufacture, buy, sell, import, export, and generally deal in electrical machinery and supplies of all classes and deseriptions; to manufacture, buy, sell, import, export, repair, convert, lease, or otherwise dispose of and generally deal in chetrie motors, electrostatic machines, contimuous eleetric batteries, interrupted eurrent battries, dry-eell electrodes, X-Ray tubes, fluoroseopes, interual body batteries, battory apparatus, milli-ampere meters, simusoidal current clectric machines, rheostats, compressor's, generator's, pumps, motors, and electrical appliances and groods of every kind and ehancter. To buy, sell, import, export, lease, or otherwise aequire and generally deal in all kinds of vehicles, machines, or appliances for the generation of electric power for the purpose of propelling cars, wagons, trucks, and rehieles of every kind and description.

\section{FORM 77. - ELECTRICAL VEHICLES.}

To manufacture, buy, sell, lease, or otherwise acquire, export, import, and gencrally deal in relicles of every elass and description propelled by electric power: to aequire by purehase, lease, or otherwise electrical vehieles for the purpose of operating the sume in earrying and transporting passengers, goods, wares, and merchandise. To acquire by purchase, lease, or otherwise to equip vehicles of every kind and description for the purpose of using and operating the same for the earriage of passengers, goods, wares, and merehandise by means of electricity, gasolenc, compressed air, or stean.

\section{FORM 78. - ELEVATORS (GRAIN).}

To crect, buy, sell, lease, or otherwise arquire and maintain and opcrate elevators for the storige of grains and eereals of every kind and description. 'To build, operate, and maintain warchouses and to do a gemeral warehouse business; to issue, register, and eertily warehonse receipts. To manuticture, buy, sell, and deal in ice.

\section{FORM $79 .-$ ELEVATOR MACHINERY.}

To manufacture, eonstruet, purehase, or otherwise acruire, deal in, sell, hire, lease, nse, repair, operate, and maintain elevators and hoisting and lifting apparatus of any and crery chlinacter and any and all parts, devices, instruments, and things atdepted for use in the ennstruction of or upon or in eonnection with or in the operation of snch elevators, hoisting and liting alp paratus of any and every character.

\section{FORM 80. - ELEVATORS (PASSENGER).}

To manufacture, buy, sell, lcase, or otlıcrwise acquirc, import, export, equip, maintain, and operate clevators and hoisting machinery of every class and descriptirn, whether projelled by electricity, air, power, steam, or otherwisc. 


\section{FORM 81. - ENAMEL AND STAMPED WARE.}

To manufacture, east, forge, roll, tin, enamel, coat, plate, bur, sell, import, export, and generally deal in all kinds of enamel and stamped ware, inchiding kitchen and houschold wares, hruschold ormanents, and cnamel and stamped articles made from iron, steel, tin, aluminum, and ot her materials.

\section{FORM 82. - ENGINEERING AND DREDGING COMPANY.}

To earry on a genembl dredging, contmeting, and enginering business in all of their branches; also to desinn. eoustruct, enlarge, extend, repair, eompletr, take down and remose, or otherwise engage in any work njon bridges, piers, docks, foundations, mines, shatis, tmmels, wells, witerworks. lighthouses, buildings, railroals, telegraph and telephone lines, eanals and all hinds of exeatations, and iron, wond, masonry, and eartl constrnetions in all parts of the world, and to make, execute, and take or receive any contracts or assignments of contracts, therefor or relating thercto or comected therewith.

To cugage in the business of mantaturing, buçing, selling, and dealing in cranes for lifting. hoisting, dredging, and eonveying inaterials of all hiuds, and in convering machinery, hrosting machinery, and conl-handling machinery of crery deseription, and in hydraulic, eleetric, puematic, and power machinery of cory

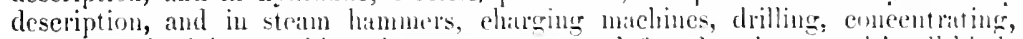
milling, and mining machines, ingot extractors and foundry plants, and in all kinds of fittings, tools, supplies, and apparatus pertaining thereto; or for any other purpose whieh now is or may be incidental or necessily for a general evintacting or cugineering business.

'To manthence or purchase, or both, all tools, machinery, and appliances necessary, proper, or eonvenient for the carring on of the sitid minufietures.

'To manufacture, buy, sell, and wenerilly deal in iron, steol, and other metals, and ans and all the produets thereof.

To quarry, mine, eut, saw, finish, prepare for market, buy, scll, and deal in mincrals and mineral sulsotunces of all hinds: to buy, leate, or otherwise acequire, use, buikl, sell, lease, or otherwise dispose of lamels or any interest thereon ; to builel, maintain, own, lease, and opreatr loads, railroads, or bridges (togesher with rights of way for the same), canal loats, steambonts, and other means and mechanism of

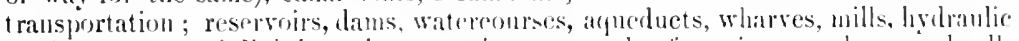
works, power and lighlume plints, equipment works, factories, watehouses, dwelling houses, and istlee works which may be necessary or convenient to the carrying out of the oljocets of the company.

'To purclatse atud ot!erwise atequire, and to operate, maintain, and dispose of the mills, plants, and business of individual, corpurations, and firms in any business similar to the business of this company or allied therewith.

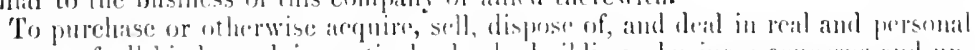

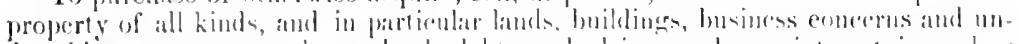

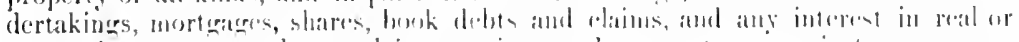

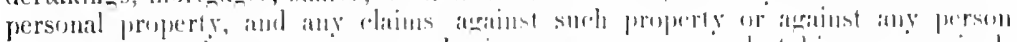

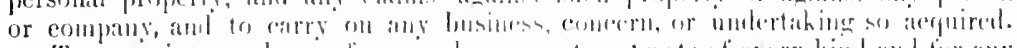

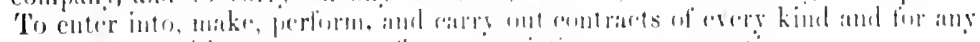

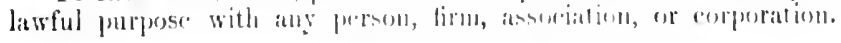

\section{FORM 83. - EXPLOSIVES.}

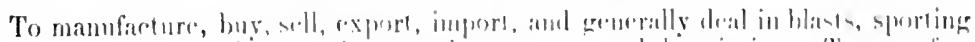

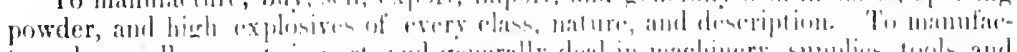

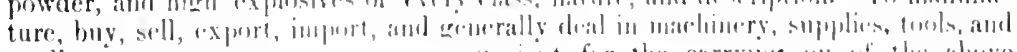

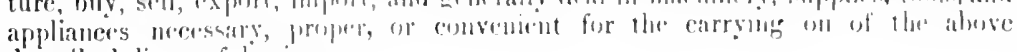
described lines of linsiness. 


\section{FORM 84. - EXPRESS.}

To earry on the business of enganging, reeiving, transporting, and delivering merehindise upon freight, of for hire, within the corporate limits of any city, town, 0) villiare in the United States, or between any cities, towns, or villages in the United states, or between any port of the United States and any port or ports of the Unifed states, or between any foreign port or ports and any port or ports of the Unted States. To earry on the business of equipping, maintaining, and operiting watems, drays, cars, and vessels of every elass and deseription for the earring on of the business herembefore provided for. 'To enter into contracts fur the transportation of merchandise between any of the loealities hereinbefore mentioned, and to enter into eontriets for thic carriage of mails, passengers, goods, wares. and merchmolise by any mens, cither by its own vessels, railways, or converances or hy the vessels, railways, or eonveyances of others. 'T'o carry on a generial express, ficight, and transportation business; to gather, receive, distribute, and deliver goods, wares, and nerehamlise of every class and deseription. To establish stores and warehouses for reeciving and delivering packages and circular matter.

\section{FORM 85. - EXTRACTING COMPANY.}

To mine and extraet gold, silver, and other preeious metals from placers and lodes or other mineral lands in any part of the United States, and in any and all foreign eountries, and to this end to purehase, lease, or otherwise aequire, hold, own, mortgage, schl, operite, and control mining property, and all neessary plants and machinery allapted for the purposes of mining and extracting gold, silver, and precious metals.

\section{FORM 86. - FANCY GLASS.}

To manufacture, buy, sell, export, import, and generally deal in stained glass, transparent vanlt and sidewalk lights, luail-proof glass for greenhouses, skylights, and ormamental stained glass of all kinds and deseriptions.

\section{FORM 87. - FARM AND DAIRY PRODUCTS.}

To proanee, purehase, sell, import, export, and generally deal in milk, butter, eheese, vegretalles, and all kinds of farm, garden, and dairy products. Also to sterilize, eondense, preserve, and certify milk.

\section{FORM 88. - FARM PRODUCTS, SOUTHERN.}

To produee, manufacture, refine, buy, sell, import, export, and generally deal in cotton, sugar caue, sugar, molasses, syrups, and tobaceo in all forms, and other produets of atgrieulture or industry.

\section{FORM 89. - FIREPROOFING.}

To manufaeture, buy, sell, import, export, and generally deal in fireproofing brick and building material of cvery kind, nature, and deseription. Also to manufacture, buy, sell, import, export, and generally deal in building material and applianees for the eonstruetion of fireproof buildings and the protection of the same from fire.

\section{FORM 90. - FISHERIES.}

To engage in the business of produeing, selling, exporting, importing, and dealing in fish and sen products, nets, lines, and scines, and all kinds of appliances fir the enching or preserving of fish. Also to engage in the business of catchine, storing, freszing, paeking, salting, canning, and otherwise preserving fish. Also to engage in the business of propagating fish and maiutaining ponds for that jurpose; to eonstruet, purehase, lease, or otherwise aequire, maintain, and operate (.), ld-strorage and refrigerator plants and refrigerating ears, and to do a general warelunse and storage homsiness, and in eomneetion therewith to issue registered, certilind, and gnaranteed warehouse receipts. 


\section{FORM 91. - FLOUR.}

To manufacture, bur, sell, export, import, and generally deal in flour, feed, breakfast foods, and other articles manutietured from grain or cercals. Also to operate in connection therewith grain warehouses, elevators, and cars for the carrying of grain, flour, and food products.

\section{FORM 92. - FOOD PRODUCTS.}

To produce, manufucture, buy, sell, import, export, and generally deal in food and cereal products of all elasses and deserijtim. Also to can, export, import, and sell meats, fish, vegetables, and fruits of all kinds and descriptions.

\section{FORM 93. - FOREIGN COMMERCIAL COMPANY.}

This corporation is formed for the carrving on, in any foreign countries, of the sereral lines of business herein deseribed. To purehase, sell, exehange, lease, or otherwise acquire real or personal property, and in particular lands, oil wells, retineries, mines, mining rights, minerals, ores, buildings, machinery, plants, stores, licenses, concessions, rights of way, light or water rights, and any rights or privileges which may seem to the directors convenient with reference to the business of the compans, and, whether for the purpose of resale, realization, or otherwise, to manage, develop, lease, mortgage, or of herwise deal with the whole or any part of such property or rights. 'To prospect, explore, develop, maintain, and earry on all or any lands, wells, mines or mining rights, minerals, ores, works, or ot her properties from time to time in the possession of the company in any mumber dremed desirable; to ereet all necessary or eonvenient refineries, mills, works, machinery, laboratories, workshops, dwelling-honses for workmen and others and other buililings, works, and appliances, and to aid or subscribe towarls or subsilize any such objects. To clear, plat for town-site purposes, manage, larm, eulvivite, plant, and otherwise exploit, work, or improse any land which or any interest in whieh maty belong to the company; and to deal will or otherwise turn to account any farm or other produets of any sueh land. To construet, purehase, lease, ur otherwise acquire, maintain, and operate private railsays, tranways, wason roads, privite telegraph and tekphone lines. To carry on husiness as merchants, shipowners, builders, or contractors ; to acquire by grant, purehase, or otherwise concessions of any property or privileges from any government or from any authority, indivilual, municipal, or otherwise, and to perform and fulfil the conditions thereif. 'T'o carry on in all its branches any kind of manufacturing and trading business. To buy, sell, and deal in generally all kinds of manufactured produets. To aequire by purchase or otherwise, under franchise or grant, all or any rights or privileges heretofore granted or liereafter to be granted by any comintry, state, or city, forign or domestic.

To generally trade in, store, earry, and trunsport all kiuds of goods, wares, merchandise, provisions, and supulies. 'T'o aequire by purchase or otherwise, to 1 wn, hold, buy, sell, or enusey, lease, murteriere, or encumber real entalle or other propers, personal and mixid. T'is erect ind construet lomse's, lmildings, warehonses, and works of every description on any land of the complang acquired by purehise, lease, or oflerwice.

'To buy, sell, or ollorwise aequire, import, export, and gonerally deal in all kinds of agricoltural markhinery; without the state of, to acquire, constroct,

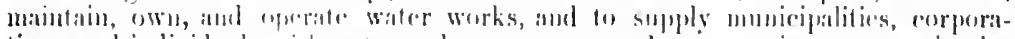
tions, and individnole with water and water pmwer; also to arepuire, ereet, maintain,

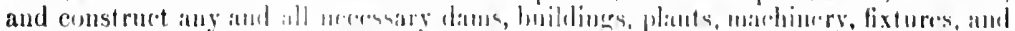

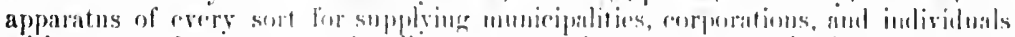

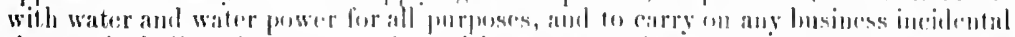

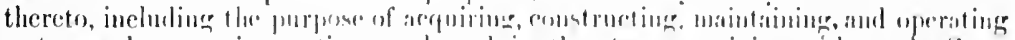

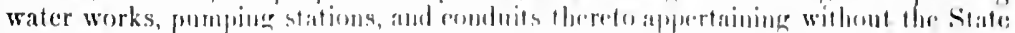

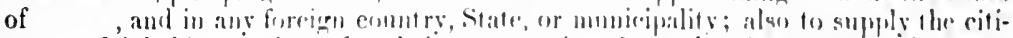
zens and inhabitants theresf and thic comporations loeated and trunsacting business 
Therein with water and water power for domestic, mechnieal, public, and fire or ir-

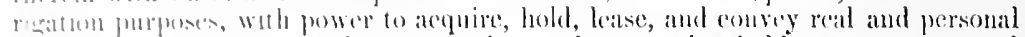
intate fire the business of the corpolat ion, and to anequire, lobld, own, possess, and

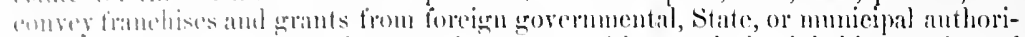
tic fir suphlying citics, villiges, and towns or either, and the inhabitants there of wist water for all purposes; also to earry on the business of operating water works. and to acquire and owin stock and bouds of other eorporations organized for like purposes, ant to aequire, own, lold, and possess all such other personal propcrly ats mat be sultable or eonvenient for the business of the company, with the right to issue honds and sccure the same by mort gatge of the franchises, rights, contricts, and property of the corporation, real and personal, and to issue common or prefermed stock, and to do all and everything necessary, suitable, or proper for the arcemplishment of any of the purposes or the attimment of any of the objeets hereinbefore enumerated which shall ut any time appear for the benefit of the corfuration; and in general to earry on any ofluer business, whether manufacturing or otherwise, which maty seem to the corporation eapable of being conveniently carried on in eonnection with the above or calenated to enhance the value or render profitible any of the corporation's property or rights.

Without the State of and in any forcign country, State, or municipality to aequire water by grant, purehase, development, or otherwise, and in connection therewith to furnish and sell water to corporations, public and private manufactories, and indivichals for fire protection, mannfieturing, domestie and irrigation purposes, and to colleet parments or rentals for the same.

'To exercise withont the State of and within any foreign comntry, State, or municipality, the right of eminent domain, and in the lawful excreise thereof to condemn for use by said company, its sneeessors or assigns, lands, tenements, hereditanchts, and watereourses for the purpose of constructing thercon artificial water ways, irrigation and eanal ditebes, aqueduets, dams, reservoirs, tanks, standpipes, pumping stations, pumping honses, water works, hydrants, mains, pipe lines, grites, and ralves.

In conncetion with the power to exercise the right of eminent domain as hereinbetore provided, said lands, tenements, hereditaments, and watereourses shall, sulject to the consent and approval of the State, country, or municipality wherein the said right of eninent domain shall be exereised, be condemned and its value assessed by a buard of commissioncrs appointed by said foreign country, State, or muncipality aeting jomtly with a like eommission appointed by the board of directors of this company. In case the two commissions camnot for any reason agree, an arbitritor shatl be appointed by the mutual consent of such foreign State, comntry, or municipality and hy the eompany, whose decision shall be final and conclusive upon broth prities to the arbitration.

Without the State of , subject to the approval and consent of the governusent, State, or mumieipality wherein the rights hereinbefore provided shall be exercised, the company shatl have the right to make such rules and regulations governing the distribution of water and tixing the priees for water distribution as shatl be deened by it from time to time nceessary and proper in the premises; sucls rules when filed with the proper anthorities of the State, county, or municipality to) beconte law.

Without the State of and subject to the approval and conscnt of the goverument, State, or municipality wherein the rights hereinbefore provided for shall be exereised, the company shatl have the right to make sueh rules and regulations for the collection of debis duc the company from corporations, public or private, and from individuals when the same shall have been incurred for water furnished hy said company to any suel corporation or individuals for the use and benefit of real estate owned or leased by them: sueh rules to provide by and with the consent of the State, govermment, or municipality that the same shall be and become a first licn against sich real estate just above referred to.

Withont the State of said Company shall have the power and in any forcign country, State, or municipality wherein it installs water works to accept 


\section{FORMS AND PRECEDENTS.}

such guaranties from forcign municipalities as to the water of such consumption municipalities as the company shall require in the premsses.

The company shall have the right to acept subsilies from foreign governments, States, or municipalities, and shall have the right to organze sub-companies for any purpose or purposes authorized by law. The said eompany shall have the riglit without the Stitte of and without the United States and in any foreign conntry, by and with the consent of the government of said country, io import all materials used in the construction of plants erected by it, and to import the same free from all govermental dues and tarifls of said foreign eomutry, provided said materi. als camot be purchased therein at prices oftered in of th. conntries.

The eompany shall have the right to sell, atssign, an a , busfer to any corporation or indiridual any or all of its property upon the eonsent of two-thirds of its stockholders first obtained at a meeting duly called for thal purpose, said sale, assigmnent, and transler to include, if the eompany so elect, ans right, grant, franehise, and privilege at ang time bestowed upon said company by any government, State, or inunicipality, foreign or domestic.

\section{FORM 94.-FREIGHT AGENTS}

To engage in the business of acting as freight agents for the purpose of shipping, transporting, and lorwarding goods, wares, and merehandise by land or by water.

\section{FORM 95. - FRUIT COMPANY.}

To buy, sell, import, export, and grenerally deal in fruits and froit products. To buy, sell, lease, or oflerwise aequire, nortgatge, sell, or otherwise dispose of real estate to any amount not limited by law. To congage in the cultivation, planting, and prodietion of fruits and arricultural products. To prepare and mannlaeture fruit and vegetable produets and hindred groods of every class and deseription.

\section{FORM 96. - FRUIT PLANTATION.}

'To plant, cultivate, guw, buy, sell, import, export, and grenerally deal in oranges, lemons, limes, pineapples, dates, lies, and all other kinds of tropieal fruits. Also to plant, cultivate, grow, sell, expert, and import all himb of veretables and berries. Also to operate and maintain packing houses and camning lactories for the packing and canning of livits, vegetables, and berries of all kimb.

\section{FORM 97. - FUEL-SAVING MACHINES.}

To manufacture, buy, sell, lease, or otherwise acquire and generally deal in smoke-preventing and fucl-saving mechanical and electrical apparatus and devices.

\section{FORM 98. - FURNITURE.}

To manufucture, jurepare. proluee, sell, import, expurt, lease, and generally deal in furniture for domestio and business nees. Alor in buy, sell, impurt, export, and generally deal in furnishines of every chass and arescription.

\section{FORM 99. - GARBAGE MACHINERY.}

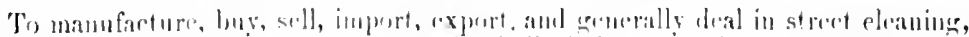

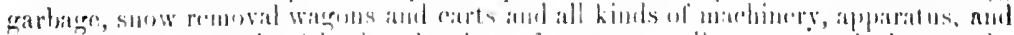

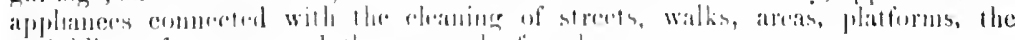

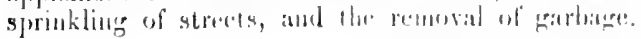

\section{FOR.M 100. FiAS.}

To manufacture, store, sedl, distribute, and supply thas, and 10 operate a gas

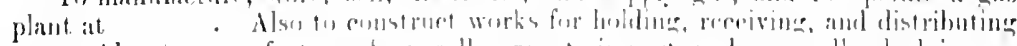

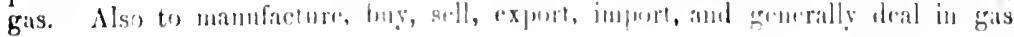


meters, pipes, stores, burners, engines, and otlicr appliances and conveniences necessary for the business of the company.

\section{FORM 101. - GAS ENGINES, BURNERS, ETC.}

To manufacture, buy, sell, import, export, and generally deal in gas generators and burners, hydro-carbon burners, incandescent und gasolene lamps, gas and gasolene entines, ant any and all machines, articles, and devices for producing and utilizing heat and power.

\section{FORM 102. - GINNERIES.}

To crect, maintim, purchase, or otherwise aequire, operate, and maintain cotton secd oil mills and gimmeries. Also, in eonnection therewith to produce cotton-seed oil. 'To buy and sell cotton seed; to manufacture, buy, sell, export, import, and generally deal in cotton seed oil, and the produets and by-produets of cotton seed. Also to imanipulate and compound cotton-sced oil with other substances, so as to make fertilizers to be sold for fertilizing land. Also to gin and compress cotton into bales for marketing purposes or otherwise.

\section{FORM 103. - GLASS.}

To manufacture, export, import, and gencrally deal in window, plate, and colored glass of all kinds and descriptions. Also to manufacture, buy, sell, export, import, and generally deal in table glasy ware, vases, and glass ware of all kinds and descriptions. Also to manufacture, buy, and import such crude materials as are necessary or conrenient for the manulacture of glass or glass ware.

\section{FORM 104. - GOLD AND SILVER WARE.}

To manufacture, buy, sell, export; import, and generally deal in gold and silver ware, both solid and plated, of all elasses and descriptions. Also to manufacture, buy, sell, export, import, and generally deal in novelties, glass ware, and fine cutlery, leather goods, and carved goods of all elasses and descriptions.

\section{FORM 105. - GRAPHITE.}

To manufacture, purify, prepare, export, import, buy, sell, and generally deal in graphite and carbon of all classes and descriptions. Also to engage in the business of manufacturng, buying, selling, exporting, and generally dealing in paints, clectrotyping, and kindred lines of business.

\section{FORM 106. - HARDWARE.}

To engage in business as jobbers and retailers of lardware of all kinds and descriptions. Also to buy, sell, export, import, and generally deal in railway, steamboat, manufaeturers', mill, plumbers', miners', blacksmitls', steam fitters', and gas fitters' supplies. Also to buy, sell, export, import, and generally deal in sheet iron, tools, cutlery, saddlery, and saddlers' goods, round and bar iron, bar and tool steel, guns, and sporting goods of all kinds and descriptions.

\section{FORM 107. - HOTEL COMPANY.}

To build, erect, construet, lease, or otherwise acquirc, manage, occupy, maintain, and operate buildings for hotel purposes, dwelling houses, apartment houses, office buildines, and other structures. 'l'o buy, own, operate, lease, and occupy lands, buildines for hotels, apartment houses, dwelling louses, oflice buildings, and business struetures of all kinds for the accommodation of the publie and of individuals. To, heep, mallige, eonduet, and operate hotels, apartment houses, dwelling liouses, restaurants, lnuch and tea roons, barber shops, hilliard halls, cafés, and bars, for the accommolation of the public and of individuals. 


\section{FORM 108. - ICE.}

To manufacture, sell, buy, export, import, and generally deal in machinery, tools, and devices of every character and description for the cutting or manufacture of ice. T'o purchase chenicals for the manulacture of artificial ice. To erect, build, purchase, lease, or otherwise acquire suitable land and plants for the manufacture and storage of ice. To engage in the busincss of wholesaling and retailing ice to middlemen and consumers.

\section{FORM 109. - INSPECTION OF ELEVATORS.}

To engage in the business of inspecting and repairing freight and passcnger elevators in office buildings, business blocks, stores, warehouses, hotels, and ilpirt ment houses, for the protection of the owners or lessees or for insurance companies engaged in the business of guaranteeing owners or their lessees against aceidents in the operation of such freight and passenger elevators.

\section{FORM 110. - INSURANCE.}

To carry on the general business of insurers of persons and property, including thereunder the transaction of a gencral lite, fire, marine, casualty, plate glass, burglary, and guaranty iusurance business.

\section{FORM 111. - INVESTMENT.}

To issue slıares of stock, debenture stock, bonds, and other obligations, to invest money in, and to hold, sell, and deliver any stock, sliares, bonds, debentures, debenture stock, and securities of any government, State, corporation, - public or private, - or other body corporate or otherwise. To valy the investments of the company, to make advances upon money held in trust ; to issue on com nission, sell, or dispose of any and all the elasses of inrestments herciubefore cnumerated, or to act as agents or brokers in connection therewitl.

\section{FORM 112. - IRON AND STEEL}

To purchase, lease, or otherwise acquirc lands in any part of the world for the purpose of prospecting for iron, coal, and other ores. "T'o mine or otherwise to remove from such lands iron, eual, and such other minerals as maty be found thereon. To manufacture, buy, sell, exprort, import, and generally deal in iron, steel, mangmese, coke, and coal. 'To sell and generally deal at wholesale and retail, in iron, steel, manganesc, coal, coke, stone, asphaltum, wood, lumber, and other materials and the products thereof.

\section{FORM 113. - LAMPS.}

To manufacture, buy, sell, import, export, aud generally deal in keroseue, electric, and gas lamps, burners, and fixtures, and deviecs of all hinds and descriptions.

\section{FORM 114. - LAND AND DEVELOPMENT COMPANY.}

To acquire by purchase, lease, own, held, sell, mertgine, or enemuleer both im-

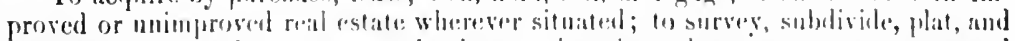

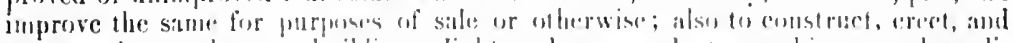

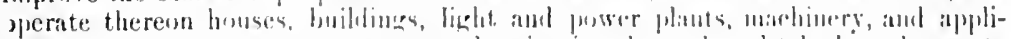

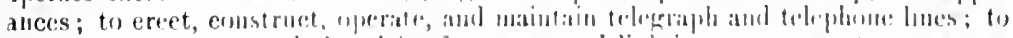

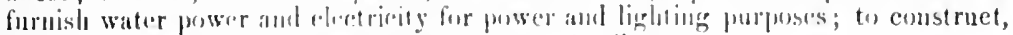
operate, and maintain robduay, trumways, and railways.

\section{FORM 115. -. LAUNDRY.}

To build, erect, purchase, l'ase, equip, or etherwise acquire a suitable plaut for

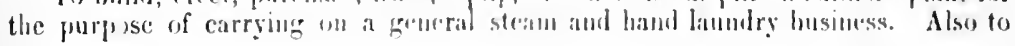


linnder, culur. Jye, disinfect. ment, clean, renovate, and prepare for use personal

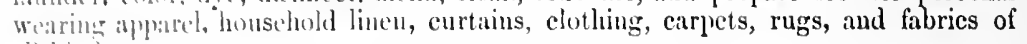
all hinds.

\section{FORM 116. - LEAD COMPANY.}

To pureliase, lease, or otherwise aequire, to own, develop, and scll lands believed ho continin lead and other minerals ; also to construct, operate, and carry on works for smelting, parting, relining, or working lead or other metals.

\section{FORM 117. - LEATHER.}

'To munfincture, purchase, export, import, sell, and generally doal in leather and all protucts thereot; also to buy and sell lands, timber, bark, lumber, and leather, both raw and mimufietured, and all kinds of leather belting.

\section{FORM 118. - LIGHT AND HEAT.}

'To mamufacture, distribute, and sell to public and private consumerz electric, sass, and vil maehines, appliances, and deviecs suitable for the production of light, heat, and power.

\section{FORM 119. - LOCOMOBILES.}

To mannfaeture, construct, purchase, or otherwise acquire, deal in, scll, hire, lease, use, repair, operite, and maintain automobiles, locomobiles, autocycles, and motor vehicles, wagons, carriages and stages of every kind and character whatsoever ; also all parts, devices, and instruments, applinces, engines, machinery, and things adapted for use in the construction of, npon, or in connection with or in the operation of such automobiles, loeomohiles, autocycles, wagons, carriages, stages, and motor rehicles of every kind and character whatsoever; also gcnerating and proselling apparatus, motive power and machinery therefor.

\section{FORM 120. - LUMBER AND NURSERY.}

To purchase, lease, or otherwise acquire real or personal property of every class and description; to raise, produce, buy, sell, exclange, and deal in trees, plants, slirubs, cereals, and any and all kinds of regetable products. To do a general nursery business. 'To grow and produce trees and timber suitable for nanufacture into lumber. 'To manufacture lumber, shingles, laths, staves, hoxes, and barrels. To buy, leasc, or otherwise acquire, mintain, and operate saw-mills and lumber rards.

\section{FORM 121. - MACHINERY.}

To manufacture, export, import, buy, sell, and gencrally deal in manufacturers', builders', and mill supplies, engines, machinery, and appliances; to manufacture, bus, sell, export, import, and generally deal in machinery of all kinds, classes, and description.

\section{FORM 122. - MAGAZINES.}

To prepare for publication, print, electrotype, hind, sell, and distribute magazincs, newspapers, books, and publications of every class and description, and to "ugerge grenerilly in the business of job and book printers, bookbinders, engravers, and electrotypers.

\section{FORM 123. - MANGANESE, ETC.}

To carry on the business of mining, milling, concentrating, couverting, smelting, treating, preparing for market, manufacturing, buying, selling, exchanging, and otherwise prolucing and dealing in manganese, copper, Jearl zinc, brass. iron, steel, and in all kinds of ores, metals, and minerals, and in the products and by-products theren of every hind and description; and by whatsoever process the same can be or why hereatter be produced, and generally and withont limit as to anount, to buy, scll. exchinge. lense, aequire, and deal in lands, mines, and mineral rights and claims, and in the above specified products, and to conduct all business appurtenant thereto. 424 


\section{FORM 124. - MANUFACTURING.}

To purchasc, lease, or otherwise acquire lands and buildings for the erection and establishmont of manufactories and workshops with suitable plints, engincs, and machinery. To mannfacture, bus, sell, import, cxport, and generally deal in machincry of all classes and descriptions.

\section{FORM 125. - MATCHES.}

To manufacture, buy, sell, export, import, and gencralls deal in friction and safety mateles of all kinds, classes, and deseriprion. Also to mamnlictmre, sell, import, export, and generally deal in boxes and receptacles for packing and ship. ping matches.

\section{FORM 126. - MECHANICAL ENGINEERS.}

To carry on the business of mechanical engineers in all its various branches; also to manulacture engines, drmamos, implenents, rolling-stock, and hadware of all kinds; also to engage in bisiness as tool makers, brass fomulers, mill workers, boiler makers, millwrirhts, machinists, manufacturers of iron and stcel compressors, merchants, clectrical, civil, and water-supply engineers.

\section{FORM 127. - MEDICAL COLLEGE.}

To build, construct, buy, lease, or otherwise acquire, equip, maintain, and conduct a college for the purpose of griving instruetion and courses of study in medicine, materia mediea, clinies, therapenties, surgery, and pathology, and in eomection with the foregoing to maintain elinies, dispensaries, and losplitils; to issue to those who have pursned such courses of instruetion therein as entitle them to the same, and to suele as have duly completed sueh contses the decrese of boetor of Medicine (II.J). Alen the erantine of diplomas to those who have not completed the conrses necessary to obtain the denree of "Doctor of Medicine," showing the completion of such work as they may have snccessiully eompleted while in the institution.

\section{FORM 128. - MEDICAL INSTITUTE.}

To build, equin, maintain, and operate institutions for the treat ment and care of the sick, poung, and intirm. To lumish massitge and cleet rical treatment of all hinds ; to furnish batlis of all kinds and descriptions; to operate dispensaries, elemical and physical laborateries; to lurnish instruction in ostengutly, massage, medical electricity, chiropoly, dermatologg, and matuicuring.

\section{FORM 129. - MERCANTILE AGENCY.}

To establish, maintain, and comdurt at genoral morrantile aneney in all parts of

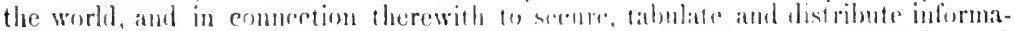

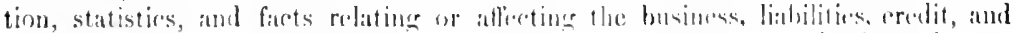

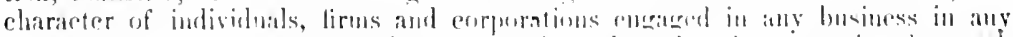

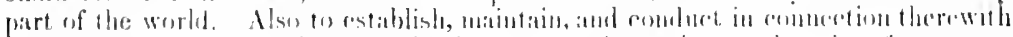

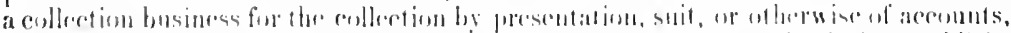

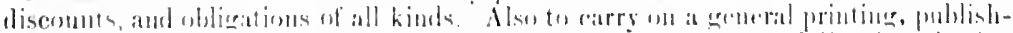

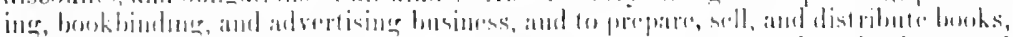
directories, reprorts, batiness, and wher matters of interest to traters, haukers, and lousiness men [encritl!y.

\section{FORM 130. MICA.}

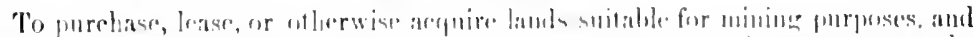

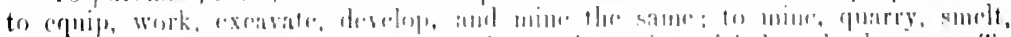

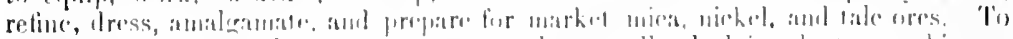

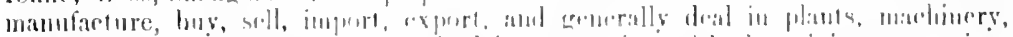

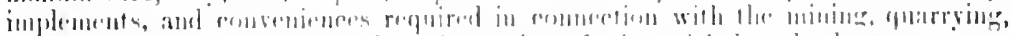

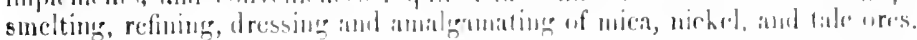




\section{FORM 131. - MINING. (Limited powers.)}

Tw prospect fur, locate, acquire by discovery, lease, licensc, option, purchase, franchise, grimt, sift, devise or otherwise, hold, possess, enjoy, develop, mine, work, operate, and expluit mines, mineral lands and elaims, mining rights, metalliferous lands and rights in or elsewhere. Also to carry on the business in all its various branches of mining for gold, silver, tin, lead, iron, and coal.

\section{FORM 132.- MINING. (Full powers.)}

(To the objects set forth in form 131 add the following :)

To enstruet, purchase, or otherwise acquire, maintain, and operate tunnels, sluices, rescrvoirs, and ditehes for mining, irrigation, and transportation purposes. Also to purchase, leatse, or otherwise acquire lands, mills, mill sites, tumel sites, buillings, machinery, power houses, pumpmer plants, pump machinery, dump rights, diteh rights, thumes, pipes, pipe lines, private railways, private tramways, private roads, easments, fianchises, and licenses. Also to purchase, construct, lease, or otherwise acquire, operate, and maintain electric lighting and power plants, buildings, machinery, applianes, and equipments appertaining thereto. To purchase, construct, lease, or utherwise acquire, operate, and mantain telegraph and telephone lines for the transmission of messiges and sound by eleetricity. 'To furnish gas, water, electricits, power, heat, and light for mining, milling, agricultural, domestic, and other uses and purposes, and to scll, lease, or dispose of the same to sueh persons or corporations, and for such price or prices and on such terms and conditions as to this corporation may seem proper. To develop, sell, store, contract for, and generally deal in and dispose of to such persons or corporations, and for such price or prices and on such terms and conditions as to this corporation may seem proper, electrical and other power for the generation, distribution, and supply of electricity for mining, heating, and power purposes. To purehase, lease, or otherwise aequire, construct, and maintain plants for the purpose of extracting values from refractory ores. To purchise, treat, refine, extract, reduce, crush, caleine, smelt, concentrate, and manipulate all kinds of ores, minerals, and metalliferons substances with a view to obtaining therefrom gold, silver, tin, lead, eopper, iron, and other metals, combination of metals, or other valuable substances with a view to preparing the same for market. Generally to engage in smelting, redueing, crushing, refining, milling, treating, assaving, and selling minerals and ores of all kinds, elasses, and descriptions. To buy sell, manufaeture, and gencrally deal in machiners, blasting powder, and ligh explosires of every deseription, fuses, caps, inplenents, candles, and conveniene's suitable for use in connection with mining and metallurgieal operations. To purchase, lease, or otherwise acpuire lands for the purpose of crecting thereon office huildings, plants, workshops, dwelling liouses, warehouses, stores, hotels, and other buildings in comnection with the foregroing purposes.

\section{FORM 133. - MINING INVESTMENTS.}

To inrest in, take over, buy, sell, pledge, and exehange stock, shares, bonds, and securities of mining companies, whether incorporated moler the laws of the several eommonwealths or under the laws of any foreign country; to make advances upon, hold in trust, buy and sell on commission, sell or dispose of any of the investunems attoresaid, or to act as anditor for any of the above or like purposes. To holl, purchiase, or otherwise aequire, to sell, assign, transfer, mortgage, pledge, or otherwise disperse of shares of the capital stock, bonds, and seeurities issued or ereated by other eorporations, and while the holder thercof to exereise all the rights and privileses of ownership, including the riglit to vote thereon. 'To cause or allow the legeril title, estatr', and interest in any property acquired, established, or carried on by the eompany to remain or to be vested or registered in the name of or carricd on by any other company or eompanies, forcign o! domestie, formed or to be formed, and cither upon trust for or as agents or nomines of this company, or upon any other terms or conditions which the Board of Directors may consider for the benefit of 
this company, and to manage the affairs or take orer and carry on the busmess of such company or companies so formed or to be formed, either by acquiring the shares, stocks, or other securities thereof, or otherwise howsoever, and to exereise all or any of the powers of holders of shares, stocks, or securities thereof, and to receive and distribute as profits the dividends and interest on such sharcs, stocks, or securities. 'To guarante the payment of dividends or interest on any share, stocks, debentures, or other seeurities issued by or any other eontract or ohligation of any corporation when in the judgment of its directors the same is proper or necessary for the business of the eompany; and provided the required anthority be first obtained from the Board of Directors for that purpose. 'T'o remunerate any person or persons or corporation for services rendered or to be rendered in placing or assisting to place, or guaranteeing the placing of any of the shares of thic eompany's capital, or any debentures or other securities of the company, or in or about the formation or promotion of the company or the conduct of its business.

\section{FORM 134. - MINING RIGHTS.}

To search for, prospect, and explore for ores and minerals, and to locate mining claims, grouuds, or lodes in the United States of America or the territories thereof, or in foreign countries, and record the sane pursuant to the mining laws of the said United States or other eountries; and to aequire mining and mineral rights or interest thercin when desirable; to mine, fuirry, work, and develop mining grounds, claims, or lodes, mining and mimeral rights; to erush, concentrate, smeli, refine, dress, analgimate, and prepare lor market ores, metals, and mineral substances of all kinds, and to do all other acts and things necessary or eonducive to the company's objects, including the ereetion of buildings or works and the installing of maclinery and appliances of every description whenever required ; to mortgage any mining grounds, clitims, or lodes, mining and nineral rights, or other property belonging to said company, and to issue bonds of the company whenever it may be determined so to do. 'To purchise, acquire by lease, license, or otherwise mining grounds, cliins, or lotes, miniug and mineral riglits, concessions or grants, or any interest therein, and to obtain pittents therefor when desirable. To buy, scll, and deal in ores and minerals, plants, michinery, tools, implements, groceries, provisions, clothing, boots and shoes, furnishing articles, hardware, wooden and metallie ware, with all other articles and things in any wise required or capable of being used in connection with mining operitions, and to make and manuficture such articles when required. To construet, carry out, maintain, improve, equip, manage, cont rol, and superintend any roads, ways, privite railways, private tramways, bridges, reservoirs, waler courses, aqueducts, wharves, piers, docks, bulkheals, furnaces, mills, crushing, concentrating, and smolting works, liydraulic works, faetories, dwelling houses, and warchouses; to purchase vessels or other means of tramsportation, execpt railroats other than private railroals, and equip and operate the same as required for the usis and purposes of the comprany, and also to do any ofluer acts and thinges relating to mining.

\section{FORM 135. - MORTGAGE AND TRUST.}

To issue, secure, or offer for sale: stocks, bonds, mortgages, and otler ohligations; to invest for individuals or corpurations any stocks, bonds, morterieres, debentures, and scenrities of any gevermuntent, state, corporation, - publis or private, - and in

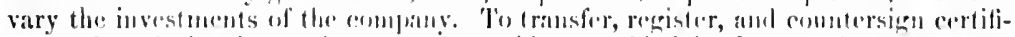

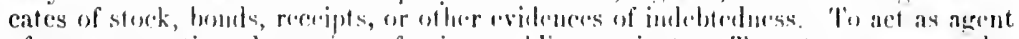

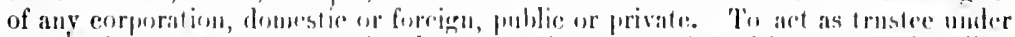

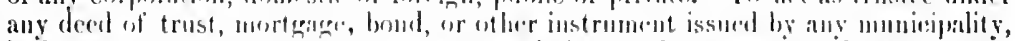

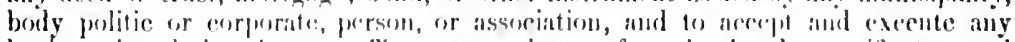
busincss in relation therele. 'T'o ace as regist rar of stocks, bomds, cortifieates, and debentures, and as transfer agent of any errporations or individuals. 'T'u act as

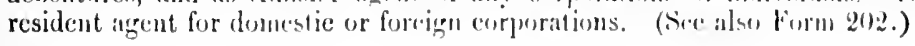




\section{FORM 136. - MOTOR CARS.}

'T) mamufacture, luy, sell, import, export, and generally deal in all kinds of :mutumubile's, motuls, migines, machines, and all kinds of maehinery and deviees for the oprestlem of steam, electricity, and other forms of power. To manufacture, luy, sell, cypurt, import, and generally deal in cars, earriages, wagons, cugines, apparatus. and redieles of every kind and deseription for the transportation of passenurers and gunds. 'To manufieture, buy, sell, import, export, and generally deal in machinery, machine supplies, and chumeering applianees incidental to the construethon of mutur cars.

\section{FORM 137. - MOTOR COMPANIES.}

To maunfacture, buy, soll, export, import, and generally deal in motors run and operated by water, stenm, or clectrieity, including the manufaeturiug, buying, selling, imperting, exporting, and generally dealingr in any and all kinds of motors and other pats and materials entered into or used in the manufacture and operation of the same, and generally to earry on the manulaeturing and selling of any articles or specialties, patented or otlucrwise, which can be carried on in conjunction with any of the matter's aforesaid in or "non the premises of the company, and for that purpose to purchise, lease, or otherwise acpuire and sell real and personal property, including all neecssary machinery adapted to such apparatus.

\section{FORM 138. - MUSICAL INSTRUMENTS.}

To mamucture, buy, sell, import, export, and generally deal in musical instruments of all kinds, elasses, and description. Also to purehase, print, publish, and sell roeal and instrumental sleet music.

\section{FORM 139. - NEWSPAPERS.}

To engage in business as proprietors and publishers of newspapers to be printed at the City of State of and to be known as " aud in connection therewith to carry on the business of job printing, engravers, publishers, lithorgaphers and electrotypers.

\section{FORM 140. - NICKEL.}

To prospeet for, acquire, lease, and develop lands eontaining or believed to contain nickel and other ores, coal, or oil. Also to mine, mill, reduce, smelt, manufacture, and prepare for market nickel and other wares and all or any produets thereof.

\section{FORM 141. - NOVELTIES.}

To manufucture, buy, sell, import, export, and generally deal in novelties of every eliss and description, whether patented or otherwise. To engage generally in buying, sclling of goods, wares, and merchandise of every elass and description.

\section{FORM 142. - OIL AND PETROLEUM.}

To loeate, purelase, lease, or otherwise acquire lands, mines, mineral claims, water rights and franchises, mill sites, timber lands, limestone quarries, and partienlarly lands eontaining or believed to contain petroleum and other oil springs and depiesits; to carry on the business of searehing for, prospecting, preparing, producing, lelining, piping, storing, transportiug, supplyiug, bnying, selling, manufacturing, ind distributing petrolenm and other oils and their products and by-produets. To comstruct, brilil, operate, and maintain oil wells, refineries, buidings, machinery, plants, stores, and warehouses. 'T'o handle, store, trimsport, and prepare for market oils and oil prodnets and by-produets, and to erect, maintain, and operate refineries, inills, works, laboratories, workshops, and dwelling louses for workmen and oflicrs. To senrch for, mospret, examine, refine, sncht, rednee, crush, eoncentrite, manipulate, and treat goll, silver, lead, copper, iron, and minerals of every elass and deseription. To mannlacture, buy, sell, import, export, and generally deal in machinery, 
pumps, drills, fuses, caps, candles, implements, and convenicnces suitable for use in connection with the oil or mining business.

\section{FORM 143. - OIL AND PIPE LINE COMPANY.}

To purchase, leasc, or otherwise acquire lands, mineral and oil riglits and privileges in the State of Also to purchase, lease, or otherwise acquire in the State of and other parts of the world, lands containing or believed to contain petroleum or other oil spring deposits. Also to store and trans. port oil, gas, brine, and other mineral solutions, and to makc reasonable charces therefor. 'To bur, sell, and furnish oil and gas for lighting, heating, and other purposes. To lay down, construct, mintain, and operate pipe lines, tubes, lanks, pump statious, comnctions, fixtures, storage houses, and such machinerr, apparatus, and devices as may be necessary to operate such pipes and pipe lines betwern various points. Also, wherever permitted by law, to lave right and power to cuter upon rights of ware, easements, properties of all persons and corporations, and to have the right to lay its pipes and pipe lines across and under any public road, railroad, right of was, street railroad, canal, or stream. To las its pipe and pipe lines across and under any street or alley in any incorporated city or town, with the cousent and under the direction of the proper authorities of such cities or towns. Also to carry on the business of producing, refining, and storing petroleum products, vegetable and mineral oils.

\section{FORM 144. - PAINTS.}

To manufacture, buy, scll, import, cxport, and generally deal in paints and painters' supplics.

\section{FORM 145. - PAPER.}

To cngage in business as manufacturers and dealers in paper, and paper substitutes of all kinds. Also to huy, sell, export, import, ind generally deal in wall paper, wood pulps, and all kinds of materials useful or necessary in the manufacture of paper.

\section{FORM 146. - PASSENGER AND BAGGAGE TRANSFER.}

To engage in the business of transfer for hire within the city of (or belween certain designated cities) passage, baggage, and fright. Also to purchase, lease, or otherwise acquire carriages, compés, hamsoms, antomobiles, baggage, express and mail wagons, carts, and drays. Also to purehase horses, barns, and warchouses in order to tacilitate the carrying on of the above lines of business. Also to store and care for all kinds of velicles, trunks, and personal property of every description in commection therewith. 'To operate and maintain one or more barns, warelouses, and storeroons.

\section{FORM 147. - PATENT MEDICINES.}

To manufacture, buy, sell, export, iupmrt, au! generally deal in patent medieines, formuls, and preparations of every kind, class, and description. Also lo carry on the business of elomists, domegists, elemileal manufacturers and denlers in pharmaccutical and menlicinal preparations. Also to prepare, buy, sell, expert, import, and generally deal in minural waters, liquors, and prepared foods.

\section{FORM 148. - PATENTS.}

To establisle, enduct, and carry on the business of buying, sefling, and otherwise dealiug in improrements, trate marks, trule names, and any letters palent,

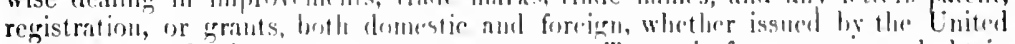

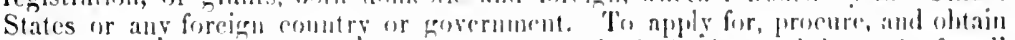

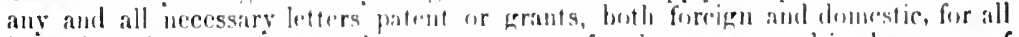
inventions, improvenemts, and secret processes for the urcount and in the name of 
the corporation, or as the agent for any person, firm, or corporation. To exploit nud develop : any and all sueh inventions, improvements, tride marks, and proeesses he cotablishing in this or any forcign country any and all necessary plants, fictories, and machinery for the mannfaeture of phitent articles of any elass, nature, or deseription.

\section{FORM 149. - PHONOGRAPHS.}

To manufacture, buy, sell, export, import, lease, or otherwise acquire, invest, and gencrally trade in somul-reproducing miehines, talking machines, and reeords for such machines, and all appurtenances thereto, together with all rights, patents, and improvemenis thereon, now held or hereafter to be obtained by purchase or otherwise, ineluding all neecssary machinery adapted for such purposes.

\section{FORM 150.-PHOTOGRAPHY.}

To carry on a general photographie business in all its various branches within the city of - To purehise, lease, or otherwise aequire the neeessary chemicals, scrcens, drugs, cameras, and apparatus for the taking, developing, and funshing of all kinds of photographs. 'T'o purehise, sell, and generally deal in cameras, photographic supplies, pietures, picture-frames, prints, drugs, chemicals, and supplies necessary or useful in the tiking, development, and printing of photograiphs.

\section{FORM 151. - PIANOS.}

To manufacture, buy, sell, import, export, and generally deal in pianos, organs, and all kinds of musical instruments. 'To scll and lease musical instrnments and any and all parts thereof. To manufaeture, buy, sell, import, export, and generally deal in all kinds of machinery, supplies, implements, appliances, substances, and materials incidental to or entering into the manufacture of pianos, organs, and musieal instruments. To purchase or otherwise acquire any interest in and to patents, brevets d'invention, licenses, eoneessions, and the like conferring an exclusive or non-exelusive or limited right or any seeret or otber information as to any iurentiou in relation to musical instruments of any kind.

\section{FORM 152. - PIPE FOUNDRY.}

To manufacture, buy, sell, export, import, and generally deal in all kinds of pipe castings and fittings.

\section{FORM 153. - PLANTATION COMPANY.}

To cngage in the buying, selling, raising, importing, and exporting of fruit and vegetable products. To cultivate, plant, produce, buy, sell, and raise all kinds of vegetable products. To do a general importing and exporting business by and between domestic and foreign ports, and also a general coastwise business to doinestic ports.

\section{FORM 154. - PLUMBERS' SUPPLIES.}

To mannfacture, export, import, buy, sell, and generally deal in all kinds of plumber supplies, including lead, steel, and copper, pipe, traps, sheet lead, solder, and iron. Also brass, wood, marble, or other earthenware material or supplies necessary or convenient iu earrying on the aforesaid business.

\section{FORM 155.-POTTERY.}

To manufacture, buy, sell, import, export, and generally deal in all kinds of pottery, tile, and earthen products. 


\section{FORM 156. - POULTRY.}

To engage in the busiuess of raising, sclling, and preparing for market all pouitry and eggs. To purchase, lease, or otherwise acquire land, buildings, and necessary equipment for the carrying on of the atoresaid business. To buy and sell chicken tood and incubators. To buy, sell, import, export, and generally deal in poultry and poultry products of every kind, class, and description. 'T'o jattel, breed, and raise, either by natural means or incubators, poultry of every kind, class, and description. To bny and sell clickcns, ducks, geese, and guinea-fowls. To priut, publish, and distribute magazines and literature of every class and description.

\section{FORM 157. - PUBLISHERS.}

To engage in business as propriet ors and pablishers of newspapers, journals, and magazines. To aequire, print, publish, conduct, or otherwise deal with any newspaper, magazme, books, or other publications ; to carry on the business of newspaper and magaziue proprietors and publishers. 'T'o carry on the business of job printers, lithographers, electrotypers, engravers, and advertising agents.

\section{FORM 158. - QUARRY.}

To acquire, mine, eut, fuish, buy, sell, import, export, and gencrally deal in marble, and all kinds of building and paving stones. Also to acquire by purchase, lease, or otherwise lands believed to contain marble, building and paring stone.

\section{FORM 159. - RAILWAY EQUIPMENT.}

To buy, lease, or otherwise acquire, construct, maintain, aud operate smelters, rolling mills, carriages, machine shogs, limmees, erushing works, and hydraulic works of every class and description; to mannficture, buy, sell, import, export, and generally deal in all kinds of rails, ties, switehes, signals, torpedoes, fises, cugines, and supplies lor railroists and street railways; to manulacture, buy, import, export, and generally deal in iron, stecl, aluminum, manganese, lend, zinc, tin, copper. and lumber.

\section{FORM 160. - REAL ESTATE. (City.)}

To purchase, lease, or otherwise aequire, sell, and exchange lands, tenements, and hereditaments situated in the eity of and vicinity; also to build, construct, reconstruct, alter, furnish, cequip, and maintain thereon ollices, ap:artment houses, business blocks, buildings, shops, and structures of all kinds tor oflur's on commission on otherwise. Also to manatge busiuress blocks, apartuent houses for owners, and to guaranty the inesme therenf, and to collect rents the relirom, and to supply to tenants and others janitor scrvice, light, heat, and power appliances,

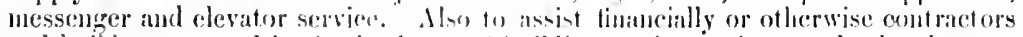

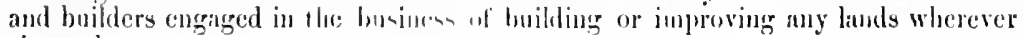
situated.

\section{FORM 161. - REALTY.}

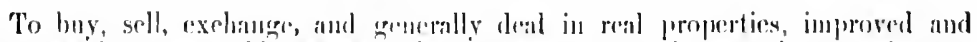

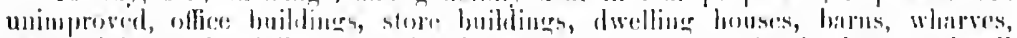

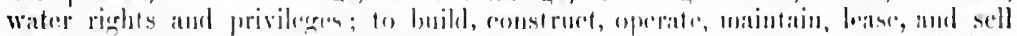

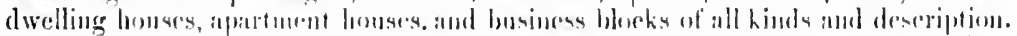

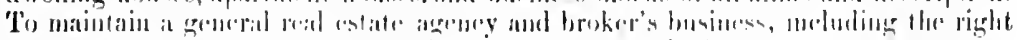

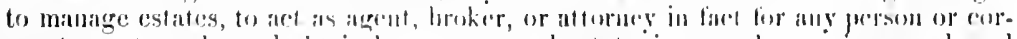

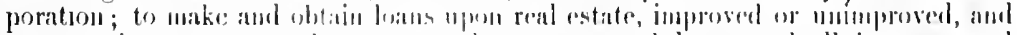
to supervise, Inanage, and protret such property and lonus, mud all interests and

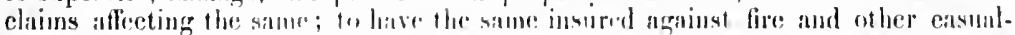
ties; to investigate the erentit, financial solveney and sufficieney of horrowers, mortgagors, and sureties upon bunds, mortgiges, and undertakings. To inprove, 
maltige, "yreate, sell, mertgage, lease, or otherwise dispose of any property, real (1) personit, and lahe morlgagr's and assignments of mortgages upon the same.

\section{FORM 162. - REDUCTION COMPANY.}

'Tu hus, lease, on otherwise alequire, construet, maintain, and operate plants of overy nature and description, for the purpose of extracting refractory ores and mincrials of every deseription.

\section{FORM 163. - REFINERIES.}

To buy, lease, or otherwise acquire lands containing or believed to contain protrolum, nitural gas, oil springs, or mincral deposits; to earry on the business of producing, refining, stering, supplying, and distributing petrolem produets of all classes and description ; to refince, store, distribute, and sell vegetable and mineral (bils: to purehlase or uflerwise atequire, lease, construct, operate, and maintain retineries, mill works, laboratories, pipe lines, storage tanks, dwelling houses for workmen and others in eomection with the purposes hereinbelore set forth.

\section{FORM $164,-$ RESTAURANTS.} of

To purehase, lease, own, and operite restanrants and lunch stands in the eity

\section{FORM 165. - RUBBER COMPANY.}

To acquire by purchase, lease, exchange, or of herwise lands, tenements, hereditaments, and property of every elass and deseription, for the planting, cultivation, and growing of rubber trees, and for the purpose of producing, buying, exporting, importing, selling, and generally dealing in rubber, and the artieles and goods of all kinds of whieh nubber is a eomponent part, together with the various materials which enter into the manulacture of such gools. To earry on the business of planters. To purchise, or otherwise aequire, manufacture, prepare for market, export, imprort, ind sell any products or by-products of rubber, and to sell, dispose of, and generally deal in the same, either in their prepared, manufictured, or raw state, both at wholesale and retail.

\section{FORM 166. - SALT.}

To manufacture, buy, sell, export, import, and generally deal in salt and the produets thereof. Also to aequire by purehise, lease, or otherwise lands believed to contain salt and other mincrals.

\section{FORM 167. - SANITARIUMS.}

To build, construet, purchase, lease, or otherwise aequire, equip, and maintain sanitariums for the treatment and care of the siek, disabled, and infirm. To maintain in ennection therewith dispensaries, lrotels, and training schools for nurses.

\section{FORM 168. - SAUCES AND PICKLES.}

To manufacture, buy, sell, import, export, and generally deal in sances, catsups, relishes, pickles, and gamishing supplies; to huy, lease, or otherwise acquire, construct, maintain, and operate sauee and piekle faetories, eold-storage receptacles, warehouses, and depots. To raise vegetables and fruits of all elasses and descriptions.

\section{FORM 169. - SAW-MILLS.}

To purehase, lease, or otherwise acquire timber-lands, tracts, and rights. To bny, sell, cxport, import, boom, saw, and prepare for market, and generally deal in timber and wood of all kinds. Also to manufacture, buy, sell, export, inport, and groureally deal in all kinds of goods and atrickes matrifietured form wood, and generally to carry on business as saw-mill proprietors, timber alud lumber dealers. 


\section{FORM 170. - SCALING.}

To scale steam boilers, bilges, water tanks, and kindred articles; to clean and furnish shafis and tumels; to build wells and hindred articles, and to do all kinds of repair work ; to build, repair, own, bus, and sell sciling works and shops of erery nature and description; to manufacture, bus, sell, import, export, and generally deal in engines, boilers, shop maclinery, fixtures, and supplies, and all hiuds of heary hardware.

\section{FORM 171. - SEPARATORS.}

To manufacture, buy, sell, import, export, and generally deal in separating maclines of all kinds, classes, and description ; to bus, lease, or otherwise acquire, construct, operate, aud maintain tactories, workshops, warehouses, and depots for the manufacture of separating machines.

\section{FORM 172. - SEWING MACHINES.}

To manufacture, buy, sell, import, export, and generally deal in sewing machines of all kinds, and all tools and appliances appertaining thereto.

\section{FORM 173. - SHEEP.}

To carry on in all its branches a general live stock and stock raising farm and range business; to buy, sell, brecd. raise, export, import, and generally deal in sheep, cattle, horses, poultry, and all hinds of domestic animals. T'o buy, lease, or otherwise acquire, construct, maintain, and operate slaughter-houses, liactories, stock yards, and to carry on a dairy business in all its sercral branchics.

\section{FORM 174.-SHIP BUILDING.}

To build, prepare, operate, sell, and charter stemships, sailing vesse's, boats, and canoes of all kinds, together with all appliames and machinery cutering noto or convenient for the construction or operation of the same. Also to mandacture, bus, sell, export, import, and generally deal in ropes, cables, windlasses, capstans, tackle, and tarpaulins of all kinds and descriptions.

\section{FORM 175. - SILK.}

To manufacture, produce, exprort, import, buy, sell, and generally deal in silk and other fabrics; 10 raise silkworus and cocoons, and deal in each and all of the products thereof; to mamufacture, buy, soll, import, expurt, and gremerally deal in cocoon sarn, thread, and ofler r like matrial, and to spin, wease, and handle the same and deal with oflece fabries. 'lo plant, raise, hur, and sell eotton plants and convert the same into fabrics. 'To plant and rabe mulberry trecs and other silkworm foods.

\section{FORM 176. - SLATE AND TILE.}

To manufacture, bux, sell, rxpurt, impert. and generally doul in slate, stone, tile, brick, marble, atud bulding materials of all himds atmd descriptions.

\section{FORM 177. SLAUGIITER-HOUSES.}

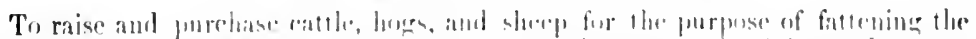

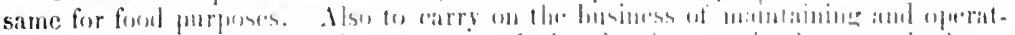

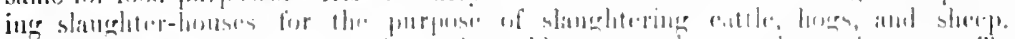

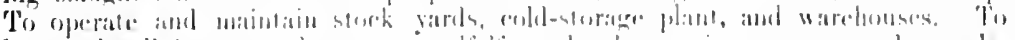

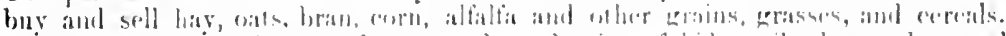

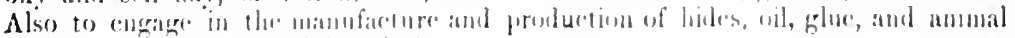
fertilizers of all kinds and descriptims. 


\section{FORM 178. - SLOT MACHINES.}

To manufueture, buy, sell, import, export, ant generally deal in slot machincs of whatserever niture and ilature; to manntieture, buy, sell, import, export, and genrrally deal in all artieles, apparatus, plants, and machinery useful in or which may be llsed in eunnetion with the furegoing deseribed business or any of its branches.

\section{FORM 179. - SOAP.}

To manufacture, buy, sell, import, export, and generally deal in soap for toilet and domestic use. Also to purchise all materials suitable or necessary for the proper manufacture of soap.

\section{FORM 180. - STATIONARY ENGINES.}

To manuficture, construet, purehase, or otherwise aequire, deal in, sell, hire, lease, use, repair, operate, and maintain stationary engines and cngines or power applying machinery and deviees of any and every ebaracter, and any and all parts, devices, ifplianees, instruments, and things adipted for use in the construction of, upon, or in eomeetion with or in the operation of such stationary engines and cugiues or power applying machinery and devices of any and every character.

\section{FORM 181. - STATIONERS.}

To engage in business as stationers, printers, electrotypers, lithographers, cugravers, bookbinders, booksellcrs, and paper dealers.

\section{FORM 182. - STEAMBOATS.}

To bur, lease, or otherwise acquire, eonstruet, maintain, and operate steamboats and other ressels of any class; to establish and maintain lines of regular service of steamboats and other ressels to be employed in inland or coastwise service in the United States and between the ports of the United States and foreign countries. To carry on the business of shipowners, and to enter into contracts for the carriage of mails, passengers, goods, and merchandise by any means, either by its own vessels, railways, or convenienees or by or over the vessels, milways, or eonveniences of others. T'o insure against loss by fire, thood, or other ealamity the cargo carried or transported upon the company's steamboats or other vessels, and upon such steamboats and vessels themselves. 'To buy, lease, or otherwise acquire, construct, maintain, and operate wharves, piers, doeks, warehouses, and depots; to manufacture, buy, sell, and generally deal in all kinds of materials, articles, machinery, engines, boilers, and lumiture entered into or suitable or convenient for the construetion, equipment, and operation of steamboats and other vessels; to design, construct, and repair vessels, ships, boats, wharres, doeks, dry docks, and piers. To carry on the business of eold-storage warehouse and any business incidental or impliedly incilental thereto. 'To issue eertificates, negotiable or otherwise, to persons warehousing goods with the corporition, and to make advances or loans upon the security of such goods or otherwise.

\section{FORM 183. - STEEL LATH AND FIREPROOFING COMPANY.}

To manufacture, sell, import, export, and generally deal in all kinds of slieetsteel latll suitable for the fireproofing of buildings and struetures of every kind and description; to manufacture, sell, import, export, and generally deal in sheet iron and steel of all kinds and description; to earry on the business of contractors and builders in all the rarious branches of said business.

\section{FORM 184. - STEEL MANUFACTURE. (Part of charter of U. S. Steel Corporation.)}

To mine, prepare for market, and transport coal. iron, steel, and all mineral substances. To manufaeture, buy, sell, deal in and deal with iron, stecl, copper, man4.94 
ganese, lumber, and other materials, and all or any articles consisting or partly consisting of iron, steel, eopper, wood, or other materials, and all or any products the reof. 'To acquire, own, leasc, oceupy, use, aud develop any linds containing eoul or iron, manganese, stones, or other ores or oil, and any woodlands or other lands for any purpose of the company. To mine or otherwise extraet or remove coal, ore, stone, and other minerals and timber from any lands owned, aequired, leased, or occupied by the company, or from any other lands. To buy, sell, or otherwise deal or tralfie in iron, steel, manganese, copper, stone, ores, cual, eoke, wood, lumber, and other materials and any of the produets thereof, and any artieles consisting or partly eonsisting thereol. 'To promote, construet, divide, acejuire, approve, manage, develop, control, take on lease or angeement, sell and use, work and dispose of any roads, sidings, private railways, pipe lines, wharves, docks, bridges, reservoirs, canals, water courses, hydranlie works, gas works, eleetrieal works, mills, foundries, furnaces, warehouses, shijs, buildings, buildings for employes and others, and other works and appliances. To construet, lease, own, operate, and sell tramsportation rights by land or water in any State or conutry subject to the laws thereot, either directly or through the ownership of stock in any emporation. To manuticture, purchise, lease, aequire, and own goods, wares, and mercliandise and personal property of every elass and deseription. 'To hold, own, sell, and otherwise dispose of, trade, deal in, and deal with the same. To aequire and undertake the good will, property, rights, franchises, and assets of crery kind and the liabilities of any person, firm, or association, either wholly or partly, and to pay for the same in casli, stock, or bonds of the eompany or oflierwise. "To the extent permitted by the local laws of any State or forigin enmutry where the property may be situited, the company may cause or allow the legal title, estate, and interest in any property, or business aequired or earried on by the compruy to remain or be vested or registered in the name of or earricd on by an individual, or to be operated by another company or companies, foreign or domestie, formed or to be formed, and either upon trust for or as agents of this company or upon any ofler terms and enditions whieh the boand of direturs may consider for the benefit of this company, to manage the affuirs so taken over. 'fo earry on the husiness of snel eompany or compranies so formed or to be formed, eitler by acquiring the stoek or other securities thereof, and aequire all or any of the powers of holders of shares, stoek, or scenrilies thereof, and receive and distribute dividends on sueh stoek, shares and securities.

\section{FORM 185. - STEREOPTICON MACHINES.}

To manufacture, construet, buy, sell, import, export, and generally deal in sterenticon machines, whether antomatic or otherwise, of all hinds and deseription; and in eometion therewith to huy, sell, lease, or notherwise aequire suitable storcs, space in expositions and fair's, and concessions of all kinds.

\section{FORM 186. - STEVEDORES.}

T'n carry on business as sterentores in the eity of and ricinity, and in commention therewith to buy and sell trucks, wherlbarrows, laristing matchin-

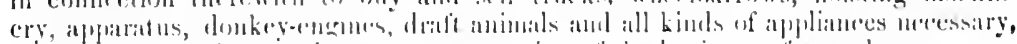
usetul, or convenient to the puner tratusation of the busimes of steredones.

\section{FORM 187.--STOCK BROKERS.}

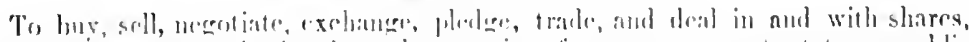

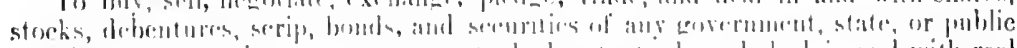

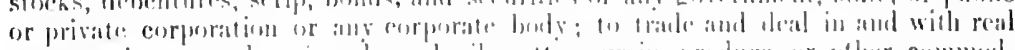

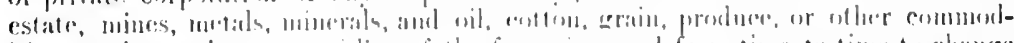

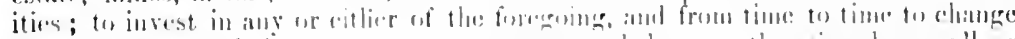

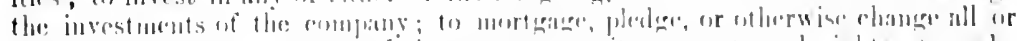

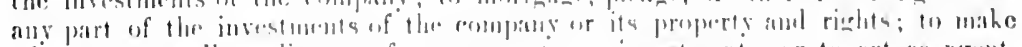

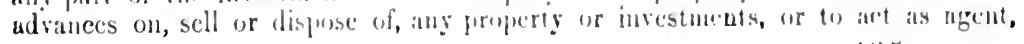


fartur, or brokir for any or cither of the corporate purposes. 'To purchase or otherwise aeguire the' (atpitial stoek, shares, debentures, serip, bonds, or other evidenees of indebtedhess of any other eorporation, and to issue in exclange its own stock, shatre bumls. delnentures, serip, or other evidences of indebtedness in payment therefor, and whike the owner thereof to exereise all the rights of ownership, inclubling the power to rote "upon such stock or shares. To purchase, receive, hold, and own nurtgrages, debentures, shares, and other securities or obligations of any publie, private, or muniespal eorporation, or bouts or other securities or chlinations of the gorernment of the United States, or of any State, distriet, territury, colony, or dependeney of the United States or iny foreign country, Slate, or coluny; to colleet and receive, dishorse and dispouse of, all interest, dividends, acemunlitions, carnings, and ineone from, upon, or on aceont of any bonds, debentures, sherks, shares, securities, contracts, evidenees of indebtedness, obligations, or ofler property lede or owned by the eorporation therein; to do any and all lawlul aters trinding to inerease or enhmee the value of the property of the company. 'To issue stock, shares, bouds, debentures, eertificates, serip, or other corporate obligations and to secure the payment thereof by mortgage, pledge, or deed of trist of of upon the whole or any portion of the corporate property or funds; to sell, pledger, or otherwise dispose of bonds, debentures, or other corporate oblinations fin proper and lawful purposes, as and when the Board of Directors shatl derm necessary, advisable, or expedient; to promote the corporate business of investment and dealing in securities in all lawhul ways; and to receive, collret, tamsmit, pay out, and disburse lunds in the eourse of its business; and to the extent anthorized by litw to lease, purehisse, or otherwise acquire, hold, use, sell, trinde, and deal in and with, assign, pledgre, mortgage, transfer, and convey real and personal property of any nime or nature; to issue and accept drafts, bills of cxehimge, promissory notes, scrip, drafts, acceptances, or other corporate obligations and negotiate the same.

\section{FORM 188. - STORAGE BATTERIES.}

To mannfacture, buy, sell, export, import, and generally deal in electrical storage batteries, machineries, and applianees for the storage of electricity for the purposes of furnishing power for business or domestie purposes.

\section{FORM 189. - SUGAR REFINERIES.}

To plant, eultivate, grow, produce, manufacture, buy, sell, export, import, and generally deal in sugar. Also to purehase, lease, or otherwise aequire sugar lands and phantalions, retiucries, buildings, mills, and machincry. 'To plant, cultivate, produce, and rase sugar cane. Also to carry on the business of refining, preparing, buying, selling, importing, exporting, and gencrally dealing in sugar eane, sugar wills, and syrujs.

\section{FORM 190. - SURGICAL INSTRUMENTS.}

To manufacture, buy, sell, and deal in surgical, ehenical, electrical, and scientifie instruments and proprictary articles of every class and description.

\section{FORM 191. - TAILORS.}

To earry on the business of tailoring and dealing in eloth and clothes and all kinds of grents' furnishing goods.

\section{FORM 192. - TANNERIES.}

To construct, buik, maintain, operate one or morc tameries in the State of Also to buy, sell, import, expert, and generally deal in hides, skinc, raw and finished, and leather of all classes and deseription. Also to purclate, sell, latse, or otluerwise acquire lands, timber, and bark required for the operation of the aforesaid line of busincss. 


\section{FORM 193. - TAR MANUFACTURING.}

To purchase, lease, or otherwise aequire lands for the erection and establishment of a manutactors or manufactories and workshops with suitable plants, engines, and machinery, with a view to manufacturing, purchasing, leasing, or otherwise dealing in coal tar, and each and every by-product of coal tar, utilizing the same in any condition, comection, or form whatsoever; to manufaeture, purehise, lease, export, import, and generally deal in eoal tar and any by-product thereof, and iny materials, articles, and things required for, or in conneetion with or incidential to the manufacturing thereut.

\section{FORM 194. - TELEGRAPH AND TELEPHONE COMPANIES.}

To acquire, mamufacture, buy, sell, and generally deal in telegrapls and telephone instruments, machines, and apparatus; to construct, ereet, build, operate, and maintain telegraph and telephone stations for the transmission and reception of messages by electricity, wire or wireless instruments ; to receive and trunsmit messages by signal or other device and by any and all other electrieal deviee's and contrivances from, upon, and by wire or wireless instruments and any and all similar, kindred, and like instruments and deviees ; to transmit and recoive messages for hire over, upon, and by wire and wireless srstems, of telegraphing and telephoning by any and all systems and devices for transmitting and receiving messiges. To buy, build, or ealuse to be built, operate and maintain stations for the lansmission and reeption of telecraph and telephone messages by means of wire or wireless strstens; to carry on the business of transmitting and receiving messages from such stations. To aequire and hold lands, propertr, aud buildings necessary or useful in the conduct of the business of telegraph and telephone companies under wire and wireless spstems, and in conncetion therewith to manufaeture and construct machiners, instruments, apparatus, wires, and any and all other materials and articles used with or pertaining to telegrapls and telephone lines.

\section{FORM 195. - THEATRES.}

To construct, purchase, leise, or otherwise acquire theatres, concert halls, and amusement places of all kinds and deseriptions. Also to earry on the business of theat rical proprictors, and music hall proprictors. Also to mamage theat rical, eoneert hall, and vaudeville companies of all kinds, elasses, and deseription. Also to entage and euploy actors, singers, dancers, athletic, theatrical, and musical artists of all kinds. Also to purelitse, own, prodier, and present, and to lieense ot hers to produce and present, theatrical plays, operas, and exhibitions of rarious hinds.

\section{FORM 196. - THREAD.}

To manufacture, buy, sell, import, export, and generally deal in ecoton, linen,

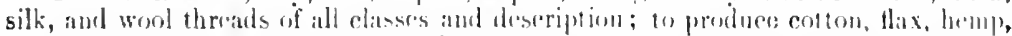

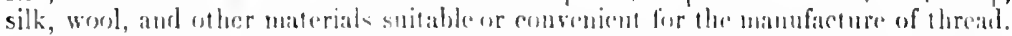

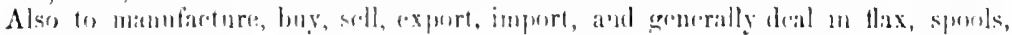
bobbins, boxes, labels, and all kimls of machines and torls necessary or useful in the manuficture of threads.

\section{FORM 197. - TOIACCO.}

To plant, grow, cultivite, rure, and manuficture tobacen. 'To export, imprort,

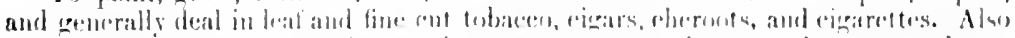

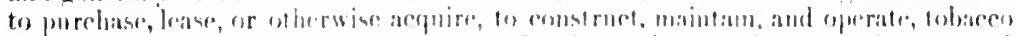

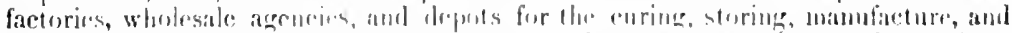
sale of whacere, cigars, cheronts, rigarettes, and smokers' smpplies. Also to buy, sell, inupren, export, and [emerally des] in pipes, rigar and cigarette bolders, cigar cutting machimes, and smokirs' supplies of all himls. 


\section{FORM 198. - TRADING STAMP COMPANY.}

To design, mannliseture, print, and engrave prenimm stamps, tickets, or coupons, and to nse, sell, or otherwise dispose of the same to merehants, manulacturers, or to any person, firm, eopartnership, or eorporation, for distribution or sale by them to their customers; to exchange such stamps, tickets, or compons for goods, chattels, wares, and merehandise; to co-operate and eontract with merchants, mamufacturers, eopartuerships, eorporitions, or other persons for the purpose of furnishing them wh preminm stamps, tickets, or coupons for their customers, and to give them grools, ehattels, wares, and merehandise in exclunge for such premium stamps, tickets, or eoupons; to carry on a general advertising business in all its branches, both as prineipals and agents; to earry on the business of printers, stationers, engravers, designers, and dealers in paper; to establish and conduct a general store for the sale or exchange of goods, chattels, wares, and mercliandise of any and every class and description.

\section{FORM 199. - TRAIN CONTROL.}

To manufacture, buy, sell, import, export, install, maintain, and gencrally deal in railroad switehes, train-controlling devices, signals, aud equipment ; to manufacture, bur, sell, export, import, and generally deal in iron, steel, manganese, coke, copper, lumber, and all or any articles consisting or partly consisting of iron, stecl, copper, wood, or other materials, and all or any produets thercof; to acquire by purchase or otherwise land or buildings, mills, plants, machinery, secret processes, or other things found necessary or convenient for the purposes of the company. To manufacture or purchase, or hoth, all tools, machinery, and appliances necessary, proper, or convenient for the carrying on of the said business.

\section{FORM 200. - TRANSPORTATION COMPANY.}

To earry on the business of engaging, recciving, trausporting, and delivering merchandise upon freight or for lire, between any port of the United States and any other port or ports of the United States, or between any foreign port or ports and any port or ports of the United States; the business of owning or chartering ressels therefor; the business of operating vessels in such service; the business of eontracting or arranging for the transportation of merchandise to or from any of such ports by rail, boat, or otherwise, or to any inland or coastwise place or places. To enter into contracts for the earriage of mails, passcngers, goods, and merchandise by any means, enther by its own vessels, railways, or conveyances, or by or over the vessels, railways, or conveyances of others; to construct, purchase, and operate steanships and other vessels of any class, and generally carry on the business of shipowners; to construct bridges, buildings, and machinery, engines, cars, and other equipments, railroads, ships, clevators, viaducts, canals, and water wars, and any other means of transportation, and to sell the' same or otherwise to dispose thereof, or to maintain and operate the same. To gather, reccive, distribute, and deliver goods and merchandise, and to carry on a general transportation, freight, and express business, and to that end to own and operate its own ressels, cars, and vehicles of whatsoever nature or description, or to contract with transportition, railway, express, and other companies for the use of their vessels, cars, and rehicles of whatsoever naturc or description, by this company, or to contract with said companies for the collection, transportation, or distribution of goods, wares, and merchandise to and from all points and places where it may seem advantageous and profitable to carry on such business. To carry on the business of storage, wharfage, warehousing, and forwarding, and the doing of every act or acts, thing or things, incidental or growing out of or connected with said business, including the owning, leasing, bolding, erecting, and maintaining of docks, bulkheads, piers, basins, and warehouses; the storage of all kinds of goods, wares, and merchandise; the storage and doeking of ships, steam vessels, and boats of every kind and description; the loading and unloading thereof; the issue of storage, dock, and ware438 
house receipts, negotiable and non-negotiable, corcring all kinds of goods, wares, and merehaudise; the eollection and receipt of dockage, whirfige, and storage dues and other compensation; the loaning of money on the pledge of goods, wares, and merchandise and other property, or on the pledge of storage, dock, or warehouse re. ceipts therefor; and the advancing of freights, duties, fire and marine insurance, and liens of every kind and nature upon goods, wares, and merchandise received on storage or for the purpose of being warehoused.

\section{FORM 201. - TROPICAL TRADING COMPANY.}

To bur, sell, import, export, manufacture, and generally deal in timber of all kinds and descriptions; to manuficture, mrepare, sell, and generally deal in cabinet and other woods; to build, maintain, and operate mills, saw-mills, tour-mills, and factories to be operated by steam, electricity, or other power; to buy, sell, and generally deal in lands; to establish, maintain, and operate plantations ; to produce, manufacture, purchase, market, export, import, and generally deal in rubber, chickle gum, tobaceo, coffee, fruits, grain, live stock, and any and all kinds of tropcal and sub-tropical products.

\section{FORM 202. - TRUST COMPANY.}

To act as trustce for individuals and eorporations, to receive deposits, issue foreign and donestic bills of exchange, and generally to engage in a banking business in all its various branches. 'To earry ou and undertake any busiuess, milertitking, transacion, or operation commonly earried on or undertaken by capitalists, promoters, finaneicrs, contractors, merchants, commission men and atrents, and in the course of such business to draw, aceept, endorse, acquire, and sell all or any negotiable or transferable iustruments and securities, inehuding debentures, bonds, notes, and bills of exchange. To sell on commission, subseribe for, iequire, hold, sell, exelange, and deal in shares, stoek, bonds, obligations, or securities of any publie or privite corporation, government, or municipality, and the company shall have express power to hold. purchase, or otherwise acquire, to sell, assign, transfer, morterige, pledge, or otherwise dispose of, shares of the capital stock, bouds, debentures, or other evidences of indebtedness created by any corporation or corporations, and while the owner theren to exircise all the rights and privileges of ownership, including the right to rote thereon. 'To form, promote, and assist financially or otherwise companies, syndicates, partnerslips, and associations of all kink, and to give any guarantee in commection therewith or otherwise for the payment of money, or for the performance of any obligation or undertakinr. 'T'o acquire, improre, mainare, work, develop, and exereise all rights in respect of, lease, mort raige, sill, dispme, of, turn to acconnt and otherwise deal with property of all kinds, and in particular business eoneerns and undertakings. 'T'o atet as fiscal agent for persoms, firms, amb corporations. To buy or otherwise aequire, to own, hold, morterare, pledere, sill, assign, and trauser or otherwise dispmen of, and to invest, trade, and dral in any goods, wares, merehandise, and property of every class and description, inclutiing patents and patent riorlits, inventums, or other improvements, tralle marks, op-

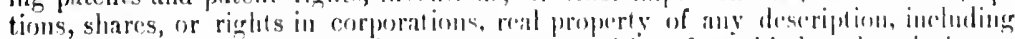

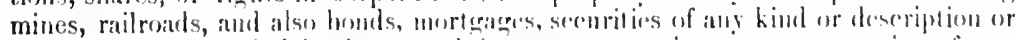

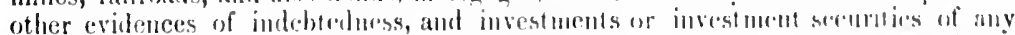

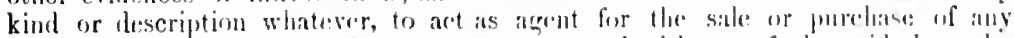

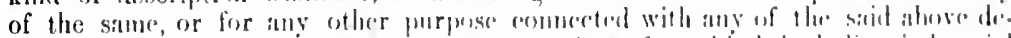

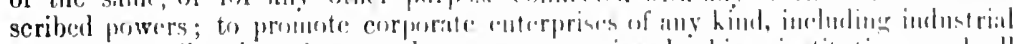

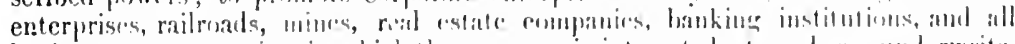

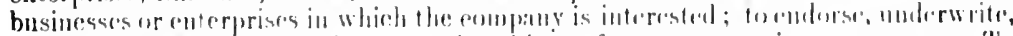

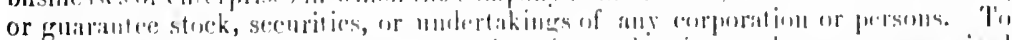

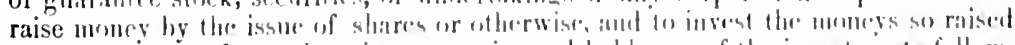

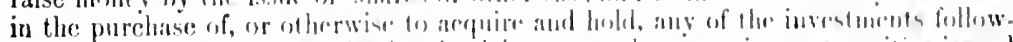

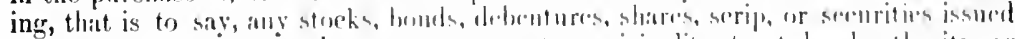

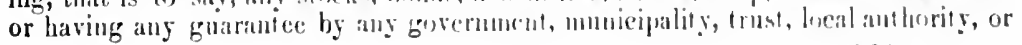


other hals, ineorporated or unincorporated, public or private, of the United States, or ans stick. bonds, dobentures, shares, serip, or securities issued or having any gmanintere hy ans corpuration or conpany incorporated, constituted, or carrying on busmess in the United states or elsewhere. 'To borrow or raise moncy by the issue or sale of any bends, mort raiges, debentures, or dehenture stock of the company, and to invest any noney so rised in iny such investments as aforesild. 'To acquirc any such investments is aforesaid by original subscription, underwriting, participation iu smdicates or otherwise, ind whether or not fully paid up, and to make payments therom as called for, or in advance of ealls or otherwise, and to underwrite or subseribe for the sinne conditionally or otherwise, either with a view to investment or for resale or otherwise, and to vary the investments of the company and generally to sell, exchinge, or otherwise dispose of, deal with, and turn to account any of the assets of the eompany. 'To negotiate loans, to offer for public subscription, or otherwise aid or assist in placing any such investments as aforestid; to give any guariantee in relation to any such investments issued by or acquired through the company or otherwise. 'To ofler for public subseription any shares or stock in the eapital, debentures, or debenture stock or other securities of, or otherwise to cstablssh, pronote, or concur in establishing or promoting, any company, association, undertaking, public or private hody. T'o guarantec the payment of dividends or interest on any stock, shares, debentures, or other securities issued by, or any other contract or obligation of, any such company, association, undertaking, or public or private body. 'To purehase, lease, hire, or stherwise acquire real and personal property, improved and unimproved, of every kind and description, and to sell, dispose of, lease, convey, and mortgage said property, or any part thereof; to acquire, hold, lease, manage, operate, develop, control, build, erect, maintain for the purposes of said company, construct, reconstruct, or purchase, either directly or throngh ownership of stoek in any corporation, any lands, buildings, offices, stores, warthouses, mills, shops, factories, plants, gas houses, machinery, rights, easements, permits, privileges, franchises, ind license's, and all other things which may at any time be mecessary or convenient in the judgment of the board of directors for the purposes of the company. To sell, lease, hire, or otherwise dispose of the lands, buildings, or other property of the company or any part thereof. To hold, purehiase, or ot herwise aequire, sell, assign, transfer, mortgage, pledge, or otherwise dispose of, shares of the eapital stock and bonds, debentures, or other evidence of indehtedness ereated by any other corporation or corporations, and whilc the holder thereof to exereise all the rights or privileges of ownership, including the right to rote thereon.

\section{FORM 203.-TURBINE ENGINES.}

To manufacture, construct, purchase, or otherwise acquire, deal iu, export, import, sell, hire, leace, use, rejair, operate, and maintain ships, vessels, yachts, launches, torpedo brats, tur-boats, and boats and vessels of any and every character, and any and all parts, devices, instruments, engines, maehinerp, materials, appliances, and thines whatsocrer adapted to be used in the construction of, upon, or in connection with or in the operation of ships, vessels, raehts, launches, torpedo boats, tugbrats, and boats and vessels of any and every character; also to equip such ships, vessels. yachts, lauucles, torpedo boats, tugr-boats, and boats and vessels of any and every cliaracter.

\section{FORM 204.-TYPESETTING MACHINES.}

To manufacture, buy, sell, import, export, and gencrally deal in machinery for the sertinte of trpe, together with all tools, implemeuts, and conveniences necessary or useful in conucetion therewith.

\section{FORM 205. - TYPEWRITERS.}

To carry on the business of manufacturing, buying, selling, leasing, operating, and distributing writing machines, typewriters, typewriter materials, appliances, 440 


\section{FORIIS AND PRECEDENTS.}

fixtures, and other materials and articles comnected with or in ans wise relating to the manufacture, sale, or use of writing machines and typewriters; to establish, mantain, and operate mimufictories, agencies, and depots for the manufacture, pur. chase, sale, exchange, delivery, and distribution of writing machines, typewriters, typewriter appliances, and supplies; to purchase, lease, or otherwise acquire, bur, sell, assign, and revise; to use or ofherwise dispose of any patents, inventions, discoveries, or rights used or employed in the business of manufacturing, buying, selling, or using of writing machiues, tyjewriters, and typewriter supplies.

\section{FROM 206. - VALVE COMPANY.}

To manufacture, buy, sell, import, export, and generally deal in values, engines, boilers, tools, and machinery of all kinds, classe's, and descripnion, and in comnection therewith to purchase, lease, or otherwise anequire lands and buildings for the erection of an establishment thereon, and mannfictories and workshops with necessary plants, engines, machinery, and structures thereon.

\section{FORM 207.-VARNISH REMOVER.}

To manufacture, buy, sell, import, exprort, and generally dial in ehemical or other products or processes tor the removal of vilnish and kindred products.

\section{FORM 208. - WAREHOUSERS.}

To carry on the business of warehousing in all of its branches; to receive on consignment or onlerwise, to store, sell, and distribute goods on commission or

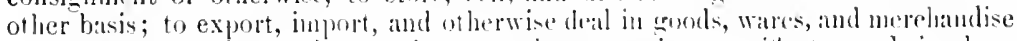
of all clases and description; to issue warehouse receipts, ecrtiticates, and circulars, megotiable or otherwise, to persons warehousing goods, wares, or mereliandise with the eompany ; to mate aldvinces on loans by way of mont erage, phedere, or deposit of warebonse receipts $n$ pon the security of the goods, wares, or merchandise stored with the company or otherwise.

\section{FORM 209. - WATCHES, JEWELRY, AND DIAMONDS.}

To buy, sell, manfacture, export, improt, and generally deal in jewelry, watches,

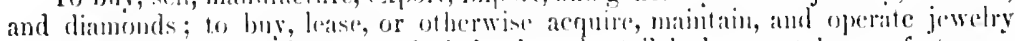
stores; to carry on the business of wholesale and retail lealers, wal ch minufacturers, and dianond nerchints.

\section{FORM 210. - WATER, LIGHT, POWER, AND TRACTION COMPANY.}

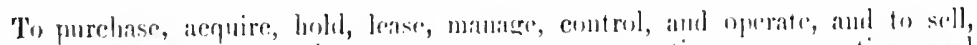

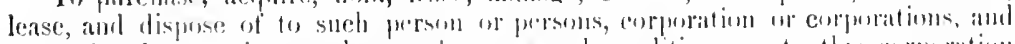

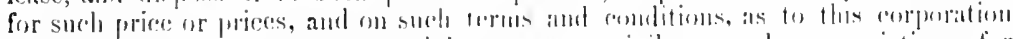

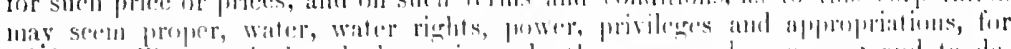

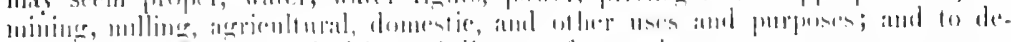

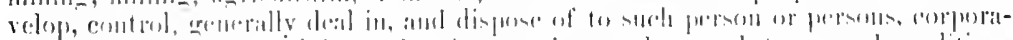

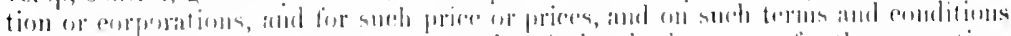

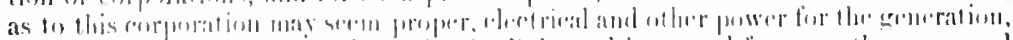

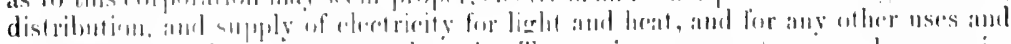

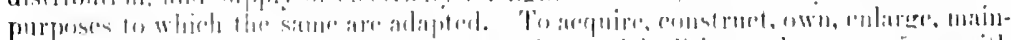

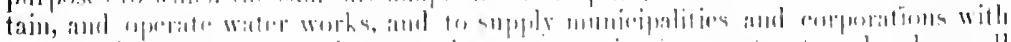

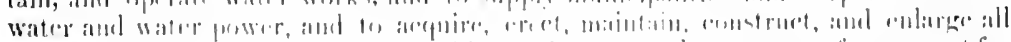

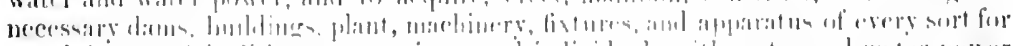

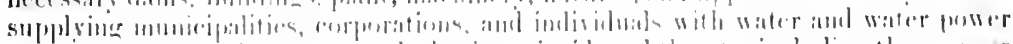

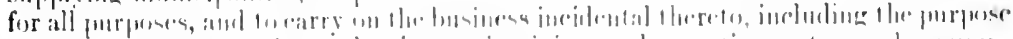

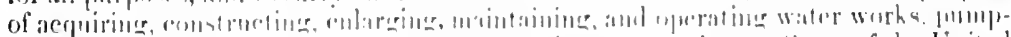

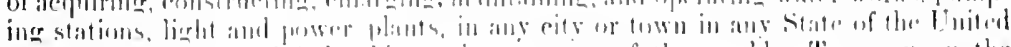

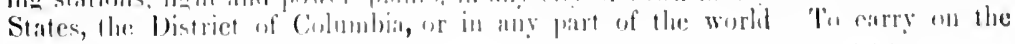


busimess of electricians, mechanical enginecrs, manufacturces, workers and dealers in plectricity, motise power, heat, and light, and any business in which the application of cherlenty ur any power, like or uherwise, is or may be useful, eonvenient, or ornamental, or any of her business of a like nature, and to manuficture and produce, tranke. and deal in and deal with any article belonging to any such business, and all applatus, appliances, and things used in conncetion therewith, or with any inventhons or patcents: to produee and accumblate electricity and electro-motive force, or other agerese, similar or otherwise, and to supply the sime for the production, trans. mission, ar use of power for lighluing, heating, and motive purposes or otherwise as may be thunght advisable; to const ruet, maintain, and operate works for the supply and distribution of electricity for lighli, heat, and power; to acquire ly purchase or" otherwise, io use, operate, and equip subways, conduits, and duets, and to obtain, accept, and use all permits, and also franchises, municipal or ofherwise; to purchase or otherwise acquire and to sell, work, or otherwise deal with land, water, water power, water power supplies, equipment, and works; to undertake, construct, acquire, and carry on works of all kinds relating to any business of the company, and to enter into sich contracts and make such arrangements as may be necessary to carry out the same.

\section{FORM 211. - WATER HEATERS.}

To manuficture, buy, sell, import, export, and generally deal in water heaters for domestic and business uses, and in eomection therewith to manulacture, buy, sell, injort, export, and generally deal in engines, boiler's, water pipes, and plumbers' supplies of all classes and deseription.

\section{FORM 212. - WATER WORKS.}

To construct, purchase, lease, or otherwise acquire, maintain, operate, and sell water works for the purpose of supplying manufactories, corporations, and individuals with water and water power for domestic or business use. Also to construct, purchase, lease, or otlserwise acquire, maintain, and sell all nccessary power honses, water towers, water-maius and pipes, convenient for the carrying on of the aforesaid line of business.

\section{FORM 213. - WEIGHING MACHINES.}

To manufacture, buy, sell, import, export, lease, operate, and generally deal in weighing machines; to apply for, acquire, by purchise or otherwisc, patents perlaining to weighing machines, and to sell or lease the same, together with territorial rights in such patents for weighing machines.

\section{FORM 214. - WHARF AND WAREHOUSE.}

To purchase, lease, or otherwise acquire lands and riparian rights of all classes and description. Also to construct, purchise, lease, or otherwise acquire docks, wharves, piers, warehouses, and public scales.

\section{FORM 215. - WOOLLEN AND WORSTED.}

To manufacture, buy, sell, import, export, and generally deal in woollen and worsted goods and ot lier fabrics manufactured and sold by other concerns engaged in the same gencral line of business.

\section{FORM 216. - YARN MILL.}

To cngage in the business of manufacturers of yarm goods, and in connection therewith to earry on the business of weavers, silk combers, and yarn spinners. Also to purchasc, sell, weave, or otherwise manufacture linen clotlis and other fabrics. 


\title{
FORMS FOR DRAIVING CHARTERS IN ALL THE STATES AND TERRITORIES.
}

\author{
ALABAMA. \\ CERTIFICATE OF INCORPORATION
}

OF THE

Compayy.

Kxow ald Mex by these Presexts: That we, the undersigned, associate ourselves together for the purpose of forming a corporation under the laws of the State of Alabama, and do declire

I. That the name of the corporation shall be Company (or corporation).

II. The objects for which the corporation is formed are :

III. The location of the principal ollice of the corporation within the State is

IV. The amount of the eapital stock shatl be dollars (S), to be divided into shares of the par value of

(8) each. (If prefersed stock is desired this clanse should read as follows: The amount of the capital stock shall be dollars (s), of which shares of the par value of dollars each shall be common stock and shares of the par value of dollar's (s) each shall be preferred stock. The preferred stock is entitled to preference and priority over the eommon stock in manner followincr, to wit: )

The amount of eapital stock with which the company will begin business will be dollars (\$)

V. That , residing in the City of , County ol State of Alabama, is hereby designated by the undersigned as eommissioner for said Compainy to receive subseriptions to the eapital stock thereof.

VI. The names and post-office addresses of the ineorporators and the number of shares subscribed for by wach are as follows:

Names.

No. of Shares.

Addresses.

VII. The names and post-oflice addresses of the directors aul oflieers chosen for the first year are as follows:

Ninnes.

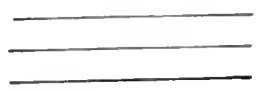

Offiecrs.
P'ost-ontlice Aililresses.

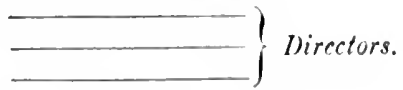

Post-iffice Adilresses.

President,

Vice-President,

Secretary,

'Treasurer,

VIII. The duration of the company shall be perpetual. 
IX. The following provisions for the regulation of the business and the conduet of the allitirs of the complamy are hereby established:

of In Hitness Where

Signed, scaled, and delivered in the presence of:

$\left.\begin{array}{l}\text { State of Alabama, } \\ \text { County of }\end{array}\right\}$ ss.

I.

do herehs eertify that

, a Notary Public in and for the said County and State, , whose names are signed to the foregoing instrument, and who are known to me, have aeknowledged betore me this day that, beinge informed of the eontents of sail instrument, they have severally exceuted the same roluntarily on the day the same bears date.

Given meler my hand this day of , 190 .

, Notary Public, County,

Alabama.

\section{TERRITORY OF ALASKA.}

\section{ARTICLES OF INCORPORATION}

OF TIIE

\section{Company.}

Te, the undersigned, , residents of the District of

Terrifury of Alaska, do by these prescnts, pursuant to and in conformity with the provisions of Scetion Five of an Act of Congress, approved March 2nd, 1903, entitled "An Aet Anending the Civil Code of Alaska, providing for the Organization of l'rivate Curporations and for other Purposes," associate ourselves together as a body politie and corporate, and we do lereby certify in writing:

Fir.t. The eorporate name and style of our said corporation shall be :

Secoml. The nature and character of the business to be carried on is as follows:

Thir. The prineipal place for the transatetion of the business of the corporation shall be at in the Territory of Alaska.

Fourth. 'The time for the commencement of this eorporation shall be the date of the tiling of these articles of ineorporation in the office of the Secretary of the Distriet of shall be tifty rears thereafter.

Fifth. This eapital stock of the corporation shall be dollars, divided into shares of the par value of share. (Alos state how the same shall be paid in.) , Territory of Alaska, and the termination thereof Sixth. The lisphest amount of indebtedness or liability, direet or contingent, to which this eorpuration is at any time subject shall be dollars.

Serenth. The names and residences of the incorporators of this corporation are as follows:

Names.

Addresses.
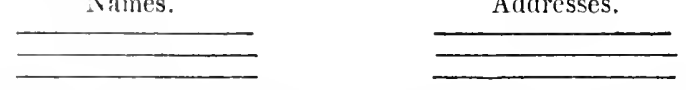

Eighth. Tlue affairs of this eorporation shall be conducted by a Board of Direetor's who shall be eleeted annually by the stocklolders. The names and post-ofice addresses of the Board of Directors for the first year are:

Names.

Addrcsses.
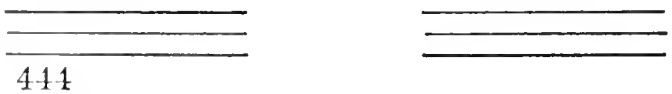
Vinth. The aumual meeting of the stockholders for the election of a Board of Direetors slall be held on the dity of in each year, and the Board of Directors so eleeted shall hold oflice for a period of one year. of

In Witness Whereof, we bare bereunto set our hands and seals this day , 190 .

State of

County of \} ss.

I, certify that

, a Notary Public in and for said County and State, do hereby , personally known to me to be the persons whose names are subseribed to the foregoing instrument, appeared before me this day is person, and acknowledged to me that ther signed, sealed, and delivered the said instrument in writing as their free and voluntary act for the uses and purposes therein set forth.

Given under my hand and notarial seal this

$$
\begin{gathered}
\text { day of , l904. } \\
\text {, Nolary Publie. } \\
\text { State of County, }
\end{gathered}
$$

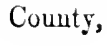

\section{ARIZONA}

\section{ARTICLES OF INCORPORATION}

OF TIIE

Krow all Mes by tuese Prösexts: 'That we, the undersigned, have this day associated ourselves tnerether tor the purpose of forming a corporation, and for that purpose do adopt the following charter:

First. The name of this eorporation shall be:

Second. 'The names of the incorporators are:

Third. The prineipal place in which the business of the corporation within the Territory of Arizona is to be transicted is at County, Arizona. The name of the agent in charge thereof, and upon whom proeess may be served in any aetion, suit, or proeecding that may be had or brought against the company in any of the eourts of Arizona, is Territory of Arizona. , residing at said City of

Fourth. The general mature of the business in wheh this evrporation shall engage is as follows, to wit :

Fifth. 'The authorized amount of eapital stock of this corporation shatl be dollars, dividerl into shares uit the par value of

dollars each. 'The buard of Directors mate ciuse sidd cajpitil stock of auy part

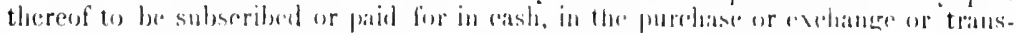
fer of real or personal property or for sorvides remdered, and issute of camse to be

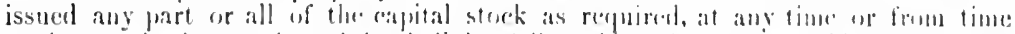

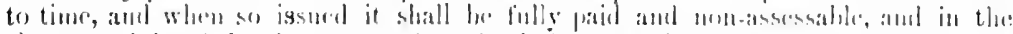

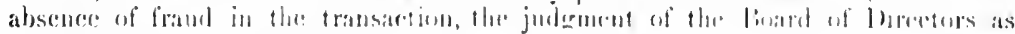

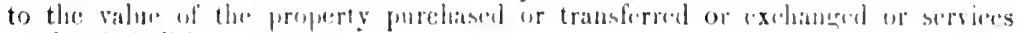
rendered shall be armerhisise.

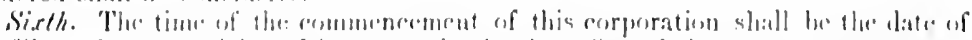

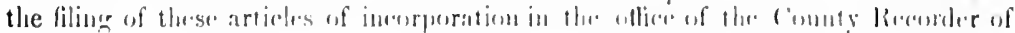

thereafier.

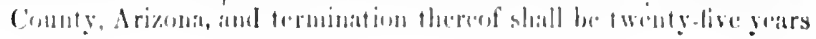

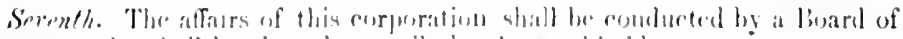
Directers, who shall be elected anumally by the blochlowders. 
Eighth. 'L'lw' ammial meeting of the stockholders shall be held on the in of escels reatr.

Iinth. The highest amount of indebtedness or liability, direct or contingent, to which this romporation is at any time subject, shall be

Tenth. The private property of the stockhollers of this corporation shall be exempt frean corporite debts of any kind whatever.

likenth. Among the powers of this eorporation shall be: (a) 'T'o have perpetual snecession. (b) To sue and be sued by the corporate name. (c) T'o have it common seal and alter the same at pleasure. (d) 'To render the shares or interesis of stuek holulers trinsferrable and preseribe the mode of making such transfers. (r) 'l'o exempt the private property of members from liability for corporate debts. (i) To make contrats, alequire and transfer property, possessing the same powers in such respect as privite individuals now enjoy. ( $\not)$ 'To mortgage all or any part of its property and ercate mortganes, bonds, debenture bonds, and other evidences of inlebtedness. (h) 'T'o establish by-laws and make moles and regulations deemed cxpedient for the managenent of the affiars of the corporation, not inconsistent with the Constitution of the United States and the 'Territory of Arizona. ( $k$ ) To authorize voting by proxy at all stuekholders' meetings. of

In Witness Whereof, we have bercunto set our hands and scals this

State of

County of \} ss.

On this , 190 .

and for the State aforsaid, residing thercin, dnly connissioned and sonally appeared.

, thercin, duly commissioned and sworn, per, known to me to be the persons described in, and whose names are subseribed to the foregoing instrument, and they acknowledged to me that they exccuted the same for the purpose and considerations therein expressed.

In Witness Whereof, I have hereunto set my hand and affixed my official seal at my office in the said State and County, the day and year last above written.

Ny commission expircs , Notary Public.

\section{ARKANSAS.}

\section{ARTICLES OF AGREEMENT AND INCORPORATION}

OH THE

Know ald MEs by tirese Presents: That the corporators hereinafter named have this day, and by these presents, formed a corporation under and in pursuanee of the laws of the State of Arkansas, in that behalf provided, for "Inerprorations for manulacturing and other lawhul business," and in evidence therest do licreby exceute the following Articles of Incorporation:

First. 'The mame of said eorporation shall be:

Sherond. 'The eorporators are:

Thirl. The place of husiness is to be loeated at, and its office for transaction of business slatl be in or at such other place as the Board of Directors may selcet.

Fourth. The general nature of the business proposed to be transacted by this corporation is :

Fifth. Thie amount of the capital stock of said corporation shall be drillars; of which dollars has been subseribed by the eorporators aforesuil, and the residne thereof may be issued and disposed of as the Board of I. iecturs may from time to time order and direct. 
of

Sixth. The said capital stock shall be divided into

shares of the value

Secenth. The affairs and business of the corporation shall be conducted and controlled by a Board of Directors, consisting of members, all of whom shall be stockholders of the corporation. Sind Board of Direeturs slatl elect one of its members as President, and one of its members as Vice-l'resident, and slatl also elect a Secretars and 'T'reasurer.

Eighth. The tirst elcetion of Direetors shall be beld immediately after the organization of the corporation, and said Directors sball serve for one year and until their successors are elected.

Ninth. 'Tlie Buard of Directors are empowered to oritin and establish all by-laws and regulations necessars to the management and business of said corporation, and alter and repeal same at pleasure.

Tenth. 'The first meeting of said corporation or organization shall be held in at the office of at o'elock on the day of , 190 . The subscribers hereto hereby waive notice of said meeting.

In Testimony Whereof, we have bereunto set our hands on this, the
day of 190 .

\section{CERTIFICATE.}

Whereas,

hare associated themselres together as a body politic and corporate, to be known as , and

Whereas, The said corporators, being the subscribers to the eapital stock of the said eorporation, have waived the filteen day's notice as required by law and called a meeting for organization, to be held in at G'clock on the day of , 190 .

Whereus, at the time and place alove set out, a meeting of the subscribers aforestid was held to organize said corporation and elect lirectors; and

Whereas, At said neeting the following gentlemen were elected Directors, to wit : , and

Whereas, At a meeting of the said Buard of Directors was elceted President, and elected Seeretary, and was elected Vice-President, and was elected Treasurer :

was

Now, 'llterefore, The said as President, and the said

as President, do, in pursuance of law, issuc this, their Certificate, verified by their oaths, and do herehy certify as fullows:

First. Said eorporation is formed for the purpose of :

Seront. Its capital stock is dollars, divided into slares of dollars each.

Thirl.

subscribers hereto.

Fourth. The names of the stockholders and the number of shares owned by them, respectively, is as follows:

Nanes.

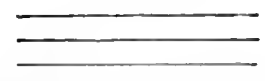

In Testimony Wheref, the said tion, and have hereunto set their hands on this
No. of Share's.

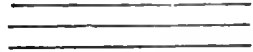

Dircetors.
I'resilent of the said eorporaBoard of birectors of said eorporation day of , 190).

, President.
Lirretors.

117 
State of Arkansas,
Connty of

on their waths say that the matters and things in the foregoing certifieate set ont are trute, 10 the best of their knowledre and bolief.

(Signed)

Subseribed and sworn to before me this day of 190 .

In Testimony $/$ hereof; I have liereunto set my hand and scal of office.

\section{CALIFORNIA.}

\section{ARTICLES OF INCORPORATION}

\section{OF TIIE}

hNow alL MEN BY tIIEse Plesents: 'That we, the undersigned, a majority of whom are eitizens and residents of the State of California, have this day voluntarily associated ourselves together for the purpose of forming a corporation under the laws of the State of California.

And the llereby Certify,

First. 'That the name of said eorporation shall be:

Second. That the purpose for whieh it is formed is:

Thirl. That the place where the principal business of said corporation is to be transacted is :

Fourth. That the term for which said corporation is to exist is years, from and after the date of its ineorporation.

Fifth. That the number of Direetors of said corporation shall be not less than five, and that the names and residences of Direetors, who are appointed for the first year, and to serve until the election and qualification of their suecessors, are as follows, to wit:

\section{Names.}

Residences.

Sizth. That the amount of the capital stock of said corporation is dollars, and the number of shares into which it is divided is, of the par value of each.

Secenth. That the amount of said capital stock whieh has been actually subseribed is dollars, and the following are the names of the persons by whom the same has been subseribed, to wit:

Names of Subseribers. No. of Shares.

Amount.

In Witness Whereof, we have hereunto set our hands and seals, this day of , A. D. 190 .

Signed and sealed in the presence of

\section{State of County of \\ On this \\ \}ss. \\ day of}

before me,

known to ine to be the person

the within instrument, and acknowledged to me that

, in the year A. D. nineteen hundred and County, personally appeared

In Witness Whereof, I have hereunto set my hand and affixed my Officiat Seal, the dag and year last abore written.

, Notary Public, County. 
$\left.\begin{array}{l}\text { State of } \\ \text { County of }\end{array}\right\}$ ss.

I,

do hereby certify the within to be a full, true, and correct cops of Articles of Incorporation of as remains on file in this office.

In Witness Whereof, I have hereunto set my hand and affixed my Otficial Scal, this day of , A. D. 190 .

\section{COLORADO.}

\section{CERTIFICATE OF INCORPORATION}

OF

Know all Uen by these Presents: That we, residents of the State of , have associated ourselves together as a corporation under the name and style of "The Company," for the purpose of beeoming a body politic and corporate, under and by virtue of the laws of the State of Culorado, and in aceordance with the provisions of the laws of said State of Colorado, we do hereby make, execute, and acknowledge these triplicate certificates in writing of our intention so to become a body corporate by virtue of said laws, which when filed shall constitute the articles of incorporation of

\section{First.}

The corporate name and stylc of our said company shall be:

\section{Second.}

The objects for which our said company is formed and incorporated are for the following purposes, to wit: (the statement of objects must be very full, as under Colorado laws there can be no anendment so as to enlarge the corporate purposes).

\section{Third.}

The capital stock of said eompany is dollars, divided into of the par value of dollars each, and said stock shall be nou-asscssable.

sharcs

\section{Fourth.}

Said company is to exist for

years.

\section{Fifth.}

The affairs and management of this eompany is to be under the eontrol of a Board of Directors, and are leerely selected to act as said Board of Directors, and to manage the afficirs and concerns of the said eompany for the first year of its corporite existence.

\section{Sixth.}

The operations of the said company will be earricet on in the Comaty of

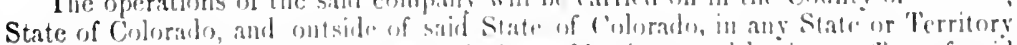
of the Unitel States, and the prioripal plare of husiuess and husiness olliere of said company shall he troated in the City of, in the County of, and State of Colorads, aforesaidt.

\section{Sirenth}

The Board of I)irectors shall hase power to make surh prudential by-laws as they may deem proper for the management of the affairs of this company, according to the statute in such case made and provided. 
Eighth.

Metings of the Board of Directors may be held without the State of Colorado, if the ly-liws so provide.

In Tistimony Whereof, we have hereunto set our hands and seals this day of $\quad$ I 190 .

$\left.\begin{array}{l}\text { State of } \\ \text { County of }\end{array}\right\}$ ss.

I,

certify that

, a Notary Publie in and for said County and State, do hereby , persmally known to me to be the persons whose names are subseribed to the foregoing instrument, appeared before me this day in person, and acknowledged that they signed, sealed, and delivered the said instrument in writing as their free and voluntary act for the uses and purposes therein set forth.

Given under my hand and notarial seal this

day of, Notary Public.

My commission expires

\section{CONNECTICUT.}

\section{CERTIFICATE OF INCORPORATION}

OF TIIE

\section{Company.}

We, the subscribers, certify that we do hereby associnte ourselves together as a body politic, incorporated under and by virtue of the provisions of the Aet of the General Assembly of the State of Comneeticut, entitled "A.: Act eoneerning Corporations," heing Chapter 194 of the Publie Aets of 1903, and all Aets amendatory thereof, and we further certify

I. That the name of the corporation is the or the word "incorporated" if preferred).

Company (or corporation,

II. That said corporation and its principal office and place of business is to be located in the City of , County of , State of Conmecticut.

III. The natinre of the business to be transaeted and the purposes to be promoted are as follows:

IV. That the amount of the eapital stock of said eorporation hereby authorized is dollars, divided into shares of the par value of dollars (3) cach. (If preferred stock is desired, this seetion should read as follows: 'I'liat the amount of the enpital stoek of said eorporation hereby authorized is dollars ( 3 ), divided into shares of eonmmon stock of the par ralue of dollars ( $\$$ ) each, and shares of preferred stock of the par value of dollars ( $\$$ ) each. The preferred stoek is entitled to preference, and priority over the eommon stock in manner following, to wit:)

V. That said corporation will commence business with a capital stock of dollars (s) $)$.

VI. The duration of the corporation shall be perpetual.

VII. The following provisions for the regulation of the business and the con. duet of the affairs of the corporation are hereby established:

VIII.

Name.

of State of

(Signatures of incorporators.)

of State of

Residence. 
State of Counecticut,

County of $\quad$ ss.

Personially appeared , being all the incorporators of the Company, made solem oath to the truth of the foregoing certificate by them respectfully subscribed before me.

State of Connecticut, , Notary Public, County, Conin.

Otfiec of the Secretary, ss.

I herchy certify that the forcgoing is a true copy of record of this oflice.

In Testimony Whereof, I have hereunto set my hand and affixed the seal of said State at Hartford this day of , 190 .

, Secretary.

\section{CERTIFICATE OF ORGANIZATION.}

The undersigned, a majority of the Direetors in cartify as follows:

I. That the amount of common stock of the autlorized eapital stock of said company subseribed for is dollars (\$)). (It there is preterred stock, the following clamse should appear: That the amount of eapital stuck of the authorized capital stoek subscribed for is dollars (\$) ).

II. 'That the amount of satid authorized capital stock so subseribed lor paid thereon iu cash is dollars (\$ )

1II. That the amount of the subscribed capital stock whieh has been paid in in property is dollars (S)

IV. The amount paid on each share of capital stock so subseribed for whieh is not paid for in full is

V. The nanes, residences, and addresses of each of the original subscribers, with the number and elass of share subscribed for by each, is as follows :

$I V$. 'That Directors and oflicers of said corporation have been duly elected and by-liws adopted.

VII. The nancs, residences, and post-offiec addresses of caeh of the officers and bircetors of said corporation are as follows:

Directors :

Names.

\begin{tabular}{l}
\hline \\
\hline Officers : \\
P'resident, \\
Vien-President, \\
Secretiry, \\
T'retsurcr,
\end{tabular}

Residences.

P. O. Adilyesscs.

Dated at

this

day of

, 190

a majority of the J)iretors.

State of
Cominty of
Jersomally apperard

ceriffeate of organzition, a majority of the Directors of

and made solems onth to the truth if the siune before we.

, subscribers of the foregoing

Company,

, Notary Publis.

(immls,

Connertient. 


\section{DELAWARE.}

\section{CERTIFICATE OF INCORPORATION.}

This is to Certify, that the undersigned do hereby associate themselves to establish a corporation muler ant by virtne of the provisions of an Act of the Gineral Assembly of the State of Delaware, entitled "An Act Providing a General (orpuration haw," and do severally agree to take the number of shares of eapital stuck at hereinalter stated, and that

rirst. The name of the enporation is :

second. The principal oflice or place of business of the corporation in the State of Deliw ware is to be located in the City of and said oflice is to be registered with the company.

Third. 'The niture of the business and the objects and purposes proposed to be trinsacted, promoted, or carried on by the corporation are as follows :

In General to carry on any other business in comection therewith, whether manufacturing or otherwise, and with all the powers conferred by the laws of Delawatre under the act hereinbefore referred to.

It is the intention that the objects specified in the third paragraph shall, cxcept where otherwise expressed in said paragraph, be nowise limited or restricted by reference to or inference from the terms of any other clausc or paragraph in this charter, but that the objects specified in cach of the clauses of this paragraph shall be regarded as independent oljects :

Fourth. 'The amount of the total authorized ceppital stock of the corporation is dollars divided into sliares of the par value of dollars cach. The amount of the capital stock with which the corporation will begin business is dollars.

Fifth. The names and places of residence of the original subscribers to the capital stock are :

Name.

Residence.

No. of Shares.

Sixth. The corporation shall have perpetual existence.

Seventh. The officers and persons by whom the affairs of the corporation arc to be conducted are its Directors, who may act through a President, Vice-President, Secretary, and Treasurer, and such assistants to them and such subordinate officers, agents, and employees as may be selected pursuant to the By-Laws of the corporation, the resolntions of said Direetors or anthority given by them.

Directors shall he elected at the prineipal office or place of business of the company, at the annual election to be held by the stockloolders on the day of in each year, between the hours of $M$. and $M$.

Eighth. The private property of the stockholders shall not be subject to the parment of corporate debts.

Ninth. The Board of Directors shall have power, withont the assent or vote of the stockloolders, to make, alter, amend, and repeal the By-Laws of this corporation, to authorize and canse to be cxecuted mortgages and liens upon the real and personal property of this corporation.

The Directors shall from time to time determinc whether and to what extent, and at what times and places, and under what conditions the accounts and books of the corporation, or any of them, shall be open to the insucction of the stockholders; and no stockholder shall have any riglit of inspecting any account or bonk or document of the corporation, except as conferred by statute or authorized by the Directors, or by a resolution of the stockholders.

The Directors shall have power to loold their meetings, and to keep the books of the corporation (except the stock and transfer books or duplicates thercof) outside of this State, at such places as may be from time to time designated by them.

The corporation may conduct its business in the State of Delaware, in other States, the District of Columbia, the Territories and Colonies of the United States and in forcign countries, and may have one or more offices ont of this State, and 452 
may hold, purchase, mortgage, lcase, and conves real and personal property out of the State of Delaware.

Witness our hands and seals this

day of

A. D. 190 .

In the presence of :

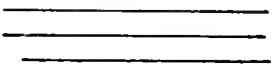

\section{$\left.\begin{array}{l}\text { State of } \\ \text { County of }\end{array}\right\}$ ss.}

Be It Remembered, that on this day of A. D. 190 , personally came betore me, , a Notars P'ublie for the State of Delaware, the original corporators named in the foregoing certifieate, who signed ind sealed the same, known to me personally to be such, and severally aeknowledged the same to be the act and deed of the signers respectively, and that the fitets therein stated are truly set forth.

In Witness Whereof, I have hereunto set my hand and seal of oflice the day and year aforesaid.

(SEAL.)

, Notary Public.

\section{DISTRICT OF COLUMBIA. \\ CERTIFICATE OF INCORPORATION.}

We, the undersignet,

of Washington, District of Columbia, do by these presents, pursuant to and in eonformity with the provisions of six hundred and five (60.5) and six humbred and six (b06) of an det of Congress, approved Mareh 3ril, I901, entitled ". In Aet to establish a Code of Law for the District of Columbia," and with the amemenents themo made by an Aet approved June 30th, 1902, ('ntitled "An Aet to amend an Act cntitled "An Aet to establish a Code of Law for the Distriet of Colıubia,", associate ourselves together as a body politic and corporate, and we do hereby certify in writing:

First. That the name of the company shall be:

Seromel. That the purposes for which sail eorjoration is formed are:

Thirel. 'That the existence ol' this eompany shall be preructual.

Fourth. 'That the capital stock of this eompany shall be

dollars, divided into shares of the par value of dollars each.

Fifth. That the mumber of tristees who shill manatee flue emeems of the conpany for the first year or until their suceessors ane clected shall be namely:

Nimes.

Residencies.

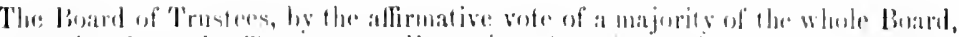

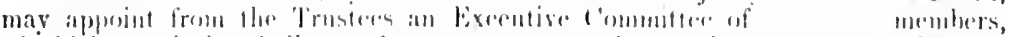

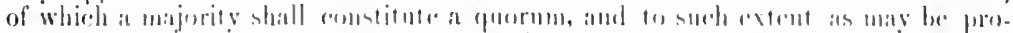

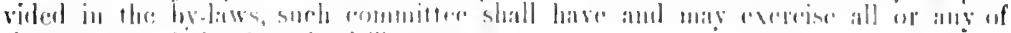

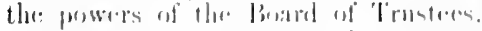

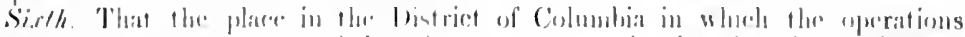

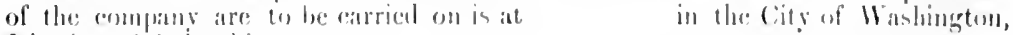
District of Columbia

IVitness ont himds this day of 190 . 
City of Washington, $\}$ ss.

1)istrict of ('ulumbil, $\}$ ss.

1.

hereby certily that

, a Notary Public in and for the District of Columbia, do writing hereto amexed, bearing date the day of 190 , personally anperted hefore me in the Distriet of Columbia on the lay and year aforesaid, and separately, severally, and individually aeknowledged the sane before me, and that they severally signed the same for the purposes therein set forth.

Given under wy liand and notarial seal

day of , 190 . , Notary Public.

\section{FLORIDA.}

(Form for publication of notice of intention to apply for charter.)

\section{NOTICE OF INCORPORATION.}

The undersigned hereby give notice that on the day of , A. D. 190 , at o'eloek $\mathrm{II}$, or as soon thereafter as they can be heard. they will apply to the Ilonorable, Governor of the State of Florida, at lis otliee, in the Capitol Building of said State, in the City of Tallahissee, for Letters Patent ineorporating them, their assoeiates and suceessors, into it body politie and corporate in deed and in law, under the name of

Company, under the following Charter and Artieles of Ineorporation, the original of whieh will be on file in the office of the Seeretary of State of said State of Florida, at the City of Tallahassee, during the time required by law for the publieation of this notice.

(Names of incorporators.)

\section{Charter of the Company.}

The undersigned hereby agree to become associated together, and do hereby associate themselves together for the purpose of beeoming a body politie and corporate under the laws of the State of Florida, the provisions of which are hereby aeepted. The following Artieles of Ineorporation shall constitute and beeme its Charter upon the issuanee of Letters Patent aceording to law :

1.

The name of this corporation shall be Comnty, Florida. Braneh
offices may be established at sueh other places as may be selected by the Board of Directors.

2.

The general nature of the business to be transacted by the said corporation shall be:

3.

The amount of capital stoek of this eorporation shall be

dollars, divided into shares of the par value of dollar eaeh : said capital stoek slall be praid for in lawtul money of the United States, ten per eent of which shall he praid within ten diys after Letters Patent shall have been granted and before said (o)rporation shall transatet any business. The mpaid balances due on stoek of the snbscribers hereto shall be paid in lawful money of the United States in sueh instalments and within suel time as may he designated by the Board of Direetors, provided that subseribers shall be cutitled to ten days' notice of demand for sueh duferred patinents. The remaining stoek shall be sold by the Directors from time to fimre, ats the same may be needed, at not less than its par value.

1.it 
4.

This corporation shall exist for a period of according to law.

years, unless sooner dissolved

5.

The business of this corporation shall be conducted by a Board of not less thais nor more thin Directors.

The Board of Directors shall seleet from themselves a P'resident, Vice-President, Secretary, and Treasurer. One person may hold the oflice of Secretiry and Treasurer. Said Board of Directors shall have authority to appoint all necessary agents of this eorporation.

Anmual meetings of the stockholders shatl be held at the prineipal offices of the corporation on the in of each year, at ten o'clock $\mathrm{A}$. II. or as soon thereafter as practicalble, at which the Board of Directors shall be duly elected by the stockholders.

The By-Laws for the government of this corporation slaall be adopted at the first annual meeting of the stockholders, or as soon thereatter as practicable.

Until a Board of Directors shath have been first dnly chosen by the stoekluolders, the business of the said corporiation shall be conducted by the following named persons and oflicers :

$$
\begin{array}{r}
\text { President. } \\
\text {, Vice-President. } \\
\text {, Secretury. } \\
\text {, Trewsur. }
\end{array}
$$

Temporary By-Laws may be adopted by said officers until the first imnual meeting of the stockholders.

6.

The lighest amount of intebtedness or liability this corporation shall at any time subject itself is dollars.

\section{7 .}

The names and residences of the subseribers to these Articles of Ineorporation, together with the amount of enpital subseribed by each, are as follows:

$$
\begin{array}{lll}
\text { Names. } & \text { licsidenees. }
\end{array}
$$

In Witness Whereof, we have hereunto set our hands this the diay of A. 1). 190 .

\section{Witness :}

(Signatures of subscribers.)

$\left.\begin{array}{l}\text { State of Floridil, } \\ \text { Comuty of }\end{array}\right\}$ ss.

I, certify that

, a Notary Pullic for the State of Floridis at tareere. do hereby

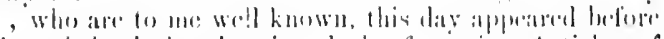

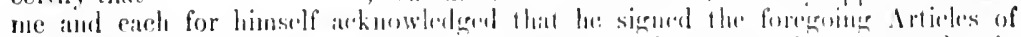

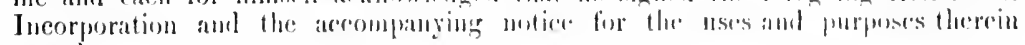
statcol.

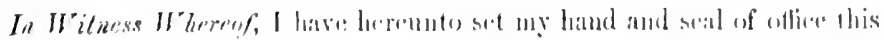
day of $\quad$. I. II. 1911.

State of liforida at larene. , Nulary I'ublic.

Commissiun $\times x$ pires 


\section{GEORGIA.}

\section{APPLICATION FOR CHARTER.}

State of Georgia, County of

The petition of respcetfilly sliows

The pretition of respcetfilly sliows he eonstituted it body corporite mider the name and style of he constinted ithody enporate Company, fir the ferm of twenty years with the privilego of renewal at the expiration of said time as provided by jaw.

II. They desire for said eorporation the right to buy, sell, hold, enenmber, and ot herwise dispose of real and personal property, which may be neeessary and advantageous to the purposes of said corporation, to sue and be sued, and to bave a common seal, to receive donations by gift or will, to make by-laws for its government, elcet directors for the managenent of its atfiurs and eonfer upon them the right to eleet otlieers and appoint employees, together with all other rights, powers, and privileges, ineident, useful, or neeessary to earry into effect the purposes of the corporation as hereinafier set forth or for seeuring debts due it.

III. The object of the eorporation is peemiary gain to its stocklolders.

IV. The pinticular business proposed to be carried on by said corporation is :

V. The capital stock of said eorporation shall be dollar's, livided into shares of dollars eich; at least ten per cent of which is to be actually paid in before commeneing business. But petitioners desire that said corporation shall have the right to increase said capital stock to any amount not exceding dollars, whenever the holders of a majority of the stock may so determine.

VI. The principal place of business of said eorporation slall be in the City of , Comnty and State aforesaid, but petitioners desire that said corporation shall have the riglit to establish branch offices or agencies at any other places, either within or without the State of Georgia, as the holders of a majority of the stock mav determine upon.

Wherefore petitioners pray that after this petition has been filed and published in accordance with the litw an order be passed by the Court declaring them a body corporate under the name and style aforesaid, and granting to said corporation all the right, power, and privileges set ont and prayed for in this application, or which may be incident, nsuit, and neeessary under the laws of said State, for the purposes of their incorporation. And your petitioner will ever pray, ete.

, Petitioner's Attorney.

\section{IDAHO.}

\section{ARTICLES OF INCORPORATION}

OF THE

\section{CoMpaxy.}

Fnow all Wen by these Presents: That we, the undersigned, at least one of whom is a bona fide resident of the State of Itlaho, have this day voluntarily associated ourselves together for the purpose of forming a corporation under the laws of the State of Idaho. And we licreby eertify :

First. That the name of the eorporation shall be :

Second. That the purpose for which it is formed shall be :

Third. That the place where the principal business is to be transacted is:

Fourth. 'That the term for which it is to exist is years) from and after the date of its ineorporation.

(not to exceed fifty 


\section{FORIS AND PRECEDENTS.}

Fifth. That the number of its directors (or trustees) shall be

(a majority must be, in all cases, citizens, and actual bona fide residents within the State), and the names and residenees of those who are appointed for the first year are:

Sixth. 'That the amomit of the capital stock of said corporation is dollars, aud the mumber of shares into which it is divided is, of the par value of dollars each.

Seventh. That the amount of capital stock which has been actually
is
Names of Subscribers.
No. of Shares.
Par Valuc.

In Witness Whereof, wc have hereunto set our hands this

A. D. 190 .

day of

Signed and exceuted in the presence of :

State of

County of

On this

appeared \} ss.

to the within instrument, and ackuowledged to me that they executed the same.

, A. D. 190 , before me

persons

In Witness Whereof, I lave hereunto set $\mathrm{my}$ hand and affixed my Official Seal the day and year in this ecrtifieate first above written.

(SEAL.)

\section{ILLINOIS.}

State of Illinois,
County of

To

We, the undersigned, propose to form a corporation,

, Secretary of State: under an Aet of the Goneral Assembly of the State of fllinois, entitlel" An Act Conecruing Corporations," approved April 15th, 18 72 , and all acts amendatory thereof; and for the purpose of such organizatiou we hereby state as follows, to wit:

First. The name of such eorporation is :

Secont. The objects for which it is lormed are:

Thirl. The eapital sluek of the company shill be

Fourth. 'The amount of each share is dollars.

Fifth. The mumher of shares is

Sixth. The location of the primcipal office is at No. , in the Comuly of , State of Illinois, ycars.

Seventh. The duration of the corporation shall be (not to execed nimety-nine)

dollars.

Strect, in the City of

State of Illimois,
Connty of ss.

I.

, a Notary Public in and for the Comnty of

and State of Illimois, do herrby certify that on the day of , 190, persomally appeated hefore me: , to me persinally known to be the stane

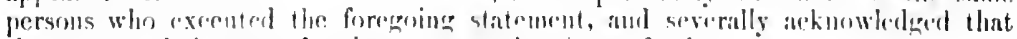
they executed the same for the purpeses therem set forth.

In Writurses Whorof, I have hereunto set my haud and scal the day and year above wrillell.

(SF,AL.)

, Nulury I'ublic. 
Secrotary of State of the Stute of Illinois:

The (ommissioners, duly anthorized to open Books of Subseription to the capital stock of the ing litte the dily of $A$. D. 190 , do hereby report that they Company, pursuant to license heretofore issued, bear. opened bisoks of Subseription to the Citpital Stock of said Company, and that the said stock was linlly subseribed; that the following is a truc copy of such subscription, viz.:

We. the nulersigned, hereby sererally subseribe for the number of shares set opposite our resprective names, to the Cipital Stock of and we sererally angec to pity the said Compiny, for each share, the sum of dollars.

Name.

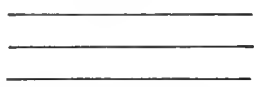

Shares.

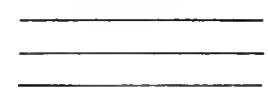

Amount.

That the aforesaid stockholders waived notice of the time, place, and object of the meeting of stockholders herein next set forth, which was held on A. D. 190 , at which meeting directors were elected as stated hercin, and the fol.' lowing is the original waiver:

We, the undersigned, being all of the stockholders of the

Company, organized under the laws of the State of Illinois, do hereby severally waive notice of the time and plate of the meeting of the stockholders of said company, and the purpose thercof, and any and all every notice required by the laws of the State of Illinois.

That on the

day of

,A. D. 190 , at the

, Illinois, at the hour of M., they convened a meeting of the subseribers aforesaid pursuant to notic: required by law, which said notice was deposited in the postoffiee, properly addressed to each subseriber, ten days beforc the time fixed therein, a copy of which said notice is as follows, to wit:

To

Yon are hereby notified that the Capital Stock of subscribed, and that a meeting of the subseribers of such stoek will be held at on the day of

A. D. 190 , at

o'clock M., for the purpose of electing a Board of Director's for said Company and for the transaction of sueh other business as may be decmed necessary. Signed

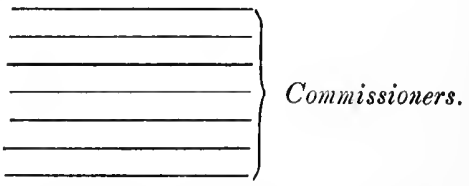

That said subscribers met at the time and place in said notice specified, and proceeded to elect Directors, and that the following persons werc duly elected for the term of ycar, viz. : 
And that the post-office address of the business office of said Company is at Numbcl and State of 1llinois.

Street in the City of

, in the County of ,

$\begin{aligned} & \text { State of } \\ & \text { County of }\end{aligned} \quad$ ss.
$\begin{aligned} & \text { On this } \\ & \text { a Notary Public in and for said County in said State, }\end{aligned}$ Commissioners. that the forcgoing report by them subscribed is true in substanee and in fact.

, Notary Public.

\section{INDIANA.}

\section{ARTICLES OF INCORPORATION}

OF TIL

\section{Coypaxy.}

We, the undersigned, hereby assoeiate ourselves together pursuant to the statutes of the State of Indiana for the organization of corporations by the following written articles :

$$
\text { Art. ONe. - NaMe. }
$$

The name shall be:

Art. Two. - Capital Stock.

The capital stock of this association sliall be dollars, divided into shares of dollars each.

\section{Art. Tirne. - ObJect.}

The object of this association and the proposed plan for the transaction of its business sliall be :

('To be stated in all cases. Carc slould be taken to name as broad an olject as possible and at the same time to aroid mentioning any of the proposed powers of the corporation.)

\section{Art. Four. - Place of Operations.}

The business of this corpolation shall be carried on in :

(To be stated in all casses. Whare the work is from one point to another, this should be stated. For milroads, mane all counties through which the roat passes and give lengtlo as near as possibla.)

\section{ArT. Firk, - Nignher or Dhreroms.}

There shatl bo

direntors fore this corpuration, whe after the first your

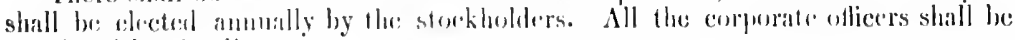
appointed by the directers.

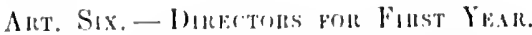

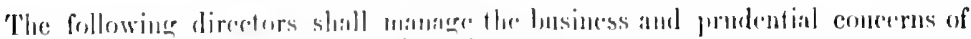
this errporation for the first veir of its existence. 


\section{Art. Sevex. - Term of Existence.}

The association shall have au existence of

(not to excecd fifty) years from the date heleot.

I" "itmes: "Thereof, we have hereunto set our hands this , 1. 1). 190 .

day of

(The subseribers affix, in addition to their names, their residenecs, and, if a stoek corpuration, the number of shares taken by caeh. In the ease of savings banks state vecupation and post-ofliee address. Articles for the ineorporation of educational and relimions corporations must be swom to. Articles for Board of Trade, stean packet, telergraph, telephone, building and loan, health resort, Y. M. C. A., boands of relief for orphans, ete., and manufacturing companies must be acknowledged as deeds are acknowledged. All others are signed mercly.)

\section{INDIAN TERRITORY.}

\section{ARTICLES OF AGREEMENT AND INCORPORATION}

$\mathrm{OF}$

KNow all Mex by these Presents: That the Corporators liereinafter named have this day, and by these presents, formed a Corporation nuder and in pursu. ance of an Act of Congress, approved February 18, 1901, entitled "An Act to put in foree in the Indian 'Territory certain provisions of the Laws of Arkansas relating to Corporations and to make said provisions applicable to said Territory," which said Aet frovides for ineorporations for mannfacturing and other lawtul business purposes in the Indian 'Territory, and in evidence thercol do hereby execute the following Articles of Ineorporation:

First. 'The name of said Corporation shall be:

Secoxid. The Corporators are:

'Tund. The place of business is to be located at and its office for transaction of business shall be in or at such other place as the Board of Directors may select.

Foekt1. "The general nature of the business proposed to be transacted by this Corporation is :

l'ifTir. T'lie amount of capital stock of said Corporation shall be dollar's; of which dollars has been subseribed by the Corporators aforcsaid, aut the residne thereot may be issued and disposed of as the Board of Directors may from time to time order and direct.

Sixti. 'The enpital stock shall be divided into

shares of the value of $\$ 2.5 \mathrm{cach}$.

SEVETH. The affairs and business of the Corporation shall be conducted and controlled by a Bord of Directors, consisting of members, all of whonn shall be stoekholder's of the Corporation. Said Board of Directors shall elect one of its members as President, and one of its members as Vice-President, and shall also elect a Secretary and 'Treasurer.

Eigintu. The first election of Directors shall be lield immediately after the organization of the Corporation, and said Directors shall serve for one year and until their suecessors are elected.

Xist1. The buard of Directors are empowered to ordain and establish all bylitws and recenlations neeessary to the management and business of said Corporation, and alter and repeal same at pleasure. 
Testu. The first meeting of said Corporators for organization shall be held in at the office of at on the said meeting. day of $\quad, 190$. The subscribers hereto hereby waive notice of day of

In Testimony Whereof, we have hereunto set our hands on this, the , 190 .

\section{CERTIFICATE.}

Whereas, politic and corporate, to be known as

have associated themsclves together as a body

And Whereas, The said Corporators, being the subseribers to the eapital stock of said Corporation, have waived the filteen days' notice as required by law, and called a meeting for organization, to be held in at o'clock on the day of , 190 .

Whereas, At the time and place above set out, a meeting of the subseribers aforesaid was held to organize said Corporation and elcet Direetors; and

Whereas, At said meeting the following named persons were eleeted Directors, to wit: , and

Whereas, At a meeting of the said Board of Directors

President, and

Secretary, and was elected Vice-President, and

was elected

Nore, Therefore, the said was elected 'Treasurer.

was elected

as Direetors, do, in pursuance of law, issue this, their Certificate, verified by their oaths, and do hereby eertify as follows:

Finst. Said Corporation is formed for the purpose of

Second. Its capital stock is dollars, divided into shares of \$25 each.

Tunnd. dollars of said eapital stoek have been actuilly paid in by the subseribers liereto.

Fourtil. The names of the stockholders and the number of shares owned by them, respectively, are as follows:

\section{Names.}

In Testimony Whereof, the said and hereunto set their hands on this

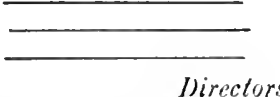

No. of Shares.

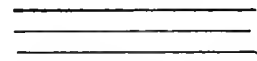

, President of said Corporation, , a majority of the Board of Direetors of said Corporation, have day of $\quad, 190$.

, President.

United States of Amerien,

Indian 'Territory, District. $\}$ ss.

on their oaths say that the matters and things in the foregoing certificatc set out aro true, to the best of their knowledge and belicf.

Subseribed and sworn to before me, this the

daly of

Directors.

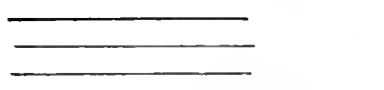

In Testimony Whereof, I lave heremito set my hand and scial of office. 


\section{IOWA.}

\section{ARTICLES OF INCORPORATION}

OF THE

\section{CoMpaxy.}

We, whose names are heremito subscribed, have associated ourselves as a body corporate, muler the provisions of Chapter 1, Title IX. of the Code of Iowa, and aets amendatory thereto, and to that end have adopted the following articles of iucorporation.

\section{Article $I$.}

The name of this corporation shall be:

\section{Article II.}

The prineipal place of business of this corporation shall be at the city of in the eomnty of , and State of lowa.

(Note. If the corporation does not transact business in this State, it is not necessary that the articles name its principal place of business, or that such principal place of business be in this State.)

\section{Article III.}

The general nature of the business to be transacted by this corporation sliall be :

(NoTE. It is customary to state the general nature of the business to be transacted quite fully, making this statement broad enough to cover all the contingencies that may possibly arise.)

\section{Article IV.}

This corporation shall have all of the powers necessary for, or incidental to, the convenient transiction of the business for which it has been organized, including the power to borrow money, and to issue its negotiable notes, bonds, or other evidences of sueh indebtedness, and to secure the repayment of the same by liens upon all or any portion of its property, real or personal, by way of mortgage or otherwise, and ineluding the power to own, lease, buy, and sell real estate; and further anong its nowers shall be the following:

1. To have perpetual succession;

2. To sue and be sued by its corporate name;

3. To have a common seal, which it may alter at pieasure ;

4. To render the interests of the stockholders transferable;

5. To exempt the private property of its members from liability for corporate debts;

6. To makc contracts, acquire and transfer property, - possessing the same powers in such respects as natural persons;

7. To establish by-laws, and make all rules and regulations neccssary for the management of its affirs.

(Note. This section ia not absolutely necessary. It is, however, customary, and the provisiona, especially with reference to borrowing money, etc., will be found in actual practice to facilitate such transactions.)

\section{Article $V$.}

The amount of the authorized capital stock of this corporation is the sum of dollars divided into

of dollars. Not less than shares, each of the par value dollars of the capital stock of this corporation slall be paid in in eash, or in property at its reasonable cash value, before the corporatiou transacts business except the business incident to its organization. 
(1) The remainder of the capital stock of this corporation shall be issued and paid in from time to time as the boar 1 of directors may direct.

(2) The par calue of all stock shall be paid in, either in cash or in property at its reasonable cash ralue, at the time that the stock is issued.

(Notz. The sentence indicated as (1) abore, may be omitted if the stock is all to be paid in when the corporation commences business. If it is not all to be so paid in, there should be somelhiug of this charaeter inserted. preseribing when the remainder of the stock shall be issueli. The sentence (1) follows the meshod usually adopted in lowa, but any method may be adopted which makes the articles state when the stock not issued when the corporation is organized shall be issuerl.)

(Sentence (2) above, should be omitled unless the stock is to be paid up as stated. If the stock is to be paid up entirely iu cash when issued, or all of it in property when issued, modif $x$ this article to conform io the facts. It is not essential that this sentence be inserted, but if the stock is to be fully paid, it is desirable that the articles should show it.)

\section{Article ITI.}

This corporation shall commence on the day of sliall continue for the term of 1 wents rears thercatter, rrith the right of reneral and prorided by law, unless sooner dissolved by a rote of not less than of the stock then outstanding.

(Note. Lnder the law it takes unanimous eonsent to dissolve before the expiration of the term unless lhe articles provide otherwise. It is therefore not unusual to put in a prorision that a designated majority, as two-lhirds or lhree-fourbhs, may dissolve the corporation. The italicized portion above is, however, not necessary, if such right is not desired.)

\section{Article ITI.}

The affairs of this corporation shall be conducted by a board of not less than nor more than

direetors

Within said limits the number of directors mas be fixed by the stockholders at any regular or spreial meeting; until otherwise iixed by the stocklolders the board of directors slatl consist of members.

The board of directors shall hare general elatrge of the business and affairs of this eorporation, and all of the powers of this corporation are vested in its board of directors except as otherwise provided by law, or by the by-laws of this corporation, and subject to such action restrieting said powers as may be taken from time to time by the stockholders, either at an ammual or at a special meeting, duly called therefor.

The directors of this corporation may delegate their powers and may in writing authorize others to act for them, is their proxies, at any meeting or ineetings of its board of directors; provided, hrwerer, that the stockholders of this corporation may at any time limit, restriet, or prohihit such delegation of power by its directors, and while so limiled or restrieted said prower shall only be delecrated pursuant to snch limitations or restrictions; and if so prohibited it shall not be delegated during the continuanee of such prohibition.

(NitF. Much of the abrve ia not necesary. It has, however, proved to be a mater of very grest convenience. In lieu of the above the following articte would till the requirenents of the law :

"The affaire of this corporation shall bu comlucled ly a board of who shall have general charge of its bualueny.")

directors

\section{Articli IIII.}

The offiecers of this corporation shall be it president, vierepresident, sceretary, and treasurer. The directore may appoint a rashier and rexentive committere and

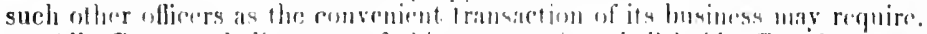

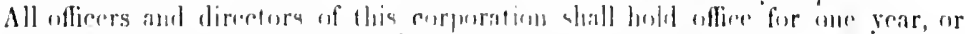

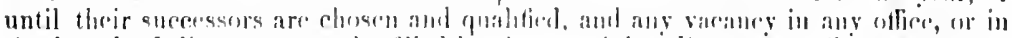
the board of directors, may be filled ly the remaining dimertus mulil the snecessor 
of the person thus elosen to fill such vacaucy is elected by the stockholders or directors, at an ammal or special meeting, and has duly qualificd.

\section{Article IX.}

The hoard of directors of this corporation slall be elected at the annual meeting of the stockholders, which shall he held on the second 'Tuesday of in each rear, conmencing with the year A.D. 19 , at the principal offiec of the company at sueh hour as may be tixed by the directors or by the by-laws. The offieers of this corporation shiall be ehosen by the directors at the annual meeting of the diretors, which shall be held each year immediately after the ammal mceting of thic stockliolders.

Until the ammal meeting of the stockholders in the ycar A.D. 19 , and until their snecessors are chosen and have qualified, of directors of this eorporation, and its officers slaall bc

$$
\text { vice-presilent, scerctary, and }
$$

president,

(NoTE. Of course any date may be fixed for the annual meeting.)

Article $X$.

Each dircetor shall be a stockholder, and if any director shall cease to be a stockholder he shall forthwith by virtue of that fact cease to be a director. Two or more offices may be held by the same person at the same time.

(Готк. The preceling article is not necessary to a legal organization.)

\section{Article XI.}

At all meetings of the stoekholders each stockliolder shall be cntitled to one rote for each share of stock held by him, which votes may be cast either in person or by proxy duly authorized in writing.

(Nотк. The preceding article is not necessary to a legal organization).

\section{Article XII.}

The highest amount of indebteduess to which this corporation shall at any time subject itself shall be an amount not in cxcess of two-thirds of its capital stock then issued and outstanding.

\section{Article XIII.}

The private property of the stockholders of this corporation slall be exempt from corporate debts.

\section{Article XIV.}

These articles may be amended at any annual meeting of the stockholders or at any special meeting called for that purpose; but wo such amendment shall be made without the affirmative vote in its favor of of the shares of stock then outstanding.

(NotE. This article is probably unnecessary but it is better to have it, and it is required, if an amendment by a bare majority of a quorum is to be precluded.) of

In Witness Whereof, we have hercunto subscribed our names on this

State of

County of

$$
\} \text { ss. }
$$

Before me, appeared

, a notary public, in and for said county, personally tical persons whose names are subscribed in the foregoing articles of incorporation, 


\section{FORMS AND PRECEDENTS.}

and each for bimself acknowledged the same to be his frec and voluntary act and deed for the uses and purposes therein expressed.

Witness mr hand and notarial seal at and State of Iowa, the day and rear last above written. , in the county of

, Notary Public in and for suid county and State.

(Note. It is not necessary that the incorporators subscribe for any stock, and they need not become stockholders.)

\section{KANSAS.}

\section{APPLICATION FOR CHARTER.}

To the Charter Board of the State of Kansas: The undersigned herebs apply to the Charter Board of the State of Kansas, eonsisting of the Attorner-General, Secretary of State, and State Bank Commissioner, for permission to organize a private corporation under the law of the State of Kansas, and for that purpose make the following statement, to wit:

\section{First.}

The name of the proposed corporation shall be:

\section{Second.}

The place where the principal offec or place of business of said corporation is to be located is :

\section{Third.}

The length of time for which said corporation is to exist shall be

years.

\section{Fourth.}

The full nature and character of the business in whieh said corporation proposes to engage is :

\section{Fifth.}

The names and addresses of the proposed ineorporators are:

\section{Si.th.}

The proposed amount of the eapital of said eorporation is be divided into shares, of dollars cael.

dollars, to

We further state that the above application is made in frood faith, with the intention that said eorporation shall aetually engage in the business specified, and none otlier.

In Winess Whereof, we, the above-named ineorporators, have hereunto subscribed our manes, this day of , 1. L. 190 .

State of Kintsits, ? $s$ s.
County of

Persomally apporeded before mi', a , in and for sidid eounty and State, the abover-1utured

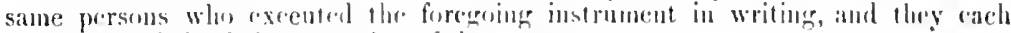
duly ackuowledged the cacerution of the situse.

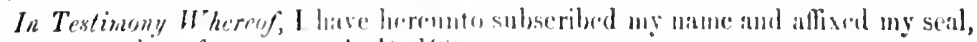
this day of , 1. 1. 1901.

(My commission expires $, 190$. 


\section{CHARTER}

OF

The undersigued, citizens of the State of Kansas, do hereby roluntarily associate oursetves fogether for the purpose of forming a private corporation under the laws of the state of hansas, and do hereby certify:

\section{First.}

That the name of this corporation slual be Tue

\section{Second.}

That the purposes for which this corporation is formed are to:

Thirl.

That the place

where its business is to be transacted

at :

\section{Fourth.}

That the term for which this corporation is to exist is :

\section{Fifth.}

That the number of directors of this corporation shall be names and resideuces of those who are appointed for the first year are:

Sixth.

That the estimated value of the goods, chattels, lands, rights, and credits owned by the eorporation is dollars.

That the amount of the capital stock of this corporation shall be dollars, and sliall be divided into shares, of dollars each.

Seventh.

That the names and residences of the stockholders of said corporation, and the number of shares lield by each, are as follows, to wit:
Names.
Residences.
No. of Shares.

In Testimony Whereof, we have hercunto subscribed our names, this day of , A. D. 190 .

\section{State of Kansas,
County, ss.}

Personally appeared bcforc mc, a Notary Public in and for

County, Kansas, the above-named who are personally knomi to me to be the same persons who exceuted the foregoing instrument of writing, and duly acknowledgred the execution of the sanne.

In Testimony Whereof, I have hereunto subseribed my name and affixed my notarial seal, this day of , A. D. 190 .

(SEAL.)

(IIy commission expires

.)

, Notary Public.

\section{Office of Treasurer of State.}
Received of
the sum of
dollars, the same being the

Charter Fee for the

Dated this

day of

, A. D. 190 .

, Treasurer of State of Kansas. 


\section{KENTUCKY.}

\section{ARTICLES OF INCORPORATION.}

The corporators whose names are bereto signed hare exceuted thesc articles of incorporation for the purpose of forming a corporation under the laws of the State of Kentuck 5 , in aceordanee with the following provisions:

1. The name of the eorporation shall be:

2. The place where the prineipal office of the corporation shall be is the City of , County of , State of Kentueky.

3. The purposes for which this eorporation is formed are :

4. The amount of the carpital stoek of this eorporation shatl be dollars, divided iuto shares of the par value of dollars each. (If preferred stock is desired, insert provision therefor at this point.)

5. The names and residences of the stoekholders and the number of shares subscribed for by each are as follows:

6. 'This corporation shall begin on , and the period of continuance shall be years (or perpetual).

7. The affairs of the corporation are to be eondueted by (state the offieers to conduct the affiirs of the corporation), who shall be elected ainually at (name, time, and place).

8. 'The eorporation shall not at any time incur a higher amount of indebtedness or liability than dollars.

9. 'Thie private property of the stoekholders shall not be subject to the corporate debts (or shall be subjeet, and state to what extent).

In Witness Whereof, we have hereunto subscribed our names this day of , A. D. 190 .

State of Kentueky,
County of ss.

I , a Notary Public in and for said county and State, do hereny certify that this instrument of writing from (here insert names of ineorporators) was this day produced to me by the above parties, and was acknowledged by the said

Given under my hand and seal this

day of

$$
\text { , Notary Public. }
$$

\section{LOUISIANA.}

\section{CERTIFICATE OF INCORPORATION}

○ト TIE

Compary.

United States of Aucricit,

Stinte of lacuisiana,

Parisliof

City of

Be If Kinern, that ron this day, the

of the monitls of

in the rear

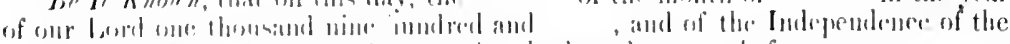

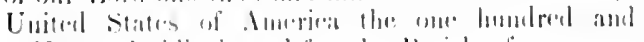
, bufure IIn,

a Notary l'uilies in atud for the l'arish of

Statle of lomisionat, duly com-

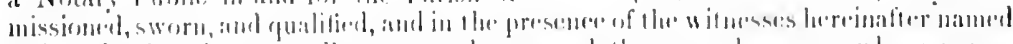

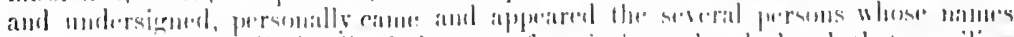

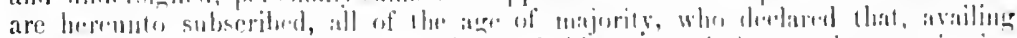
themselves of the provisions of the laws of this shate retative 10 the organization 
of corporations, they hereby form themselves into and constitute a corporation for the objects and purposes, and under the stipulations hereinater set forth, viz.: (If a limited corporation is to be formed, the above elause should read, from the words "arvailinir themselves" as follows: Availing themselves of . Aet 36 of 1858 an wall as the gererend laws of the State relative to the organization of eorporations, they laceby form themselves into and eonstitute a corporation for the objeets and purpeses, ind under the stipulations hereinater set forth:)

\section{Article $I$.}

The nime and title of this corporation slatl be:

and by that nitme it sball eujoy suecession for the term of years from the dite hereof, muless sooner dissolved. It shall have power to sue and be sued, to borrow money, hold, pureliase, lease, sell, and hypothecate real and personal property: to make and use a corporate seal; to mame aud appoint direetors, managers, and agents, and to establish such by-liws, rules, and regulations for the management of the business and allairs of said eorporation as may be neeessary the same to alter at pleasure; ilso to make and issue bonds and other evidenees of debt, and to secure same by mortgage or otherwise.

\section{Article II.}

The domicile of this cosporation shall be in the City of or other legal process shall be served on the President, or, in his absence, on the vice-President.

Article III.

The objects and purposes of this corporation shall be to:

\section{Article $I T$.}

The capital stock of this corporation shall be fixed at shares of dollars each, payable

dollars, divided into , or its equivalent.

\section{Article $V$.}

All the powers of this eorporation shall be vested in a Board of Direetors, composed of directors, of whom shitl constitute a quorum for the transaction of business. They shall eleet from their number a President, VicePresident, and a Secretary and Treasurer.

The following-named persons shall constitute a quorum of Directors:

President,

Viee-P'resident,

Secretiny,

Treasurer,

and they shill hold office until the in , 190 , or until their suceessrio's shall lave been duly clceted. Any failure to hold an anuual meeting shall not catuse a forfeiture of this act of incorponation, and any vacancy oceurring in the Board of Directors, from any cause, shall be filled by the remaining Dirertors.

'The Burd of Directors shall elect its officers, and shall appoint sueh agents and nanagers as may be necessary, and shall fix their compensation. The Board shall also have the right to dismiss said employees at pleasure.

All acts of sale, purchase, lease, or others, shall be signed by the or. in case of his absence, or inability to atet, by the

\section{Article VI.}

On the day in , 190, ammually, begimning with the year 190, there shill be held a mecting of stoekhlolders, to elect Direetors for the ensuing year which meeting shall be called after day's notice; said notice to be 
deposited in the mail, postage prepaid, and direeted to each stocklolder, at his or her last known address. At said meeting said Directors shall be eleeted by ballot, and a majority of the rotes east shall be necessarr to elect, and each share of stoek shall be entitled to one rote, and the shareholder shall vote in person or by written proxy. Only shareholders shall be eligible as Directors.

\section{Article VII.}

Any stoekholder who may desire to dispose of his share or shares of stock shall give the refusal of the same to this eorporation, or any member thereof, and no stock shall be transterred except upon the books of the company. No stockholder shall be held liable for any contraets or faults of this corporation, in any further sum than the umpaid balance on his respeetive shares.

\section{Article VIII.}

This aet of incorporation may be modified, changed, or amended, or said corporation may be dissolved by a vote of three-fourths of the stock represented at a general meeting held for that purpose after due notice shall have been grwen by publication for dass in one of the newspapers published in, and in case of dissolntion two eommissioners shall wind up and settle the aflairs of this corporation, and in the event of a disagreement between then, they shall seleet an umpire, whose decision shall be final.

At the termination of this aet of incorporation the business and affairs of this corporation shall be likewise wound up and settled by commissioners clected by the stocklolders at a meeting ealled lor that purpose, after twenty days' notice as abore.

Thus done and passed in my offiec, in aforesaid, the day, month, and vear first above written, in the presence of , witnesses of lawful age, residing in , who hereunto sign their names together with said appearers and me, notary, after due reading of these presents.

Original signed,

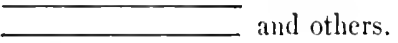

(City), (Date), 190 .

, Notary Public.

I, the undersigned, Recorder of Mortgarges in and for the parish of State of poration of the book , folio

$$
\text { Sirned. (City), } \quad, 190 \quad \text {. }
$$
, do hereby certify that the above and foreroing act of incor-'

Signed:

, D. R.

I, a Notary Public for the Parish of , aforesaid, do herchy certify the above and foregoing to be a true and correct enpe if the origimal act of incorporation of the Comprany, and of the eertitionte of the Recorder of Mforteniges thereto attached, the whole extant and on lile in my current motarial register.

In faith whereof I grant these presents under my signature and the impress of my seal ol oflice.

Signed :

the , $\Lambda . \mathrm{D} .190$.




\section{MAINE.}

\section{ARTICLES OF ASSOCIATION.}

In aecorlance with the Revised Statutes of the State of Mainc, Chapter 47, Scetions $6,7,8$, and 10 , we, the undersigned, whose residenees are set opposite our respective nimmes, hereby associate ourselves together by these witten Artieles of Agreement for the purpose of forming a corporition under the laws of the State of Maine, the purposes of which said eorporation are :

The first mecting of said associates shall be held in accordance with the provisions of Section 17 of Chapter 48 , at the office of

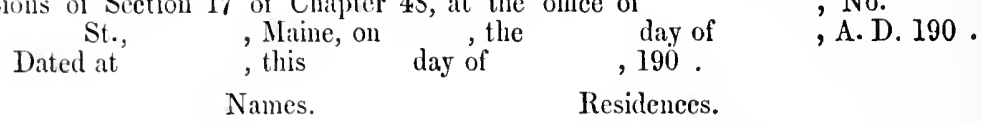

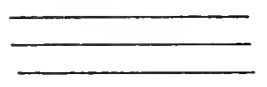

\section{Waiver of Notice of First Meeting of Incorporators.}

We, the undersigned, being all the signers of the foregoing Articles of Association, hereby waive notice of the time, place, and purpose of the first meeting of the signers of said Artieles of Association as required by Seetion 17 of Chapter 48 of the Revised Statutes of the State of Maine, and acts additional thereto and amendatory thereof, and do hereby fix the day of o'elock in the forenoon as the time, and the office of

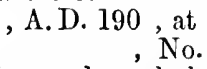

, A.D. 190 , at , No.

, Maine, as the place of said meeting, and we do hereby severally eonsent that said first meeting be held at the time, place, and for the purposes aforesaid, to wit:

1. 'To organize into a eorporation.

2. 'To adopt a corporate name.

3. To define the purposes of the eorporation.

4. To fix the amount of eapital stock, and divide same into shares.

5. 'To eleet a President, not less than three Directors, a Clerk, a Treasurer, and all other necessitry offieers.

6. To adopt a Code of By-Laws.

7. 'To aet upon any further business which may properly come before the meeting.

Dated at , Maine, this

day of , 190 .

\section{First Meeting.}

Pnrsuant to the forcgoing Artieles of Association and Waiver of Notice of First Mecting of Incorporators, signed by all the incorporators, a meeting of said signers of said articles was held at the offiee of

in the Maine,

190, No. at $\quad \begin{aligned} & \text { Street, } \\ & \text { o'clock }\end{aligned}$

Of the signers the following were present:

The meeting was ealled to order by was chosen Chairman and presided, and chosen Clerk.

The elerk was then duly sworn as appears by the following certificate : 


\section{State of Maine.}

Cumberland, ss.

$$
\text { Portlaxd, }
$$

Then personally appeared mentioned in the forconing Articles of Agreement, and faithfully and impartially perform the duties of his offiee. Before me,

, Justice of the Peace.

The original Articles of Association and Wairer of Notiee of First Meeting of Ineorporators were presented and ordered to be made a part of this reeord.

On motion it was Voted: To organize a corporation under Sections 16, 17, 1s, and 19 of Clapter 45 of the Revised Statutes of Haine, and aets additiontal thereto and amendatory thereof.

On motion it was Voted: That the name of the corporation slatl be:

On motion it was Voted: That the purposes of said corporation shall be as set forth, stated, speeified, and defined in the Artieles of Assoeiation, whieh are expressly reterred to and made a part of this rote.

On motion it was Voted: That the place of business of this eorporation shall be at , Maine, but the eorporation may maintain other genernl offiees and plaees of business at sneh other place or plaees, either within or without this State, as the Directors may from time to time determine to be for the interests of the eorporation.

On inotion it was Voted: That the eapital stock of this corporation shall be and is hereby fixed at dollars, divided into shares of the par value of dollars each.

On motion it was Voted: That the ehairman appoint a Committee of one to examine and report at onee the names and residene's of persons who have subseribed for stoek in this eompany, and the amomnt of stoek subseriber for by each. The Clerk was appointed as such Committee, and made the following report of the list of stocklolders, and the report was aeepted, and the persons therein named were deelared to be stockholders in this eorporation.

\section{REPORT OF COMMITTEe.}

Names. $\quad$ Residences. No. of Shares.

The following subseriptirms for stock were then filed:

Serscruptos for Stock.

$$
\text { , Mane, , } 190 \text {. }
$$

We, the undersigned, hereby severalls agree, ach with the other, and with the

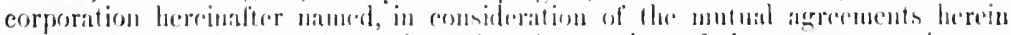
eontaned, to make, pay for, and reseive the mumber of shares sel mplosite our respective names, of the capital stock of the ('impintis.

$$
\text { Nimes. Residneres. No of Slares. }
$$

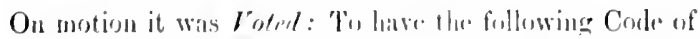

$$
\text { Br-laws: (Hore ingerl pame.) }
$$

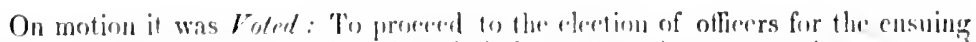

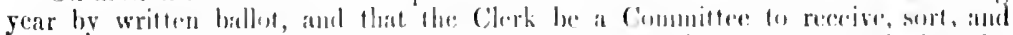
coust the retes thrown. Ilaving attended to that duty, he reporterd that for

dircetors,

for 'Treasurer, that for Clerk, $\operatorname{receisin}$

recrivint received votes, bring all the voltes thrown; that votes, heinge all the vetos thrown; votes, being all the votes thrown; 
that for soentary,

reecived

rotes, being all the rotes

thrown, and the report was acepted and the persons therein named were declared to be duly elected to the respertive others.

The Clerk was then duly sworn, as appears by the following Certificate:

\section{State of Maine.}

Cumberland, ss :

Portland, $\quad, 190$.

Then personally appeared the above-named , and being duly sworn, made oath that he would faithfully and impartially perform the duties of his silid olliee.

Before me,

, Justire of the Peace.

On motion it was Voted: To proceed to the election of an Exeentive Comnittee of nembers, and that the Clerk be a Committee to reeeive and sort and count the rotes thrown. Having attended to that duty, he reported that for members of the Excentive Committee had reecived rotes, being all the rotes thrown.

On motion it was Foted: To prepare a Certifieate of Ineorporation setting forth the name and purposes of the corporation and other partienlars required by said Chapter 48, and the same was aceordingly done.

On motion it was Voted: 'To adjoum.

Adjonrued.

Attest :

Secretary.

\section{Ratification of Records.}

We, the undersigned, being all the members of said corporation, hereby acknowledge that the above are true records of the organization of the aforesaid corporation, and all the proceedings of the aforesaid meeting, and hereby consent to approve, ratify, and eonfirm all of the aforesaid proceedings and the above reeords thereof.
Dated
, Maine, this
day of
190 .
A true copy of the records of the proceedings of the first meeting.

Attest :

, Clerk.

\section{CERTIFICATE OF ORGANIZATION OF -A CORPORATION UNDER THE GENERAL LAW.}

The undersigned, offieers of a eorporation organized at , Maine, at a meeting of the signers of the artieles therefor, duly called and held at the office of
, in the City of
, on the
day of
, A. D. 190 ,

hereby ecrtity as follows:

The limes of said eorporation is:

'T'he purposes of said eorporation are:

The amount of eapital stock is

The amount of eapital dors.

The amount of eapital stock already paid in is

The par value of the shares is dollars.

The names and residenees of the owners of said shares are as follows:

Names.

Residences.

No. of Shares.

Unissued and in the Treasury. 


\section{FORIS AND PRECEDENTS.}

Said corporation is loeated at The number of directors is

The name of the Clerk is

The undersigned

Treasurer ; and the undersigned of said eorporation.

li itness our hands this

ss.

Then personally appcared forcgoing certificate that the same is true.

Before me, day of in the County of

, and their names are

, and his residence is

are a majority of the Directors

, A. D. 190 .

, President.
, Treasurer.
Directors.
190.

and severally made oath to the

, Justice of the Peuce.

State of Maixe.

Attorney General's Otliee,

I hereby ccrtify that I have examined the foregoing certifieate, and the same is properly drawn and sigued, and is contormable to the Constitution and laws of the State.

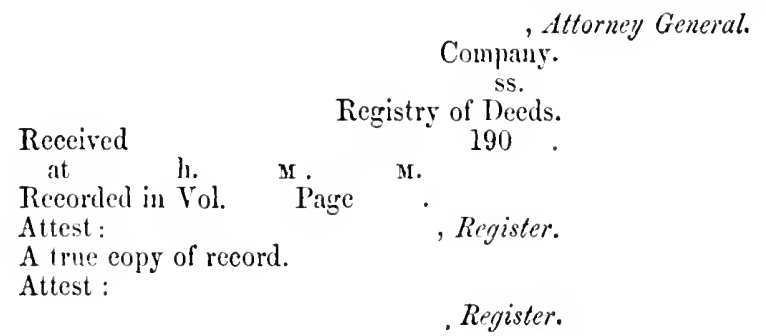

MARYLAND.

CERTIFICATE OF INCORPORATION.

State of Maryland,
County of

Certificate of Incorporation of the

Kune all Wen by these l'resents: That we, the midersiencol, do form ourackes into a conpration moler the provisions of the laws of the State of Maryland, and do certify:

First. That our names in foll, and residenees, are as follows:

Seromt. That the mame of the enromation shall be the of the City of (or Comuty of)

Therel. 'That the purposes for which the corporation is formed are ne follows, to wit:

Fourlh. That the term of existence shall be forty (fo) years, begiming 199 , ind ending 190 .

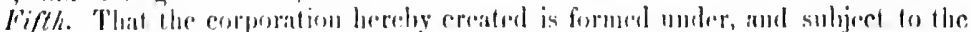
following articloa, omdlitions, and provisions, to wit: (here insert provisions for the regulation of the intermal atlairs of the corporations). is at

Sixth. That the place where the operations of the company shall be eaturied on , and the prineipal otfiec will be leseated nt 
Sementh. The amount of cinital stock shall he

Eighth. The sitil stock shall be divided into

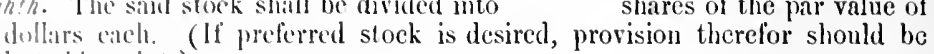
inserted at this point.)

linth. 'That the number of directors shall be Jincetors whe shall mamatre the comeems of the o as follows:

I'ituess our hands and scals this dollars. shares of the par value of
ovision therefor should be That the names of the
tion for the first year are corporation for the first year are day of $\quad, 190$.

State of Maryland,
Connty of

I herby certify that on this day of , in the year of , before me, a Notiry Public in and for said Comnty and State, personally appeared (here insert the nimes of five ineorporators), and did each acknowledge the aforcgoing instrument to be their respective act.

In Testimony Whereof, I have hereunto subscribed my name and affixed my official seal the day and year above written.

, Notary Public.

\section{MASSACHUSETTS.}

We, whose names are hercto subscribed, do, by this agrcement, associate ourselves with the intention of forming a corporation according to the provisions of Chapter 437 of the Aets of the year 1903, of the Commonwealth of Massachusetts, aud the Acts in amendment thereof and in addition thereto.

The name by which this corporation shall be known is

The location of the principal office of the corporation within the Commonwealth is the of , and outside Commonwealth, the of , State of

The purposes for which the corporation is formed and the nature of the business to be transacted by it are as follows:

The total amomit of the capital stock to be anthorized is par value of its shares is, preferred dollars, common number of its shares is, preferred , common

dollars. The dollars. The

(State the restrictions, if any, imposed npon the transfer of stock, and if there are to be two or more classes of stock, a deseription of the different classes, and a statement of the terms on which they are to be creatcd, and the method of voting thereon.)

( State any other provisions not inconsistent with law for the conduct and regulation of the business of the corporation, for its voluntary dissolntion, or for limiting, defining, or regulating the powers of the corporation, or of its dircetors or stuekholders, or any class of stockholders.)

The first mecting shall be called by of (or if notice is waived); and we luereby waive all requirements of the statutes of Massachusetts for notice of the first meeting for organization, and appoint the day of at o'clock II., at as the time and place of lolding said meeting.

The names and residences of the incorporators, and the amount of stock subscribed for by each, are as follows:

Name.

Residence.

Amount subscribed for.
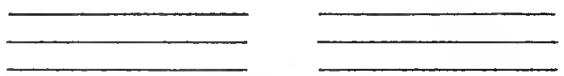

In witness whereof, we have hereunto set our hands, this in the year nineteen hundred and

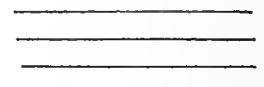

day of

\section{4}




\section{NOTICE OF FIRST MEETING.}

To

You are hereby notified, that the first mecting of the subscribers to an agreement to associate themselves with the intention of forming a eorporation to be known by the name of dated for the purpose of organizing said corporation by the adoption of by-laws, and election of otficers, and the transiction of such other business as may properly come before the meeting, will be held on , the day of o'clock, M., at One of the subscribers to said agreement. Statc of
County of ss.

I certify that I have served the foregoing notice upon each of the subscribers by copy served as follows (state whether delivered in hand, or deposited in the post-office, postpaid, addressed to each at his place of bnsiness or residence, or left at his residence or usual place of business) seven days at least before the day fixed for the first meeting.

County of, ss.

Subscribed and sworn to,

Before me,

\section{, Justice of the Peace.}

We, being a majority of the directors of the

Company, elected at its first meeting in rompliance with the requirements of Section 11 of Chapter 4.37 of the Acts of 1903, do lierchy certify that the following is a true eopy of the agreement of association to form said eorporation, with the names of the subscribers thereto:

We, whose names are hereto subscribed, do, by this agrecment, associate ourselves with the intention of forming a corporation according to the provisions of Chapter 43 $\tilde{z}$ of the Acts of the year 1903 of the Commonwealth of Massachusetts, and the acts in amendment thereof and in addition thereto.

The name by which the corporation shatl be known is

The location of the principal office of the corporation within the Commonwealth is the of , and outside the Commonwealth the , State of

The purposes for which the corporation is formed and the mature of the business to be trausacted by it are as follows:

The total amount of its eapitil stock to be authorized is par value of its shares is, preterred ber of its shares is, preferend , common

dollars. The

(State any other provicions set ont in the original certifieate.)

The first inceting shill be called lyy.

of (or if uotice is doillars. 'The numwaised), and we lareby waive all regiuirements of the statutes of Massachinsetts for notice of the first meeting for organization, and aly proint the day of at o'elock, M., at as the time and place of holling salid first meeting.

The nanes and residences of the incorporators and the amonnt of stock sub. scribed for by each are as follows:
Nitine.
Residener.
A monnt subseribed for.

In Wilness Wherof, we hate luerento set our hands this day of iil the year nineteen hundred and

That the first meeting of the subseribers to said agreement was held on the day of in the gear nincteen hundred and 
That the amomnt of the eapital stock now to be issned is shares of prelerred stuck and shares of common stock, to be paid for as follows:

Amoust and Class of Stock Issued.

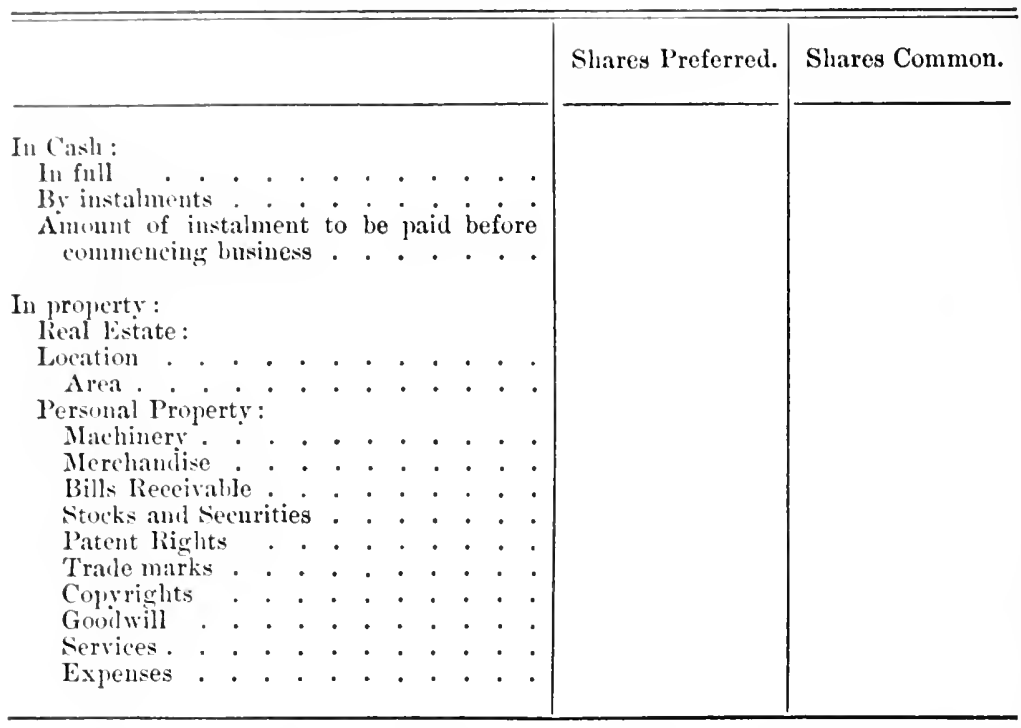

(State elearly the nature of sueh services or expenses and the amount of stock to be issned therefor.)

The name, residence, and post-office address of eaeh of the officers are as follows :
Name of Office.
Name.
Residence.
P. O. Address.

President,

Treasurer,

Clerk or Sceretary,

Direetors,

In Witness Whereof, we have hercunto signed our names this in the year nineteen hundred and

\section{Commonwealtu of Massachúsetts.}

County of , ss.

Then personally appeared the above-named , and severally made oal h that the foregong certificate by them subscribed is true to the best of their knowledge and belicf.

Before me,

, Notary Public.

\section{MICHIGAN.}

\section{ARTICLES OF ASSOCIATION}

OF

We, the undersigned, desiring to become incorporatcd inder the provisions of Act 232 of the Public Acts of 1903, entitled "An Act to revise and consolidate the, 476 
laws providing for the incorporation of manufacturing and mercantile companics or any union of the two, and for the incorporation of companies carrying on any other lawful business except such as are preeluded from organization under this act by its express provisions, and to prescribe the powers and to fix the duties and liabilities of such corporatious," and the acts amendatory thereof and supplementary thereto, do hereby make, execute, and adopt the following articles of association, to wit:

\section{Article $I$.} is

The name assumed by this association, and by which it shall be known in law,

\section{Arlicle $I I$.}

The purpose or purposes of this corporation are as follows:

\section{Article III.}

The principal place , in the County of at which operatious are to be conductcd is at , State of

\section{Article IV.}

The capital stock of the corporation hereby organized is the sum of dollars, of which

shall be preferred stock. 'The preferred stock shall be subjeet to redemption at par on the disy of $\quad$ A. 1). 199, and the liolder shall be entitled to a dividend of per cent per amum, pavable whiels slatl be cumulative and payable before any dividend shall be set apart or paid on the common stock. The preferred stocklolders shall be entitled to vote for directors.

\section{Article $V$.}

The number of shares into which the capital stock is divided is par value of dollars cach.

of the

\section{Arlicle VI.}

The amount of common stock subscribed is preferred stock subscribcd is dollars.

dollars. The amount of

\section{Arlicle rII.}

The annount of eommon stoek actually paid in is the sum of dollars, of which dollars lats been paid in cash, and dollars las heer paid in other property, an itemized description of which, with the value at whieh each item is takon, is ats follows, vi\%:

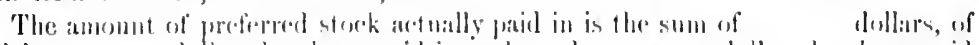

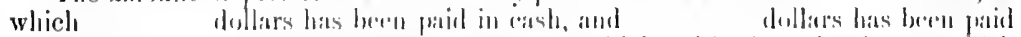
in other propurty, an itrmized deseription of which, with the valuation at which each item is titken, is ats follows, viz.:

\section{Irlick rIII.} at

The office in the State of Miehigan for the transaction of business shall he kejt 
Article IX.

The term of existenee of this corporation is fixed at hereol.

years from the date

\section{Article $\mathrm{X}$.}

The names of the stockholders, their respective residences, and the number of shatres of stuek subseribed for by each are as follows:
Nimes.
Residence.
No. of Shares.

In Witness Whereof, we, the partics hereby associating, for the purpose of giving lengl ellicet to these articles, hereunto sign our names, this day of A. D. 190 .

Nimes.

Names.

\section{MINNESOTA.}

\section{ARTICLES OF INCORPORATION}

$\mathrm{OF}$

\section{Article $I$.}

The name of this eorporation shall be:

\section{Article II.}

The general nature of the business of this eorporation shall be:

The prineipal place of business of said eorporation shall be:

\section{Artiele III.}

The time of eommeneement of said eorporation shall be eorporation shall continue for the period of years from said datc.

, and said

\section{Article IV.}

The eapital stock of said corporation shall be dollars, to be divided into shares of when subseribed for and issued.

dollars each, and shall be paid for in

\section{Article $V$.}

The lighest amount of indebtedness or liability to which said corporation shall at any time be subjeet shall not exceed $\$$

\section{Article VI.}

The names and places of residenee of the persons forming said corporation are :

\section{Article VII.}

The government of said corporation and the management of its affairs shall be vested in a boird of directors, composed of not less than nor more than 


\title{
FORIS AND PRECEDENTS.
}

, all of whom slrall be elected from the stockholders of said corporation, and a majority of whom shall be eleeted by the stockholders at the regular annual meeting thereof, which shall be held at the general ice of the company, in the City of , on the of , and stuall hold offiee until their suceessors are elected and qualified. The method of electing said direetors shall be declared and provided for by the By-Laws. Until the first ammual meeting of the stockholders the following-named persuns shall eonstitute the Board of Directors:

\section{Article VIII.}

The officers of this corporation shall be a President, Vice-President, Seeretars, Treasurer, and , all of whom shall be chosen by the Burral of Directors, and any two of said offiees, except those of President and Vier-P'resident, and President and Treasurer, may be held by the same person, and sueh Board of Directors shall have such ofher officers or agents as the interest of the corporition shall from time to time demand. Cutil the lirst annual meeting of the board of Directors, and until their successors are eleeted and have qualified, shiall be President and

and Treasurer.

Vice-President, , Sccretary,

Witness our hands and seals this day of , 190 . In presence of

\section{$\left.\begin{array}{l}\text { State of Minnesota, } \\ \text { County of }\end{array}\right\}$ ss.}

On this day of

, 190 , personally appeared before me , all to me known to be the parties who signed the foregoing instrument, and each for himself acknowledged that he signed the same as his tree act and deed, for the uses ind purposes therein expressed.

(SEAL.) , Notary Public, Co., Minn.

\section{MISSISSIPPI.}

\section{THE CHARTER OF INCORPORATION}

\author{
$\mathrm{OF}$
}

Section One. Be it known, That and their associates, sucerssors. and assigns, are hereby crated and constituted a borly corporate, and as such slubli have sueression for a jeriond of liffy years.

Section Tieo. The domicile of silid ronporation shall be at

Mississippi, but may be changed to any ofluer print within llississippi by a vote of

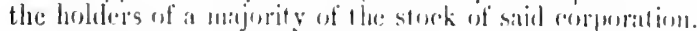

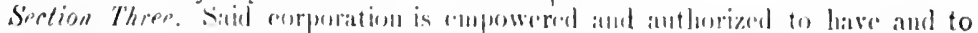

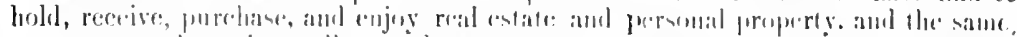

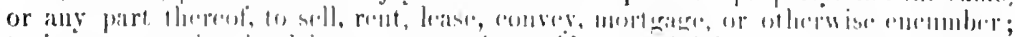

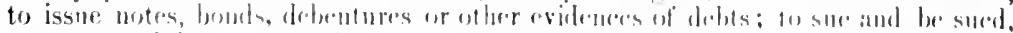

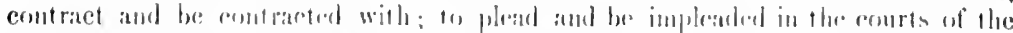

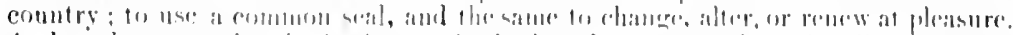

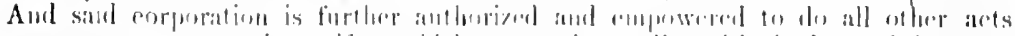

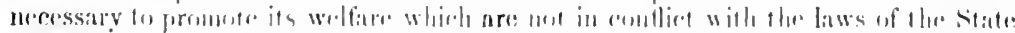

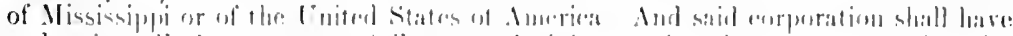

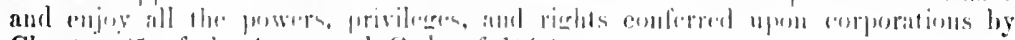

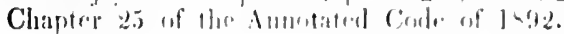

Section Four. The purposes for which the eorporation is crested are, and it is 
locroy authorized and empowered to

, and said corporation is further iumburized to do all ants neeessary and eonvenient in the judgment of the offieers or direcers of said corporation, for the wellare and business of said eorporation; and sibil corporition shall hare, possess, and enjoy all the rights, powers, and privileges cinumeritul in or ereated or conferred by Chapter 25 of the Amotated Code of $159:$. Which are neecssary and proper for carrying out the purposes of this coliuture.

S'retion Fire. The capital stock of said eorporation sliall be

divided inte shises of each, hut said capital stock may be increased or diminished at any time by a vote of the holders of a majority of the capital stock of saill corporation.

Section Si.r. The miungement of the business of said corporation slall be confincd to such a number of directors as may be fixed, and altered from time to time, by a rote of a majority of the stock issucd by said corporation; said directors shall be stoekholders of said eorporation; the majority of said directors shall constitute a quorum for the transaction of business. The said directors shall elect from their number a P'resident, and also elect a Viee-President, a Secretary, and a Treasurer, and way appoint or eleet such other offiecrs, agents, or cmployees as they may deem proper; shall hold oflice until their successors are duly elected and shall have qualified, and shitl lave power to fill all vacancies in their number caused by death, resiguation, ol otherwise.

Section Seven. The directors of said corporation shall have power and anthority to make any and all needful rules, by-laws, and regulations for the control and management of the business affirrs and property of said corporation, and may from tiuce to time alter or renew the same as they may see fit.

Section Eight. At all stockholder's' meetings a vote of the holders of a majority of the stock then present in person or by proxy shall decide all questions legally submitted at such meeting. Each stocklolder shall be entitled to one vote for each share of stock held by him, it, or her, but all elections of directors or managers of said corporation shatl be held in accordance with Section 194 of the Constitution of Mississippi and Section 837 of the Annotated Cote of Mississippi.

Section Nine. No stockholder of any such corporation shall be in any way personally liable for the debts of said corporation beyond the amount of his, her, or its unpaiil subseription to said stock.

Section Ten. All subscriptions to said capital stock shall be paid for in cash or property.

Section Eleven. Any two of said ineorporators may opeu books of subscription to the capital stock of said eorporation, and as soon as shall have been subscribed, said corporation may organize, elect directors, and commence business.

Witness our hands and scals this day of $\left.\begin{array}{l}\text { State of } \\ \text { County of }\end{array}\right\}$ ss.

Personally appeared before me , who acknowledged that they signed and delivered the foregoing instrument on the day and year therciu mentioned.

Given under my hand and official seal this the day of , 190 .

\section{MISSOURI.}

\section{FORM FOR INCORPORATING MANUFACTURING AND BUSINESS} CORPORATIONS.

Know all Men by these Presents : That we, the undersigned, desirous of forming a corporation under the laws of Missouri, and more particnlarly under the provisions of Artiele IX. Chapter 12, R. S. 1899, governing the formation of inanufacturiug and business companies, do hereby cnter into the following agreement: 
First. That the name of the eorporation shall be (Name desiguating the business contemplated; but not the name of any eorporation existing under the laws of this State for similar purposes. When the name of a persen or firm is assumed, it must be joined with some word designating the business to be earried on, followed by the word "eompany" or "eorporation").

Seconil. That the eorporation shall be loeated in the City of County, Missouri.

Third. That the amount of the eapital stock shall be $\$ 2,000$ nor more than $\$ 10,000,000)$ dollirs, divided into

(not less than par value of dollars each (if preferred stock is desired, provision therefor should be iuserted here); that the same has been bona fide subseribed and

(not less than one-half) thereof aetually paid up in liwful money of the United States, and is in the eustody of the persons heremafter named as the first Board of Direetors.

Fourth. That the names (not less than three), places of residenee of the shareholders, and the number of shares subscribed by each are:

Name.

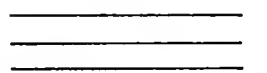

Residence.
Number of Shares.

Fifth. That the Board of Direetors shall be eomprosed of

sharcholders (not less than three nor more thau thirteen, at least thrce of whom shall be citizens and residents of Missouri); and the names of those agreed on for the first year are

Sixth. That the coiporation shall eontimue for a term of

(not cxeeeding filty) years.

Seventh. That the eorporation is formed for the following purposes (see sec. 1319 of the Revised Statutes of Missouri) : 190 .

In Testimony Whereof, we have hereunto set our hands this day of ,

\section{State of Missouri,
County of}

On this

day of 190 , before me personally appeared (names of all the stockholders), to me known to be the persons described in and who exceuted the foregoing instrument and acknowledged that they exeented the same as their free act and deed.

In Testimony Whereof, I have hereunto set $\mathrm{my}$ hand and aflixed my notarial scal the day and year last above mentioned.

$$
\begin{aligned}
& \text { My commission expires } \\
& \text { (SEAL.) }
\end{aligned}
$$$$
\text { - Notary I'ublic. }
$$

\section{MONTANA.}

State of Montana,
County of

We, do by these presents, pursuant to and in couformity with Artiele I. of Chapter I., 'Title I., and Part IV. of the: Civil Code of the State of Mone tana, associate onrselves together, and do licreby addopt the following Articles of Incorporation :

1. The encporate name of said company is hereby declared to ler:

2 The objects for which the comprany is formed are as follows: 
3. The names of the eity, town, or locality, and county in which the operations of the salid company are to be carried on are:

4. The sitit company shall commence on the day of in the reale one thousand nine humdred and , and shall continue in existence for ila term ol years.

5. 'The number of trustees who shall manage the concerns of said company for the first three months, shatl be , and their names and addresses are

(i). 'l'he' eapital stock of the said company shall be dollars, which shall be divided into shares of dollars each.

i. Amomnt actually subscribed is dollars, subscribed by (here insert names and addresses of subseribers).

๖. The stock is asscssable.

Hitness Our hands and scals, this

day of $\quad, 190$.

$\left.\begin{array}{l}\text { State of Montana, } \\ \text { Comity of }\end{array}\right\}$ ss.

On this day

, A. D. 190 , before me

in and tor said county and State, personally appeared

a

, whose names

are subseribel to the foregoing instrument as the parties thereto, known to me to be the same persons described in, and who exeented the said foregoing instrument, and who each of them duly acknowledged to me that they each of them respectively excented the same.

In Tritness Whereof, I have hercunto set my hand and affixed my official scal the day and year in this certificate first above written.

\section{NEBRASKA.}

\section{ARTICLES OF INCORPORATION}

OF THE

\section{Company.}

We, the undersigned, incorporators, do hereby, in pursuance of the Statutes of the State of Nebraska in such cases made and provided, associate ourselves as a body politie and corporate in the manner and for the purposes hereinafter mentioned.

Art. $I$.

The said corporation shall be named and known as

Company.

Art. II.

The principal place of transacting the business of the corporation shall be in the City of County, Nebraska.

A.t. III.

The general nature of the busincss to be transacten by the corporation is: Art. IV.

The authorized capital stock of the corporation shall be dollars, divided into shares of dollars cach; which shall be fully paid up when issued, of such shares shatl be subseribed for and fully paid up upen the organization of the corporation, the remaining shares, or any part thereof, may be issued at any time by the Board of Directors. The stockholders of the eompany statl be entitled to a pro rata distribution of all subsequent issues of stock, in such manner and under such rules and regulations as may be prescribed hy the Board of Directors. Said stock may be paid for in cash, or its equivalent in property necessary and uscful to the corporation in the transaction of its business. 
Art. $V$.

The highest amount of indebtedness or liability to which the corporation may at any time subjeet itself shall not exceed an amount equal to the capital stoek issued.

per cent of

Art. VI.

The corporation shall date from and eommence on the 190 , and it shall terminate on the day of 190 day of , Art. VII.

The affairs and business of the corporation shall be conducted by a Board of provided.

Directors, and by the officers by them to be eleeted, as heremafter

$$
\text { Art. VIII. }
$$

The first meeting of the stockholders shall be held on the date of the conmencement of the corporation, or as soon thereatter as practicable, and thereafter their regular aumal meeting shall be lield iu the City of day of At said first meeting, and at the ammal meetiugs thereafter, the Board of Directors shall be eleeted by the stockloolders from their own number, to hold office until the ammal meeting next alter their election and until their successors are clected and qualilied.

\section{Art. IX.}

The Directors shall in each instance, as soon as convenicnt after their election, elect from their own mumber a President, Vice-President, Secretary, and Treasurer, who shall hold office mut the anmul meeting next after their election and until their successors are elected and qualifich. Any two of satid ofliees may be held by one and the same person, except the offiees of President and Vice-l'resident.

\section{Art. $X$.}

The Board of Directors shall have full power and authority to make all rules and by-laws for the proper government and control of all the business atrairs of the corporation, and they may alter and amend the same at pleasure.

\section{Art. $X I$.}

Vacancies occurring in the Board of Directors shall be filled by the stocklolders, and other offiees vacaut from whatever cause shall be tilled by the Buard of Directors.

$$
\text { Art. XII. }
$$

These articles of incorporation may be anended at any time. Fvery anculment shall he first approved by a two-thirels vote of the entire Buard of Directors, and apon being so approved, it shall be entered at large apou the records of the

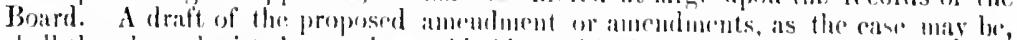

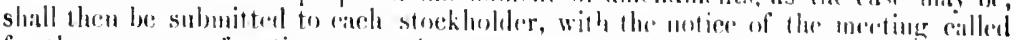
for the purpose of voting 1 pon the same, which notier shall be given ten dats at least prior to the date fixed for the meeting. If such andendment or andendments, or either of them, shall then be approved by the hulder or holders of fwo-thieds of

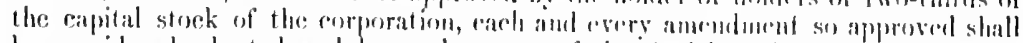

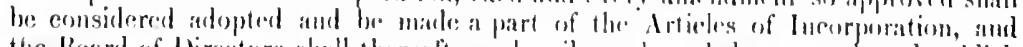
the Broard of lirectors slatl therealler subseribe, acknowledge, reeord, and publish the same, as hy law required.

In Testimony Wherefo, we have herenuto set our hands this

In presener of : 
State of Nebraska, \} ss.

County of

() 11 this day of

of otlice leedel) in and for

qualitied came

personally before me (name of officer and title

County, Nebraska, duly commissioned and , to me well known to be the identical persons whose minmes are allixed to the foregoing articles of ineorporation, and they severally acknowleded the excention of the same to be their voluntary act and deed for the purposes in said articles expressed. In testimony whereof I lave hereunto subscribed ny hand and aflixed my official seal the day and date last above written.

Notary Public,

County,

Nebraska.

\section{NEVADA.}

\section{ARTICLES OF INCORPORATION}

OF

\section{Company.}

Know all Men by these Presents: That we, the undersigned, have this day voluntarily associated ourselves together for the purpose of forming a corporation under the laws of the Statc of Nevada; and we hereby certify:

First. 'The name of this corporation is

Second. The location of the principal office of this corporation in the State of Nevada is in the Building, Number Countr of , and State of Nevada.

Thirl. The objects for which this corporation is formed are:

Fourth. The total authorized eapital stock of this corporation shall be dollars (not less than $\$ 2,000$ ), divided into shares of the par value of dollars per share. The amount of subscribed capital stock with which it will commence business is subscribed is dollars (not less than $\$ 1,000$ ). The amount actually dollars, and the amount aetually paid up is dollars. (At this point should be stated a description of different classes of stock, terms of their creation, and amount of each class subscribed, and the amount paid thereon; or if a non-stock corporation, state the terms and condition of memberslip.)

Fifth. The names and post-office addresses and residences of each of the original subscribers to the capital stock, and the amount subscribed by each are as follows:

Names (not less than threc). P. O. Address and Residence. No. of Shares. Amomint subscribed.

Sixth. The period of existence of this corporation is unlimited.

Seventh. The members of the Goveruing Board of this corporation shall be strled dircetors, and shall be

in number.

Eighth. The capital stock of this corporation after the amount of the subscribed price or par value has been paid in, or it has been issued as fully paid up, shall not be subject to assessment to par debts of the corporation.

(Unless provision is made in these articles for assessment upon paid up stock, no paid up stock, and no stock issued as fully paid up, can ever be assessable or assessed, and the articles of incorporation cammot be amended in this particular.)

Ninth. (IIere may be added such regulations and details as may be desired for regulating the busincss, officers, etc.)

In Witncss Whereof, we have hereunto set our hands this day of A. I). 19 .

Witnesses:

(Signatures.) 
State of

County of

\} ss.

Be it remembered that on this dar of , A. D. 190 , personally appeared before me, a in and for said County and State,

known to me to be the persons deseribed in, and who executed the foregoing instrument, who acknowledged to me that they excented the same frecly and voluntarily, and for the uses and purposes therein mentioned.

\section{NEW HAMPSHIRE.}

\section{ARTICLES OF AGREEMENT.}

The undersigned, being persons of lawful age, hereby associate under the provisions of Chapter 147 of the Public Statutes of New Himpshire, by the following articles of agreement:

Article 1. The name of this corporation shall be:

Article 2. The object for which this eorporation is established is: on is :

Article 3. The place in which the business of this corporation is to be carried

Article 4. The amount of the eapital stoek to be paid in slatl be:

Article 5. The first meeting of the corporators shall he lield:

Names (at least five).

Post-Office Address.
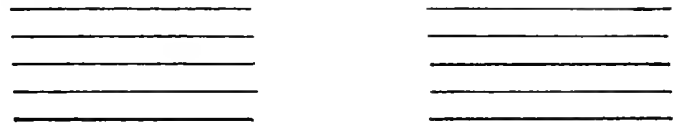

NEW JERSEY.

\section{CERTIFICATE OF INCORPORATION}

OF THE

Te, the undersigned, in order to form a eorporation for the purposes hereinafter set forth, under and pursuint to the provisions of the Art of the lecerislature of the State of New Jersey, entitled "An Act Concerning Corporations (Rorision of 1996)," and the aets annendatory thereof and supplenemal thereto, do hereby certify as follows:

\section{Article $I$}

The nane of the eorporation is:

\section{Artirle II}

The primeipal and recristered oflion of the Complany is in the
buildinz,

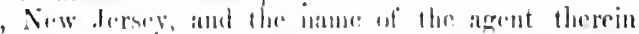

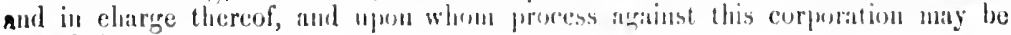
served, is

\section{Artirlin III}

The oljoects for which and for cach of which the corpuration is formed are:

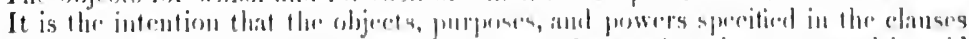

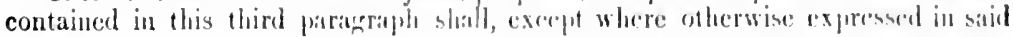


paragriluh, he nowise limited or restricted by reference to or inference from the terms of any other elanse of this or any otler paragralu in this charter, but that the objects, purposes, and powers speciticd in each of the clauses of this paragraph shall be restirded als inlepeudent objects, purposes, and powers.

\section{Article IV.}

The following provisions for the regulation of the business and the conduct of theralliairs of the Company are hereby established:

'The corporation mily isse and apply its surplus carnings or aceumulated profits anthorized hy law to be reservel, to the purchase or acquisition of property, and to the purchase or aequisition of its own capital stock from time to time, to such extent and in such mamner and upon sueh terms as its Board of Directors shall determine; and neither the property nor the capital stock so purchased and acquired, nor any of its eapital stock taken in payment or satisfaction of any debt due to the corporation, shill be regarded as profits for the purposes of declaration or payment of dividends, unless of herwise determined by a majority of the Board of Directors or a majority of the stoekholders.

'The corporation in its by-laws may prescribe the number necessary to constitute a quormm of the Board of Directors, which number may be less than a majority of the whole number.

'The Board of Directors slatl have power, without the assent or vote of the stockhollers, to make, alter, reseind, or amend the by-laws of the corporation, to fix the amount to be reserved as working capital, to anthorize and camse to be exccuted mortgages and liens upon the real and personal property of the corporation; and from time to time to sell, assign, transfer, or otherwise dispose of any or all of the property of the corporation, but no sueh sale of all the property shall be made exeept pursuant to the rote of at least two-thirds of the Board of Directors.

The Board of Directors from time to time shall determine whether and to what extent, and at what times and places, and under what conditions and regulations, the acconnts and books of the corporation, or any of them, slall be open to the inspection of the stoekliolders; and no stoekloolder shall have any right of inspecting any aceonnt or book or dineument of the corporation, except as conferred by statute or anthorized by the Board of Directors, or by a resolution of the stockholders.

The Board of Directors shall have power to hold its meetings, to have one or more offices, and to keep the books of the corporation (exeept the stock and transfer hooks) outside of the State of New Jersey at such places as may be from time to time designated by them.

\section{Article $\vec{r}$.}

The Company shall be authorized to issue eapital stock to the amount of dollars. The number of shares of which the capital stock shall consist is shares of the par valuc of dollars each. (It preferred stock is desired, insert provisions therefor at this point.)

\section{Article $V I$.}

The names and post-office addresses of the incorporators, and the number of shares of stock for which severally and respectively we do hereby subseribe, the agerergate of our said subseriptions being dollars, is the amount of capital stock with which the Company will hegin business, are as follows:

$$
\text { Names. Pust-Ofliec Addresses. No. of Shares. }
$$

\section{Article VII.}

The duration of the Company shall be perpetual. of 190 . 
State of

County of

\} ss.

Be It Remembered, that on this

day of

Public in and for said County, personally appeared

, 190 , before me, a Notary

, who I am satistied

are the persons named in, and who execited the foregoing certificate, and I having first made known to them the contents thereof, they did each acknowledge that they signed, sealed, and delivered the same as their voluntary act and deed.

\section{, Notary Public.}

(For use when aeknowledgment is taken out of the State.)

State of

County of

I, \} ss

Court for the said County, the same being a Court of record, Do Ilereby Certify that , whose name is subseribed to the Certifieate of the proof or acknowlednment of the annexed instrumeut aud thereon written, was at the time of the taking of such proof of ackuowledgment a Notary Pubhe, in and for said Comuty, duly eommissioned and sworn and anthorized by the laws of said State to take the acknowledgments and proots of deeds or eonveranees for lands, tentments, or lieredituments, in said State of And further, that I an well aequainted with the handwriting of sueh Notary Public, and verily believe that the signtare to said certificate of proof of acknowledgment is genuine.

In testimony whereof, I have hereunto set my hand and affixed the seal of the said Court and County the day of , 190 .

, Clerk.

\section{NEW MEXICO.}

\section{ARTICLES OF INCORPORATION}

OF TIIE

\section{Company.}

We, the undersigned, for ourselves, our associates and successors, have associated ourselves together for the purpose of formug a eorporation muder the laws of the Territory of New Nexico, United States of America, and we hereby certify and declare as follows:

I. The full names of sail persons desiring to form this Company are as follows:

II. The eorporate name of the Compraty is:

III. The objects for which the Compring is formed and its pmrposes are as follows:

IV. The anount of eapital stock and the number of shares into which the sime shall be divided is the patr value of

V. The term of existence of the said corporation is fifty yours from the date of this writing.

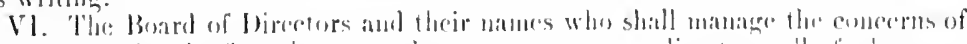
the Company for the first there munthe are directors, all of whom ane

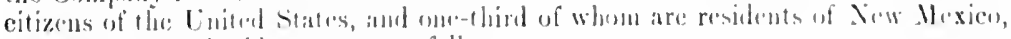
whose Hatmes and andresses ante ats follows:

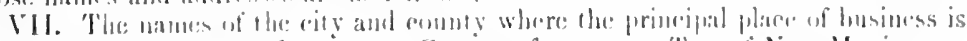

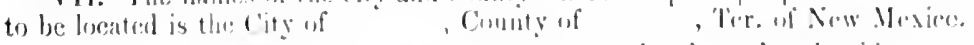

In Testimony thorofof, we hitw hereunto set onr hanly and scals this day of $\quad, 191)$. State of
County of ss. came

I ecrtify that on this 
persons deseribed in and who executed the foregoing instrument and severally duly acknowledingd to me that they liad signed and executed the same.

In Hitness Whereof, I have herenut o set my hamd and alfixed my official seal at said County the diyy and year last above writien.

\section{Territory of New Mexico. Olliec of the Sceretary.} , Notary Public,

Certificate. I,
was filed for record in this offiec, at Secretary of the Territory of this office, do hereby eertify there A. D. 190 ,

\section{Articles of Incorporation}

OF THE

\section{Compaxy,}

and also, that I have eompared the foregoing eopy of the same with the original thereof now on tile, and declitre it to be a correct trauseript therefrom and of the whole thereof.

In Witness Whereof, I have hereunto set my hand and affixed my official seal this day of, 190 .

, Secretary of New Mexico.

\section{NEW YORK.}

\section{CERTIFICATE OF INCORPORATION}

OF THE

We, the undersigned, all uatural persons of full age, two-thirds being citizens of the United States and one-third residents of the State of New York, desiring to form a stock corporation, pursuint to the provisions of the Business Corporation Law of the State of New York, do hereby make, sign, acknowledge, and file this certifieate for that purpose as follows:

First. The nime of the proposed corporation is:

Second. The purposes for which this corporation is formed are:

Third. The amount of the capital stoek is capital with whieh the Company will begin business is

dollars. The amount of tollars.

Fourth. The number of shares of which the capital stock shall consist is slares of the prar value of dollars per sharc. (II preferred stock is to be issued, provision therefor should be made at this point.)

Fifth. The principal oflice of the corporation is to be located in

Sixth. The duration of the Company will be ninety-uine (99) years.

Seventh. The number of its direetors sliall be

Eighth. The names and post-office addresses of the directors for the first year are:

Names.

Post-Office Addresses.

Ninth. The names and post-office addresses of the subseribers and the number of shares which each agrees to take in the corporation are as follows:

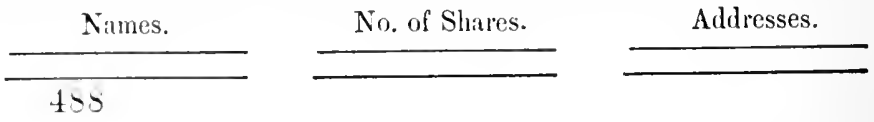


Tenth. (Here insert provisions for the regulation of internal affairs if desired.)

In Testimony 1 Thereof, the subscribers have made, signed, acknowledged, and C.led this certiticate.

Dated,

State of
County of ss.

I hereby certify that on this

day of , 190 , before me personally camc , to me personally known, and known to me to be the persons described in and who exceuted the foregoing instruncut, and severally duly acknowledged to me that they executed the same.

, Notary Public.

(For use out of the Statc.)

State of

County of $\}$ ss.

I,

, Clerk of the County of

, and also Clerk of the

Court for the silid County, the same being a Court of Record, Ino Hereby Certify, that

, whose name is subscribed to the Certifieate of the proot

or acknowledgment of the annexed instrument, and thereon written, was, at the time of the taking of such proof or acknowledgment, a Notary l'ublie in and for the County of , dwelling in the sitd count $y$, commissioned ant sworn, and duly anthorized to take the same. Aud further, that I an well arequatinted with the handwriting of such Notary, and verily believe that the signature to the said eertificate of proof or ackuowledgment is gennine.

In Testimony Whereof, I have hereunto set my hand and atixed the scal of the said Court and County, the day of, 190 .

, Clerk.

\section{NORTH CAROLINA.}

\section{CERTIFICATE OF INCORPORATION}

OF THE:

\section{CoMpixy.}

This is to certify that we

do lereby associate ourselves into a corporation, under and by virtue of an atet of the berislature of the state of North

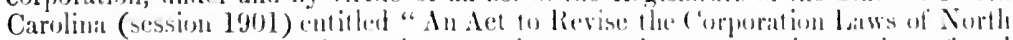

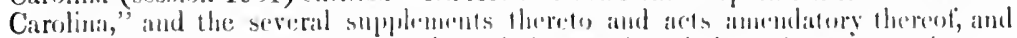
do severally agree to take the mumber of shatres of eiphital stuek set opluosite our respective inutues.

First. The natue of the corpuration is

Compiny.

Serond. 'The location ol the principat otliere in this State is at No. Strect, in thr.

$$
\text { of , Cintusty of }
$$

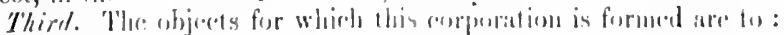

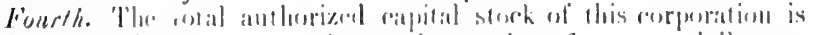

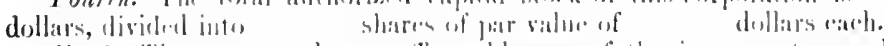

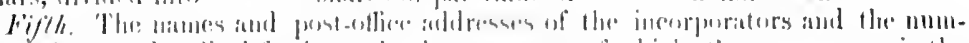

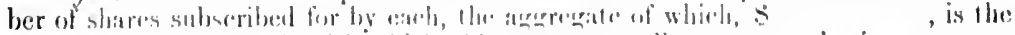

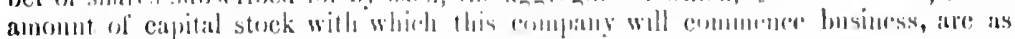
follow: :

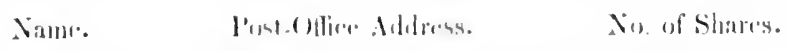

Sizth. The period of enistance of this corboration is limited to 
Serenth. (Here insert any provisions for the regulation of internal allairs of the corpretation that may be desired.)

In 1 ifness $^{\prime}$ "hereof, we have hereunto set our hands and seals the of $\quad, 190$.

day

(SEAL.)

Signed, sealed, and delivered in the presence of

(SEAL.)

Stitle of

County of

'This is to eertify that this day before me, a , personally appeared , who I an satisfied are the persons named in and who executed the foregroing eertiticate of ineorporation, and I having first made known to them the contents thereofi, they did each acknowledge that they did sign, scal, and deliver the sane as their voluntary act and deed, for the uses and purposes therein expressed.

In Testimony Whereof, I have heremto set my hand and affixed my official seal, this day of , A. D. 190 .

\section{NORTH DAKOTA.}

\section{ARTICLES OF INCORPORATION}

OF THE

Company.

Know all .Men by these Presents: That we, the mndersigued, have this day voluntarily associated ourselves together for the purpose of forming a corporation under the laws of the State of North Dakota. And we hereby certify:

First. 'The name of the said corporation is the

Second. The purpose for which it is formed is to carry on the business of in the County of and State of North Dakota.

Third. That the plaee where its principal business is to be transacted shall be the of , County of , and State of North Dakota. But it may have a business office without this State at the City of , State of , and any meetings of incorporators, stockholders, or directors may be lreld at either of said offices.

Fourth. That the tem for which it is to exist is years from and after the date of its incorporation.

Fifth. That the number of its directors shall be, , and that the names and resideuces of those who are appointed to scrve mntil their suceessors are elected and qualified are:

Names.

Residences.

Sixth. That the amount of the capital stock of this corporation shall be dollars, divided into shares of the par value of dollars each.

Secenth. That the amount of said eapital stock which has been actually subseribed is dollars, and the following are the names of the persons by whom the sime lias been subseribed and number of shares liekd by each:
Names of Subseribers.
No. of Shares.
Amount.

In Winess Whereof, we have hereunto set our hands and seals this day of , one thousand nine hundred and

(Signaturcs and seals.)

Signed and sealed in the presence of 
State of North Dakota,
County of

On this day of

, in the rear one thousand nine liundred and , before me, a Notary Publie in and for said county, personally appeared, known to me to be the persons who are deseribed in, and who executed the within instrument, and they each duly aeknowledged to me that they exeeuted the same.

In Witness Whereof, I have hereunto set my hand and affixed my offieial seal the day and year last above written.

(SEAL.)

, Notary Public,

Co.

\section{OHIO.}

\section{ARTICLES OF COMPANY FOR PROFIT.}

These articles of incorporation of the

Compans witnessetls: That we, the undersigned, all (or a majority) of whom are eitizens of the State of Ohio, desiring to form a eorporation for profit, under the general eorporation laws of said State, do hereby eertify:

First. 'The name of said eorporation shall be :

Second. Said eorporation is to be located at and its prineipal business there trimsacted.

in County, Olio,

Third. Said eorporation is lormed for the purpose of :

Fourth. 'The eapital stoek of sitid eorporition shall be dollitrs, divided into shares of dollars cateh. (If preferred stock is to be issued, provision therefor should be inserted at this point.)

In Witness Whreof, we have hereunto set our hands this day of , A. D. 190 .

(Signatures.)

$\left.\begin{array}{l}\text { State of Olio, } \\ \text { County of }\end{array}\right\}$ ss.

Personally appeared before me the undersigned, a in and for said county, this day of , A. D. 190 , the above named and each severally acknowledged the signing of the foregoing artieles of incorpora. tion to be his free aet and deed for the uses and purposes therein mentioned. (SEAL.)

Witness, my hand and oflieial seal on the day and year last aforesaid.

State of Ohio, ?

County of $\}$ ss.

I, Clerk of the Court of Common Pleas within and for the comnty

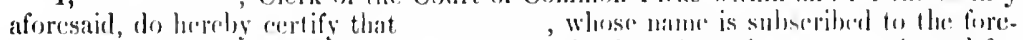

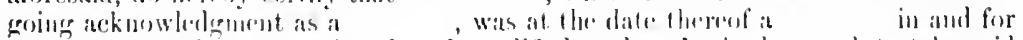

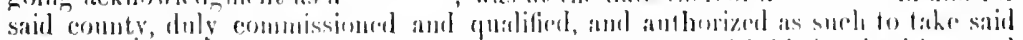

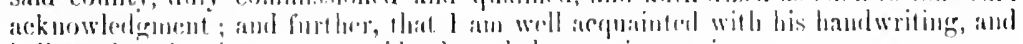

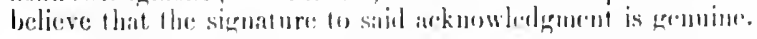

In. Witness Whereof, I hase hereustos sol my hamd and alfixid the sead of said Comrt at

(skAL.)

this

dity of

, A. (). I90. 


\section{OKLAHOMA.}

\section{ARTICLES OF INCORPORATION.}

Be It Known, That the undersigned, eitizens of the Territory of Oklahoma, do hereby voluntarily assoeiate ourselves together for the purpose of forming a privitte corporiation, under the laws of the Territory of Oklahoma, and do hereby ecrtify :

\section{First.}

That the name of this corporation shall be

\section{Second.}

That the purpose for which this corporation is (are) formed is (are) to :

\section{Third.}

That the place(s) where its principal business is to be transacted is (are) at:

\section{Fourth.}

That the term for which this corporation is to exist is :

\section{Fifth.}

The number of directors or trustees of this corporation, and the names and residences of such of them who are to serve until the election of such officers and their qualification :

Names.

Post-Office Addresses.
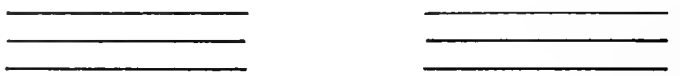

\section{Sixth.}

That the estimated value of the goods, chattels, lands, rights, and credits owned by the eorporation is dollars.

That the amount of the eapital stock of this corporation shall be and shall be divided into shares of dollars each. of

In Testimony Whereof, we have hereunto subscribcd our names this , A. D. 190 .

Territory of Oklahoma,
County ss.

Personally appeared before me, a Notary Public in and for said County, Territory above named, , who are personally known to me to be the same persolns who executed the foregoing instrument of writing, and duly acknowledged the exeeution of the same.

In Testimony Whereof, I have hereunto subseribed my nanc, and affixed my Notarial Seal this day of $\quad, 190$. 


\section{OREGON.}

\section{ARTICLES OF INCORPORATION.}

We, and and whose names arc hereunto subscribed, do hereby associate ourselves togetlicr for the purpose of forming a corporation under and by virtue of the laws of the State of Oregon for the formation of a private corporation.

Aiticle $I$. The name of this corporation shall bc sliall be perpetual.

, and its duration

Article II. The enterprisc, business, pursuit, or occupation in which this cor. poration proposes to cngage is : be at :

Article III. The principal office and placc of business of this corporation shall

Article $I V$. The capital stock of this eorporation slall be dollars.

Article $V$. The capital stock of this eorporation shall be divided into shares, of the par value of dollars each.

(If the corporation is formed for the purpose of navigation or making or construeting any railroads, roads, canal or bridge, the termini of the same or the site of such bridge must be set forth.)

In IVitness Whereof, we, the undersigned, have hereunto set our hands and seals this

In the presence of

State of Oregon,
County of ss.

Be It Remembered, that on this day of , 190, hefore me, the undersigned, a Notary Public in and for said County and State, personilly appeared , all to me personally known, and known to me to be the undividuals named in, and who executed the foregoing articles of incorporation, and scverally acknowledged to me that they exceuted the sime.

In Witness Whereof, I have hercunto set my hand and notarial seal the day and year last above written.

$$
\text { , Notary Public for Oregon. }
$$

\section{PENNSYLVANIA.}

Notice is hereby given that an application will be made to the Governor of the State of Pennsylvauia on , A. D. 19(), by under the Act of Assembly of the Commonwealth of Penusylsania cotitled "An Aet to provide for the Incorporation and Regulation of ecrtain Corpurations," approsed April 29th, 197t, and the supplements thereto, for the chitrter of an intended corporation to be called, the character and object of which is to and for these purposes to have and possess ant enjoy all the rights, bencfits, and privileges of the said Aet of Assembly and its supplements.

, Solicitors.

(The above is the form tor publication of notice of intention to apply for charter.) 


\section{PENNSYLVANIA.}

To tile Goverior of tile Comonwealti of Pennsylyania :

Sir, - In compliance with the requirements of an Act of the General Assemby of the Commonwealth of Pennsylvania, entitled "An Act to provide for the incorporation and regulation of certain corporations," apj)roved the 29 th day of April, A. D. $18 \% t$, and the several supplements thereto, the undersigued, of whom are citizens of Pennsylvania, having associated themselves together for the purpose hereinilter specitied, and desiring that they may be incorporated, and that letters patent may issue to them and their successors according to law, do hereby certify :

1. The nime of the proposed corporation is:

2. Said corporation is formed for the purpose of :

3. The business of said corporation is to be transacted in :

4. Saicl corporation is to exist for the term of

years.

5. The names and residences of the subscribcrs and the number of shares subscribed by each are as follows:
Names.
Residence.
No. of Shares.

6. The number of directors of said corporation is fixed at, and the names and residences of the directors who are chosen directors for the first year are as follows :

\section{Name.}

Residence.

7. The amount of the capital stock of said corporation is divided into shares of the par value of dollars, and beiur dollars, of said corporation, whose name and residence is :

(Signatures of Incorporators.)

State of Pennsylvania,
County of

Before me above named who, in duc form of law, acknowledged the
going instrument to be their act and deed for the purposes therein specified.

, in and for the county aforesaid, personally came the

Witness my hand and seal of office, the day of , A. D. 190 .
(SEAL.)

State of Pennsylvania,
County of ss.

Personally appeared before me, this day of A.D. 190, who being duly sworn, according to law, depose and say that the statements contained in the foregoing instrument are true.

Sworn and subscribed before me, the

day and year aforesaid.

\section{RHODE ISLAND.}

\section{ARTICLES OF ASSOCIATION.}

Know all Mes by tilese Presents: That we, all of lawful age, hereby agree to and with each other:

1. To associate ourselves together for the purpose of constituting a corporation 494 
under and by virtue of the powers conferred by Chapter 176 of the General Laws of the State of Rhode Island.

2. Said corporation shall be known by the name of :

3. Said eorporation is constituted for the purpose of engaging in business of :

4. Said eorporation shall be loeated in :

of

5. The capital stock of said eorporation shall be common stock in the amount dollars, to be divided into shares of the par value of dollars, and preferred stoek in the amount of thousand chollars, to be divided into shares of the par value of dollars each. (The advantages of the preferred stoek orer the common, if ans, must be set forth.)

In Testimony Whereof, we have hereunto set our hands and stated our residences this day of , A. D. 190 .

(Signatures and addresses.)

State of Rhode Island, County of

, ss.

In the of in said County this das of

A. D. 190 , then personally appeared before ne, each and all known to me and known by me to be the parties exeenting the foregoing instrument, and that they acknowledged the said instrument to be their free aet and deed.

\section{SOUTH CAROLINA.}

\section{DECLARATION AND PETITION FOR CHARTER.}

State of South Carolina,
County of

'To the Secretary of State of South Carolina :

The undersigned prelitioners (insert names aud residenees), by this their declaration would respeetfully show:

1st. 'That their nimes and resilenes are as above griren.

2nd. The name of the proposed corporation which they desire to form is: .

3rd. The place at which it proposes to have its primeipal place of business, or to be located, is:

4th. The general nature of the business which it proposes to do is:

5th. The amount of the eapital stock to be dillars parable:

6th. The number of shares into whieh the eapital stoek is to be divided is of the par value of dollars each.

7th. (Any other matters which may be alvisable to set formh.)

Wherefore your petitioners pray that the Secertary of State do issue to them

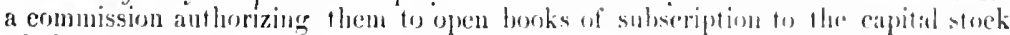
of the proposed eorpromition, after days public notice in the a newspaper published in the eounty of

And your petitioners will ever pray, etc.

Datc.

(Signatures.)

\section{Retrre of Corporators. (South Caholisa.)}

State of South Carolina, ?

County of $\int^{\text {ss. }}$

To the: Secretary of State of South Carolina:

Whereas, dilit ente in the office of Secretary of

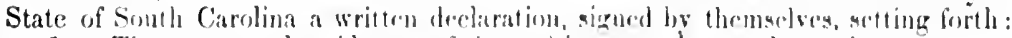

1st. The manes and residence, of the pretitioners to be, ay above giren,

2nd. The name of the proposed eorporation to be with principal 
place of business at

to do.

3ril. The amount of the eapital stock to be

of shatres into whieh the same is to be divided to be of

dollan's cach; and

Whereas, the above named petitioners were appointed by you a Board of Corporators, the mulersigned, bemg a majority thereof, respectfully certify:

1st. 'That all the requirements of an Aet entitled "An Act to provide for the formation of eertain eorporations and to detine the powers thereof" approved the ath diy of Mareh, A. D. 1596, and all amendments thereto, have been duly and fully complied with, fifty per cent of the aggregate amount of the capital stock having been subseribed by bona fide subseribers.

2nd. That, pursuant to notiee published as required, a mecting was held on , at which a majority of all stock in value, being present, in person or

by proxy, the following were elected Directors:

3rd." Thit subsequently there was eleeted as President, President, ; as Secretary and Treasurer

4th. That over twenty per cent of the aggregate capital stock has been paid to said 'Treasurer.

Wherefore, your petitioners pray that a charter be issued in the name and for the purposes indicated in their written declaration.

(Signatures.)

\section{SOUTH DAKOTA.}

\section{ARTICLES OF INCORPORATION}

\section{OF}

Kxom all Men By these Presents: That we, the undersigned, for ourselres, our assoeiates and successors, have associated ourselves together for the purpose of forming a eorporation under and by virtue of the statutes and laws of the State of South Dakota, and we do hereby certify and declare as follows, viz.

\section{First.}

The name of the corporation shall be

\section{Second.}

The purposes for which this corporation is formed

\section{Third.}

The place where the principal business of this corporation shall be transacted is in the City of this State, at the City of South Dakota; but it may have a business office without , State of , and any meetiugs of incorporators, stocklsolders, or directors of this company may be lield at either of said offices or places of business; and the books of this corporation may be kept at either of said offices or places of business; and any incorporator or stockholder of said company cntitled to be present and to vote at said meeting may be represented by proxy.

The domiciliary office of this corporation shall be at the oflice of in the aforesaid City of

, Soutl Dakota.

\section{Fourth.}

The term for which this corporation shall exist shall be twenty (20) years, with such right of renewal for other and similar periods as may now or hereafter be permitted under the laws of South Dakota. 
Fifth.

The number of Directors of this corporation shall be , and each Director shall hold at least one share of stock. The names and residences of the Directors who are to serve until their successors are elected are as follows :

Names.

Residences.

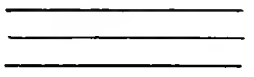

Sixth.

The amount of capital stock of this corporation shall be and is ), dirided into

shares of the par value of

dollars

$(\$$

In Testimony Whereof, We have hereunto set our hands this day of 190 .

(Signatures.)

$\left.\begin{array}{l}\text { State of } \\ \text { County of }\end{array}\right\}$ ss.

Be It Remembered, That on this das of , A. D. 190 , betore the undersigued, personally appeared the above named well and personally known to me to be the sane persons deseribed in, and who executed the foregoing instrument, and severally dnly acknowledged to me that they executed thic same.

In Witness Whereof, I have hereunto set my hand and afixed my oflicial scal at said county, the day aud year last abore written.

\section{State of County of \} ss.} , Notary Public.

, being duls sworu, each for limself deposes and says": That he is one of the persons described in, and who sinned the forengine Artinles of Incorporation as an ineorporator therein; that he has prad lhe sitld articles and knows the contents thereof ; that the ineorporators intended in good fitith fo fiorm at corporation for the murpuse of a lawhil business as sef finth in salid articles, and not for the purpose of entbling any eorporattions to atroid the provisions of sectims 770 to 781 inchusive of the Revised Pertal Coxle of 1903 of the state of sinth Dakota relating to unlawful trusts and combinations, and litws annembitury thereto.

Subseribed and sworn to before me this

diay of

..1. 1). 190.

, Notury l'ublic:

\section{STATE OF TENNESSEE (ORDINARY FORM PRESCRIBED BY STATUTE). \\ CHARTER OF INCORPORATION.}

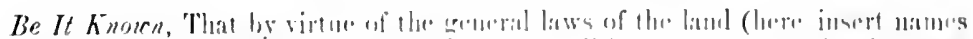

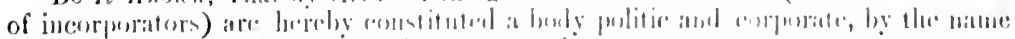

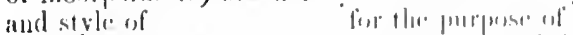

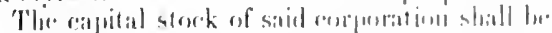

Wullitrs

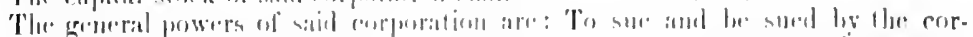

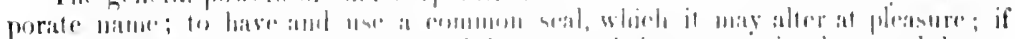

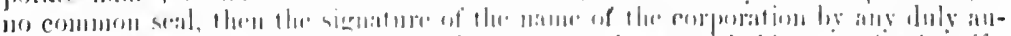

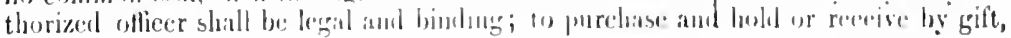


in addition to the personal property owned by said eorporation, any real estate necessing for the transaction of the corporate business, and also to purehase or aceept any real estate in parment or part payment of any debt due to the eorporafim, and scll realty for corjoriation purposes; to establish by-laws and make all rules and resulations, not inemsistent with the laws and Constitution, deened expedient for the manterement of eorporate atliars, and to appoint such subordinate oflieers and arents in addition to a P'resident, Sceretary, or Treasurer, as the business of the eriporation may require, designate the name of the office, and fix the compensation of the othere

The hollowing provisions and restrietions are eoupled with said grant of powers: A biture to chet officers at the proper time does not dissolve the eorporation, but those in oflies hold until the eleetion or appointment and qualifieation of their suecessors. 'The term of all otheers may be tixed by the by-laws of the corjoration; the sinne not, however, to execed two years. The eorporation may, by by-laws, make reunlations eoneerming the subseriptions for, or transfer of stock; fix upon the amount of eapital to be invested in the enterprise; the division of the same into shares; the time required for payment thereof by the subseribers for stock; the amount to he ealled for at any one time, and in case of failure of any stockloolder to pay the amount thus snbscribed by him at the time and in the amounts thus called, a right of action shall exist in the eorporation to sue said defanlting stockholder for the same. The Board of Dircetors - which may eonsist of five or more members, at the option of the corporation, to be elected either in person or by proxy, by a majority of the rotes cast, cach share representing one vote - shall keep a firll and true record of all their proceedings, and an amual statement of receipts and dishursements shall be copied on the minutes, subject at all times to the insplection of any stockholder. The books of the eorporation shall show the original or sulsecquent stoekholders, their respective interests, the amount which hits been paid on the shares subseribed, the transfer of stoek, by and to whom made; also other transaetions in which it is presumed a stockholder or creditor may hare an interest.

The amount of any unpaid stoek due from a subseriber to the corporation shall be a fund tor the payment of any debts due from the corporation, nor shall the transfer of stock by any subscriber relieve him from payment unless his transferee has paid up all or any of the balance due on said original subseription.

By no implication or construetion shall the corporation be deemed to possess ans powers except those herehy expressly given or necessarily implied from the nature of the business for whicli the charter is granted, and by no inference whatever shall said corporation possess the power to discomt notes or bills, deal in gold or silver coin, issue any cvidenee of debts as eurrency, or engage in any business outside the purpose of the eharter.

The right is reserved to repeal, anuul, or modify this eharter. If it is repealed, or if the anendments proposed, being not nerely auxiliary but fundamental, are rejected by a vote representing more than half of the stoek, the corporation shall eontinue to exist for the purpose of winding up its affairs, but not to enter upon any new business. If the amendments or modifications being fumlamental are accepted by the corporation as aforesaid, in a gencral mecting to be called for that purpose, any minor, married woman, or other person under disability, or any stockbolder not arreeing to the aeeptance of the modification, shall cease to be a stockholder, and the eorporation shall be liable to pay said withdrawing stoek holders the par value of their stoek, if it is worth so much; if not, then so mueh as may be its real value in the market on the day of the withdrawal of said stoekholders as aforesaid; Provided, That the elains of all ereditors are to be paid in preferenee to said withdrawing stockholders.

A najority of the Board of Directors shall constitute a quorum and shall fill all vacancies until the next eleetion. The first Board of Directors shall consist of the five or more eorporators who shall apply for and obtain the charter.

The said corporation may have the right to borrow momey and issue notes or honds upon the fitith of the eorporate property, and also to "xiente a mortgage or nortgages as further seeurity for repayment of money thus borrowed. 
Said corporation shall have the power to raise, buy, sell, and deal in agricultural products, operate flouring and other mills, and deal in merchandise.

Anuually, during the month of January, the President shall make and publish in a newspaper printed in the county where the prineipal office of business is loeated, or if no newspaper is printed in that connty, then in an arljoining, or the nearest county where a newspiper is printed, a sworn statenient, showing the amount of the capital stock and existing liabilities, and a list of the nimucs of the stoekholders.

Nothing but cash shall be taken in paluent of any part of the capital stock, or land at a fair eash raluation, or patents to the amount of their value, as agreed on by the subscriber and the corporation, and no loan of mon y shall at any time be made to any stoekholder thereof, and any such loan shall ruter the Direetors eonsenting thereto individually liable for the anount thereof; this ability to extend in lavor of innocent stockliolders as well as ereditor's.

The making of a false statement, to be printed as aforesaid, shall render all persons assenting thereto indwidually liable to all persons deating or trading with stid Company upon the faith of said fratululent statement.

If the indebtedness of said Company shall at any time exeed the eapital stoek paid in, the Direetors assenting thereto shall be individually liable to the ereditors for said exeess. The stoektholders are jointly and severally liable individually at all times, for all moneys due and owing to the liborers, servants, elerks, and operatives of the Compauy in ease the corporation becomes insolvent.

If the Directors declare and pay any dividend when the Company is insolvent, on which deelaration of a dividend wonld diminish the amount of the eapital stoek, they shall be jointly and sererally liable to ereditors for the anount of diridends thus declared. Any Direetor may aroid hiability by roting against the dividend, or by filing his objections in writing ats soon as he aseertains a dividend has been madle.

We, the undersigned, apply to the State of 'lennessee, lyy virtue of the laws of the land, for a Charter of Ineorporation lor the purposes and with the powers, ete., declared in the foregoing instrument.

Witness our hands, this day of, 190 .

\section{TEXAS.}

\section{CHARTER OF}

State of Texas, ?

County of $\}$

Know all Wen by these Presents, That we, and , all of said

Connty, do hereby associate onrselves together als a private eorporation under and by virtue of the laws of the state of 'Texis, and do hereby andopt the following

\section{Articles of Inconporation.}

1. The nane of said eorpmrition sliall be:

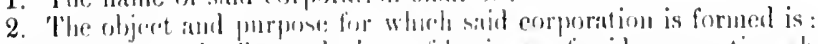

3. The prineipat oftloce and place of lomsiness of said corporation shatl be in the City of Comaty, T'ixas.

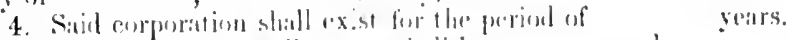

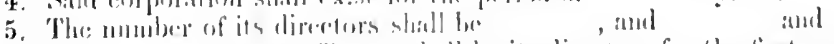

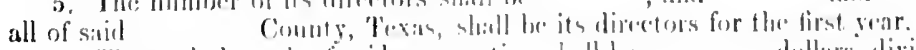

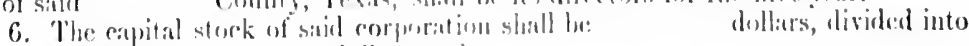
shatres of dullars ianly.

In Hiturss Wherefo, we have herennto signed our names this the? 
State of Texas,

Cominty of $\}$

bifore , a notary public in and for said and

County, on tinis dily personally appeared , each known to me to be the persou whose names are subseribed to the foregoing instrument, and sererally acknowledged to me that they executed the same for the purposes and consideration therein expressed.

Given under my hand and seal of oflice this the day of , A. D. 19 , Notary Public,

State of Texas, County, 'T'exas.

County of $\}$

I, , of

Connty, Texas, upon oath do hereby state that fifty per eent of the authorized eapital stoek of said , amounting to dolliars, has been subseribed, and ten per cent of such authorized capital stock, amounting to dollars, has been paid in.

Sworn to and subscribed before me by , this the day of, A. D. 19 . , Notary Public, County, Texas.

\section{UTAH.}

\section{ARTICLES OF INCORPORATION}

OF

Tuis Agreemext made aud entered into by and between , all of , State of Utah, Witnesseth:

That the parties are desirous of forming a corporation under the laws of the State of Utali for the purposes and on the terms liereinafter stated:

\section{Article One.}

Said eorporation shall be called and known by the name of , and is organized at

Article Two.

Said corporation shall exist and continue for a term of fifty years unless sooner dissolved or disincorporated aceording to law.

\section{Article Three.}

The object, business, and pursuit of said corporation shall be to :

\section{Article Four.}

The plaee of the general offiee and business of said corporation shall be at , State of Utah.

\section{Article Five.}

The amount of the capital stoek of said eorporation shall be the face or par value of

dollars each.

shares of

\section{Article Six.}

The amount of the eapital stock subseribed by each of the incorporators above named, parties to this agreement, is as follows, that is to say: 


\section{Article Seren.}

The officers of said corporation sliall be:

\section{Article Eight.}

To be eligible to an offiee in this corporation the person must be the owner, as shown by the books of the eorporation, of at least one share of the eapital stock thereof, and the President and Treasurer must be directors of said corporation; the Secretary may or was not be a direetor of said corporation, and if a director may be joined with the office of 'Treasurer.

\section{Article Nine.}

The following named persons, parties hereto, slall bc directors of said corporation until the next annual meeting of the stockholders thereof, ats hereinafter pro. vided, namely: And the said shall be President, said shall be Secretary and Treasurer, and until their suecessors shall be duly elected and qualified. Any racancy eaused by the resignation, death, or removal of either or any of the said directors or officers, may be filled by the Board of Directors.

\section{Article Ten.}

The term of office of the officers of said eorporation after the first annual meeting, shall be have duly qualified. , and until their sueeessors shall be duly elected and shill

\section{Article Eleven.}

The annual stoekholders' meeting of said corporation for the election of officers and for the transaction ol any such other business as shall lawfully eome before it, shall be held on the in each rear, at Utal, aud representation of a majority of the eapital stock of said corporation shall be necessary to legally loold said meeting, and all stockholders' mectings of said corporation shall be either general or speeiat. The offiects of said corporation, at such nectings, slatl be elected and deelared to be elected to said offiees rospeetively. Kach stockholder shall be entitled to as many votes as he loolds of said eapital stock. Stoek representation, by proxy, duly appointed, slall be allowed at all meetings of said eorporation, either gemeral or speeial. No publie notice shatl be required of the holding of the annual stoekliolders' meetings. Speeial meetings of the stoekholders may be ealled hy the President or by any diretors, and uotice thereof shall be sufficient if personally served on each stockholder, or by letter postpaid, addressed to him at his place of residence.

\section{Article Tirelve.}

transact business of the eorperation.

\section{Article Thirten.}

The private property of the stockloblukers of the eorporation shall unt be liable for the debts of the corporition.

\section{Article Fourten.}

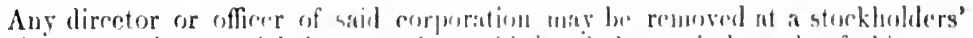
meeting, general or special, hy vote of worthirds of the capital stork of this eorporation, and any ofliene or direetor may resign he filing a written resignation with the Secretary of the eorporation. 
Article Fifteen.

The eapital stock of said eorporation subseribed by the conseyane to satil eorporation by of the is fully paid by - (For all eorporations but mining and irrigation eompanies there must be inserted here a full deseription of the property eonveyed havugg a fair cash value equal to the par value of the stock for which it is transierred.)

\section{Article Sixteen.}

It shall be the duty of the Board of Directors to elect a manager who shall have the general supervision and management of the busincss of said corporation.

In Witmess Whereof, siul parties have hereunto set their hands and seals the day and year first above written.

$\left.\begin{array}{l}\text { State of Utah, } \\ \text { County of }\end{array}\right\}$ ss.

, bcing each severally duly sworn, on oath do depose and sar that they have commenced to carry on, and it is their bona fide intention to earry on, the business mentioned in the foregoing agreement and Articles of Incorporation, and affiants verily believe that each party to said agreement has frid and is able to and will pay the amount of stock subseribed for by him, and that ten per cent of the eapital stock and ten per cent of the stock subscribed by each stockholder has been paid in. 190 .

Subscribed in my presence and sworn to before me this

day of

(In the ease of all but mining and irrigation companies the following affidavit must be made.)

$\left.\begin{array}{l}\text { State of Utall, } \\ \text { County of }\end{array}\right\}$ ss.

, , and , being each severally sworn, on oath deposes and says that he has examined and appraised the

conveyed by

to the corporation by these artieles formed, in full payment of their eapital stock, and they do each hereby on their oath say that the said property so conveyed to said corporation is reasonably worth the sum of dollars, and that said sum of dollars is a fair eash market value of said property.

Subseribed in my presence and sworn to before me this day of, 190 .

\section{VERMONT.}

\section{ARTICLES OF ASSOCIATION}

OF TIIE

We, the subscribers, hereby associate onrselves together as a corporation under the laws of the State of Vermont, to be known by the name of

the purpose of

State of Vermont, with a eapital stock of shares of 190 .

Dated at , in the County of

Subscribers.
, in the County of dollars, divided into , in the , this day of , A. D.

Post-Office Address.

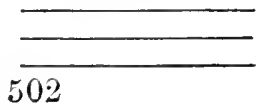




\section{VIRGINIA.}

\section{CERTIFICATE OF INCORPORATION}

$\mathrm{OF}$

(Corporation or Incorporated).

This is to certify that we do hereby associate ourselves to establish a cornoration under and by virtue of the provisions of an Act of the General Assembly of the State of Virginia, entitled "An Act Coneerning Corporations," which became a law on the 2lst das of Mar, 1903, for the purposes and under the eorpome name liereinafter mentioned, and to that end we to by this our certifieate set forth as follows:

First. The name of the company shall be the

Corporation (or incorporated). at

Second. The principal office of the company within the State shall be located

Third. The purposes for which this company is organized are:

Fourth. The capital stock of the compauy shall not be less than dollars, nor more than dollars to be divided into shares of the par value of dollars each. (If preferred stock is desired, a statement of the anomit thereof, together with the terms on which it is ereated must he set forth.)

Fifth. The existence of this eompany shall be perpetual.

Sirth. The names and residences of the officers and Directors who shall manage the aflairs of the comprang for the first year are as follows:

Name.

Residence.

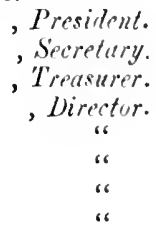

Seventh. The amount of real estate to be held by the company shall not exered acres of land at any one time.

Eighth. The following provisions for the regulation of the business and the conduct of the afficirs of the company are hercby established:

In Witncss Whereof, we have hercunto set our hands and scals this day of , 190 .

(1... s.)

State of

County of ,

$\mathrm{I}$, the State of , a Notary Publir in and for the

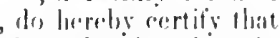
signed to the writing abuse besiring dite the

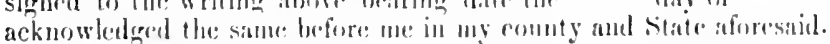

Given under my hiond this dity of , 190 . , Nolury Public.

\section{VIRGINIA.}

In the C'irruit Court of

$$
\text { r'ounty: }
$$

The forenging certificate for inerorercition of the to me, , Judige of the

Court of

was preaculal , in termil 
time (or vacation) and hatring becu examined by me I now eertify that the said certitiane lin incorporation is, in my opinion, signed and acknowledged in accordintec with an . Iet of the General Assembly of Virginia entitled "An Act Concerning Corporations."

Given under ny hand this day of, 190 .

\section{WASHINGTON.}

\section{ARTICLES OF INCORPORATION}

OF TIIE

\section{Conpany.}

This is to certify that we, eitizens of The in the Connty of
beme desirous of forming a corporation pursunt to and in conformity with the laws of the State of Washington, lo hereby make and subscribe and acknowledge in rriplieate the following articles of ineorporation:

Arfirle First. 'The eorporate name of this Company shall be: follows :

Article second. The object for which the said corporation is formed is as

Aiticle Third. The capital stock of this corporation shall be which shall be divided into stares of dollars each.

dollars,

Article Fourth. The time of existence of this Company shall be fifty years, commeneing from the date of these articles.

Article Fifth. The trustees of this corporation shall be (not less than two) in number, and the names and residences of those who are to manage the concerns of this Company for the first months (not less than two and not more than six montlis) are:

Article Sixth. The principal place of business of this corporation shall be at the City of in the County of and State of Washington. In Testimony Whereof, we have signed these articles
of , on the of, 190. articles in triplicate at said

(Signatures.)

State of Washington, $\}$ ss.
County of

Be It Remembered, Thit on this day of signed, a Notaly Public 14 and for the State of Washington, personally appeared both (or all) personally known to me and known by me to be the identieal persons named and deseribed in, and who exeented, made, and subseribed the foregring articles of incorporation, and they did severally, each for himself and not one for the other, acknowledge to me that they mitde and subscribed the foregring artieles of ineorporation freely and voluntarily and for the uses and purposes therem nentioncel.

In Witness Whereof, I have hereunto set my hand and affixed my official seal the day and year in this eertificate first above written.

$$
\begin{gathered}
\text { Notary Public in and for the State of Washington, } \\
\text { residing at in } \\
\text { Connty, Washington }
\end{gathered}
$$

State of Washington,
County of

being duly and severally sworn, on oath severally say, each for himself, and not one for the ofher, that he is one of the trustees whose name appears in the Artieles of Ineorporation of the Company; that he will support the Constitution of the United States of America, and the constitution and laws of 
the State of Washington, and that he will fatithully perform the dutics of trustee of said Company to the best of his ability.

Subscribed and sworu to beforc me this day of (Signatures.) Notary Public in and for the State of Wishiunton,
residing at in
County, Washington.

\section{WEST VIRGINIA.}

\section{CERTIFICATE OF INCORPORATION.}

I. We, the undersigned, agree to become a eorporation by the name of

II. The principal place of business of said corporation shall be located at No. , Strect, in the City (2) town, village of in the county of and State of - Its clief works will be locaterl in (3)

(Insert number and name of street if in a city having street numbers; if not, strike out. 2. Erase the word city, town, or villuge as the case may be. 3. Give locition of chine works of, at same place as prineipal place of business: say" "The (hief Works will be bocitret at the same place." If the chief works are not in West Virginia, it is unly neceesitry to stallo the name of the State or Territory in which they are located : if the chief work and principal place of business are both in West Vircinia, then it is necosary to state the maristerial District and County in which the chief works are hoated, thus, "in the loistrice of in the County of "in the Slate of West Virminia," or, if the nature of the case may require it, say "in the district of and County of, and elsewhere in the State of West Virginia." If there be no chief works, say, "Said Corporation will liave no cluief works.") fillows :

HI. 'The objects and purposes for which this corporation is formed are as

IV. The amount of the total aulhorized capital stock of said corporatim shall be value of of dollars, which shall be diridesl iuto sliares of the prat dollurs cach; of which authurized capital stock the allownt becen paid.

$V$. Thic names and post-rfftec addresses of all the incorporators, and the number of shares of stock subscribed lise by cach are ats fiollows:

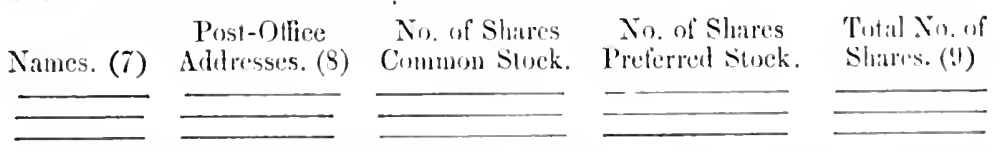

VI. This corperation is to expire (1)

VIl. (IIcre insert any sperial provisions desirel : and also mumber of arese of land desired to hold in West Virginat, if surh number be above ten thomand acres.)

Given moder our hands this day of $\quad, 190$. (ill the incorpuriton's intest sign here.)

State of

Conuty of

I, $\gamma$ ss.

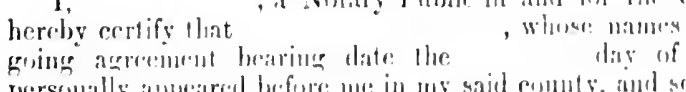
, a Nolary Public in and for llar Comnty and State afereanil,

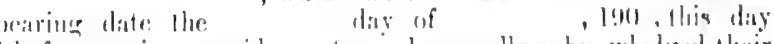

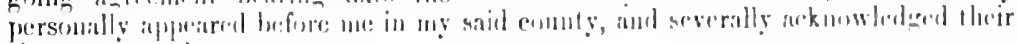
signilutres on the samme.

And I finthere certify that and , twe uf the imenrpura.

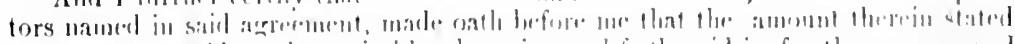

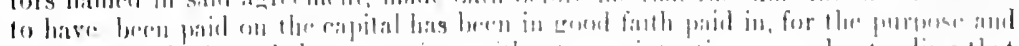

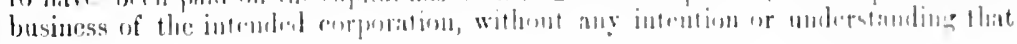


the same shall be withlrawn therefrom before the expiration or dissolution of this C'orpuration.
Given muler my hand and oflicial seal this
day of , 190
, Notary Public.

(The followinir atticlavit must be made by at least two of the incorporators named in the anerenem! wherein it is stated that the "principal place of business" is located in West Virsinia, and for which it is proposed to pay the rate of annual license tax prescribed for resitent corporations.)

Stite of

County of

\} ss.

I,

a Notary Public in and for the County and State aforesaid, do heroby certify that and , two of the persons who have executed the foregoing agrecment, bearing date of the day of 190 , this dis personally appeared before me in my said comnty, and made oath that the statement in said agreement, to wit, "that the principal place of husiness of said corporation shall be loeated at "in the Comnty of and State of West Virginia" is true, and that said principal place of business and ehicf works liave been loeated as therein stated in good faith, and not for the purpose of evading any law of the State of West Virginia, and especially not for the purpose of avoiding the payment of the difference betwecn the amount of the ammal license tax on the charters of corporations laving their principal place of business within the State of West Virginia, and those corporations laving their prneipal place of business or chicf works withont said State; and that said eorporation named in said agreement proposes in good faith to carry on its business and to have its principal place of business and its chief works (if it have such) within the State of West Virginia.

Given under my hand and official seal this

day of

, 190 .

(SEAL.)

\section{WISCONSIN.}

Know ald Men by these Presents: That the undersigned, adult residents of the State of Wisconsin, do hereby make, sign, and agree to the following

\section{ARTICLES OF ORGANIZATION.}

Article I. The undersigned have associated, and do hereby associate themselves together for the purpose of forming a corporation under Chapter 86 of the Wisconsin Statutes of 1899, and the aets amendatory thercof and supplementary thereto, the business and purposes of which corporation shall be business is to be carricd on within the State of , which said the Cominty of in said State.

Article II. The name of said corporation shall be , and espccially within shall be in the

Article III. The capital stock of said corporation shall be , and its location same shall consist of face or par value of , and the shires, each of which said shares shall be of the dollars.

Article $I V$. The general officers of said corporation shall be a President, VicePrcsident, Sccretary, and Treasurer, consist of stockholders. (Provision may be here made for dividing the directors into threc classes if desircd.)

Article $V$. Thic principal duties of the President shall be to preside at all meetings of the Board of Directors, and to have a general supervision of the affairs of the corporation.

The principal duties of the Vice-President shall be to discharge the duties of the President in the event of the absence or disability, for any canse whatever, of the latter.

The principal duties of the Sccretary shall be to countersign all deeds, leases, 506 
and converances executed by the corporation, affix the seal of the corporation thereto, and to such other papers as shall be required or directed to be sealed, and to keep a record of the proceedings of the Boind of Dircetors, and to siblely and systematically keep all books, papers, reords, and doements belonging to the corporation, or in any wise pertaining (1) the business thereof.

'The principal duties of the Treasurer shall be to keep and aecomt for all moness, credits, and property, of any and every mature, of the erporition, which shatl come in his hands, and keep an acenrate aceount of all moners receired and disbursed, and proper vouchers for moneys disbursed, and to render such aceounts, statements, and inventories of moners irecived and disbursed, and of money and property on haud, and generally of all mitters pertaining to this oflice, as shall be required by the Board of Directors.

The Board of Directors may provide for the appointment of such altitional officers as they may deem for the best interests of the eorjoration.

Whenever the Board of Direetors may so order, the ollices of Seeretars and Treasurer mag be liekl by the sime person.

The said officers shall perform such additional or different duties as shall from time to time be imposed or required by the Buard of Directors, or as may be prescribed from time to time by the By-Laws.

Asticle VI. Only persons holding stock according to the regulations of the corporation shiall be members of it.

Article VII. These articles may be amended by resolution setting forth sueh amendment or amendments, adopted at any meeting of the stucholders by a vote of at least two-thirds of all the stuck of said corporition then ontstanding.

Article VIII. The existence of this eorporation shall be years (or perpetual).

Article IX. (Any other provisions for the regulation of the internal affairs of the corporation not incoissistent with law mity be inserted.)

In Witness Whereof, we have hereunto set our hamis, this ,A. D. 190 .

Signed in presence of

State of Wisconsin,
County of ss.

Personally came before me this

day of day of above named , to me known to be the persons whin cisecutal the foregoing instrument, and ackuowledged the same.

, Notary Public, Wisconsin.

State of Wisconsin,
County of ss. and

, heing each duly sworn, doth each for limself de. pose and say that he is one of the original signers of the abewe derelaration and art-

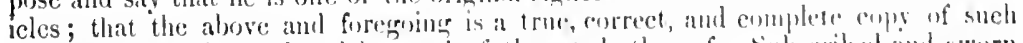
original declaration and articles, and of the whole therenf. Sulberibed ind sworn to before ine, this day of , A. I). IJj)

, Notary I'ullic.

WYOMING.

\section{CERTIFICATE OF INCORPORATION}

oY TII :

C')

Krow alt Mesi br Tuear. Prespests: That we, the underaigned, eitizens of

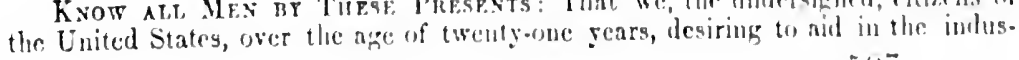


trial (or prolunive) interests of the country, do by these presents voluntarily asso-

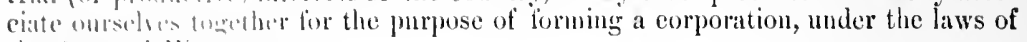
the statle of 11 inumur.

And we trobos cortity :

f'irst. That the corporate name of our said corporation is and shall be the Company.

Sreonl. That the blbject for which our said corporation or Company is formed is (here state objeet, eontining same to one geneal line or department).

Thior. 'The capital stock of our said Company shall be dollars, to be divided into shares of the par value of dollars each and nonassessable. (If preferred stock is to be issuch, provision therefor must be inserted at this point.)

Fourth. The term of existence of our said Company shall be (not exceding fifty rears), from and alter the date of this certificate.

flifth. 'The atlitirs and mimagement of our said Company shall be under the control of trustees (not less thin three, nor more than uine), and are hereby seleeted and appointed to act as such trustees, and to manage the affinits and concerns of our said Company for the first year of its existence, and until their suceessors are eleeted and qualitied according to law and the by-laws of our said Company.

Sixth. The nume of the town in whieh the operations of our said Company shall be carried on is the City of, Comty of, and State of - (If the Company is formed for the purpose of earrying on any part of its business in any place outside of the State, add: "and the said business is also formed for the purpose of carrying on part of its business ontside of the State of Wroming, to wit, in the City of , County of, and State of and elsewhere in the United States as the trustees of our said Company may by resolution or otherwise direct"), but the name of the town and eounty in which the prineipal part of the business within the State of Wyoming is to be transacted is the City of , in the said Comty of, at which place its principal otlice and place of business shatl be loeated.

Seventh. All suits against our said Company shall be commeneed in the said County of

In Witness Whereff, we have executed this ecrtifieate in duplicate this day of , A. I). 19 .

If the adoption of br-laws is to be delegated to the trustees, the following clause should be inserted: The trustees of our said Company shall have the exelusire power to make such prudential by-laws as they may deem proper for the management and disposition of the stoek and business aifairs of our said Company, not inconsistent with the laws of the State, preseriting the duties of officers, artifieers and servants that may be employed, for the appointment of all officers, and for carrying on all kinds of business within the objects and purposes of our said Company.

Witnesses:

State of Wyoming,
County of ss.

I, hereby certify that , a Notary Public in and for the said County and State, do , who are personally known to me to be the same persolis whose names are subscribed to the foregoing instrument, appeared before me this das in person, and each separately acknowledged that he signed, scaled, and delivered the said instrument as his free and voluntary act, for the uses and purposes therein set forth.

II eommission expires

Given under my hand and notarial seal this

day of

A. D. 190 , Notary Public. 


\section{GENERAL OBJECT CLAUSES.}

\section{GENERAL TRADING CLAUSE.}

To manufacture, export, import, bus, sell, and generally deal in goods, wares, merchandise, and property of every class and description.

\section{GENERAL PURCHASING CLAUSE.}

To purchase, lease, or otherwise acquire all kinds of personal property which the corporation may deem necessary or conrenient for the purposes of its business.

\section{REAL ESTATE CLAUSE.}

To purchase, lease, or otherwise aequire real estate, improved or unimproved, without limit as to amount, in any State or Territory of the United States or foreigu country.

\section{PATENT AND TRADE MARK CLAUSE.}

To apply for, acquire, buy, sell, assign, lease, pledge, mortgage, or otherwise dispose of letters patent of the United States or of any foreign enuntry, and all or any rights, territorial or otherwise, thereunder. 'Tu apply for, aequire, huld, sell, assign, lease, mortgage, or otherwise dispuse of patent rights, lieenses, pribuges, inveu. tions, trade nurks, trade names, and pending applieations therefor, relating to or useful in connection with any business of the corpolation. 'T'o use, namufacture, or grant licenses under any lettrers patent owned or controlled by the company, and to expend mones in experimenting upon and testing the validity or value of any patent rights the company may acquire or proposes to aequire.

\section{ACQUIRING AN ESTABLISHED BUSINESS.}

To acquire by purchase or ofherwise property, real or personil, and the good will, riglits, and assets of all kinds under sueh terms and eonditions ats may he deemed adrisable, of any person, firm, or eorporation, and to pay for the same in cash, stock, - common or preferred, - bonds, or other securities of the corporation.

\section{HOLDING STOCK IN OTHER CORPORATIONS.}

To subseribe for, purehase, or otherwise anequire, and held with the same riglits of ownership therein as may he premitted to mallural persons, the shares, lomids, and obligations of any corpolation organized mole the laws of any Statu, Territory, district, or esolony of the Cuntel States or of any forrigh eomentry:

\section{CONDUCTING BUSINESS IN OTHER STATES.}

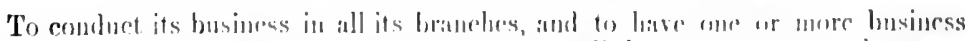

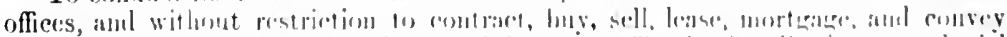

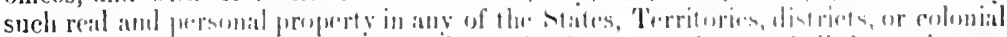

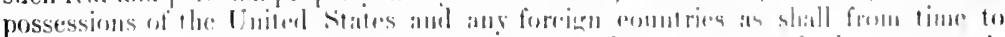

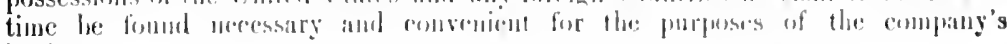
business.

\section{ACQUISITION OF COMPANY'S OWN S'TOCK.}

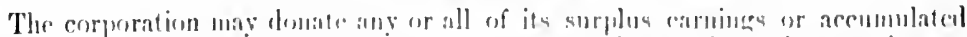

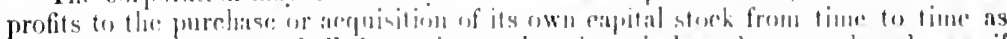
its board of directors shall dopermine, and such capital sterk so purehemel may, if 
the directors so determine, he deposited in the treasury of the company as treasury steck, to be thereatiter disposed of as such treasury stock for the purpose of procuring working eapital for the company.

\section{BOND CLAUSE.}

Th issue bonds to any anount authorized by law for the purpose of sceuring funds for eorporate purpoises, and to secure the payment of the same by mortgage or deced of trust upon the whole or any part of the real and persoual property of the company at any time held by it.

\section{AUTHORIZING THE ISSUANCE OF PROMOTION STOCK.}

To remmerate any person, firm, or eorporation for services rendered or to be renkered in sclling, pledging, or guarantecing the disposal of any of the shares of the caprital stoek of the company, or of any bonds or other securities of the company that may from time to time be issucel.

\section{POWER TO DISPOSE OF ALL CORPORATE PROPERTY.}

The board of directors shall lave the power and anthority to sell, assign, mortgage, convey, or otherwise dispose of all the property and assets of the corporation on such terins and conditions as they shall prescribe whether for cash or property or stock and bonds in other corporations.

\section{CLAUSES REGULATING BUSINESS.}

\section{CLASSIFICATION OF DIRECTORS.}

The directors shall be divided as equally as possible into classes, to be known as directors of the first, second, third elasses, etc. The terms of office of director of the first cliss shall expire on the first Nonday of , 190 , and the second class on the first Monday of , 190 , etc.

\section{FORM FOR CLASSIFICATION OF DIRECTORS.}

The members of the boarl of dircetors shall be classificd with respect to their length of term of office, by dividing them into classes, cach consisting of of the whole number of the board of directors.

Tine directors of the first elass shill be elected for a term of one year, and the directors of the second elass for a term of two years, and the directors of the third class for a term of threc years, etc.

At cach ammual election the successors of the class of directors whose terms shall expire in that year, shill be elected to hold office for a term of years, so that the term of office of one class shall expire each ycar.

\section{POWER TO ADOPT AND ALTER BY-LAWS.}

The hoard of directors shall have power without any action on the part of the stockholders to make, alter, amend, or repeal by-laws for the corporation.

\section{AUTHORITY TO ISSUE BONDS.}

The directors and officers of the company are authorized to make and issne mortgatge bonds at such times and in such amounts as to them shall be decmed advisalile.

\section{EXECUTIVE COMMITTEE.}

The board of directors may, by means of a resolution adopted by a majority of the whole board at a meeting duly called for that purpose, designate

directors 
to constitute an executive committce, which committee shall hare and exercisc all the powers and rights of the full board of directors in the management of the business and aflairs of the corporation.

\section{REMOVAL OF OFFICERS AND DIRECTORS.}

Any officer or director, whether elected by the stoekholders, or named in the certificate of incorporation, or eleeted or appointed by the board of directors, may be removed at any time, by affimative vote of a majority of the stocklolders of the corporation.

\section{LIEN ON STOCK FOR INDEBTEDNESS OF THE COMPANY.}

The corporation shall at all times have a first lien on all the shatres of its stocktolders and on dividends declinred thereon for any and all indebtedness of such stockholders of the corporation.

\section{EXAMINATION OF BOOKS BY STOCKHOLDERS.}

Except where otherwise provided by law, the board of direetors shall have the power to detcrmine under what conditions and regulations, and at what times and places, the accounts and books of the corporation shill be opened to the inspection of stockholders.

\section{CUMULATIVE VOTING.}

The by-laws shall provide that at all elections of directors each stockholder shall be entitled to cast as many rotes as shall equal the number of shares of stock held by him, multiplied by the number of direetors to be elected, and they shall further provide that sueh stockholder shall have the right if he so desires to cast all of such votes for a single director or clistribute them anong the number to be voted for or any two of them as he maty see fit.

\section{HOLDING STOCKHOLDERS' MEFTINGS WITHOUT THE DOMICILIARY STATE.}

To maintain an offiee withont the Siate of (here name the domieilialy Statc), at the city of , State of , and any meetings of ineorpuraturs, dirreturs, or stoeklestders of this company may be held at rither of said utliees ar flatees of business, and the books of this eorporation may be kept at rither of said others or places of business, and any ineorporator or stockluslder entifled to be present and to vote at any or manization or strokholder's' meetings may be represented and rote at such mecting by proxy in writing.

\section{PREFERRED STOCK CLAUSES.}

\section{PREFERRED STOCK CLAUSES (Short Form).}

The capital stork of the ermprouy slatl eomsist of

slitres of eommon

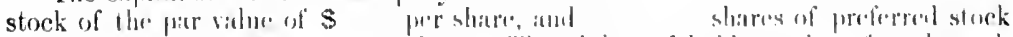

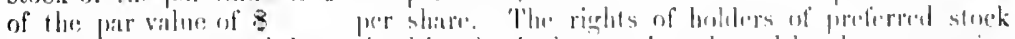

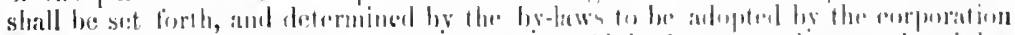

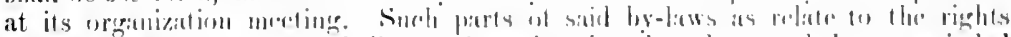

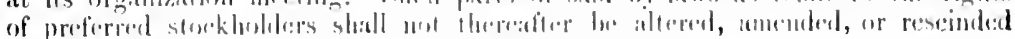

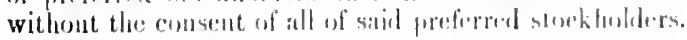

PREFERRED STOCK CIAUSFS (Long Form).

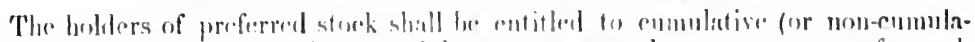

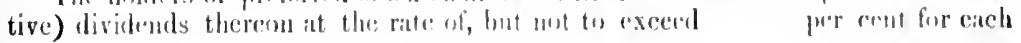


and every fiseal year of the company payable out of any and all surplus or net profits amminlly (scmi-ammally or quirterly), and when declared by the hoard of directurs. In the event of ilissolution or" liquidation of the corporation the holders of the prefermel stock shall be entitled to receive the par value of their preferred shares ont of the assets of the corporation belore anything shall be paid thereon to the hulders of the common stuek. 'The liolders of preferred stoek shall (not) he ('ntitled to (any) all voting powers in the corporation. 'The preferred stock shall be subject to redemption at the option of the corporation at any time alter the dily of $\quad 190$, at the price of $\$$ for cach share, and the amount of dividends cummlated and mupaid thereon at the date of redemption.

'The holders of preferred stock sliall have the right at any time to convert the same into common stock of the corporation by presenting the same to the treasurer of the corporation for cancellation, and shall then be entitled to receive forthwith an amount of common stuck equal to the par value of the preferred stock so tendered for purvoses of conversion into common stock.

\section{PREFERRED STOCK CLAUSE (Long Form).}

From time to time the preferred stock and the common stock may be increased according to law, and may be issued in such amounts and proportions as stall be determined by the Board of Directors, and as may be permitted by law.

'The holders of the preferred stock shall be cutitled to receive when and as declared, from the surplus or net profits of the corporation, yearly dividends at the rate of per centum per anum, and no more, payable quarterly on dates to be fixed by the By-Laws. The dividends on the preferred stock sliall be cumulative, and shall be payable before any dividends on the commou stock shall be paid or set apart; so that, if in auy year dividends amounting to per centum shall not have been paid thereon, the deficiency shall be payable before any dividends shall be paid upon or set apart for the commou stock.

Whenever all cmmulative dividends upon the preferred stock for all previous years shall have been declared and shall have beeome payable, and the accrued quarterly instalments for the current year shall lave been declared, and the Conspany shall have paid such cumulative dividends for previous years and such accrued quarterly instalments, or shall have set aside from its surplus or net profits a sum sufficicnt for the payment thereof, the Board of Directors may declare dividends on the common stock, payable then or therealter, out of any remaining surplus or net profits.

In the event of any liquidation, or dissolution, or winding up (whether voluntary or involuntary) of the corporation, the loolders of the preferred stock shall be entitled to be paid in full, both the par amount of their shares and the unpaid dividends acerued thereon, before any amount shall be paid to the holders of the commou stock: and after the payment to the holders of the prelerred stock of its par value, and the unpaid accrued ilividends thereon, the remaining assets and funds shall be divided and paid to the holders of the common stock pro rata according to their respective shares.

\section{COMPOSITE FORM OF MINUTES}

For New York, New Jersey, South Dakota, Arizona, Nevada, West Virginia, Delaware, Distriet of Columbia, and other States.

(In District of Columbia in all cases use "Trustee" for "Director," and "District" for "State.")

\section{Minutes of Incorporatons' Meeting.} Company.

1. The first mecting of the corporation was held on the 190 , at o'elock in the noon, at the (principal or business) office of the company, in the City of , State of , pursuant to a written waiver of notice, signed by all the iucorporators fixing said time and place. 
2. The following incorporators were present in person :

The following incorporators were represented by proxy:

3. On motion duly made and seconted, Mr. was clected Chairman, and Mr. was apprinted secetary of the meeting.

4. The Chairman reported that the errtifieate of incorporation of the eompany had been filed in the offiee of the Secretary of state of on the

day of $\quad 190$. The Seeretary presented a eopy of said certiticate of ineorporation, and on motion duly made and sceonded, a copy thereof was orderent spread upon the minutes:

(Insert eopy of certificate of ineorporation.)

(In the following States Section $t$ is onited and seetions referred to inserted in its place: Delawire, A; Arizona, A; New Jersey, A.)

5. The Secretary presented and read the wairer of notiee of the meeting, which was ordered spread upon the mimutis:

\section{(insert waiver of untice.)}

6. The proxy (or proxies) above mentioned was (or were) presented and ordered filed.

(Form of proxy same in all States. See Appendix.)

7. Messrs. and were apprinted inspeeturs of clection, and the oath was duly administered to them.

(All States except New York, South Dakota, and District of Columbia. In the two latter provision as to inspectors omitted.)

8. The Secretary presented a firm of hy-latws for the regulation of the athairs of the company, which were read article by irtiele and unamimonsly adopted, and a copy thereof ordered spread upon the minutes:

(Insert hy-litw..)

9. The Secretary presented the following transfers of subscription, to titke effect when accepted by the compiny.

\section{Transferror. Transferee. No. of Shares.}

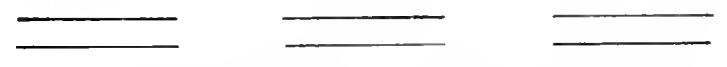

(Form of transfer same for all States. Ser Apuremlix.)

(Not necessary in States where ineorponators ned mol be sulseribers to stock: for exampld, Sonth Dakota, Arizona, and Distriet of Columbit.)

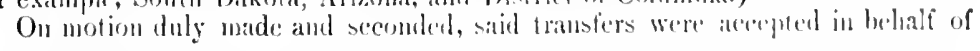
the complany.

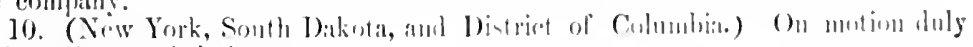
made and seconderl, it was

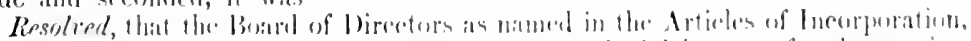

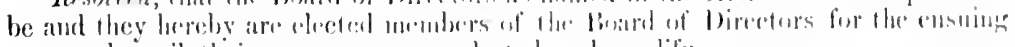

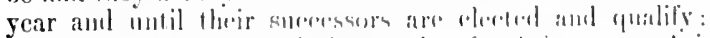

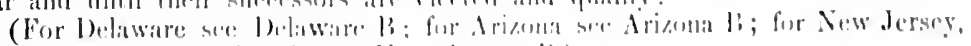

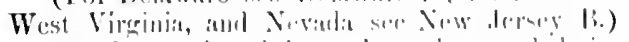

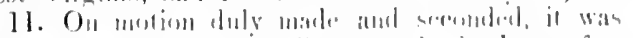

Resolverl, that in cimpliatere wath llar latws of

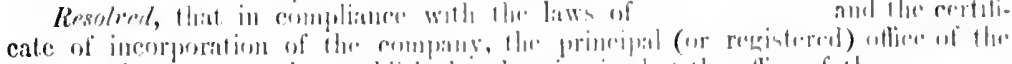

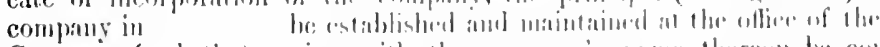

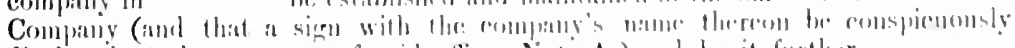

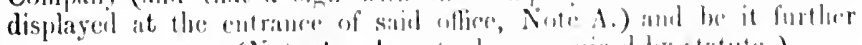

(Ciste A. Insert where mernired ly st:atute.)

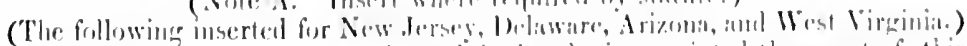

Resolved, that be and be hereby is appointed the agent of this 
compan! in charere of salil oflice aud upon whom process against this company misy he served: and be it further

hesolect. thit the President and secretary be and they hereby are authorizod to sign and seal with the company's seal i certificate of anthorization to said Inomproting Company in the form presented at this mecting.

12. C pun motion iluly made and seconded, ind by the affrmative vote of all present, it wils

heselent, that the Board of Directors he and they hereby are authorized and directel on isiste shates of the capital stock of this compiny to the full amount inthurized by the certifieate of ineorporation, in such amounts from time to time as maty be determined by the Board and as may be permitted by law, and in their diseretion to aceept iil full or part payment of any slare or shares such property as the forat may deternine sliall be neessary for the business of the company.

13. (The following clause is inserted where stock is made full paid by issunnce of stock fir. property or patent rights. 'This form is applicable to all States.)

Upon motion duly made and seconded, and by the aftirmative vote of all pres. cnt, the following preambles and resolution were unanimously adopted:

Wherees, has oflered to assign to this company the following described property (if property, give deseription suffieient to identify the same; if patent rights, crive number of patent, late of issue and name and description of artiele patented), all in eonsideration of the issuance of stock of this company to the amount of dollars; and

Whereus, it appears to the stockholelers that such property (patent rights, ctc.) is necessily for the business of the eompany, and that the same is of the value of dollars; Now, therefore, be it

Resolect, that the Board of Direetors be and they hercby are authorized in their liseretion, to purehase the property (patent rights, etc.), above mentioned, for the said price and to issue said stock in payment thereof.

14. Upon motion duly made and seconded, and by the affirmative vote of all present. the following preambles and resolution were adopted:

Whereas, it lias been agreed between each of the incorporators and

(name of trinsferror), that the stock to be issued in payment of the property authorized to he purchised by the resolution set forth above shall include the stock subscribed by the incorporators: Now, therefore, be it

Resolverl, that the Board of Directors be and they hereby are anthorized and dirccted to atcept said property (patent rights, etc. ) as full payment of the subscription for stock of the incorporators, and to issuc fill-paid stock to the incorporators or their assigns to the amount of their respective subscriptions.

(This section is omitted where the incorporators are not subscribers to the stuek.)

No furtlier business was presented, and on motion the meeting adjonrned.

, Secretary.

Approved:

, Chairman.

(Delaware A.) The Chairman reported that the certificate of incorporation of the eomprus was filed on the day of 190 , at c'elock in the noon in the office of the Secretary of State, and a certified cons tlere of recorded in the office of the Recorder of Deeds for the County of $\mathrm{New}$ Cantle, on the diy of 190 , in Certificate of Incorporation Reeords, vol. page ,etc., and presented a copy of said certificate of incoproration, which was, on motion duly made and scconded, ordered spread 口ирен the mimutes:

(Delaware B.) On motion duly made and seconded, it was

lipsoled, that the ineorjorators proceed to the election of Directors. The polls were therenpon opened, and remained open mitil all the incorporators had voted. The polls thereupon being closed, the vute wis canvassed, and the Chairman re. 
ported that the following named persons were unanimously elected Directors persons, to wit: rotes representing

Name. shares having been cast for each of said

Number of Votes.

The Secretary reported that all the newly clected Directors were subseribers to at least three shares of stoek of the eompany and therefore eligible to nomination and election as Directors.

(Arizona A.) The Chairman reported that the eertifeate of ineorumration of the compans was filed in the offee of the County Reeorder of Mitricopa County, Territory of Arizona, on the disy of 190 , and a certified cops the reof filed in the office of the 'Territorial Auditor on the dily of 190 , and presented a eops of said ecrtificate of ineorporation. On motion duly made and seeonded, a cops thereof was ordered spread upon the minutes:

(Arizoni B.) ilessrs.

were nominated for diretors of the company to hold oflice for the ensuing year. No other nominations having been had, the polls were duly opened, and ballot having been duly hatd, and all the stoekholders haring roted, the polls were deelared elosed, and the Chairman announced that the foregoing gentlemen had been duly eleeted Directors of the company.

(New Jersey A.) The Chairman reported that the certiticate of ineorporition of the company was recorded in the office of the Clerk of the day of 190 , and was tiled on the daf of ", 190 , in the office of the Secretary of Statr, and presented a copy of said certificate of incorporation, whieh was, on motion dnly made and seconded, ordered filed, and a copy thereof ordered spread mpon the minutes:

(New Jersey B.) Messrs. were nominated for Dircetors of the companr, to hold offiee for the ensuing year. No other nominations having been made, the polls were duly opened, and ballot having heen duly hat, and all the stockholders having voted, the polls were deelared elosed, and the inspeetors presented their certificate showing that the aforesaid gentlemen had been duly elected Directors of the company.

\section{A P P E N D I X.}

\section{Waiver of Notice of Meetisg of Ixcorporators.}

We, the undersioned, incorporators of the

Company, a corporation under the laws of the State of , herebs waive untice of the time, place, and purpose of the tirst meeting of the corporation, and fix the day of 190), at o'elock in the nom, as the time, and the villiee of the company in the Citr of

as the place of stith merting.

And we do hereby waive all refunirements of the statute's of an to notice of this mecting and publieation theronf and consent to the transaction of sueh business as may enme befire said metings.

Ditted 190.

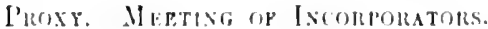

The undersigurel (Xiote. I-il subseriber to shares of stork of the

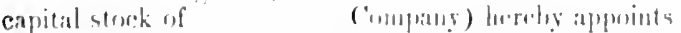

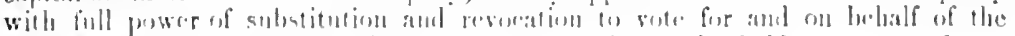

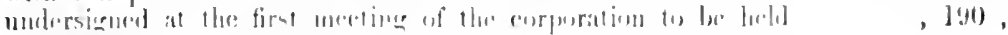
and at ing idjourmment therersit.

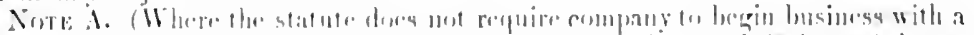

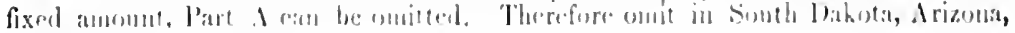
and Dintrict of Columblia)
Hiturss my hand and seal this
day of , 190. 


\section{Trissfliz of Subscription.}

The undersigned, for good and valuable eonsiderations received, has sold, assigned. translerred, and set over, and by these presents does sell, assign, transfer, and set over unto the righi, title, and interest of the undersigned as a subseriber to and an ineorporator of the Company, to the extent of

slates of the capital stoek thereof, and hereby requests and direets the said company to issue the certifieate for said share to the aforesaid transleree or his nominec or issigus.

'This transfor to take effect upon the aceptance thereof by the company, the undersigned meanwhile retaining the right to vote npon said shares.

In Witness Whereof, I have hereunto set my hand and seal this of

Witness: , 190 .

\section{Inspectors' Oatil and Certificate.}

\section{State of}

Comity of \} ss.

and

being severally sworn, upon their respective oaths do promise and swear that they will faithfully, honestly, and impartially perform the duties of inspectors of eleetion, to be lield this day for Directors of the Comprany, and a true report made of the same.

Subseribed and sworn to before me this

$$
\begin{array}{ll}
\text { day of } & , 190 . \\
& \text { Notary Public. }
\end{array}
$$

\section{Notary Public.}

The undersigned, inspectors of eleetion, report that having taken an oath im. partially to eonduct the election of direetors of the above-named company, we did receire the votes of the stockholders by ballot, and that the following persons received the number of votes set opposite their respective names, to wit:

\section{For Directors.}

Dated

Numiber of Votes.

\section{MINUTES OF THE FIRST MEETING OF DIRECTORS.}

1. The first meeting of the board of direetors of the office of the company in the City of
day of

, Inspectors. day of 190 , at
2. Present: Nessrs.

Company was held at , on the 2. Present
directors.

3. Mr. was chosen temporary chairman, and Mr. constituting a majority of the board appointed temporary secretary of the meeting.

4. The secretary presented and read a waiver of notice of the meeting, signed by all the directors, and same was ordered spread upon the minutes:

(For form of waiver, see Appendix. Same in all States.)

5. (Insert following elause for New York only:)
Messrs.
and
were appointed inspectors of election for the ensuing rear.

6. The minntes of the first meeting of ineorporators were read.

7. The following gentlemen were unamimously elected officers of the company to serve for one year and until their successors are elected and qualify :

President,

Vicc-President,

Second Vice-President,

Third Vice-President,

Secretary,

Treasurer,

$\left.\begin{array}{l}\text { General Manager, } \\ \text { Counsel, }\end{array}\right\}$ (if desired).

516 
8. (Insert for New Jerser, Nerada, and Delaware.)

It was ordered that the secretary take the oath of utice and subscribe the writ. ten oath in the form presented at this mecting. The seeretary thercupon took and subscribed the oath, and entered upon the discharge of his dities.

\section{(For form of oath, see Appendix.)}

9. It mas ordered that the troasurer crise a bond in the sum of dollars in the form presented at this meeting, to be approved by the board, and subunited to them for their approval as to the sulieiency of the surety. 'The treasurer thereupon presented his bond, signed by himself as principal and as surety, and same was approved and ordered filed.

(By-laws generally make the giviner of a bomd at discretion of boand.)

10. (Where director resigns, use the fullowing forn for aceeptance of resignation and election of his suecessor:)

The secretary presented the resirnation of

as director of the company, and on motion duly made and seconded, sane was acepted and ordered filded.

Mr. was thereupon duly elected a direetor of the eomprany to till the racancy caused by the resignation of iir.

(For form of resignation, see Appendix. Same in all States.)

11. Upon motion duly made and seeonded, it was

Resolved, that the scal presented at this meeting, an inpression of which is (Seal) directed to be made in the marrin of the minute-bouk, be and the sane herebs is adopted as the sail of the corporations.

12. Upon motion duly made and seconded, it was

Resolved, that the president and be and they herehy are anthorized to issue eertifieates of stock in the form submitted to this meeting:

(President and secretary must sipn in Sumth Dakna; in Now York, Arizona, Nevada, West Virginia. and l istriet of Colnmbia, presilent and secretary or treasurer; in Delatware and New dersery president and heasurer.)

13. Upron motion duly made and secomded, it wits

Resolved, that the treasurer be :und he hereby is anthorized to open a hank account in behali of this company whth the bank of and be it further

Resoleed, that until otherwise ordered, sitid batuk be and it herely is autherized

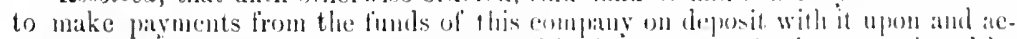

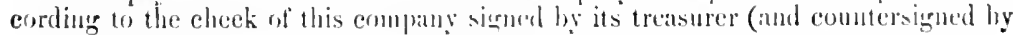
the president if so provided in the by-litws).
14. Messirs.
were alpprinted members of the exeentive committee, with all the powers given in the luglatss of this eompany.

15. Upon motion duly madre and secomeled, it was

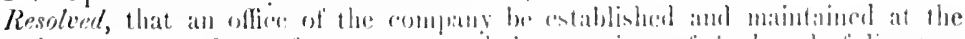

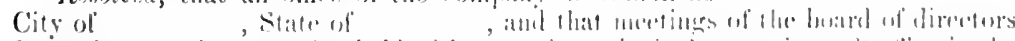

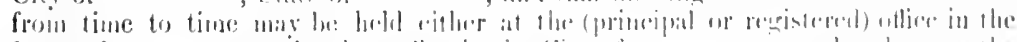

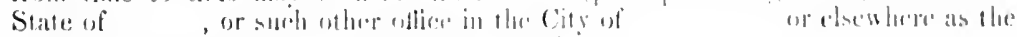

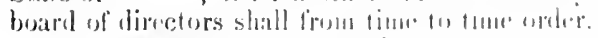

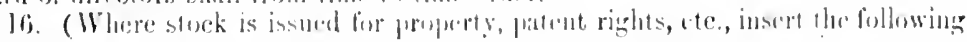
clanse:)

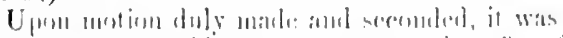

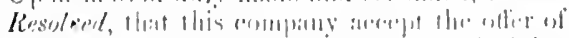

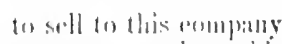

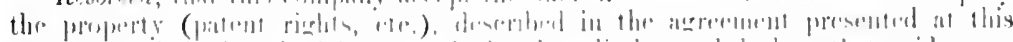

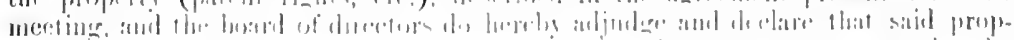

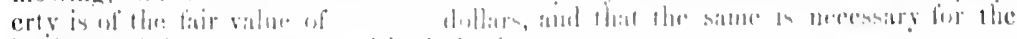

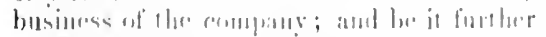

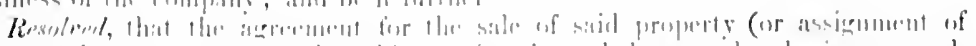

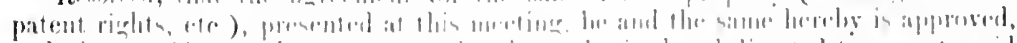

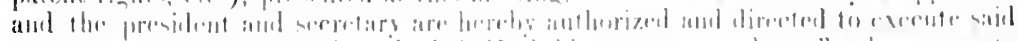

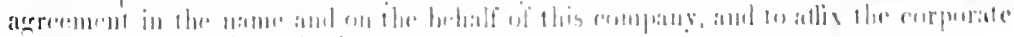
seal thents: imel he it further

Resolent, that the prentilint and

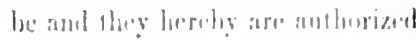


and directed to issue certificates of full-paid capilal stock of this company to the aggrerente amount of dollars, as provided in said agreement.

1\%. L pon motion duly made and seconded, it was

hervled, that payment of the subscriptions for stock of the incorporators be decmed to be minde by the property anreed to be sold to the eompany as set forth in the preeching resolition, it having been arrecd between eorperittors thit the stoek to be issued to sait

and the insaid ilereenent should include the stock subseribed by the incorporators.

'The secretary presented the resignation of as director of the eompany to tilke elliet

MI:

of $\mathrm{Ml}$.

elected a director.

was nominated to fill the vacancy eaused by the resignation

(This clause inserted where temporaly or dummy dircetors resign at the first mecting.

No further busiucss was prescuted, and on motion the meeting adjourned.

Approved :

, Secretary.

, Chairman.

\section{APPENDIX.}

\section{Talyer of Notice. First Mleeting of Board of Directors.}

We, the undersigned, Directors of the

Company, a corporation under the liaws of , hereby waive notice of the time and place of the first mcetinc of the Board of Directors, and of the business to be transacted at said meeting. We desirnate the day of , 190, at o'clock in the noon as the time, and the office of the company in the City of as the place of stid meeting. The purpose of said meeting being the election of officers, the authorization of the issue of stock of the company, the authorization of the purchase of property necessary for the business of the company, and the transaction of such other business as the Board may deem proper.

Ditted

\section{Secretary's Oath.}

State of

County of

$$
\} \text { ss. }
$$

, Secretary of the

Companf, being by me duly sworn, upon his oath docs promise and swear that he will faithfully diselarge the duties of secretary of the aforestid company to the best of his skill and ability.

Subscribed and sworn to before me this Notary Public.

, Secretary

\section{Directors' Resignation.}

I hereby tender my resignation as Director of the

Company, to take effect when accepted by said eompany. 


\section{COMPOSITE FORM OF BY-LAWS}

\section{For New York, New Jersey, South Dakota, Delaware, Arizona, West Virginia, Nevada, District of Columbia, ete.}

(In the District of Columbia in all cases use " Trustee " fur " Director" and "District " for "'state.")

\section{Article I. Offices.}

Sec. 1. The registered (or principal) ottice shall be in the eity of State of The arent in eharge of said uliee, upon whom process arainst the company may be servel, is

of

See. 2. The empruy nay also have an othee in the eity of , Slite may appoint. , and alsu have otfices in sueh other plitees as the board of tirecturs

\section{Article II. Meetings of Stochilolders.}

Sec. 1. The annual meelings of the stnetholders of this eorporation shall be held at the registered (or prineipal or business) ollice of the eorpuration in the eity of , state of , on the day of in each sear at o'chek M. for tha election of direetors and sueh onler busi-

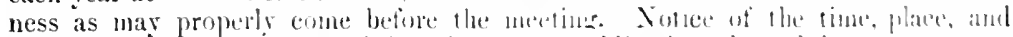

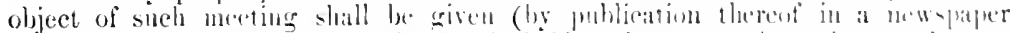

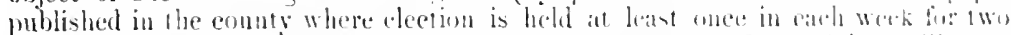

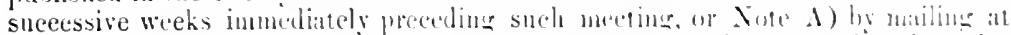

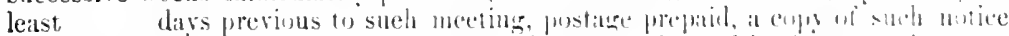

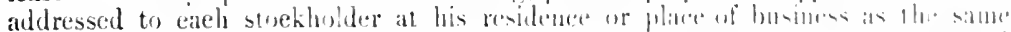

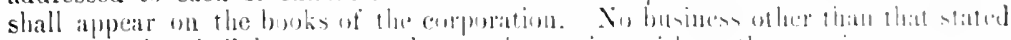

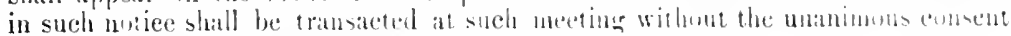
of all the storklolders preant thereal in person or by prosy.

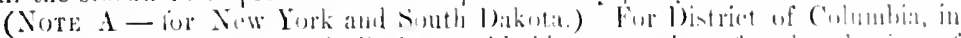

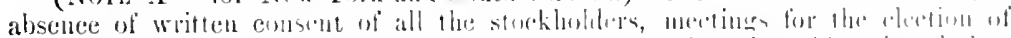

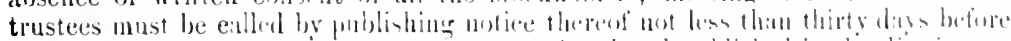

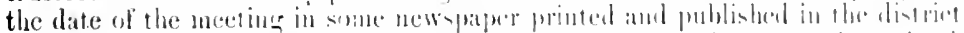

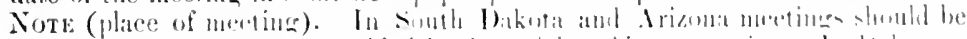

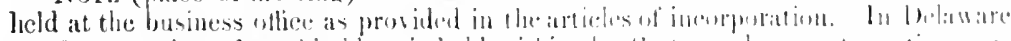

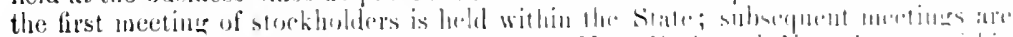

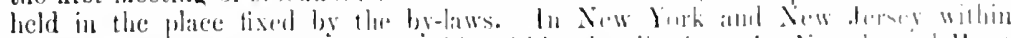

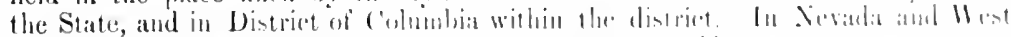

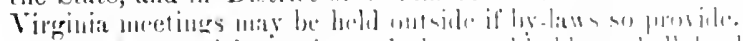

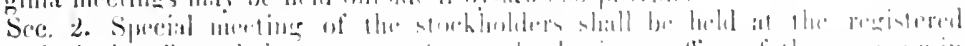

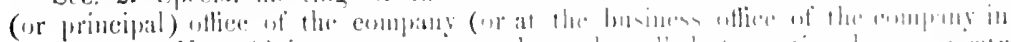
, Nite .1) in

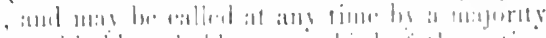

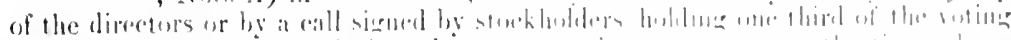

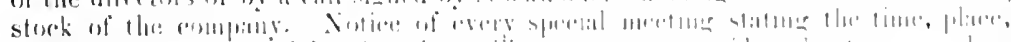

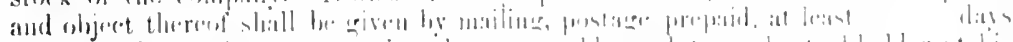

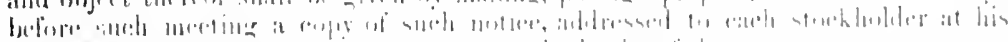

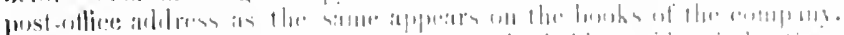

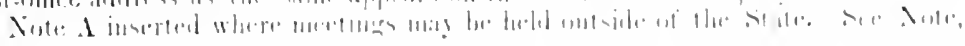
see. 1 .

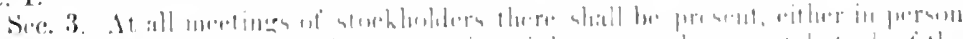

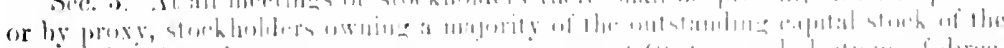

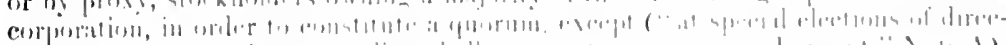

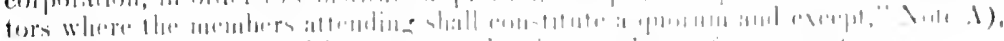

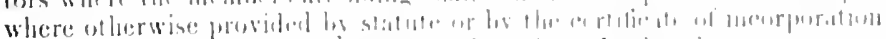

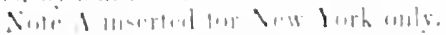

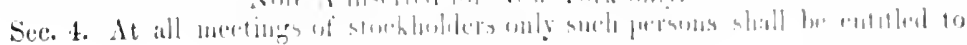


rote in person or by proxy who shall appear as stockholders on the transfer books of the corporition for (Xiste.1) days immediately precediug such meeting.

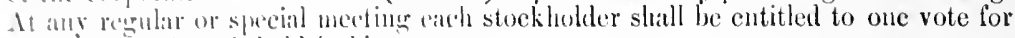

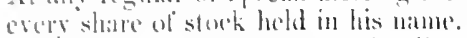

Where anmulative roting for dircetors laas been provided for, insert the following provision:

"la all dections for diretors ench stockholder may eumulate his shares, and grive one camblidate as many votes as the number of director's multiplied by the number of his shares of stoek shall erfual, or clistribute them on the same principle among. ats many eimdidates as he shall think tit."

Note A. ln Now lork trinsfors must be allowed up to within ten days of election. In Now dersey, Nevada, and Delatware up to within twenty days. In Ilest Vireninia no tethite time is tixed.

NoT: 1 . Cummlative rotine if desired shonld always be provided for in the certifieate of ineorporation. In West Virginia cumnlative voting for directors is required hy statute and must appear in by-laws. In Nevarda stockholders have right of voting cumnlatively unless artieles of ineorporation provide otherwise. Statutes of Distret of Columbia do not permit of eumulatire roting.

See. 5 (for New Jersey and Nevala). At each meeting of the stochholders a full, true, and complete list, in alphabetieal orler, of all the stockholders cutitled to vote at such meeting, with the number of shires hehl by each, certified by the secretary or the treasmrer, shall be fmmshed. At least ten days before each amual mecting, a like list, eontaning also the residences of the stockholders, shall be filed in the registered othee as required by statute.

See. 6 (all Stites cxcept New York). At all eleetions of directors the polls shall be opened and closed, the proxies shall be reeeived and taken in charge, all funstions touching the qualitication of voters and the validity of proxies, and the acecptance or rejeetion of votes shall be deeiderl and all ballots shall be received aut counted by two inspectors. Such inspectors shall be appointed by the presiding offieer of the ineeting, shall be sworn to faithfully perform their duties, and shall, in writing, certify to the returns. No candidate for election as director shall be apprimted or iet as inspeetor.

See. $\tau$ (for New York only). Two inspectors of election shall be elected at each annual nuecting of the stoekholders to eonduct the eleetion of directors for the ensuing year. Sueh inspeetors slatl be sworn to the faithful discharge of their duty, and in event of the absence, inilbility, or refusal of either to serve, the meeting may appoint an inspector in his place.

See. At the ammal meetings of stockholders the following shall be the order of business: 1. Calling of roill; 2. l'runf of uotice of meeting ; 3 . Report of presilent; 4. Report of treasurer; 5. Rejort of secretary; 6. Report of committees; 7. Appointment of inspeetor's of election of dircetors; 8 . Elcetion of directors; 9. Iliseellaneous business.

See. 9. At all meetings of stockholders all questions, except the question of an ampudment to the by-liaws and the eleetion of dircetors, and all sueh other questions the manner of deciding whieh is especially regulated by statnte, shall be determined by a majority vote of the stockholders present in person or by proxy ; provided, however, that any qualified roter may demand a stock vote, and in that case such strek rote shall immediately be taken, and cach stockholder present in person or by [m, sy, slatl be entitled to one vote for each share of stock owned by him as provided in section 4. All roting shall be rira coce, except that a stoek vote shall be by ballot, each of which shall state the name of the stockholder voting and the number of shares owned by him, and in addition if such ballot be cast by a proxy, it shall atso state the name of such proxy.

\section{Article III. Directors.}

Sce. 1. The dircetors of this corporation, of whom at least $(\Lambda)$ shall be a resident of , shall be eleeted by ballot, for the term of one year, at the aumual meeting of strokliolders, exeept as hereinater provided for filling vacancies. 


\section{FORMS AND PRECEDENTS.}

The directors shall be chosen by a plumity rote of the stocklohers, voting cither in person or by proxy at each annual election. The direeturs shall eacli hold at least (B) shares of stock.

Note A. In New rork, New Jersey, and Delawalre at least one direefor shall be a resident of the State; in Distriet of Columbia, a majority of trustees

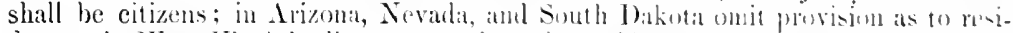

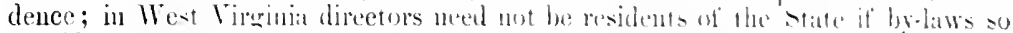
provide. In West Virginia number of alimetors must be set out in by-linws.

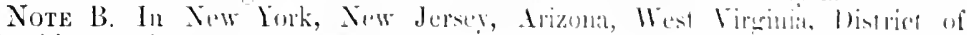

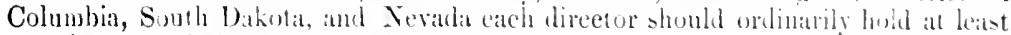
one share; in Delaware three shares.

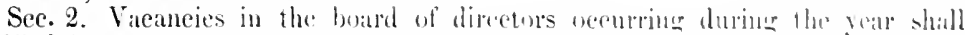
be filled for the unexpired term by at majority rote of the remainime direeturs at any special meeting called for that purpose or any regular meetine of the bourt.

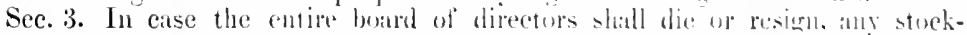
holder may call a speeial meeting of stockholders in the same matnuer that fles

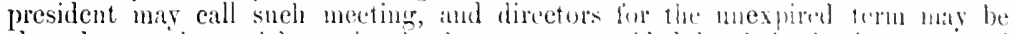
elected at such speeial meetiug in the manner provided for their election at anmal meetiugs.

Sce. 4. The board of directors maty alopt sueh rules and renulations for the conduet of their meetings and manarenemt of the allairs of the corporation as they deem proper, not ineonsistent with the litws of the state of by-laws.

Sec. 5. The board of directors slath meet on the day of erery month or these

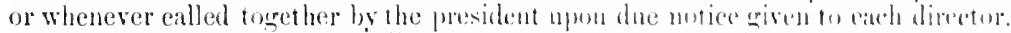

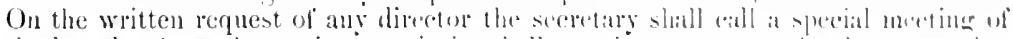

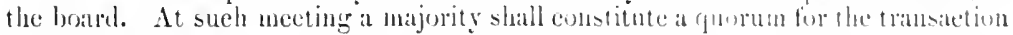
of business.

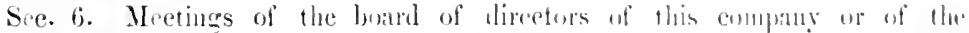

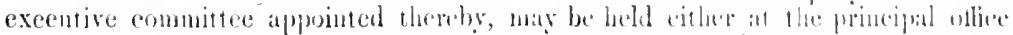

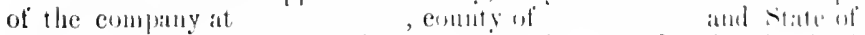

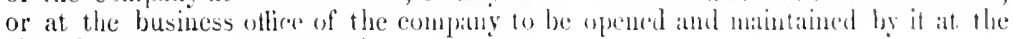
city of , state of

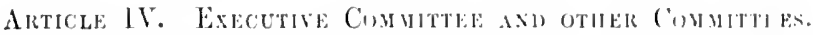

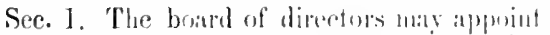

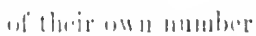

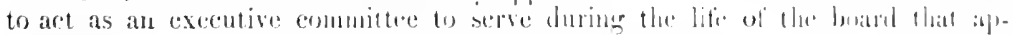
pointed it.

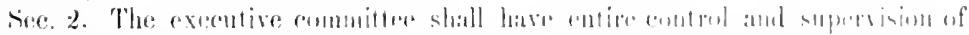

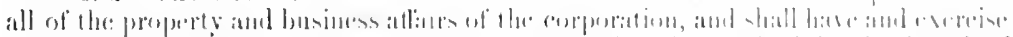

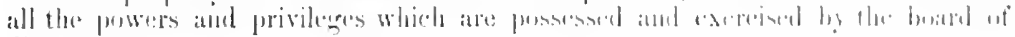
direcoters.

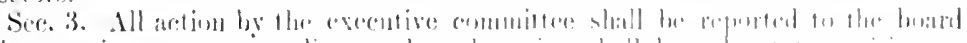

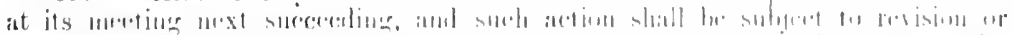

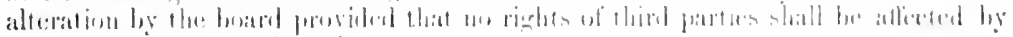

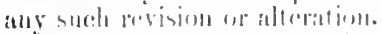

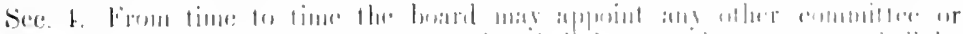

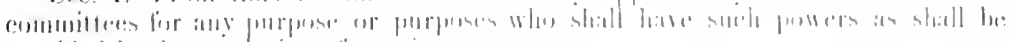

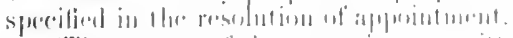

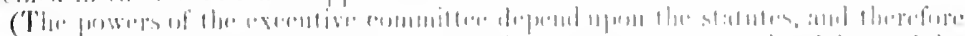

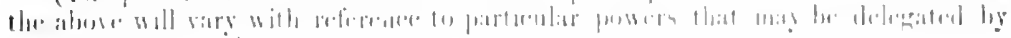

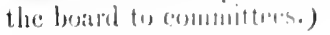

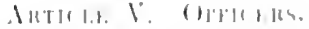

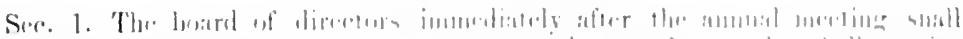

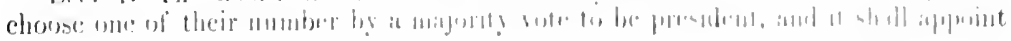


a rice-president, secretary, and treasurer and such subordinate officers as it shall

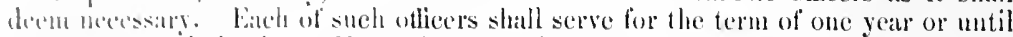
the mext ammial election. Vaemeies oceurring among the oflieers maty be filled by the buated of directurs for the unexpired term.

Sie. 2. The president shall preside at atl meetings of the board of directors, and shall ant at chairmim at, amd call toorder all meetings of the stockholders. 1he shatl sign all eertificates of stock (and commersign all checks, bills, and notes drawn by the treasurer). He shath submit a complete report of the operations and condutions of the eompany for the vers to the directors at their regular meeting in and to the stockholders at their regular meeting in of each year, and from time to time shall report to the directors all matters within his knowledge which the interests of the eompany mity repuire to be bronght to their notice; he shall be an ex officio member of all standing eommittees, and shall have the general purers and duties of supervision and management usually vested in the office of a pressident of at eorporition.

Sec. 3. The tirsi, second, and third vice-presidents shall, in the allsence or incapacity of the president, perform the duties of that oflicer in succession aceording to hlocir rank unless the board shall otherwise determine.

Sec. t. 'The treasurer shall have the custorly of all the funds and securities of the corpuration, and deposit the same in the name of the corporation in such bank or binkis as the dircetors may eleet; he shall sign all eluecks, drafts, notes, and orders tor the payment of money (which shall be comntersigned by the president) and he shall paly ont and dispose of the same under the direetion of the president. Ile shall at all reasonable times exhibit his books and accounts to any director or stoekholder of the company upon application at the offiee of the comprany during business hours. (Ile shall sign all eertificates of stock signed by the president, Note 1); he shall give sueh bond lor the faithful performance of his duties as the buard of directors maty require.

Note A. 'The president and secretary must sign in Sonth Dakota. In New York, Arizona, Nevada, West Virginia, and District of Columbia, ordinarily the president and secretary or treasurer. In New Jersey and Delaware, the president and treasurer.

Sec. 5. 'The secretury shall keep the minntes of proccedings of the board of directors and the minutes of the meetings of stockholders; he shall attend to the grving and serving of all notiees of the company; he shall affix the seal of the company to all eertitieates of stock; he shall hatre ehitrge of the certificate book and sueh other books and papers as the board may direet; he shall attend to such correspondence as may be assigned to him, and perform all the duties incidental to his oflice. Ile shall also keep a stock book containing the numes, il phabetically arranged, of all persons who are stockholders of the eorjoration, showing their plaees of residenee, the mumber of shares held by them respeetively, the time when they respectively beeme owners thereof, and the amomnt paid thereon, and sueh book shall be open for inspeetion of stoehloolders during the usual business lrours (in New York at least three hours) at the office of the cumpany, ("He shall be sworn to the faithful discharge of his duties," Note $\Lambda$.) ("Ile shall sign all ecrtificates of stock signed by the president." Sec section 4, Note $\Lambda$.)

\оть 1. Necessary in Delaware, Nevada, and New Jersey, and usually proviled.

(In the District of Columbia the following should be added to the powers of the secretary :)

If at any time he shall not reside within the Distriet of Columbia he shall see that all proper transfers shall be mate in the stuck book of the company kept at the registered uffice of the company in the District of Columbia.

(The following section should be inserted where counsel is provided for:)

See. 6. The counsel of the company shall prepare all such contracts and agreements required in the business of the company as maty be referred to him by its offieials; the shall inspect and bass nyon all such instruments as maty be presented to the company and be of sufficieut importance to justify such examination. He 


\section{FORMS AND PRECEDENTS.}

shall also advise with the officers of the company in such legal matters pertaining to the affairs of the company as may require his comsideration.

\section{Article VI. Capital Stock.}

Sec. 1. Subscriptions to the capital stoek must be paid to the trcasurer at such time's and in such instalments as the boand of dircetors mar by resolocin re'quire. Any failure to pay any instalment when required to be piad by the buard of directors shiall work a fortenture of such share of stoek in arreats.

Note. If preferred stock is provided for, the provisions and conditions of its issue should be set forth lure.

If stock is to be mate full-paid in the begimning, in consideration of the transfer of property, etc., section 1 may be omitted.

Sec. 2. Certificates of stoek slatl be numbered and recoistered in the order they are issued, and shall be signed by the president and by the treasurer ("Secre. tary," see Art. V. sec. 4 , Note A), and the seal of the corporation shatl be atlixed thereto. All certificates shall be boumd in a book, and shall be issued in consecutive order therefrom, and in the matrin theresf shall be entered the name and andress of the person owning the shares therein represented, the number of shitres and the date of issuime thereof. All certifieates exehaned or returned to the corpotation shall be marked cancelled, with the date of eanedlation by the secretary, and shall be immediately pasted in the certificate book opposte the memorambun of its issue.

Sec. 3. Transfers of strares shall only be made upon the bueks of the curporation by the holder in person or by puwer of at torney duly executed and ank now led ged and filed with the secretary of the corporation, and on the surrender of the certilieate or certificates of sucli shares.

Sec. 4. The board may appoint a transfer agent and a registrat of thansfers, and may reguire all stock certificates to bear the signature of either or both.

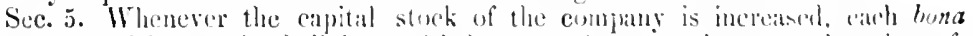

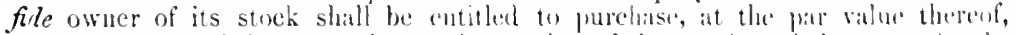
an amount of stock in proprortion to the number of shares of stuck he owns in the corporation at the time of such increase.

\section{Article Vil. Invihexds.}

Sec. 1. Dividends shall be declared and paid ont of the surplus profits of the corporation as often and at such times as the buard mily detromime. No dividend shalt be declared or paid that tends to curtail the eflective opreration of the business.

\section{Alticle VIII. Sell.}

Sec. 1. 'Tles seat of the corporation shall be in the form of a cirrte, and shall bear the name of llo eorpusation and the yoar of its incorporation, and the words "corporate seal" (name of State).

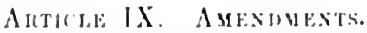

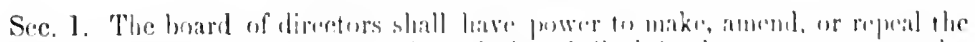

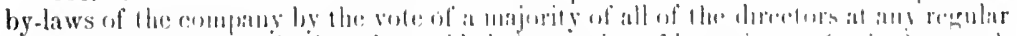

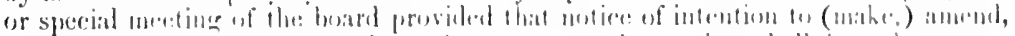

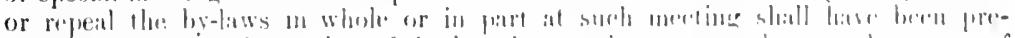

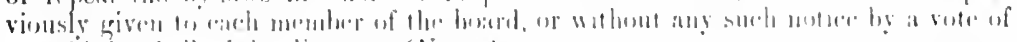

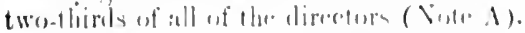

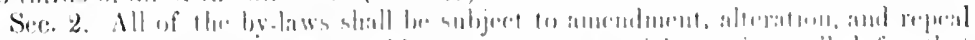

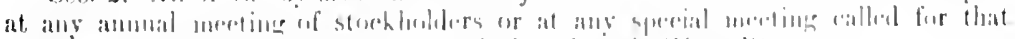

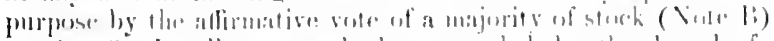

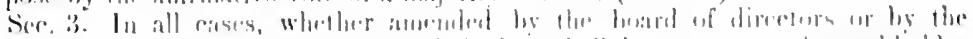

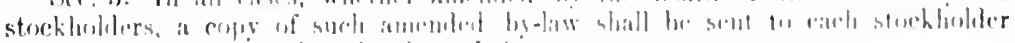

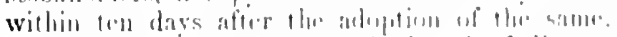

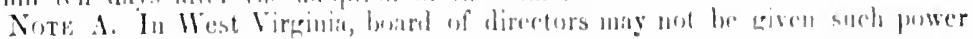


to "mahe, ate." les-liws. Certifiente of ineorporation shonld generally provide for aneminent hy directors where this power is desired.

Tort: 13. Ithat constitutes a valid rote dejends upon the statutes of each Statc.

\section{MISCELLANEOUS FORMS AND PRECEDENTS.}

\section{SUBSCRIPTION AGREEMENT BEFORE ORGANIZATION.}

Whores, the organization is eontemplated of a corporation muder the laws of the stite of , to be known as the or by sueh other name as may be selected, with a capital stock of not less than 8 " for the purpese of

and it is desired by the undersigned to beeome stoekholders in said eorporation.

Hure, therefore,

do herebs pronise and agree to and with each other all

the undersigned, in consideration of the mutual promises and agreements herein contained, that they will pay to the Treasurer of sidid eorporation as soon as he shall have been eleeted to that offiec, on demand, the sum of dollars, being the subseription priec of shinres of the capital stoek of the said corporation, or sueh part thereof as may be ealled for. 'The stoek thus paid for to be delivered at the carliest possible moment after the organization of the company, and meanwhile proper reeents to be issued to the mulersigned.

We hereby further agree in consideration as aforesaid, that our scveral sub. seriptions to the eapital stock of said

herebr made for the use and benefit of said Company to be formed, are Company, and that when sitd is duly formed and organized, that the said subseriptions hereby made may be enforeed by it either at law or otherwise as the Board of Direetors of said eompany may hereafter determine.

Names.

Residenees.

\section{PROXY}

For Meeting of Incorporators and Subseribers.

to , one of the incorporators of the Company, and a subscriber shares of the stock thereof, hereby appoints

as prox s with full power of substitution and revocation to vote for and on belalf of the undersigned at the organization mecting of the eorporation to be held at on the day of , 190, or at any adjoumment thereof.

Witness, my himd and seal this day of , 190 .

In the presence of :

\section{PROXY AND WAIVER OF NOTICE (Combined).}

Knon all Hen by these Presents, That I, the undersigned, being the owure of shares of the eapital stoek of the Company, a corporation organized and existing under the laws of the State of , do hereby eonstitute and appoint my true and lawful attorney, for me and in my nane and stead, to vote upon the stoek owned by me or standing in my nitme, as my proxy at a special (or anmual) meeting of the stoekholders of said company, to be held at the office of the eompany in the City of

State of , on the day of , 190 (hereby waiving all statutory requirements as to notice of said meeting and publication thereof), and on such other day or days as the meeting may be thereafter lield by adjourn- 
ment or otherwise, aceording to the number of rotes I am now or may then be entitled to east, hereby granting the saicl attornes full power and anthority to act for we and in my name at said meetine or meetings in roting for the eletion of direetors of the eompans, or in the transaction of such other busimess as may properly eome beiore the meeting, as fully as I enuld do if persomally present, hereby granting the said attorney finll power of substitution and revocition, and hereby ratifying and confirming all that my said attoney or substitute may do in my name, place, and steal.

In Witness Whereof, I have hereunto set my hand and seal this of , 190 .

Witness:

day

\section{TRANSFER OF SUBSCRIPTION.}

For value reeeived, the undersigned does hereby sell, assign, transfer, and set orer unto al! his right, title, and interest as an incorporator of and as a subseriber to the capritil stock of the extent of shares of the capital sock thereto.

I hereby request and direct the proper oflicers of said Company to issue a certificate for said shares to the aforesaid assignce or his assigns.

In Witness Whereof, I have hereunto set my hand and scal this day of Dated, 190 .

Titness :

\section{FORM OF LETTER ADDRESSED TO CORPORATION OFFERING TO TRANSFER PROPERTY IN EXCHANGE FOR CAPITAL STOCK OF A CORPORATION.}

To the Stockholders of the

Conmany:

I am the owner in fee ol the following deseribed real estate (or, in case uf personal

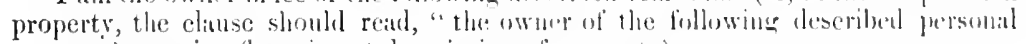
property), 1, wit: (here insert deserifution of proferty).

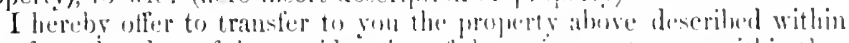

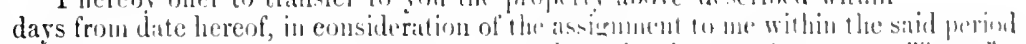

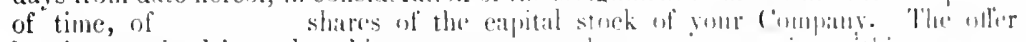

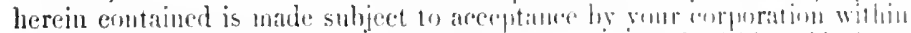

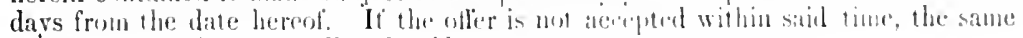
shall forthwith beeone mull and roid.

Rir:pretfully sulsuitted.

AGREEMENT FOR THE SALE OF REAL OR PERSONAI, PROPERTY

TO A CORPORATION IN EXCHANGE FOR I'T'S CAIITAL S'TOCK.

This acrerencot made: of 1110: City of

of the first pitet, and the:

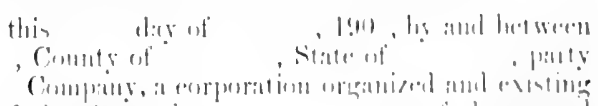

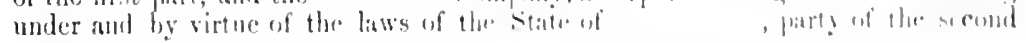
part.

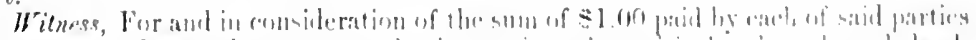

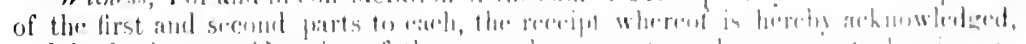

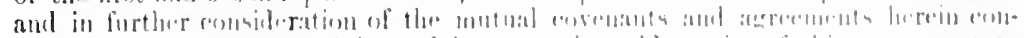

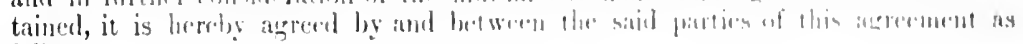
follows:

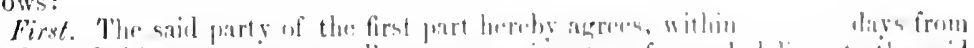

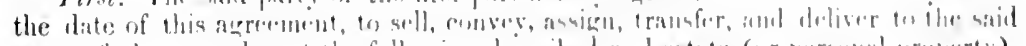

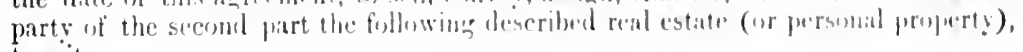
to wit: 
(IIre insert description of the property to be sold, conveyed, transferred, assirned. and delimered.)

Scrond. Sitid party of the first part hereby warmuts that it is the owner in fee of said real atate above ileseribed (or, in case of personal property, that it is the owner of the persollal property above described) all of whieh is hereby warranted to be free and oldir loum all liens, charges, inemubrumes, taxis, and assessments whatsoever.

Third. The said party of the secoud part hereby agrees that lorthwith, upon due comverance to it (in case of personal property upon the due transter, assignment, or deliver ) of said real estate by said party of the first part, it will, in eonsideration therefir, assign, transfer, and deliver to silid party of the first part

shatres of the eommon stoek of the Comprany (party of the second part heroto) of the par value of dollars per share, aggregating $\$$ in anıunt.

In Witness Whereof, the said parties of the first and second parts have hereunto set their hands and seals this day of, 190 .

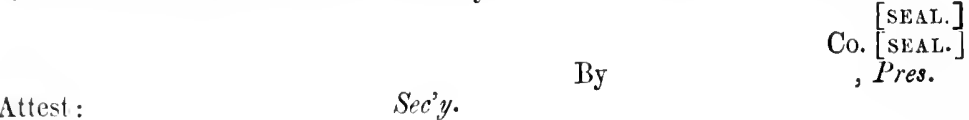

$\left.\begin{array}{l}\text { State of } \\ \text { County of }\end{array}\right\}$ ss.

On this day of , in the year, before me personally came , to me known and known to me to be the individual deseribed in, and who exrcutal the foregoing instrument, and who acknowledged to me that he executed the sime.

$$
\begin{aligned}
& \text {, Notary Public, } \\
& \text { State of }
\end{aligned}
$$

\section{$\left.\begin{array}{l}\text { State of } \\ \text { Connty of }\end{array}\right\}$ ss.}

On the day in the year before me personally came

me known, who being by ne duly sworn did depose and say that he resided in ; that he is the President of

Company, the corporation described in and whieh exeented the above instrument; that he knew the seal of said eorporation; that the seal alfixed to said instrument was sueh eorporate seal; that it was so affixed by order of the Board of Direetors of said eorporation, and that he signed his name thereto by like order.

$$
\begin{gathered}
\text {, Notary Public, } \\
\text { State of }
\end{gathered}
$$

\section{FORM OF TRUST AGREEMENT.}

(This agreement will be found very convenient where it is desired to get stock back into the treasury as full-paid and non-assessable stock, subject to sale below par if desired.)

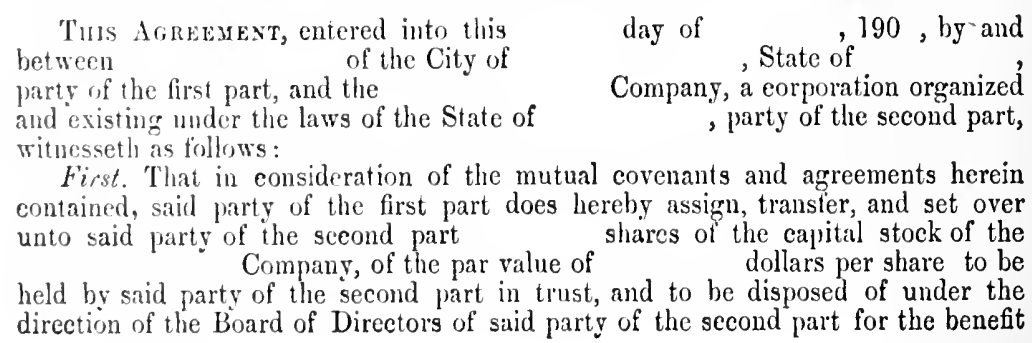




\section{FORMS AND PRECEDENTS.}

of the stockholders of sasd parts of the second part with a riew to sccuring the necessary tunds with which to carry on the business of said

Company, and to proside a working eapital therefor.

Second. The said patety of the sceond pant lereby accepts the assignment and transfer of sitid shares of the cilpitit stock of sitid

Company to be held by and disposed of by it for the pmrposes above stated.

Third. Said parts of the sieond part further corenants and asreses that it will at all times hold and dispose of, at such prien and under such terms and eonditions as its Boalled of Directors maty prescribe, said shares of said eaprital stock of sadil Company, with a view to securing andequate and sufficient capital with which to cary out the purposes for which said Company was formed.

In Wimess IThereof. said partics of the first and second parts lave heremto set their himds and seals this day of

$B !$
190 .

, Purty of the first purt.

Company.

, Presiderit,

, Purty of the secout purt.

\section{State of County of

$$
\} \text { ss. }
$$

Ont this day of

, 190 , before me personilly eame

to me known and known to me to be the person deseribed in and who exceuted the foregoing instrument, and duly ackwowledged to we that he exeroted the sime.

$$
\text { , Sotury P'ullie. }
$$

County.

\section{State of \\ County of

$$
\} \text { ss. }
$$

On this das of , 190 , before me peronally eame

who being by me dibly sworn did depene and say : What he pesieled in the City of

$$
\text { ; that le was the l'resident of the }
$$
corporation described in and which exeented the foresenge instrument; that he

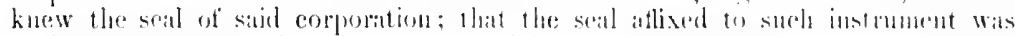
such corporite seal; that it was so allixed by order of the boand of bireeturs, and that loe signed his name thereto lyy like ordir.

$$
\begin{aligned}
& \text {, Nolury I'ublir, } \\
& \text { County. }
\end{aligned}
$$

\section{CERTIFICATE OF COMMON STOCK.}

(Number.)

$$
\text { Ineorpurated under the liaws of }
$$

$$
\text { Xisure of (onmuntion. }
$$

Citpitial sireh, 3

This erefifies that tal storek of the

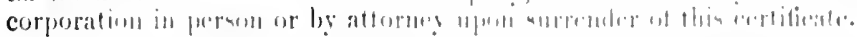
in the cowner of shomes of the eapie

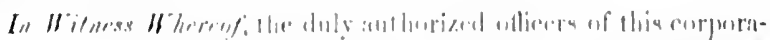

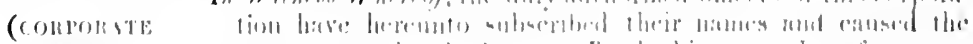
$\$ 1,1 .$.

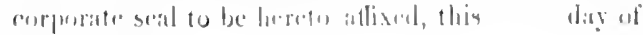
A. [). 19). 


\section{CERTIFICATE OF PREFERRED STOCK.}

(Nimber.)

(Sliares.)

Incorporated minder the laws of

Name of Corporation.

Capital Stoek, $\$$
Common Stoek, $\$$

This is to certify that assessible shates of the par value of $\$$ eich of the preferred capital stock of the Company, transferable only on the books of the corporation in person or by proxr, or by atiorney upon the surrender of this certifieate.

'The holders of preteried stoek are entitled to reecive, and the Company is bound to pay out of any and all surplus protits whenever asecrtained, (non) cumulative divilends thereon at the rate of amb not exceeding per cent per anmum, pryable in quarterly, yearly, or litif-yearly instalments as the Board of Dircetors mis direet, betore any dividends shall be declared or paid on the common stock.

"The preferred stock is subject to redemption at par on the dity of 190 , or at any other period thereatter that the Board of Directors may select. (The locklers of preferred stoek shall not be entitled to any roting powers in the corjoration.)

In Witness Whereof, the duly authorized officers of the corporation have hereto subseribed their names and eaused the corporate seal to be hereto affixed this day of, 190 .

(SEAL.)

\section{CERTIFICATE OF INSPECTOR OF ELECTION.}

The undersigned, having been duly appointed Inspector of Election of directors of the Company, pursuant to the statute in such case made and provided at the annnal meeting of the stoekholder's of sidid corporation held for that purpose on the day of , 190, at the ofliec of the company in the City of , do hereby certify that at such elcetion there were present and voting shares of the stock of saicl corporation with the following result, to wit:

The said persons above named having received a majority of all the votes cast at such election are hercby declared by us to have been clected directors by a majority of the whole number of shares outstanding in said company.

\section{RESOLUTION OF DIRECTORS AUTHORIZING THE CONTRACTION OF A SPECIFIC DEBT.}

Whereas, it appears to this board that

dollars arc nccessary with which to enable the company to meet its obligations now due and owing; and

Whereas, there is no money in the treasury of the company at the present time with which to mect said obligations, Now, therefore,

Be it resolved, that the proper officers of this corporation be and they hereby are authorized to contract a loan for this company to the amount of 


\section{FORMS AND PRECEDENTS.}

dollars, and to give therefor a promissory note of this compans for said amount, same to bear interest at the rate of per cent per anmun until paid, and to become due mont hs after date thereof, and the said oflieers atre herelsy authorized to seeure parment of said note by siving a mortgange on sueh real estate of the company as may be required or as may be expedient.

I,

, Seeretary of the

ration organized and existing under the laws of the State of

Company, a corpo-

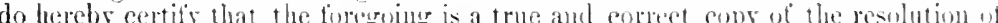

the Board of Direetors of said enrporation, duly athopted at the regular meetine of said Board of Direeturs held at the offiee of satid eompany on the dar wit Board of Directors. , 190 , and that the sane is entered as such in the minute book of said
Iritness $m y$ hand and the seal of said corporation the
day of , Secretary.

(SEAL.)

\section{WAIVER OF NOTICE OF ASSESSMENT.}

We, the undersioned, hereby waive notice of the time and place of the pasment of our respeetive subscriptions to the capilat stock of the comprus, and also waire all requirements of law as to notice of assessment and parment thereof.

And we herely anree to pay the sane to the 'Treasurer of sail Compang in sueh amounts and in such time or times as the Board of Director's maty menuire.

\section{CERTIFICATE OF THE SECRETARY OF $\Lambda$ CORPORATION TO THE PASSAGE OF A RESOLUTION.}

I,

Secretiry of the

Compriny, lureby ecrtify that hen Resolution above set forth is a full and froe copye of the same as passed hy the

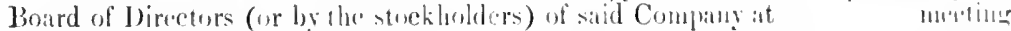

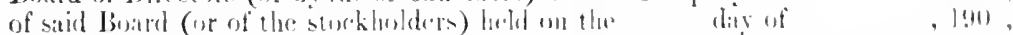
as taken from and emmared with the original resolution as recordent in the minue book of the Comprany 190 .

Iritness my hand and the seal of the Comprany this

$$
\text { dity nit }
$$

$$
\text { Seretary. }
$$

\section{(COMPORATE}

SEAL.)

\section{APPOINTMENT OF AGENT.}

A1:1,1, lim,

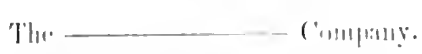

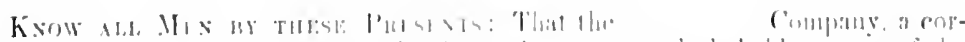

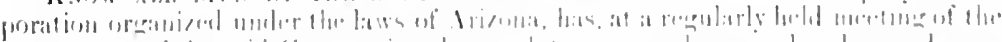

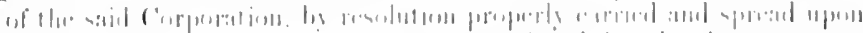

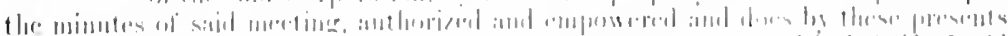

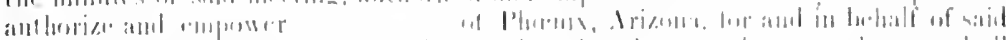

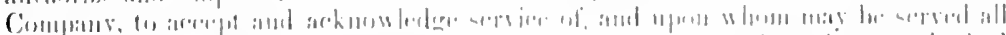

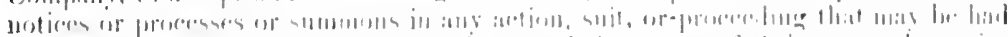

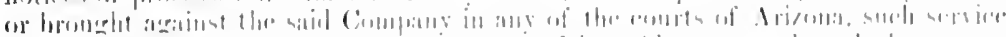

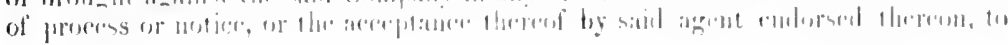


have the same fores as if served personally upon the Corporation or the President and serertatry therewt, the said Corporation hereby revoling any power of at torney or approintment of Atrent heretofore made by it for the purpose designated above.

Milness the signature of the President and Secretary of said Company this disy of $\quad, 190$.

, Secretary.

, President.

\section{APPOINTMENT OF AGENT.}

West Virginia Form.

h.ow all Mex by these Presents:

That

, a corporat ion ineorporated and organized under the laws of the State of West Virginia, and in conformity therewith, hath made, constituted, and appointed, and by these presents doth make, constitute, and appoint

of , in the County of, Stite of, its true and lawful attorney for it and in its nime, place, and stead to aceept service on behalf of said corporition, and upon whom service may be hat of any process or uotice, and make sueh return for and on belialf of sneh corporation of its property for taxation to the assesole of the county or distriet wherein its business is earried on as is required by the forty-tirst section of the twenty-ninth ehapter of the Code of West Virginia, and to list the property of said eorporation for taxation in any other manner required by the laws of said State, giving the said attorney full power to do everything whatsocrer requisite and neeessary to be dome in the premises as fully as such corporation conld do itself, and hereby ratifying and confirming all that the said attorney shall lawfully do or eause to be done by virtue hereof.

In IVitness Whereof, the said lath signed these presents by its president and caused the eorporate seal of said corporation to be hereunto affixed, this day of, 190 .

(SEAL OF

CORPOR.ITION.)

By

, President.

State of

County of

I,

certify that

, to wit:

, a Notary Public in and for the County and State aforesaid, do personally appeared before me in my said county, and

being by me duly sworn, did depose and say that he is the President of the Corporation deseribed in writing above, bearing date the day of , 190 , authorized by said Corporation to execute and ackmowledge deeds and other writings of said Corpuration, and that the seal atfixed to said writing is the corporate seal of said Corporation, and that said writing was signed and sealed by him, in behalf of said Corpomition, by its anthority dnly given. And the said acknowledged the said writing to be the act and deed of said Corporation.

Given under my hand and oflieial seal, this day of , 190 .

(SEAL.) , Notary Public.

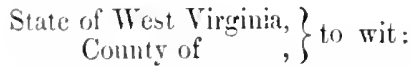

I, Clerk of the County Court of said County, do hercby certify that the foregoing Power of Attorney was this day presented to me in my said office, and together with the certificate thereunto annexed was duly admitted to record therrin.

Given under my hand, this day of , 190 


\section{CERTIFICATE OF FOREIGN CORPORATION.}

\section{NAMING AN AGEST CPON WHOM SLMMONS MAY BE SERYED.}

Krow all Mex by these Presexts:

That the , a corporation duly organized, creatod, and existing umer and by virtue of the laws of the State of and having its prineipal oflice or place of business in the City of , in said state, does lierehy designate and appoint , resiling in the City of, in the state of lie being a citizen of said state, als its agent for th. ...id state of , upon whom service of summons and all other lexal process naty be hat and made in all aetions or proceedings against said Corporition 13 an! of the courts of sat state of , according to the statutis in such cast: made and provided.

The said Corporation hereby designates the City of , in the sad state of , as its principal place of husiness in said state.

In Testimony Whereof, the said Corporation has, by its President, caused these presents to be signed and sealed with its eorporate seal at the City of, , in the State of , on this day of ${ }_{\text {By }}, 190$.

President.

\section{(Corporation Acknowledgment.)}

\section{FORM OF TRUST DEED TO BE EXECUTED BY A CORPORATION IN CONNECTION WITH A BOND ISSUE.}

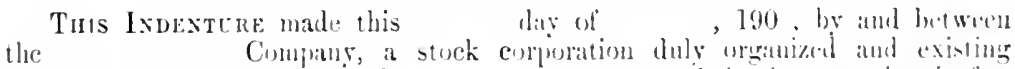
under the laws of the State of party of the tirst part lunemation called the Company amb the Trust Company, a corpmanimu orean-

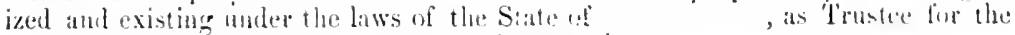
purperses hereinitien set lorth, palty of the secont part:

Wilnesseth, Whereas, the said party of the first part is a corporalion duly organized and existing under the litws of the state of , atul hats arequired several plants and purperties hereinafter described, and

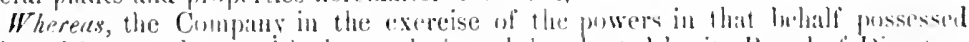

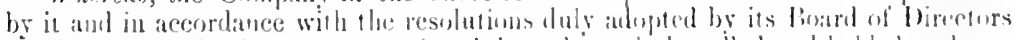

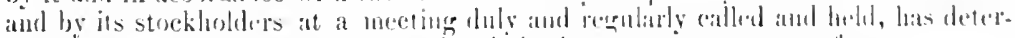

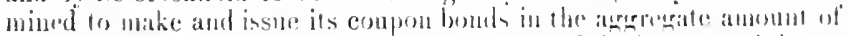

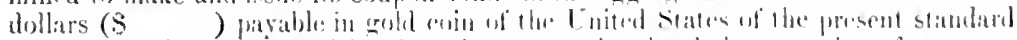

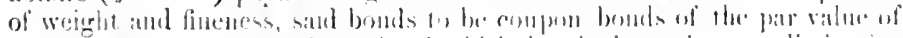

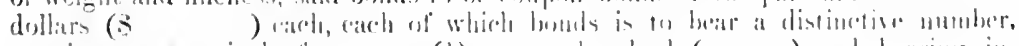

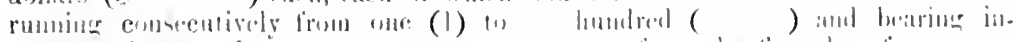

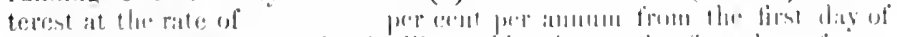

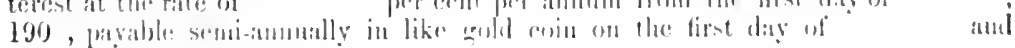
inl risch yetar, itul

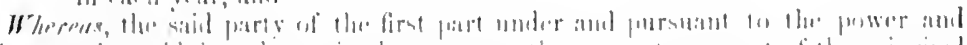

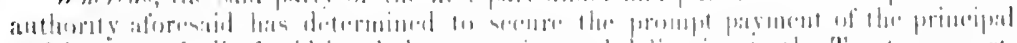

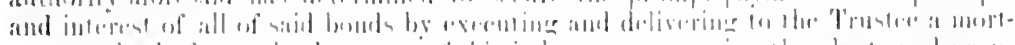

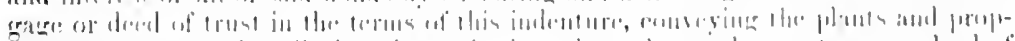

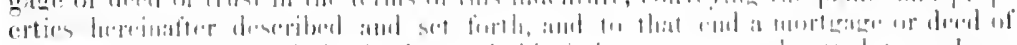

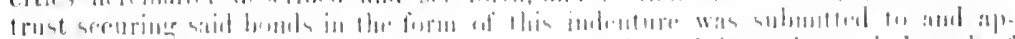

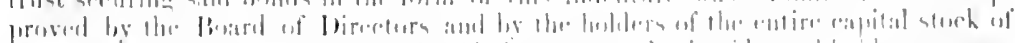

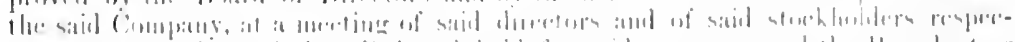

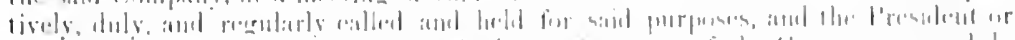

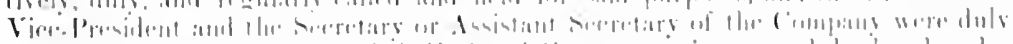

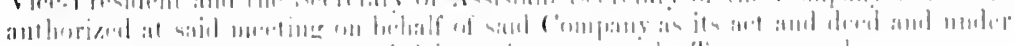

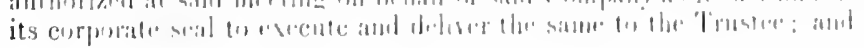


Wherers, the form of bonds and the coupons to be attached thereto, and of the eretitieate to be signed by the Truster for the anthentication of said bouds were all satil meeting serevilly and respretively submitted and approved by said resoluthons of the bivird of Diretors and of all the stocktolders of the Company, and are substintially of the following tenor, to wit:

\section{(FORM OF BOND.)}

\section{Uxited States of Aulerica.}

No.

\section{Company.}

\section{First Mortgage}

per ecnt Sinking Fund Gold Coupon Bonds.

KNow all Mex by these Presexts: That the (a corpuration organized and existing under the laws of the State of is indebtrd and for value reeeived, herehy promises to pay to the bearer or holder hereof, at its agenes or oftice in the City of New York, dollars (8) ), in gold eoin of the United States of the present stamdard of weight and theness on the day of , 190 (unless before that time this bond shatl hawe been retired) with interest thercon from , 190 , until the payment or redemption of this bond, at the rate of per cent per anmum, payable scmi-annually, at said office in like gold coin on the first day of and the first day of of ach year thereafter upon preseutation and surrender of the ammexeil conpons therefor as they respectively mature. Both the principal and interest of this bond ane payable withont reduction for any tax or taxes which the Company maty he recuired to pay thereon or to retain therefrom under or by reason of any present or future law of the United States or of any State, county, or municipality therein.

This bond is one of a scries of coupon bonds of the

Company, known as its First Nortgage per eent Sinking Fund Gold Coupon Bonds issued or to be issued to an amount not to execed in the aggregate the prineipal sum of dollars (s) all of which said bonds are issucd or to be issured under and sceured by a mortginge or deed of trust dated 1, 190, executed by the Company to the Trust Company (of' the City of , ) as 'I'rustee, to which mort gage or deed of trust reference is here made for a description of the property so deeded or mortgitgert, the mature and extent of the scenrity, the rights of holders of bonds under the same, and the terms and conditions upon which said bonds are issued and sicenred.

This hond is subject to redemption on the day of , 190, and (on the first day of of cach year therafter until its maturity at par with the interest then accrued thereon under the operation of a sinking fund which permits the Company to redeem at least onc-tenth of the entire issue of said bonds annually, and is subject to redemption on the terms and in the mamer provided in satid dreed of trust.

This boud shall pass by delivery. This bond shall not be issued or become obligatory for any purpose intil it shall have been authenticated by the certificate heresn chidorsed of said 'l'rustee muler said mort gane or deed of trust.

'This bond may be registered in the owner's name on the Company's books in the City of or at any other place which the Company may downine, such recristry being uncel on the bond by the Company's transler agent, altere which no transtion shall be valut muless made on the Company's books by the recrintered cwner and similarly endorsed on the bond, but the same mal be dis. chared from registry by being transforred to bearer after which it shall be transferable by delivery, but it may again be recristered as betore.

lirgistry of this boml as aibure shath not restrin the negotiability of the coupons by delivery nercly", but the eoupons may be surrendered and the interest made 


\section{FORYIS AND PIECEDENTS.}

parable only to the registered owner of the bond. such surrender to be ecrtified as follows:

"This is to certify that the coupous representing the several instalments of interest to beconge due on the within bonds hate been surmendered to the compiny and cancelled, and interest on this lond when here. after due will be payable to the registered owuer hereof, is eertified hereon, or to his ordel:.

Dilted

In Hitness Whereof. the Company has eaused his iustrument
to be signed by its President, and its eorporate seal to be bereunto allixed amb to "Transfer Agent." to be signed by its President, and its emporate seal to be heremnto allixud and to be attested by its Seeretary, and conpons fior said interest with the entrared siguature of its Theasurer. 10 be attiched thereto this first day of

Attest :

, Srepetury.

By , 196.

Compair, , Piesident.

\section{Tristee's Certificate.}

This is to eertify that this bond is one of the bonds described in the above mentioned indenture of mortgitge or deed of lrust dated 1,190 .

By

'lerst Connsis, Trustere, , Tinst Officer.

\section{FORM OF COUPON.}

On the first day of , 1911 , the

Company will jay the

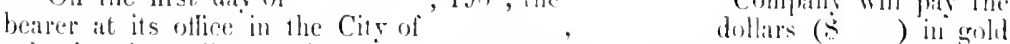

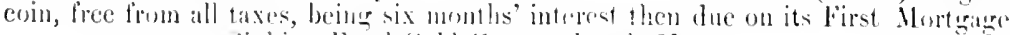
per ecut Sinhing Fund (inld Cunpon bonds No.

and

, Trowsurer.

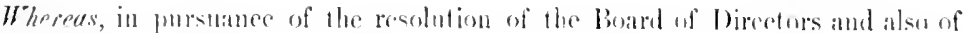

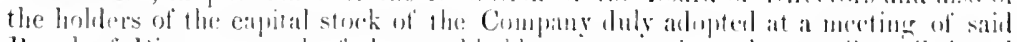

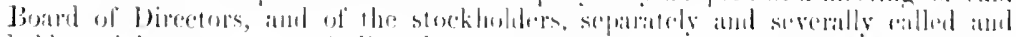

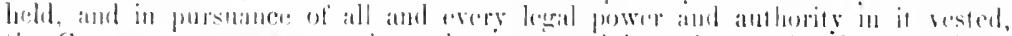

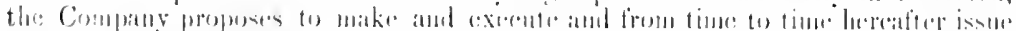

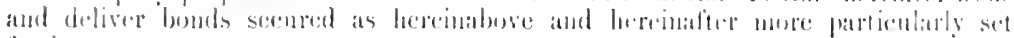
linth:

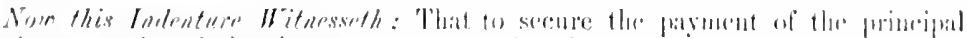

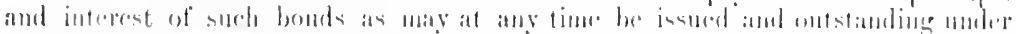

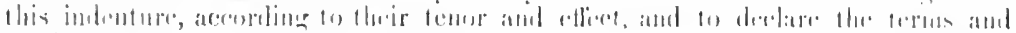

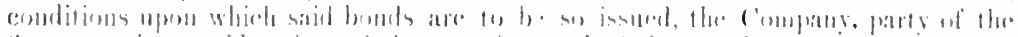

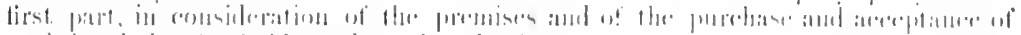

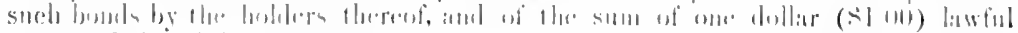

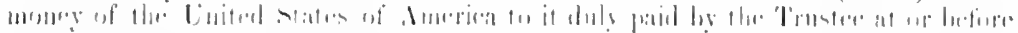

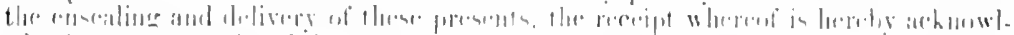

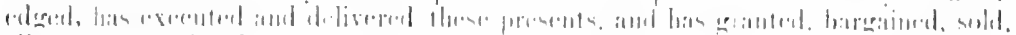

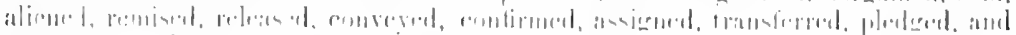

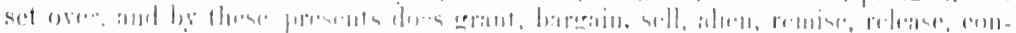

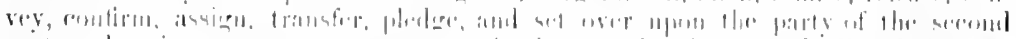

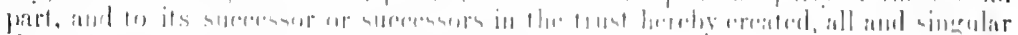

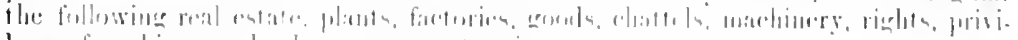

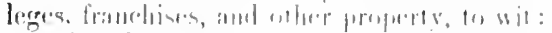

of

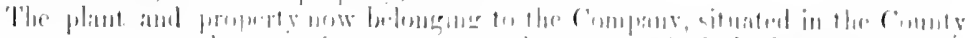
lows, 10 wit:

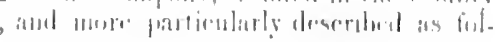


Tugether with the buildings and structures, erections and constructions now or hereafter placed thereon, and in addition thereto all machinery, fixtures, appli:me's, implements, and appurtenanees of erory kind and eharacter which are now 1): mar be luereafter at any time sitnated lying and heing in, on, or about the said plants, promises, and property deseribed lierein, and used or provided for use in and albunt the operation of sad plants and property, and the carrying on of the business of the Company in the same, whether the same are now owned by the said bary of the tirst part, or shall hereafter be aequired by it, it being the intention lerefot that said plants, premises, and property shall be and are hereby conveyed as an aefire-going, operating plant.

To Hace and to Ilold the said above described premises, property, rights. franchises, and alppurtenances, mnto the said party of the second part and its lawlud suecissor's or ansigns forever.

but in Trust Tevertheless, for the bencfit, security, and protection of the persons and eorporations, firms and partnerships, who may be or becomc holders of the aforesaid bonds and interest eoupons, or any or either of them, and for enforeing the payment thereof when payahle, aceording to the true intent and meaning of the stipulation of this mortunge or deed of trust and of said bonds and of said interest eoupons, and withont preferenee, priority, or distinction as to licn or otherwise of aus of said bonds over any of the others by reason of priority in the time of the issie of negotiation thereof or otherwise, provided, however, and these presents are upon the express endition that if the party of the first part, its successors or assigns, shall well and truly pay or canse to be paid unto the holders of the honds to be issucd herenuder, the prineipal and interest to become due thereon, to said holders at the time and in the mamer stipulated in said bonds and in said interest coupons aceording to the true intent and meaning thereof, and shall well and truly keepe, observe, and perform all and singular the covenants, promises, and conditions in the said bonds hereby secured and in this indenturc expressed to be kept, observed, and performed by or on the part of said party thereby granted, slatl ecase, determine, and be void, otherwise to remain in full force. And it is expressly corenanted and agreed by and between the parties hereto that the specific trusts, ises, and purposes, conditions and covenants upon which said property and franchises hereby mortgaged and conveyed are to be held by the Trustec and sub. jeet to which the sail bonils secured liereby are to be issued and to be lield by each and crem holder thereol, are as follows, that is to say:

First. 'This mortgage or' deed of trust is to be a continuing lien to secure the full and final payment of the principal and interest of all bonds which mas be from time to time issued and negotiated under the same, but so that the total aggregate amrunt of said bonds so issued and negotiated shall not exceed dollars (\$) ), and to be issued mpon the terms and of the denominations, and to mature and beeme payable in the manner and at the place and time or times hereinbefore stated, with interest payable as so stated.

Second. The coupon bonds intended to be sceured hereby shall from time to tim. he excented by the

Company and delivered to the Trustce, and the Trustce shall authenticate and deliver the same pursuant to any directions that may be contained in a resolution or resolutions of the Board of Dircetors of the Company, a certified eopy of which shall first be lodged with the Trustce, and the T'rustee shall not be under any duty to look bchind the same, and shall not be in any way responsible for the issue and negotiation of any of such bounds or the applieation of their proeecds. Only such of said bonds as shiall be so authenticated by the 'Trustee by signing the eertificate endorsed thereon, shall be scenred by this insrertgage or deed of trust, or he entitled to any lien or benefit hereunder, and such certifieate of the Trustee shall he conclusive evidence that the bond so certified has becn duly issued hereunder and is entitled to the bencfit of the trust hereby ereated.

Thisl. 'The

Company covenants and agrees that it will fully and entirely pay off and satisfy the whole of the said bonds to be issurd hereunder, principal and interest, according to the terms hereof, without delay and without deduction from either said principal or interest for any assessments, taxes, govern. 5.34 


\section{FORIS AND PRECEDENTS.}

mental and other charges now or hereafter imposed upon said bonds or any interest thereon, either by the United States or by any State, country, or municipil authority which the

Company imas be required to deduet therefrom.

Fourth. Until default shall be made in the parment of the principal or interest of any of the bonds hereby secured or any part thereot, as and when the same shall become due and payalde, or in the pertormance or observance of any eondition,

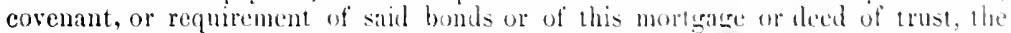
Trustce shall permit and suller the

Companr, its suceessors and assigns, to possess, operate, and enjoy the real and personal property hereby mortgaged with the appurtenances thereto belonging. in any manter unt inenisistent witl these presents, and to receive and use the total incomes, rents, issues, and pusts thereof.

Fith. When and as the interest conpons antached to the bunds herebr seeured mature and are paid by the Comprany or by any person on corporat tion for it or on its behalf, they shall be cancelled." All compus manuing betore the delivery of the bonds by the party of the seeved part shall be eut ofl and cancelied by the party of the second part before delivery of such bouds.

Upon the payment at maturity or retiaes prior to the maturity by the payment of any bonds hercinbefore provided for, the sime shall be cancedled and delivered forthwith to the Trustees.

Sicth. The Company eovenumts and agrees that it shall and will from time to time pay and dischatrece before the sane shall fall into arrears, all taxes, water rates, assessments, and gurermmenal rlarges lawfully impused mpm the franchises and lands anul other herobs morteraged premiscs, or any part therent,

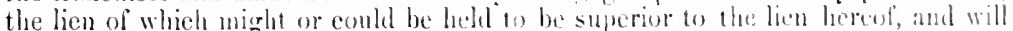
pay and dischatree all eleims of every kind and nature which maty hereather become a lien upon the hereby mortenged premises or ans part thereof, priver wn the lien

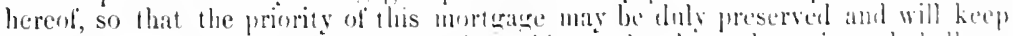
said mortenesed premises or any part therest in gevel urder and repatir, and shall now

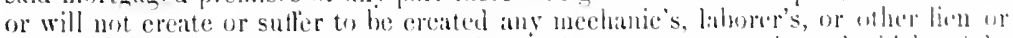
charge whatsoeser upon the morteated primises or any part thereot which might

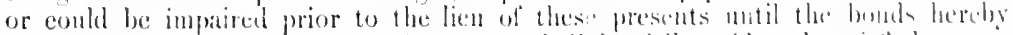

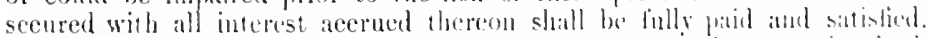

Serenth. The

Compromy cosenants and anderes hat it shall and will at all times, until said bonds hereby secured with all interest alecended the reon

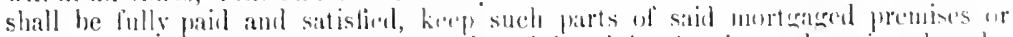

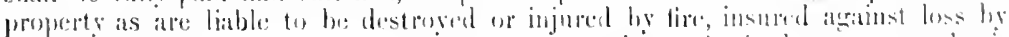

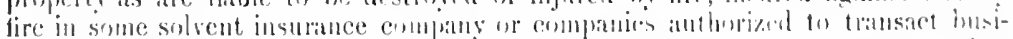

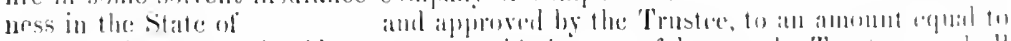

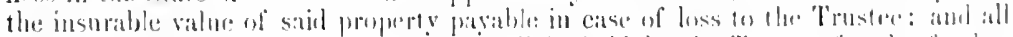

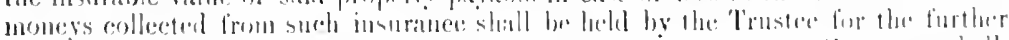

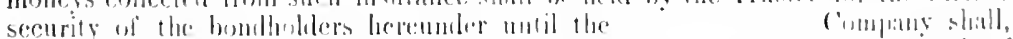

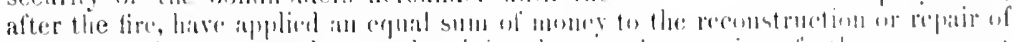

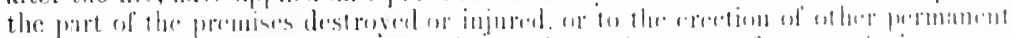

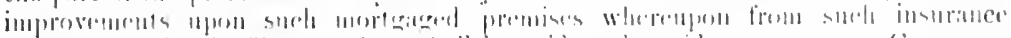

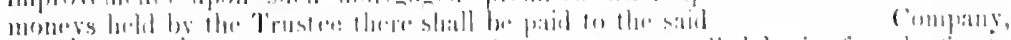

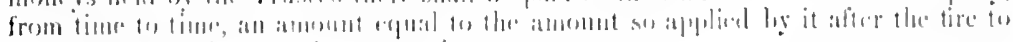

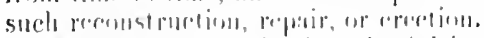

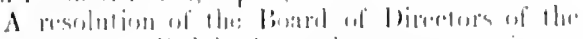

Complany, sating

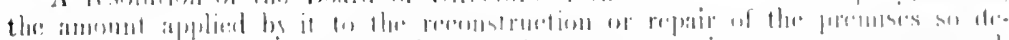

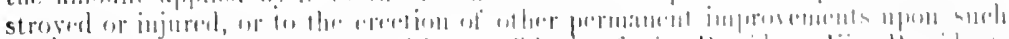

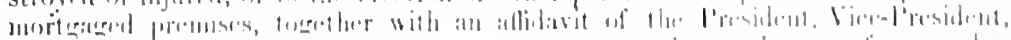

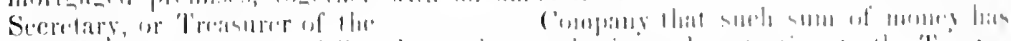

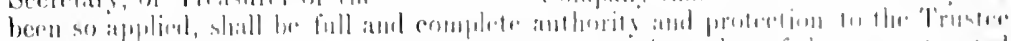

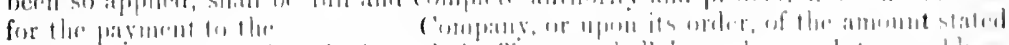

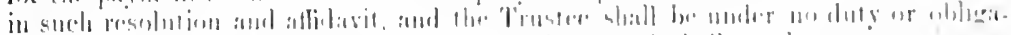

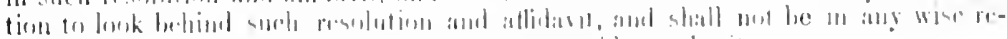

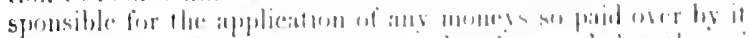

Eighth. It is further cosentaled and agrend that the said 
pary slatl well and truly par or canse to be paid all prior liens and indebtedness of whatserver nature and deseription that now exist against the property covered

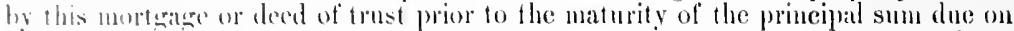
sitid bemls, and the sitid

Company does herchy agree to proeure a release thereof from the holders of sidid lien or said indebteduess, but no duty to see to such payment or the proeuring of such release is hereby imposed on the 'Trustee.

Winth. The Company shall and will from time to time during the continuanee of this lrust and morlgange mike, execute, and deliver all suet further instruments and converanees as may be neeessaly to rest in said Trustee and its sureessors the within deseribed and all subsecfuently aequired property and rights of property 10 facilitate the excention of said trust.

Tinth. II is furlher coveninted and agreed that the personal property hereinhefore deseribud and hereby eonveyed, or intended so to be, shall be held and be taken to be fixtures and apjuntenanees of the premises, and as part thereof, and are to be used and sold therewith and not separate, execpt as herein expressly provided.

Elerenth. The Company shall be permitted, without reference to the Trustee, to alter, remove, sell, or dispose of any buildings, fixtures, machinery, or other persmal property laesein deseribed as covered by or loeated upon the mortgaged premises hereinater deseribed whiel eannot be advantageonsly used in the judieious operanion and management of the business of said Company, provided always that said Comprany shall and it hereby agrees in such ease that it will replace any buildingrs, fixtures, machinery, or other personal property so altered, removed, sold, or dispesed of by acquiring subjeet to this mortgrice, other buildings, fixtures, machiners, or other jersonil property equal in value to the property so altered, remored, sold, or disposed of, the same being erected at the option of satid Compans upon real estate that may now or hereafter be owned, leased, or otherwise acquired by sild Company, or which may hereafter be owned, Jeased, or otherwise acquired by said Compruy, or in lien of the foregoing the said Company shall be permittid, without reference to the 'T'rustee, to alter, remove, sell, or dispose of any buildines, fixtures, machinery, or of her personal property erceted upon the mortgaged premises abore described which cimnot be advantageously used in the judicions operation and management of the business of said Company by paying to said Trustee the appraised value of such property, and any such sums so received by stid Trustec shall upon reruest of sild Company be investerl in bonds seenred by this mortgage, or in bonds, mortguges, or securities anthorized by law for the inrestment of funds of sivings banks in the City of New lork, which bonds, mortgages, or seeurities stakll be leckl for further seeurity of the bonds secured be this mortange; but until default in the payment of the prineipal or interest of the bonl seeured herehy or some part thereof, the interest and ineome of said bouds, morturages, or securities shall be paid to the Company. No duty or responsibility is ingresed upon the 'Trustee by the provisions of this article, exeept to receire such finds as may be paid to it by the Company, and invest the same as leterin morided.

Terlfth. For the purpose of providing against any depreciation of the security reserved herein by reason of any eanse, and for the further purpose of providing the necersary funds with which to make payments of said bonds either as they mature (1) as they una be retired under the enditions herein set forth, said Company shall set inside: and reserve from and after the first day of , from its carnings, an amount refual in ralue to one-tenth in amonnt of the prineipal due upon all bronds issued and outstanding ou that day, and shall set aside and reserve for the same purpose alter the tirst day of $\quad, 190,190,190,190,190,19$, $19,19,19$, a similar proportion of the principal due 11 pon all bonds outstanding on these dars respeetively, such reservation to be for the purpose of providing a sinking fund under the eonditions hereinafter set forth.

(Ju or before the first day of of each year, eommencing in 190 , while the lien of these presents shall eontinue, the Company shatl pay over to the Trustce all moneys reserved as aforesaid for the purpose of a sinking fund. Immediately npon receipt of moness by the said Trustee from said Company for the

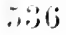




\section{FORMS AND PRECEDENTS.}

sinking fund as provided lerein, the Trustee shall forthwith on receipt ol said

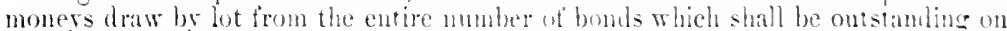
the first day of, 190 . and in each year thereatier unt the vear 19 , such a number of bouds for redemprion as at shatl bave funds to redum at par, the same not to exceed in any eatse the sum of one-tenth of the antunut of bonds outstanding on the dar when such partnent to the Truster beennes due aud

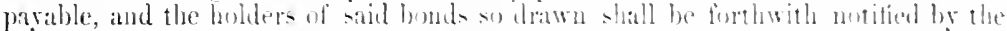

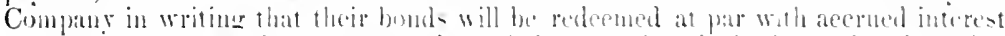
thereon to the first das of somember of the rear in which the sath redemptim

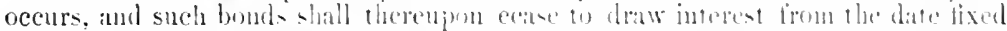
for redemption, and shall be redeened he the said Trustee an and ather that day and at the price aforesaid out of the moni'y phaced in its hands on account of said sinking timl.

All bomls whieh shell barre been from time to time purelatsed or redermat

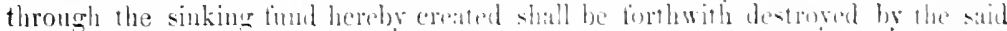

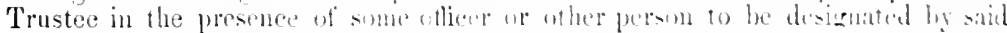

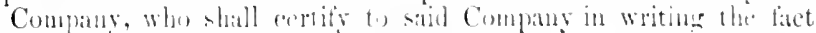
of said destruction and the unmber of houd so destruste

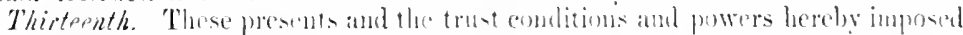

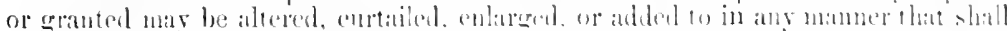

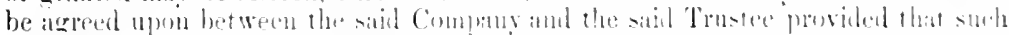

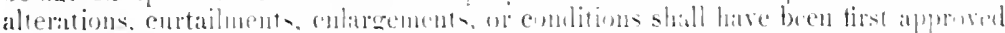

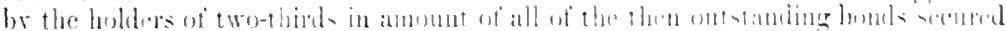

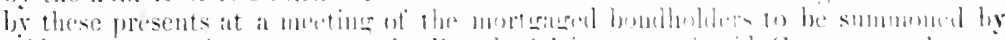

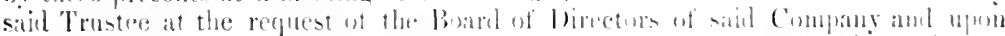

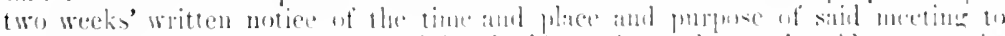

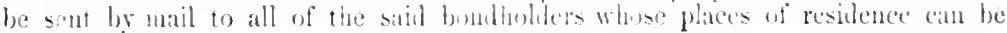
iscertinitued.

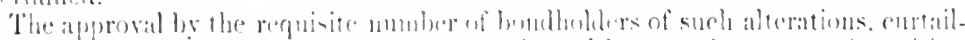

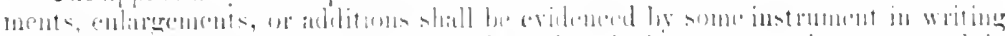

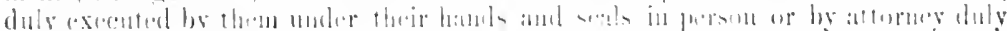

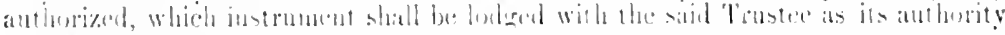
for insiation thereto.

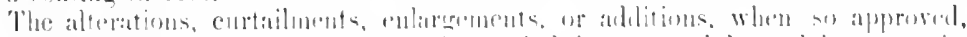

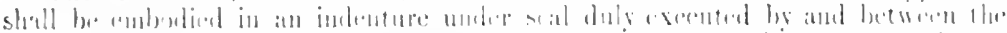

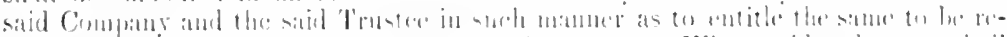

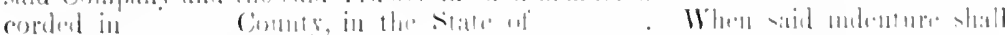

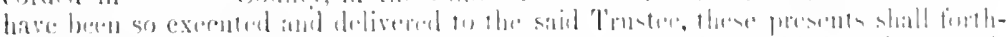

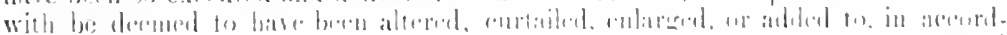

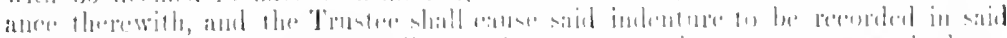

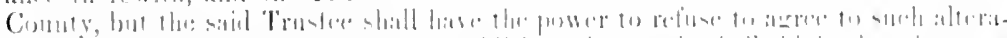

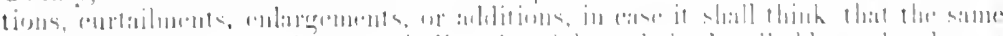

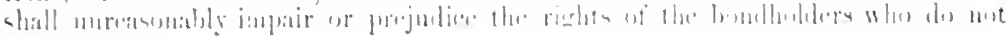

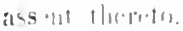

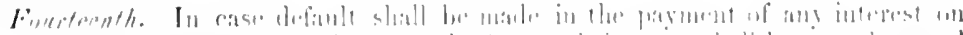

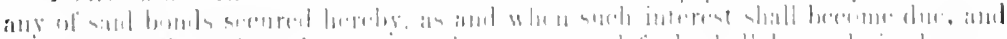

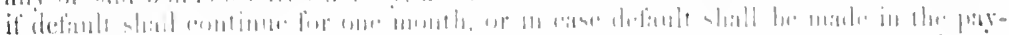

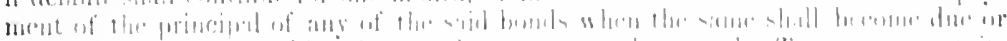

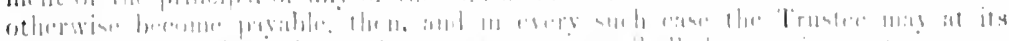

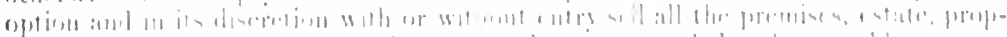

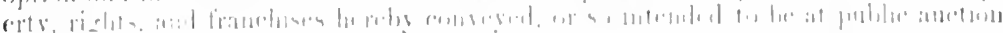

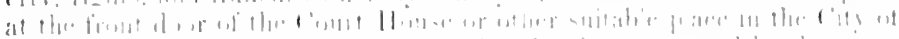

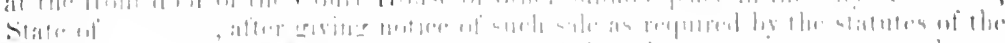

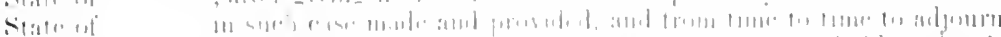

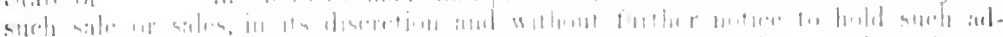

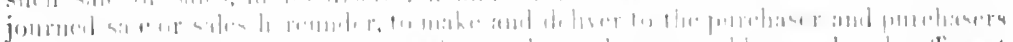

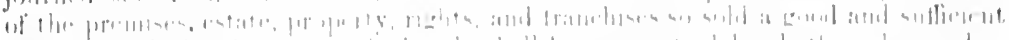

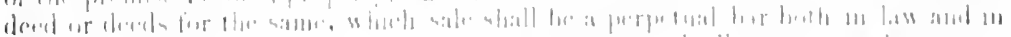
equily ingatust the siail

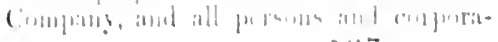


tims lawfulls claming or to claim hy, through, or under it, and upon the making of said side the principal of all the bonds hereby seeured and theu outstanding shall fortlewib berome due and parable, anything in sidul bonds to the contrary now withstanding, and upon the making of any such sale the said Trustee slaall apply the procecds thereot ats follows, to wit:

lst. The piyment of the eosts and expenses of such sale or sales, including a reasomable romprusition to said 'l'ruster, its agents, attorney, and connsel, and all expense's, liabilities, and adranees made and ineurred by said 'l'rustec in managing and maintaning the property hereby eonveyed or intended to be conveyed and ail taxes ind issessments superior to the lien of these presents.

End. The parment of the whole amount of principal and interest which shall then be owing or unpaid npon the bonds scenred hereby withont preference or prionity whaterer, whether the said principal by the tenor of said bonds be then due or yet to become due, and in ease of the insuthicieney of such proceeds to pay in full the whole amonnt of such prineipal and interest owing and unpaid upon said bonds, then to the parment of sneh mincipal and interest pro rata without preference or prioritr, but ritably to the aggregate amomnt of sueh prineipal and acerued aud mipaid interest.

3rd. 'T'o pay' over the surplus, if any, to whomsoever may be lawfully entitled to receive the same.

Fifteenth. It is further declared and agreed that the receipt of the Trustee who shall make the sale herembefore authorized shall be a suffieient diseharge to the purchaser or purehasers, his or their heirs, or assigns, or persmal representatives, and such purehaser or purehasers shill not, after paying such purehase money and receing such reecipt of the I'rustee therefor, he obliged to sec to the application of such purchase money upon or for the trusts or purposes of these presents, or to be in any wise answerable lor any loss, misapplieation, or non-application of such purchise money by the Trustee.

Sirteenth. In ease default stall he made in the payment of the prineipal or interest of said bonds, when same shall beeome due and payalle, or in the observance or perlormance of any covenant or condition in said bonds, or herein contained on the part of the party of the first part, and such default shall continue for six months, it shall be the duty of, and it is hereby made obligatory upon the Trustee, upon the request in writing of a majority in interest of said bonds secured and then outstanding, executed and acknowledged by the holders thereof, or their attorneys therenuto duly anthorized in writing, and inon proper indemification to proceed forthwith to enforee the rights of sicil Trustee and of the bondholders, herennder, by sale or entry, or both, according to such requisition, or ly judicial proceedmgs for such purpose, as the Trustee, being advised by counsel, learned in the law, shall deem most expedient in the interest of the hothers of the bonds secured therehy; the choiee betwecn such remedies being left to the diseretion of the Trustce.

Serenteenth. The several remedies granted hereunder shall be cumulative and non-exchnsive one of the other, and shall be in addition to all other remedies to enforee the lien of these presents.

Eighteenth. Upon the filing of a bill in equity or other commenecment of judicial procecdings to enforee the rights of the 'l'rustee or of the bondholders under these presents, the said 'Irustce shall be cutitled, as a matter of right, to the appointment of a receiver or receivers of the property herchy mortgaged, and of the carniugs, ineome, rents, issue, ant profits thercof, pending such proeedings.

Nineteenth. Upon payment, when due, of hoth principal and interest of all the bonds which shall have been issucd thereunder, the 'l'rustee shall, upon the written request of the Company, enter satisfietion of this mortgage upon the records, and shall do, make, exeeute, and deliver such deeds, iets, instruments, or assuranees as may be neessary to vest all the mortgaged premises and property of the said free and discharged from the lien of these presents.

Twentieth. Upon the terms and conditions stated in this article, and not otherwise, the

Trust Comprany hereby accepts the trust of this instrument, 
and the

Company and all present and future holders of bonds and coupons secured hereby expressly assent and agree to, and acknowledge themselves bound by, said terms and conditions. 'The Trustee shall not be answerable wa ansbody for the default or misconduct of any agent or atturney appointed hy it in pursuance hereof, if sueh agent or attoruey shall have been seleeted with reisonible care, or for anything whatever in eonnectim with this trust. eseept wifin misconduct or gross negligenee after personal notice and distinet specitieation in writing from some person interested in the trust. 'l'he Trustee shall ineur un liability to anybody in acting upon any notiee, request. consent, ecrtiticate, bund, doeument, or paper believed by it to be genume and to thave been signed by the froper person. It shall be no part of the duty of the Trustee to see to the insurance of ang part of the property herebs convered in trust, or itself to etlect sueh insume. The Trustec may become the owier of bonds and enupons secured hereby with the same rights which it would have if it were mot 'Trustee.

The T'rustec shall not be personally liable for ang debts contracted hy it, of for ans damage to person or property or arising out of uon-payment of salaries, non-fulfilment of contracts, or for any other turt oblination and liabilits arising during any period wherein the Trustee stanll manage the trust properties hereunder. The trust estate is herebs made primarily liable to sueh persons for cress such liability and for every liability of any kind which the Trustee maty inem thereunder; and for eompensation for services aid reimbursements of all the expenses herender with interest. the 'Truster shall have a first lien upon the property herdys convesed. The Trustee stall not be under any ohligition or duty to periorm ang act licreunder, to take any action towards the excention or enforeeneut of the trust herehy created, or to defend any suit in respeet hereof, execpt upon request in writing of some person or persons interested in the trust, nor unless first salisfactorily indemnified, nor muless sitisfactury provisions he made to furnish the Trustere with additional indemnity aganst thability fom time to time as in the judgment of the 'Trustee nase be required for its protiction: nor shali the Trustee be required to lake notice of iny defiult hereunder, or to take any action in respeet of any defaults, unless requested to take notice in respect thereif hy a writing signed by the holders of at least a majority in interest of the houds tereby sceured and then intstandiug, and tendered reasonable indemuity as aforesaid, anythus herein contaimed whe conttrary notwithstandias, but neitlier any suel roquest nor this provinim therefor shall atfect any discretion herein or elscwhere especially given th the Trustee.

Auy noney received by the Trustee under any provisun of this indenture may

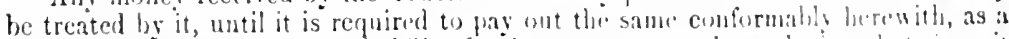
general deposit, withent any liability for interest save surbo as. during that time, it altows to its general depesitors. The 'Truster shatl unt he respumible for the recording, registration, or filing of this instrument or any instrument ef further assurance, or for the atlixing or cancellation of any revenue stanys or for the cotimation or pryment of any taxes, or for uent complying with the laws of , with respeet

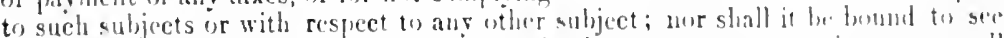

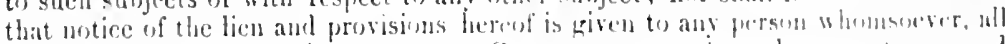
of which matter the said Compang corrumits and aferes to sele and perform.

The Trustee may, in its diacretion, alvise with legal counsel to be sebected and

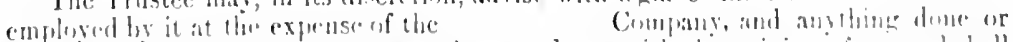

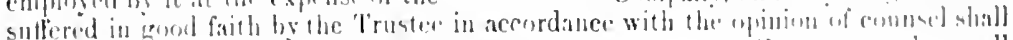

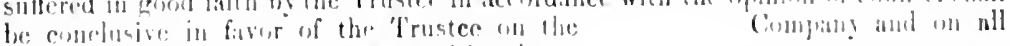
bolders of bunds and comproms secured herely.

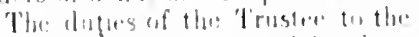

Comprany, nomd to the latilers of

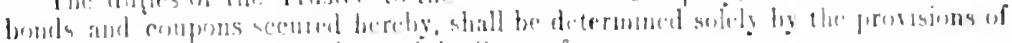
this instrubent and by the laws of the state of

Thto:

Combany acrece, from time to time, on demaml, to pay to

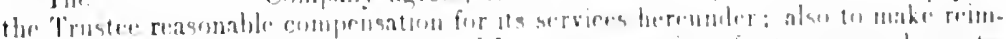

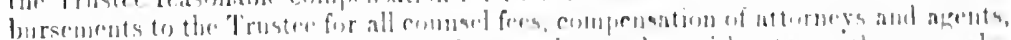

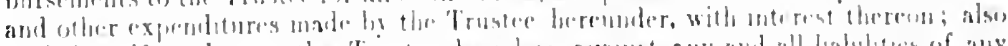
to indemify and save the frustere harmless aganst ong and all hatulitus of any 
kind which the Truste may incur in the exereise and performanee of its powers and duties hereunder, incliding any penalty or liability suifered by the 'Irustee under this instrument, or hecause of any action taken by it thereunder for noucomplian, with the laws of , or, conecrning forcign corporations or uthew ise: and fir such indemnificatiou, reimbursement, and payment of 'I'rustee's compensition at tirst lien is herehy imposed in favor of the Trustee upon all the moperty and humb hereby conveyed in trust.

The" revitals and statements herein, and in said bonds and conpons contained, sare only the eertiticate of authentication by the 'Trustee, shall be taken as statements liy the party of the lirst part, and shall not be considered as made by or as impering any ohligation or liability upen the Trustee, nor shall the 'Trustee be held responsible for the leginlity or rididity of said bonds or conpons under any provisions of the laws of , or otherwise.

And it is further eorenanted and agreed that the Trustee may resign and disclarue itself of the trust hereby created by notice in writing to the

Company to be given at least three moniths before such resignation is so given. It a vaciney in the office of Trustec hereunder shall oceur, a new 'Trustee slall be appointed is follows:

'l'en lisss' notice shall be given to each holder of the bonds hercby secured, apprising them of the fact that a change of Trustee hereunder is mecessary, and that muless objection is made within ten days from the date of sueh notice by a majority of the bondhollers, a new 'T'rustec, to be designated in said notiee, will be appointed. If the majority of the bondholders disapprove of the choice designated for sueh m.W Trustee, the matler shall be left to the present Trustec, the said Trust Company.

In executing this indenture the Trustee makes no covenant or representation as to the title or interest of the Company in, or to, the property de. seribed therein, and it shill be no part of the duty of the Trustee to see that any of the property intended to be convesed in trust hereunder is properly and legally subjected to the lien hereof.

It is cxpressly understood that the Trustce shall be under no duty or liability in respect to any tax which ma be assessed against the property or against the owncrs of the bonds hercby secured, in respeet to the property hereby conveyed, nor shall the Trustec be under any dinty to pay, or see to the payment of, such tax, or take any notice thereof to the holders of the bonds secured bercby, or any other person, and for any expense or liability which the 'Trustee may ineur by reason of, or growing nut of, any such tax, the T'rustec shall have a lien on the property hereby scanted prion tio the lien of the bonds hereby secured.

The Trustee shall have the right to require proof of the ownership of any bond by the production of the bond. The holding and date of holding of bonds by any bondholder executing any paper or instrument provided for herein, and the amounts and issuc number of the bonds held by such person may be proved by a certificate in writine exceuted by any depository approved by the Trustce showing that such person han on deposit with such depository the bonds described in such certificate at the date therein mentioned.

In ease any bond seeured hereby shall become mutilated or lost, then upon the surremler of such mutilated bond to the Trustee, or upon filing with the Trustee evidenee of sueh loss, and giving indemnity which the Trustee shall consider satisfactors, the Comprany in its discretion may issue, and the Trustee may certify a new bond bearing the same serial number and in identical form in subistitution or exchange for the brond so mutilated or lost.

Whenever in this deed of trust the existence of any situation, matter, conclusion, or fact of any character, or the suffieiney or validity of any iustrument, paper, or procereling, or of any prof or evidence of any fact of any claracter, shall be preseribed as a condition of, or in any manner with respect to, any action or proceeding on the part of the 'Trustee, or shall be deemed necessary to be ascertained by the Trustce as the basis of an opinion by the Trustec, a certified copy of a resolution of the Company, together witb a certificate of the President and Vicc-l'resident, Treasurer, Secretary of the

Company, verified 
under oath, shall in the discretion of the Trustee be sufficient cridence of any such fact, situation, matter or conclusion stated therein, and shall be complete proteetion on its part upon the fitith thereot; but the Trustee may, in its reasonable diseretion, require other evidence.

The Company corcnants and ayrees that it will pay the Trustee hereunder its necessary tees and expenses in the exceution of the trust hereby ercated.

In Witness Whereof, the party of the first part has eaused these presents to be signed by its President, and its corpolate seal to be herento allixcl, and attested by its Secretary and the praty of the second part, in tohe'n of its atedentiune of alde trusts and the obligations hereby imposed upon it, has cansed these presents to be signed by its second Vice-President, and attested by its Secretary, and its seal to be hereunto affixcd, the day and vear tirst hercin written.

\begin{tabular}{|c|c|c|}
\hline & By & $\begin{array}{l}\text { Compars. } \\
\text {,President. }\end{array}$ \\
\hline & By & , nice-resisten \\
\hline
\end{tabular}

State of

County of \} ss.

Before me, , a Notary Public, in and for the Connty of Slate of , on this day fursinally alpeatred

, knowin to me to bis the person whose name is subseribed to the foresumer instrument, and hum to me to be the P'resident of the

Conmpany, a corporation, anul anckunwledgred to me that he executed said instrument for the purposes and consideration therem expressed and is the act of said corporation.

$$
\begin{gathered}
\text {, Notary Public, } \\
\text { Co. }
\end{gathered}
$$

\section{State of
County of ss.}

Bufore we, State of , on this diay Netary Public, in

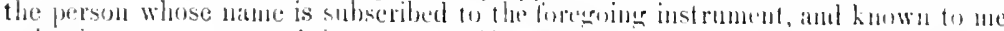

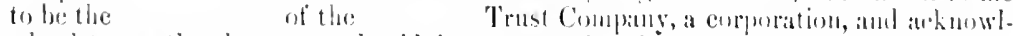

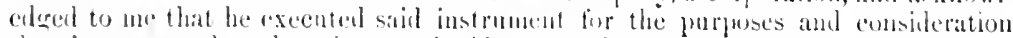
therein expressed, and as the act of sail corperation.

$$
\text { , Nolury Pulbic, }
$$

\section{AFFIDAVIT OF MAILING NOTICE OF S'TOCKHOLDERS' MFETING.}

Sirite of $\quad$ Conty of

lir is the Sorrertary of the

ilug andere the latso of the Stite of

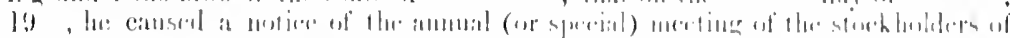

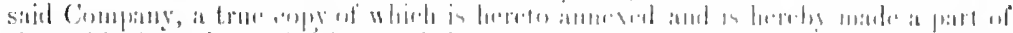

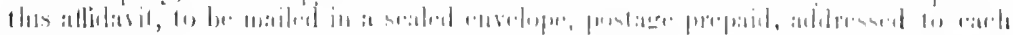

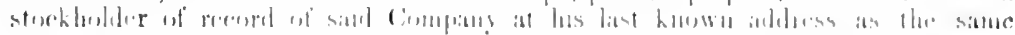
appesars on the busho of the Complanty.

Sworn aud sulsoribed to before we this

$$
\begin{aligned}
& \text { laty of , I!! . } \\
& \text {, Sutury I'ullie. } \\
& \text { (a)mity }
\end{aligned}
$$




\section{FORM FOR CER'IIFICATE OF AUTHORIZATION TO COUNTERSIGN CERTIFICATES OF STOCK.}

$$
\begin{aligned}
& \text { The Coupany, } \\
& \text {, Registrar. }
\end{aligned}
$$

This is to Centify, That at a meeting of the Directors of the Comprang, duly conrened and held on the day of, 190 , the following resulutions were adopted:

kisuleed, That the

Company be and is hereby appointed the licgistar of the shates of the stock of this Company.

F'thether kesolved, 'That said Company is anthorized to countersign, when sinned by the P'resident and Secretary of this Company, an original issue of certilieates of shares of this Conupany to the number of shares of Common stock and shares of Preferred Stock, and to enter the partienlatrs of the holdings of said shatres in the register from time to time.

Further lesuled, 'That the

Company may apply and act under instructions of

, Counsel of this Company, in respect to any legal question arising in eomneetion with said Agency.

Further Resulied, That the Secretary be and is hereby authorized to sign, and seal with the Company's Seal, a Certitieate of Authorization to said Company in the form submitted at this meeting.

That the cotal authorized ecpital stock of said Company is $\$$ into $\$$ of Common Stoek and $\$$

That said shares are the par value of $\$$ of Preferred Stock. , divided

That certifieates of stock are now outstanding.

'That the property for which the above-mentioned shares are issued has been actually convered of lamsicried and delivered to the Company.

'That the Uiticers authorized by the foregoing resolutions to sign certificates of stock will sign as follows:

'The l'resident will sign

'The Secretary will sign

Nimes of Officcrs.

Addresses.

$$
\begin{aligned}
& \text { President, } \\
& \text { Vire-President, } \\
& \text { Treasurer, } \\
& \text { Secretary, } \\
& \text { Altorney, }
\end{aligned}
$$

Names of Directors.

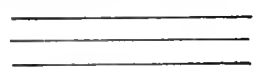

Addresses.

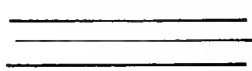

Business address of the Company,

Date of Annual Heeting,

Notice fur calling Ammual Meeting as required by the By-Laws.

Signed and sealed in behalf of the Company by authority of the Board of Directors, this day of, 190 .

For the Company,

, Secretary.

$\left.\begin{array}{l}\text { State of } \\ \text { Comlnty of } \\ \text { On the day of }\end{array}\right\}$ ss.

eame

deprose and say that he resided in in the year , to me known, who, bcing by me duly sworn, did ; that he is the

instrument; that he kinew the seal of said corporation; that the seal affixed to said 
instrument was sueh eorporate seal : that it was affixed by order of the Board of Directors of sild Corporation, and that he signed his name thereto by like order. Sotary Public.

Counts.

\section{UNDERWRITING AGREEMENT.}

\section{CUMPAYY.}

Covering Tear, First Mort,ige, per cent, Sinking Fund, Coupon

Gold Bonds; redeemable at and interest.

Dated , 190 .

Interest Payable

\section{Trustee.}

Tuts Agreanest, made and entered into this diy of and between of the eity of

, State of

first put (hereinafter called "the Maumers"), and the several subscribure th this syndieate atgrecment, parties of the secont part:

Whereas, the parties of the first bat have oreanized a eorporation known as the Company," nuder the laws of the State ut, with a capital of divided into shatres of the par value of 5 each, which will isithe

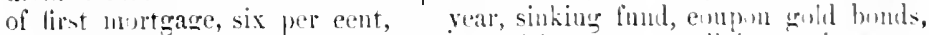
subject to eall at and acermed interest, of which will he wad an part payment of the property purehased and will be keft in the treanury for its usc, leaving whieh are hereby underwritt'n.

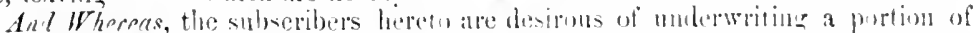

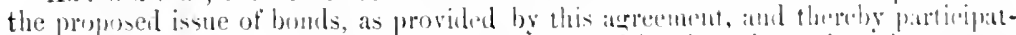

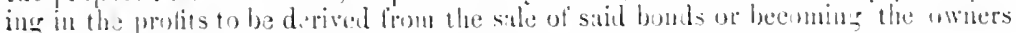
therent. Nin, this agrement witnesuth :

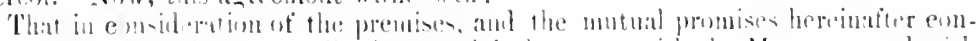

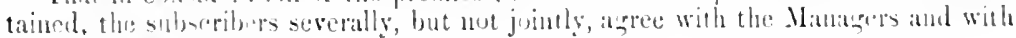

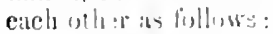

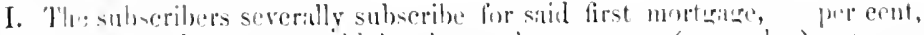

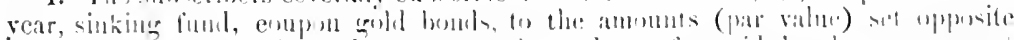

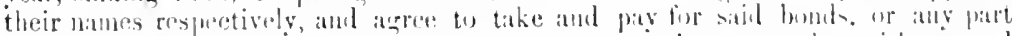

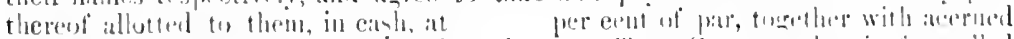

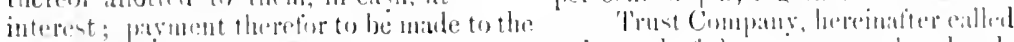

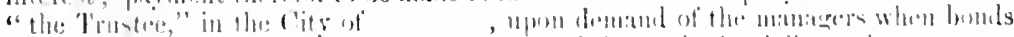

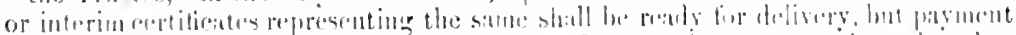

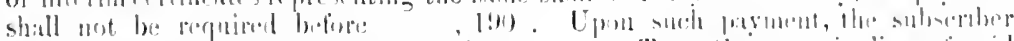

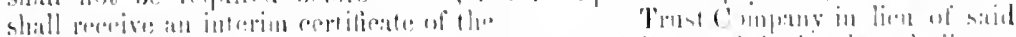

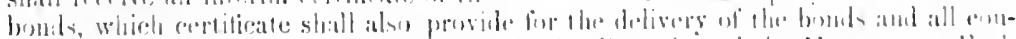

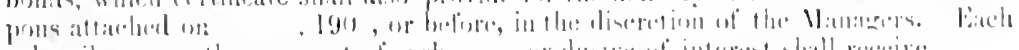

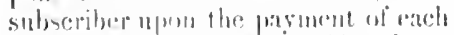
frar value of lomile afiriesaid and

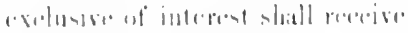
par value of llar said utuek.

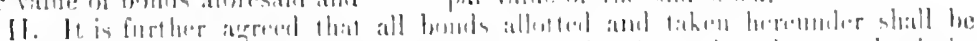

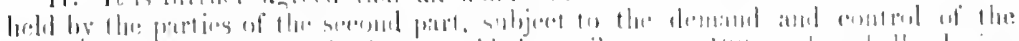

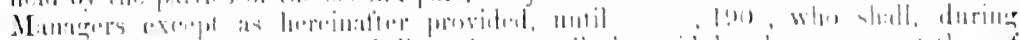

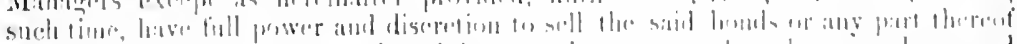

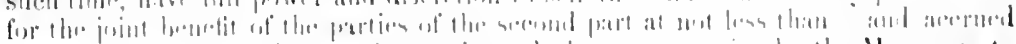

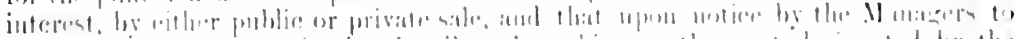

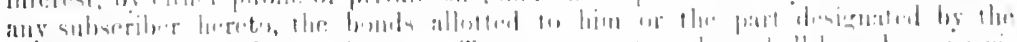

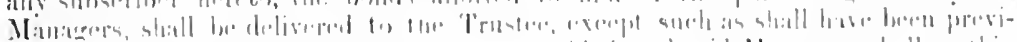

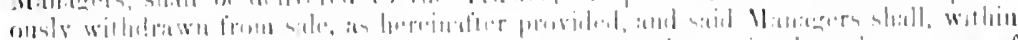

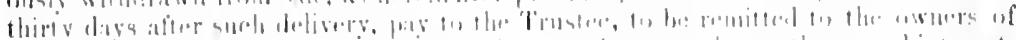

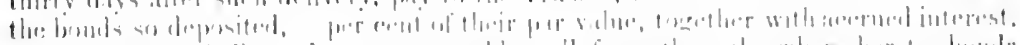

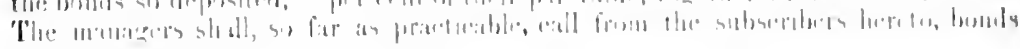
pro rellit.

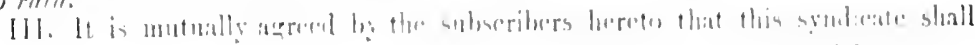


huld all of the sitid bonds subseribed for as a joint loolding for a period of six months

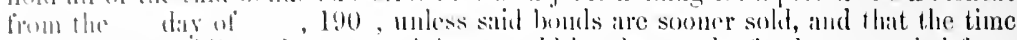
for the joint heiding of any rematining unsold bonds may be further extended for a preriod to be determined hy a rote of two mhirds in interest of the subseribers. Any

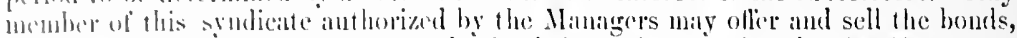
as opportunity veeurs, at a priee to be fixed firom time to time by the Mamagers: satil prier, howerir, not to bo less than and acerued interest, to the syndieate,

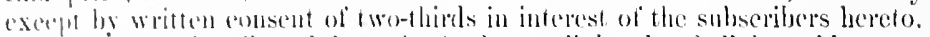

11. Any subseriber duly anthorized to sell bonds, shall be paid a commission of nene pre exentum of the pate value of the bonds sold by him, said commission to be faid by the Manatgers and eharged to the symdicate at fhe time of such sale and delivery ; any syndieate member selling any bonds shall at the time notify the Mana-

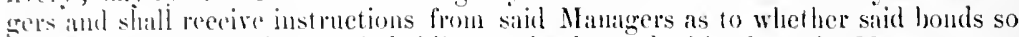
sold shall be delwered from his holding, or bo drawn by him from the Managers.

In the erent of his being instructed to detiver his own bonds, he shall immediately renit to the said 'lruster, 10 the eredit of the Mtangers, the diflerence bet ween the cost, vis.: and interest, and the selling price of the bonds; and in the event of dratwing them from the Miunagers, he shaill pay the 'l'rustee, lor the erelit of the Mantarers, lor the bonds, at the full authorized selling priee, together with acerued interest to date of delivery.

V. Any subseriber liereto may withdraw his bonds from this underwriting agrement, proviled sueh subseriber notifies, in writing, the Mamagers, at the time of sirning the mulerwriting arrecunent, of his or their intentions so to do; such party so withdrawing bonds ingrees, dlming the life of the underwriting agrecment and any extension thereof, not to offer for sale or sell any of such bonds, and waves prolits, exeept stock hereunter.

VI. The right and power to enforce this agreement, when the same shall become binding, operative and effectire, is hereby vested exelusively in the Managers, who alone shall have the right to cnforee payment of all obligations assumed by the subscribers liereto.

VII. In ease for any reason, whether before or after this agreement las otherwise become binding, operative, and ell'etive, the Lamagers shill determine to abandon this underwriting plan, and the organization of the corporation, and shall so deckare, then this agreement in all its parts, ineluding the obligation to deliver said bonds or any of the stoek, shatl be and beeme lorth with null and roid, and the subseribers hereto shall be notilied accordingly by the Managers, and all moneys paid lierenuler shall be returned.

ViII. The T'rustee shatl be the depository of the Mamagers and shall hold the joint funds and protits arising heremuler, and shall distribute the same from time to time in accorlance with the dircetions of the Manigers, pro rata anong the subscribers hereto, except that it shall paly therefiom the commissions and expenses arising lecreunder.

IX. The manterers shall recire no eompensation for their services as Nanagers and slatl not be liable under any of the provisions of this agreement, or in or for any matter therewith commected, provided reasonable care and discretion shall have becn "xereised by them in the diseharge of their daties.

X. T'lis agreenent shall be binding upon the parties of the second part only when subscriptions hereto shall have been made to the extent of at least

Right is resered to reject any subscription or to allot a less amount than that subseribed for.

In Witness Whereof, the parties of the first part have signed an original hereof, and the subscribers, parties of the seemal part, have signed said original or a counterpart thereof, all of which shall be taken and deemed as one criginal instrument.

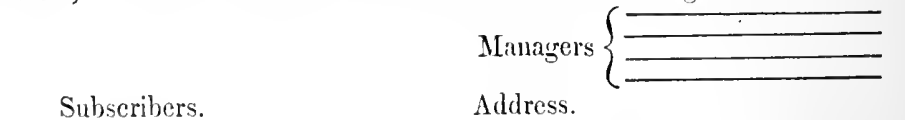

$\frac{\text { Subseribers. }}{5 \pm 1}$




\section{VOTING TRUST AGREEMENT.}

This Agremest made this the undersigned, stochtolders of the part, and Trust Company, party of the second part:

Witnesseth, That in consideration of the munal eovenints and agreements hereinafter set forth, and in further consideration of the sum of one dilliar by each wi the parties paid to the others, the receigt of which is hereby acknowhelend, the sat parties to this agreement herebs asree by and with each wher as fulluws, to wit:

First. 'l'he said parties of the first prirt do hereby assign ant trinster amt atere to deliver unto the said party of the second part, the number of shares of sterch of

the

the State of party of the second part until the

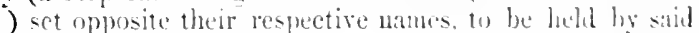
dity of , 190 ; in trust, lmwever, for said parties of the tirst part, their executors, abministraturs, and assigus, at all times subject to the terms and enditions hereinatier set forth.

Second. Said parties of the first part do hereby cosenant and agree that sitid party of the second part as voting trustee for said parties of the first part, shatl. for a period of

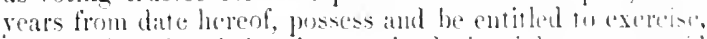

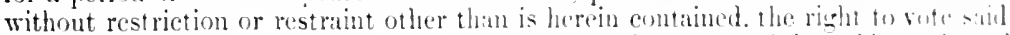
shares of stock in said Cimplany hereby eonveyed by said prartin's of the first part to said parts of the second part.

Thisd. The said pary of the second part does hereby promise and azere with

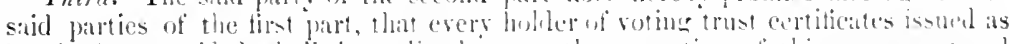

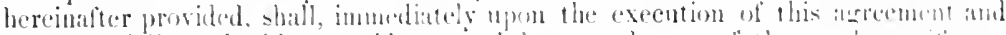

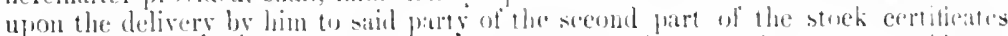
hereby assigned, receive from said party of the seemel part roting trus eertificates to an argregate amount erpual to the anument of stoch so delivered, which certiticate shall be in the following form, to wit:

\section{VOTING TRUST CERTIFICATE.}

\section{ISSEFE) BYY TII}

\section{'T'uest Conpasy.}

Tuis is to Certify, hiat

[iuscrt mane of stuckluglder] will

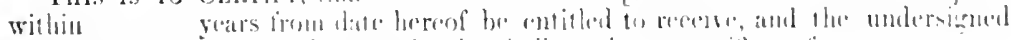

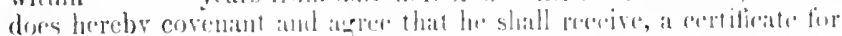

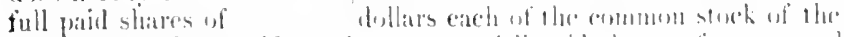

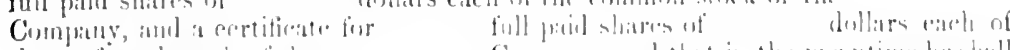

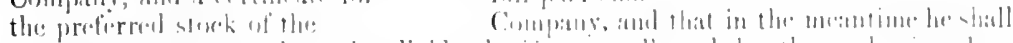

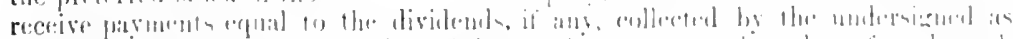

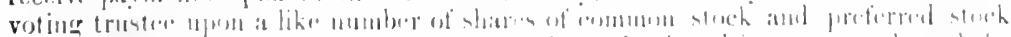

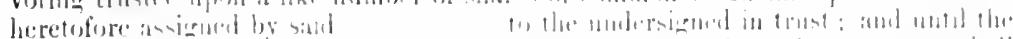

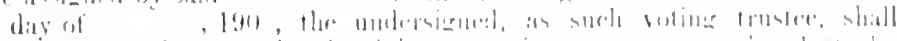

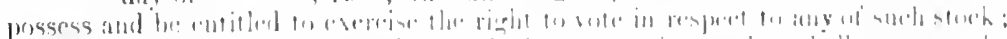

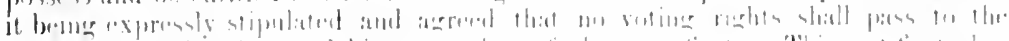

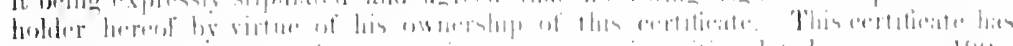

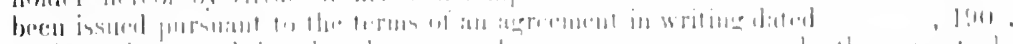

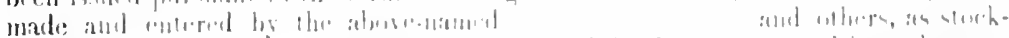

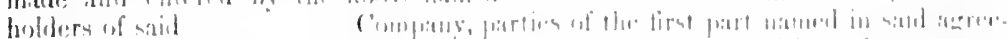

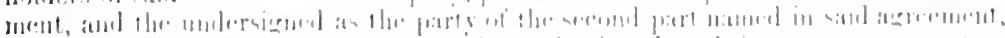

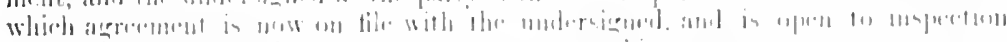
at ally fime he the sitil

oir lim : :

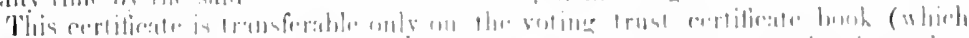

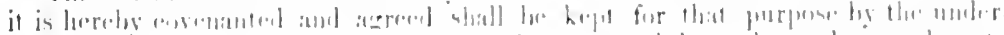

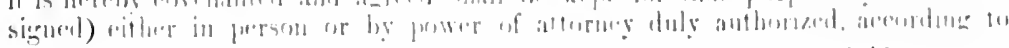


rules which hav been established for that purpose by the undersigned and upon surremele hereof: and mintil so transfered the mulersigned may treat the registered holder as the owner hereof for all purposes whatsoever, exeept that delivery of such certiticates herein shall not be made withont the surrender hereof.

In Wilness Hhereof, the said

Trust Company has caused these presents to be signed by its President and its Corporate Seal to be heremto affixed, and to be atrested by its Secretary this

Attest : Trust Conliny,

, Secretary.

, President.

Fourth. That cach and all of the covenunts and agrecments containcd in the foregoing form of roting trust certilicate are hereby made part and parcel of this arreement, and shall be and are hereby made binding upon the several parties to this angeement, their executors, administritors, suecessors, and assigns.

Fifh. At any time mil the expiration of this agreement as liereinbefore prorided, the said jaity of the second part may receive any additional full paid shares of the capital stock of the Comprany, either common or preferred, mpon the terns and conditions of this agrcement, and it shall deliver in exchange therefor roting trust ecrtifieates as hereiubefore provided.

Si.cth. In roting stoek held by it, the said party of the second part shall cxercise its best julgment and diseretion at all times in roting for the election of suitable Airectors for said

Company, to the end that the affairs of the Company shall be carefully and intelligently managed, and in voting on all other matters which may come before it at any stockholder's' meeting of said Company, shall exereise like judgment and discretion.

Seventh. It is hereby corenanted and agreed that the said party of the second part shall not be liable or incur any responsibilits by reason of its acts of omission or commission in the premises, except for wilful misconduct or gross negligence in the cxecution of the trust hereby ereated, and which is hereby aecepted by said party of the second part.

In Witness Whereof, the sevcral parties to this agrcement have hereunto set their hands and seals this day of, 19 .

\section{CERTIFICATE OF INCORPORATION}

$\mathrm{OF}$

\section{Uyited States Steel Corporation (as Amended) (New Jersey Charter).}

Te, the undersigned, in order to form a corporation for the purposes hereinafter stated, under and pursuant to the provisions of the Act of the lesrislature of the sitte of New Jersey, entitled "An Act concerning Corporations (Revision of 1S96)," and the acts amendatory thereof and supplemental thereto, do hereby certify as follows:

I. The mame of the corporation is United States Steel Corporation.

II. (Clanse designating office and agent in New Jersey.)

III. The objeets for which the eorporation is formed are :

To manulieture iron, steel, manganese, coke, enper, hmber, and other materials, and all or any articles consisting, or partly consisting, of iron, stecl, copper, wood, or other materials, and all or any products thereof.

'To acquire, own, lease, occupy, use, or develop any lands containing coal or iron, manganese, stone, or other ores, or oil, and any wood lands, or other lands for ans purpose of the Company.

"To mine, or otherwise to extract or remove, coal, ores, stone and other minerals and timber from any lands owned, acquired, leased, or occupicd by the Company, or from any other lands.

$$
\tilde{\jmath} \pm 6
$$


To bur and sell, or otherwise to deal or to traflic in urou, stecl, manganese, copper, stonc, ores, coal, coke, wood, lumber, and other nuaterials, and any of the products thereof, and ally articles comsisting or partly consisting therent.

To construet bridges, buildings, machincrs, ships, boats, enerines, ears, and other equipment, railroads, locks, slips, elevators, water works, unts works, and lletrie works, viaduets, aqueducts, cantals, and ofler water-wats, and any other means of transportation, and to soll the same, or otherwise to disjose thereof, or to maintain and operate the same, exeept that the Company shall not maintain or operate any railroad or eanal in the state of New Jerser.

To apply for, obtain, register, pureliase, lease, or otherwise to acquire, and to hold, use, own, operate, ant introduce, and to sell, assign, or otherwise to tismose of, any trade marks, thide nauses, patents, inventions, inumovements, and proersses used in eonnection with or sceured under letters patent of the Unitul states, or elsewhere or otherwise, and to use, cxereise, develop, grant lieenses in respect of, or otherwise to turn to acconut any such trate marks, patents, license's, processe's, and the like, or ans such property or rights.

To engage in any other mannficturing, mining, construction, or transportation business of any kind or character whatsorver, and to that end to aequire, hell, own. and dispose of any and all property, assets, stocks, bonds, and rights of any and every kind, but not to engate in any business hereunder which shatl require the axereise of the right of eminent domain within the State of New Jerser.

To aequire by purchase, subscription, or otherwise, and to hould or to dispose of. stocks, bonts, or any other obligations of any eorporation formed for, or then or herctofore chagaed in or pursuing, any one or more of the kinds of husiness, purposes, objects of operations absere indicated, or owning or holding any noropery of any kind lerein utentioned, or of any conporation owning or holding the stoeks or the obligations of any such eorpromation.

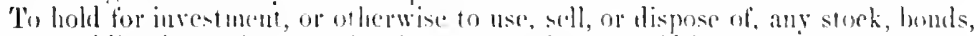

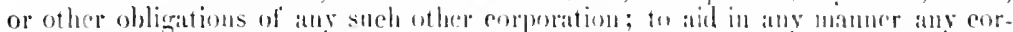

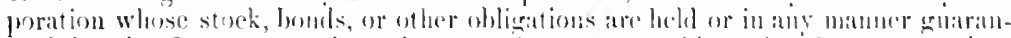
teed by the Comprays, and to do any ofher aets or thinges for the preservation.

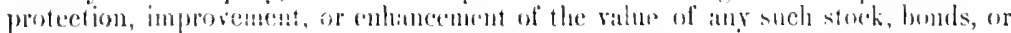

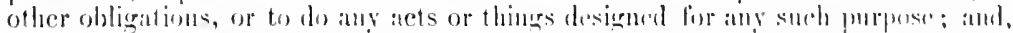

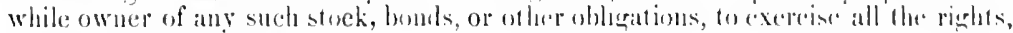
powers, and privileges of ownership thereof, and to exereise any and all wother power therens.

The business or purpose of the Company is from time fo time to do any ome or

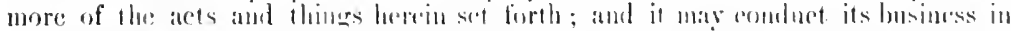

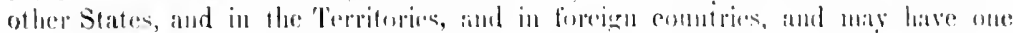

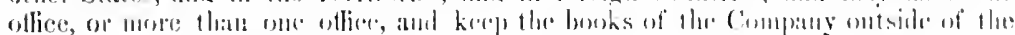

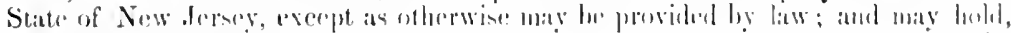

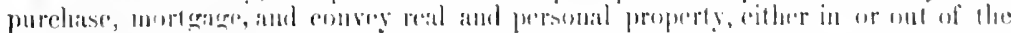
State of Now Jerner.

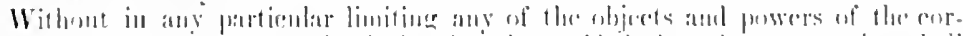

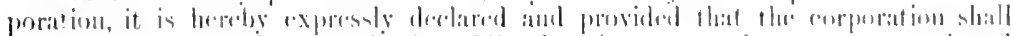

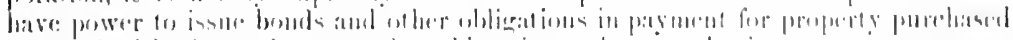

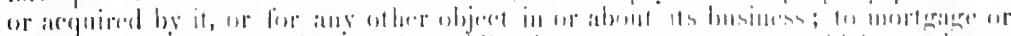

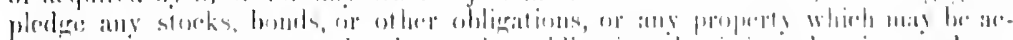

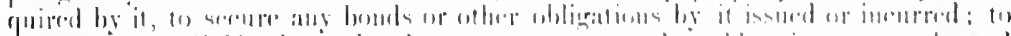

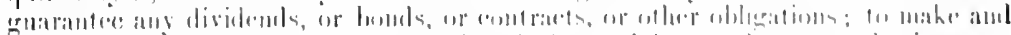

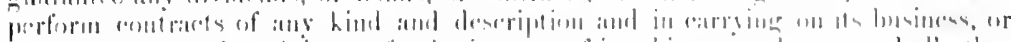

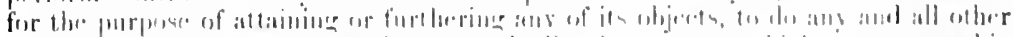

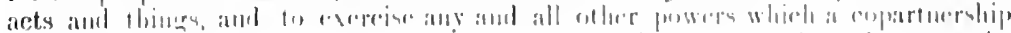

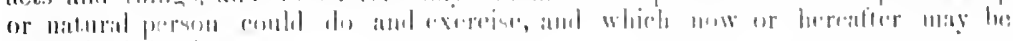
anthorizend by law.

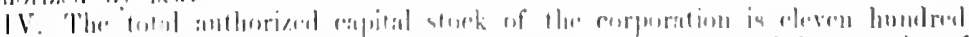

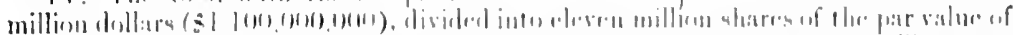

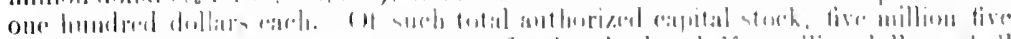

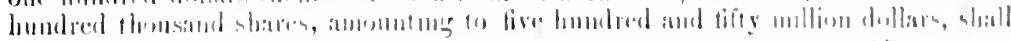


he preferred stuck, and tire million five humded thousand shares, amomiting to five humelod and tify million doblars, shall be eommon stock.

From time to time, the preferred stock and the common stoek may be increased aceording to law, and maty be issued in such amounts and proportions as shall be

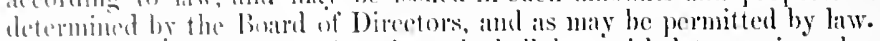

The lonklers of the proferred stuck shill be entitled to receive when and as declarel. from the surphus or net profits of the eorjoration, yearly dividends at the ritte of seren pere centum per anmm, and no more, payable quarterly on dates to be fixpt by the by-lues. The divithemts on the prefermel stock shall be eumulative, and shill be parible before any dividend on the common stoek shall be paist or set aplert ; so that, if in any perir dividends amounting to seven per eent shall not have been patil thereon, the ileticieney shitl be payable before any dividends shall be paid upon or set apart for the common stoek.

Whenever all eumulative dividends on the preferred stoek for all previous years shall have bern declated and slatl have become payible, and the acerued quarterly instalments for the eurrent year shall have been declared, and the Company shail lave paid such commlative dividends for previous years, and such aeerned quarterly instalments, or shall have set aside from its surphins or net profits a sum suffieicnt for the parment thereof, the Board of Directors may deelare dividends on the common stoek, payable then or thereatier, ont of any remaining surplus or net profits.

In the event of any liquidation or dissolution or winding up (whether voluntary or involuntary) of the corporation, the holders of the preferred stoek shall be cntitled to be paid in full both the par amount of their shares, and the unpaid dividends acerucd therem, before any anount shall be paid to the holders of the common stock; and after the parment to the hollers of the preferred stock of its par value, and the unpaid aecrued dividents thercon, the remaining assets and funds shall be divided and paid to the holders of the commou stock according to their respective shares,

V. The names and post-office addresses of the ineorporators, and the number of shares of stock for which severally and respectively we do hereby subseribe (the augregate of our said subscriptions being thousand dollars, is the amount of capital stock with which the eorporation will commence business), are as follows:

(IIcre follow the names and post-office addresses of each of the incorporators, and the number of slares of stock sulsocribed for by cach.)

V1. The duration of the corporation shall be perpetual.

vil. The number of Directors of the Company shall be fixed from time to time by the by-litw; but the number, if fixel at more thim three, shall be some multiple of three. The Divertors shall be classified with respect to the time for which they shall severally hold office by dividing them into three elasses, cach consisting of onethird of the whole number of the Botrd of Dircctors. The Directors of the first class shiali be elected for a term of one year; the Directors of the sccond elass for a term of two vars ; and the Directors of the third elass for a term of threc years; and at each annual clection thic suecessors to the class of Direetors whose terms shall expire in thit year shall be elected to hold office for the term of three years, so that the term of office of onc elass of Directors shall expire in each year.

'The number of the Dnectors may be increased as may be provided in the by-laws. In ease of any inerease of the nimber of the Directors the additional Directors shall be cleeted as may be provided in the by-laws by the Directors or by the stockholders at an annual or special meeting ; and one-third of their mumber stall be clected for the then uncxpired portion of the term of the Dircetors of the first class, one-third of their mumber for the mexpired portion of the term of the Direetors of the sceond class, and one-third of their nmmber for the unexpired portion of the term of the Directors of the third class, so that each elass of Directors shall be inereased equally.

In case of any vacaney in any elass of Jircetors through death, resignation, disqualification or other canse, the remaining Dircetors, by affirmative vote of a inajority of the Board of Directors, may eleet a sucessor to loold office for the mexpred portion of the term of the Direetor whose plaec shall be vacant, and until the rlection of a suecessor.

$5+8$ 
The Board of Directors shall have power to hold their mectings outside of the State of New Jersey at such places ats from tume to time mas be desingated by the br-laws or by resolution of the Board. The by-laws mas maseribe the muber w Directors necessary to constitute at quorum of the Buald if loirecturs, which number may be less than a majority of the achole number of the bitertos.s.

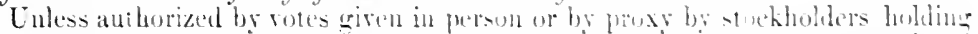
at least two-thirds of the carpital stock of the corporatim. whith is reprerented and

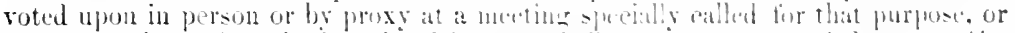

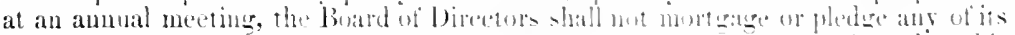

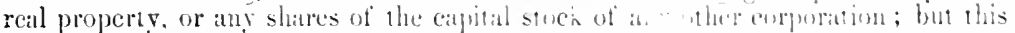

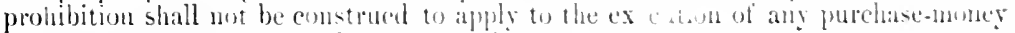
mortgrage or aus wher purchase-mom? hem.

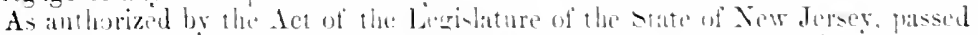

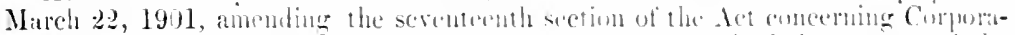

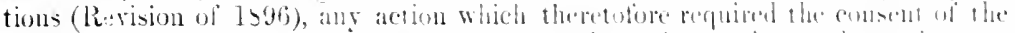

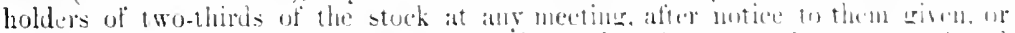
required their consent in writing to be tiled, mat be taken ugon the consme wh, and the consent griven and fited by, the holders of two-thirds of the stuck of rach elins represented at such mecting iu persou or by broxy.

Aus oflicer clected or appointed by the boatd of birectors may be remered at any time by the atfirmative vote of a imajority of the whole linard of birectors.

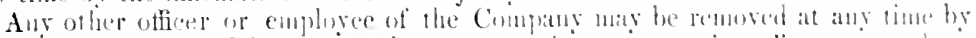

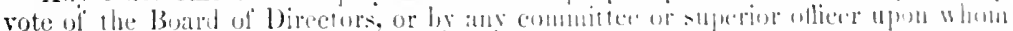
such power of renoval mag be confered by the by-tias or by a sote of the board of Directers

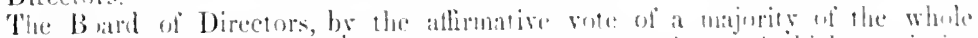

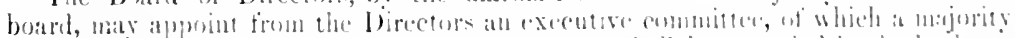

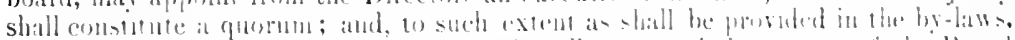

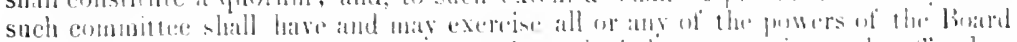

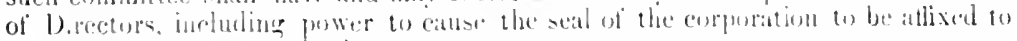
all patpers that maty retpuine it.

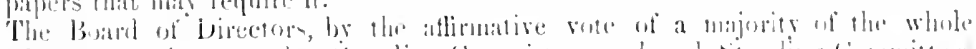

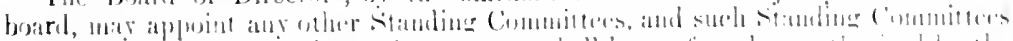

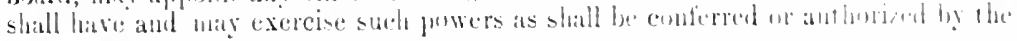
by-laws.

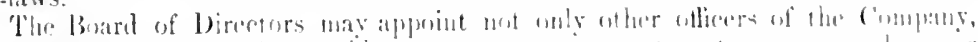

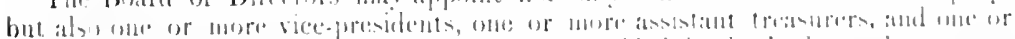

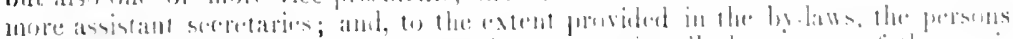

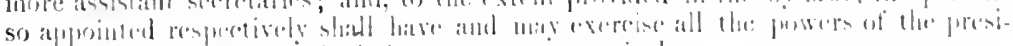

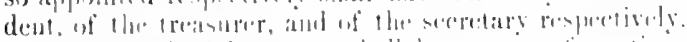

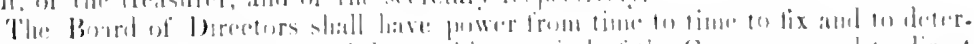

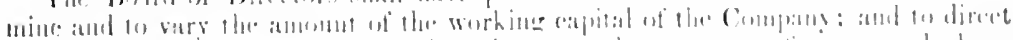

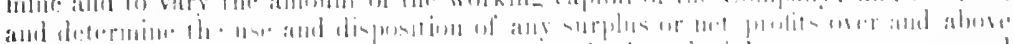

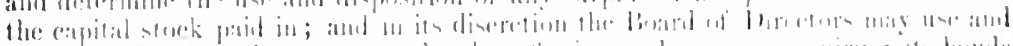

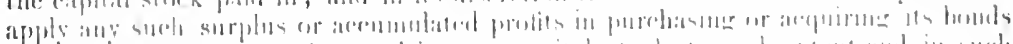

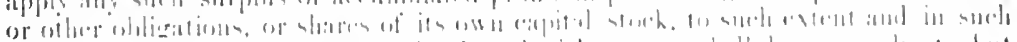

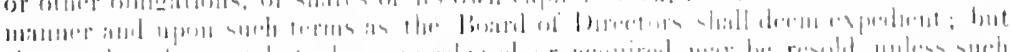

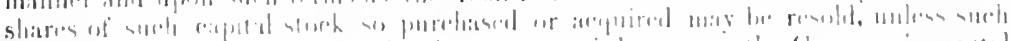

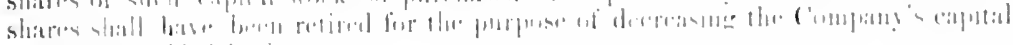

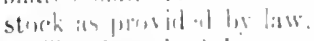

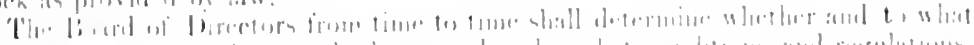

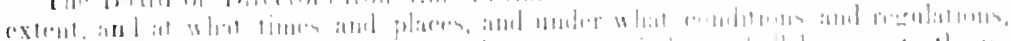

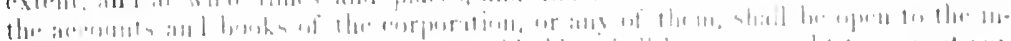

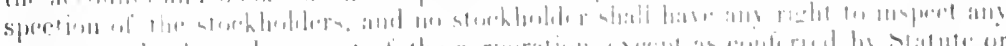

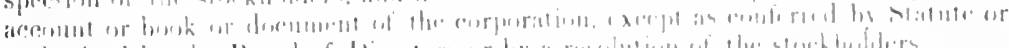

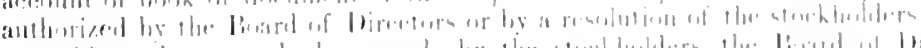

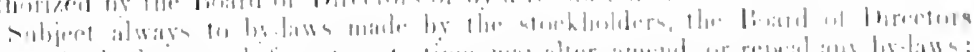

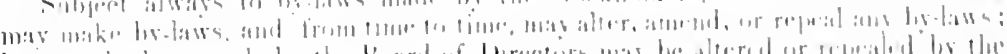

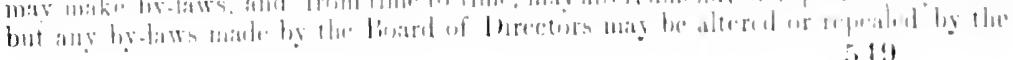


strekholders att any annunl meeting, or at any special mecting, provided notice of such prenpused alderation or repeal be included in the notice of the meeting.

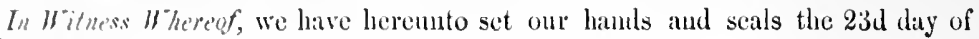
Fibruary, 1901.

(Sigriatures of Incorporators.)

\section{CERTIFICATE OF INCORPORATION}

$\mathrm{OF}$

\section{Aoditing Company (New Jersey Cirarter).}

Article 1. The corporate name is:

ARTICLE 2. The objects of the corporation are:

'To open, take chirge of', maintain, keep, institute, examine, audit, certify to, and guniantee the correetness of the books and aceomts of all persons, firms, partnerships, corporations, banks, trust estates, trust companies, Building and Loan Assuciations, beneticial associations, and all other natural or corporate beings whittsoever.

To furnish all persons, firms, partuerships, and corporations with complete and modern srstem or systems of auditing and accounting, and to act as controller or auditor thereof, and to issue certificates of efficiency to accountants.

'T'o act as a collecting agrency for its patrons, take assirnuncuts of claims against debtors of its patrons and others, and sue thereon in its own name, il not prohibited, to act ats mereantile agency, to investigate and recommend persons desirous of doing business with its patrons and other's, and to issue ccrtificates as to the responsibility of persons, firms, partnerships, and corporations.

To make and keep, by means of photograthy or otherwise, complete and aceurate copies or records of the books and accounts of all persons, firms, partnerships, corporations, trust estates, Building and Loan Associations, beneficial associations, municipalities, and the records of all other natural or corpomite beings whatsoever.

Said corporation shall indemnify and save harmless its patrons from any and all costs or expenses, loss or tlamage, arising ont of any error committed by said corporation or its agents in the duties aforesaid, and said corporation hereby expressly waives all rights to any benefits of any statute of limitation now in force or hereinafter to be cinacted.

As subsidialy objects and powers the corporation may

Mamuficture, purchase, or otherwise aequire, roods, wares, merchandise, and personal property of every elass and deseription, and hold, own, mortgage, sell, or otherwise dispose of, trade, deal in, and deal with the sanc.

Aequire and unlertake the good will, property, rights, franchises, and assets of every kind and the liabilities of any person, firm, partnership, or corporation, either partly or wholly, and pay for the same in cash, stock, or bonds of the corporation or oflerwise.

Enter into, make, perform, and carry ont contuats of every kind and for any lawful purpose with any person, firm, association, or corporation.

Borrow or raise money without limit as to amount by the issuc of, or upon warrants, bonds, debentures, and other negotiable or transferable instruments or otherwise.

Ilold, purehase, or of herwise acquire, sell, assign, transfer, mortgage, pledge, or otherwise linpose of shares of the eapital stoek, bonds, debentures, or other evidenees of indebtedness ereated by any other eorporation or corporations, and while the owner thereof exereise all the riglits and privileges of ownership, including the right to vote thereon.

Trs apply for, purchase, or otherwise acquire, and to hold, own, use, operate, atnd to schl, itssign, or to otherwise dispose of ; to grant liecnses in respeet of, or to otherwise turn to acennt any and all inventions, improvements, processes, and trade unirks used in emmection witl, or secured under, letters patent, or eopyright of the Cinitad States of Aneriea, or elsewhere or otherwise, and with a view to the 


\section{FORMS AND PRECEDENTS.}

working and development of the same, to carrs on anr business, whether mannacturing or otherwise, which the eorporation may think ealeulated directly or indirectly to effeetuate these ohjeets.

Condnet business in any of the States, Territories, eolonies, or depentheies of the United States, in the Distriet of Colmmbia, and in any and all forelinn eonntries; to have one or more offiees therein, and to hold, purelase, and ennses and morterase real and personal properts without limit as to amomit therein, but al iwats subject to the laws thereot.

Remuncrate any person or corporation for serviees remtered, or to be rendered in placing or assisting to place or guaranteeing the placing of any of the hatres of the eapital stock of the corporation, or any debentures or other seculities of the corporation, or in, or about the formation or promotion of the corpulition, or in the conduet of its bus ness.

Subject to the prorisions of law, purchase, hold, and reissue the shitres of its capital stock.

Do any and all the things herein set forth to the same extent as natural persons might or could do, and in any part of the world.

In general, the corporation maty earry on any other busmess in eonnection with the foregoing, whether mamulacturing or otherwise, and hatse and exrreise all the powers conferred he the laws of New Jersey upon eorporations formol muler the act hereinafter reterred to; it being hereby explessly movided that ilue funeruing enumeration of specifie powers slatl not be held to limit or restriet in any: manner the general powers of the eorporation.

Antele 3. The eorporation shall be anthorizel to issue eapital shet to the

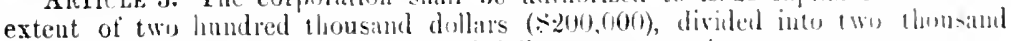
shares of the par value of one lumidred dolliars (slou) each.

Article t. In furtherance and not in limitition of the powers cunferred by statute, the Besird of Directors ance exponsoly antlanizad:

To hold their meetings, to have one or hione oflioe, and to kiep the bonks of

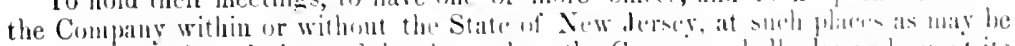

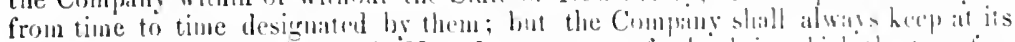

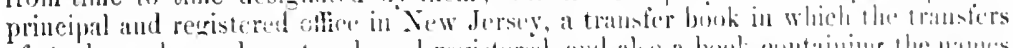

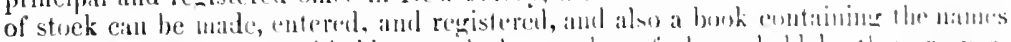

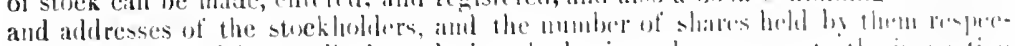
tively, which whall be at all times during the business lours open tij the inspetion of the stuchtordders in persum.

To deterutue from time (1) time whether, and, if allowed, muder what anditions

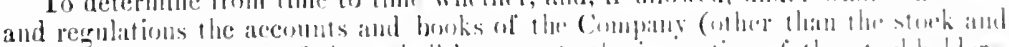

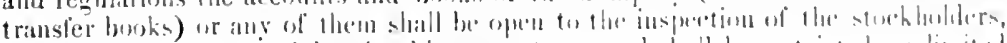

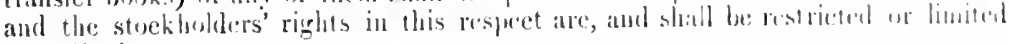
aceordiunsty.

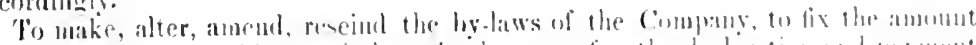

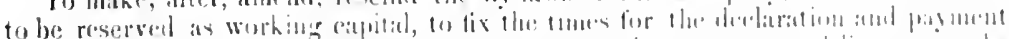

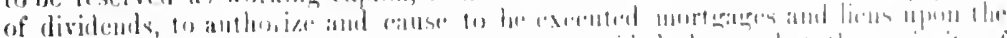

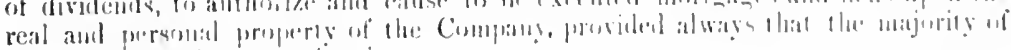

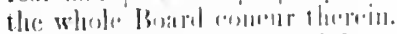

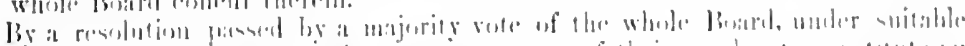

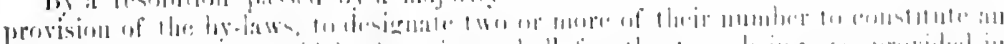

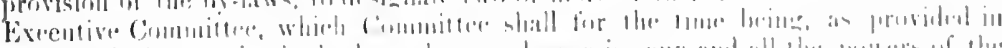

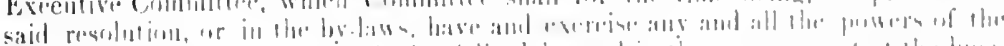

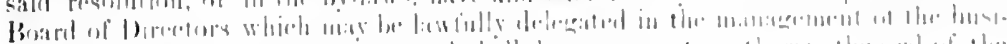

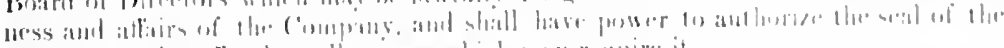

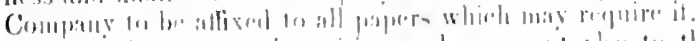

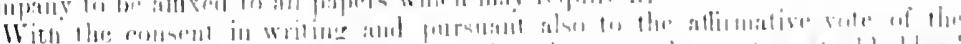

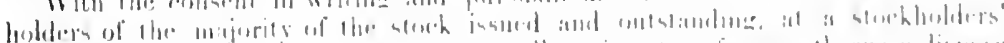

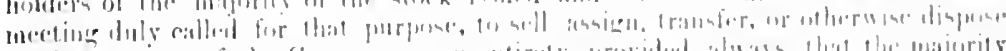

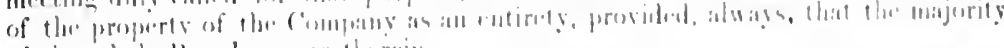

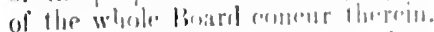

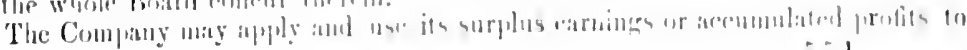
$\therefore i 1$ 
the purelase or aequisition of property, and to the acquisition and purchase of its own eapitil sterk from time to time, to such extent and in such manner, and upon stede trous ats its board of birectors may determine; and neither the property nor

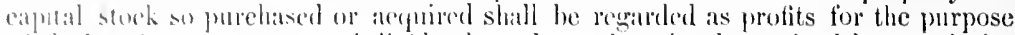
of denlantion or pirment of dividemls, unless ofherwise determined by a majority of the biatral of loirectors.

T'lar comporation reserves the right to anend, alter, or repeal any provision contained in this ecrtitieate of ineorporation, in the manner now or lerealter prescribed ly statule, and all rights eonferred to stoekholders are granted subjeet to this rescreationt.

Alf disputes between members of the corporation, or between it and its patrons, shall be seltled by anbitation; the party elaimant delivering personally or by Luitud states mail to the party defendant at his home or place of business, the claim veritied by atticlarit, to which elaim the party defendant shall have sixty days to reply. 'The party elaimsut may then appoint an arbitrator, giving written notice thereof to the party defendant, who shall within ton days appoint the second arbitrator, or the first arbitrator shall then make sueh appointment, both of said arbitrators to be rersed in the subjeet matter of dispute; said two arbit rators shall then appoint the third who shall be learned in the law and shall preside over the Board, whose hearings shall be held at such time and place as may be fixed by the Board. Upon due notice, the parties shall submit in writing to said arthitrators all the liacts verified by affidavit, and may be heard by counsel. 'The deeision of said arbitrators, or a majority of them, shall be final and eonclusive and withont appeal. If the award is not sctiled or eomplied with within twenty days, the suecessful party, if the awird is for moner, may file the same in the Contrt laving jurisdiction and proceed to exceution and sale in the usual course for the enloreement of said award; or, in case the award is in equity, the successinl party may file a bill reeiting only these proeeedings and the award, and praying for thic aid of said Court to enforce compliance therewith.

Articte 5. (Clause designating offiee and agent in New Jersey.)

In aceordance with an Aet of the Legislature of the State of New Jersey entitled "An Aet Concerning Corporations" (Revision of 1896) and the Acts amendatory thereof and supplemental thereto, for the purpose of forming a corporation of unlimited dnration to do business within and wilhout the State of New Jersey, the undersirned do respectively sulsseribe for the eapital stock with which the corporation will begin business, and do agree to take the number of shares set opposite our names, and have accordingly sinned this certilicate and affixed our seals thereto. No, of Shares

Name. taken by each Subscriber.

Amount

\section{CERTIFICATE OF INCORPORATION}

OF

\section{Brokerage Company (New York Cirarter).}

We, the undersigned, being all persons of full age, all being citizens of the Enited States and all residents of the State of New York, desiring to form a Stoek Corporation pursuant to the provisions of the Business Corporations Law of the State of New York, do hereby make, sign, acknowledge, and file this certificate for that purpose as follows.

\section{NAME.}

First. The name of the proposed corporation is:

\section{OBJECTS.}

Second. The purposes for whieh it is formed are to buy, sell, negotiatc, exchange pledge, trade, and deal in and with shares, stocks, debcntures, scrip, bonds, and se552 
curitics of any government, State, or public or private corporation, or any corporate bods; to trade and deal in and with real estate, mines, motals, minnrils, and cill. cotton, grain, produce, or other commodities; to invest in any or cither of the foregoiug, ind from time to time to ehange the investments if the Comprany; to mortgige, pledge, or of herwise chatre all or any part of the insesments of the Company or its property and rightss ; to make adrances on, sell, or dispese of any property or investments; or 10 act ats agent, fictor, or broker for any or eitleref of the corperite

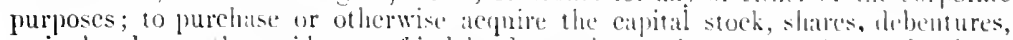

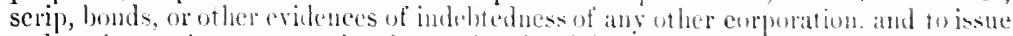
and exchange its own stuek, shares, bonds, debentures, serip, or wher evidences

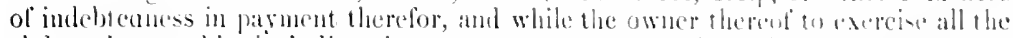
rights of ownership, inchding the prower to vote upon sueh stuch ur shitrs; fo pur-

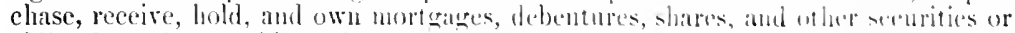
obligat ions of any public, private, or muncipal corporation, on bouds or wher securi. ties or obligattions of the Gorermment of the Luted States, of of ans Statte district,

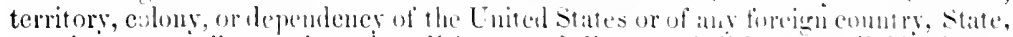
or colony ; to collect and receive, disburse and dispose, of all interest, dividende, ate-

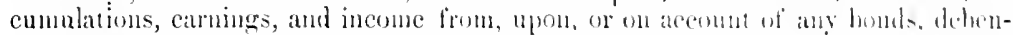
tures, stocks, shares, securities, contratets, evidences of debt, obligations, wr uther property lield or owned by the corpuration thereto; to do any and all lawhel ats tending to increase or conhane the ralue of the property of the Cimprany; to issure

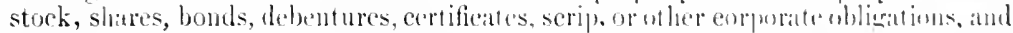

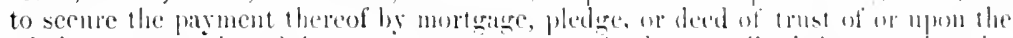

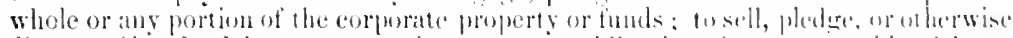
dispose of bonds, debentures, or otheremporate abligations for proprer and law ful eor-

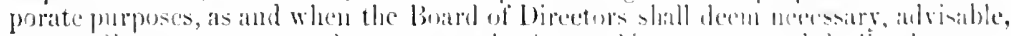
or expediant: to promote the emporatle business of investment and dealline in secur-

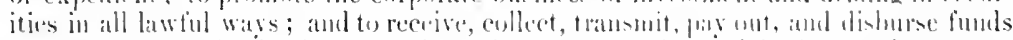

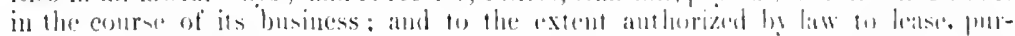

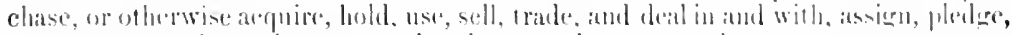

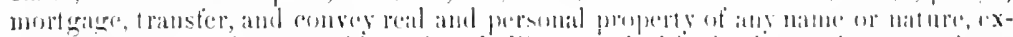

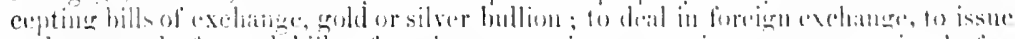

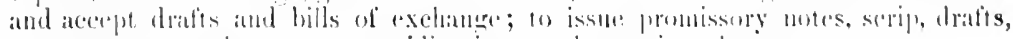

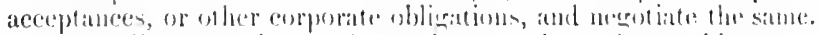

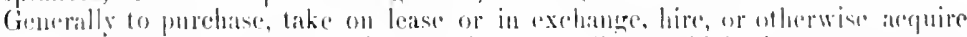

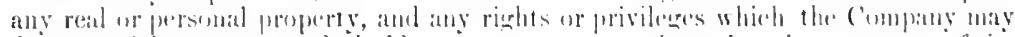

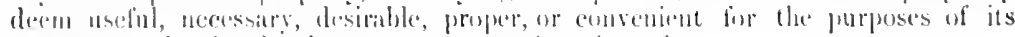
business or in the development or extension thered.

\section{Amocit of Cantal, Strock.}

Therel. The amount of retpital storek is dolliars (s. of capital with which the Company will beriu husiness is

). Thir antement dullars

\section{Nenurk rit SHalles.}

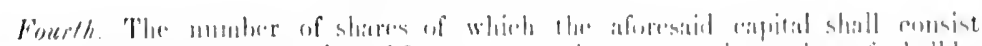

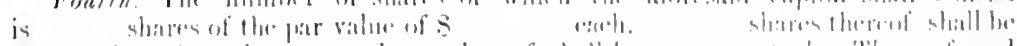

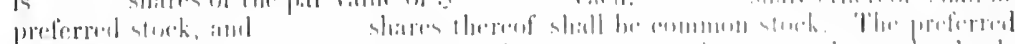

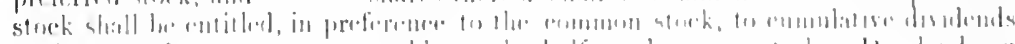

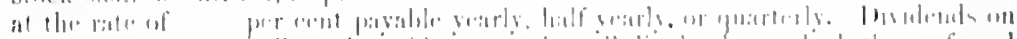

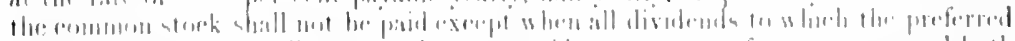

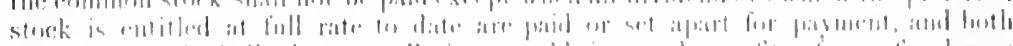

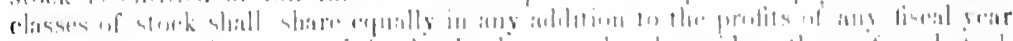

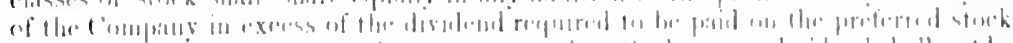

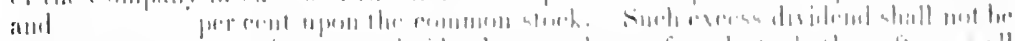

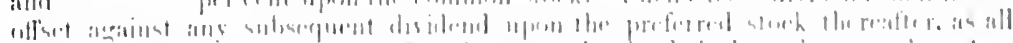

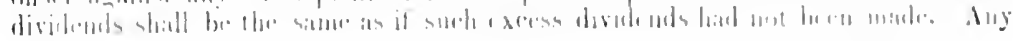


distribution of assets ofher tham prolits shall be paid, as far as the same will go, firs upon the prefirmed st ele to the amount thereof, and its per cent cumukatue dividends that atre mupad if any, less the amount paid thereon, iu any previous distributien of such assets; next upon the eommon stoek to the amount of the pia therem, less the amomit, if ally, paid thereon in any previous distribution of such assets, and then upon the two classes of stock equally per share.

\section{Principal Office.}

Fifth. The principal office of this Corporition is to be located in the Borough of Maulattan, in the City, County, and State of New York.

\section{Duration.}

Sirth. Its duration is to be perpetual.

\section{Number of Directors.}

Seventh. The number of its Directors is to be

\section{Directors for the First Year.}

Eighth. 'Tlie names and post-office addresses of its Directors for the first year are as follows :

Names.

\section{Post-Office Addresses.}

\section{Subscribers to Capital Stock.}

Ninth. The names and post-offiec addresses of the subseribers, and the number of shares which each agrees to take in the corporation are as follows:

Tenth. The Direetors need not be stockholders of the corporation. A majority of the stoekholders slatl be necessary to constitute a quorum for the transaction of business at any meeting of the Board, but a less number may adjourn such meeting. All Diretors shall hold offiee until the election of their suceessors, and Directors sliall not be subject to removal during their respective terms.

Vacancies in the Board of Directors may be filled by the remaining Directors, provided there is present at the neeting at which suel vacuncy is filled a majority of the full Board of Direetors as authorized by the eertifieate of incorporation.

The Direetors may hold their meetings, have an office, and keep the books of the corporation, exeept the stock book, out side the State of New York.

The Board of Direetors by the allirmative vote of a majority of the whole Board may appoint an Executive Committee of three members of the Board, of whom a najority shall eonstitute a quorum. Sueh Exeeutive Conmittee shall have any and all powers of the full Board of Directors whieh may be lawfully delegated. The t(rm of offiee of each member of sueh Committee shall continue until the expiration of his term as Director and until his sucenssor shatl be eleeted: vacancies in this eommittee slall be filled by the Boand of Dircetors.

liy-lats may be made ly the Board of Dircetors except as otherwise provided by law, and may be altered in sueh manner as may be therein provided.

Strokholders shall have no right exeept as eonferred by statute or by the by-laws of the corporation to inspeet any books, pilpers, or aceounts of the corporation. The transfer books of the corporation maty be elosed by order of the Board of Directors or the Exeeutive Committee for thirly days or any shorter time, before any meeting of the stockholders and until the day after the final adjournment of such inecting.

In Witness Whereof, we have made, signed, acknowledged, and filed this ccrtificate. Dated, February, 190 . 


\section{CERTIFICATE OF INCORPORATION.}

\section{Trust and Inigstext Compari (Delawake Chakter).}

This is to Centify, that the undersigned do hereby associatr themselves to establish a comporation under and be vintue of the provisions of an tet of the General Asscubly of the State of Delaware, entitled "An Aet P'mriding a General Corporation Law," and do severally agree to take the number of share's of capital stock as hereinafter stated, and that

\section{First.}

The name of the corporation is

\section{Compaxy.}

\section{Second.}

The principal office or place of business of the corporation in the State of Delaware is to be located in the City of Wilmington, New Castle County, and said office is to be registered with

\section{Third.}

The nature of the business and the oljects and purposes proposed to be transacted, promoted, or carried on by the enrporation are als follews:

To carry on a banking and trust complany business, and in munction there-

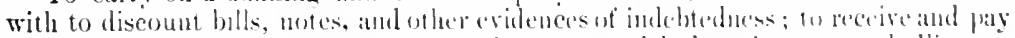

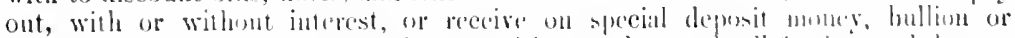

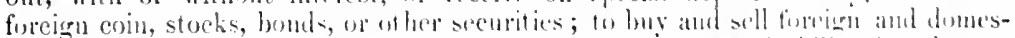

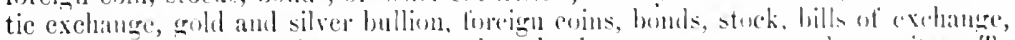

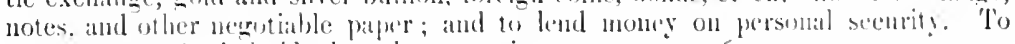
act ats trustee for indwilluals and corporations.

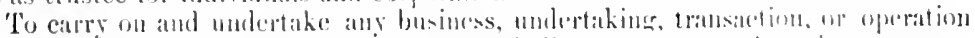

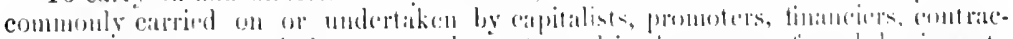

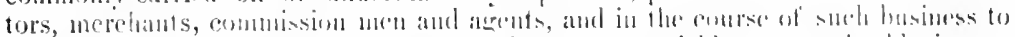

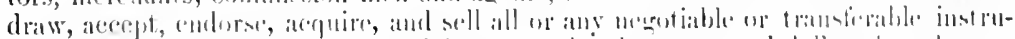

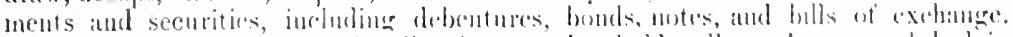

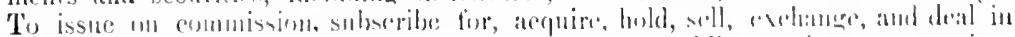

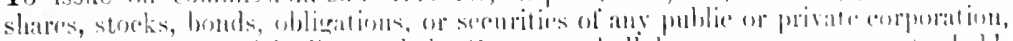

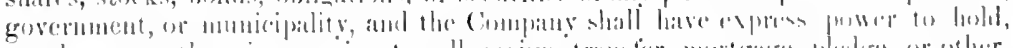

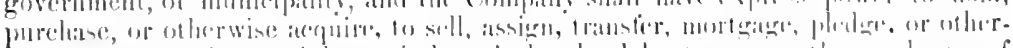

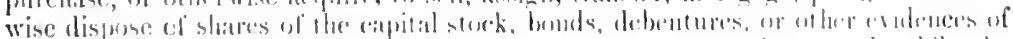

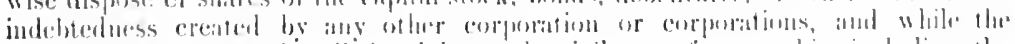

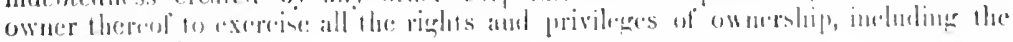
right to vote therent.

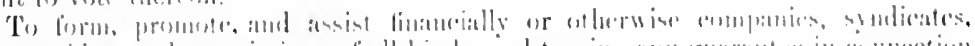

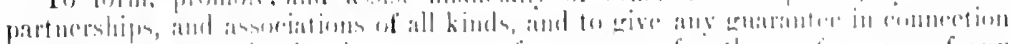

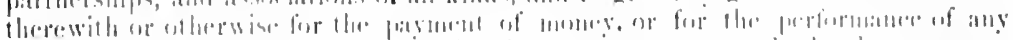

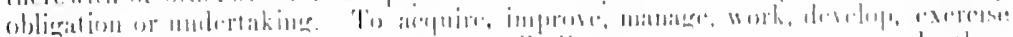

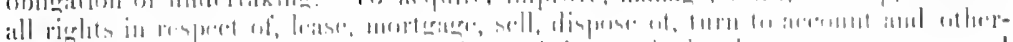

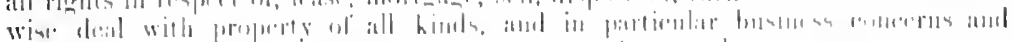

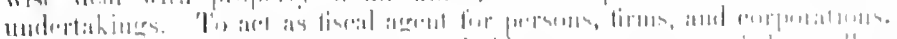

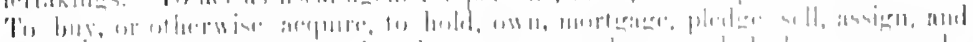

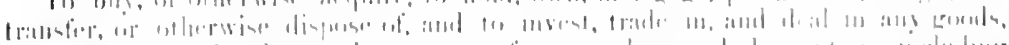

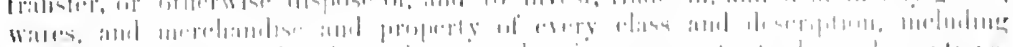

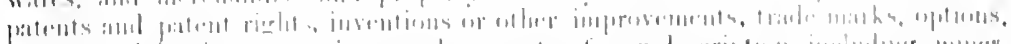

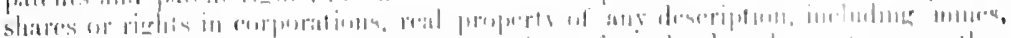

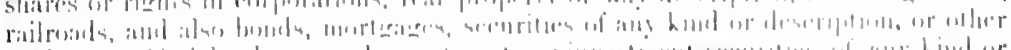

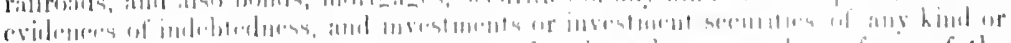

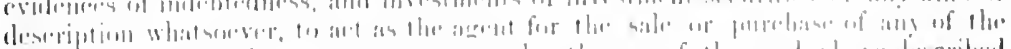

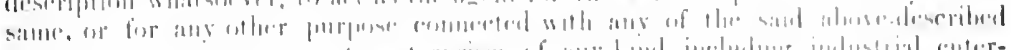

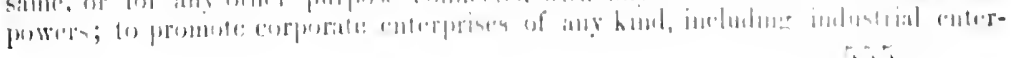


prises, railnads, mincs, real estate companies, banking institutions, and all busimess's (1) cuterprises of any charater, and to own and operate or fintme the same; to alid in any mamner any eorporation or enterprise in which the Company is interested: tio cultorse, milerwrite, or guarante stock, securities, or undertaking of any renperation or persons.

'Ti mine money by the isste of shares or otherwise, and to invest the moneys so raised in the purehase of, or otherwise to actuire and hokd any of the investments following, that is to say, any stocks, bonds, debentures, shares, serip, or seeurities issued. or having any guarantec by any governunent, munieipality, trust, local antherity, or other hody, incorporated or unineorporated, public or private, of the Luited Siates, or in any comntry or State muler the protetion of the United States, or any stock, bumls, d bentures, shares, serip, or seenrities issucd or having any entraninte by any corporation or emmpany incorporated, constituted or carrying on business in the United States or elsewhere.

'lu borgur or raise money by the issue or sale of any bonds, mortgages, debentures, or debenture stock of the Company, and to invest any money so rassed in any such inverstments ats atoresitid.

'To acquire any such investments as aforesaid by original sulscription, underwriting, participation in syndieates or otherwise, and whether or not fully paid up, and to make payments thereon as called for, or in advanee of calls or otherwise, and to muderwite or subseribe for the same conditionally or otherwise, and either with a riew to investment or for re-sale or otherwise, and to vilry the investments of the Company, ant generally to sell, exchange, or otherwise dispose of, deal with, and turn to account any of the assets of the Company.

'To negrotiate loans, to ofler for public subseription, or otherwise aid or assist in placing any such investments as afuresaid; to give any guarantec in relation to any such investments issued by or aequired througl the Company or otherwise.

To ofle for publie subseription any shares or stuck in the capital of, or debentures or kehenture stock or other securties of, or otherwise to establish or promote, or eoneur in establshing or promoting, any company, association, undertaking, or public or private body.

To guarantee the payment of dividends or interest on any stock shares, debentmres, or ofher securities issued by, or any other eontract or obligation of any such company, association, modertaking, or public or private body.

'To jurehase, lease, hire, or otherwise acquire real and persomal property, improved and unimproved, of every kind and description, and to sell, dispose of, lease, convey, and nortgage said property, or any part thereof ; to acquire, hold, lease, manage, operate, develop, control, build, creet, maintim lor the purposes of said Company, eonstruct, reconstruet, or prurehase either directly or through ownership of stock in any corporation, any lands, buildings, oflices, stores, warchouses, mills, shops, factories, plants, gas houses, machinery, rights, easements, permits, privileges, framehises, and lieenses, and all other things which may at any time be necessary or eonvenient in the judgment of the Board of Direetors for the purposes of the Company. 'T'o sell, lease, hire, or' otherwise dispose of the lands, buildings, of other property of the Company or any part thereof.

'To hold, purchiss, or otherwise acquire, to sell, assign, transfer, mortgage, pledtre, or otherwise dispose of shares of the eapital stock and bonds, debentures, or other evidences of indebtedness created by other corporntion or corporations, and while the hother thereof, to exereise all the rights and privileges of ownership, inchinger the right to rote therem.

T'o couduet its business, and have one or more offiees, and unlimitedly and withont restrietion to hold, purchase, lease, mortgage, and comvey real and personal projerty in or ont of this State, and in sueh place and places in the several States, 'Territories, eolonial possessions, or territorial aequisitions of the United States, as shall from time to time be found necessary and convenient for the purposes of the Companu's business.

In General, to carry on any other business in conncetion therewith, whether mannfueturing or otherwise, and with all the powers conferred by the laws of Delaware under the aet hercinbefore referred to. 
It is the intention that the objects specified in the third paragraph slall, except where otherwise expressed in stid paragraph, be nowise limited or restrieted by reference to or inferenee from the terus of any of her clause or paragraph in his charter, but that the objects speeified in each of the clauses of this paragraph shath be regarded as independent objects.

\section{Fourth.}

The amount of the total authorized cilpital stock of the corporation is dollars (S) divided into sliares of the par ralue of dollars each. The amount of citpital with which the corporation will begin business is dollars.

$$
\text { Iifth. }
$$

The names and places of residence of the original subscribers to the capital stock are :
Names.
Residences.
No. of Shares.

\section{Sixth.}

The corporation shall have perpetual existence.

\section{Serenth.}

The prisate property of the stoekholders shall not be subject to corporate debts.

$$
\text { Eighth. }
$$

The offecrs and persons by whom the athairs of the corporation are to be eonducted are its Directors, who imat act throngh a l'resident, lier-l'resident, secre-

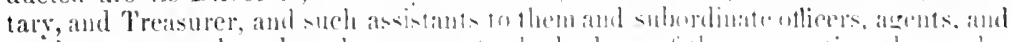

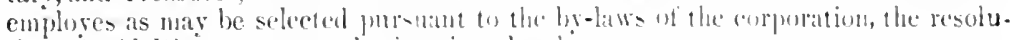
tion of said Directors, or anthority griven ly thiom.

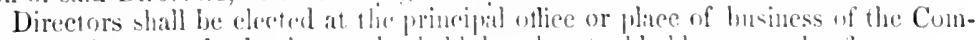
pany at the annual clection to bo held lye the stockluhlers on the first

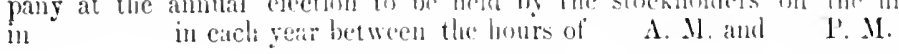

\section{linth.}

The Bond of Directors shall hase fower without the assent or vote of the strockholders to make, alter, anmmi, and repent the by-laws of this corpuration,

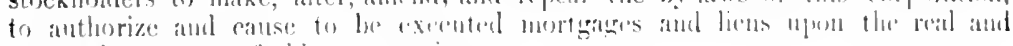

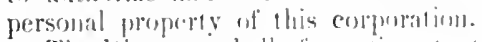

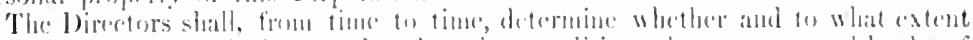

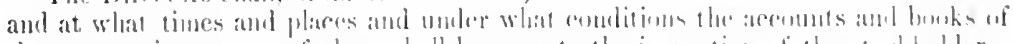

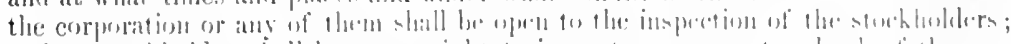

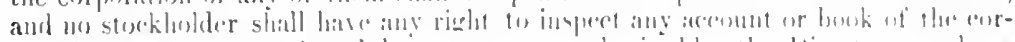

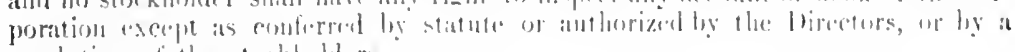
resolution of the storklindidrs.

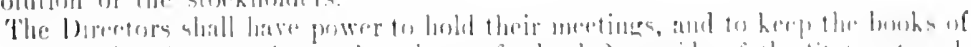

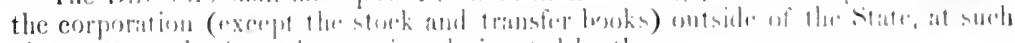

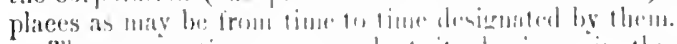

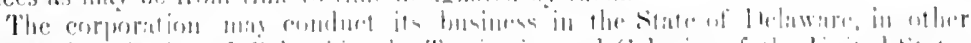

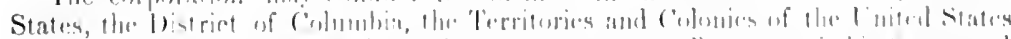

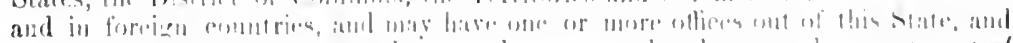

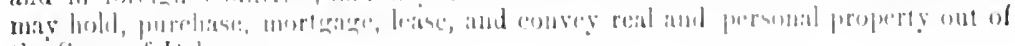
the: State: if I Mitwate.

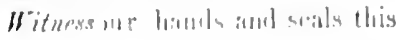
day of, 190 .

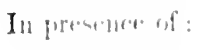




\section{CERTIFICATE OF INCORPORATION}

OF

\section{Oll Company (Soutil Dakota Cinartir).}

Kyow all Mex by tuese Presents: 'That we, the molersigned, , tor ourselves, our associates and sucecssors, have associated ourselves together for the purpose of forming a corporation under and by virtue of the statutes and latws of the State of South Dakota, and we do hereby certify and declare as fullows, to wit:

\section{First.}

The name of this corporation shall be :

\section{Second.}

The purposes for which and for each of which the corporation is formed are as follows :

'T'o purchase or otherwise acquire in the State of and other parts of the world, lands eontaining or believed to contain petroleum and other oil springs or deposits.

T'o earry on the business of producing, refining, storing, supplying, and distributing petrolcum products in all its branches; also to refine, store, and sell vegretable oils and animal oils. To eonstruct, purchase, lease, operate, and maintain pipelines and tanks tor the distribution and storage of oil.

'To purchase, sell, exehange, lease, or otherwise aequire real or personal property of all kinds in the United States of America or elsewhere, and in particular lands, oil wells, refineries, mines, mining rights, minerals, or buildings, machinery, plints, stores, licenses, concessions, rights of way, light or water, and any rights or privileges which may seem to the Directors convenient with reference to the business of the Company, and, whether for the purpose of re-sale, realization, or otherwise, to manage, develop, lease, mortgage, or otherwise deal with the whole or any part of such property or rights.

To prospect, explore, develop, maintain, and carry on all or any lands, wells, mines, or mining rights, minerals, ores, works, or other properties from time to time in the possession of the Company in any manner deemed desirable; to erect all necessary or convenient refineries, mills, works, machinery, laboratories, workshops, dwelling houses for workmen and others, and other buildings, works, and appliances, and to aid in or subscribe towards or subsidize any such objects.

To clear, manage, firm, cultivate, plant, and otherwise explore, work, or improve any land which or any interest in which may belong to the Company; and to deal with or otherwise tum to account any farm or other products of any such land.

To construct, maintain, alter, make, acquire, charter, lease, hire, or work private railways, tramways, wagons, private telegraph lines, telephones, steamers, ships, pipe lines, docks, reservoirs, wells, iqueducts, works, private roads, strcets, hotels, dwelling houses, factories, shops, stores, gas works, picr barges, boats, wharves, and other works, plants, or machinery of every deseription; and to contribute to the cost of making, providing, carrying on, and working the same; to cnter into contracts or arraugenents with any municipal or otlicr body, corporation, company, or person, as to interchange of traffic, runuing powers, joint works, or otherwise that mar seem to be expedient.

To carry on business as merchants, refincrs, warchousemen, chemists, storekeepers, cirriers, shipowners, builders, or contractors in the United States of America or elsewhere, and any other business that may seem directly or indirectly conducive to the developinent of any property of the Company or any property in which it is interested, or to benefit the Company; to acquire by grant, purchase, or otherwise, concessions of any property or privileges from any government or from any authority, supreme, municipal, or otherwisc, and to perform and fulfil the conditions thercof. 
To appls for, obtain, purelase, or oflerwise aequire any patents, brecets, inven. tions, licenses, conecssions, and the like in the Lnited stattes of Americal or elsewhere, conferring an exclusive or non-exclusive or limited riglit to llse. or any secret or other intormation as to any insention or process secret or oflerwise, that may seem eapable of being used for any of the purposes of the C'omplany. or the aequisition of which may seem ealentated directly or indirectly to benetit the Com-

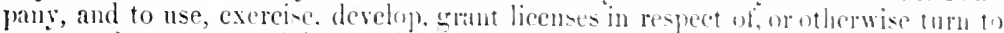
accomt the properts, rights, and intormation so acruired, with a riew tothe working and development of the same, and to carrs on such business, whether mant-

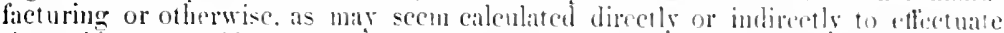
these objects, provided that none of the power's enumerated above shatl he comatrued as authorizing the Company to engate in any business that comes within the provisions of special statutes in South Datiotia.

To hold, purchise, or otherwise accplite, to sell, assien, trim-for, morterige,

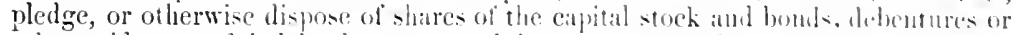
other evidences of indebteduess ereated by any enrpation or porjuratims, and while the holder thereof to exrecise all the rights and privileges of townership, including the right to vote thereon.

'To hase one office, to carry on all or any part of its operations and buninese and

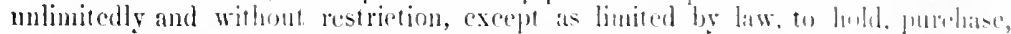

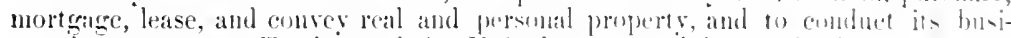
mess in any state or Territory of the Luited states and in any forcign comutry or place, but subject always to the laws thereot.

\section{Thirl.}

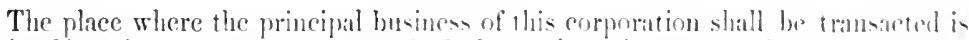

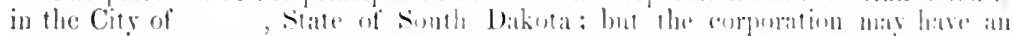

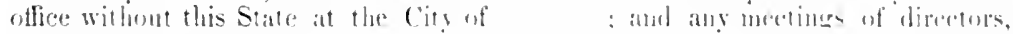

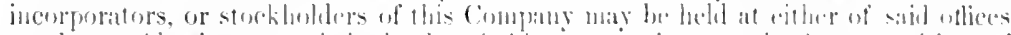

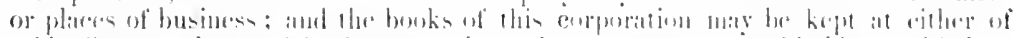

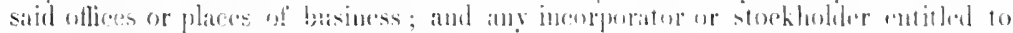

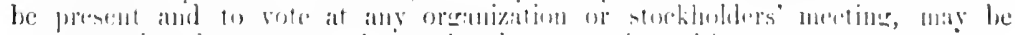
representerd and bole at such inecting hy proxy in writher

'The domiciliary ofties of this eorpuntion shitl be att the oflied of the in the aforesatid City of , south bathotil.

\section{Fisurth.}

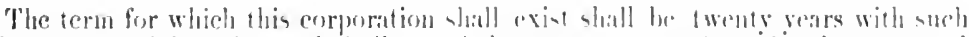
right of renewal for other and similar periods an may now or herealter he permuthd under the laws of Sonth Datiota.

\section{lith.}

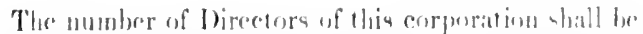
and rand liruetur

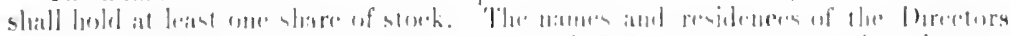

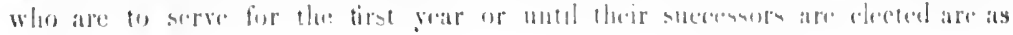
followy:

$$
\text { Xitures. }
$$

$$
\text { lingideners. }
$$

\section{Sirs!h}

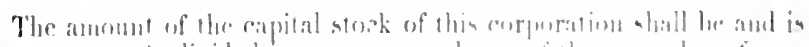
$(\$$

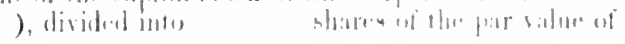

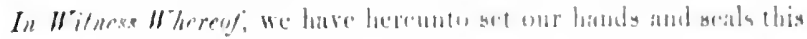
, 190.
}

cacl. 


\section{ARTICLES OF INCORPORATION}

\section{Minge Compay (Nevada Charter).}

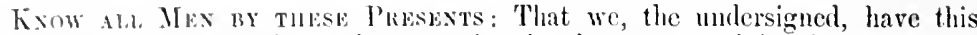
dar volumbrily associated ourselves together for the purpose of torming a corporativin under the laws of the State of Nevata. And we hereby eertify:

\section{First.}

The name of this eorporation is

\section{Company.}

\section{Second.}

The location of the prineipal offiee of this corporation in the State of Nevada is at of , in the City of, County of, Statc of Nevada.

\section{Third.}

The objects for which this corporation is formed are:

'T'o purehatse, loeate, take on lease, or ofherwise acquire any mines, mining rights, and lands in any part of the United States, and any interest therein, and to operate, work, and develop the same. Also to mine, mill, reduce, smelt, and prepare for market gold, silver, copper, and other ores, minerals, and metallie compounds. Also to earry on quartz, placer, and lode nining of all kinds and deseriptions.

'T'o eonstruet, purehase, or of herwise acquire, maintain, and operate flumes, water works, and irrigation ditehes for mining purposes. Also to purchase, construet, lase, operate, and maintain electric light and power plants, buildings, constructions, machinery, appliances, and equipments; 10 purchase, construet, lease, operate, and maintain private tramways, private railways, and private roadways.

'To buy, scll, and generally deal in, store, carry, and transport all kinds of goods, wares, and merehandise, provisions, and supplies.

'To acquire by diseorery, lease, license, bond, option, purchase, franchise, gift, devise. conreyance, agrement, or otherwise, and to hold, possess, enjoy, develop, and operate placer, guart, or lode gold, silver, or other mines, and tumels and tunnelling and mining property, and any right, title, or interest therein, as also such lands, mills, mill sites, tunnel sites, buildings, fixtures, dump and dump rights, flumes, pipes, and pipe lines, as may be decmed by the Directors for the time being to be necessary or proper for the proper working, development, exploration, or enjorment of the Compans's properties.

Also to treat or reduce ores or mincrals, to receive, slip, or transport ores, minerals, or supplies to or from any part of the workings upon the Company's property, or for the accomplishment of any other purpose for which the Company is firmermed.

'T'o hold, purchase, or otherwise acquire, to sell, assign, transfer, mortgage, pledtere, or otluerwise dispose of shares of the eapital stock, and bonds, debentures, or other evidenees of indebteduess created by other eorporation or corporations, and while the lobler thereof to exereise all the rights and privileges of ownership, incheling the rieght to rote thereon.

T'o eonduct its business and have one or more offiees, and unlimitedly and withont restriction to purehase, hold, lease, mortgage, and eonvey real and personal jroperty in or out of this State, and in such place or places in the several States and Territories of the United States, eolonial jossessions, or territorial aequisitions of the Cuited States, and in foreign eomntries, as slakll from time to time be found neeessary and eonvenicut for the purposes of the Company's husiness.

The Dirretors shall have the power to appoint three of their mumber as an Exceutive Commitee. Sueh Executive Committe when so appointed shall have and excreise all the powers of the full Board of Directors. The Directors shall 
have power to adopt, repeal, or ameud by-laws without referring the same to the stockholders for approval or rejection.

\section{Fourth.}

The total authorized capital stock of this corporation shall be dollars, divided into shares of the par vilue of dolliars each.

The amount of authorized stuch sulsseribed and paid up is dollars. The capital stoek shall be common stock, and the ternus upon which such steck is created is that it shall be issued for property to the full par value thereot, and such stock shall be issued as fully paid up, and the eapital stock of this corporation, after its full par value has been fully paicl np, or whieh has been isoucd as fully paid, shall not be subject to assessment to pay debts of the corporition.

\section{Fifth.}

The names and post-office aldresses and residences of each of the original subscribers to the capital stock of this corporation, and the anount subscribed by each are as follows:
Name.
P. O. Address
No. of Shares.
Amount and Residence. Subscribed.

Sixth.

The period of existence of this corporation is unlinited.

\section{Serenth.}

The members of the governing board of this corporation shall be styled Dircetors, aud shall be 190 .

In Witness Whereof, we have hercunto sct our hiunds this day of ,

\section{CERTIFICATE OF INCORPORATION}

\section{$\mathrm{OP}$}

\section{Conl Compasy (West Vhogram Chamter).}

I. We, the undersigned, agree to become a compration by the nane of CoMPayY.

II. The primejpat place of busin'ss and chinef works of sail corjumatim shall be located in the connty of

1II. The objects and purposes for which sabl corpuration is formed are as follows:

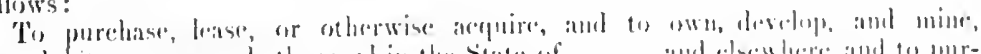

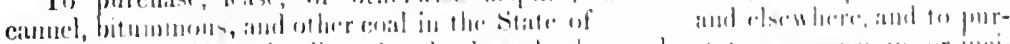

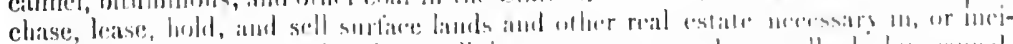

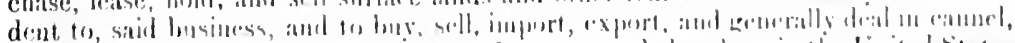

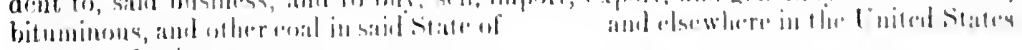
or in ally foreign comblot?

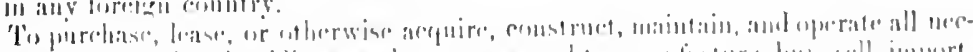

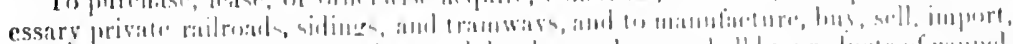

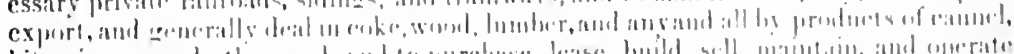

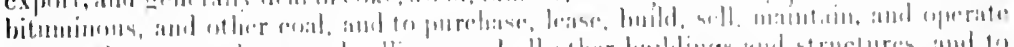

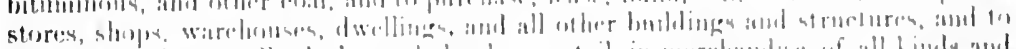

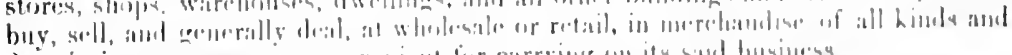

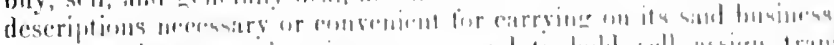

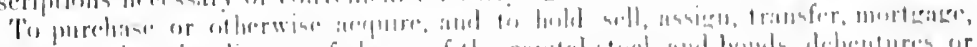

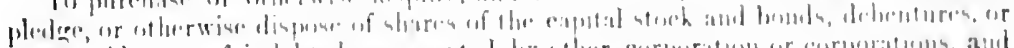

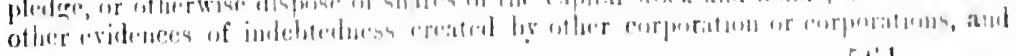


while the lwher thereof, to excreise all the rights and privileges of ownership, meduling the right to rote theseons.

to conduet its said business and have one or more offices, and unlimitedly and withent restrietion to jurehase, hold, lease, mortgage, and convey real and personal projerty in or out of silid state of , and in such place and places in the sevrral stites and Territories of the United Stites, its enlonial possessions or territorial acyuisitions, and in foreign eonutries, as shall from time to time be found necessary and convenient for the purposes of the business of said corporation.

ii. 'The anount of the total authorized eapital stock of said corporation shall be dollars (S ), which shall be divided into shares of the paur value of dollars eath; of which authorized capital stock the annumit of dollars has been subseribed, and the amount of dollars lias been paid.

$Y$. The names and post-otice addresses of all the incorporators and the number of shares of stuck subseribed for by each are as follows:
Ninnes.
Post-Office Addresses.
No. of Shares.

VI. Said eorporation is to expire on the

Given under our hands this day of , A. D. 190 .

\section{CERTIFICATE OF INCORPORATION}

OF

\section{Transportation Company (Arizona Charter).}

Tins is ro Centrify that we, , have this day associated ourselves together for the purpose of forming a corporation under the laws of Arizona, and for that purpose do alopt the following eharter:

First. The name of this corporation is the

Second. 'This Company shall kcep a loeal office at kecp other prineipal offiees and places of business at

Company.

, Arizona, and may , State of and at such other plaees and in sucb States as the Board of Directors may establish, at which place or places all incorporators', stockholders', and Directors' meetings may be held, and all corporate business be transacted.

Third. The anount of the eiluital stock of this eorporation slall be $\$$ divided into shares of the par value of $\$$ each, and said capital stock shall be paid at such time as the Board of Directors may desiguate, in money, properts, labor, good will, or any other valuable right or thing.

Fourth. 'The objects for which this corporation is formed are, as principals, agcuts, or otherwise, to do in any part of the world any and every of the things herein set forth to the same cxtent as natural persons might or could do, and in furtherance and not in limitation of the general powers conferred by laws of Arizona, it is hereby expressly provided that the corporation shall lave the following powers :

(a) To manufacture, purchase, or otherwise acquire, and to hold, own, mortgage, pledge, and to sell, assign, or otherwise dispose of, to invest, trade, deal in, or deal with goods, wares, merehandise, and property of every elass and description.

(b) To apply for, purchise, or otherwise acquire, and to hold, own, use, operate, and to sell, assign, or otlierwise dispose of, to grant licenses in respect of, or otherwise turn to aceount any or all inventions, improvements, formulæ, and processes used in connection with or sceured under Letter's Patent, Copy Rights, or Trade Marks of the United States, or elsewhere, or otherwise, and with a view to developing the same, to carry on any other business, whether manulacturing or otherwise, which the corporation may think calculated directly or indirectly to cifectuate threse objects.

( $)$ To purchase or otherwise aequire, and to hold, sell, assign, transfer, mortgage, pledge, or otherwise dispose of, the shares of eapital stock or other evidenee of indibteducss created by other corporation or corporations, and while the 562 


\section{FORMS AND PRECEDENTS.}

holders of such stock, to exercise all the rights and privileges of omership, including the right to rote thercon.

(d) Generally to purchise, take on lease or in exchange, hire, or otherwise acquire, any real and personal property, and any rights, privileges, or franchiscs which the corporation mas think necessary or convenient for the purpose of its business, and, in full, to do any or all things in any part of the world not prolibited by the laws of Arizona.

(e) 'To construet, hire, purehase, and operate steamboats and other vessels of any class, and especially the coustruction of steamboat hulls and barges atter and upon the plans of the new method .. composite construction; to estabiish and maintain lines or reenlar services of si, auboats or other vessels on the River and its tributaries; and generally to earry on the business of shipowners, and to enter into contracts for the carriage of mails, passengers, goods, and merchandise br any ncans, either by its own vessels, ritways, and cuncerances, or by or over the vessels, converances, ind railwars of others; to insure against loss by fire, flood, or other calamity, the cargo earried or transported upon the Com. pany's steamboats or other iessels; tis construct, purchase, tatke on lease, or otherwise acquire and work any riliway wharf, pier, duck, lunilding, or works capable of being advantagconsly used in connection with the business of the Company as a shipping company, and in connection with any of the objects aforesaid, to carry on the business of a railway comprans, railwas contractors, ship builders, engineers, manuf icturers of machinery and car builders: to acquire enne'ssions or licenses for the establishment and workine of lines of steambats and of her vessels between any ports of the world, or for the formation or working of any railwas, wharf, pier, duek, or other works, or for the workine of any pulslic converance.

(f) Tor build, make, operate, maintin, buy sei], deal in and with. win, lease, pledge, and wherwise dispose if steambonts and vessels of crory nature anul hind whatsiever, tugether with all materials, articles, tomls, machimery and appliances ent ring into, or suitable and cunvenient for the construction or equipment thereof. and together with encinces, boilers, machinery and ippurtenances of all kinds, and tackle, anporel, and faniture of all kinds; the transportation of gronds, merchandise, and passengers upen land or water, binilding, repairing and designing houses,

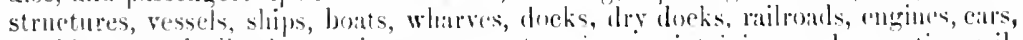
machinery, and all other equipunent; constructing, maintanine, and opreratine rail-

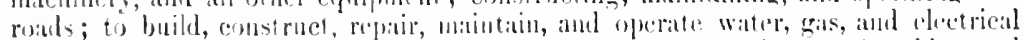
works, tumels, brilges, viudurte, cambls, wharves, purks, and like works of internal

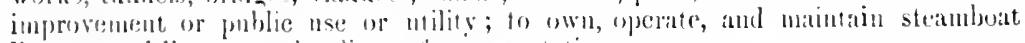
lines, vessel lines, or enther lines of trimsprertation.

(g) To earry on the business of colle storace and warthousing and all the

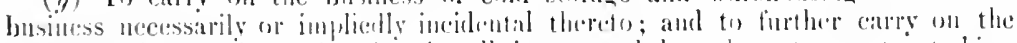

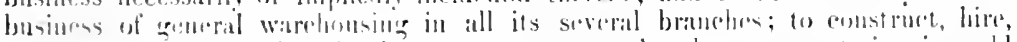

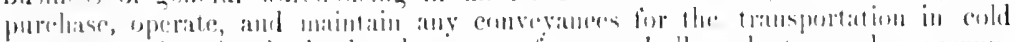

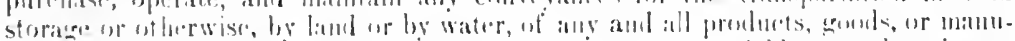

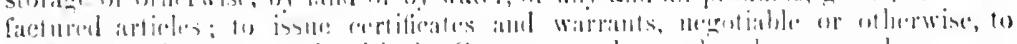

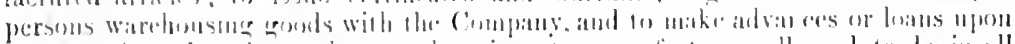

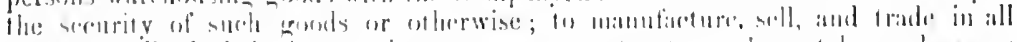

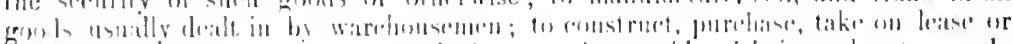

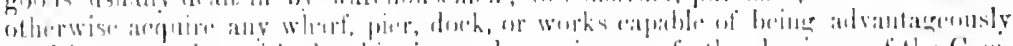

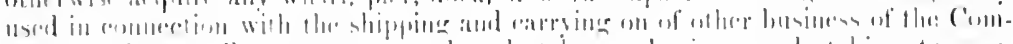

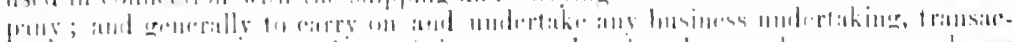
timal, or of

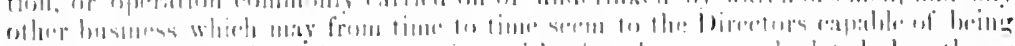

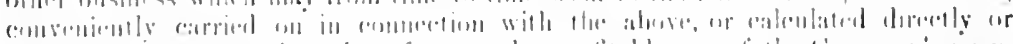

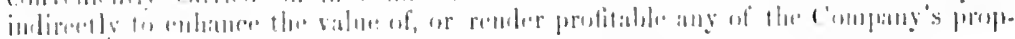
ertien ur righlis.

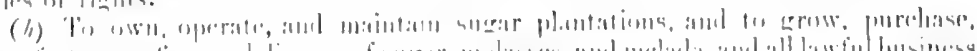

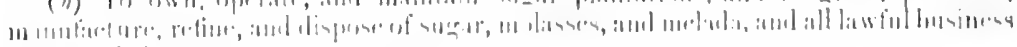

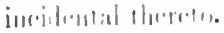

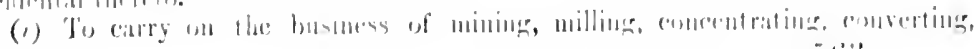
iti:; 
smeking, treating, preparing for market, manufacturing, buying, sclling, cxchang. ing, and otherwise producing and dealing in coal, gold, silver, copper, lead, zinc, brass, iron, stecl, and in all kinds of ores, metals, and mincrals, and in the products and by-products thereof of every kind and deseription, and by whatsoeser process the sime ean he or may herealter be produced; and gronerally and withont limit as to amonnt, to buy, sell, exchange, lease, acquire, and deal in lands, mines, and mineral rights and elaims, and in the above specified products, and to conduet all business appurtenant thereto.

(i) The corporation shall also have power to conduct its business in all its branches, and unlimitedly to hold, purehase, mortgage, and eonvey real and personal property in any State, 'Territory, or colony of the United States and in any loreign country or plice.

Fith. The affairs of this corporation shall be condueted by a President and Board of Directors, who shall be eleeted annually, as the by-laws shatl provide, and a roting power of at least 51 per ecut of the capital stoek shail be pooled, and that right vested in the incorporators hereof, and that said right to endure for the liletine of the Company, and the Board of Directors can without further authorization make, alter, anend, and rescind the by-laws, and amend the articles in any of the particulars herein of this Company, and to tix the amount to be reserved as working eapital.

Sixth. 'This corporation is formed to endure for twenty-live years after its articles are duly exceuted, but its charter rights may be renewed before its elarter expires, from time to time, for periods not exceeding twenty-five years at a timc, perpetually.

Secenth. The private properly of the stockholders of this corporation shall be and is hereby made forcver exempt from all liability for its debts or obligations, and there shall be no individual liability on the part of either Direetors or stockholders.

Eighth. The capital stock of this eorporation slatl be and is hereby made full paid, and forever non-assessible by this eorporation for any purpose. In accepting property in exchange for stock the judgment and appraisal of the Directors shall be final ind eonclusive.

Ninth. The Board of Directors shall, as soon as praeticable after the organization of the Company, instruct the Treasurer to set apart a eertain sum of money, at such times as will jointly be agrecel npon, which sum of mouey shall be lich by the Treasurer, as aud for a Sinking Fund to be utilized for the replacing of any of the Company's boats or propertics of any description that may meet with disaster, or for general repairs in any way upon the Company's holdings ; to anticipate the payment of any obligations which may not be elassed as regular expenses; to meet any contingency of any kind and thus make absolutely eertain at all times the solvency of the Company ; to insure against loss the cargo transported upon the Company's steamboats or other vessels; to apply to any and all of the things which the Board of Directors may in their right determinc.

Tenth. All stockholders of this company shall have the right to inspect the stock and transfer books of this corporation in the prescince of the Presitent and Board of Directors, after proper reasons have been given for the request to so examine.

Eleventh. Slould a stochloblder so desire, a proxy ean be given to the President or any member of the Boand of Directors, and such person will act for him the same as if he himself were present.

Terelfth. It will not be lawful for this Company to join with, or pool its interests with any other corporation of any kind or inature whatsoever, or have as a member of its Board of Directors any officer of any other company ; thus stringently excluding at representative of any shiareholder or shareholders of a competing company, or any company, whether on land or water, from having any voice whatever in the management or clirection of this Company.

Thirteenth. This Company will not permit the listing of the stock of this corporation on any cxehunge created lor the sole purpose of the bartering and selling of the securities of eorporations.

Fourteenth. There shall be no greater amount of indebteduess incurred, either directly or indirectly, by the Boand of Diretors of this Company, at any time, than shatl exceed in anount or be equal to two-thirds of the eapital stock.

$$
56+1
$$


Fifteenth. Without in ans particular limiting any of the objects and porrers of this corporation it is herebr expressly declared and provided, that should it become necessary and decided by thuse in control, this corporation shall lave power to issue bonds in payment for property purchased or acquired bs it, or lor any other object in and about its business; and said bonds atter issue and betore their maturity, can be retired by the decision and rote of a majority of the holdings of stock, and new certificates of stock can be issued to the stockloblders at par.

In Witness Whereof, we have herennto set our hands aud seals this day of , A. D. 190 .

Signed, scaled, and delirered in the presence of

\title{
CERTIFICATE OF INCORPORATION
}

\author{
OF TIIE
}

\section{Vehicle Motor Compaxy (District of Colcmia Cinarter).}

We, the undersigned,

, of Washington. District of Columbia, do by these presents, pursuant to and in contomity with the provisions of six hundred five (605) and six hundred six (606) of an Act of Congress approsed March 3rd, 1901, entitled "An Act to Fstablish a Code of Litw lin the District of Columbia," with the amendments thereto made by an Aet approved June 30th, 1902, entitled "An Act to amend an Act entitled 'An Act to Establish a Code of Law for the District of Columbial," associate oursedies together as a body politic and corporate, and we do hereby certify and declare in writing:

First. T'te name of the corporation shall be

Compaxy.

Second. That the purpuses for which said corporation is formed are: To manuficture, own, sell, assign, and transfer, deal in, and deal with all kinds of automobiles, motors, engines, lanuches, machines, or all kinds of machinery or contrivances for the generation of steam, electricity, gatsolene, or other form of power now known or which mily hereafter be discovered; the mimulicture and sale of ears, carriages, watrons, boats, and vehicles of every kind and description for the transportation of her than railhosul of passengers or gonds, whether the same shatl be propelled by motor, enerine, machine, or otber contrivinces operated by steam, eleet ricity, gasolene, or other form of puwer ; the mantuficture and sale of maichinery, machine supplies, and engincering anphlinues, whether incidental to the constrietion of motor velicles or not, and the acpmisition and sale of inventions, paldont rights, letters patent, and tande marks covering any and all of the articles to be

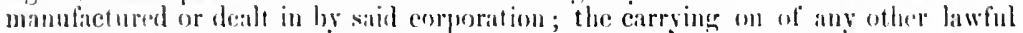
trade or business incident io the alloresaid purposes, or either of theni.

'os mamefacture, purchase, or otherwise arepuire, hold, own, sell, assign, and transfer, invest, trade, deal in and deal will ermels, wares, and merehandise of

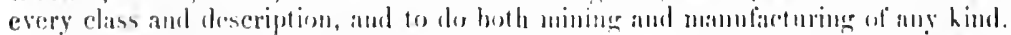

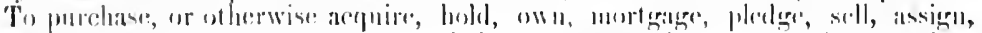

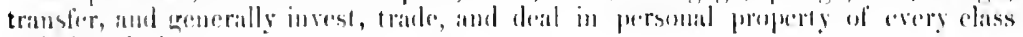
and description.

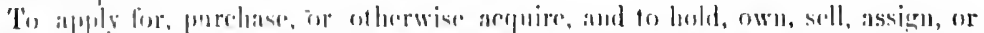

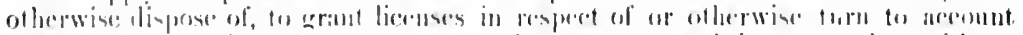

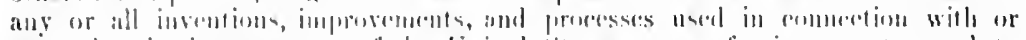

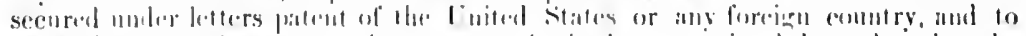

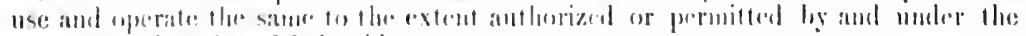
laws of thre Distriet of ('olmulitit.

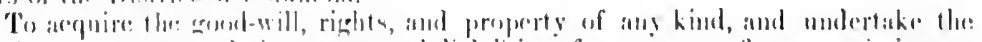

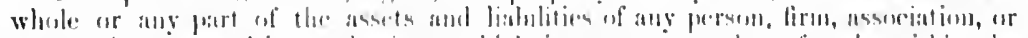

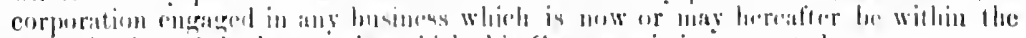
antherization of the lisws moler which this Compang is incorperated. 
To have one or more ofliess, fo carry on all or any of its operations and business ind unlimitedly and without restrietion, to hold, purchase, lease, mortgage, and consey res] and prersomil property, and to carry on its business in any State or 'lerritury of the l'nited states and in any foreign eountry or place, but always subject io the laws thereot.

Third. 'That the existence of this Company shall be perpetual.

Fonth. 'That the eipital stock of this Company shall be divided intor shatres of the par value of dollars each.

dollars,

Fifh. That the number of Thustees who shall manage the eonecrns of the Cumpruy for the first year or until their suecessors are elected shall be, uamely:

Names.

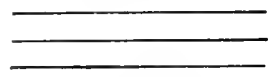

Addresses.

The Board of Trustees by the affirmative vote of a majority of the whole Board, may alpoint from the Trustees an Exeeutive Committee of three members, of which a majority shall constitute a quorum, and to such extent as may be provided in the hy-liws, such Committee shall have and excreise all of any of the powers of the biurd of 'T'rustees.

Sirth. 'That the place in the District of Columbia in which the operations of this Company are to be carried on, is, situated at, in the City of II ishington, District of Columbia.

In Witness Whereof, we have made, signed, and acknowledged this certificate this . day of, 190 .

\section{CERTIFICATE OF INCORPORATION}

\section{Typewriter Company (Connecticut Charter).}

We, the subscribers, certify that we do hereby associate together as a body politic, ineorporated muder and by virtue of the provisions of the Act of the General Assembly of the State of Connectient, entitled "An Act Concerning Corporations," being Chapter 19.4 of the Public Acts of 1903, and all acts amendatory thereol, and we further eertify:

\section{First.}

The name of the corporation is

\section{Company.}

\section{Second.}

That said corporation and its principal office is to be located in the City of , County of , and State of Connceticut.

\section{Third.}

The nature of the business to be transacted and the purposes to be promoted are ats follows:

To manufacture, import, export, buy, sell, and generally deal in typewriters, office furniture, and all office supplies of any kind or description; to carry on the business of manufacturing, exporting, importing, buying, and selling typewriters, typewriter supplies, materials, appliances, and all other materials and articles comnceted with or in any wise relating to the manufacture, sale, or use of writing machines and typewriters. 'To establish and maintain manufactories, stores, agencies, and depots for the manulacture, purchase, sale, exchange, delivery, and 
distribution of writing machines, tspewriters, typewriter appliances and supplies, office furniture and oftice supplies. 'T'o manufacture, export, and import, buy, sell, and generally deal in machinery of every kind.

To apply for, obtain, register, purchiase, or otherwise acquire, and to hold, own, use, operate, iuduce, and to sell, assign, or otherwise dispose of any and all inventions, improvements, and proeesses used in conncetion with or secured inder letters patent of the United States, or otherwise to use, exereise, develop, and graut liecuses in respect of or otherwise turn to account any and all sueh patents, inventions, improvements, and processes.

To hold, purehise, or otherwise acquire, to sell, assign, tramsfer, nurtginge, pledge, or otherwise dispose of shares of the capital stock and bonds, debenture's, or other evideuces of iudebteduess ereated by other corporation or eorporations, and while the holder thereof to exercise all the rights and privileges of ownership, including the right to vote thereon.

To the same extent as uatuml persons might or could do to purehase or otherwise acquire, to hold, own, maintain, work, develop, sell, conver, mortginge, or otherwise dispose of, without limit as to amount, within or without the state of Counecticut and in any part of the world, real estate and real property, and any interest and rights therein.

To conduct its business and have one or more offices, and unlinitedly and without restriction to hold, purchise, lease, mortginge, and convey real and personil property in or out of this State, and in such plice and places in the several States and Territories of the United Stites, colonial possessions or territorial atequisitions of the United States and in foreign countries, as slatl from time to time be found necessary and convenient lor the purposes of the Company's business.

\section{Fourth.}

That the amount of the capital stoek of said corporation hereby anthorized is dollars, divided into shares of the par value of dollars each.

\section{Fifth.}

That said corporation will commence business with a capital stock of dollars.

\section{Sixth.}

The duration of the corporation shall be perpetual. of

In Witness Whereof, we have hereunto set our hands and seals this

Residence.

\section{SUGGESTIONS RELATIVE TO THE DRAFTING OF CHARTERS AND THE PIREPARA'TION OF MINUTES FOR 'THE OLGANIZATION MEETINGS OF CORPORATIONS.}

In presentiug at fow sugherestions redition to the incorporation and oreanization of

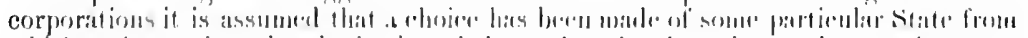

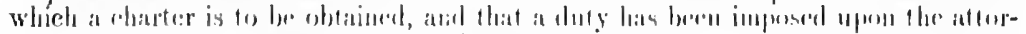

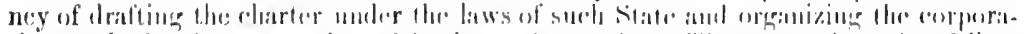

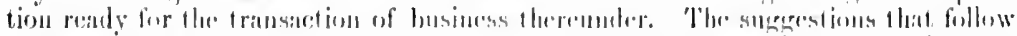

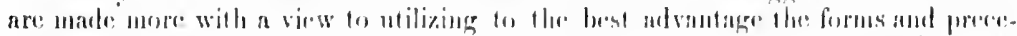
dents to be fomml in the present work rather than with the hope of presenting anything grartienlarly new or original nomer this line. 


\section{THE DRAFTING OF THE CHARTER.}

First, ascertain whether all the purposes the insertion of which in the charter is desired by the client may be enbodied in one chatres. By reference to the "Symensis Digest " contained in l'art II. of this work, this question ean be readily answeret. Next, tmrn to the forms for charters of the various States and Territories fount in l'art 111. of the present work, and make use of the skeleton form therein found, for thatting a charter under the laws of the particular States in which this particular charter is songht. The only clanses of the ehanter to which particular reference need he male here are what are known as the "Object Clause," the "Preferrel stock Clanse," and the "Clanse for the Regulation of the Intcrnal Allivirs of the Corporation."

In drafting the first of these, the "Olject Clause," reference should be first had to the "Sprecific Object Clauses" found in Part III. pp. 403-442, of this work. Forms for clralting the more eommon of such specilic "Object Clauses" will be found thercin. Next, it will often be found convenicnt and uscful to add to the "Sprecific Object Clauses" certain "General Object Clauses;" such, for example, as those permitting a corporation to purchase and hold its own stock and stock in other corporations as well, and to acquire patents, patent rights, trade marks, etc., and to hold real and personal property without linit, and to transact business in other States and 'lerritories and forcigin countrics. Sometimes, too, it is of advantage to insert a clause anthorizing the corporation to acquire an cxisting business or to engage in a general merchandise business. Such forms will also be found in Part III. pp. 509-510, hercin.

Next, attention is called to the " Preferred Stock Clanses," forms for which will be found on pp. 511-512 of Part III. lierein. In comnection with the clause for the regulation of the intemal affairs of a corporation, attention should first be dirceted towards ascertaining whether the iusertion of such a clanse is permitted under the laws of the particular Commonwealth from which the charter is to be procured. (Sec Part IIL. Table X, p. 550.) Examples of such clauses will be found on pp. 510-511 of Part III. herein. A stock subscription agrecment should ordinarily he signed by all of the incorporators before the articles of incorporation are signed. (Sce Part III. p. 524.)

Fisally, sce that the requisite number of incorporators sign the articles and acknowledge their cxccution (when the same is requared) before a notary public or other officer anthorized to take acknowledgments. In some of the States, notably New Jersey, if the artieles are acknowledged withont the State, a certificate must be obtained certifying to the officer's due appointment as well as to his authority to take such acknowledgments.

\section{THE PROCURING OF THE CHARTER.}

Ordinarily three copies of the charter shonld be prepared: the first of these snould be signed and acknowledged by each of the incorporators, and becomes the original; the sceond is for the purpose of filing (when duly certificd) in local connty office (when the same is required by statute), and the third - after being properly certified - remains the property of the corporation.

In most of the Commonwealths at the time the charter is presented to State ufficials for filing and recording, it must be accompanied by a sufficient remittance to cover not only the organization tax but the filing and recording fees as well. (Sce Part II. pp. 211-40\%.) After the certificatc of incorporation is issued by the proper State oflicials, a certified copy thereof should (when the same is required by statute) be promptly filcd in the proper county office. 


\section{ORGANIZING THE CORPORATION.}

\section{(See Compositc Form of Minutes and By-Laws, Part III. pp. 512-524.)}

The organization mecting of the corporation must be held within the domiciliary Statc of the conporation muless such meetings are expressly anthorized by statute to be he!d without such domiciliary State. The most convenient practice is for the incorpsuators to sign a written wiiver of notice tixing the time and place of the meeting. (See Palt III. p. 5l5.) If other stockholders than the ineorporators have sigued the preliminary stock subscription agreement, they also must sign the written waiver here relerred io. 'The meeting orginizes by the election of a Chaiman and a temporary Secretary. Either the charter itself (if onc is issued) or, in licu therof, a certitied copy of the certificate of incorporation should be presented and entered at length in the minutes.

'The By-Laws shonld next be adopted section by section and entered in the minntes. If the ecrtiticate of incorporition nimes the first Boild of Directors, it is not nceessary to elect a new Boird at the organization meeting. Where such Directors are not named in the certitieate of incorporalion, the next order of business is the election of Directors. When required by stalute (or when not required, if the incorporators so desire), Inspectors of Eliction shonld be appointed and sworn. If the persons so chos:n as Directors are not subscribers to the capital stock of the corporation, they may become qualified either by subseribing for stock or by having one of the incorporators who is a subseriber to the calpital stock assign lis stock subscription to them. (Sec Part 1II. p. 524.)

If it is the intention of the corporation to take over certan property (either real or personel) in exchange for its capital stock, the following suggestions mar be mads: Let some party whe is not an officer or director in the corporition ofler to cuter into an arreenciat with the latter relative to the sale of such property for stack. (S.e Palt III. p. 52.5.) Then drift the minutes of the incorporators' meeting, so that provision is male fire the acceptance of snele ofler in exchange for a ceratin specified number of shitres in the corporation. The resolution thus passed

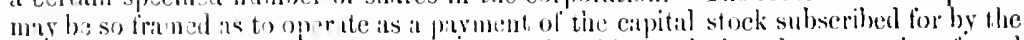
inesporaters. (s e Part III. p. sls.) Under this resolution the matter is referred to the Borrd of Direetors for more formal action. 'The Band may, if it sees fit,

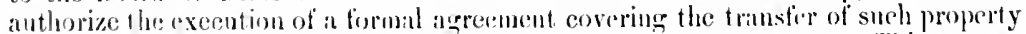
for stock in sulustantially the lorm set forlh in Part III. p1. 5:5-526. This secures

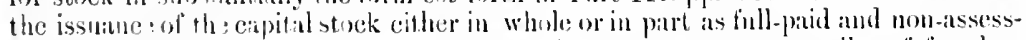
able, providing the Directors in appraising the property are not genity of fiand or

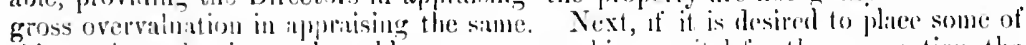
this stock so thet it an:y be sold to procure working capital for the corpuration, the party to whon it is issued may tramstior the same in trust on the eorporation for that

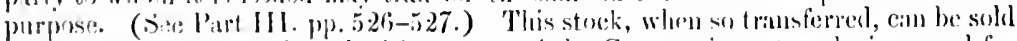

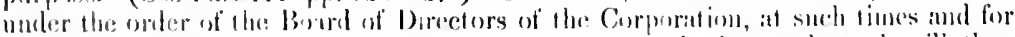

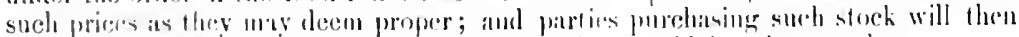

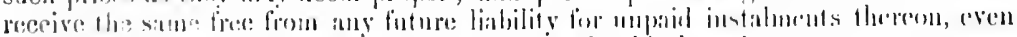

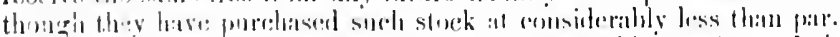

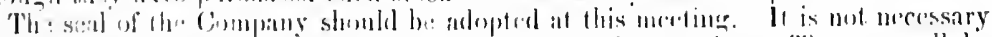

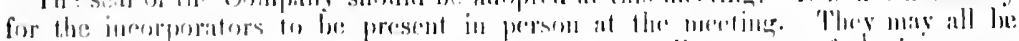

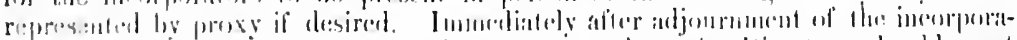

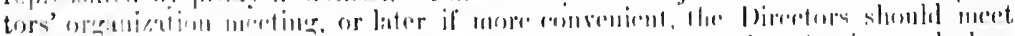

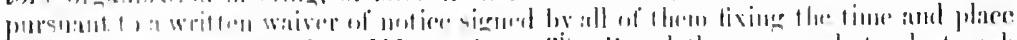

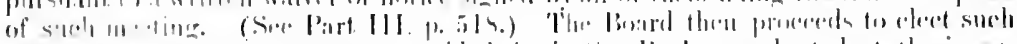

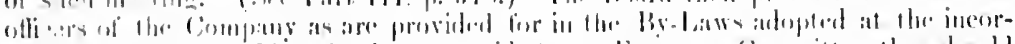

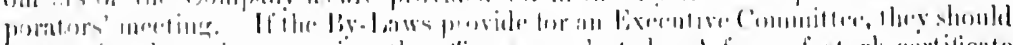

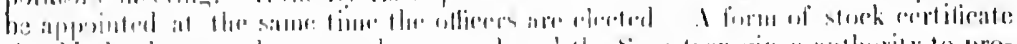

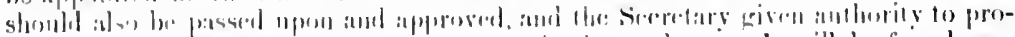

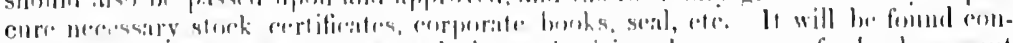

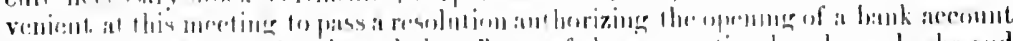

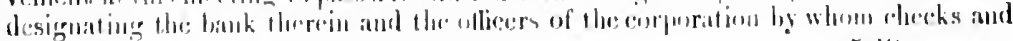


dralts shall he signod. (Se Par! III. p. 517.) Where it is neessary to provide fin the mantaining of the demiciliary ofliee for the eorporation or the appointment of : a ristered ingint, this should he attended to at the first meeting of the Pirectors. (Se l'ar 111, p.517.) The issumee of stock in exehange for property should be provided for by resolution in accordance with the terms of a similar resolution passed be the incorpurators at their ormanization meeting. If the stock is to be paid for in eash, a resolution substantially in the following form slould be passed by the buard, to wit:

RESOLIED, thit an assessment be, and the same liereby is, made of dollars per shatre from the amount unpaid upon the shares of the eapital stock of the Company, and that the sime be paid to the Treasurer of the Company on or before the diay of , 190 . 
TABLE I.

\section{TABLE OF ORGANI\%ATION TAXES PAYABLE UPON INCORPORATION.}

\section{(Capitalization.)}

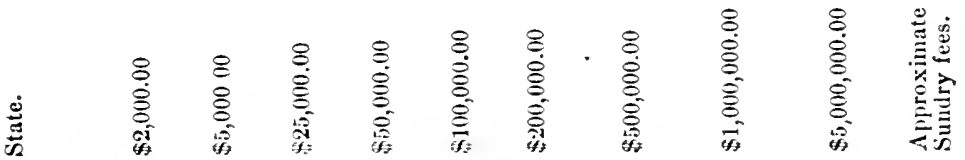

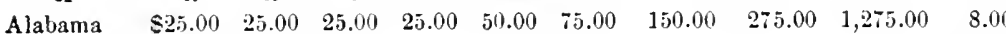

Alaska Merely tiling fees.

Arizona Merely tiling fees.

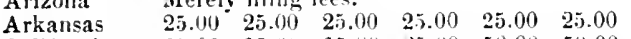

California $\quad \begin{array}{llllll}15.00 & 15.00 & 15.00 & 2.5 .00 & 50.00 & 50.00\end{array}$

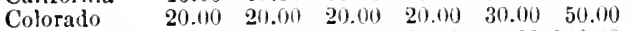

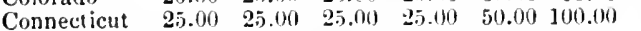

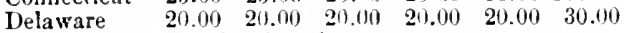

Dist. of Col. Merely tiling fees.

Florida

Georgia

Idaho

Illinois

$5.01910 .00 \quad 5000 \quad 100.00200 .00 \quad 250.00$

No organization tax

$\begin{array}{llllll}5.00 & 5.01 & 5.00 & 10.00 & 10.00 & 20.00\end{array}$

$\begin{array}{llllll}30.00 & 50.00 & 70.00 & 95.019 & 145.011 & 245.00\end{array}$

$\begin{array}{llllll}10.00 & 10.00 & 25.00 & 50.00 & 100.00 & 200.00\end{array}$

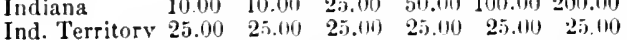

$\begin{array}{lllllll}\text { Iowa } & 25.00 & 25.00 & 40.00 & 65.00 & 115.00 & 215.00\end{array}$

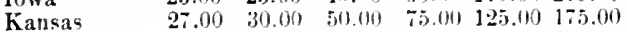

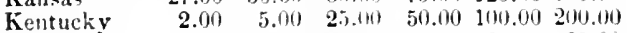

$\begin{array}{lllllll}\text { Louisiana } & 25.010 & 25.00 & 25.60 & 25.010 & 25.019 & 25.00\end{array}$

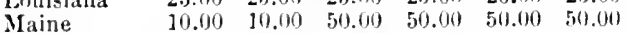

$\begin{array}{lllllll}\text { Marvland } & 250 & 625 & 31.25 & 62.511 & 125.00 & 250.00\end{array}$

$\begin{array}{llllll}\text { Irassachusetts } 10.00 & 10.00 & 10.010 & 12.50 & 25.00 & 50.001\end{array}$

$\begin{array}{lllllll}\text { Michigan } & 5.01 & 5.6 i j & 12.59 & 25.00 & 50.00 & 100.00\end{array}$

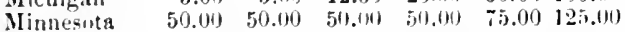

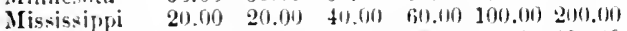

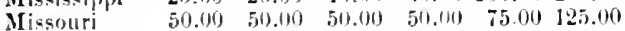

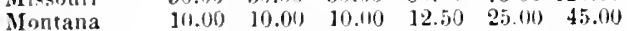

$\begin{array}{lllllll}\text { Tebraska } & 10.00 & 10 .(10) & 10.011 & 10.60 & 10.00 & 20.00\end{array}$

$\begin{array}{lllllll}\text { Nevalia } & 15.00 & 15.100 & 15.00 & 15.00 & 15.00 & 30.001\end{array}$

N.IIampshire

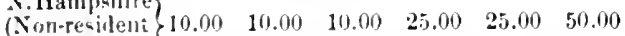
corporations)

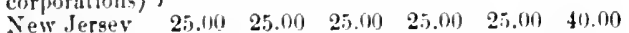

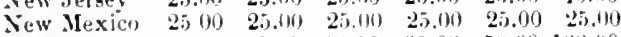

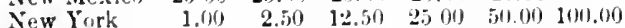

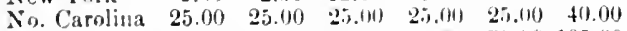

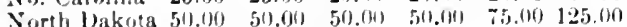

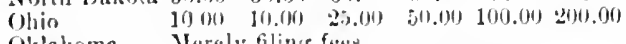

Okla

Derely filing feet.

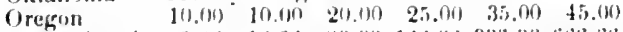

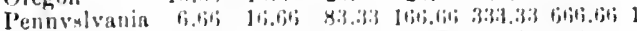

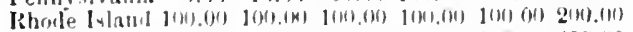

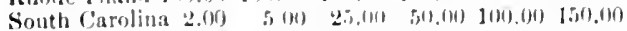

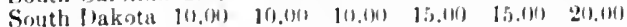

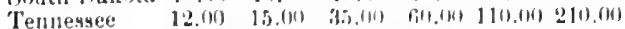

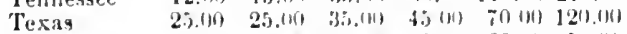

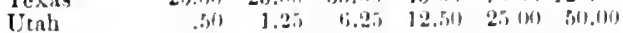

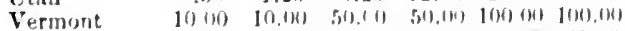

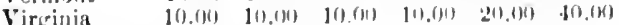

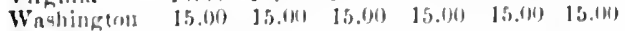

Wr. Yirginit

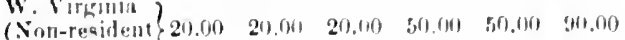
corporations)

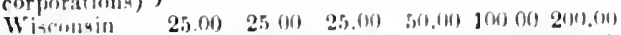

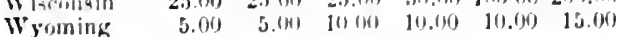

5.00

45.00

$\begin{array}{llll}25.00 & 25.00 & 25.00 & 10.00\end{array}$

$\begin{array}{llll}75.00 & 100.00 & 150.00 & 10.00\end{array}$

$\begin{array}{llll}110.00 & 210.00 & 1,010.00 & 12.00\end{array}$

$250 .(11) \quad 500.00 \quad 2,500.00 \quad 5.00$

$75.00 \quad 150.00 \quad 750.00 \quad 11.00$

12.50

$250.00 \quad 250.00 \quad 250.00 \quad 18.00$

30.00

$\begin{array}{llll}20.00 & 25.00 & 25.00 & 12.00\end{array}$

$5+5.001,045.00 \quad 5.1145 .00 \quad 7.00$

$500.0101,000.00 \quad 5,000.00 \quad 5.00$

$\begin{array}{llll}25.00 & 25.00 & 25.00 & 10.00\end{array}$

$515.0113,015.00 \quad 5,015.00 \quad 35.00$

$33.500 \quad 525.00 \quad 1,325.00 \quad 27.50$

$500.0001,(1000.00 \quad 5,1000.00 \quad 5,00$

$\begin{array}{llll}25.00 & 25.00 & 25.00 & 60.100\end{array}$

$50.00 \quad 100.00 \quad 500 .(10) \quad 1800$

$625.60 \quad 1,250.600 \quad 6,250.00 \quad 1000$

$\begin{array}{llll}125.001 & 250.00 & 1.250 .00 & 5.00\end{array}$

$250.00 \quad 5100.00 \quad 2.5010 .00 \quad 7.00$

$275.00 \quad 52500 \quad 2,52 \% .00 \quad 21.00$

$250.00 \quad 250.00 \quad 250.6100 \quad 20.00$

$275.011 \quad 525.00 \quad 2.525 .0100 \quad 5.00$

$\begin{array}{llll}42.50 & 142.50 & 342.50 & 6.00\end{array}$

$\begin{array}{llll}50.00 & 100.00 & 500.110 & 18.00\end{array}$

$\begin{array}{llll}75.00 & 150.00 & 750.00 & 13.00\end{array}$

$\begin{array}{llll}50.00 & 100.00 & 200.00 & 6.50\end{array}$

$\begin{array}{llll}100.00 & 200.00 & 1,000.00 & 8.00\end{array}$

$50.00 \quad 100.00 \quad 5010.00 \quad 25.00$

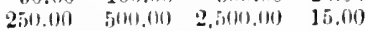

$1010.000 \quad 2011.000 \quad 1.0106 .00 \quad 10.000$

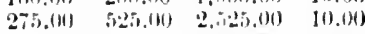

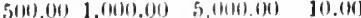

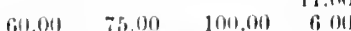

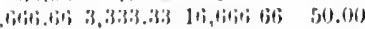

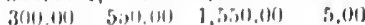

$20.191 \quad 2010(0) \quad 40.001 \quad 3.000$

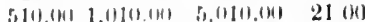

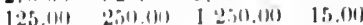

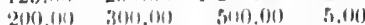

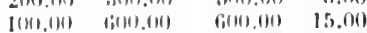

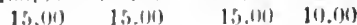

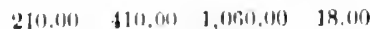

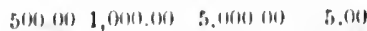

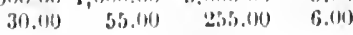

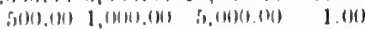

270 (10) $5020.0602,520.100$ Xine 


\section{TABLE II.}

\section{TABLE OF ANNUAI FRANCIISE TAX UPON IOMEN'TIC CORPORATIONS.}

\section{(Capitalization.)}

\begin{tabular}{|c|c|c|c|c|c|c|c|c|c|}
\hline$\frac{\dot{\Phi}}{\tilde{D}}$ & 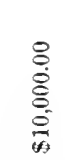 & 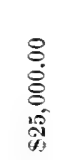 & 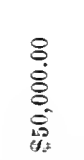 & $\begin{array}{l}8 \\
0 \\
\delta \\
\delta \\
8 \\
\\
\end{array}$ & 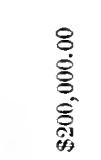 & 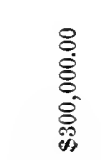 & $\begin{array}{l}8 \\
8 \\
8 \\
8 \\
8 \\
8 \\
8 \\
0 \\
0 \\
0\end{array}$ & $\begin{array}{l}8 \\
8 \\
8 \\
8 \\
8 \\
8 \\
8 \\
8 \\
-1\end{array}$ & $\begin{array}{l}8 \\
8 \\
8 \\
8 \\
8 \\
8 \\
8 \\
0 \\
0 \\
\infty\end{array}$ \\
\hline Alabana & $\$ 10.00$ & 15.00 & 25.00 & 50.00 & 75.00 & 125.00 & 200.00 & 300.00 & 500.00 \\
\hline Alaskal & nome & lnolle & none & none & none & none & notne & none & none \\
\hline Arizona & none & none & none & nolle & none & nolle & rone & none & none \\
\hline Arkallsas & none & none & nolle & none & none & nowe & none & none & none \\
\hline Califormia & none & none & none & none & none & none & none & none & nolle \\
\hline Colorado & none & .50 & 1.00 & 2.00 & 4.00 & 6.00 & 10.00 & 20.00 & 100.00 \\
\hline Connecticut & none & none & nolle & none & none & none & none & none & none \\
\hline Ielaware & 5.09 & 12.50 & 25.00 & 50.00 & 10000 & 150.00 & 250.00 & 500.00 & $2,000.00$ \\
\hline Jist. of Col. & none & mone & none & none & none & none & none & none & none \\
\hline Florida & none & none & none & none & none & noue & none & none & none \\
\hline Georria & notie & none & none & none & nowe & none & none & none & none \\
\hline Idalo & none & bone & llone & none & none & none & none & mone & none \\
\hline Illinois & none & none & none & none & none & none & none & none & none \\
\hline Indiana & nolle & none & none & none & none & none & none & none & none \\
\hline Iowa & none & none & none & none & none & none & none & none & none \\
\hline Kinnsas & none & none & none & wone & none & none & none & none & nome \\
\hline Kentucky & none & none & notie & llone & none & none & none & none & none \\
\hline 1.ouisiuma & none & none & none & none & none & none & none & none & none \\
\hline Maine & 500 & 5.00 & 5.00 & 10.00 & 10.00 & 25.00 & 2500 & 50.00 & 15000 \\
\hline Marylaud & nome & none & none & none & none & none & none & none & none \\
\hline Mla-s. & 10.00 & 25.00 & 50.00 & 10000 & 20000 & 300.00 & 500.00 & $1,000.00$ & $5,000.00$ \\
\hline Mlichiran & none & none & none & none & none & none & nowe & none & none \\
\hline Minnesota & none & none & none & none & none & none & none & none & none \\
\hline Mlississippi & none & none & none & none & none & none & none & none & none \\
\hline Missouri & nolle & none & none & none & none & none & none & none & none \\
\hline Montana & none & none & none & none & none & none & none & none & none \\
\hline Nebraska & none & none & none & mone & none & none & none & none & none \\
\hline Nevada & none & none & none & nolle & none & none & none & none & none \\
\hline N. Hampshire & e mone & none & none & bone & none & none & none & none & none \\
\hline New Jersey & 10.00 & 25.00 & 50.00 & 100.00 & 200.00 & 300.00 & 500.00 & $1,000.00$ & $4,000.00$ \\
\hline $\begin{array}{l}\text { New Mexico } \\
\text { New York }\end{array}$ & none & none & noule & none & none & mone & none & none & $11012 \theta$ \\
\hline $\begin{array}{l}\text { (On basisuf } 6 \\
\text { per cent divi- } \\
\text { dend) }\end{array}$ & 15.00 & 37.50 & 75.00 & 150.00 & 300.00 & 450.00 & 750.00 & $1,500.00$ & $7,500.00$ \\
\hline N. Carolina & 5.00 & 5.00 & 10.00 & 25.00 & 50.00 & 100.00 & 100.00 & 200.00 & 500.00 \\
\hline X. Dakuta & mone & none & none & none & none & none & none & none & none \\
\hline Ohio & $11 \% .00$ & 25.00 & 50.00 & $101) .00$ & 200.00 & 300.00 & 500.00 & $1,000.00$ & $5,000.00$ \\
\hline Oklahoma & nonie & & & & & & & & \\
\hline Oreginli & 15.810 & 20.00 & 3000 & 50.00 & 70.00 & & & & 200.00 \\
\hline J'ennysirania & 50.00 & 125.00 & 250.00 & 500.00 & $1,000.00$ & $1,500.00$ & $2,500.00$ & $5,000.00$ & $25,000.00$ \\
\hline Rhorle Island & mone & norte & nolle & none & none & none & none & none & none \\
\hline So. Carolina & 5.00 & 12.50 & 25.00 & 50.00 & 100.00 & 150.00 & 250.00 & 500.00 & $2,500.00$ \\
\hline Si. I)akota & none & none & none & mone & llone & none & none & none & none \\
\hline 'Tennessee & none & none & none & none & none & none & none & none & none \\
\hline Texas & 10.00 & 10.00 & 10.00 & 20.00 & $30.0 n$ & 50.00 & 50.00 & 50.00 & 50.00 \\
\hline Itah & nolve & none & none & none & none & none & none & none & none \\
\hline Vermont & 10.00 & 10.00 & 10.00 & 15.00 & 25.00 & 35.00 & 50.00 & 50.00 & 50.00 \\
\hline Virginia & 10.00 & 10.00 & 20.00 & $\$ 0.00$ & 60.00 & 60.00 & 10000 & 200.00 & 600.00 \\
\hline Washington & 10.00 & 10.00 & 10.00 & 10.00 & 10.00 & 10.00 & 10.00 & 10.00 & 10.00 \\
\hline $\left.\begin{array}{l}\text { W. Virginia } \\
\text { (Non-resident } \\
\text { corporations) }\end{array}\right\}$ & 20.00 & 20.00 & 50.00 & 50.00 & 90.00 & 130.00 & 210.00 & 410.00 & $1,060.00$ \\
\hline Wisconsin & none & none & none & none & none & none & none & none & none \\
\hline Wyoning & none & none & none & none & none & none & none & none & none \\
\hline
\end{tabular}


TABLE III.

TABULATED QUESTIONS AND ANSWERS RELATIYE TO THE BUSINESS CORPORATION ACTS OF THE SEVERAL STATES AND TERRITORIES.

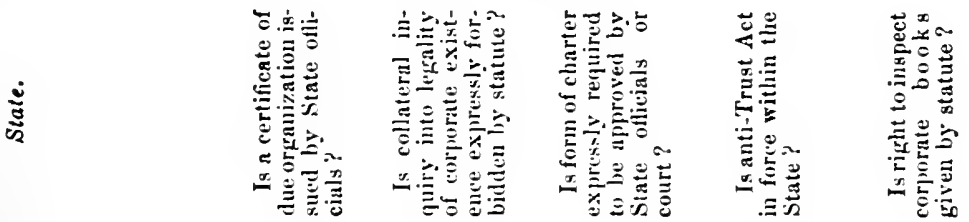

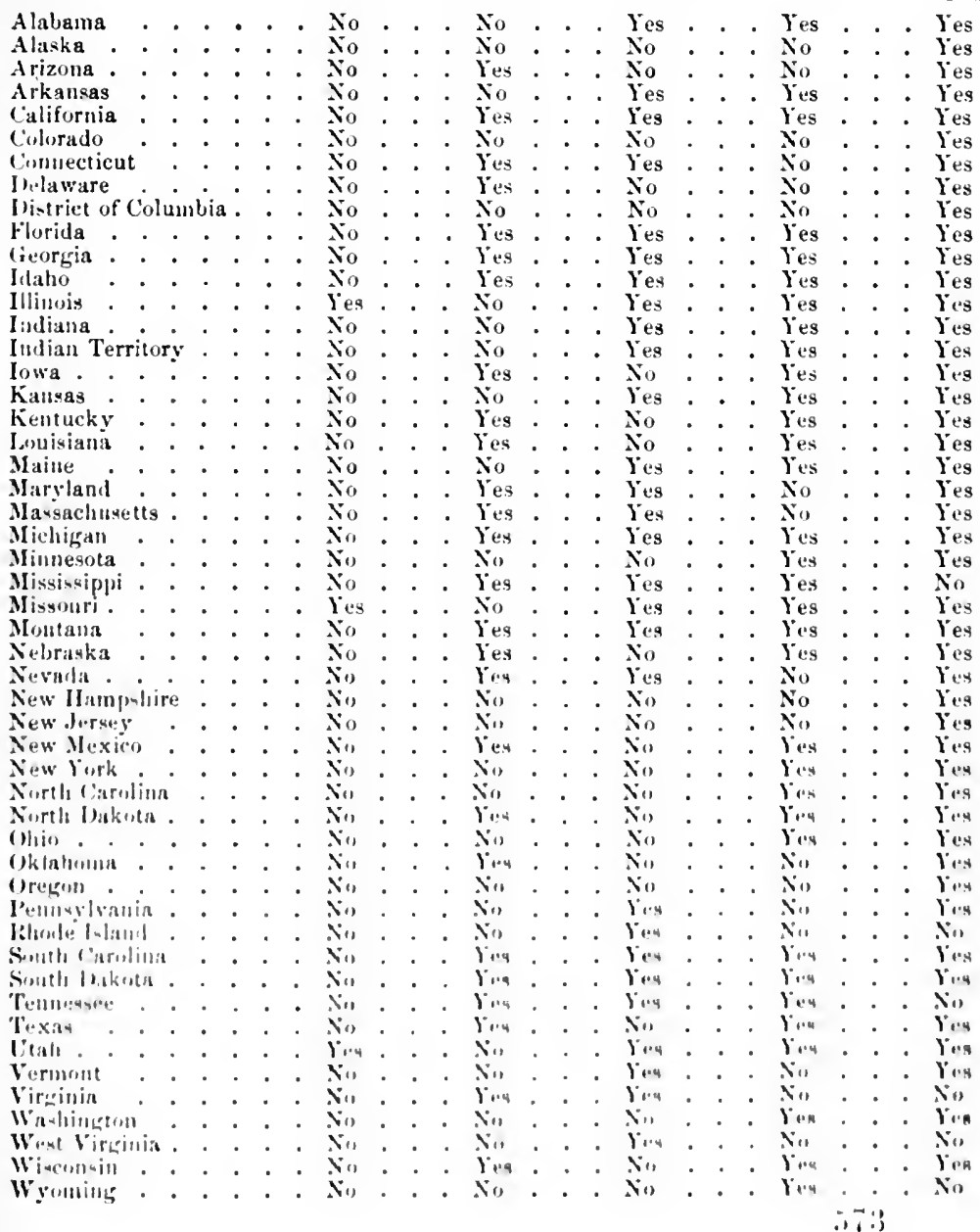




\section{TABLE IV.}

\section{TABULATED QUESTIONS AND ANSWERS (Continued).}

\begin{tabular}{|c|c|c|c|c|c|c|c|c|c|c|c|c|}
\hline 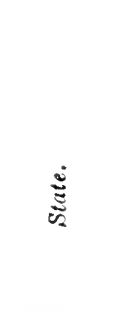 & & & 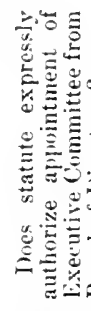 & & & 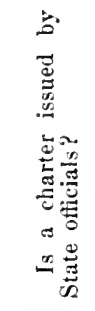 & & 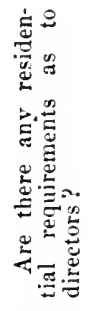 & & 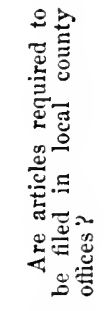 & & 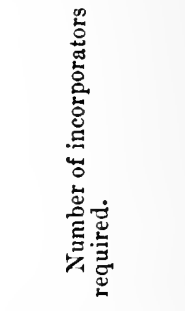 \\
\hline Jabama & & & No & & & No & & No & & Yes & & Three or more \\
\hline aska • & & & & . & . & No & . & Yes & & es & & ee or \\
\hline zona. & . & . & - & . & • & Yes & . & $\mathrm{N}$ & & Yes & & or \\
\hline ansas & - & & . & - & . & Yes & . & - & . & Yes & & er \\
\hline alifornia & . & - & & - & - & - & - & - & - & Yes & & or more \\
\hline lorad! & & - & & - & - & Yes & - & No & - & es & & ee or more \\
\hline necticut & & - & Ye & - & . & No & - & $\mathrm{N}$ & & Yes & & ee or more \\
\hline are & & & Ie & - & & No & & $Y$ & & Yes & & ore \\
\hline $\mathrm{C}$ Col & lum & lbia & & - & - & - & - & - & & - & & e or 1 \\
\hline Floriula. & - & - & & - & - & - & - & - & & $\cdot$ & & ee or \\
\hline horiat. & - & · & & - & - & - & - & $\cdot$ & $\cdot$ & - & & $\mathrm{or}^{\circ} \mathrm{m}$ \\
\hline hois: & • & $\cdot$ & & - & $\cdot$ & • & - & - & & Ye & & ore \\
\hline ois . & & & & & - & Ye & & - & & $\mathrm{Ye}$ & & ven \\
\hline fndianıa . & & & & & $\cdot$ & - & - & & - & - & & ee or more \\
\hline $\begin{array}{l}\text { met. Territe } \\
\text { mwa. . }\end{array}$ & ory & & & & - & - & • & • & & - & & nore \\
\hline$\dot{0}$ & & & & • & • & & & & • & - & & or more \\
\hline $\mathrm{ky}$ & - & • & & & - & • & - & - & $\cdot$ & & & or more \\
\hline ky & • & . & & & & $\cdot$ & & - & & $\cdot$ & & ee or more \\
\hline an & & & & & & & & & & • & & ee or \\
\hline Pand & & & $\mathrm{N}$ & & & - $\mathrm{N}_{0}$ & i & & & . & · & nore \\
\hline sachuse & etts & & Yes & . & . & Y & & & & - No & : & $\begin{array}{l}\mathrm{Fi} \\
\mathrm{Tl}\end{array}$ \\
\hline ligin & $\cdot$ & & No & - & . & $Y^{\circ}$ & & . & & - Ye & & ee or more \\
\hline Minnesota. & & - & No & . & . & Ye & - & . & & Ye & & ee or more \\
\hline Mississip̣pi & & & $\underline{N}$ & - & - & - & - & - & - & . & & or more \\
\hline Missouri & - & & $N$ & & & . & . & - & . & . & & ee or more \\
\hline ontana & & & & & - & - & - & . & - & . & & nore \\
\hline Nebraska & - & & - & & - & - & . & . & . & - & & $r$ more \\
\hline Nerada. & & & Yes & - & - & - & $\cdot$ & . & - & - & & nore \\
\hline 11 amp & shir & re & No & - & - & $\cdot$ & $\cdot$ & - & - & - & & iore \\
\hline Jersey & & & Yes & - & & . & & - & - & Ye & & hore \\
\hline Itexic & & & No & & . & - & - & - & . & - & - & or \\
\hline York & & & N & & . & • & - & - & . & Ye & & ee or \\
\hline th ciaro & olin: & & N & & & - & - & . & . & Yes & & or more \\
\hline in Dake & otat & & $N$ & & - & $Y_{t}$ & . & . & . & No & - & e or \\
\hline 0. & & & . & & & - & & - & . & . & & or more \\
\hline lahoma & - & & - & - & - & $\cdot$ & - & . & - & . & - & tore \\
\hline & & & • & - & - & - & - & - & - & - & - & e or \\
\hline ny yon & nia & - & . & - & . & - & - & $\mathrm{Y}$ & - & - & & or more \\
\hline 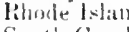 & & & - & & . & - & - & - & - & - & - & e or more \\
\hline 1 Carol & lina & & $\mathrm{T}$ & & & $\cdot$ & & - & - & - & $\cdot$ & ore \\
\hline l] Dake & ot at & & - & - & - & - & · & - & - & - & - & Iore \\
\hline nessee & . & 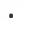 & - & - & . & - & · & - & - & - & - & \\
\hline Texas - & 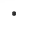 & $\cdot$ & - & & - & $\underline{N}$ & - & - & - & - & & ee or more \\
\hline Termont & & & & & & - & - & - & . & . & & or more \\
\hline Vermont & & & & & & $\stackrel{N}{N}$ & · & - & . & - & - & or more \\
\hline ni: & & - & Ye & & & - & & - & $\cdot \cdot$ & • & & Three or more \\
\hline & & & & & & - & & • & $\cdot$ & - & & Two or more \\
\hline & & - & $N$ & & & $N$ & & & $\dot{.}$ & & & $\begin{array}{l}\text { or more } \\
\text { or more }\end{array}$ \\
\hline Vyoming & & & - No & & & - No & & - No & & & & 'Three or more \\
\hline
\end{tabular}




\section{TABLE V.}

\section{TABULATED QUESTIONS AND ANSWERS (Continued).}

\begin{tabular}{|c|c|c|c|c|c|c|c|c|c|c|c|c|c|c|c|c|}
\hline 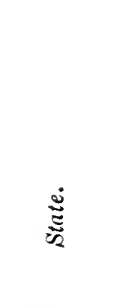 & & & & 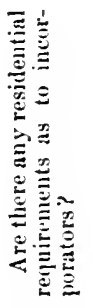 & & & & 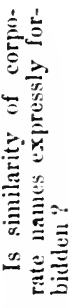 & & & 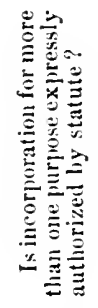 & & & & & 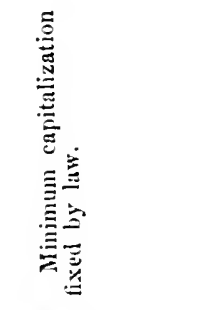 \\
\hline Alabama & . & - & & - No & . & & . & Yes & & & . Yes & . & & & . & $\$ 2,000$ \\
\hline Aluska. & . & . & . & - Yes & . & . & . & No & . & . & Yes & . & . & · & . . & None \\
\hline Arizona. & . & . & & - No & . & . & . & No & . & . & - No & . & . & . & . & None \\
\hline Arkansas & • & . & . & - No & . & . & . & No & . & . & No & . & - & - & . & Xone \\
\hline $\begin{array}{l}\text { Califormia } \\
\text { Culorado }\end{array}$ & - & - & . & - Yes & . & . & . & Yes & . & . & No & . & . & . & - & None \\
\hline $\begin{array}{l}\text { Culorado } \\
\text { Connecticut }\end{array}$ & & • & - & - Xo & . & . & . & Yes & . & . & Yes & . & . & . & • & Nine \\
\hline $\begin{array}{l}\text { Connecticut } \\
\text { Ielaware }\end{array}$ & & $\cdot$ & • & - No & . & . & . & Yes & . & - & - Yes & · & . & • & . . & $\$ 2,000$ \\
\hline $\begin{array}{l}\text { Delaware } \\
\text { Dist. of Cul }\end{array}$ & im & bia & & - S广o & • & · & . & Yes & $\cdot$ & $\cdot$ & - Yes & - & · & · & $\cdot \cdot$ & 8.000 \\
\hline $\begin{array}{l}\text { Dist. of Cul } \\
\text { Florida }\end{array}$ & um & Dia & & - 今o & $\cdot$ & $\cdot$ & · & So & · & $\cdot$ & No & - & • & · & · & None \\
\hline Florida: & : & . & $\dot{.}$ & . No & · & · & • & Yes & $\cdot$ & $\cdot$ & Yes & $\cdot$ & · & $\cdot$ & $\cdot$ & $\begin{array}{l}\text { None } \\
\text { None }\end{array}$ \\
\hline Ilaho. & . & . & & - Yes & $\dot{.}$ & $\dot{.}$ & : & $\begin{array}{l}\text { Ies } \\
\text { No }\end{array}$ & . & $\dot{.}$ & - $\mathbb{N}_{0}^{0}$ & $\dot{.}$ & $\dot{.}$ & $\dot{.}$ & $\dot{.} \cdot$ & - None \\
\hline Illinois. & · & · & . & - No & . & . & . & Yes & . & . & - No & . & . & . & . & - None \\
\hline Indiana . & $\therefore$ & • & - & No & . & . & . & Yes & . & . & - les & . & . & . & . & None \\
\hline $\begin{array}{l}\text { Indian Tern } \\
\text { luwa. . }\end{array}$ & itor & $y$ & . & - No & . & . & . & No & . & . & No & . & . & • & . & None \\
\hline $\begin{array}{l}\text { luwa } \cdot \\
\text { Kansas: }\end{array}$ & · & $\cdot$ & . & - $\mathrm{X}_{0}$ & & . & . & No & & . & No & . & . & - & - & None \\
\hline $\begin{array}{l}\text { Kansas : } \\
\text { Kentucky }\end{array}$ & • & • & & . les & $\cdot$ & . & . & Yes & $\cdot$ & $\cdot$ & - No & . & . & - & . & None \\
\hline $\begin{array}{l}\text { Kentucky } \\
\text { lunisiana }\end{array}$ & - & . & - & - No & $\cdot$ & . & . & Yes & · & $\cdot$ & Yes & · & . & - & - & None \\
\hline $\begin{array}{l}\text { Lulusiana } \\
\text { Maine }\end{array}$ & $\cdot$ & - & • & No & $\cdot$ & - & · & $N_{0}$ & $\cdot$ & - & Yes & - & - & - & · & 85,1000 \\
\hline $\begin{array}{l}\text { Matibe } \\
\text { Mlarylantl }\end{array}$ & $\dot{\cdot}$ & $\cdot$ & • & - Nos & $\cdot$ & • & $\cdot$ & $N_{0}$ & • & · & Yes & · & - & - & . & 51,000 \\
\hline Ml: $19-a c b u=0$ & its & & - & - $\mathrm{Nes}$ & : & $\dot{.}$ & : & $\begin{array}{l}\text { Yoo } \\
\text { Yes }\end{array}$ & $\dot{.}$ & $\dot{.}$ & - Yes & . & $\cdot$ & $\cdot$ & · & $\begin{array}{l}\text { - Solne } \\
\text { SI, }\end{array}$ \\
\hline Michigan & . & . & . & - Ni) & . & . & . & Yes & . & . & - $x_{0}$ &. & Min. & $s$ & $1,0) 0$ & Max. $225,000,000$ \\
\hline Ninuessta. & . & . & . & . No & . & . & . & les & - & . & - Su & - & . & . & . . . & $. \quad s 10,000$ \\
\hline Misismippi & $\cdot$ & . & - & $N_{11}$ & . & . & . & $x_{0}$ & . & . & . Yes & . & . & & . . . & . Nome \\
\hline Missouri & - & - & - & $N$ & . & . & - & Yos & . & . & $N_{11}$ & - & Min &.$S$ & 2,000 & Max. $510,000,000$ \\
\hline Montanil & . & . & • & No & $\cdot$ & . & . & $N_{0}$ & . & . & $N_{11}$ & . & . & . &.$\quad$. & Solle \\
\hline Subranka & - & - & - & $N_{0}$ & $\cdot$ & - & . & $x_{10}$ & . & . & No & $\cdot$ & . & . & . & . Nint \\
\hline $\begin{array}{l}\text { Nevala } \\
\text { New llamin }\end{array}$ & & $\cdot$ & - & No & . & . & . & Yis & . & . & Yies & · & in. & . & . . . & . $82,0(0)$ \\
\hline 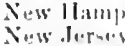 & whir & res & • & No & • & . & - & Yes & . & - & $N_{11}$ & $\cdot$ & $\mathrm{Mil}$ & $n$ & & 1, II: $1 x, s 1,0001,000$ \\
\hline Nuw In:rues & & . & . & $\therefore \%$ & . & . & . & Yes & . & . & Y.4 & . & - & . & . & . $\quad-20100)$ \\
\hline New .I! exic & & . & . & $N_{0}$ & . & . & . & Yes & . & . & Yix & . & . & . & • & Ninse: \\
\hline New lork & & - & - & Yes & . & . & . & Yos & . & . & Y.s & . & . & . & . & $\sin (1)$ \\
\hline Nurth laru & lina & & . & Nin & . & - & . & $Y \cdot s$ & . & - & Yes & $\cdot$ & . & - & · & Ninte \\
\hline North Latis & itia & . & - & $Y \cdot 4$ & . & - & - & $\mathrm{Nin}_{11}$ & . & . & $N$ & . & - & . & . & Nintw: \\
\hline Olinor. . & $\cdot$ & - & - & Yix4 & . & . & . & Yis & . & . & Nin & . & . & . & . & Nine \\
\hline Oklahromia & . & . & . & $j: 4$ & . & . & . & $\stackrel{x}{*}$ & . & . & Sin & . & . & . & . & Nin!. \\
\hline ()res'ill . & & . & . & $\therefore$ & . & . & . & $\operatorname{lin}$ & . & . & $N_{11}$ & . & . & . & . & Ninno \\
\hline lencuaslsan & & . & . & $9 \cdot 4$ & - & . & . & N"1 & . & & $\therefore$ & . & . & . & . & Xin! \\
\hline l:luesle |wlat & & . & . & $X_{n}$ & - & . & . & $1, \times 4$ & . & . & Nin & . & . & . & . & Xinne: \\
\hline Simuth Garn & lima & & . & $\therefore$ & . & . & . & $\therefore$ & . & . & . $\quad X_{11}$ & . & . & . & . . & Xull, \\
\hline Sumll, liak & it: & . & . & $Y \cdot 4$ & . & . & . & Nin & . & . & Nis & . & . & · & $\cdot$. & Non!" \\
\hline 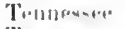 & $\cdot$ & . & . & 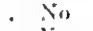 & . & . & . & Yinu & . & . & $\therefore$ & - & - & - & $\cdot \cdot$ & Noll. \\
\hline Truxas. & . & . & . & Ying & . & . & . & $\mathrm{Nin}$ & . & . & $\therefore$ & . & . & . & • & Xinlle: \\
\hline Itali . & $\cdot$ & $\cdot$ & . & Y.י4 & . & . & . & Y..4 & . & . & $\therefore$ & . & - & . & $\cdot$. & Xinln. \\
\hline Virmont & - & . & - & $\therefore$ & . & . & . & Y.4. & . & . & $1 \% 4$ & - & . & . & . $\cdot$ & Sink \\
\hline Yirçinia & $\cdot$ & $\cdot$ & - & $\therefore i$ & . & . & . & Ying & - & . & $Y \cdot 4$ & . & . & - & $\cdot \cdot$ & Ninn \\
\hline Wabingfol & & $\cdot$ & . & . $\quad N$ & . & . & . & Yin & . & . & 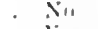 & . & . & . & - & Ninno \\
\hline W. Virfrim & & . & . & $N_{11}$ & . & . & . & Y.4 & . & . & $Y \cdot{ }^{\prime}$ & . & . & . & - & Ninn \\
\hline 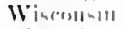 & . & . & . & - Yina & . & . & . & 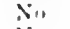 & . & . & Y.4 & . & . & . & . . & · Ninle \\
\hline Wyoming & . & . & . & . No & . & . & . & $N$ & - & . & $x_{11}$ & & . & & $\cdot \cdot$ & 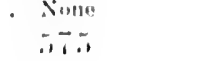 \\
\hline
\end{tabular}




\section{TABLE VI.}

\section{TABULATED QUESTIONS AND ANSWERS (Continued).}

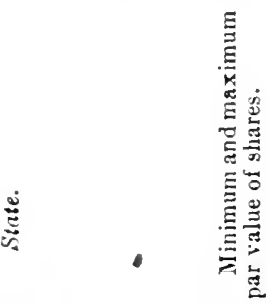

Alabama . . Any amount

Alaska . . . Any amount

Arizona. . . Any :mount

Arkansis : \$25

Califormia : 81 to $\$ 100$

Colorado: : \$1 to $\$ 100$.

Comnecticut . Min. \$25

lelaware . . Any amount

Dist of Columbia. Any amount

Floriclis . . .

Georitit: : Any amount

Ifaho : . Any amount

Illinois: . . $\$ 10$ to $\$ 100$.

Incliana. . . Max. $\$ 100$

Ind. Territory . . \$25 . .

Jowa. . . Any amount

Kansas • . . Any amount

Kentucky . . Any amonnt

Loujsiana . . Any amount

Maine . . . Any anount

Margland . - Any amount

Iissachusetts D Miir. \$5.

Michiran . $\$ 10$ to $\$ 100$

Minnesota: . \$1 to $\$ 100$

Mississippi. Any amount

Missouri . . Alyy amount

Montana . . Any amount

Nebra-ka . Any amount

Nevala . : Ally amount

New IIampslire. \$25 to $\$ 500$

New Jerey . . Any amount

New Vexico . Any amount

New York . . \$5 to \$100.

North Carolina . Any amount

North Dakota . Any amount

Olio.. . . . Any amount

Oklahoma . . Any amount

Gregon . . Any amount

lenniryania . Not over 8100

lihode Island . . Any amomnt

South Carolina Ani amount

Sontli lakotia. . Any amount

'Tennessee Sloo or less

Texas . . . Any amount

Ttah. . . Any amount

Vermont Camunt exceed $\$ 100$

Virginia . . . Any amount

Washinston Any amount

West Virginia. Any anount

Wixconsin. . Any amount

Wyoming . . Any amount

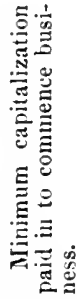

Twenty per cent . . . Twenty-five per cent

No limit. . . . None

No limit . . . . . None

No limit . . . . None

No limit . . . . . None

No limit . . . . . None

$\$ 1,000 \ldots \$ 1,000$

$\$ 1,000$. . . . . $\$ 1,000$

Ten per cent . . . . Ten per cent

Ten per cent . . . Ten per cent

Ten per cent . . . Ten per cent

No limit . . . . None

No limit . . : . All

No limit... . . None

No limit . . . . . None

No limit. . . . . None

Twenty per cent . . Twenty per cent

No limit . . . . . . Fifty per cent

No limit . . . . . None

No limit. . . . . None

No limit . . . . . None

No limit . . . . None

Ten ner cent . . . . Fifty per eent

No limit . . . . None

No limit . . . . . None

Fifty per cent . . . All

No limit . . . . . None

No limit . . . . . None

No limit. . . . $\$ 1,000$

No limit . . . . None

$\$ 1,000: \div: \div: \$ 1,000$

No limit . . . . None

$\$ 500 . .2 . . \$ 500$

No limit . . . . None

No limit . . . . . None

No limit : $: 0_{0} \cdot$ Ten per cent $^{-}$

No limit . . . . . None

No limit : : : One-lualf

Ten per cent . . . . Ten per cent

Nolimit. . . . . None

Twenty per cent . . . Fifty per cent

- No linit . . . . . None

Unlimited, except brewery cos. Nome

Ten per cent . . . Fifty per cent

Ten ver cent . . . Ten per cent

One fourth . . . . One fourth .

Nolimit . : $:$ Minimum capitalization

No limit . . . . . None

$10 \%$ of subscriptions . . Five shares

Twenty percent . . . Fifty per cent

No linit. . . . None 


\section{TABLE VII.}

\section{TABULATED QUESTIONS AND ANSIVERS (Continued).}

\begin{tabular}{|c|c|c|c|c|c|c|c|c|c|c|c|c|c|c|c|c|c|c|}
\hline ڤँ & & & & & 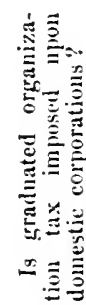 & & & & 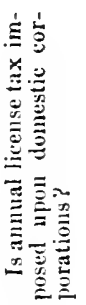 & & & & & 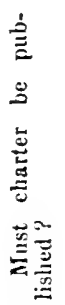 & & & & 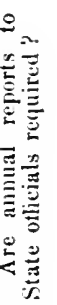 \\
\hline Alabama & & & & & . Yes & & & & Yes & & & & & No & & & & No \\
\hline Alaska. & $\therefore$ & : & & & - No & & . & . & No & . . & . & & . & No & . & : & & Yes \\
\hline Arizona . & . & . & . & . & . No & . & . & . & No & . . & . & & & Yes & . & : & & So \\
\hline Arkansas & . . & . & . & . & . No & & . & . & No & . , & 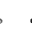 & & & No & . & . & & Yes \\
\hline California & - & . & . & . & . Yes & . & . & . & No & . . & . & & & No & . & . & & No \\
\hline Colorado & : & . & : & . & Yes & . & . & . & Yes & . & . & & . & No & . & . & & Yes \\
\hline Connecticut & : & . & & . & - Yes & . & . & . & . No & . & . & & . & No & : & . & & Yes \\
\hline $\begin{array}{l}\text { Delaware } \\
\text { D }\end{array}$ & & & & : & - Yes & . & . & . & Yes & . & . & & & No & . & . & & Yes \\
\hline Distriet of $\mathrm{C}$ & olun & mbi & & . & . $\mathrm{N}_{0}$ & . & . & . & No & . & . & & & No & & . & & Yes \\
\hline Floridla. & . & . & . & . & Yes & . & . & . & No & . & . & & . & Yes & . & . & & Yes \\
\hline Georgia: & $\therefore$ & : & . & . & No & . & . & . & No & & . & & . & les & . & . & & No \\
\hline ldaho: & - . & . & 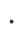 & . & & & . & . & No & . & . & & . & No & . & . & & So \\
\hline Jlliwois . & & . & . & . & Yes & & . & . & - No & . & . & & & $x_{0}$ & . & . & & Yes \\
\hline Indiana . & & : & : & . & Yes & & . & : & $N_{0}$ & . & . & & & $\mathrm{N}_{10}$ & . & . & & Yes \\
\hline Indian Terri & tory & $\therefore$ & . & . & $x_{0}$ & & . & . & No & & . & & & No & . & . & & Yes \\
\hline Iowa. & . & : & 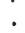 & 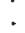 & Yes & & . & . & - No & . & . & & & Yes & . & . & & res \\
\hline Kansas . & . & . & . & . & Yes & & . & . & $N_{0}$ & . & . & & & No & . & . & & ges \\
\hline Kentucky & . & . & . & . & Yes & & . & . & . No & . & . & & & $\mathrm{N}_{0}$ & . & . & & io \\
\hline Ioni-iana & . & . & . & . & $\mathrm{Ni}$ & & . & . & . No & & & & & Yes & . & . & & Yes \\
\hline Maine. & . & . & 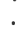 & & Yes & & . & & Yes & & & & & No & . & . & & Yes \\
\hline Maryland & & . & . & & Yes & . & . & is & (conditio & & & & & No & . & . & & Nin \\
\hline Milsaehuset & ts. & & & & Yes & & . & . & les &.$\quad$. & . & & & No & . & . & & les \\
\hline Micluifan & . & • & & . & Yes & & . & . & - No & . & . & & & $x_{0}$ & . & . & & les \\
\hline Minnesota & . & . & 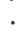 & . & Yes & & . & . & . No & . & . & & & Yes & . & . & & No \\
\hline Miscissippi & . & . & - & & $Y+4$ & & . & . & $x_{i 1}$ & . & . & & & Yes & . & . & & Non \\
\hline Mi-souri & . & . & . & . & Yes & & . & . & No & . & . & & & Sin & . & $\cdot$ & & Yos \\
\hline Montana & . & . & . & . & Yes & & . & . & & & & & & & . & . & & Yess \\
\hline Nubrakka & $\therefore$ & . & . & . & Yes & & . & . & . No & . & . & & & Yes & . & . & & les \\
\hline Sevala. & & . & . & . & Yes & . & . & . & so & . & & & & $N_{11}$ & . & . & & $N_{n}$ \\
\hline New Hamps & hire & . & . & . & Yes & & . & . & $\mathrm{Nin}$ & . & . & & & 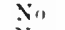 & . & . & & $y$ \\
\hline New Jorkey & & . & & & Yis & & . & . & lis & & . & & & $x_{i 1}$ & . & • & & less \\
\hline New Mrxice & , & . & . & . & Yey & & . & . & . Ni & . & . & & . & Ye's & . & . & & Nin \\
\hline New York & & . & . & & Yes & & . & . & Yin:s & . & . & & . & No & . & . & & Yen \\
\hline Nortlı Carol & & . & . & & $Y_{1.4}$ & & . & . & Ye'4 & . & . & & & $N_{11}$ & . & . & & $Y \because 4$ \\
\hline Sortli lakes & & . & . & . & & . & . & . & Ni) & . & . & & & $\mathrm{Nin}$ & . & . & & $N_{0}$ \\
\hline & & . & 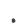 & 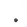 & Yin & & 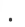 & . & Yins & . & . & & & & . & . & & lec \\
\hline ()klibloma & & . & . & . & $\therefore i$ & & . & . & $\therefore$ & . & . & & & Nu & . & . & & Y.u. \\
\hline Oreginll & & . & . & & . Y.4 & & . & . & 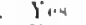 & . & . & & & $\mathrm{N}_{11}$ & . & . & & Y... \\
\hline Pentiaglyani & & . & . & . & Y:4 & & . & . & - $Y_{14}$ & . & . & & & $Y \cdot 4$ & . & . & & $\because \cdots$ \\
\hline Rhorde: I-lan & & . & & & Yiny & & . & . & $\therefore$ & . & . & & & Nin & . & . & & $\therefore$ \\
\hline South tarreli & ina & . & . & & lin & . & . & . & Yin & . & . & & & 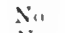 & . & . & & $Y \cdot 4$ \\
\hline Simblh lakot & & . & & & Y*4 & & & . & $\therefore$ & . & . & & & $\therefore$ & . & . & & y.... \\
\hline Tonnesus:s & . . & . & & & $Y: 4$ & & & . & $\therefore$ & . & . & & & $N_{10}$ & . & . & & Yex \\
\hline Trxay & & . & & & Y.4 & . & . & . & Y.4.4 & . & . & & & $x_{1}$ & . & . & & Nin \\
\hline Liali . & & & & & Yus & & . & : & : & . & . & & & $\mathrm{N}$ & & . & & ..." \\
\hline Vermont & & . & & & los & & & - & $Y \cdot 4$ & . & · & & & $\therefore$ & - & • & & No \\
\hline Vir rinia & . & . & 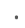 & & $y^{4} 4$ & & $\cdot$ & & Y."4 & . & & & & $\because "$ & & . & & Y...4 \\
\hline Wathingem & & . & & - & Yus & & . & . & Y"u & - & . & & & Q." & & - & & 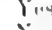 \\
\hline What Virgin & ian. & • & & . & Yin & & . & . & Y...4 & . & . & & & $\therefore$ & & . & & $\therefore$ \\
\hline Wiqcorlain & & & & & $Y: 4$ & & - & & $\stackrel{N .1}{ }$ & . & & & & $\therefore$ & & . & & $Y \cdots$ \\
\hline Wyomims & & & & & - Yi.. & & & & Nin & . & & & & $x_{10}$ & & & & \\
\hline
\end{tabular}


TABLE VIII.

\section{TABULATED QUESTIONS AND ANSIVERS (Continued).}

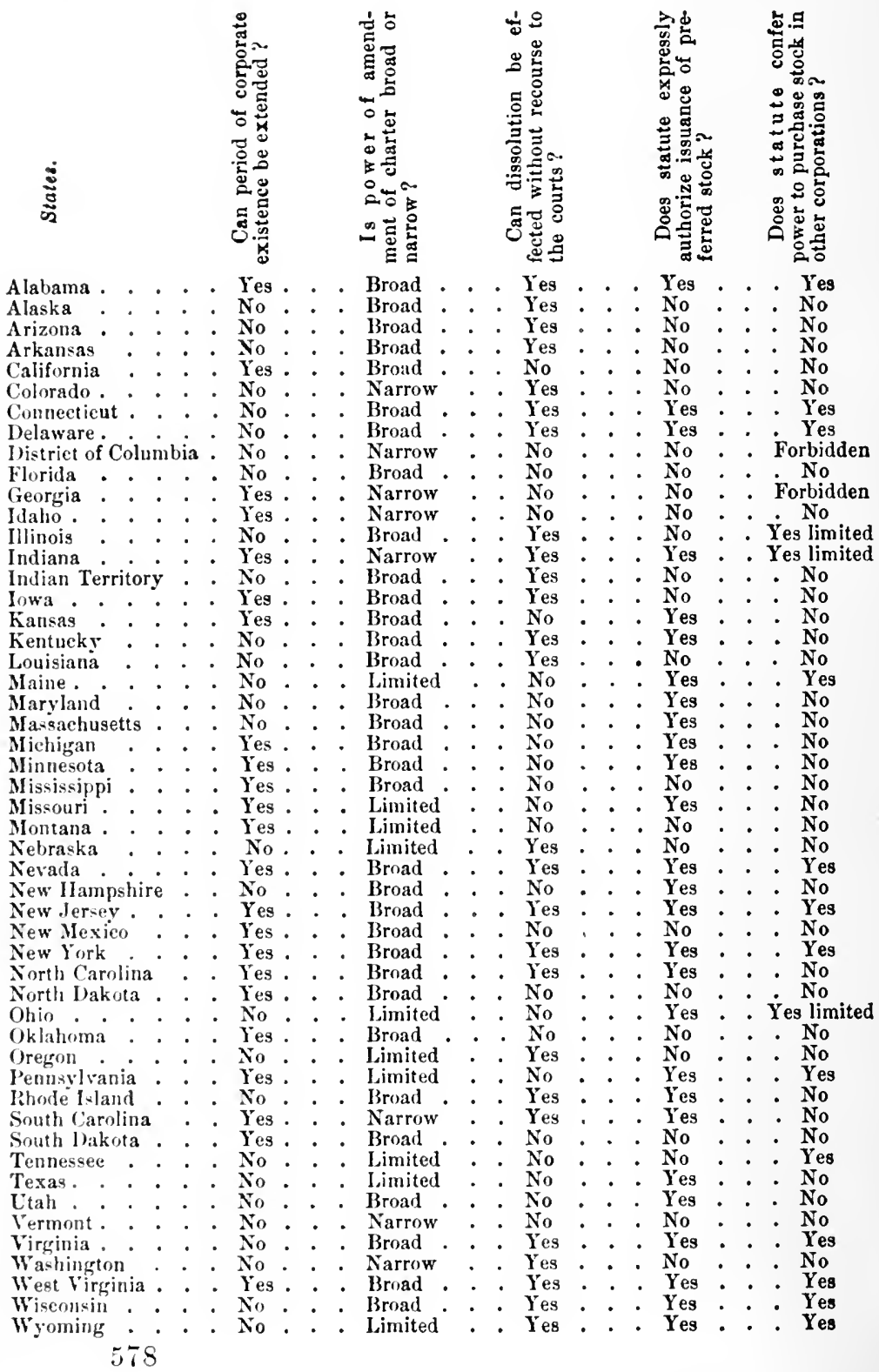




\section{TABLE IX.}

\section{TABULATED QUESTIONS AND ANSWERS (Continued).}

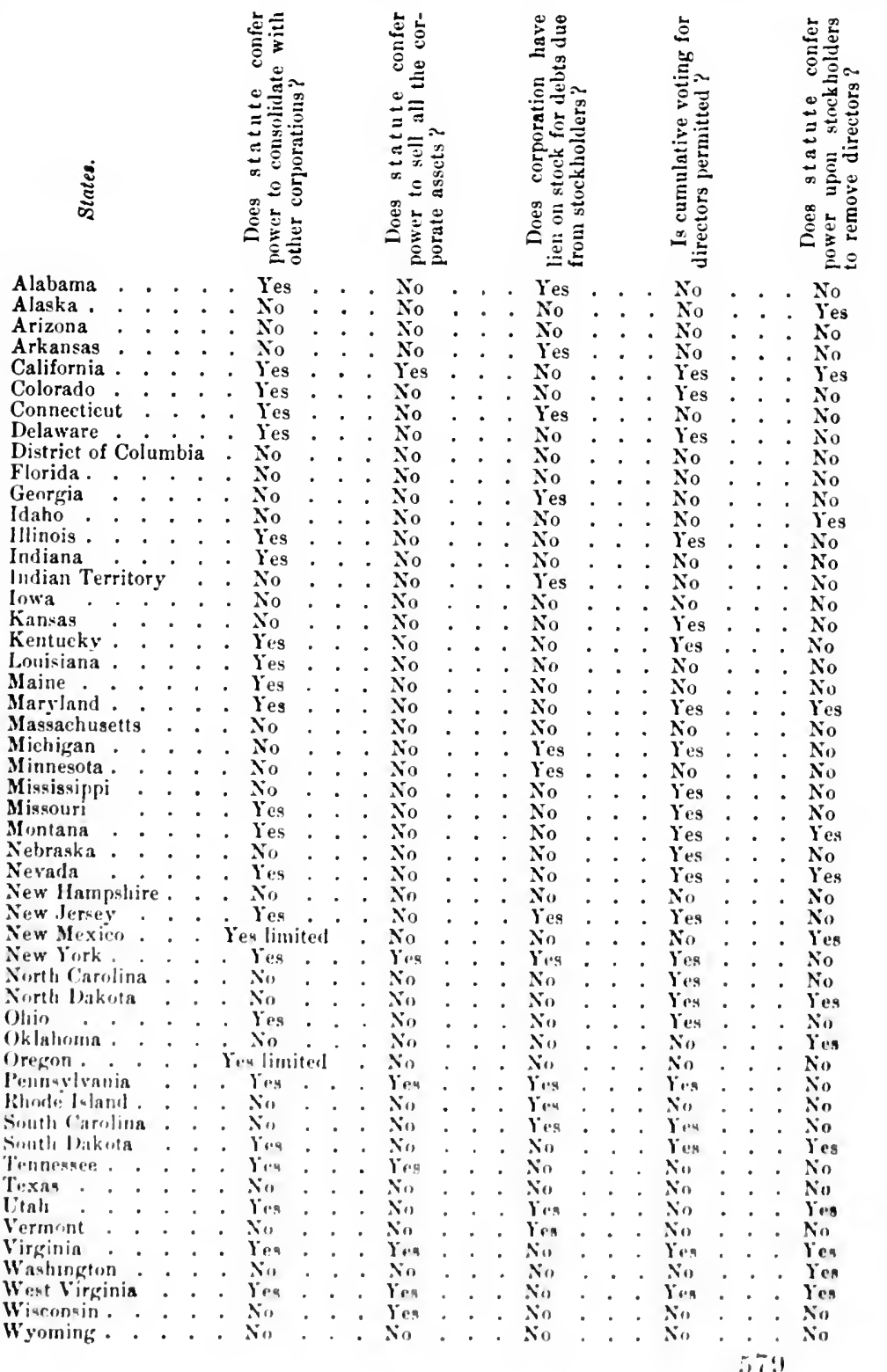




\section{'IABLE X.}

\section{TABULATED QUESTIONS AND ANSWERS (Continued).}

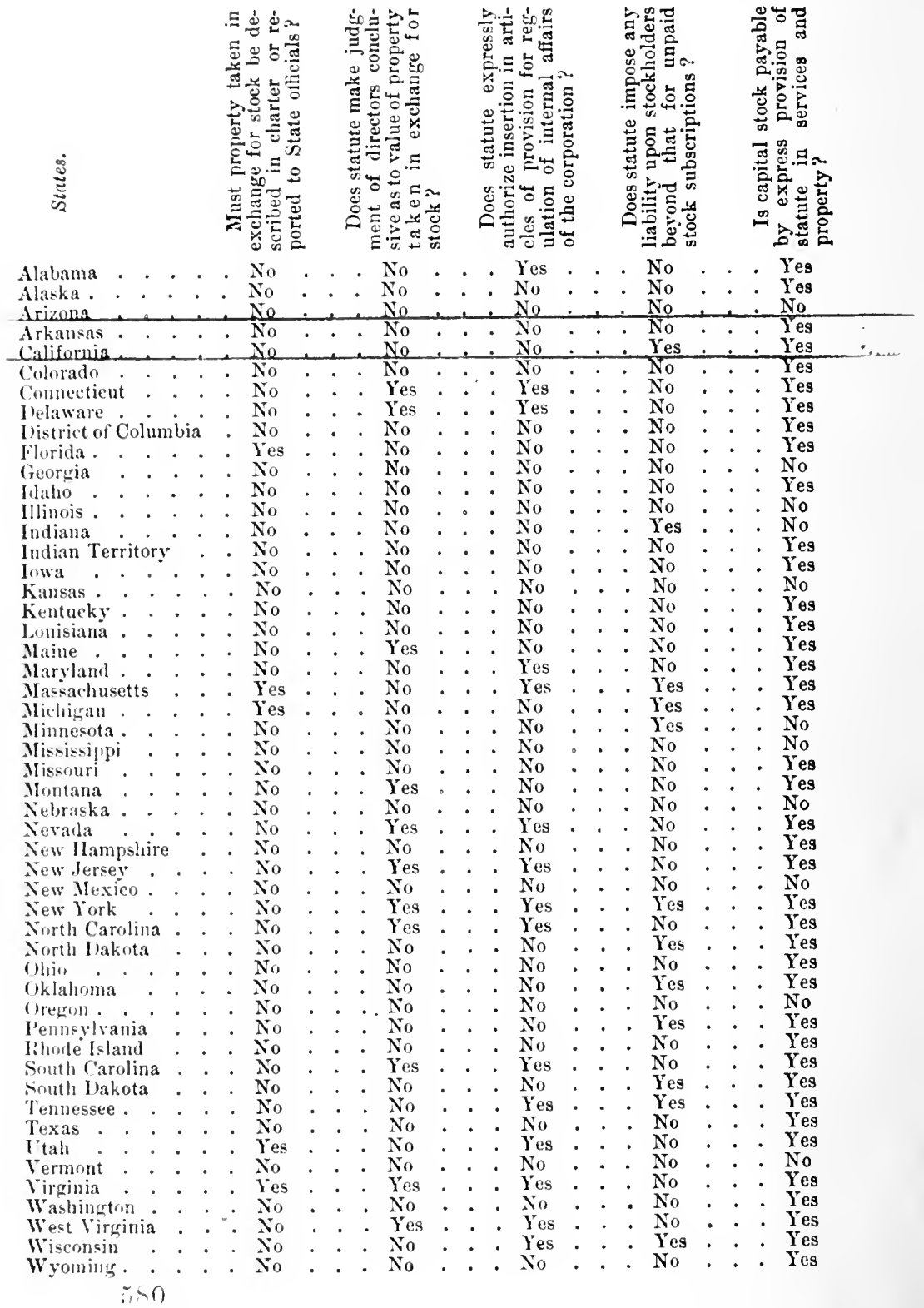




\section{TABLE XI.}

\section{TABULATED QUESTIONS AND ANSWERS (Continued).}
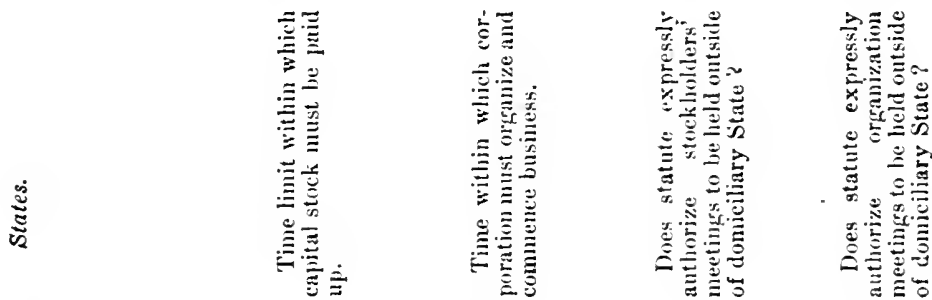

Alabama . . . . . None . . Five rears. . Yes.. . . No

Alaska . : . . . None: . Nolimit. . . No . . . No

Arizona _. None . Fiverears . No No . No . No

Arkansas . . . . . None . . Nolimit . . . No . . . N

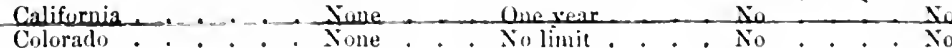

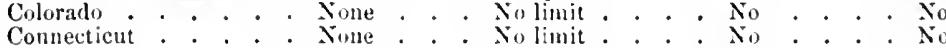

Delaware. . . None. . Twovears.. Yes. Yes

District of Columbia . . None . . . Nulinit . . . No . . . No

Florida. . . . None. . Nulimit. . . No . . . No

Georgia . . . . None . . Two vears . . No . . . No

Idaho . . . . . . Nune . . Ome vear. . . No . . . . No

Illinois. . . . . . None . . . lwovears . . . No . . . . No

Indiana - . . Iffecon 18 mos. . Nulimit. . . No : . . No

Indian Territory . . None . Nolinit... No . . No

Iowa . . . . . None . . . Two vears . . No . . . No

Kansas. . . . . . None. . . One vear. . . . No . . . . No

Kentueky . . . . None . . Twoyears . . . No . . . No

Iougiana . . . . . None . . . Nolinit . . . No . . . . No

Maine . . . . . . None . . Twopears . . . No . . . . No

Marylaul . . . . Four years . . No limit . . . No . . . No

Masachusetts . . . None . . Nolimit... No . . No

Michigan . . . . . None - . . Nolimit . . . Jes . . . No

Minnesota. . . . . None. . . Nolimit. . . Ves. . . . No

Missis-ing . . . . None . . Nolimit . . . No . . . No

Missonri . . . 50 immerfately . Nolimit . . . No . . . No

Montana . . . . Nome. . Mue year . . . No . . . No

Nebrakka . . . . None . . Nue year. . . No . . . No

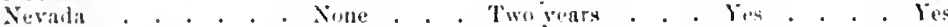

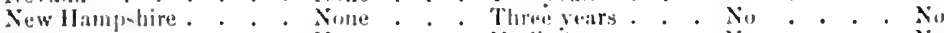

Now lar-o. . . . . Nome . . Nolinit . . . No . . . . No

New Mexieo . . . . . Nonte . . . Two vears . . . Yo . . . . No

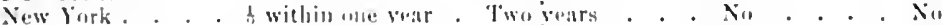

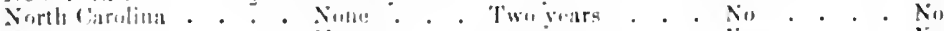

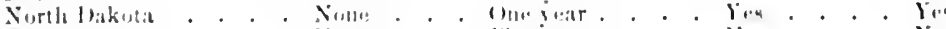

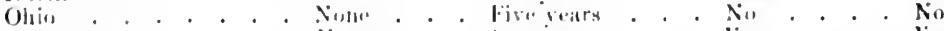

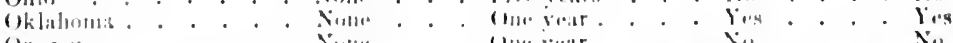

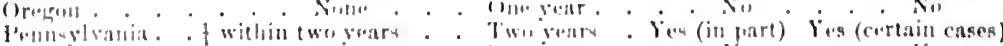

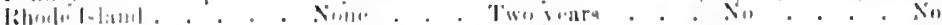

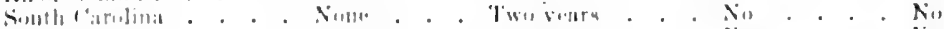

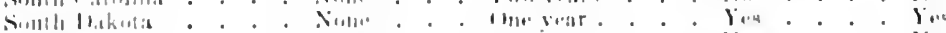

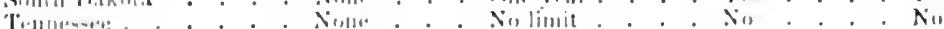

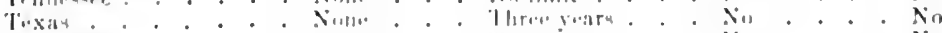

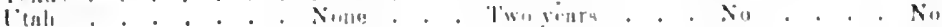

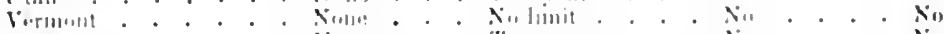

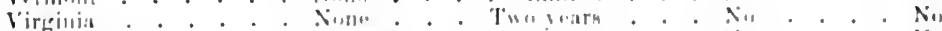

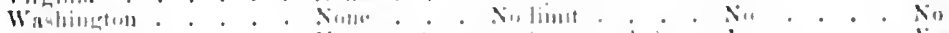

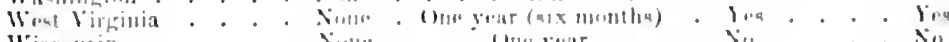

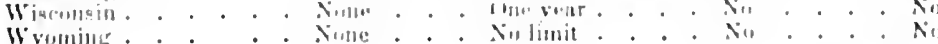

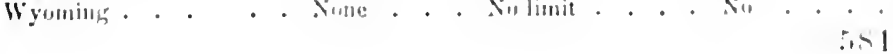




\section{TABLE XII.}

\section{TABULATED QUESTIONS AND ANSWERS (Continued.)}

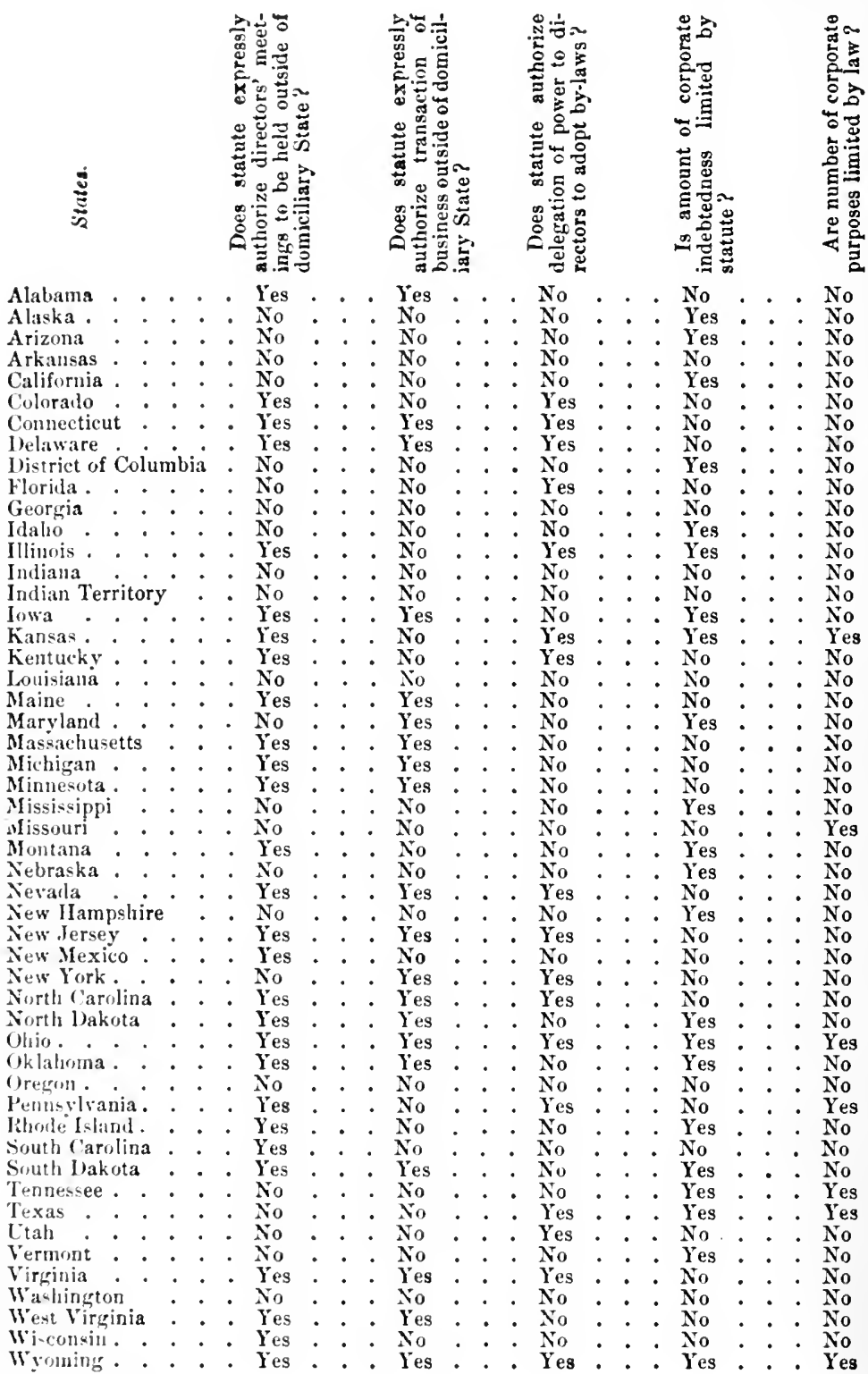
582 


\section{TABLE XIII.}

\section{TABULATED QUESTIONS AND ANSWERS (Continued).}

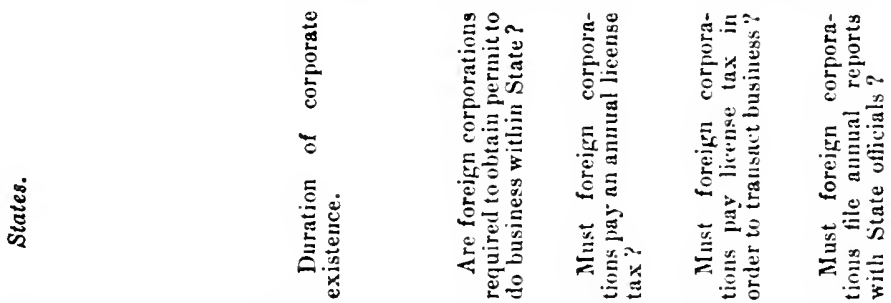

Alabama . . . . Unlimited . . Yes. . Yes.. Yes. . No

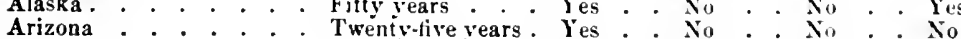

Arkansas . . . . . Unlimited . . Yes . . No . . Yes . . No

California_. Eiftyears-. . Yes . . No . Yes . No

Colorado . . . . . Twenty years: . Yes: . Yes. . Yes: . Yes

Connecticut . . . : Unlimited . . Yes: : No : No: Yes

Delaware . . . . Unlinited . . Yes. . No. . Yes . . No

District of Columbia . . Unlimited . . No . . No . . No . . Yes

Florida . . . . . Unlimited . No . No . No . No

Georgia. . . . . . Twenty years . . No . . No . . No . . No

Idaho . . . . . . Fifty veirs . . Yes.. No . Yes. . No

Illinois . . . . . . Ninety-nine years. Yes. . No . . Yes . No

Indiana : . Fifty vears, others perpetual. Yes $\dot{N}_{0} \cdot$ Yes $_{0} \cdot$ No $_{0}$

Indian Territory . . Culimited . . Yes.. No . . Yes. No

Iowa - . . . . . . Twenty years . Yes. . No . . Yes. . No

Kansas . . . . Twenty vears, Yes. No . Yes. Yes

Kentucky . . . . . . Unlinited . . Yo . . No . . No . No

Louisjana. . . . . . Nincty-nine vears. Yes. No . No. Yeg

Maine . . . . . . Cnlimited . . No . . No . . No . . No

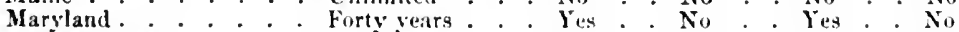

Massachusetts . . . . Inlimited . . Yes. . Yos. . Yes. . Yes

Michigan. . . . . . Thirty vears. . Yes. . No. Yes. . Yes

Minuesota . . . . . Thirtv veirs. . Yes. No . Yes . Yo

Mississippi . . . . Fiftyears . . Yes. . No. . Yes. . No

Missouri. Fes. Fifticars. Yes. Yes

Montana . . . . . Twenty years . Yes. . No . . No . Yes

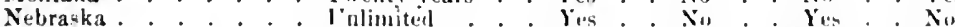

Nevarla . . . . P'nlimitel. . Yes. No. Retaliatory. Yes

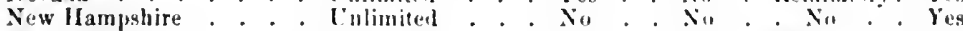

New Jorsey . . . . . Inlimited . . Yos. . Yus . laetaliatory. Yes

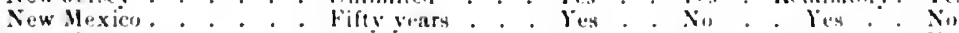

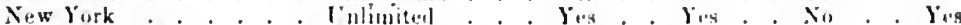

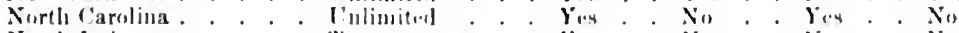

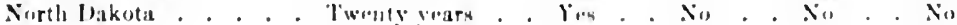

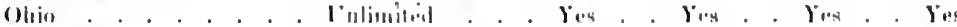

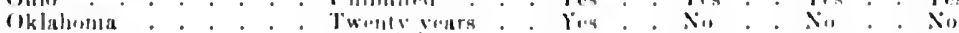

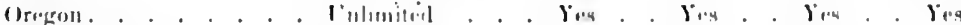

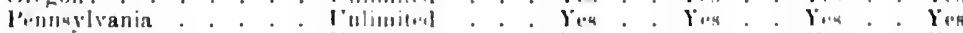

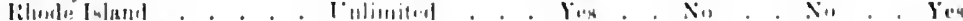

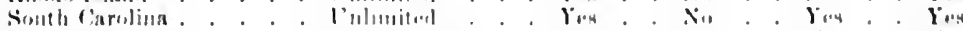

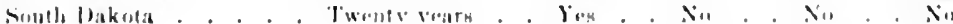

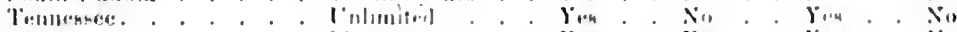

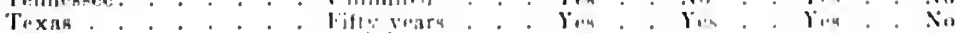

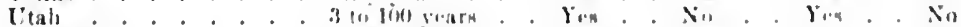

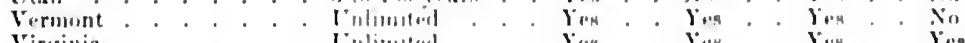

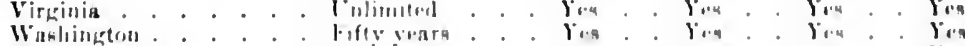

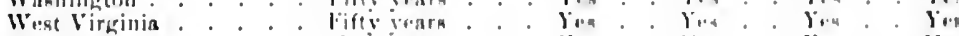

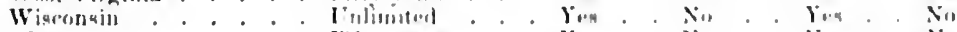

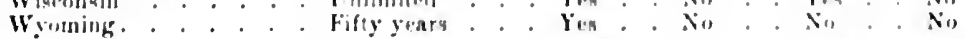




\section{TABLE XIV.}

\section{TABULATED QUESTIONS AND ANSWERS (Continued).}
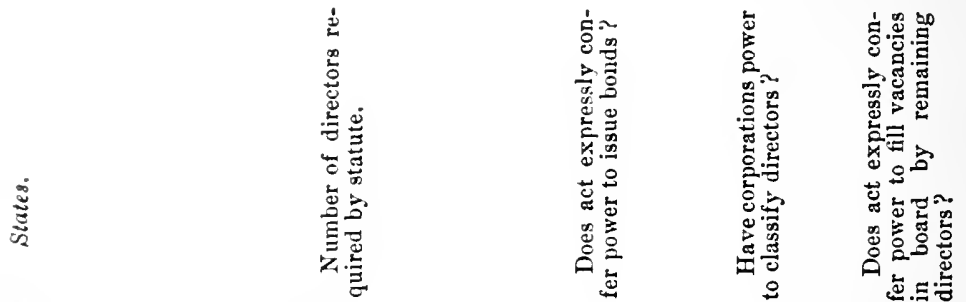

Alabama . . . . Three up

Yes

Aliskia

Three up

No

No: $:$ Yes

Arizona . . . . . One or more . . . . No

Arkansas

Three or more

No $\cdot$. No

l'aliformia

Five or nore

Yes

Coloralo.

Three to thirteen

No. $\cdot$ Yes

Deliware.

Three or more

No . - Yes

Inistriet of Columbia

Florita

Three to fifteen

Georuia

One or more

Ilaho

Olie or more

Illinois

Five to elever

Yes

Yos: Y : Yes

Yes: Yes . Yes: : Yes

Indiana - . - . Three to thirteen

Five to eleven

No . . Yes

No

No: . Yes

No . . No

'Three or more

No . . Yes

Yes... No

(1) wa

One or more

Kansas

Three to twenty-four

Louisiana

Three or more

Maine.

Marvland

One or more

No

No: $:$ Yo

No . . No

Massachusetts : $:$. $^{\text {M }}$. Three or more

No . . No

Yes... Yes

No: $:$ No

Yes . . No

Three or more
Three to fifteen

Minnesotia

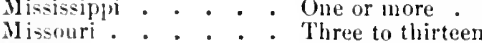

Montana . . . . . Three to thirteen

Nebraska

One or more.

Nevada

Three or more

No . . Y Yes

Yes... Yes

No . . Yes

Yes. . No

No . . No

New llampshire . . . Three or more

New $J_{\bullet}$ rsey . . . . Three or more

Three or more

New Mexico

Three or more

Yes . . Yes

No . . Yes

New York

Three or more

No . . No

Yes... Yes

No $:$ No

Yes . . Yes

North Carolina

Three to eleven

Yos: Y Y Yes

North Lakota

Three to eleven

Yes... Yes

Ohir . . Five to fifter

No . . Yes

Oklahoma . . . . Three to eleven . . . Yes

Oregon Three or more . . No

No $\cdot$ Yes

P'enucyluania

Three or mord

No . Y Yes

No . . . No

lahorle Foland

Three or more . . . . Yes

Yes . . Yes

South rarolina.

One or more... . No

South lakota.${ }^{*} \cdot$. Three to eleven . $:$. Ye

No

Tennessee

Five or more. Yes

No: $:$ Yes

Texas. . . . . Three to thirteen

No. Yes

Ttah - Three to twenty-fire Yos

Yes: $:$ : No $:$ No: $:$ Yes

Vermont . . . . . Three ormore . . . N

Virginia. Three or more

No . . No

Washington .

Two or more

Yes

Yes... Yes

No. . Yes

est Tirginia.. . One or more . . . . Ye

No . . Yes

Three or more

Yes

Wyoming . . . . Three to nine. Yes 


\section{TABLE XV.}

\section{TABULATED QUESTIONS AND ANSWERS (Continued).}

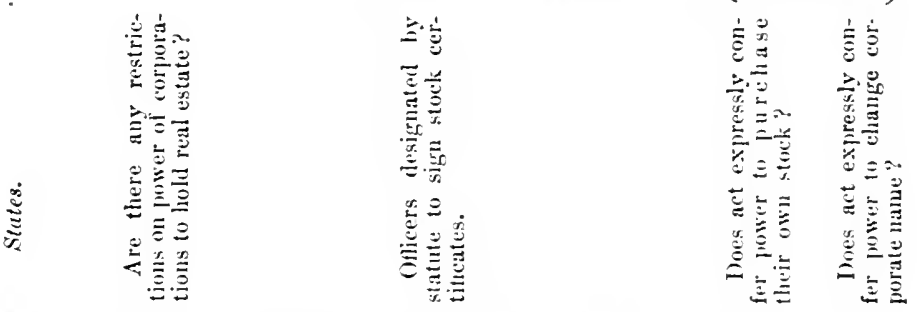

Alabama . . No . . Presilent and Secretary or Treasurer. No Yos

Alaska . . . No . . Not derimated . . . . . . No. . Yes

Arizona - . No . . Notdesignated . . . . . . . No . . Yes

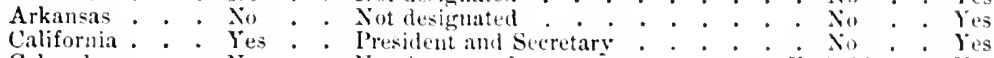

Colorado . . So . . Not designated . . . . . . . Forlidalon . Ves

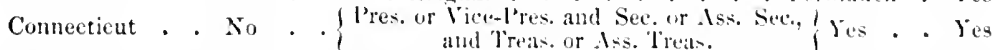

Delaware . . So . President and Treasurer . . . . Yos . Yes

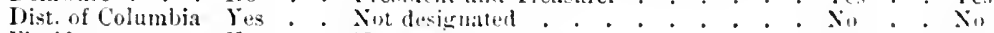

Flurida. . . Jes. . Nut designatud . . . . . . . . Nu . . Yes

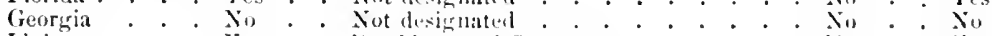

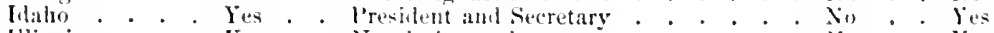

Illinois. - . Jes - . Not de-innated . . . . . . . . N11 . Yes

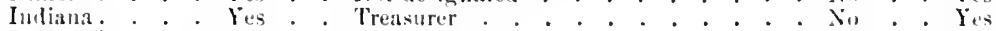

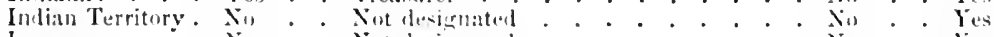

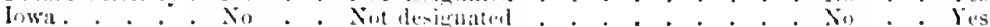

Kansas. . . No . . Nut deninnated . . . . . . . No . . Yes

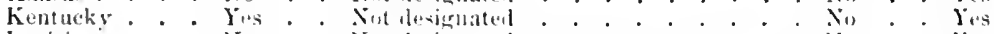

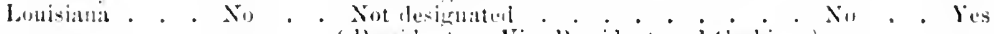

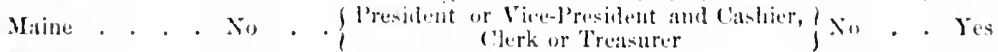

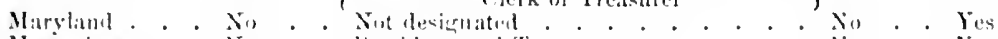

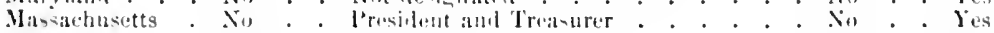

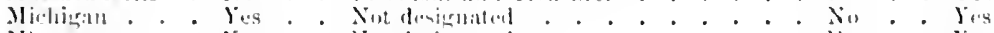

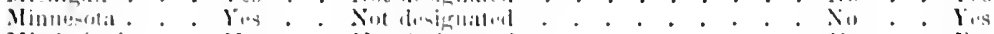

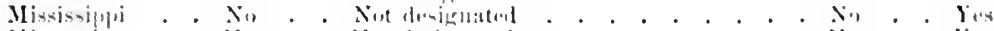

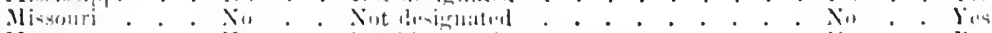

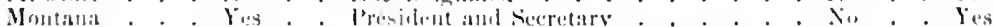

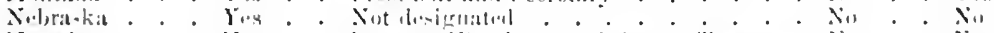

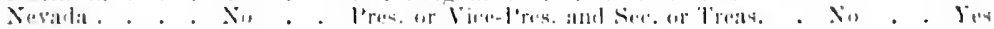

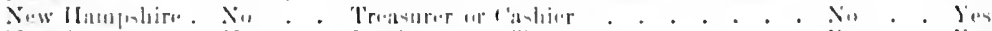

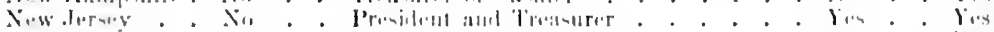

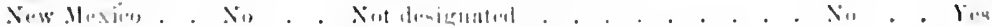

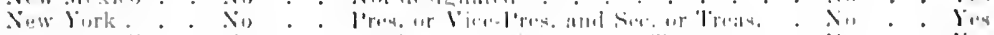

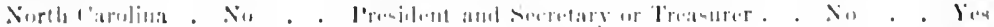

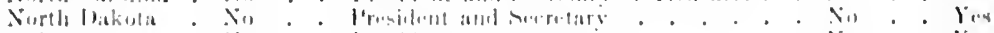

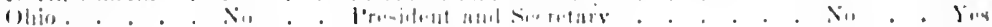

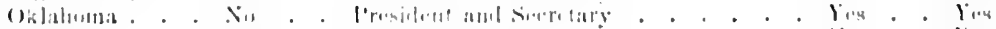

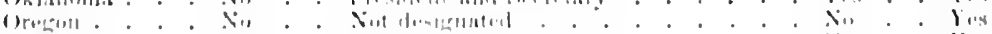

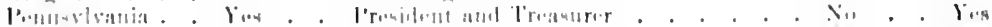

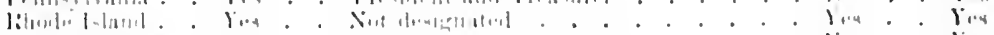

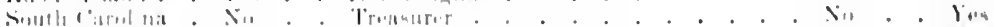

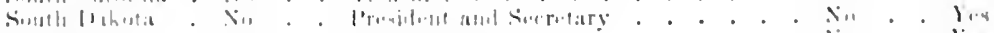

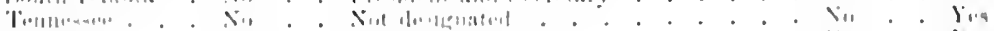

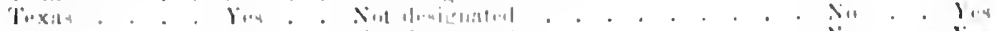

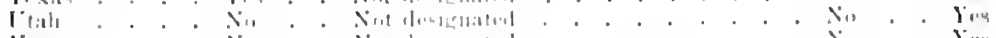

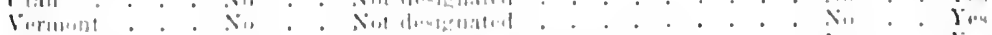

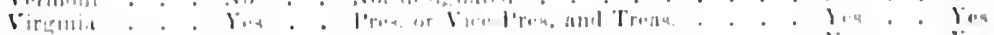

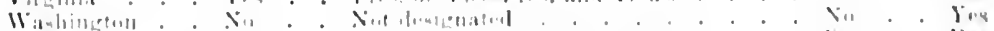

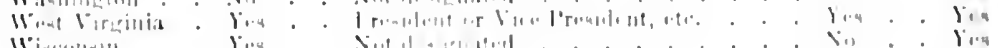

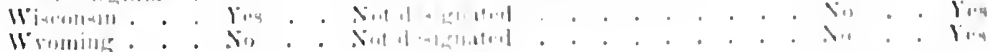

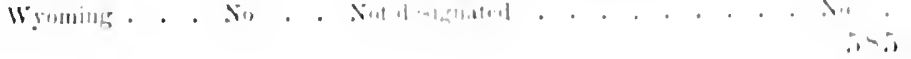




\section{TABLE XVI.}

\section{TABULATED QUESTIONS AND ANSWERS (Continued).}

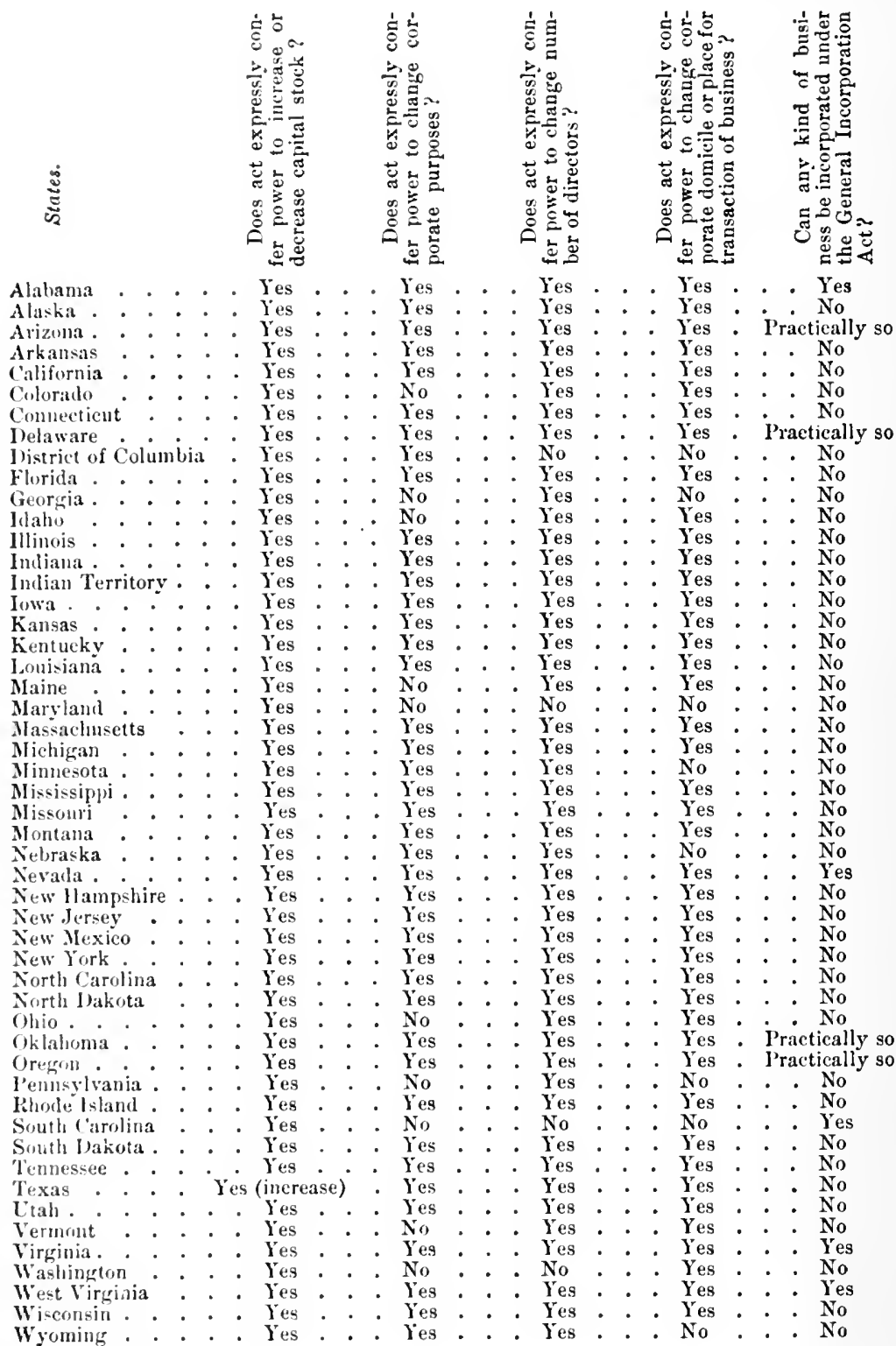




\section{TABLE XVII.}

\section{TABULATED QUESTIONS AND ANSWERS (Continued).}

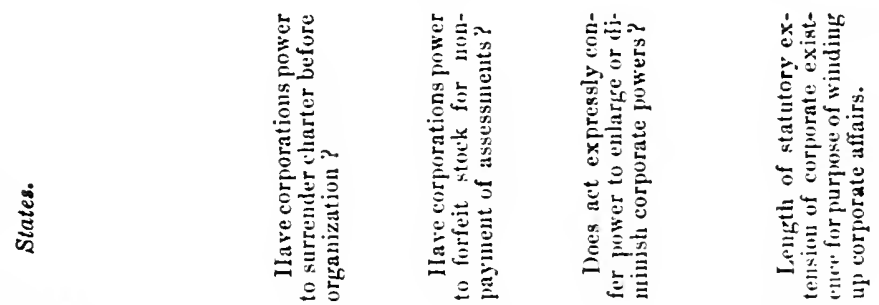

Alabama. Tes... Yes.. . Fiverears

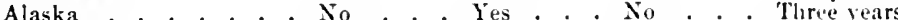

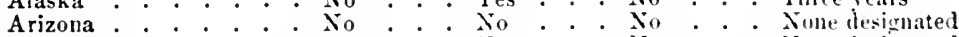

Arkansas . . . . No. . les. . No. . None desirnated

California . . . . No . . Yes. . No . . Nonedesignated

Colorado . . No . Yes... No . . None desifrnated

Connecticut . . . . No . . . Yes . . Yes . . Nine designated

Ielaware . . . . Yes:. . Yes. . Yes. . All necessary time

Iistriet of Columbia . . No . . . Yes . . No . . . None designated

Florida . . . . . No . . Yes: . No. . Three rears

Georgia . . . . No . . Yes. . No . . None designated

Idaho. . . . . . No . . Yes . . No . . None designated

Illimois . Yes. . No . . . 'Twovears

Indiana : . . . . No . . Yes . . No . . Threc years

Indian Territory. . . No... Yes.. No. . None designated

Iowa... . . . . No

Kansas: $: \div$ No

Kentucky . . . . . No

Iouisiana . . . . . No

Maine. . . Yes

Maryland . . . . . No

Massachusetts. . . Jes

Michigan . . . . . No

Minnesota . . . . No

Mississipui . . . . No

Missouri. . . . . . No

Mlontanil..... No

Nelıraska . . . . No

Nevala . . . . . Yes

New llamprshire. . . . No

New lersey . . . . Ye

Nine desirnated

Any necessary period

Aliv necessary period

None designated

lihree viours

All necessary time

Thrie veirs

Thire vears

Three vears

Three vears

None idsignated

None do-isnated

None desiguated

Ninfe designated

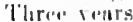

Nome designated

Ninge demizonater

New Mexien . . . . No

North rarolina . . . Ye

Yos

Xime dienifinated

North Iakota. . . . .

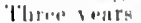

Ohic Jo

Oklahoma . . . . . No

Orepou . . . . Ni

lennerlinnia . . . . No

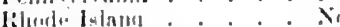

South tarulina . . . Xo

Sobutl, liakota. : . : No

Teuturague . . . . No

Tr:xus. . : . . N

Utah . . . . . X゙

Vermont. . . . . No

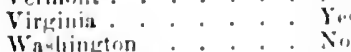

Wut Virmina. : * : Yus

Wisconujn. . . . Y Yon

Wyoming: : : . . . No

Notro despontent

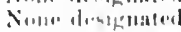

Nonle dimignated

Five vare

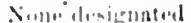

Plirie verire

Nille viongenated

Dola deregrated

Ina" varn

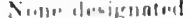

Xinlo danginated

Thro renta

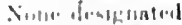

Niulne dempenated

None denignoted

Tlarew verse

Nines draignated 



\section{GENERAL INDEX.}

[The references are to pages.]

A.

ABANDONMENT,

non-user of corporate franchise as a ground for forfeiture . . 1is-159

of corporate powers . . . . . . . . . . . . 158-159

suspending ordinary business . . . . . . . . . . . . . 159

ABSENT STOCKHOLDERS,

may rote by proxy . . . . . . . . . . . . . 49,101

ACCEPTANCE,

by State of surrender of charter . . . . . . . . . . 15i

necessity of accejitunce of resignation of directors . . . . 101

ACCEPTING BENEFIT,

in its relation to doctrine of estoppel . . . . . . . . 633

ACCOUNT BOOKS. (See Buns or Accoust.)

ACKNOWLEMGIMNT,

of certificate of incorporation . . . . . . . . . . $79-80$

ACQUIFSCENCE,

effect of . . . . . . . . . . . . . .

AC'TIONS,

by crellitors . . . . . . . . . . . . . . . 112-113

by State to enforce forfeiture of charter. . . . . . 157-15is

by stockholders. . . . . . . . . . . . . . . litj-157

for assessments . . . . . . . . . . . . . . . . 1.2.

ADOP'TION. (Sice Ratricatmox.)

ADOPTION OF bY-LAW' . . . . . . . . . . . . 99-100

by directors . . . . . . . . . . . . . . . 7 .

ADVANTAGISS,

of corporate orgatization . . . . . . . . . . . . . 1-5

AFFIIDSIIT,

aufi-trust . . . . . . . . . . . . st

as to anoment of stock patil in . . . . . . . . . .2 73

sulseribed . . . . . . . . . nl

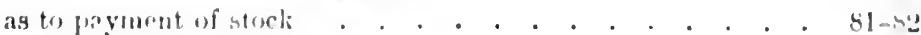

as to fullication . . . . . . . . . . . . . . nol

AGEN',

ifleriutment of . . . . . . . . . . . . . . . 1sin

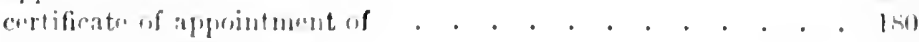

services of process upon . . . . . . . . . . . . . . 181 
AGREEMENTS,

to consolidate . . . . . . . . . . . . . . . 77

voting trust . . . . . . . . . . . . . . . 103

ALIENATION,

of franchise of being a corporation not permitted . . . . 51-52

ALIENS,

power of, by corporations . . . . . . . . . . 51-52

may be directors . . . . . . . . . . . . 101

may becoms incorporators . . . . . . . . . . . . 13

ALTERATION,

of by-laws . . . . . . . . . . . . . . . 100

of charter . . . . . . . . . . . . 46, 145-152

of name . . . . . . . . . . . . . . . . . . . 41

of number of directors . . . . . . . . . . . . . 46

of par value of shares . . . . . . . . . . . . 57

AMBIGUITIES,

in corporate grant is resolved in favor of public . . . . 77-78

AMENDMENT,

change of capitalization . . . . . . . . . . . 41

corporate agent . . . . . . . . . . . 47

domiciliary office . . . . . . . . . . . 42

duration of corporate existence . . . . . . 40-41

name . . . . . . . . . . . . . . . 41

number of directors . . . . . . . . . 46

par value of shares . . . . . . . . . . 57

place of business . . . . . . . . . . 47

powers . . . . . . . . . . . 56-57

purposes . . . . . . . . . . . 46, 145-152

decrease of capital stock . . . . . . . . . . . . 41

increase of capital stock . . . . . . . . . . . . 41

of charter by directors . . . . . . . . . . . . 146

stockholders . . . . . . . . . . . 145-152

of charters . . . . . . . . . . . . . . 145-152

before organization . . . . . . . . . 58

AMIOTION,

of directors . . . . . . . . . . . . . . 60-61

of officers . . . . . . . . . . . . . . 60 61

AMOUNT,

limitations upon amount of capital stock . . . . . . 69-70

of stock paill in . . . . . . . . . . . . . . . . 72

subscriptions . . . . . . . . . . . . . . 70-71

with which a corporation may begin business . . . 73

ANNUAL LICENSE TAX,

upon foreign corporations . . . . . . . . . 199-202

ANNUAL MEETING,

date of . . . . . . . . . . . . . . . . . . 74

place for holding . . . . . . . . . . . . . . 40

ANNUAL, REPORTS. (See REPORTs.)

ANTI-TRUST AFFIIAVIT . . . . . . • . • . . 81

ANTI-TRUST I.EGISLATION . . . • • • • • . 167-168

590 
APPLICATION FOR CIARTERS,

form of . . . . . . . . . . . . . . 80

refusal of . . . . . . . . . . . . . . 80,82-83

APPOINTMENT,

of executive committee . . . . . . . . . . . . 107-108

of resident agent . . . . . . . . . . . . . . . . 180

APPRAISAL OF PROPERTY,

by directors . . . . . . . . . . . . . . . 137-138

by State officials. . . . . . . . . . . . . . . . 139-141

taken by a corporation in exchange for capital stock . . . 137-138

ARTICLES OF AGREEMENT,

purpose of . . . . . . . . . . . . . . . . . 10

ARTICLES OF ASSOCIATION, synonymous with eharter

ARTICLES OR CERTIFICATE OF INCORPORATION, acknowledgment of . . . . . . . . . . . . 79-80 amendment of . . . . . . . . . . . . . . . . 145-152 contents of . . . . . . . . . . . . . . . . . . 11 defects in . . . . . . . . . . . . . . . . 80 evidentiary effect of . . . . . . . . . . . . . . . . 26 filing, publishing, and recording of . . . . . . . 80, 86-87 miscellaneous provisions relative to contents of . . . . . 76-77 publishing . . . . . . . . . . . . . . . 80 recording . . . . . . . . . . . . . . 86-s7 remarks on . . . . . . . . . . . . . . . . . . 9 signing. . . . . . . . . . . . . . . . . . . . 79 synonymous with charter. . . . . . . . . . . . . . 11

ASSENT OF S'TUCKHOLDERS,

to by-laws . . . . . . . . . . . . . . . . . 100

t) preferred stock . . . . . . . . . . . . . . . . 45

ASSESSMUNTS,

forfeiture of shares for non-payment of stock . . . . . 108-103

ASSETS, power to levy . . . . . . . . . . . . . . . . 45-49

of corporations liable for their lelts . . . . . . . . . . 11 t power of corporation to dispose of its entire . . . . . . 51-52 ATTORNEY-GISNERAL,

approval of articles by . . . . . . . . . . . . . . 77

bringing of quo warranto procecdings by . . . . . . . . 157

13.

BENEFITS,

doctrine that the reception of benefits under an ultra rires contract cuts off the right to set up its illegality . . . . . . . . 033

BEQLEST'S

power of corporation to acrupt . . . . . . . . . . . . 33

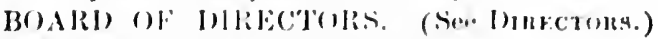

BOARD GF MANA(BEMLNT . . . .

BONA FHDE PURCHASERS OF SIIARES,

liability of, to creditors. 
BONIEII INIEBTLDNESS,

limitations upon .

. (See Part II.)

BONHIIOH,IERS,

right to participate in election of directors . . . . . . . 57

BONI)S,

power to issue . . . . . . . . . . . . . . 60

BONUS,

to be paid to the State upon creation of corporations . . . 84-85

BONLS sTOCK,

BOOKS,

inspection of corporate . . . . . . . . . . . 165-167

open to inspection of creditors . . . . . . . . . . 165-167

stockholders . . . . . . . . . 165-167

what books corporations required to keep . . . . (See Part II.)

where kept . . . . . . . . . . . . . . 65-66

BOOKS OF ACCOUNT. (See Books.)

BORROIY,

incidental power of corporations to . . . . . . . . 60

BREACHES of TRUST,

by directors

$174-176$

BURDEN OF PROOF,

when thrown upon creditors in attacking valuation of property

taken in exchange for stock . . . . . . . . . . . 125-137

when thrown upon stockholders in attacking valuation of property

takeu in exchange for stock . . . . . . . . 125-137

BUSINESS,

entire, may be transacted outside of domiciliary State . . . . 40

power to trausact, outside of domiciliary State . . . . 38-40

principal place of . . . . . . . . . . . . . . . . 66

BUSINESS CORPORATION,

Ineaning of term . . . . . . . . . . . . . . . . 9

BY-LA ITS,

adoption of . . . . . . . . . . . . . 99-100

alteration of lirectors

book of . . . . . . . . . . . . . . . 100

definition of . . . . . . . . . . . . . . . . 99

inherent power to make . . . . . . . . . . . . . . 33

mode of enacting . . . . . . . . . . . . . . . . . 33

power of directors to adopt . . . . . . . . . . . 55-56

of stockholders to adopt . . . . . . . . . . . . 99

to enact . . . . . . . . . . . . . . . . 33

to inflict penalties for violation of . . . . (See Part II.)

statutory provisions relative to . . . . . . . . . . 100

CAPITAL,

C.

liability of directors for declaring dividends out of . . . . . 174 what is, when applied to corporations . . . . . . 67-68 592 
CAPITAL STOCK,

decrease of . . . . . . . . . . . . . . . . . . 41

definition of . . . . . . . . . . . . . . . . 67-69

increase of . . . . . . . . . . . . . . . . . . 41

issuance of . . . . . . . . . . . . . . . . 112-113

limitation upon amount of . . . . (See Part III. Table Y.)

manner of payment of . . . . . . . . . . . 69, 112-113

payment of, in cash . . . . . . . . . . . . . . . 113

property. . . . . . . . . . . . . 120-122

CERTIFICATE OF CAPITAL STOCK, services............ 120

when must issue . . . . . . . . . . . . . . .110-111 who entitled to . . . . . . . . . . . . . . . . 110-111

who must sign . . . . . . . . . . . . . . . . . 110-111

CERTIFICATE OF INCORPORATION. (See Articles of Ixcorporation.)

CERTIFICATE OF ORGANIZATION,

synonymous with charter . . . . . . . . . . . . . . 11

CHANGE IN ARTiCles. (See Amendmext to Articles.)

CHANGE OF CORPORATE NAME . . . . . . . . . . 41

CHARTERS,

construction of . . . . . . . . . . . . . . . . 77-78

creation of corporations under . . . . . . . . . . . . 9

definition of . . . . . . . . . . . . . . . . . . 10

essentials of . . . . . . . . . . . . . . . . . . 11

form in whicl granted . . . . . . . . . . . . . . . 86

nature of . . . . . . . . . . . . . . . . . . 10

(See also Akticles of Incomporation.)

CITIZENS,

selection of matters to be inserted in . . . (See P'irt III. 568-570)

meaning of term in feleral constitution . . . . . . . . . 18I

CITIZENSHIP OF CORPORATIONS . . . . . . . . . . 66

CLASSIFICATION,

of directors . . . . . . . . . . . . . . . . . 57-58

of incorprration acts . . . . . . . . . . . . . . 7-8

COLLATHRA, ATTACK,

upon corpmat" existence . . . . . . . . . . . 21-28, 58-92

ujom corpurate pwers . . . . . . . . . . . . . 21-28

upen corporate purposes . . . . . . . . . . . . . 21-28

COMBINATIONS,

in restraint of trale, unlawful trusts for the control of corpora-

COMITYY,

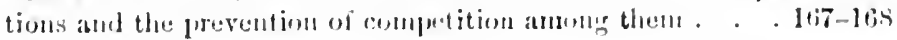

doctrinll of stitt"

$151-190$

COMMENCE RESINESS,

time within whinl corporation must organize and . . . . 10!1-1/11

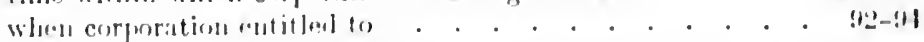

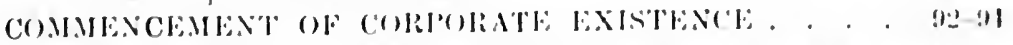

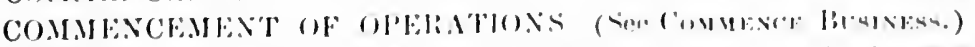

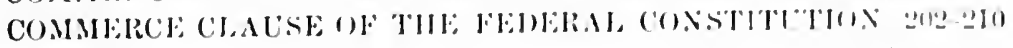


COM.MERCLAL, Paper. (See Negotiabe Instruments.)

COMMISSIONERS,

to take stock subscriptions . . . . . . . . . . . . 99

COMIIT'TlE,

exentive . . . . . . . . . . . . 56, . . 57-108

COMMON LAW POWERS,

definition of . . . . . . . . . . . . . . . 30-31

enumeration of . . . . . . . . . . . . 30-31

COMPANY,

does not imply incorporation . . . . . . . . . . . . 14

COMPEIITION,

combinations or trusts among corporations for the prevention

of . . . . . . . . . . . . . . . 167-168

CONCLUSIVE,

meaning of, in relation to evidentiary effect of documents . . . 26

CONDITIONS,

imposed upon domestic corporations with reference to transaction

of business within State . . . . . . . . . . . 145-179

imposed upon foreign corporations with reference to transaction

of business within State . . . . . . . . . . 180-210

CONDITIONS PRECEDENT,

to coming into existence as a corporation . . . . . . . 93

CONDITIONS SUBSEQUENT,

forfeiture of charters on the happening of . . . . . . . 93

CONSOLIDATION,

meaning of . . . . . . . . . . . . . . . . 40

payment of taxes upon . . . . . . . . . . . . . 85

regulation of right of . . . . . . . . . . . . . . 178-179

CONSOLIDATION OF CORPORATIONS,

when power exists

CONSTITUENT AC'TS,

power to perform outside of domiciliary State . . . . . . 40

CONSTITUTIONAL LAW . • . . . . . . . . . 181, 202-210

CONSTITUTIONAL PROVISIONS,

creating individual liability of stockholders for corporate debts $169-174$

CONSTITUTIONAL RESTRAINTS,

relative to impairing the obligations of contracts . . . . 153-15t

upon the creation of corporations . . . . . . . . . . . 9

CONSTRLC'TION OF CHARTER . . . . . . . . . . . 77-78

CONTRACTS,

impairing obligation of . . . . . . . . . 77-78

power of corporations to make . . . . . . . . . . 60

CONTROL OF CORPORATIONS,

who cutitled to . . . . . . . . . . . . . 102

CORPORATE AGENTS,

power to appoint . . . . . . . . . . . . . . . 33

CORPORATE BOOKS. (See Books.)

CORPORATE ELECTIONS. (See Elections.)

594 
CORPORATE EXISTENCE,

collateral attack upon . . . . . . . . . . . . 21-2s, s5-92

duration of . . . . . . . . . . . . . . . . . $73-i t$

extension of . . . . . . . . . . . . . . . . . 170-177

power to extend. . . . . . . . . . . . . . . . 40-41

proof of . . . . . . . . . . . . . . 24-21

right of State in direct proceedings to attack . . . . . . 90-92

when comnences . . . . . . . . . . . . . . . 92-94

CORPORATE NAME,

not alienable ......... . . . . 32

power to ehange. . . . . . . . . . . . . . . . . 41

right to . . . . . . . . . . . . . . 31

CORPORATE OFFICERS,

election of . . . . . . . . . . . . . . . . . . 105-1117

power to appoint . . . . . . . . . . . . . . . . 33

CORPORATE POWERS,

at common law . . . . . . . . . . . . . . 3n-31

classification of . . . . . . . . . . . . . . . 29-30

collateral attack upon . . . . . . . . . . . . . . 21-23

consolidation of . . . . . . . . . . . . . . . . . 29

definition of . . . . . . . . . . . . 30, 34.59

enumeration of . . . . . . . . . . . . 31-35

express . . . . . . . . . . . . . 30, 34,35

financial . . . . . . . . . . . . . . . 60

implied . . . . . . . . . . . . . 30-31, is

incidental . . . . . . . . . . . . . . . . 30, $59-60$

power of ainution . . . . . . . . . . . . . . 60-61

to give anl accept evidences of debt . . . . . . . . 60

mortgare and pledge . . . . . . . . . . . . 60

purchase corroration's own stock . . . . . . 36-37

purchise stuck in other corporations . . . . . . 3i-33

CORPORATE: PLRPOSES,

collateral attack upon . . . . . . . . . . . . 15-19

illogal . . . . . . . . . . . f fi-

numble of . . . . . . . . . . . . . . . . 10-20

CORPORATE SEAL,

right to anlopt and use a . . . . . . . . . . . . . . 32

corpromitons,

camnot li. created by volmutary agrenent . . . . . . . . 10

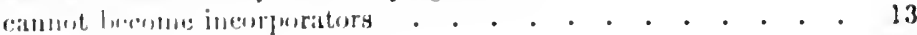

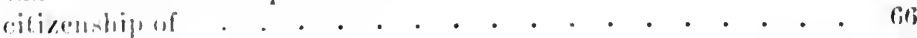

common law prwers of . . . . . . . . . . . . . . 35

conmelidation of . . . . . . . . . . . . . . 34, 17-179

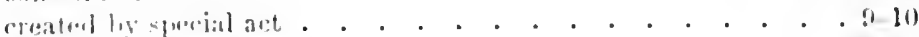

de fucto corpurations . . . . . . . . . . . . . . Mi-8s

J. fillition of . . . . . . . . . . . . . 87-8x

Innicilo of . . . . . . . . . . . . . . . .

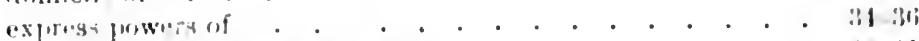

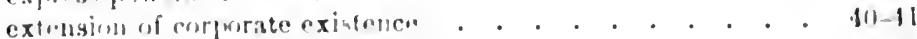

for what fmrjoses may be formed. . . . . . . . . . . I: 
CORPORATIONS - continued.

inciulental powers of . . . . . . . . . . . 59-60

nume of . . . . . . . . . . . . . . . . . . . 14

power of minority stockholders to compel purchase of holdings . 47

to amend articles before organization . . . . . . 58

appoint executive committee . . . . . . . . 56

authorize đirectors to adopt by-laws . . . . . 55-56

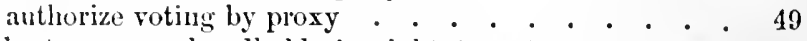

bestow upon bondholder's right to rote at corporate

elections . . . . . . . . . . . . 57

borrow money . . . . . . . . . . . . 60

change corporate domicile . . . . . . . . . . 47

cliange corporate name . . . . . . . . . . . 41

change corporate purposes . . . . . . . . . . 46

change number of directors . . . . . . . . . . 46

change par value of shares . . . . . . . . . 57

change principal place of business . . . . . . 47

classify directors . . . . . . . . . . . 57-58

diminish corporate powers . . . . . . . . . 57

dispose of corporate assets as an entirety . . . . 51-52

enforce a lien upon stock to secure payment of corporate

debts . . . . . . . . . . . . . . 47-48

enlarge corporate powers . . . . . . . . . . 56

forfeit stock . . . . . . . . . . . . . . 48-49

increase or decrease capital stock . . . . . . . . 41

insert provision for regulation of internal affairs . . 53-55

issue preferred stock . . . . . . . . . . . 41-45

issue stock in exchange for services or property . . 49-50

lery assessments . . . . . . . . . 4 48-49

make contracts . . . . . . . . . . . . 60

perform constituent acts . . . . . . . . . . . 40

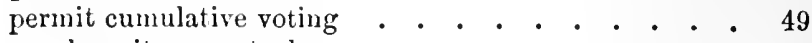

purchase its own stock . . . . . . . . . 36-37

purchase stock in other corporations . . . . . 37-38

surrender charter before organization . . . . . 58

transact business outside of domiciliary State . . . 38-40

voluntarily dissolve the corporation . . . . . 52-53

steps necessary to creation of . . . . . . . . . . . . 12

time within which corporation must organize . . . . . . 109-110

where can be created by special act . . . . . . . . . 9

CORPORATOR . . . . . . . . . . . . . . . . 12

COLNTY OFFICES,

filing and recording in . . . . . . . . . . . 86

CREDTTORS,

directors' liability to . . . . . . . . . . . . . . 174-176

right of, to enforce stockholders' liability for corporate debts . 169-174 insprect corporate books . . . . . . . . . 165-167

stockholders' liability to . . . . . . . . . . . 169-174

CUMULATIVE VOTING,

at corporate elections . . . . . . . . . . . . 49

596 
D.

DARTMOUTH COLLEGE DECISION • • • • • • • • 153

DATE OF ANNUAL MEETING . . . • • • . . . . 74

DEBTS,

limitation upon account of corporate . . . . . . 74-75

power of corporations to incur . . . . . . . . 60, 74-75

DECREASE OF CAIITAL STOCK . . . . . . . . . . 41

DE F.ACTO CORPORATIONS, . . . . . . . . . . . s7-90

DEFALLT,

in payment of anuual tax, effect of . . . . . . . . 160

DEFINITIONS,

busmess corporation . , . . . . . . . . . . . 9

capital stock . . . . . . . . . . . . . . . 68

incorporation . . . . . . . . . . . . . . . . . . 9

incorporator . . . . . . . . . . . . . . . . 12

shares of stock . . . . . . . . . . . . . . . . 68

DE JURE CORPORATIONS . . . . . . . . . . . S6-?0

DELEGATION,

of powers of board of directors to executive committee . . . 107-10s

DEVISES,

power of corporations to accept . . . . . . . . . . 33

DIMINISHMFNT,

of corporate powers. . . . . . . . . . . . . . 53

\section{DIRECTORS,}

adoption of by-laws by . . . . . . . . . . . . . 75

applaisal of property by . . . . . . . . . . . 137-13s

classification of . . . . . . . . . . . . . . 57-58

election of . . . . . . . . . . . . . . . . . . . 100-101

first meeting of . . . . . . . . . . . . . . . . . 105-1117

named in certificate are directurs de jure . . . . . . . . . 67

power to alopt by-liws . . . . . . . . . . . . . . 55,96

appoint executive commit tee . . . . . . . . 50

change number of . . . . . . . . . . . . . $11 ;$

vote by firsxy . . . . . . . . . . . . . 106

qualification of . . . . . . . . . . . . . . . 101-1112

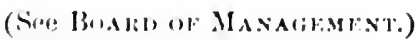

stitutory liability of

$171-170$

DIRECTORY PIOSISIONS,

Wlat are

91

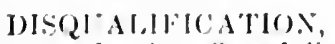

for the onlice of ilirectur

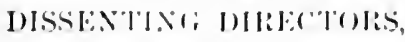

provision for the exonration of from statutory liability . . 151-157

D)ISSOL.T.TON,

involuntary . . . . . . . . . . . . . . . . . 156-167

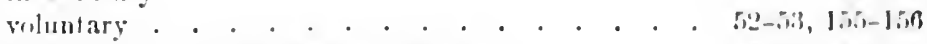

DISGOLETION OF (ORPORATIOSS . . . . . 52-53, 1.11-1.57 
DISTINCTION,

letween de jure and de facto corporations . • . . . • 87-88

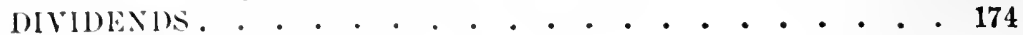

DOC"TRINE OF ESTOPPLL . . . . . • . . . • 63-65

DOCTRINL OF STATE COMITY • • • • • • • • . 184-190

1)OCTRINE OF ULTRA VIRES. . • • • • • • • 61-65

1)OING BLSINESS,

what constitutes doing business by a foreign corporation . . 190-195

DOMESTICATION,

of foreign corporations. . . . . • . . . • . . 198

DOMESTIC CORPORATIONS • • • • • • • • • • 145-179

DOMICII,

corporate . . . . . . . . . . . . • . . $65-66$

DOMICILE OF CORPORATIONS,

power to change corporate . . . . . . . . . . . 47

DOMICILIARY OFFICE . . • • • • • • • • • 65-66

DOLBLE LIABILITY,

of stockholders to creditors . . . . . . . . . . 173

DUMMY,

directors . . . . . . . . . . . . . . . . 14

incorporators . . . . . . . . . . . . . . . . 14

DURATION,

of corporate existence . . . . . . . . . . . 73-74

limitations upon . . . . . . 154-155

of office for directors . . . . . . . . . . . 102

E.

EFFECT,

ELECTION,

of appraisal of property by directors . . . . . . . 137-138

state officials . . . . . 139-141

of corporate officers . . . . . . . . . . . . 107

ELECTIONS,

corporate . . . . . . . . . . . . . 100-104

of directors . . . . . . . . . . . . . . 100-104

ELEEMOSYNARY CORPORATIONS . . • • • • • • • . 9

ELIGIBILITY,

as an incorporator . . . . . . . . . . . . 14

to office of director . . . . . . . . . . . . . . 100-104

ENLARGEMEN'T,

of corporate powers . . . . . . . . . . . . 56

EQUAL PROTECTION OF LAWS . • • • • • • . . 181

ERROR OF JUDGMENT. . . . . . . • • . • • . 136

ESTOPPEL,

doctrine of, in pais . . . . . . . . . . . . . 63-65

in case of ultra vires contracts . . . . . . . . . . . 63-64

to deny corporate existence . . . . . . . . . . . . . 28 598 
EVIDENCE,

meaning of conclusice . . . . . . . . . . . . 26

prima facie. . . . . . . . . . . . . 20

of corporate existence . . . . . . . . . 24-26, 8i-s8

EXCESSIVE DEBTS. . . . . . . . . . . . $74-75$

EXECUTION,

of articles of incorporation . . . . . . . . 79-80

EXECLTIVE COMMITTEE,

appointment of . . . . . . . . . . . 107-108

power of directors to appoint. . . . . . . . . . . . . . 56

powers of executive committee of directors . . . . . . . . 56

EXEMPTION,

of stockholders from personal liability . . . . . . . . . . 75

EXISTENCE OF CORPORATION. (See Corporate Existexce.)

EXPIRATION OF CHARTER . . . . . . . . . . . . 176

EXPRESS POWERS,

definition of . . . . . . . . . . . . . 34-37

enumeration of . . . . . . . . . . . . 31-37

EXTENSION,

of corporate existence . . . . . . . . . . . . . 176-177

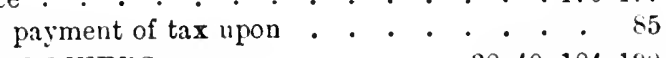

EXTRA-TERRITORIAL POWEIRS . . . . . 38-10, 184-190

F.

FALSE REPORT,

liability for directors making . . . . . . . . . . 171

FEDERAI, COCRTS,

right of foreign corporations to remove cases to . . . . . 198

FEES,

organization . . . . . . . . . . . . . 84-85, 177-178

FICTITIOL'S INCREASE,

of stock . . . . . . . . . . . . . . 12:

FICTITIOLS STOCK . . . . . . . . . . . . . . 72,14 . . .

FILING; CHARTER,

in local connty oflices . . . . . . . . . . . 86-87

with State oflicials. . . . . . . . . . . . . . 82-51

FINANCIA, POWlERS OF CORPORITIONS . . . . . . 60

FINES,

power to ruforce by-laws by penniary fines . . . . . . . 33

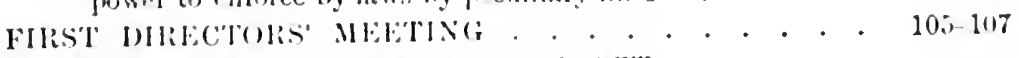

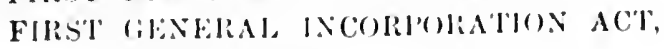

reforences to

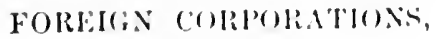

anmual licengr tax on . • • • . . . • . . • . . 189-20?

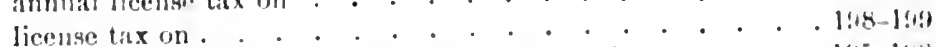

penalty for transacting business without pormit . . . . . 195-1!18

power to "xclumle

what constitutus loing business on the part of . . . . . 190-195 
FORFIGN I.IITS,

extra-territorial force of statutes enforeing liability upon direc-

tors and stockholders . . . . . . . . . . . . 169-176

FOLFEITLRE OF CIARTERS,

for insolvency . . . . . . . . . • . . . . . 160

for misuse or abuse of corporate powers . . . . . . . . . 159

for non-payment of taxes. . . . . . . . . . . . . . 160

for non-performance of conditions precedent . . . . . . 160

subsequent . . . . . . . 160

for non-llser of corporate franchises . . . . . . . . 158-159

for violation of express statute . . . . . . . . . . . 160

FORFEITLRE OF SHARES . . . . . . . . . . . 48-49

FOR.I,

in which charter is granted . . . . . . . . . . 86

FRANCHISES,

corporation . . . . . . . . . . . . . . . . 11

FRANCIISE TAX,

distinction between franchise tax and property tax . . . 177-178

distinguished from organization tax . . . . . . . . 84-85

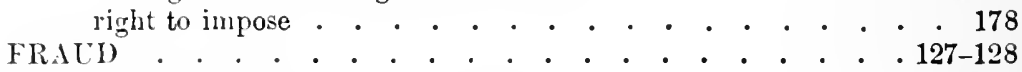

FR.AUDLLENT ISSUE OF SHARES • • • • • • . . . . 33

FULL ILABILITY CORPORATIONS • • • • • • • • • . 174

FULL-PAII STOCK. . . . . . . . • • • • • • • • 142-143

FUNDAMENTAL CHANGES IN CHARTER. . . . . . . 145-152

GIFT OF SHARES,

G.

effect of, on liability of stockholders . . . . . . . 143-144

"GOOD FAITIL RULE,"

for payment of shares in property other than money . . . . 123-125

statement of . . . . . . . . . . . . . . . . . . . . . . .

GRADUATED ORGANIZATION TAX,

right to impose . . . . . . . . . . . . . . . 178

GRANT,

validity of . . . . . . . . . . . . . . . 85

power to . . . . . . . . . . . . . 32-33

H.

HOLDING OVER BY DIRECTORS . . • • . • • • • 102

I.

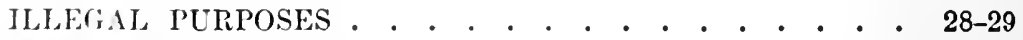

IMMUNITY,

from fersonal liability by publication of articles . . • . . 80

IMPLIEI POWERS . • • . • • . • • • • • • • • • • 59

INCIDENTAL POWERS • • • . . . . . . . . . 59-61

INCORPORATION,

defintion of . . . . . . . . . . . . . . . . . . 9

purposes for which corporations may be formed . . . . 17-19 600 
INCORPORATION ACTS,

classification of . . . . . . . . . . . . . . . 7-8

INCORPORATORS,

aliens may be . . . . . . . . . . . . . . . . . 13

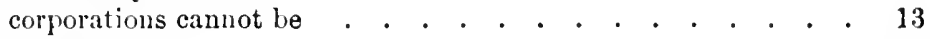

definition of . . . . . . . . . . . . . . . . . . 12

dummy . . . . . . . . . . . . . . . . . . . 14

infants cannot be . . . . . . . . . . . . . . . . 13

married women mar be . . . . . . . . . . . . . . 13

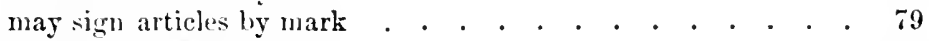

must be known persons . . . . . . . . . . . . . 13

organization meeting . . . . . . . . . . . . . . 95-96

privileges of . . . . . . . . . . . . . . . . . . 11

qualifications of . . . . . . . . . . . . . . . . . 12

synonymous with corporators . . . . . . . . . . . . 12

INCREASE,

in par ralue of shares . . . . . . . . . . . . . . . 57

of capital stock . . . . . . . . . . . . . . . 41

INDEBTEDNESS,

limitation mpon corporate . . . . . . . . . . . . 7l-75

INDIVIDLAL LIABILITY OF STOCKHOLDERS . . . 1 1:!-17.

INFANTS . . . . . . . . . . . . . . . 13

INSOLVENCY,

forfailure of charter for . . . . . . . . . . . . . 160

INSPECIION OF BOOKS ANI) RECORDS,

by creditors . . . . . . . . . . . . . . . . 165-1617

by stochholders . . . . . . . . . . . . . . . . 16i.-1tit

INSPECTUN OF CORPORATE BOOKS. . . . . . 165-167

IXSPCTOLS OF ELLCTION . . . . . . . . . 103-104

INTERNAL AFPAIRS.

frovisions for the regulation of . . . . . . 53-55, $76,168-169$

INTERPRETATRON OF CHARTER. . . . . . . 77-7S

INTER-STATE CoMALRCE,
clane of the Fuleral ('onstitution . . . . . . . 2010-210

INTROHलCTIN . . . . . . . . . . . . . . . . . 1

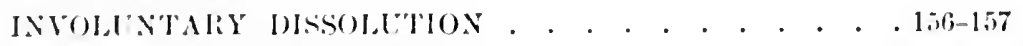

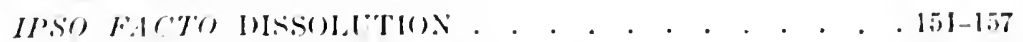

HSO HACTO FORFETTRE . . . . . . . . . . . 167-160

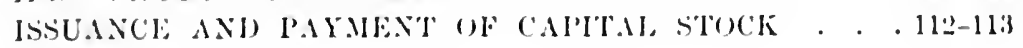

L.

LABOR DERTS,

liability of atrokholders for . . . . . . . . . 17:3-174

I.A.TI),

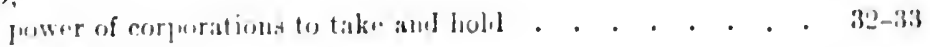

LAW A.VI F.AC\%,

gunentions of

125 
LEADING INCORPORATING STATES, enmmeration of . . . . . . . . . . . . . . . . 3,7 LEASES,

power of corporations to accept leases in exchange for stock . 50, 121

LEGISLATIVE AUTHORITY,

essential to creation of corporations . . . . . . . . . . 10

LEGISLATIVE CONTROL,

orer domestic corporations . . . . . . . . . . . 145-179

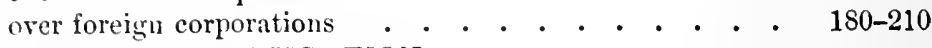

IEGISLATIVE INIESTIGATION, into corporate affairs . . . . . . . . . . . . . . 164

LEGISLATIVE REGULATION, of internal affairs . . . . . . . . . . 167-168

LEGISLATIVE REQUIREMENT, of annual report . . . . . . . . . . . . . . 164-165

LEGISLATURE . . . . . . . . . . . . . . 145

LETTERS PATENT, when conclusive as to fact of incorporation . . . . 24-28

LIABILITY, of directors. (See Dinectors.) of stockholders. (See StockHoLders.)

LIABILITY OF STOCKHOLDERS, exemption from . . . . . . . . . . . . 74-75 LICENSE TAX, LIEN, upon foreign corporations . . . . . . . . . . . 198-199

corporation's lien upon stock of its members to secure debts due it . . . . . . . . . . . . . . . . 47-48

\section{LIMITATIONS,}

upon amount of capital stock . . . . . . . . . . 69-70

upon corporate existence . . . . . . . . . . 74-75, 154-155 upon power to hold real property . . . . . . . . . . 32-33

LIST OF SHAREHOLDERS,

failure to keep alphabetical list of stockholders not an ipso facto dissolution . . . . . . . . . . . . . 176

MAJORITY, of directors rule in private corporations . . . . . . . . 102 of stockholders entitled to control in private corporations . . . 102 MANDAMUS, right of . . . . . . . . . . . . . . . . . . . 84

MANDATORY PROVISIONS . . . . . . . . . . . . . 91 MANNER OF PAYMENT OF CAPITAL STOCK • • 69, 113, 120 MANUFACTURING CORPORATIONS . . . . . . . . . 173 MARRIED WOMEN, may be incorporators . . . . . . . . . . . . . 13 MAXIMCM AMOUNT, of indebtedness . . . . . . . . . . . 82 602 
MEETING,

date of annual . . . . . . . . . . . . . 74

organization . . . . . . . . . . . . . 95-98

MEETINGS,

of directors . . . . . . . . . . . . . 105-107

for election of directors, where held . . . . . . . . . 104

of stockholders . . . . . . . . . . . . .40,96-98, 104

MERGER. See Coxsolidatiox.

MINING COMPANIES . . . . . . . . . . . . 131-132

MINISTERIAL DUTIES . . . . . . . . . . . . . . . 84

MINORITY STOCKHOLDERS,

power to compel purchase of their stock upon consolidation $55-59,102$

MISCELIANEOUS PROVISIONS,

relative to contents of articles of incorporation . . . . $76-77$

MISCONDLCT OF DIRECTORS. (See Amotion.)

MISTAKES OF JUDGMENT,

in appraisal of property taken in exchange for stock . . . . 136

MISUSER,

a ground for forfeiting corporate charter . . . . . . . . 159

MONEY,

paynent for stock in . . . . . . . . . . . . . . 113

"MONEY OR MONEY'S WORTH" RULE. . . . . . . 113

MOR'TGAGE,

corporate . . . . . . . . . . . . . . . 60

power to . . . . . . . . . . . . . . . . 60

MORTGAGE BUNDDS . . . . . . . . . . . . . . 60

N.

NAMES OF CORPORATIONS,

corporate nane not alienable . . . . . . . . . . 31

purpese of . . . . . . . . . . . . . . . . . 11,31

power to change . . . . . . . . . . . . . . . . 41

protection of corporate . . . . . . . . . . . . 31

right to a corjorate name . . . . . . . . . . . . 14,31

sinilarity in corporate name forbidilen . . . . . . . . 14,31

NEGIIGENCE,

liability of lirectors for . . . . . . . . . . . . 175

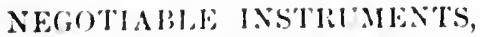

corporate powers relating to . . . . . . . . . . . . lin

NON-ASSESABLE STOCK . . . . . . . . . 141-112

NONPAYMENT OF TAXES.

forfuture of chaturefor . . . . . . . . . . . . . . 100

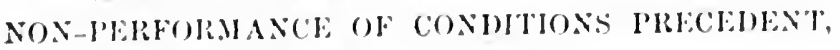

forfeitume of clartur for . . . . . . . . . . . . . . 160

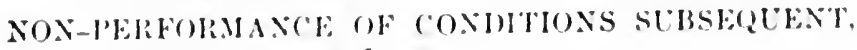

forfeiture of chartur for . . . . . . . . . . 160 
NON-LSEli,

dissolution of corporations for

$158-159$ NOTICE.

of director's' meetings . . . . . . . . . . . . . 106

of incorporators' meetings . . . . . . . . . . . . 96

O.

OATII,

of inspectors of election . . . . . . . . . . 103

OFFICE

of office

101

OFFICLRS,

of corporations . . . . . . . . . . . . . . 107

ONE-MAN CORPORATIONS . . . . . . . . . . 13-14

ONLS PROBANDI. (See BURdEN OF Proof.)

ORGANIZATION MEETING OF INCORPORATORS,

how called

where held . . . . . . . . . . . . . . . . . .

ORGANIZATION OF CORPORATIONS,

certificate of . . . . . . . . . . . . . . . 109

steps necessary to complete . . . . . . . . . . . 98-99

ORGANIZATION TAX . . . . . . . . . . . . 84-85

distinguished from franchise tax . . . . . . . . . . 85

graduated . . . . . . . . . . . . . . . . . 85

right to impose . . . . . . . . . . . . . . . . 178

ORGANIZE,

time within which corporations must . . . . . . . 109-110 OLSTER,

judgment of, in quo warranto proceedings . . . 112-113, 157, 198 OVERVALEATION,

of property delivered in exchange for stock . . . . . . 122-137

$\mathbf{P}$

PAID UP STOCK, meaning of . . . . . . . . . . . . . . 142-144

PARTNERS,

liability of incorporators as . . . . . . . . . . 80, 173

PAR VALLE,

change in . . . . . . . . . . . . . . 57

of capital stock . . . . . . . . . . . . . . . 70

PATENT RIGHTS . . . . . . . . . . . . . . 50, 121

PAYMENT OF CAPITAL STOCK . . . . . . . . 112-120

certificate of . . . . . . . . . . . . . . . 109

in property . . . . . . . . . . . . . . . . 120-122

in services. . . . . . . . . . . . . . . 120

PENALTIES,

for violation of by-laws . . . . . . . . . . . . 33 604 
PENALTY,

for failure to organize and commence business . . . . . . . 110 upon foreign corporations for transacting business without permit . . . . . . . . . . . . . . . .195-198

PERPETUAL SLCCESSION, right of . . . . . . . . . . . . . . . . 31-32

PERSONAL PROPERTY, power to hold . . . . . . . . . . . . . . . . 32-33

PETITION FOR INCORPORATION, synonymous with charter. . . . . . . . . . . . . . 11

PLACE OF BUSINESS . . . . . . . . . . . . . . . 66 power to change. . . . . . . . . . . . . . . . . 47

PLEDGE, power to . . . . . . . . . . . . . . . 60

PLEDGEES,

liability of, for unpaid stock subscriptions . . . . . . . 172

POLICE POWEL . . . . . . . . . . . . . . . . . 160-164

POWER,

to impose organization taxes. . . . . . . . . . . . . 85

POWER OF ATTORNEY, signing articles by . . . . . . . . . . . . . . . . 79

POWER OF STATE LEFISLATLRES, over foreign corporations . . . . . . . . . . . 180-181

POWERS OF CORPORATIONS,

cannot be created by by-law . . . . . . . . . . . 29

classifieation of . . . . . . . . . . . . . . 29-30

collateral attick upon . . . . . . . . . . . . 21, 23

common law . . . . . . . . . . . . . . 30-31

consolidation . . . . . . . . . . . . . . . . 33

express. . . . . . . . . . . . . . . . $30,34,36$

incirlental . . . . . . . . . . . . . . . . $30,5 \%-60$

to acquire and hold property in trist . . . . . . . . . . 33

to achuire, hold, and dispose of real and personal property. . 3:-33

to anumd articles before orgatuization . . . . . . . . . . . . 58

to apfoint corpurate ollieers and aconts . . . . . . . . 33

to apnoint executive crmunitio. . . . . . . . . . . . 56

to antlurize direnctors to alopt by-laws . . . . . . . . 55-is\}

to inthoriz: voting by proxy. . . . . . . . . . . . . . 19

to bestuw upm bondibolders right to voto at corporate elections. 57

to borrow money . . . . . . . . . . . . . . . . 011

to change corpmiate domicile. . . . . . . . . . . . 17

to chatug corporate name. . . . . . . . . . . . . 11

to "hatuge coringratie purposeg . . . . . . . . . 46, 115-152

to chatige unphluer of durectors . . . . . . . . . . . 16

to dhan par value of shares . . . . . . . . . . . 57

to change frimeipal place of husiness . . . . . . . . . 17

to clasuify lirentors. . . . . . . . . . . . . 57-58

to duminith corpmrate powers . . . . . . . . . . . 57

to disinse of corjuritte assets as an entirety. . . . . . . 51-62 
POWERS OF CORPORATIONS - continted.

to enforce a lien upon stock to secure payment of corporate

debts .

$47-48$

to enlarge corporate powers . . . . . . . . . . . . 56

to establislı by-laws. . . . . . . . . . . . . . . . 33

to extend corjorate existence . . . . . . . . . . . 40-41

to forfeit stock . . . . . . . . . . . . . . . . . 48-49

to holel meetings for election of directors without domiciliary State . 104

to increase or lecrease capital stock . . . . . . . . . . 41

to insert provision for regulation of internal affairs . . . . 53-55

to issue preferred stock. . . . . . . . . . . . . . 4I-45

to issue stock in exchange for services or property . . . . . 49-50

to levy assessments . . . . . . . . . . . . . . . 48-49

to make contracts . . . . . . . . . . . . . . . . . 60

to organize subsidiary companies . . . . . . . . . . . 37

to perform constituent acts . . . . . . . . . . . . . 40

outside of domiciliary State. . . 40

to permit cumulative roting . . . . . . . . . . . . 49

to purchase its own stock . . . . . . . . . . . . . 36-37

to purchase stock in other corporations . . . . . . . . 37-38

to sue and be sued . . . . . . . . . . . . . . . . 34

to surrender charter before organization . . . . . . . . 58

to take property by devise . . . . . . . . . . . . . 33

to transact husiness outside of domiciliary State . . . . . 38-40

to voluntarily dissolve the corporation . . . . . . . 52-53

PREFERRED STOCK,

included in amount of authorized capital . . . . . . 68

power to issue. . . . . . . . . . . . . . . . 41-45

PRINCIPAL PLACE OF BUSINESS. . • • • • • • . 66, 82

PROMOTERS . . . . . . . . . . . . . . . . . . 120

PROMOTION STOCK . . . . . . . . . . . . . . . 120

PROOF OF CORPORATE EXISTENCE . . . . . 24-26,87-88

PROPER'TY . . . . . . . . . . . . . 49, 50, 120-122

(See Payment for Simares.)

PROPORTIONATE LIABILITY . . . . . . . . . . 169-174

PROXY,

right to vote by . . . . . . . . . . . . 49, 104-105

directors cannot vote by, at board meetings . . . . . . 106

PUBLICATION,

of ammual reports . . . . . . . . . . 164-165, 175

of articles of incorporation . . . . . . . . . . 80

purpose of . . . . . . . . . . . . . . . 80

PLBLIC POLICY,

corporate purposes opposed to . . . . . . . . . . . 29

PURPOSES,

collateral attack upon corporate . . . . . . . . . 16-28

corporate . . . . . . . . . . . . . . . . . . 15-19

for which corporations may be formed . . . . . . . . 15-19

illegal . . . . . . . . . . . . . . . . . 28-29

606 
PURPOSES - continued.

more than one purpose . . . . . . . . . . . 19-20

number of . . . . . . . . . . . . . . 19-20

power to change corporate . . . . . . . 46, 145-152

Q.

QUALIFICATION SHARES . . . . . . . . . . 101

QUALIFICATIONS OF DIRECTORS . . . . . . . . 101

QUESTIONS OF LAW AND FACT . . . . . . . . 125

QUORUM,

at corporate elections . . . . . . . . . . . . 102

at stockholders' meetings . . . . . . . . . . . . . . 102

of directors . . . . . . . . . . . . . . . . . . . 106

of incorporators . . . . . . . . . . . . . . . . . . 96

QUO WARRANTO

157

R.

RATIFICATION

REAL ESTATE,

power to liolil. . . . . . . . . . . . . . . 32-33

REASONAILENESS,

of corporate by-laws . . . . . . . . . . . . 100

REC'ORDATION,

of articles of incorporation . . . . . . . . . . 86-87

RECOLDS,

corporate . . . . . . . . . . . . . . . . . . . . . . . . . .

REDLCTION OF CAPITAL,

corporate powers relative to . . . . . . . . . . 41

REGULATION.

of internal affairs . . . . . . . . . . 53-55, 168-169

provision for . . . . . . . . . . . . 76

of right of consolidation . . . . . . . . . . . . 178-179

REMOVAl, OF IDIRETORS . . . . . . . . . 60-1;1

RLDEWAL OF CIIARTER . . . . . . . . . . . 153-154

REPEAL . . . . . . . . . . . . . . . . . 90-100

of by-laws. . . . . . . . . . . . . . . . . . . . . . . . . . . . . .

of charters. . . . . . . . . . . . . . . .153-1.1

REPOR'S:

allunal . . . . . . . . . . . . . . . . 161-llii

legialistive requirement of annual . . . . . . . . . 16il-165s

statutery lialility of directurs rolative to. . . . . . 174-175

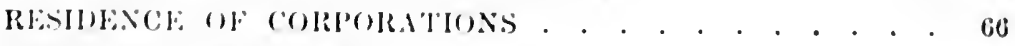

RESTR.AINT (H: TR.AI)

combinatims in . . . . . . . . . . . . . 167-168

RE'TALATORY TAXATIOX,

of foreign corprorations

199 
RIGHT,

of perpetual succession. . . . . . . . . . . . 31-32

to impeach corporate existence . . . . . . . . . . . 88-92

Ríli:

gool faith . . . . . . . . . . . . . . . . 123-125

speculative value . . . . . . . . . . . . . . . . 125-137

true value . . . . . . . . . . . . . . . . . 122-123

RLLLis,

for construction of charter . . . . . . . . . . 77-78

S.

SEAL,

affixed to certificate of incorporation . . . . . . . . 86

power to arlopt and alter . . . . . . . . . . . . . 32

use of, by incorporators . . . . . . . . . . . . . . 79

SECRETARY OF STATE,

effect of certificate of due incorporation . . . . . 21-28, 88-92

mandamus against . . . . . . . . . . . . . . . . 84

SERVICE OF PROCESS,

appointment of agent upon whom process may be served . . . 180

SERVICES,

payment of stock in . . . . . . . . . . . . . 49, 120

SIGNING ARTICLES OF INCORPORATION • • . . . . 79

SIMILARITY,

of corporate name forbidden . . . . . . . . . 14, 31

SOLE STOCKHOLDERS . . . . . . . . . . . . . . 13-14

SPECIAL AC'T,

incorporation by, forbidden . . . . . . . . . . . 9-10

SPECIAL LIABILITY . . . . . . . . . • . . . 173-174

SPECIAL REQUIRENIENTS,

as to articles of incorporation . . . . . . . . . . 81-82

SPEClLATIVE VALUE RULE . . . . . . . . 125-137

STATE,

police power of . . . . . . . . . . . . . . . 160-164

powers of, in creation of corporations . . . . . . . . 10,85

right of, to attack corporate existence . . . . . . . . 90-92

repeal charters . . . . . . . . . . . 153-154

STATEMENT,

of goorl faith rule . . . . . . . . . . . . . . 123-125

of true value rule . . . . . . . . . . . . 122-123

of speculative value rule . . . . . . . . . . . 125-137

STATE OFFICERS,

mandamus against. . . . . . . . . . . 84

STATE OFFICIALS,

appraisal of property by . . . . . . . . . . . 139-141

power to accept or reject articles . . . . . . . . . . 82-84

STATUTES OF MORTMAIN . . . . . . . . . . . . 32

608 
STATLTORY LIABILITY, of directors . . . . . . . . . . . . . . . . 174-176 of stockholders . . . . . . . . . . . . . . 169-174

STATUTORY LIMIT, of indebteduess . . . . . . . . . . . . . . . 74-is STOCK,

amount paid in . . . . . . . . . . . . . . . $22-73$ with whieh eorporation may begin business .
assessments . . . . . . . . . . . . . . $108-109$ eapital . . . . . . . . . . . . . . . . . . . $67-63$ extinguishment of . . . . . . . . . . . . . . . . 37 full paid . . . . . . . . . . . . . . . . . . 142-143 issuance of, in exchange for services or property . . 49-50, 112-137 legislative authority necessary to issuance of . . . . . . . 65 non-assessable . . . . . . . . . . . . . . . . 141-112 par value of . . . . . . . . . . . . . . . . . . 70 power of corporation to purchase its own . . . . . . . $36-37$

power to decrease forfeit . . . . . . . . . . . . . $45-49$ increase . . . . . . . . . . . . . . . 41

statement in articles as to manner in which same shall be paid for 69 STOCK CERTIFICATES . . . . . . . . . . . . .110-111 STOCKIIOLDERS,

doulle lialility . . . . . . . . . . . . . . . . . 173

exemption in articles from personal liability . . . . . . .

liability for deiss of the corporation . . . . . . . . . 16:-17. labor clains . . . . . . . . . . . . . . 173-17! mpaiıl stock subscriptions . . . . . . . . 16:-17:2

liability of pleignes . . . . . . . . . . . . . . 172 transferees. . . . . . . . . . 17: transfirors. . . . . . . . . . . . . 17: trustres . . . . . . . . . . . . 172 special liability . . . . . . . . . . . . . . . 173-174

STOCK NoTls . . . . . . . . . . . . . . 121

STOCK SUBSCRIPTIONS, affilavit as to . . . . . . . . . . . . si itmonnt of . . . . . . . . . . . . . . . . . 71-71

SUBORHARTE GFELERS ANT ARENTS, apprintmmit of . . . . . . . . . . . . . . . . 107

SUBSCRIPTONS FOR STOCK,

athatuit as to . . . . . . . . . . . . . . . . . sil

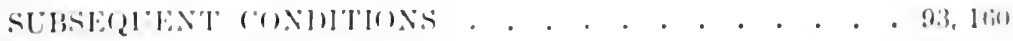

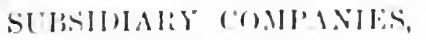

puser encergatuize. . . . . . . . . . . . . . 37

SCE,

lowertu. . . . . . . . . . . . . . . . 34

SLRPLLSARE, . . . . . . . . . . . . . . 
SIRREXINE OF CIIARTER,

before organization

SUSPENSION OF BUSINESS $156,158-159$

$\mathrm{T}$.

TAX.

orqanization . . . . . . . . . . . . . . 84-85

TAX.1'ION,

of domestic corporations . . . . . . . . . . . 177-178

TAXING POINR,

of the State as limited by the inter-state commerce clause of the

Federal Constitution . . . . . . . . . . . 202-210

TENDENCY,

in favor of incorporation . . . . . . . . . . . . . 9

TENURE OF OFFICE. . . . . . . . . . . . . . 102, 107

TERMINATION OF CIIARTER . . . . . . . . . . 151-155

TIME,

of corporate existence . . . . . . . . . . . . . . 73-74

within which corporations must organize and commence busi-

ness . . . . . . . . . . . . . . . . . . 109-110

TRADE MARK,

name of corporatfon protected as a . . . . . . . 15

TRADE NAME,

corporation protected in equity in use of its name . . . . 15

TRAMP CORPORATIONS . . . . . . . • . . . . 185

TRANSFER,

of entire corporate assets . . . . . . . . . . . 51-52

of shares . . . . . . . . . . . . . . . 171-172

TRANSFEREES,

liability of, for unpaid stock subscriptions . . . . . 171-172

TRANSFERORS,

liability of, for unpaid stock subscriptions . . . . . . 171-172

TREASLPY STOCK . . . . . . . . . . . . . 121-122

TPLE VAILE RULE,

statement of . . . . . . . . . . . . . . . 122-123

TRLST,

power to acquire and hold property in . . . . . . . . 33

votiug . . . . . . . . . . . . . . . . 103,105

TRLSTEE,

power of corporation to act as . . . . . . . . . . 33

TRLSTEES,

liability of, for unpaid stock subscriptions . . . . . . . 172

TRLST FLND DOCTRINE. . . . . . . . . . . . . 114

TRLST LEGISLATION . . . . . . . . . . . . . . 167-168

610 
ULTRA VIRES,

doctrine of

UNIFORMI TAXATIOY 61-65

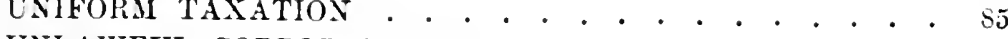

UNLAWFUL CORPORATIONS . . . . . . . . . . . 10

UNPAID STOCK . . . . . . . . . . . . . . 142-145

USER . . . . . . . . . . . . . . . . . . 88

V.

VACANCIES,

in board of directors, power to fill . . . . . . . . . 102 VALUATION,

of property taken in exchange for stock . . . . . . . . 13i-141

VALUE, PAR . . . . . . . . . . . . . . 70, 110-111

VERIFIED REPORTS . . . . . . . . . . . . . . . . 1Tt

VIOLATION OF EXPRESS STATLTES,

forfeiture of charter for . . . . . . . . . . . . 160

VISITORIAL POWERS,

of State legislatures relative to corporations . . . . . . 161

VOLUNTARY IISSOLUTION . . . . . . . . . 52-53, 155-156

VOLUNTARY SURRENDER OF CHARTER . . . . . . . 5S VOTING,

cumulatire - . . . . . . . . . . . . . . . . 49

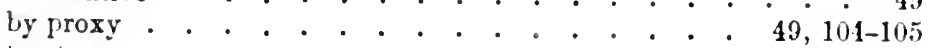

trusts . . . . . . . . . . . . . . . . . 103,105

W.

WHAT CONSTITUTES DOING BLSINESS,

on the part of foreign corporations $190-195$

WINIJNG; LP. (Ser Ilisglution aNd Forfeiturf.)

WORDS AND PLRASES . . . . . . . . . . . . (Sec passim.) 



\section{INDEX TO SYNOPSIS-DIGEST OF THE INCOR- PORATION ACTS OF THE SEVERAL STATES, TERRITORIES, ETC.}

[The references are to pages.]

\begin{tabular}{|c|c|c|c|c|c|c|c|c|c|c|c|c|}
\hline BAMA & & & & & & 217 & MIssocori & & & & & \\
\hline ALASKA. & . & . & & & & & MONTANA & & & & & \\
\hline RizoNA & . & . & . & . & . & & NEBRASKA & & & & & \\
\hline IKANSAS & & . & & & & & NEYADA. & & & & & \\
\hline HORNL & & & & & & & X.W Hand'sh & $1 \mathrm{KL}$ & & & & \\
\hline WLORADW, & & & . & & . & & NHW JEREEY & & & & & \\
\hline NXEctict & & & & & & & NEW MExico & & & & & \\
\hline WABE & & & . & . & & & XKW YoRk. & & & & & \\
\hline ICT of & & ,LI: & & & & & Netetn Canotet & & & & & \\
\hline INIox & or ( & & xab. & & 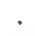 & & Nurtu l)akot. & & & & & \\
\hline $111 \mathrm{~A}$ & . . & . & . . & & 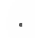 & & (1)m, . . . & & . & & & \\
\hline & . & . & . & . & & & HOMA. & & & & & \\
\hline & . & . & . & • & & & . . & - & & & & \\
\hline & . & . & . & 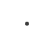 & . & & TYANIA & & & & & \\
\hline 1) is. & & . & . & . & & & & & & & & \\
\hline & & & . & & & & (1) line'u & & . & & & \\
\hline$\therefore$ 'TE & BU:IT & & $Y$ & . & . & & RUune: Istaxin & & & & & \\
\hline & . . & . & . & & & & th CAnut.1 & & & & & \\
\hline & . & . & - & & & & H DAkOTA & & & & & \\
\hline ChY & . & . & . & • & & & KーSER . & & - & & & \\
\hline IANA & . & . & . & • & & & $s$. & . & - & & & \\
\hline & & & . & & & & & & & & & \\
\hline & & . & & & & & & & & & & \\
\hline A.AN" & & . & . & • & & & & & & & & \\
\hline Irill:- & $-F: T 1$ & & . & & & & . & & & & & \\
\hline & . & . & & & & & -T Vhlisist. & 1.1 & & & & \\
\hline & & & & & & $2 ! 19 ! 3,111$ & Mincossis. & & & & & \\
\hline $1-511 \cdot 1$ & & & & & & :31)1-:311; & llyomen: & & & & & :) \\
\hline
\end{tabular}





\title{
INDEX TO FORMS AND PRECEDENTS.
}

\author{
[The references are to pages.]
}

A.

ACKNOWLEDGMENTS,

of articles of incorporation for the sereral States and Terri-

tories.

$413-508$

AFFIDAVIT,

as to mailing notices of stochholders meeting . . . . . . . 541 AGENT,

appointment of . . . . . . . . . . . . . . . 529-531

AGREEMENT,

for sale of real or personal property in exchange for capital

stoch . . . . . . . . . . . . . . . . 525-.120

placiurs shares of stock in trust for corporations . . . . . . 52ti

to take stock in corporition to be formed . . . . . . . . 52l

to underwriturs . . . . . . . . . . . . 54:511

to voting trust . . . . . . . . . . . . . . . 5li-jlti

AI,ABA.MA,

form for certificate of incorporation in . . . . . . . . 413

ALASKA,

form for articles of incorporation in . . . . . . . 411-145

APPOINTINE.NT,

of itgent . . . . . . . . . . . . . 529-5:31

ARI\%ON.1,

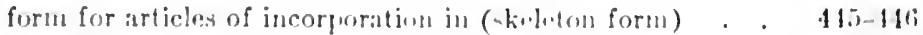

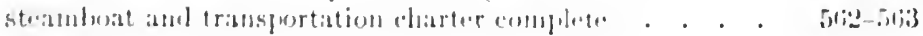

AlRASSAS,

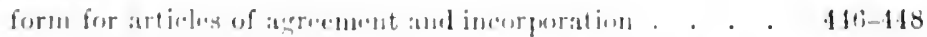

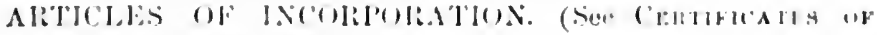

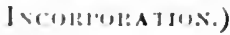

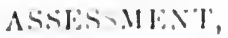

of stowk

500

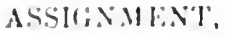

of subcription . . . . . . . . . . . . . . . 525

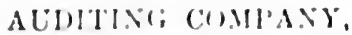

charter of (1114l.r Now Jersey lawg) . . . . . . 5.0-5io 
1).

li.1.K,

certificate to be filed with, on opening account

517

$13(1) \times 1)$

form of . . . . . . . . . . . . . . . . 532-533

trunt decl and bond . . . . . . . . . . . . . 531-541

B(ONI)S,

lirectors anthorized to issue . . . . . . . . . . . 510

mulerwriters' agreement for . . . . . . . . . . 543-544

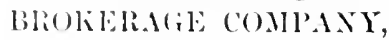

chatrter of (under New York laws) . . . . . . . 552-55t

BTSINLST,

clauses regulating business . . . . . . . . . . 510-511

classification of directors . . . . . . . . . . . . . . . . . 510

holking stucliholders' meetings without domiciliary State . . . 511

power of directors to lispose of all corporate jroperty . . . . 510

power to make, alter, amend, or repeal by-laws . . • . . . 510

power of directors to issue lonkls . . . . . . . . . . . 510

appoint executive committee . . . . 510

removal of officers and directors . . . . . . . . . . . 511

lien on stock for indeltedness of company . . . . . . . . 511

examination of books by stockholders . . . . . . . . . 511

cumulative roting . . . . . . . . . . . . . . 511

preferred stock clause, short form . . . . . . . . . 511

long form . . . . . . . . . 511-512

transaction of business without domiciliary State . . . . . . 509 BI-LA IIS,

form of . . . . . . . . . . . . . . 519-524

directors authorized to make, alter, and repeal . . . . . 510

CALIEOPNIA,

C.

form for articles of incorporation in . . . . . . . . 448-449

CAPITAL CLALSES,

from charters of

Aurliting Co. . . . . . . . . . . . . . 551

Brokerage Co. . . . . . . . . . . . 553-551

Conl Co. . . . . . . . . . . . . . . 562

Mlining Co. . . . . . . . . . . . . . . 561

Oil Co. . . . . . . . . . . . . . . . 559

Steauboat and Transportation Co. . . . . . . 562

'Trust and Investment Co. . . . . . . . . . 551

Typewriter Co. . . . . . . . . . . . . . 567

Linited States Steel Corporation . . . . . 517-548

Vehicle Motor Co. . . . . . . . . . . . . 566

preferred stock . . . . . . . . . 511-512, 547-548, 553-554

CERTIFICATE OF ACTHORIZATION,

to counter:ign certificates of stock . . . . . . . . . 512

CERTIFICATE OF SECRETARY,

to passage of a resolution . . . . . . . . . . . . . 529

(j) 1 ; 
CERTIFIC.ATES OF INCORPOR.ITION,

skeleton forms for use in all States and Territories . . . 443-50s

of Auditing Co.

$550-552$

of Brokerage Co. . . . . . . . . . . . . . . . . 552-55t

of Cual Co. . . . . . . . . . . . . . . . . . 51il-5t2

of Jining Co. . . . . . . . . . . . . . 560-5il

of Oil Co. . . . . . . . . . . . . . . 5 . . . . . . . . . . . . . .

of Steanboat and Transportation Co. . . . . . . . 562-56.5

of Trust imml Investment Co. . . . . . . . . . . 5.5-5.5

of Typewriter co. . . . . . . . . . . . . . . 566-5ti

of Cinterl states Steel Corporation . . . . . . . 5lti-550

of Vehicle Motor Co. . . . . . . . . . . . 565-5t3ti

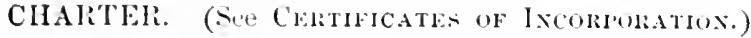

COAL COMPANY,

form for charter of (under West Virginia laws) . . . . 561-502

COLORAIX),

form for certificate of incorpration . . . . . . . 419-150

COMLANIES,

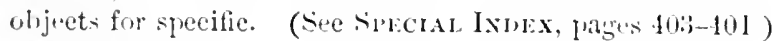

CONNECTICI'T,

form for entificate of inconpmation (skeleton form) . . . 450-1.51

Tymeriter co charter comlete . . . . . . . . . jtitj-jiz

CUMLLATIVE VOTING . . . . . . . . . . . . 5I

I).

IUEI) OF' TLLST,

securing isste of bouls . . . . . . . . . 531-511

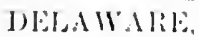

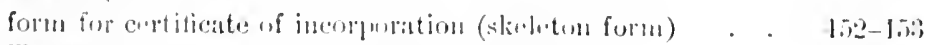

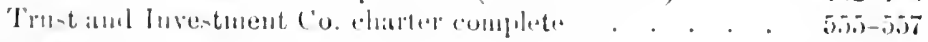

Dhrictorit,

minutes of first meeting of . . . . . . . . . . 51ti-nts

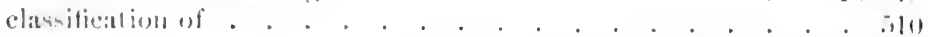

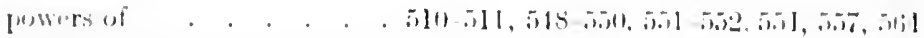

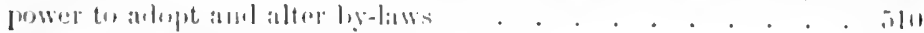

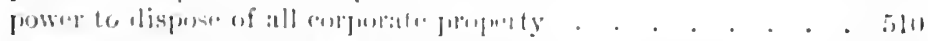

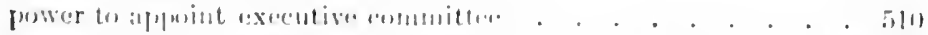

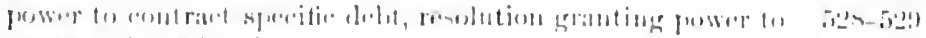

fower to issllo lume . . . . . . . . . . . . . . . 5lo

rellusial of . . . . . . . . . . . . . 5ll

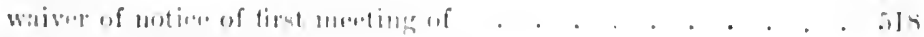

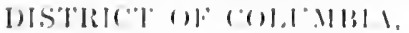

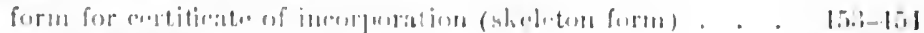

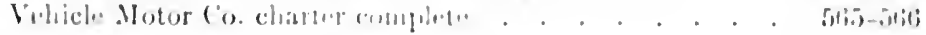

F.

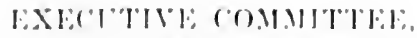

alirectors antlusisent les inpoint

510 
FLORIDA,

$$
\text { F. }
$$

form for notice of incorporation and charter of corporation in 451-455 FOREIGN CORIORATIONS,

appointment of agent by . . . . . . . . . . . . 531

G.

GEYERAL OBJECT CLAUSES • • . • . • . • • • 509-510

acquiring an established business . . . . . . . . . . 509

acquisition of company's own stock . . . . . . . . 509-510

authorizing the issuance of promotion stock . . . . . . 510

bond clause . . . . . . . . . . . . . . . . . 510

conducting business in other States . . . . . . . . 509

holling stock in otler corporations . . . . . . . . . . 509

patent and trademark clause . . . . . . . . . . 509

purchasing cliuse . . . . . . . . . . . . . . . 509

trading clause . . . . . . . . . . . . . . . . 509

GEORGIA,

form of application for charter . . . . . . . . 456

I.

IDAHO,

form for articles of incorporation . . . . . . . . 456-457

ILLINOIS,

form for statement of incorporation . . . . . . . . 457-459

INCORPORATORS' MEETING,

minutes of . . . . . . . . . . . . . . . 512-516

proxy for . . . . . . . . . . . . . . . 515, 524

waiver of notice of . . . . . . . . . . . . 515, 524

INDEX,

special object clauses . . . . . . . . . . . 403-404

INDIANA,

form for articles of incorporation . . . . . . . . 459-460

INDIAN TERRITORY,

form for articles of agreement and incorporation . . . . 460-461

INSPECTORS',

oaths and report . . . . . . . . . . . . 516, 528 IOWA,

form for articles of incorporation . . . . . . . . 462-465

K.

KANSAS,

form for application for charter and form of charter . . 4 465-466 KENTLCKY,

form for articles of incorporation . . . . . . . . . . . 467

618 


\section{INDEX TO FORMS AND PRECEDENTS.}

\section{L.}

LETTER, LIEN,

offering to transfer property in exchange for stock . . . . . 525

on stock for iudebtedness due company . . . . . . . . 511

LOUISIANA,

form for certificate of incorporation . . . . . . 467-469

II.

MAINE,

form for articles of association and certificate of organization $470-473$

MARYLAND,

form for certificate of incorporation . . . . . . . . 473-474

MASSACHUSET'S,

form for articles of association and certificate of organization 474-176

MEETINGS.

minutes of first directors' . . . . . . . . . . 516-51s

wativer of notice of first directors' meeting . . . . . . . . . . . . . . . . .

minutes of incorporators meeting . . . . . . . . . 512-516

proxy for incorporators metiug . . . . . . . . . . . . .515

waiver of notice of incorporatur's meeting . . . . . . . . . . . 515

MICHIGIN,

form for articles of association . . . . . . . . $470-478$

MINING COMHANY.

form for charter of (under Nevada laws) . . . . . . 560-561

MINNESOTA,

form for irticles of incorporation . . . . . . . 478-479

MINUTES,

of first meeting of directors . . . . . . . . . 516-51s

MISSISSIPII,

of incopporators' neeting . . . . . . . . . . . 512-516

form for charter . . . . . . . . . . . . . . 170-180

MISSOLRI,

form for agrement of incorporation . . . . . . 480-1is

MONTIN.1,

furm for articles of incorjuration . . . . . . . 181-152

MORTYidili.

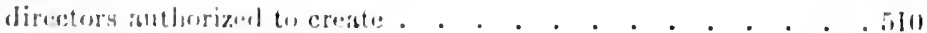

securang isstu of bouls. . . . . . . . . . . 531-511

$x$

NElilisks,

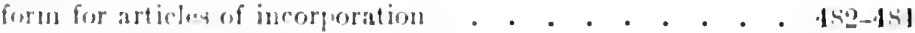

NIVAMA,

form for articles of imorguration . . . . . . . . . 4h 155

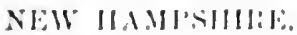

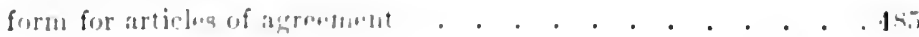


NEW TERSET,

form for certificate of incorporation (skeleton form) . . . 485-487

Amliting Co. charter complete . . . . . . . . . . 550-552

l'uitel states Steel Corporation charter . . . . . . 516-550

NEW MEXICO.

form for articles of incorporation . . . . . . . 487-488

xlill lork,

furm for certificate of incorporation (skeleton form) . . . 488-489

Brokerage Co. charter complete . . . . . . . . 552-554

NORTII CAROIINA,

form for certiticate of incorporation . . . . . . . . 489-490

NORTII IALOTA,

form for articles of incorporation . . . . . . . . 490-491

NoTICl,

waiver of notice of directors' meeting . . . . . . . . . . . 518

incorporator's meeting . . . . . . . 515

OATII,

O.

of inspectors . . . . . . . . . . . . . . 516

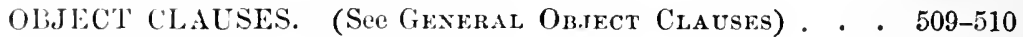

OFFICERS,

(See Siecific Object Clauses) . . . 403-442

lemoval of . . . . . . . . . . . . . . . . . . . . . . . .

OHIO,

form for articles of incorporation . . . . . . . . . . . 491

OIL COMPANY,

charter of (under South Dilkota laws) . . . . . . . 558-559

OKLAHOMA,

form for articles of incorporation . . . . . . . . . . . . . . . . .

OREGON,

form for articles of incorporation . . . . . . . . . . . 493

ORGANI\%ATION,

subscription agreement before . . . . . . . . 523-524

ORGIANITATION MEETING,

minutes of . . . . . . . . . . . . . 512-516

ORGANI\%ING,

the corpuration . . . . . . . . . . . . . . 569-570

P.

PATENT RIGIITS

IENXSYLTANI,

form for notice of application for charter, etc. . . . . 493-494

PREFERREH STOCK CLAUSE,

long form . . . . . . . . . . 511-512, 517-548, 553-554

short clanse . . . . . . . . . . . . . . . . .511

PRIXCIPAI, OFICE,

withont the state. . . . . . . . . . . . . . . . . . . .

(;0) 
PROPERTY,

directors empowered to sell . . . . . . . . . . . 510 PROXY,

for incorporators' meeting . . . . . . . . . . 515, 524 and wairer of notice combined . . . . . . . . . 52t

R.

REGISTRATION OF STOCK, form for . . . . . . . . . . . . . . . 542

REGLLATION OF BLSINESS,

clauses for. (See Busress Clatses.)

REMOVAL,

of oflicers . . . . . . . . . . . . . . . . . . . . . . . . . . . . .

of directors . . . . . . . . . . . . . . . 511

RHODE ISLAND,

form for articles of association . . . . . . . . 491-195

SOU'TII CAROLINA,

S.

form for declaration and petition for charter, etc. . . . 49j-496

SOLTI DAKOT.L.

form for articles of incorporation (skeleton form) . . . . 196-197

Oil Co. charter complete . . . . . . . . . . . . 558-559

SPYCIFIC OIBJECT CLACSLS. (See Silcial INDEx, page 103.)

SIOCK,

authority for purchase of company's own . . . . . . . . . 509 certificate of common . . . . . . . . . . . . . . 527

proferred . . . . . . . . . . . . . 505

clauses in clister for preferred . . . . 511, 512, 517, 510, 55:i, 5it

holling stock in other corporations . . . . . . . . . . 509

STOCKHOH.DEL,

organization meeting of, minutes of . . . . . . . . 512-515

proxy for menting of . . . . . . . . . . . . . 5li, 52.

SUBSCRIJ'TION,

atgreenunt before organization . . . . . . . . . . . 5:1

transfor of . . . . . . . . . . . . . . . . 5l6

SLGGESTIONS,

relative to the freparation of clarters, 1te. . . . . . 5fit-5igo

'T.

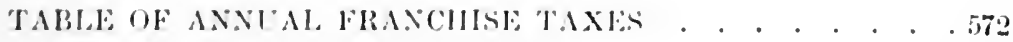

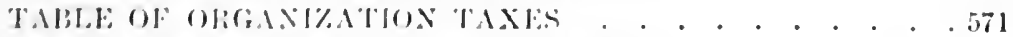

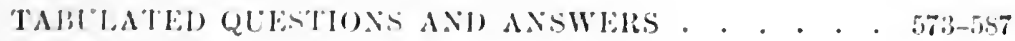

TENDESLE,

form for charter of incorporation . . . . . . . . 4a7-149

TEX.S.

form for clarter . . . . . . . . . . . . 199-500 
TRANAFER OF SLBSCRIPTION • • • • • • • . 516,518

TRLST AND, LNGSTMENT CO.,

charter of (under Delaware laws) • • • • • • • • 555-557

TRI'ST INELE,

securing issue of bond (form for) . • • . • • . 531-541

TYPEWRITER CO.,

charter of (under Comeeticut laws) . • • • . . 566-567

$\mathrm{U}:$

UNDERWRITERS' AGREEMENT . . . . • . • . . 543-544

UNITEI) S'TATES STEEL CORPORATION,

charter of . . . . . . . . . . . . . . . . 546-550

U'TAII,

form for articles of incorporation . . . . . . . 500-502

V.

VEIIICLE MOTOR CO.,

charter of (under District of Columbia laws) • • • • 565-566

VERIIONT,

form for articles of association . . . . . . . . . . 502

VIRGINIA,

form for certificate of incorporation, etc. • . . . . 503-504

VOTING TRUST AGREEMENT . . . . . . . . 545-546

W.

WAIVER,

of notice of assessment . . . . . . . . . . . . . . . . . 29

first meeting of directors . . . . . . . 518

WASHINGTON,

organization meeting . . . . . . . . . 515

form for articles of incorporation . . . . . . . 504-505

WEST VIRGINIA,

form for certificate of incorporation . . . . . . 505-506

WISCONSIN,

form for articles of organization . . . . . . . . 606-507

WYOMING,

form for certificate of incorporation . . . . . . 507-508 




UC SOUTHERN REGIONAL LIBRARY FACILITY

AA $000729625 \quad 4$ 
$x^{2}+x^{2}+x^{2}-x^{2}$

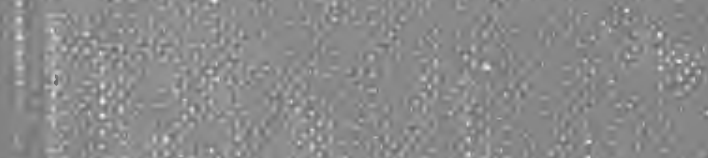

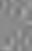

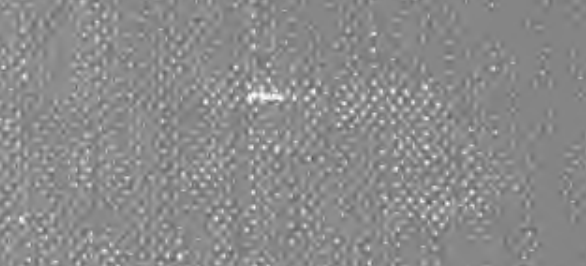

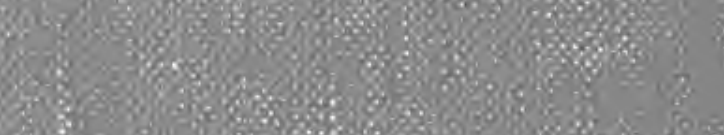

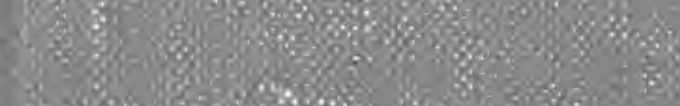

$=$

48

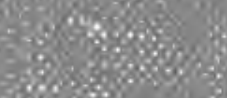

$8 \%$

$y=\frac{8}{3}=2$

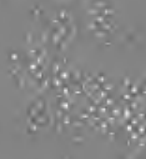

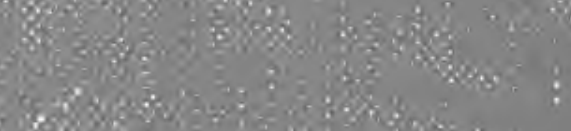
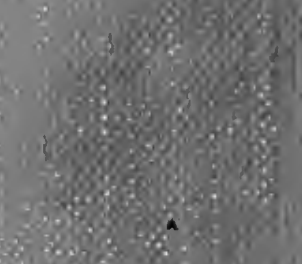

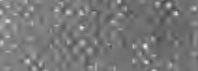

(3)

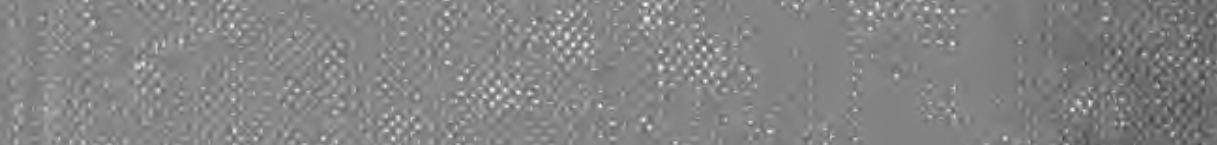

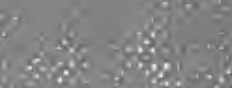

as

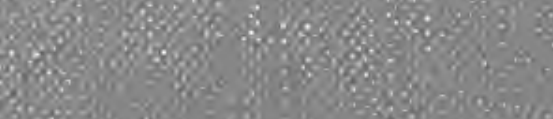

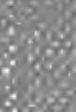

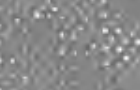

$x+2=$

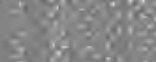

$=0$

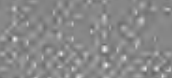

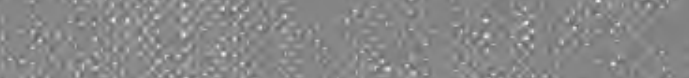

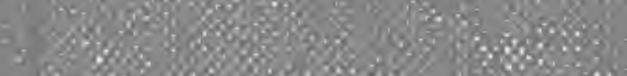

Y8:

\% $8 \%$

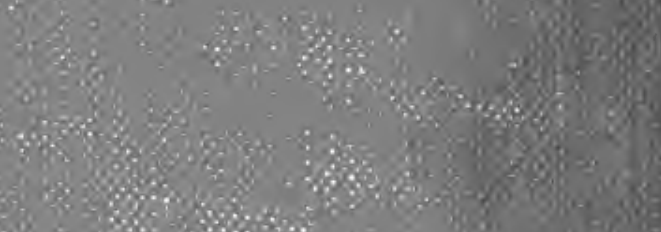

$\times<\%$

$3 \times$

$\%$

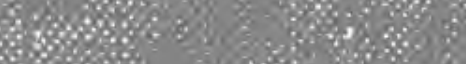

\begin{tabular}{|c|c|c|c|}
\hline & & & \\
\hline
\end{tabular}

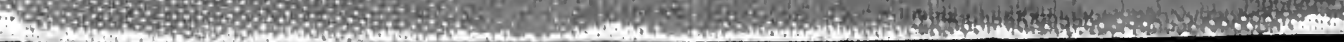

